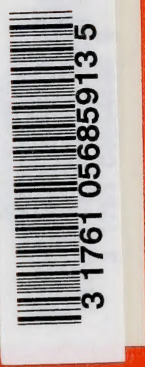


Digitized by the Internet Archive in 2007 with funding from Microsoft Corporation 




\section{New York State Museum}

Frederick J. H. MerRill Director

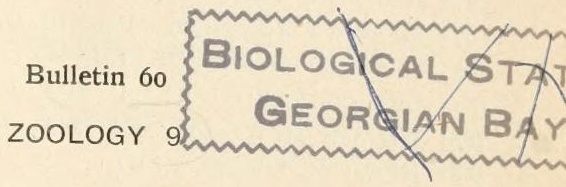

CATALOGUH OF THE

FISHES OF NEW YORK
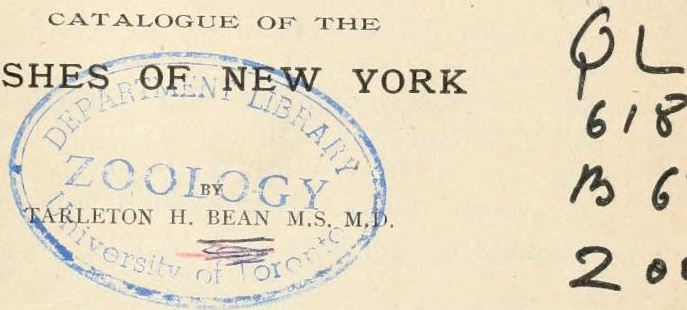

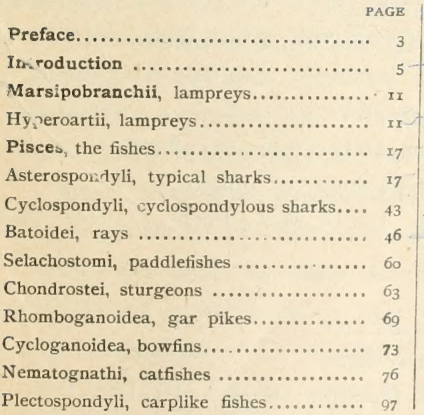

Apodes, eels .... ................... $16_{9}$

Isospondyli, isospondylous fishes....... 177

Iniomi, lantern fishes ................ 285

Haplomi, pikelike fishes............... 287

Synentognathi, synentognathous fishes.... $33_{7}$

Hemibranchii, half-gills ............. 335

Lophobranchii, tuftgills .............. 347

Acanthopteri, spiny-rayed fishes........ 35x

Plectognathi, fishes with ankylosed jaws.. 608

Pediculati, pediculate fishes............ 733

Recorded distribution of New York

fishes ... ....................... 739

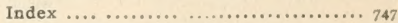

\section{ALBANY}

UNIVERSITY OF THE STATE OF NEW YORK

I 903 


\title{
University of the State of New York
}

\author{
REGENTS
}

With years of election

I892 William Croswell Doane D.D. LL.D.

Chancellor, Albany

I878 Whitelaw Reid M.A. LL.D. Vice Chancellor - New York

I873 Martin I. Townsend M.A. LL.D. - - - Troy

r877 Chauncey M. Depew LL.D. _ _ _ _ _ - New York

I877 Charles E: Frtch LL.B. M.A. L.H.D - _ - Rochester

I88I William H. WATSON M.A. M.D, LL.D. - _ - Utica

I88I Henry E. Turner LL.D. _ _ _ _ _ _ Lowville

r883 St Clair McKelway M.A. L.H.D. LI.D. D.C.L. Brooklyn

I885 Daniel Beach Ph.D. LL.D. - _ _ _ _ Watkins

r888 Carroll E. Smith LI.D. - _ _ _ _ _ - Syracuse

I89o Pliny T.Sexton LL.D. - _ _ _ _ _ _ Palmyra

I89o T. Guilford Smith M.A. C.E. LL.D. - _ Buffalo

I893 Lewis A. Stimson B.A. LL.D. M.D. - _ - New York

I895 Albert Vander Veer M.A. Ph.D. M.D. - - Albany

I895 Charles R. Skinner M.A. LL.D.

Superintendent of Public Instruction, ex officio

1897 Chester S. Lord M.A. LL.D. - _ _ _ Brooklyn

I9oo Thomas A. Hendrick M.A. LL.D. - _ _ - Rochester

igor Benjamin B. Odell JR LL.D. Governor, ex officio

igoi Robert C. PruYN M.A. - _ _ _ _ - Albany

1902 William Nottingham M.A. Ph.D. - - - Syracuse

1903 Frank W. Higgins Lieutenant Governor, ex officio

1903 John F. O'Brien Secretary of State, ex officio

I903 Charles A. Gardiner B.A. LL.B. M.A. Ph.D. - New York

SECRETARY

Elected by Regents

I900 James Russell Parsons JR M.A. LL.D.

DIRECTORS OF DEPARTMENTS

I888 Melvil Dewey M.A. LI.D. State Library and Home Education 189o James Russell Parsons JR M.A. LL.D.

Administrative, College and High School $D^{1}$

i 890 Frederick J. H. Merrill "Ph.D. State Museum 


\section{New York State Museum}

Frederick J. H. Merrill Director

\section{Bulletin 60}

ZOOLOGY 9

CATALOGUE OF THE

\section{FISHES OF NEW YORK}

\section{PREFACE}

In 1836, under the influence of public interest, Secretary of State John A. Dix presented to the legislature a plan for a natural history survey of the state, which was carried out with success and credit and resulted in the publication of a large number of valuable reports. Not the least important of these were the contributions of James E. De Kay to the zoology of New York, which appeared in 1842 and 1843.

Since that time comparatively little official recognition had been given to the progress of biologic study, till in 1897 the writer secured the able services of $\mathrm{Mr}$ Gerrit S. Miller jr in preparing a preliminary list of New York mammals. Following this appeared in October 1900 a key to the land mammals of northeastern North America by the same author, and in April 1900 a check list of the birds of New York by Dr. Marcus S. Farr, who is now engaged in the preparation of a detailed catalogue of the birds of New York. A list of reptiles and batrachians by Messris Eckel and Paulmier has recently appeared; and in the present bulletin Dr Tarleton H. Bean gives to the citizens of the state the benefit of his natural talent and long training as an 
ichthyologist. It is hoped and believed that the results of this work will be of much practical use to the public at large and to the teachers and students in the schools of the state.

By special request of the author his synonymies are printed in the form in which they were prepared by him.

Albany N. Y. July 1902

Frederick J. H. Merrill 


\section{INTRODUCTION}

New York has an extensive water area and a great diversity of surface. Its principal drainage basins are: the Great lakes, the St Lawrence river, including Lake Champlain, the Ohio basin, the Susquehanna, the Delaware, the Hudson and several small streams adjacent to it in the southeastern part of the state. The inland lakes, in the central and western part of the state, almost all communicate with Lake Ontario. Chautauqua lake belongs to the Ohio basin. Lake Otsego and two small lakes east of Keuka lake, empty into the Susquehanna. The Adirondack lakes for the most part belong to the St Lawrence drainage basin, some of them emptying into Lake Champlain, and a few into the upper waters of the Hudson.

Long Island has a larger number of species than all the remainder of the state. The number of marine species in its waters is 217 , and its fresh waters contain 27 species, of which 13 have been recently introduced.

In the bays of the south side of the island, wherein the water is brackish or nearly fresh, and where there is a luxuriant growth of water plants, young menhaden and alewives are extremely abundant.

One of the fresh-water fishes is a hybrid trout, artifically produced; another is the black-nosed dace, which is perhaps doubtfully recorded from Long Island; and 13 species have been recently introduced, as before remarked.

The permanent residents in fresh water are the following: horn pout, chub sucker, roach, brook trout, striped mud minnow, banded pickerel, chain pickerel, fresh-water killy, pirate perch, fresh-water silverside, sunfish, yellow perch, and Johnny darter. Most of these 13 species, or perhaps all of them, could easily have been introduced by man within the last century or two.

Mitchill recorded only three fresh-water species from Long Island. Theșe are: yellow perch, brook trout and pickerel. To the pickerel he applied the name Es ox lucius, a species 
which does not occur on the island. He mentioned also the bony-scaled pike, Es ox os e us, concerning which he says: "A few years ago I had a large and complete specimen from Long Island, which agrees in the main with the descriptions extant." This was doubtless a mistake of locality. The yellow perch was transplanted by Mitchill in 1790 from Ronkonkoma pond to Success pond, in Queens county, a distance of 40 miles. Prior to 1790 , he states, there were no yellow perch in Success pond. De Kay also knew only a few species of fresh-water fishes in Long Island waters - the yellow perch, roach, banded pickerel, and brook trout.

It seems probable that some of the early writers on New York fishes must have had access to collections from Long Island, and yet a number of species might have existed without discovery during the time of their observations. The present number of species whose date of introduction is not recorded is very small, and most of the so called native fishes represent species which lend themselves readily to the purpose of artificial introduction.

It is a matter of record that some species of fresh-water fishes identical with those found in Long Island waters, have been swept out of the Hudson river by spring floods, and several such species have been seen at Gravesend bay, Long Island. It is certain that incursions of fresh-water forms could have taken place from time to time in the streams of the north side, and also on the south side of Long Island. Once established in that way, their wider dissemination through the agency of man, aquatic birds, and even through their own movements could be very easily accomplished.

Of the fresh-water fishes known to Mitchill and De Kay, the brook trout can live in fresh and salt water indifferently; the chain pickerel is frequently found in brackish water; the yellow perch is one of the fish which have been brought down from the Hedson by floods into Gravesend bay; the roach is a common resident of lakes in New York and Brooklyn parks, and its distribution has been greatly extended through the agency of man. 
The number of fishes included in this catalogue is $.37 \%$, of which $: 31$ are named, and the following four, which have only resently heen discovered in the state. shomld be added to the list: no. Ti:

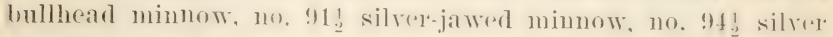
'hub, no. 2.5., northern darter. Of these species 217 are marin, 141 fresh-water, and 17 anddromous. The mumber of introluced species is 15 , and the number wlyose occurrence in New Tork watris is doubtful is 18. The small mumber of freshwater species would be remarkable but for the fact that no rxtensive investigations have recently been made of the fiesh waters of the interior of the state, and the catalogue is in that respect simply incomplete.

The andromous species are the following: no. 1 sea lamprev, no. : :5 common sturgerm, 110. 97 short-nosed sturgeon, no. 101 sel, no. 112 hicliory shar, no. 112 branch herring, no. 114 glut herring, no. 115 slıad, no. 1:30 quinmat salmon, no. 1:31 Itlantic salmon, no. 1:3t stechluead, no. 1:5 rainbow trout, no. 14: smelt, no. 170 10-spined sticklelbck, no. 171 two-spined stickleback, no. ¿g0 striped hass, mo. zfil whit prech. Besides these, the following marine species oceasionally rum up into fresh water for shorter or longer distances: 110. 15s silver gar, no. 2.2:) bluc-

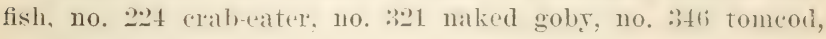
no. 368 hogehoker.

The introduced specirs are: no. T1 tench, no. 74 golelen ide, 110. 99 goldfish, no. 100 (‘n?), no. 1:30 quinmat salmon, no. 1:31 Atiantir salmon, no. 1:3̈2 landlocked salmon, no. 1:3:) Lalie Talıo trout. 110. 134 steelhead, no. 1:35 brown tront. 110. 1:36 Lenchleren tront. 110. 137 rainbow tront, 110. 1:3 swiss lake tront, 110. 141 saibling, no. 142 golden trout.

The fishes whose pretinence to the New York fanma is douhtful are the following: no. $73 \mathrm{Leuciscus}$ m a $\mathrm{r}^{\mathrm{g}} \mathrm{ar} \mathrm{r}^{\mathrm{i}} \mathrm{a}$,

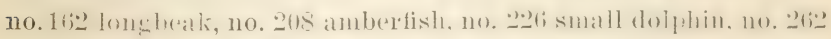

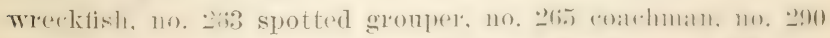

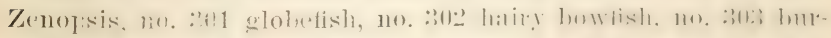

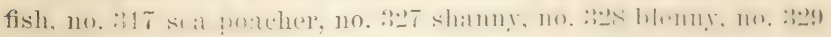

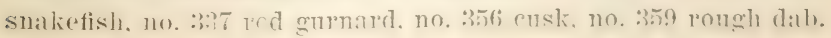


The tishes represent g! families. The dampereys indude 4 spereies: llw sharks 1s spereies: the ratfishes 11 species, of which 2 are matrint: surkers ! speeies; minnows or carres 39 species ; herrings 10 spereses salmon family, which includes the tromt

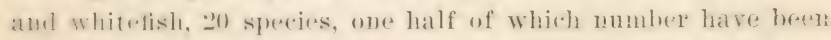

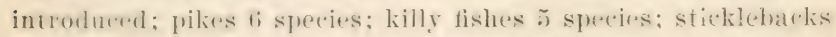

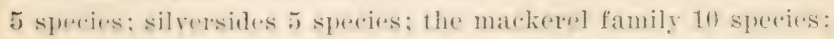
the pompano family 18 speries: smofishes $1: 3$ sperems perehes. including the darters, 17 species; sea basses 8 species; meakfish family 11 speries; serulpins $S$ species, equally divided between the fresh and salt waters; seat robins 5 species, one of which. the red gurnard, probably never oceurred in our waters, though it has been assigned to Jew York; codfishes 12 speciess, one of them a fremanent resident in fresh water; flomuders 10 sfeceies. but one of these is of doubtful occurrence.

The species whose existence in New York waters has only recently bern reported, and which are not numbered in this (atalogue, are the bullhead minnow, Clio la vigila x Baird \& cirard. the silverejawed minnow, Er icymba bu ce a ta Cope, silver (hub, II y bops is amblops Rafinespue, and the northern darter, Et heos tom a horea le Jordan. The first three of these suecies have beren found in the restern part of Niw Vork, and the northern darter has been recoleded in the basin of st Lalwrene river, from Montreal to Lake ()nlario.

Ther matmes msed in this ratalogne atre substantially those (moploged hy Jordan and Evermann in bulletin 47, [nited states

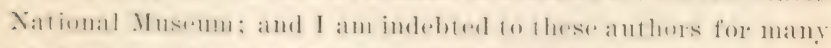
of the deseriphions of the exenera. There are some departures. fom

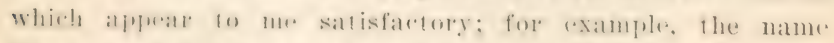

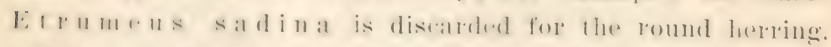

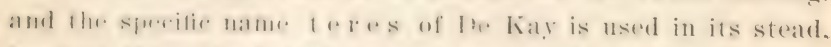

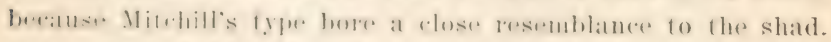
It has a spot hehimel the gill eover, at wide and foothless mouth.

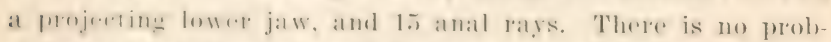
ahilits that Mildhill hat the roumd herring hefore him for this description. 
The glut herring in my list is called C 1 u p e a c $y$ a no no to n Storer; Mitchill's name, a e s t i r a 1 is, appears to be a synonym of mediocris and mat tow a ca of the same author. Its relation to the hickory shad was long since pointed out by Dr Gill. Mitchill stated that the fish has seven or eight dark roundish spots extending in the direction of the lateral line. His figure shows a row of eight dark spots on the side extending to the end of the dorsal fin on the level of the eye.

The name Coregonus labradoricus, for the Labrador whitefish, is omitted because that species is identical with the common whitefish. The characters by which the Labrador whitefish were supposed to be distinguished are untenable, precisely the same characters being found in the whitefish and there being no other basis of separation.

The author has discorered that $K$ ir $t$ a $\mathrm{n} d$ ia $l$ a $\mathrm{c}$ in ia $\mathrm{ta}$ Swain is identical with K. vagrans Goode \& Bean.

The species Querimana grans is believed to be the young of M ugil trichodon Poey; and the genus Queri$\mathrm{man}$ a was found to be the young state of II $\mathrm{ugil}$.

The name $\mathrm{Ne}$ o mae $\mathrm{nis} \mathrm{blackfordi}$ is retained for the red snapper for the reasons clearly given in the 19th Report of the Commissioners of Fisheries of New York, 1890. There is absolutely no proof that the name a y a should be applied to this species.

The synonymy given for the species is limited usually to authors who wrote specially on the fishes of New York, or adjacent regions, and to the well known general catalogues of recent writers on ichthyology. One principal aim has been to give as many references as possible to illustrations of species.

The descriptions of the fishes are based chiefly on collections studied by the author, many of which were obtained in his own field work. The results of investigations made by parties for the United States Fish Commission have also been incorporated in the text.

Illustrations of the species would have added greatly to the report; but the time was not arailable for obtaining drawings 
for this furpose. Artiticial lieys also would have bern an additional advantage; but, as references are given in erery case to bulletins 14 and to of the Tuited states Sational Musenum. which antain romplete series of artificial keys, this feature was omitted.

The atuthor hopes ere long to freprate a new aceount of the fishes of Xem Jork, containing illustrations of all the species, together with keys for identification, but can not complete such an mulertalking till after the inland waters of the state bave been more thoroughly and systematically inrestigated.

Washington D. C. 1902

Marleton H. Bean 


\section{Class MARSIPOBRANCHII}

\section{Order HYPEROARTII}

\section{Family PETROMYZONTIDAE}

\section{Lampreys}

\section{Genus pemronyzon (Artedi) Linnaeus}

Lampleys with the supuomal lamina armed with two or thee separate teeth, pointed, and close together, not forming a crescent-shaped plate; anterior lingual tooth with a median depression; buecal disk large. with numerous teeth arranged in concentric series; dorsal fins seprate, the second joined to the caudal.

\section{Petromyzon marinus Linnaeus}

\section{Great Sea Lamprey; Lamprey Eel}

Petromyzon marimus Lixidits, syst. Nit. ed. X, 230, 175s; Mitchill, Traus. I.it. and Phil. Soc. N. Y. I. 461, 1515; Günther, Cat. Fish. Brit. Mus. VIII, 501, 1870; JordAN \& GILbert, Bull. 16, U. S. Nat. Mus. 11, 1883; Jordan \& Everaman, Bull. 47, U. S. Nat. Mus. 10, pl. I, fig. $3,1896$.

Petromyzon amerienmus Le sretr. 'Trans. Im. Phil. Soc. Phila. I, :3S;, 1S1s; De Kay, N. I. Famma, Fishes, 379, 11. 66, lig. 216, 1St2; Storer, IIist. Fish. Mass. 275, pl. XXXYIII, fig. 4, 1867.

Petromyzon appendix DE K.1Y, X. Y. Fauma, Fishes, 381, pl. 61, fig. 211, 1842 ( oung).

Body cylintrie, eellike, stout, somerhat compressed behind. The mouth is terminal, subcirculat in shatpe and suctorial. It is strongly armed rith large conical teeth or cusps mounted on papillae, those of the inner series being bicuspid. Guarding the throat are crescent-shaped plates, bearing pectinate lingual teeth; a pair of these plates on either side and another forir below them. The mandibulary plate has seven cusps.

There are seren branchial alyeltures on each side of the hearl, the first not far behind the rate; the distance of the last ofening from the tip of the snout is comtaned aluont fire times in the total length. Eye rather sustl, rovered by membratur. The first dorsal originates in aboul the midelle of the longlh: il is

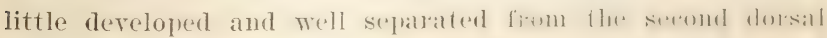
which is confluent with the anal. 'The anal is very low and 
only about half as long as the secont dorsal. The rent is fart back, opposite the origin of the second dorsal.

The sperimen described, number 106ist in the [r. S. National Museum collection, is 28 inches long.

The sea lamprey or lamprey eel inhabits the north Atlantic, ascending streams to spawn and sometimes becoming landlocked. In some interior waters of New York the landlocked form has received the name, un icolor, of De Kay, The species ranges southward on our coast to Virginia. In the Delaware, susquehamma and their tributaries this is a common fish. Its larval form, which is blind and toothless, is extremely abundant in mudly sandflats near the mouths of small streams and is a rery important bait for hook and line fishing.

'The sea lamprey grows to a length of 3 feet. It is dark brown in color, mottled with black and white. In the breeding spasmm in spring the males have a high fleshy ridge in front of the dorsal. The spawning is believed to take place in May or Juur. The eels cling to the rocks by means of their suctorial mouths and the eggs are deposited in shallow water on a rough bottom where the "urrent is swift. Some observer's state that they make nests hy heaping up stones in a circle and deposit the eges muln the stones. The ovaries are large, but the eggs are very small.

The food of the lamprey is chiefly animal matter and the fish is somewhat of a parasite, burrowing into the side of shad, sturgeon and some other species. The tecth are adapted for this methorl of ferding. The tooth-bearing bone of the upper side of the mouth contains two teeth which are placed close towether. (In the hone corresponding with the lower jaw there are seren or nine stout cusps. There are numerous teeth aromed the disk. the first row on the side of the mouth containing hiomspid teeth; the ofhers are simple. The tooth on the front of the formure has a derep median groove. The species is adaphod for lastromeg itself to other fishes and extracting from them their blood. 
The lamprey is considered a good food fish in some localities, but in other places it is rarely eaten. In Connecticut and Massachusetts the species is highly esteemed. It is preserved by salting for sereral werestis before nsing. The fish is sometimes caught with the hands or by means of a pole arued with a hook in the end. Is it is found in shallow water and will not usually relinquish its hold on the bottom, its capture is easily effected.

The sea lamprey has been obtained in Gravesend bay in small numbers in March, April and June. It is not adapted to captivity because of the impracticability of furnishing it with proper food.

\section{2 . Petromyzon marinus unicolor (DeKay)}

\section{Lake Lamprey}

Ammocotes unicolor De KAy, N. Y. Fauna, Fishes, 383, pl. 79, fig. 250, 1842. Petromyzon marinus subsp. dorsatus Wilder in Jordan \& Gilbert, Bull. 16, U. S. Nat. Mus. 869, 1882.

Petromyzon marinus unicolor MEek, Ann. N. Y. Ac. Sc̈i. 2St, 1886; JordAN \& Evermann, Bull. 47, U. S. Nat. Mus. 10, 1896.

De Kay described this lamprey under the name $\mathrm{A}$ m mo coe tes un icolor in Zoology of Tew Tork; or the New Tork Fauna, pt 4, Fishes, 1. 38:3, pl. 79, fig. 250. His description was made from a specimen $t$ inches long and -30 of an inch in depth. The plate represents it as having the dorsal scarcely perceptible, beginning to rise at about the middle of its length, but at no point exceeding $\frac{1}{10}$ of an inch in hight. The anal is similar to the dorsal and like the latter continuous with the caudal. Dr De Kay received specimens from the Rer. Zadock Thompson, who obtained them from Lake Champlain.

This variety is distinguished from the common marine lamprey only by its size, its miform dark coloration, more pronounced dorsal ridge, and the less degree of separation of the dorsal fins. It inhabits the lakes of northern and central New York and is not anadromous.

Prof. Seth E. Meek has published in the Annals of the Tru York Academy of sciences $4:-2$ !) , the following notes on the species. 
The lake lamprey is found in larger numbers than the brook lamprey, and reaches a much larger size.

loming the spring of 1 sisti more thatil at thousand individuals were laken from cilygal lake inlet, and all of them within 5

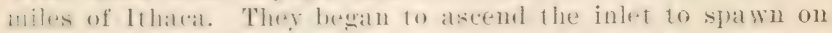
Mray 21, and continued to do so until late in June.

The-ir nests are exravalions made in the bed of the stream, in shallow waller, usually just above ripples. The egas are deposited in the tine sand and sratrel at the bottom of these

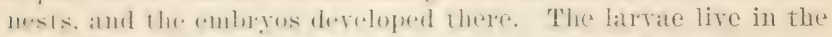
satul along the enlege of the stream just below the water line.

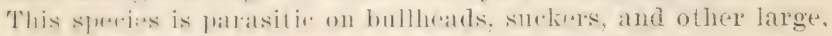
soft-rayed fishes.

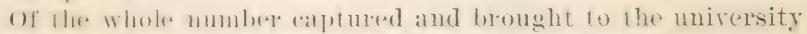

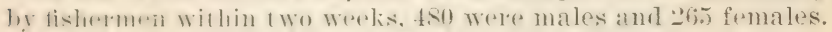

The longest male speedmen was 17 inches, and the shortest 9 inehes. The lomgest frumale measured 14 inches, and the short-

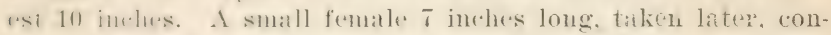
tained eggs which were quite immature.

Duriag the spring a rest is deseloped upon the bark of the

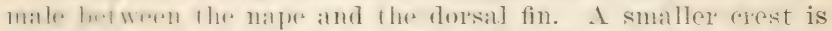
derelopul nfom the vellat surfice of the female, between the rent and lye aludal tin. This was at first supposed to be char-

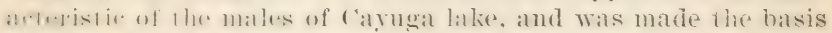

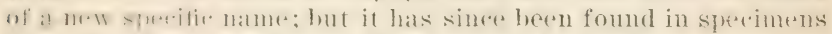

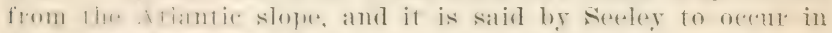

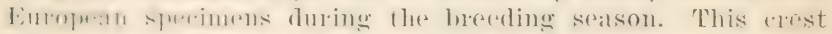
is sealsulnal and sexulal. The sexess, al other seatsons, ran not be easily distinguished, if at all.

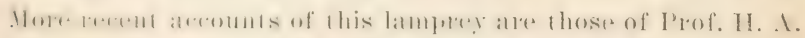

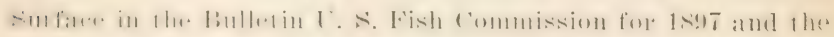
fth anmunl lieport of the Commissioners of Fisheries, Game and Forest of the state of tere Tork.

\section{Genus mcurnyomyox Girard}

biflers from loe trom y o $n$ in having the anterior lingual

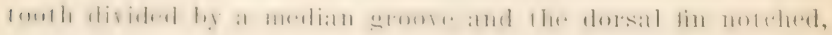
but not separated into two portions. Size small. Habitat, fresh waters of eastern Tinited states.

\section{3) Ichthyomyzon concolor (Kirtland)}

\section{Nileer Lamprey}

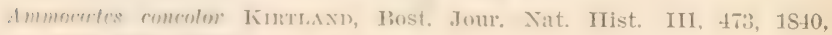
whth plate (larra)

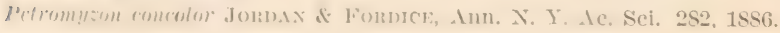


Ichthyomyzon aryenteus Jordax \& Gimbent, Bull. 16, [. S. Nat. Mus. 10. 1882.

Ichthyomyzon concolor Jondax of Ethimaxis, Bull. ti. L. S. Nat. Mus. 11. 1896.

The silver lamprey belongs to the subgenus I ch th yo on y z o $n$ of Girard. The tooth on the fromt of the tongue is divided in two parts by a median groore and the dorsal fin is continuous but deeply notched. The maxillary tooth is bicuspid; the teeth on the disk are in about fonr series and all small. The tooth-bearing bone of the lower part of the mouth has seven cusps. The head (from tip of disk to first gill opiening) is two fifteenths of the total length; with the gill openings its length is contained four and three fourths times in the total. There are 51 muscular impressions from gills to vent. Ther body is rather stont, compressed posteriorly. The hearl is moat and the bucral disk large with its edges not conspicuously fringed. rolor bluish silvery, sometimes with blackish mottlings. Above atch gill opening there is a small bluish bloteh:

The silver lamperey or mud exel is found in the Great lakes region and the (thio and thississippi valleys. It wrows to at length of 12 inches and is usually fomnd in deerl watere. hut rmus up the small streans to spawn in the spring. It is a trumblesome parasite on the lake stmeren, the paddlefish, yellum perch and some other species. It becomes fixed to thre skin hy means of its surtorial disk and the irritation of its teeth sometimes causes deef ulcers at the point of attachment. This lamprey has the same feruliarities of derelopment as the seal lamprey and sometimes remains in the larral contition, blind and toothless, till it has reateherl al lelleth of s inches.

\section{Genus Lampetra Gray}

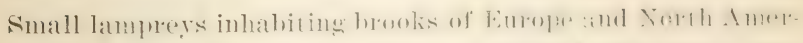

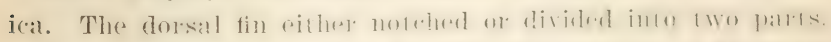

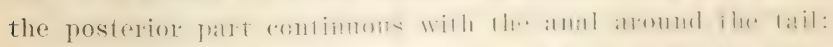

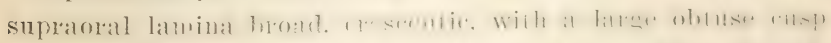

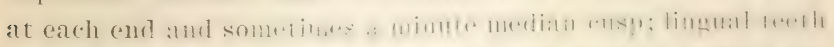

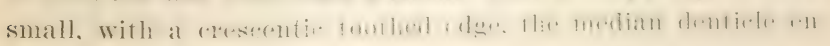


latrent: hmanl disk smatl, with fro teeth which are nerer tricuspid.

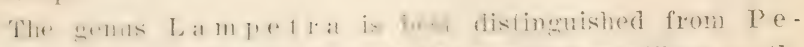

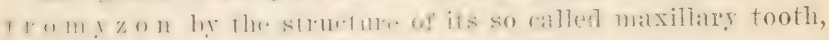

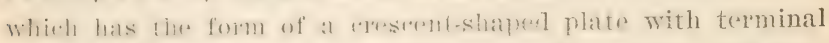
ansps and. somelimes, an adtitional mulian cusp. In P'etrom y o o n this hom plate is short and comtains two or three teeth which are very closely placed.

\section{Lampetra wilderi (Gage)}

\section{Small Black Lamproy; Pride}

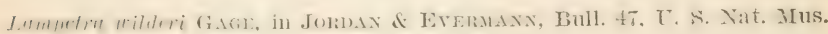
$13,1896$.

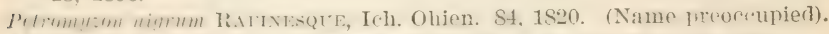

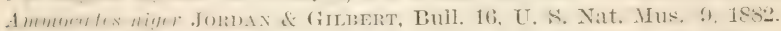

Ammocates branchialis Jordan \& Fondee, Ann. N. Y. Ac. Sci. 293, 1886; GLGE, in Wilder Quarter-Century Book, 436, 1893.

The high dorsal fin is dirided into tro parts by a derep noteh.

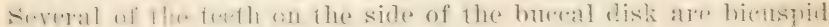
ame the pos single. The mandibulary plate is nearly straight :me has right or lo rusps of nearly requal size. The leneth of

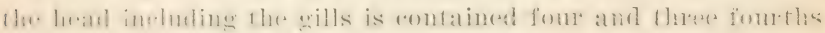
limes in fle folat. There are fï mus.ulat jupressions from gills

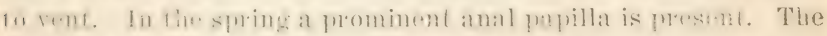

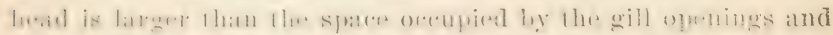

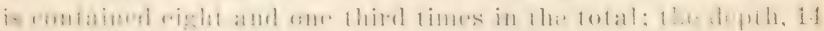
times. The ryes are large; the month moulerately small. The

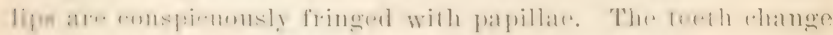

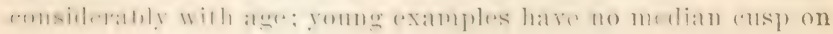
the maxillary plate.

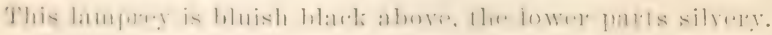

The brook or mud lamprey, also known as the small black

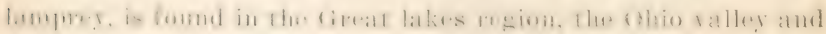

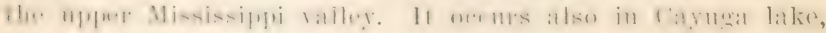

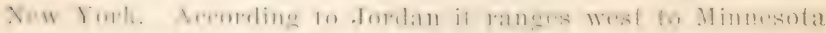
and south to Kentucky. It grows to a length of $S$ inches. Dr Inrdan considers it identieal with the common brook lamprey of liureper, . I. h r a n $\mathrm{n}: \mathrm{h}$ i a l is. 
This lamprey ascends the small streams in the spring to spawn jus as the silver lamprey does. It is parasitic and its spawuing habits are similar to those of the sea lamperey. It rlings to stomes and elokts of wath whilw depesiting its reges and is beliered by some presons to die after spawning. The probability is that it goes to deep water where it remains till the spawning season again approaches.

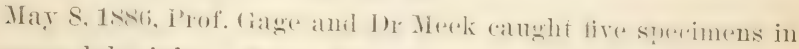
Caruga lake inlet. More of them were seen but not captured. May 22 they risited the inlet a second time but saw no specimens.

The five individuals obtained wre all males. and all were busily engaged in building nests. They ascend the inlet to spawn about two werks earlier than the large lake lamprey, and in smaller numbers.

The life history of the brook or small black lamprey is well related by Prof. Surfare in the articles referred to in the notes on the lake lamprey.

\section{Class PISCES}

Subelass SELACHII

Sharks and Skates

Order ASTEROSPONDYTI

Typical Sharks

Family PSEUDOTRTAXIDAE

Genus pseudotriais Capello

Body elongate; month wide, with a very slum lathial fold around the angle; snont depressed, rommled, moderately long; nostrils inferior, near the mouth, but not conflue wh with it; eyes oblong, lateral, withont nictituluw menhane: spirates well dereloped behind the eyra gill openings noderatte, in arlvanee of the pectoral; jaws armed with numeroms rows of small. 1rianspid teeth; first dorsal fin, opposite the spate he ween pertorals and rentrals, long amil low, gratually indratsing in hight posteriorly; second dorsal behind remtrals, ofगuste and similat lo a alal; ren-

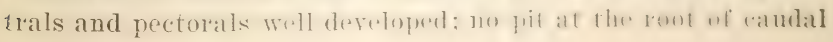


tin. the basal lole of which is very low and long; slin with minute asperities.

\section{Pseudotriakis microdon Capello}

\section{Peixe Carago (Portugal)}

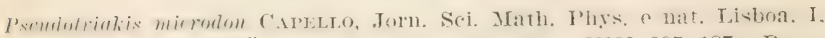

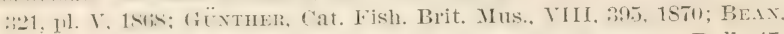
Proe. U. S. Nat. Mus. VI, 147, 1883; Jorday \& Everatans, Bull. 47, U. S. Nat. Mus. 27, pl. IV, fig. 14, 1896.

The greatest hight of the body is at the origin of the first lorsal; it is contained eight and three serenths times in the total length. The hight at the origin of rentrals is contained nine and one half times in total length. The hight of hearl at the first gill opening is a little greater than that of bodr at the renlat origin, while its hight at the angle of the mouth is a little less than wire elexenth of the total length. The least hight of the tail erguals the hight of the anal, and is rontained 2.: times in total length.

The head is somewhat depressed in front, with molerately sharp snout, which is nearly twice as long as the distance of its fip from the momb. The distanere from snout to last gill opening is andained fire times in total length. The distance from st1m to first gill opening, measured horizontally, equals twie the hight of boty at origin of second dorsal. The distanee butwen the tirst and last gill openings equals nearly twioe the longlh of the eye. The hight of the first gill opening is about

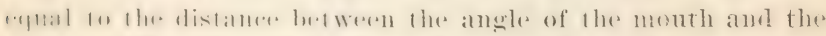
spilate. The hight of the heath at angle of mouth is contaned 11 limes ans! an llar lirst gill opening nine times in fotal length.

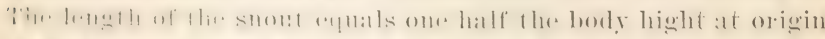

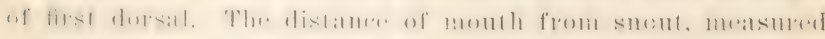
on the axis of the fish, equals one third width of mouth. The distaner from suont to angle of mouth, obliquely taken, equals one foum the distance from snont to last gill opening. The distance betwern eye and spirate equals that from mouth to nostril. The distance from angle of mouth to spiracle is about "pual to hight of first gill oprening. The spiracle is moderately 
large, the length of its opening being contained twien in the. hight of fourth gill opening. The oblong eye is placed near the dorsal profile; the length of the orbit is about one half the greatest hight of second dorsal; the length of the ere equals about one fourth width of mouth. The length of upper jaw is slightly more than that of lower, and nearly equals the distance between the spiracles. The distance from the mouth to the nostril is ahout one fouth least hight of tail; the distauce between nostrils equals four times the distance from eye to spiracle. The interorbital space equals one half the length of second dorsal base. The distance between the spiracles equals four times their greatest length.

The first dorsal is very long and low, highest behind its middle, the length of its base equal to seren times its greatest hight; its distance from the snout is a little more than twice the greatest length of pectoral. The second dorsal is distant from the end of the first a length equal to nearly twice its greatest hight; the length of its base is somewhat more than the body hight at origin of first dorsal. The second dorsal begins at a distance from the end of the first, which is equal to the hight of body at rentral origin; the length of its base equals twice the interorbital distance; its hight equals nearly twice the length of the orbit. The anal is entirely under the second dorsal, but its base is a little less than five serenths as loug as that of the latter; the greatest hight of the anal equals the least hight of caudal peduncle.

The caudal originates at a distanee from the end of the serend dorsal about equal to the hight of the anal; it is divided by at noteh into a short upjer portion, whose length is rery litlle more than the greatest hight of first dorsal, and a rery low and long lower portion. the longest matroin of which is matrly a wice as long as the snout. The distance of thw matulat from the end c.f anal base equals one fouth the length of serentel dorsal hatee.

The distance of peretoral from sliont is contaimal five times in total length; the length of peretoral expals meally i wire the wilth of its base, and is a little more than ome ninth of fotal lenglh. 


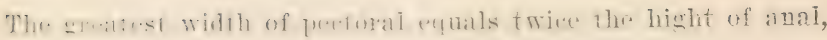
and is contained $12 \frac{1}{3}$ times in total length.

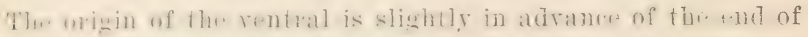

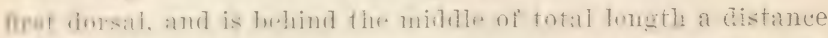

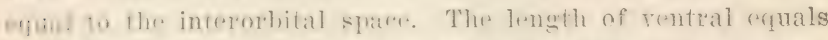
that we lowel jaw. The widih of rentral base mpmals that of

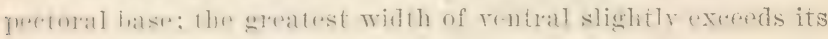
length.

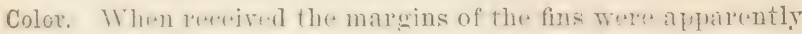
fartel: the wiginal rolor was probably gragish heow with dark mareins on all the fius rxrept the first dorsal. Caprello states that his example was chestnut brown.

Remarks. The gills and mouth were obstrueted by sind? The only parasiles disiorered on the animal were a comple of isopods, one of which was found in the eye cavity.

MEASUREMENTS

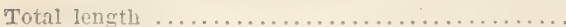

Body

Hight at origin of first dorsal. . . . . . . . . .

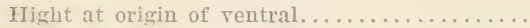

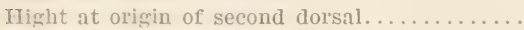

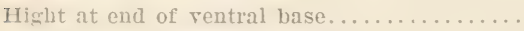

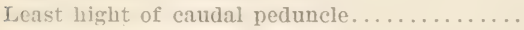

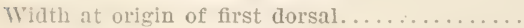
Hent

Distance from tip of snout to first gill opening Ilorizontally $\ldots \ldots \ldots \ldots \ldots \ldots \ldots \ldots \ldots$

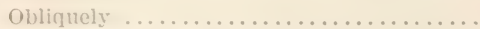

bistance from tip of snout to last gill opening.

bistance from first gill opening to fifth.......

Distance from lirst gill opening to fourth.....

Distance from first gill opening to third.......

Distance from dirst gill opening to second.....

Il jeght of first sill opening. ...............

Ifight of second gill opening..............

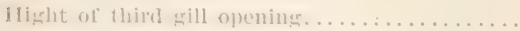

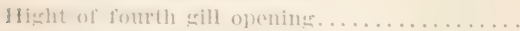

llisht of difth sill opening $\ldots \ldots \ldots \ldots \ldots \ldots \ldots$

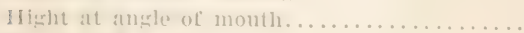

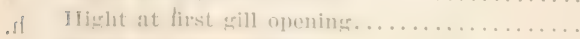

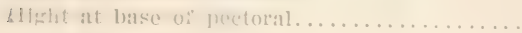

Huniredtlis Millimoters of length $2950 \quad 100$

$\begin{array}{cc}350 & 12 \\ 310 & 10.5 \\ 210 & 7 \\ 210 & 7 \\ 118 & 4 \\ 250 & 8.5\end{array}$

425 14.4

450 15.3

583 20

133 4.5 102

62 27 75 73 72 70 is 
MEASUREMENTS

Distance from tip of smout to eye (horizontally). Distance from tip of snout to mouth (horizon-

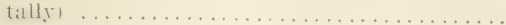

Distance from tip of snout to mouth (obliquely).

Distance from tip of snout to angle of month (horizontallyi

Distance from tip of snout to angle of mouth cobliguely)

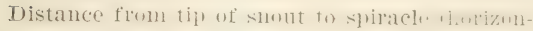
ta.11 y

Greatest length of spiracle.

Length of opening of spir'acl

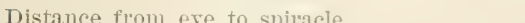

Distance from angle of mouth to spiracle.....

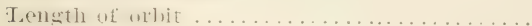

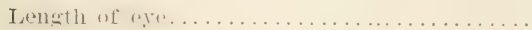

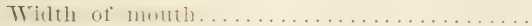

Liength of upper jaw to angle of mouth......

Length of lower jaw to angle of mouth.......

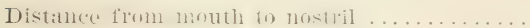

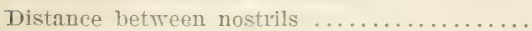

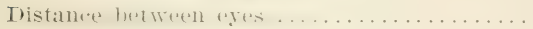

Distance betreen ejes on cartilage..........

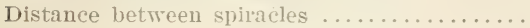
First clorsal

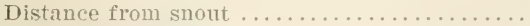

Length of liase

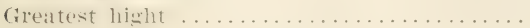

second dorsal

Distance from end of first dorsal............

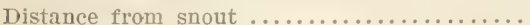

Length nt hak . . . . . . . . . . . . . . .

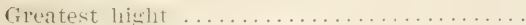

Lungth of justuriol matrin .............

Anal

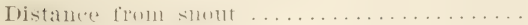

Length of base . . . . . . . . . . . . . . .

Greatest hiwht

Length of anterior margin

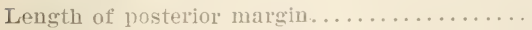

Caudal

Distance from end of second dorsal..........

Distance of tip from end of second dorsal.....

Irleatust wilill
Millimeters

Hundreiths of length

176

6

511
$1+7$
$\therefore 151$

3

5

4.5

111.3

204 ;

5. 7

ati

:...

31

it

Sil

2.7

1:4

$\because .3$

चना

ㄴ19

!)

21.7

T. $t$

T.:

$: 30$

12.

$+.2$

$1 \times 2$

112

2.1. ; ;

ii. 2

t.s

i. $\bar{\imath}$

16: $11 \quad: 4$

(i⿱艹) … 7

9.5

310

1950

10.5

int.

67

1.is

1.5

5. 1

$\therefore$

$2+157$

70.7

․․11

8.5

$11 ! 1$

$+$

:...:

47 


\section{MEASUREMENTS}

Length of upper lobe.

98

117

91

Distance of lower lobe from anal base........

Length of anterior margin of lower lobe.......

Length of longest margin of lower lobe......

\section{Pectoral}

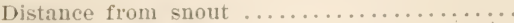

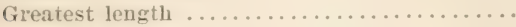

Willth or bas

Greatest width

\section{Ventral}

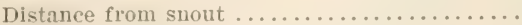

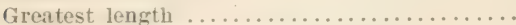

Length of posterior margin (last ray).........

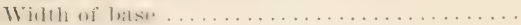

Greatest width

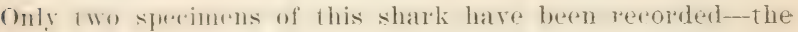
$1 y$ eleseribal by fapello from the coast of Poltugal. and an example alum ! feet. s imeles long which came ashore in excellent condition at 1 he. Amagansest life-saving station on Leng

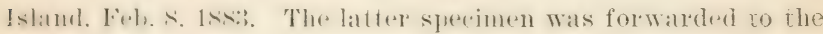
U. S. Tational Museum, Washington D. C.

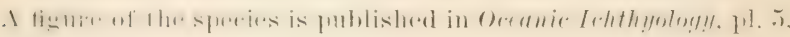
fig. 17 .

\section{Family gALEIDAE}

\section{liequiem shartis}

\section{Genus moseres Cuvier}

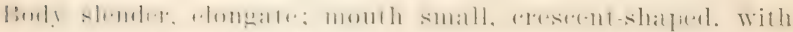

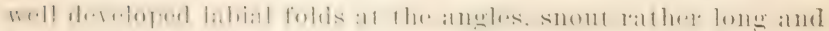

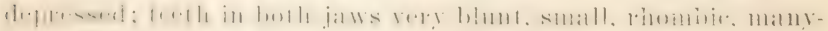

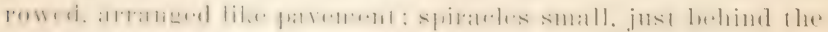
"yes; "Yo larege, oblong; joctorals large; rentrals well de-

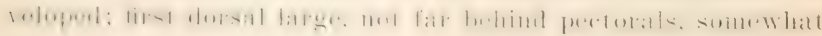
litrerer fhan serond dorsil ; anal opposite fo and smallex than seround dorsal; basil lolw of caudal little developed, the tail neatly straight; (mulnyo wilhoul placental attachment to the 111011s. 


\section{MIustelus canis (Mitchill)}

\section{Dog Shark; Smooth Dogfish}

Squalus canis Mitchil, Trans. Lit. \& Phil. Soc. N. Y. I, 4S6. 1815.

Ifustelus canis DE KAY, N. Y. Fauna, Fishes, 355, pl. 61, fig. 209, 1512; Storer, Hist. Fish. Mass. 251, pl. XXXVII, fig. 2, 2 $\theta$, 1867; JomDAY \& Gilbert, Bull. 16, U. S. Nat. Mus. 20, 1883; Jordax \& Everuinx, Bull. \pm i, U. S. Nat. Mus. 29, 1896.

Body cylindrie, elomgate, tatreling greatly from thr dorsal fin to the tail: hearl flattened above, ome fometh of total leugth without caudal; snout obtusely pointed. one thind as long as the head. Hight of hody enuals one half length of head. Nostrils large, semilnuar, midway between tip of suout and angle of mouth. Eye two fifths as long as the suont. Teeth in about 10 roms, smooth, flattened, the posterior edges of each tooth slightly elevatul. sipirarles small, circular. near the lower postriur angle of the "Ye. Cill openings moderate, half length of snout. the last two over the base of the pectorals. Hight of dorsal tim, mrasured from middle of its base, slightly greater than depth of body. Length of pectoral erpual to base of dorsal. End of rentral base midway hetween tip of suout and tip of caudal. the length of the fin scarcely one thirel length of head. 1'audal fin as long as the head, its lower lobe short, blunt, about one third as long as the mpler. Color ashen gray abore, sometimes with pale spots, white beueath; outer alges of the dorsals and anal with a black nargin, specially in young: ir is ereenish jellow. Length 3 feet.

This is knomn as the dogshark. smooth dogfish and houndfish. It is extremely common in the lorth thlantic and is a somece of great anmoyance to anglers. The shark is not eaten

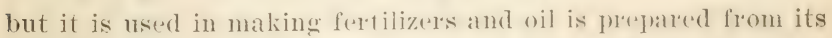
lirer. It occurs in frratresend bay in dugust, september and October. In catptivity it is restless amel delirate, often coming to the surface of the water and siruswling as if trying to escape. Its food comsists of small ('rustale(2ams, seatured. 1*t1.

\section{Genus GALEocerdo Müller \& Henle}

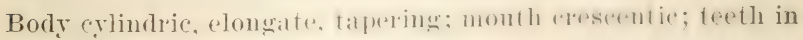
both jaws large, oblipue. roalrsty serrate on hoth margins; 


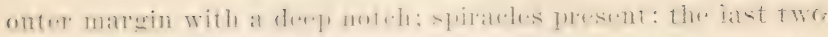

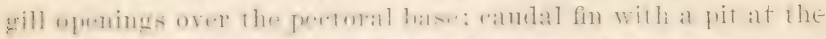

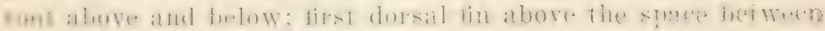
pectorals and rentrals. Size large.

\section{Galeocerdo tigrinus Müllel \& Henle}

\section{Tiger Shar\%; Leopard Shar\%}

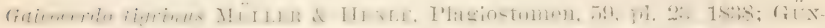
Trer, Cat. Fish. Brit. Mus. VIII, 378, 1970; JondAN \& Gilbert, Bull. 16. U. S. Nat. Ius. 21, 1SS3; Jordan \& Everurañ, Bull. 47, U. S. Nat. Mus. 32, 1896; Smiti, Bull. U. S. F. C. for 1897, 8S, 1898.

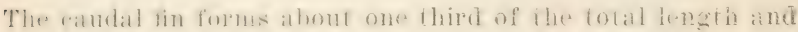

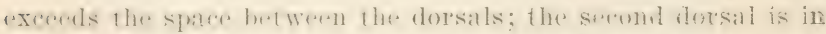

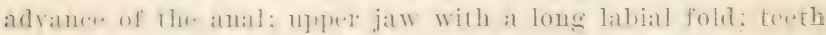

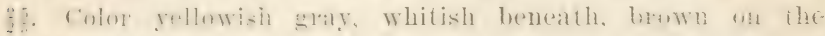

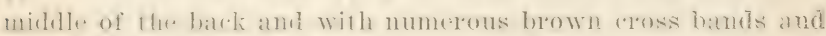

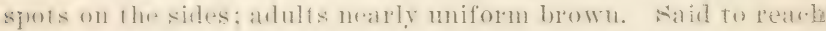
a length of 30 feet.

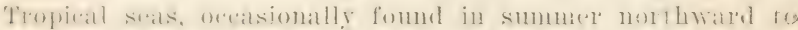
Cape Cod and to San Diego.

I) H. M. Smith las published the following reanted of its.

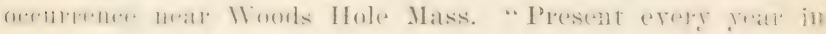

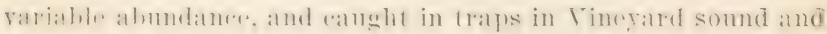

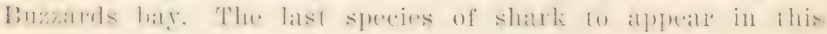

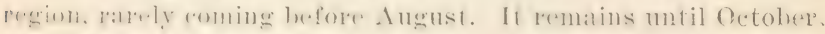

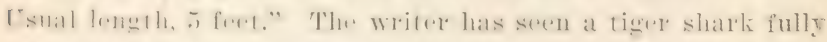
9 feet long in a trap at Marthas Vineyard.

\section{Genus rironace Cintor}

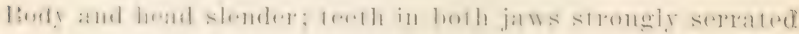

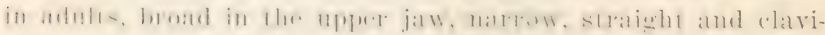

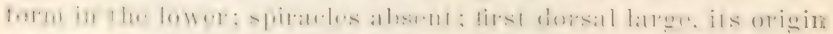

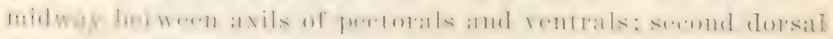

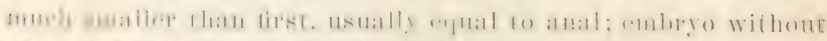

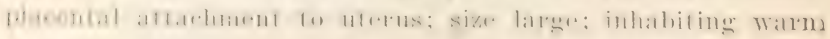
seits. 


\section{Prionace.glauca (Linnaeus)}

\section{Great Blue Shark}

Squatus glancus LrNwatus, Syst. Nat. ed. X, 235, 1758.

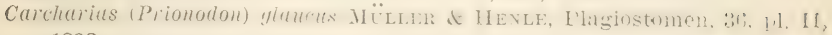
1838.

Carcharias glaucus Günthen, Cat. Fish. Brit. Mus. VIII, 36t, 1870.

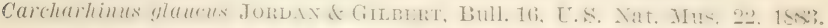

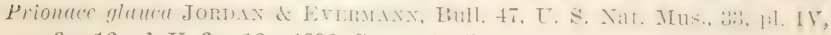
fig. 16; pl. V, fig. 16a, 1896; Sмmтr, Bull. U. S. F. C. for 1897, 88, 1898.

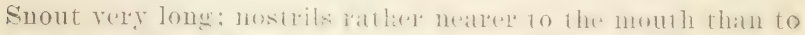
the tip of suout ; sliwhi whoure al the angle of the mouth: treth of the ulpere jatw oblipue. slightly constrieted neall the hase;

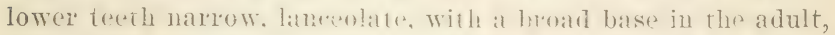

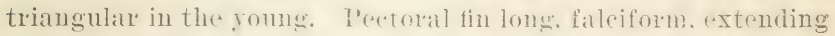
to below the dorsal. rolor light hinish way above. paler below.

The great blue sluak is (ommonn in thr Mreliterraturam and is found occasionally on onl Atlantie and Pacitic coasts.

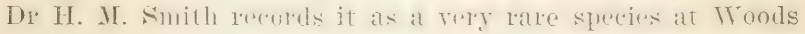
Hole Mass.. only a single infivinual hejeg eretainly kuome from that locality, taken from a trap in July 1877.

\section{Genus carcuarmos Blainville}

Body rather rohnst. Ihe head hroad and remessent: mouth inferior, with the terth in lontl jaws strongly serrater in the

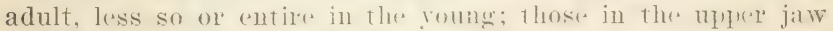
broad or narrow, those below nallew, stratight, and nuarly erect.

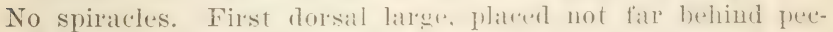
torals; pectorals faleate: secomel dorsal surall. Embryos attached by placenta to the uterus.

\section{Carcharhinus obscurus (Le Suemr)}

\section{Duskiy Shark}

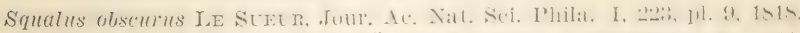

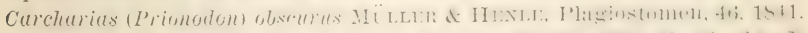

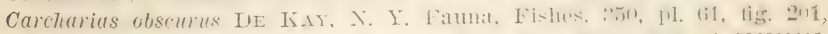

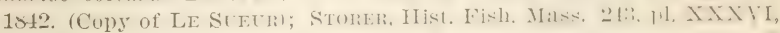
fig. 2, 1867; Günther, Cat. Fish. Brit. Mus. VIII, 366, 1870.

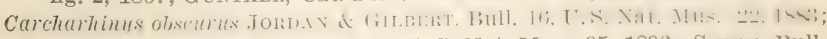
Jordan \& Evermañ, Bull. 47, U. S. Nat. Mus. 35, 1896; Smiti, Bull. U. S. F. C. for $1897,88,1898$.

Head broad, somewhat poimted. flatirmed above ambl helow; snout sharp edged, rounded and wide at thr emel; pres latrent, 


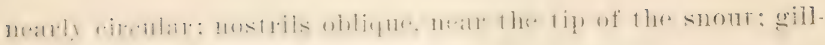
openings nuequal, the first large, the last small and orer the

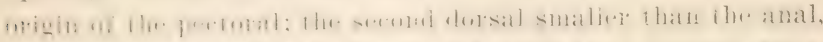

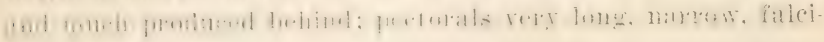
form. Thrir outer maregin four times the inner. Color dusky

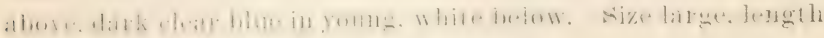
9 or 10 foet.

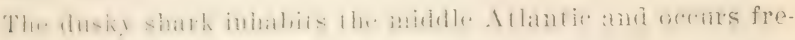
quently on oul coast in summer. Abundant in Great Egg bay where it is called the "man-eating shark." A specimen

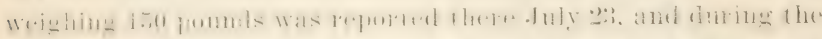

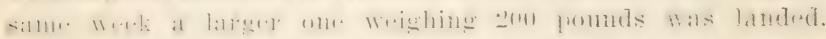

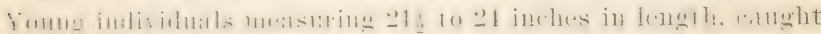

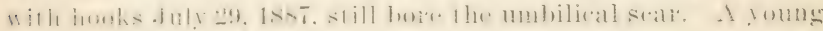

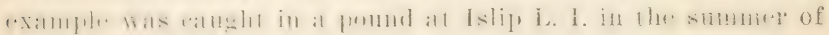
189.

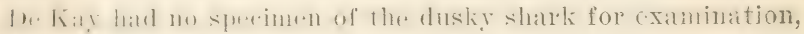

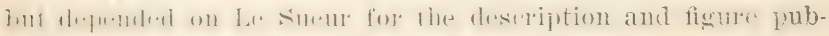
lishrel in his Tere Tor\%: Fauma. Mitchill has made no reference to the species.

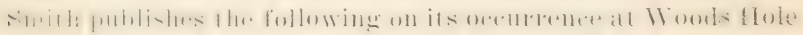

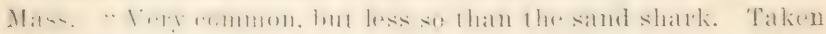

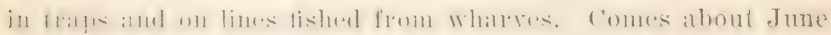

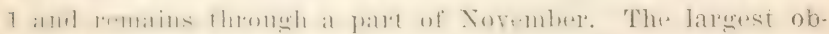

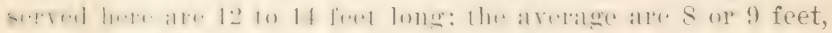
and the smallest are 21 feet." Storer says it is not a common

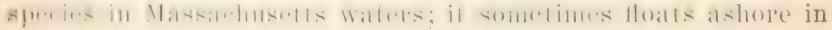
the night or becomes entangled in the mackerel nets.

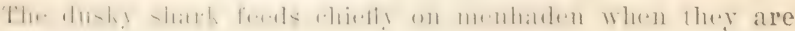
schooling.

\section{1) Carcharhinus milberti (Miiller \& Ienle)}

\section{llilbert's shar\%}

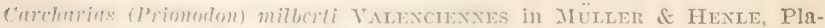

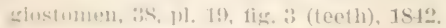

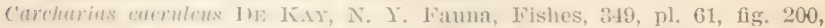

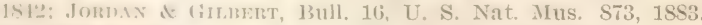

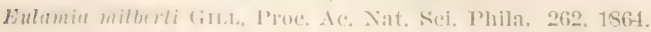




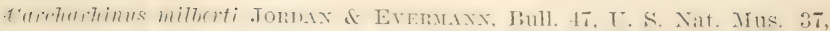
1896; Surti, Bull. U. S. F. C. for 1897, 8s, 1898.

Small blue shark Mitcint, Trans. Lit. \& Phil. Soc. N. Y. I, 487, 1815. Lamna caudata DE KAY, N. Y. Fauna, Fishes, 354, pl. 62, fig. 205, 1842.

Borly stout. its druth one fifth of the length without raudal;

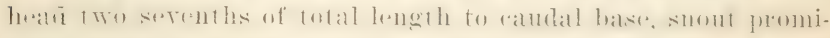

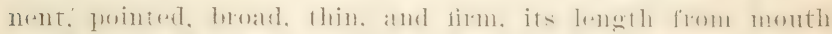
foplat to width of mouth: distance bitwern nostrils two thirds

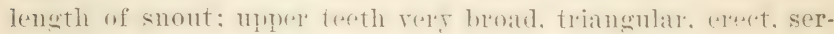

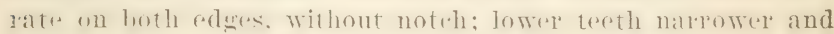
more finely serrated : will openings complatively narrow; forst dorsal hewins rese hehind origin of pertoral, its hight somemhat

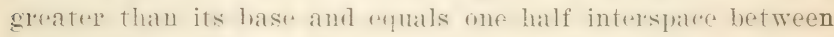
dorsals: serond dorsal rry smatl. its base one fifth interspace between dursals; ramlal molerate, its length rontained two and two thirds times in length of hody, its lower lobe less than one half as long as the mpere; pertorals rather small. not falcate, the length eontained there and one half times in total length without caudal.

The foung are slate blur on the mpler parts. the same color but less flomonumerl on the sides, and the lomer parts rhitish; adults are miform bluish gray ahore. lighter on the sirles of hrad and hody. white bemeath. the iris gremish blur. some

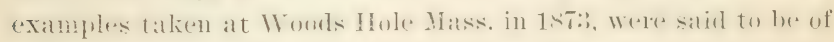
an intense almost indigo blue.

The hlue shatk orruls alome ome east roast in smmmer from

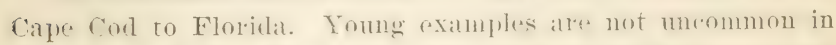

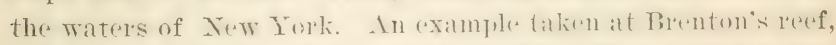
on the coast of Rhore Island, measmert 7 fert, $t$ inclues and weighed 161 pounds.

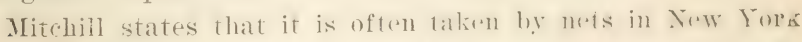
waters, as it commonly hites oft the line when hoskesl. Indi-

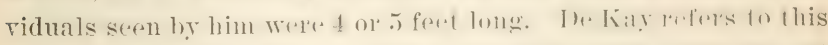

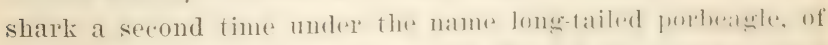

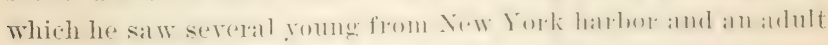
from Brenton's reef, on the coasi of liholle Istamil. 


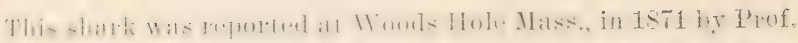

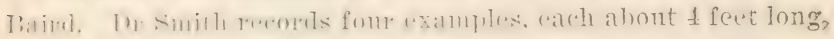

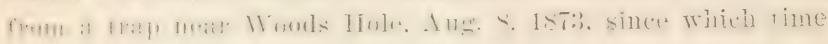
none have been observed.

The species feeds chiefly on fish.

\section{Genus aprovodox Gill}

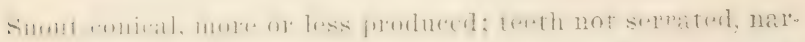

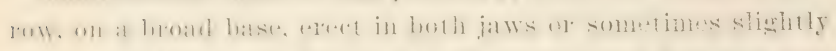

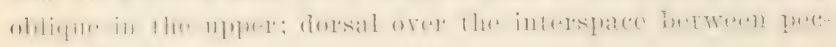
torals and ventrals.

\section{Aprionodon isodon (Val. in Müller \& Henle)}

\section{Tiburon}

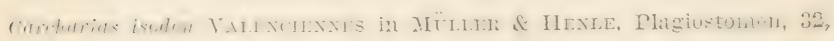
$18+1$.

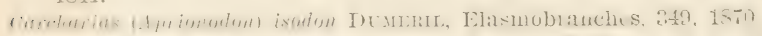

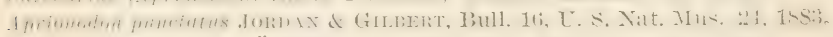
Carcharius prenctabus Güxmmen, Cat. Fish. Brit. Mus. VIII, 361, 1870.

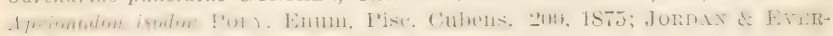
MAxх, Bull. 47 , U. S. Nat. Mus. $42,1896$.

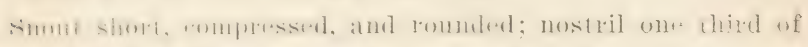

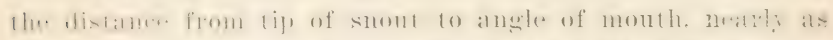

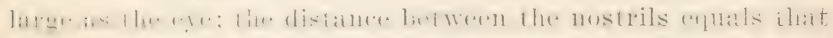

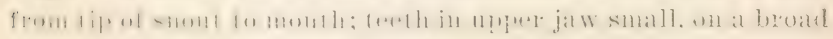

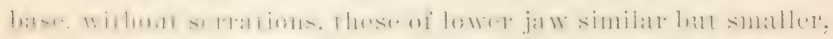

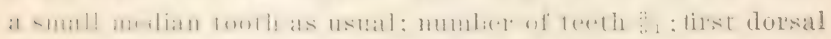

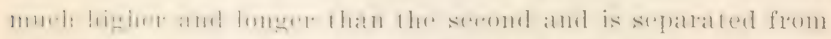

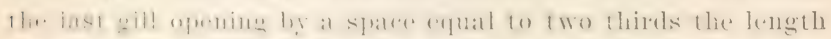

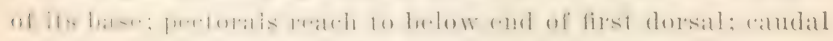

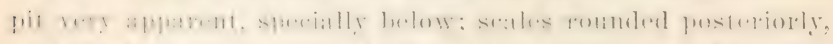

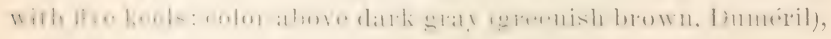
whilish helnw.

The spreins is recorded from New Iork, Virginia, and Cuba. 'The tym spreimm in the Musée d'Histoire Xiturelle, Paris, is O.

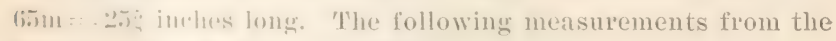
y.ju: are given ly Miillex and Henle. 
From tip of snout to nustril.

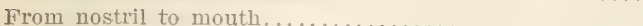

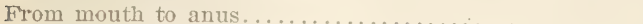

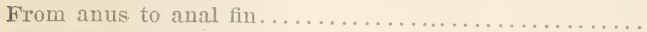

Base of inal fin.

Hight of atril tin.

From anal fin to caudal. .....................

Leugth wi caulal fin.

Distance from pectoral to rentral. ................

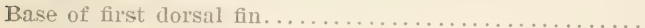

Hight of first dorsal fin. . .

Base of seconth dorsial tin

Hight of reround dersal fin.

Lemetle of pectoral tin. . .

Width of pectoral fin

Trittle of munth.

\section{Genus scomrobov Müller \& Henle}

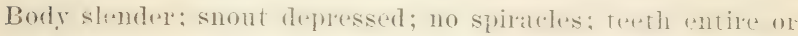
little serrated, obligue and flat, the points direetrol sidewise so that the inner margins ale more or less nearly horizontal, the teeth in front more neally erect: texth not swollen at the hase. each of them with a reep noteh su the onter matein belom the share point; labial folds conspicuous; first dorsal orer the interspace between pectorals and rentrals seromb dursal rery small: ventrals small; size small.

\section{Scoliodon terrae novae (Richardson)}

\section{Sharp-nosed Shark}

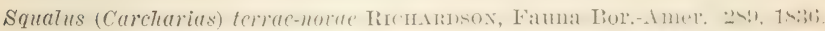

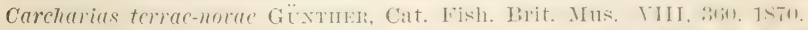

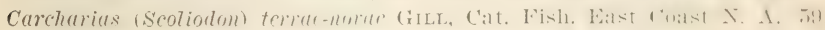
1861.

Squalus punctatus Mitchils, Trans. Lit. \& Phil. Soc. N. I. I, 4S3, 1815.

Saoliodon terrae-novae Jordan \& GmberT, Bull. 16, U. S. Nat. MLus. 24, 1883; Jordan \& Evermann, Bull. 47, U. S. Nat. Mus. 43, 1896.

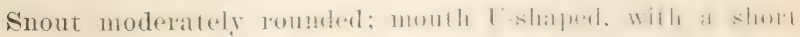

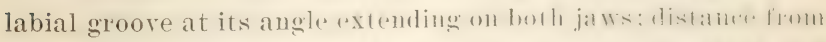

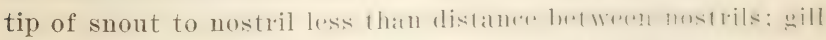

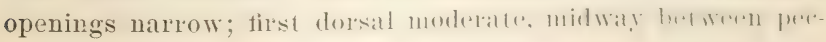




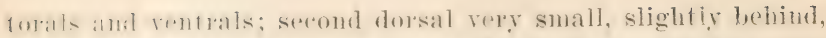
amel 1:14h+1. mathre than anal; anal fin much shorter than dis-

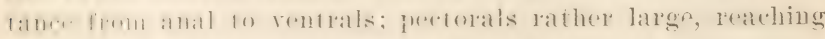
about to middle of first dorsal; ventrals small.

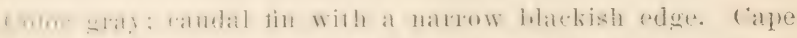

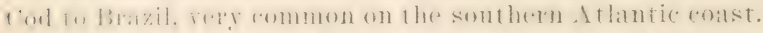

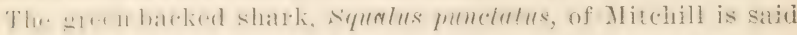

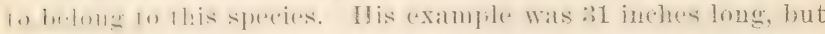

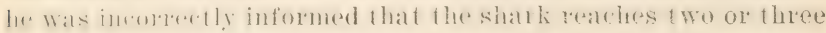
times that size. Mitchill wrote:

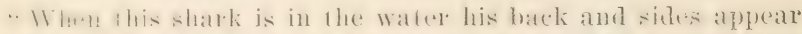

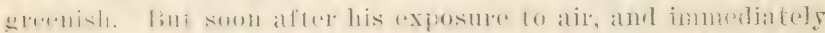

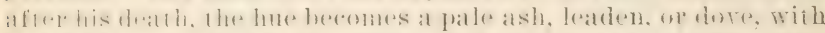

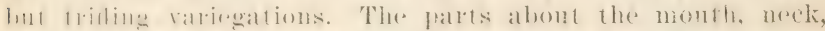

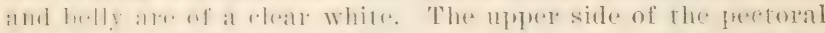

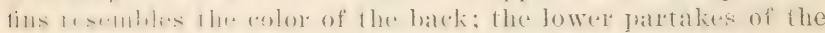

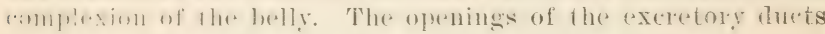
on the snout and lips are blackish.

"Thr shatk is r.ry rommon on the coast of our seuthern states; it reaches the length of 3 feet."

\section{Family SPIYTNIDAE}

\section{Hammerheaded. Shark:s}

\section{Genus spmrax Rafinesque}

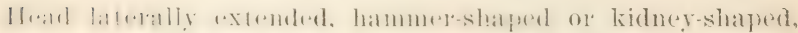

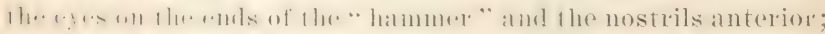

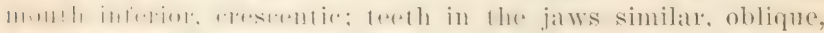

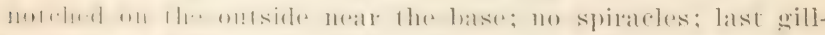
(1)

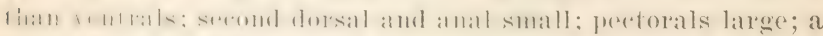

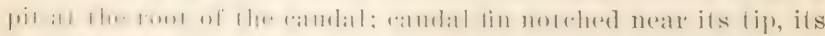
lower lobe developed.

\section{1: Sphyrna tiburo (Limnaeus)}

\section{sthoechlheal shark: Bonnethead}

Sigulus limuro Iaxisutus, Syst. Nat. ed. X, 234, 1758.

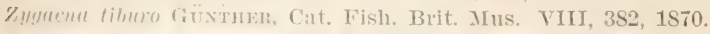

lienireps liburo (iıl, Ann. N. Y. Lye. Nat. Hist. VIII, 412, 1861; Jorday d Ginmot, 13ull. 16. U. S. Nat. Mus. 25, 1883.

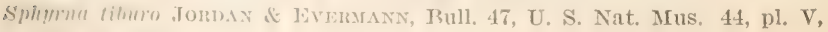
fier. 19, $189 \%$. 
Body slender and little compressed; head flat, semicircular in front, posterior margins of "hammer" short, free, the lateral margins continuous with the anterior; first dorsal high, midway between pectorals and rentrals; second dorsal much smaller, produced behind, higher and shorter than anal; rentral and caudal fins moderate; pectorals large; mouth small: tereth small, very oblique, deeply uotched on the outer margin. Itrad one sixth of total length to tip of caudal, slightly longer than wide.

Color uniform ashy, whitish beneath. Length 5 feer. At lantic and Pacific oceans, occurring on our coast from Long Island southward.

Neither Mitchill nor De Kay mentions the shovelhead shark, though both record the hammerhead. Prof. Baird found it a common fish in Great Egg bay in 185t, but the species was not seen there by the writer in 1887.

\section{Sphyrna zygaena (Linnaeus)}

\section{Hammerhead Shark}

Squalus s!nflent Lixidefs, Syst. Nat. ed. X, 234, 1758; Mitchul, Trans. Lit. \& Phil. Soe. N. Y. I, 482, 1815.

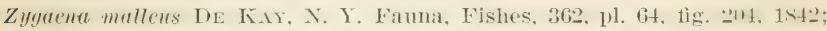
Storer. Hist. Fish. Mass. 262, pl. XXXVIII, fig. 3, 1867.

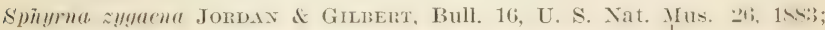

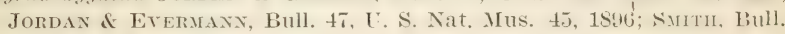
U. S. F. C. XYII, SS, 1898.

Body elongate, cylindric; head hammer-shaped, its width two or three times its length; nostril near eye, prolonger into a groove which rums along nearly the entire front margin of the head; ege large. placed near the angle formed by thr anterior and lateral margins of the " hammer ", enabling the animal to look above and beneath; three rows of white. hyaline twell in each jaw, those in upper jaw entire, areute, triangulats, the ir tips directed outward from the center, with a shomble an the men side; in the eenter a few with shoulders on both sides: aill ope-nings short and small, the last smallest and plated over the pere toral base' first dorsal larere, guadrilateral, slightly lwhind peretorals, higher than wide. deeply concate behind, and peinted 


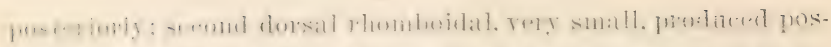

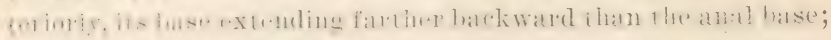

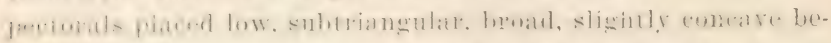

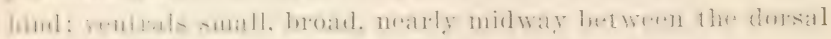

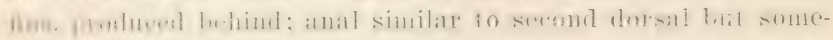

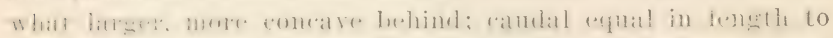

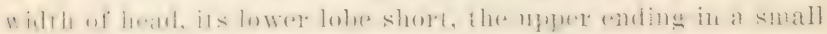

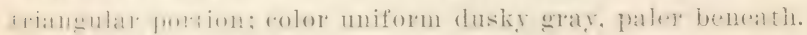

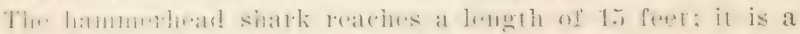

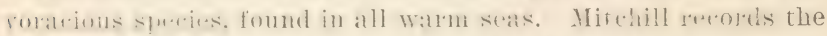

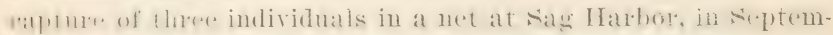

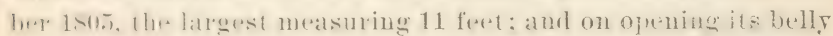

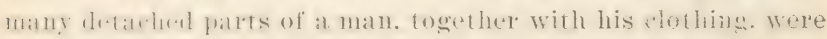
fomme in it. He had a sipermen from the hat of Sen York. A). Kay hate a sperimen en inches long which was talien in a r.in. in Jiew Jork harbor and he saw eximples + feet longe in

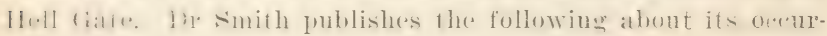
rence at Woods Hole:

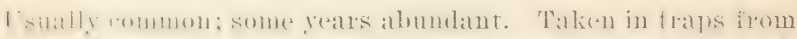

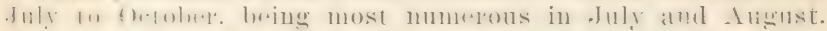

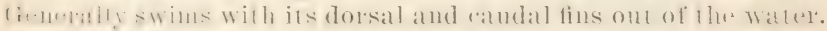

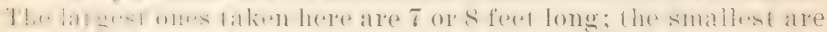
moler 1-1 feet; and the average are 4 feet. 'The name "rakehead" is an old local designation of this species.

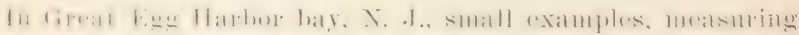

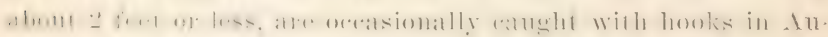

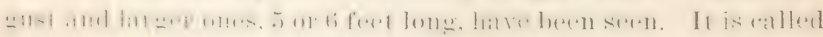

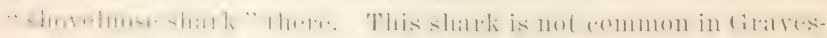

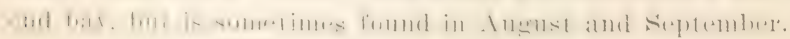

\section{Family ALOPIDAE}

\section{Thresher sharks}

\section{G('mus Muoris Rafinesque}

barly fusifum, moklerately doneate, the snout short and hlumf; month horseshon-shatperl; teeth distant, flat, triangular,

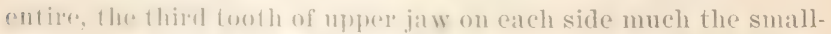
ast; gill opunings moderate, the last smallest and placed just 
anterior to or slightly wer the per.toral base; no nietilating

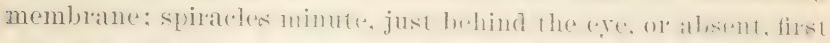

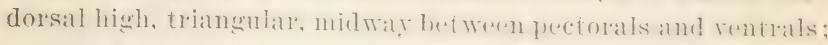
second dorsal and anal rely smatl: perotorals long and wide. deeply concare buhne? rentrals wilne than high, helow the interspace betwern the torsals; atulat withoul kerel, excesel.

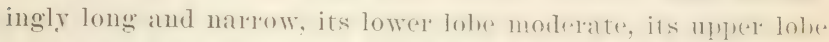

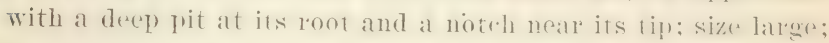
a single specius inhaliting most wallu seas, aud rasily known ly. its long tail.

\section{Alopias vulpes (Gmelin)}

\section{Thresher Shark; Swingle-tail Shark}

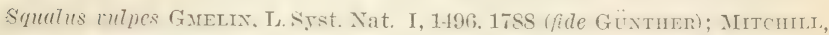
Trans. Lit. and Pliil. Soc. N. Y. I, 48:, 1815.

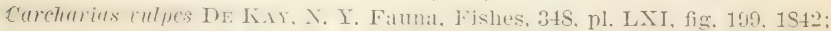

Storer, Hist. Fish. Mass. 245, pl. XXXVI, fig. 3, 1867. Alopecias vulpes GüNTHER, Cat. Fish. Brit. Mus, VIII, 393, 1870.

Alopias rulpes Jordix \& Gimert. Bull. 16, U. S. Nat. IIus. 27. 1SS:3; Jordan \& Evermann, Bull. 47, U. S. Nat. Mus. 45, pl. VI, fig. 20, 1S96; Siпth, Bull. U. S. F. C. XVII, 89, 1898.

Body fusiform, moderately elongate, its greatest hight one fourth of the length to the pit at the root of the caludal; head two serenths of the same length; cre one ninth as long as head; no nictitating membrane; snout short, twice as loneg as the rye, Flat, triangular tecth of moderate size, with entire extges, in both jaws, the third teoth of the uplere jaw on eateh sirle much smaller than the others: spiracles just helind the eyen, minute or wanting; gill openings moderate, the last one over the hase of the pectoral; first dorsal large, midway hetwern peretorals and rentrals; second dorsal and anal very small: rambal romgate, slendere, forming atheut one hall of the total lenghth a rit

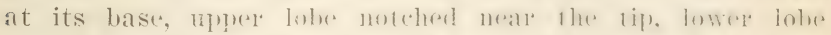

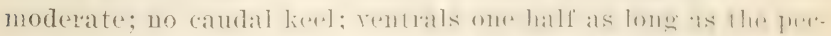

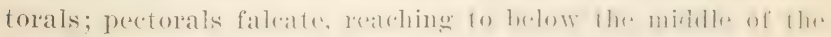
first dorsal.

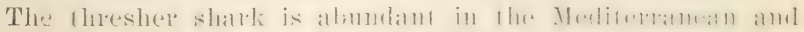

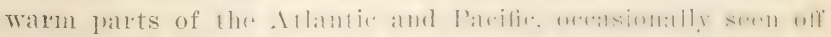

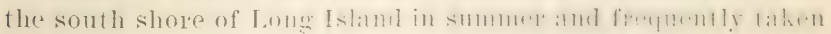
in Vineyard sound. It reaches a length of 20 feet. 


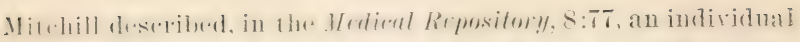

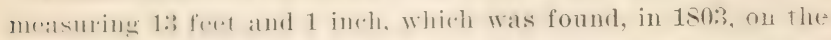

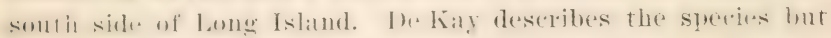

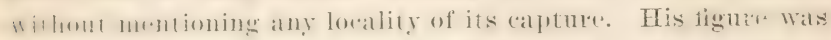

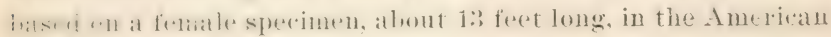
musenm.

.1, 11 mols Hol, Mass, 1 he thresher comes in April and rematins till lall. in the fall. It js common in Vineyated sound and is fomml also in linzalde bay. In the lall the boat fishremen, fishing for ent at liay Head, wateh them with lines bated with flesh herring. Indivinals zo fext lomg have been caught at Menemslıa.

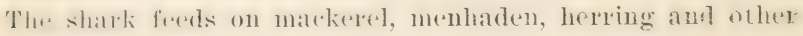
small fishes.

\section{Family CARCHARIDAE}

\section{Sand Sharks}

\section{Genus carcunis Rafinesque}

limbl morlerately elongate; the suout pointed; mouth large,

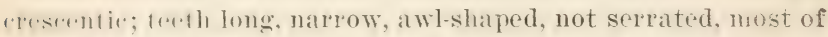
1h.11 with om, or fwo small basal eusps: spiracles minute. Prore-

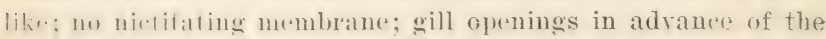

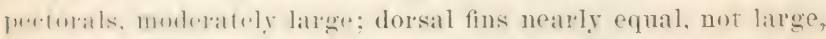

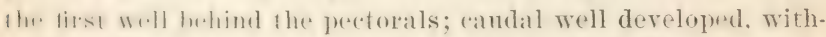

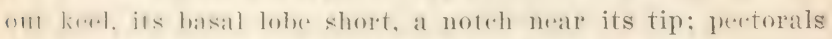
sher1. mol rrathling to heginning of dorsal; size moderate.

\section{Carcharias littoralis (Mitchill)}

\section{Sand, shark}

Siquilus lilloralis Mrtenir.r, Am. Month. Mag. II, 32S, 1S1S; LE Sueur, Jour. Ac. Nat. Sci. Philat. I, 22-2.

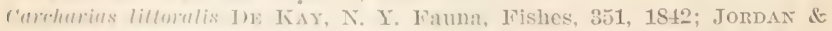
Evemax, 13ull, 47, U. S. Nat. Mus, 46, 1596; Sxurm, Bull. U. S. F. C.

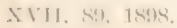

Emenmphutus litmolis (int, I'roe. Ac. Nat. Sei. Phila. 260, 1 S64.

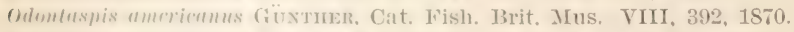

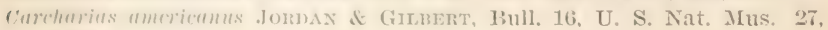
$1.4 \times 3$

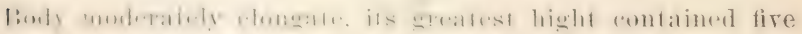

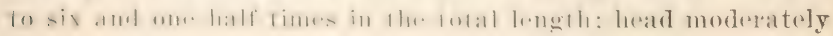


pointed, its length nearly one fourth of the total in half glown individuals; eye small, lomger than derene its length one fifth that of the snout, which is nearly ome fometh as long as the head. The spiracle is located behind the rye at a distane aynal to three times the diameter of the are. 'Two rows of tereth in function in nuper jaw and three rows in lower: longest tooth of the lowe" jaw as long as the "ye. slightly longer than the longest tooth of the nyere jaw; treeth long. aw l-slapped, mostly with one or two small eusps at the hase. the first and fourth of upper jaw and the first of lower jaw without rusps. Space oecrupied by gill openings enuals one fouth of the length of the head; the depth of the gill openings apuals four times the length of the eye. The distaner from the snont to the nostril equals the distance between the nostrils. The withle of the mouth, including the labial folds, collals a wo tifths of the length of the head. The first dorsal hase is cutirely within the first half of the total length; it is about one third as long at: llye hear. and somenhat exceeds the hight of the fin. The peetolal is one half as long as the head and, when extendert, does not quite reach the vertical through the dorsal origin. The rentral origin is slightly behind the end of the first dorsal base: the length of the fin is nearly one third of that of the head. The caulat. measured from the pit at its root, forms two serenths of the total length.

This small but roratious shark is (ommmon on our Atlantic coast, specially from Cape coul to cape Mattrias. It preys on the smaller fishes. The last indirjolual ohserverl by me in Great Sonth bay during the summer of 1 segs was swimming close to the surface near the inlet at Fire Island, September 16.

Mitchill described this shark moler the name of the gromed shark (S q u a 1 us 1 it to ra 1 is) in the Americun Monthl!

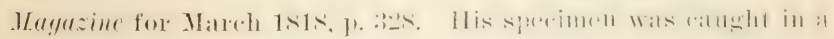
set net near New York city, and measured about j feet. He mentions a larger individual. \& foret $9 \mathrm{im}$ ines lome. which weighed

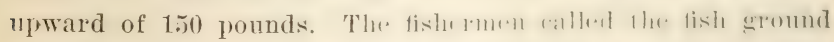
shark because it is usually fomml along slmos. or within soundings. 
Anopling to 1) smith this is the rommonest shark of the

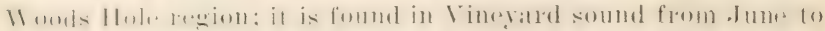

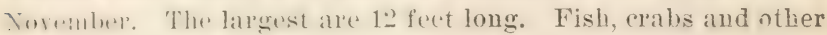
animals are found in its stomach.

sume of the texth of a large individual were secured from A. P'. fatun at southampton in July. Insteat of a single basal

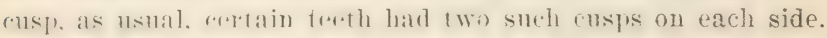

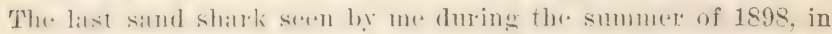

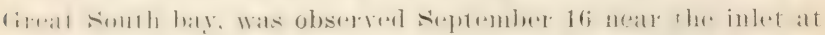
Fire islatud, swimmine slowly westwat near the surface. A list of specimens follows.

$\begin{array}{clr}\text { (Teeth) Southampton, Atlantic ocean } & \text { July } \\ 3 & \text { Clam Pond cove, Great South bay } & \text { Sep. } 6 \\ \text { \& } & \text { Clam Pond cove, Great South bay } & \text { Sep. } 6\end{array}$

I romme malw rewived from Gravesend bay fme 26. 1895, lived in "aptivity till Dee. 19. 189. when the temperature of the walle in its pool was ago $\mathrm{F}$. The following notes were made from the recently dead specimen:

colur, lironz. graly with light brown blotches, the largest about as long as the ere; belly and other lower barts whitr: ere rellowish: tips of pmetorals, ventrals, dorsals. anal and ratulal abow and lwlow with a narrow blark streak; numerous minute dark spereks on the under surfare of snout and suborbital region, extending back to angle of mouth.

Two rows of terolt in fumetion abowe and three below. Length of longest fouth in lower jaw, one half inch; in upper jaw, threes eighths inch.

MEASUREMEN'TS

Jength

Fect Inches 6

Depth of body.

… $61 / 2$

Least depth of caudal pedumele.

$\cdots$

Tip of snout to perpendieular through last gillopeuing $15 / \mathrm{s}$

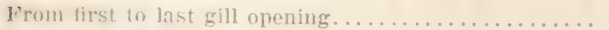

Depth of gill openings.

… 10

Snout

....

Eye to spiracle.

$\ldots$

2

Eye 
Tiklth of nostril.

\begin{tabular}{|c|c|}
\hline Foet & Inches \\
\hline$\ldots$ & 5 \\
\hline$\ldots$ & $1^{1}{ }_{i}$ \\
\hline & $1: 2$ \\
\hline & $2 \pi / s$ \\
\hline$\cdots$ & 4 \\
\hline & 1 \\
\hline & $3 * i$ \\
\hline & 16 \\
\hline$\cdots$ & $31 / 2$ \\
\hline$\cdots$ & 3 \\
\hline & $11_{4}$ \\
\hline$\cdots$ & 5 \\
\hline$\cdots$ & $23 \dot{i}$ \\
\hline$\cdots$ & $2^{1 !}$ \\
\hline$\cdots$ & $11 / 8$ \\
\hline$\cdots$ & 3 \\
\hline$\cdots$ & 12 \\
\hline$\cdots$ & $93 / 8$ \\
\hline$\cdots$ & 3 \\
\hline$\cdots$ & $10^{1}$ \\
\hline$\cdots$ & $2^{1}$ \\
\hline
\end{tabular}

Distance between nostrils.

Nostril to front of mouth.

Length of mouth opening.

Width of mouth, including labial folds.

Leugth of labial fold.

Labial fold to first gill opening.

Snout to first dorsal

First dorsal base.

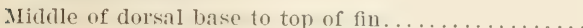

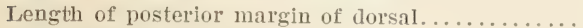

From first to second dorsal.

Length of second dorsal base.

Middle of second dorsal base to top of fin

Posterior margin of second dorsal.

Second dorsal to caudal pit.

Caudal from pit

Lower caudal lobe

Terminal caudal lobe.

Snout to pectoral, obliquely.

Length of pectoral.

214

Extended pectoral not quite reaching to perpendicular through front of dorsal.

Ventral origin slightly behind end of first dorsal base

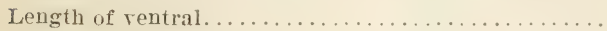

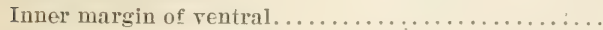

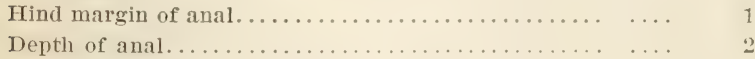

Anal base to origin of lower caudal lobe............ $13 \%$

\section{Family LAMNIDAE}

\section{Mackerel Sharks}

\section{Genus isurus Rafinesque}

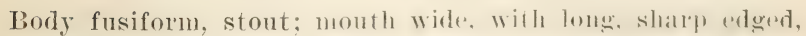
lanceolate, entire teeth having no basal cusps: spilateles minnte or absent; gill openings wide, all in atdrander of furetorals. lateral,

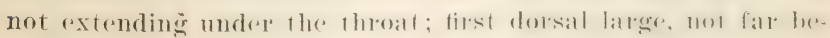
hind origin of pectoral; second dorsal and anal rery small; gete- 


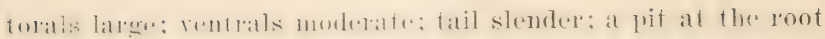

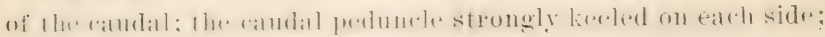

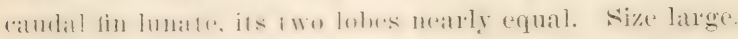

\section{Isurus dekayi (Gill)}

\section{Mackerel Shark}

Lamna punctate DE KAY, N. Y. Fauma, Fishes, 352, pl. 63, figs. 206. $207,18+2$ (not Squnlus munctutus Mrtchuld); Storm, Hist. Fish. Mass.

249, pl. XXXVII, fig. 1, 156it. (This is probably creme cormubica). Isuropsis delayi GuL, Ann. N. Y. Lyc. Nat. Hist. 1ૅ3, 1861.

Isurus dekayi Jordan of Gildent, Bull. 16, U. S. Nat. Mus. 874, 188;; Jornax \& Evernanx, Bull, 47, U. S. Nat. Mus. 48, pl. VI, fig. 21, 1896.

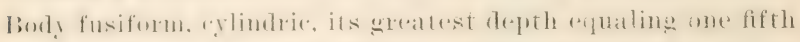

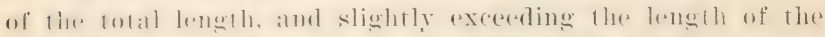

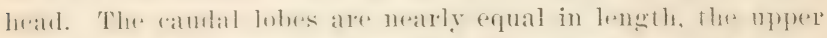

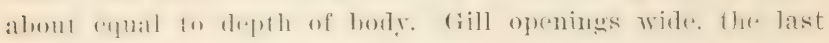

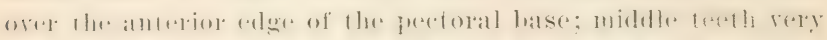

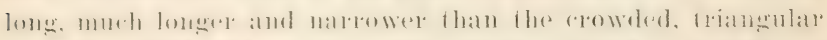

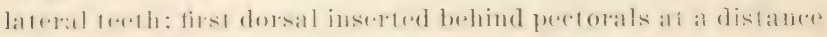

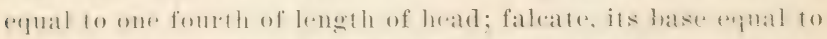
onr. thise of ils distamer from tip of suont, its hight meaty ome

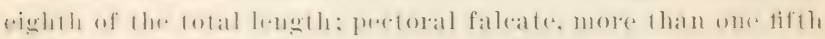

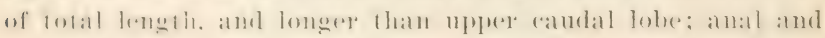

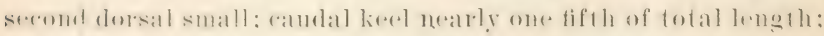
deep pits at the root of the caudal above and below.

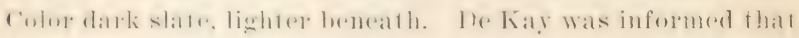

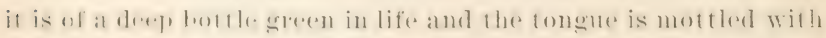

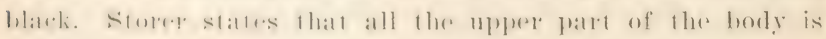

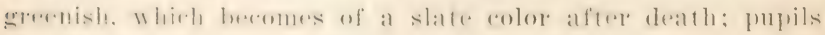
black; iris dusky.

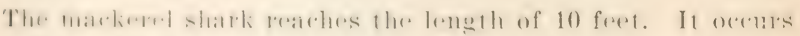

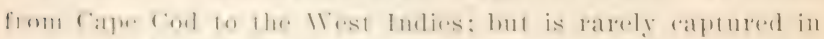
most lor'alities.

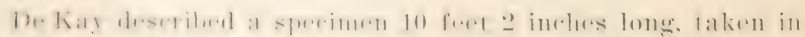

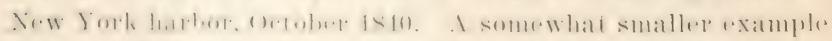

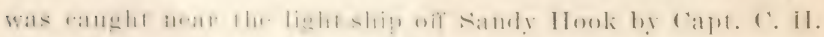

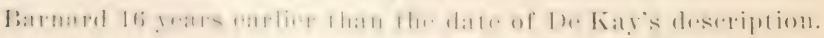

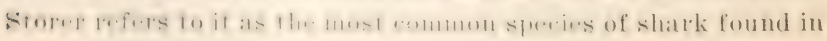


jaw on each side small: gill openiugs wide and all of them in advance of the pertoral hase; first dorsal falcate, inserted over the axil of the peromal; secomi dorsal and anal rere small,

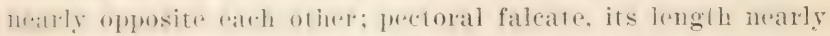
ryual to greatest dipulh of hody and equals distane from angle of mouth to last gill opening.

Color dark slate. Whitish beneath. Found in the Atlantic and l'acifie, north to Massalchusetts bay and the Gulf of Maska; ralled salmon shark at Kadiak. Reaches a length of 10 feet.

The porbeagle, salmon shark, or matheret shark is a rery powerful and destruetire sperejes, and it has a wide distribution. If the figure of $\mathrm{L}$ a $\mathrm{m}$ n a $\mathrm{f}$ u $\mathrm{n}$ ( $\mathrm{t}$ a $\mathrm{t}$ a storer be rorret, his matelerel shark must be La mu a cornubica and not Is u r us dekay i. The advancerd position of the firs! dorsal seems to indicate this.

\section{Genus Carcmarodox Smith}

Agrees with Is u rus and $\mathrm{L}$ a m na except in dentition; teeth large, flat, coret, triangular, serrate; first dorsal unoderate, nuill:" midway between pectorals and rentrals; second dorsal and anal rery small; pertorals large; rentrals moderate; andulal

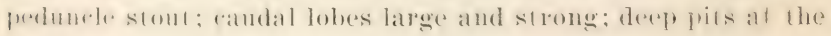
base of the caudal fin above and below.

\section{Carcharodon carcharias (Linnaeus)}

\section{Great White Shark; Man-eater}

Sifualus carcheries Inxxafus, Syst. Nat. ed. X, 235, 1759.

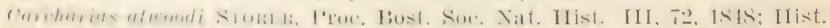
Fish. Mass. 246, pl. XXXVI, fig. 4, 1867.

Carchurulon careharias Jordax \& Ginmert, Bull. 16, U. S. Nat. Mus. 875, 188:; Jomidn d Evemand, Bull. 47, U. S. Nat. Mus. 50, 1896.

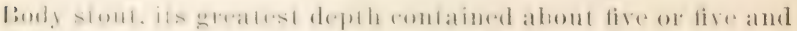

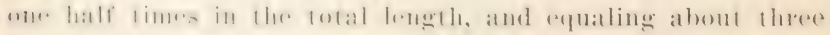

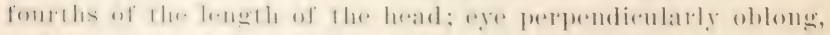

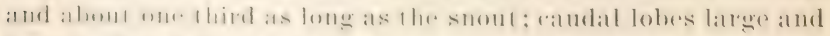

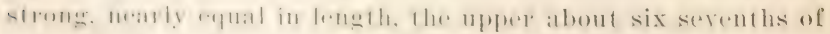

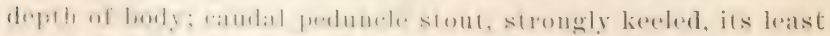
deght 100 thite of smome. deep pits at lhe base of the caudal 
fin above and below; the snout obtusely pointed, about one fifth to one sixth of length of head; month rery large; both jaws with large, triangular, serrated teeth in five rows, those in the lower jaw narrower, about 24 in each row abore and 22 below; spiracles minute or wanting: gill openings wide and all in adrance of the pectoral fin; first dorsal moderately litrge, inserted nearly midway between pectoral and rentral bases; second dorsal and anal very small, subequal, their bases scatreely more than one half as long as the snout; pectoral large, reaching to below the end of the dorsal when extended, rentral moderate, its length equal to nearly one fourth of that of the head. Color leaden gray, lower parts white; tips and edges of pectoral black. This shark reaches a length of 30 feet and a weight of nearly 2 tons. It is found in the temperate and tropical parts of the Atlantic and Pacific oceans, but is rare in New York waters.

The ferocity of the man-eater shark may be inferred from the following account of a specimen 13 feet long taken at Provincetown Mass. and brought to Boston for exhibition.

My specimen was captured at Provincetown June 16 When first seen it was swimming in about 10 feet of water on the Long point side of Provincetown harbor. A boat's crew having given chase, a harpoon was thrown into it, when it instantly turned toward the boat and seized it with great ferocity near the bows, in which act several of its teeth were broken off. It was eventually killed by being frequently lanced.

Jordan and Evermann record an indiridual about 30 ferel long, caught near Soquel Cal. which had in its stomach a young seal lion weighing about 100 pounds.

\section{Family CETORHINIDAE}

\section{Basking Sharks}

\section{Genus Cetonmus Blainville}

Body stout, the skin much wrinkled and beset with smill spines; suout blunt; head small; mouth moderate, wilh numerous small, conical teeth without cusps or serrations; spiracless minute, above the corners of the mouth; gill openings very wide 
extending from the hatek almost atound the throat, all of them in advanee of the purtorals: tirst dorsal latrege, midway between

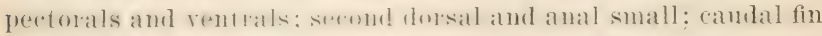

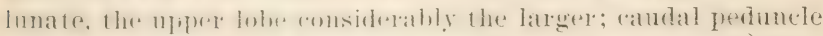

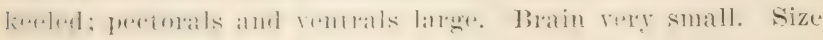
very large.

\section{Cetorhinus maximus (Gunner)}

\section{Basking Shark; Elephant Shark}

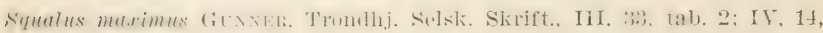
tab. 3, 1765; Mrcnill, 'Trans. Lit. \& Phil. Soc. N. Y. I, 4S6, 1815.

Selachus maximus DE KiAY, N. Y. Fauna, Fishes, p. 357, pl. 63, fig. 208

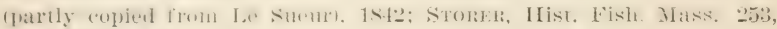
pl. XXXVII, fig. :3, 1867.

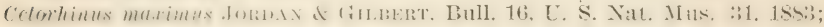
Jordan \& Evemixx, Bull. 47, U. S. Nat. Mus. 51, pl. VII, fig. 23, 1896.

Body very stoul, I he skin wrinkled, rough. beset with small spines, its grealtest dellt rontained about five times in the total

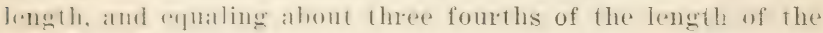

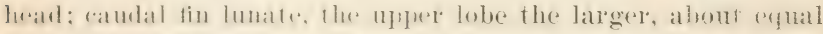

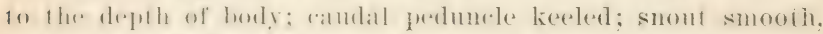

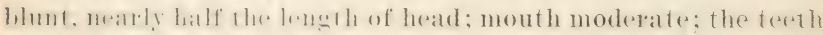

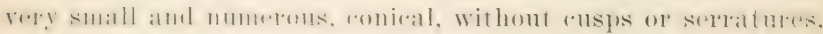

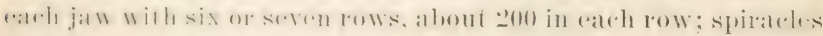

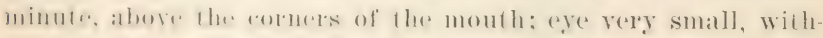

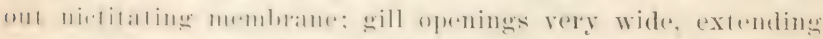

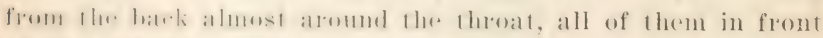

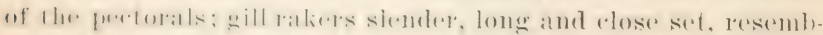

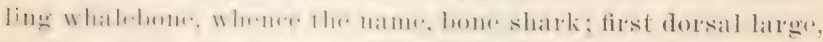

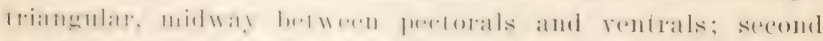

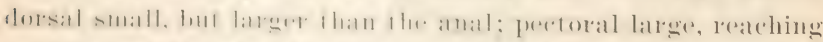

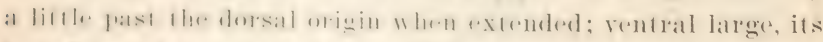

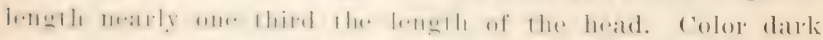
slate or leaden ahove, lighter bencath.

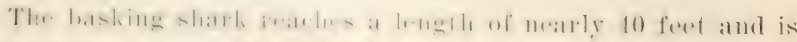
the largest of the shatris. It is an inhabitant of Aretic seas,

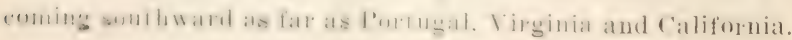


Mitchill refers to its (apture at l'rovincetown Mass. and to its name of bowe shark becaluse of the fremliat structure of is gills. De Kay mentions the suecimen whirh was raptured in the lower harbor of Xerr lork in 1s-o.s, from which he mates

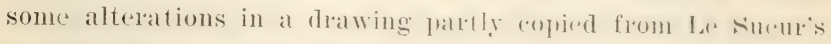
sketeh of the same fish. Storele descleibed an indivilual measmeing 33 feet 3 inches. The says it is ralely observed ou the roast of Massachusetts. It beconues gregarious only in the brexeling seasou.

The oil made from the livel of the basking shati was at one time considered valuable.

\section{Order CYCLOSPONDYLI}

Suborder CYCLOSPONDYLI

Family SQUALIDAE

Dogfishes

Genus squarus (Artedi) Linnaeus

Body slender, ("longate; mouth slightly arehed, with a long, straight, de(2), oblique groove on earch side, without labial folds; teeth small, simple, equal in both jaws, their yoints turned asiele so that the inner margins fordu a cutting edge; spirarles well developed, neal the eye; gill openings moderate, all in arlvance of pectorals; first dorsal largere than the second, far in front of the rentrals, which are behind the middle of the body: sreond dorsal behind rentrals; dorsal spines strong, not grooved: caudal fin with unequal lobes, the upper elongate, broats, subtruncate at the end, the lower short and romuled: frectorals large and long, placed low down; ventrals midway hetween end of first and beginning of second dorsal. No anal fin.

\section{Squalus acanthias Linnaeus}

\section{Spined Dogfiste}

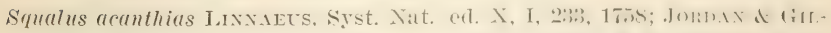
Bert, Bull. 16, U. S. Nat. Mus, 16, 1883; JordAN \& Evemaxx, $13 u l l$. 47 , U. S. Nat. Mus. $5 \pm, 1896$.

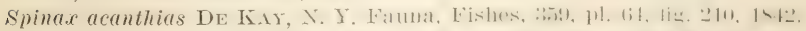

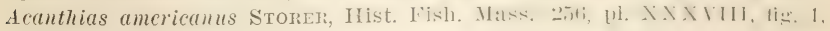

1a, 1867 .

Acanthias vulgaris Güntrer, Cat. Fish. Brit. Mus. VIII, 11., 1850. 
Body slemer. moderately long. its greatest depth about one wighth of the total lenghth, and about three fourths of the

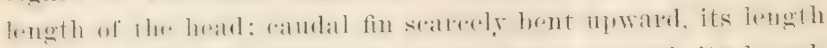

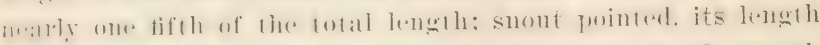

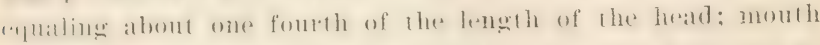

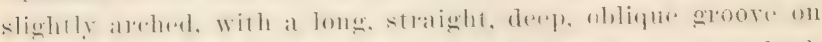

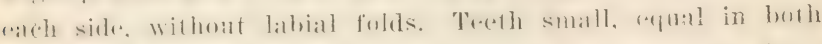

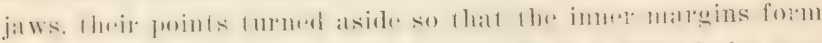

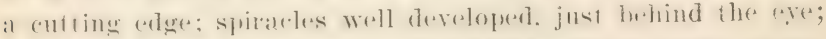
"ye barge whlonge its diameter two thirds of the length of the smout: mo nirlitating memhranr: giil openings narow slits, in front of the peetorals: first dorsal moderate. latere that the second, far in alliance of the postmedian rentrals, which ale in front of the small second dorsal: peretoral when extended rrarhes fo below the first dorsal spine, its ienglh contained ahout siven times in the total. incluting vaudal fin; ventral one fourth as long as the head.

Color dark slate or gray on upper parts, whit ish below, numerous white spots on the bark, becoming faint or obsolete with age. Thr. spimed dogfish irathes a length of :3! feet and the

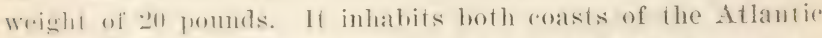
and is roorded also from cuba. It is found in Graresend baly,

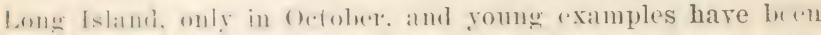
taken al sombampion in the same month. The species is tommon in smmmer and fall on the fishing banks off the Yow Jersey coast. It is not hardy in captirity.

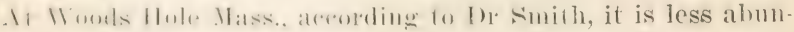
dam than formely and was rompatratirely seatree in 1897. When

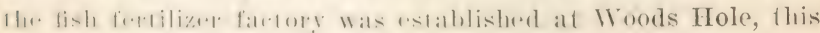
nas flu promeipal fish wilized in lhe manufacture of oil and Euamo: later, the seatrity or irrenularity of the supply necessitated the use of menhaden.

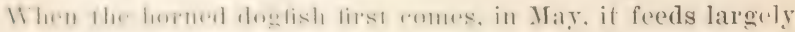
on rtenophores.

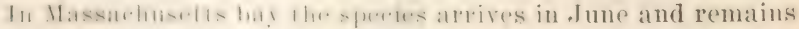

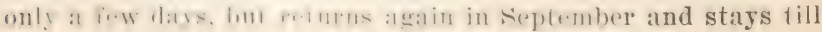


the middle of Norember. These fish are usually caught with the hook and often contangle themselves in nets, to which they do great damage. They feed on mackerel, whiting and other fishes.

The oil of the liver is an artirle of "ommerce, the flesh is useful for ferfilizers, and the skin has been used for polishing: on some parts of rape Cod the fish has been dried for furel.

Mitchill mentions the spined dogfish only in one of his minot papers. De Fiag recorded it as common on the New York coast. The found remans of the soft relm and seales of fishes in its stomach.

\section{Suborder TECTOSPONDYLI \\ Family squatrinde Angel Sharks}

\section{Genus souatina Duméril}

Body flat, depressed as in the rays, the snout obtuse or slightly concave in front; nostrils on the front margin of the snout with skinuy flaps; mouth anterior; teeth in many series, conical, pointed, distant: spiracles wide, transverse, behind the eyes; gill openings wide, very near each other, partly inferior and partly hiden by the Iextoral fins; two small, subequal dorsal fins on the tail behind the ventrals; no anal fin; caludal small, the lower lobe longer than the upper; males with small prehensile organs; vertebrae tectospondylous.

\section{Squatina squatina (Linnaeus)}

\section{Angel fish; Monkfish}

Squalus squatina LinNaEus, Syst. Nat. ed. X, 233, 1758.

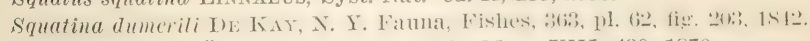

Rlina squatina Güntmer, Cat. Fish. Brit. Mus. VIII, 430, 1870.

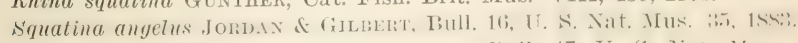

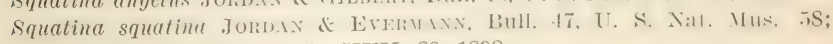
Sмптн, Bull. U. S. F. C. XVII, 89, 1898.

Body raylike in shate, Hat, depresod, its greatust depth less than one fourteenth of the futal length and about ome third of

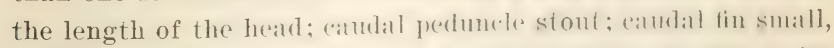
its lower lobe the longer; snouf slont, rounded; nustrils on its front margin, with skinuy liaps. Mouth anterior, its width 


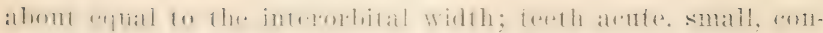

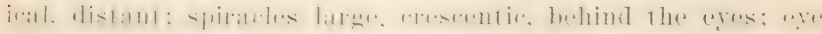

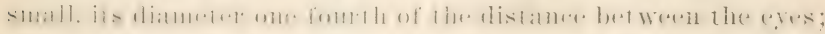

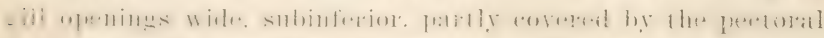

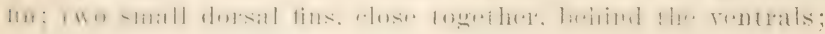
anal fin wanting; pectoral fins very large, widely expanded, deeply notehed at the base; ventrals very large, their length

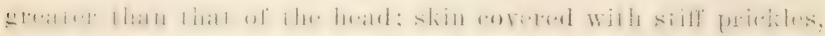
largest on the median line of the back.

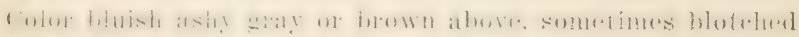

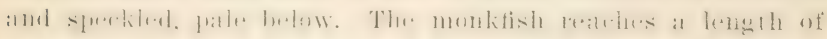
1 feet. It is easily recognized by its peculiax shape. It in-

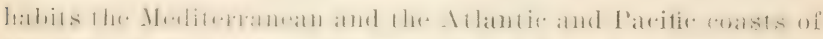

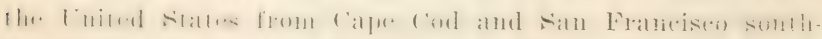
ward. It is not common in New Jork waters, but it appenrs

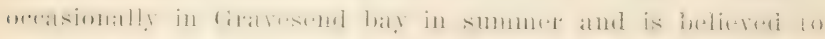
oecur in this state only in bays adjacent to the Atlantic.

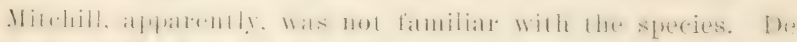

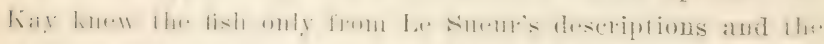

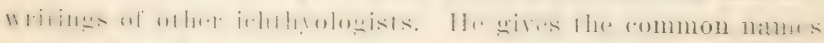

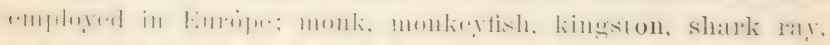

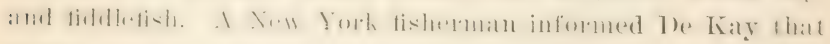
it was known to lim as the little bullhead shark.

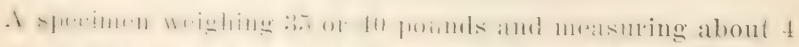

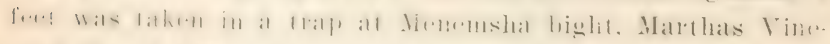

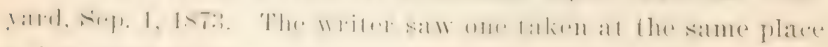
a few years later.

\section{Order BATOIDEI}

\section{Rays}

Suborder SARCURA

Family RAJIDAE

Sliates

Genus ra.s (Artedi) Linnaeus

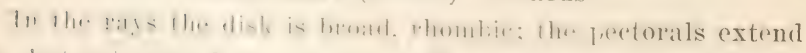
fo, hut not alomel the snont; the ventrals are large and deeply

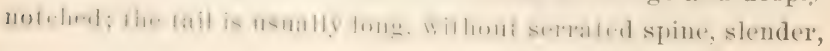


rounded, or derpessed, with camdal fin small or alsent, with two

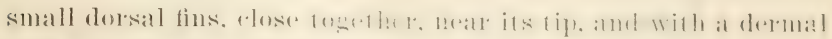

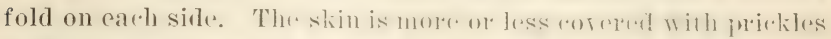

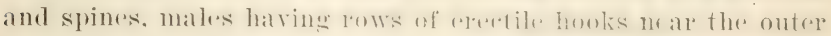

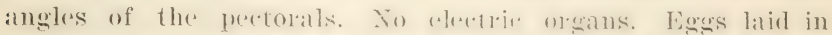
leathery, four-angled rases, batring two long tubulat tendrils at

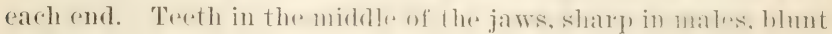
in females.

\section{Raja erinacea Mitchill}

\section{Common Skate; Prickily Skate; Hedgehog Ray}

Raja evinaceus MrtcmuL, Am. Jour. Sci. Arts, IX, 290, pl. 6 (male), 1525;

DE KAY, N. I. Fauna, Fishes, 372, pl. 78, fig. 246, 1812.

Raja eglanteria Guxther, Cat. Fish. Brit. Mus. VIII, 462, 1870.

Raia erinacea Jordax \& GIlbert, Bull. 16, U. S. Nat. Mus. 40, 1853.

Raja crinacea Jomdax \& Evermans, Bull. 47, U. S. Nat. Mus. 68, pl. IX, fig. 29, 1896; Sмптн, Bull. U. S. F. C. XVII, 89, 1898.

loisk rlomboid. with the amgles rombed; its length mearly equal to its width: spines latresest on the anteriol extemsions of the pertorals. where they are close set. strong. laterally com-

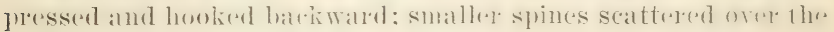

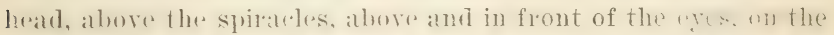

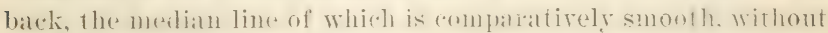

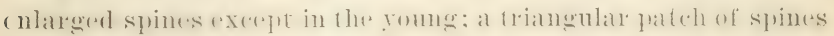

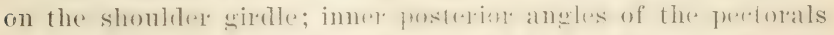
nearly swonth. Males have two rows of latroce, erectile hoolis,

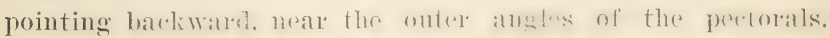
Females have glomps of small stales on carle sile of the vent. Tail ahout as long as the disk: a dremal fold on carle siele; dornal fins rough, connereted at the hase: month small; jaws cmererl, with small teeth in ahmot fil lows atmere and ts helow, the miolde oues sharp in males, all hlunt in females. color lioght

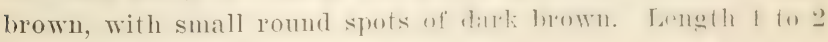
feet. (After Garman)

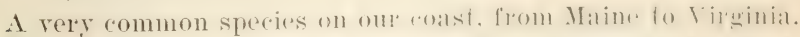

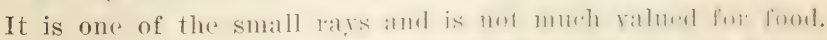

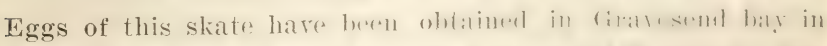

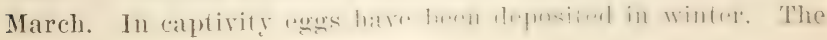




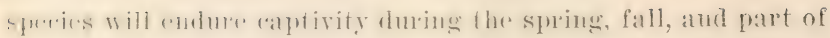
the winter, but not at all in summer.

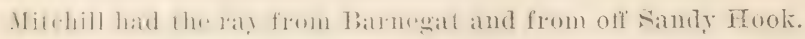

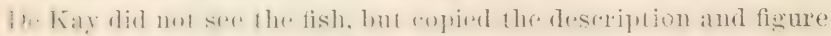
of Mirchill. Smith refere to it as the " summer skate " or " bonnet skite." It is found at Woods Hole from June to October.

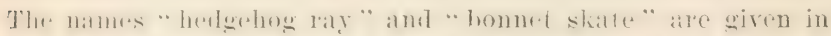
allusion to its habit of rolling itself up when canght. At South-

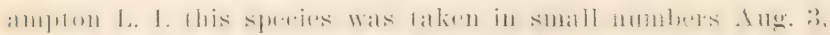
1898.

\section{Raja ocellata Mitehill}

\section{Spotted Skate; Big Skate}

Raju occllat Mrtcmit, Trans. Lit. \& Phil. Soc. N. Y. I, 47\%, 1815; Jordax

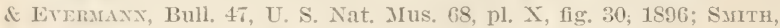
Bull. U. S. F. C. XVII, 89, 1898.

línill ocellata DE KA, N. Y. Fauna, Fishes, 369, not pl. 65, fig. 212, 1842; Jordax \& Gilbert, Bull. 16, U. S. Nat: Nus, 40, 1853.

similar in shalme to R. r. i n a "ea, but larger, with a wider munth and with many more rows of foreth. The length of the disk slightly exereds its width. The spines are arranged as in li. .r. i na reat. hut additional rows are present down the hark and on thr. sides of thr tail. Tail nearly as long as thr tiosk;

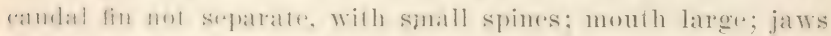

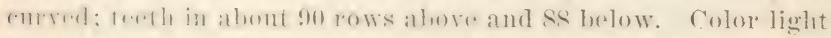

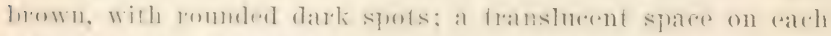

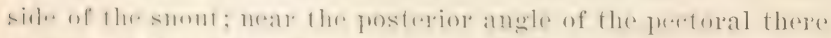

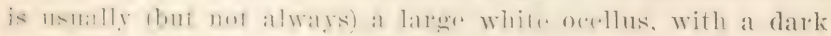

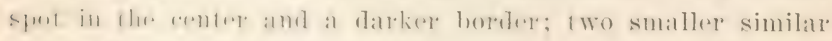
sjots often present. (After Garman)

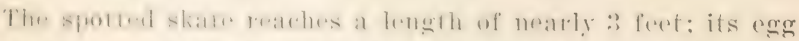

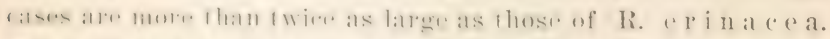

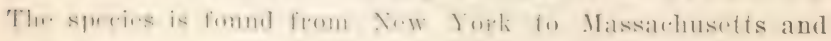
northward.

1). Mitehill described a specimen which was :30 inches long

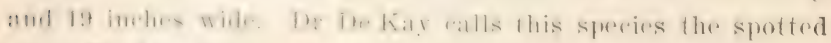
ray. Ifo found the stomach of one filled with rock erabs,

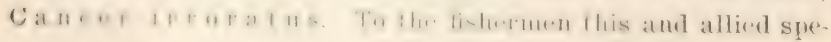


cies are known as skate. It has no commerejal value in Great South bay. In the traps at Islip skates realpleatr on October first on theil fall migration. I female was canght near the

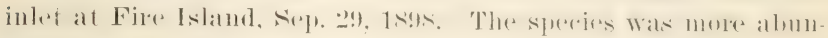
dant later in the fall.

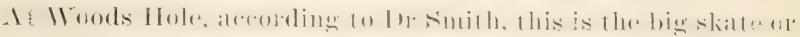
winter skatr. It is common from February to June and from

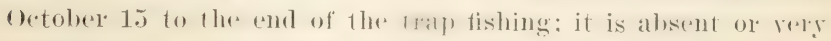
rare in summer.

\section{Raja eglanteria Bosc}

\section{Clear-nosed Skate; Brier Ray}

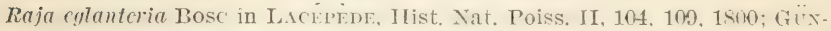

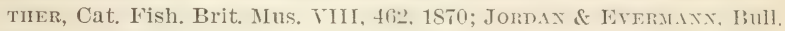
47, U. S. Nat, Mus. 71, 1896; Smin, Bull, U. S. F. C. XVII, 89, 1898. Raia eglanteria Jondax \& Gilment, Bull. 16, U. S. Nat. Mus, 41, 1S83. Raja diaphanes MitcmLL, Trans. Lit. \& Phil. Soc. N. Y. 47S, 1815.

Differs from $R$. e rinacea and $R$. ocellata in its acutely produced snout, smaller spines and translueent spate on each side of the rostrum. The leneth of the disk (12 inches) equals four fifths of its width (1.̃ inches). Suines small and rery sharp, most mumerous on the front part of the peretorat. the head, the snout, the middle of the hack and the tail betwern the rows of enlarged spines; anlared spines around the cyes and spiracles, on the middle of the snout. in a median row along the back, and in two rows along wark side of the tail. The spines on the tail are rere sharp, larese and small ones altermating in the rows; a latre spine in the mirlde of earh shoulder; a spine between the dorsal fins: tail as lomg as the disk. and with a median and two latral rows of moderately latege spines and one or more intermediate rows of murle smaller omes; ('amblal fin absent or rery small; dorsals small, the anterior larger, one ninth the length of tail in hight: mouth morlerate: teeth in alout 50 rows in upper jaw and 48 in the lower.

Color pale brown, with mumreons batnds. bars. lines and blotehes of darker; darker spous in the midhle of the furetoral; each side of the snout with a pale, translucent area. 


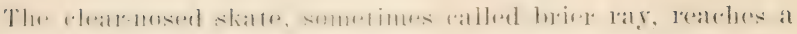
length of $\rightleftharpoons$ ferel 01 more. It inhalbits the easteru coast of the

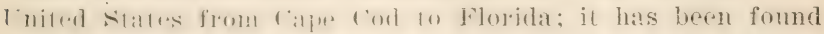

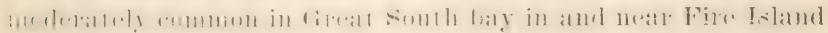

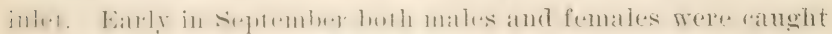

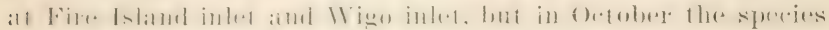

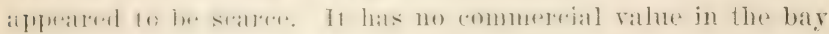
and is usually thrown away.

At Woods Hole Mass, it is not common. A few are taken every year in traps at Menemsha, Marthas Vineyard.

\section{Raja laevis (Mitchill)}

\section{Barn-toor sliate}

Ruju laevis Mtтemil, Am. Month. Mag. II, 327, 1S18; Jordax \& Evermaxx, Bull. 4i, U. S. Nat. Mus, 71, 1S96; SMrr, Bull. U. S. F. C. XYII, \$?, 1598 .

Ruia laeris DE Iir, N. Y. Fauma, Fishes, 370, 1842; Jorday \& Gilbert, 13ull. 16, U. S. Nat. Mus, 42, 1853; Stonen, Hist. Fish. Mass, 266, pl. XXXIX, fig. 2, 1867 .

Similar in shape to R. eg la $n$ teria, but larger and with fewer rows of teeth. The length of the disk equals three funtlse of its wirlh. The spimes of the bodr are ferw and

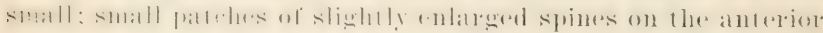

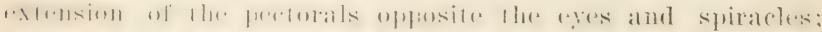

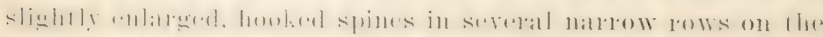

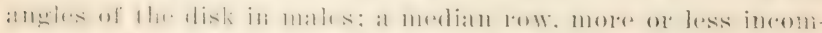

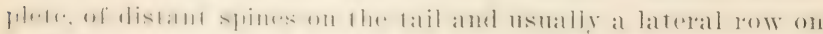

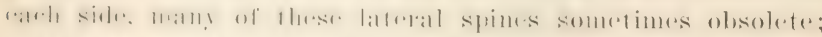

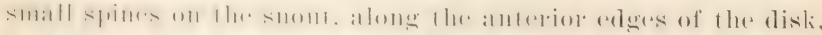
and on the top of the head. Tail nearly as long as the disk: Iwo subregual dorsal fins, searcely late as long as the snout,

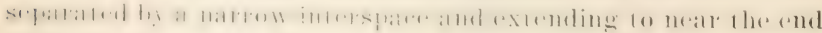
of the tail; no eantal fin; eye one fifth as long as the snout; month larese, jaws emered, treath in about 30 rows in each jaw; length of elaspers of the male equals one third of the width of thr disk. Color usmally brownish with paler spots, these sometimes suremmled by dark rings. 
The barn-door skate reaches a length exceeding $t$ feet; it is

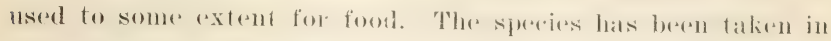
Gravesend bay in oretober. It suffers in captivity for the want of sand and mud and luxatuse of the latek of suitalule food, its average duration of life is 3 or 4 months.

Mitehill described an individual measmeing t!) inchess which Wals ralught al a whatf in the East river Nor. 5. 1515. A1 Woods Hole Mass. it is common in spring and fall, rale in smmmer.

\section{Family NARCOBAtIDAE Electric Rouss}

\section{Genus Tetrovirce Gill}

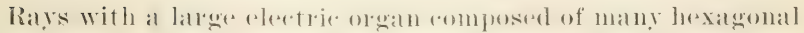
tubes between the pereforal fins and the head; disk rery broud. abruptly contrateded all the tail; two flowsal fins, flue tirst mueh the larger, its origin not far in advance of the end of the ren-

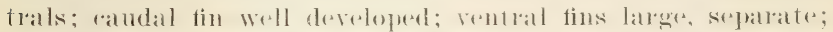

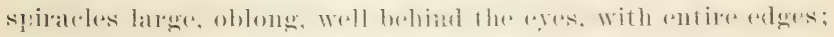

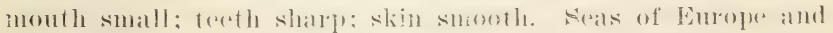
America.

\section{Tetronarce occidentalis (Storer)}

\section{Torpedo: Cramp Fish; Numb Fish}

Torpedo oceidentalis STORER, Am. Jour, Sci. Arts, 165, pl. 3, 1843; Hist. Wish. Mass. 271. pl. XXXIX, fig. 5, 1867; Jordan \& GILbert, Bull. 16, U. s. Nat. Mus. 39. 185:3.

Reja torpedo MLItchuL, Trans. Lit. \& Phil. Soc. N. Y. I, 476, 1815.

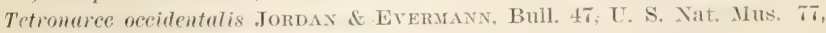
pl. XI, fig. 33, 1896; SмттाI, Bull. U. S. F. C. XYII, S9, 1898.

Length of disk explats six serenthe of its with allut more that one half the total length; length of base of rentrals equals one fomth the width of disk: eyes small, pated there times their diametex from tip of snomt, and about the same distallere firom

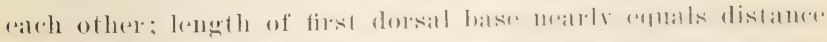

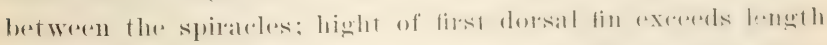

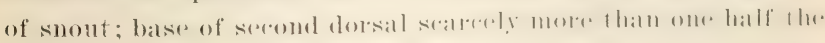

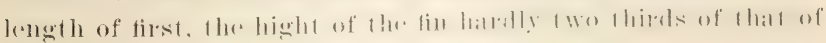




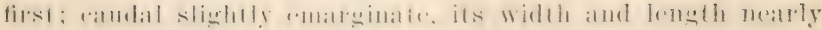

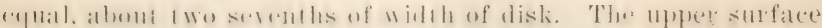

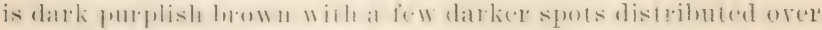
it; beneath white.

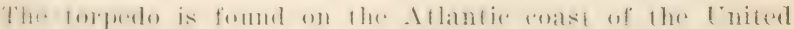
stalles from falpu fort for Floridal it oc\%lus also in the Mest

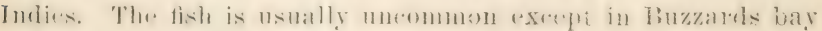

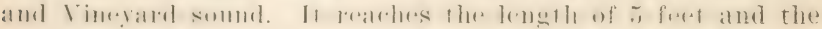
wright of 100 poumds.

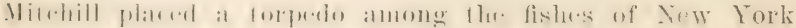

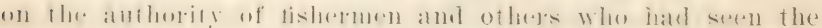

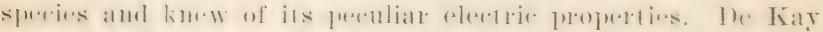

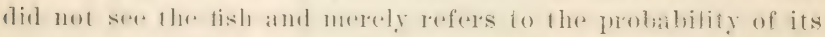
occurrence and its relation to the genus Torpedo.

The existemere of a torpede on the coast of Massarlunsetts

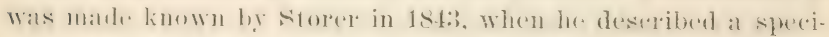
men ratught al Wrellteret, in Norember 18t2. Capt. Atwood, at well linewn former resident of Provincetown Mass. informed

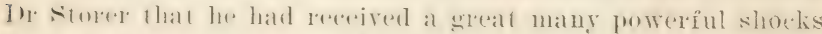
from the tish which theew him to the glomed; these were por

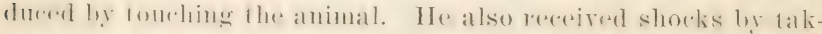
ing hold of a harpuen whieh was struek into the fish. Storer

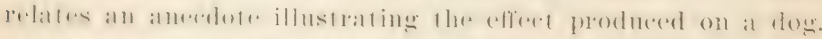

Mir Xewrombst, the oldest fisherman in Boston matrel. stated

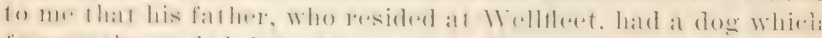

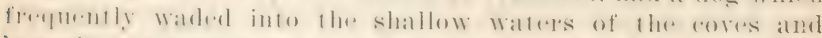

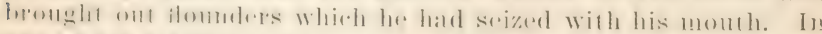

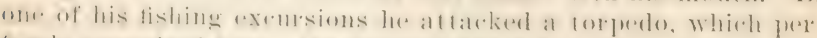

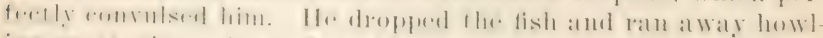

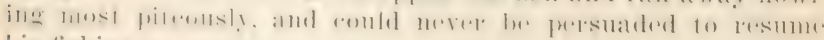
his fisling.

At lloods Ifole Mass. the torpedo is most abundant in Oefober and Norember. At times as many as six are taken at one lift of a trap at Menemsha. The suallest weigh 4 or $\bar{a}$ pounds, the lirgest 75 pounds. 


\section{Suborder MASTICURA}

IVhip-tailed Rays

\section{Family DASYATIDAE}

\section{Sting Rays}

\section{Genus Disxatrs Rafinesque}

Disk usually broader than Jong; pectoral fins united in front to form the tip of the snout: tail rery slender and clongate, finless, but often with one or two memheranous fohls, aml with a

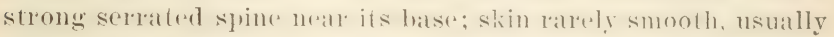
more or less spinoms ol pritily, tail with mumelens smill spines

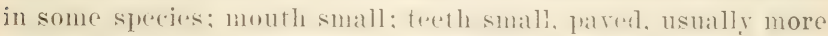

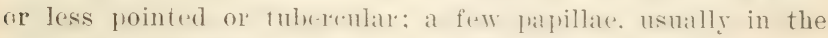
mouth behind the lomere jaw; nostrils elose terentlere nasal valres forming a rectallowlat flatp. which is joined to the upper jaw by a narrow fremum; sprirarles large. plated tose behind the eyes. Ororiviparous.

\section{Dasyatis centrura (Mitchill)}

\section{Common sting Ra!y}

Raja centrura MitchiLL, Trans. Lit. \& Phil. Soc. N. Y. I, 479, 1815.

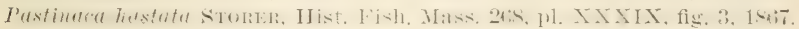
Dasibatis centrura Jordax \& Gilent, Bull. 16, U. S. Nat. IIus. 67, 1893. (From Garman)

Trygon hastata Güxtmen, Cat. Fish. Brit. Mus. VIII, 476, 1870.

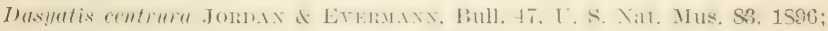
Sinth, Bull. U. S. F. C. XVII, 90, $189 S$.

Disk quadrangular, about whe fomph withe than long: anterior margins sinuous, concare oplyosite the "yese convex toward the slightly protuberant suont and romolded over angles: posterior straighter, rery litthe (onsex; hinder anghes blumt: ren-

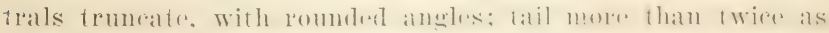

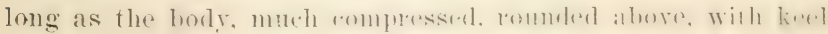
or cutaneous expansion bele:we with ome or more stronge serrated spines at the termination of the anterture tilth of its length, rough on all sides with spines or tulweles. Till late whown the

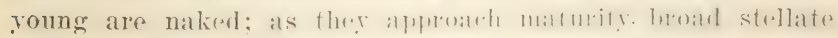

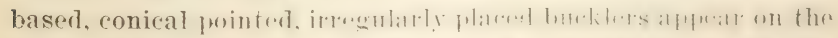

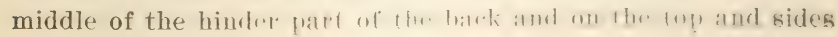




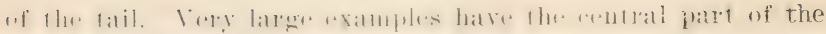

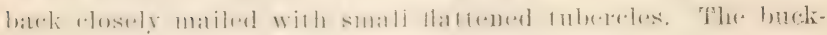
ier's bear more resemblance to those of the $R$ a ja $e, r$ a $d$ i a $t$ a and clar ata, than to the tubereles of pastinaca, hasi t ta. or tubereulata. Mouth arched forward. With five

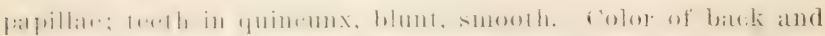
tail olive brown; light to white below. From pastinaca,

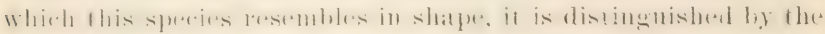

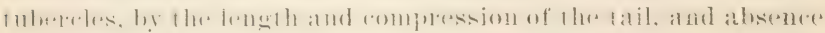
of all trace of keel or expansion on its upper side. A young specimen measures from snout to tail 1:3.8, in length of tail

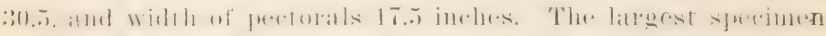

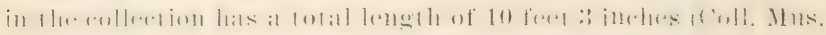
Comp. Yool. ('ambridge Mass.). Common south of Catpe Cod. Oecasiomally found northward. (After Garman)

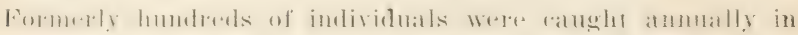

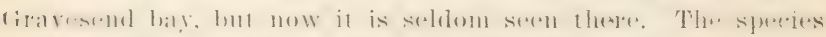
will live in raphivity several montls in the spring and stmmmer.

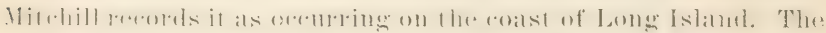
tail, he states, is 5 feet or more in length. Storer described a

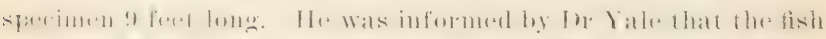

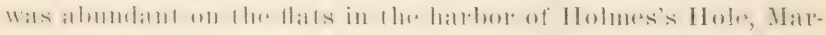
thas Vineyard, in July and Angust. Near Woods Hole Mass. it is common during summer, appearing early in July.

The sting ray is much dreaded by fishermen, who say that

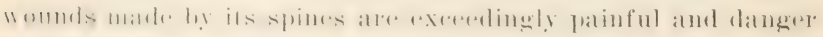
ons, the slime serreted by the tish acting as a poison.

\section{Subgenus DisYats}

2!) Dasyatis hastata (I)e Kay)

Kit

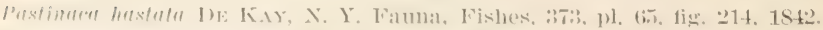

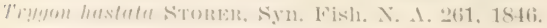

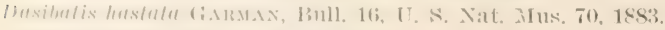

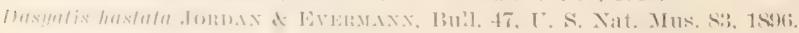

The slimg rays of the subgems b a s y a t is differ from the

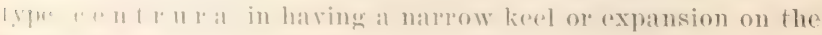
!:til hoth aloove and lorlow. 
Disk with the shape and proportions of D. centrura; anteriol margins meatly stralight, me+ting in a blunt angle on

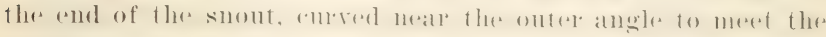

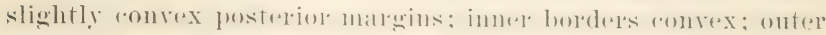

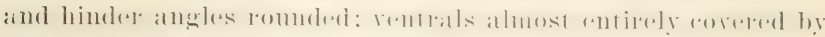

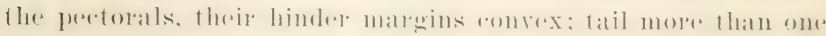
and ome half times as lomg as the disk, with a low lies on the

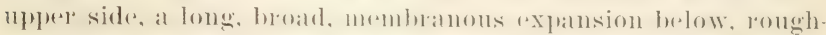
rmed with small aspereities, and with ome or mole sorrated spines

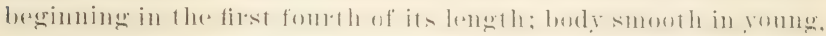

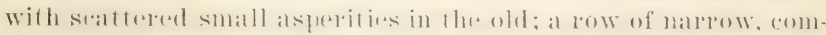
flessed tubereles on the midhle of the hatek and hatse of tail.

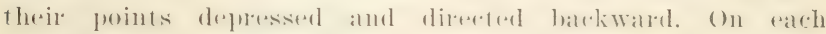

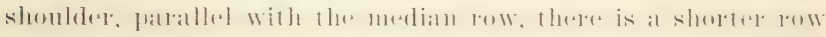
vallying in length areoroling an age. Month with thres patpillate; jaws more curved than in $c$ e $n$ tr $r^{\prime} \mathrm{r}$ and less than in sa bina. ('olor bluish or uniform olive bown above. white beneath. West Indies to Brazil. north to Rhode Island.

De Kay y deseription of his whipsting lay is hased on a female

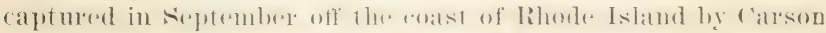
Brevoort of Now lerk. The iemeth of the tish was is fexet 6 inches and its weight 110 pommls. Mr IBrevoget stated that the

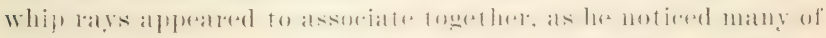

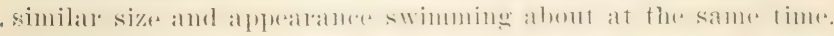
They moved showly together thoongh the watre, along the redges

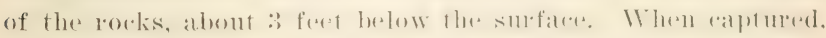

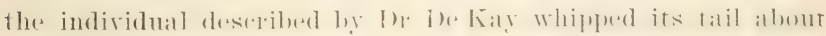

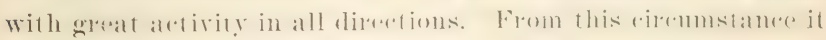
derives the name of whip ray.

\section{Dasyatis say (Le Suew1)}

\section{Southern sting Ray}

Raja say' Le Sueur, Jour. Ac. Nat. Sei. Phila. I, 42, 1817.

Myliobatis? say DE KAT, X. T. Famma, Fishes, :376, 1842.

Trygon sayi Müller \& Hexle, Plagiostomen, 166, 1S.11; I)rmarit, Elasmobranches, $603,1870$.

Dasybatis sayi GARMAx, Bull. 16, U. S. Yat. Mus, (69), 18s:3.

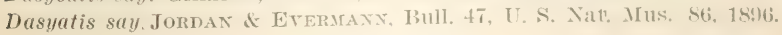


Disk yuadrangular, alunt one sixth wirler than Iong, anterior

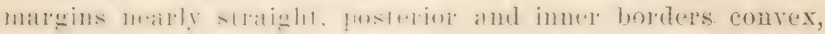
outer and fosierior angles rombled snout not protruding be-

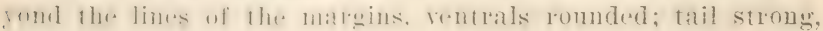

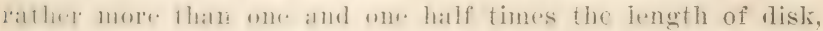

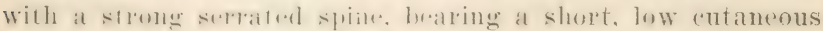

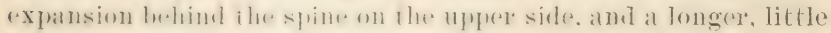

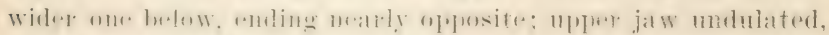
lower prominent in the middle: terth sma?l, smooth in poung

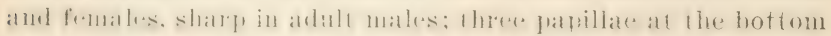

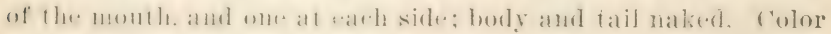
olive beown in adult. redilish or yellowish in young; lower surfare whitish. New lork to Florisla and Brazil. (Afere Carman)

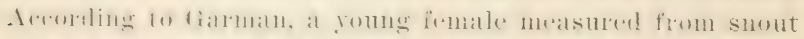

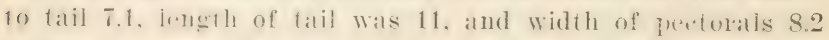
inches.

Le. Surur's tym was from the New Tersey roast. Miilley and

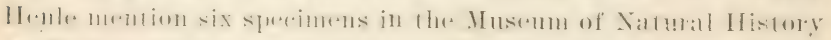
at l'aris. Whirh ware sent from Jiew lork by Milbert. The

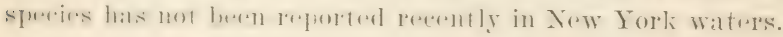

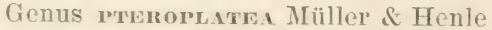

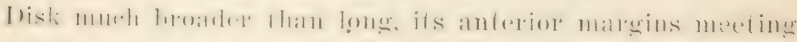

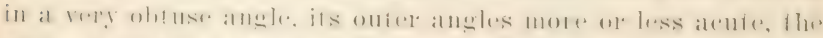

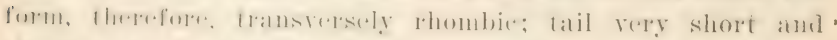

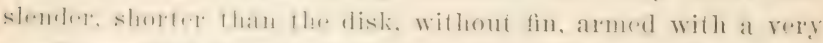

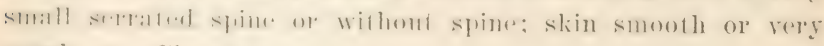
nearly so. Size large.

\section{:31 Pteroplatea maclura (Le Sueur)}

\section{Butterfly Ray}

lifin marlara LE Simur, Jour. Ac. Nat. Sei. Phila. I, 41, 1817.

I’ustimara mavlura DE KAY, N. Y. Fauma, Fishes, 375, pl. 65, fig. 213, 1842.

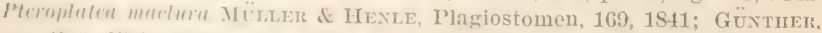
('ut. Fish. 13rit. Mus. VIII, 487, 1870; Jordax \& Girment, Bull. 16, 1. S. Xat. Mus. 16, 18s;; Jordax \& Evermax, Bull. 47. U. S. Nat. Mus. Si, 1s:4; smmн, Bull. U. S. F. C. XVII, 90, 1S?S.

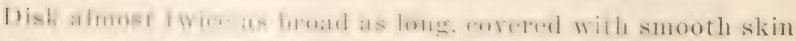

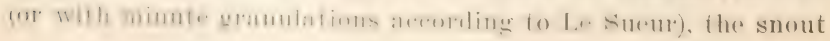


very little projecting. so that the anterios matruin of each pectoral is slightly comcatre; tail two fiftles to one third the: length of disk, with a slight dermal fold above and below, and with one or two spines rery neatr its hase or sometimes without spines; "Yes small and near the snout; spirateles latrege, neal" the eges; nostrils small, mear the month. not restending to the

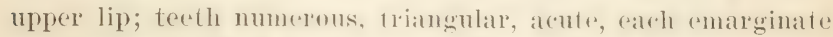
at the base behind; rentrats short, broad and rounded, their length less than onr tifth of that of disk. Color hrownish olive, sometimes bluish, timely malbled with gratyish, and fincly speckled; anterior odge of disk with hlotches of pallel; tail with four dark bloteless above, forming half rings. ('ape Cod to Brazil, common soutliward.

The species is now rarrely seren in ciraresend hay. It does not endure captivity.

Le Sueur's description was based on a specimen 6 feet 7

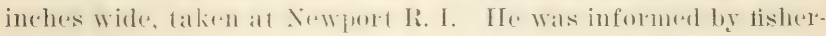
men that it rearehes the wilth of 15 feet. We raly copied Le Sueur's description and figure.

Di smith salys it is latre at Woods Hole, and appears in Angust and fiefotember when fressent. It has the local name of Angel fish at Woods Hole.

\section{Family MYLTOBATIDE}

\section{Eagle Rays}

\section{Genus myนonats Duméril}

T)isk hroad; pretoral fins culing latcrally in an acute angle, not continued forward around the snout, but ceasing on the sides of the head and realpearing in fromt of the suont as a flesty protuberance exphalic fiml; lail very long and slender, whiplile, with a small dorsal tin neal its root, and one or more

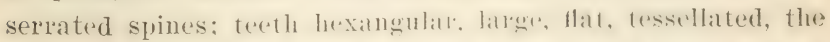

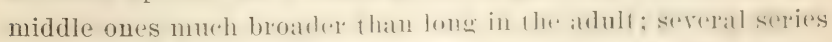

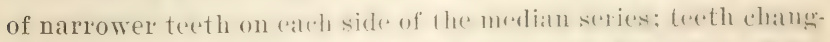

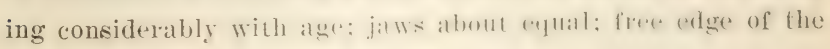
nasal valve not deeply emarginate; skin smooth. 


\section{:32 Myliobatis freminvillei (Le Sneur)}

\section{Eagle Ray}

Myliobatis fréminvillei Le Sueur, Jour. Ac. Nat. Sci. Phila. IV, 111. 1824; DE KAY, N. Y. Fauma. Fishes, 376, 1812.

If plobutis uentu Storer, IIist. Fish. Mass. 269, pl. XXXIX, fig. 4, 1867. Iyllisutis fremincillei Jordax \& Gilbert, Bull. 16, U. S. Nat. Mus. 51, 1883; Jorday \& Evermaxy, Bull. 47, U. S. Nat. Mus. 89, 1896; SMIth. Bull. U. S. F. C. XVII, 90, 1898.

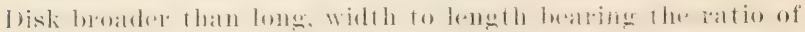

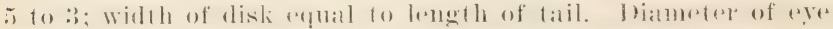

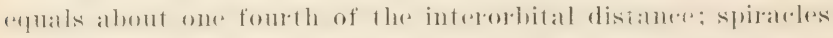
behind hlo eres and ome and ome half times as lomg. Wialth of

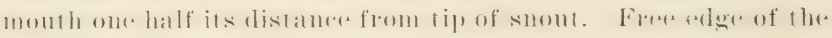
nasal valve not deeply notrher. Reaches a length of 4 feet.

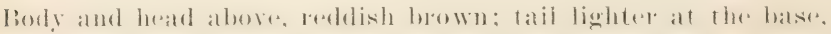
but nearly black toward the tip; lower parts whitish.

The species is not uncommon, from Cape Cod to Brazil. It probably feeds on mollusks.

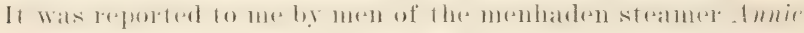

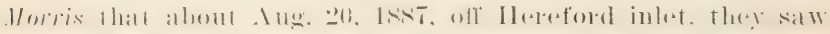

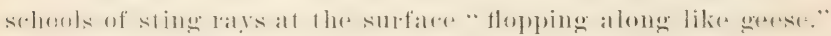

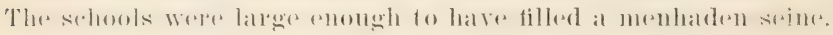
The rays were said to have two spines on the tail.

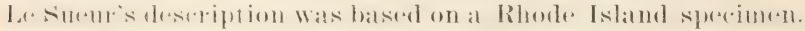

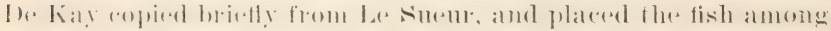

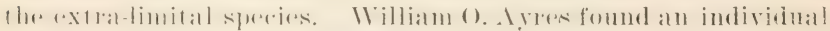

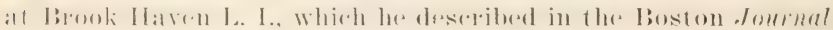

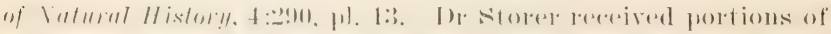
a specimen from Holmes Hole Mass. I) Smith records it as

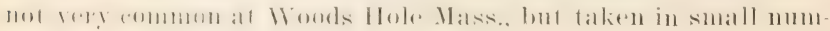
bers erery yoar in traps.

\section{Gemus mHxopters. Kühl}

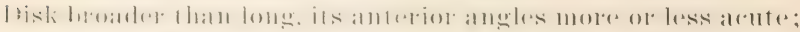

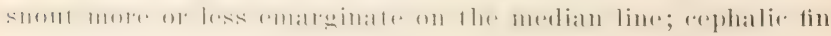
emareginate and placed on a plane below the level of the pectorals, the snout thus appearing four-lobed; free border of the nasal valve not rmatrinale: terth in 5 to 20 rows, the median 


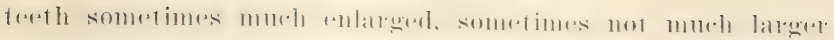

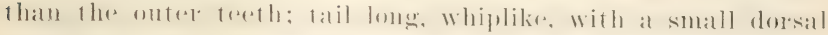
spine behind the dorsal fin which is at the base of the tatil: ventral fins oblong, truncated behind.

\section{:3:) Rhinoptera bonasus (Mitelill)}

\section{('ou-nosed Roty}

Raju bontsus Mitched, Trans. Lit. \& Phil. Soc. X. Y. I. 479. 1S15.

Rlimoptera quadriloba DE KAY, N. Y. Fauma, Fishes, 375, pl. 66, fig. 217, 1542; Guxtmer, Cat. Fish. Brit. Mus. VIII, 494, 1870: Jornax \& Gillbert, Bull. 16, U. S. Nat. Mus. 51. 18s.

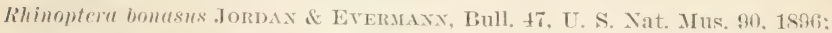
SмнтI, Bull. U. S. F. C. XTII, 90, 1898.

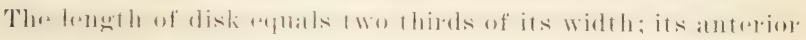

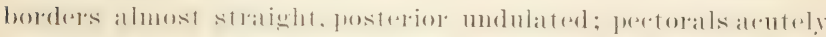

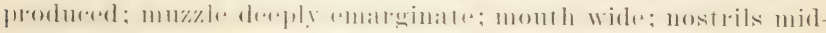

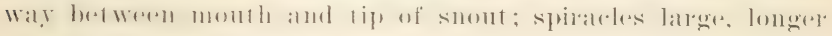
than eye; teeth in seren rows in each jaw, the median teeth

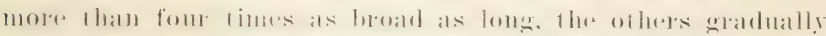
diminishing in size ont watrd: tail very slemeler as lome as the borly; a small dorsal tin at hase of tail and a slemelere seleate

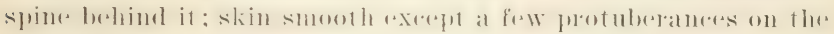

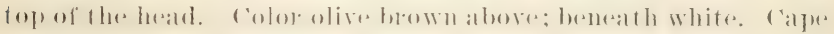
Cod to Forida: not rare:

This species is now rarely seen in Graresend bay, where it was at one time very common in the antumn. When Mitchill

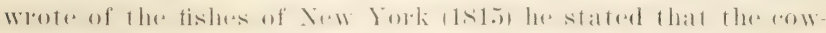

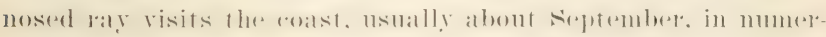
ous shoals, rntering the bay and ratnging lory txtensively orer the flats where the soft clam lires.

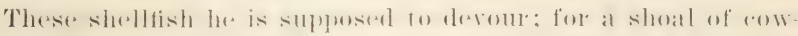

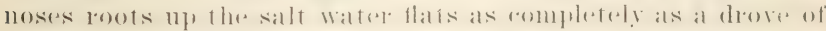

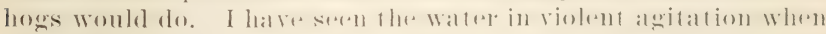
these fishes were at work in the bottom. 'They render it so

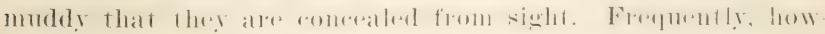
ever, they rise to the top and may be distinctly observed. I

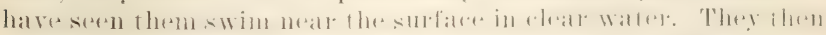

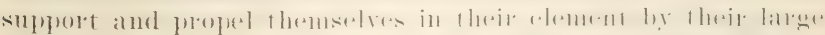

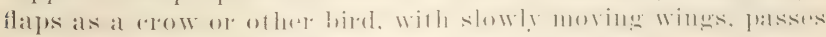
through the air. They maty be said to tiy rather than to swim. A full grown indiridual weighs about 100 pounds. 
Mitrhill also stafes lhat the fisheromen usually allow these

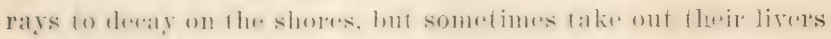
for conversion into oil.

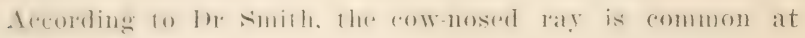
Woods Hole Mass.

Subclass TELEOSTOMI

True Fishes

Series GANOIDEI

Ganoid Fishes

Order SELACHOSTOMI

Padulefishes

Family POLYODONTIDAE

Padalefishes

Genus rouxodox Lacépède

IBory fusiform, elongate, somerwat compressed; skin smouth or with minnte ossiffeations; snout froduced inco a rery long spatulate fromess. the inner frate composed of the produced nasal homes, the sides flexible and supported by a bouy neet work; month wirle. ferminal. but orerhung hy the suont, without maxillaries, lut wilh foolhed fremaxillaries; mumcrous fine, deciluous ferth in the jaws and on falatines; no tongue; nosirils

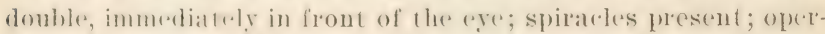

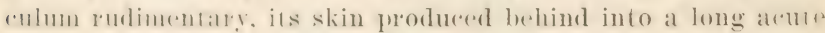

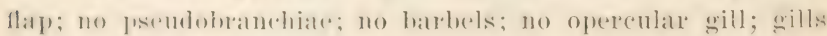
four and onr lıalf: gall ralkres numbrous, very long and slemeler.

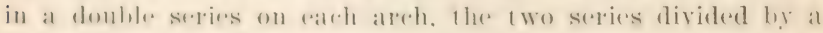

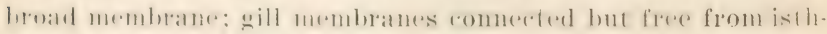

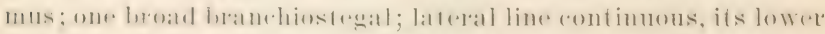

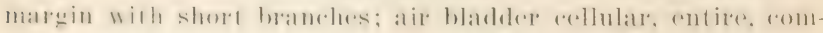

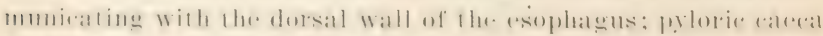

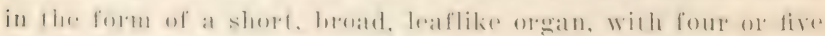

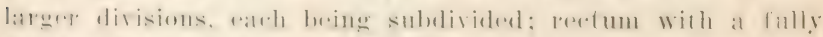
develomed spiral valse; dorsal tin pesterior, withoul spines; anal

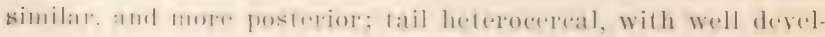


oped lower (andal lohes so that the fin is mearly equally forked; sides of the bent portion of the tail armed with small rhombic plates; upper caudal fulcrums narrow, numerous; pectorals moderate, placed low; rentrals abdominal, many-rayed.

Rivers of the middle United States.

\section{Polyodon spathula (Walbaum)}

\section{Paddlefish; Spoonbill Cat}

Squalus spathula Watbaum, Artedi, Gen. Pise. 522, 1792.

Polyodon feuille LACÉPÈde, Hist. Nat. Poiss. I, 403, 1800.

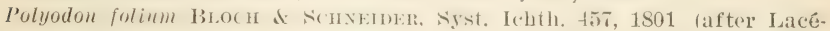
pède); Mrtchil, Am. Jour. Sei. Arts; XII, 201, 1827; Kintland, Bost. Jour: Nat. Hist. IV, 21, pl, 2, fig. 1, 1814; GüntHer, Cat. Fish. Brit. Mus. VIII, 346, 1870.

Polyodon sputhula Jorisix if Gin.ment, Bull. 11;, U. S. Nat. Mus. S3, 1SS8; Jordan \& Evemanan, Bull. 47, U. S. Nat. Mus. 101, 1896.

The body of the paldllefish is fusiform with the snout much produced, spatulalike. Body sealeless, corered with smooth skin; mouth broad, terminal, somewhat resembling that of the shark; teeth in jaws rery numerous and fine, deciduous; spiracles with a minute hatres. The opereulum is rudimentary, its flap of skin long, reatring almost or quite to the rentral fins; psendobranchiate absant; gill alleles five, the last rudinentary; gill raliers lomg and in a domble series on each alreh; gill membratues connected, free from the isthmus; nostrils double, situated at base of blade; a continuous lateral line from uplex part of head along dorsal outline to tail; eye small, directed downward and to the side; dorsal and anal fins far batk. composed of soft rays, nearly opposite; tail heterocereal, well forked; sides of the bent portion of the tail armed with rhombic plates. The pectoral fins are of noderate size and placed low; rentrals many-rayed, abdominal. The distaner from "ye to end of snout is about one thirel of the total lenghth, including atulal. 'The' depth of the borly is contained fome and one half times in the distance from ere to hase of caudatl. The hight of llu dorsal fin about equals the depth of the body.

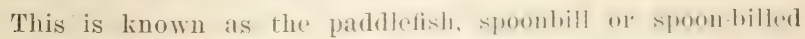

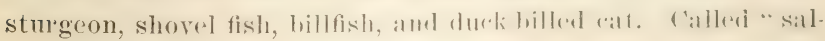


mon" in western hotels. The names are derired from the re-

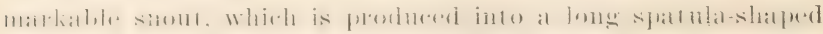
proeess, covered above and below with an intricate network and with rery thin flexible edges. The head and snout form nearly half of the entire length of the fish. The dish can not be con-

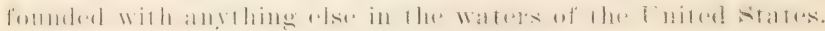
There is in china a similar fish. which, howerer, belongs to a alifirinent genus.

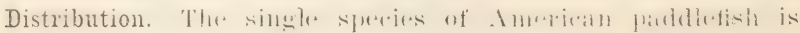

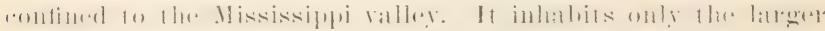
streams in l'ennsylvania. It is rommon in the lllegheny and the Monongahelat rivers.

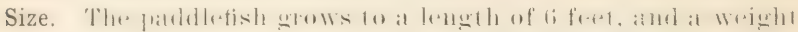
of :30 pounds or more.

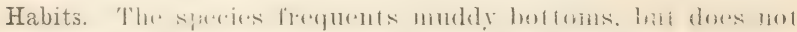
feed on the mud and slime, as many persons have supposed.

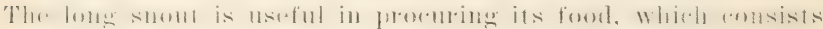
chiefly of entomostracaus, water worms, acpatic plants, leeches, bretles and inseret larvare.

Prot. S. A. Forbes, director of the Illinois Jaboratory of Satmal History, has published the first and most satisfactory areount of the fereding habits of this shatklike fish. He found rery little mud mixed with the food. Frof. Forbes was informed by the fishermen that the paddlefish plows up the mud in feeding with its spatulalike snout and then swims slowly backward through the water.

"The rematiably dereloperl will rakers of this species are

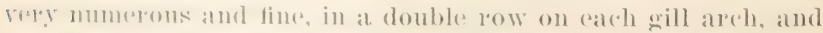
they are twier as long as the tilaments of the gill. By their interlateing they form a strainer seareely less effective than the fringes of the balexen plates of the whale, and probably allow Her patsilge of the fine silt of the river hed when this is thrown into the water he the shovel of the fish but alrests everything

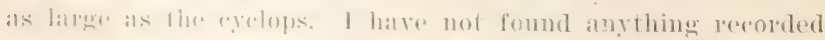
as fo the spallning hathids of the patellefish. The youme have

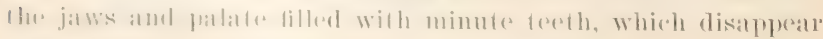
will :1, 


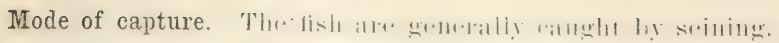

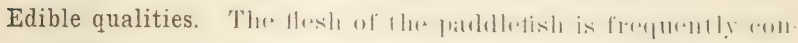

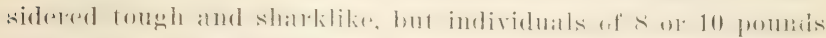
are skimned, and sold in some of the western markets freely, and are thought by some persons to be farly good for the table.

\section{Order CHONIROSTEI}

\section{Strityeoms}

Family ACIPENSERIDAE

Sturgeons

\section{Genus acmexsen Linnaeus}

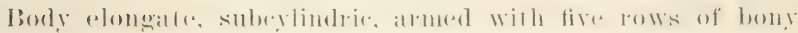

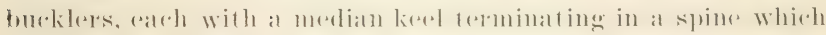

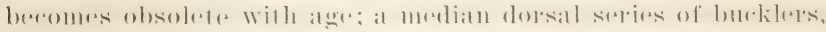

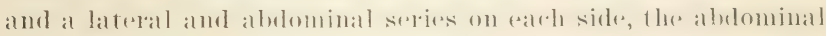

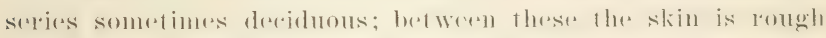
with small, irlenglat plattes. Hratd entereal with bomy plates

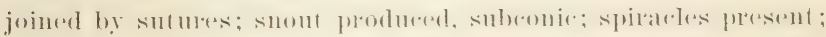

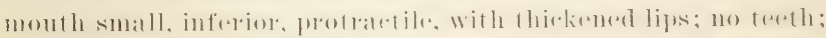

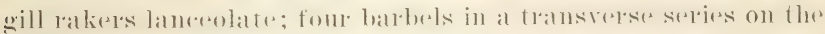

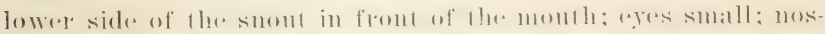

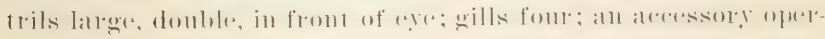

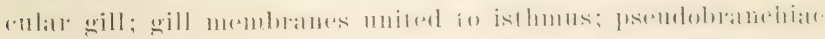

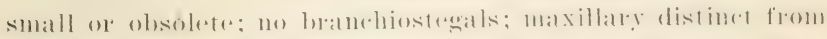

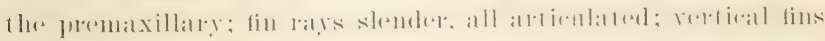
with fulcrums; pectorals placed low; rentrals many-rayed, bes-

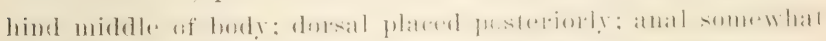

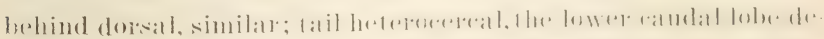

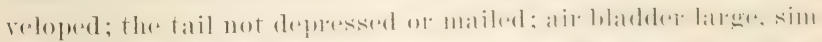

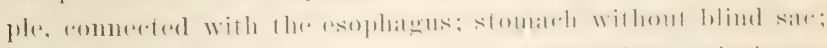

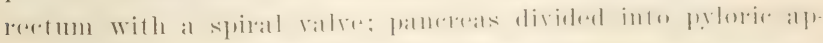
pendages. (After Jordan and Evermanm)

\section{Acipenser sturio Limmaeus}

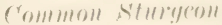

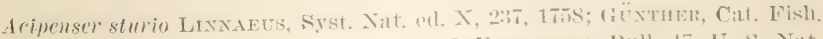
Brit. Mus. VIII, 342, 1870; Jordax \& Everimax, BuH, 47. IT. s. Nit. Mus, 105, 1S96; Smrn, Bull. U. S. F. C. XVI, 90, 1898. 


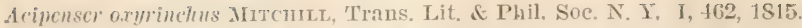
Acipenser oxyrtineus DE KAy, N. Y. Fauna, Fishes, 346, pl. 5S, fig. 189 (young), 1St2.

Aeipenser sturio rar. oxymhynchus Jomdax \& Gilbert, Bull, 10, U. S. Nat. Mus, S6, 1853.

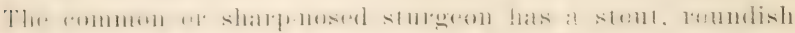

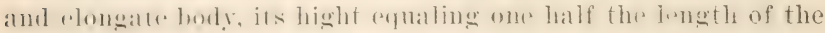
Jead and one sixil! of lhe total without the ramelal. The least

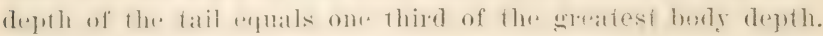
'Tle. hratl is long. one thirel of total withoul the ramblal, and the smomt is as lome as flew rest of the head in the romme. The eye is one sixth as long as the snout. 'Two pairs of short. slender'

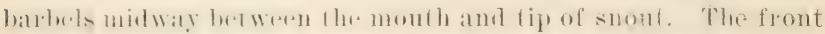

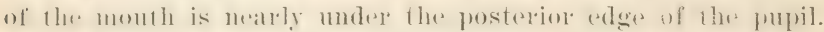

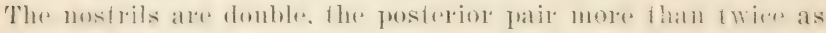
latere as the antromer. 'The dorsal and anal fins arre platred far

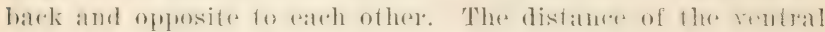

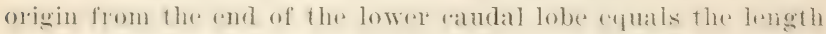
of the he:at. The nepere catudal lobe is nearly twire as long as

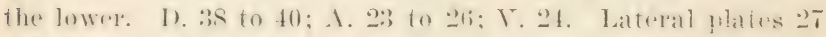

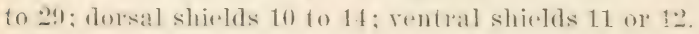

The eolor of the mpler pate is dark olive graty. sometimes hrownish: h he lower garts ale light gray or whitish. The puphis are black; the iris golden.

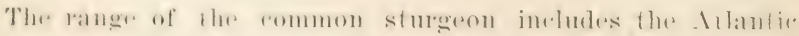

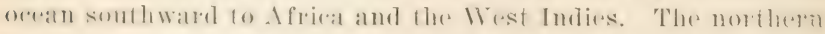

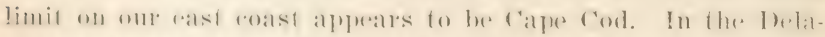

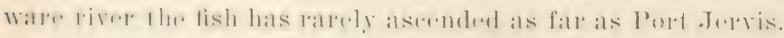

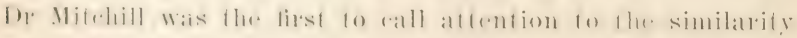

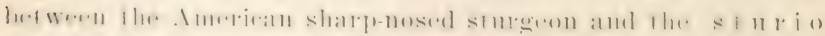

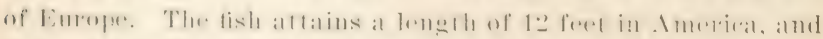

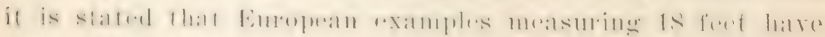
been taken.

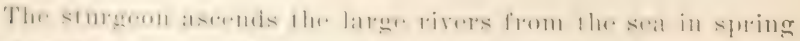

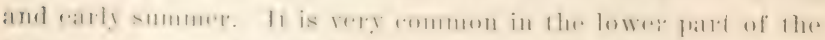

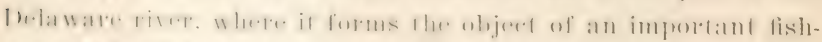

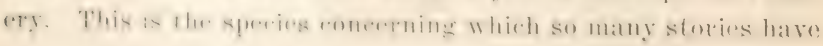


been related as to leaping into boats and injuring the oecupants.

The mouth of the sturgen is furnisher with a rery protractile roundish tube having powerful museles and intended for withdrawing from the mud the varions small shellfish and erustaceans on which the anmal subsists. The mouth is surpounded also with numerous fentateles. with tartile properties, which are utilized in procuring food.

The reproductive habits of the sturesen and the (xmbergoge of the spereses have been marle the subject of an exhaustive study by Prof. John A. Ryder of the Tniversity of Pennsylya-

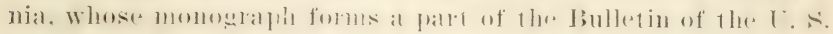

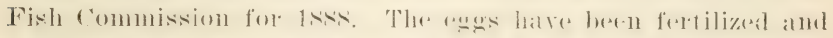
developed artitially by seth firen and others many years ago, and in some falls of Emroge the hatehing of the species

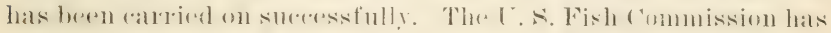
also recently taken up the cultur. both of the marine and the

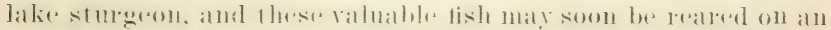
extensive scale.

The utilization of the flesh. the slin and air bladder and the eggs of the sturgeon is so wrell linown as fo require little more than passing montion in this plare. The smoking of the flesh and the manufacture of raviar from the eags are rery important industries along our eastern coast.

The sturgeons arr asily taken in gill nets and pounds, but the great strength of the fish freciuently entails considerable loss of apparatus.

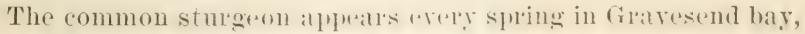
and sometimes in the fall. It is hardy in captivity.

I female 8 feet long was hought fiom the month of the

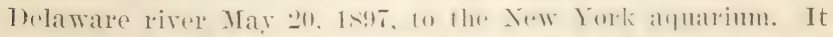
sermed to take no food till December 1, when it began to feed

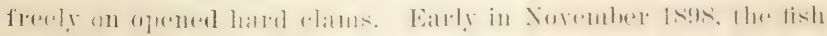
was still alive and healthy. 


\section{$: \because 6$ Acipenser rubicundus Le Sueur}

\section{Lalie sturgeon}

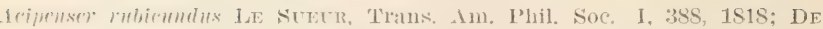
К.у, Х. Y. Fauna, Fishes, 34t, pl. 58, fig. 191, 1St2; Güxther, (ait. Fish. Brit. Mus. IIII, 338, 1870; Jompdx \& Gllbent, Bull. 16, I. S. Nat. Mus. si, 185:3; Jordax \& Evemuxx, Bull, t7, U. S. Nat. Mus. 106i, 1s:34.

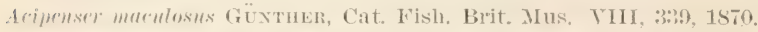

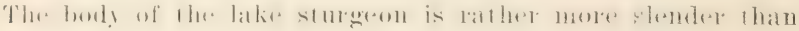

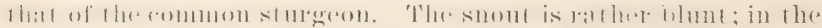

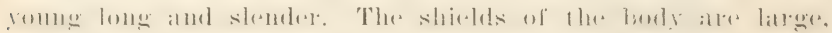

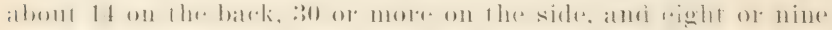

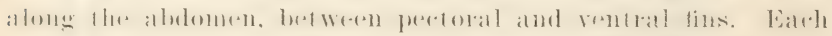

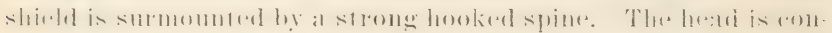
atimel there and whe thirel limes in the length withoul tail. barbels four, rather long; eye small; dorsal and anal fins small. plated fat back as in the pike. I). $35 ;$. 1. 26.

This is known as the lake stureeon, Ohio river sturgeon, rock

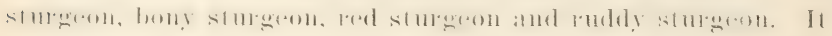

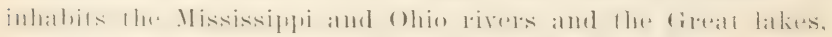
and is abmindant in the Alleghemy. From the lakes it aseonds

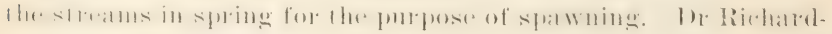
son states the northeren limit of the stureceon in North Ameriea to be about the foth parallel of latitude.

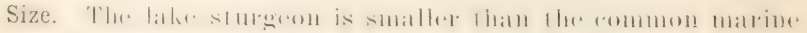
sturegeon, the arerage adult being less than 5 feet in length. The areage weight of 14,000 matule stulegen taken at Silldusky (). Was about at) pounds. It frequently reaches a lengeth (1) li fint.

Habits. In the lakes the spereies, areording to oloservations of dilmes 11 . Miluere inhabits eompanatively shoal watels.

'The foud of this stmogenn is mate up' chiefly of shellfish,

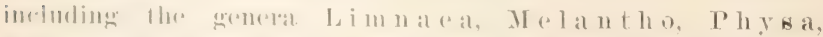

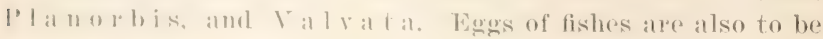
fommal in ils stomalrell.

In Lalie liric the spereics spawns in .Jume, for which pulpose

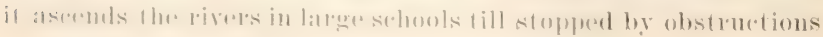




\section{Acipenser brevirostrum LeSueur}

\section{Short-nosed Sturgeon}

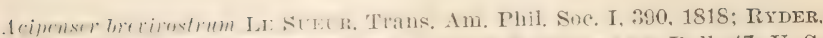

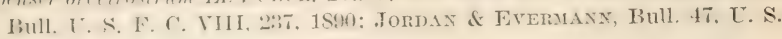
Nat. IIus. $106,1596$.

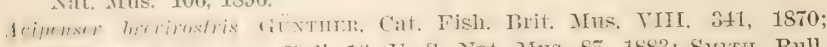

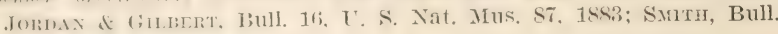
U. S. F. C. XVII, 90, 1898.

In the shert-nosed stureen the snout is very blunt and only about one fomlth io one thise as long as the head. The fom short barbels are a litile nearer to the end of the snout than to the mouth. and do not reach to the mouth. The head is one fifth to two ninths as long as the total to the fork of the tail: the distance between the eyes slightly greater than length of snont and sonewhat more than one third of leneth of head. The arrage number of bucklers in the dorsal series is 10 to 11 in the lateral series, 25; in the rentral row, seveu to eight Vo preanal serutes. The unarmored part of the slin, areording 10 rerent oliservations of Prof. Tohn . 1. Ryder, is almost free from prickles and ossifications. D. $33 ; \mathrm{A} .19$ to $2.2 ;$ T. 17 to 21 P. : : to to: 1 ; ( io) its lower lobe two fifths as long as the upper measuring from the fork. The rolor of the skin of the uppes falls is reblish brown: lower parts noarly white: peritomeun dark brown; viscera almost black.

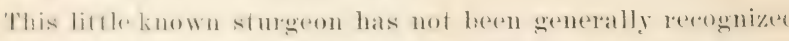
anywhere exeret in the lelaware and in Gravesend bay; onl

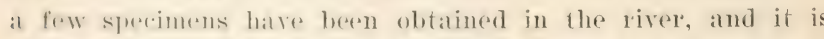

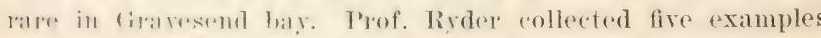

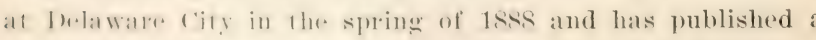
destrifuim at the spereies in the linllerin of the I. N. Fish Com mission for that year.

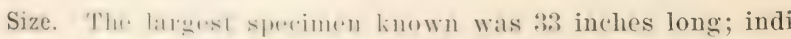

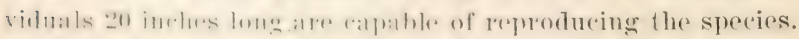

Uses. It the forsint lime the short-nosed sturgeon prob

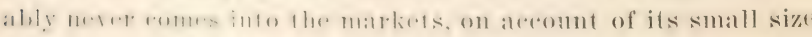

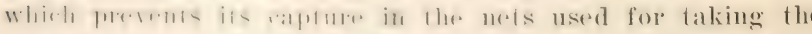

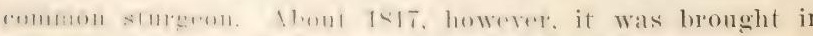

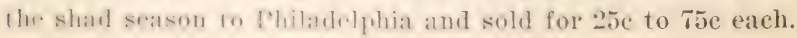




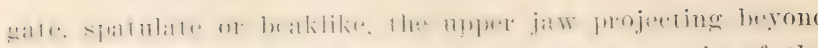
the lower: premaxillaty forminge most of the matregin of the

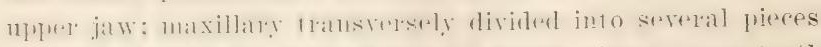

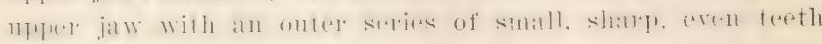

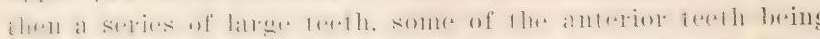

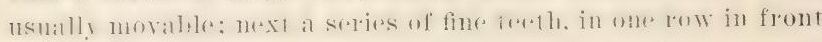

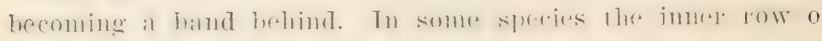

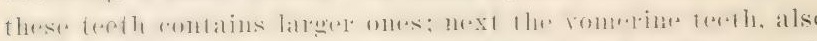

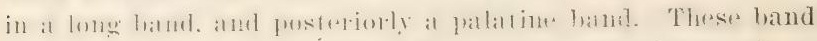
on the roof of the momth arr fiemuenty somemhat confluen

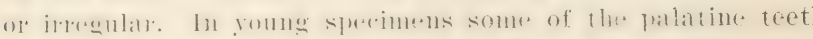

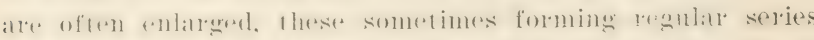

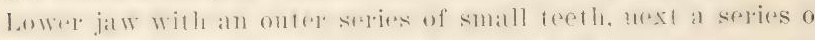

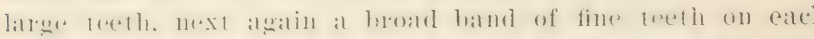

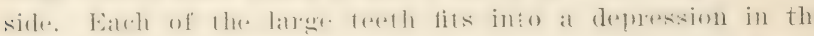

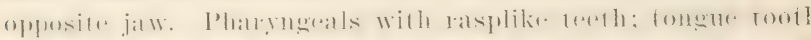

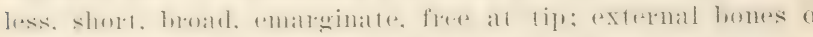

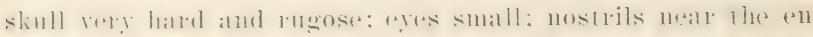

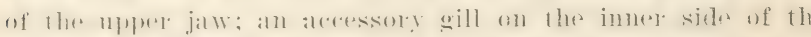

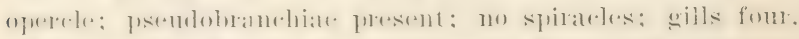

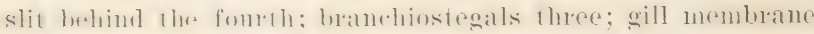

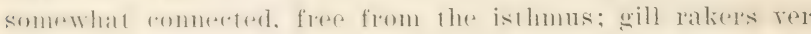

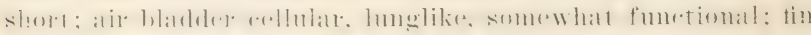

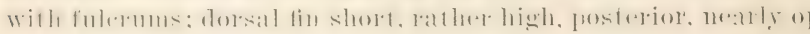

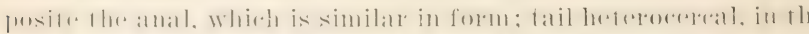

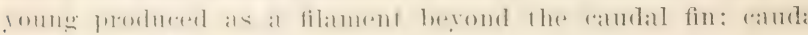
l

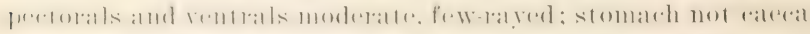

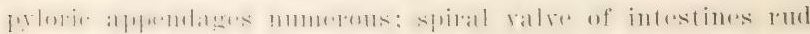
mentary.

Fishes of the fresh waters of North America and Chin (After Jorkan and Evermann)

\section{Lepisosteus osseus Linnaeus}

\section{G(1) Pilie; Billfish}

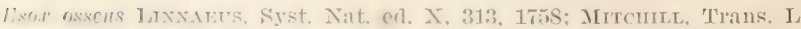
(Nhil. Soce. N. Y. I, 44., 1S15; Am. Mfonth, Mag. II, 321, 1815.

fepisesteus bison Dr KAY, N. Y. F'ama, Fishes, 271, pl. 43, fig. 139, 18 : 
The garpike attains to a length of 5 to 6 feet, of which the head and snout usually form about one third. The body is comparatively slender, cinaling about one twelfth of the entire length.

This species is more abmulant in the Great lakes and large streams than in the small rivers. It is emphatically a fish of prey and extremely tenacious of life. It spawus in shoal water, or in the streans, in the late spring and early summer mouths. Occasionally taken from the northern end of Caruga lake, but not so numerous as formerly.

The girlpilie is said to be nowhere used for food, because its flesh is tough and is beliered to be unwholesome. I have seen it, howerer, with the bill eut off and the skin remored, offered for sale in the market at Washington D. C.

\section{Lepisosteus platostomus Rafinesque}

\section{Short-nosed Gar}

Lepisosteus plutostomus RAFinesque, Ichth. Ohien. 72, 1820; Kirtland Bost. Jour. Nat. Hist. IV, 20, 1S44; Jornan \& Ereratasn, Bull. 47 U. S. Nat. Mus. 110, pl. XXII, fig. 49, 1896.

Lepidustens plutystomus Gixtmer, Cat. Fish. Brit. MIus, VIII, 329, 1870 Jordax \& Gilbert, Bull. 16, U. S. Nat. Mus. 91, 1883.

Lepisasteus platyrhineus DE KAY, N. Y. Fauna, Fishes, 273, pl. 13, fig. 137 $18+2$.

The short-nosed garpilie has an elongated body, its deptl beingeontained seren and one half times in the length; the length of the heat is less than one third of the length of body to base of tail; distane from eye to tip of snout greater than from ey to postrior erdee of operele; uppere jaw slightly longer than the lower; hoth jaws with many long, sharp teeth. Dorsal and ana fins placed far hack, near the tail; ventrals in middle of length

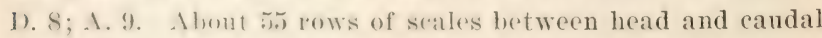
Fins all more or less blatek spotted. The specimen deseribed

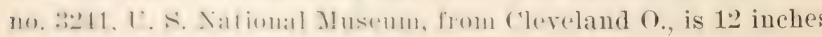
long.

The short nesed garl, heranse of its shorter suout, which ever

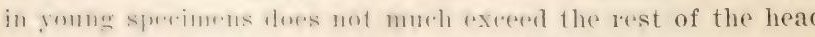

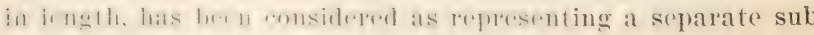
genus, Cylindrosteus of Rafinesque. 
This fish seldom exceeds 3 feet in length. Its habits are presumably the same as those of the long-nosed gar, and it is equally worthless for food. It may be readily distinguished from the long-nosed species by the shape of its snout and by its more robust form.

The short-nosed gar inhabits the Great lakes and the Ohio and Mississippi valleys. It is mole abundant in the southeru part of its habitat. It was not recorded from waters of New York by either Mitchill or De Kay.

\section{Order CYCLOGANOIDEA}

\section{Bowfins}

Family AMIDAE

\section{Bowfins}

\section{Genus Ama Linnaeus}

Body oblong, compressed behind, terete anteriorly; head subconical, anteriorly bluntish, slightly depressed, its superficial bones corrugated and rery hard, searcely corered by skin; snout short, rounded; lateral margins of upper jaw formed by the maxillaries, which are divided by a longitudinal suture; jaws nearly eren in front; cleft of the month nearly horizontal, extending beyond the small eye; lower jaw broad, U-shaped, the rami well separated; between them a broad bony plate, with radiating striae, its posterior edge free; jatws each with an outer series of conical teeth, behind which in the lower is a band of rasplike teeth; bands of small teeth on the vomex and pterygoids; palatines with a series of lareser, pointed teeth; premaxillaries not protractile; tougne thick, searenty free at tipl: nostrils well separated, the anterior with a short barbel; suborbital very narrow; a bony plate corering the cheek, similar to the plates on the top of the head; opereulum with a broad dermal border; branchiostegals 10 to 12; no pseudobranchiate op opercular gill; no spiracle; gills four, a slit behind the fourth: will membranes not comnected, free from the isthmus; ( wo premliar, long, lancer). late, obliquely striate appendateres on wath side of the isthmus. projecting backward and covered by the bramehiostrabl rays, 
1he anterior wholly adnate to the isthmus, the posterior free lwhint: isthmus scathless: gill rakers stoutish, rery short; scales of molerate size, rathep firm, creloid, with a membranous funder: laterat line present: donsal fin long and low, nearly muiform: llar gosterior ats not mueh higher than the others; tail somewhat heterocereal more so in the roung), convex lehind: no fulerums: anal fin sho:t and low; pectoral and vential tins short and rounded, the rentrals ucarer anal than peetorals; rerteluat amphieoclian or donble concarre, as usual among fishes, none of them sperially modified; abdominal and raudal

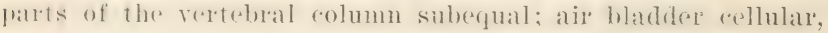
bitid in front. lunglike, connected by a glottis with the pharyn, and capable of assisting in respiration; stomath with a blind

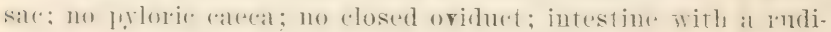
mentary spiral valre. Fresh waters of the Tnited States. (After Jordan and Erermann)

\section{Amia calva Linnaeus}

\section{Bowfin; Mudfish}

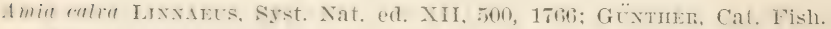
Brit. Mus, VIII, 325, 1870; DE Tír, N. Y. Fauna, Fishes, 270, 1842: Jordan \& Gilbert, Bull. 16, U. S. Nat. MIus. 94, 1883; Jordan \&

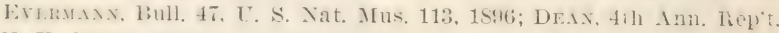
‥ Y. Comm. Fish, Game, Forests, 246-56, pl. of \& 0 and fig. I-VIII, 1899.

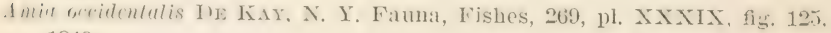
$1 S 12$.

The mulfish has a well rommderl, robust hody; head moles or

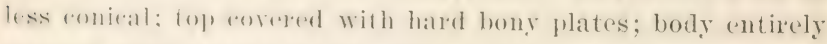

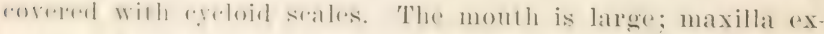

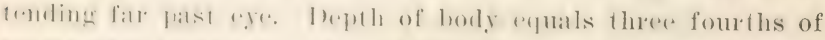

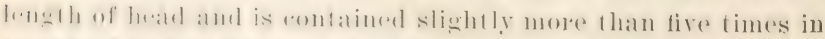

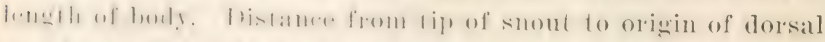

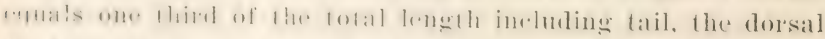

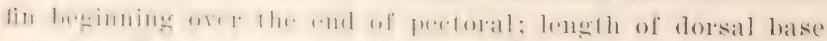

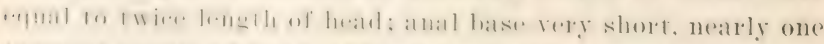

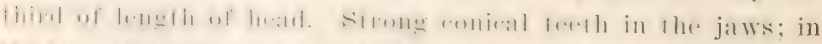

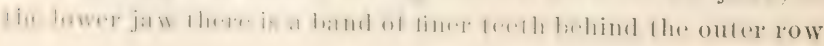


of large ones. The romer, palatine and pterygoid bones are finely toothed. A small harbel at anterior nostril. Lalteral line continuous; through 6.2 seales. There ate seren lows of scales between dorsal and lateral line aud 11 or 12 from lateral line to ventral. D. $50 ;$ A. 10 or 11.

The color in life is dark olire, the sides with greenish redienlations, the belly whitish; round dark spots on the lower jaw and gular plate. The male has a roundish black spot with an orange border at the base of the caudal fin.

The bowfin has rarious rommon names, among them mudfish, dogfish, law were, grindle, and John-a-grindle. Its range is als extensive as its character is generally worthless. It is found in the Great lakes and tributary streans, in the Ohio and Mississippi valleys southward to Texas, and in eastern waters from Pennsylvania to Florida.

The female bowfin is larger than the male, reaching a length of 2 feet, while the male seldom exceeds 18 inches. The male is still further distinguished by the presence of a large black spot or spots, margined with orauge or crimson, at the base of the tail fin. The female also has the caudal spot, but very faintly developed. The greatest recoreded weight of this fish is 1:2 pounds.

Habits. This is one of the most rolatcious of all fishes. It feeds on all other fish of suitable size and also destroys other animals within reach. The eapture of the bowfin by means of the trolling spoon has recently come into greatly increased faror with angler's because of the game qualities of the fish and its wonderful tenacity of life. The species has been known to live out of the water, exposed to the sunlight, 12 hours or more. The young may be kept in an arfuarimu or other receptacle without change of water for months. The spatwing stason of the bowfin is in May and June, and stagnant sloughs are latrorite localities for this purpose. The cagss and young ane proterted by the parents, and the young remalin in the peols aftere the

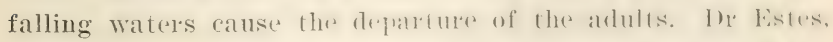
who has made the brest obsertitions on the reproduction of this 
species, states that the little ones are protected in the mouth of the farent when suldenly alarmed. The jumping of the bowfin is one of its most chararereistic habits. Dr Estes saw them turn complete somersaults while in the air.

Thr. howfin is not a food fish, its flesh being soft and unSavory: ret l) foode foumd hem highly esteemed as a sweet morsel by the megroes of the south. The roung are in great demand as batit for pilie and pickerel, and both these and the arlults are interesting for the aruarium because of their eolors, the ease with which they andure aptivity, the peculiarities of their anatomic structure aud their affinities with extinct ganoids.

It is seldom talin near Ithaca and is not common at the northern end of Cayuga lake.

\section{Series TELEOSTEI}

Bony Fishes

\section{Subclass OSTARIOPHYSI}

Order NEMATOGNATHI

Catfishes

Family SILUTIDAE

Catfishes

\section{Genus Fexcmerys Swainson}

Ibuly rather elongate, little compressed; head depressed,

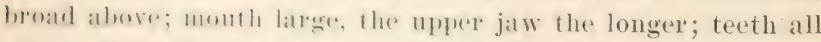
villiform, those of the romere and palatines forming a more or

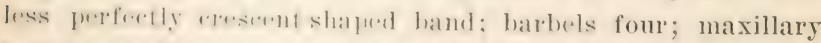
barluls batullike, lery lome: a wo short harbels on ehin; nostrils

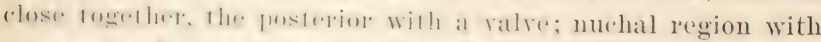

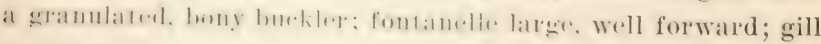

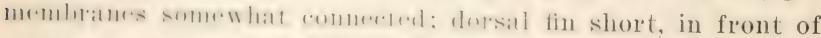
rentrals, with whe sharp spime and sesen rays; pectorals with a

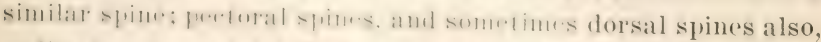

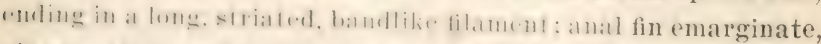

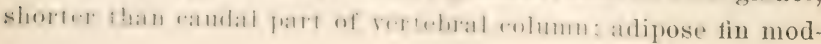


erate, free behind; candal fin widely forked; ventral rays six. species all marine; in tropical American water's.

\section{Felichthys marinus (Mitchill)}

\section{Sea Catfish; Gaff Topsail}

Silurus marinus Mrtenlld, Trans. Lit. \& PLil. Soc. N. Y. I, 439, 151 Ј.

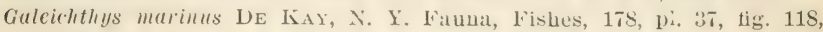
1842.

A'lurichthys marinus Gïntmen, Cat. Fish. Brit. Mus. T, 17s, 1864; Jordar \& Gilbert, Bull, 16, U. S. Nat. Mus. 111, 1883.

Felichthys matimus Jordax \& Evermaxi, Bull. tī, U. S. Nat. Mus. 11S, pl. XXill, fig. 52, 1896; Smith, Bull. U. S. F. C. XVII, 90, 1898.

Body somewhat compressed, moderately elongate, its depth at dorsal origin two ninths of length to base of middle caudal rays; caudal peduncle slender, its least depth little more than one third of greatest depth of body; head short, snout rounded, length of head one fourth of total length to base of middle caudal rays; occipital buckler small, oblong, nearly uniform in breadth; band of palatine teeth nearly continuous, variable; maxillary barbel, pectoral fin and dorsal fin about equal in length; eye oblong, small, one fifth length of head; snout about one fourth of length of head; maxillary barbel reaches nearly to ventral origin; pectoral filament about to vent; dorsal, when laid back, almost to adipose fin; ventral origin slightly nearer tip of snout than base of middle caudal rays; caudal lobes unequal, the upper two serenths of length to middle caudal rays, the lower as loug as the head; adipose fin small, one third higher than wide, its length contained three and two thirds times in that of head; anal base one sixth total length to base of middie caudal rays, longest anal ray two and one third times in head; rentral one half as long as head. 1). 1, 7; 1. 2:; (16 dereloped); P. I, 12; T. I, 5; B. 6. Tetebrate $20+30$. Color, glossy bluish above, silvery or mille white below.

The sea catfish is found from cape Cod to Texas; common southward. Mitchill says it " is an "xifuisite fish for cating;" but the species is generally not valued for food. Wu Kaly also was informed by persons who hate eaten it that the fish has an

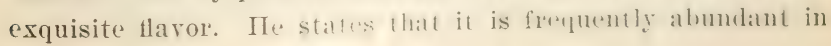


Communifaw erext. on the Jersey side of the harbor of New lopk. It swims frepuently with its long dorsal above the surfar\%, in the matmere of shatlis and imitates those anjmals in roracity. Mitchill had a specimen 20 inches long.

II IImols Jole Mass.. arcording to Dr suith, the species is ynile latre and few hate heen seen recently: one wats atught in a trap at Menemsha in 1886.

\section{Genus Hexineritichux Bleeker}

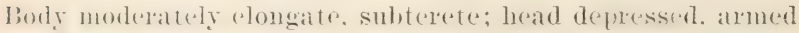
with a homy shichl ahove, behind which projects an oceipital shirhl a smaller, creserent-shaped shield at the base of the doresal syine: these shielels usually exposed but sometimes aovered by 1h. skin: skull with a fontanel; mouth moderate, the npper jaw the longer: teeth villiform or gramular, in at band in each jatw: teeth in one or two patches each on the vomer aud patatines. the palatine patches without a backward projecting angle (1) the inner matregin; palatine teeth fixed; barbels six mo nasal hatrbels). close together, the posterior with a valve; maxillary barluels short, terete; ryes with a more or less free orbital niale-

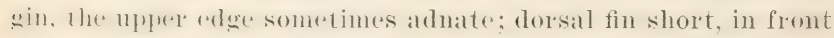

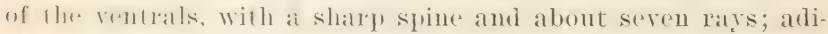
juse tin well developed, posteriorly free: caudal fin dexply

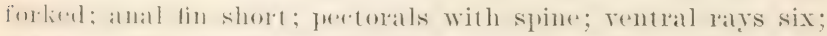
skin smonth. nakiel. "xrept on the oreipital and nuehal regions. whele it is ustlatly eomfluent with the surfatee of the bony bueklers. Species marine.

\section{Hexanematichthys felis (Limnaeus)}

\section{Sea Catfish}

Silurus felis LixvedUs, Syst. Nat. ed. XII, 503, 1766.

A rius milberti Güxtmen, Cat. Fish. Brit. MIus. Y, 155, 1864.

Arins equestris Güxtmen, 1. с. 173, 1864; BAmD \& Ginand, Ichth. U. S. \& Irex, Bomnd. 32, pl, 15, 15.99.

Arius felis and equestris Jondax of Gumbex, Bull. 16, U. S. Nat. MIus. 110, 14.:S.

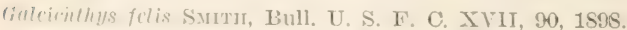

Hermemalivhlhys folis Jomdix \& Evemaxn, Bull, 47, U. S. Nat. Mus. 47,

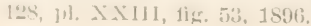


Body tapering, elongate, terete, its depth at dorsal origin one fifth of length to base of middle caudal rays; caudal peduncle short, its least depth two fifths of greatest depth of body; hear rather elongate, pointerl, its length contained three and two thirds times in total to base of middle caudal rays; occipital process with a median keel, about one third of length of head, its tip convex; fontanel forming a narrow groore; top of head comparatively smooth: maxillary barber three fourths as long as the head; longest mental barbel litte more than one half of length of head; eye oblong, placed high, its length one half the length of snout, which is one third the length of head; dorsal origin somewhat behind middle of pectomal fin; dorsal hase about equal to snout, highest ray slightly exceeds greatest depth of body; pectoral fin reaches about to below end of dorsal base; ventral origin midway between tip of snout and end of middle caudal rays, length of fin two and one third times in hear. Distance from rent to anal origin erquals longest anal ray. Length of anal base equals one half the length of lead. Caudal lobes unequal, the upper one fourth longer than lower. D. I, 7; P. I, 6; A. 16 (13 developed); V. I, 5.

Color steel blue. sides and belly silvery. lower parts pale. Cape Cod to Trxas; common southward along the sandy coast.

Curier and Valenciennes received a specimen from New Tork, forwarded by Milbert. Of its ocemreuce at Woods Mole Mass. Dr Smith made the following record: "Reported to have been common in spring in Vineyard somel many geats ago. being often taken with cod; now (1S!S, rery ratex and only oratsionally observed since the fish commission station at Woods Hole was established. I specimen was taken in 1sst, since which time none has been reported."

\section{Genus ictalunus Rafinesque}

Body slender, elongate, compressed posteriolly; head slemdere,

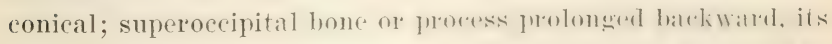
emarginater apex receiving the atrminate antertore point of the second interspinal, thus forming a continums bony hridge from 
the hearl to the dorsal spine; mouth small, teminal, the upper jaw longer: teeth subulate, in a short band on each jaw; dorsal fin high, with one long spine and usually six rays; adipose fin

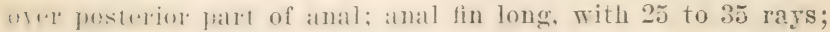
rentral fins eath with one simple and seren branched rays; pertoral fins wich with a stont spine, retrorse serrate within, and about nine rays: andal fin elongate, deeply forked, the lobes pointed, the upper the longer. Coloration pale or silvery, nsually with dark spots on the sides. Fresh waters of North Anmira, sperially in river chammels and ripples in large streams.

\section{Ictalurus punctatus (Rafinesque)}

\section{Channel Cat; Spotted Cat}

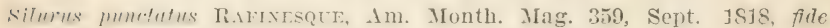
Jordan.

I'tulurus munctulus Jomsax, Bull. Buffalo Soc. Nat. Пist. 95. 1876; Man. Vert. 300, 1876; Jordan \& Gilbert, Bull. 16, U. S. Nat. IIus. 108,

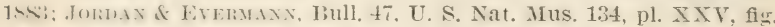
$58,1596$.

fmimrs condu-fmatus Gïntume, Cat. Fish. Brit. Mus. T, 102.1861.

The body of the spotted catfish is rather long and slender., the depth contaimed five times in the length without eandal and rpual to the lergeth of the dorsal spine. The head is moderate, conver alowe, its length being slightly less than one fourth the folal length. The maxillary barbels are very long, longer than laral; ege moderate, five and one half in head; pectoral spine two thirds of lergeth of head; hmmeral process long and slemeler, on: half the length of peretoral spine; adipose fin well

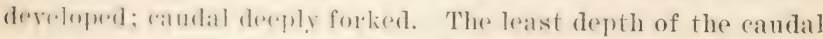
pedurele enpals me half the depth of body at last dorsal ray. D. I, $6 ;$ A. $24 ; \mathrm{V} . \mathrm{I}, \mathrm{S}$.

This specius is varionsly slyled the chamnel rat, white eat, silver cat. blue eat and spotfed rat. It is found orer a rast extent of enmtry eommising the Mississipri and Ohio vallers and the cirati lakes region. In the rastern states it is absent

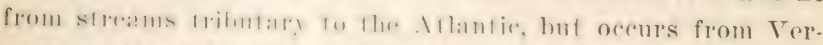

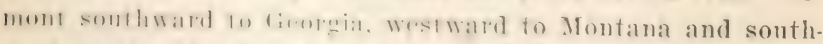

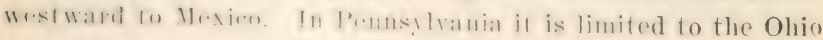
and its afluents. 
The adults of this species are bluish silvery, and the young are spotted with olive. It is one of the handsomest of the family of catfishes and an excellent food fish. The spotted cat grows to a length of 3 feet and a weight of 25 pounds. It is extremely variable in color and in number of fin rays, and has, consequently, been described under more than 20 different names. It is most abundant in large clear streams. This species is less hardy than most of the other catfishes.

\section{Genus amerurus Rafinesqque}

Body moderately elongated, robust anteriorly, the caudal peduncle much compressed; head large, wide, obtuse; superoccipital extended backward, terminating in a more or less acute point, which is entirely separate from the second interspinal buckler; skin corering the bones thick; eyes rather small; mouth large, the upper jaw usually the longer; teeth in broad bands on the premaxillaries and mandibles; band of upper jaw convex in front, of equal breadth, and withont backward prolongation at the angle; dorsal over the space between pectorals and ventrals, higher than long, with a sharp spine and about six branched rays; adipose fin short, inserted over the posterior half of the anal; anal fin usually short, with 20 or 21 rays, but varying from 15 to 35 if certain fork-tailed species really belong to the genus; caudal fin short, truncate in typical splecies, more or less forked in forms approaching I c t a 1 u r u s; rentrals with one simple and seren branched rays; pectoral fins each with a stout spine, which is commonly retrorse serrate behind; lateral line usually incomplete; species numerous in nearly all fresh waters of the eastern United States.

\section{Ameiurus lacustris (Walbaum)}

\section{Lake Catfish}

Gadus lacustris WALBAUM, Artedi, Gen. Pise. 144, 1792.

Amiurus borealis GüNTher, Cat. Fish. Brit. Mus. V, 100, 1864.

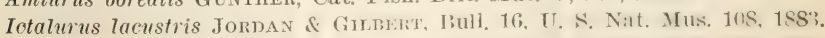

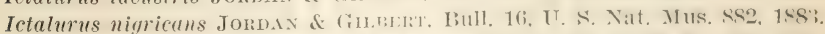

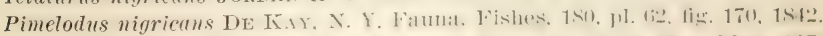
Ameiurus lacustris Jordin of Evrmsix, Bull. 47. U. s. Nat. Mus. 137, 1896. 


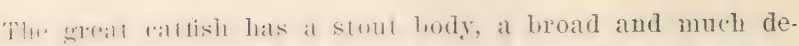

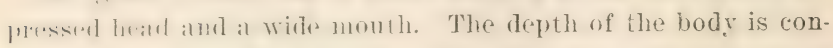
linimel tim limms in folal lemelh, without caudal; the head

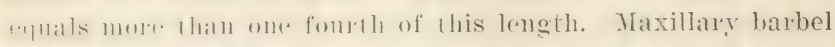
ats long as anal hats. almost as long as the head; eye rather slabll: dorsal hase sholt, ond half the hight of fin; adipose fin

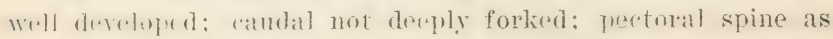
lone as dorsil spine. one half the length of head; least depth

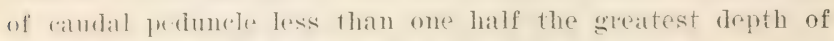
borly. I). T, .) to 6; 1. 2.5: T. I. S.

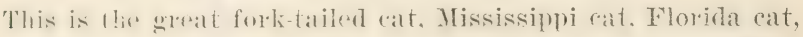
flanmel-month rat and great blue cat of rarious witers. It is

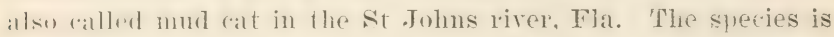
highly valdillle, as we should suppose flom its wide distribution.

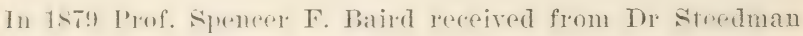

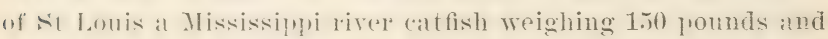

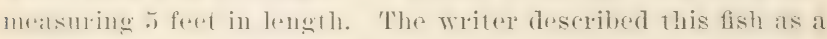

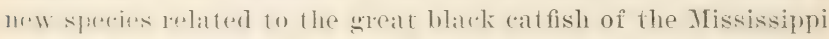
ralley, A miurus n igicans. At the present time it is somm what fouluful whether or not this is merely an orergrown imblivinal of the spereses muler romsideration, and the matter

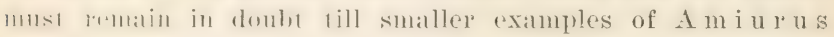
pouderos us have been obtained.

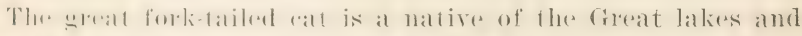
lhe (1hin and Mississippi valleys, and in the southern states its

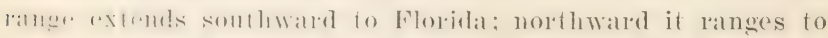
Ontario.

This rallish realelues a weight of 100 pounds or moler, and, if

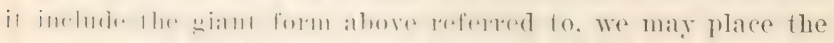

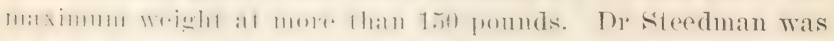

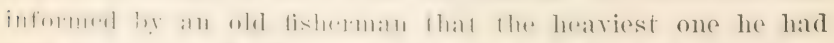

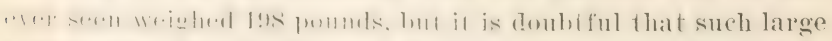

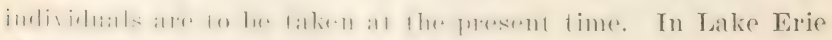

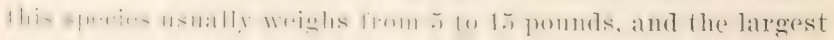
specimerus reach 40 pounds. 
The habits of this tish an [Hwsmmathl about the same as those of other spereses of the family. (In axome of the great size of the fish it nalmally forefers lakes and lange rivers. It is a bottom feeder ant will lake almost any kint of hait. This species is wonderefully whatems of life. It spatwos in the spring and protects its poung. Whith follow the patront fish in

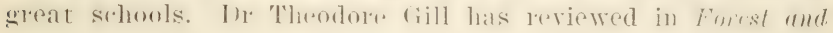
Stream the subject of the catfishes' eare of their young.

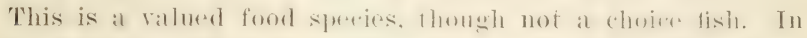

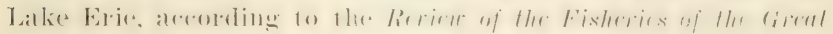

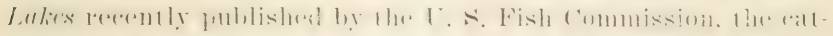
fish ramk next to whitefish in number of pounds taliren.

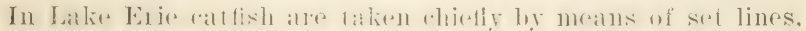
and the dishing is lus doring the months of . Jume, July and Auguse. The methou of fishing is thus deseribed in the review

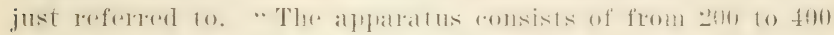
hooks aftalehed hy shore lines to a matin line. whirh is from J to 27 fathoms lome. atcoleling to the plate in which set. and

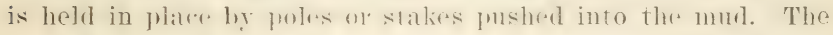
lines are nsually set in tly. like. Hut oreasionally short ones are fished in the hayous and marshes. ratfish are laken with a bait of herring, Coregonus a r ted i, or grasshoppers,

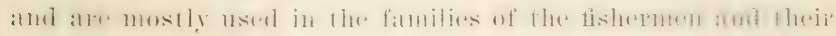
neighbors or sold to peddlers. . . The size of the catfish

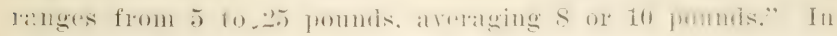

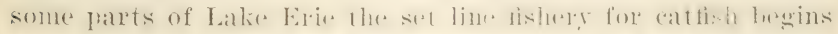

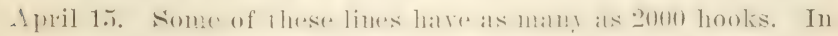

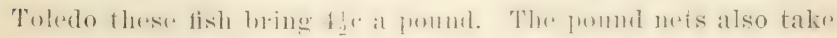

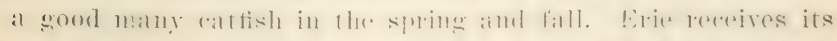

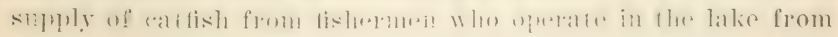
Erie to Elk Creek with set lines during the summer months.

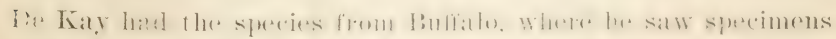

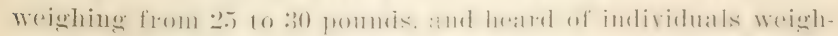

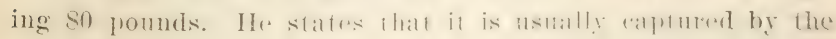
spear. 


\section{Ameiurus natalis (Le Sueur)}

\section{Yellow Cat}

Pimelodus natalis LF Suevr, Mém. Mus. d'Hist. Nat. V, 154, 1819.

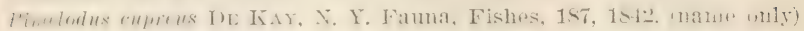
A miurus natalis Güntmer, Cat. Fish. Brit. Mus, V, 101, 1864; Jord.1 \& Grlbert, Bull. 16, U. S. Nat. Mus. 105, 1883.

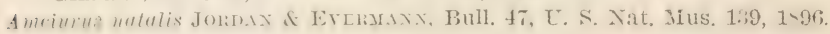

The y.llow eatfish is roloust, and has a rather hroad head. 'The momb is wide, with the nuper jat usually innger than the lower. sometimes equal. The dersal profile gradually aseends from the snout to the dorsal spine. The deptle of the body at dorsal spine is rombined four and two thirel times in the total length to base of tail. The lemgth of the head is tontained three and two third times in the hody length, and eptrals lemeth of anil hase. Eye moderalle: maxillary barbel reathing end of heat: lumeral shield litte dereloped; dorsal and pectoral spines strong. shorter than soft rays; hight of dorsal eyual to trice the length of its base; adipose fin long as in Not u $\mathrm{I}^{\circ} \mathrm{us}$. Opposite to and longer than anal; catudal rounded. D. I. 6; . 1. 24; I. I.. S.

The yollow rat, or chubly cat. is fomnd from the fireat latics to Yirunina and 'Texas. It has many varjeties: threw of whirle

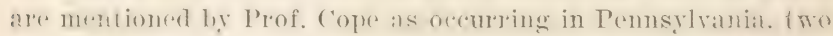
of them in the ohio rivere and its tributales and the thime in Latir Erie. The sureies is not remlited to the region wast of the . Illeghanirs. I)r Merk saw only a single specimon from Cayuga lake.

The lomglh of the rollow cat sometimes rearlues a fert but averages much less.

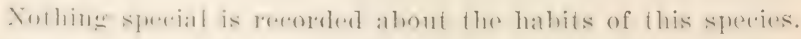
It is most abundant in sluggish streams.

\section{Ameiurus vulgaris (Thompson)}

\section{Long-jaued Catfish}

Fimfoulus rul!garis 'Tnomsox, Hist. Vermont, 1:S, 1812.

Aminrus vulyuris Niscox, Bull. Ills. Mus. Nat. Ilist. 50. 1576; Jonn.x \& (illma:t, 13ull. 16, U. S. Nat. Mus. 105, 1853 .

A miurus deknyi .Jondsx, Mau. Vert. 302, 1S76; Goode, Fish. \& Fish. Ind. U. S. I, pl. 'mi, 1SS1; BeAN, lishes P'enna. 15, pl. 18, fig. 24. 
Ameiurus rulfaris Jondax \& Eversmax, Bull. 47. U. S. Nat. Mus. 140, 1896.

This catfish has a stout budr; its depth is one fourth of the total length without candal. The head is containel alonut three and three fourth times in this length. Eye rery small; mouth

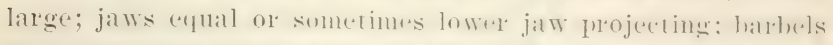

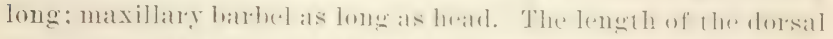
base is less than one half that of the anal, while its hight is five sixths of the same lenght a alipuse fin well dereloguel. The pectoral spine is stout and ahout two thirels as long as the fin.

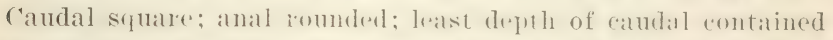
two and one thirel times in weatlest degth of horly. I). I. i; i. $1 \mathrm{~S}(20) ; \mathrm{V} . \mathrm{I}, \mathrm{S}$.

The long-jatwed attish is foumd in the Great lakes region and Westward to Manilobal. It is helixwel to be very neally related

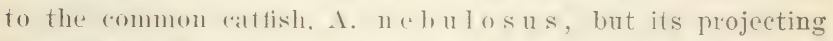

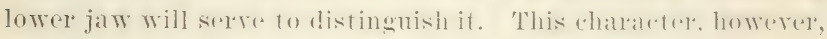

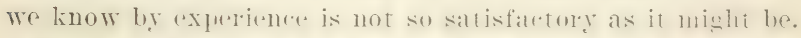

The speceses reateles the length of 15 inelues and llet weight of 4 pounds. It is oecasionally talirn in the (Ohio rirer. Wut is more abundant in Lalie Erie. Torelatn and Evermamn state its range to be from Termont to Mimmesulat aml Illinois, chirtly north-

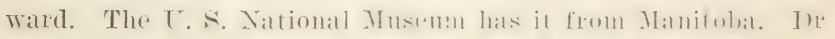
Meck found a single spereimen which was calloht mear Ithaca among more than 100 of the common hullheats. It ser.ms to be

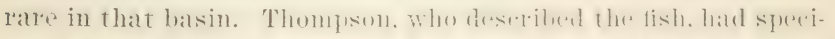

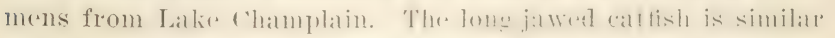

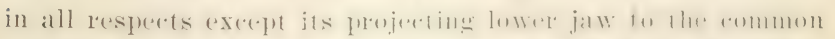

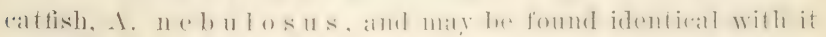

\section{Ameiurus catus (Limnaeus)}

\section{Thite Cat; Channel Cat}

Silurus catus Lrxaeus, Syst. Nat. ed. X, 305, $175 \mathrm{~S}$.

Pimelodus atrarius DE KAY, N. Y. Fauna, Fishes, 1SJ, pl, 36, fig. 116, 1812.

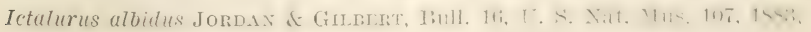

Ictalums lophius JoRDAN \& GILBERT, 1. c. 107, 1883. 
Aminns ulbidus Jonndx; Bull. 10. U. S. Nat. Mus. S1, 1S77, figs. 15 \& 16 , 1877; BEAx, Fishes Penna. 14, pl. 18, fig. 23, 1893.

Amciurus cutus Jomp.x \& Evemaxx, Bull, 47, U. S. Nat. Mus, 138, 1896.

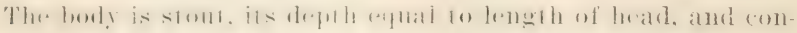

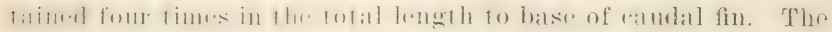

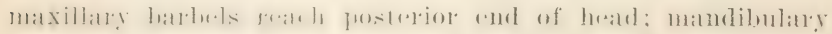

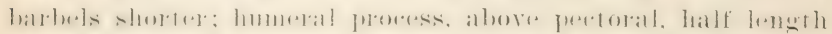

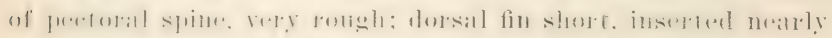

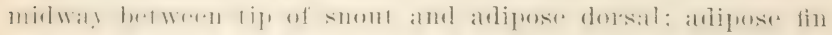

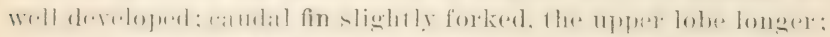

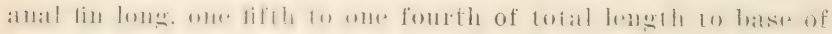
caudal. 1). I, 6; 1. 19 to 22. Pale olive bluish, silvery below

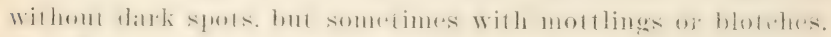

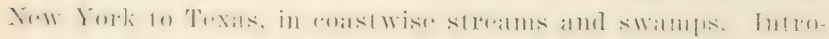
duced into California and now abmudant there.

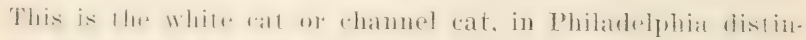

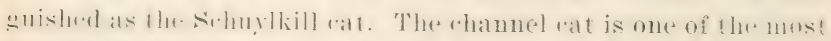

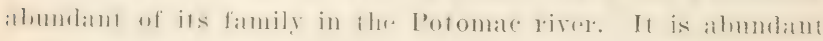
in the Susquehamma and common in the Schuylkill.

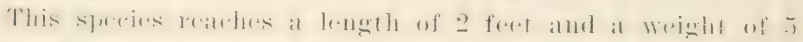

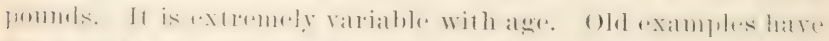

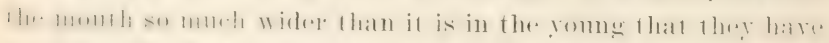

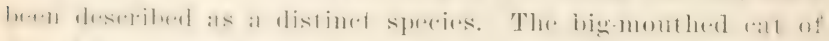

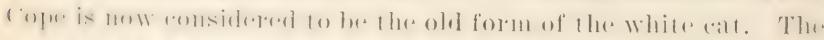

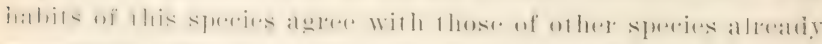

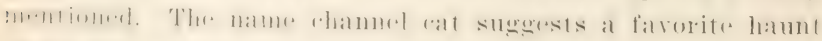
of the fish.

Is a food fish it is highly prized.

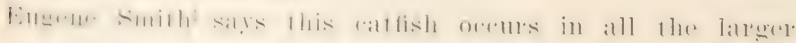
streams subject to the tide in the vicinity of New Tork eity. The camdal is fureate. The anal has 20 or more rays.

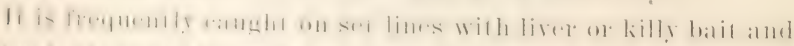

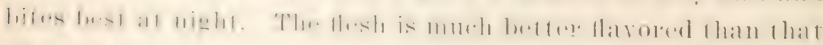
of 1 . $110,11010 \leqslant 11 \times$.

\footnotetext{
'Himn. Soe. X. Y. Proce. 1857. no. 9, p. 11.
} 


\section{Ameiurus nebulosus (Le Sueur)}

\section{Horned Pout; Bullhead}

Pimelodus nebulosus LE Sterr, Mém. II d'U ist. Nat. V, 149, 1819.

Pimelodus catus DE Kir, N. Y. Fauma, Fishes, 1S2, pl. 37. fig. 11!, 14.2. Amiurus catus JordaN \& Gilbert, Bull. 16, U. S. Nat. Mus. 104. $18 \$ 3$.

Silurus catus Mitemli, Trans. Lit. \& Phil, Soe. X. I. I, 4:3:3, 1815. (not s'ilurus catus Linnaeus)

Amiurus nebulosus BeAr, Fishes Penna. 16, pl. 19, fig. 25, 1893.

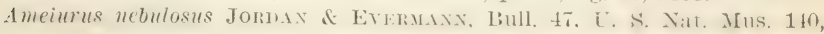
1896.

The common catfish has a very stout body, head head and a short stout candal perluucle. The depth of hody about equals length of head, and is contained from lluee and one lialf to fout and one half times in the lenghte Barhels wight: maxillary harbels as lomg as head; dersal protile from tip of snout to dorsal fin stragight and rather steep; month wide and terminal; teeth awl-shaperl, in hroad hands on the intermaxillaries and dentaries; dorsal situated in f'ont of middle of body; slert and high; adipose fin stout; anal latrge, its base equaling length of head; caudal supare or slightly (malloginate. I). I, 6; . 1. 200-22; P. I, 6.

This is known as the common rattish, hullhead. homponout, bullpout, and minister.

'This species has a wider distribution than the white cat, its range including New Fingland and axtending southward to South Calolina, West to Wisconsin and sonthwest to Texas. It

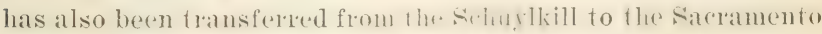

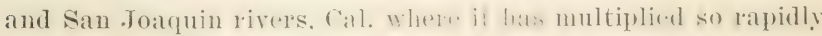
that it is mow one of the most rommmon tishes of those streams.

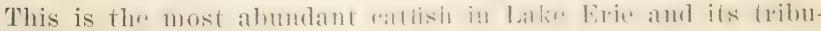
taries.

The spereies reaches a matimum length of $1 \mathrm{~S}$ inches and a

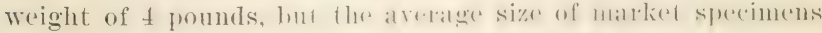

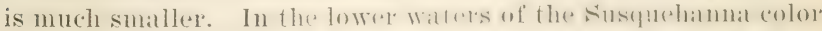
varieties of this specises alle mot murommon. Ome of them

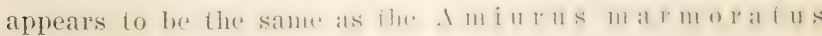

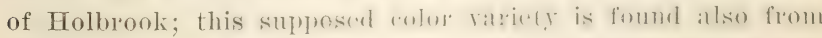

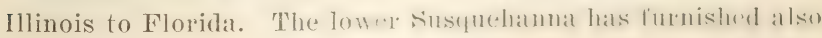
some singularly rolored axamples of this lish, distinguishad hy 
large arras of jut blark eomhimed with lemon and while. These frealis are anong the most interesting and heatiful obsered in this family of fishes.

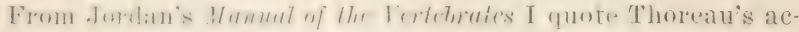
count of the habits of this species:

The lormal pout atre " dull and blundering fellows," foud of the mud, and growing lwst in weedy pouds and rivers without ('ureme. They slaty wear 1he bottom. moring slowly abont with their hathels wirlely spread, watching for anything catable. They will hake any lind of hatit. from an angleworm to a piece of a tin tomato ratl, withom coquetry, and they seldom fail to swallow the look. They are very tenacious of life, "opening and shutting their months for half an hour after their heads have berne "nt off." They spawn in spring, and the old fishes lead the young in great seloouls near the shore, secmingly earing for them as the hen for her chickens.

Thr. spertes was obtathed in swan river at Patrhogue X. Y. Aug. 12., 1s!9. Joung were stined in Bronx river in August.

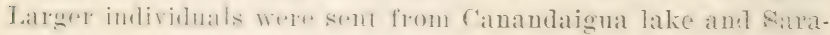
nar. lake in Coventwe. Suremal albinos were obtained from the

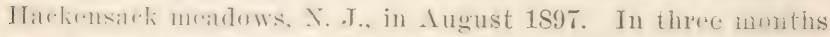

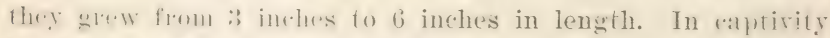

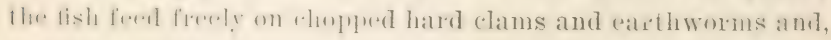
occasionally, liver.

The Lollow ing bores arr from Eugrue suith, in looc. Limn. Soc. N. Y. 1897, p. 11-12.

lery dariable in eolore from dark blatelish and olive to brown

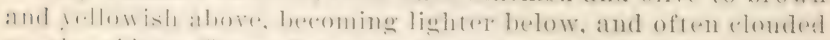

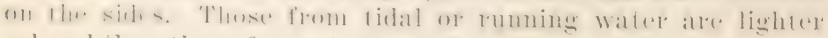
colored than those from stagnant places or ponds.

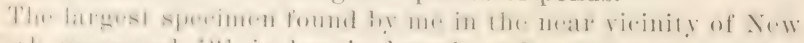

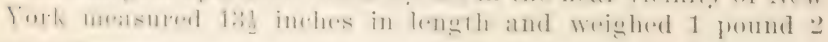
ounces.

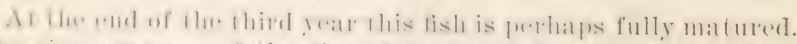

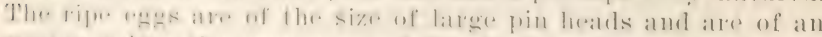

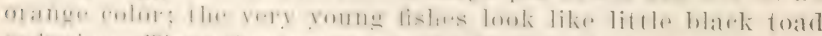

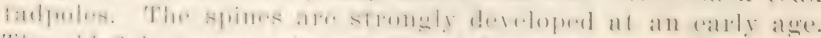

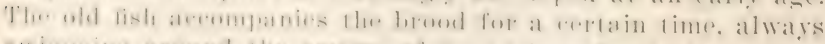

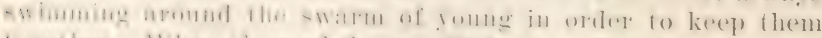

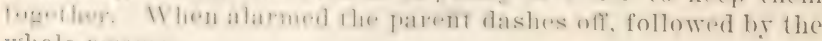
whole swarm. 
Dr Meek found the speries rery abundant throughont the entire Cayuga lake basin. H. Evermaun and Barton . Bean obtained the following syrecinens in the st Lawrence river basin in 1894.

1, St Lawrence river, Cape Vincent N. Y. June 21.

3, Racket river, Norfolk N. Y. July 18.

Dr. Evermann also collected specimens at the following localities of the Lake Ontario region in 1894.

Stony creek, Henderson Harbor, July 3, 4

Black river, Huntingtonville, July 5

Mud creek, Cape Vincent, June 25

Mouth Salmon river, July 25

Chaumont river, July 10

Creek, Pultneyrille, Aug. 7

Mouth Little Salmon creek, July 25

Sandy creek, North Hamlin, Aug. 20

Long pond, near Charlotte, Aug. 17

Stony Island, July 2, 3

Lakeview hotel, 7 m. n. e. of Oswego, July 17

Marsh creek, Pointbreeze, Aug. 21

49 Ameinxus nebulosus marmoratus (Ifolbrook)

\section{Marbled Cat}

Pimeloüus marmoratus Holbrook, Jour. Ac. Nat. Sci. Phila. 5t, 15\%.

Amiurus marmoratus Jordan \& Gilbent, Bull. 16, U. S. Nat. Mus. 104, 1 SS3.

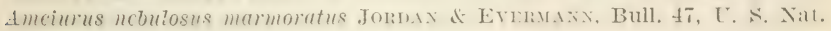

Mus. 141, 1896.

Body moderately elongate, its depth ahout one fourth total

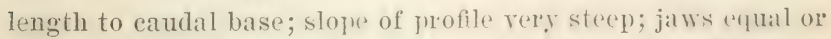
subequal; dorsal tin high, its spine more than one half as long as head, and nearer to adipose fin than to tip of snout: head long, three and one fourth times in total length to anmlal base; barbels long; anal rays 21; hody muth moltled with hrown, greenish and whitish. Lowland strams and swamms irom Xew York to southern Indiana and Floridas. The ty tre of the ma r' moratus of Holbrooli mals frum somt in Carolinat. 


\section{Ameiurus melas (Rafinesque)}

\section{Black Bullhead; Brown Catfish}

Silurus melas TAfinesque, Quart. Jour. Sci. Lit. Arts. Lond. 51, 1820.

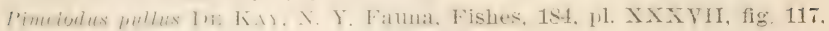
1812 ,

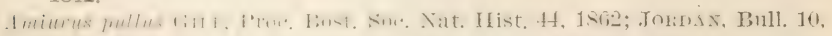
U. S. Nat. Muis, 93, figs, 46, 47, 1877; Goode, Fish. \& Fish. Ind. U. S. I, pl. 233, fig. 1, 18St; BEAN, Fishes Penna. 16, 1893.

Amoiurus moles Jordax \& Evermaxx, Bull. 47, U. S. Nat. Mus. 141, 1896.

The borly of the hlack hullhrad is stout. short and deep. Its

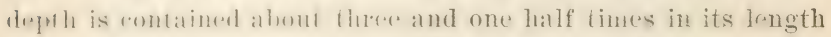
to tail: in very derelexamules hut there and one fifth times. The Jength of the heat! is eontained thexe and one half times in this

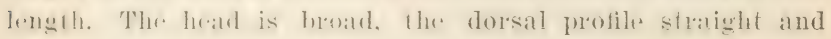
rather stere lime lip of smout to dorsal fin; "ye rather smatl; batrbels loner: caudal peduncle stout. Dorsal 1, 6; the spine sllong and sharply pointerl. The hight of the dorsal fin ryuals

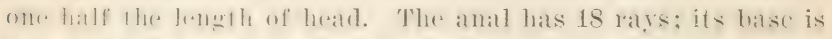

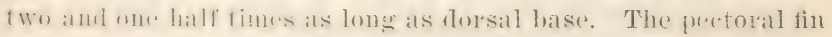

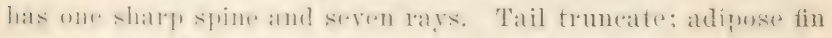

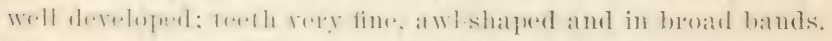

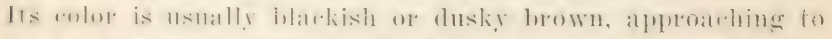

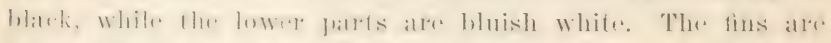

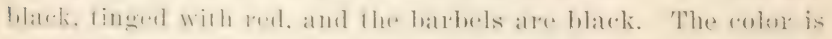

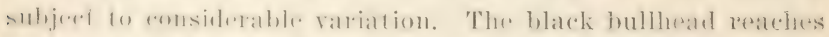

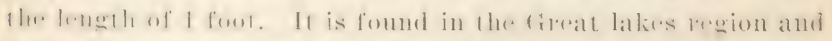

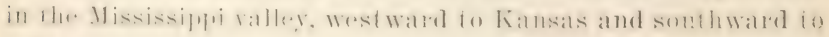
Tir.is.

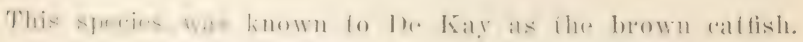

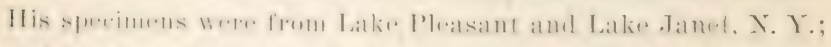

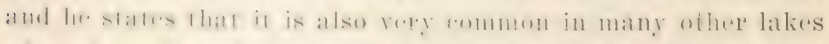

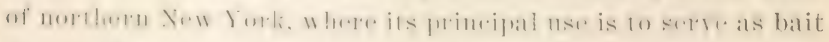
for the lake tront. Dr Jordan had it from the Genesee river.

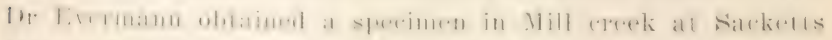

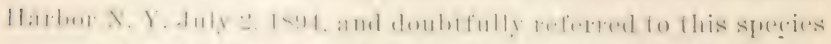

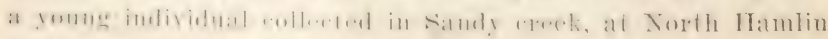
ล. I. A $11 \mathrm{n} .20,1894$. 


\section{Genus xomurus Rafinesque}

Body moderately elongate, robust exeret in "andal part, which is much compressed; head flat and broad; wouth terminal, hroad; teeth in hroad rilliform bands on premaxillaries and dentaries; teeth of upper jaw frolonged barkwarl into an elongate, triangular extension: adipose fin adnate to the back: a poison gland at the base of the prectoral spine. Represented hy a single species inhabiting riress and rhannels.

\section{Noturus flavus Rafinesque}

\section{Stone Cat}

Doturus flatus Iidfriesque, J hth, Ohitn. 6s, 1S20; STorer, Syn. Fish. N. A. 154, 1846; Jotrdan \& Gllbert, Bull. 16, U. S. Nat. Mus, 100, 1853;

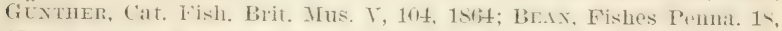
1893; Jordan \& Everarann, Bull. 47, U. S. Nat. Mus. 144, 1S96, pl. XXVII, fig. 63, 1900.

l'imclodus flatus LE: Kir, X. Y. Fauna. Fishes, 1si, 1812 (after Kintland).

The stomerat has a modreately elongate body, whose great(st depth and width are nearly equal; the tail is much compressed, and the head flat and broal. The greatest depth of the hody is nearly our fifth of the tutal length without the ratudal; the least depth of the eaudal prinurle "fuals nearly one half the length of head. The mouth is trminal, horizontal, its width equal to postorhital part of head and to length of maxillary larbel; longer barbel on chin not yuit. on" half as lone as the head. Nasal barbel when latid bark leatrhes end of eye. The width of the band of teeth in the nures jatw equals oate thired the length of head; the batekwathl poulongation is little lomger than the eye. The distance between the ryes repuls length of suout and eye. The suout is nne half as lome as the postorbital part of the head. The dorsal origin is at a distance from tip of snout nearls equal to one thire of the fotal length without rau-

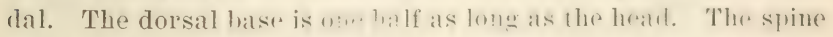
is very sharp and as long as the sunnt. The longest ray is nearly one half as lomg as the head. Thr velltal mogin is not far behind the end of the dorsal base; the fin reathes a litule beyond the vent, but not to the amal wrigin. The feretoral reacless to berow the thirel dorsal ray, its spinr allout fwo fifthe as long 
as the heat. The anal origin is a little nearer to base of eatudal

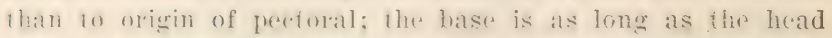
without the smout, one fifth of total to batse of ramelal, and the lungerst ray equals one half the length of heat. The very low anlipuse dorsal logins orel the anal origin and continues into

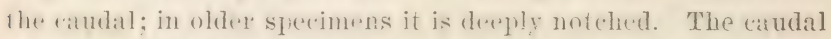
is roumled. I) I, (i; 1. 16; V. 9; I'. I, 9. T.ength of the speci-

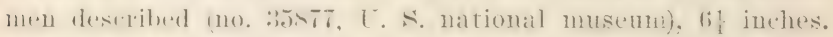
In spirits the ryper parts are grayish brewn, ant the lower surfice of head and body pale. In life the fish is mearly uniform yellowish brown.

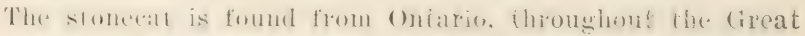
lakes region, south to Virginia and Texas, west to Montana and Wyoming. It inhabits the larger streams. Dr Erermann obbained two specimens at Nine Mile point, in the Lake Ontario region, June 11, 1893.

The speries has very little value as food on awount of its small size. It seldom exceeds 12 inches in length, but it is a very goon bat for blati bass. The stomeats are mien areaded

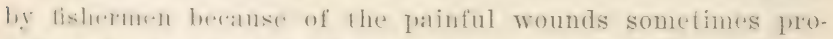
dureal by lheir peretoral spines. There is a minute pore in the

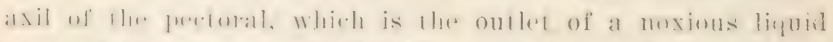
s.r.r.ml by a poison whand. When this poison is discharged into a wound, it causes an extremely painful sore.

\section{Genus scmumons Bleeker}

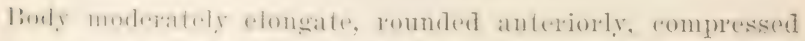

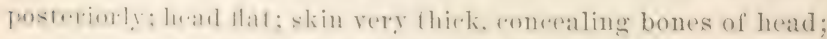

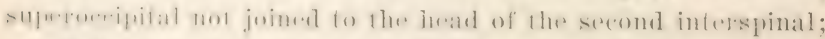

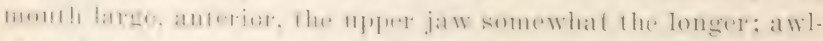

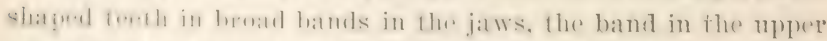

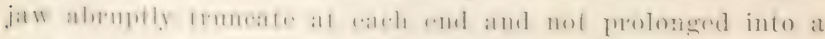
backward extension as in Leptops and Noturus;

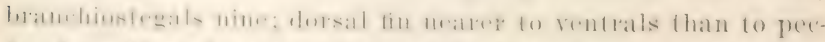

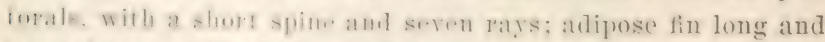

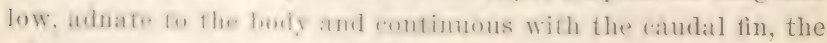
alipuse tmembant sometimes high and continuous, somelimes 
longest ray apuals length of jostorbital part of head. The lom adipuse fin hergins orer ilue anal origin and is continuous witl the ramelat. The rentral origin is moler the rnd of the dorsa

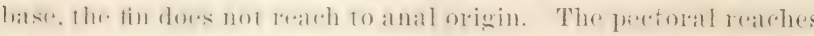

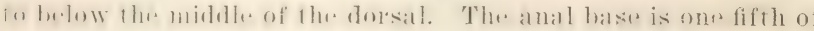

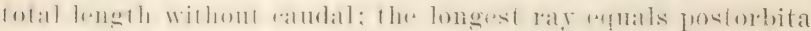

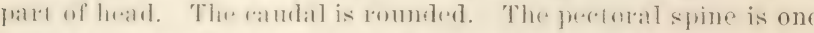
half as lomg as the head. The humbal process is one third as long as the head. D. I, 6; A. 13-15; P. I, 8. Color in spirits dark hown: the lesly and under surfare of head paler.

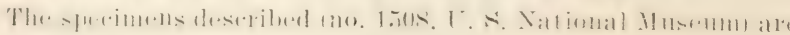
from 3 to 4 inches long.

The gemenal color is bownish, without hotehes. Jordan in

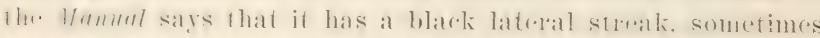
with two otherestreaks above this. I have fomed rome with this fratture: it is the lattrat line itself which looks darker in color.

The eyes aresmall. leadlike and at night wlisten like adamant

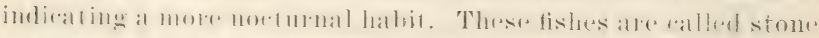

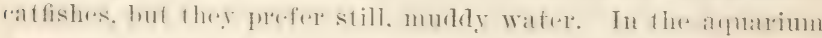
it is eren more hatrly than the e.ommon catfish and often lies on is side for homs as if dead, or remains suspended in the water in various odd positions. (After Eugene Smith) ${ }^{1}$

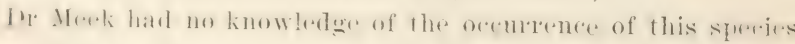
near Ithata. The musem of Cornell Eniressity has a few

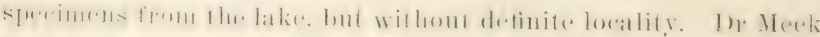

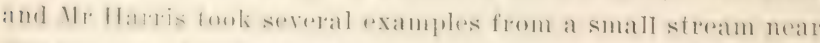

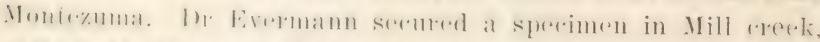

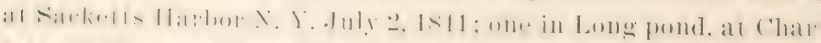

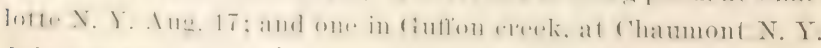
July 7 of the silme yeair. In general it ranges in the Great lakes region, Ihrongh the Mississippi and Hho vallers, and in Xew

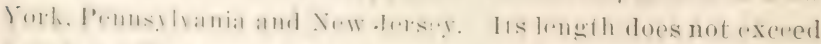

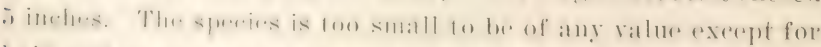

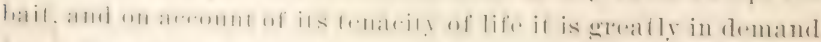

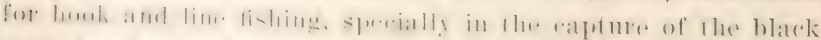
bass, for whind it is ane of | he lus bats linown.

${ }^{2}$ Linn. Suc. ․ Y. P'roc. 1S97. no. 9, p. 12-13. 


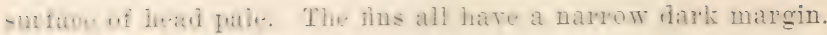

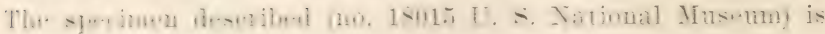
1.) inches long.

This species, like the others of its genus, is called stone cat,

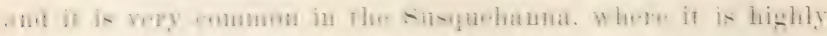

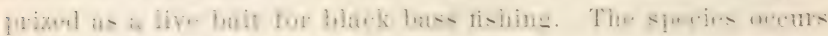

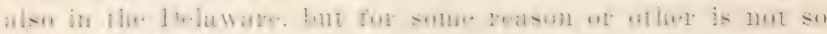

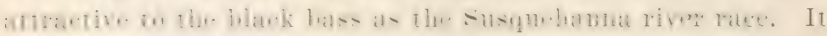
groms to the length of 10 inches.

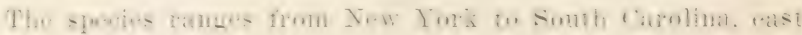
of the Alleghenies.

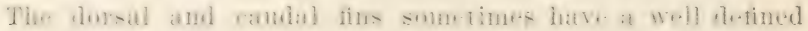

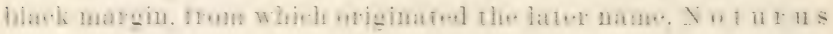
marginatus. This is the Pimelodus lirrée of curier and Talenciemnes and the P. le mniscatus of Le

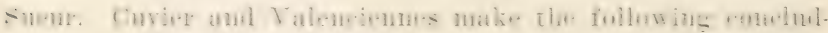

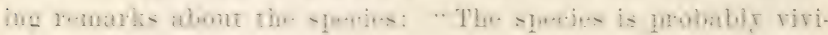

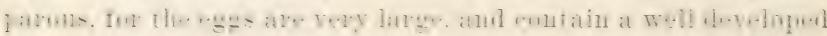

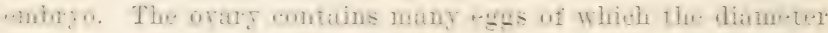

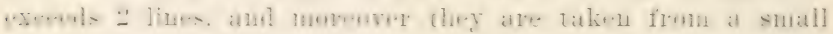
animal, for our example is 3 inches long:"

$5 \pm$ Schilbeodes miurus (Jordan)

Tariegated Stone Cat

Totumes mimus Jonds, Ann. Lyc. Nat. Hist. X. T. 371, 1S7т, Bull. 10, U. S. Nat. Ius. 10u, figs. 60, 61, 1s7; Jordax \& GIlbert, Bull. 16, L. S. \at. Mus. :9, 1Ss3.

Schilbedes mimus Jordax of Evermar, Bull. 4i, L. S. Tat. Mus. 14S, 1sit, pl. XXIX, fig. GS, 1 सM0.

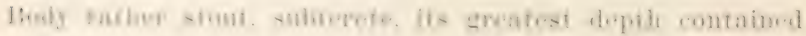

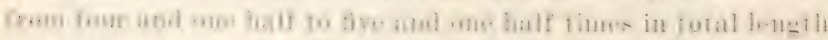

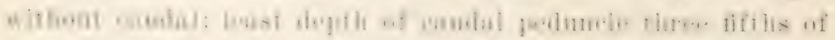

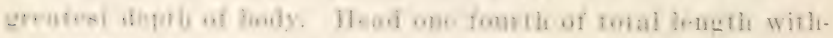

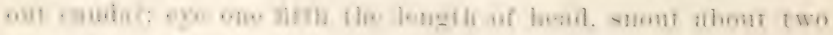

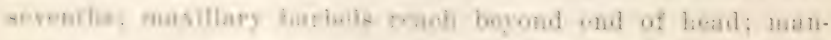
diihulang barbel three fifths as long as the liead; lower jaw

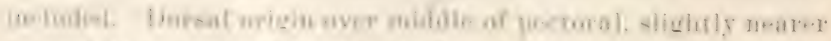

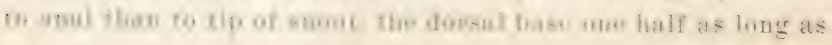


the hearl; alipose fin with a hewp noteh but conneeter with the caudal, its length about efual to head; anulat romulecl, its middle rays fom fifths as long as the head: anal hase as long as

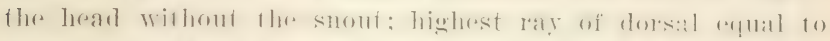

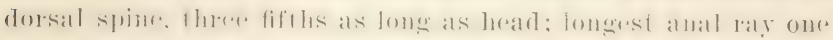

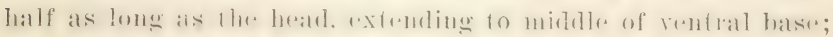
ventral fin one half ats longe as the heral; humeral process short.

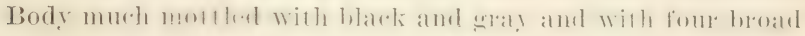

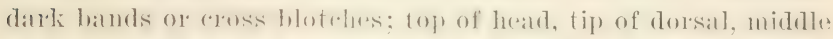
of adipose fin, and edge of catulal blackish; occiput darli. I). I. 6; A. 13 to 15 ; V. I, S; P. I, S.

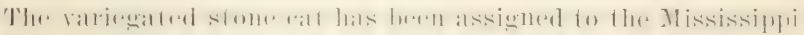

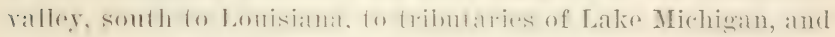
(o) the (thio salley. Where it is ammmon. It appears to hate

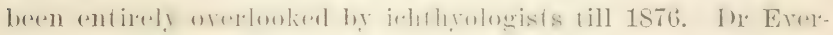

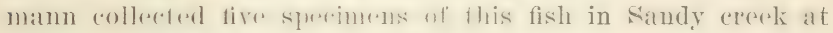
North Hamlin X. Y. Ams. 211. 18!)!. The probability is that it will be fomei in other witces of the cireat lakes region. The individuals used for illustration are from ? inches 10 t! inchess long.

\section{Order PLECTOSPONDYLI}

Carplitie Fishes

Suborder EVENTOGNATHI

Carps

Family catostomidae

\section{Suckers}

\section{Genus carpiodes Rafinesque}

Body oblong; the dorsal oulline more ore less arelexd; llow rentral outline nearty stratight depth from onr half to one

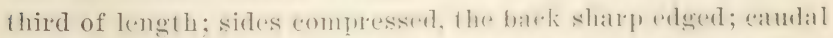
peduncle short and derep; hearl shorel and deep; its uphere surface rounded; eye moderate, median or anterine: suburlital bomes well dereloped: fontanel preseme: month small, horizontal and

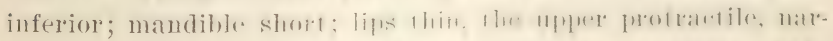

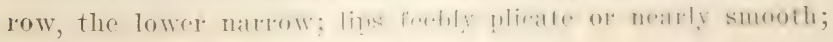




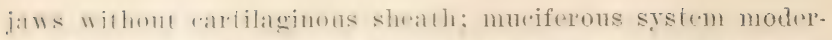

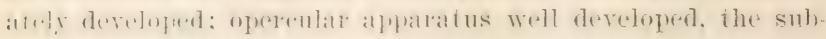

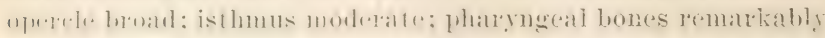

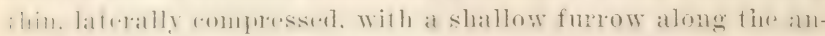

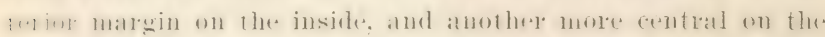

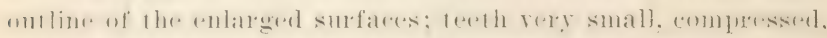

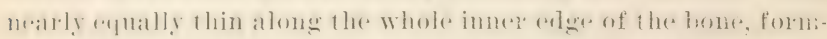
ing a fine. amblike arest of minute serratures, their cutting

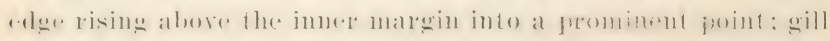

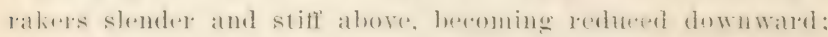
seales large, abeut eyual over the body: lateral lime we.ll dre

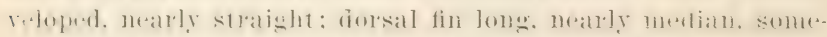

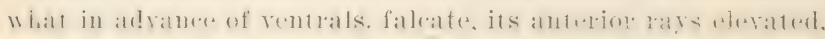

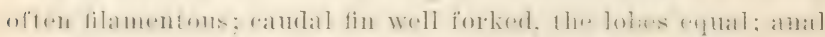

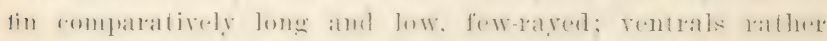

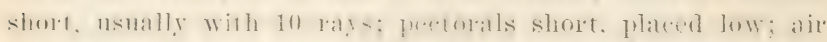
hatdere with two thambers. Size medium or rather large. (After Jordan and Erermann)

\section{Carpiodes thompsoni Agassiz}

\section{Lake Carp; Drum}

Calostomus cyprimus Trompson, Hist. Vermont, 133, 1812.

C'urpiodes thompsoni Agassiz, Am. Jour. Sci. Arts, 191, 1855; Core, Proc. Ac. Nat. Sci. Phila. 285, 1S64; JondAx, Man. Vert. 297, 1S76; Jordגx. Bull. 12, U. S. Nat, Mus. 198, 1SiS; Jord A GILbert, Bull, 16, U. S. Sat. Mus. 119. 1883.

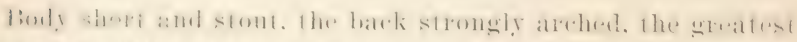

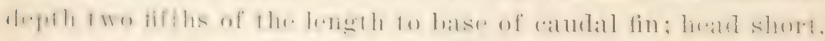

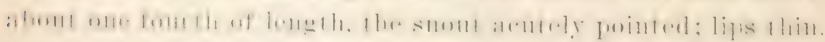

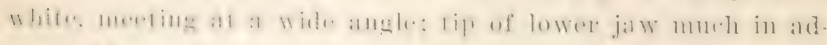
vamee of nostrils; maxillatry reaching to below front of orbit;

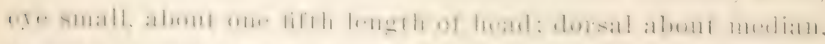

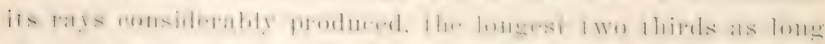

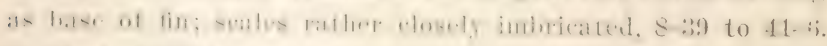
1). $27 ; 2.7 ; \mathrm{T} .10$.

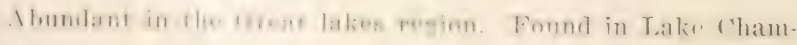
plain. 


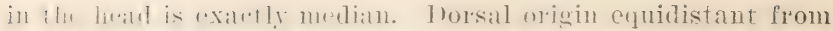

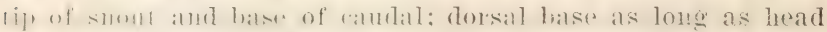
willonl smont: longest raty one sixlh of rotal beneth without

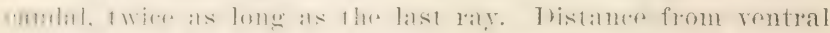

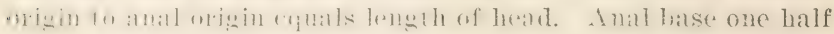
as lomg at dorsal balke: lomeret anal mat equal to longest of

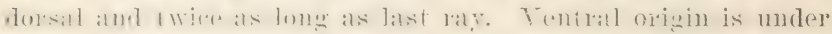

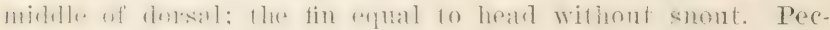

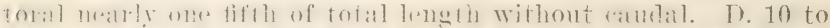

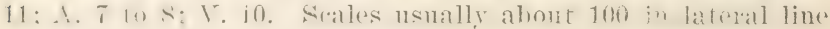
and in 28 rows from dorsal origin to ventral origin.

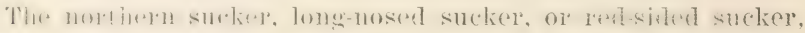

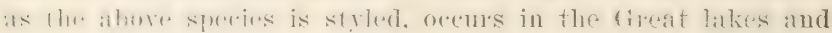

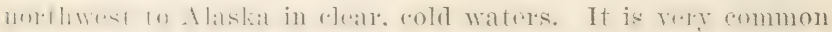

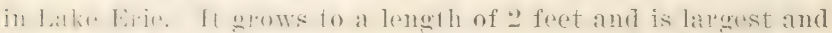
must ahmutam mollhwalet, in . Maska rearhing a weight of a

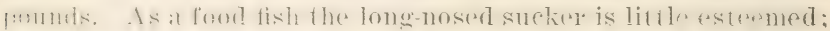

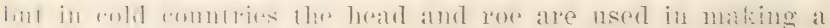
palatable somp.

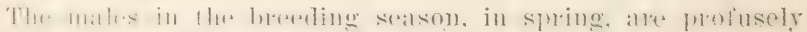

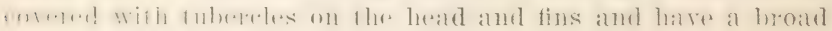

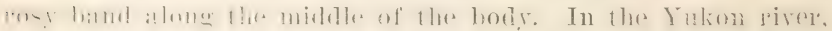

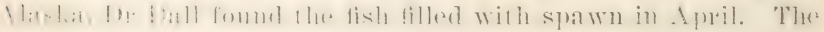
cogs are of moderate size and rellow in color. Nelson has

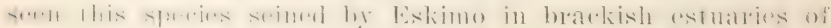

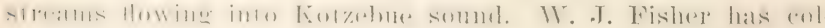
lected specimens on the peninsula of Alaska.

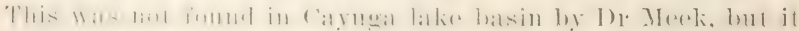

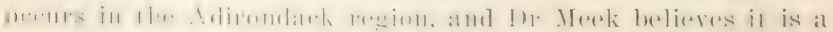

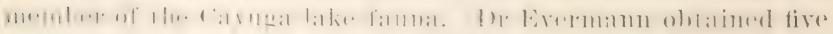

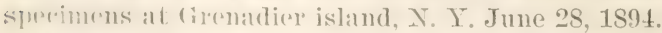

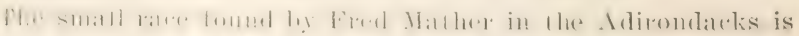

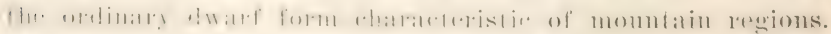

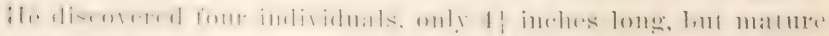

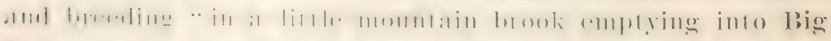
Mnose neally north of the IBig Moose club house, by a bark 
adulis an linht olive varying to faler and sometimes darker: sides silvery.

The speectes reatehes a length of 22 inches, and a weight of 5 founds. It is a very common inhabitant of ponds and streams of the lowlands, and a small ratere oecers in certain cold mountain streams of the Adirondack region, wher it is dwarfed in siz. and changed in color but does not differ in essential

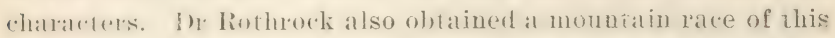
surker in Twin lakes, ('ol., at an elevation of 9.en feet above the sea level.

The common surker is a rery indifferent foud tish in the estimation of most people, but, when taken from cold waters and in its hest condition, its flesh is very palatable. It takes the howk reatily when bated with eommon eatrithorms.

\section{Dr Richardson says:}

It is a common fish in all parts of the fur countries alounding in the rivers and eren in landlocked marshes and pomels. but preferring shallow glassy lakes with mud bottoms. In the beginning of summer it may be seen in numbers foreing its way up rorky streams, and even breasting strong rafids, to arrive at its frepere spatwing places iu stony rirulets; soon after. watrls it leturns to the lakes. Its food. judging from the contemls of the stomatehs of those which I opened, is chiefts soft inseres: hut in one I found the fragments of a fresh-water slu-ll. In the winter and autumn it is common in nets, and in the spatwing saason t.Jume) may be readily speared, or even ialien hy the hamd in shallow streams. It is a rery soft, watery fish, hut devoid of any umpleasant liaror, and is considered to be ane of the best in the (ontutry for making soup. Like its congermers, it is singularly tenations of life, and may be frozen and thawed again without being killed.

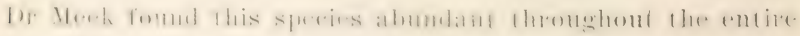
Caymar lake basin, where it is known as the common white suckere.

19. Keverabun. in his manuseriphs on the lishes of lake Ontario,

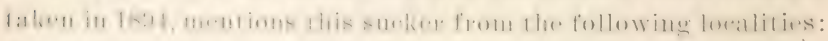
Sstony ereesk, l3latek rirere, Mud ereek, Cape Vincent, mouth Sal-

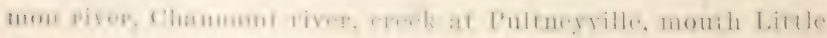

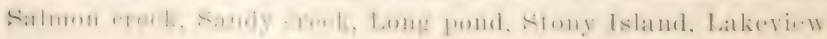


hotel, 7 miles northeast of Oswergo, and Marsh creek. In the St Lawrence river basin he and liarton $\mathrm{A}$. Bean obtained the young in Racket river. Norfolk $X$. Y., July 18 and in the st Lawrence river. 3 miles below Ogdenshure, July 17. In the Lake Champlain basin these two rollextors secured roung and half grown speeiurns in the saranac rirer. at Plattsburg July 2S, 1894.

The writer received specimens from Canandaigua lake in Norember of 1896 and 1897 , and seined the young in Broux river in August 1597. The small mountain form was secured from Saranac lake in Norember 1S97. It is conspicuous for its small size and its red color. The Canandaigna lake suckers, receired in Norember 1s96, throre in eaptivity till Juls 1897, when the warm water killed them.

Color brownish, olivaceous above, silvery below; the young are much blotrehed and marked on sides and back. It is occasionally caught on the hook. Young ones, in captivity, though they always grub about, and though they take food offered them, do not thrive and gradually starve. Thes remain wild and take alarm easily and often leap ont of their tank. This species enters slightly brackish water. Euyene Smith ${ }^{1}$

\section{Catostomus nigricans Le Sueur}

\section{Hog Sucker; Stone Roller}

Cutostomus nigricans I.E Stetr. Jour. Ac. Nat. Sci. Phila. I. 102. 1417;

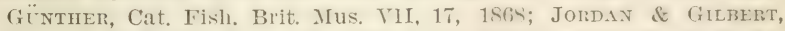
Bull. 16, U. S. Nat. Alus. 130. 1Ss3; Ben. Fishes Pemna, 26, pl. 21, tig. 31. 1993; Jordar of ErenMaxy. Bull. 47, T. S. Nat. Mus. 181, 1890; DE KAY, N. Y. Fauna, Fishes, 202, 1812.

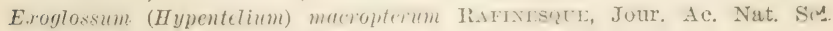
Phila. I, 420, pl. 17, fig. 3, 1817.

The stone roller has a peruliar physingueny. The heat is flattenerl on top, the interorbital stace is concalve and the frontal bone short, broar and thick. Thre borly is subterete, its depth being enntatined funt and whe thite times in the length

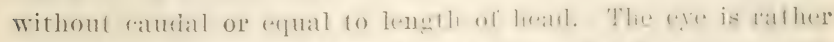

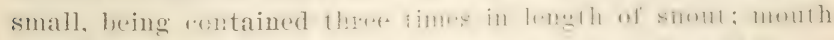

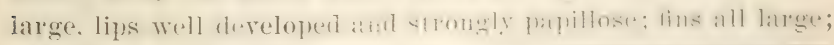

${ }^{1}$ Linn. Soc. N. Y. Proc. 1S97. no. 9, p. 13-14. 


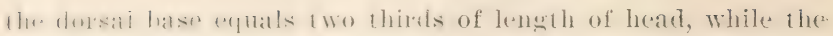

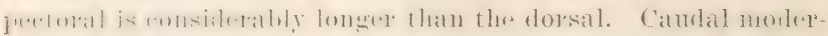

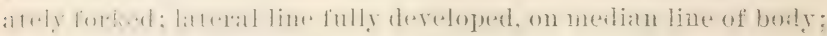
seales moderate, equal. I). 11; A. 7; V. 9. Scales 7-52-7.

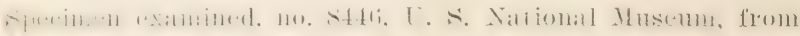
Capuga lake, N. Y.

The stom. roller hats at wirle distribution ant a rematrable

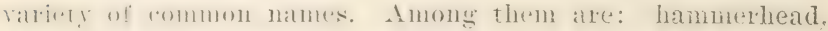

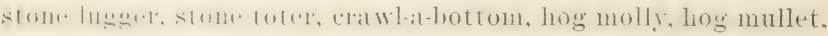

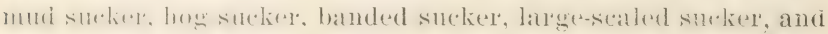

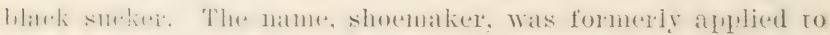

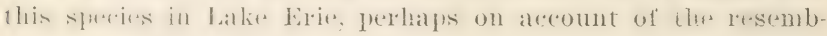
lance of its color to that of shoemaker's pitch.

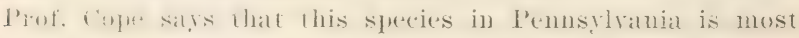
abmulatu in tribntaries of the Ohio and in the suspluthamma.

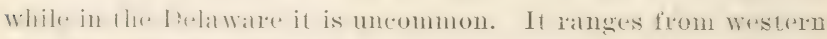

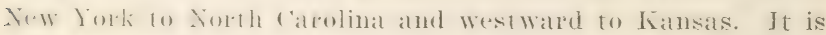
the most remalliable-looking of all the suckers of tew Jork,

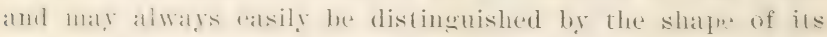

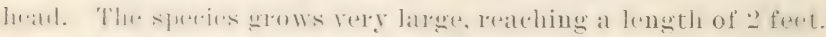

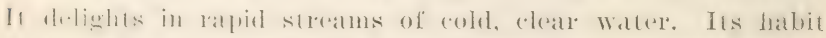

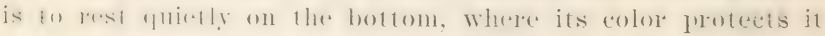

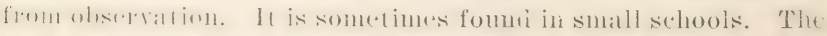

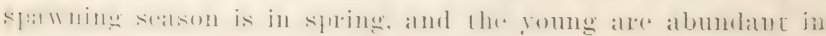

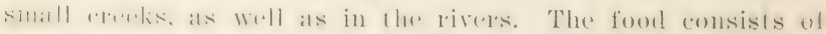

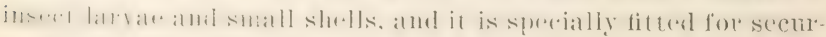
ing its prey under stones in the rapids.

As a food tish this sucker has little value.

\section{Genus wmuxzox Jorian}

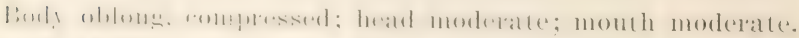

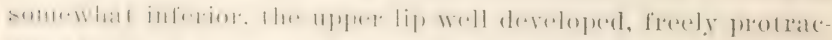

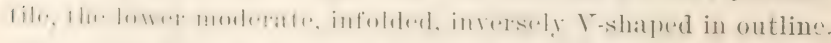
fllicalle, with 12, to "2) folds on each side; lower jaw without

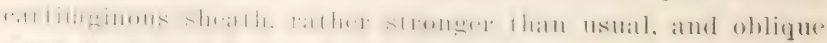

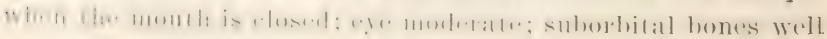


derelofed, not muth narrower than the fleshy gated of the relerek

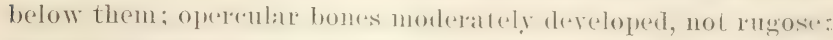
fontanel rather latrege; gill rakers rather loug; pharyngeal boues weak; the reeth tuite small, slender, and weats, ratpid!

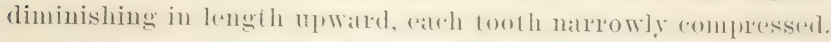
with a cust) on the inner matrein of the (*utting sulfater; seales rather large, mere or less croweled forwalled; no latleral line; dorsal fin rather short and high, rays nsually 11 or 12z; jectoral fins moderate; anal fin high and short, more or less ematrumate or bilobed in adult males; caudal fin moderately forked or lunate, its lobes subergual. Air bladrler with two chambers. Iffer Jordan and Evermann)

\section{Erimyzon sucetta (Lacépède)}

\section{Chub Sucker}

Cyprinus sucetta LACEPEDE, Hist. Nat. Poiss. V, 503, 606, 610, 1803.

Catostomus sucetta Le Sueur, Jour. Ac. Nat. Sci. Phila. I, 109, 1817.

Labeo gibbosus DE KAY, N. Y. Fauna, Fishes, 194, pl. 32, fig. 101, 1812 (dorsal incorrect).

Catostomus tuberculatus DE KAY, N. Y. Fauna, Fishes, 199, pl. 31, fig. 97, 1842.

Labeo esopus DE KAY, N. Y. Fauna, Fishes, 195, 1842.

Erimyzon goodei JorDAx, Bull. 12, U. S. Nat. Mus. 148, 1878; JordaN \& Gulbert, Bull. 16, U. S. Nat. Mus. 134, 18s3; Goode, Fish, and Fish. Ind. U. S. pl. 221,1884 .

Erimyzon sucetta (part) BEAN, Fishes Penna. 27, 1893.

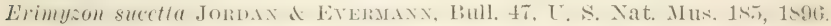

The body of the chul, suchere is oblong, rather olect) and (o)m-

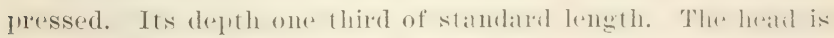

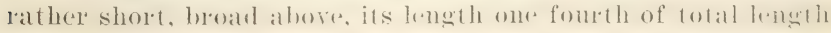

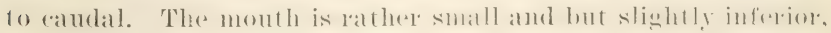
jootractile. The ere is contained five times in lemgth of hemel and slightly less than twice in its distance from tip of stlont. Dorsal short, rather high, platerel in midelle of henghts: rentrals

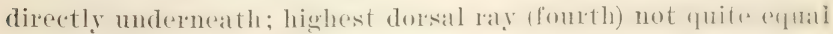

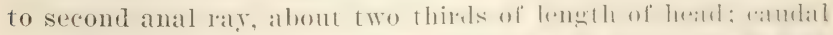

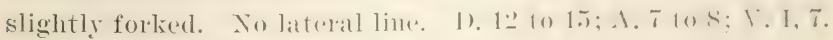
Ścales 37 to 40 ; transverse 13 to 1 .

The chub sucker here destribed is the southern furm which

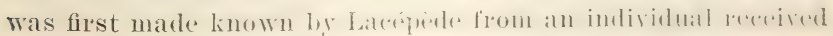


from f hatrleston s. C. Iordan and Evermann now give the disoribution of this form as rextruding from Virginia to Toxas. It alymats a reath a lithle farther northward if the references

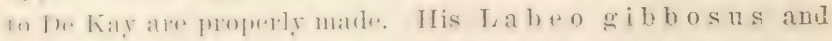
esopus and the Catostomus tuberculatus seem to indicate the southern chub sucker.

The speress reatehes the lenght of 1 fout. It has rery little valut as foul, hut the youmg furmish excellent foud for the larger

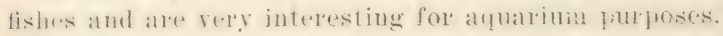

\section{Erimyzon sucetta oblongus (Mitchill)}

\section{Chub Sucker; Creek Fish}

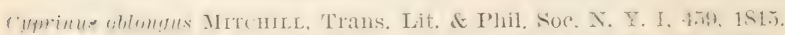

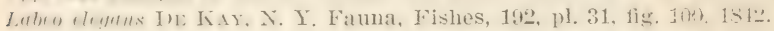

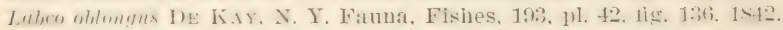
Moxostoma oblongum Günther, Cat. Fish. Brit. Mus. VII, 21, 1868.

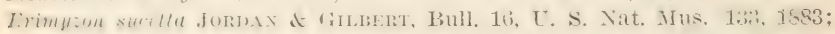

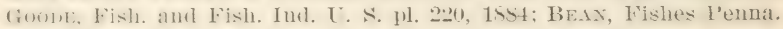
27,1893 (part).

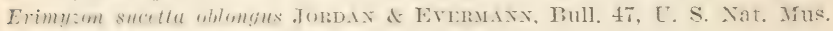
186, 1896, pl. XXXVI, fig. 89, 1900.

The northern chub surker has the body more slender, its greatest devih being less than one third of the total length with-

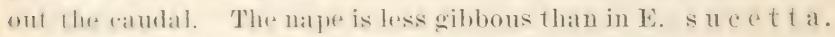
The ramblal ferlunele is more slender, its greatest depth being scarrely one third of the ereatest deptin of the body (two fiftus in s $11 \cdot 6+1$ a). The head is small and short, the ere less than one fifth as lone as 1 lo. learl. the dorsal base shorter and the fins containing fower rays (11 in sucet t a oblo $\mathrm{ngus}, 14$ in s $u \in \in t \quad \mathrm{a})$.

This is known as thu rhub surkerr, sweet sucker, rounded smeliet. wawhlish amd mull, It has a wide range, pratetically im.luling all the waturs of the Inited sitates east of the Rocky mountains.

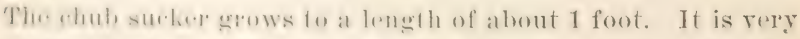

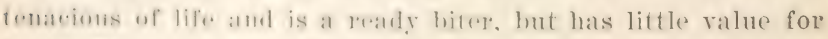

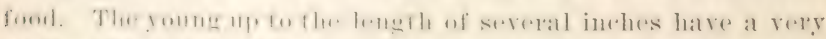

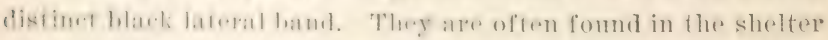

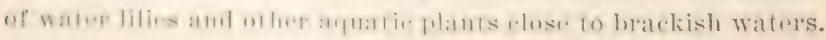


Dr Evermann collerted two specimens in Black ereck, tributary of Oswego river, at Scriba Corners N. Y. July 17, 1894. Dr Meek found it very common about Cayuga and Montezuma N. Y. but did not obserre it near Ithac'a. In the market of New Iork. according to De Kar, the chub sucker makes its appearance in October, Norember and December. Specimens nere seined in Bronx river in August 1897.

A soung example sent from near Princeton N. J. by Prof. Ulric Dahlgren in September 1897 showed the following voluntary change of color. When it arrived, it had the broad, longitudinal, median band well dereloped and the rertical bands obsolete; but soon after it was placed in a tank it obsemred the longitudinal band entirels and developed the rertical bands.

The food of the chub sucker consists chiefly of minute crustaceans, insect larvae and aquatic plants.

\section{Genus moxtrema Jordan}

Body rather elongate, subterete, becoming deep and rather compressed with age; scales rather large and nearly uniform in size; lateral line interrupted in the adult, but with perfect tubes, imperfect in partly grown individuals, and obsolete in the roung; head moderate, rather broad above; mouth moderate, inferior, horizontal; the upper lip well developed, freely protractile; the lower rather small, infolded, inversely V-shaped in outline, lower jaw without cartilaginous sheath; eye moderate, rather high, nearly median; suborbital bones nell dereloged; opercular bones well dereloped, not rers rough; fontanel rather large; gill rakers rather long; isthmus moderate; pharyngeal bones essentially as in M $\mathrm{M}$ x o s to $\mathrm{ma}$; dorsal fin rather short and high, inserted somewhat nearer to tip of snout than to base of caudal; pectoral fins molerate, placed low; anal high and short; rentrals short, midway between tip of snout and hase of caudai; caudal fin moderately forlied, the lobes equal: air bladder with two chambers. Heat in males tuberenlatur in spring. 


\section{IMinytrema melanops (Rafinesque)}

\section{Striped sucker; Spotted Sucker; Sand Sucker.}

Catostomms melanops Riafnesque, Ichth. Ohien. 57, 1820; Krrtuard, Bost. Jour. Nat. 11ist. V, 271, pl. 20, fig. 3̈, $18+5$.

C'utostumus fasciutus Güxtmen, Cat. Fish. Brit. Mus. VII, 19, 1868.

Jinylreme melenops Jordax, Bull. 12, U. S. Nat. Mus. 138, 1STs; Jordax

of Gilbert, Bull. 16. U. S. Nat. Mus. 136, 1S83; BeAn, Fishes Penna. 28, pl, 21, fier. 32, 1893; Jomdan \& Evenmaxn, Bull. 47. U. S. Jat. Mus. 187, 1896, pl. XXXYI, fig. 90, 1900.

Lomy oblong, robust in adults, its greatest dopth one fourth lotal lenglle to base of caudal; head moklerate, suluonical, its lingle (ontatined about four and one half times in total lougth; ry. plarenl high and in the middle of length of head, its dianeter

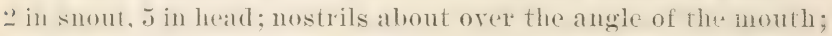
sarales langer, tirm, in about ts longiturinal and 12 or $1: 3$ transrelse lows; dorsal origin orel tip of pertoral, its base as long

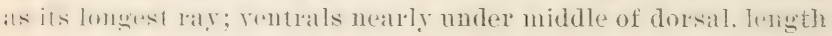

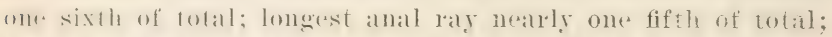

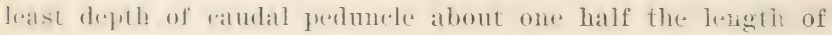

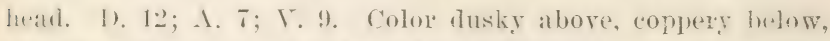
msually a dusliy blotrh behind dorsal fin; scales mostly with a. latk sfun al the hase. the spots forming longitudinal siripes.

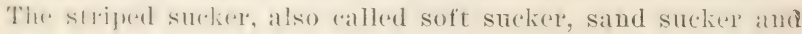

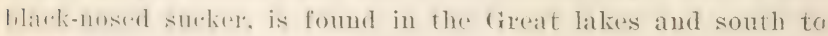

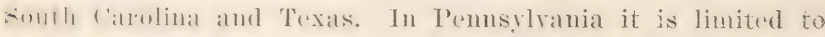
Lak Ere Ereand the ()hio valley. In Xew Iork it is to be expected in Latke (Hutrio and its lleibntalles, and should also oceur in Chautauqua lake.

The striped surekerews to a length of $1 \mathrm{~s}$ inches. ()ld males

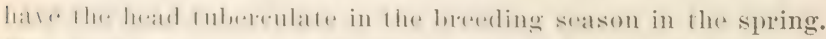

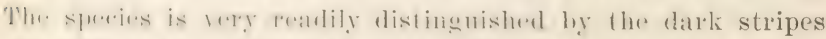

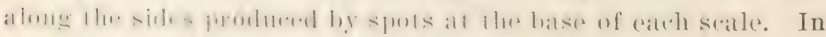
the yommen of this sucker there is no lateral line, but in adults it is almost entire.

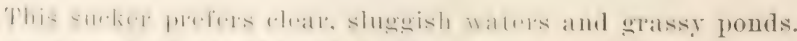

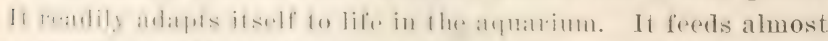

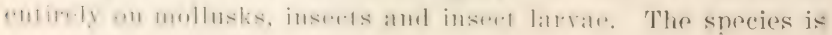


not much esteemed as a food fish, though it is soln in large numbers.

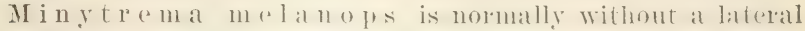
line, but this fature is ocealsionally lat lially developed and has caused some confusion in assigning certitin individuals to their proper genus; indered, one author has described and figmed the striped sucker as two speries, belonging to two different genera, having been misled by this undeveloped character.

\section{Geuns moxostoms Rafinesque}

Body moderately elongate, sometimes nearly roumd, usually compressed; scates large, nearly miform in size; lateral line comfrete, straight or anteriorly curved; head varying in length, subconical; ege usually rather latge, placed moderately high; suborbital bones very narrow; fontanclle well developed; mouth varying much in size, inferiol, the mandible horizontal or nearly so; lips umusually wroll developed, the form of the lowere valiging, usually with a slight mediatu fissmer, but never deeply incised; lips with trausverse folds which are ralely broken up to form papillae; jaws without cartilaginous sheath; muciferous system well developed; opereular bones moderately dereloped, nearly smooth; isthmus broald; gill ratiels weak, moderaterly loug; pharyngeal bones rather weak, the teeth rather coaldese that in Erimyzon and Catos tom us, strongly comperessed, the lower five or six stronger than the others, which rapidly diminish in size upwatre eateh with a prominent internal ensp; dorsal fin nearly median, morlerately long; anal fin short and high, with

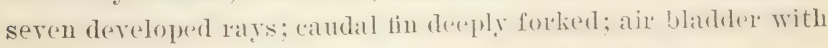
three chambers. (After Jordan and Evermann)

\section{Moxostoma anisurum (Rafinesqüe)}

White-nosed Sucker

Catostomus anisurus Rafinesque, Ichth. Ohien. 54, 1820; Kimtland, Bost. Jour. Nat. Hist. V, 269, pl, 20, fig. 2, 18t5; Stoner, Syn. Wish. N. A. $172,1846$.

Catostomus carpio GüNTher, Cat. Fish. Brit. Mus. VII, 20, 1SGS.

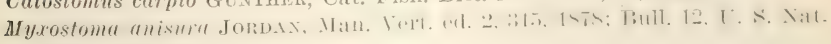
Mrus. 126, 1878. 
Moxostoma anisurum Jorday of Gilbert, Bull, 16, U. S. Nat. Mus. 141,

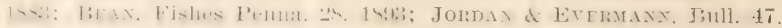
U. S. Nat. Mus. 190, 1896.

The body is elongate litte compressed, slightly arched antetuofly. its areatest dejoth contaned three and one third times in the lingth to ent of scalles. The head is moderate, flat and incad alure, its length less than one fourth of the total without the raudal. Mouth slightly inferior; nuper lip thin, lower smongly l'shapued; eye large, about one haif as iong as the snout, which is rather blunt and does not projert much besond the moulli; fins all well developed. The iorsal is large; its first ray is as long as the base of the fin, or about seren eighths as long as the head. CPper margin of dorsal nearly straight. ?metorals narly reach to rentrals; the upper caudal lobe narlow and lomger than the lower. D. 15 ; 1. 7 to 8 ; T. S. Scales $\therefore$ to 4 - $4: 3$ 10 $44 ;$ to 5 . Mere described in part from a specimen measuring 16 inches, from Ohio.

The white-nosed suclier is found sparingly in the ohio river and the reat lakes region; widely distributed, but nowhere almmbant. Cuvier and Valenciemes rereived from Milbert a

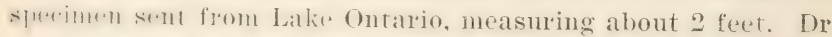
Jordan salys this is rery dosely related to the common red hurse. from whirh it ran hardly be distinguished except by its fins. II Lixrmann collexted a single specimen at Fox island,

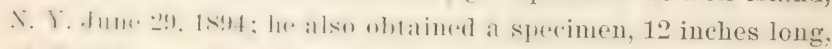

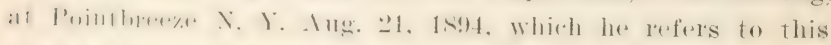

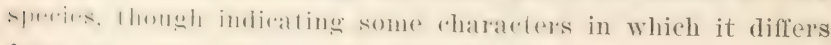
from the normal form of the white-nosed sucker.

\section{6:3 Moxostoma aureolum (Le Sueur)}

\section{lied Horse}

C'utostomins aurcolus LE Simur, Jour. Ae. Nat. Sci. Phila. I, 95, 1817; De K.1Y, X. Y. Famm, Fishes, 201, pl. 42, fig. 133, $18+2$.

Cutratmmus oncidu DE KAY, N. Y. Fauma, Fishes, 19S, 1S42. Oneirla Lake.

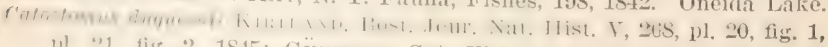
11. 21, fig. 2, 1815; Gïмтmen, Cat. Fish. Brit. Mus. VII, 18, 1868, Foughiogheny River, Pa.

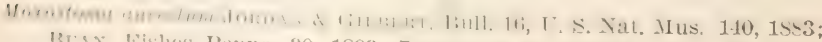

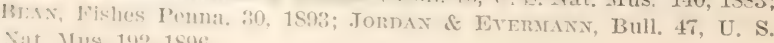

fiat, Mus 1!12, 1896! 
Bods oblong, the back in front of dorsal elevated and compressed, head short, conical, broad betwern eyes. The ere is rather large, one fomth length of head, which is contained tive times in total length without raubal. The depth of the body is contained three and one half times in this length. Cauml peduncle derep, compressed, its least depth equal to one half the length of head; mouth small; the snout some what jrojecting: fins all well dereloped; the anterior rays of dorsal longest, is long as dorsal base, pectoral or longest aual rays, equaling length of head; caudal forked; seales large, about equal in size all orer the body, and finely striated. I) 1.5; A. S. Sicales li thi -6 ; lateral line complete.

The red horse has the additional names of golden red horse. golden sucker, mullet, golden mullet, and lake mullet. It inhabits the Great lakes and the region northward, also the Ohin valley. It is common in Lake Erie but not in the Ohio.

This species grows to a length of 18 inches and is one of the handsomest of the suckers. Prof. Forbes records it from lalies of northern Illinois, also abundantly in the central part of that state.

Dr Erermann, in collecting fishes of the Lake Ontario region, secured it at the following localities: Lake Ontario, 4 miles off Nine Mile point, N. I. June 12, 189:3; lake shore, 3 miles west of Oswego, July 17, 1894; mouth salmon rirer, July -2.5, 1894; Long pond, Charlotte N. Y. Aug. 17, 1s94; sandy ereek, North IIamlin N. Y. Aug. 20, 1894.

Dr. Meek identified a single sperimen of the so called common red horse of Cayuga lake with II oxostoma ma erolw. pidotum, and stated, on the authority of Mr Kipp, that it is common at the northern end. Jordin and Evermann, howerer.

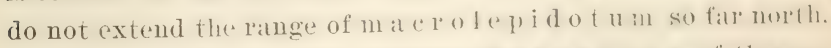

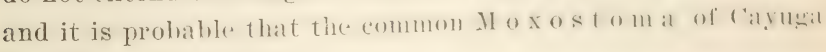
lake is M. a $\mathrm{ur}_{\mathrm{r}} \mathrm{O} 1 \mathrm{um}$.

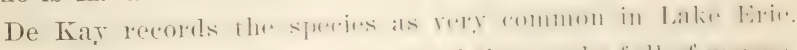

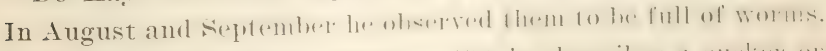

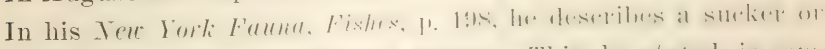
mullet under the name (Ineidal surlier. This, he stated, is com 


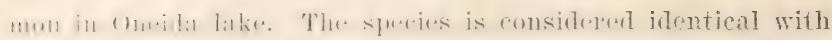
Il oxostoma a $n$ re ol $\mathrm{nm}$. Fis description shows a rery close agreement with that of a $\mathrm{ur}$ e o $1 \mathrm{um}$ giren abore.

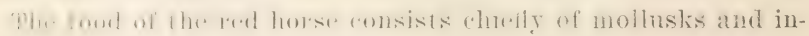
secrs. It is not a choice food fish.

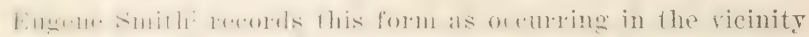

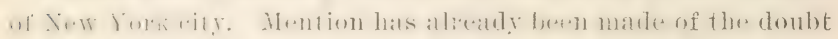

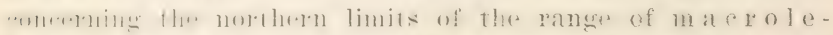

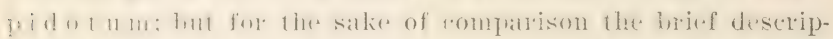

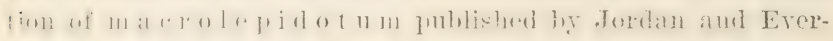
mann is giren herewith.

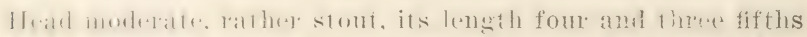

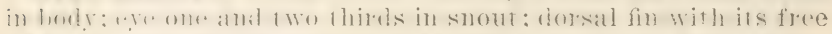

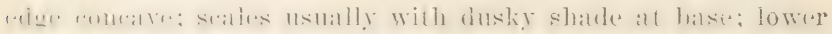

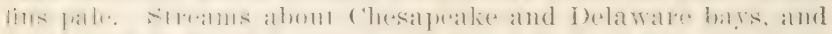

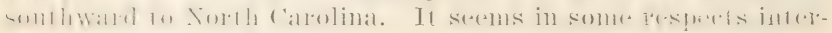
mediate between II. a u reolum and M. crassilabre, lut we can not at present identify it with either.

\section{Family CXPRINIDAE}

\section{Carps}

\section{Genus campostom Agassiz}

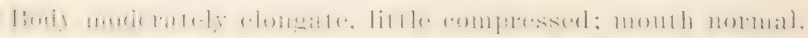

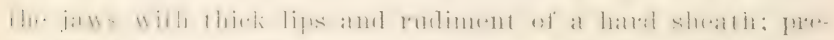

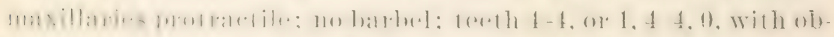

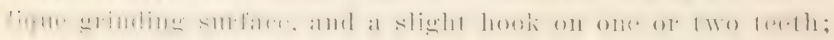

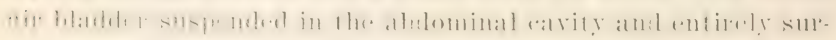

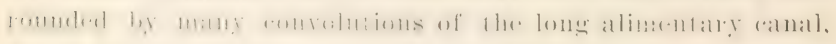
which is six to nine times the total length of the body; ovaries

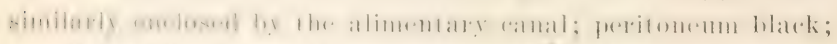

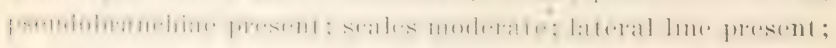
dorsal nearly orer ventrals; anal short; no spines. Herbivopons. Sexual dilferences rery great, the males being covered with latere tubereles in spring. The singular arrangement of the intestines in relation to the a ir bladeler is peenliar to $\mathrm{Ca}$ m1) os tom a among all known fishes. (After Tordan and Everm:11111

'1.inn. Sur. x. Y. Irox. 1897. no, 9, p. 11. 


\section{Campostoma anomalum (Rafinesque)}

\section{Stone Roller; Stone Lugger}

Rutilus anomalus RAFixesque, Ichth. Ohien. 52, 1820.

Exoglossum dubium Kirtlaxd, Bost. Jour. Nat. Hist. V, 272, pl. 21, fig. 1, 1845 .

Campostoma dubium Güxtrier, Cat. Fish. Brit. Mus. VII, 1S3, $18 c 8$.

Compostoma anomalnm Agassiz, Amer. Jour. Sci. Arts. 218, 1555; Jordax \& Gilbert, Bull. 16, U. S. Yat. Mus, 149, 1883; Bean, Fishes Penna. 32. 1893; Jordar \& Evermaxy, Bull. 47, U. S. Nat. MIts. 205, 1596, pl. XXXIX, fig. 95, 1900.

In the stone roller the body is moderately stout and not

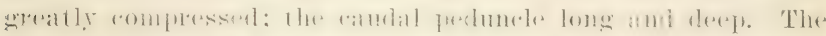

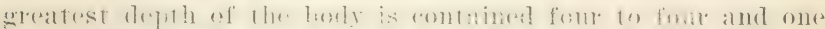

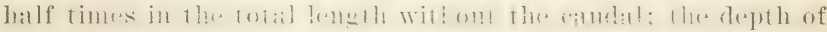

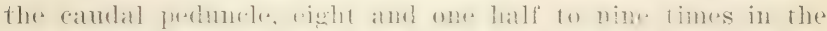

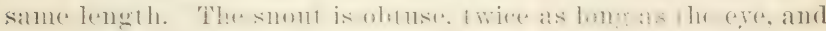

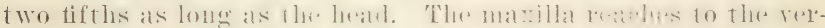

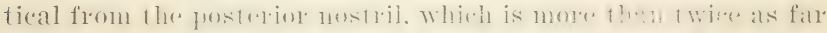

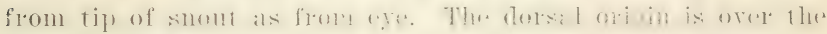

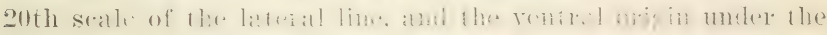
19th. The dorsal base is one half and its longest ray two

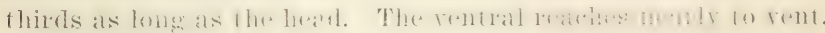

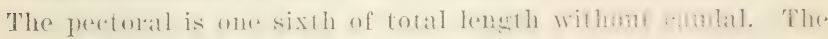

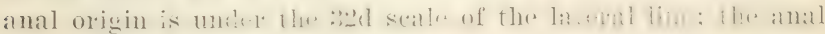

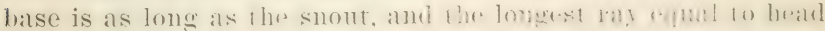

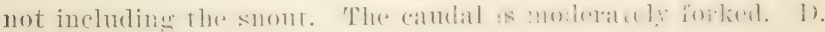
8; A. 7 or S. Scales $8-52$ to อั3-8; teeth 4-4.

Color in spirits hownish above lower pans mats. In living

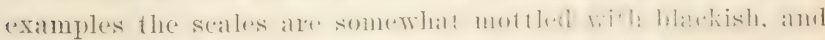

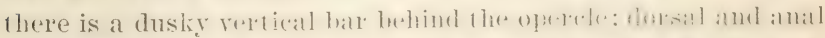

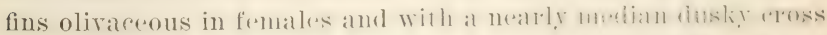

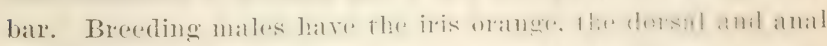

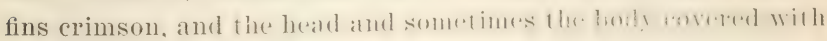
large roundish tubercles.

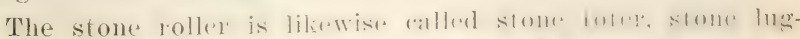

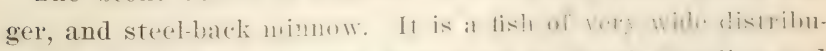

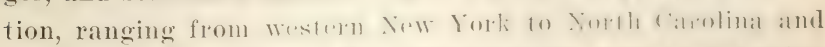

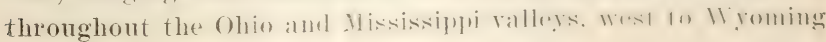




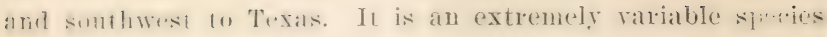

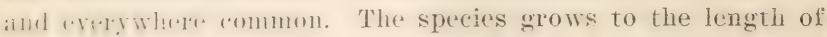
righl imelirs. It has mo importance as food for man. It feeds

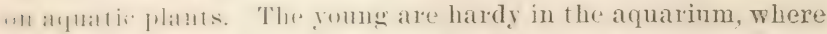
Hher fiad on ronfervate and diatoms. The sexes are rerg unlike.

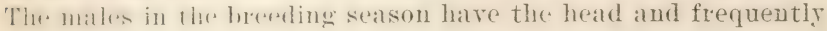
ihe r.mire houly envered wilh large tubereles and the npper half

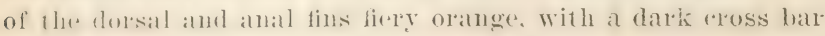
about the middle of these fins.

Thr. dish is rather sliggish. but when frightemed its morements are rery rapid. It is a bottom feeder.

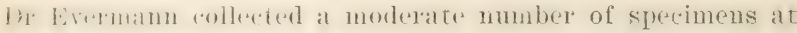
the following Vew Vork localities: Salt brook, $1 \frac{1}{2}$ miles abore

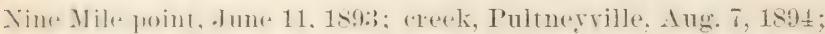

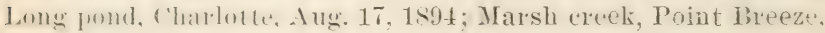
Aug. 21, 1894.

\section{Genus cmrosomus Rafinesque}

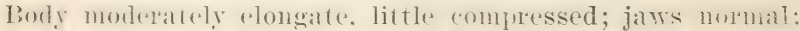

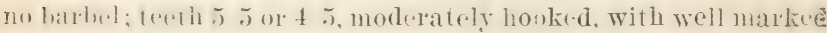

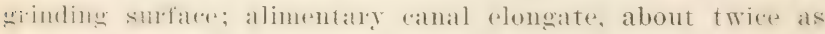

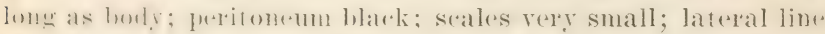
slort m. Wanting; dorsal lwhind rentrals; anal basis short. siz. small. folors in spreing brilliant. the pigment bright red. This m-111s is of sommohat doubtful relationship. and shows

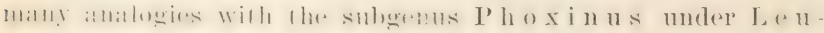
ciscus. (After Jordan and Evermann)

\section{Chrosomus erythrogaster Rafinesque}

\section{Rea-bellical Dace}

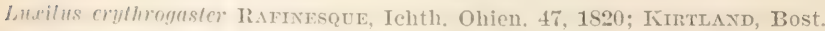
Jour. Nat. Ilist. IV, pl. II, fig. 2, male and female, 1844.

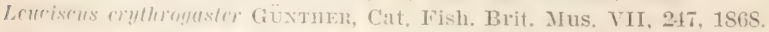

Chrasemas eryllmutester Cope, Trans. Am. Plil. Soe. XIII, 391; Jordax \& firmant, 16ull, 16, U. s. Nat. Mus. 15:3, 18S3; BeAn. Fishes Peuna. 32.

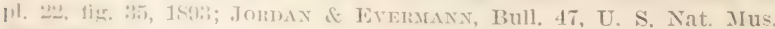
$2019 \% 18541 \%$

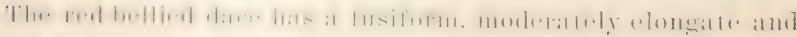
thiek body, whose ereatest hight is contained from four and 


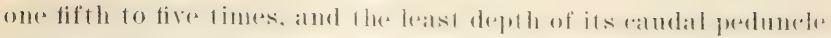

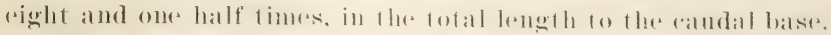
The head is conical with pointed snout as long as the eye, which is about one fometh as lomg as the head. The head enguals one fourth of total length fo atulal hase. The maxilla realehes nearly to below the front of the eye. The lateral line varies in developmestesometimes reatehing to abore the origin of the

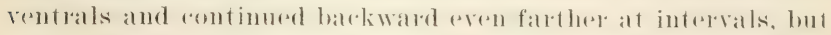
usually not extending to rentrals. 'The thosal origin is over

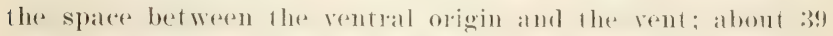
rows of scales between it and the nape. The dorsal base is one half as long as fles head: the lomgest raly expuals head with-

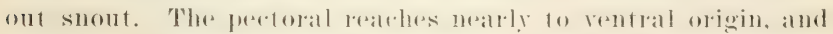
the rentral reatehes rent. The anal hase is 1 wo fifths as lomer as the head: the longest ray equal to longest of the dorsal. The ratudal is moderately forkede its midelle rats two thirds as long as the outer. I). 8; 1.7; V. 8; P. 12. Scales 18-80

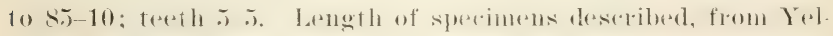
low creek, 3 inches. I narrow dusky line along the top of the batek; two natrow, datli batnds on the sides. the lower one fassing forwated on the head to tip of suont; the spate betweren the bands and below bright silvery. Brereling mates hatre the bases of the dorsal, anal and atudal fins and the areal betweren the dark batnds seatrlet, while the hody is anteled with minnte tubercles, and the fins generally are rivid yellow.

The I. S. Fish fommission pattirs ohtatimed this mimmom at

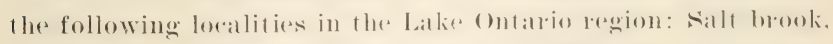

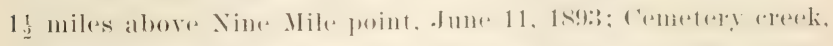

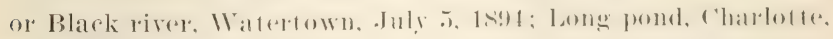
Aug. 17, 1894. I am muble to find a reference to this species in the works of Mitehill and De Kaly.

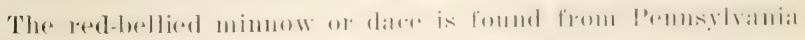
to Dakota and Tennessee. Tt is abundant in small streams, and is a strikingly beautiful fish. Along the sides are two

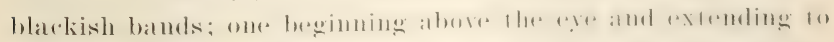

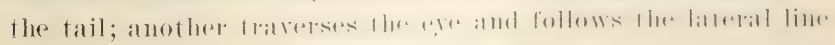


to the base of the (atudal. where it ends in a black spot. The belly and the spate befween the bands are bright silvery, replated by scarlet red in heredimg males, which have the same rolor at the bases of the dorsal, caudal and aual fius. In the hight of the breseling season the fins are bright yellow, and the body is coresed with small tubereles. Aceording to Prof'. cope the redthellied minmow is not found in the Delaware, but it oreurs in the susqueliamma and is common in the streams of western l'emsylyania. It reathes a length of $;:$ incles, and is similar in its halhits to the stone roller, with which it asso. riates. It prefers clear streams, which have their origin in springs. Is an aquarium fish this is seareof excelled in beanty and hardiness, and as a bait for the blark bass it has few superiors.

\section{Genus minognathus Agassiz}

Body rongate, somerhat compressed; mouth horizontal, the jaws normal, sharp edged; lower jaw with a slight, hard protuberanee in front; no barbel; npper jaw protracile; feeth 1 4. cultriform, with oblique grinding surface and little if any hook: alimentary canal elongate, three to 10 times the length of the body; peritoneum black; seales large; lateral line confinmons: dorsal inserferl before rentrals; anal basis short. sige moderate. Sexual thamges rery slight, no red or blitck pignent distinguishing the males in spring. Species mumeroms. mostly southwestern, not well known.

\section{Hybognathus nuchalis Agassiz}

\section{Sitrery Minnow}

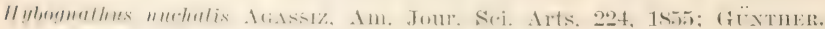
Cat. Iish. Brit. MIus. VII, 184, 1868; Jordan \& GILbert, Bull. 16,

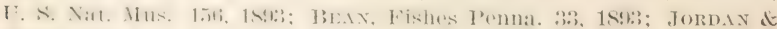
Evmmax, Bull. 47, U. S. Nat, Mus. 213, 1896.

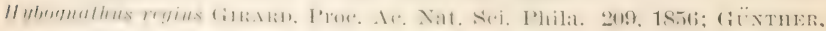
Cat, Fish. Brit. Mus, VII, 185, 1S6S.

H!hum river, N. J.).

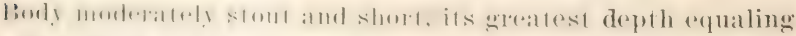

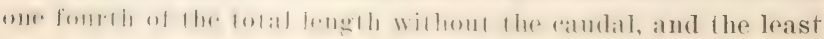


depth of the caudal pedunele equaling nearly one half of the greatest depth of the body; hody compressed, its greatest width less than one half its hight. Head short, its upper and lower profiles tapering equally into the short and not very obtuse snout, which is as long as the eye. and three elevenths as long as the head. Mouth small, slightly oblique, the jaws nearly equal, or the lower slightly included, the maxilla without a barbel, and reaching to below the anterior nostril. The dorsal origin is over, and the rentral origin under, the 12th seale of the lateral line. The dorsal base is two thirds as long as the head; the longest dorsal ray equals the distance from the nostril to the end of the opererulum, and the last ray is less than one half as long as the longest. The rentral does not reach to the vent; its length two thirds that of the head. The anal origin is under the 24 th scale of the lateral line; the anal base is scarcely as long as the postorbital part of the head; the last anal ray is one third, and the longest anal ray two thirds, as long as the head. The perctoral is four fifths as long as the head, and reaches to below the 11 th sale of the lateral line. The caudal is moderate in size and deeply forked, the middle rays less than one half as long as the external rays. 1). ii, 7 ; $\mathbf{A}$. ii, 7; V.s; P. 15. Avales $6-38$ to 39- - t: teeth $4-4$ long, much compressed, and with a loug oblique grinding surface. Intestines seren to 10 times as long as the body. The lateral line is gently decurved on about the first six sales, thence straight and median to the root of the caudal fin. Color in spirits light brown with a broad silvery band, the fius all pale. Olivaceous green above, translucent in life: sides silvery, with bright reflections; fins unspotted. Length 4 to 7 inches.

The silvery minnow, or blunt jaw, is found in clear streams from New Tork to Georgia and Texas, west to the upper Missouri. In the Potomar rivel weurs a latege variesty which reaches a length of 7 inches. This variety has a larger eye and a deeper body than the western form.

The L. S. Fish Commission colleretors in the Lathe (Ontarion region obtained specimens at the following localities: Salt 


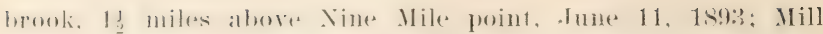

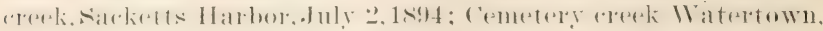
July 5, 1894. The fish was most abundant at Mill creek.

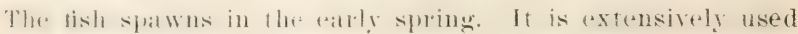
for food along with the Notropis hudsonius, the so

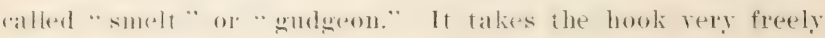
during the spawning season.

\section{Genus mompales Rafinesque}

Bodr rather robust, little compressed; head short and

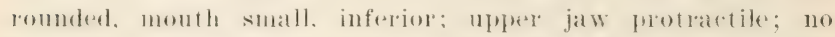
barhel; teeth 4-4. with oblique grinding surface, usmally only one of the tresh lookled dorsal orer ventrals, its first frudi-

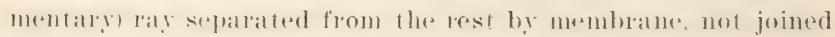
to them as nsual in mimmos, this rhat:arter mosi distinct in adult males, in which the skin of the tirst ray is thickened: anal basis short: intestinal ranal elongate: feritonemu blatk:

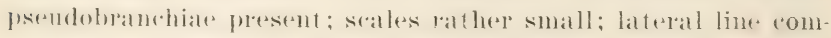
plete or variomsly incomplete. Sizte small. Breeding males with much blarli pigment and with largere warts on the head. elfter Jordan and Evermann)

\section{Pimephales promelas Rafinesque}

\section{Fathead: Blachlead Himnow}

Pimephules momeles Iiafresque, Iehth. Ohien. 53, 1820; Kinthaxin, Bost. Jour. Nat. Hist. II , 475, pl. 27, fig. 2, 1841; Stonen, Syn. Fish. N. A. 166, 18t6; Gïтнея, Cat. Fish. Brit. Mus, VII, 181, 1868; Jordax \& Gutвепт, Bull. 16, U. S. Nat. Mus, 158, 1883; Brax, Fishes Penna. 35,

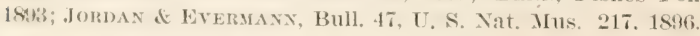

Ther fathead minmow has a shome de+e and modelately thick ludy and the head short with a very ohtuse snomt. The greatest

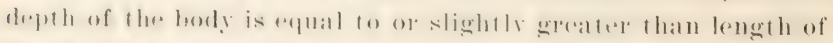
lereat and is antained from there and 1 wo thirds to four and one

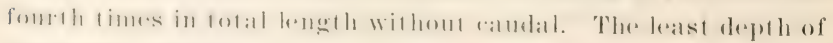

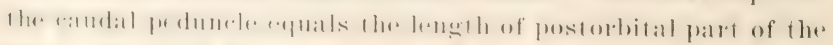

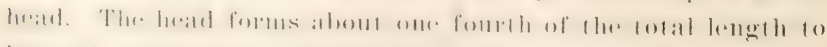
base of eandal; the width of the head cquals two thirds of its

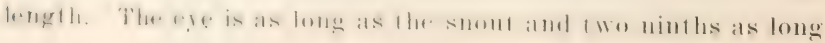


as the head. The month is very small, terminal, slightly oblique; the maxilla not rearching rertial thromgh hinder nostril. The dorsal origin is above, and the ventral origin below the 21st srate of the lateral line. The dorsal batse is two thirds as long as the head; the first ray is about as long as the ege, and the longest as long as the head without the snout. The ventral reaches a little luepond thes anal origin; its length equal to dorsal base. The anal base explals neatry one half the length of head, and the longest ray is as long as the dorsal base. The caudal is moderate and not deseply forked. The lateral line is continnous on about 20) to 2 s' sales, and in one specimen continued with interluptions almost to the candal base. I). i, s; A. i. 7 ; V.

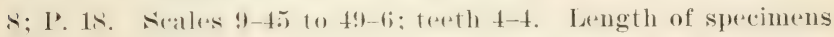
described, 3 inches. Color in spirits light brown, top and sides of head darkel. I hroad dark band on the base of the dorsal, most distinet anteremly and sometimes absent behind. Males in spring ate dusky, with blatk head and the snout and rhin with numerous coarse tubercles.

The fathead or blatekhead is an inhabitant of the Ohio valley. and the (areat lakes region west to lobkotal and southwest to Texas. It is eommon in sluggish broolis. and instanees hate besen known of its distribution by the artion of cyclones. In Pennsylvania it is common in tributaries of the Ohio.

The T. S. Fish fommission has obtained speedmens from the following localities in the basin of Lalie (Intario: Salt brook,

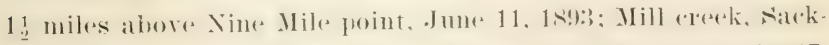

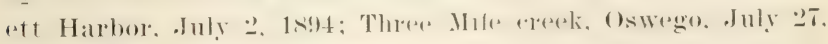
1894. where the greattest number of molividuals was taken. Dre

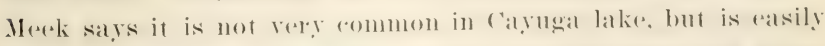
distinguished from the other minnows by its rery long intestines.

The fatheatd glows to a lexgth of 23 inches. The sexes differ in rolor, the females being olivareoms. While the males ame dustay and in the spring hate the head blate and the smout restered with numerous latge tuluereles. The speecies hats no value ats food, but is an interesting one for the atmatrimn. Its food consists of mud and algate. and it serems to forefore a mudely boltom. 


\section{Pimephales notatus (Rafinesque)}

\section{Blunt-nosed IInnow; Spotted IIinnow}

Minnilus notatus RAFINesque, Ichth. Ohien. 47, 1820.

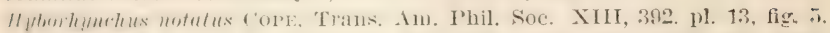

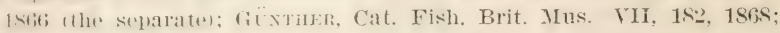

Jordax \& Grlmert, Bull, 16, U. S. Nat. Mus. 159, 1883.

Pimephales motutus Jomux, Cat. Fish. X. A. 22, 185.; Beax, Fishes Penma. 36, 1893; Jordan \& Evermans, Bull. 47, U. S. Nat. Mus. 218, 1896.

The humt-nosed minnow has a modexately elongate body and a slemeler candal pedumele. The head is somewhat eonieal with a short and hlunt smout. The greatest depth of the body nearly ryuals lenglh of head and is two ninths of the cotal length withent ramdal. The least depth of the caudal peduncle eyuals about one half of greatest depth of body. The suont is as long as the cye and one fomth as long as the head. The mouth in very small, inferior. nearly horizontal, the maxilla reaching to below the anterior nostril and provided with a short, thick, somewhat elub-shaped harbel. The dorsal origin is slightly behind the rentral origin and over the 17 th seate of the lateral line. The dorsal base is two thirds as long as the head, and about equal to the longest ray. The rentral origin is under the lith stale of the lateral line; the fin does not reach to the vent. The anal origin is undere the 27th seale of the lateral line; the hase of the anal is two tifths as long as the head, and the longest ray is rymal to the postorbital part of the head. The caudal is moderately large and forked. The lateral line eurves rery slightly downward ats far as the rentlal origin and then follows

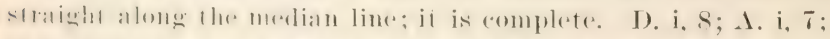

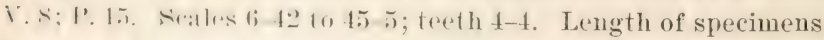
described.: inclues. color in spririts light brown; the fins except

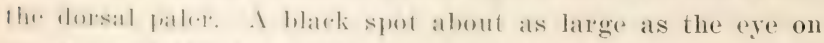
llar from of the dersal. In life the sides ale bluish. Breed ing males hat1. Hhe halek on the dorsal continued batekward on Itre memblatue andering the latys and the head blatek, while the

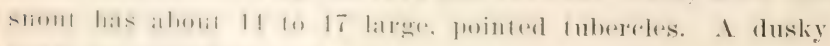
shace sometimes present at base of candal. 
The blunt-nosed minnow is a larger species than the fathead, reaching a length of 4 inches, and its range extends from Quebec to Delaware, west to Kiansils and south to Mississippi.

B. W. Evermann and IP. A. IBean obtained it for the I. S. Fish fommission in the st Lawrence river, :3 miles below Ogdensburg, July 17, 18\%4, in abumdance. They found it common also at seioto ereek, Coopersville X. Y. July 19, 1894. In the Lake Ontario region the Fish Commission collected the species at Cape Vincent, (irenadier island, sarelietis IIarbor, Pointbreeze, IIuntingtonville, Charlotte, Stony Island, Pultueyville, Chaumont, Irrmlerson bay, and Salt brook. Livingston Stone obtained the fish at calpe Vincent in the sit Latwence river, and presented it to the state musemu at Albany. It is found in large numbers in the southern end of 'alyga liake, and in streams on the flats. Not very abundant at the northern end of the lake and in streams near Ithaca, above the falls, aceording to the records of Dr Seth E. Meek.

The blunt-nosed minnow differ's from the fathead in its larger size and in having a complete lateral line, but the sexual differences are similar in the two species. The males in spring have the head black and the snont with many large tubercles. The species is extremely variable and changes greatly with age. It frequents small and muddy streams, and its food consists of decaying vegetable matter.

\section{Genus semotmus Rafinesque}

Body stont, moderately compressed and elongate; mouth terminal, wide, the rpler jaw protraletile; a small barbel just above the end of the maxillary; in most Ameriean minnows the barbel is at its tip; the maxillary barbel sometimes absent in young individuals; teeth $2,5-4,2$, hooked, without grinding surface; scales rather large; lateral line complete; a short intestinal eanal; dorsal placed behind remtrals; base of anal short. Vertebrae $22+20=4 \%$. Fisques of large size in clear, swift streams from Canada to Tirginial, Wrest to Missouri and Wyoming. 


\section{9) Semotilus bullaris (Rafines(que)}

\section{Fullfish: Wind Fish; Dace; Chivin; Situer Chub}

(yp)inus bulluris RAFnesqCE. Amer. Month. Mag. II, 120, Dec, 1817.

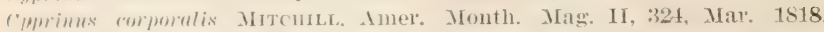
P'revious notice in same work, vol. I, 2S9, July, 1817, insutficient to hold name. The Corporaalen of the Inteh, moreover, was the striped speceies. atromaculatus.

semotilus bulluris Jordax. Man. Vert. ed, 1, 1Sit; Jordan \& Gildert, Bull. 11;. I. s. Xat. Mus, 2.2., 1853; Beax, Fishes Penua. 50, pl, 24, tig. +1. 1s93: GоOne, Fish. \& Fish. Hud. T. S. pl. 228, upper tigure, 1884.

lenciserk nitilus DeKay, X. Y. Famm, Fishes, 209, pl. 33, fig. 105, 1842. Lake Champlaiu.

Lencisens chrysepterus DE Kar, N. Y. Fauma, Fishes, 211. pl. 30, tig. 45 (poor), 1842, harbor of New York.

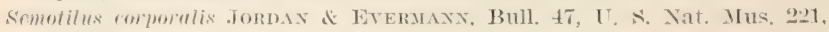
$1 \times 9 \%$

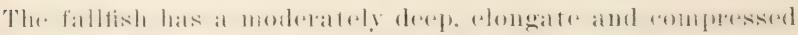

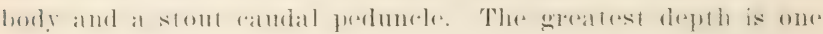

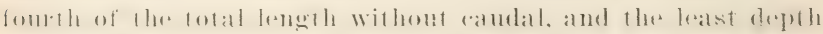
of the pedumcle equals three eighths of length of hesd. The

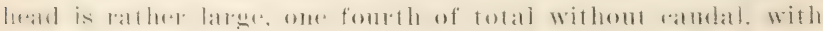
fminted smout. Which is two serenthe of the headts lemgth. The

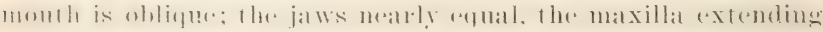

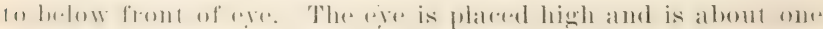

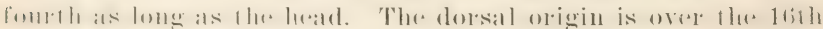
or 17 th seale of the lateral line; the base of the fin is one half.

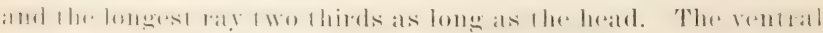
origin is monder the 15 th seale of the lateral line; the fin does not

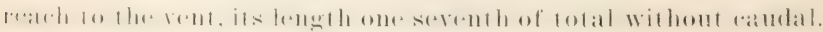
The anal origin is monder the 27th seale of the lateral bine: the

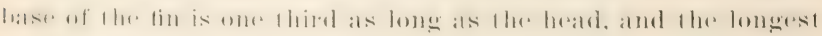
lay is as long as the ventral. The candal is latroe and deeply forkel. The lateral line emres downwad abruptly orer the jertoral. beroming median over the end of that fin. I). ii, 7 ;

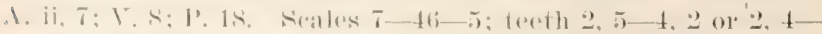
1, 2. all more of less strongly hooked. In spirits the upper parts are gratyish boown, the sides and rheeks silvery, the lower parts

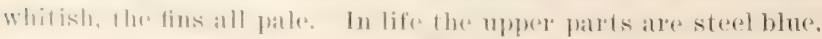
the sides amd buly silvery; brending males in spring have the 
belly and lower fins rosy. The specinens described, no. 9202. U. S. National Musemm, are from 5. to $6 \frac{1}{1}$ inches long.

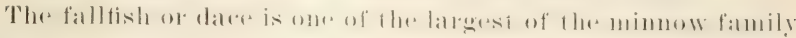
in Sew York, reaching a length of 18 inches, and it is one of the most beautiful species as well as game in its qualities. Is a

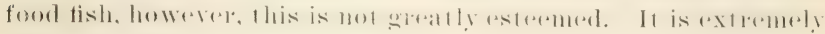
common in the belawate rivere and its tributaries and moder.

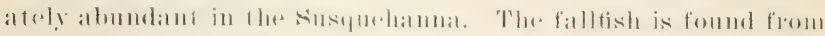

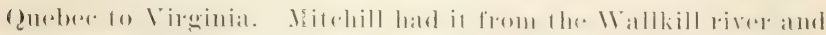

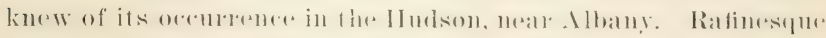

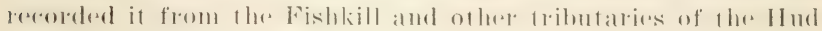
son. I) Ka! linem it from Lalke ('hamplatin and from Xem lork harbor. Evermann and Bean collected it in Scioto creek, at

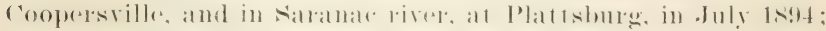

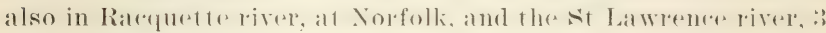
miles below Ogdensburg, in the same month.

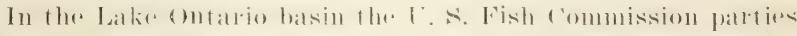
found it at Nacket Harbor, ("enterville, Watertown, Oswego.

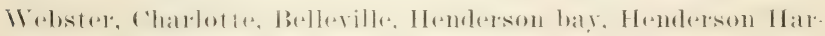
bor, and Salt brook, near Nine Mile point.

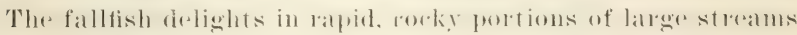
and in thre derel rhamnels. ()n boing heoked, it tights despere ately for a short time, but its resistance is soon overcome.

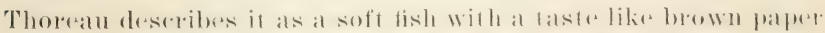

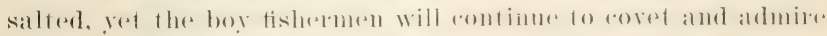
this hamdsome and ubignitoms representative of the minmow

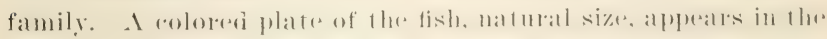
3d. Ammat Report of the Commissioners of Fisheries. Came and Forest of the state of New York, 1s.9s, facing p. 146. There is also a good aceount of the fish by A. N. Cheney on p. 24t and 245 of the same repolt.

70 Semotilus atromaculatus (Mitchill)

\section{Horned Dace: Chub}

Cyprinus atromeculatus Mtтculde. Imer. Month. Mas. 11, 324, Mar. 181s. Wallkill river.

Leuciseus atromaculutus TDE KAY, X. Y. Famma, Fishes, 2210, pl, 322, tign, 102. $18+2$. 


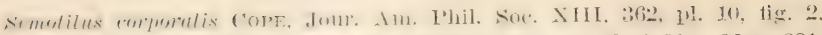

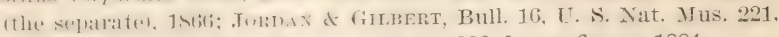
18s3; Goode, Fish. \& Fish. Ind. U. S. pl. 228, lower figure, 1884.

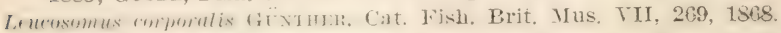

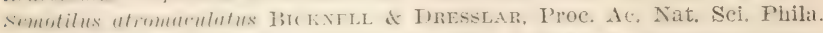

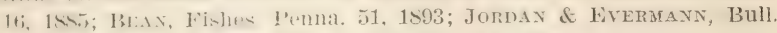
47. 1. S. Xat. Mus, 2..... 14.4ti; pl. XL, fig. 100, 1900.

The vhub, has at shendx and moderately elongate body, its greatest hight inmenliately in front of the rentrals, about equal to the lremelt of the head without the snout and contained from fonr on menty tive times in the total length without the caudal. The greatest thirkness of the hody is about two thirds of its wreatest hight. The head is thirker than the body aud rather slont will an obluse and moderately declivous suont, whose lengell is abont two sevenths of that of the head and considerably grealler than the dianeter of the eye. The ere is rather small, flared high, is diameter nearly one fifth of the length of

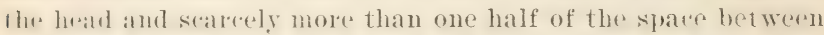
the eres. The mouth is moderate, very slightly oblingur, the jalls subeyual or the lower slightly included; the end of the maxillat rarbes rery slight ly past the vertical through the fromt of llu tre. Maxillary barkel not evident in this example. fhomgle nsmally pesent in latege individuals. The lateral line is ahruply bent downward over the first half of the pectoral, straight and nealy median during the rest of its course. The origin of the dowst is over the 27 th suate of the lateral line. and thr rentual origin is moler the etth seale. The length of

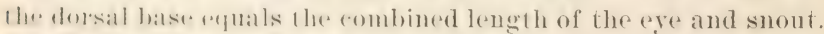

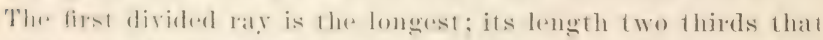
uf thr. lowal. Thlu last lay is one half as lomg as the longest.

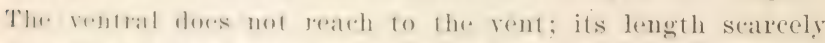

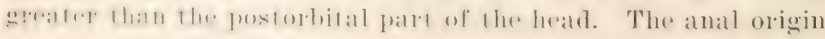

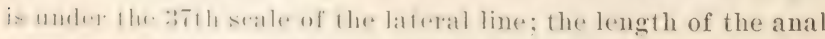
hat 5 is a lithle mome thatl ome thirel that of the heate and the

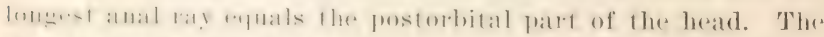

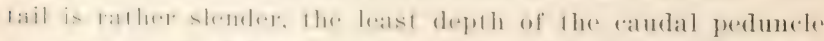

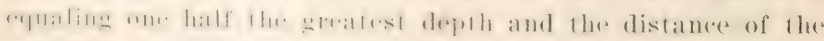

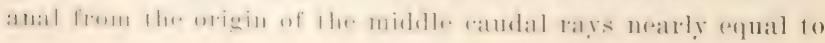


the length of the head. The pectoral when extended reaches to below the 16th scale of the laterat line. The caudal is moderate in size and not very deeply forked, its middle rays being ahout two thirds as long as the external rays. I) ii, 7 ; $\Lambda$. iii, s:

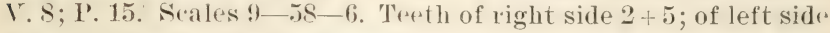
$2+4$. Those of the left side strongly and those of the right side less strongly hooked. Treth of the upper row with a well developed grinding surface.

The length of the specimen described, no. 216ti1, I. S. National Museum, from the suscpulamna river at Bainbrige Pa., is 4 ! inches.

The color is bluish brown above; sides with a distinct dusky baud, not so wide as the eye and becoming obsolete in the adult. Young spereimens hate the end of this band more pronounced, forming a black spot at the base of the caudal. A small black spot always mesent on thr front of the base of the dorsal, its size in the specimen described being about two thirds of that of the eye. In life the belly is whitish. Breeding males have the belly rose tinted and the black dorsal spot bordered with red; they have, also, rather large tubercles on the snout.

The common chub, creet chub, smaller fallfish or horned dace has a wider distribution tham $\mathrm{s}$. bu $11 \mathrm{lar}$ is, but it does not grow quite so large, seldom exceeding 1 foot in length. Its range extends from Nen England to Missouri, southward to Georgia and Alabama. It is extremely common and ascends the small streams.

The U. S. Fish Commission collectors in 1894 took numerous specimens at the following localities: Sacketts Harbor, July 2; Centerville, July 24; Watertorn, July 5; Oswego, July 25; Tebster, Aug. 9; Charlotte, Aug. 17; Belleville. July 12; Шеnderson bay, July 4; Henderson Harbor, July 3, and Salt brook,

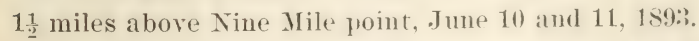

Dr Meek reported it as abundant throughout the Cayugal lake basin. Large examples are foume in Camandaigua lake. One of them measured 14 inches in July 1897 . The fish is lilled by 


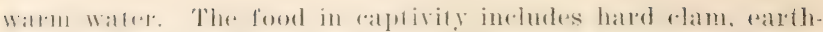
worms, and, oceasionally, live killifish.

1. N. Cheney refers to this species on page 245 of the $3 d$

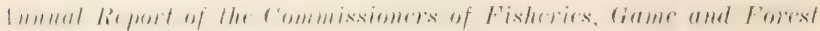
of the state of Vere lork.

In l'emsthaniat it is the (ommonest minnow in the Allegheny

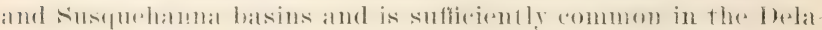
wate. Accombling to Prof. Cope it reaches $t$ pounds in weight and is a fair food tish.

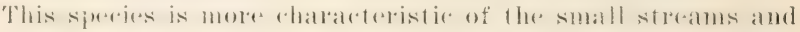

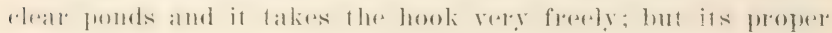

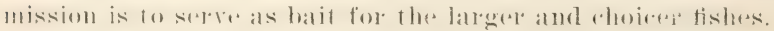

\section{Genus Tryca Cuvier}

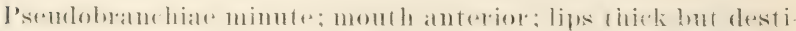

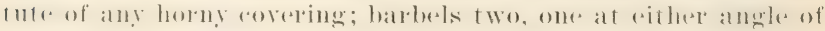

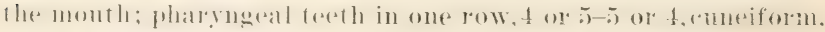

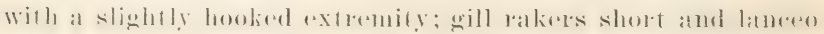

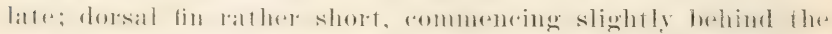

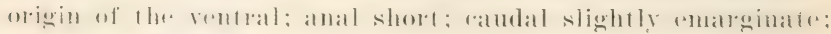

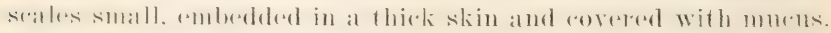
Latrial line complete. (After Day)

\section{.71 Tinca tinca (Linnaeus)}

T'ench (Introduced)

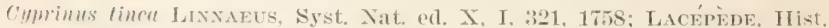
Nat. l'oiss. V, 491, 5.933, 1800.

T'incu velgaris Curier of VAlexcrennes, Hist. Nat. Poiss. XYI, 322, pl.

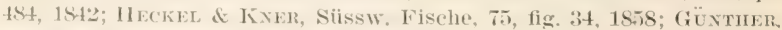
Cat, Fish. Brit. Mus. VII, 264, 1Stis.

Tinat tincu Jompax \& Evemaxx, Check List Fishes N. A. 512, 1896.

13. 3; 1). 12 to 13 (s or 9 developed); P. 17; T. 9-10; \. 9-10.

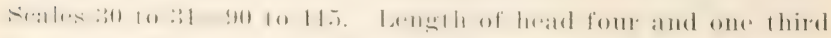

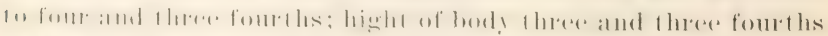

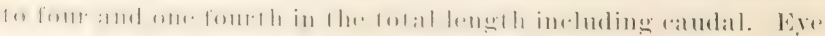
six and one half to seven and one half in length of head; two and one fourth in lengeth of snont; f wo to two and one fourth in distance hetwern eyes. Interorbital space llat. The thickness 
of the head equals its length exclusive of the snout. Snout

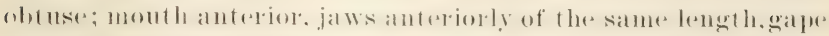
wide, eleft rathere shallow: the maxilla reatehes te beneath the posterior nostril; lips thick. iborsal origin were the end of the ventral base, and the fin extends almost to above the anal origin; all the fins romeded. Ln the mates the tirst or eren more of the ventral rays are thicker than in the female. Lateral line

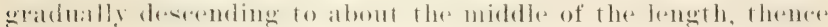

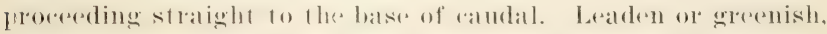
lightest beneath; tins blackish.

The tench has been introduced into the United States. An individual taken in the Potomate live neat Washington l). ('. liats a grinding surfare well developed on the pharyngeal tereth. a chatrater conererning whith no mention is made in the curent descriptions.

The temele now extends thromghout the fresh waters of Europe into those of Asiat Minor. Its northern limit is sald to be in Finland. It maly or maty not be native to England. The speecies prefers still waters in which alpuatio plants abound. It is rery tenacious of life and has beren observed to live a whole day out of Water. Its food consists of inserets, larvare. Worms, and regetable substances.

Spawning lakes place in hume and July. The regges are smatl and adhesive. The rate of growth is ratlere rapid under fator-

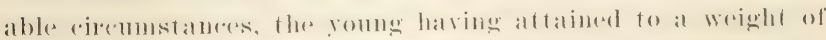
1 pound in their tirst yeatr. Individuals of the weight of $10 \mathrm{or}$

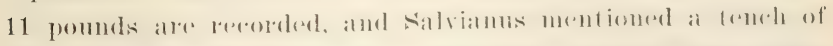

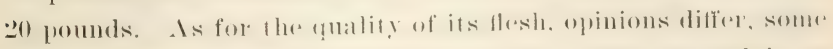
persons ronsidering it muplatable, while others regatrd it as delicious and wholesome.

\section{Genus haciscos Guvier}

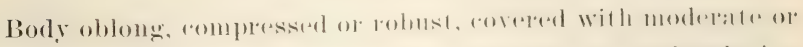

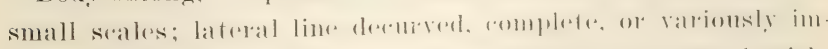

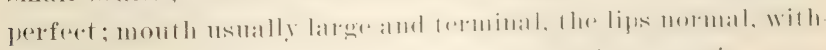
out barbel; teeth mostly $2,5,-4,2$ (in American species some 


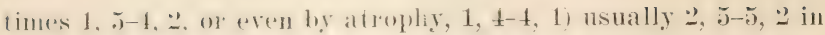
lhe European 1ype. houled, with rather narrow grinding surfate or nome: anal hasis short ol mole or less elongate; dorsal lin posterior. msually hehind ventrals: intestinal ranal short.

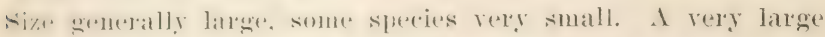

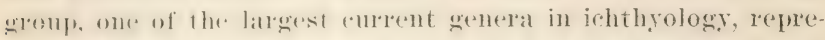
senterl hy numbous speries in the rivers of Europer, Isia, and Jorth Imerival. . Intividual irrogularities in dentition are common in this genus.

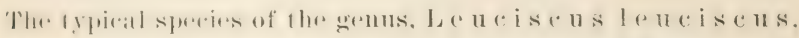

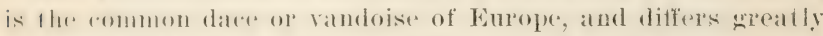
from any of the Ameriatn forms. The presence of ratoms intermediate speries, howerere, malies it impossible to draw any satis fatetory line between the dares. Le us is e us on the one hand, and stroh rextreme forms as the long-mouthed minnows, C: linostomns, on the other.

f I inostom $1 \mathrm{~s}$ is a peculiat group of small, tine-sealed mimnows. Wilh the gatpe of the mouth lateger than in any other

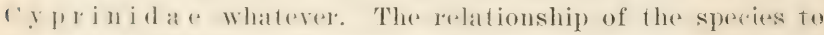

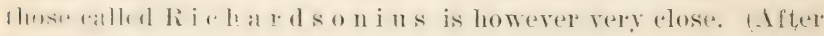
Jordan and Evermann)

\section{subgenus chosmonus Girard \\ i: Leuciscus elongatus (Kirtlaud) \\ hed-sided shiner}

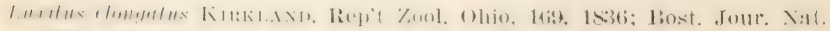
list. III, 333!, pl. IV, fig. 1, 1811.

lenciscus proriger Güntuer, Cat. Fish. Brit. Mus. VII, 245, 1868.

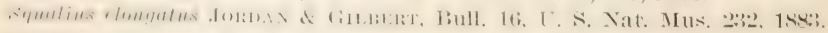
l'horinus clongutus 13EAx, Fishes Penna. 52, 1593.

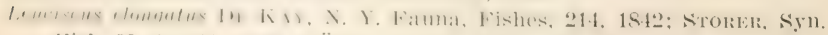
Wish. N. A. 161, 1Sf6; Güxtuer, Cat. Fish. Brit. MIus. VIT, 245, 1868; Jormax de Evmmax, Bull. 47, U. S. Nat. Mus. 240. 1896.

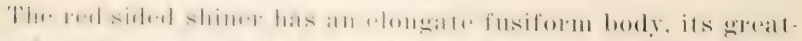

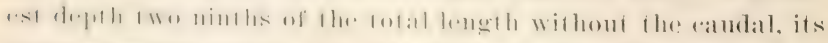

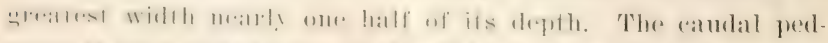

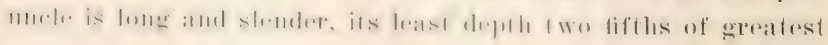




\section{Subgenus growores Rafinesogue}

\section{7:) Leuciscus margarita (Cope)}

\section{Pent llinnou}

('limastomus margarita Cope. Cypr. Рenn. 376, pl. 13, fig. 1. 1866.

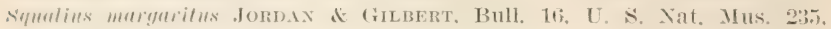
$1 \mathrm{KS:B.}$

Plorinus mar!uritus BEAx, Fishes Penna. 53, .189:3.

Lenciscus margarita Günther, Cat. Fish. Brit. Mus. VII, 246. 1868; Jordax d Evemixi, Bull. t7. U. S. Nat. Mus, 241, 1896.

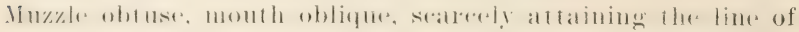
the anterior margin of the orbit; head four times in body to

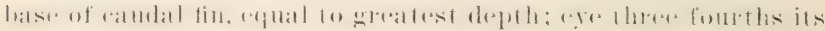

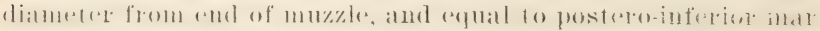
gin of opereulum. Ficales less exposed on anterior than on posterior regions: 11-58-8 to 9. The lateral line is discon-

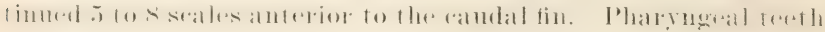
slender, 2, 5-t, 2. Dorsal originating behind origin of ventrals, i, s; A. I, S; I. S, extending three fourths from its origin to the anus; I'. 17, reaching two thilds way to rentrals.

From origin of catudal to first dorsal ray . . . . . . . . . 12

From first dorsal ray to hind margin of orbit........ 9.5

From first dorsal ray to end of muzzle........... 13.5

From first anal ray to caudal base............... S

From end of muzzle to base of ventrals........... 12

'T'olal length, 22 inches 6 lines.

(o)loration above light olive, without dorsal line. but dalkele

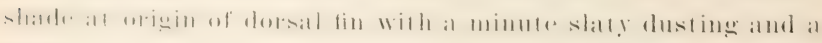
fow lateral sperckles of the same. Sides to lialfway above the

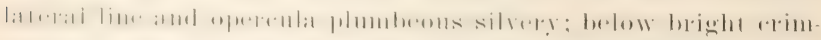
som lin midsmmmer) to lower materins of pectoral and renteal

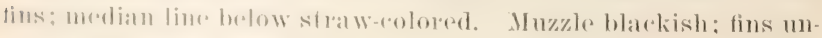

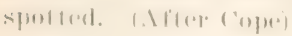

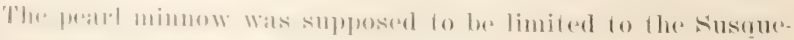

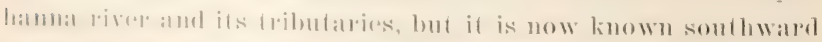

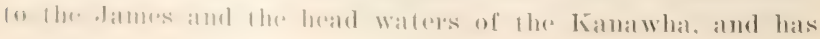


been reported, somewhat doubtfully, from Cemetery creek, at Watertown N. Y. by Dr Evermann.

It is a stout-bodied little species, growing to a length of 3 inches.

\section{Genus mous Heckel}

Pharyngeal teeth in two series, $3,5-5,3$, four of those in the principal row laterally compressed and hooked at the tips; lateral line complete; eyes small. Scales small; dorsal and anal fins short, without thickened anterior rays; mouth small, terminal, oblique.

\section{Idus idus (Linnaeus)}

Golden Ide (Introduced)

Cyprinus idus Linnaeus, Syst. Nat. ed. X, I, 324, 1758.

Leuciscus idus Cuvier of VAlexcifxyes, Hist. Nat. Poiss. XTII, 22S, 1S14; Günther, Cat. Fish. Brit. Mus. VII, 229, 1868.

Idus melanotus Heckel of Kixer, Süssw. Fisciue, 147, figs. 77, 7S, $185 \mathrm{~S}$.

Idus idus Jordan \& Evermann, Cheek List Fishes N. A. 512, 1896.

Body moderately elongated and compressed; Jeast hight of caudal peduncle two fifths of greatest depth of body, which is two serenths of total length without caudal; length of head one fourth of total length without caudal; eje large, four times in head and twice in interorbital distance, about as long as the snout; mouth small; jaws equal in length, the maxillary reaching to below the posterior nostril; pharyngeal tecth 5, 3-3, 5, hooked, not serrated; dorsal ontline almost regularly arclued, similar to rentral outline, top of head slightly dattened; dorsal origin at, or somewhat behind, the middle of the length, directly over the origin of the rentral, its hight nearly equal to length of head; rentrals in advance of dorsil, and extending to the rent; pectorals short, not reaching to ventrals; caulal decoly forked, its lobes equal; lateral line decurved, its serond half well below the median line. Vertebrae $26+21=4 \overrightarrow{7}$. Reaches a length of 18 or 20 inches and the weight of 1 pounds. 1). 11-12; $A$. 13-14; V. 10. Scales 9 or $10-56$ to 59-7, four and one half series between the lateral line and ventral fin.

A variety known as the golden ide, orfe, or gold nerfling has been introduced, for ornamental purposes, into Amerima ponds. 
Thr. hatk ant sirles arr. rermilion or orange red; belly silvery; a lunal indistinet hand of violet tint rums longitudinally to the taii, and divides the derep reed of the back from the pale tint

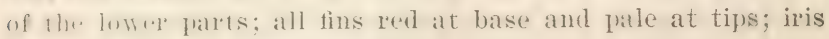
golden red, with a black pupil.

\section{Genus amramis Cuvier}

\section{Subgenus rotemgores Rafinesque}

burly subelliptir, strongly compressed, both hack and belly curverd; hate narrowly compresserl, almost carinated; belly behind rembral fins forming a lieel orer which the seales do not fass. Ifatl small, conic; mouth small, oblique or horizontal, withum barluls: stales rather large; lateral line continuous,

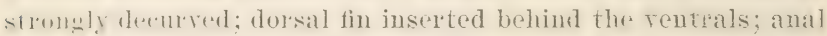
fin wih its hase more or less elongate; teeth $5-5$, hooked, with -rinding surfater the colges nore or less crenate or serrate; alimentary anal short, though rather louger than the body; size rather large.

siereal speries. one of them in coastwise fresh water's from Tova seotial 60 Mary]and, west to Dakota; another in rivers of Whe fonth Alantic states and south to Texas. I peruliar form in Central park, New York city.

\section{Abramis crysoleucas (Mitchill)}

\section{Roach; Golden Shiner}

Cyprinus crysoleucas Mitcmus, Rep. Fish. ‥ X. 23, 1814.

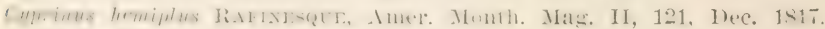
Lake George, Lake Saratoga.

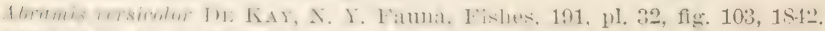

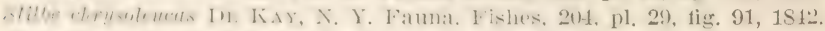

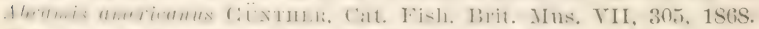

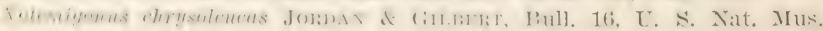
250, 1883; Beax, Fishes Penna. 53, pl. 24, fig. 42, 1893.

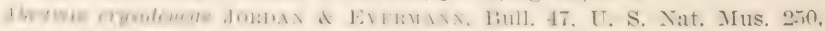
1S96, pl. XLV, fig. 111, 1900.

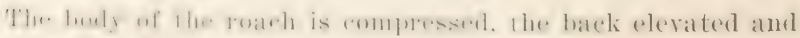

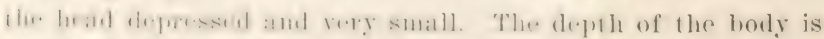

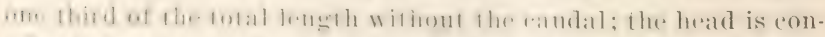

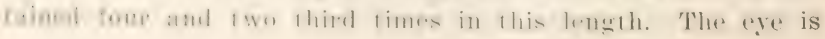


contained three and one loalt times in the length of the hear. The mouth is small, oblifur. thr maxillatry not reaching to ver. tical through frout of ere. The arosal fin is much higher than long; its base is epual to the luast depth of the caudal peduncle or twice the diameder of the :yr. situated on midelle of borly opposite the spatee betrexu the ventral and aual fins. Inal louger than dorsal, its longest ray slightly excoeding the length of the base. Catudal forked. Tateral line much decurred on lower half of body behind pectorals. D. s; 1 . 1:3. Seales 10-53-3. Teeth $5-5$, hooked and with grinding surfatee.

The roach, shimer, golden shiner or bream is oue of the eommonest fishes of the eastern stiltes. It is found from NeW England to Minmesota amel somuhwarl. I variety of the roaleh replaces the common noflheres form from North Carolina to Texas.

Evermann and Fean olutained it at Rouse Point $\mathrm{Y}$. Y. and in Scioto creak. Coopersille Y. I. July 19, 189t. In the Lake Ontario basin, the l. S. Fish Commission hals it from:

Salt brook, $1 \frac{1}{2}$ miles abore Nine Mile point June $11,189:$
June 21,1894
June 27,1894
July 5,1894
July 7,1894
July 10,1894
July 17,1894
July 25,1894 Cape Vincent

Grenadier island

Black river, Huntingtonville

Guffon creek, Chaumont

Chaumont river

Black creek, Scriba Corners Mouth Salmon river, Selkirk

Dr Meek secured it in sluggish Water. on the flats near Ithatrar. The roach is alundant in the lakes of C'entral parti and in the. Bronx; it was not found in the latrese lake of Prosperet parli. Brooklyn.

Eugene smith records its occurrence in thr virinity of Nem

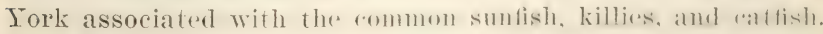

The roach grows to a lenghth of 1 foot and a wighte of 1 ! pounds. It frequents slugerish wallers, abuunding in hal yous and

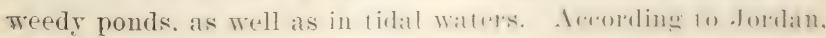


its farorite shelter is the yellow pond lily. It mas be readily distinguished hy its shaje, which resembles that of the shad, and by the rery long anal fin, which contains from 14 to 17 rays. The colors of this tish are groenish above and the sides siltrery with gollen reflertions. Fins usually rellowish; lower fins scarlet in breeding males.

Though the roath is not a good food fish, it is taken by the hook in large numbers and is a rery useful species for bait.

The roach, wites Eugene Smith, is an actire fish and lives well in the atuatrum, becoming rery familiar with its keeper. Owing to the small size of its gullet, the smaller individuals will at length starve unless their food is much comminuted. The fish spawned in captivity in May, and early in Ilecember of the same year the youmg were 1 ! inches long. The adults do not: like earthworms, hut feed freely on chopped hard clams.

\section{Abramis chrysoleucas roseus subsp. nov.}

\section{Irish Roach; Pearl Roach}

Abramis crysolencas subspecies, BeAn, Bull. Amer. Mus, Nat. IIist. X. Y. LX, 334, 1897.

The ". Irish roach" or "pearl roach" of a lake in Central frark, Aiw Jork eity, is eren more distinct from the typical northron roach than is the subspecies bos c i of the rivers of the fouth Mtantir states, and should receive a name. This form is rablily distinguished from A. crysoleneas by its shori and dwe body, uniform size of scales on all parts of the besly, amel the lurmanent remilion color of the pectoral, ventral, and anal tins. In example stumied in the New York aquarium has 1. i, 7; . . i. 12; V. i. s, s'alles $10-48-4$; teeth 5-5, hooked, wenate, and with a grimling surfare. The lateral line apparenils is not so stromgly derurved as in A. cerysolencas.

This is a lwantiful tish and estremely shy in eaptivity. Two females and a male were maty to spawn in the aquarium

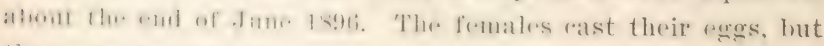
they were immediately caten by the fish. 


\section{Genus мотroprs Rafinesque}

Body oblong or elongate, m-xe or less compressed; mouth noranal, mostly terminal and oblique. sometimes subinferior; no barbels; teeth in one or two rows, those of the larger row always 4-4, hooked, sharp edged, or with a narrow grinding surface; scales large, often closely imbricated, those before the dorsal rarely rery small; lateral line complete or nearly so, usually decurved; dorsal fin inserted above, or more usually behind, the rentrals; anal fin short or moderately long; abdomen rounded, never sharp edged. Coloration more or less silvery, often brilliant, the males in spring usually with red or white pigment and the head with small tubercles. A rery large group of small fishes, specially characteristic of the fresh waters of the eastern United States, containing about 100 species, many of them characterized by extensive individual variations. (After Jordan and Evermann)

\section{Notropis bifrenatus (Cope)}

\section{Bridled Irinnow}

Mybopsis bifrenutus Cope, Crpr. Penza. 3\&4, 1S66; Gürtner, Cat. Fish. Brit. Mus. VII, 211, 1868 (as a doubtful species).

Hemitremia bifrenata Jordiv \& GilberT, Bull. 16, U. S. Nat. Mus. 162, 1883.

Totropis bifrenatus JondAx, Check List Fishes N. A. 22, 1885; JondAN \& Evermann, Bull. 47, U. S. Nat. Mus. 258, 1896.

Front convex between the orbits; length of muzle equals diameter of iris band and pupil, sometimes nearly equals orbit. Iris colored in continuation of the lateral band. The lateral line rarely extends half way to the dorsal fin, while the pores of the same may be observed at the bases of the suales for half the remaining length of the animal. Length of the litrgest specimen, 19 lines; breadth of muzzle at nares. 1.5 lines. Radii of the scales strong.

Color above straw, the scales delinatuly bown relged; below impure white, with a narrow blatele lime along base of anal fin to caudal. Along each side from calutial tin alromm the end of muzzle including the end of the mamdithe a shining blate band 
mor and nme half suales in width. This is bordered above on the muzhle. forming an arr from orlit to orbit, ly an orange band, which is stromely matrind alove hy the brown of the top of the

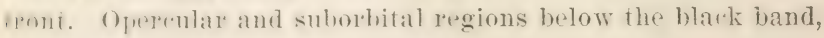
pure silvery. (Rearranged from Cope)

Head form and one tifth: lepth four aud one fifth: "ye three. I). \&: . . 7. Nuales 5-36-3; teeth 4-4. Borly rather slender,

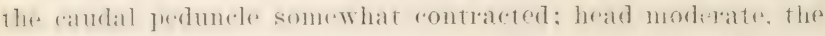
muzale rery obtuse; mouth oblique. the jaws al,ont equal, npper lip offusite lower gart of pupil; eye latge, longere thith suout; Jatural line dereloped for a rexy short distance. 19 seales before dorsal. Length $1 \frac{1}{2}$ to 2 inches.

This lithl. mimnow has no common name. It is fonud from Massalr]ust. Is fo Maryland and is abundant in tribularies ot the Holawall river. On ateount of its conspremous aolors. is is a useful hait for game fishes. spereially the blark bass.

\section{Notropis anogenus Forbes}

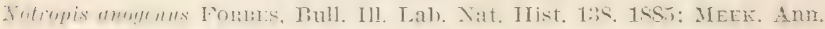

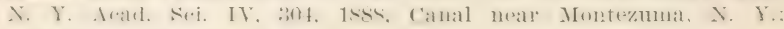
Jordax \& Evermakx, Bull. 47, U. S. Nat. Mus. 259, 1896.

Treal four and one fomilh; d.pth four and two fifths; eye tirree and our. fontle. 1). s: 1. T. Lateral line 34 to:37, 13 before dorsal. Trefle 4 t. Very similat to $x$. heterodo $\mathrm{n}$, but with the lattrat line nsually eromplete; the month rery small and rers obligun. alumst wholly antrefor; the lower jaw included, the

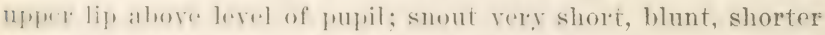
thatu r.ye. Jusky: a dusliy lattatal batud through ere, ending in

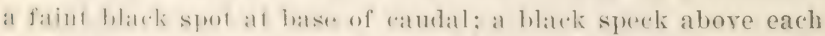

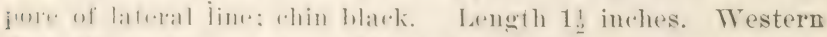

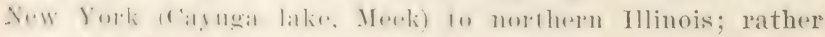
scarce. (After Jordan and Evermann)

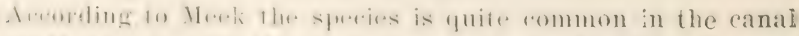

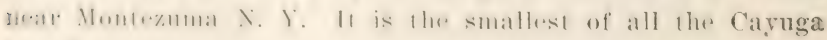
lake fishres.

\section{Notropis cayuga Meek}

Notmpis men!gu MEFk, Ann. N. Y. Acal. Sei. IV, 305, 1Sss, Cayuga Lake,

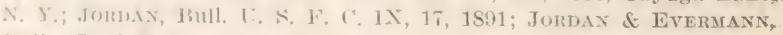
liull, 17, U. \&, Nat, Mus, 240, 1896. 
borly; terth 4-4, often crenate. Body moderately stout, the batck somewhat elevated; head rather pointed, the muzzle acuminate; mouth oblique, lower jaw projecting, upper lip opposite npper rim of pupil; maxillary extending to opposite front of orlit; 1:; seales in front of dorsal; lateral line usually more or less imperfect. ('olor olivaceous; chin black; a blackish rostral band; sides with a leaden or dusky band. Length 21 inches. New York to Michigan and Kansas, common. Variable. (After Jordan and Evermann)

fommon in all the sluggish water' on the flats neir' Ithaca. Not fomml at the north and of the lake, where it seems to be replaced by Notropis anogenus. Meek

Th. I. . . Fish Commission collectors have obtained it at Cape Yin»nt X. J. June 21, Stony Island, July 2 and 3, and at Guflon creek, Chaumont, July $7,1894$.

\section{Notropis blennius (Girard)}

\section{Straw-colored Minnow}

Albumops Ulennius Girari), Proc. Ac. Nat. Sci. Phila. 194. 185t;. Paeifie R. R. Surv. X, 261, pl. 57, figs. 13-16, 1858.

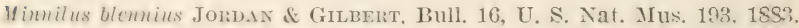

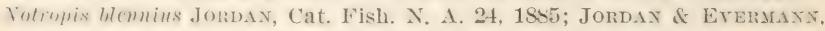
Bull. 47, U. S. Nat. Mus. 261, 1896.

looly slender, clongate, its greatest depth one fifth of total I.ngth without eaudal; head rather large, one fourth of total langth without cautal; the eye large, a little longer than snout, wne third as long as the head; mouth small, inferior, horizontal, the maxillat reatehing to front of orbit; snout very obtuse; dorsal a lithl meare to tif of smout than to base of caudal, its origin ahom or. end of puetoral, its longest ray three fourths as long as the hemil: feeth 4 1; 1:3 to 15 rows of scales before dursal. The lentral is mule. lhe hase of the dorsal, its length

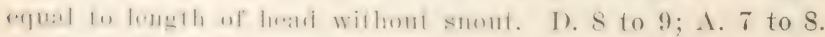
Seales 5 to $6-32$ to $38-4$.

Cuhor pate olivarcums: sides usnally gale; usually a darker dorsab baml amd a smald farli blow.h before dorsal, sometimes a

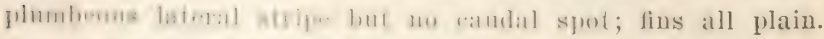
Length 2 to $2 \frac{1}{2}$ inches. 
This small minnow is found in the Great lakes region, westward to Dakota and south to Texas. The U. S. Fish Commission collectors secured a modurate number of specimens in 1894 at the following localities.

Cape Vincent

June 23

Grenadier island

June 27

Little Stony brook, Henderson bay

July 4

Big Sandy creek, Belleville

July 12

Mouth Salmon river, Selkirk

July 25

Great Sodus bay

Aug. 6

Dr B. W. Evermann and Barton A. Bean secured 12 examples in Scioto creek, Coopersville N. I. July 19, 1894. They also took many specimens July 17 in the St Lawrence river, 3 miles below Ogdensburg X. T. Dr Erermann observed a diffuse plumbeous band along the side, each scale in the lateral line punctate with black, making the lateral line rery conspicuous. In many a rery small black spot was present at base of caudal. The dorsal was ver y low, only fire ninths length of head.

\section{Notropis procne (Cope)}

\section{Shiner}

Hybognathus procne Cope, Proc. Ac. Nat. Sci. Phila. 279, 283, 1864.

Hybopsis procne Core, Cypr. Penna. 385, pl. XI, fig. 2, 1866.

Lcuciscus procne Günther, Cat. Fislı. Brit. Irus. VII. 260, 1868.

Cliola procne Jordax \& Gilbert, Bull. 16, U. S. Nit. Mus. 169, $183 ?$.

Totropis procne Jordan, Cat. Fish. N. A. 23, 1S55; BeAN, Fishes Penna.

37, 1893; Jordan \& Evermann, Bull. 47, U. S. Nat. Mus. 264, 1896.

This little minnow has a short, slender and compressed body and a very slender caudal peduncle. The greatest depth, at the dorsal origin equals the leugth of the head, which is about one fourth of the total without caudil. In some described specimens the head is contained four and three fourths times and the depth of the body five and one fourth times in lotal length without caudal. The snout is short and obtuse, shorter than the eye, which is two fifths as long as the head. The mouth is terminal and small, the maxilla not reaching to front of eye, and the jaws equal. The lateral line is enenty curved down- 
Ward orel the feremal and. in the specimen examined, becomes imforupled in its posterior half. The dorsal origin is orer the

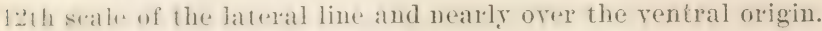
Whe dorsal base is a little more than half as long as the head, nut the longest ray is as long as the head. The rentral reaches to the anal origin. The anal base is half as long as the head and the longest anal ray is four fifths as long as the head. The (audal is moderately forked. 1). S: A. T; Y. \&; P. 13. Siales -7-92 to :-4:3: teeth 4-4. Iength of specimen described, from Ifave de cirate Mrl. "2l inches. Color in spirits light brown. the belly pale and lower half of head silvery. I narrow dark line along the top of the batek and a narrow dark median band continued forwated on the nose. Fins all pale. In life the bods is olivareous with a dark latral stripe. The long tail suggests the name proc ne, a kind of swallow.

The shiner is foum from western New Jork to Marrlant.

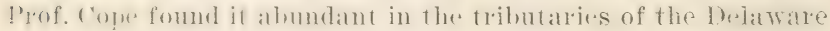
and susfumelamma. in slow moving streams. It reaches the length of $2 \frac{1}{2}$ inches.

Eugene smith reords it as " very plentiful in the smatl? hrocks direfly rumnine into tide water. It apjears to approach the seat more relosely than any of her minnow, though it is uerele fomm in hatrkish water. It delights in strong currents. but in raftivily lives well in the aquarium, feeding voracionsly. It

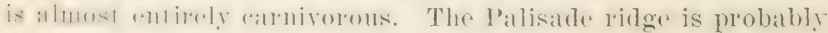
Qhe furthes linit of this speres towards the east. It is met with in company of the suckers and the roach."

It has prored an excellent bait for the game fishes.

\section{Notropis hudsonius (DeVitt Clinton)}

\section{Spanon-cater; Smelt}

Chupe hulsonia De WitT Crivtox, Ann, Lyc, Nat. Hist. N. Y. I, 49, pl. 2, fig. 2, 1S24 (fide Günther).

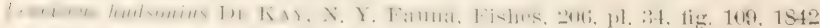
(Audson river and tributaries)

Ilybonsis hulsonius Core, Cypr. Penna, 3S6, pl. 12, fig. 3, 1866.

Cliola Trulsonia Jommax of Gilisert, Bull. 16, U. S. Nat. Mus. 171, 1853. 
Notrouis Tudsonius Jordax, Cat. Fish. X. 1. 24. 1855; BeAn, Fishes Penna. 38, 1S93; Jorman \& Everaraxd, Bull, 47, U. S. Nat. Mus, 269, 1s96, pl. XLVII, fig. 119.

The spawn-eater has a moderately elougate and compressed body, its greatest hight contained four and one half times in the total length without caurlal, and about equal to length of head. The head is conic:al, with short, blunt snout equal to the diameter of the "Ye, which is contained three and one half times in the length of the head. The space between the eves equals length of postorbital part of head. Mouth small, nearly horizontal, the lower jaw rery slightly the shorter, the maxilla reaching the rertical through the posterior nostril. The lateral lime is slightly curved downmard over the pectoral, straight and median for the rest of its course. The origin of the dorsal is orer, and of the ventral under. the 1:3th s'ale of the lateral line. The dorsal base is two thirds as long as the head, and the longest ray as long as the head. The ventral reaches nearly or quite to the rent. The anal origin is under the 24 th seale of the lateral line; the anal base is one half and the longest anal ray four fifths as loug as the hearl. The caudal is large and deeply forked, its midelle rays half as long as the outer. D. S; A. S or 9; V. S; P. 14. Scales 7-3S-5; treth 2, 4-4, 1 or 2, with a narow grindiug surace on at least two. Length of specimens described from Washington 1). r. 3. to $4_{4}$ ineles. Color in spirits pale brown, the fins and all of head except uppere surface pale; a broad median silvery hand, its greatest width about equal to diameter of exe; a dusky spot at the root of the caudal in the young.

The spawn-eater is said to oceur from Lake Superior to New York and southward. In Pennsylyania begins a form elsewhere described as $X$. a m a I us. whirh dillers in the structure of the pharyngeal teeth.

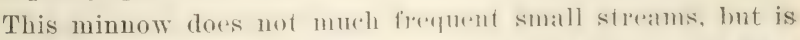
abundant in the Delatware river and also in Lake Frere. 1), hay records its occurrence in the Hudson and its tributaldes.

In the Lake Ontatio region the I'. S. Fish ('ommission eollectors obtained numeroms spextmems in these lowalities. 
Silt brook, 1! miles abor Nine Mile point

\section{Cape Vincent}

Grenadier island

ITorse island, sackitts Turbor

Mouth Salmon river, Selkirk

Three Mile creek, Oswego

Great Sodus bay

Long pond, Charlotte

Lake shore, mouth Long pond

Nine Mfile point, Webster

June 10-11, 1593

June 21, 1894

June 27,1894

June :20, is94

July 25, 1894

July 27, 1894

Aug. 6, 1894

Aug. 17, 1894

Aug. 17, 1894

Aug. 23, 1894

East end Lake Ontario

1894

Livingston stome also collected the species at Cape Tineent Aug. 9, 1898.

In the Lake Champlain basin Evermann and Rean obtained it at sioto cresek, Coopersville, and Rouse Point July 19, 1894.

The sfrawn-ater reaches the length of 10 inches. Iis teeth are usually four in the principal row and two in the inner. Its spawn-eating habits are not verified.

\section{Notropis hudsonius amarus (Girard)}

\section{Gudgeon}

II udstrius umurus Gim.ten, Proc. Ic. Nat. Sci. Phila. 210, 1856. (Chesapeake Bay; Potomac river at Washington)

Hybopsis storerianus Core, Cypr. Penna. 386, 1866.

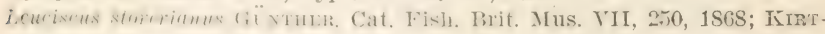
LAND, Bost. Jour. Nat. Hist, V, 30, pl. IX, fig. 2, 1847.

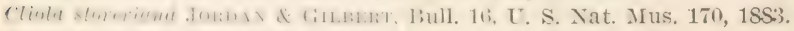

Notropis amams BEAv, Fishes Penna. 39, pl. 23, fig. 37, 1893.

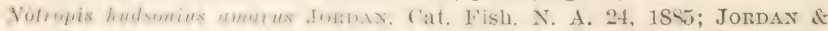
Everaman, Bull. 47, U. S. Nat. Mus, 270, 1896.

The guigeon has a moderately elongate and compressed body and a slomber rambal perdmele. The greatest depthequals one fometh of the total lengeth to base of randal, and the least depth

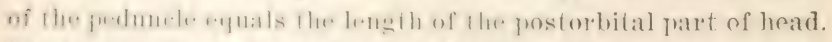

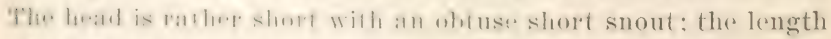

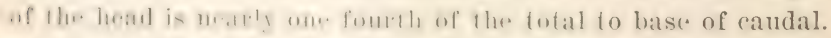
The snont is one fourdh and the e.re one third as long as the besul. The magilla rextemis le dhe reftical through the front of 
the eye; the lower jaw is slightly included; the mouth is slightly oblique. The width of the head equals nearly two thirds of its length. The distance between the eyes equals the length of the orbit. The dorsal origin is over, and the rentral origin under, the 10 th seale of the lateral line. The length of the dorsal base equals two thirds that of the head, and the longest dorsal ray is four fifths as long as the head. The anal base is as long as the postorbital part of the head and the longest ray is about two thirds as long as the head. The rentral reaches nearly to the rent, and the pectoral to below the Sth scale of the lateral line. The lateral line is rery slightly bent downward over the pectoral. The caudal is moderate in size and deeply forked. D. ii, 7; A. ii, 7; V. S; P. 15 . Seales $6-36$ to 39-4; teeth 1, 1-1, 1 or 1, 4-4, 0 in the example described, from the Susquehanna river. Length $4_{4}^{1}$ inches. The teeth are slightly hooked, and two nr three on each side have a developed grinding surface. The color in spirits is light brown, the sides of body and lower half of head silvery; the young have a narrow dusky median lateral band, which is sometimes continued on the snout, and a more or less distinct small dark bloteh at the base of the caudal. The fins are all pale.

The gudgeon or smelt of Pennsylvania is a variety of $\mathrm{N}$. hu d s o n i us of Clinton, which ranges from Lake Superior to New York and south in streams cast of the Alleghanies to Georgia. The southern form is the variety a ma rus of Girard, which exhibits some difference in its pharrngeal teeth. The species is an extremely variahle one. It grows to a length of about $S$ inches. Prof. Cope records it as abundant in the Susquehanna, specially in the lower part of the river.

This is a handsome silvery fish, and is as much used for food as its associate, the silvery minnow.

\section{Notropis whipplii (Girard)}

\section{Silverfin}

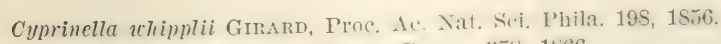

Photogenis spilopterus Cope, Cynt. Pemma. : 3 s, 1 s66.

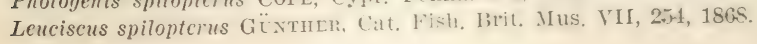


Invias lientuliensis Kuntaxi, Bust. Jour. Nat. Hist. T. 27, pl. VIII, fig. $3,18+7$.

IIypsilepis kentuckiensis Cope, Cypr. Penna, 371, 1866.

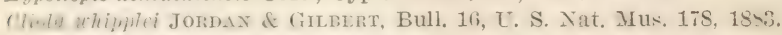

Cliola analostana Jordax \& GILBERT, op. cit. 179,.18S3.

Notropis whipplei BEAN, Fishes Penna. 39, 1893.

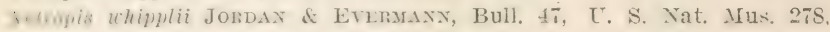
1896, pl, XLVIII, fig. 121, 1900.

'The silrerfin has a moderately elongate body, which is fusiform in the adult. The eaudal peduncle is short and stout. The ik.pulh of the body at the ventral fin equals nearly one fourth oi the total length to the eaudal base. The head is conical, comfHessind and with a pointed suout a little longer than the eje, whirh is two ninths as long as the head. The mouth is moderale. ierminal, slightly oblicue, the jaws nearly enual, the maxilla rearling to rertical throngh frout of rye. The hrat is two nimlls of the lotal bugth without caudal. The dorsal origin is a littl. hehind the rentral origin and orer ihe 15 th seale of the lateral line. The length of the dorsal base equals one seventh fof the tolal without caudal, and the longest ray is as long as fle. head without the snout. The rentral reaches nearly to the anal. The anal begins moler the 21st suale of the lateral line: ils hase is as long as the dorsal base, and its longest ruy is alunt iwo thirds as long as the head. The caudal is large and mudratfely forlicel. The lateral line curves downward over the

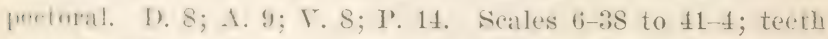
1. 4-1, 1, with more or less serrate edges. Length of specimen dieseriberl, from the susquellamua river, 4 inches.

In spirits the bate is brown, the sides dull silvery, the scales will a dusky margin, and the lower parts are whitish. A narfow and long blatk bloteh on the membrane between the bith

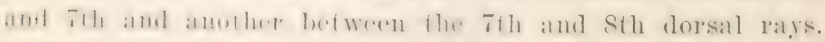

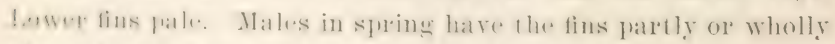
sharget will while pigment, and in the hight of the hereding

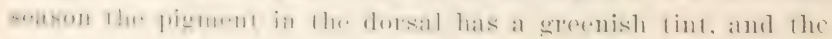
top of the hear and suout is covered with minute tubereles.

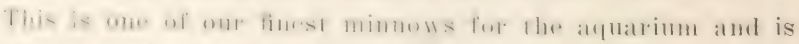
user [u] as food and bait for larger fishes. 
The silverfin ranges from western New York to Virginia and west to Minnesota and Arkansas. It is a common and variable species. It reaches a leugth of $t$ inches. In Pennsylvania it oceurs in all the rirers and creeks, but according to Prof. Cope is least common in tributaries of the Delaware.

According to In Meck it is common on flats near Fall creek and in the southern chel of Cayuga lake. Evermann and Bean took it in scioto creek, Coopersville $\mathbf{X}$. I. in July 1894. In the Lake Ontario region the L. A. Fish Commission secured the following specimens:

Grenadier island

IIorse islaud, sirrliretts Marbor

Cape Vincent

Mill creek, Sacket Harbor

c'emetery creck and Islack rirer, Watertown

Chaumont river

Great Sodus bay

Creek near Pultneyville
June 27,1894

June 30,1894

June 21, 1894

July $\quad 2,1894$

July 5,1894

July 10,1894

Aug. 6, $189 \pm$

Aug. 7, $189 \pm$

Specimens ware obtained also by Livingston stone at Cape Tincent Aug. 9. 1s9s, and presented to the state Musem.

\section{Subgenus ruxmus Rafinesque}

\section{S6 Notropis cornutus (Mitehill)}

\section{Shiner; Redfin}

Cyprinus cormulus MItchile, Amer. Montl. Mag. I, 2S6, July, 1517. (meager preliminary notice); op cit. II, 32t, Fel. 1s1s. (Wallkill river, N. Y.)

cylrinus megalops RAminesque, Amer. Month. Mag. II, 121, Dic. 1S17. (Hudson river, above the falls)

Leuciseus vittatus DE KAY, N. Y. Fauna, Fishes, 212, pl. 34, fig. 10S, $1 S 42$. (Chittenomia and other tributaries of the Mohawk; also in Molawk) Hypsilepis cornutus Core, Proc. Ac. Nat. Sci. Phila. 158, 1867.

Leuciscus cormutus DE Kis, N. Y. Fanna. Fishes, 207, pl. 29, fig. 92, 19.12; Günther, Cat. Fish. Brit. Mus. VII, 249, 1868.

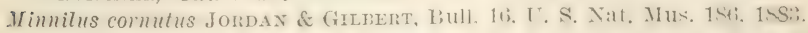

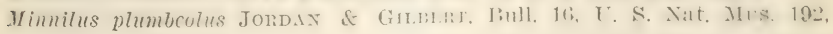
1883 .

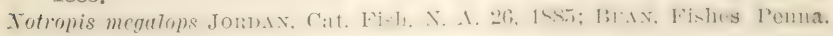
$40,1893$.

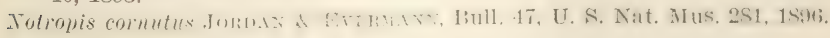


The redtin when young has the body moderately elongate, but it beromes derener with age and much compressed. The caudal peelunele is short, and its depth equals length of postorbita? part of head. The depth of the body at the rentral is contained three and one third to four times in the total length without the candal. The hrad is short, deep and thin, its length one fourth of the total without candal, its width about one half its length. The eye is as long as the suout and two serunths as longe as the hearl. Irouth moderate, terminal, oblique, ihe maxilla reaching about to rertical through front of eye. The dorsal origin is orer, and the rentral origin under, the 12uth seale of the lateral line. The length of the dorsal base equals nue serenth of the total without the caudal, and its longest ray one fifth of the same length. The rentral reaches nearly or unite to rent. The anal origin is under the $23 d$ scale of the lateral line. The anal base is one half, and the longest ray two thirds as long as the head. The caudal is large and deeply forked. The lateral line deseemels in a long curre, becoming straight aud median wrer the anal origin. I). 8; A. 9; T. 8; P. 15. Sirales 7 -41) 10 41-4; tewth $2,44.2$, with narrow grinding surface. l.rogth of sperimens drescribed, from 4 to $4 !$ inches.

Thre upper parts of this fish are steel blue and the seales are dusky at the edere and base. The sides are silvery, orerdabe with a gile line; there is another gilt band along the back. The: ficlly is silvery exerph in spreing males, in which it is a bright ros.5 entor. The male in the breeding season has the lower jas and the iop of the heat ame nape corered with small tubereles. In the hrwaling andition this is a rery handsome spereses, though

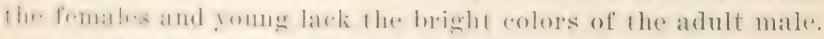

The realtin is kmown also as the common shiner, dace, roughtwatal, and bambled dace. It is a very widely distributed spectes.

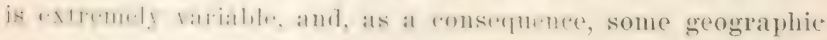

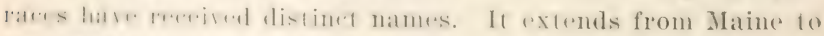
16. Rawely mumbains. Int is atsont from the farolinas and

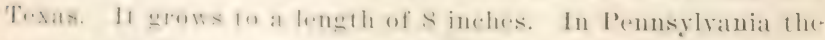

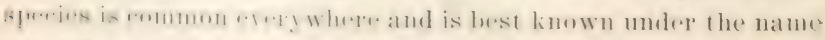
of redfin. It reaches a very large size in Lake Erie. 
Mimilas mbllus and dinemus Jordar \& Gilmert, Bull. 16, U. S. Nat. Mus. 202, 1883.

Juthlis uthrinoides Jordax, (at. Fish. X. 1. 27, 1S55; Merk, Ann. N. Y. Acad. Sei. IV, 308, 1888; BEAx, Fishes Penna. 44, 1893; Jondan \& Everumx, Bull. 47, U. S. Nat. Mus, 293, 1896.

The emeratel mimnow or rosy minnow has a long and thin boily and the caludal peduncle moderately short and deep. The greatesi depth of the body is contained four and thres fourths to five and one half times in the total length to candal hase; the least depth of the candal peduncle is contained $11 \frac{1}{2}$ times in the same lenglu. The greatest width of the borly is one half its hight. The heat is of moderate size, its length two ninths of the total to andal base. The snout is short and somew hat pointed, its length one fourth that of the head. Eye large, about three and one fourth times in length of head; month obliyue, moder. ate. the maxilla reatehing frout of eye. The dorsal origin is mirlway between the eye and the base of the candal, orer the 17th scalle of the lateral line. The base of the fin is two fifths as long as the head, and the longest ray equals the length of the hleal without the snout. The rentral origin is under the 13 th seatle of the lateral line and the fin scarcely reaches to below the cond of the dorsil hase. The pectoral reaches to below the wighte or ninth sale of the lateral line. The anal origin is molde the zath seate of the lateral line; the base is one half as lome as the heate and the longest ray erpuls the smont ame

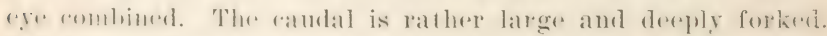
The lateral line swerps downward in a long and shallow eneve. leweming nearly median orer the anal base. [). ji. T: .1. ii. 9: V. S; I. 14. Scales 6-39-4; teeth 2, 4-4, 2 or 1, some of them with a slight hwok amb narrow grimeling surface. The spereimens

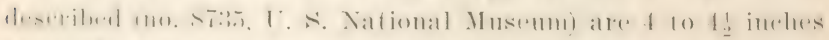

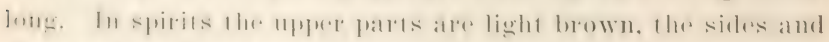

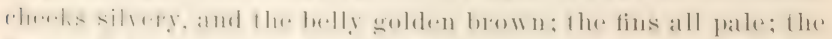

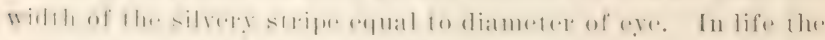

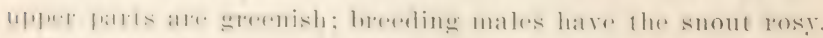

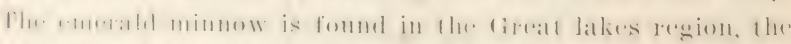
whic wall.y amd smulh on Troneseser, being abundant in lakes 
and in rapids of rivers. The variely found in Pemsylvania has a shorter snout and a smallex eye than the typutal at her in o ides and has received the specific name d i ue mu $\mathrm{s}$; but the differences are not sulpusenl (1) be constant. The emrald minnow reaches a length of 6 inches; it is gregarious like other minnows: and its golden lateral stripe on at cher green ground makes it a handsome species.

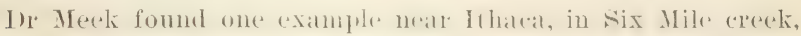
below the falls. I few speimens were also found in a small stream near Montezuma dry dock, in company with $\mathrm{N}$.

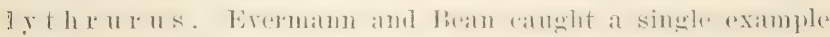

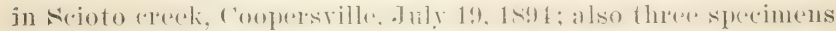
in the st Lawrenere river. :3 miles below Ogdensburg July 17,

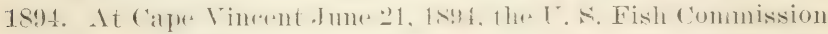
collectors took 2y spremens, and at (Aremadier island, June 27, they obtained 14 individuals. Livingston sitone also rollected the species at ci!ne Vine'nt Ing. 9, 1s!s, and presented specimens to the State Museum.

\section{Notropis rubrifrons (Cope)}

\section{Rosy-faced .IFinnow}

Alburnus rubrifrons CoŕE, Proc. Ac. Nat. Sci. Phila. 85, 1865. Alburnclus rubrifrons Cope, Cypr. Penna. 38s, pl. XIII, fig. 3, 1866. Leuciscus rubrifrons Günther, Cat. Fish. Brit. Mus. VII, 255, 1868.

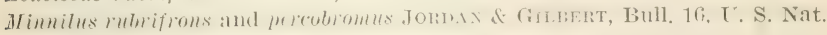
Mus. 202, 1883.

Notropis dilcctus Beax, Fishes Penna. 44, 1893.

Notropis rubrifions Jordan, Cat. Fish. N. A, 27, 1SS5; Jordax \& Ever-

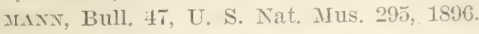

The resy-faced mimow has the hody morletately lomge and thin,

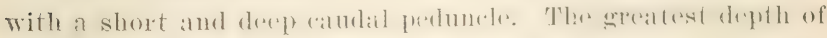

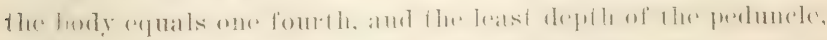

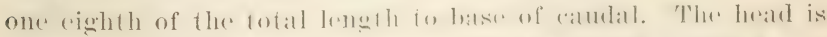
morlerate in sim, its with onw half of its length, which is one

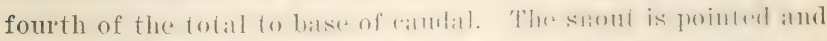

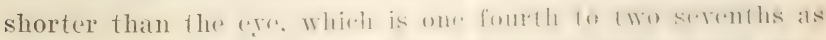

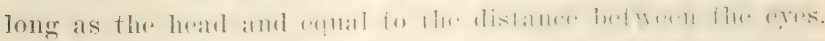

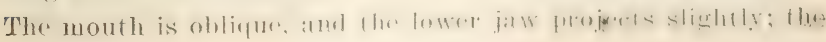


maxilla peathes neatrly to lwhor the front of the pupil. The

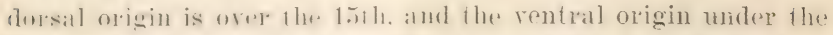
12̈h seale of the litterat line. The base of the dorsal is half as

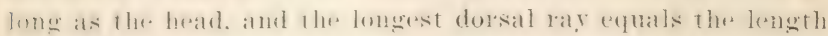
of the heald without the snout. The rentral reaches to the rent. which is muler the 1sh seale of the bateral line. The anal batse is as long as the snemt and eye combined, and the longest anal ray is two thirds as long as the head. Thre modal is moderate in size and derply forked. The lateral line cures sently downward orer the pectoral. D. ii, 7; A. ii, S; V. S; P. 13. Scales 6-36-1: te+th 2. 4 4, 2. hooked. The specimens described are 2 ineles long. In spirits the bedy is palle bown: a silvery shade along the median line: the head silvery exeept abowe: belly golden: tins all palle. In life the upere parts are olive green and 1he sides silvery. Males in the hereding eondition in spring have pritkles on the smout and the forelead; gill covers and dorsal hase with a rosy thush. The name dilete ths neans delightful.

The rosy-faced minnow, though reaching a lengih of ouly : inderes or less. is a rely beatutiful fish. It is almantant in the

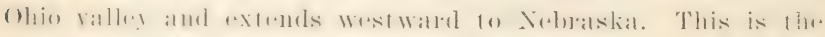
A lburnellus rubrifrons of Cope.

The l. S. Fish rommission eollections of 1894 antain this minnow from sill loook, $1 \frac{1}{2}$ miles ahore Xine Mile point Jume 11.

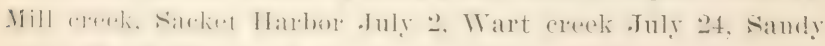
creek, North Hamlin Aug. 20.

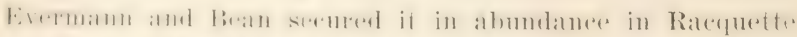

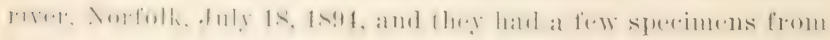
Scioto creek, Coopersville, July 19, 1894.

\section{Notropis amoenus (Abbott)}

Almurnellus amemus Aвиотт, Amer. Nat. TIIT, 334, 1874. Taritan River. ‥ I.

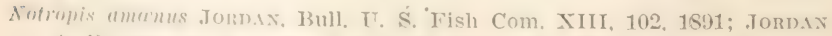
divimuxi, liull, 47, U. S. Nat. Mus, 296, 1896.

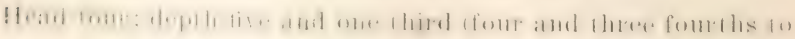
five and une half); "ye thee and one third. D. S;A. 10 . Scales 
6-39-3. Close to $\mathrm{Notrop}$ is r u brifrons, but the scales before dorsal smaller, as in N. photogenis. Body elongate, compressed; eye large, longer than snout; mouth large, oblique, the jaws subequal, the maxillary reaching to below front of eye; 22 to 25 rarely 18 to 20 ) suales before dorsal; lateral line much decurved; dorsal high, placed behind rentrals; pectorals moderate. Transluent green, sides silvery, with sometimes a faint plumbeous band croding in an obsewe plumbeous spot. Length $3_{3}^{3}$ inches. Clear streams east of the Alleghanies from the Rarlitan to the Neuse; abundant; formerly confounded with $\mathrm{Y}$. photogen is of which it mas be a variety. (After Jordan and Exermann)

Eugene Smith ${ }^{1}$ says it is perhaps a variety of $\mathrm{X}$. photogenis (Cope). Abbott mantions it from the Raritan river, near New Brunswick N. J.

\section{Notropis umbratilis lythrurus Jordan}

\section{Redfin}

Notropis lythrurus JondAN, Proc. U. S. Nat. MIus, 476, 1884.

Hypsilepis diplaemia Cope, Proc. Ac. Nat. Sci. Phila. 162. 1867.

Minnilus diplaemius JornaN \& Grbbert, Bull. 16, U. S. Nat. Mus. 197, 1883.

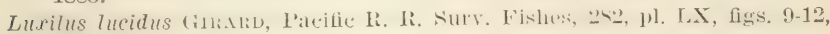
1858.

Notemigonus lucidus JoRdAN \& GILBERT, op. cit. 249, 1883.

Notropis lythrurus MEEK, Ann. N. Y. Ac. Sci. IV, 307, 1858.

Notropis mmbratilis lythrurus Jordar of Evermax Bull. 17, L. S. Nat. Mus. 300, 1896.

Head four and one fouth; dephth fom to four and one half;

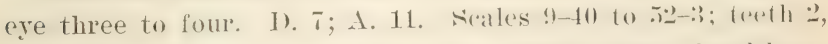
4-4, 2. Body compressed, the atulal pedumele bong; head long, conical, rather pointed; montle latere, moderately oblipues the premaxillary on level of pupil, the naxillaty reatehing to lectow

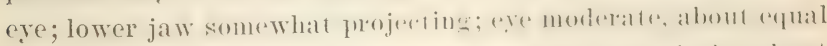

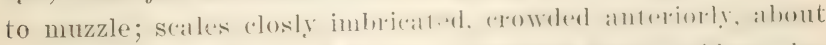

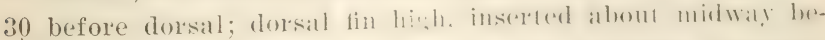
tween rentrals and an:al: Ju: torals mot reatehing lentrals;

${ }^{1}$ Linn. Soc. N. Y. Proc. 1897. no. 9, p. 18. 
rentrals reathing to vent: "atudal fiu loug. Coloration dark steel blue alove; pale or silrery helow; a more or less evident black spot at hase of tomsal in front; the fins otherwise all plain. Males with the anterior dorsil region and the head prorusely 11.1.mel with small whitish 1 uhereles, the belly and lower fins being of a loright briek red in the spring. Females veres pale olive, sometimes almost colorless. Length $3 \stackrel{1}{1}$ inches. Mlinuesota to western Xip Vork (c ayuga lake), North C:arolina, AlatLama, and Kansas: geonerally ahundant in small, rene streams. (After Jordan and Evermann)

Ir Heek took a simgle specimen from a smail stream near the Montezuma dry dock.

\section{Genus muncmins $\mathbf{A g a s s i z}$}

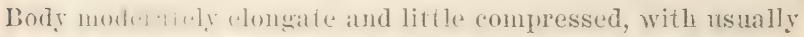
stout ratulal jwinnele and long. conical nose; head rather large,

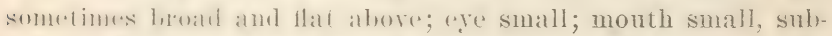

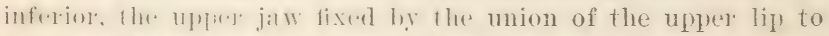
the skint of the foreheal: rud of maxillary with a small barbel. Torth உ, I 1, 2 isometimes 2, 4-4, 1) those of the principal row usuall! lumlinl. Willum erinding surface. A short intestinal

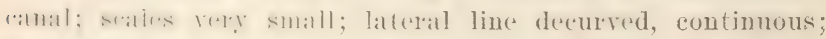
dorsal wigin sliuhl ly helinel rentral; base of anal short. Sumall

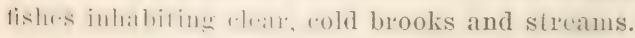

\section{Rhinichthys cataractae (Cuv. \& Val.)}

\section{Long Nosed Dace; Niagara Gudgeon}

Gubio cularetue Cevier \& Valenciennes, Hist. Nat. Poiss. XVI, 315,

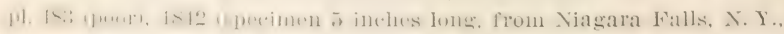
Milbert); DE IAY; N. Y. Fauna, Fishes, 394; 1842. (After Cuvier and Valenciennes)

I.'uciscus uusutus AYmes, Bost. Jour. Nat. Hist. IV, 299, pl. XrII, fig. 3

(very bad), 1SH. West Hartford, Conn. Specimen 51/4 inches long.

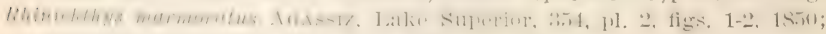

Guxtren, Cat. Fish. Brit. Mus. VII, 189, 1868.

lhinichthys uasulus GüNTHER, op. cit. VII, 1 S9.

Aryyrcus nasulus Core, Cypr. Penna. 369, pl. XII, fig. 5, 1 S66.

Ceratichthys catroctac GuntIIER, op. cit. VII, 176, $187 \mathrm{~S}$.

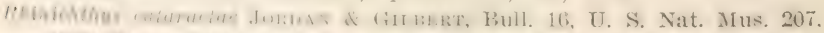

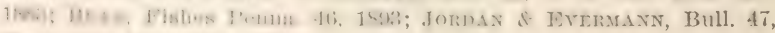
U. S. Nat. MIus. 306, 1596. 
The long nosed dace has a moderately elongate body, with short and stout caudal peduncle and a moderate sized head. The greatest depth is contained four and two thirds times in the total length without caudal; the least depth of the caudal peduncle eight and one half times. The wirth of the body equals the combined length of snout and eye. The length of the head is one fourth of the total without caudal and three times the length of the snout. The eye is placed high, one fifth to one quarter as long as the head and abont two thirds as long as the interorbital width. The mouth is horizontal, small, placed under the snout, the lower jaw the shorter, the upper lip thick and prorided with a small barbel at each end. The maxilla reaches to below the posterior nostril. The dorsal origin is above the $23 d$ scale of the lateral line, and the ventral origin is under the 20th. The dorsal base is one half, and the longest ray four fifths as long as the head. The ventral reaches a little beyond the rent aud almost to the anal origin. The pectoral reaches nearly or quite to the origin of the rentral, being longer in males. The anal origin is under the 34 th scale of the lateral line and a litte behind the end of the dorsal. The anal base is one half, the lomgest ray three fourths as long as the heat. The caudal is romparatively large and well forked. The lateral line drops gently downward in a short curve over the pectoral and becomes median over that fin. D. ii, 7 ; A. ii, 6; T. S; P. 12. Scales $13-57$ to $65-10$; teeth $2,44,2$, three of the principal row looked. I.ength of the sperimen described (no. S505, U. A. National Museum) $3 \frac{1}{2}$ inches.

In spirits the color is brown mottled with grayish; the under surface of head sharply defined and pale; the fins all pate. Breeding males in spring have the lips, cheeks and lower fins crimson. The sides are without a black lateral band. which is characteristic of the black nosed species. The general color is olivaceous or dark green with the lower parts paler. The batek is nearly black. Some of the scales are mottled with dark and olivaceous. The yommg have a trace of a dusky lateral baud. The fish reaches the length of $5 \frac{1}{2}$ inches. 
The long nosed dace or Viagara gudgeon is found in New England and the Middle states, and in the Great lakes region in rear, cold water. In lemenslvanial, according to Cope, it is limited fo the r:1pids and swift waters of the eastern part of the state.

Evermann and bean rollected so specimens in saranac river, Plattshurg I. Y. July äs, 1894, but did not find it in the st Latwence river or in the Lake Ontario tributaries. Though Dr Mreek oblathed no sperimens of this speeces from rapuga lake basin, he helieres it a memher of the fama, as it is common in

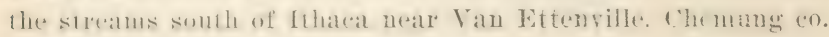
N. Y.

The long nosid dace freduents rapids and rocky pools, and is assoriated in momataiu regions with the brook trout. Its morements alleswift and powerul and it is a rery shapely litale fish. As a bait for the black bass it is scarcely surpassed.

\section{Rhinichthys atronasus (Mitchill)}

\section{Black Nosed Dace; Brook Minnow}

Cyprinus atronasus Mitcmle, Trans. Lit. \& Plil. Soc. N. Y. I, 460, 1815.

(Wallkill Iiver; Fresh-water trout brooks of New York); Amer. Month.

Mag. 1, 2S9, Aug. 1S17. Mut-fish, from Wallkill Creek.

cymrinus villatus 1iAfrissque, Amer. Month. Mag. II, 121, Dee. 1S17.

Ifudson River above the falls.

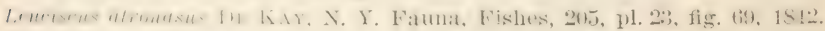
lihinichlhys atronasus Güntmer, Cat. Fish. Brit. Mus. VI1, 191, 186s;

Jomdx \& Giment, Bull. 16, U. S. Nat. Mus. 208, 1883; MeEk, Ann.

N. Y. Acad. Sei. 30S, 1886; BeAN, Fishes Penna. 47, pl. 23, fig. 39, 1S!:3; Jomin \& Evemaxi, Bull. 47, U. S. Nat. Mus. 307, 1896. Arum tus ahomusus STonen, Hist. Fish. Mass. 122, pl. XXI, fig. 4, 1867.

The lolark mosial dater has a moderately long and stout bolly.

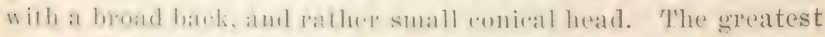

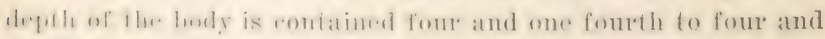

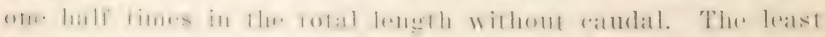

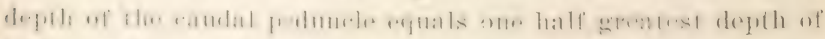

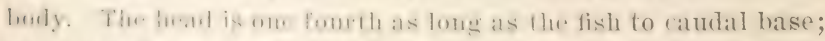

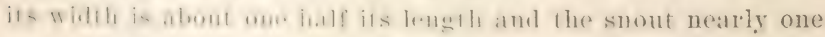
thind bo two serentle. The t? is as long as the snout and

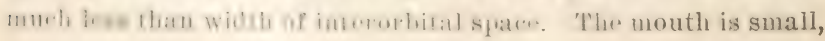


slightly oblique and with matrly equal jaws; the maxillary barbel small or wanting; the maxilla rearhes to below the front edge of the pusterior nostril. The dorsal origin is nearer to root of caludal than to tip of snout, orer the 26 th srate of the lateral line. The length of the hase is contained two and one third times in that of the head. and the longest ray equals length of heat without snout. The ventral origin is slightly in adrance of the dorsal origin. and the fin extends to the vent. The prectoral reatehes to the lith siale of the lateral line. In breeding males it is grably thielienterl. The anal origin is behind the end of the dorsal hatse. under the 34 th scale of the lateral line; the fin is valdiable in length with sex and age. sometimes fire sixths as long as the lead. The caudal is small and not deeply forlied. The lateral line curres downild orer the pectoral, soon becoming median. D. ii, 6 or 7 ; A. ii, 6 ; V. S; P. 11. Scales $10-56$ to $63-10$; teeth $2,4-4$, 2, three of the principal row strougly hookerl. Length of the specimens described

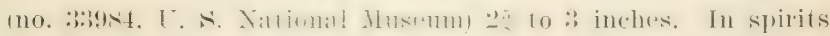
the upper parts are brown aud are separated from the silvery lower parts by a dark lateral band, as wide as the short diametry of the eye and continued on the suout. Breeding males in spring have the lateral hand aud the lower fins crimson, running into orange in summer. In the yommg the dark median band extends on the tail fin.

The black nosed dace or "rockfish" is represented in wur waters by two forms, one of which is found in the eastern part of the direat lakes reegion and from Matme to Virginial dhis is replaced in the upper latie region and in the Ohio vallery sonthward to Georgia allel Alabamal. hy the hlunt nosed vatrety, Rhinichthys obtusus of Agassiz.

The species grows to the length of 3 inches.

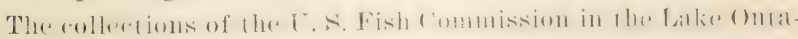
rio region contained this speries from a creat many localities:

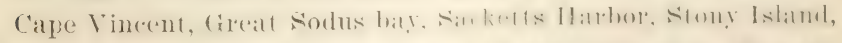
Grenadier island, Oswego, lammat lista, Belleville. P'ulaski, Wart creek, Huntingtonville, Hendersom hay, and Webster'. The 
fish wr. fakin in . Jum, July and August and were rather common in most places.

Evromann and loran took onr example in the st Lampence

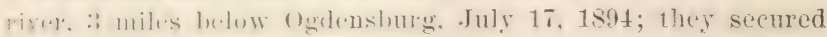
right sperinens in lhe sitranate, at Plattsburg, July 28, 1894.

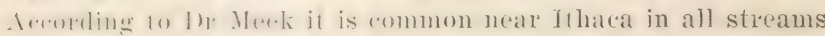
abore and below the falls; but was not found by him mear Montezmmat. Mithill described the fish from fresh-water brooks of Now Jork containing trout, chiefly from the Wallkili, where Rafinesuruc also knew of its occurrence. De Kay states its habitat (1) he relear, fresh-water streams and rimlets of New Tork and aljoining states. Eugene smith found it associated with darte.l's, bobs and small minnows in the vicinity of Niw Tork city.

This fish furefers clear small brools. Swift and actire in its morrments and beatiful in eolors, it is one of the most interating inhabitants of the waters in which it lives. In the aquarimm bugene. Sulth observed it to eat roraciously of animal food and to be more hardy than any other minnow.

\section{Genus mxвorsis Agassiz}

lionly robust, or variously elongate; mouth terminal or infiriur. With lifs thin or somewhat fleshy, a conspicuous barkel al ways imesm and lolminal on the maxillary; a second barbel arm.times fresent an ath side; premaxillaries protractile. Theth \& 1. of 1. A 1. 1, of 1): hooked, the grinding surfare narrow

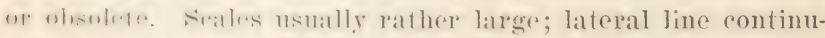
wns. lmsal inserfed orer, in front of, or slightly behind renIr.als: anal bisis short. Males usually with nuptial tubereles, amul smmeliness llusled with perd. A large and varied gromp,

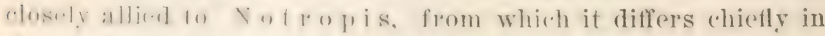
the presenee of the small maxillary barbel. (After Jordan and Evermann) 


\section{Subgenus ERLyistax Jordan}

\section{Hybopsis dissimilis (Kirtland)}

\section{Spotted Shiner}

curilus dissimilis InImtixd, Bost. Jomr. Nat. Hist. III, 341, pl, Ir, fiz. 2, 1811.

Ceratichthys dissimilis Cope, Cypr. 1'emua. 3ts, 11. 12, fig. 1, 1Sti6; Güntmrn.

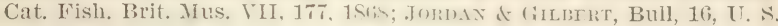
Nat. Mus, 215, 1883.

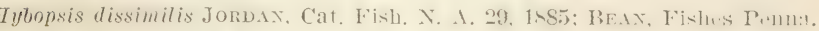
48, 1893; Jordan \& Evermann, Bull. 47, U. S. Nat. Mus. 318, 1896.

The spotted shiner has a long and slender hody, its gleatest lepth being nearly one tifth of the fotal length without the audal. The caudal perlumll. is long and low, its least depth wo fifths of greatest depth of hody. The width of the body equals two thirds of its depth. The head is moderately latrge, ts length one fourth of the total without the caudal. The suout is long but obtusely rounded at the point, its length one and one half times the diameter of the eye. which is two serenths of the length of the head. The mouth is small, incerior, horizontal, the maxilla reathiug to helow the anterior ustril and with a small barhel at its hind end. The gill openngs are separated by a rery broad is thmons. The dorsal begins vere the 16th seale of the lateral line and slighty in advanere of the rentral; the dorsal hase is one hall as long as the heald; the longest ray is as hug as the leatl without the snout: the ast ray is as long als the suout. The rentral reaches to thr rent, its length one serenth of lhe total without the ramdal. The pectoral rearehes to bolow the 1:3h stathe of the lateral line.

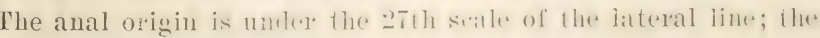
anal base is short, erualing the diame-1or of the eye; the longest ary is as long as the rentral; the lact ray is one third as long

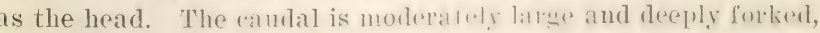
the middle rays one half as long as the external ralys. The lateral line is nearly straight and median. 1). ii, S: .1. ii, ti; V. 7; P. 15. Scales 6-13-5; iecth 1 t, hooked and with a short grinding surface. In spirits the batek is brown, the lower parts are whitish, and the sides an hombly striped with silvery. In 


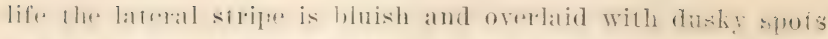

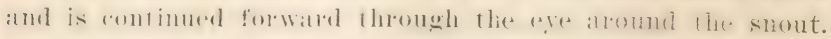

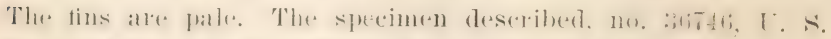

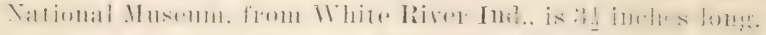

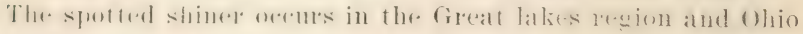

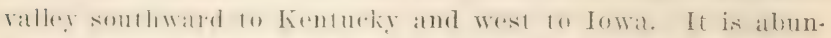

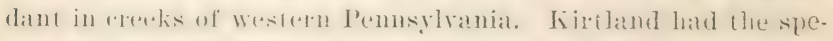
ries from lhe Mahoning river and from Take Live. The speries is most rommom in the fireat lakes atul in the rhammels of

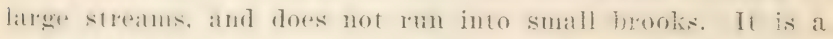
reatry hifer and is raught in large numbers by bonk timinge. It

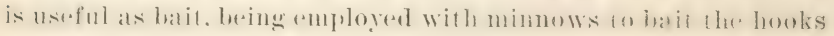
on "set lines."

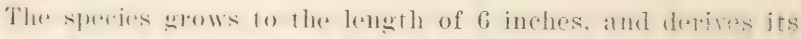
natme from the bluish band along the sictes whirh is intere rupled so as to form spots. The sides are bright sillery in color and the tius unspotted. The body is long and slender.

\section{Subgenus Hxвorsis Agassiz}

\section{Hybopsis storerianus (Kirtland)}

\section{Lake Minnow}

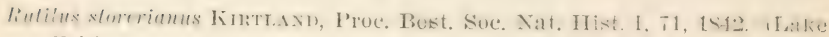
Evie)

Leneisens storerianus Krrtund, Bost. Jour. Nat. Hist. V, 30, pl. 9, fig. 2, 1817 ; GüNther, Cat. Fish. Brit. Mus. VII, 250, 1868.

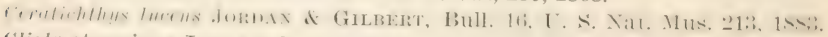
rliola sloveriana Jorndx \& Gilbert, op. cit. 171, 1853.

Ilybopsis storerianus JorndN, Cat. Fish. N. A. 2S, 1SS5; Jordax \& FrerM.1.x, Bull. 47 , U. S. Nat. M[us. 321, 1896.

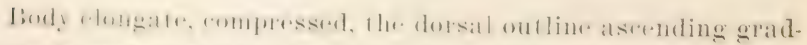

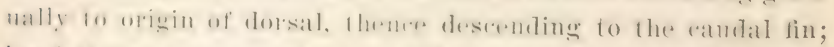

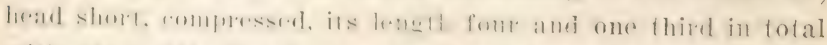

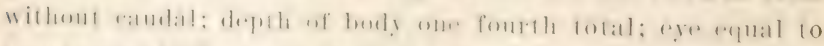

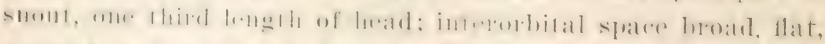

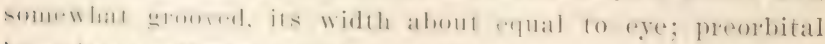

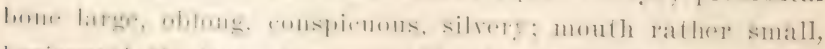

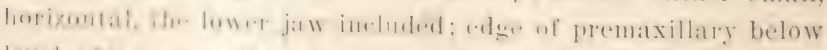

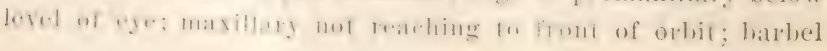




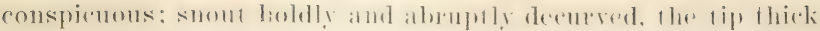
ened, forming a sort of pald: latreral line somm what deremred. Rows of scales along bark anrerging behind dorsal, where the upper series run out, as in Notropis cornutus. Fins rather higher and more falcate than in H. ken $14 \cdot k i 12 n s i s$ : dorsal fin inserted well forwand, over ventrals: pereforal fins pointed, not reathing rentrals: rentrals not reathing rent: raudal long. derely forked. Teesh usually 1, 4-4, 0. hooked, without grinding surfare. Translucent greenish abore: sides and below brilliantly silvery; cheeks and opereles with a bright silvery luster: fins plain: a slight plumbeous lateral shade; no randal spot: no red. Length if to 10 inches. Lake Erie to Nebraska and astern Wyoming, Tennessee, and Arkansas; abundant in the lalerer streams, specially in Iowa. (After Jordan and Evermann)

Kirtland found the lalie minnow only in Lake Erie, where it was frepuently taken with seines in fishing for other species. The U.A. Fislo commission recently added it to the famma of the Lake Ontario bisin, three specimens having been collepted in Long pond, Charlotte, Aug. 17, 1894.

\section{Subgenus vocoms Girard}

\section{Hybopsis kentuckiensis (Rafinesque)}

\section{Horned Chub: River Chub}

Luxilus kentuckiensis RAFIXEsQUE, Ichth. Ohien. 48, 1820.

semotilus biguttatus KintI.tinn, Bost. Jour. Nat. Hist. III, 3tt, pl. V, fig. 1. 1811.

Lenciscus bigutatus DE Ki.u. X. Y. Finma, Fishes, 214 cextralimitalu. 1842.

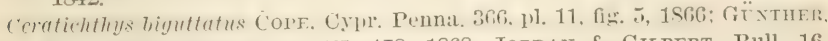
Cat. Fish. Brit. Mus, VII, 178, 1868; JondaN \& Gilbert, Bull. 16. U. S. Nat. Mus. 212, 1883.

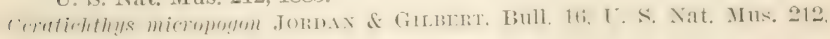
1883.

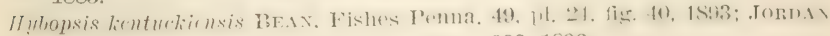
\& Evermann, Bull. 47 , U. S. Nat. Mus, 322, 1896.

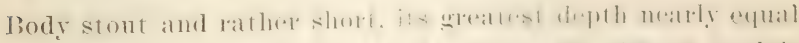

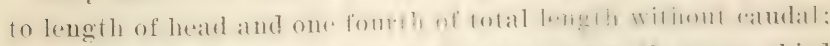

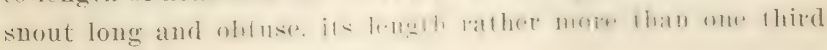




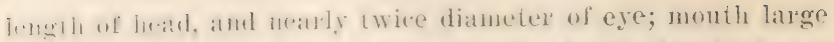
ame flaterl low, the maxilla reathing to below frent of eye. thr lower jat shorter than upper; dorsal origin slight!y nearer 11. ront of ratulal than to tif uf suout, its base one half as long $\therefore$ h he he:al and 100 thirds as long as its longest ray: wentral

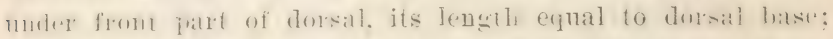
anal origin! ander 2uth sale of lateral line, longest atual ray abunt one stemoth of total to aludal hase. pectoral fwo thirds

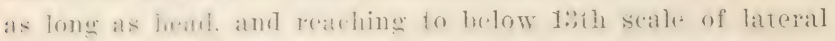

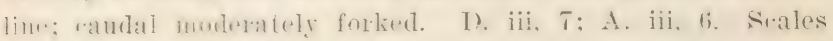

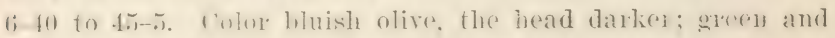
(n)prery refletions on the sides. Fins pale oranger, pinkish in spring: lower parts white. Preeding males have the top of heall swollen into a rest and rovered with coarse tuhereles, from whith arises the natme horned (hub; they hare also sometimes a red spot on eareh sige of head. The young have a broarl dark median hamd and a dusky spot at the base of the tail fin.

liafinrsure states that the fish is known as Indian chub. mattail amel shiner. other names in eastern localities are nigger

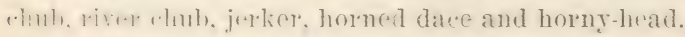

The spereies ranges from Penmsyluania westward to Dakotal and stuth 10 . labatma. In Permstranial it is common in the

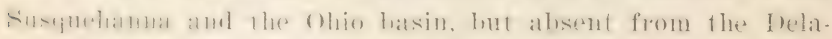

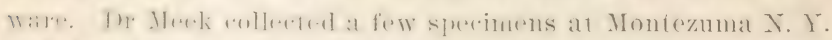
and lomm nome in any of the ollur localities investigated.

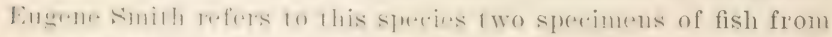

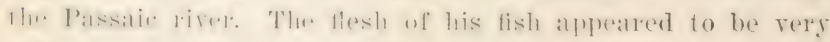
soft.

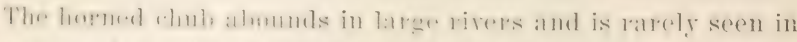

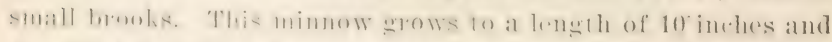

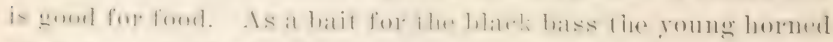

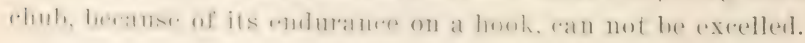

\section{Genus covesws Jordan}

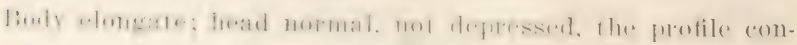
vex; mouth terminal, normal, a well dereloped barbel on the sunterior side of maxillary, just above its tip). Teeth 2, 4-4, 2, 
hooked, withont grinding smfater. Sirales rather small; lateral line continuous. Dorsal fin orer or slightly behind rentrals; anal basis short. Size rathey lange. This genus is elosely ra. lated to the section $\mathrm{Xoc}$ om is umber II y bopsis. from which it may be separated hy the eresenere of $t w 0$ terth in the lesser row, hy the position of the barbel, and hy lhe smatler seales. Its relations with $\mathrm{s}$ (em ot ilus are afually rlose. The species are not well known. (After Jordan)

\section{Couesius plumbeus (Agassiz)}

\section{Lake Chub; Plumbeous IIinnow; Morse Lake Minnow}

Gobio plumbeus Agassiz, Lake Superior, 366, 1850.

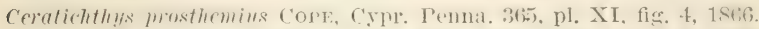

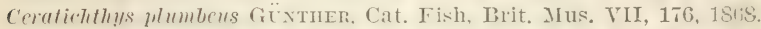

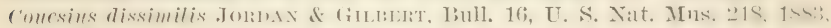
in part.

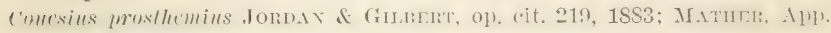
12th Rep. Adirondack Surv. 30, 1886.

Coucsius plumbeus Jondax of Evemaxx, Bull. 47, U. S. Nat. Mus. 32:3, 1896.

Body moderately elongate and some what compressul: whaltest depth four and one half to fom and two fluirds in total

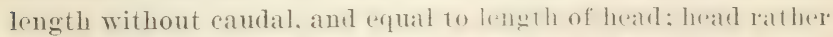
flat above, not much ratived above the level of the eyes; interorbital space nearly one and om half times lemg diameter of eye, which equals snout and is one fourth length of heald: head four and one third in total without watal; maxillary ratrhing to below frout of orbit, a small harkhel plareed high al its lije lower jaw well included. scales small, smaller in arlvamer of dorsal fin. Lateral line beginning high up on the nalpe. abruptly descending to the median line ores the frectoral fin, and llemene rumning nearly straight to the calutal tin. Torsal origin mislwas betweren tip of snout and hase of catudal fin. over midelle of rentral base, longest ray two thirds of head. lenedle of hatse ome half of head; rentral seareely longer thath dersil hatse, the tin not reaching rent; longest anal ray refual to reniral, hase of

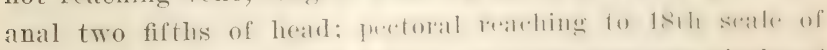

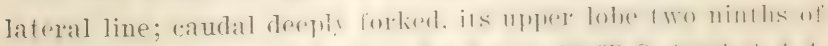

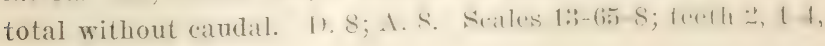




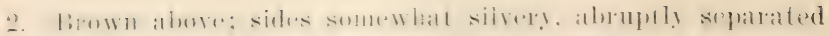

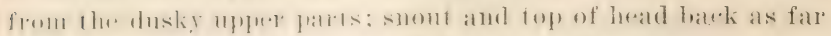

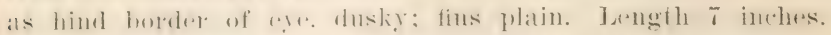

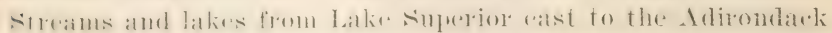

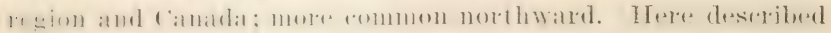

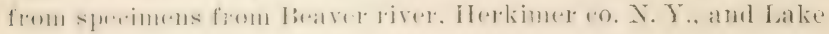
Lomond, near St John N. B.

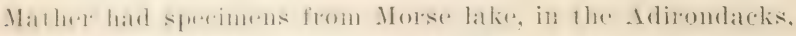
and it is reported also from serenth lake. Fulion chatio. The

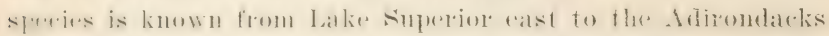

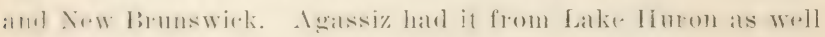
as Lake Superior.

\section{Genus Exogrossur Rafinesque}

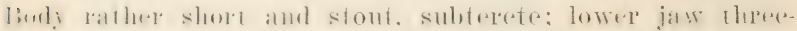

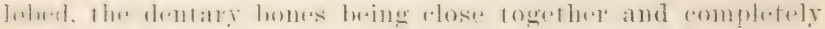

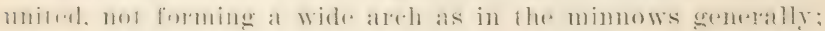

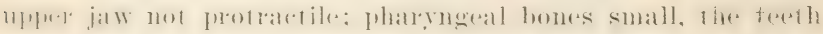

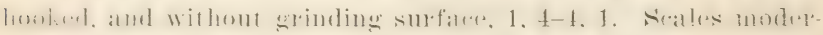

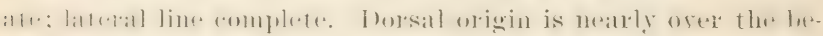

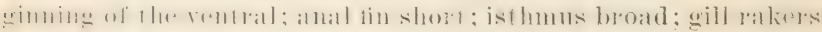

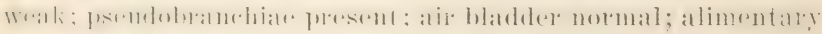

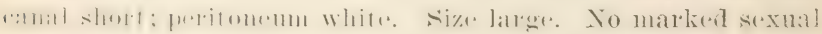

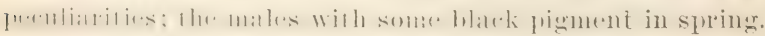

\section{9s Exoglossum maxillingua (Le Sueur)}

\section{Cut-lips: Nigger. Chub}

Cyprinus merillingua Le Seecr, Jour. Ac. Nat. Sci. Phila. I, S5, 1S17, Pipe Crrek, Marylanul.

Limglessum annulatum Riminesęe, Jour. Ac. Nat. Sci. Phila. I, 421, 1 S1S. IIndson River.

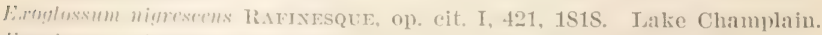

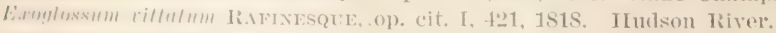

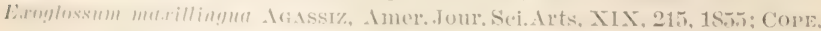

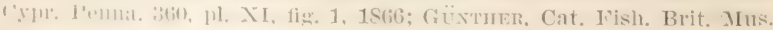

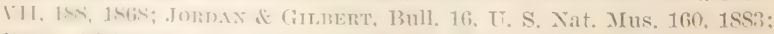

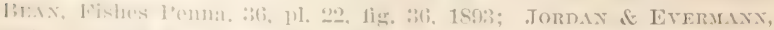

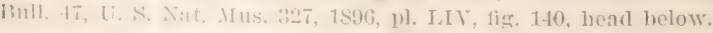

The rul-ligs has a stont, short and thick body, its greatest hight neaty erpual to the lemglle of the head, and one fourth of 
the total without caudal. The caudal peduncle is short and deep, its least depth about one half the head. The snout is short and obtusely conical, its length somewhat greater than the eye and nearly equal to one third of the head. The maxilla reaches to below the nostrils, its length equaling that of the snout. Head four and one fifth in total to base of caudal. The dorsal origin is nearly orer the rentral origin and in the rertical through the $23 \mathrm{~d}$ seale of the lateral line. The dorsal base is about one half as long as the head, and its longest ray equals twice the distance from the dorsal origin to middle of eye. The pectoral is about as long as the longest dorsal ray, and the rentral reaches to the anal origin. The base of the anal is one half as long as the longest anal ray. The caudal is moderately forked. D. S; A. 7. Scales 9-5t-6; teeth 1,4-4, 1 . Length of specimen described, 43 inches; from Takoma Park D. C. Color brown or olivaceous, darker above; a short and narrow dark bar above root of pectoral; young with a dusky bar at the caudal base. Fins dusky, their extremities pale.

The cut-lips may be readily distinguished by the three-lobed lower jaw, the dentary bones being closely united and the lower lip represented by a fleshy lohe on earh side of the mindible.

The cut-lips is known also as (hub, butter chub, nigger chub, and day chub. It is a rery common species in the susquehama and its tributaries. Its range is not extrnsive, reaching only from western New Jork to Tirminia. In New York it occurs in Lake Ontario, the st Lalwence, Lalie Champlain. Cayuga lake, and the Hulson river. The F. S. Fish Commission has it from the following New York localities in the Ialke Ontario basin:

Mouth Salmon river, Selkirk.

Big Sandy creek, Belleville.

Wart creek, Buena Vista.

Little Stony brook, Henderson baj.

Big Stony creek, Henderson Harbor.

Spring brook, Pulaski.

Black river, Huntingtonville.

All of these were obtaned in fuly, 1s!4. Evermalnm and Bean collected it also in the sit Lawremee, :, miles below Ogdensburg, 
July 17. 1s94, and in scioto ereek, Coopersville and Saranac river, Plattsburg, July 19, 1894.

1) Mrek foumd it in sinall numbers in Six Mile creek and Fall rreck below the falls. It inhabits clear running water.

The fish grows to the length of 6 inches and may be at once distinguished from all of the other minnows by its three-lobed lower jaw. It is beliered that this singular structure of the mouth enables the fish to scrape mollusks from their hold on rorkis. as its stomach usually contains small shellfish. It takes the hook readily.

\section{Genus carassius Nilsson}

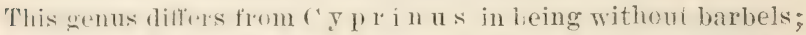
its pharyngeal texth atre compressed, in a single series, 4 -t.

Trmperate Asia and Europe. Inomesticated and degenerated into numerous rarieties. (After Günther)

Tharyngeal teeth spatulate, fom in a row on earh side; mouth teminal, withont barbels; base of the dorsal tin elonEate: anal tin short: both fins with a spine which is serraterl behind. (After Heckel and Kner)

body oblong, dompurssed and eleraterl; mouth terminal, withont harbels; fwhth 4-t, molar, hut compressed; seales large; latral line entinuons ; dersal fin rery long. with the third ray deselopel into at stout spine, which is serrated behind; anal shert wilh a similar spine; rentrals well forward. (After Nilsson)

\section{Carassius auratus (Linnaeus)}

\section{Goldfish (Introduced)}

Cyprinus auratus Imsinaus, Syst. Nat. ed. X, I, 322, 1758; Cuvier \& VAlexomines, Hist. Nat. Poiss. XVT, 101. 1812; DE KAY, N. Y. Fauna, Fishes, 190, 1S12; Stomer, Hist. Fish. Mass, 115, pl. XXI, fig. 1, 1867. (1) 1863; Atlas Ichth. Cypr. 74, 1863; GüNTner, Cat. Fish. Brit. Mus. VII,

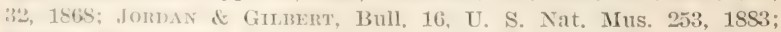
Goome, Fish of Fish. Ind. U. S. I, pl. 231, 1SSt; BEAn, Fishes Penna. 51, 101. 25, 1ig. 43, 1593; Jomdan \& Evemman, Check List Fish. N. A. 512. $189 \%$.

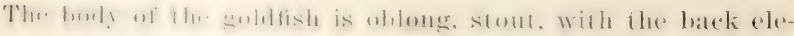

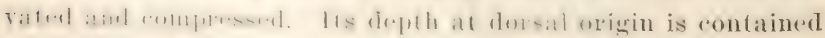


about two and one half times in the total length without the tail; the head is contained three and one third times in this length. The head is small in front of eye, being depressed on snout, and the dorsal profile from tip of snout to dorsal fin is very steep. The rather small eye equals one fifth or less of length of head. Mouth terminal, oblique, rather small, the maxilla not reaching the vertieal from front of eye. No barbels. Teeth compressed, 4-4. The dorsal fin is high and long, commencing over the serenth scale of the lateral line and rumning back to near the caudal; its longest latys, first and second, a little longer than the spine, ergnal to one half of depth of body, or length of lead from pupil to its pesterior end. From the third to the latst the rays gradually dereace in size, the last being less than half the length of the longest. The first dorsal spine is minute. one fourth the length of second, which is strong and coarsely sermated. The anal is short, the length of its base being but two thirds the length of its longest rays; first spine small, one thirel the length of second, which is stout and sererated. I'ertomel fin broad and rounded, its length three fifths of that of heiul, or erfual to lougest anal ray. It reaches to ventral, which is placed well forward. Caudal fin large; scales large, deepere than long; lateral line median, eomplete, almost straight. I). II. 18; A. II, 7 ; I. 9. Scalles $5-30-6$. The speecimen described is from the fish yonds, at Washington D. C. Iength 8 inches.

The common gollfish or silverfish is a native of Asia. whenee it was introdued into Europe and from there into Americal, where it is now one of the commonest arpurium fishes and is extremely abundant in many of our streams. In Pennsyliania it abounds in the Delaware and Schuylkill river.

De Kay made the following rematis about the goldtish, or golden carp, as he styles it.

The golden carp, or goldfish, ats it is more gemerally alled, was introduced from China into Enope in the early fare of the 17th century, and probably shortly after fomm its way to this country. Tley bread freety in ponds in llis and the adjoining states. They are of no usr as an artine of food, but ane liept 
in wass rases as an ornament to the parlor and drawing-room. They are said to display an attachment to their owners, and a limited obedience to their commands.

They atre introduced into lakes, ponds, fountains and reserroils enerally. An individual was kept in a fountain at 420 street and thth aremue, New York, by Patrick Walsh nine rears, and was then presented to the aquarium.

At the Cold spring Harbor hatchery, I. 1., several rarieties wre hatched from the same lot of eggs. These included the normal form, the typical fautail, and one which was so deepbodied that it could starcely balance itself in swimming.

'The goldfish in the New York aquarium were never troubled by fungus or parasites.

In many of our streams and ponds, the goldfish has run wild, and hundrerls of the olivaceous type will be seened to one of a red color. In the fauna of the moratine ponds atud in quarry holes. thr gollfish stands first. It will breed in foul water

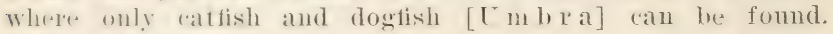
Eugene Smith

The goldfish is extremely variable in color and form. It is nswally orange, or mottled with black and orange, get in some stranus. and even in pond culture, silvery individuals are often mor. rommon than any of the mottled varieties. The species glows to the lengh of 12 inches. It spawns early in the spring and iv subject to many dangers and is attacked by numerous

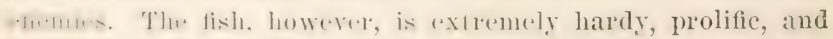
tenacious of life.

\section{Genus cremus Linnaeus}

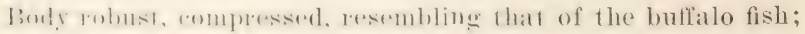

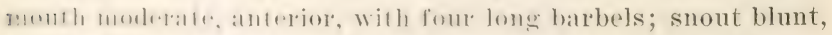

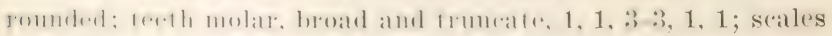

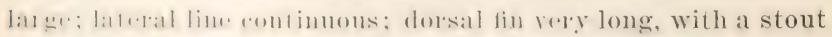

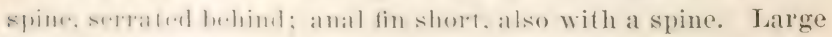
fislues of the fresh watres of . Isiat: introdued into Europe and

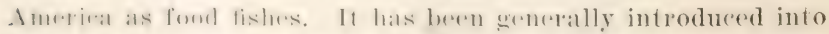
fwirale fumels in mearly all parts of the lnited states; from

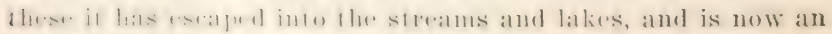


abundant fish in most of our larger, warmer river's and in the ponds and bayous of the Mississippi valley. On the south shore of Lake Erie (and in the Mississippi near Quincy Ill. and the Delaware river) it has become well established and is of considerable commercial importance. (After Jordan and Evermann)

\section{Cyprinus carpio Linnaeus}

\section{Carp (Introduced)}

Cyprinus carpio Linnaeus, Syst. Nat. ed. X, I, 320, 1758; Cuvien \& VALenciennes, Hist. Nat. Poiss. XVI, 23, 1812; De KAY, N. Y. Fauna, Fishes, 1SS, 1812; Heckel \& Kixer, Süssw. Fische, 51, fig. 21, 1858; Günther, Cat. Fish. Brit. Mus. VII, 25, 1568; Jordan \& Gilbert, Bull. 16, U. S. Nat. Mus, 254, 1883; Goode, Fish. \& Fish. U. S. I, pl. 230, Leather carp, 18s1; American Fishes, 411, figure, 18s8; BEAN, Fishes Penna. 55, pl. 1, colored, 1893; Jomdan \& Evemaxy, CheckList Fishes N. A. 512, 1896.

The carp has a stout and moderately elongate body and a small head. The greatest depth equals one third of the length without the caudal fin. The length of the head is nearly one fourth of the total to the base of the tail. The caudal perbuncle is about two fifths as deep as the hody, and the caudal fin is strongly forked. The eye diameter is contained six and one? half times in the length of the head. The mouth is moderate, the upper jaw not extending to front of ere. The dorsal begins at a distance from tip of snout equal to twice length of head; the length of its base equals twice length of pectoral; the longest ray equals length of head withont the snout; the last ray is two fifths as long as the head. The anal begins under the 15 th ray of the dorsal; its longest ray is fwo thirds as long as the head and more than twice as long as the last ray; the length of its base is about two fifths of length of head. The ventral begins under the second ray of the dorsal; its length nearly equals longest dorsal ray. The fuectoral is nearly one fifth of total length without the caudil. The long spines of the dorsal and anal are strongly serrate along their hinder edges. I harbel on the upper lip and another at the angle of the month on each side; the longest bartw. alwout equal to diamerter of "yo. Three varieties are recognized, the scale, the mirror and the 


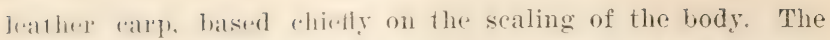

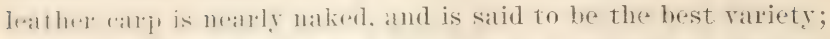
the mirror carp has a fer large scales irregularly placed; und the sate ratriety has the hody completely scaled. The color

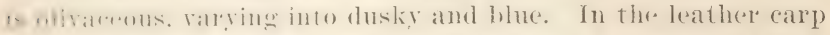

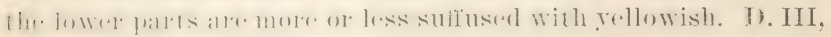
20 ; A. III, 5; V. I, 7; P. 15. Scales 5-38-5.

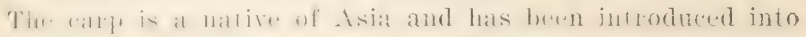

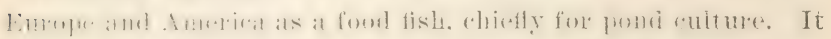

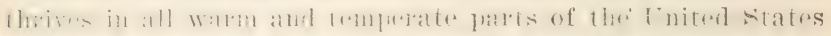

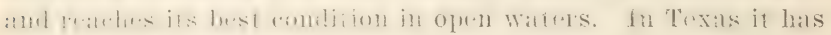

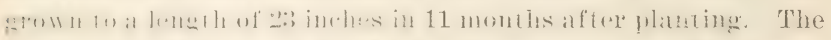

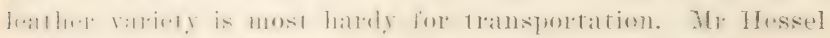
hats taken the ralle in the liblek and rasplan seas: salt watere

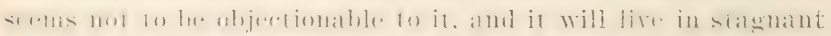

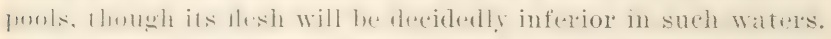

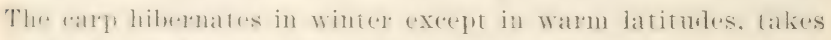
Int foul and does not grow: its increase in size in templuate latitudes occurs only from May to August.

Reproduction. The spawning satson begins in May ame comlimus in somer lowalities till dugust. A carp weighing \& to j)

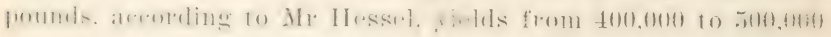
engrs; the scale carp contains rather more than the other varie-

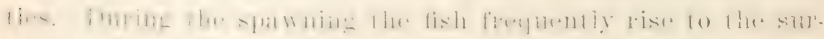

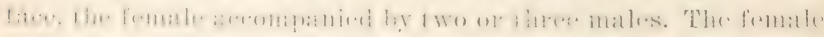
drops the egges at intervals during a period of some days or

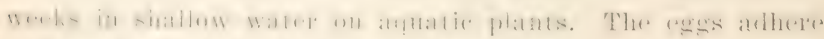

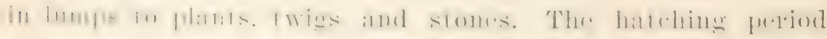
varies from 12, to 16 days.

Size. Acorring to Hessel the average weight of a carp at

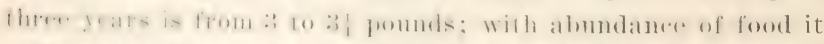

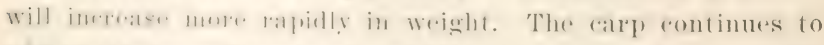

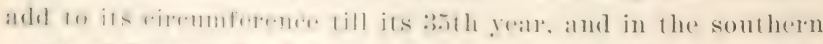

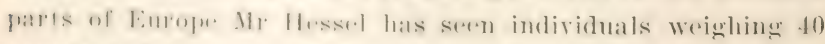

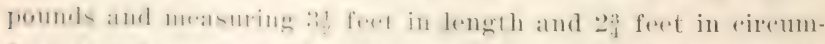

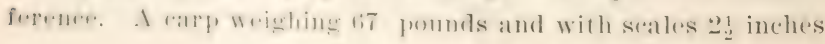


in diameter was killed in the Danube in 18:2: There is a record of a giant specimen of 90 jounds from Lalke Zug in Switzerland. Examples weighing $2 t$ pounds have hren citught recently in the Potomac river at Washington D. C.

Food. The carf lives principally on regetable food, jureferaby the seeds of water plants such as the water lilies. Wild rice and water oats. It will eat letture, (ab)bage, soaked barley, wheat, rice, corn. insects and their larvae, worms and meats of rarions kinds. It wan radily br caught with dough, grains of barley or wheat, worms, maggots, wasp larvae, and sometimes with pieces of beef or fish.

During the summer of 1 s. t two female leather carp died in captivity as a result of retention of the eggs.

Large individuals are found in Frospeet park lake. Brooklyn, where the sprecies was introducerl. The food of the fisth in ratptivity inchudes bard ram, arthworms, what, corn, lettuce and cabbage. Its growth is remarliahle. I leather carp has fully doubled its weight in one year.

Linnaeus says the anl Was introllaral into England about

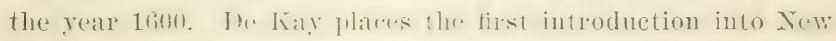

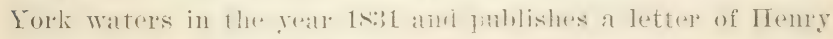
Robinson, Newlury, Oranger (o)., who broughe them froms France, reared and lned the-m sticersefully in his ponds, and planted from one dirzent to a wo dozent ammally in the IIndson dur

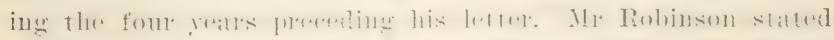

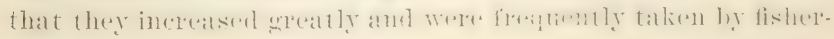
men in their nets.

\section{Order APODES}

Eels

\section{Suborder ENCHELYCEPHALI}

\section{Family anguillidae \\ True Eels}

\section{Genus avgurul Shaw}

Body elongate, subterete. compressed posteriorly, corered with small, linear, embedicel scales which are placed obliquely, some of them at right angles to others: lattral liue well derel- 
oped; head long, conical, pointed; eye small, well forward, over the angle of the mouth; teeth small, villiform, subequal, in bands on each jaw and a long pateh on the vomer; tongue free at tip; lips rather full, with a free margin behind, attached by a frenum in front; lower jaw projecting; gill openings rather small, slitlike, about as wide as base of pectorals and partly below them; nostrils superior, well separated, the anterior with a slight tube; vent close in front of anal; dorsal inserted at some distance from the head, confluent with the anal around the tail; pectorals well dereloped. Species found in most warm seas (the eastern Pacific excepted) ascending streams, but mostly spawning in the sea. (After Jordan and Evermann)

\section{Anguilla chrysypa Rafinesque}

\section{Eel}

Anguilla chrisypa RAfivesque, Amer. Month. Mag. II, 120, Dec. 1S1\%. Lake

George; Lake Champlain; Hudson River above the falls.

Anguilla rulgaris Mitchild, Trans. Lit. and Phil. Soc. N. Y. I, 360. 1515,

Goode, Fish \& Fish. Ind. U. S. I, pl. 239, 1884.

Muraena bostonicnsis Le Suecr, Jour. Ac. Yat. Sci. Phila. S1, 1821.

Anguilla tyrannus GindrD, Iehth. U. S. Mex. Baly. Surv. 75, pl. to. 18.9.

Anguilla blephura Rafixisque, Amer. Month. Mag. II, 120, Dee. 1817. Soutl: shores of Long Island.

Muracua rostrata LE Stetr, Jour. Ac. Nat. Sei. Phila. S1, 1821. Caynga Lake.

Anguillu tenuirostris I)E KAY, N. Y. Fauna, Fishes, 310, pl. 5i3, fig. 173, 1S12. Anguilla rostrata DE Kay, op. cit. 312, 1S12. Copied from Le Suemr.

Lalies Cayuga and Geneva, N. Y.; Jordan \& Grlmert. Bull. 16, U. S.

Nat. Mus. 361, 1S53; Bean, Fishes Penna. 95, pl. 30, fig. 58, 1s9:\%.

Anguillu macrocephala DE KAY, op. eit. 313, 1St2. After Le Sueur. Saratoga Lake, N. Y.

Angmila bostonicnsis STorer, Hist. Fish. Mass. 214, pl. XXXIII, fig. 1, 1S67. Anguilla chrysypa Jokdax \& DAvis, Rev. Apod. Fish. 668, 1892; Jordax \& Evermann, Bull. 47, U. S. Nat. Mus. 348, 1896, pl. LV, fig. 143.

In thr.e the body is elongated, roundish throughout most of its exteni, compressed behind. The saales are deeply embedded aml rery irregularly placed, some at right angles to others. The hearl is conical, clongated with pointed snout and small (ye), weregt in the male. The lower jaw is longer than the "plum. The jaws with small teeth in bands; a long patch of dewh wh the romer. The gill openings are fartly below the 
pectoral fins, small and slitlike. The beginning of the dorsal is at a distance of nearly twice the length of the head behind the gill opening. The anal hegins still farther back, and the rent is rose to its origin. The dorsal and anal fins are contimuous aroumd the tail. Ilight of body nearly two thirds the length of the hearl, whirh is rontained about eight and one fourth times in the total. The distance from the gill opening to the vent expuls two and one half times the length of the heat. The color varies greatly, but is usually dark brown, more or less tinged with rellow: lower parts paler. In the male referred to the muner parts were silvery gray shamply separated from the sattiny white of the abdomen. In the eel the lateral line is very distinct.

The eel appears to have only one common name. It is one of the best known and most singular of our fishes, get its breeding habits ar. oven now enveloped in doubt. The species ascends the rivers of rastorn Vorth America from the Gulf of st Lawrence to Mexico. the former being the northern limit of the sper.ies on ont anast. In he Ohio and Mississippi valleys it is

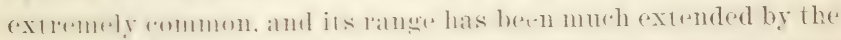
oprening of ranals and hy artiticial introulnetion. It has been transferred to the Pacific coast.

The rel hals heen linown to exceed a length of 4 feet. The arerage length of indiviluals however is about 2 feet. The female is latrore than the male. paler in color, and is different in cortain ofher fartirulars. Which will be mentioned in the description of the species.

This is a very important fool tish. It is caught chiefly when descending the rirers in the fall. In 1 srig about a ton of cels mere calught in a single fish basket above Harrishurg. At the prestent time this method of capture is illegal. Both ardults and rome exts aseend the streams in spring, the roung coming in millions, but in the fall run small eels are seldom seen. Till a compratirely recent date it was not certainly known that the eels have agges which are developed outside of the body. Even now the breeding 
habits are monown, but it is supposed that spawning takes flawe latw in lhe fall or during the wiuter near the mouths of rivers on modry hotoms. In . Jordan has expressed the belief that lhe and somedines hreeds in fresh water, since he bas fomml romme pels less than an inch long in the beadwaters of

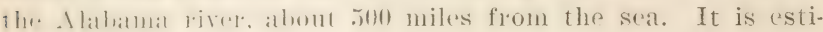

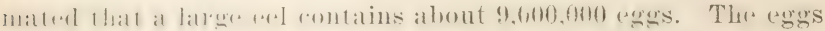

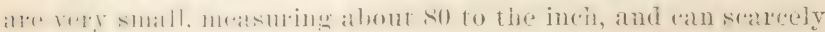
be seen by the maked eye.

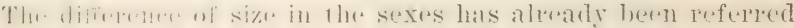

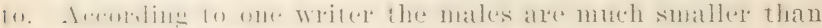

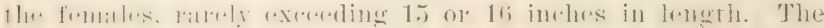

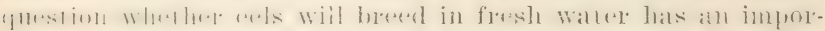

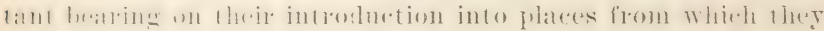

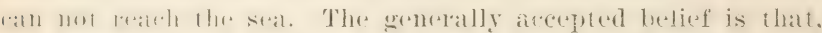

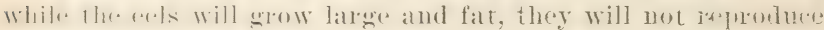
under such circumstances.

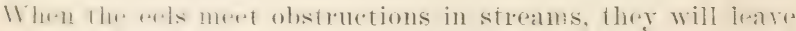

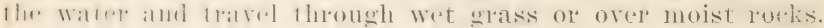

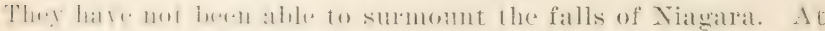

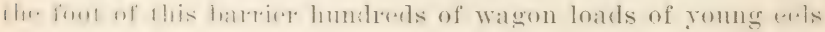

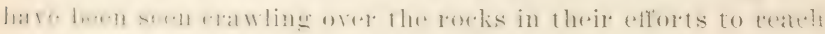
the upper water's.

1). Mitchill heard of an eel, which was caught in one of the

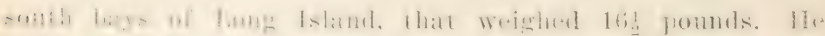

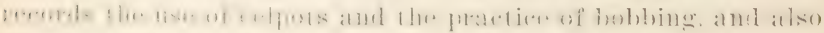

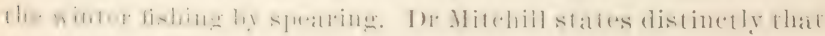

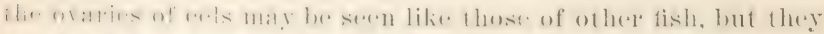

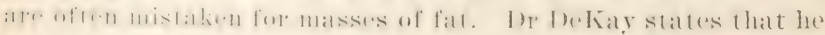

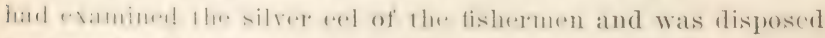

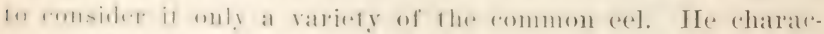

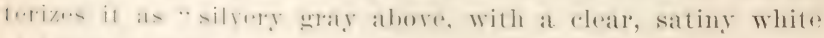
ablomen. sepatratial from the rolof above by the lateral line."

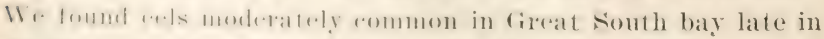

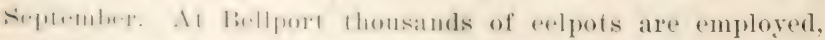

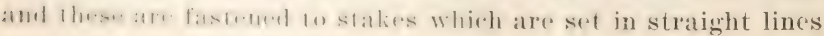


orer a large extent of the bottom. These stakes project from four to six feet above the surface of the water. At lihe l'oint cove, Great River beach and Fire Island we found five individuals of a kind of exl known to the tishermen as silver eel. These were taken between September 25 and Gctober 7 , and they were the culyones of the lind seen byus. Ther aftracted attention at onee, both on areomint of their colors, barge eyes, short snouts and long pectoral fins, ats rompatend with the rommon form. There is still some doubt in my mind as to whether this represents a distinet speries or not. It may le the silvere eed, I ng u i 11 a

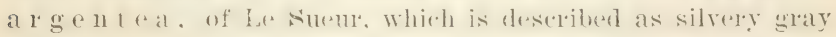
above, seratrated form the silvery white abelomen by a distinct lateral line. Inut, to whaterer speetes they may be referred, the greatest interest attaches to them because they hate grovers, on examination by Prof. John A. Ryder, to be males with the generative glands so well dexeloped as to leave no doubt concerning the sex of the individuals. I'rof. Ryder has published a report on these spereinems, with figures showing sections of the syrskian oreans, and amnoumeres the fact that the male eed hals now been positively indentified from at least two joints along on watern coast. the oher lowality being Woods Eole

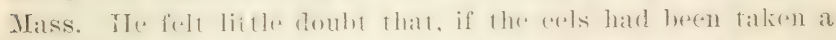

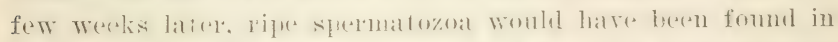

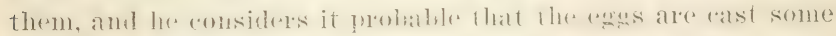

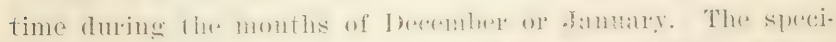

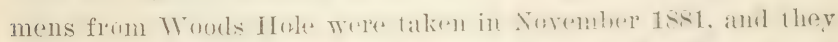
show slightly latwere syrstiall organs than in the Fire island specimens.

In captivity cels live many yeats. They delight to lie hured in the mud or simd with only their heats ont, ready for anything edible to come within reach. Muscils and snatils are picked out of the shells by them. (After Eugene Smith ${ }^{1}$ )

The eel in captivity is particulary liable to attarks of fungus, which do not always rield to treatment with salt or bratkish

${ }^{1}$ Linn. Soc. N. Y. Proc. 1897. no. 9, p. 29. 
water; but the parasite can be orercome by placing the eel in a poorly lighted tank.

In Cayuga lake, X. Y., according to Dr Mreek, the eel is not common. but is occasionally taken at each end of the lake.

II. II. Lallou malies the following remarks abont their feeding habits:

Ther are among the most roracious and carnivorous fishes. Thry eat most inland fishes except the gar and the (chul... They are particularly fond of game fishes, and show the delicate taste of a connoisseur in their selections from choiere trout, bass, pickerel and shad... On their hunting exrursions they overturn huge and small stones alike, working for hours if necessary, beneath which they find species of shrimp and rayfish, of which they are exceedingly fond. . Ther are among the most powerful and rapid of swimmers. . They attack the spawn of other fishes open-mouthed, and are eren said to surk the eggs from an impaled female. . They are owllike in their hithits, committing their depredations at night.

\section{Family LEPTOCEPHALIDAE}

\section{Conger Eels}

\section{Genus heptocephalus (Gronow) Scopoli}

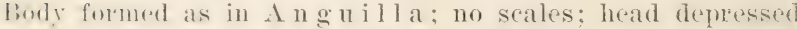
aluse. anterorly pointed; lateral line present; mouth wide. ils r.ft extending at bast to below middle of ere; teeth in outer series in with jaw ("gulul and elose set, forming a cutting edge, mo ranines, hand of romerine tecth short, tongue anteriorly frex; rertical fins well dereloped, confluent around the tail, ferloral tins well developed, dorsal beginning elose behind jwertorals: qill opunings ratlere large, low; eyes well developed; fostrem mostril near ere, anterior near tip of snout, with a shur tuble: lower jaw not projerting. Skeleton differing in

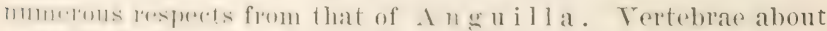
Eliflum. In most warm seas. This gemus contains the well kmun and widely distributed rongere aed and three or four

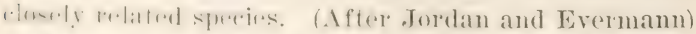

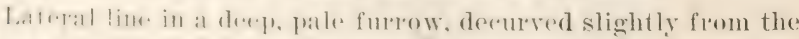
heal t. la.tow dersal origin. very conspicuous pores in its anterior thiret. 


\section{Leptocephalus conger (Linnaeus)}

\section{Conger Eel; Sea Eel}

Muraena conger Linsaeus, Syst. Nat. ed. X, I, 215, 1758.

Anguilla conger MrtchıL, Trans. Lit. \& Phil. Soc. N. Y. I, 360, 1815.

Anguilla oceanica Mitchill, Jour. Ac. Nat. Sci. Phila. I, 407, 1818, off New York.

Conger occidentalis DE KAY, N. Y. Fauna, Fishes, 314, pl. 53, fig. 172, 1812, very poor:

Conger vulgaris G̈̈̀then, Cat. Fish. Brit. Mus. VIII, 38, 1870.

Conger niger Jordax \& Gilbert, Bull. 16, U. S. Nat. IIus. 362, 1883.

Leptocephalus conger Goode, Fish \& Fish. Ind. U. S. I, pl. 240, 18s1; JorDAN \& Evermand, Bull. 47, U. S. Nat. Mus, 354, 1896, pl. Lvil, fig. 148, 1900; Sмптн, Bull. U. S. F. C. XVII, 90, 1898.

Dorsal fin begins opposite to or just behind tip of pectoral; eye one and one half in snout, five to six in head; snout three and one fourth to four and one fourth in head; gape extending nearly or quite to below hind margin of eye; head one and four fifths to one and six sevenths in trunk; tail longer than rest of body; pectorals three and one half in head; upper lip full, with conspicuous pores. Length of head one ninth of total length, depth of body two fifths length of head. Pores in lateral line rery conspicuous. Color dirk olive brown, sometimes nearly black, abore; chin, space behind pectorals and lower parts soiled white.

The conger eel ocrurs on hoth coasts of the Atlantic, on our coast extending from Cape cod to Brazil, but not often coming into shallow bars. An exeeption is noted in Great Egg Harbor bay, where the tish is not rare in summer. It is sometimes caught in Graresend bay also in summer, and occasional indi-

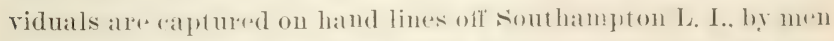
fishing for sea bass and scup. The fishermen dislike to handle the species on account of its pugnateity and strength; it snaps viciously at ererything neal it when captured in our waters; yet, strangely enough, the writre hals seen at humilesel or more, taken on trawl lines off the north coast of Frances, in al boat at one time, and not one gave evidence of ferocity.

In captivity in the aquarium the seat aed suffers sererely from fungus attacks, which are not reliered by changing the fish from salt water to fresh. Perhays the salinity of the water in some 
lowalities is too low, and relief might be obtained by suplying sea water of normal ocean density.

The romng and larval form of the conger is a curious, elongate, transfrant, bandlike creature with a minute head, a rery small mmulh and with the lateral line, belly, and anal fin dotted with black points.

An indiridual nearly 8 feet long was captured with a hand line hy . I. I. Latto in the oceau, near Southampton I. I. Aug. 3, 1S98, while fishing for sea bass and scup.

In the Woods Hole region, according to Dr suith, "it comes in July and remains until fall; rery common for sereral pears, but rather rare formerly. Fishermen as a rule do not distinguish it from the common ext. I feew are taken in reaps and with lines, hut many linge ones, weighing from \& pounds upwarl, are "anght in lobster pots. A specimen in the collution weighs 10 pounds. One raught on a liue at Filnouth. Aug. :30. 1s!9, wrighed 12 pounds. The smallest observed are 15 to 20 inches long."

Ifrehill derelared the dlesh to be very dainty eating. Deray salid the Hesh has a freculiar moarery taste. He discorered that is is a virious animal, snapping when eaptured at everything 11+a11 it. In Fanne the congere eel is among the cheapest and least esteemed of the food fishes.

The whervations of Ir Otto Hermes, director of the Berlin aynatium, on the hathits and the reproduction of the conger eel arre of rayg great interest. IReference is made to them by Goode

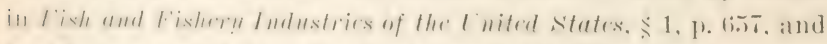

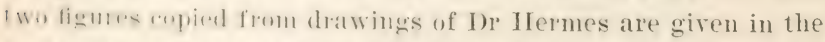

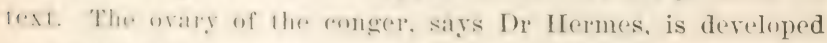
in raplatity, and this is often the ailuse of the death of the eel.

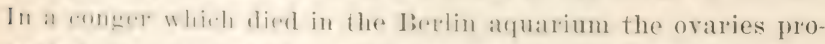

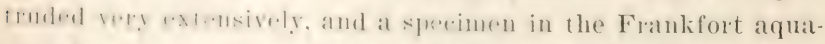

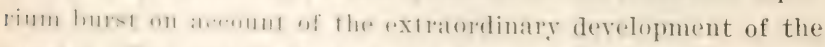

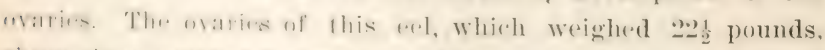

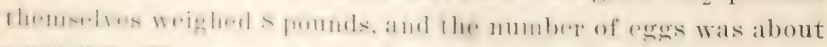

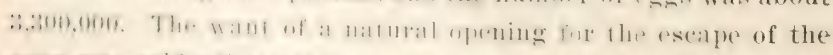

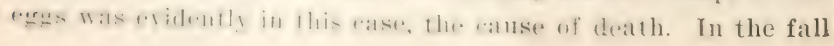


of 1879 Dr Hermes receired a number of small sea tols tiakn in the ricinity of Harre. These eels ate greedily and grm ratpidly. Only one was tardy in its development, so that it could easily be distinguished from the rest. This one (fied . Jn!n? 20, 18s0, and was examined the same day. It proved to bu a sexually mature male and served to clear up some very doubtful problems in the reproduction of the species, as we.l as its ally, the commm eel.

\section{Order ISOSPONDYLI}

Isospondylous Fishes

Family' ELOPIDAE

\section{Tarpons}

\section{Genus tarpox Jordan \& Evermann}

Body oblong, complessed, rovered with very large, thick, silvery, crcloid scales; beliy narow, but not carimated, its erlge with udinary seales; month large, oblique, the lower jaw prominent, maxilary hroad, extending beyond the rye: villiform teeth on jaws, vomer, palatines, tongue, sphenoid, and pteregeid bones; eye very large, will an adipuse eyelid; latiall line nearly straight, its tubes radiating widely over the surface of the seales: branchirstegals 2:3; psendubranchiae wantine: gill rakers loug and slenter; dorsal fin short and high. inserted behind the ventrals (ovel the ventrals in X $\mathrm{e} g \mathrm{a}$ lo fls), its last ray elongate and filamentous as in Megalops, il o r o s o n a and Opisthone 111 a ; anal fin much longer than dercal, falcate, its last ray frodured; caudal widely forted: prectorals and

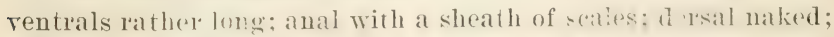
caudal more or less sualy; a collar of la wa siales all the nape. Vertebrae alont $5 \pi(28+29)$. Size very laty... the largest of the herringlike fisho's. (After Jordan and Evermanm)

11:3 Tarpon atlanticus (Cuv. \& T'al.)

Tarpulit: Tarpon; Grande Écaille; Silver King

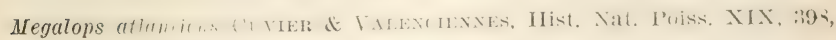
1846. (ivi: lialoune

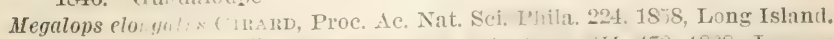

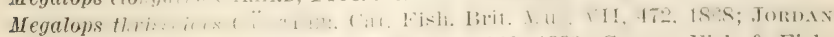
\& Grlbert, Br:1l. 16, U. S. Nat. Mus. 262, 1883; Goode, Fish \& Fish.

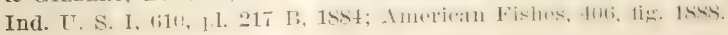




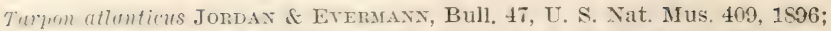
711. IXVII, fig. 177, 1900; Simth, Bull. U. S. F. C. XVI, 90, 1895; Everimyx of Marsir. Fishes Porto Rico, Bull. U. S. F. C. 1900; S0, fig. 10,1900 .

Judy longate, compressed, not deep, its greatest hight about win. fomlth of total length without caudal. Length of head n'ally refual to greatest hight of body. Mouth large, oblique, the lower jaw very prominent, the maxillary extending beyoud the vertical from hind margin of eye; ẹe moderately large, two thirds longhth of snout, two elevenths length of head; dorsal orimin midway hetween tip of snout and end of middle caudal rays, dolsil liase two fifths as long as head, dorsal dilament mearly as long as the head; rentral origin midray between tip of smont and end of anal fin, the rentral fin two fifths as long as the hratd; batse of amal three fourths as long as the head; Ju+toral fin as long as the longest lay of dorsal: candal deeply forliel, its longest rays equal 10 dorsal filanent. size large, weight ratrhing nearly 200 pounds and length 6 or 7 ieet. Color silvery, darker abore. D. III, 12; A. III, 23; P. 13; V. II, 9. Scales 12-17.

The harpon inhabits the westeru Atlantic from Cape Cod to Brazil and the West Indies, being rather uncommon northward, hut aloundiut toward the south, ascending rivers in pursuit of smallwistises on which it feeds. The species grows to the length of $T$ fene and the weight of 150 pounds, or upward. It is not juimed for foud, but is now very celebrated as a game fish of

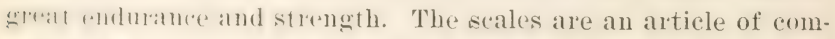
more as rmiosities. Fishermen dread the tarpon because it laifs thengh their nets with great violence, and the Pensaleola stillers hatre linmwn of persons being killed or severely injured hy jo leapling anainst flem from the seine in which it was imelos.el. Is to the erlible qualities of the flesh opinions differ, but the fact is that the species is seldom eaten.

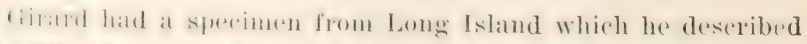

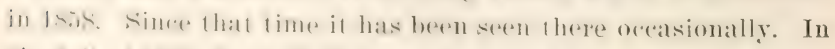

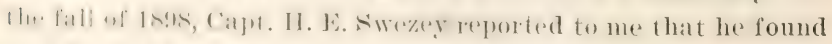

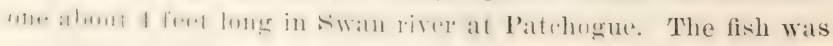


recently dead, and he helieves it came into the river alive. In the ricinity of Woods Hole Mass. it is now a regular summer visitor. According to Dr. Smith, it is "taken every year in traps at South Tartmouth, also ocrasionally at Quissett and at Menemsha, in latter part of Septrmber. All are about one size, so to 100 pounds. Fishermen (all them 'big seale fish.' An effort has been made to find a market for them in New Bedford, but the people did not like them, owing to the toughness of the flesh."

The tarpon evidently breeds at Porto Rico, as Evermann and Marsh collected a number of individuals measuring from $2 \frac{1}{4}$ to $3 \frac{1}{4}$ inches at Fajardo in February 1899, these apparently being the first young of the species so far recorded.

\section{Genus Exops Linnaeus}

Body elongate, subcrlindric; scales small, silvery; head moderate; conical anteriorly, with rery long jaws, the lower slightly included; branchiostegals 30; ere large and placed high; dorsal fin high in front, the last rays short, origin of fin about midway between tip of snout and end of middle caudal rays, the fin depressible into a scals sheath; anal fin short, well behind end of dorsal, also depressible into a sheath; pectorals and rentrals each with a long appendage; caudal fin long and deeply forked; opercular bones thin, with expanded, membranaceous borders, a collar of scales on occiput; lateral line continuous, nearly straight, its tubes simple; large pseudobranchiae. Vertebrae $43+29=72$. Large fishes of the open seas. The young are ribbonshaped, elongate, and pass through a series of metamorphoses similar to the changes observed in the congers.

\section{Elops saurus Linnaeus}

\section{Big-eyed Herring}

Elops saurus LinNaEus; Syst. Nat. ed. XII, I, 51S, 1766; DE KAY, N. Y.

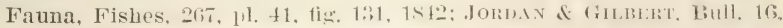
U. S. Nat. Ius. 261, 1883; Goode, Fish \& Fish. Ind. U. S. I, 611, pl.

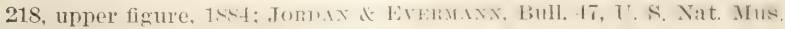
410, 1896; pl. LXVII, fig. 17s, 1900; BEAN, Bull. Amer. MLus. Nat. Hist. IX, 334, 1897; Sмmтн, Bull. U. S. F. C. XVII, 90. 1895; BeAN, 521 Ann.

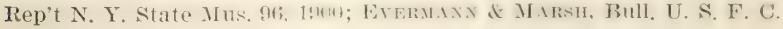
for 1900,81 , fig. 11, 1900 .

Elops inermis MхтснгL, Trans. Lit. \& Plil. Soc. N. Y. I, 445. 


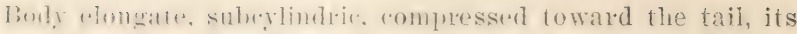

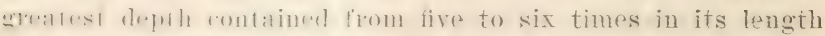

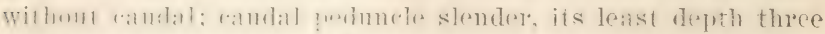

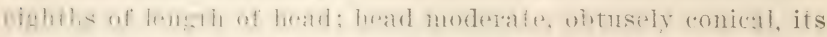

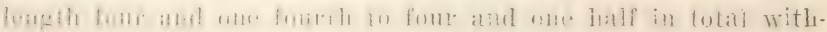

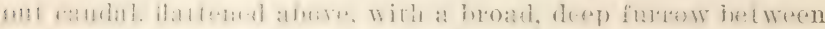

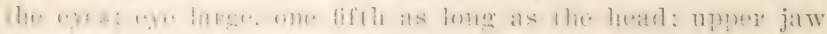

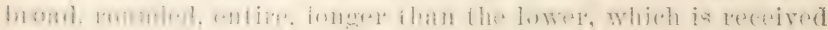

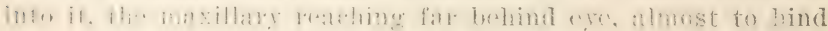

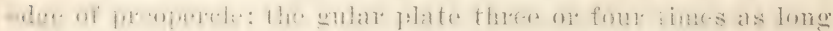

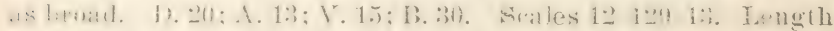

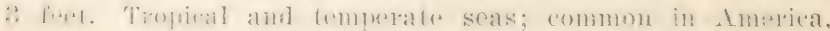

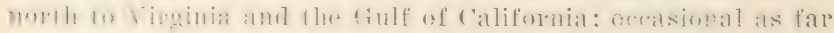

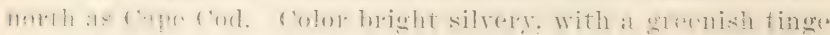

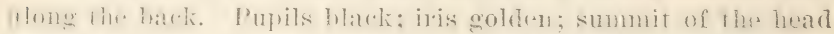

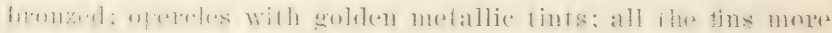

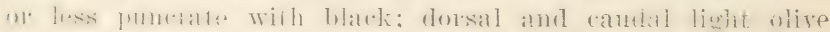
brown; lower fins tinged with yellow.

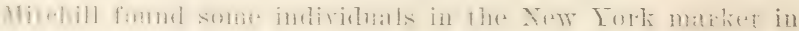

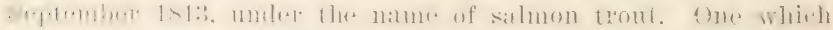

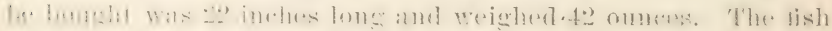

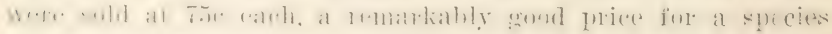

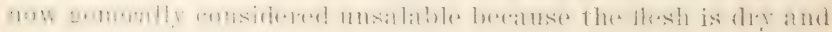
bo11:

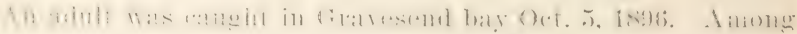
the fishermen there it is linown as "seering" and "cisco".

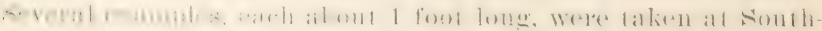

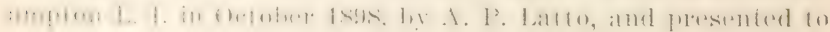
the sitate Musemm.

It ('ilfur cod, aceording to ])y. Smith, it is "common in fall,

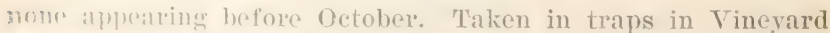
sionul and in herring gill nets at Vineyad Haven. Arerage jometh, 1s to "u inches. No young observed."

"Plur lish does not breat on om coast. The young are known

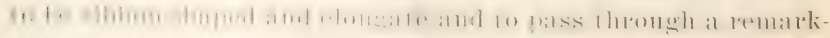

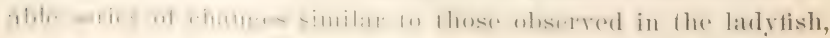
A I ) I : v 11 l pes. 


\section{Albula vulpes (Linnaeus)}

\section{Ladyfish; Bone Fish; Banana Fish}

Esox vulpes Lrixaeus, Syst. Nat, ed. X, I, 313, 1758.

Butirinus vulpes DE KAY, N. Y. Fauna, Fishes, 268, 18t2, name only.

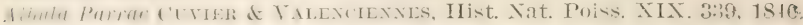

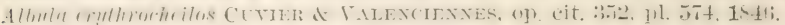
dluula conorhynchus Güntrer, Cat. Fish. Brit. Mrus. VII, 468, 1868.

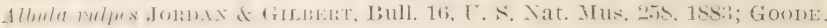

Fish \& Fish. Ind. U. S. I, 612, pl. 218, lower fig. 188t; BeAx, 19th Rep. Comm. Fish. N. Y. Separate, 42, pl. XXIII, fig. 31, 1890; Jordan it Evermaxn, Bull. 47, U. S. Nat. Mus. 411, 1896, pl. LXVIII, fig. 179,

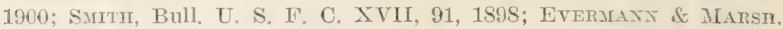
Bull. U. S. F. C. for 1900, 82, fig. 12, 1900.

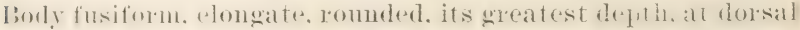
origin. entalimel four and 1 wo thirds times in total lemeth to

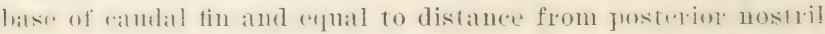
to rend of head: atudal peduncle rather slendere, its least depth

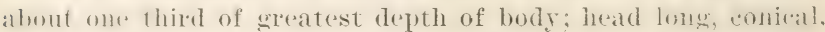
1he. suont rather acutely pointed, length of head about there

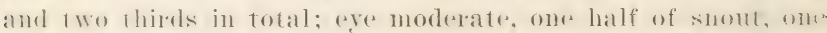
difth of leral, platerl high; month inferior, small, lhe maxilial mol reathing to helow front of eye: collar of emlarged scales an the natwe extending down to the base of the pectorat: flotsal origin about midway between tip of smont and base of candal. the hatse of the fin a little more than one half the lengeth of hrarl, the longers ray as long as the head without the snout. the last ray ont thirel as long as the longest. The pectoral reaches t) helow the 1.5th seale of the lateral line. The rentral origin

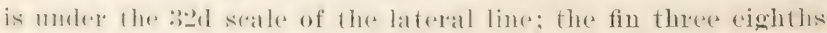
as lolly as the hrad. Inal origin remllally distant from baste of andulal fin and r.mel of rentral hase, flow longest raly one thirel

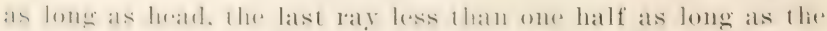

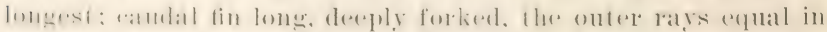

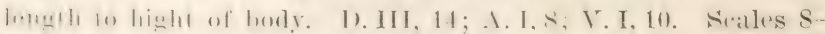

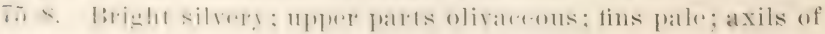

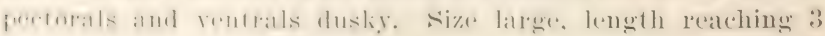
feret.

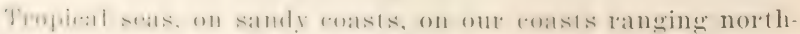

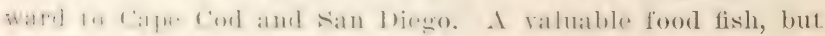




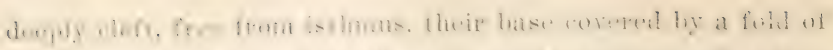

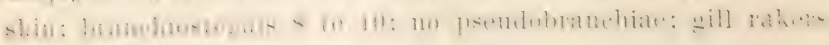
short. thick and fer in mumbers; a straight and well dereloned lateral line: belly wi whont sentes; no adipose fin; dorsal fin orer the cantial part of the rertebral colmme anal long and low;

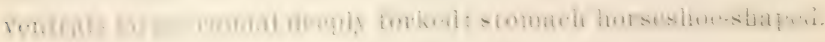
with blind sac; intestine short; one prloric appendage; a bladder lantere and simple. The eggs fall into the abdominal cavity before exchusion.

\section{Fiodon tergisus (Le Sueur)}

\section{Irooneye: Toothed. Herring}

Hiolon temisus Le Stect. Jour. Ac. Nat. Sci. Plila. I, 3̈b, Sept. 1s1s, Ohio liver ami Lalie Erie.

Hiolon cludulus LE SLEXT. op. cit. 36T̄, Sept. 1S1S, Pittsburg.

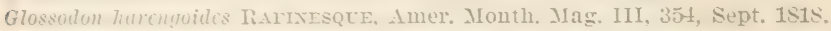
Ohio River:

Cumrints (thramis ? Smithii RIcr.ındsox, Fauna Bor.-Amer. 1II, 110, tig. $1 \mathrm{sist}$

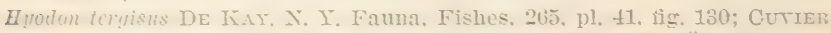

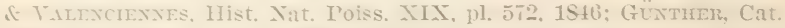

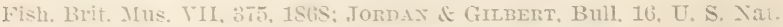

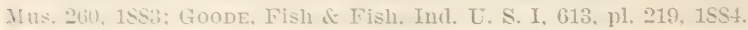

Hyotin clodulis 1) Ii.1x, op. cit. 266, 1842. but tig. 164. pl. 51, represent: uluseritles.

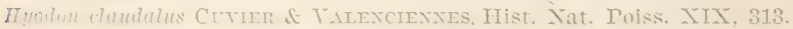

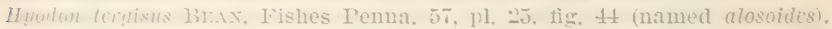

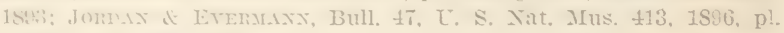
1.XY11, 1ig. 180, 1900 .

'The slatpe of the boily is similat to that of the northern mooneye. The bully has a slight but obtuse keel in front of the ventrals and is commessed to a rather sharp edoge behind the veritrals. Ilead short. its lemeth two ninths of total without entrial: the eye much longer, about one thired the length of heai. The stratest depth of the body is nearly one thirel of total lermile. The peremal is as lemer as the head without the snout; Ihe vemtral nut muele more than two thirets the length of head. its oricin muler the 1Sth seale of the lateral line. The anal

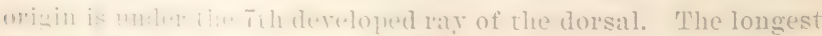

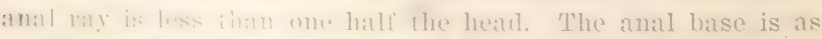
lomer as the lueatl: its last ray is less that one half the longest 


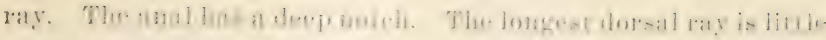

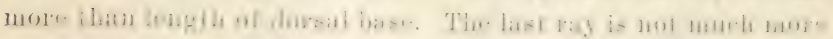
than onc lanlf the longest. The caudal is deeply forked. D. 12; A. 28 to 32 . Scales $(j-58-8$. U Uper parts greenish in life, the sides and abdomen brilliant silvery.

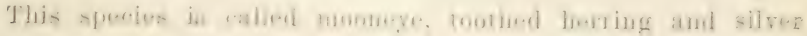

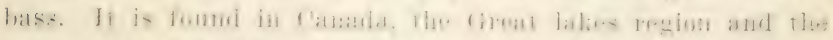

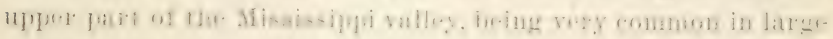

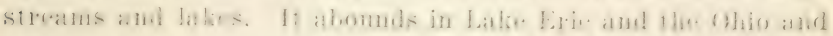

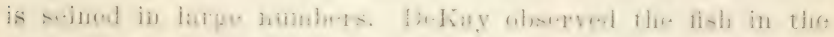

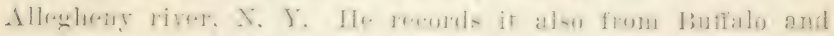

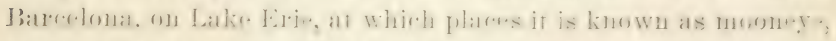
shiner, and lake lurring. Ifr saye it is very indithent food.

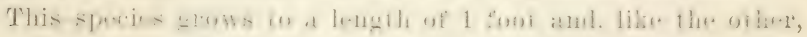

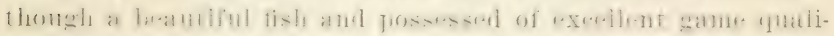

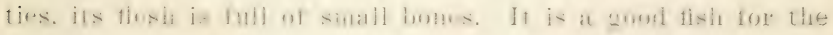

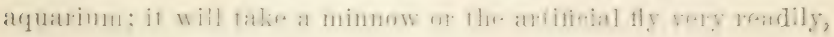
and the utmost skill is required in its capture. Its fond consists of insects, small fishes and crustaceans.

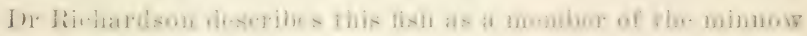

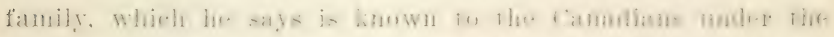

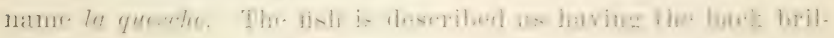
liant green, sides and abdomen with a silvery luster. The

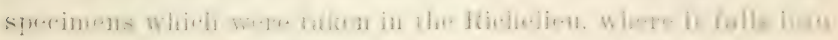
the St Lawrence, were about 9 or 19 inches long.

\section{Hiodon alosoides (Rafinesque)}

Torthern Irooneye; La Quesche

Ampliodon alosoides Rafrassqu, Jour. Phys. Paris, 421, 1319. Ohio Rirer. Hyodon ampliodon Rafratsque, Ichth. Ohien. $42,1520$.

Hiodon chrysopsis Ricmirdosox, Fauna Bor-Amer. III, 232, 1836.

Hyodon alosoides Jorndx \& GILEert, Bull. 16, L. S. Nat. Mus. 259, 18:3; Goode, Fish \& Fish. Ind. U. S. I, 612, 1884.

Hiodon alosnirles BEAx. Fishes Penna. 5\%, 1893 (not figured); Jordar \& Everarixz, Bull. $4 \bar{\tau}$, U. S. Nat. Mus. 413.1896.

Hyodon clodalis DE KAY, X. I. Famna, Jishes, pl. 51, fig. 164, not description, 1812.

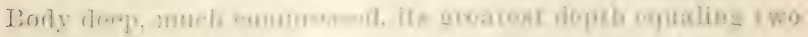

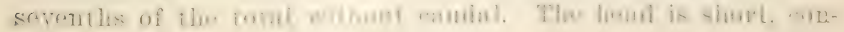


fining llue lungth of the "yr about three and one half times and enualing a little more than one fifth of the total without anulul. "the smont is rery blunt, the mouth large and oblique, the maxilla bath hing berond the mitdle of the we. There is

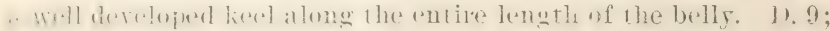
A. 32 . Seales $6-56-7$.

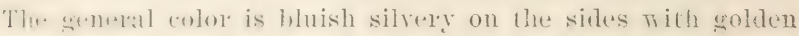
jeflections.

The northern mooneye is found from the ohio river throughwut the dirat lakes region to the Saskatchewan. It is rery com mton in Manitobat and other parts of British Ameriat. In Pennstrlyania it is limited to the western region.

1). Kay must have had the northern meonege for study, thomgh his dexpiption sems to apply to another specties. The figme of his II yod o n a lodalis represents a fish with a short dorsal fin, quite unlike his account in the text.

The northern momere is rery readily distinguished from the othere speries of the genus by its short dorsal fin, which eon-

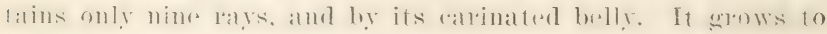

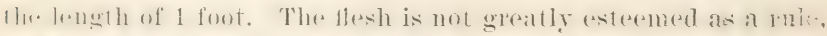
funt the tish is beatutiful and has excellent game qualities.

dirbardson says the tish inhabits bales which commmnicate

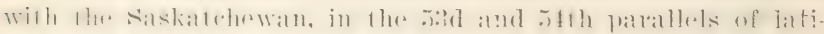

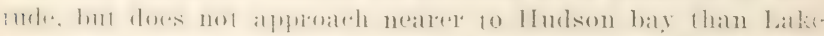
Wimigen. This we knew lo be a mistake. He says furthere

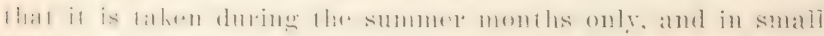

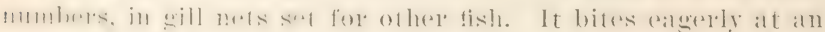

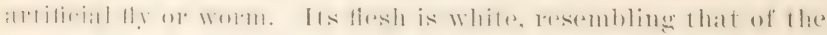
perch in flavor, and excelling it in richness.

Family DOROSONIDAN

\section{Givard Shads}

\section{Genus morosoma liatinesque}

The anus 1) or os o m a has a herringlike body, with a slont and obtuse snout. The body is much eompressed and is roverenl with moderately latre, thin, cycloid seales. The head is sealeless, short and small: the eye large and provided with 


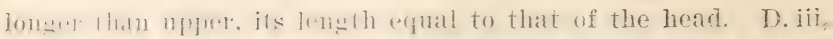

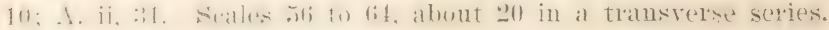
simes in flont of rentla!s 17 , and from rentral to ront 12.

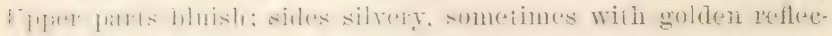

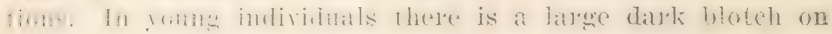

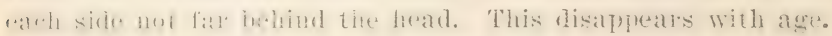

The mat shad, also lanwm ats wizatrel slad, winter shat, stink

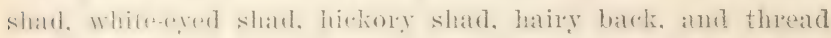

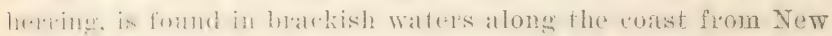

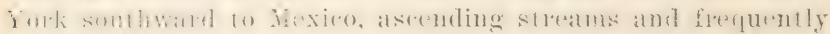

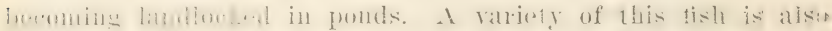

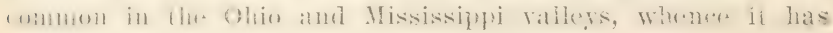
spread through canals into Lakes Erie and Michigan.

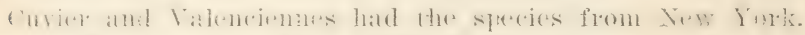
Wheme it was sent by Millart. Wh Kaly mentions it only als an

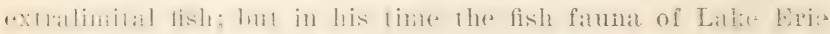
was rery little known.

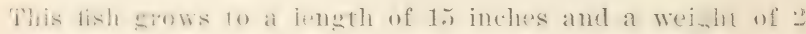

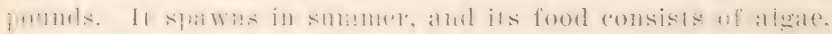

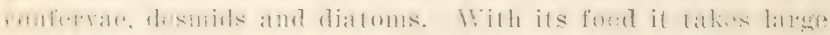

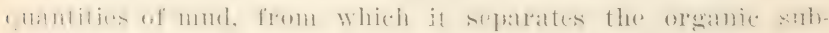

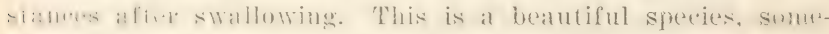

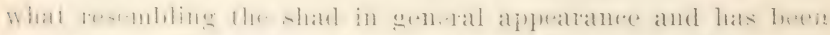

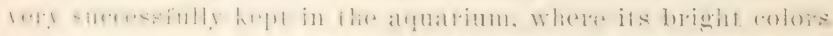

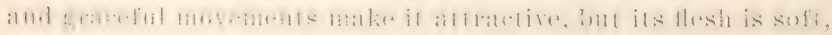

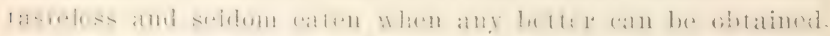

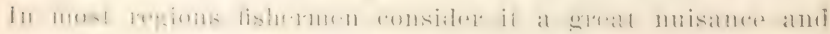

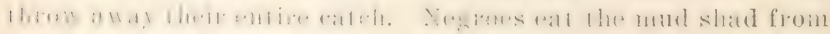

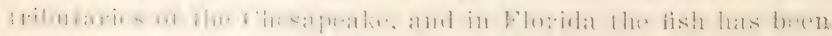
ntilized to some extent in making guano. The name gizzard shatel allucles to the form of the stomach, which is rery much like that of a hese.

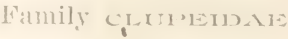 \\ llerrings}

lindy oblumg or clongate, more or less compressed, covered wilh ewhoid or pectinated scales; belly sometimes rounded. somelimes compuressed, in which atse it is often armed with 


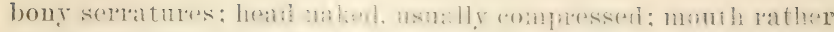

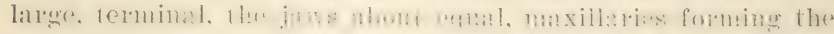

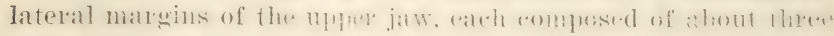

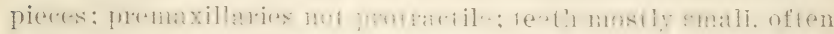

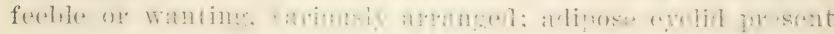

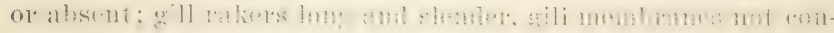

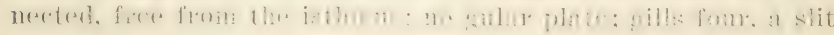

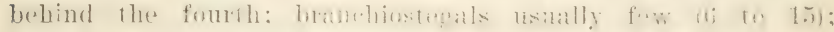

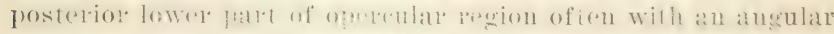

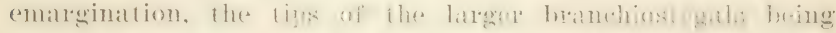

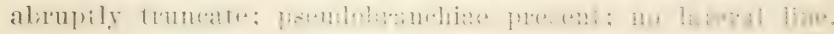

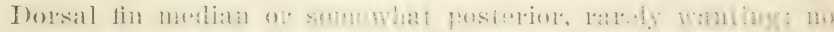

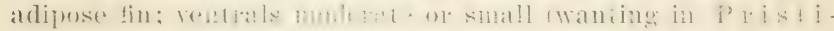

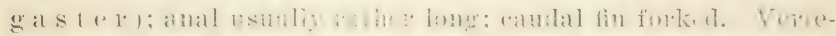

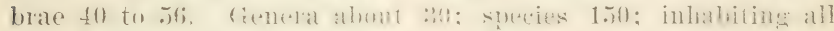

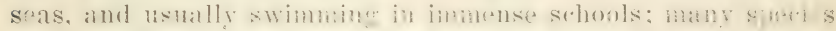

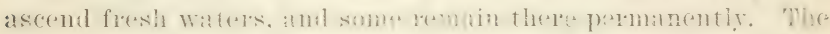

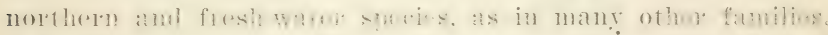

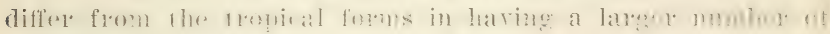
vertebral segments.

\section{Genus Empyrats Blecker}

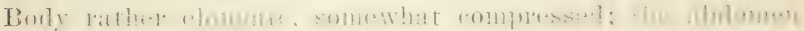

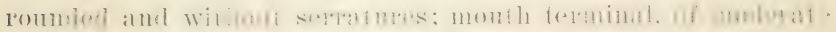

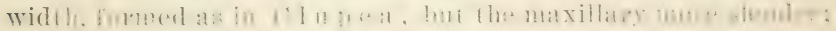

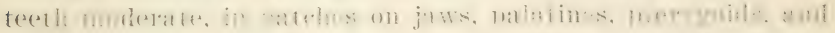

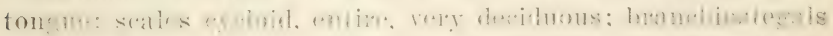

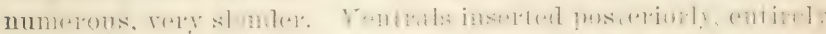

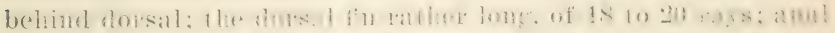

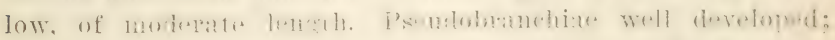

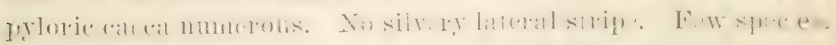
Asiatic and American. (After.Jordan and Evermann)

\section{Etrumeus teres (De Ḱay)}

\section{Round Herring}

Alosa teres DE KAr, N. Y. Fauna, Fishes, 262, pl. 40, fig. 128, 1812. New York harbor.

Etrumeus teres Güxthen, Cat. Fish. Brit. Mrus. VII, 467, 1868; Jomdax \& Gilbert, Bull. 16, U. S. Nat. Mus. 263, 1883; BeAN, Bull. U. S. I. C. VII, 148, 18ss; 19th Rep. Comm. Fish. N. X. separate, 44, 1590.

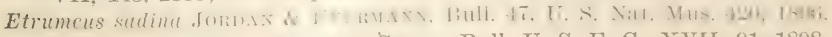
not Clupea sadina MItcinll; Smitr, Bull. U. S. F. C. XVII, 91, 1898. 


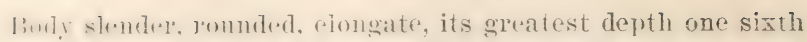

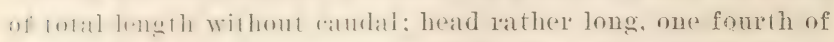

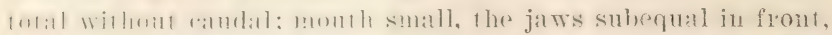

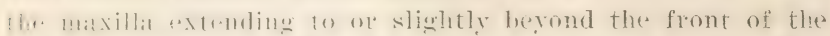

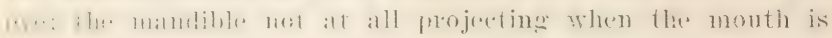

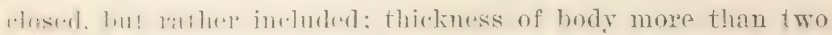

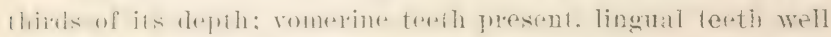

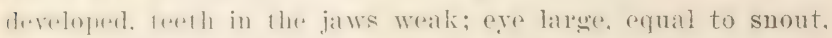
there and one third in lenghth of heat: dorsal origin midway letwern tip of snont and origin of anal. the longret dowsal ray

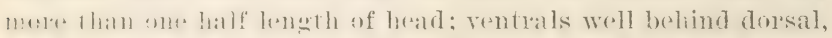

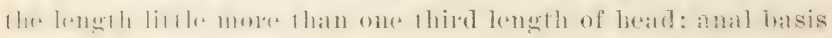
shorl. alume one lhirel lewenth of head; axillary seales abore

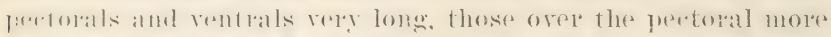
llan onv loalf as long as the fin. I). 1S; A. 12. Colnr, bright silvery: latrier aloove, with a tinge of blue and yellow on the silles. Heat metallir silvery with enppery reflections: iris "wolden: dorsal and atudal tinged with yellow, the remaining

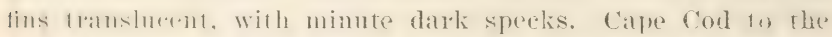

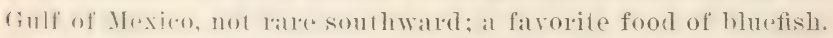

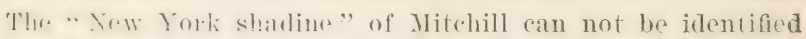

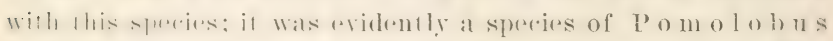

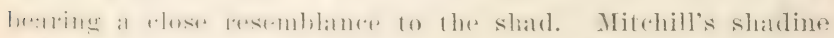
latel a sjol lwhind the gill rover, a wide and toothless momth,

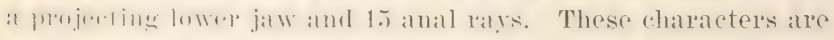
in efyusition to the linown rhatraters of the round herring.

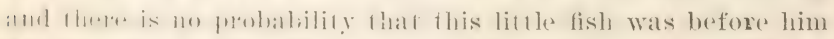

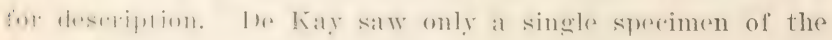
round herring from the harbor of New York. A copy of Mitchill's ${ }^{1}$ deseription is here given for comparison.

1:3 New Tork Shadine, Clupea s a d i n a

In selegant species with a small smutty spot behind the gill rover; hut wilh meilher spots nor stripes on its back or sides. Month wile and toothless. Tongue small.

liack delirately variegated with green and blue. Tateral line

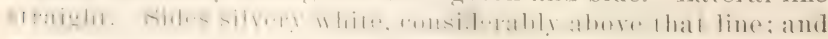

Mitchill. 1,it. and Phil soc. X. Y. Trans. 1s15. 1:4.\%. 
below it quite to the belly. The white reflects vividly green, red, and other splendid hurs. IItad rather elongatred. Lower jaw projecting.

fiales rery easily decislums. Formu neat, later, and slender. Gills rise into the throat on "ath side of the root of the tougue. Fyes pale and latere. Tail derply forked. On aceonut of the eren commertion of the false ribs, the belly is not at all sereated. but quite smooth. I semilramspatent splece in frout of the eves from side to side.

Rays: Br. 7; P. 16; V. 9; D. 1S;A. 15; C. 19.

This spereies was not talien in Gireat South bay. but on the orean beach adjacent to the Blue Point lifesaving station.

It is the slender herring described hy In Ir. Kay from a simgle specimen taken with a seinc in New York latrbor in the lateri part of October. IIe found it associated with numerous spereimens of the bigered herring, E lo ps s a u r us. Mekay states that the Elops appeared to be known to the fishermen as the round herring, but the name is more applicable to the litule species now under consideration. Sereral specinens were seined on the ocean beach at Blue Point Lifesaving station, October 7 . None were ohtained in the bay. September 24, 51 exam. ples of this fish were found lying on the beach, in the vicinity of the same station, having been driven ashore by bluefish. In August 1890 great schools of round herring were stranded in this way. Prof. Baird foumd a number of specimens along the beach of Great Egg Harbor bay in 18J4, and a single specimen was seined by Capt. Thomas Stexhma in the same locality in October 1857.

Young individuals, from $4 \frac{1}{2}$ to $4:$ inches long, weres taken in Gravesend bay July 30, 1896. They were associated with foung mackerel, of slightly larger size, in hunche's and sthools. John B. DeXyse satw some schools that he estimated to contain 25,000$)$ fish.

Dr Smith says it is apparrently ratre at Wuods Mlole; linown to

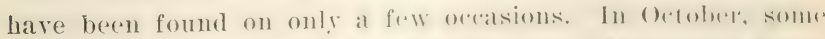

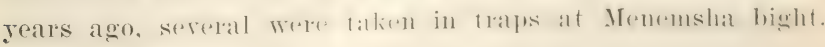
Marthas Vinejard. 


\section{Genus cuvpea (Artedi) Linnaeus}

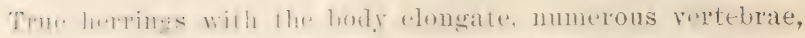

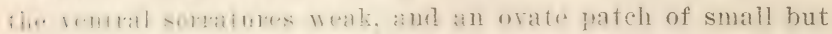

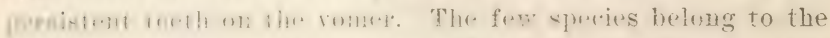

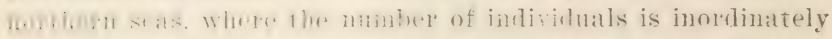

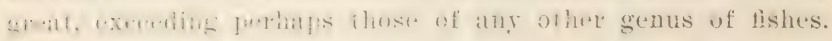
Not anadromous, spanning in the sea.

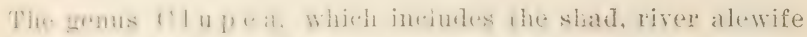

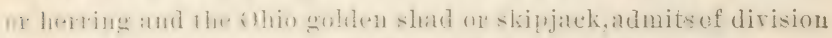

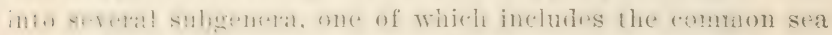

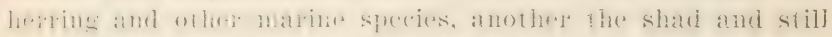
amother the liver ale-wives. The last have the suborbial bone

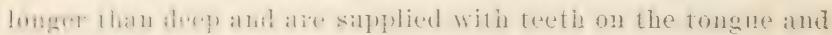
in some species in the jaws.

\section{Clupea harengus Linnaeus}

\section{Sea Herring}

Clupea harengus Lrvisteus, Syst. Nat. ed. X, I, 317, 1755; Mrtchil, Amer. Month. Mag. II, 323, Mar. 1818; Ourier \& VAlexcrexxes. Hist. Nat. Poiss. XX, 30, pl. 591, 1847; GÜNTher, Cat. Fish. Brit. Mis. VII, 415, 186S; JomdiN \& Gilmert, Bull. 16, U. S. Nat. Mus, 265. 188?: 1,0oDr, Fish \& Fish. Ind. U. S. I, 519, pl. 204, 1894; BEAx, 19th Rep. Comm. Fisl. N. Y. separate, 42, pl. XXIT. fig. 32, 1S90; Jordax ¿ Evimaxy, Rull. 47, U. S. Nat. Mus. 421, 1S96, pl. LXX. fig. 185. 1960; Swti, Bull. U. S. F. C. XVII, 91, 189 .

ryner halec Mitemill. Trans. Lit. \& Phil. Soc. N. Y. I, 451, 1815.

C'Iupea musilla MrtemLL, op), cit. 452, 1815.

cluper coemulea Mitcmis, on. eit. $457,1815$.

chupe clongale DE KAY, X. Y. Fauna, Fishes, 250, 1842; Storer, Hist. Fish. Mass, 152, pl. XXYL, fig. 1, 1867.

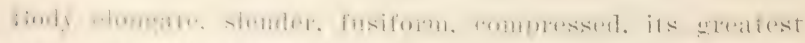

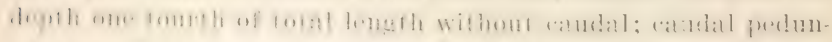

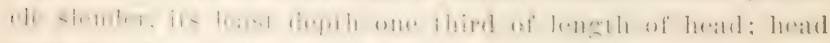

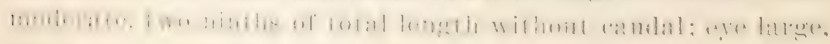
thres ant one half to four in head, and with a well developed

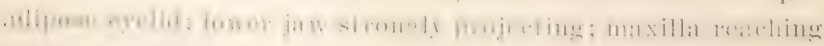
10 holow mislule of jupil, its length the sevenths of length of freall; werelis lomger Ihan high; an orite pateh of small teeth mom vomer. palatime ferth minmte or wanting, small teeth on the

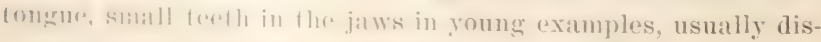


aprearing with age; will rakers rery long and slenter, ahout 40 on the lower frate of the first arell: dorsal origin midway

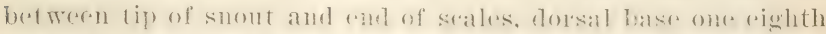
of total length without rantal, lomgest torsal ray ryual to jos

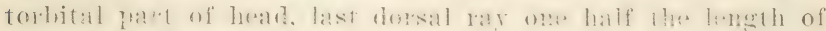

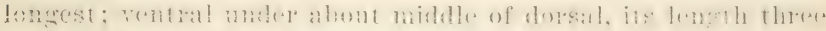

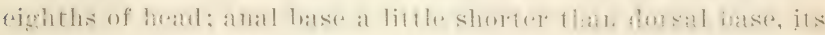

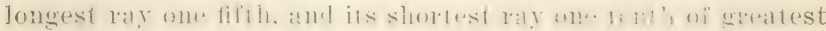

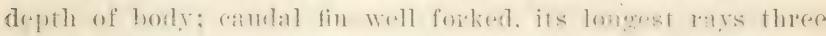

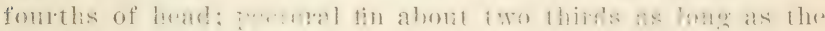

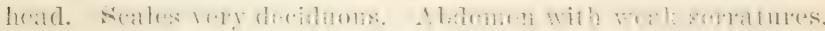

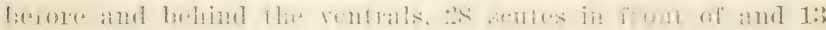
behind the ventrals. D. 18; A. 17. Scales 14-5T. Vertebrae

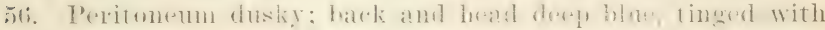

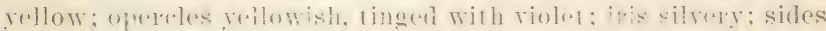

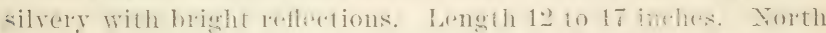

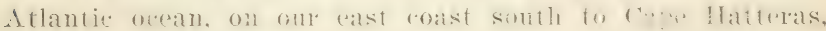
spawning in the sea.

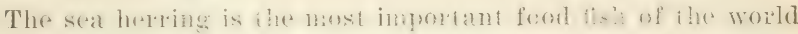

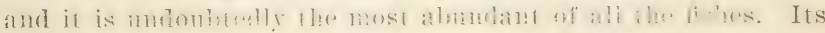

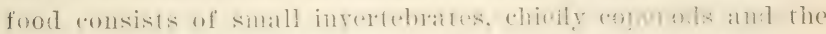
larvar of worms amd mollusks. It forms the rmot imporiant

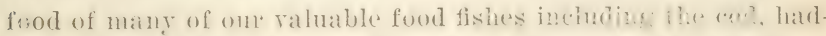

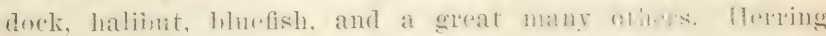

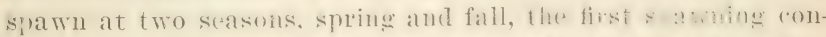

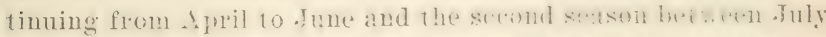

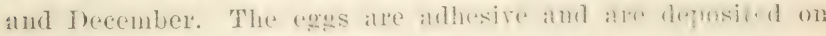

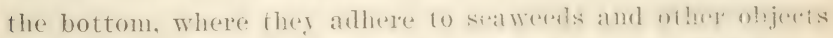

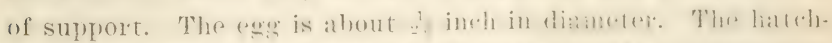

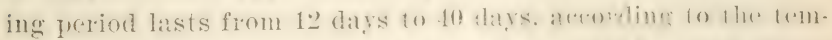

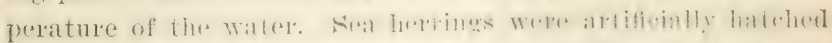

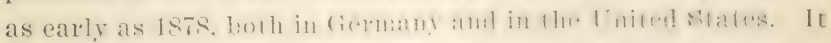
has been estimated that lhe ammat yield of stat herring is $3,000,000,000$ fish, principally taken in Norway.

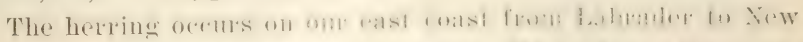

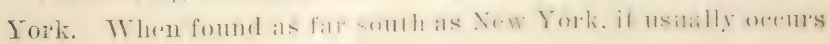




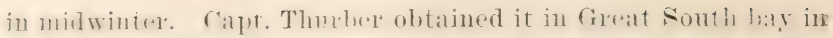
the fall.

The yonng of thw seat herring is well known as the rhitebait of England and the Inited states, thongh in the latter country

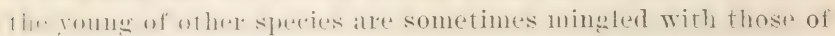
the sea herring.

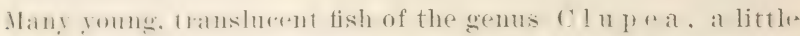

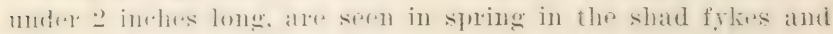

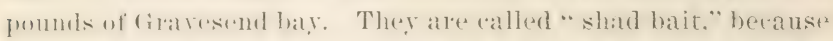

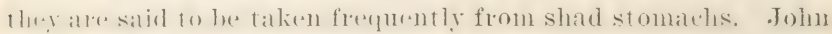
I3. I). Nyse bromght some of t]em to me for examination Ip. :30). 1896. They showed the following characters.

1). 1s: . 1. 17. Musenlat inpressions along sides of lody about (5). The rentral is rex slighty in alvanee of the origin of the

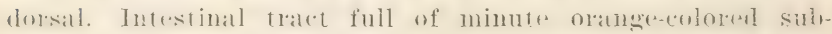
stamers lasembling entomostraca. A row of black dots on sides. low down, "xtending from pertoral to anal. Iris silrery: top of eye rery dark.

Latlene seat herring, aceording to M. I. I) Nyse, atr ratre in

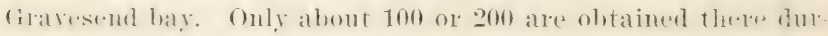
ing fall and winter.

lommg wamples. from $4_{3}^{3}$ to 6 inches long, were obtainul in that bay Nov. 23, 1897.

In the riteinity of Wouds Inole Mass. ateording to Dr simith.

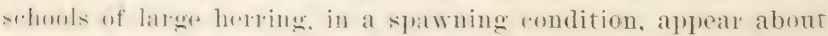
(H.toher f.j and remalin till very eold weather sets in, their depar-

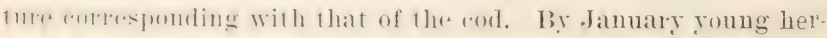

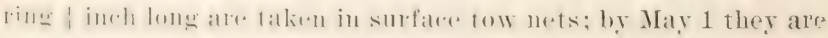

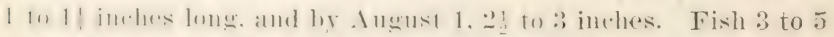

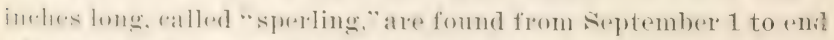

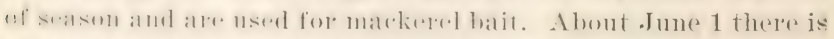

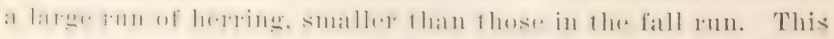

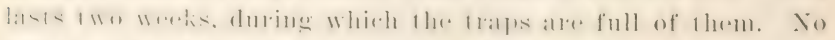

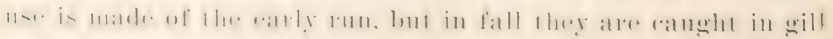
nots for food and bait. 


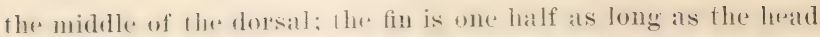
The pectoral reatrehes the 14 th series of scalles of the lateral line its length is two thirds of that of the head. The anal is moderately long and low; its longest ray about twice the lengtl of eye and one balf the length of its base. The longest dorsal ray equals postorlital part of head. The ratudal is deeply forked. There are of:? gill rakers below the angle of the firs areh. I), iii, $15 ;$ A. iii, 16 . Seales $15-52$ to 58 . Scutes $20+13$ to 14

The body is blue with reflections of gresen and gold; the lower parts silvery.

The golden shat or skipjate is a common inhabitant of the Ohio and Mississippi valleys and the Gulf of Mexien. In Penn syivania this tish is ronfined to the Ohio and its tributaries. I prefors laregestreams. It has made its way into the fireat lalkes through eanals. The presence of the solden shad in the sal water of the Gulf of Mexien was discovered by silas steam near Pensalcola Fla. This species grows to a length of 18 inehes

Inlike most other species of herring, this one, arrorting to observations of Prof. S. A. Forbes of Illinois, is predaceous feeding on other fishes. Two examples examined by him har "aten gizzard shad, Do r os o 11 a , and another one, individual of some midentitied fish. The young of the golden shad, 21 inche long, had ronsumed nothing hut torestrial insects, inchudins flies, small spiders, ete.

Is far ats I ran learn it never aserolds small streams. In the lower part of the Mississippi valley it migrates into salt water In the uperer portion of this region its permanent residener i in fresh water. The name skipjark is given in allusion to it habit of skipping along the surface of the water.

Ther fish is full of small bomes, and its flesh is reputed to b

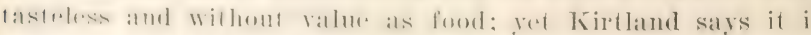

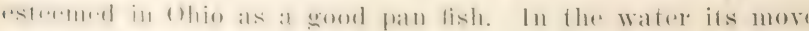

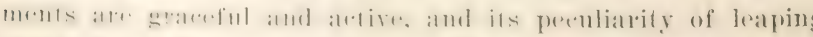

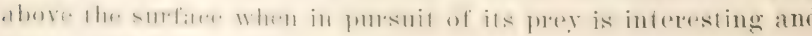
musual in this family. 


\section{Pomolobus mediocris (Mitchill)}

\section{Hickory Shad; Fall Herring; Shad Herring}

Inpea mediocris Mrtcmle, Trans. Lit. \& Phil. Soe. N. Y. I, 450, 1s1.5. New

York; Jordax \& Gilbert, Bull. 16, U. S. Nat. Mus. 266, 1893; MCDonAld, Fish of Fish. Ind. L. S. I, tot, pls. 216., 216B, 18s4; Brid, 19th Rep. Comm. Fish. N. Y. separate, 43, pl. XXV, fig. 34, 1890.

Inpea mattowace MitchilL, Trans. Lit. \& Phil. Soc. N. Y. I, 451, 1815.

Long Island.

Iupce virescens DE KAY, N. Y. Fauna, Fishes, 252, pl. 13, fig. 37. 1S42.

losa mattowace DE KAY, N. Y. Fauna, Fishes, 260, pl. 40, fig. 127, 1842.

losa lincata Storer, Hist. I'ish. Mass. 162, pl. XXYI, fig. 2, 1867.

Unea mattowaca GunTher, Cat. Fish. Brit. Mus. VII, 438, 1868.

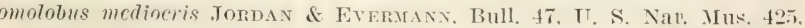
1896, pl. LXXI, fig. los, 1900; SMitr. Bull. U. S. F. C. XVII, 91, 1898; BEAN, 52d Ann. Rep. N. Y. State Mus. 96, 1900.

Head comparatively long, its length being contained four mes in. that of the body; the profile straight, and not very eep, form more elliptic than in others, and less heavy forward; wer jaw considerably projecting, upper jaw emarginate. The epth of the body is contained three and three eighths times in e length. Opercles rather less emarginate below and behind tan in P. pseudoharengus. Fins low; dorsal fin serted nearer snout than base of caudal. Bluish silvery; des with rather faint longitudinal stripes. Peritoneum pale. ength 24 inches. Cape rod to Floridal rather common; not ighly valued as a food fish; not ascenting streams to spawli. . 15; A. 21. Lateral line 50; abdominal scutes $20+16$.

This species is referred to by Dr. Hitchill as the Staten Island rring, Ciupea mediocris, which he says grows very rge for a herring, being frequently 18 inches long and almost big as a small shad. It has "six or eight brown spots, longiidinally, below the lateral line, as reported by an inhabitant that part of the bay of New York which borders on Staten land." Mitchill, also, has the same spereses moler the name of

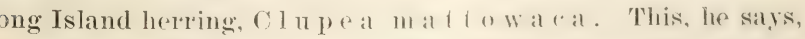
also called the autummal or fall lirreme as woll as shat rring and fall shad. Mitrhill rengnized it als ponbahy the 11-grown fish of the C. me d i o cris. He was not able to stinguish it from that speries. The lenglh of the sreenhate. 


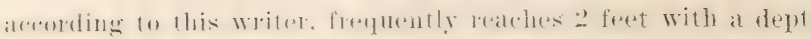

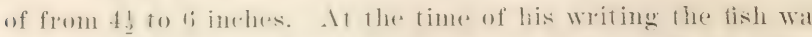
taken in or.tolue and Noxemlere in seines on the surf side of the

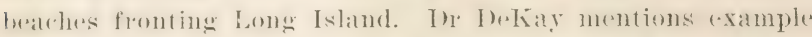
in the matret rarly in July. whieh are bromght from the Cor necticut river. where they ale ealled weresick. II states thit the speeritir name hestowed on it hy Mitrhiil was derived frol the aboriginal name of the island. Maltowate or Mattewax. I freat south bay labe name greenbark is well established fo lhe speetes. I single "xample was seined september s! at Fir

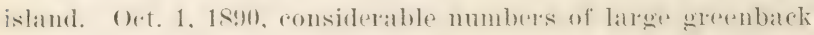
were alught in a tratp at Islip. Thr hirkory shat is ranght i Gratresend baly during septrmber. October and Xorember but less plentiful than it was formerly. Latrge hickoryshat. waighin from $\frac{1}{2}$ poumel to 20 pounds. Were shipped from waters nea

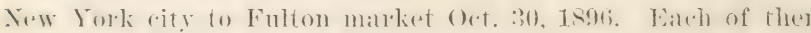

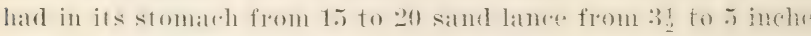

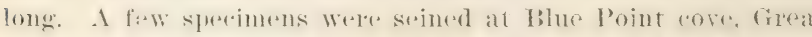
Somth baly, amd at Howell's point, in the same bay. Ang. 31, 1s!?

d) Woods Itole Mass. it eomes in the spring. but is mos

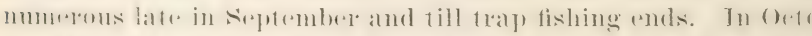

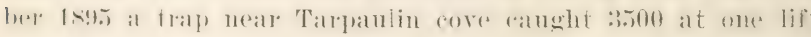
These henght loc ateh in Xew York. In spring and summe the fish has no market value, but it sells in the fall.

The Hame hiekory shat is applied to this speecies from th

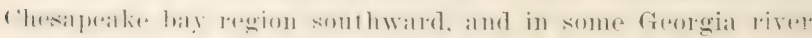

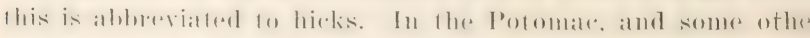

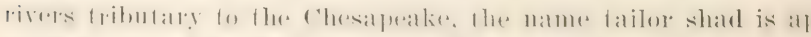

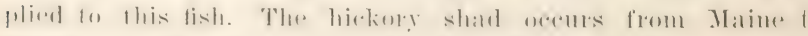

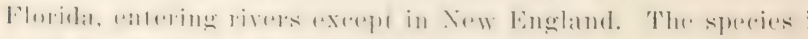

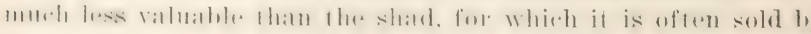

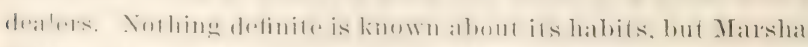

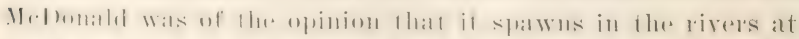

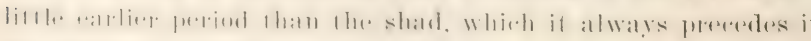
the ascent of the streams in spring. 


\section{Pomolobus pseudoharengus (Wilson)}

\section{Branch Herring; Alewife}

lupea pseudoharengus WiLson, Rees's Eneycl. IX, about 1811.

Tupea vernalis MrtcmiLl, Rep. Fish. N. Y. 22, 1814; Trans, Lit. \& Phil. Soc. N. Y. I, 454, 1815; Jordax \& Gilbert. Bull. 16, U. S. Nat. Mus, 267, 1893; BeAx, Fish \& Fish. Ind. U. S. I, 588, 1881; Fishes Penna. 58, pl. 25, fig. 45, 1893; Goode, Fish \& Fish. Ind. U. S. I, pls. 207, 208, 1884.

losa tyrannus DE KiAY, N. Y. Fauna, Fishes, 258, pl. 13, fig. 38, 1842. omolobus vernalis Goone \& BEAx, Bull. Essex Inst. 24, 1879.

omolobus pscudoharengus Gil, Rep. U. S. F. C. I, S11, 1873; JordAN \&

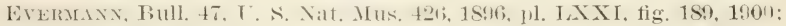
Smith, Bull. U. S. F. C. XVII, 91, 1898; BeAN, $52 d$ Ann. Rep. N. Y. State Mus. 96, 1900.

Body deep and heary forward, muh compressed. Its greatest L"pth, at dorsal origin equals one thirel of total length to base of andal. The least depth of randal freduncle equals but one half of ength of head. The head is short, being almost as deep as long, bout one fifth of the standird length. The eye is large, deeper han long, its length slightly greater than its distance fom tip of snout-about three and one half in head. Maxillary broad, xtending to the rertical through pupil: upper jaw emarginate. ower jaw slightly projecting. Lengle of dorsil base almost equal o that of head; its highest ray about two thirds as long as the ase, or equal to anal base. The anal is low, its longest ray peing equal to length of exe. Caudal dexply forked, partially aled near base. Lemeth of pertoral less than that of dorsal aase. D. $16 ; \mathrm{A} .17$ to 19 . Seales $15-50$ to 54 .

In the male the dorsal is highere its longest ray about equal o length of dorsal base, or two thirds the length of head.

color on blatk blue silvery and palder on sides and underneath; black spot behind head; diusky lines on body, which are only risible on large examples.

Described from no. 2оmac river. Length 11 inches.

The branch herring. river herring 11 alewife has a variefy of additional names. It is the allwile al allwhe of commertient eiver, the spring herring of rem lork, the higereed and wall- 
eyed herring of the Altemarle, the sawbelly of Maine, the gray back of ilassachusetts, the gasperean of Canada, little shad o rertain localities, and the Cayuga lake shad of New York. Th rended range of the brandh hering is from the Neuse river X. (', to the Miramithi river, in New Brunswick, ascendiug streams 10 their head waters for the purpose of spawning. The tish is found abundant in Cayuga and Seneca lakes, N. Y., where it has probably made its way naturally. In Lake Ontario, since the introduction there of the shad, the alewifo has become se phentiful as to (anse great difficnlty to fishermen, and its periodi ral mortality is a serious menace to the health of perple living in the vicinity. The belief is that the fish were mintentionally introduced with the shad. In Pennsylvania the buach alewif orems in the Delaware and the Susquehanna in great numbers in early spring.

The I. . Fish fommission, in 1894 , obtained sperinens at the following localities of the Lake Ontario region.

Cape Vincent

Grenadier island

IIouth Salem river, Sellkirk

Long pond, Charlotte, N. Y.

Lake Shore, mouth Long pond

Sandy creek, North Hamlin

June 21

June 27

July 25

Aug. 17

Aug. 17

Aug. 20

Not a native of rayuga lake but often found there in lares mumbers. Known to the fishermen as sawbelly. It is thought 10 have beren infordued into the lakes of central New Jork by lhe statre tish rommission. Large numbers are often found dear

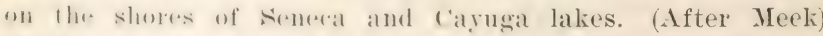
ll. Kay salys it appear's in Now York water's with the shad about llu dirst of April. but nerer in suftieient numbers to form a separate fishery.

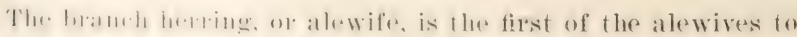
apluale in firalesemel haly; if comes wilh the shate. It endures

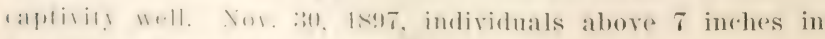

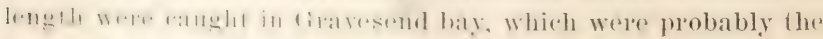
young of the year. 
This alewifr seldom exceds 1 foot in length, the average market examples being about 10 inches. The weight of the largest is about $\frac{1}{2}$ pound, and the arerage weight is about 5 or 6 ounces.

The tish enter the river's parlier than the shad and return to the sea, or to estuaries adjacent to the river mouths, at some undetermined date in the fall. During the summer months enormous schools of full grown, but sexually immature alewives migrate along the coast, feeding on small crustaceans and themselves furnishing food for bluefish, sharks, porpoises and other medaceous animals; but none of them are known to enter fresh waters. In the rivers the alewires appear to eat nothing, but they can be raptured with small artificial flies of rarious colors. 'Their eggs are somewhat adhesive and number from 60,000 to 100,000 to the individual. They are deposited in shoal water; spawning begins when the river water is at $55^{\circ}$ to $60^{\circ} \mathrm{F}$. The period of hatching is not definitely known, but is believed to exceed four days.

During the spring and summer the young grow to a length of 20 or 3 inches; after their departme from the streams nothing is known of their progless, hut it is believed that they reach maturity in four yeal's. We have no meaus of learning the age of the immatne fish seen in great schools off shore, and thus far the rate of growth is unsettled.

The branch alemifr, thongh full of small bones, is a very valuable food tish aur is consumed in the fresh condition as well as dry salter, piekled and smoked. The fry can be reared in ponds by placing adults in the waters to be stocked a little before their spawning stasou; and they furnish excellent food for bass, rockfish, trout, salmon, and other choice fishes. The proper utilization of the immense orersupyly of these fish in Lake Ontario has berome a serious eronomic problem.

Alewires are caught in sines, gill nets, traps and pounds and they are often talien by anglere with artitirial llies. 


\section{Pomolobus cyanonoton (Storer)}

\section{Glut Herring; Blueback}

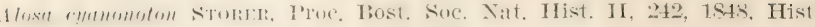
Fish. Mass. 161, pl. XXVII, fig. 1, 1867.

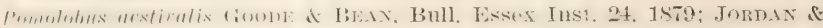
Evermaxy, Bull, 47. U. S. Nat. Mus. 426, 1896, pl. LXXI, fig. 190, 1900: Sufrtir, BuHl. U. S. F. C. XYII, 91, 1898.

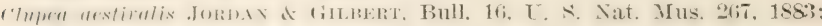
McDonald, Fish \& Fish. Ind. U. S. I, 579, pls. 209, 210, 188t, not

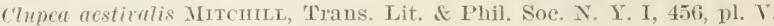
fig. $6,1815$.

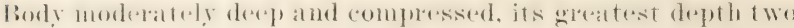

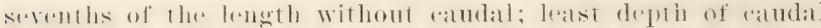
periunte two sevenths of greatest depth of bory; bead short one fifth of total length without ratudal. the maxillat extenting to helow the midnle of the ere, its width about ome thirel of its

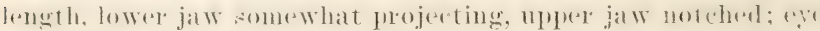

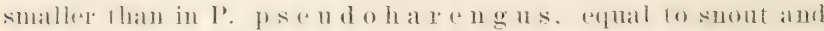

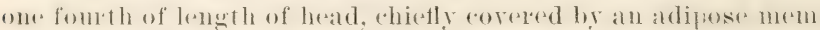

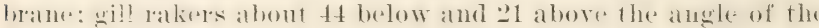
first alleh. the lomgest about apuat to iris; lower andal lobe the

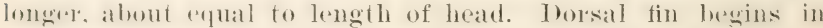
adranee of ventral oregin, overe the lizth row of seales: the longest raly is about three fourths as long as the base of the fin and lwire as lomg as the last ray. Inal base two and one half

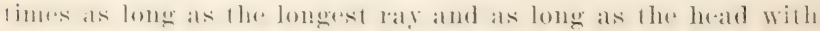

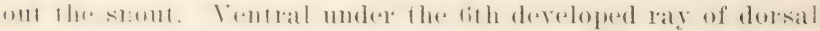

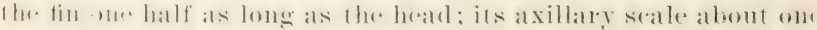
hall as lomg as lhe rentlal fin. I small black spot behind the

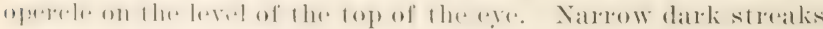

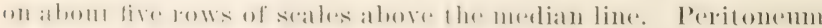
very dark. 1). iii, 15; $\Lambda$. ii, 1S; V. i, S; P. i, 15. Scales 13-53

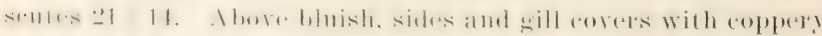

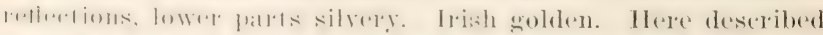

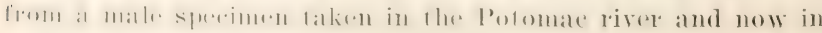
Hhe I. ふ. National Musemm.

Milchill's natme, a es t i ra lis, can not be applied with any

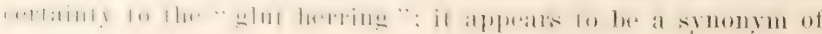


mediocris and mattowaca of the same author. Its

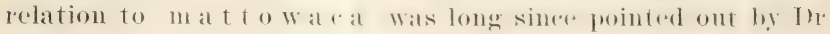
Gill. The description herewith appenderl appeats to male this conclusion inevitable.

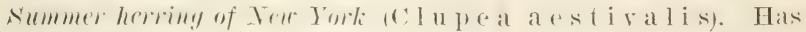
a row of spots to the number of seren or eight, extending in the direcetion of the lateral line. Tail forked. Bally serrate;

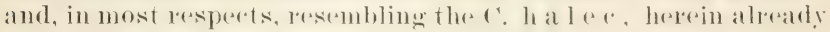
described. Rays: Br. 6; P. 15; V. 9; D. 16; A. 19; C. 19.

The figure shows a low of right datk spots on the side extend. ing as far batek as the end of the dorsal fin on the level of the

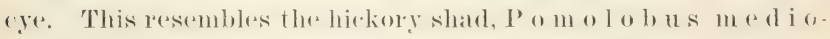
(. r is, mote than anything ase, and it probalily was that species.

The glut herring arrives later than the branch herring and does not aseond streams far above salt water. It alpexars lo spawn only in the latrexe streatns or their tidal tributaries and

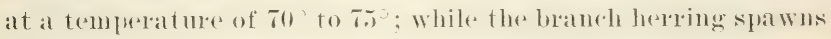
in water as low as . o to to and ascends far up the streams ind their small fresh-water branches.

In Gravesend bay the ghut herring is alled shad herring. Nor. 30,1897 . two young fish of the Year, measuring about 7 inches in length. Wereolotained form that bay. In Great south bay the species is alled hereing. A single eximple wats secured there on sep. 29, 1s.00. In 1s:s it was not collexted eithere in Great south bay or Mreox, in both of which the branch herring was abundant.

At Provincetown the spereses is known as the bluebatek and kionk. Iceorting to storer. it apjeates there in suall numbers in May, but is not abmudant before Jume 10, and it remains on the coast for a short time only. The alewife. or hamell herring.

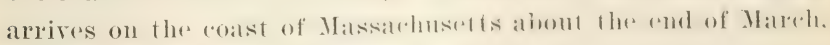
and is taken till the middle or last of May.

\section{Genus arosa Cuvier}

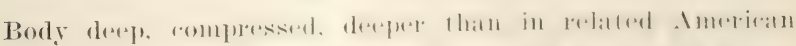

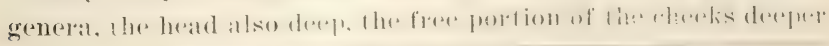




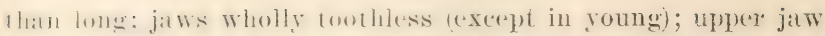
with at shatr. dwe nolch at tip. thw premaxillaries meeting at

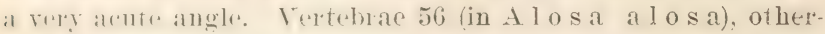
IIs as in l'omolobus, to which gemus Alosa is very

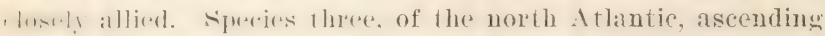
rivers; highly valued as food fishes. Though rely full of small bones, the flesh is white and rich, but not oily.

\section{Alosa sapidissima (Wilson)}

\section{Shad.}

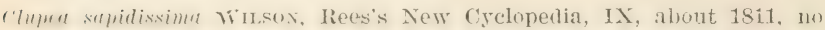
lagination, no date; Iisfinesqte, Amer. Month. Mag. 11, 205, Jan.

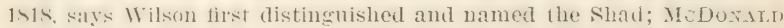
in Fish \& Fish. Ind. U. S. I, 594, pls. 212, 213, 1881; BEAN, Fishes Penna. 60, pl. 2, 1893; Cheney, 4th Ann. Rep. N. Y. Comm. Fish. colored plate'facing p. 8, 1899.

Clupea alosa Mitchile, Trans. Lit. \& Phil. Soc. N. X. I, 449, 1815.

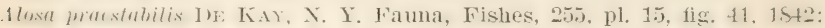
Stoner, Mist. Fish. Mass. 154, pl. XXVI, fig. 2, 1867.

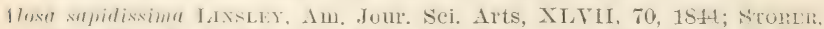
Syn. Fish. X. 1. 206, 18t6; Jolndx \& Evermaxx, Bull, 47, U. s. Xalt.

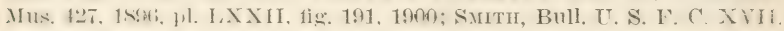
91, 1898.

The American Shat. Goode, American Fishes, 400, fig. 1858.

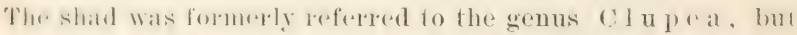
diflers foum the lypiral seat herring in the shape of the cheek home. Whirh is somm what derper than lome. The adult is tooth. l.se, iml the yommg has woll developred, though small, teeth in thr. jalws. Whirh somelimes jelesist till the fisin has reached at

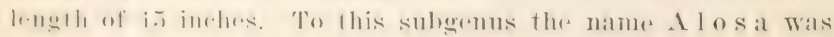
given by Cirviex.

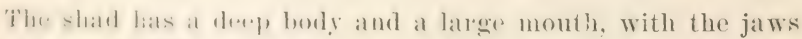

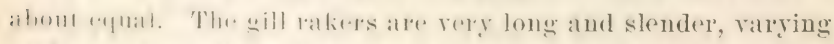

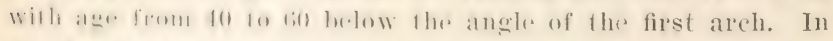

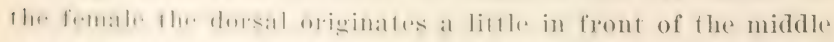

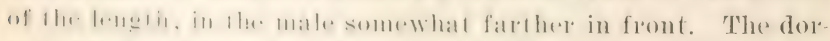

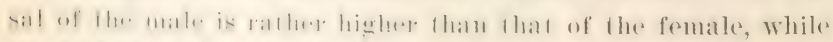

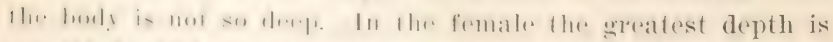

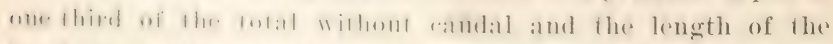

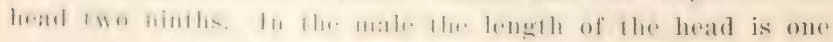


fourth of the total withont raudal. The dorsal has 1:3 divided rays and 4 simple ones; anal 19 divided and 3 simple. Scales $16-60$ to 65 . Scutes $22+16$.

The color is bhuish or grenthish with murh silvery; a dusky bloteh close behind the head, two thirels as large as the eye, and frequently from sereral to many, in one or two rows, behind this. The lining of the belly walls is pale.

The shad is known also as the white shad, and in the colonial days it was known to the negroes on the lower Potomac river as the whitefish. It is found naturally along the Atlantic coast of the United States from the Giulf of St Latwence to the Gulf of Mexico, asernding streams at various dates from January in its extreme southern limit to June in far northern waters. In the Delaware and susquehauna it makes its appearance in April and departs after spawing; but remains sometimes as late as July 18, and many die.

The original distribution of the shad has been widely extended by artificial introduction. In certain rivers flowing into the Gulf of Mexico the fish has been established by planting. In the Ohio river a fishery has bern created by the same method; and in the Sacramento river, Cal., the shat was successfully introduced, and it has colonized not only this rirer but all suitable rivers from san Franciseo to southern Alaska. It is now one of the common marlet speecies in San Franciseo and other west coast cities.

In the Susquehanua the shat was formery one of the most. important native food fishes, but its range is now very limited on account of obstruction by dams. 20 years ago the fish commissioners reported that a few shat are taken yearly above the Clark's Ferry dam, none or at most a few dozen above the: Shamokin dam, none above the Yanticolie dam and none above Williamsport. The largest run of shat that has been known to pass the Columbia dam wats that of 1stit. "In 1st1 the finest. Columbia shad were hatked in the market at Tarrisbure, 30 miles from the fisheries. al comsiderably less than al dollat at pair. The catch at Columbia exceeded 100,000." 
The whstrutions in the ilelatwatre hatre boen almost entirely

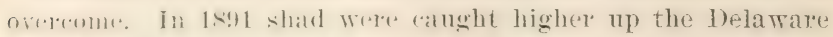

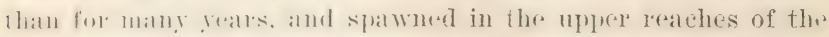

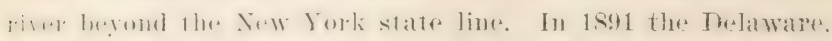

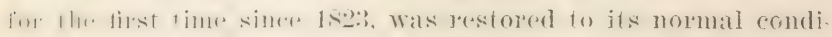
lion hy means of the fishway at Lavkawaxem; and, according fo rol. riay. if is at present the best shad river in the (e) untry.

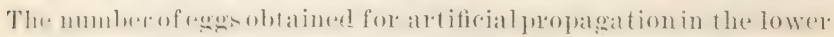
livel Was umasually smatl, but the number natmally dejossted in

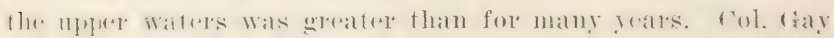

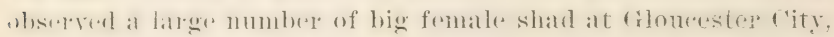

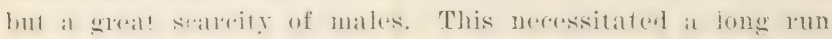
up the river hefore sparming. The cause is believed to be the

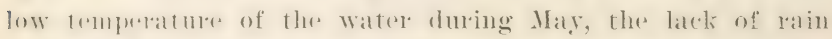
rotling otl the nsual smply of warm surface water and the

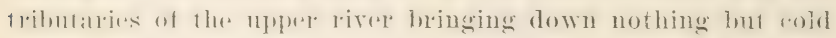
spring watre. ketping the trmperature of the river helow the normal for cyatwing purfoses. ('onserguenty, the shate as anded more that : 301 miles. Mr Ford noticed that erery ponl

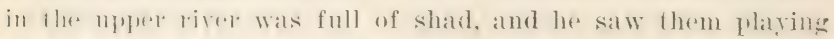

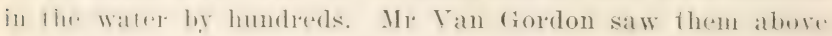

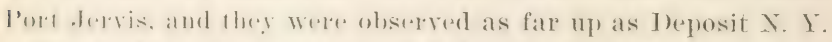

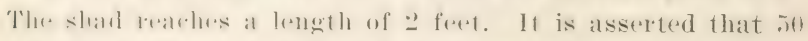

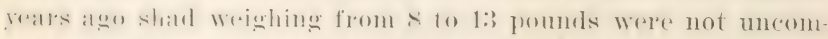

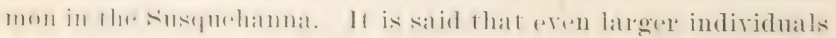

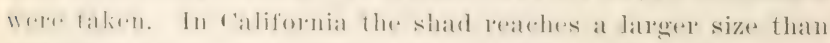

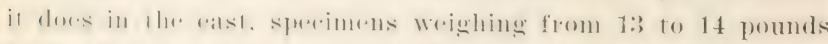

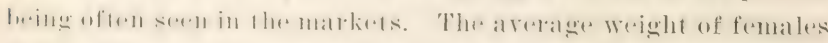
is $4 \mathrm{or}^{5}$ pounds. The male is much smaller.

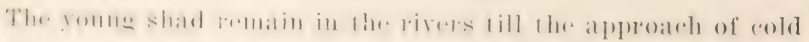

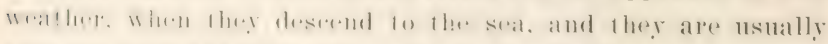

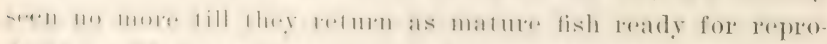

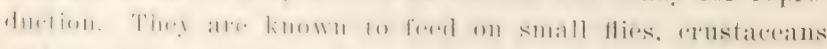
and insect larvas. They have heen fed with fresh-water cope-

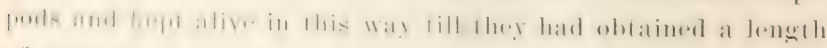
of more than 1 inets. In the eare ponds, at Washington, Dx 
Hessel succeeded in rearing shad on the Da ph $\mathrm{n}$ i a and Cyclops to a length of 3 or 4 inches, and one time, when they had areess smereltitiously to an abumdant smply of young calp, well feel individuals reatehed a lementh of ti inches hy the

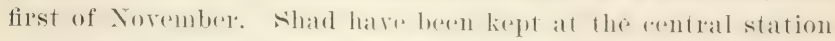
of the I. S. Fish (ommissiom over the winter, but all the age

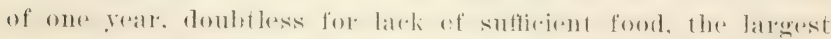
was less than 4 inches long. It this age they were seen to (a)ture smaller shate of the siatson of 1,91. whirh were an inch or mole in lengile. The rommissioner of tisheries detereted young shat also in the art of (atting rontug faliforniat salmon; and on one oreasion found an modigested minnow, 2 or :3 inches

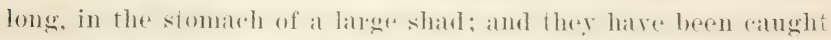
with mimnows for bait. The mineijal growth of the shad takes

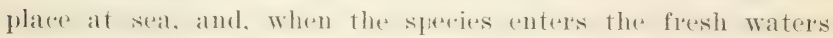
for the purpose of spawning. it ratses to ford. but will sometimes tale the artitivial fly and live minnows. The migratory

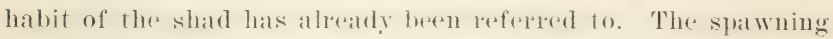
habits have bexn thus deseribed by Matrshall Mr.Tomald.

'The farorite spatwing grounds are on sandy flats bordering streams and on silnd batrs. Thlor fish aplear to associate in

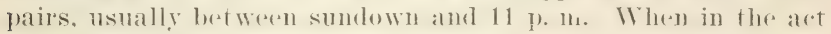
of spawning they swim elose together near the surfater, their dorsal fins projecting aloove the water and their morements producing a sommel which the fishrment rall " washing." Thr: eges are expressed by the fomale while in rapid motion: the male following elose and rjecting his mill at the same time.

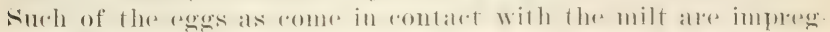

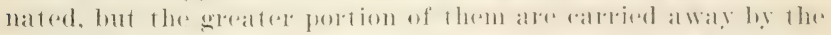

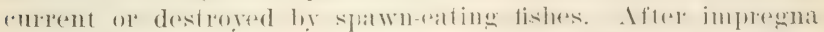
tion the age sinks to the bottom, and under fatvolable anditions develops in from three to eight days.

According to Seth Green, the embryo shad swim as soon as they break the shell, and make their way to the middle of the stream, where they are comparatively safe from predaceous fishes. I mature female shad of 4 or

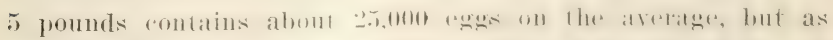

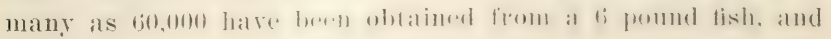




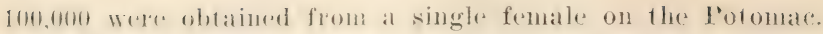
There is greal montality among the shad after spawing. Tead fish of hoth sexes are frepuently seren floating in the water in the late months of summer.

Mirrhill states that thr shad visits New York amually about

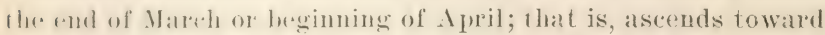
the soures of the Hudson; that it usually weighs 4 or 5 pounds, hut somedimes as muth as 12 pomols. Ior Kay says a large valdety, sllpposed to be an old fish, and weighing from to to 12 founds, were frequently taken in the Hudson, undere the name of yellow hatelis. Thu shad, in his time, ascended the river bo miles, fo sfatwo, and reserended in the latter part of May. The introdurigon of gill nets. he writes, has caused a seareity of the tish and will drive them from the river before many rears.

Viels set otl shore in ciravesend bay in the fall frequently imluse latroe yuantities of romng shad, sometimes a fon and a half at one time, during their migration seaward, but they are at once liberated. The fish are usually about 6 to s inches long. Oct. 17, 1895, 60 or 70 were caught in John 13. De Nyst's pound, among them a male 11 inches lomg and $2: 3$ inches dere, and a female 12 inches long

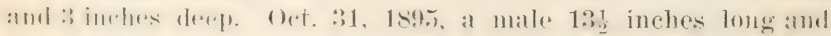

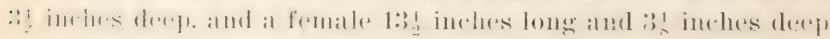

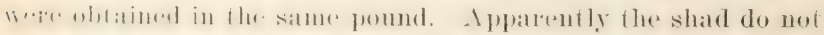

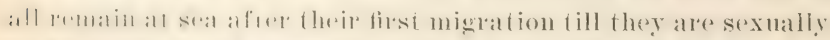

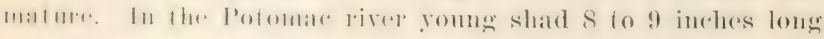

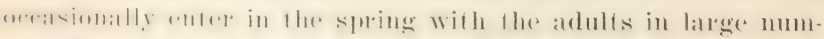

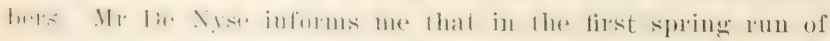
small shad in Gravesend bay fully $90 c_{0}^{\prime}$ are males.

\section{Genus sumowrat Guvier and Valenciennes}

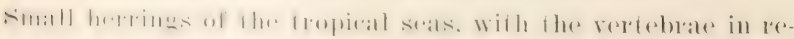

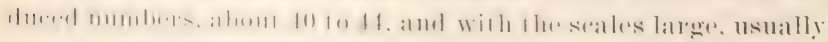
lirm and allorent, often crossed by vertical striae. Tentral

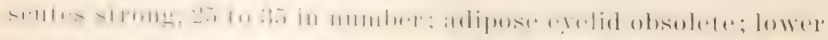

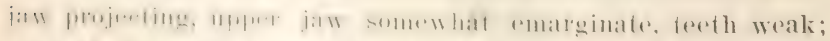

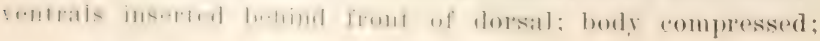


cheeks not deep; gill rakres lomg and numeroms; othrelwiset essentially as in Pomolobus. The genus s a r d i ne 11 a , as here understood, covers a wide diversity of forms and may he dirisible into serexal general when the anatomy of the spereies is better known. (After Jordan and Evermann)

\section{Sardinella species}

\section{Scaled Sardine}

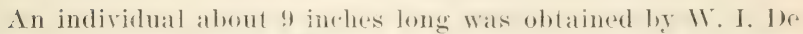
Nyse in Gravesend bay in 1seg. This was the only one observed in that locality, and it is the only record known of the oceme rence of a fish of this genus north of Florida. The specinten was seen and identifed as a s a r d i ne 11 a by the writer, but, before he had opportunity to malie a dotailed study, it disappeared from the tank in which it was placed and could not be found.

\section{Genus oristroxema Gill}

Characters essentially those of sita 1 i n e 11 al, exeept that the last ray of the dorsal is froduced in al long filannent as in Dorosoma, Iregalops and rarpon. Species fer, American.

\section{0pisthonema oglinum (L. Sueur)}

\section{Thread Herring; Shad Herring; Sprat Herring}

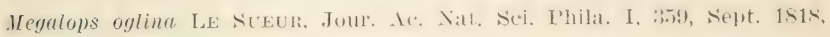
Newport, R. I.

Megalops notata LE Sueur, op. cit. 361, Sept. 1818. Guadeloupe.

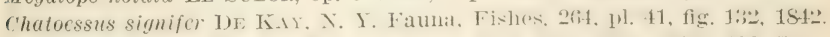

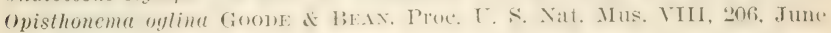
S, 1885.

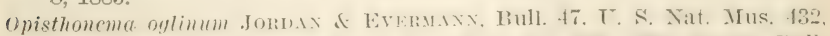

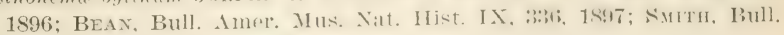
U. S. F. C. XVII, 91, 1898.

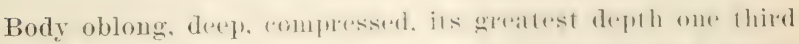

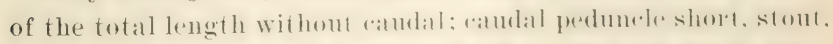

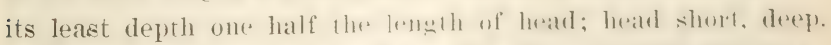

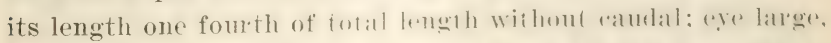

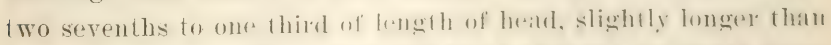

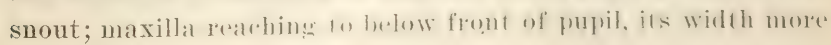




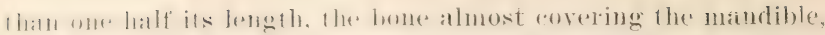

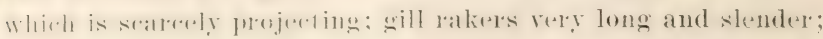

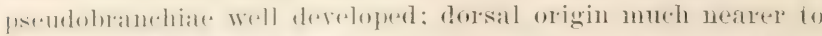

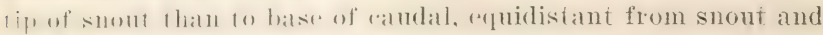
wreill of anal. hase of dolsill as long as the longest ray and two thirds as lome as the head, filament rearehing to hase of eamdal.

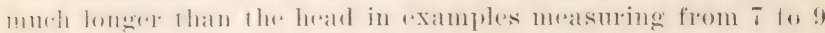
juelues: anal base as long as the hrad without the suont, its

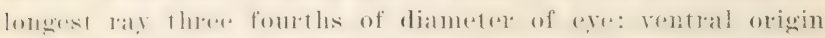

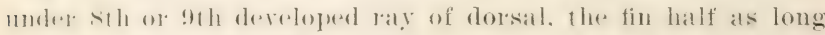

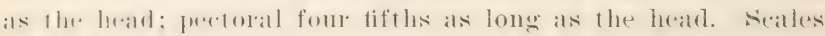

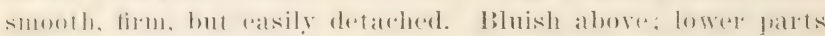

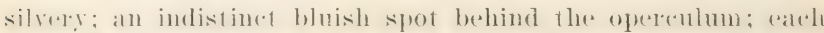

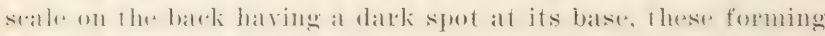
strealis as in the ghot herring. Length 12 inches. 1). 19; . 1. 24.

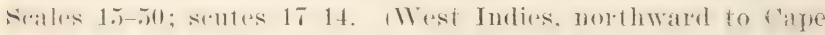
Cod in summer.)

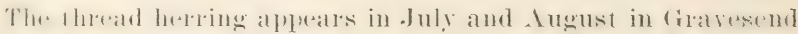

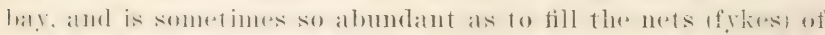

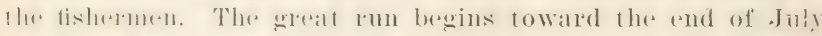
and lasts 1 wa werelis. The tish is known there as the spreat herringe.

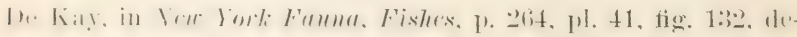

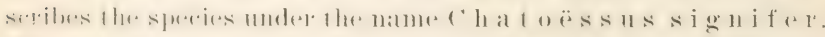

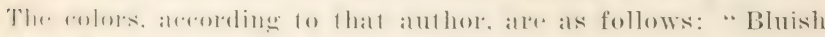
aluor. Will a sel ies of datk points alonge the sides of the barke.

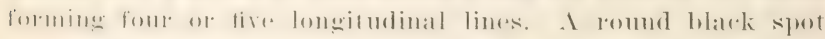

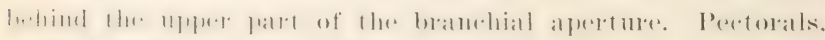
bellals amd anal while. Jorsal and atulal yellow: the meme

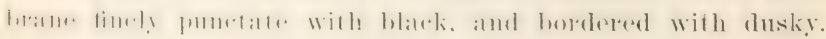
lrides white varied with yellowish." He further says: "It

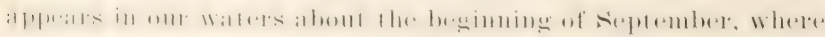
it is offem ealled the shad herring. It has also the names of

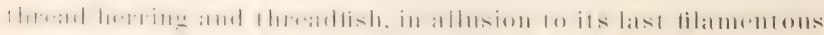
(1) 
In the Woods Hole region of Cape Cod it is very rare, according to Dr Smith. A number were taken in the fall of 1871. In 1885 it was common in Buzzards bay and Vineyard sound in July. It remained about a month, and specimens were taken in traps at almost erery lift. During the next four years the fish was also noticed, but none has been seen since 1890 .

\section{Genus mevoontra Gill}

Body elliptic, compressed, deepest anteriorly, tapering behind; head very large; cheeks deeper than long; mouth large, the lower jaw included; no teeth; gill rakers very long and slender, densely set, appearing to fill the mouth when it is opened; gill arches angularly bent. Seales deener than long, closely imbricated, their exposed edges rertical and fluted or pectinated. Dorsal fin low, rather posterior; anal fin small. Intestinal canal elongate. Tertebrae 48. Peritoneum dusks. Species few; inhabiting the Atlantic; spawning probably in brackish water in the spring. Coarse, herbivorous fishes, not valued as food, but the young of the greatest ralue as food to other fishes. (After Jordan and Evermann)

\section{Brevoortia tyrannus (Latrobe)}

\section{Menhaden; Mossbunker}

Clupea tyrannus Littrone, Trans. Am. Phil. Soc. Phila. T, 77, pl. 1, 1S02, (Chesapeake bay)

Clupea menhaden Mircinll, Trans. Lit. \& Phil. Soc. X. Y. I, 45?, 1)l. V, fig. 7, 1815, New York; G ̈̈xther, Calt. Fish. Brit. Mus. VII, 420, 186 S. Alosa menhaden DE KAY, Y. Y. Fauma. Fishes, 2J9, pl. 21, fig. 60, 1542; STorer, Hist. Fish. Mass. 158, pl. XXVI, fig. 4, 1867.

Brevoortia tyrannus Goode, Proc. T. S. Nat. Mus. I, 531, 1S7s; Fish \& Fish. Ind. U. S. I, 569, pl. 205, 1S\$4; Jorm.1. \& Gilmert, Bull. 16, U. S. Nat. Mus. 269, 1853; BEAx, 19th Rep. Comm. Fish. N. Y. separate, 4t. pl. XXV; fig. 35, 1890; Bull. Amer. Mus. Nit. Hist. IX, 336, 1S97; 521 Ann. Rep. N. Y. State Mus. 96, 1900; Jordas \& Evermaxs, Bull. 47,

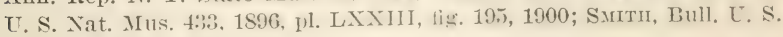
F. C. XVII, 91, 1898.

The menhaden has the exposed surfaces of its scaldes rery narrow and deep. The body is similate in shatpe to that of the shad, the depth being one third of the length without caudal, and somewhat greater than the length of the head. Mouth large; jaws toothless. The maxilla extends to below the hind 
matrin of the "ye. The ere is about as long as the snout, one fifth of longth of head. The fins are small, the pectoral not much mo1\% lhan half the length of the head and twiee as long as the ventral. The dorsal base is equal in length to the pee[m:1]: lomgest dorsal ray more than twice as long as the last ray and about two fifths of length of head. The anal rays are shorter than those of the dorsal; length of anal base little more than one laalf the length of head. The origin of the dorsal is about midway betwen tij of snout and end of middle caudal rays. The sirles and fins are silvery, yellowish, the upper parts bluish. Behind the head there is a large dark spot, larger than the pupil, and behind it numerous smaller dark spots.

The memhaden has received mole than 30 (common names, anong which the one here emploved is the best known and most suitable. In New Jersey it is frequently called bunker or mossbunker. and in some other loralities it is the bony fish. It is also ralled buefish, because of a erustarean parasite which is found in the mouth.

The menhaden reaches a length of 15 inches or more; its arexanc size is about 1 foot. It is foumd along our cast coast from Maime lo Floridat. swimming in immense schools and fluctuating areally in almulanee. In rertain localities its movements ares affected chiefly by temperature.

The use of the menhadenas a somre of oil and a material for frelilizrls is so woll known as scarcely to need mention here. Is an relihle lish it is not generally rstermed; in most localities it is seldlom matrm, 1 homgh in somme places it is considered a good

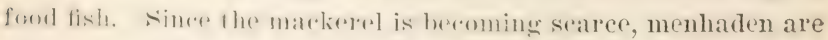
often salted in barrels as a substitute for that fish.

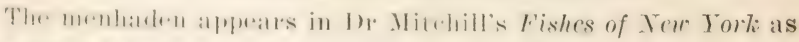

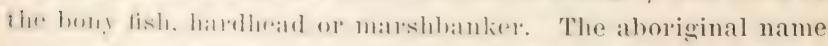

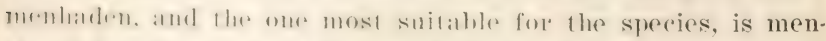

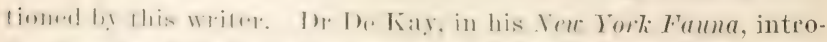

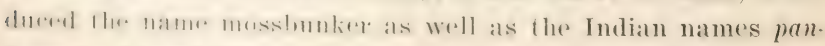

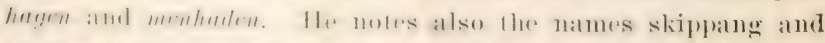

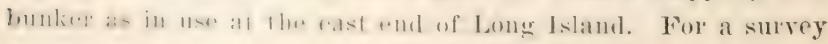


of the 30 or more additional appellations of this well known fish, the reader is referred to the complete history of the American menhaden by Dr G. Brown Goode.

The menhaden comes into Gravesend bay in May and through the summer. Occasional individuals are seen there in the fall as late as November. The fish can be kept alive in the winter in captivity, provided the water temperature does not fall below $50^{\circ} \mathrm{F}$. It makes its appearance on the shores of Long Island about the beginning of June, sometimes in May, and remains till the cold season sets in. A few specimens were taken September 22 in Blue Point cove in 1854, and Oct. 1, 1890, many thousands were caught in a trap at Islip; these were large and very fat fish. The use of the menhaden as a bait fish is too well known to need special mention. In "chumming" for bluefish near Fire island inlet this is the farorite bait. In 1898 the young were obtained at Duncan's creek, Howell's point and Nichols's point August 29. Adults were sent from Islip by W. F. Clark August 18.

In the ricinity of Woods Hole Mass., according to Dr Smith, menhaden arrive in schools about May 20, but scattered fish are taken in March with alewires; they remain till December 1, sometimes till December 20, hut are most ahmolant in June. When the schools first arrive, the reproductive organs of many of the fish are in an adranced stage of derelopment, hut after Tuly 1 nowe with large ovaries are found. Iate in fall the fish again have well dereloped roes. The smallest fish are about an inch long; these are found in little schools about the shores and wharres as early as July 15. The young are abundant throughout summer and fall. The arerage length of adults is $13 \mathrm{ol}^{*} 14$ inches; one fish 18 inches long was caught at Woods IIole in 1870.

Family ENGRAULIDIDAE Anchories

Genus stouernorus Lacepède

Body oblong, compressed. anvered with rathere latege, thin, deciduous scales; belly romuled. or wealkly compuressedl snout conical, compressed, projerting beyond the very large mouth; 
maxillary narrow, little morable, usually formed of three pieces, extending backward far behind the eye, to the base of the mandihle, or beyond, not beyond gill opening; premaxillaries fery small; teeth small, subequal, present at all ages, usually on the jaws, vomer, palatines, and pterygoids. Anai fin moderate, free from caudal (its rays 12 to 40 ); no pectoral tilaments; dorsal inserted about midway of body, posterior to rentrals: pertorals and rentrals each with a large axillary scale. Adipuse cyelid obsolete. Tertebrae about 40 (40 to 42$)$ in species exanined. Flesh rather pale and dry, more or less translucent, the bomes firm. Psendohranchiae fre sent; brauchiostegiels nine to 1.4; gill rakers long and slender; gill membrames separatie, frer from the narrow isthmus.

\section{Stolephorus brownii (Gmelin)}

\section{Striped Anchovy}

Atherina brownii GMeLrN, Syst. Nat. I, 1397, 1788.

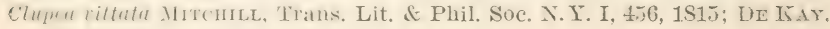

N. Y. Fauna, Fishes, 25t, 1812.

Engraulis vittata BAInd, 9th Ann. Rep. Smith. Inst. 347, 1855.

Engraulis brownii GüNTren, Cat. Fish. Brit. Mus. VII; 389, 1868.

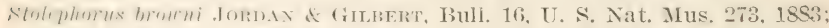

Beñ, Bull. U. S. F. C. VII, 149, 18ss; 19th Rep. Comm. Fish. N. Y. 279,1890

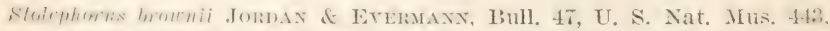

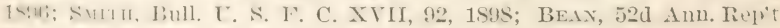

ז. Y. State MIus. 97, 1900 .

limly modreatrly elomgate, compressed, but thicker than in $\therefore \quad m \mathrm{i}+\mathrm{chi} l \mathrm{i}$, its gleatest depth two ninths of the total lenglh wifhomt ramblal, and equal to length of head without the

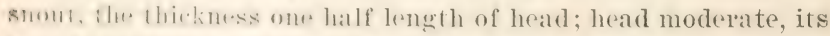

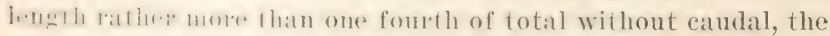
simmin shole and nhlusely pombed, one fifth of length of head,

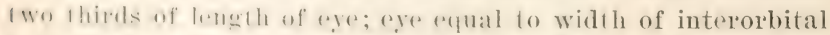

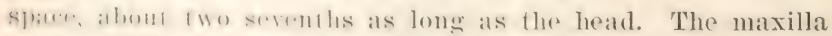
reatulus as far liak as the mandible, hul not to hind edge of opereln. The matudible is pallty covered by the maxilla, its tip

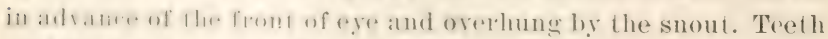
monl.ratu! strong, those on the fusterior fout of the maxilla 
raking forward. Gill raker's rather long and slender, numernus, the longest on first arch three fourths as long as the eye. Origin of dorsal fin midway between base of caudal and front of eye, its length of hase four sivenths of length of head, its longest lay one half as long as the hratl. a sheath of scales at base; anal with a strong sheath of scales, its base as long as the head withont the suont: rentrals small, originating in adrance of dorsal origin. the length refual to ere; axillary scale of pertoral one hatf as long as the head. Width of silvery band one fourth the length of head. 1). 1.1 to $15 ; .1$. 20. Scales 40 to 42 . Upper parts light brown; sides silver:; a broad, bright silvery lateral stripe. Length sometimes above $\sigma_{0}$ inches. Here described from an example talien at Lifesaring station no. ㄹ, Long Island, and now in the U. S. National Museum.

The species oceurs from rape cod southward to Brazil and the West Indies.

This is the satin striped herring of Mitchill's Fishes of New York, p. 456. By some of the fishermen in Great South bay it is supposed to be the whitebait and is so called. The anchory was extremely abundant in the bay in September 1884. I found it at the mouth of swan creek, in Blue Point cove, near the Lifesaving station, at Oak island and at Fire island. Specimens were seen as late as October 7 .

This anchory forms a rery important part of the food of the young weakfish and bluefish in (ireat South bay. It is present in rery large numbers and could be ntilized as a food species. The largest examples of this fish which we have seen were taken in Great Egg Irapbor bay in Angust: indiriduals measuring 51 inches in lengeth were taken in the sulf by hundreds, and watkfish were feeding on them ravenously. In two hatuls of a 20 fathom seine we took here 54 weakfish.

This species was not eommon in firrat south bay during the summer of 1898. It was found at lilue I'oint cove Angust 18 , and young were obtained at Nirhols's point September 1.

Dr. Smith records it as usually abundant at Woods Hole, occasionally rather uncommon. Found from August to late in fall. More numerous than any other anchovy. 


\section{Stolephorus argyrophanus (Cur. \& Tal.)}

\section{Silvery Anchovy}

Engraulis argyrophanus Cuvier \& VAlexciexses, Hist. Nat. Poiss. XXI. $49,1818$.

St, phorus perftsciatus Jorndx \& Gilbert, Bull, 16, U.S. Nat. Mus. 273, 18s?. not Engraulis perfasciatus Poey, Mem. Cuba, II, 312, 1858.

Stotcphorus curystole swir \& MeEk, Proc. Ac. Nat. Sci. Phila. 24, 1854; BEAx, Bull. U. S. F. C. VII, 150, pl. III, fig. 19, 1885.

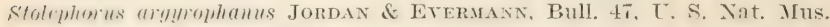
44. 1s\$6; Bfax, Bull. Amer. Mus, Nat, Hist, 337, 1897; SMtTr. Bull. U. S. F. C. XVII, 32, 1898.

Body rongate, much more slender than in $\mathrm{S}$. b x $\mathrm{O}$ w $\mathrm{i}$, and not so much compressed; head not so deep as in $\mathrm{S}$. b row ni i, more pointed, the snout rather sharp; eye rather small, four and one half in head, not larger than suout: maxillary terth well developed, mandibulary teeth vers slender; gili rakers rery long, as long as the eye; maxillary'shorter iban in s. brown i, not reaching quite to the base of the mandible: belly slighly compressed, not serrated. Scales very deridumus. Tintrals short, very slighty in frout of dorsal; caudal peduncle long and slender: dorsal inserted seareely nearer caudal tiran smont. Nilvery stripe hroad, half wider than the eye, borlered above hy a dusky streak. Head three and four fifths; depth 6. I). 12: 1. 20). Length 1 inches. West Indies; occasional northward. A specimen in our rollection from Woods Hole Mass. (After Jordan and Gilbert)

The ypes of this species were obtained by fiuhl and ban Ilasselt in the "yuatorial Allantic. Cuvier and Talenciennes, in their original deseription of the fish, contrast it with s. h) 10 " $11 \mathrm{i}$ and ollers. flom whirh it is distinguished by its form and by other characters.

It has llar hody longer and slenderer; the eleft of the mouth

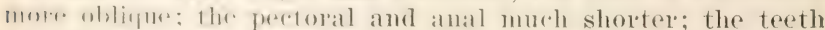
fratsilfly small. 13. 11: I). 15;.1. 17. The color is blue, more

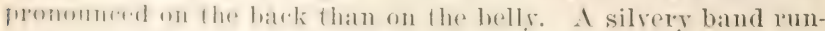
ning along the sides. Cuvier and Talenciennes

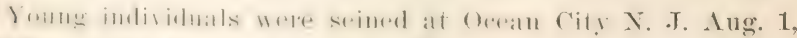

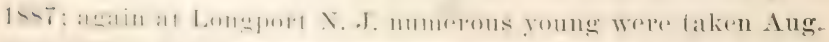


29, 18S7; no adults wele seen. I figure of the roung is published by Dr Bean in bulletin for 1859 of the U. S. Fish Commission, vol. $7, \mathrm{pl} .3$, fig. 19. The 'xample figured was nearly $1 \frac{1}{2}$ inches long. It has the following characters: The hight of the body is one sixth of the total length without caudal; least hight of caudal peduncle one third of length of head. Head rather large, two sevenths of total length without caudal, with obtusely pointed snout which is about equal to the eye and one fourth as long as the head. The maxilla does not reach to the hind edge of the preopercle. Dorsal origin nearer to caudal base than to tip of snout; the base of the fin as long as the longest ray and one half as long as the head. Pectoral short, three sevenths as long as the head; rentrals in adrance of dorsal, under the 16th row of scales, the length two fifths of length of head; anal origin under the end of the dorsal, anal base about two thirds as long as the head and one fifth of total length without caudal; longest anal ray one half as long as the head; can-

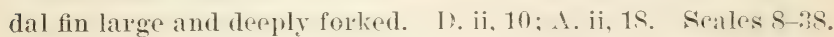

Many individuals were collected at Fire island near the end of September. None were seen in ofher parts of the bay. The species is known there as whitebait, like the othrs anchovies. In Gravesend bay the species is not common, but it occurs more frequently in bays communicating directly with the Atlantic.

\section{Stolephorus perfasciatus (Poey)}

\section{Banded Anchovy}

Engraulis perfasciatus PoEx, Mem. Cuba, II, 312, 185S; Grxtritr. ('at. Fish. Brit. Mus. VII, 391, 1868.

Stolephorus perfasciatus SwAIx \& MeEк, Proc. Ac. Nat. Sci. Phila, 34, 1sst; Jordan \& Everirann, Bull. 47, U. S. Nat. Mus. 441, 1896.

Body elongate and not much compressed, its greatest hight about one sixth of total length without caudal and two thirds of length of head, its greatest thirkmess more than one third of length of head; least hight of raudal peduncle equal to thickness of body behind the heild; head long. with pointed smont, one fourth of total without raudal, snout equal to ("ye and two ninths of length of heal. The maxillat "xtemls halckwald to 
front rdge of preopercle and not to joint of mandible. Interortital spate ergual to ere: gill rakers numerous, about as long as the cye; treth minute and weak, nearly uniform in size. Worsal origin about milway between tip of snout and base of

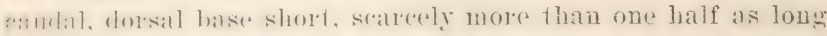
as lavild. and alont expal to longest dorsal ray; rentrals little

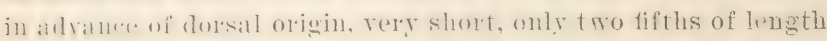

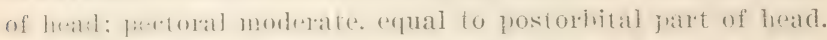
Axillary stale very slender, less than one half as long as the luatel. Width of silvery band about wejual to length of eye. 1). ii, 12: . 1. i, 1.5 to 16. Scales 44 to 4.). Here described from sureinus obtained at Noank Ct. and in Graresend bay, L. I., the largest about 3 inches long.

lplu parts light brown, sides silvery; dark punctulations on base of tandal and sometimes on anal; belly ren in alcoholic specimens with iridescent colors.

The example obtained in Gravesend bay was collected by IV. I. De Nyse. It has D. 12 ; A. 15 or 16 ; scales 45 .

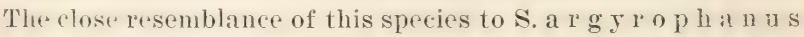
ruv. \& Val. makes a farther comparison of the two necessary. P'erhaps, as long ago suggested by Dr Günther, ${ }^{1}$ the two are identiral. S. a r groph a $\mathrm{nus}$ was collected in the equatorial Mlimtir, and Pocy's species, perfasciatus, is from f'ub: and P'orto Rien. There seems to be little to distinguish them exref the slighty greater number of anal rays in $\mathrm{S}$.

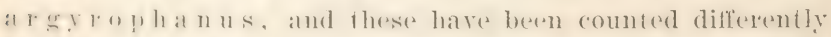

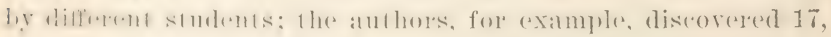
while Dr. Jordan found 19 in the same type.

\section{Stolephorus mitchilli (Cur. \& Val.)}

\section{Anchovy; Whitebait}

Engramis mitchilli Cuvien of VAlenciennes, Hist. Nat. Poiss. XXI, 50, 1818. New York; Carolina; New Orleans.

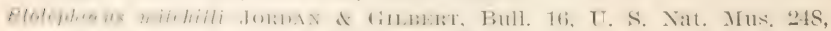
1853; Jordax, Cat. Fish. N. A. 38, 1885 (name only); BEAN, Bull. U. S.

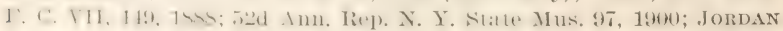
id Evmmaxi, 13ull, 47, U. S. Nat. Mus. 416, 1896; Smin, Bull. U. S. F. C. XVII, !2 1898 . 
of the spercies the lower jaw is included within the upper, the month is smatl, and the intermaxillary bone broad and more or less rertical in position. These two may be readily distinEnished by the structure of the gill rakers, and the size of the mouth. The remaining five whitefishes have the lower jaw as long as, or longer than, the upper, the mouth large, and the intermaxilary narow and not rertical in position. They are easily separated from one another by the shape of the body, and the size and contour of the scales. The relations of the groups are shown in the following key.

1 Lower jaw shorter than upper.

1 a Mouth very small, upper jaw not reaching to eye; gill rakers short and stout, 13 to 16 below angle of first arch (P ros 0 pi $\mathrm{u} \mathrm{m}$ )

QUA D R I A TERALIS

16. Mouth moderate, upper jaw reaching beyond front of eye; gill rakers long and slender, 20 or more below angle of first arch (Coregon $\mathrm{s}$ )

2 Lower jaw equal to or longer than upper.

CIUPEIFOR MIS

$2 a$ Body slender, elongate; scales small, and convex on their free margin; lower jaw longer than upper ( $\mathrm{Arg}$ y o s o mus)

O SME R I F O R M IS

1' IS O GN A T II U S

A RTEDI, II OXI

$2 b$ Body deep, short; scales large, deep, the free margin scarcely convex; jaws equal (A 110 s o mus)

T U L I I E F :

\section{Genus comegones (Artedi) Linnaeus}

Fody oblong or alongate, compressed; head more or less contal, compressed, the snout mor or less projecting berond the lower jaw; mouth small, the maxillary short, not extemding heyoud the orthit. with a well developed supplemental bone; troth extremely minute, if fresent; seales moderate, thin, ryoloid, rather firm. Morsal fin moderate; andal fin dereply

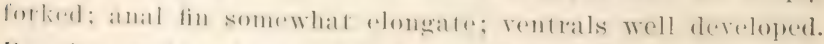

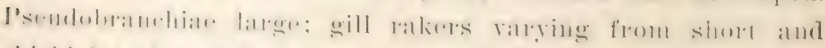

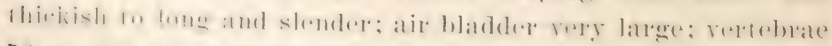

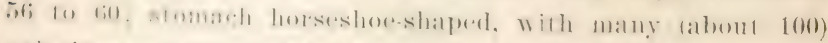

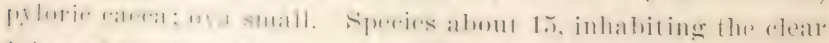

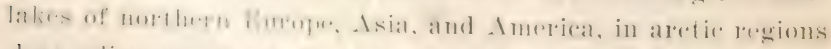

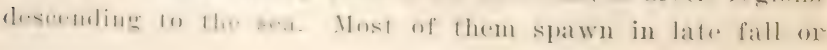


winter near the shore, at other seasons often frequenting considerable depths.

\section{Coregonus quadrilateralis Richardson}

\section{Round Whitefish; Frostfish}

Coregonus quadrilateralis Richandsox, Frauklin's Journ. 714, 1823. Fort Enterprise, British America; Agassiz, Lake Superior, 351, 1850; Günther, Cat. Fish. Brit. Mus. VI, 176, 1866; JordAy \& Gilbert, Bull. 16, U. S. Nat. Mus. 298, 1Ss:; BE.1x, Fishes Peuna. 66, pl. 26, fig. 47. 1593; Bull. Amer. Mus. Nat. Hist. IX, 337, 1597; Jordax \& EverMann, Bull. 47, U. S. Nat. Mus. 465, 1896.

Salmo (Coregonus) quadrilateralis Ricmarosox. Fauna Bor.-Amer. III, 204, pl. 89, fig. 1, 1836. Great Bear Lake.

Coregonus notae angliae Prescotr, Amer. Jour. Sci. Arts, XI, 342, 1851.

Lake Winipiseogee, N. H.

Coregonus novae angliae G̈̈хтнеn, Cat. Fish. Brit. Mus. VI, 1S6, 1866.

This is a small species and rery readily distinguished from all other Ameriean species except Williamson's whitefish by its diminutive mouth. The body is slender, elongate, subterete, its greatest depth slightly exceeding one fifth of total leugth to base of caudal. The head is long, its length one fifth of total without caudal, and the snout is thin and obtuse at tip. Thr broad maxilla does not reach to below the front of the eye. its length less than one fifth of length of head. I). 11; A. 10. Scales in lateral line, s0 to 90. Ipper parts dark bluish; sides silvery.

This species is callerl frostfish in the Mdirondacks; other names are Menominee whitefish, romdfish, shad-waiter, pilotfish and chiver, the last term applied to the fish in Maine.

The roundfish is found in lakes of New England, sometimes running into streams, the Adirondack region of Tew York, the Great lakes and northward into British America and Alaska. Its diștribution has been extended by transplanting on alceount of its great value as food for the Jalke tront and other larde fish of the salmon family. It seldom exreeds a length of 12 inches and a weight of 1 pound. Lilir some other spereses of whitefish. it spawns in shallow parts of lakes or aseemes the il small tributary streams for that purpose. The food consists of small 
sholls and crustaceans. The species frequents derpl waters, where it falls an easy prey to the voracious lake trout.

The romulfish is arellent for the table. Its apture with hook and line is difficult because of its rery small month and its mal,it of reliring into deepl water. In the Great lakes it does not wmslinte an important rement of the fishere, but in mortheru lewions it is one of the most useful and highly prized of the food fishes.

This small whitefish is one of the chararteristir spreres of the Alliwmlark likk.s. Jane's Annin jr sent specimeus for identifiattion from Hoel pond and Big Clear lake, in Franklin comnty, x. Y., and from the third lake of the Fulton Chain. Ire states lhat the tish spatwins in the little inlets or on the sand beaches. It nerer apprars till about the time the water begins to chill and frexze ahout the edges. On the Fulton Chain of lakes the spawning season of 1895 was practically closed about Norember 20 .

The frostfish, according to $\mathrm{Mr}$ Annin, is "a delicions morsel."

The following notes were made on fresh examples received from the third lake of the Fulton Chain Nor. 26, 1895.

A male 113 inches long to end of caudal fin had the midile candal rays. from end of seales, 5 inches long; upper caudal lole, measured horizontally, $1 \frac{7}{5}$ inches; head, $1 \frac{13}{16}$ inches; maxilla,

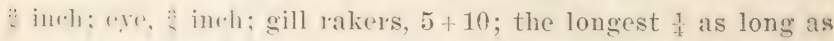

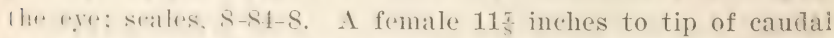

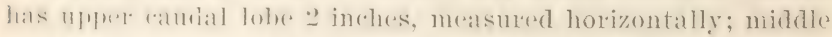

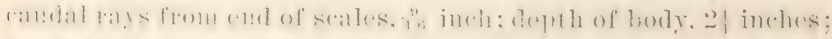

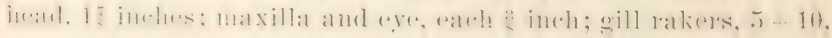
the longest 7 as long as the eye; scales, S-79-8.

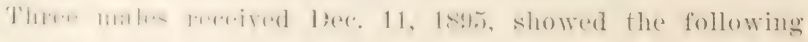
colors.

In the math. A: inelues long. from Hoed pond, the back and sides wore dark sterel graty; the belly white; pesetoral, rentral

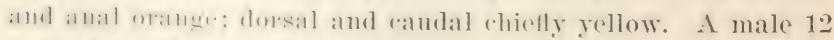

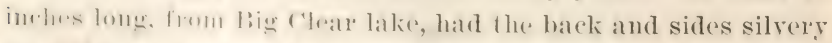

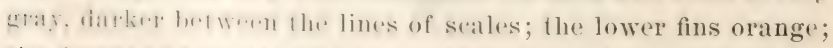
the dorsal and ratulat with trates of yellow.

A male $11 \frac{1}{5}$ inches 
long, from Big Clear lake, showed the same colors as the last. The following measurements in inches and notes were taken.

\begin{tabular}{|c|c|c|c|}
\hline & $\begin{array}{c}\text { Hoel pond } \\
\delta\end{array}$ & $\begin{array}{c}\text { Big Clear } \\
\text { lake } \\
\delta\end{array}$ & $\begin{array}{c}\text { Big Clear } \\
\text { lake } \\
t\end{array}$ \\
\hline 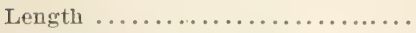 & $13 \%$ & 12 & $111 / \mathrm{s}$ \\
\hline Caudal lobe, horizontally........... & $2 \frac{3}{16}$ & $17 / 8$ & 1 is \\
\hline Middle caudal rays................ & $3 / 4$ & $5 / 8$ & $\ddot{1 i s}$ \\
\hline 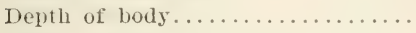 & $21 / 2$ & $2 \%$ & 2 บ \\
\hline Least depth of caudal peduncle..... & $7 / 8$ & $3 / 4$ & $\begin{array}{ll}11 \\
16\end{array}$ \\
\hline 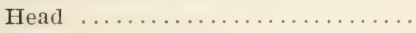 & 2 & $13 / 4$ & $1 \%$ \\
\hline 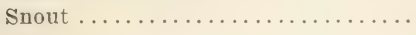 & $1 / 2$ & $\ldots$ & $\ldots$ \\
\hline Eye $\ldots \ldots \ldots \ldots \ldots \ldots \ldots \ldots \ldots$ & $\frac{7}{16}$ & $\frac{7}{16}$ & 3is \\
\hline Maxilla $\ldots \ldots \ldots \ldots \ldots \ldots \ldots . . . \ldots$. & $1^{\frac{7}{6}}$ & $3 / 8$ & 觔 \\
\hline
\end{tabular}

In all, the gill rakers are miunte, and number: $5+10,5+10$ and $5+9$. The scales are: $10-86-9,10-76-9$, and 9-S6-S.

An example sent by the Xew York Commission of Fisheries, Game and Forest, from Sarauac Lalke, Nor. 23, 1897, showed the following characters.

\section{MEASUREMENTS}

Inches

Length, including caudal. .................. 13

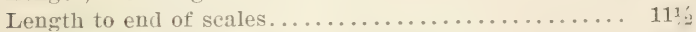

Length of middle caudal rays (from end of scales)...... Ts

Length of upper caudal lobe (obliquely)........... 21 s

Depth of body at dorsal. ..................... 2 \%

Least depth of caudal peduncle................

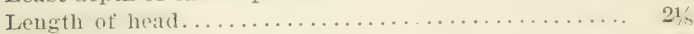

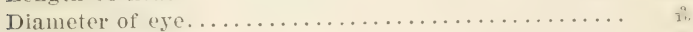

Length of maxilla (does not reach orbit) ............

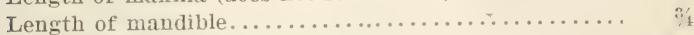

Distance from snout to dorsal origin............ 5 's

Length of dorsal base.......................... 1 .

Length of longest dorsal ray................ 1 is

Length of last dorsal ray..................

Distance from snout to ventral origin............. 5 , s's

Length of rentral. . . . . . . . . . . .

Length of ventral appendage..............

Distance from snout to anal origin.............. $s_{;}$

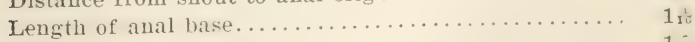

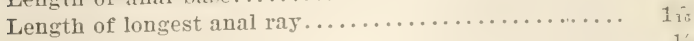

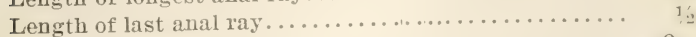

Length of pectoral. ..................... 2

Distance from snout to adipose fin............. $99^{1}$ í

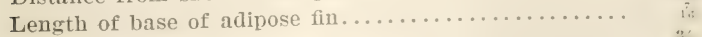

Width of adipuse fin . . . .

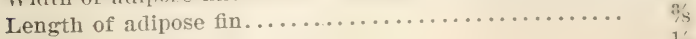

Length of longest gill raker....................... is 
I) $11 ; 1.11 ;$ T. i, 10; P. i, 1t. Scales, 10-84-8. Gill rakers, $6+10$, the longest $\frac{1}{8}$ inch.

I'mplish gray; lower parts whitish; pectorais, ventrals and intal vermilion; are pale golden; head, specially behind the eyes, wifh irilesent gold and purple tints; caudal, chiefly rermilion in life.

The fish is a male with ripe milt. There are numprous small tulereles on the scales of the sides above and below the lateral line.

\section{Coregonus clupeiformis (Mitehill)}

\section{('mmmon Whitefish: Labrador. Thitefish; Shadumiter}

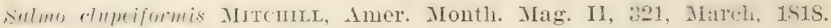
Lake Huron; Cayuga Lake.

furtumus ulims I.]: Siftr. Jour. Ac. Nat. Sci. Phila. I, 232, May, 1818.

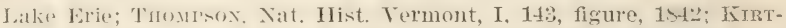

LAND, Bost. Jour. Nat. Hist. III, 477, pl. XXVIII, fig. 3, 1811; DE KAT, N. Y. Fauna, Fishes, 247, pl. 76 , fig. 240, 1842; Guntyer, Cat. Fish. Brit. Mus. VI, 184, 1866.

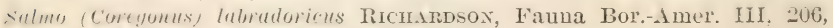
1836.

Coregonus sapidissimus AgAssiz. Lake Superior, 344, 1850.

Coregonus latior AGASSIZ, op. cit. 348, 1850.

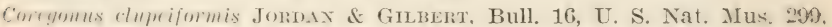
1.4.; foont, Amer. Fishes, 4S9. figure, 1885; BeAn, Fishes Penna. 67, color pl. :3. 149:3; Jorndx of Erermaxn, Bull. 47. U. S. Nat. Mus. 465. 1896, pl. LXXVI, fig. 202, 1900; CHeNey, Third Ann. Rept. N. Y. Comm. Fish. color pl. facing p. 190, 1898.

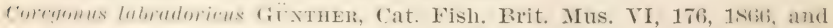
of autliors generally.

The enmmon whitefish of the Givat lakes is so well known that it satrely meres an elaborate description. The body is

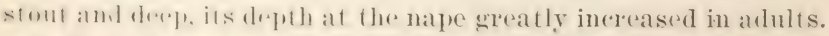

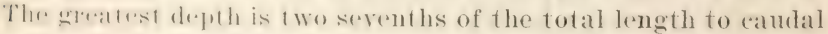

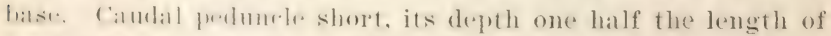

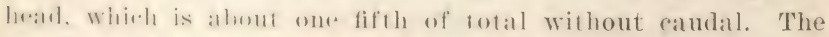

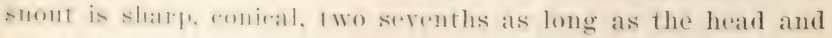

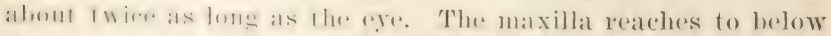

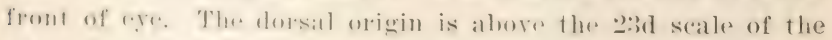

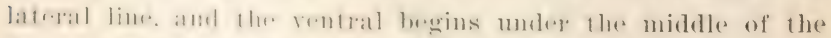

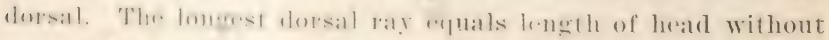
smmul, alligmen lin stoml and low. The dorsal and anal bases 
are equal to each other and two thirds of length of head. D. 10 divided rays; $A .11$ dirided rays: $T .11 ; 1$. 15 . Scales in lateral line $7 t$ to so. The upper parts are gravish or light olive in color; the sides white and lustrous in life.

Names. The name whitefish is thoroughly identified with this species and is seldom raried except by means of the prefix "common" or "lake." A well marked variety in Otsego lake, N. Y., has long been known as the Otsego bass.

Distribution. The common whitefish occurs in the Great lakes and northward into British Imerica; its northern limit is not definitely known. In Alaska, where the species was formerly supposed to exist, it is replated by a similar, but well marked form, the Coregonus richardsoni of Günther. The rariety known as Otsego bass is found in Otsego lake. If we may judge from the yield of the fisheries, Lake Michigan hats more whitefish than any of the other lakes; Superior ranlis sereond; Erie third; IIuron fourth; and Ontario is sady in the rear.

Size. The largest individual on record was taken at White-

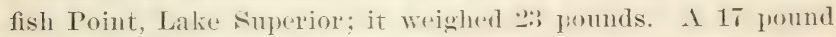
spreimen was caucht at Termilion, in Lake Erie in 1sti. The size varies greatly with locality, ranging in general all the way from $1 \frac{3}{4}$ pounds to 14 pounds. In Lalie Frie in 1885 the arerage weight was betwen 2 and ? pounds. The length of adults will average 20 inches.

Habits. There is a morement of the whitefish in many lakes from the deele water early in the smmmer into the shoal water near the shore. In the mirsummere howerer, the usual retreat

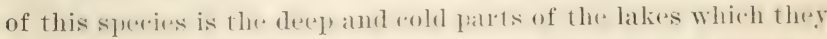
inhabit. Igain, as the spanning stason appoaches in () ctober. the whitefish come towarel the shome to deposit theip exgs. It is said that they do not spawn till the water has reached at temperature of about $40^{\circ}$. Aftre spawning they again retire to deep water, where they remain during the winter. 'Mr Milner observed that the shoreward nigration viries with lowality, and is influenced also by depth of water and temperatume. In Lake Erie, for example. which has a high summer temperature, there 
is no shoreward migration in summer. It is to be noted also. that the whitefish moves along the shore, and in some calses it ascends rivers for the purpose of spawning. It is believed also that when the feeding grounds of the whitefish are polluted by mud, the fish temporarily seek other localities. There appears to be a suring and summer migration likewise from lake to lake. Shawning takes place during October, November and December, on shoals or occasionally in rivers. The female is larger than the male. According to the observations of George Clark, the two sexes, in the act of spawning, frequently throw themselves together above the surface, emitting the spawn or wilt with the rents close together. Spawning operations are most active in the erening, are continued at night, and the ngus are de-. fosited in lots of sereral hundred at a time. The mmilser of egas in a fish of $7 !$ pounds was 66,606 ; the average muber being weatrey 10,040 for each pound of the female's weight. The jwriod of incubation defends on the temperature. The visuat time of distribution of the young is in March and Arvil. The rey youmg are described as swimming near the surface and not in sehools. They are very active and soon seck deey water 10 escape from their enemies. Their food consists chicfly of smatl (rustareans. The adults subsist on the same food witl? the addition of small mollusks.

Growth. The only means of determining the rate of growtl of the whitefish is by artificial rearing. Simmel llilmot had younge fish which were 5 inches long at the age of four months. The growth under natural comditions must be eren greater than this. Mr Wilmot. himself, has seen whitefish measuring 7 inches in December in his ponds.

Enemies and diseases. The egrgs of the whitefish are destroyed in immenser numbers by the lake berring, Coregon us

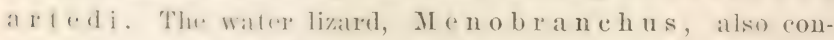
smmes vist numbers of the egges. The young whitefish are eated esamsinely hy the pike perreh, black hass, pike, pickerel and freshwatre line. The latie trout also feed on the whitefisle. A leach faranitie on the whitefish proves very troublesome to that spe- 
cies, and the scales are liable to a peculiar roughness which has been observed late in November or during the spawning season. There is also a lernean which fastens itself to the gills and other parts of the whitefish.

Uses and capture. The excellence of the flesh of the whitefisti is so well known as searcely to require mention. Its commercial ralue is great. In Lake Erie in 1885 , according to statistics collected by the U.S. Fish Commission, $3,500,000$ pounds of whitefish were caught, more than $2,000,000$ of this amount by fishermen from Erie alone. In this rear Erie county had 310 persons employed in the fisheries. The eapital invested in the business was nearly s.jo,000. The wholesale value of the fish products was upward of $\$ 400,00(1)$. The whitefish was the third species in relative importance, blue pike ranking first and the lake herring second. In Erie county whitefish are caught chiefly in July, August and November, and the bulk of them are taken in gill nets. Pound nets are also employed in the capture of whitefish.

Artificial propagation. ('arl Müller of New Tork and Henry Brown of Xew Haven are 'redited with the first attempt to propagate the whitefish artificially. Their experiments were made in Lake Saltonstall. near the city of New Haven. The result of the experiments, which were repeated in 185s, is not known. In 1868 seth freen and sammel Wilnot bexam a series of experiments in the same direction, and in $1869 \mathrm{~N}$. W. Clark, of Clarkson Mich. took up the same work. In 1870 a half million eggs were placed in hatching boxes by Mr. Clark. In 187:, through the aid of the C. S. Fish Commission, Mr. Clark's hatching house was doubled in caracity. and a million eggs were taken from Lake Michigan. Sine that time hoth the national and state governments have mate lhe whiteish the object of their most extensive operations.

Dr Meek saw no specimens of whitutish from Cayuga lake, but he thinks it is an inhabitant. The $\mathrm{C}$. . . Fish Commission ohtained a specimen at Cape Tincent X. Y. Tor. 17, 1891.

A roung individual was receeved from Trilson, Yiagara co. X. Y.; eaught in a gill net in Lake Ontario and sent hy Jamms Annin jr. 


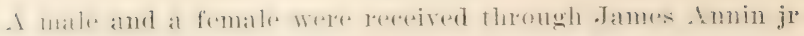

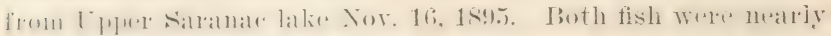

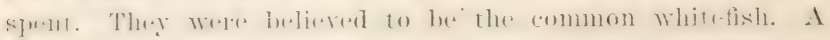

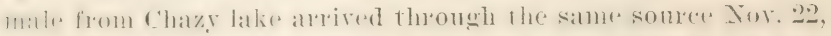

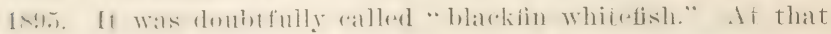

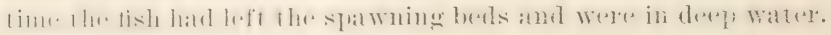

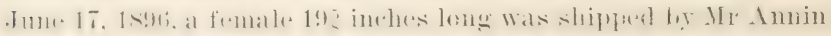

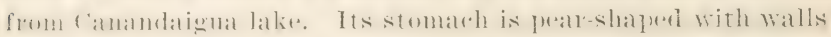

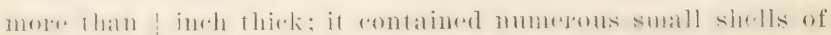
several genera, not yet identified.

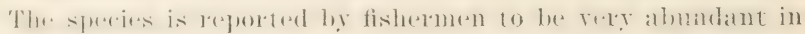

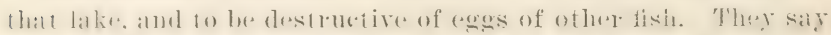

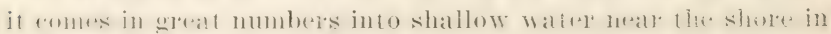

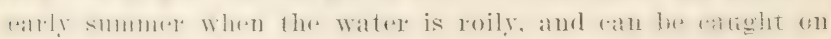

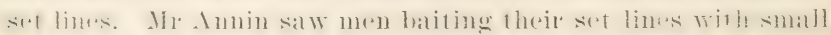

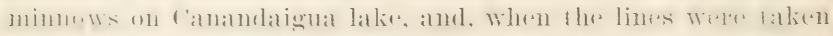
nip in the monthing. the whitefish was found on the hoolis. It

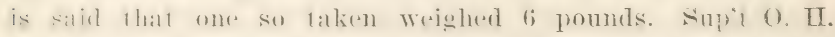

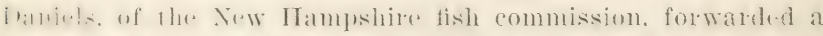

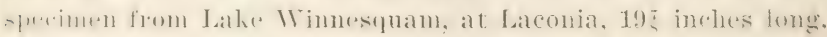

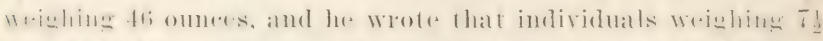

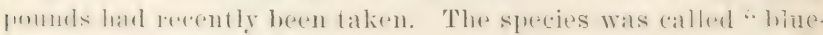
fin" and whitefish.

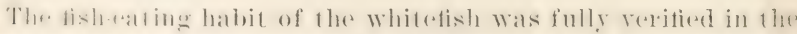

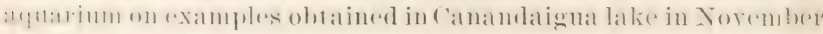

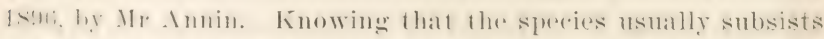

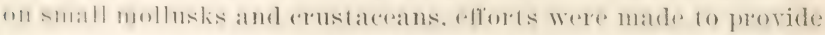

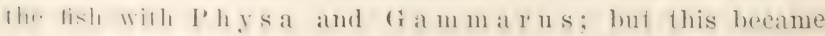

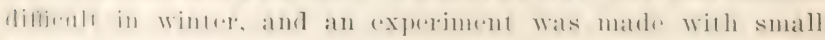
killifish (Fundulus heteroclit.us and majalis),

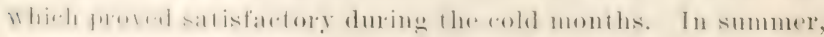

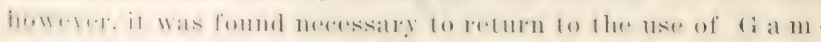

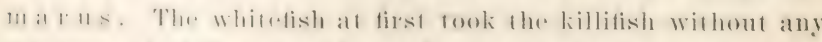

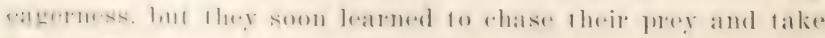
it much as trout do.

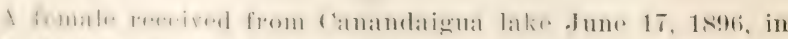

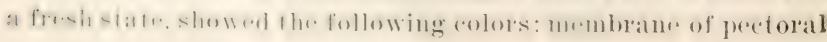


ans dusky; that of the peetorals tinged with lemon yellow; rentrals dusky at the tip; anal pale; andal pale exerpt a narrow lusky portion of the midlle rays; reses pearly with golden iridescence. The maxilla reaches about to frout of eye. The adipose dorsal extends straight batekward, and its base is rovreed with a sheath of small scales $\frac{3}{16}$ of an inch wide. The will rakers are? - 17, the longest 3 of an inch. Tery small teeth are present on the tongue. The eggs are minute.

In a mate example, 16: inches long, received Nov. 16, 1895,

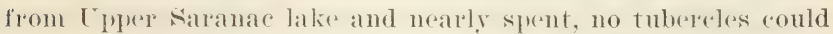
be seen on the seales; hut several of the males from camandaigua lake had them weell developed. There is a great difference in the development of the lingual texth, some of our individuals showing only a tratere of them, and it seems as if there may be some redation between their condition and the sexual maturity of the fish. For example, in a male 14 ineles long, sent frem the fourth lake of the Fultom Chain Nov. 9. 1s!t, the lingual tereth were present in a large pateh; in three maless, only a little smaller but sexually immature, from saranac lalke Nor. 11, 1s.7. the tereth on the tongue could be pereesived by the fouch only. The following measurements, in inches, and addi. tional notes, were made from the fresh fish.

MEASUREMENTS

Length, including caudal. ............

Length of middle caudal rays (from end

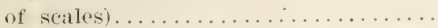

Length of upper caudal lobe (horizon-

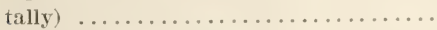

Length of longest caudal ray..........

Depth of body at dorsal. .............

Least depth of caldal perluncle........

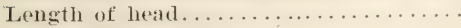

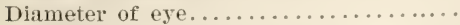

Length of maxilla.................

Distance from snout to dorsal origin....

Length of dorsal base..............

Length of longest dorsal ray...........

\begin{tabular}{|c|c|c|}
\hline $\begin{array}{c}\text { Canandai- } \\
\text { gua lake, } \\
\text { June 17, } \\
1896 \\
+\end{array}$ & $\begin{array}{c}\text { Upper } \\
\text { Saranac, } \\
\text { Nov. 16, } \\
1895 \\
\hat{\delta}\end{array}$ & $\begin{array}{c}\text { Chazy } \\
\text { lake, } \\
\text { Nov. 22, } \\
1895 \\
\hat{\delta}\end{array}$ \\
\hline $195 / \mathrm{s}$ & $171 / 1$ & $151 / 2$ \\
\hline 1 & ii & $T / 6$ \\
\hline 3 & $31 / 2$ & $\ldots$ \\
\hline $31 / 4$ & $\ldots$ & $\ldots$ \\
\hline $43 / t$ & $31 / 2$ & $\ldots$ \\
\hline $11 / 2$ & $\ldots$ & $11 / \mathrm{s}$ \\
\hline $33 / 8$ & $2::_{4}$ & $2{ }^{1}=2$ \\
\hline $5 / 8$ & $5 / 5$ & $1 / 2$ \\
\hline 1 & $3 / 4$ & $5 / 8$ \\
\hline 8. & $\ldots$ & $\ldots$ \\
\hline $21 / 5$ & $\ldots$ & $\ldots$ \\
\hline $21 / 2$ & $\ldots$ & $\cdots$ \\
\hline
\end{tabular}


MEASUREMENTS

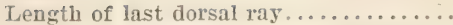

Distance from snout to rentral origin...

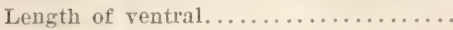

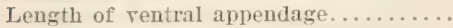

Distance from snout to anal origin.....

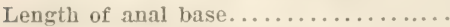

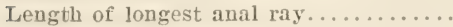

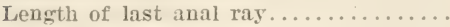

Length of pectoral .................

Distance from snout to alipose fin.....

Length of base of adipose fin..........

Length of adipose fin...............

Width of base of adipose fin..........

Length of longest gill raker...........

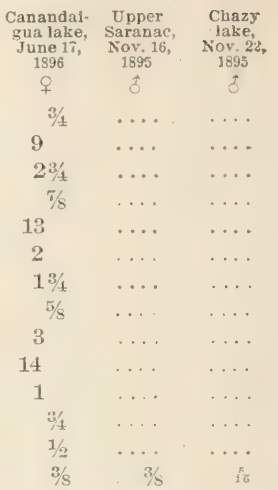

Taking the fish in the order above given, the gill ratires are: $9 \ldots 17,11$ 16. and 9 5 17. The scales are: 10-76-5, 10-57-9, and 11-81-10. The branchiostegals in various specimens examined are !) 10 10; divided dorsal rays, 10 to 11 ; anal rays. 10 to 11 .

\section{Genus Argyrosomus Agassiz}

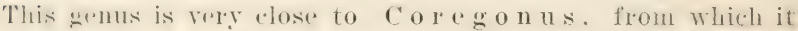
dithers in the hatger momh and more produred jaws, the juremaxillares hring placed nearly horizontally, and the lowere jatw

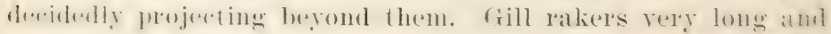

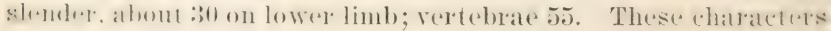

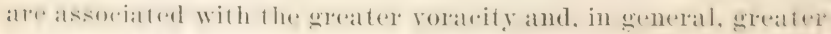

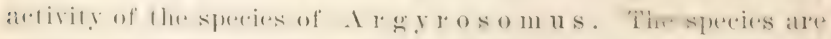
mumroms in the morthern parts of Furoper. Asiat and Vorth America, and all are valued as food.

\section{Argyrosomus osmeriformis (H. M. Smith)}

\section{Smelt of New York lakes}

Coremonus homi IBrax; Proc. U. S. Nat. Irus. Y, 658, 1S83; Goode, Fish ot F'lsh. Inel. U. s. pl. 197 B, 1S5t; not Coreqonus hoyj Gill.

Coregonus osmeriformis Sintr, Bull. U. S. F. C. XIV, 2, pl. 1, fig. 2, 1835.

Lakes seneca and Skaneateles, New Xork.

Arglnowamus osmeriformis Jolidan \& Evemarax, Bull. 47, U. S. Nat. Mus. 4hat, 1S!\% 
Body elongate, moderately compressed, slender; head less compressed than body, its greatest width equaling one half the distance from tip of lower jaw to nape, the lower jaw projecting considerably eren when the mouth is closed; mouth large, the maxillary reaching to the vertical through the anterior margin of the pupil; preorbital bone long and slender, more than one third as long as the head; supraorbital as long as the eye, four times as long as broad.

The greatest hight of the body is considerably less than the length of the head, and is contained five times in the total length without caudal. The greatest width of the body is less than one half its greatest hight. The least hight of caudal peduncle equals the length of the orbit and about one third of the greatest hight of the body. Scales small, nine in an oblique series from the dorsal origin to the lateral line, 82 tube-bearing scales, and eight in an oblique series from the ventral origin to the lateral line.

The length of the head is one fourth of the total length to the end of the lateral line. The distance of the nape from the tip of the snout is nearly one third of the distance from the tip of the snout to the origin of the first dorsal. The length of the maxilla is one third of the length of the head. The mandible is one half as long as the head. Lingual teeth present. The eye is as long as the snout and one fourth as long as the head. Gill rakers long and slender, the longest fire sixths as long as the eve; there are 55 on the first arch, 35 of which are below the angle. The insertion of the dorsal is nearer the tip of the snout than the end of the middle caudal rays. The longest ray of the dorsal equals the greatest length of the rentral and is contained seren times in the total length to the end of the middle caudal rars (six and two thirds times in length to end of lateral line). The length of the pectoral is one sixth of the standard body length.

The insertion of the rentral is midway between the snout and the end of the middle caudal rays. When the ventral is extended, the distance of its tip from the rent is only one 


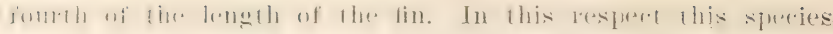
differs widely from C. a r ted i .

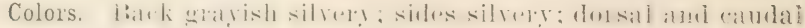
with darker tips.

Radial formula. D. iii, 9; A. ii, 13; V. i, 12; P. i, 16. Scales. $9-82-8$.

\section{MEASEREMENTS}

Current number of specimen.

32,162

\begin{tabular}{|c|c|}
\hline $\begin{array}{l}\text { Jiflli- } \\
\text { meters }\end{array}$ & $\begin{array}{l}\text { Hundredth } \\
\text { of length }\end{array}$ \\
\hline $2-2: !$ & ... \\
\hline $21 \pi$ & 100 \\
\hline$\checkmark$ & \\
\hline 41 & 19 \\
\hline $1 \mathrm{~s}$ & 8 \\
\hline 40 & $151 / 2$ \\
\hline 15 & $T$ \\
\hline
\end{tabular}

\section{Head:}

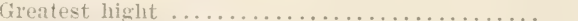

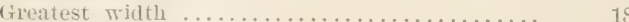

Ilight at ventrals...................... . . . 40

Least light of tail.................... 1 .

Greatest length .................... 52

Distance from snout to nape............. 36

Greatest width ..................... 20

Width of interorbital area............... 12

Length of suout...................... 14

Length of opereulum................. 13

Length of maxillary..................

Length of mandible................... 26

biameter of eye.................... 13

Dorsal (first):

Distance from suout. ................ 112

Length of base. ..................... 20

Ifength of longest ray................

Length of last ray.................... 11

$2 \pm 1 \%$ $161 / 2$

9 $51 / 2$ $6^{1 / 2}$

$$
6
$$$$
8
$$

8

Distance from snout. .................. 162

Lenerth of bise...................... 24

l.ength of longest ray.................. 20

lAngth of list ray.................... s

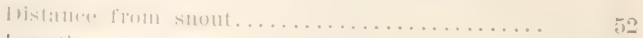

I, $+11: 51$ h

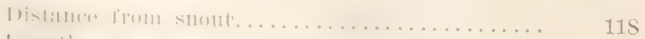


head without suour. The ventral begins under the middle of the dersill. its longest ray twe thirds of length of head. The pereforal is slightly longer than the rentral. The anal base mplats the lenghte of its longest may, which is nearly one half the lenglh of head. The adipose dorsal is slemdere its width one half its hight. and about one half the length of eye; 25 to :30 will raliers bulow the angle of the first arch. D. 11; A. 10 (comnting only divided rays in dorsal and anal); T. 10. Scales 9-sils. The upper parts are greenish or bluish black; the sides silwry and with narow pale stratis along the rows of scales, specially above the lateral line.

This -pereses is known as the lake herring or cisco. The name riseo is applied more partieularly in the small lakes of $1 \mathrm{~T}$ isconsin. Indiana and Xew York. The lake herring is most abundant in the direat lakes, extending northward into British Anerial: rastward it has been obtained from Labrador. It becomes variable in erertain parts of jts habitat, notably in Labatulor and in the lakes in which it is known as cisen. In 1xs. more individuals of this speres were taken in Lake Erie than in all the other Great lakes put together, more than 19.1010.6mu pounds having been ranght there out of a total of less than 26,000,000.

The arerage length of this spereses is about 1 foot. and the wright ! to 1̈ omoes, hut examples measuring 19 inches in length and weighing 2 pounds have been recorded.

The lake burring frepuents shoal waters moderately, and

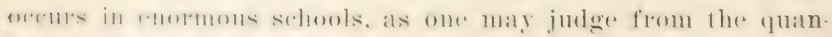

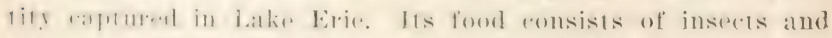

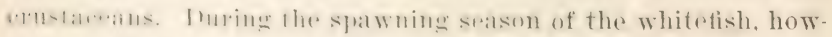

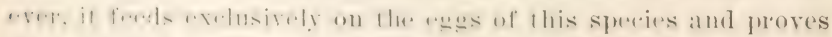

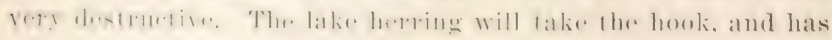

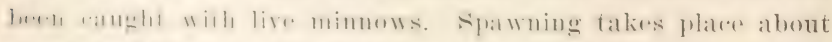
the end of Torember in shoal waters.

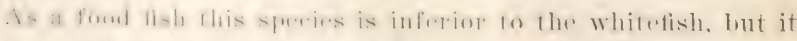

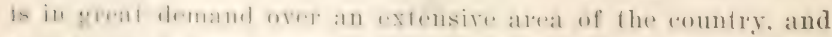

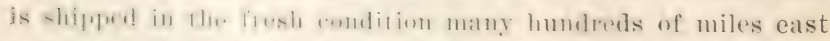

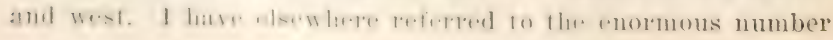


taken in 185a in Lake Erie. These are caught chiefly in pound and gill nets. The eateh in 1855 amounted to more than one third of the entire quantity of fishes taken in this lake. There is no apparent diminution in the number of these fishes, and their artificial propagation has not been practised.

A male and a female were forwarded by Mr Annin from Threemile bay, Lake Ontario, Nor. 22 and 25, 1895.

\section{MEASUREMENTS}

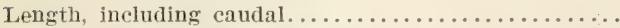

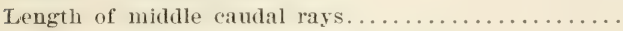

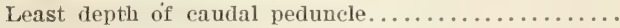

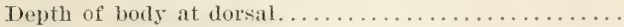

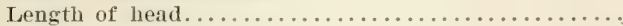

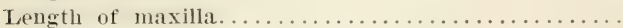

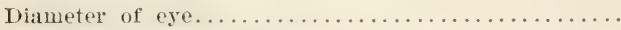

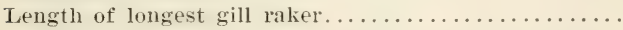

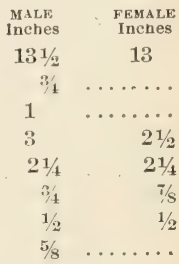

The male has $17+31$ gill rakers; the female, 47 . Scales of the male, 8-74-s; of the female, 76 .

In the female the maxilla reaches to the front of the pupil; the lower jaw projects a little; the dorsal and anal each have 10 divided rays; the dorsal has a black tip; the pectoral is dusky above; the ventral and anal are pale; the caudal is dusky towards its margin.

The cisco, according to $\mathrm{Mr}^{*}$ Amnin, lives in deep waters and spawns in brooks in December.

Ir. Meek saw a few specimens of the species from Cayuga lake. The C.S. Fish Commission obtained four specimens at Cape Tincent X. I. Nov. 11 and 17, 1891. The U. S. National Museum has a number of examples from Lake Champlain, some of them from Vergennes lt., and others from Ticonderoga N. I. TeKay says the shad salmon oceurs in the smaller lakes in the interior of the state, which still communicatr with our inland seas.

\section{Argyrosomus hoyi Gill}

\section{Mooneye Cisco; Shiner}

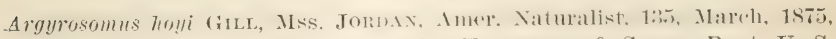
Lake Michigan, near Racine, Wis.; Evermand \& Smitr, Rept. U. S. F. C. XX, 310, pl. 22, 1896; BEAN, Bull. Amer. Mus. Nat. Hist. IX, 342, 1897, Canandaigua Lake; Jordan \& Evernaxn, Bull. 47, U. S. Nat. Mus. $469,1896$. 
Corenomus hoyi Jondix, Man. Tert. ed. 2, 275, 1Sis; Jordax \& GILBERT, Bull. 16, U. S. Nat. Mus. 299, 1853; SмIтH, Bull. U. S. F. C. XIV, 6, pl. 1, fig. 1, 189 .

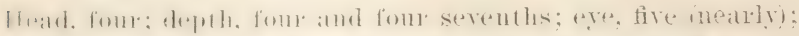

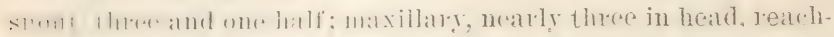

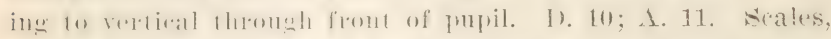
\&

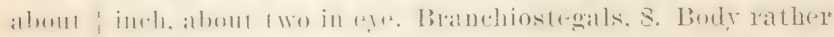

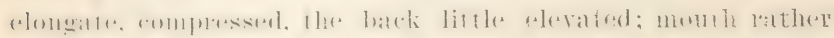

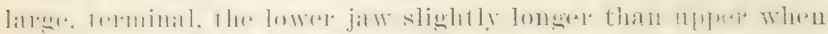

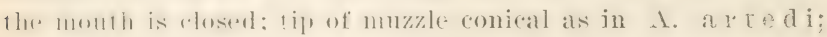

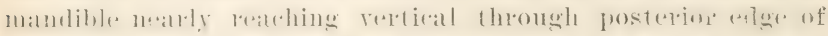

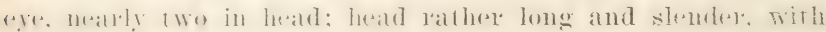

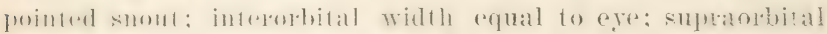

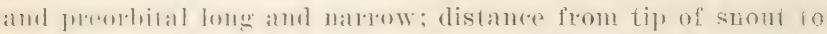

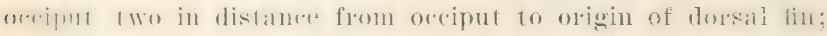

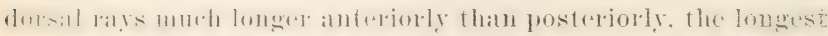

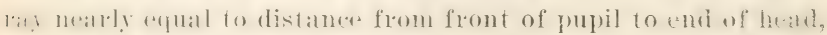
1he last ray only ome thirel as long; longest anal ray two and 1016. laalf in head. last anal Jay l wo fifths as lomg as the lomgest:

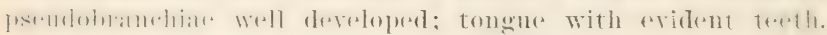

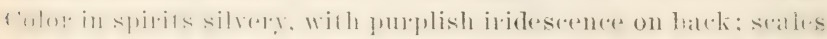
willun! funtrlulalions: helly whilish: dolsal and rabulal tius

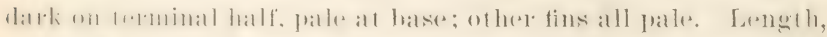

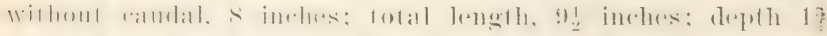

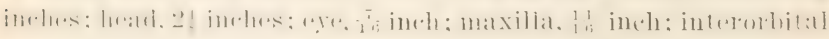
width equal to diameter of eye.

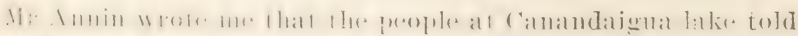

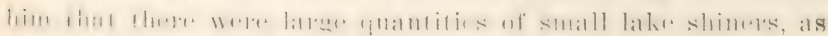
thry are alled, in the lake. A fisherman said that they are seen

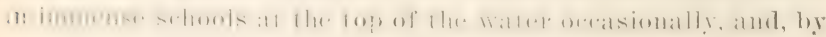
firing a yun loaderl with shot into thom, men ean stum them so as fo pick ul, quite a number. They a re palgerly sought after for molling hat for the salmon tromi fomme in that lake.

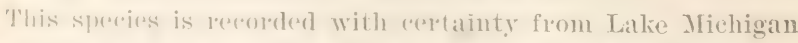
minly. If is talim in geill neis in elesp water and, notwithstandinc ils small si\%e, has hereme commereially important. It is 
here for the first time announced as a member of the Now York fauna, and the description leatres no doubt of the rorrertness of the identifeation. The fish examined, a female with rige exgrs. was taken in Callandaigua lakr, Itec. 19), 1896, by Mr Annin's men. It was the only one alught, and was raptured by leecoming gilled in the funmel of the net. Mr Amnin is saltistiest that this is the bake shinere of the fishermen, which they sometimes see in immense sehomk al the sulfare, and kill for 10olling bat by shooting them.

\section{$12 S$ Argyrosomus prognathus (H. M. Smith)}

\section{Long Jawo; Bloater}

Coregonus progmathus Hegi M. Suтт, Bull. U. S. F. C. XIV, 4, pl. 1, fig. 3, 1895. Lake Ontario, at Wilson N. Y.

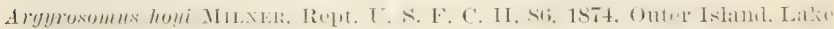
Superior, not of GILL.

Argyrosomus progmathus Evenanix \& Smiti, Rept. U. S. F. C. XX, 31t, 1). 26, 1896; Jondix of Exemmaxy, Bull. 47, U. S. Nat. Mus. 471, 18!ti.

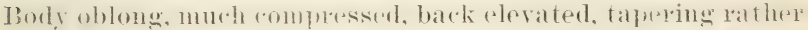
abroptly toward the natrow atudal peduncle, the adult tish hat ing a slight nuchal hump as in ('. c. lu po i f o r m is ; greatest depth three and one half to four in hody length: leead lather short and derel, pointed. four to four and one third in length: greatest width half the length, aranial ridges prominent: smont stratight, its tip on level with lower alge of pupil: top of heat

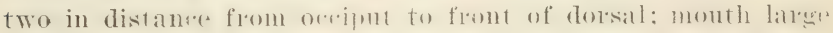
and strong. maxillary reatehing to opposite midkle of phipl, two and one half in head, lenghth theere times its width, mandible

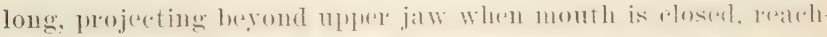

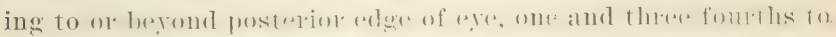

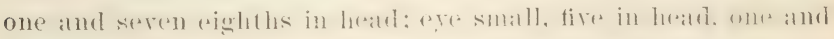

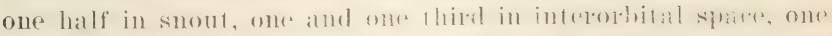

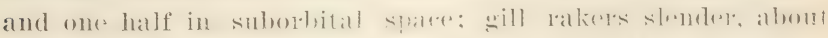

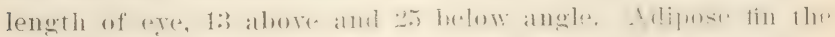

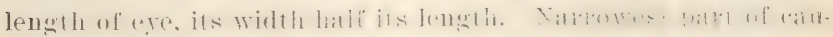

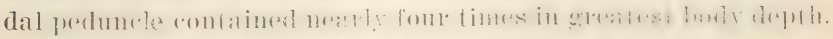

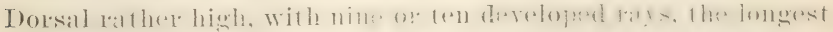

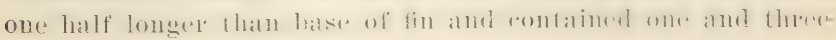


fomllis times in greatest body depth, three and one fourth times in distance betwern dorsal and snout, and one and one half fimes in heatl: free marein slightly concave; origin midway

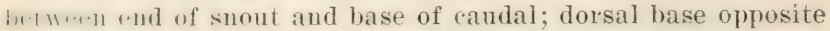
ninw saltes. Inal with 10 to 12 dereloped lays, the longest ray "yual to hase of fin and two thirds of hight of dorsal. Tentrals as lomg as dorsal is high, their origin midray between anterior rdge of orhit and base of caudal. Tentral appendage short. rovering about three suales. Pectorals as long as rentrals. s'ales rathrr large, about 75 in lateral line, seren or eight above the lateral lint, seven or eight below the lateral line. Lateral line slraght except at origin, where it presents a rathrr marked 'urr. sides of body uniformly bright silrery, with pronounced buish rollertion in life; the back dusky, the under parts pure white without silvery color. Above lateral line, light longitudinal stripus involving central part of scales extend whole length of ludy. Fins flesh rolor or pinkish in life, the dorsal and candal nsually showing dusky edges; postorbital area with a bright

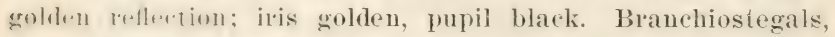
eight. Average length, 15 inches.

Habital: Latie Ontalor. Lake Mirhigan, Lake Superior, and doulntess the +ntire freat lake basin, in deep water. This fish

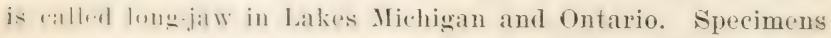
Wr. whatm.d from John s. Wilson of Wilson $\mathrm{X}$. Y. and from

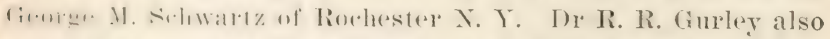

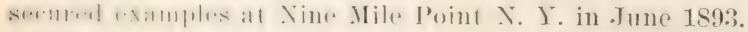

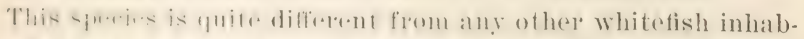
jirne thr. tirnal litle hasin. It maly lu alt once distinguished

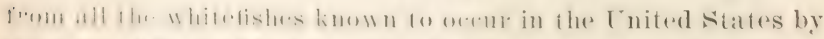

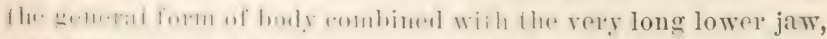

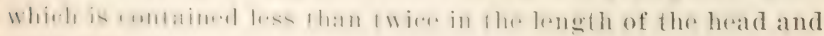
extrubls batekwal to or beyond the posterior edge of orbit.

\section{2!) Argyrosomus tullibee (Richardson)}

\section{T'ulliber: Homgrel Whitefish}

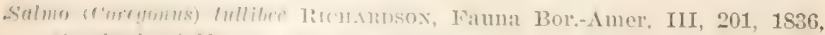
C'mmberlant Ifunse, Pinu Island Take. 
Coregonus tullibee Günther, Cat. Fish. Brit. Mus. VI, 199, 186t; Jordax \& Gilbert, Bull. 16, U. S. Nat. Ius. 301, 18s3; Jordan, Cat. Fish. N. 1. 43, 1885; BEAn, Fishes Penna. 70, pl, 27, fig. 49, 1893.

Argyrosomus tullibe Jordan, Man. Vert. ed. 2, 361, 187s; Evermaxy \& Sumir, Rept. U. S. F. C. XX, 320, pl, 28, 1896; Jordax \& Everuaxu, Bull. 47, U. S. Nat. Mus. 473, 1896; BeAn, Bull. Amer. Mus. Nat. Hist. IX, $343,1897$.

The body of the tullibee is very short, deep and compressed; its greatest hight about one third of the length without caudal. The head is pointed, as in the blackfin, the mouth large, with the lower jaw scarcely longer than the upper. The maxilla extends to below the middle of the eye. The ere equals the snout in length and is two ninths of length of the head. Scales much larger on front part of body than on the caudal peduncle. The gill rakers are loug, slender and numerous, about 30 below the angle on the first arch. D. 11; A. 11. Seales in lateral line 74, eight rows above and seven below lateral line; pyloric caeca, 120. The upper parts are bluish; sides white and minutely dotted. The spermary, according to Richardson, is wood brown.

This species is usually called the tullibee, but in Lakes Erie and Michigan it is sometimes styled the mongrel whitefish on the supposition that it is a cross between the common whitefish and the lake herring.

The tullibee has been taken recently in Lake Michigan; and Dr E. Sterling had a specimen from Lake Erie. It is found occasionally in other's of the Great lakes and extends northward into British America; but is comparatively little known to the fishermen and is very rare in collections. This fish groms to a length of 18 inches.

The late F. C. Gilchrist was the first to describe the habits of the tullibee, and this he did in Forest and stream in the following language.

In September they will again be found gradually nearing the shoal water, feeding heavily, and plump with fat and the now swelling ovaries. Later on they appear to eat little or nothing and derote all their time to playing until about the 25th of October, whan they have settled down to the business of propagation, which they have finished by Norember 10. They prefer shallow water close to shore with clean sand to spawn on, and 


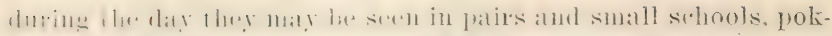

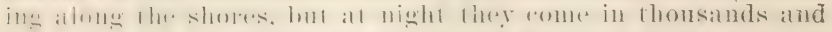

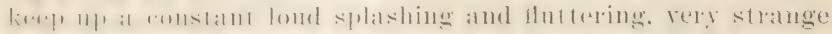

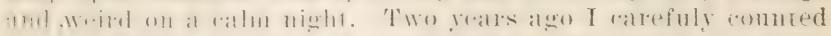

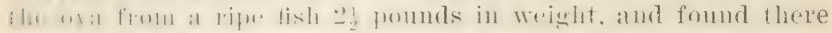

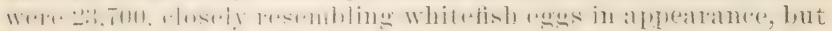

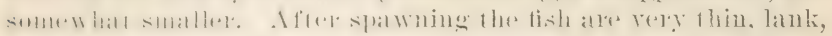
dull in color, and quite unfit for human food.

Jimes Innin jl furnished me the following notes, on the sparning of the tullibee in Onondaga lake, $\mathbf{X}$. Y.

?hr.!

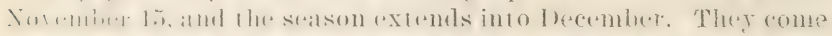

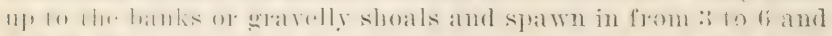

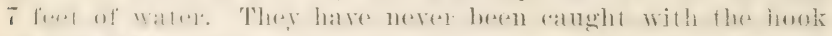
in lhis lalix: and an old fishermatn told me that he had tried

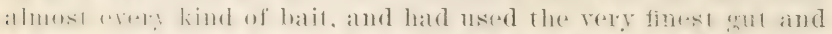

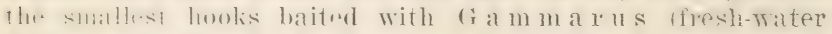

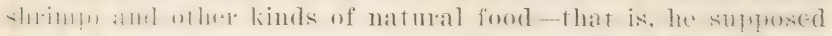

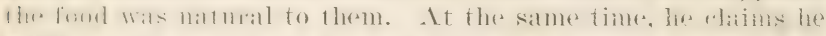

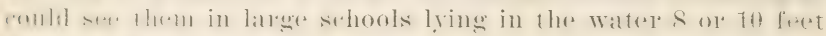
from the surface.

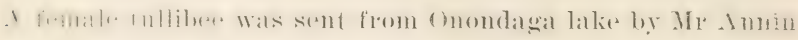
Nox. 18, 189\%, and another of the same sex Nov. 25, 1896.

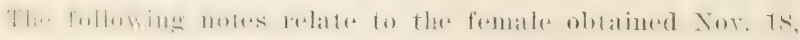
1.5!).

Inches

Length to end of caudal. . . . . . . . . . . . . . . . . . $1 / 2$

Length of upper caudal lobe....................

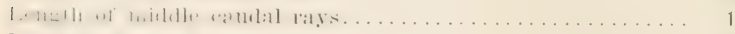

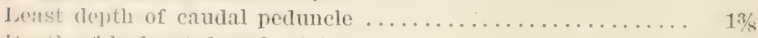

I) epth of body at dorsal origin...................

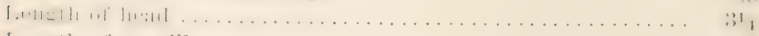

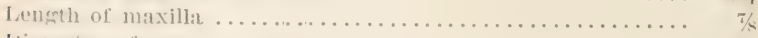

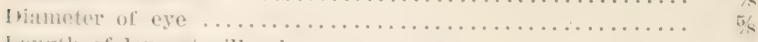

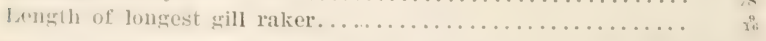

The mandible projects slightly. I. S; D. 11; I. 11; Y. 11. śaulus $8-75-8$; gill raliers, $17+2 \tau$.

The fomale received Nor. 25, 1596, is 15 inches long.

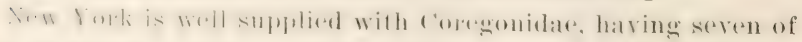
the 16; North Imerioan species. C. quadrilateralis is the frostlish of the Adirondacks and the Great lakes. C.

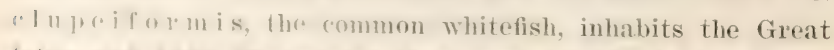

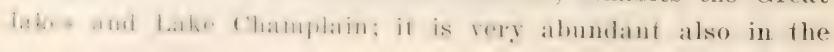


Adirondacks. Argyrosomus osmeriformis is a shapely lithle herring of seneral and skaneatedes dakes. A.

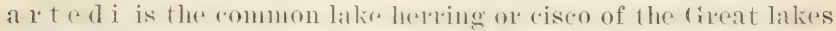
and Latie champlain. A. hoy i, the halie shinere or Hoy's

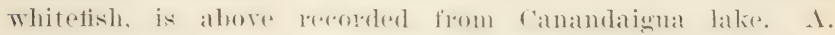
prog a the the the long-jaw. the only summer spawning whitefish so far as known, lires in Lake Ontario: and, finally, A. t u $1 \mathrm{libee}$, is the fine whitefish of Onondaga lake.

\section{Genus oxcormychus Suckley}

Body elongate, subfusiform, or compressed: mouth wide, the maxillary long, lanceolate. usually extending beyond the ere; jaws with moderate treth, which herome in the adult male fnormously enlarged in fromt; romer long and nitrow, flat, with a series of terth hoth on the head and the shaft, the latter series companatiwely short and weak; palatiues witli a sories of teeth: tongue with a marginal series on each side; tecth on romer and fongue often lost with age; no teeth on the hyoid bone; branchiostegals more or less increased in number; seales moderate or small; dorsal fiu moderate; anal fin comparatirely elongate. of 14 to 20 rays p pyloric apjendatges in incleased number; gill ralker's rather numerous; ova large; sexual peeuliarities rery strongly developed ; the snout in the adult males in smmmer and fall greatly distorted, thr premaxillaries prolonged, hooking over the lower jaw, which in turn is greatly elongate and somewhat hooked at tip. the teeth on these bones also greatly enlarged. The body becomes dere and compressed, a fleshy hump is dereloped before the dorsil fin, and the seales of the back become embedded in the flesh; the flesh, which is red and rich in spring, becomes dry and pool. Silmon, mostly of large size, ascending the rivers tributary to the north Parcific in North America and Asia, spawning in the fall.

\section{0ncorhynchus tshawytscha (Walbalum)}

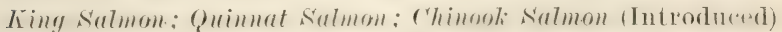
Salmo tshawytscha WAlbaur, Artedi. Gen. Pisc. III, 71, 1792.

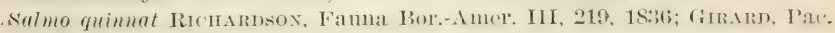
R. R. Exp. Fish. 306, pl. 67, 1858.

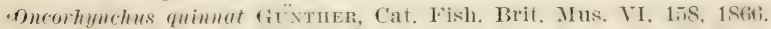


Oncorhynchus orientalis GüNTHER, op. cit. 159, 1866.

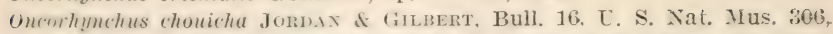
1K83; Stone in Fish of Fish. Ind. U. S. I, 479, pl. 186, lower fig. 185t; IBix, Bull. L. S. F. C. IX, 190, 11, XIXI, fig. 1. 1591; Fisiles Penna. $72,1898$.

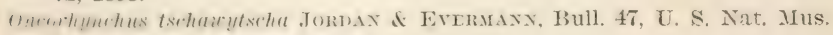
479, 1S96, pl. LXXVII, fig. 206, 1900.

borly stomt, moderately elongate, its greatest depth contained thre and twothirds to four times in total length without caudal; raudal fedumele short and stout, its least depth one third of greatlest depth of buly; huad conical, pointed, its length one fomrth of total length without caudal; eve small; less than one half of length of snout, and about one seventh of length of head; maxilla slemder, its width scarcely one fourth its length, which is one lialf the length of head; nostrils nearly midway betwern eye and tip uf snout; teeth small, longer on sides of lower jaw than in fromt. vomerines few and weak, disappearing in the males; gill rakris usually about $2: 3$, of which 14 are below the angle uf the first arelı; dorsal origin midway between tip of snont and hase of upper extermal caudal rays, the base of the fin its long as the lomgest lay, one half as long as the head, the last la! I wo fifths as long as the longest; adipose fin orer the end of Hhr anal, its width suarerly one half its length, which is two s.lumblis of the length of the head. The anal base is three fifths as long as I he head! thr longest anal ray is two fifths as long as the head am more than twice as long as the last ray. The ven1ral is muler the last rays of the dorsal, midway between front uf egr and has of raurlal, its length one half the length of head. ils aplu-molage une half as long as the fin. Pectoral as long as lustorthilal falle of head. 13. usmally 17 or 18; D. 11; A. iii, 15 or

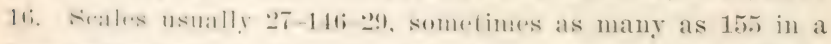

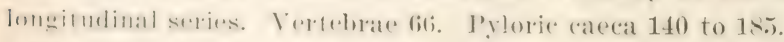

The quinnal silumen is the lategest and finest of the l'aleifie

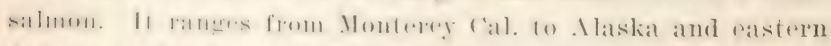

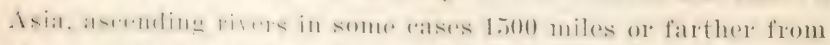

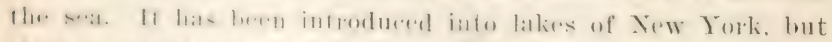

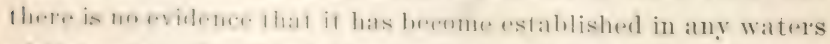

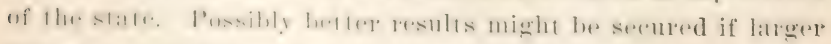
fish were selereted for the experimental stocking. 
The resulis of the "rperinent of introducing this salmom into Jew Jork waters are as yot unknown, but it is to be hoped that it will be sucicseful. Since the change of method by which barger listi are cmployed for lrausplanting, the untlook appears to be more favorable.

\section{Genus salvo (Artedi) Linnaeus}

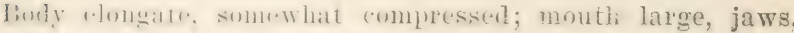

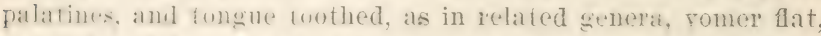
its shaft mut lepressed, a few teeth on the cherron of the rouer. hehind whirh is a sonewhat irregular simgle or louble series of tweth, whirh in the migratory forms are usually dudobuns with age s saldrs larese or small, 110 to 200 in a longitullinal serjes;

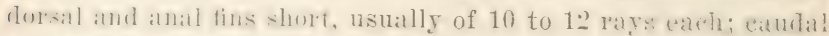

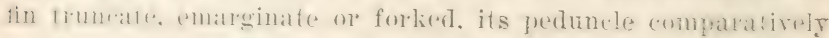

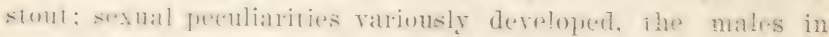
typiral spreies with the jaws grolonged and the front teeth fanlarger]. Ilie lower jat being houlied npward at the end and the

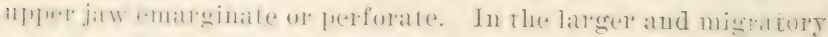

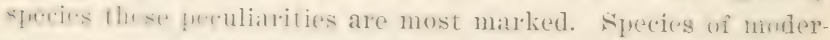

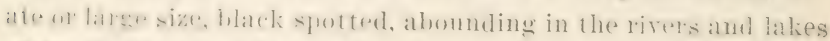
of Xorth Ammrear, Aria and Europe; no fresh-water speres

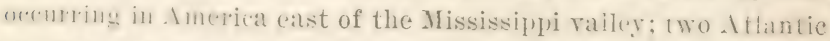
spreres, marine and anadromous. The nommigratory spreies

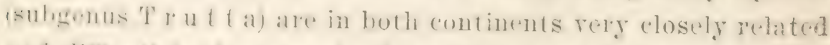

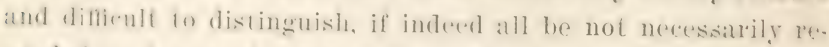
grarded as forms of a single ome. The exerssive variations in rolor and form latre given ris. 10 a host of nominal species.

\section{Salmo salar Linnaeus}

\section{Atlantic Salmon.}

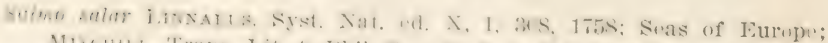

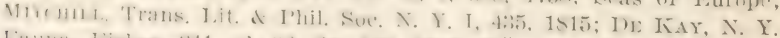

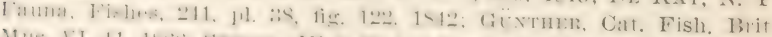

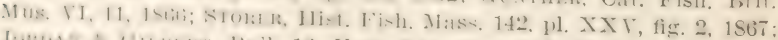

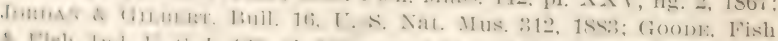

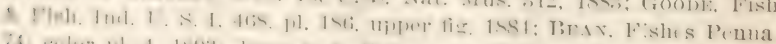

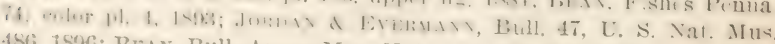
186; iS96; Br.ı ; Bull. Amer. Mus. Nat. Ilist. IX, 344, 1897. 
The Atlantic salmon has a moderately thick and elongate body. The greatest hight, at the origin of the dorsal fin, is two minths of the total length without caudal. The caudal peduncle is rather slender; its least depth abont one third of the greatest depth of body. The head is comparatively small; its length in the female about one fifth of total without caudal. The eye is placed at a distance from the top of the head equal to its own diameter. It is one half as long as the snout, and about one serenth of length of head. The maxillary reaches a little past the "ye in adults. Its length equals the depth of caudal peduncle. The dorsal origin is midway between tip of snout and adipose fin. The adipose fin is long and narrow, its width one half its length, and anual to length of eye. The base is slightly longer than its longest ray, and nearly one eighth of total without caudal. The last dorsal ray is about one third of length of dorsal base. The rentral origin is nearly under the end of the dorsal baste. The length of the fin equals one half the length of head. The appendige is two fifths of the Iength of the fiu. The feetoral is as long as the dorsal base. The distance of the rentral origin from the anal origin is a little more than length of heatl. The longest anal laty equals length of ventral. The last ray is two fifths of length of longest. B. 11; D. 11 divided rars and 3 rudiments; $A$. 9 divided rays and

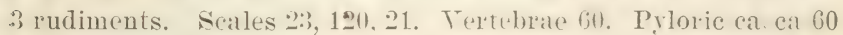
to 70 . In the adult the upune parts are brownish or grayish; the sides silvery. Numerous X-shaped or XX-shaped black spots on the upper half of the body, side of the head, and on the fins. Males in the breeding season have red blotehes along the sides. In the young there are from 10 to 12 dark crossbars mingled with red blotches and black spots.

The salmon in America has but at single common name. When the joung have reached a length of 2 inches and taken on the rermilion spots and dark cross bauds, they are called parr, and retain this name while they remain in fersh water. Before descending to the sea in the siecond or third spreing, the parr assumes a bright silvery coat and is then known as a smolt. 


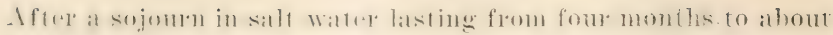

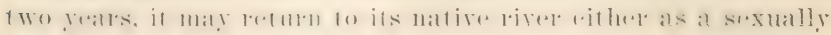

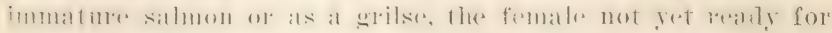

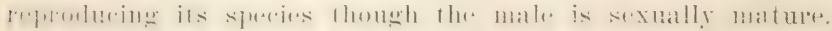

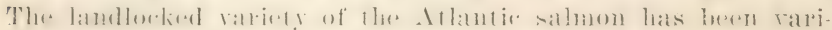

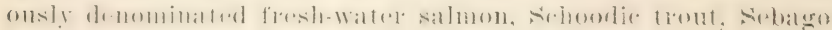

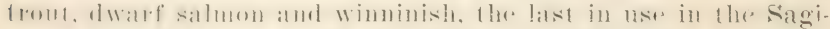
naw region. In some Nova Seotian rivers a misnomer, grayling, is applied to the landlocked salmon.

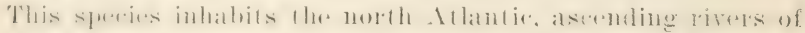

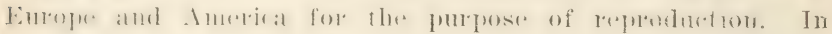
Europe it extends southward to France, and in the United

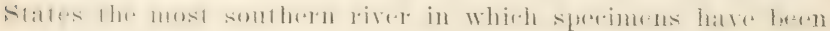
obtained is the Potomac. It occur's in small numbers in the

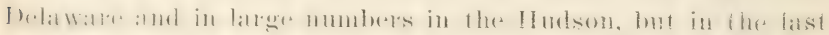

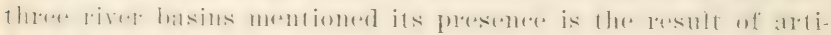

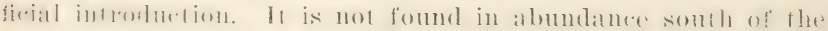

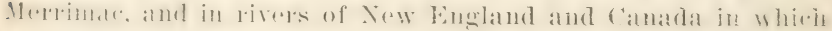

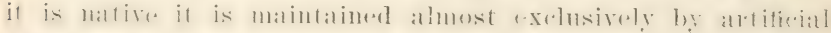
ruhture. The usual weight of the Atlantic salmon ranges from

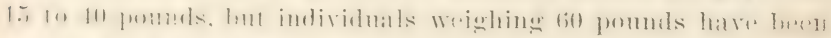

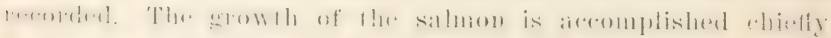
in the oceam. Is a rule the adults enter the rivers on ar rising

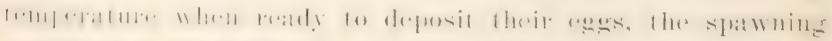

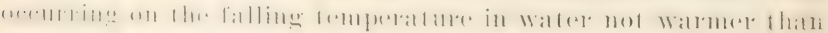
5) ()$^{\circ}$. The tine of entering the Delaware and Hulson is April, the commerticut a little later, the Merrimac still later; to the lenolseot the salmon come most abundantly in June and July; and to the Miramiehi from the middle of June to Oetoher. The silmon is not mull afrected by chamges in temperature of the water, muluring a range of fully 15\%. The eggs are deposited in shonal water on sandy or gravelly bottom, the parent fish making derep drumessions by means of their noses or by flopping motions of the tail. The period of egerepesiting lasts from 5 to 1.2 dilys. Thr slatwning season begins about the middle of oretoler and may rum into Decrmber. In some European 
rivers the season rontinues till Fobrualy. The egers are about one foneth of an ineh in rlimmeter, and the female is estimated to have about 1000 for each pound of her weight. In the Penolseot, areording to the observations of Mr Itkins, an

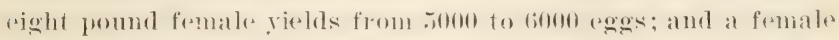
of to poumds about 15,000 reges. The hat Thing period ranges

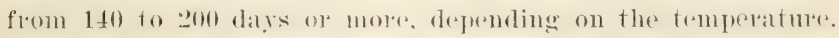
A newly hatreled salmon is about thres foulths of an inc!l lonx. and the yolk sarek is absollorel in from a month to six werelis. It then begins to ferel on small organisms in the watter. It the age of 1 wo months it modsures 1$]_{2}^{1}$ inches and begins

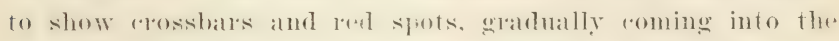
frare stage. In the sea the salmon fereds on herring. caplin. silnd laner. smelt and othel smatl fishes, hesides relustareans: but during its stay in fresh water it takes no food.

Among the worst enemies of salmon eggs are trout, eels, suckers and forges. Numerous speejes of hirds destroy the fiy, among them sheleleakes, limgtishers, gulls and terems.

The value of the salmon as a fond and game fish is so well known as to repuine no description lexe. Those that find their Way into malliet are usually alught in pound nets, gill nets or seines, and the hulk of them are taken at or near the mouths of the streams which they are about to ('nter for the purpose of spatwing. Many are capturert in the mpler realehes of streams by the spear.

Eggs of the Atlantic salmon, just on the point of hat ehing.

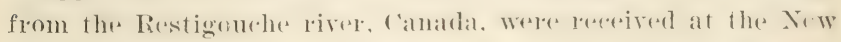

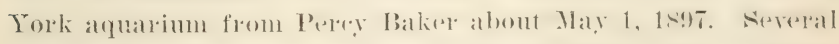
humdred healthy emberos were obtained fiom them. These

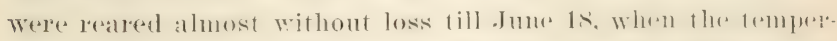
ature of the water hatd leatehed Fi and neaty all pereished. Tovember 27, one of the few surviroles was :3:3 inelues lomer. Liver was the principal food of the fry.

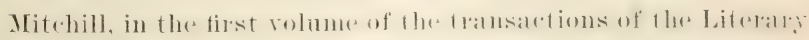

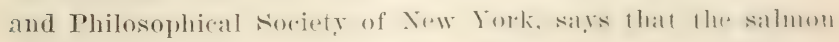

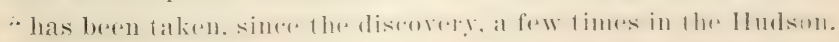




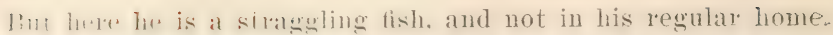
Then is no straty mignation of salnou to this rivele. Though

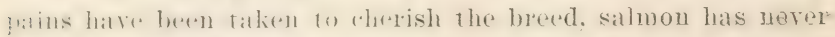
ifriplented the Ilutson in any other matuer than as a stray."

In 1812 DeKay published the following note:

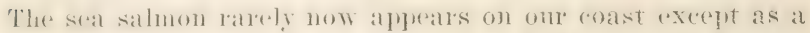

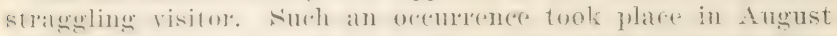

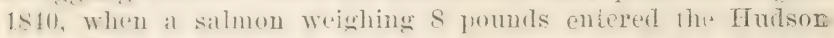

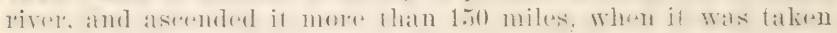
near Troy. . It now is only seen on our northern bor-

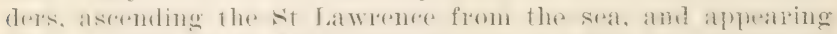
in lakk (lntaldo in April, and learing it again in orfober or November. They were formerly very aloundant in the latirs in

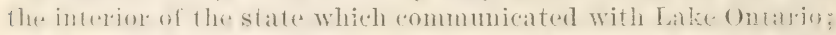

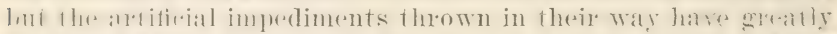

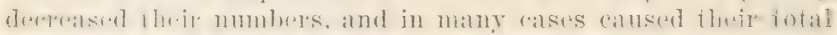

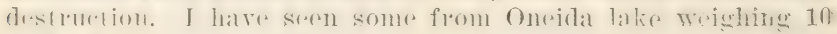

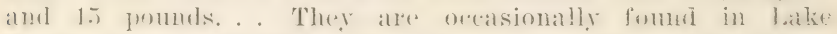
(Ontarin during the whole year: hut, as the sime instinet whirels compuls them to aserend rivers also leats them again to the seat,

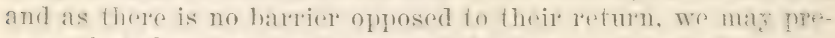
sume that these are siclily or possibly barren individuals.

Experiments for restorling the II

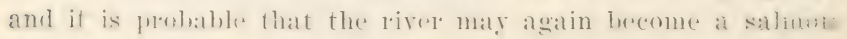
stream.

\section{Salmo salar sebago (Girard)}

\section{Landlocked Salmon (Introduced)}

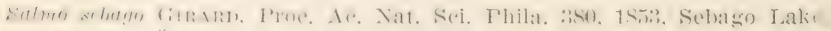
Maine; Güntmen, Cat. Fish. Brit. Mus. VI, 153, 1866.

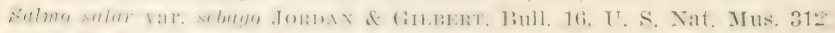
1853.

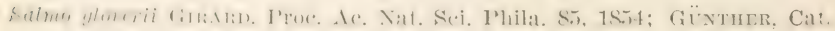
Fish. Brit. Mus. VI, 153, 1866.

Salmo salar sebago Jondar et Eveminas, Bull. 47, U. S. Nat. Mus. 4ST: 1896; Bran, Bull. Amer. Mus. Nat. Hist. IX, 344, 1897.

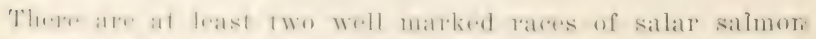

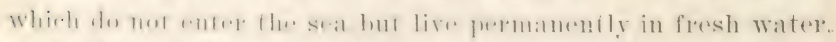

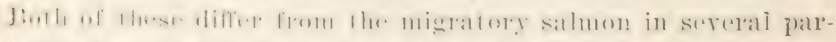

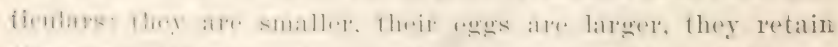

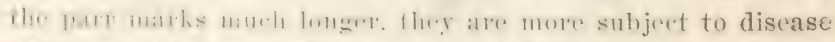

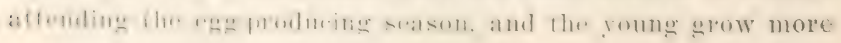


rapidly. The o 11 a 11 a $n \mathrm{i}$ i he of the saguenay river rountry is the farthest remored from the typical sea salmon by its rery much smaller size, larger fins and different pattern of coloration.

The larger of the two landlocked silmon of the Tnited States is found in the four rive basins of the state of Maine, the Presumpscot, Seber, Inion and St croix. Here the weights vary considerably, spawning fish ranging all the way from ? pounds to 10 or 12 poumls, while oceasional individuals reach 25 pounds. The sebago form is the one that has been introduced into the Aliromdack lakes and other New York waters. Sparning begins late in October, but is at its hight in Norember. Eggs are shipped in January. Fobruary and Maroh, and the fry are ready for planting in June.

At Gresen lakir. Ire... the landlocked salmon often endure a summer temperatume above soc F.. but they refuse to take food when the water reaches $75^{\circ}$.

This salmon has ber introluerd into New York waters from Maine, and appears to hare hecome estahlished in sereral localities. A very fine example was obtained from the South side Sportsmen's Club of Long Island, but it was injured in transportation and nerer recorered. In 1 juril 1596 several individuals from Maine were presented by Fugene G. Blackford. One of these lived in a tank of salt water in the New York aryarium for 19 months, and was then frightrmed by visitors when the water was drawn low for cleauing, and injured itself so badly that it died after a few hours of struggling. The following measurements were obtained from the fresh fish.

Inches

Length ......................................

Middle caudal rays from end of scales................. $15 \%$

Depth .................................... t

Least depth of caudal peduncle.................... $15 / 5$

Head ..........................................

Snout ....................................... 111

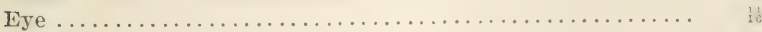

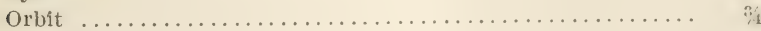

Snout to dorsal............................... $01 / 2$

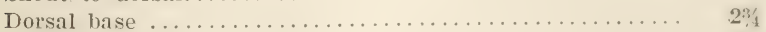

Longest dorsal ray........................... $23 \%$

Last dorsal ray ............................... 
Inches

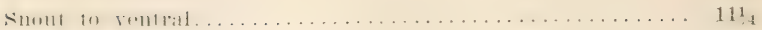

Length of rentral. . . . . . . . .

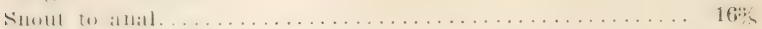

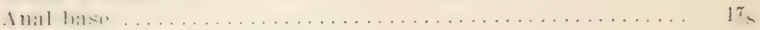

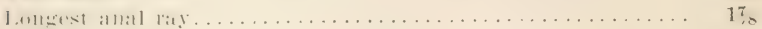

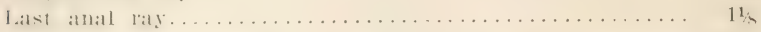

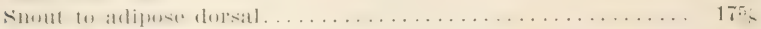

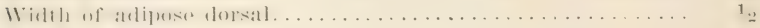

Length of adipose dorsal. . . . . . . . . . . . .

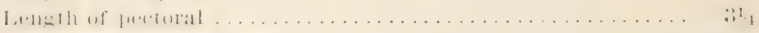

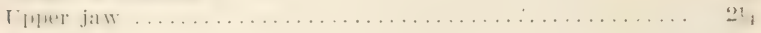

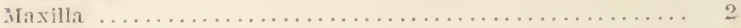

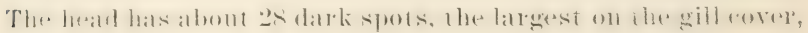

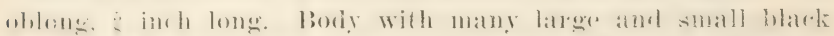

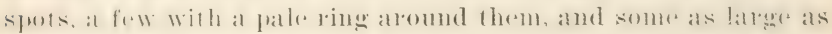

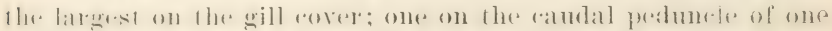

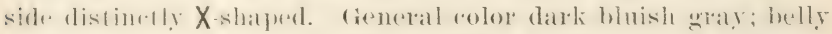

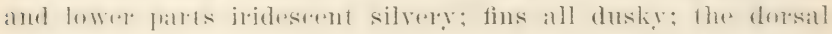

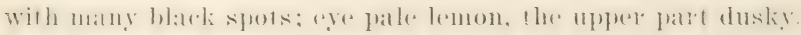

Gill rakers, 9+11, the longest $\frac{5}{15}$ inch. B. 11; D. 10. Seales, $21-123-20$.

\section{1:3:) Salmo henshawi Gill \& Jordan}

\section{Lake Trahoe Trout; Red-throat Trout (Introduced)}

Salmo henshaxi Ginl \& Jordan, Man. Vert. ed. 2, 358, 1878, Lake Tahoe; Rept. Chief Ling. Part 3, 1S78, App. NN, 1619, pl. IV; Jorda., Proc. U. S. Nat. Mus. I, 75, 187 .

Sulmo purpuratus var, henshati Jordan \& Gilbert, Bull. 16, U. S. Nat. IIus, 316, 1883.

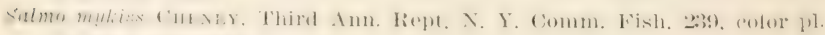
facing p. 238, 1898 .

Salmo myliss henshani Jomdax, Bull. U. S. F. C. IX, 14, pl. II, fig. 5, 1891; Joridax of Evermax, Bull. 47 , U. S. Nat. Mus, 493, 1896.

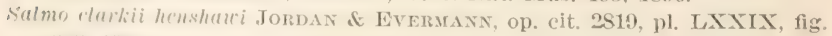
2015. $15 \%(K)$.

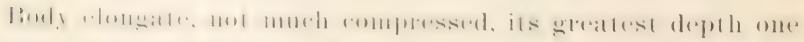
fonth of the fotal lemgih without caudal; caudal peduncle

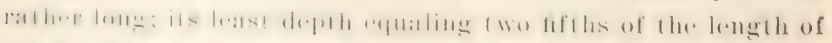

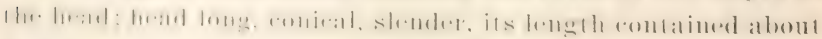
four limes in the folal to caudal base; a slight keel on the top

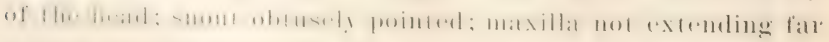

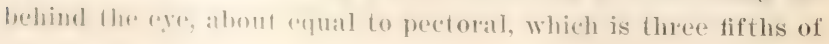


length of head: gill rakers short and stout, about 18 on the first areh. of which $1: 3$ are below the angle: vomeriue teeth in two long, altrenating series; hyoil teeth rather weak, in at sinall Jateh; dorsal tin small, its last rays two thirds as long as the highest; anal fin rather high; (andal short and distinetly forked. I). 9 to $11 ;$ 1. 12; B. 10. Neales 27 to :37-160 to $200-27$ to 40: pyloric caeca 50 to 60 .

rolor dark grexn in life, varying to pale green; the sides sile very with a broat (opplery shate which extends also on the rhereks and opereles: a yellowish tinge on the sides of the lower jaw and red ol olatnge dashes between its rami; back ererywhere covered with latere, roundish black spots; dorsal, adipose fin and randal tin with similat spots, and a few on the anal: belly with black spots.

The Tahoe trout is at larege spereses inhabiting Talooe lake. Pyramid lake, Welober lake, Domuer lake, Independence lake.

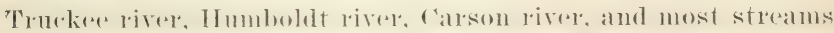
of the rast slope of the Niereal Sevada: it orems also in the lead waters of Feather river, west of the sierrat Nerada, probably by introduction from Nerada.

The usual weight is 5 or 6 pounds, but individuals weighing 20 to 29 pounds are recorded.

Egegs of the Lalie Tahoe (f'al.) trout were obtaincd by James Amnin jr at caleflomia X. Y.. and young fish reared at his establishment weres sent to the arquarium in November 1896. They throve till the latter part of Junc 1897, when they were overcome by the warm water. They could not endure a transfer to the cooler salt water, like most of the other fish of the salmon family.

It Caledoniat station, areording to Mr Cheney, this fish begins to spawn before the middle of March and contimues for two

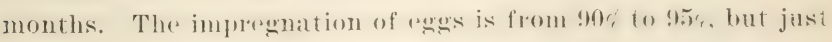
before the hatrhing pexiod a latege number of the ergess lourst and the embryos ane lost. There is loss too betweren the hatehing and feeding times. and the fey do not foed as realily as the brook trout. Altogether. Mr Annin, the superintemelent of 
and caudal fius profusely covered with small black spots, no red between the rami of the lower jaw.

The steelhead trout is found in coastwise streams from southern Califoruia to Bristol bar, Alaska. It spawns in the late winter and early spring; ripe eggs were obtained at Sitka, Alaska, June 10. Spent fish of this species are frequently taken with the spring run of the king salmon.

The economic value of the steelhead is rery great; the fish reaches a weight of 30 pounds, though the arerage weight is under 20 pounds, and the non-anadromous forms seldom excerd 5 or 6 pounds.

From information furuished br Mr Annin it appears evident that some of the eggs of trout receired at Caledonia N. Y. many sears agn from the MreLend river, Cal., as rainbows, really included both rainhows and steelhearls. He finds certain females producing deep salmon colored eggs, while in the same pond and receiving the same food as other females which furnish very light colored, almost white, eggs. Some of the females also differ from others in going to the spraming beds nearly two months earlier. It is nom linown also that the McLeod rontains a small-scaled form of the rainhow, known to the Indians as the no-shee, and this also may easily have been sent to thr east under the name of rainbow. Striking differences in the appearance and habits of so called rainbors introduced into the various states, lend color to this supposition.

Steelheads were obtained for the New York aquarium in Norember 1896, from the U. S. Fish Commission. They were hatched from eggs shipped from Fort craston Cal. to the station at Craig brook. Ife. The length of the trout when receired ranged from 4 to $4 \frac{1}{2}$ inches. After one year they were 10 inches long on the average, and weighed many times as much as they did when received. Xone of them at any time showed a reô lateral band such as is present in the rainbow, and they are farther distinguished by the fresenes of white tips on the ventral and anal fins; the dolsal also has a small white tip. They hare been kret almost from their arrival in salt water. and 


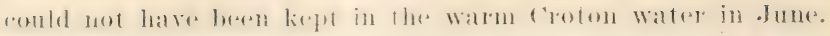

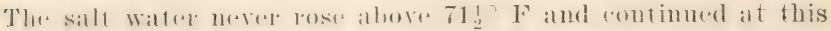
high temperature ouly 10 days.

The X. Y. Fisherestiame and Forest f ummission planted some of these tront in a lome Island stream and some in a lak in

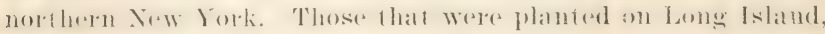

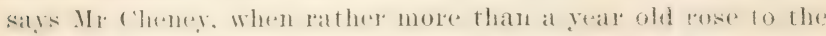
fly of the tlonl tisheroman and made a most galliant fighil. hut it

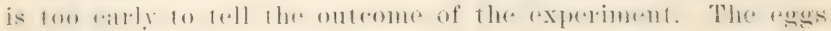

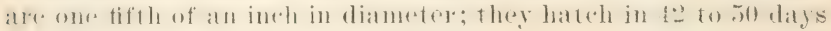
with water at $50^{\circ}$.

\section{Salmo fario Linnaeus}

\section{Brown 'Trout (Introduced)}

Salmo fario Lrvaeus, Syst. Nat. ed. X, I, 30, 1758; Blocm, Ichth. I, 121, taf. 22, \& 157, taf. 23, 1785; Richardson, Fauna Bor.-Amer. III. 144, pl. 92, fig. 3, A \& B, 1836; DAr, Fish. Great. Brit. \& Ireland, If, 95, plates CIX, fig. 3, OXIII, CXIV, CXVI, fig. 1, 188t; BEAN, Fishes Penna. 7S, color pl. 6, 1893; Jordan \& Erermann, Check-List Fish. ‥ A. 512, 1896.

Sulmo fario ausonii Güxtren, Cat. Fish. Brit. Mus. YI, 64, 1866.

Salar ausonii Cormer \& Yalenciendes, Hist. Nat. Poiss. XXI, 319, pl. 61S. 1818.

The hrown trout of Europe was introduced imto the Thifed

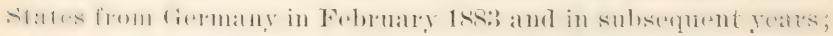

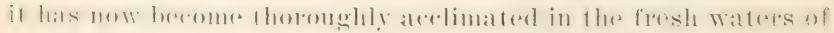
many of the states.

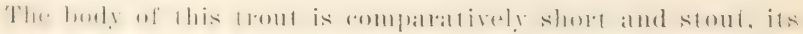

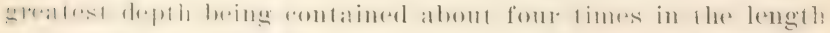

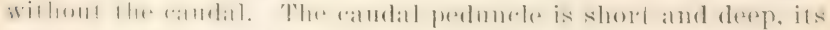

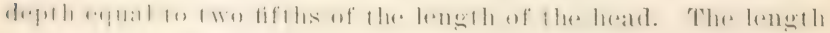
of the head in adults is one fourth of the total length without catudal or slightly less. The diameter of the eye is about one lifth of the length of the head, and less than length of snout.

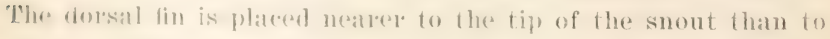
the root at the tail; the lomgest raly of this fin equats the dimtance forem the eye to the ent of the operele. The venteal is

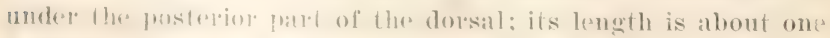
hatf that of the head. The adipose dorsal is platered over the end 
of the anal base'; it is long and expanded at the "'nd. The eandal is emaleginate in young (xamples, hut nearly truncate in sperimens 10 inches long. The le+tolal is neatry one sixth of the

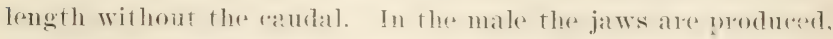
and very old ones have a hook. The maxilla extends to the hind matgin of the ere. The triamsulat hetal of the romer hats at

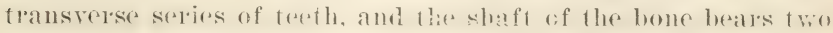
opposite or altirnating series of strong persistent terth. I).

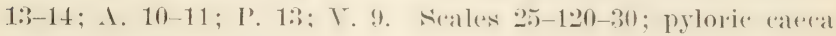
38-51; vertebrae 57-58.

On the head, borly and dolsal fin usually numeroms red and

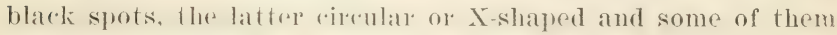
with a late horder: a yellowish margin usually present on thr front of the dorsal and anal and the onter part of the ventral. The dark spets are fer in mumbre below the lateral line. The ground colol of the horly is hoomish or brownish hlack, vareing with food and locality.

Names. In European comntries in which this speries is native

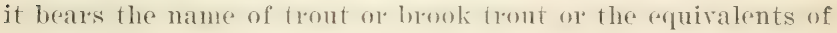
these terms. In Commany it is broliforelle: in Italy, trotu: in France, truite. In the Lnited sitates it is known as the brown trout and rom lisele trout, the latter in homor of Hex rom Behr,

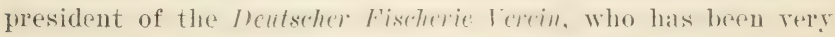
active in the acclimation of the fish in America.

Distribution. The hown trout is widely distributed in continental Eurofe and inhabits lalies as well as stroums, specially

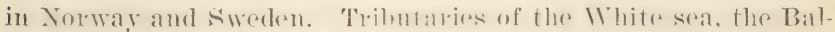

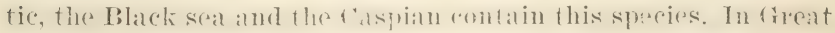
Britain it lives in lalies and streams and has reached a high state of yerefection: in fiermatn: and Anstrial, howerele the frout

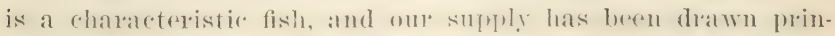

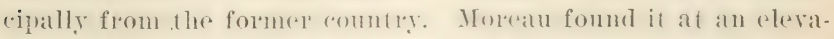
tion of 7000 feet in the Pyemess, and a color valuety is native to northern Algeria in ahond : $T^{2}$ north latiturle. In the I nited

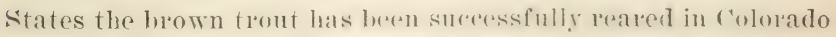

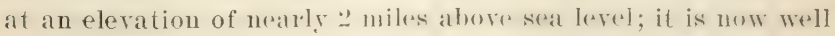


wablisled in New York, Pennsylyania, Maryland, Missouri, Miehigan, Wisconsin, Nebraska, Colorado, and seremal orher states. This trout has proved to he well adaptred to thre magion wat uf the Rocky mountains, which has no native black spotted sireies, though the western streams and lakes coutain many forms in a high state of development.

Size. Inder falorable conditions the brown trout has been rredited with a weight of 2.2 pounds and a length of 35 inches. In Jew Zealaud rivers, where it was introduced with unusual sueress. it now approximates equal size; but in most localities 10 pounds is about the limit of weight and 5 or 6 pounds is a grod average, while in some regious the lengh seldom exreeds 1 foot and the weight ranges from $\frac{1}{2}$ pound to 1 pound. In the Thited states a wild speeimen, seren years old, weighed about 11 promds. In a well in scotland an individual aged 15 years m+alsured only about 1 foot in length. These illustrations will serve to show how much the growth of a brown riout is anreted hy its sumoundings and food supply. The sperions has tren known to become srxually mature when two years old and 8 inches long.

Irabits. The brown trout thrives in clear, cold rapid streame and at the mouths of streams tributary to lakes. In its morements it is swift, and it leaps orer obstructions like the salmon. It feeds uswally in the morning and evening, is more actire during ereving and night, and of fen lies quietly in deep pools or in the shatow of overhanging bushes and trees for hours at a time. II fords on insects and their larvar, worms, molluslis and small fiste s and, lilie its relatire, the ranbow trout, it is fond of the teges of tisher. In Europe it is described as rising eagerly to the surtame in pursuit of gnats and is said to grow more rappidly when fed on insects.

Reproduotion. Alawning begins in October and continues

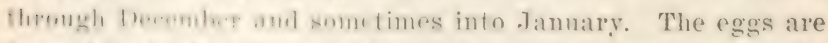
frmm I in to of an im.h in diameler and pellowish or reddish in color: llaps are dejusited at intervals during a period of many

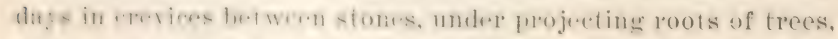
and sometimes ia dests eseavatied hy the spawning fishes. The 
parents corer the eggs to some extent with gravel. The hatching period varies according to temperature from 40 to 70 days. Females aged three rears furnish on the arerage about 350 eggs each, but indiriduals of this age have yielded as many as 700 , and even at the age of two years some females produce from 400 to 500 . When they are four or fire jears old, the number of eggs has reached 1500 to 2000 . The young thrire in water with a temperature of about $50^{\circ} \mathrm{F}$. Sterility in the females is common, and breeding females hare been obserred to cease reproduction when eight years old.

Qualities. The brown trout is in its rime from Mar to the last of September. Its flesh is rery digestible and nutritious, and deeper red that that of the salmon when suitahle food is furnished; the flarne and rolor, howerer, rary with food and locality. Insect food produces the most rapid growth and best vondition. This speries las been so long known as one of the noblest of the game fishes and its adaptability for capture with artificial flies because of its freeliug habits is so rell understood that I need not dwell on these familiar details.

The brown trout is remarkably hardy in captivity. A large female, received from Eugene (r. Blackford in April 1896, and placed in a salt-water tank at the aquarium, lived there and throve till 1898. Inuing most of the time the trout was in salt water, but at certain intrrals fresh water was substituted for a short time, specially when symptoms of fungus made their appearance. In Norember 1896 she excavated a shallow depression in the gravel bottom and deposited a lot of eggs. The fish was extremely shy, and nerel lost its fear of the attendants. Liver and live killifish were used for its food.

A very beautiful and interesting hybrid is produced by crossing the brown trout and the brook 1rout. The following is a description of this hybrid:

Salmo (HYBRID = fario + fontinalis)

\section{Hybrid Trout}

In a paper publisherd seren years ago the writer stated, as a result of his studies, that. when a large-scaled trout is crossed 


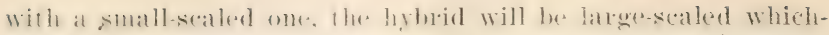

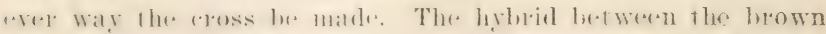
fromt and the brook is a latenesoled form, and it is sterile as

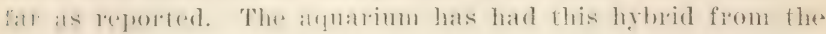

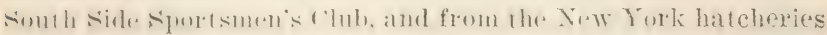

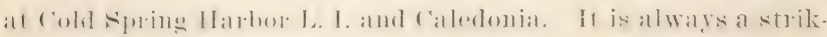

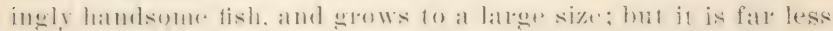
hatrly than either of is glatents. The rooss has always heren

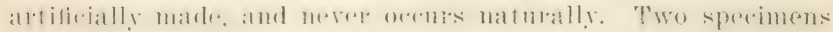
studied gave the following measurements in inclies:

\section{MEASUIRMENTS}

1:xt1, -m, l:11:-11

Length of midlle caudal rays from end of scales.

Depth of body

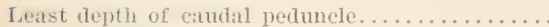

Length of head.

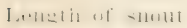

1.1.11

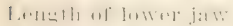

Drameter of ere. ............

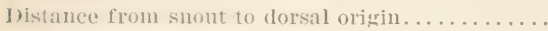

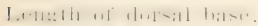

Leneth of longest dorsal ray . . . . . . . . . . .

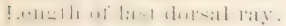

Iristance from snout to rentral origin...........

I. ength of ventral.

I) istanee from snont to anal origin.

Lenglh of anal base,

length of longest anal ray . . . . . . . . . . . . . .

l.merth of last anal ray.

Caledonia N. Y. Oakdale N. Y. June 10, 1896 Niar. 23,1897 Jauses Annin jr G. P. Slade

\begin{tabular}{|c|c|}
\hline$!+1$ & $1 t^{\prime}$, \\
\hline $3 / 4$ & $\ldots$ \\
\hline $17 / 8$ & $31 / 5$ \\
\hline $7 / 8$ & $\cdots$ \\
\hline 2 & $31 / 4$ \\
\hline${ }^{1}=$ & 11. \\
\hline $1^{1}{ }_{1}$ & $\ldots$ \\
\hline $1{ }^{\prime}$ & $\ldots$ \\
\hline 16 & İi \\
\hline $3 \% / 4$ & $\cdots$ \\
\hline 13 & $\cdots$ \\
\hline 1 . & $\cdots$ \\
\hline$n_{1}$ & $\cdots$ \\
\hline $4^{1 / 2}$ & $\cdots$ \\
\hline $11 / 8$ & $\cdots$ \\
\hline 6 & $\cdots$ \\
\hline $7 / x$ & $\cdots$ \\
\hline $11 / 1$ & $\cdots$ \\
\hline $1 / 2$ & $\ldots$ \\
\hline
\end{tabular}

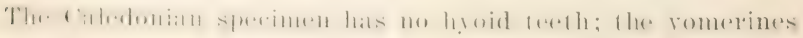
are in a very suatl patch on the liead of the bone only. The gill

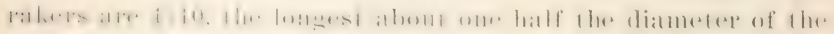

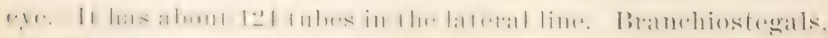
10. 'The following color notes were taken from the fresh fish.

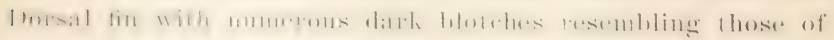

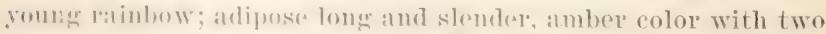
obsemer dusky hlotulus, one of these very indistinct; lower half of sidus pink; vontral, anal and caudal piuk: rentral and anal 
with a milk white front malein, that in the anal limited behind by a dark line as in book trout: sides reticulated with large meshes of lemon rellow interspersed with darker purolish or olive. Thorsal blotehes are mingled with pale lemon. Pectoral pale vermilion. Eye silvery white with yellowish reflections.

The specimen from ()akdale. L. I. Weighed 20 ounces. It has a triangular pateh of romerine teeth, as found in font i n a l is. but conitinued behind hy sereral teeth in a single row, the entire length of the vomerine series being $\frac{7}{16}$ of an inch.

\section{Salmo trutta levenensis (Walker)}

\section{Loch Leven Trout (Introduced)}

Salmo tevenensis Wa LKer, Wern. Mem. I, 541, 1811; YARrelt, Brit. Fish. ed. 2, II, 117, 18ł1; ed. 3, I, 257, fig. 1859; Günther, Cat. Fish. Brit. Mus. VI, 101, 1866; DAx, Fish. Great Brit. \& Ireland, II, 92, pl. CXVI, fig. 2 \& 2a, 188t; BAIRD, Rept. U. S. F. C. XII, LVIII, 1886.

Salmo trutta levenensis Jordan \& Evemann, Check-List Fish. N. A. 512, 1896.

The Loch Leven trout of freat Britain was introduced into

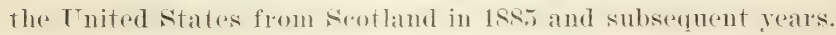
It is somewhat closely related to the Furopean brown trout, s a $1 \mathrm{mo}$ f a r io, and has been artitierally crossed with that species in the Trnited sitates, so that it is sometimes differult to find the pure bred Loch Levems in fish cultural establishments at lome.

The body of the loch Leven is mote slemeler and alongate than that of the brown trout, its ereatest depth contained four and one fourth to fome and one half times in the total length

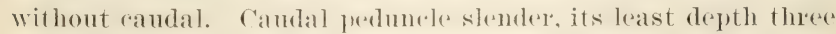
righths of the greatest depth of the horly, and equal to length of snout and eye combined. The head is rather short and conical, its length two nintles to one fifth of the total length without (atudal. The smont is one fometh or slightly more than one fourth as long as the head. The interorhital spare is somewhat convex, its width apual to thres fifths of the lemgth of postorbital flate of hrad. The rye is of morlerate size, its long diametere contained tive and ome latf to six limes in the length

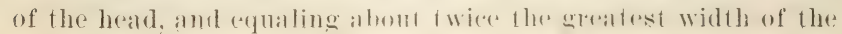


maxilla. 'The maxillal reathes to of slightly heyomel the himd maryin of the reve. Terth rather strong. those in the intermaxillary and mandihle the latresest, triatrentar head of romer with

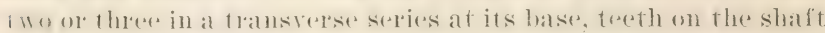

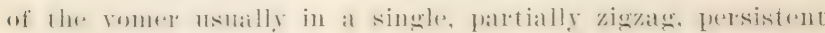
series. Mandihle withoul a hook and little produced even in brerting males. Inorsal origin distant from tip of snout about

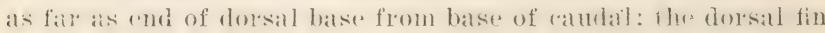
higher than lomg. its base one eighth of total lemgth without aturlal, its lomgest ray epual to longest ray of allal tiu. The anal fin is mueh higher than long. its distance form the base of 1he ventral epualing length of the head. The vestlat origin is nearly moler the middle of the dorsal: the tin lueing as long

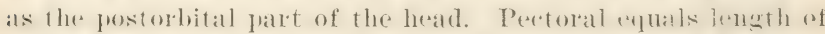
leatl without the snout. Adipose fin very small. is wirloh one

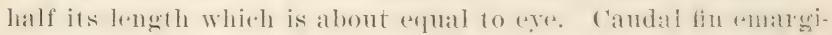
nate muless fully extended, when it becomess trumeate. Hhe ontere rays about one seventh of total lometh including (anulal, ). 1:3 1. il. 41; .।. 12 = iii. 9); P. 14; Y. 9. Suales 24 to $28-118$ io

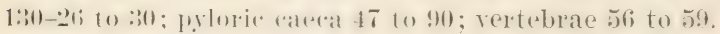

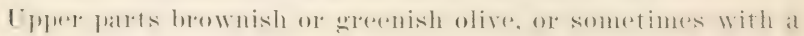

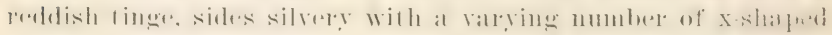

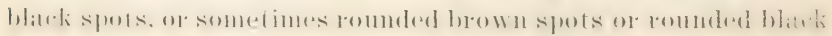

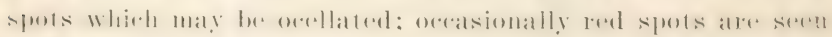

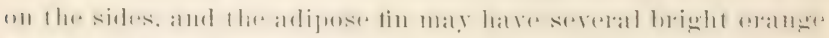

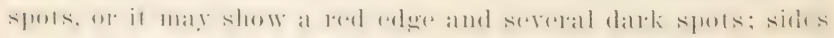

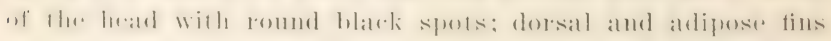

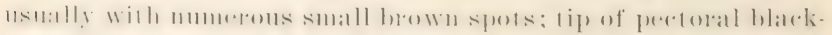

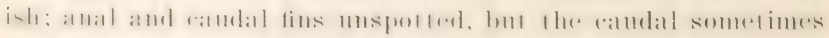

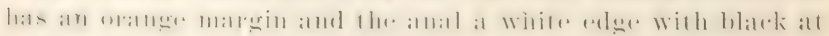

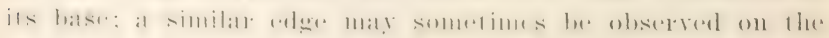
ventril.

The loreh Leven trout is a nonmigratory species, inhabiting Loch Leven and ofher laties of southern Seotland and of the morth of Emgland. Its range in Great Inritain and on the con-

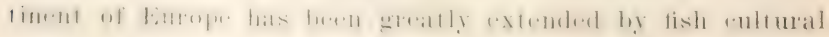


operations, and the fish is now fairly well known in the United States, though mixed to some (xtrnt with the brown trout, as remarked above.

The Loch Leven trout has beren resolded of the weight of $1 \mathrm{~s}$ pounds, but the areage weight at fi rears of age is abont 7 prounds, though some individuals of that age may reach 10 pounds. The natural food of this species includes fresh-water mollusks (snails, B uce i n u m, etc.), crustaceans, worms and small fish. In captivity it is reared on liver. horse flesh, chopped clams and various other meats.

As a food fish the Loch Leven is highly esteemed on aceount of the red color and the delicate flatror of its tlesh when obtained from suitable waters; in some localities the flesh often becomess white from lack of food or improper food.

The spatwning season may begin late in september or early in Oetober and continue till Dexember. In Michigan it corresponds with that of the brook trout. The egg varies from about $\frac{1}{5}$ to $\frac{1}{4}$ inch in dianeter. I trout weighing 2 pounds contained 1944 eggs, the weight of which was $\frac{1}{2}$ pound.

The Loch Leren will take the artificial fly as readily as the brown trout and the brook trout. Its great size and strength add to its attractions for the angler.

\section{Salmo irideus Gibbons}

\section{Rainbow Trout (Introduced)}

Salmo ivideus Gibbons, Proc. Cal. Ac. Nat. Sci. 36, 1855, San Leandro Creek, Mlameda Countr; Cal.; Jord.x \& Gilbert, Bull. 16, I. S. Nat. Mus. 312, in part, 1883; BEAx; Bull. U. S. F. C. XII, 36, pl. V, figs. 2 \& 3, 1894; Fishes Penna. 77, color pl. V, 1893; Ann. Rept. N. Y. Comm. Fish.; Jordan \& Evermann, Bull. 47, U. S. Nat. Mus. pl. LXXXI, fig. 216, 1900.

salmo irideus shasta Jordax of Evermax, Bull. 47, L. S. Nat. Mus. 502. 1896.

Body short and deep, its greatest depth equaling two sevenths of the total length without caudal. The least depth of caudal peduncle equals one half the length of head. The head is short and deep; its length is contained about four and two thirds times in the total length without the candal. The snout is short, 


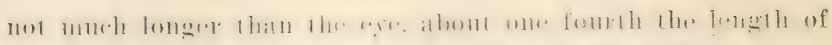

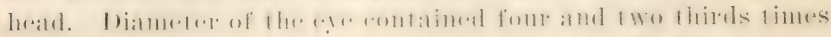

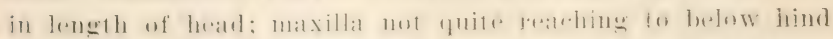

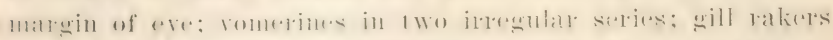

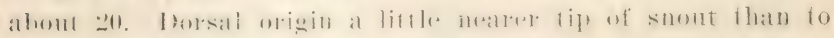

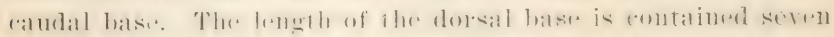

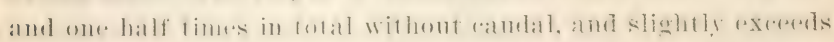

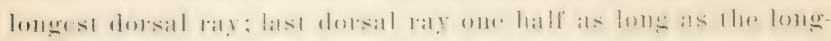

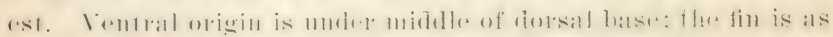

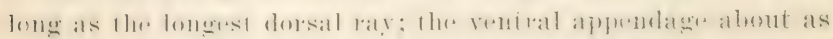

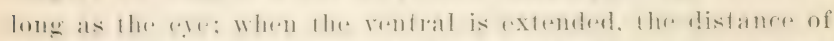

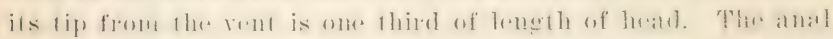

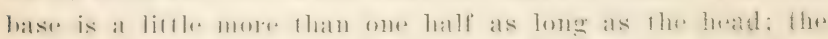

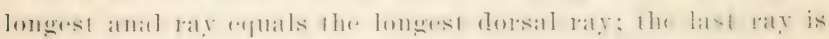

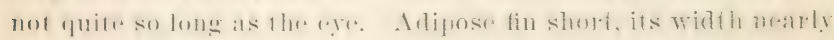

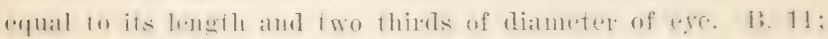

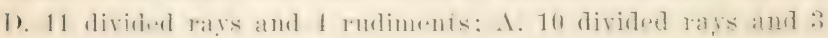
rudiments. Seales 21-1:35 to 140-20.

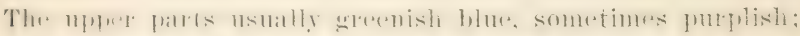

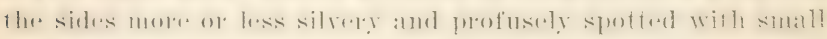

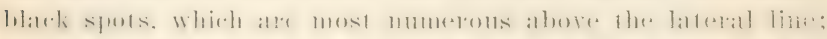

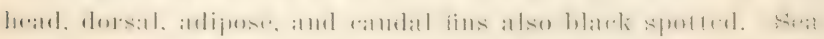

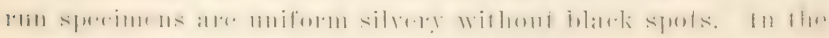
breeding season the broat erimson lateral band becomes

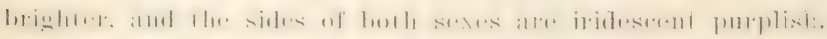

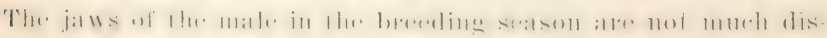
forted, but they are very much lareser than in the female.

I'he ranbow trout is a native of the momtain streams of the l'areifie coast and rameses from Califormiat to southern Alaska. A smal! example was talen at Sitkat, in 1880, by Admixal T. A. Bondelsee, T. S. X.. and is now in the collection of the T. S.

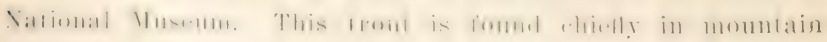
streams west of the Sirulea Nevalas. Ti rarely descends into the lower sirreledes of the revers, hut oceasionally does so and

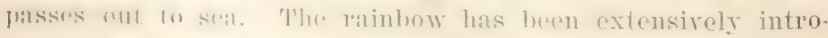

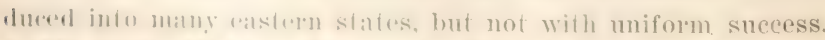

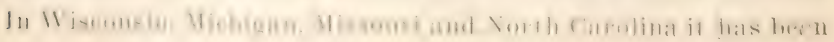


well acclimatized, amel it is also farly astablished in New York. The aremge individuals of this spereies are less than 1 foot in length, but sperimens meatsuring more that $\ddot{z}$ feet and weigh-

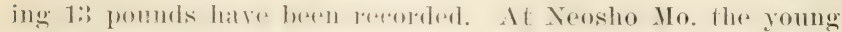
have beren artiticially grown to a length of nearly 1 foot in a year.

The raintow feeds on worms, inseret larvate and salmon eggs. In streams in whith the California salmon and rainbow exist together, the rainbow is more destructive to the salmon eggs than any other species. Sinawning takes place in winter and rarly spring, varying with trmperature and loeality. The bulk of the egges are usually taken in January, February and Mareh, and the average rield from wath female is about 900 eggs. A few of the females spatwin when two years old, but about one half of them lowgin at theer yeats. The egg is from $\frac{1}{5}$ to inch in diameter" it has a rir.h realm color when first taken, changing to pink or flesh color before hatehing.

The rainhow will live in water of a murh higher temperature than the hook tront will rendure and it thrives in tidal streams

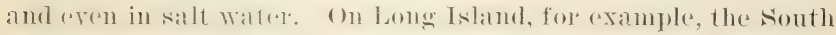
side syortsmen's club obtains a grate deal of fine sport with this trout in thr astuary of its trout brook. The flesh of the

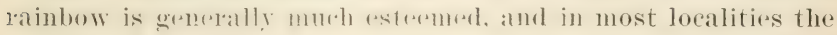

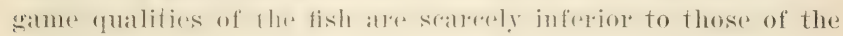
brook trout.

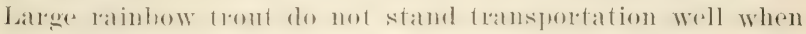
ice is nsed to rool the water in which they are carried. They frequently injure their cyes, and berome blind soon after the end of a jonmey. Thery are inveterate tighters, and the strongest invariably rules and halrasses the rest. Contrary to what has been stated heretofore, they will not endure high truperatures as weell as the hook tromt, at least in the aquarimu.

138 Salmo lemanus Cuvier

\section{Swiss Lalie Trout (Introduced)}

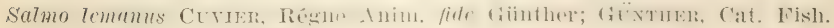
Brit. Mus. VI, 81, 1866. 


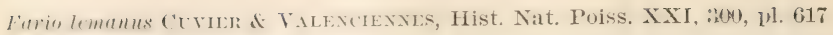
(male) 1818.

swiss lake trout Itrixs. Rent. T. S. F. C. XYIT, XVIIT, XIX, 1893 amt 1894 .

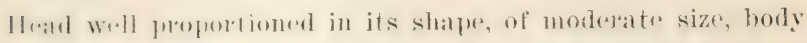

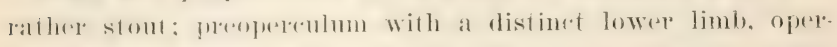

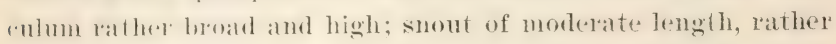
froduefed in the male sex, in which a mandibular book is developed in the sfatwing season; maxillary longer than the snout, and at least as strong and hroad as in $x$. f a r i o: in specimeus 12 inches long it extents somemhat behind the vertical from the hind matrin of the orbit. Teeth moderately strong. those on the vomer in a single series, alternately bent woward the right and left. Jersistent throughout life. Pertoral fin rommerel, is length being less, and in yomeg individuals more than, one half of its distance from the rentral. The candal becomes trum(atte with age; in speximens of from 12 to 1.5 inches in length it is (motrginate, the middle rays being half as long as the onter ones. The hind part of the hody of moderate depth; there are 1:3 or 14 scales in a trausverse series deserending from behind the adipose fin forward to the lateral line.

Bark ementish, sides and belly silvery, mumerous very small X shapuel hlark spots on the sides: opereles and dorsal fin with mmmeroms blate dots; the other fins gremish. T). 13; 1. 12: I'. 14; I. 9. Nialex 206 10 28-115 to 128 36; pyloric caeca $45-52$; vertebrae 57 (once), 58-59. (After Günther)

Atrompts hate beren made from time to time to introduce into

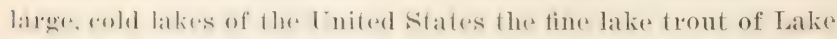

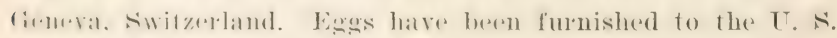
Fish ('mmmission ly the swiss govermment, and these were

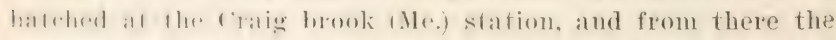

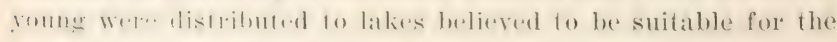

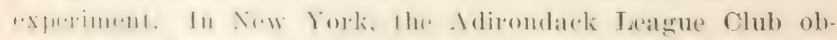

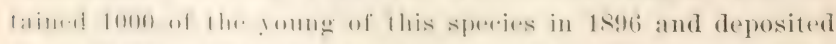

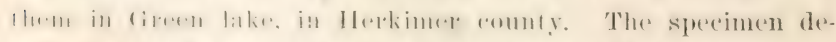

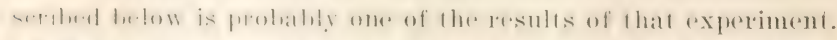

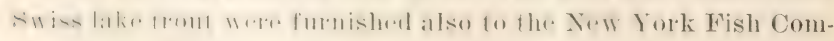


mission for planting in Lake George, and 100 yearlings were presented to the New York aquarium.

I specimen taken in Grem lake, Adirondack League Club meserve, Herkimer (o., July 29, 1899, was forwarded to the I. ... Fish Commission, Washington I). C., and there described by 11. W. C. Kendall. from whose notes the following account is drawn.

The total length of the specimen is $11^{3}$ inches. When first taken it was reported to measure $11_{x}^{3}$ inches. The body is moderately elongate, its greatest depth contained three and three fifths times in the total length to base of caudal. Head large, slighty more than one third of total length to base of "audal; eye rather large, alout one fifth of length of head; suont long. about three tenths of length of head; teeth on jaws. palatines and tongue long, curred and sharp, those of the lower jal longest, shaft of romer long with a zigzag row of sharp teeth; gill rakers short, the longest one third of diameter of iris, $t+11$ on right side $5+10$ on left side. Hight of longest dorsal ray two thinds of length of head. Pectoral five eighths as long as the head. B. 11-1:; 1). ii, 9; 1. i, S. Scales in lateral line 115 .

Gencral appearince of sa 1 mo sa $l$ ar sebago, from which it would probably not be distinguished by the casual observer if caught where the landlocked salmon oceurs; but the $1 \mathrm{e} m \mathrm{~m} \mathrm{nu \textrm {s }}$ is distinguishable by the hearier appearance forward of the dorșal fin.

Color in spirits, brownish on back, top of head and sides of head; sides and belly very silfery; large roundish black spots abore lateral line for ward and on cheelis and opercles; perpendicularly elongate spots forward helow lateral line; black of all spots most intense on edges of scales; posteriorly the spots show only on the edtes of the scalles, being variously crescentic. double or triple arescentic. I or double $\mathrm{X}$ shaped; fins pale with slightly dusky tinge; dorsal with 5 transverse rows of black spots.

$\mathrm{Mr}$ De Witt, who sent the sperimen, furnished the following notes on Green lale, from whener it was forwarded. "Maximum depth 4.2 feret, with temperatture at hotfom at that depth. as far as I have heen ahte to aseretain, about 40 ? Has no 


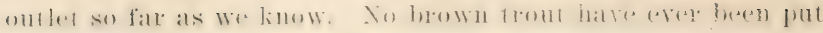

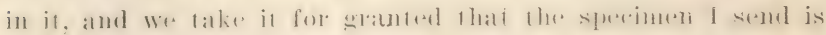
ome of the "Swiss trout?"

\section{Genus crestromse Gill \& Jordan}

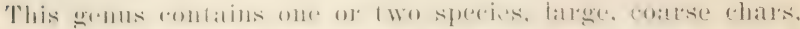

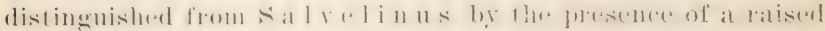

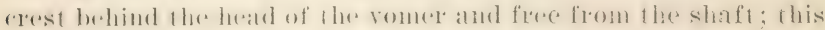

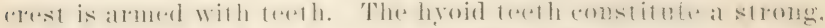

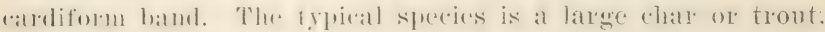

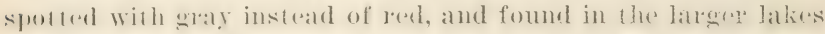

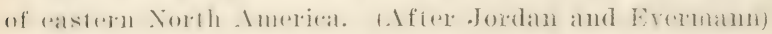

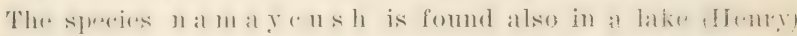

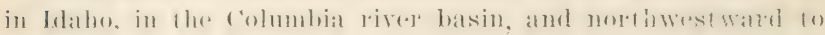
northern Alaska.

\section{Cristivomer namaycush (TValbatum)}

\section{Lake Trout; Salmon Trout}

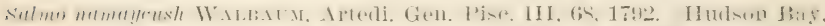
based on the Namaycush Salmon of Pemnant; Ricmandson, Fauma Bor:-Amer. III, 179, pl. 79 \& pl. 85, fig. 1, 1836, Great Lakes; 'Trosísox; Nat. Hist. Vermont, I, 140, figure, 1842; Krntlaxd, Bost. Joun. Nat. Hist. IV, 25, pl. III, fig. 2, 1844; Güntmen, Cat. Fish. Brit. Mus. VI, 123,1866 .

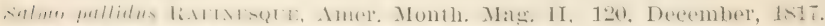

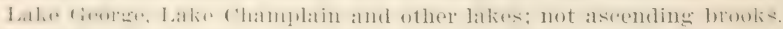
Sulmo amethystinus Mrtenild, Jour. Ac. Nat. Sci. Phila. I, 410, 1818. Sulmo hoodii IRicnamoson, op. cit. 17, pl. S2, fig. 2, pl. S3, fig. 2, 1836. S'ulmo confinis I) İ Kr, N. X'. Fauna, Fishes, 23S, pl. 38, fig. 123, 1842. Sulmo amethystus DE KAr, op. eit. 240, pl. 76 , fig. $2+1$.

Śulmo adironducus Nomns, Ameriean Anglex's Book, 255, 1805.

Sulmo siscouct GüntuEn, Cat. Fish. Brit, Mus, VI, 124, 1866.

Nalvelims numulensh Jompdx of Gmbert, Bull. 16, U. S. Nat. Mus. 317. 1S5:;; (ioonx, Fisls. \& Fish. Ind. U. S. I, 4S5, pl. 191B, 1SS4; BEAx, lishes I'emma. \&2, color pl. S, 1893.

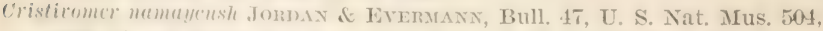

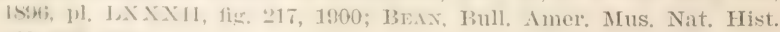
$1 \times, 318,18: \%$.

The dake troul (o) Xamblyous has a stout and moderately

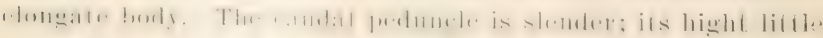
more: Hatn one third of the ereatest hight of the fish. The eve is large, phaced meil the loj) of the head, two thirds as long as 
the snout, and contained foul and a hatf to five and a half times in lenghle of head. The maxillat leatehes far luehind the ere: its length nearly late that of heate The oregin of the lomsal is midwaly hetwern lipe of smomt amrl noot of tail. The lemgth of the hase repuals lemeth of maxillat its lomgent raly one sixth of tolal without cautal. The ventral is moler the hinel

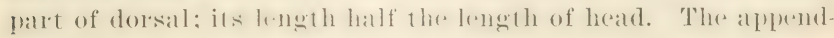
age is very shore, alumet half the length of eye. The fin, whem rxtended, leatelues neally to the rent. The distance between rentral orignin and anal origin is one tifth of total length without caludal. 'The anal hase is alunt one thiled of length of heari the longest ra!y half of length of heatl the last ray eyual to "ye. The frectoral is mearly 100 thirels as lomg as the heald. B. 11 to 12 ; 1). () 10 10 besides sereral rudiments; 1 . It anr] several rudiments; V. \%. Soales of lateral line about 20).

The coloration is woremely valialle. generally grayish, in the varjety linown as the tulati, nearly blark. Alaskan specomeus

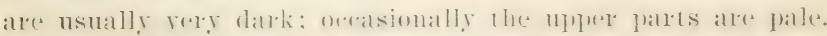

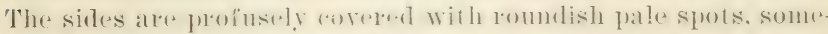
times with a redelish tinge. () n the hatek and top of head there

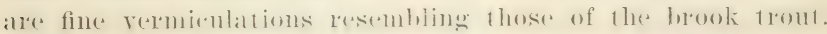
The caudal in adrlition to mumerous pale spots hals matmy small dark blotches.

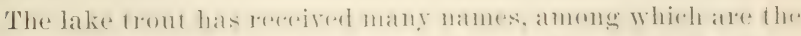
following: Matkinat, Nannalyols, fowne, tulati, and salmom

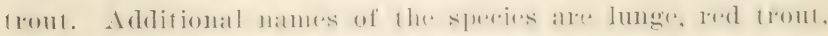

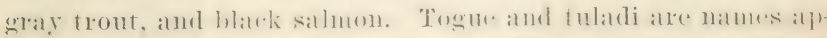
plied in Maine. Niw Mrmuswirle and ramada; Maclinall anel salmon troul in the fireat lakes region, the latter used also in New York. Namaycush is of course an Indian name.

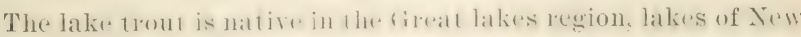

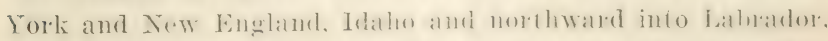

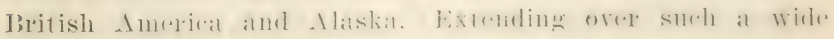

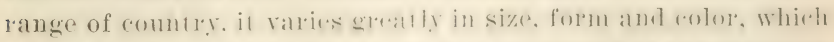

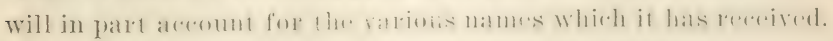
It has been found above the Aretic circle in Alaska. 
This is one of the latrest spredes of the salmon family resident in fresh walles. It reatehes a lingth of 3 feet, and specimens weighing fll pumbls are not monemmon. It is said that an 1.xample of !n ponnds and ti feet in length has been taken.

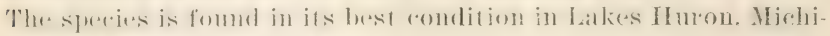
gan and superior. In Mlaska it grows 10 a largo size, and is a very shapely and beautifully colored fish.

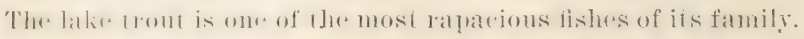
In Lake Miehigan it feeds largery on the eiseo and other smatl whitedishes. It Two Riress Wis. a lake trout measuring $2: 3$ inches was fombl 10 rontain a burhot about 16 inches long. The Eluttomy of this speries is proverbial. It will devour tab].

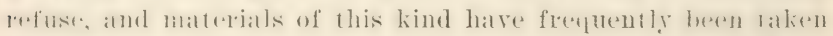
from ils stomaleh. Even twigs, leates and pieres of woen bare bern takm hy this trout. The species is mueb more sluggish

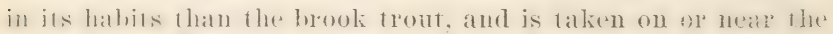
lwomm. The gill and pound nets in which this species is principally captured are set in deep water.

The spaw wing of the lake trout usually beggins in oretober and romlinues into Vovember. For this purpose they rome uy an

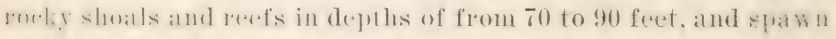
mat the edgers of rock raverns, into which the eggs settle. Ther

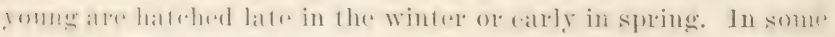
lanalities dhe dephth of the spatwing areats ranges from 15 fathmus fo whly 7 forel. Mr Milner found 14.948 egegs in a lake tront meighing 21 promels. In the hatlehery, with a water tempera-

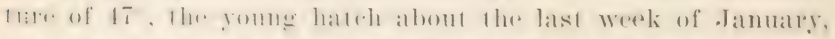

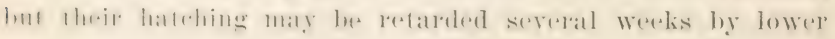
temperatures.

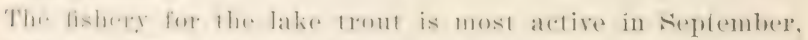

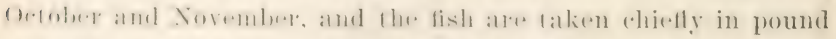
atul gill mets. In some regions matry of them also atre raught

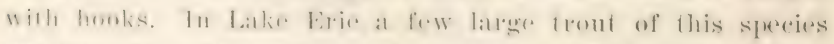

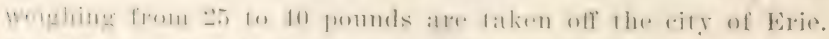

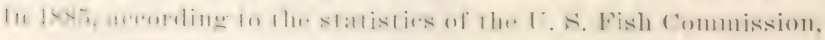
[010.0110 poumds of lake frout were taken in Frie county, Pa. 
The only New York examples of lake trout were receired from James Amnin jr. Caledonia, in the fall of 1896. They lived and grew rapidly till the warm water killed them in .June 189They could not rmblue transfer to salt water of a lower tempere ature, as so many other trout will do, and nothing else could lwe utilized to tide them were till the completion of the refrigerating plant.

Owing to the extensive individual and race valdation among trout refored to this spereis, it seems desirable here to give some notes and measmements made from individuals obtained from New Hampshipe and Vermont. Two bake trout weighing about $4_{4}^{3}$ pounds ach were shipped in a can only a few inches longer than the fish. from Roxhury Vt. November 17 , and, after an express journey of 20 hours without an attendant. one of them survived in good condition, while the other was nearly dead on arrival and died within one hour. The latter was a female, and appears to have injured itself sererely by jumping in the can; it was not in good condition when it left Termont. 12 large brook trout shipped with the lake trout in two cans arrived without injury; these and the lake trout were presented by John Wr. Titcomb, Fish and Game Commissioner.

Commissioner X. Wentworth of Hudson Center N. H. forwarded the New Hampshire lilke trout, one from Newfound lake, the other from Lalie Winnepesauker. They rere sent to determine whether the trout of the fwo lakes, which the fishermen assert are diflerent species, really are distinct. The commissioner wrote that " the Newfomd trout has darker flesh, more like the seal salnom. This is not caused by their fool, ats both lakes are alire with smelt. The limnepesaukee lake trout are better biters: tons of them are caught through the ine every winter. The Newfoum trout are hardly ever caught through the ire. A few were canght last winter for the first time to my knowledge. I am sure there is but one valliety of lake trout in Xewfoumd lalie. Wh had one in our tamks this fall that womkl weigh 25 pomols." The only ditherences to be

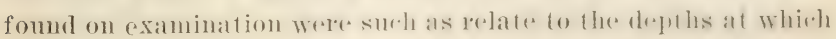




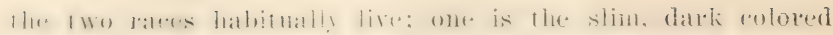

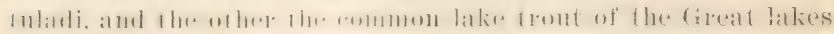
region.

It is necessary; howerer, to call attention to the lake trout

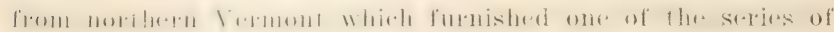

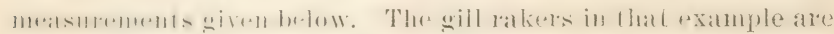

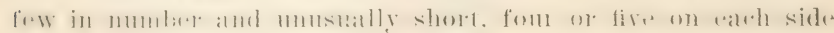
being reduced to mere spiny tubereles.

The following table gives dimensions in inches.

MFASUREMENTS

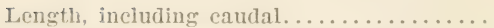

Length to base of middle caudal rays......

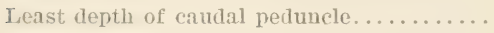

Greatest depth of body...............

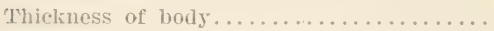

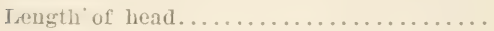

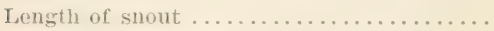

Length of postorbital part of head........

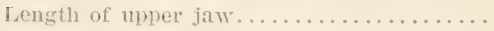

Length of maxilla $\ldots \ldots \ldots \ldots \ldots \ldots \ldots \ldots$

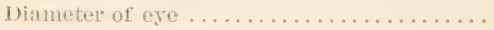

Interorbital width $\ldots \ldots \ldots \ldots \ldots \ldots \ldots \ldots$

Distance from snout to dorsal. ..........

I.ength of dorsal base. . . . . . . . . . . .

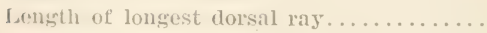

Leneth of last dorsal ray..............

From end of dorsal to adipose fin........

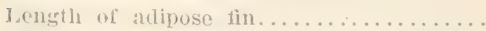

Width of base of adipose fin............

Distance from snout to rentral..........

leneth of longest ventral ray...........

length of last ventral ray.............

fength of ventral appendage............

Distance firom snout to anal. ..........

fength of anal hase $\ldots \ldots \ldots \ldots \ldots \ldots \ldots \ldots$

lengtli of longest anal ray . . . . . . . . . .

longth of last anal $1: 1 . \ldots \ldots \ldots \ldots \ldots \ldots \ldots$

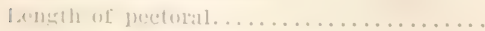

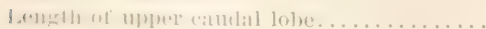

lemplly ot lower catulal lobe.

Janghth of longest rill raker.
Newfound Winnlpiseo- Roxbury lake gee lake vi.

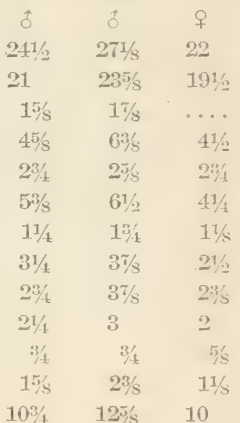

$25 / 5 \quad 21 / 2 \quad 21 / 5$

$3 \quad 23 \% \quad 23 \%$

$11 / 2 \quad 13 / 8 \quad 11 / 8$

$41 / 2,5 \quad 41 / 4$

$3 / 4 \quad 1 / 4$

$3 / 5$ is $3 / 5$

$121 / 4 \quad 14 \% / 8 \quad 115 / \mathrm{s}$

$25 / 5 \quad 27 / 8 \quad 23 / 8$

$13 / 8 \quad 11 / 2 \quad \ldots$.

$1 / 1+3 / 5 \quad 5 / 8$

$16 \quad 18 \% / 5 \quad 151 / 2$

$2 \quad 3 \% \quad 1 \% / 5$

$231.21 / 2 \quad 21 / 2$

$\begin{array}{lll}1 & 1 & 3 / 4\end{array}$

$31 \frac{1}{2} \quad 31 \frac{1}{2} \quad 31 / 4$

$3^{3 /} \quad 3 \% \quad \ldots$

$3 \frac{16}{3} \quad 3 \% \quad \ldots$

is is iा


In the Newfound lake fish we have:

li. 11;1). 11; 1. 10 (coumting divided lalys only); I. i, s; P. i, 12.

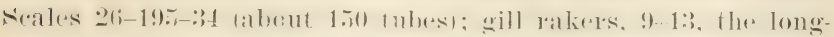
est a little more than one half the length of eye the ome in the angle chub-shapest at the tip. It is a male with stmermatres modrattely small but soft. The besty is geray, datkele on the batek.

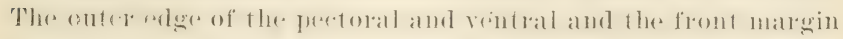
of the anal are white as in fon $\mathrm{t}$ in a $\mathrm{l}$ is. A white tip to the lowere randal lobe and a very smatl one at the top of the dolsal. otherewise the coloration is like that of ordinary latie trout. which hate the furtoral. ventral and anal ehiefly vermilion in the breeding season.

The male from Winnepesaukee lake has:

B. 12 to 13 ; D. $10 ;$ A. $10 ;$ V. i, S; P. 12 . Gill rakers $8+12$, the longest about one half as long as the exe. The gand rolor is a little lighter than in the Xerfound latie trout. and the rermilion of the peetorals, rentrals and anal is lexs intense. The spere maries are larger that in the sperimen from Newfomd, and in about the same stage of derelopment: the hody is ronsiderably stouter.

The female from Roxhmy Vt. shows the following additional character's.

B. 12 ; D. $10 ; A .10$; T. i, S. Gill rakers $S+12$, the longest

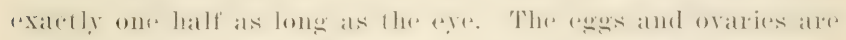

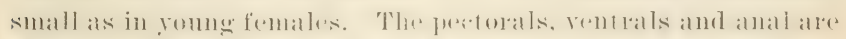

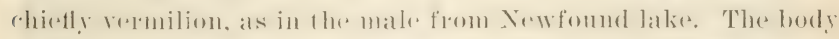
is silvery gral with numerous smatl. whitish spots. these present also on the dorsal.

Hon. 11. II. Salge is anthorily for the information that the

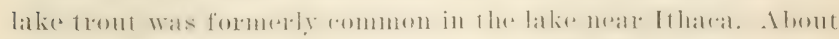

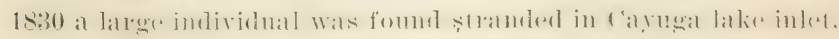
about $1 \frac{1}{2}$ miles from the lake.

\section{Genus sazveurus (Nilsson) Richardson}

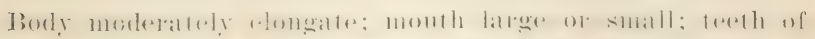

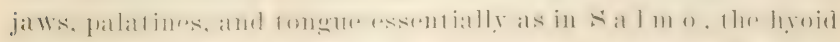

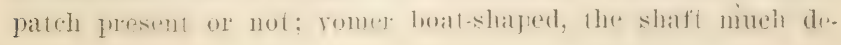




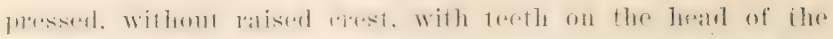

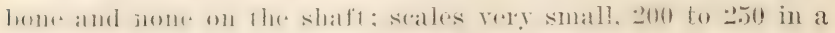

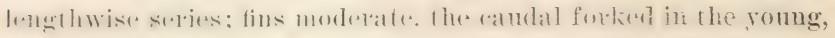
frumeale in some sper.es in the amblt: sesual peculiarities not stonty matrirl. 1he males with the fortuaxillaries enlarged and

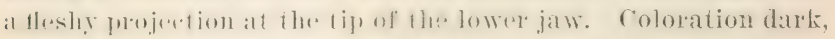
with romml, rimson spots, lhw lower fins sometimes with mar-

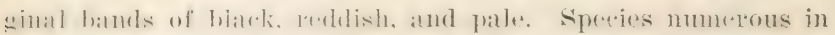
ller reatr streatus and lalies of the northern parts of buth rom-

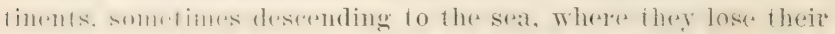

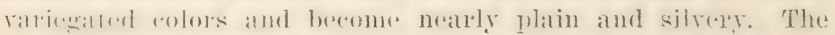

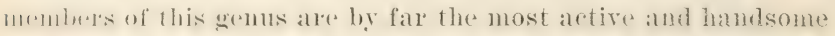
of the tront, and live in the coldest, clearest and mosit sereluded waters. (After Jordan and Erermann)

\section{Salvelinus fontinalis (Mitchill)}

\section{Brook Trout}

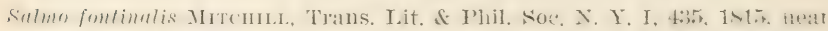
New York; Ricmardoson, Fauna Bor-Amer. III, 176, pl. 83, fig. 1, 1836; DE KAx, N. Y. Fauna, Fishes, 235, pl. 38, fig. 120, 1842; Güntmer, Cat. Fish. Brit. Mus. VI, 152, 1866.

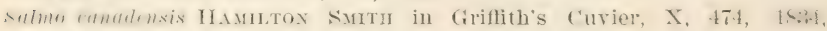
Canada.

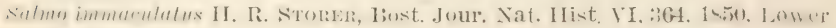
St Lawrence.

Sulmo crythoguster DE KA工, N. Y. Fauma, Fishes, 236, pl. 39, fig. 136, 1812. Buione fontinalis DE ISAY, op. cit. 244, pl. 20, fig. 58, 1812.

Salvelinus fontinalis JordaN, Proc. U. S. Nat. Mus. I, S1, 1878, in part;

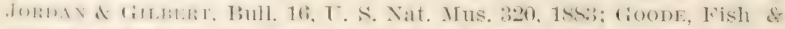

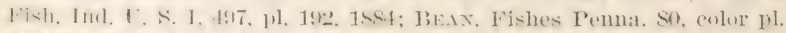

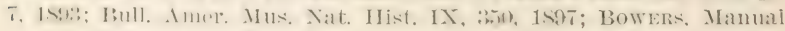
Wish Cult. ed. 2, color pl. frontispiece, 1900; Jordax \& Everuaxx, 13ull. 47, U. S. Nat. MIus. 506, pl. LXXXII, fig. 218, 1900.

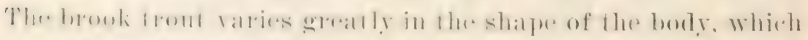

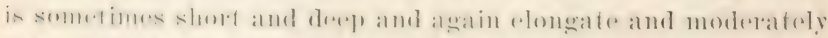

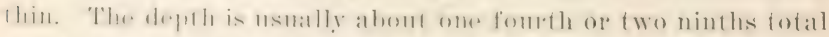

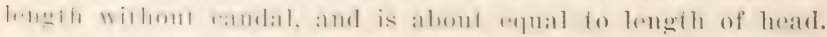

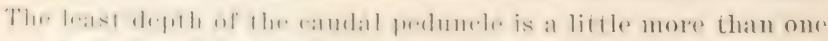

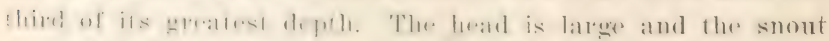

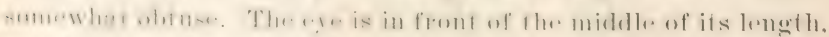

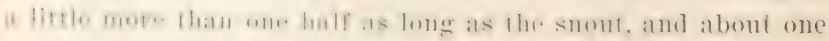


sixth of longih of head. The dorsal fin is about midway between lip of suout and root of lail. The length of its base equals about half its greatest depth of body. The longest ray equals length of rentral. The rentral origin is a little behind the middle of the dorsal. In the male, when latid backwaled, it reateles mearly to the velut. The length of the appendage (xyuals that of the eye. The anal base is two thirds as long as the ventral, its lomgest lay equal to ventral. The adipose fin is short and stout, its width two thirds of its length and about two thirds of length of (2ye. D. 10; 1. 9. Seales in lateral line 2.5 to 235 ; six gill rakers above the angle of the first arch; 11 below.

The coloration is highly variable with age and locality. The upper palts are usually grayish much mottled with dark olive or blark. 'The dorsal fin and anterior part of caudal base and top of head are also mottled. The caulal has narow dark bars. The lower fins dusky with a rexamy white interior edge bound behind by a narow blatk streak. On the sides numrous pale brownish blotches encircle small vermilion spots.

The brook or sjeckled trout of the east is indigenous to the region east of the Alleghany momtains and the Great lakes region, extending from North rarolina on the somth to Labratdor on the north. The distribution of this trout has been wonderfully extended by artiticial introduction, as it has alwalys hexn a farorite with fish culturists. It is now 10 be found thriving in many of the western states and territories, and is particularly thrifty in Nebraskal, Colorato. Nevala, and cali-

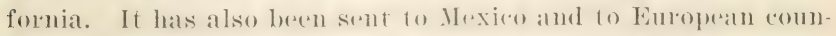

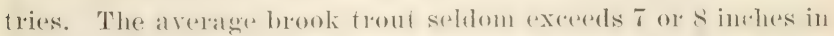

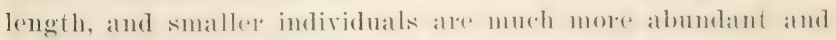
require legal protection. In the notelleasteren patet of ifs habitat the brook trout glows murh latrerer, sperimens weighing from 3 to 6 pounds being not wncommon; and in one of the Rangeley lakes an indiridual woighing 11 pommls is reoolded; while Seth Green took a 12 pommel spereimen in the sault ste Marie, and Hallock montions one which was said to Weigh 17 pounds. 
The brook tront does not flourish in water warmer than $68^{\circ}$,

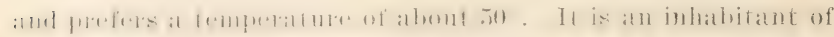

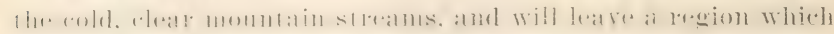

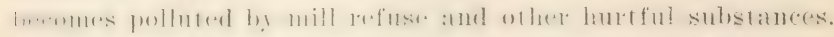

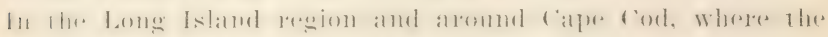

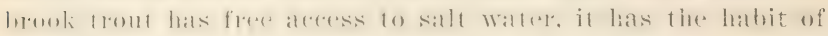

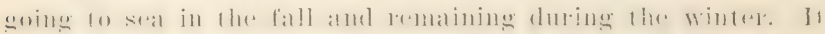

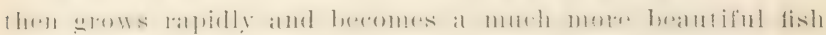
than many which live exclusirely in fresli water. In hot

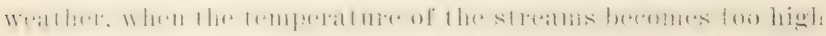

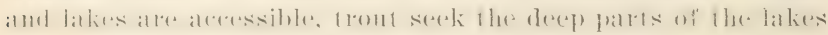
and the vicinity of cold springs. In streams they are to be

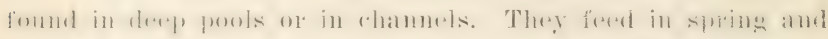

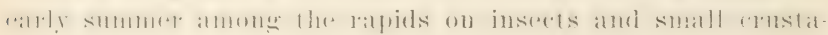
('eatins.

The brook trout is a nest-builder. Cavities are made in the gravel, and the nest is shaped with the tail, and the larger

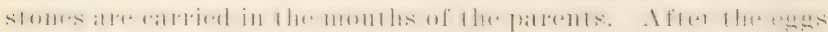

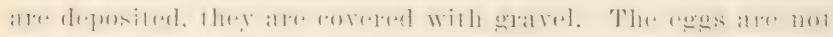

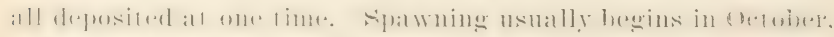

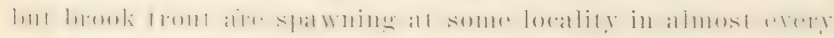
momth of the year except midsummer. The egg is about $\frac{1}{5}$ inch in diameler, and varies in color from pale lemon to orange red. The aremage yicele of the female is from 400 to 600 . Livingston sionc has taken 1800 from a fish weighing 1 pound.

The period of hatching will depend on the temperature, manging from 165 days in water of $37^{\circ}$ to 32 days in water of 5.1 . The yolk sack is absorbed in from 30 to 80 days, and after its absorption the yomng fish begin to feed. The rate of

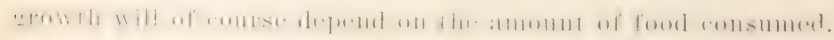

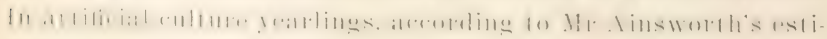
mate, will arratge 2 ounces; fish of two years $t$ ounces; of three yours, sommes, and of four years, 1 pound.

'The value of the hrook trout as a food fish and its game quali-

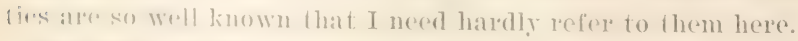

The hrouli fromi is well adapted to domesticalion in aquarium lamkis; it soon orereomes its fear of moving objects, talies its 
food regularly, and is always attrartive because of its beanty and gateeful novements. It will live in fresh and salt water. When it is attacked by fumgus in forsh water, the follasite is pasily killed by introdureing salt water, gradually increasing in salinity, and the tront is not at all injured or inconvenieneed by the treatment. In raptivity the food romsists almost entimely of rhopperl hated ratus and liver for the young, while hated rlams,

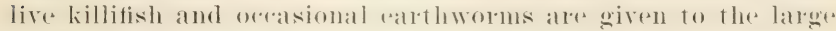
fish. The increase in size with surh ferding is rematkable. I brook trout, from ( aledonial X. Y., not more than :3! inches lone

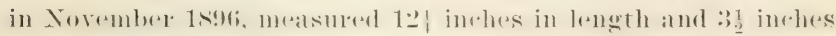
in depth Dec. 10, 1897 .

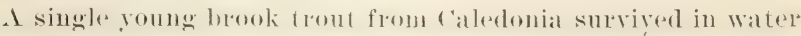

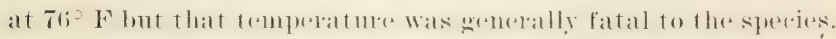

1) Merk has foumd the Hout in suall streams on the mplands throughout the Cayuga lake basin.

Mitchill knew this tish rhiefly as an inhahitant of Lomgr Island waters, and has given an interesting ateount of the fishing at Nichols, Patchogue and Fire Plater. where a Mr Robbins, in 12 days in the summer of 1\&14, (alught 190) trout weighing 1:3!) pounds, 11 oumers. The largest at Patrhogue weighed 20

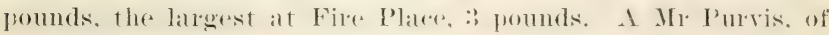

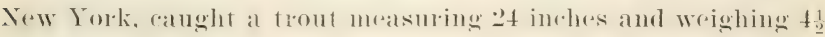
pounds at Fire Place.

It that time, aceording to Mitehill, the trout was " bought at the rxtratagant prier of a guarter of a dollar for a single fish not mole than 10 or 12' inches long. and Nem York anglers traveled "awaty to Hempstrat and Islip for the pleasmere of catching and eating him."

\section{Salvelinus alpinus (Linuaeus)}

Saibling (Introduced)

Salmo alpinus Lixxaecs, Syst. Nat, ed. X, I, 309, 1758, Iapland. West Gothland.

Salmo salvelinus LinNaEus, op, et loc, cit. Lintz in Austria.

Salmo salmarinus LinnaEUs, op. cit. 310, 1758.

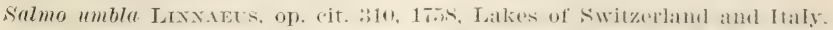

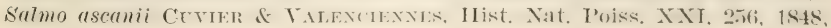
Norway. 


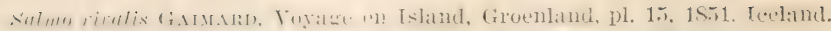

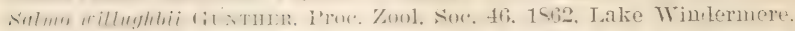

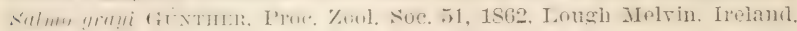
Salmo colii Güxtmer, Proc. Zool. Soc. 12, 1863, Lough Esk.

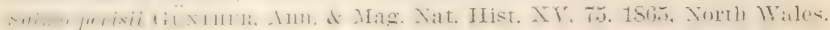

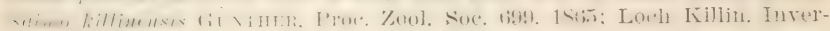
nit...

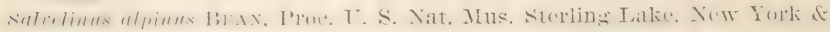
New Jersey; Jondax \& Evenmaxw, Check-List Fish. N. A. 293, 1896; and Bull. 47, U. S. Nat, Mus. 508, 1896.

\section{Salvelinus alpinus (Linnaeus) \\ Sälbling; Saibling (Introduced)}

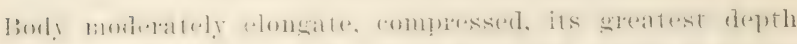

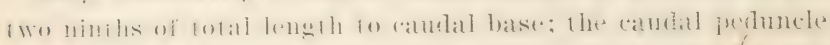

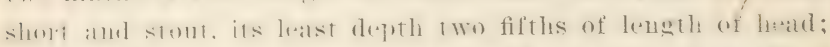

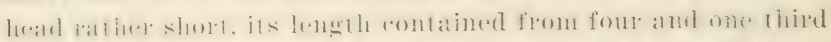

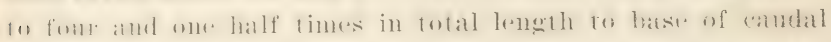

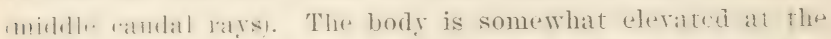

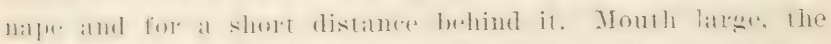

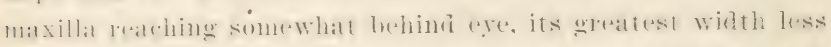
Hatn wne fourth of its lenghth, the mplex jaw one half as long ats

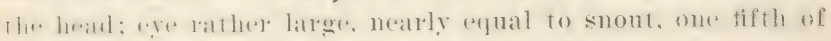

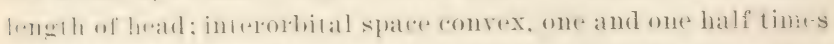

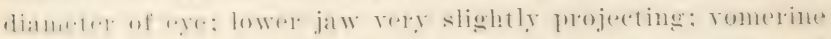

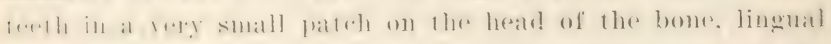

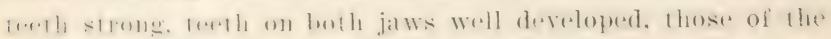

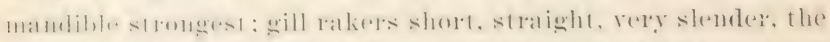

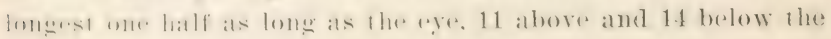
ancle of the first aleh.

'The dorsal origin is nearer to tip of snout than to base of caudal, its distance from the snout equaling twice the

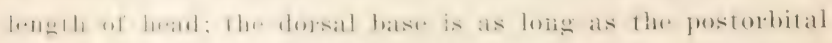
part of head; the longest dorsal ray is two thirds as loug as the luad. and weally twier as long as the last ray.

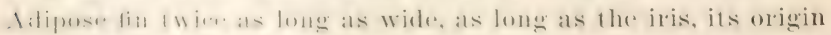

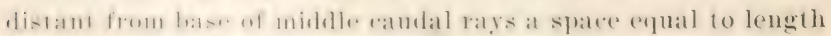

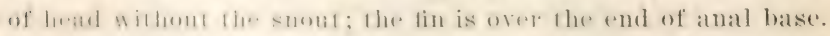

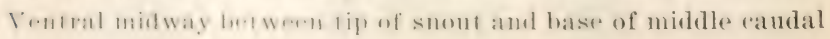


The allal hase is fome ninths as long as the head; the last ray of lhe fin is one half as lomg as the longest, which is one half as lome as low head. The peretoral reathes almost to below the migin of the dorsal. its lunghte two thirts of length of head.

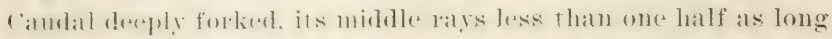
as lihe onter. Which alle requal to length of head without the snout.

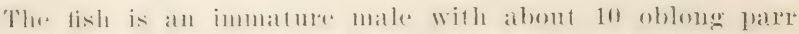
mallks on thre sides and with a frw natrow dith blotehes simmlat ing late hatnds on the bateli from neal the nathe to at point lwhind the dorsal tin: numerous pale spots along the middle of the sides, ratels of which no doubt had a vermiliou spot in the renter in life.

Sterling lake is in New York and Yew Jersey; and it was stated that the trout ale found in streatus (muptying inte the lake. This is moteworthy as being the only instance as far as linown, of suressful introduction of thr sabling info out watrers.

\section{Salvelinus alpinus aureolus (Bean)}

\section{S゙unupe Trout; Golden Trout; Silcer Trout (Introduced)}

Sulcelinus aureolus BEAx, Proc. U. S. Nat. Mus. 628, 1887, Sunapee Lake, New I Iampshire.

Sulvelinus alpimus arreolus Jordax, Forest \& Stream, Jan, 22. 1891; Quackentos, Trans. N. Y. Ac. Sei. XII, 139, 1893; Jordax \& ErerMax, Bull. 47, U. S. Nat. M[us. 511, 1896, pl. LXXXIII, fig. 220, 1900. salmo alpimus Gamux, Ameriean Angler, Feb. 5, 1891.

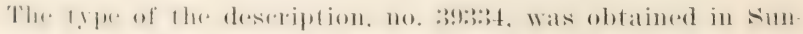

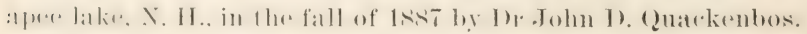

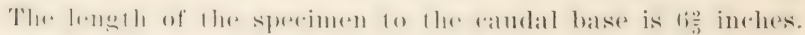

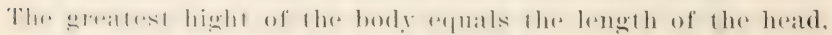

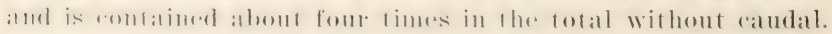

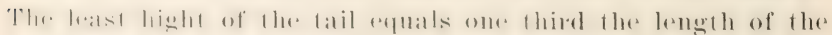

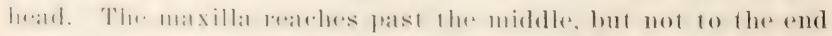

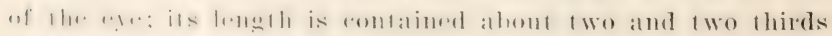

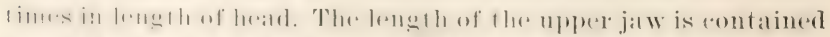

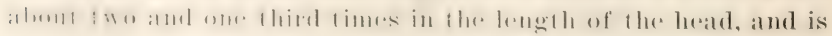
"rpual to the longest anal ray. The eye is a little longer than 
the snout, and is rontained four and two serenth times in the length of the head. Hyoid teethe well developed. The first dorsal is a little nearer the tip of snout than to the base of "audal, and the length of its hase is one half the length of the head. The adipose dorsal is distant from end of first dorsal a spalee requal to twiee the length of the ventral. The anal is at a distance from the snout equal to about three times the length of the headd. The longest anal laty is equal to the length of the npper jaw. The length of the midelle randal rays is equal to twiee the diameter of the eye. The ventral is situited midway between the tip of the snout and andal bases its length equals one half the length of the head. The length of the peretoral is about twier the width of the interorbital area. B. 10; 1). iv, !) A. iii, 8; P. 13; Y. 9. Scales 35-210-40; gill raker's $6+10-12$. The pereuliarity of the will rakers of this trout is that they are always curled up at the ends and not straight, as in the o qu as a from Maine.

Sides silvery white. Back with about six well defined bandike markings, besides some irregular dark blotehes. There are about 10 parr matris on the sides, and numerems small, roundish, white spots. In colors this ehat is differemi from the o q u a s a from Maine, but, if fresh spereimens of the Maine trout were compared with this gomng fish, the differenere in color might not be so great.

The specinem deseribed is a goung male with the spremalues showing as a mere slight ribbon. Its stomath rontained an earthworm and the wing rases of a sequash beetle. The other two specimens (somewhat smaller) are females far from maturity.

In a female, no. 37408, 11 inches in total length, both parr marks and bands across the back show very plainly. This female has a few fere eges in the abdominal ratrity and serems to be nearly spent. In examples of this size the tail is derply forked, the middle rays being less that one half as longe as d he external rays.

In males the pectoral is always longer than in females of equal size. 


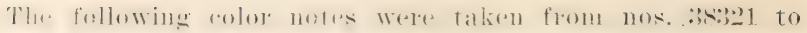

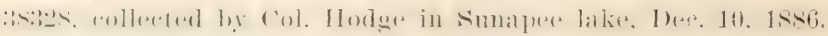

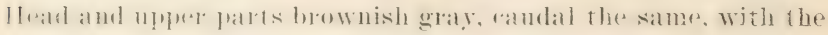

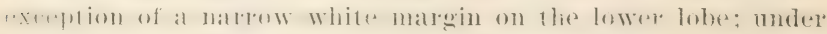

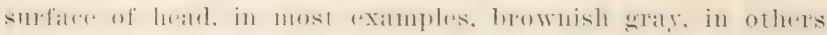

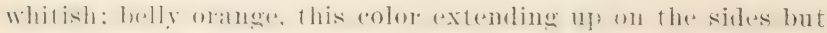
nol on the misldie line of the hody; anal orange. with white

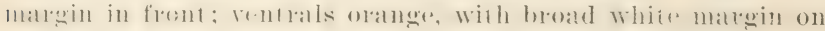

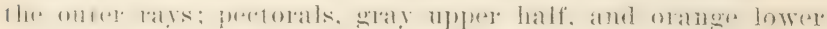
half: thosal selaty, lighter along the hase: sides, both above and

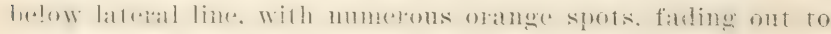
whitish. The latrest of these spots ate little more than ome third as long as the iris. No mottlings anywhere.

\section{MIASUREMENTS}

Current number of specimen

Locality

Length to base of caudal......... Body:

Greatest light ............

Greatest width ............

Ilight at rentrals...........

I.ast hight of tail.........

Length of longest gill rakex. . II roncl:

Greatest length ............

Distance from snout to nape...

iroatest width .............

17 idth of interorbital area...

Length of snout............

Lerusth of opereulum ........

Lemgth of maxillary.........

fength of uplex jazw. . . . . . .

Lemeth of mandible.........

listancer from snout to orbit.

iliameter of orbit. ..........

lliammer uf iris............

1Hus:1 |first):

listance frum smunt.........

J.entath of lnase. . . . . . . . .

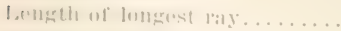

Julleth wi last ray.
37408 오

SUNAPEE LAKE, N. II.

$\begin{array}{cr}\begin{array}{c}\text { Millime- } \\ \text { ters }\end{array} & \begin{array}{c}\text { 1eoths } \\ \text { of } \\ \text { length }\end{array} \\ 257 & 100\end{array}$

51

25

49

21

$\pm$

$$
51
$$

36

21

18

11

1:?

31

25

31

1:2

13

!)

112

ng

:12

15
20

$91 / 2$ 19

8

$11 / 2$

21

14

9

$6 \%$

$\pm$

5

S

$91 / 2$

12

5

5

31,2

$4: 1 / 2$

11

$121 / 2$

7.12:3
39334 है

SUNAPEE LAKE, $N$. H.

$\begin{array}{cr}\begin{array}{c}\text { Millime- } \\ \text { ters }\end{array} & \begin{array}{r}\text { loctis } \\ \text { of } \\ \text { length }\end{array} \\ 160 & 109\end{array}$

100

$231 / 2$

...

36

13

2

S

$11 / 3$

$3 \mathrm{~S}$

27

18

$231 / 2$

$16^{22}$

11

$61 \%$

4

$\%$

....

14

$161 / 2$

$81 / 3$

21

10

13

5

$61 / 2$

5

S1/2

47

$11 \%$

13 714 


\section{MEASUREMENTS}

Carrent number of specimen

Locality

Dorsal (soft) :

From origin of first. ........

Length along hind margin...

Iength of base........... Anal:

Distance from snout........

Length of base............

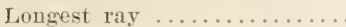

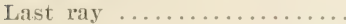

Candal:

Length of middle rays from end of seales.............

Iength of external rays...... Pectoral:

Distance from snout........

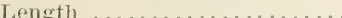

Ventral:

Distance from snout.........

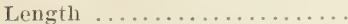

Iength of appendage........

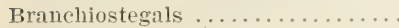

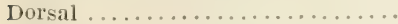

Anal

I'ex+tor:al

Ventral

Number of scales in lateral line...

Number of transverse rows above lateral line................. Number of transverse rows below

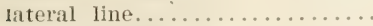

Nunher of gill rakers..........

Number of caecal appendages....
37408 ㅇ

SUNAPEE LAKE, N. H.

$\begin{array}{cc}\begin{array}{c}\text { Millime- } \\ \text { ters }\end{array} & \begin{array}{c}100 \text { ths } \\ \text { of } \\ \text { leogth }\end{array}\end{array}$

39334 रे SUNAPEE LAKE, N, II. $\begin{array}{cc}\begin{array}{c}\text { Millime- } \\ \text { ters }\end{array} & \begin{array}{c}\text { of ths } \\ \text { of } \\ \text { length }\end{array}\end{array}$

\begin{tabular}{|c|c|c|c|}
\hline 90 & 35 & 60 & $371 / 3$ \\
\hline 9 & $31 / 2$ & 6 & $32 / 3$ \\
\hline 5 & 2 & 3 & $1 \% 3$ \\
\hline 183 & 71 & 117 & 73 \\
\hline 22 & $81 / 3$ & 15 & 9 \\
\hline 28 & 11 & $161 / 2$ & 10 \\
\hline 13 & 5 & S & 5 \\
\hline 18 & $6 \% / 3$ & 13. & S \\
\hline 41 & $15 \% 3$ & 32 & $19 \%$ \\
\hline 53 & $201 / 2$ & 36 & 22 \\
\hline 37 & $141 / 3$ & $2 t$ & $14 \%$ \\
\hline 127 & 49 & 84 & $521 / 2$ \\
\hline 31 & 12 & 20 & $121 / 3$ \\
\hline 14 & $51 / 3$ & 8 & 5 \\
\hline 10 & $\ldots$ & 10 & $\ldots$ \\
\hline 9 & $\ldots$ & $y$ & $\ldots$ \\
\hline 8 & $\ldots$ & $\$$ & $\ldots$ \\
\hline$\ldots$ & $\ldots$ & $1: 3$ & $\ldots$ \\
\hline I, 8 & $\ldots$ & I, 8 & $\ldots$ \\
\hline & $\cdots$ & 210 & \\
\hline $3 \pm$ & $\cdots$ & 35 & \\
\hline 38 & & 40 & \\
\hline is & & $\frac{6}{111}-12$ & \\
\hline$a 39$ & $\ldots$ & & \\
\hline
\end{tabular}

The golden tront is a native of Simapee lake and loan Iloke pond, in Xew IIampshire, and of Flood's pond, in Maine. I ountless it exists in other lakes of NeW Fugland and british North America.

It is a large spereies, reatehing a length of 20 inches and the

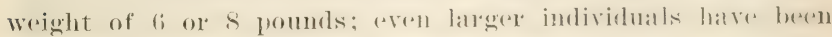
reported. Statwning takes platere in smanpere lake on reefs in shallow water and not in the streams tributary 10 the lake: the 


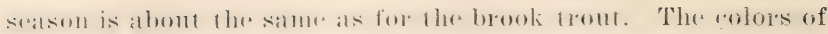

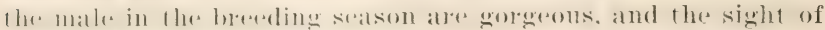
a host of spatwhing tish in the water is one to be remembered.

Ilany latrege and smatl tront of this kiml have herell deposited in Lake George and other suitable waters of the state.

\section{Family ARGENTIXIDAE}

\section{Smelts}

\section{(remus osmencs (.Irtedi) Limmatens}

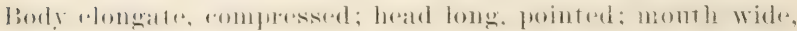

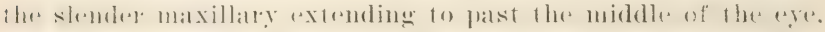

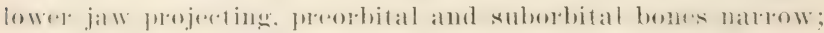
maxillates and formatillatres with tine teeth. lower jall with

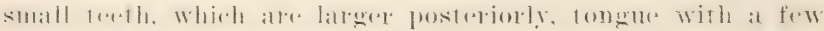

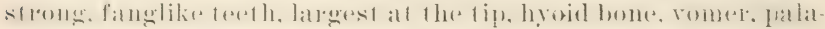

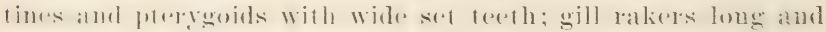

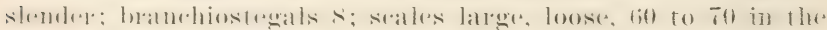
fourse of the lateral lime: dorsal small, about midway al the

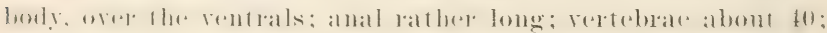

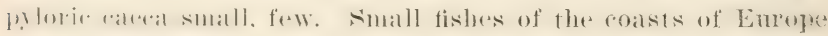

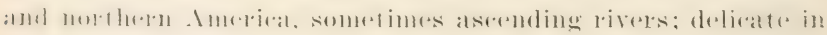

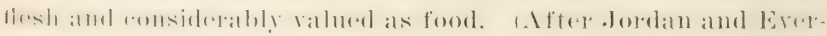
mat11n!

\section{Osmerus mordax (Mitchill)}

\section{Smelt: ice Fish}

Ltherine morder Metemer, 'Trans. Lit. of Phil. Soe. X. Y. I, 446, 1815, New jork.

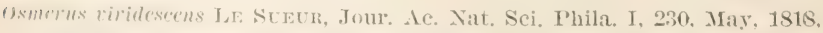
lioston to Newport; De K.12. X. Y. Fama, Fishes, 243. pl. 39, fig. 124. 1812. streams flowing into Long Island Sommd. Hackensack of Passaic

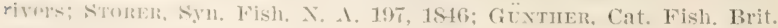

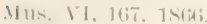

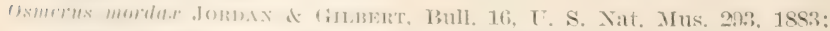

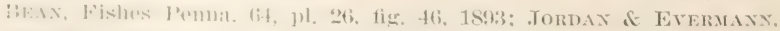

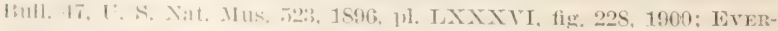

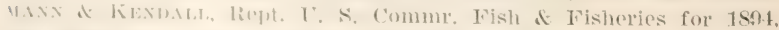

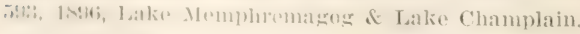

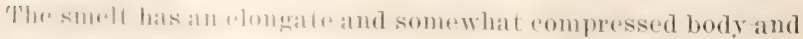
a lomer pointel heald, wilh the lower jaw projecting. The mouth 
is large, the maxilla extending slightly behind the ere. Small teeth on the intermaxillaries and maxillaries and the firont of the lower jaw. Posteriorly the teeth of the mandible are larger. The tongue is armed with a few large fanglike teeth. and theres are widely set teesth on the vomere, palate, and pterer goid bones and at the root of the tongue. Gill rakers long and slender; bramehiostegals eight; the dorsal small, nearly median over the ventrals; anal moderately long; seales large, thin. easily dereidnous, in about fo rows along the sides; lateral line short, not extending murh beyond the end of the peretoral; a few small pylorio catea. The hight of the body is nearly one fifth of the total length, without andal, and nearly equal to the length of headr. The "ye is nearly one fifth as long as the head. The pertoral equals the longest dorsal ray in length and, also, length of anal base. The rentral is one half as long as the head. Longest anal ray not much more than one half the anal base. D. ii, $8 ;$ A. iii, $14 ;$ V. ii, 7 .

The npere parts are gerenish; a boal sibery band alonge the sides; body and fins with numerous minute dusky points.

The smelt is known along our ast roast from Labrador fo Virginia. It probably extends still farther north, but the reeord of W. A. Stearns, published in the procedings of the National Museum for 188:3. p. 124, fixes the most northern locality known at present. Ife found the smelt aommon in August in shoal water off the whatres of cape Ineton. In Pennsylyania the fish is eommon in the spring in the Thelaware and sirehyllill rivers. In numerous lakes of Maine. New Ilamplaire. and other New Eugland states, the smelt is ammon landlocked. and thrives as well as in the salt water.

De. Kay knew the smelt as a marine spereses aseending the Hackensalek and Passale rivers. The spereses orems also in Lakes champlain and Mempluemagoge. In the former lake it

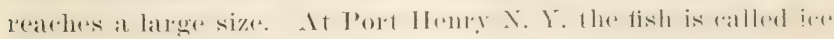
fish.

Its range has beren wielely extended by artificial iutroduction.

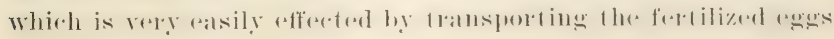




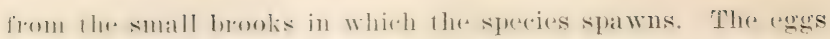
alle allhesive and attarh themselves to stomes, and their transportation is accomplished rery easily.

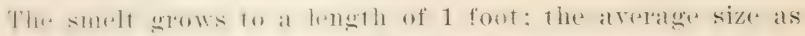
fonmel in lhe matrele is about 7 inches. It enters the rivers for

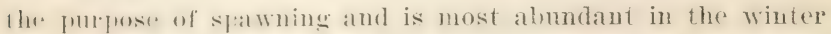

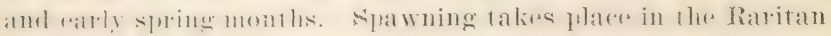

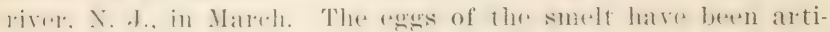
tirially latr.hed he Mr Tirardo. Fred Mathex and other fish culturists.

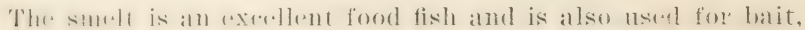

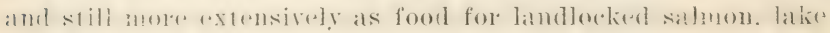

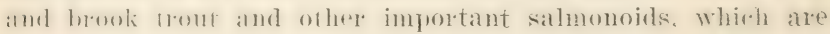
artifiritly ratred in lakes. It has provert to be one of the hest fislus for this fmlpose. Immense guantities of sallelis ale

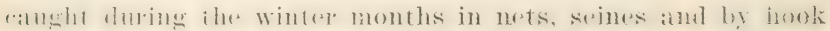

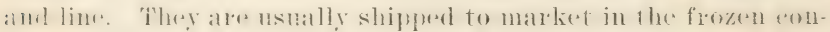

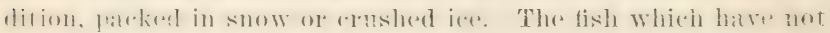

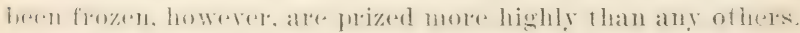

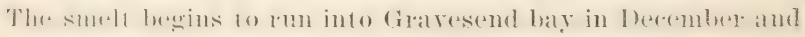

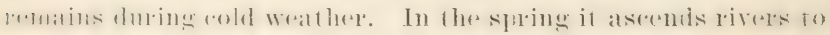

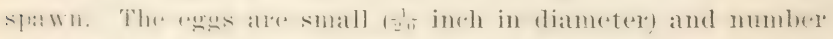

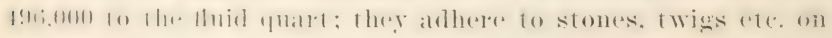

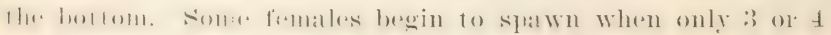
inches long.

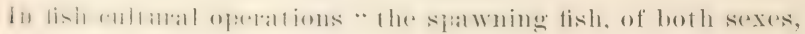

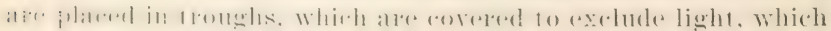

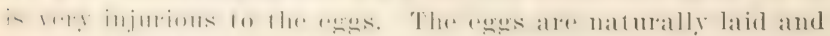

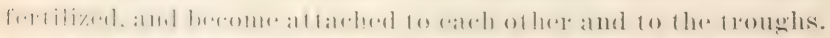

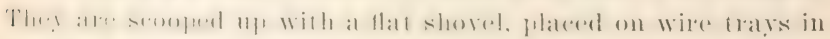

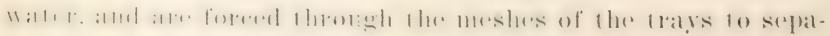

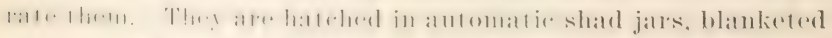

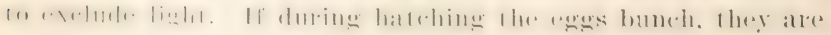
removed fiom the jal's and again passed through the meshes of Ilow wire: tratss."

'lue fry are hatrly in transportation. 
In eaptirity the adults live till about the end of June, when the water beeomes too warm and they die. Their food ronsists mainly of shrimps and other small crustaceans.

\section{Order INOMI}

\section{Lantern Fishes}

\section{Family SYNODONTIDAE}

\section{Lizard. Fishes}

\section{Genus synowus (Gronow) Bloch \& Schneider}

First superior phatrongeal atrtilaginous, second without teeth, third and fourth separate. with teeth: lower pharygeals sept arate; boty elongate, subterete; hat depressed, the snout triangular, ratlere pointed; interorbital region transversely con"ave; mouth very wide; permaxillaties not protractile, very long and strong, more than half length of head, maxillaries "losely ronnected with them, very small or obsolete, gremaxillaries with

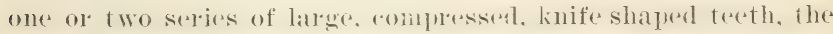

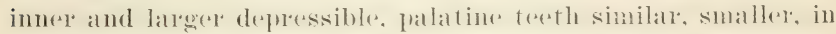
a single broad band; lower jaw with a band of rather latrge teethe the inner and largere teeth depressible, a patrote of strong, depressible teeth on the tougue in fromt, and a kong row along the hroid bone; jaws nearly equal in front; eye rather large, anterior, supratorlatal forming a fleojection abowe the eye;

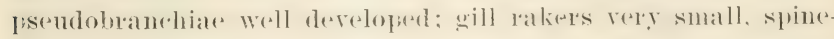
like; gill membranes slightly eommertedi top of head nalied; rhecks and opereles sealed like the holy; hoty revered with rather small, atherent, recloid sealess lateral line present: no luminous spots; dorsal fin short. ratlure anterior: pertorals moderate, inserted high; rentrals anterior. not far behind peetorals, large, the inner lats lonerer than the outer: anal short; andal narrow, forked: rent gusterior. much mearel base of randal than base of ventrals; batm-hiostegals 12 10 16: stomaleh with a long, blind sac and many pylorie caecal skeleton rather firm. 


\section{Synodus foetens (Linnaeus)}

\section{lizal)d Fish}

Sulmo foctens Lrxweus. Syst. Nat, ed. XII. I, 513, 1766, South Carolina.

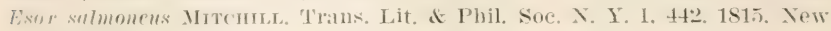
In1k.

Samms merienmus Crrifr. Regne Anim. ed. II, 314, 1829, Mexico.

Sturus foctens Güxtifi, Cat. Fish. Brit. Mus, Y, 396, 1864.

symodus foetens JorDAx of Gilment, Bull. 16, U. S. Yat. Ifus. 250, 1883;

BFx, Bull, U. S. F. C. VII, 148, 188s, 19th Rep. Comm. Fish. X. I.

27.5. 15!10; Jormax d Evermaxx, Bull. 47, C. S. Nat. Mus, 538.1896,

pl. LXXXY111, 1ig. 236.1900.

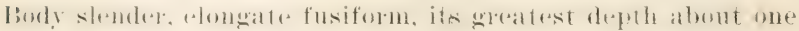

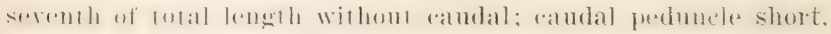

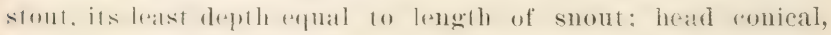
shatply fointed, its length contained four and one thisd times in

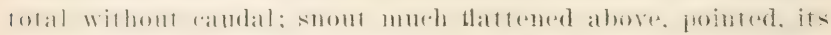
longth alume we fomth the length of head, and nearly iwice

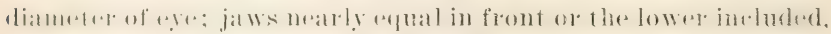
maxilla reathing well behind orbit, the upper jaw as long as

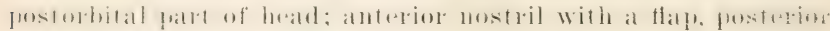

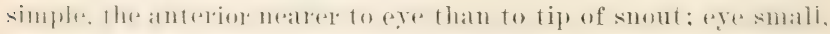

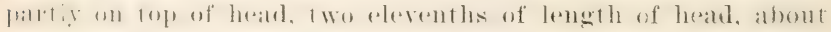

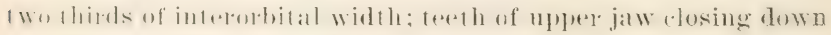

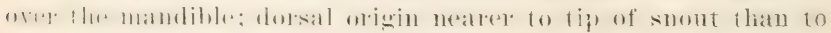
base of caudal, over the 18th scale of the lateral line, dorsal

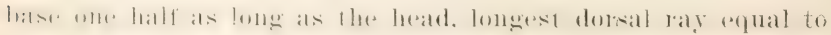

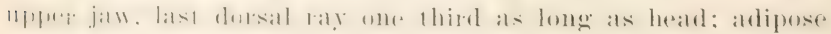

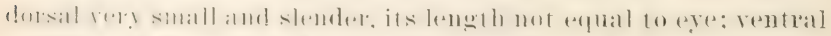

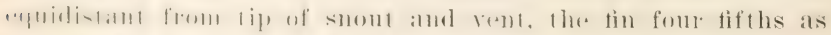

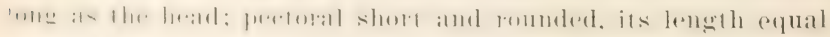

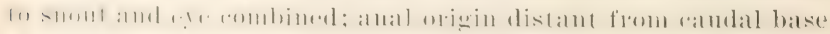

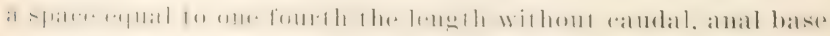
three fifths as lome as the head. lomegest anal ray one half as lomp as heatl without the snout, last anal bay one half as long as anal base: caudil derply forked. the middle rays less than

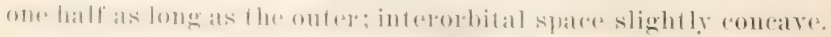
1). 11), the limst two and the last simple: 1. 14; Y. S; P. 14. Seales

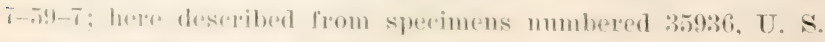
Sittonal Mnsemm, from Nire island. I. I. 
Color of npper patts olive brown or grayish, sides below lateral line paler. belly yellowish. pectorals. ventrals and anal with a yellow tint, catudal dusky, dorsal with traces of narrow bars, inside of mouth and of gill openings yellow.

The lizard fish reatehes a length of 12 inches; it is found from

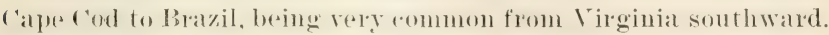
It romes into shallow waters during the summer and remains on the New York coast till ortober. It is a volacious species, of no value as food.

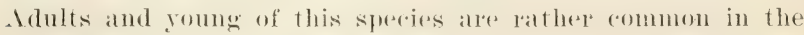
Great Egg bay region, X. J.

It Beesleys l'oint. Nex. ㄹ, 1sit, a small individual was found to have swallowed a P l e u r o nectes a merica $\mathrm{n}$ us, which

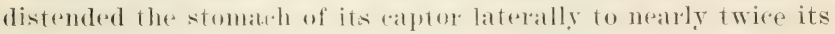
normal width.

Abundant in tholomghfares neat Fomers Point Iugust :30. (One individual taken is $7: 3$ inches long. Some very latege omes

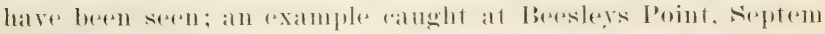

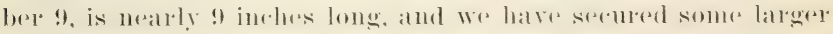
than this.

The species is mknown to the fishermen.

The lizard fish, alled saud pile by somes anthols, is the trout pike of Mitrhill. Desides beatring theses names, it is known as snaketish, cigar tish and speatrish. The speries appears not to

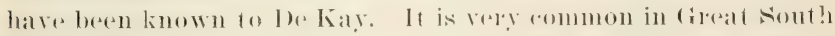
bay, :36 specimens having been talien in the latter palt of september and the first two days of () tober. Mitchill's examples feom the heald of Xew York bay were from s to 9 inches long. in Great Ege Harbor bay, thomgh it is a rery common fish, the fishermen have no name for it.

\section{Order HAIt,}

Pikelike Fishes

Family UNBRIDAE

I/ ud linnows

Genus чмm a (Kramer) Müller

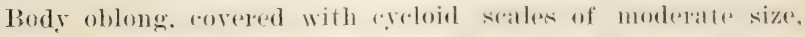
without radiating striase; no lateral lins: head shortish. little 
deporsed: eye lather small: reft of mouth moterate; rentral fins biaged, below or slighty in front of dorsal; anal fin much

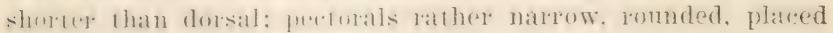

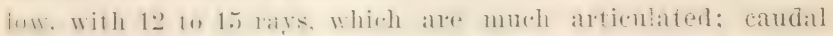

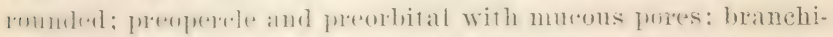
ostegals six: gill rakels slont, thick. Size small. Threw speries. very similat to wath other, inhalbiting the waters of the Tuited States and Austria.

\section{Umbra limi (Kirtland)}

\section{Hud Hinnow; Dogfish}

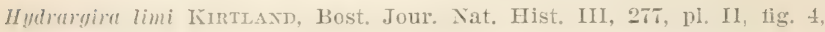
$18+1$.

Hydiryira fusca Tmomsox, Nat. Hist. Vermont, 137, 1842, Lake Champlain.

Hydrargira atricauda DE KAY, N. Y. Fauna, Fishes, 220, 1812. Hydrargyra fusce Storer, Syn. Fish. N. A. 1S2, 1846.

Limbra limi Güntiner, Cat. Fish. Brit. Mus. VI, 232, 1866; Jordar \& GILBerT, Bull. 16, U. S. Nat. Ius. 350, 1853; BeAx, Fishes Penna. S8, 1893; Jorida \& Jivermax, Bull. 47, U. S. Nat. Mus, 623. 1896.

The mul minnow has a romplatratively short and stout body its depth nut repual ho the length of the head and about one fourth uf lolal without anulal. The length of the head equals iwo s.remlhs of the tolal. The head is flattened above and rathere

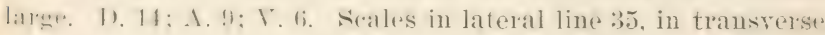
series 15 .

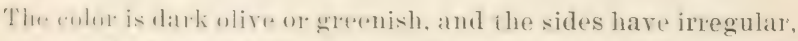
matrom. palt hatls. Which ate smmelimes ubscule or absent. I black bar at the base of the tail.

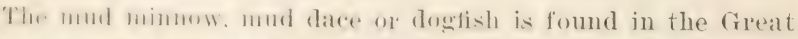

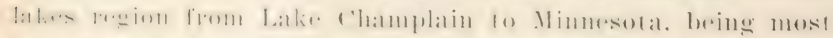

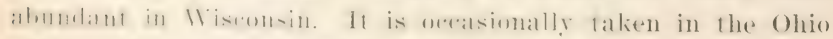

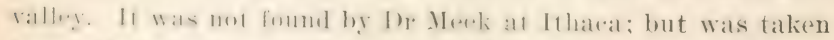

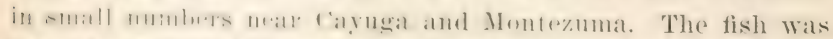

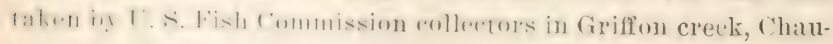
mont. N. Y. July $\bar{T}$, and in Mill creek, Sacketts Harbor N. Y. July". He Kay hat specimens from Lake Champlain.

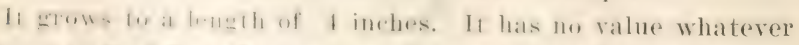

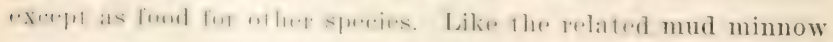


noxt mentioned, it is hardy and interesting in the aquarium. The name mud minnow relates to a singular habit of the fish of burrowing into the mud when the water evaporates out of a pond. It has been related that this fish has been plowed up in ponds and swamps which have become dried ont. Prof. Baird has recorded the following fact about this species. "I locality which with the water perfectlyclear, will appear destitute of fish will perhaps yield a number of mudish on stiring up the mud on the botton and drawing a seine through it. Initches on the platins of Wisconsin or mere bog holes affording lodgment to nothing beyond tadpoles may thus be found full of m e l a n u a s."

The mud minnew shipped from caledonia X. Y. hy James Annin jr in wet moss has survived a 12 hours jomrney; but it has never frowed hardy either in balanced tanks or in running water. This is remarkable, becaluse there is evidence to prove that the species can endure alternate freezing and thawing without permanent injury.

\section{Umbra pygmaea (De Kay)}

\section{Striped Mud IImnow}

Lenciscus pygmaeus DE KAY, N. Y. Fauna, Fishes, 214, pl. 42, fig. 134 , 1842, Tappan, Rockland Co., X. Y.; Stoner, Syn. Fish. N. A. 16:2, 18t6. Fundulus fuscus Arres, Bost. Jour. Nat. Hist. IV, 296. pl. XIIT, tig. 2, 184t, Brookhaven, Long Island.

Melanura anmulata AgAssiz, Amer. Jour. Sci. Arts, 135, 1854.

Umbra pygmate Jordax, Bull. L. S. Yat. Mus. X, 53, 1577; BEAx, Fishes Penna. SS. 1893; Jordan \& Evermaxy, Bull. 47, U. S. Nat. Mus. 624, 1S96, pl. XCIX, tị. 26S. 1900; Meırixs, Bull. Amer. Mus. Nat. Hist. $\mathrm{X}, 317,1898$.

Tmbíl limi pugmaca Blatciner, Proc. Ae. Nat. Sci. Phila, 13.1885. Melanura pygmaea BEAN, Bull. U. S. F. C. VII, 147, 1888.

The body of the mud minnow is oblong, robust; its greatest depth is contained slightly more than four times in the total length without the caudal and not equal to length of head. The snout is short; eye moderate about equal to snout, four and one half in head. Cardiform teeth on premaxillaries, lower jaw, vomer and palatine bones. The gill openings are very wide, the rakers short and rather numerous; jaws short, gape of mouth 


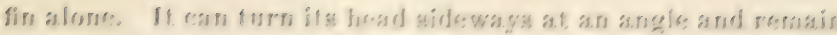
so whiles in these posation.

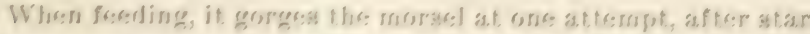

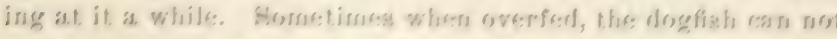

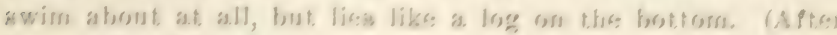
Singerene: Sirsith ${ }^{1}$ )

$$
\begin{aligned}
& \text { Fumily toctorse } \\
& \text { fritest }
\end{aligned}
$$

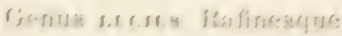

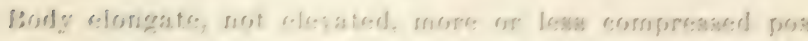

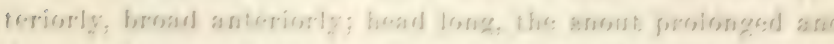

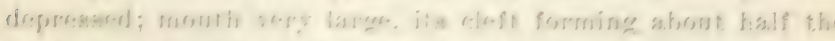

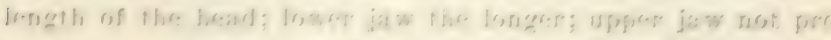

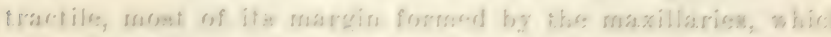

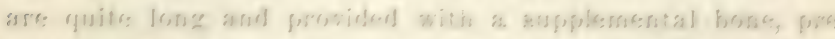

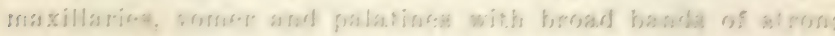

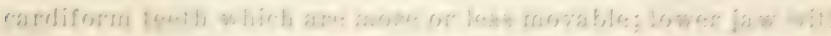

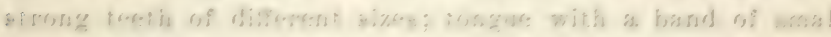

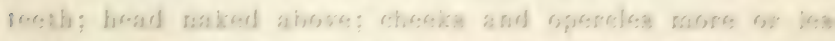

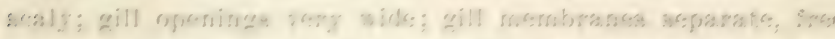

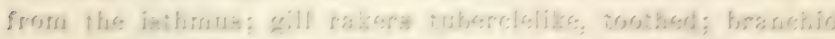

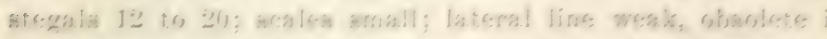

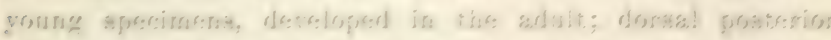

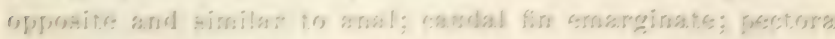

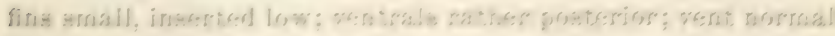

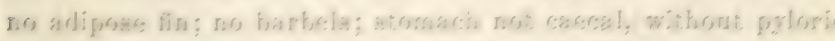

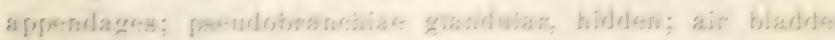

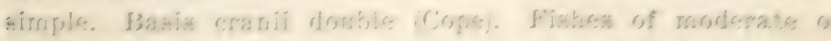

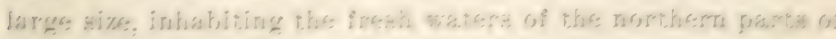
Europer, Asia and Wromth Anecrima.

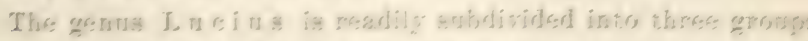
discingtrisherl hog theis size, scaling and coloretion. In the firs

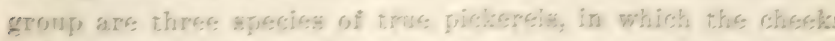

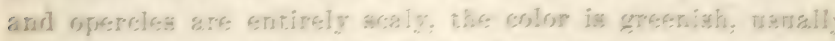

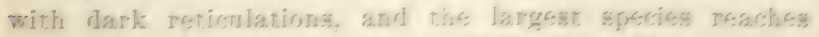

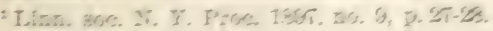


length of about 2 foet. To this group the subgeneric name Ifeno\%a is sometimrs applied; it includes the banded pick..1\%l, the little pickered and the chain pirkerel, all of which occur in Yew York.

\section{Lucius americanus (Gmelin)}

\section{Banded Pickerel}

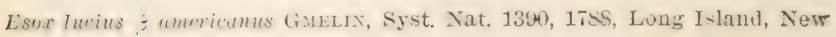
York.

Estor niger 1.x Strut, Jour. Ae. Nat. Sei. Phila. I, 415, 1S1S, Jake Saratogn, New York; Stomm, sym. Fish. A. A. 1s5, 1St6: Gixiner, Cat.

Fish. Brit. Mus. VI, 229, 1866.

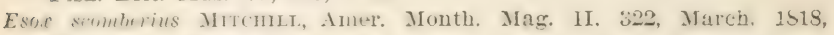
Murderer's Creek, New York.

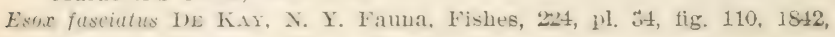
streams and ponds of Long Island.

Esar rareneli Holbion, Ichth. s. C. 211, 1860, Charleston. S. C.

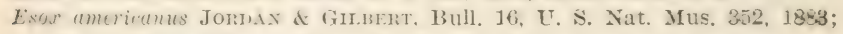

Bean, Fishes Penna. 89, pl. 28, fig. 53, 1893.

Jucius umerimuls Jornax de Everiasis, Bull. 47, U. S. Nat. Mus. 130, 1896.

The handed pickerel has an flongate body; its depth rontaimed alout fove times in the total length without caudal; the lerigh wi the head three and one fometh times in the standar.i bnelf. The smont is rontained two and two thirds times in the lengh of lle lead, and the eye five and one half times in

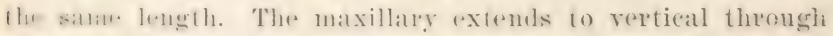

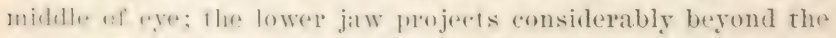
nygur. Truh in the jaws stromg, dipected backwards. The r.m11:al is platral in mirlde of hody, the dorsal and anal fins far hark, offmsitr warh other; thein longest rays of about the same l.ngeth. monh lomere than the hases of the fins. Caudal deeply ematreinate. 18. 11-1:3: 1). 11-14: .1. 11-1:. Scales in lateral

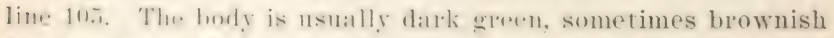

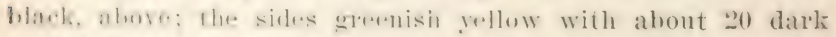

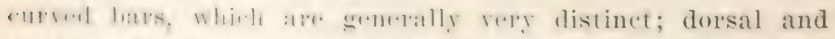
cauditl tins dirk brown, Ihe ohlere tins lighter, sometimes red-

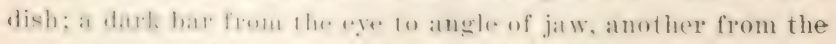
snout through the eye to upper edge of operele.

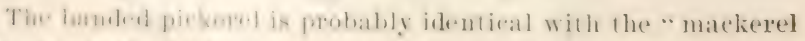

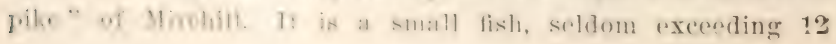


inches in lencth. and will nut awerage more than $\frac{1}{2}$ pourd in weight. It monrs only tast of the. Alleghanies. from Massachusetts to Plorida in coastwisi streans. In Prunsylvania it is limited to waters in ther rastern part of the state, and the same is true in New York.

This fiekerel is ton sunall on has much importance as a food fish. It resembles in general alpearance and habits the litule

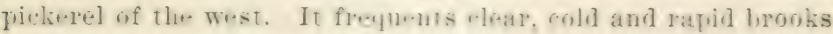
and is saili to assoriat, with the brook trout without injury to the latter.

Dee. 30. 1895, Jankes Annin jr snt from Rockland $\mathrm{X}$. Y. a small pickerel whieh had attracteri his attention on aceount of its colors ant markings. It was tak-n in a small spring brook, tributary to the Braret kill. which, about 10 or 15 miles below,

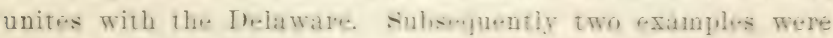
forwarded alive from the sume place and one of them is still living in the aguarium 15:7\%. The following untes and measure ments, in inches. relate to th... tirst individual of unletemined sex, the organs being undereloped.

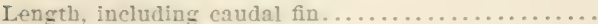

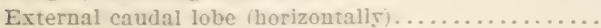

Middle caudal rars (from end of scales) ............

Lewatli of hroul.

$73 / 4$

$11 / 6$

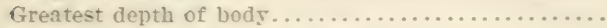

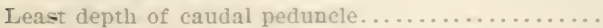

Length of snout.

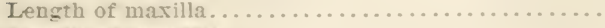

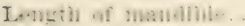

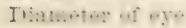

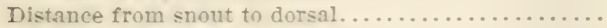

I.ength of is was liss...

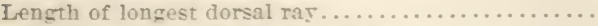

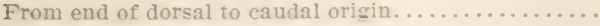

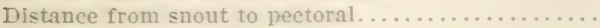

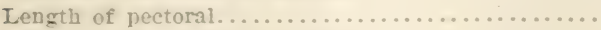

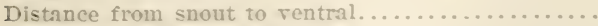

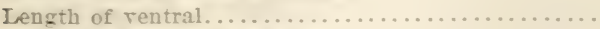

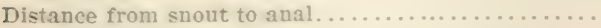

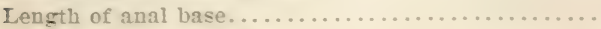

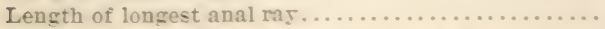

From end of anal base to origin of lower caudal lobe. 
B. 12 : D. $12 ; 1.11 ;$ T. 9. Suales, 24-110. The maxilla reaches: to betow the middle of the fupil. The mandible projects $\frac{1}{15}$ of an inch when the mouth is closed. The diameter of the eye is contained five and two thirds times in length of head. The stomateh was tmptr, hut insect remains were roided from the rent.

Colors. About 20 oblique. interrupted. dark bands on the body: a narrow oblique dark band under the exe and four rather

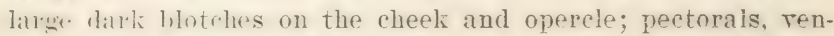
trak aneI anal orange: a tinge of orange on the dorsal and eaudal: general anlor wlivaceous gray, with golden retiections; lower fatrts a ratny white; iris lemon mingled with pale bromn: peritoneum silvery.

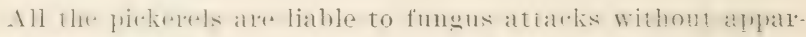
('mt "aluse. hut, as a rule, they can be cured by the salt water treatment. Theip food cousists of small live killifisl, which they arproath slowly and deliberately till within 5 or 6 iuches. when they rush, seizr. and stop as abruptls as if stopjed by an obstruction.

Eugene smith sils this pickerel is often found in brackish water in the virinity of Now Jork, and is then more hrown in

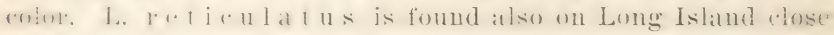
to salt water, as at Water Mill.

\section{Lucius vermiculatus (Le Sueur)}

\section{Little Pickerel}

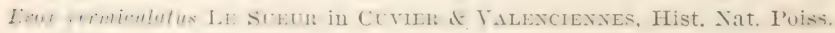
XVIII, 333, 1816, Wabash River, Indiana.

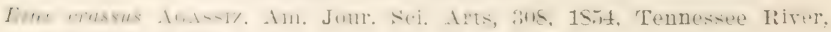
Huntsville, Alabama.

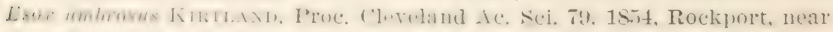
Cleveland, Ohio; Cope, Trans. Am. Phil. Soc. Phila. 409, 1 S66.

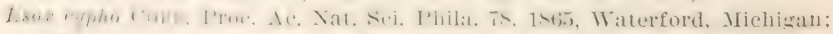

Giviner, Cat, Fish. Brit. Mus. VI, 230, 1866.

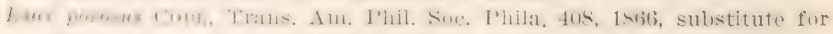
c y pho.

Esot sulmoneus Jominax \& Gilbert, Bull. 16, U. S. Nat. Mus. 352, $18 s 3$.

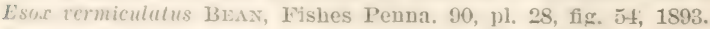

Lurius remiculatus Jordax \& Evemaxi, Bull. 47, U. S. Nat. Mus. 627, In:Hi: 
The little pickerel has a short. stout body and a long head. The greatest depth is nearly one fifth of the length without caudal and two thirds of length of head; length of head two sevenths of total without caulal: eye two fifths of length of snout, oue sixth of length of head. The maxilla leatehes to below middle of eye. Cheeks and opercles fully sraled; Horsal origin twier as far from eye als from end of seales, its base two

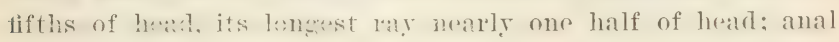
nuder dorsal and with slightly longer rass; rentral nearly midway between tip of smout and end of seales, its length equal to snout and to pectoral. B. 11-13; 1). 12; 1. 11 or 12 . Scales in lateral line 105.

Body green or grayish, usually with many irregular streaks or reticulations, which are sometimes entirely lacking; sides of the head generally rariegated; a dark bar extends downward from the eye, and another forward. Fins plain, but the caudal is sometimes mottled at its base.

This pickerel inhabits the valleys of the Ohio and Mississippi rivers and streams flowing into the Great lakes from the southward. In ponds formed in the spring by the overflow of river banks it is one of the characteristic fishes and is often destroyed in great numbers by the drying up of such bodies of water. In Pennsylvania the little pickerel, or tront piekerel, is common in the Ohio and its tributaries. Prof. Cope mentions it also as an inhabitant of the susquehanna river, in which it is probably not a native.

The L. . Fish Commission olitained a moderate number of specinens in the Tala (matrin region at the following Xew Jork localities.

Black creek, tributary of Oswego river, Scriba Corner

July 15

Lakeriew hotel, $7 \mathrm{~m}$. west of Oswego July 17

Wart ereek July 24

Great Sodus bay Aug. 16

Outlet Long pond, $4 \mathrm{~m}$. west of Charlotte Marsh creek, near Point Breeze Aug. Aug. 21 
This fish grows to the length of 1 foot and is, therefore, too small to have much importance for food.

\section{Lucius reticulatus (Le Sueur)}

\section{Chain Pickerel; Green Pike}

Esox reticulatus I.x Steln, Jour. Ac. Nat. Sci. Phila. I, 41t, 1S18, Connecticut River, Adams, Mass.; Philadelphia, Pa.; DE K.IY. N. Y. Famna, Fishes, 223, pl. 34, fig. 107, 1812; Kirtuan, Bost. Jour. Yat. Hist. IV, 2:3, [1. X, fig. 2, 1841; GCxtuer; Cat. Fish. Brit. Mus. VI, 220, 1866; Jorinan \& Gilbert, Bull. 16, U. S. Nat. Mus. 3̋̈̈, 1S83, Bean, Fishes Penna. 90, pl. 29, tig. 55, 1893.

Esox tridecmlineatus Mitcmul, Mirror, 361, 1825, Oneida Lake. N. Y.

Esox phaleratus (SAY) LE Sueur, Jour. Ac. Nat. Sci. Phila. I, 416, 1818, St Augustine, Fla.

Erox uffinis IIolbrook, Ichth. S. C. 198, 1860, Charleston. s. C. Lucius reticulatus Jomdan of Evermanx, Bull. 47, U. S. Nat. Mus. Riz. 16rif; Evermani \& Kendall, Rept. U. S. Commr. Fish \& Fisheries. for IS?4. 597, 1896; Mearns, Bull. Amer. Mus. Nat. Hist. X. 317, 1898; Proc. U. S. Nat. Mus. XXI, 344, 1898.

The chain pickerel has a long and slender bodș, its depth near the midnle equaling about two thirds of the length of the hrear and rontained five to six times in the total without caudal. The caudal proluncle is slender. its depth little more than one thired of greatest depth of body. The snout is long and pointed, as lone as the yostorlital part of the head and about three times the length of the eye. which is one serenth to one eighth of length of hearl. The dorsal base equals two fifths of length of hearl, its lomgest ray equal to snout. The anal begins under the third or fourth ray of the dorsal, its longest ray nearly one half as loner as the hearl. caudal deeply forked. Tentral half way from tip of smont to end of suales, its length equal to snout and sightly sreater than length of frectoral. B. 15; I). 15; A. 14. Scales in lateral line about 125. The rhecks and opercles are completely scaled.

The color is usually greenish, sometimes brown or almost blarli. (Ju the sides are many narlow, dark lines connected by cross sirriks, forming a network which suggested the name

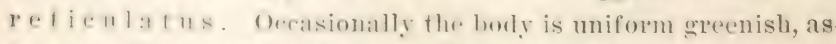

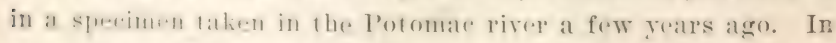

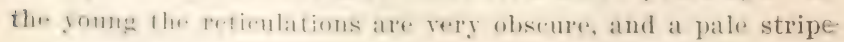


is found along the middle line on the second half of the body. In adults the sides are often golden or olive yellow, and have dark reticulations. A distinct dark band under the eye.

The chain pickerel is known under other names; it is the jack of the south, the federation pike of Oneida lake, $\mathrm{N}$. Y. the green pike of the Great lakes and the eastern pickerel of many writers. It does not occur west of the Alleghanies, but is found from Maine to Florida and Alabama east of this range of mountains. It lives in ponds, lakes and streams and occurs within the same territory as L. a m erican us, but farther away from the coast. (After Eugene Smith. ${ }^{1}$ )

At Water Mill this pickerel occurs in or near brackish water at the east end of Mecox bay, and it is in rery plump condition, on account of the abundance of small fishes on which it feeds, for example, the silversides, young sunfish, and small killifishes of several kinds.

Dr Meek notes that the species seems to be subject to individual variation. In many respects the specimens from Cayuga lake appear to be intermediate betreen reticulatus and vermiculatus. It is not very common.

The pickerel is rommon in pouds and streams of the Hudson Highlands, according to Dr Mearns, and is taken in winter as well as in summer. A specimen weighing $3 \frac{1}{2}$ pounds was eaught in Poplopen's pond in 18s2. It is abundant also in Cauterskill Iake, of the Catskill mountains. The U. S. Fish Commission obtained it in Black river, \#untingtonville N. Y. July 5. Examples were sent from Canandaigua lake, and young were obtained in Bronx river.

This pickerel is the largest of its group, reaching a length of 2 feet and a weight, occasionally, of 8 pounds, though this is much above the average.

Like the pike, this is one of the tyrants among fishes, a fierce and hungry marauder; and yet it has been introduced by fishermen into many waters in which it is not native and has greatly multiplied. In the Potomac, the Connecticut, the Delaware and

${ }^{1}$ Linn. Soc. N. Y. Proc. 1897. no. 9, p. 29. 


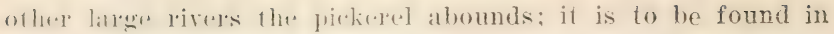
latrece mumbers lying in wait among the river grasses or in pouds muler the. sheltr.r of leafy water plants for the minnows which

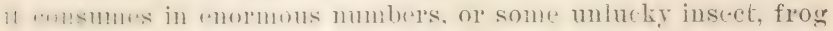
or smake which attracts its roracious appetite.

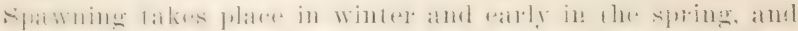

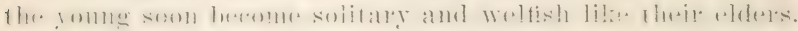

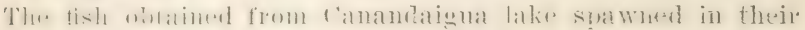

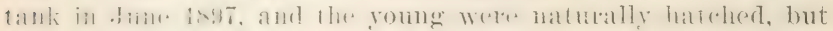

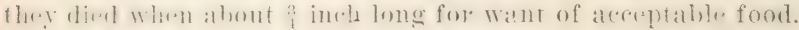

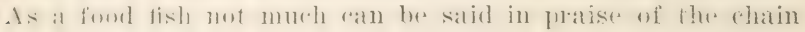

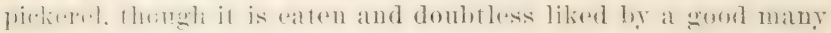
jutople. The flesh is often eoalse and watry and is always full of smatl homes. This fish, lowerele, furnishrs comsidreable

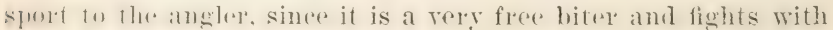
gleall huldness and stubbormmess when hooked. It is caught by trolling with a spoon or still fishing with live shiners, pickerel frogs and many other baits. A minnow gang is often rexy +flertive in pickerel fishing. The hooks must be tied on sim!! as a protertion for the line from the sharp teeth of the fish.

This spreies is always hard to keep in good courlition in ('aptivity, herause of its liability to fungus attacks. The salt water treathurnt, howerere, keegs the fungus in check.

\section{Subgenus hucrus}

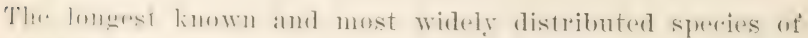

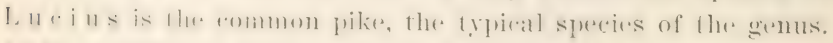

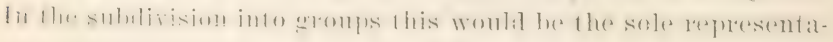
five of the I u cius group, which has the cheelis fully scaled and the lower half of opereles naked. The sides are pale

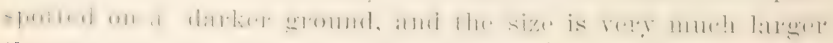
than that of the pickerels. Fossil remains of the pike have beren found in quaternary deposits in Europe.

\section{1.๊0) Lucius lucius (Limnaeus)}

Common Pilic: Piclierel

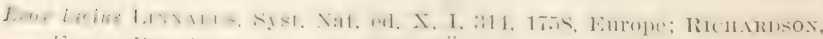
Fanma Bor.-Amer. III, 121, 1836; Güxtmen. Cat. Fish. Brit. Mus. VT,

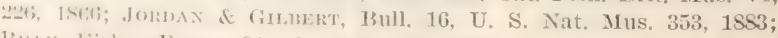
Ist:1., Fishes 1'enna. 91, pl. 29, fig. 56, 1893. 
Esox estor IE Sueur, Jour. Ac. Nat. Sci. Phila, I, 413, 1818, Lake Erie;

De KAT, N. I. Fauna, Fishes, 222, 1S12; Storer, Syn. Fish. N. A.

$18 \pm, 1816$.

Esox boreus AGAssiz, Lake Superior, 317, 1850, Lake Superior.

Lucius lucius Jorday \& EverMand, Bull. 47, U. S. Nat. Mus. 629, 1896, pl. C, fig. 269, 1900; Everurant \& IKendalt, Rept. U. S. Commr. Fish \& Fisheries for 1894, 597, 1896.

The pike has a stout. Alomgate horly and a lomg head, with hroad and frodurer! smont. The greatrest degth is about one fifth of the length without "antal. The candal feduncle is nearly equal to one half depth of body. The eye is nearly median and abont one sixth of length of head, which is is of total without caudal. 'The mouth is very large and strongly toothed. The tongue, roof of mouth, pharynx and gill arches bristle with teeth in cardlike hands, giving the fish extratordinar power in seizing and holding its prey. The dorsal and anal fins are near the caudal. The dorsal base is a little longer than its longest ray and equals depth of body at its origin. Tentral fin midway betwexn tip of suout and end of tail fin. $B$. 14 to $16 ;$ D. 17 to $20 ;$ A. 16 or 17 . Seales in lateral line 120 to 125.

The ground color of the body is grayish varying to bluish or greenish gray. The siles are thickly covered with pale blotches, none of them as latge as the ere arranged nearly in rows. The dorsal, anal and candal fins have many rounded, dark spots. Adults without dark bar below "ye. Vaked part of operele bounded by a whitish streak. In the yomeg the sides are

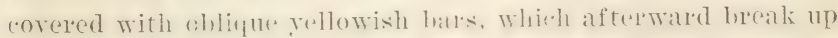
into the pale spots of the adult.

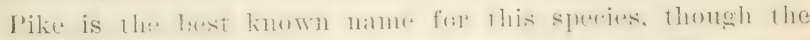

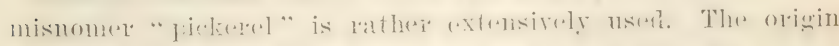

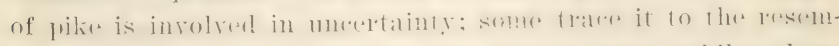

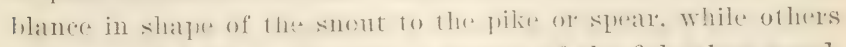
helieve it to refer to the darting motion of the fish when spereling through the water. The nime pielerel is nserl in Vermont

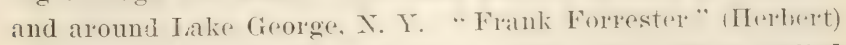
styles it the great northeren pirkerel. The name jack is alphlied in Great Britain to young pike. Brochet is the French mame, hecht the German and luccio the Italian designation of the 
sprecies. In Prof. Corres palper in earlier reports of the Pennsylrania Fish Commission the names lake pike and grass pike are used for the fish.

Distribution. In the north temperate and aretic regions of North America, Europe and Asia the pike is equally common. In North America it extends from Pennsylyania to high northern latitudes. In daskia, Towusend and others found it ahove the aretie cirele, and latl and Nelson took it in abundanes in the Yukon. From fireenland and the islands of the Aretic ocean the pilie appears to be absent. The identity of our American fike with the common one of Europe was recognized by Cuvier and Richardson more than half a century ago; the former comfared specimens from lake IIuron with European examples, and Richardson with the English pike, and both were unable to find specific differences between the two.

The pike is said to be common in Lake Champlain and in all its larser tributaries. In the Lake Ontario region thr I. S. Fish commission collectors secured it at the following places. Jurl rerek, ('alpe Vincent X. Y. June 25. 1894, Chammoni rires. July 10, outlet Long pond, 4 miles west of chatrotte X. I. Aug. 17.

1). Mereli found the species in Caynga lake. where he siigs he was mahl. to find any other fish of the genus except the pickerw. James Annin jr obtained the pike in Silver lake, Tyoming (o). ․ I. July 1, 1s:96. He reports that it does not oceur in Canandaigua lake.

()n the continent of Europe the largest recorded specimen was litken al liregenz in 1sfiz; this was said to weigh 14.5 pounds. In somland a pike measuring more than 7 feet and weighing 72 fommls hats been reported. We do not find monsters like these in Anminal. "Frank Forrester" mentions individuals of 16 to

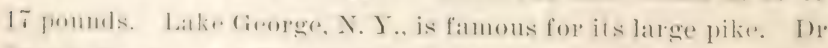
Frank Preshery of $\mathbb{W a s h i n g}$ on W. C. caught one there in 1889 Wrighimg a lithl. more than 16 promds, and more than 30 csamples, arratging in exress of 70 pommls each, were taken that

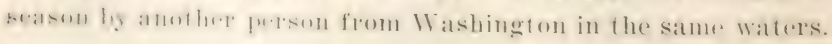


Some of the largest pike were upward of 4 feet long. The arerage length is about 2 feet.

The fishing season generally begins June 1 and ends December 1 ; but many of the states have no close season. In Pennsylvania the close time lasts from December 1 to June 1.

The pike is a voracious fish and destroys everything within its reach in the form of animal life; other fish, water birds and mammals are consumed in enormous numbers. From its concealment, like a beast of prey it darts out suddenly on its victims and seldom misses its mark. The pike is even more destructive than the pickerel, and two of the latter, measuring 5 inches in length, have been reported to eat more than 100 minnows in a day. Spawning takes place in winter and early spring on shallows and frequently on orerflowed meadows. The eggs are about $\frac{1}{8}$ inch in diameter, and a female weighing 32 pounds was estimated by Buckland to contain 595,000. The young pike has a rery large yolk sac. The period of hatching varies, with the temperature of the water, from 14 to 30 days. The female is said to be larger than the male; the fish breeds at the age of three years. At the age of one Jear the fish may reach a length of 12 inches, and, if well supplied with food, it will increase in weight from 2 to 3 pounds yearly.

The pike is a fairly good food fish and forms an important element of the Lake Erie fisheries. As a game fish the species is widely known; it can be readily caught by trolling or spinning or on lines set under the ice. Live minnows and frogs are favorite baits; and Dr Henshall says it will rise to a large, gaudy fly. In Lake George the white chub is one of the best known baits.

\section{Subgenus mascalongus}

The largest member of the pike family is the single representative of the section Mascalong $\mathrm{us}$, in which the lower half of the cheeks, as well as of the opercles, is scaleless. The scales are smaller than in the other groups.

The sides and rertical fins are profusely covered with roundish black spots on a pale ground. The branchiostegals number 17 
(1) 1!). I color raliety is orasionally met with having the body uniformly dark gray, unspotted.

\section{Lucius masquinongy (Mitchill)}

\section{ILascalonge; Spotted Mascalonge}

Esox masquinong!! Mrrcmil. Mirror, 297, 1824, Lake Erie.

Esox masquinong!y (Mtitchild) Kintland, Fishes of Ohio, 194, 1838, Lake Erie.

Esor nobition Trompsox, Proc. Bost. Soc. Nat. Hist. III, 163, 1850, Lake Champlain; Jordax \& Gubert, Bull. 16, U. S. Nat. Mus. 353, 1883; Bedx, Fishes Penna. 93, pl. 29, fig. 57, 1893.

Incius mesquinongy Jordax \& Evermans, Bull. 47, U. S. Nat. Mus. 629, 1896. pl. C, fig. 270, 1900; Everuann \& Kendalt, Rept. U. S. Commr. Fish of Fisheries for 1844. 598, 1896.

Thor mascalonger has a stout and moderately elongate body, its greates defols, midway between the pertolal and remtral tins, one fifth lo one sixth of the total leugth to the end of the scales. Thu raudal poduncle is short and slender, its depth one third of writest dwilh. The length of the head is two serenths of the fotal without the ('andal, and the small eye equals iess than one fonth the length of snout. The ere is nearly in the middle of thr length of the head. The mouth is rerg large; the maxilla (xtends to helow the hind matgin of the ere. The teeth are as in the pike. hut ('ven more formidable. Trorsal and anal fal latrk. Ihe wrein of the former a little in advance of the anal

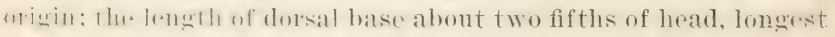

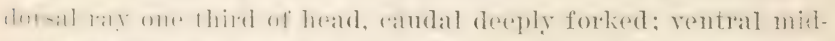

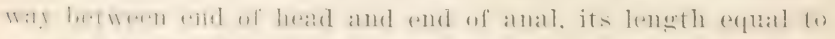

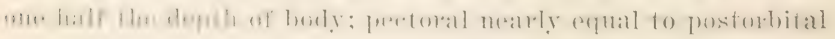
pill of hrat. B. 17-19; D. $17 ; A .16 ; \mathrm{V} .12$. Scales in lateral line: 150 .

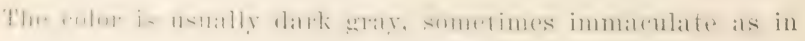
the colol valiety i m m a $\mathrm{m}$ la tus, but generally with numer-

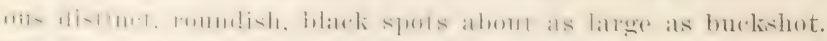

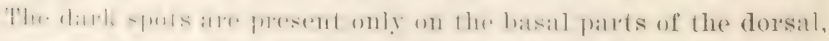
amal and randal fins. 'The lower patres ate pale, the belly white.

Thr. na:mor af this wiant pilir is apparrently derived from the

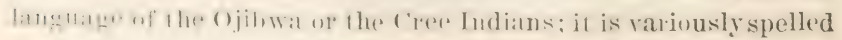


and its meaning is uncertain, though the roots, according to: H. W. Henshaw, are probably mask (ugly) and kinongé (fisb). In the books it appears as muscalonge, muskellunge, muskallunge. mascalouge and maskinonge, all variations of the same term. Some writers style it the great pilie, and by other's it is confused with the common pike, E. l u c i us. Prof. Cope mentions also. the name blue pike.

The mascalonge is recorded by Prof Cope from Conneaut lake, Crawford co. Pa., the specimen measuring 17 inches in circumference behind the eyes. It is found occasionally in the Ohio valley. The sureies. howerer, is most abundaut in the Great lakes region. In Lake Erir favorite loealities are Thmkirk and Barcelona N. Y., Erie Pa. and Nills' Grove O. The northern limit of the fish is not definitely fixed.

It is asserted by some proms that the fish inhabits Cayuga lake, but others deny this. In Meek was unble to find it there after diligent search. It was known in Lake Champlatin name than a half century ago and wis described by Rev. Zarlock Thompson. Mitchill and Kirtland had it from Lake Erie. De Kat confounded thr mascalonge with the pilit, and apparently had no example of the formere. In the st Lawrence river the species is well known.

It is recorded that in $1865 \mathrm{Mr}$ s.chultz canght a mascalonge at Milwaukee weighing 100 pounds. In 1861 Fred Ilvord declared that he had an 85 pound specimen in Maumee bity. The arerage length of the species is about is feet, and there is reason to believe that a leugth of 8 feet is sometimes rearcherl. Individuals weighing 50 pounds are moderately common. With the exception of the lake trout and some of the salmon, his is undoubtedly the largest game fish in the United States.

The fish seem not to be gregarious, but oeem malully in pairs. Their food consists mainly of smaller fishes, and their voracity is notorious. In the spawning season in small rivers falling into Lake Simeoe, Richardson states that they foed on small fishes and on gelatinous green balls which grow on the sides of banks under the water. 
This is an excellent food fish, but not common enough to hare much commercial importance. Is a game fish it has few superjors. The spoon bait is rery effective in the capture of malsialonge, and live fishes are extensively used. A correspondent of Land and IIater describes a singular and successful lure male from a young brown calf's tail, through the center of which the shank of the hook was passed and fastened to a swivel.

\section{1.:- Lucius masquinongy immaculatus (Giarrard)}

\section{Unspotted ICascalonge; Barred Mascalonge}

fistr immurmlutus (i.Mra.ARI) Ms: noticed in several fishing journals, Eagle

Lake, Northern Wisconsin, fide Jordan \& Evermans.

Esox masquinongy immaculatus Jordar, Man. Vert. ed. 5, 89, 1888.

Lucius muxquinum!l immuculutus Jordax of Evermaxn, Bull. ti, L. S. Nat.

Mus. $630,1896$.

Lucius lurius immuculatus BEAN, by error, Bull. Am. Mus. Nat. Hist. IX, 353,1897 .

Iboly molerately stout and elongate, its greatest depth one sixth of the todal length without caudal; least depth of candal freduncle contained two and two serenths times in greatest depth of bodr, and nearly four times in length of head; head long, its length nearly three and three fourths times in total without ratulal: the maxilla extending to below the front edge of the jupil, its length about one third of length of head; snout abont two fifths as long as the head; eye about one elerenth as long as the heats: the grill rakers mere clumps of spiny tubercles. The dersal tin is distant from tip of snout a space equal to two and three fourths times length of head; the longest dorsal ray is three s.opuths as long ats the head, and only a little longer than the dorsal hiane. The rentral is nearly as long as the snout. The ana! base is me third as long as the head; the longest anal ray is as lomg as the snont, and equal to the pectoral. B. 18-19; D. 16-1s ateveloped ratsis; 1. 15-16 (developed rays). Scales about

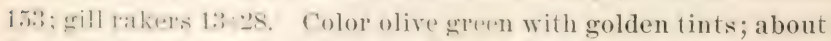
20 rulire, botehlike, irregular dark cross bands and sereral farts of batuls and hlotehes intervening: lower third of pectoral pink: dersal, candal and anal with dark hlotches forming pseudohamal-; iris f.mon yellow on a silvery white ground; no black sprots. 
Examples of unspotted mascalonge were received at the New York aquarium from Chautauqua lake, N. Y. which belongs to the Ohio river drainage system. It appears that the typical spotted form also inhabits the Ohio basin, but occurs rarely. $\mathrm{Mr}$ Annin sent one individual Dec. 4, 1895, and two on May 4, 1896; from these three were obtained the following notes and measurements in inches.

\section{MEASUREMENTS}

Dec. 4, 1895 May 4. 1896 May 4, 1896

Length, including, caudal fin.......

Iength to end of scales...........

Length of caudal lobe (horizontally).

Length of middle caudal rays......

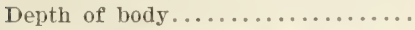

Least depth of caudal peduncle...

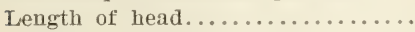

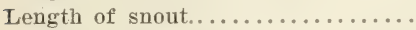

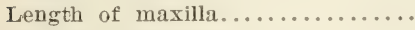

Length of mandible.............

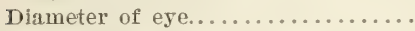

Distance from snout to dorsal.....

Length of dorsal base...........

Length of longest dorsal ray.......

Distance from snout to ventral.....

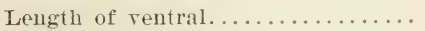

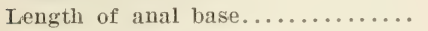

Length of longest anal ray........

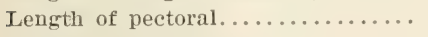

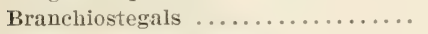

Dorsal rays (developed)...........

Anal rays (developed).............

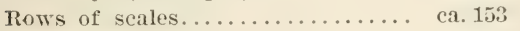

Gill rakers ............... $13+28$

\begin{tabular}{|c|c|c|}
\hline $231 / 2$ & $27^{1 / 8}$ & $257 / 8$ \\
\hline$\ldots \ldots$ & $237 / 8$ & 23 \\
\hline $35 / 8$ & ........ & $\ldots$ \\
\hline $11 / 2$ & ...... & $\ldots$ \\
\hline $35 / 8$ & 4 & $37 / 8$ \\
\hline $11 / 2$ & $13 / 4$ & $15 / 8$ \\
\hline $5 \%$ & $65 \%$ & $61 / 8$ \\
\hline $23 / 8$ & $2 \frac{3}{4}$ & $21 / 2$ \\
\hline $21 / 2$ & $23 / 8$ & $21 / 8$ \\
\hline $33 / 4$ & $41 / 4$ & $3 \%$ \\
\hline $1 / 2$ & 1ช & गี \\
\hline$\ldots \ldots$ & $181 / 8$ & $163 / 4$ \\
\hline$\ldots \ldots$ & $23 / 4$ & $27 / 8$ \\
\hline$\cdots \cdots$ & $2 \pi / 8$ & $25 / 8$ \\
\hline$\ldots \ldots$ & $131 / 2$ & $123 / 4$ \\
\hline$\ldots \ldots$ & $21 / 2$ & $23 / 8$ \\
\hline$\ldots \ldots$ & $21 / 4$ & $2 \frac{5}{15}$ \\
\hline$\ldots \ldots$ & $23 / 4$ & $2 \mathrm{\tau}$ \\
\hline ..... & $23 / 1$ & $21^{9}$ \\
\hline 19 & 18 & 19 \\
\hline 18 & 16 & 17 \\
\hline 16 & 15 & 15 \\
\hline
\end{tabular}

In all the specimens the maxilla exfends to below the front edge of the pupil. The gill rakers are mere clumps of spiny tubercles. In the two males the diameter of the eye is contained from four and one third to five times in the length of the snout, and from 10 to 11 times in the length of the head.

In the indiridual of Dec. 4, 18!). the lateral line tubes are distributed over various parts of the sides without much regularity except in the median line. There are no black spots. About 20 entire, blotchlike, irregular rooss bands and sereral parts of bands and blotehes intervening. The lower third of 
the fuetoral is pink. The dorsal, caudal and anal with dark hotrhes making gsemelo bands. Iris lemon yellow oreilying silvery white. The gemeral eolor is olive green with golden tints.

The 1 wo males of May 4 , 1896, fumished the following color notes.

Olive green tinged with golden bronze; sides with ahout 23 irregular dusky blotches resembling interrupted bands: dorsaỉ, caludil and anal with numerous large dusky blotehes, those on dorsal and anal almost forming bands; iris lemon pillow and silvery in the lareger, almost rermilion and orange in smatlar : a dark bloteh at upper edge of opercle.

The Chantaufua lake mascalonge, according to James Anuin jre who seme the speermens, is a very fine fool and galle tish,

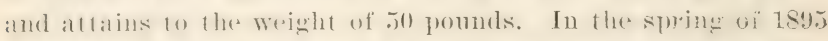

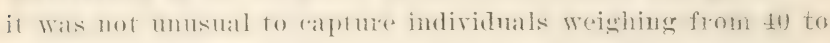

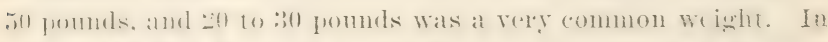
wintere the tish frepluent meally the same localities as in summere, lw-ing fonme in the virinity of water plants. When the lake

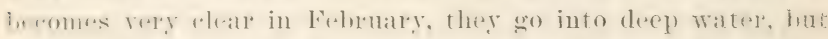
they live in deep water more or less all the year.

Fur the tish millure operations the nets are set as soon affer tire first of Ayril as the iee latres the lake. The fish begin to syan a a lin days after and rontinue till the latter part of April.

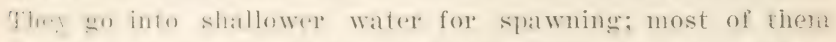
syatwa in from lo to 1.5 feet of water. They do not resort in lhe. gratrel, like many other fish, but to mud, eqenerally going inte hals. The enges all flated in hoxes, all of which are prolisted with sereens at 10 a and bettom. The bottom has an extra

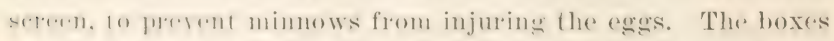
ale stuk from 1 fout to 2 feret moler the surface of the water.

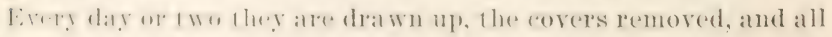
bad eagrs and sediment eleaned out.

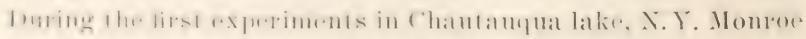

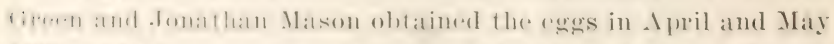

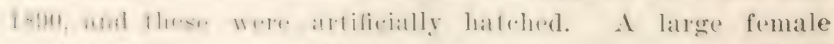

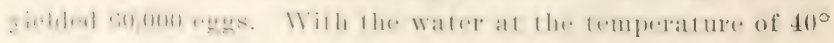


to $16^{\circ}$ very few of the eggs were developed, but when it meared $60^{\circ}$, in May, better results were secured. May 27, 7.,0mo soung fish were planted in the lake. The eggs were hatched in a box suspended about 4 feet from the bottom in 18 feet of water.

\section{Family pOEcIlimat}

\section{Killifishes}

\section{Genus fuxnulus Lacépède}

Body rather elongate, little elrvated, compressed behind; mouth moderate, the lower jaw projerting, jaws each with two or more series of pointerl teeth, usully forming a narrow band, bones of the mandible firmly united; scales moderate; gill opening not restricted above, the oprere with its margin not adnate to shoulder girdle; rreopere'e, rreorbital, and mandible with mucous pores; dorsal and anal fins similar, suall, or rather large, the dorsal inserted either in front of, above, or behind, the front of anal; ventrals well developed; air bladder present; sexes differing in color, size, and derelopment of the fins, the anal fin in the male normal; intestinal canal short; first superior pharyngeal without teeth, second with teeth, third and fourth coossified, with treth. Species rery numerous, mostly American, inhabiting fresh watr's and arms of the sea. They are the largest in size of the crprinodnuts, and some of them are rery brightle colored. They are oviparous and feed chielly on animals. Some of them are bottom fishes, burying themselves in the mud of estuaries: others swim freely in river (chammels and bays; still other's are "top minnows." surfare swimmers, feeding on floating insects in swamps and streams.

\section{Fundulus majalis (Walbaum)}

\section{Bass Killy}

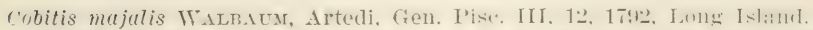

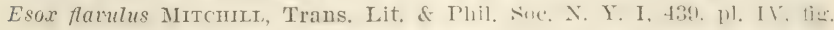
8, 1815, New York:

Esox zonatus MitchilL, op. cit. 440, 1815, New York.

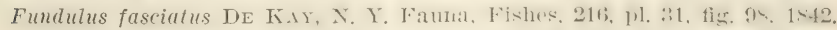

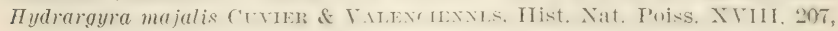
1846. 


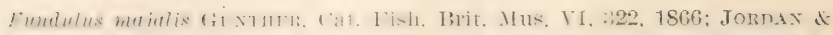
Gilbert, Bull. 16, U. S. Nat. IIus. 331, 1SS3; BEAx, 19th Rep. Comm. Fish. X. 1. 274, pl. XXII, figs. 2s \& 29. 1890; Fishes Penna. S4. yl. 27. fig. 51, 15!n; Jondx a Fremaxx, Bull. 47. T. S. Nat. Mus. 630, 1896. pl. CI, figs. 271, 271a, 271b, 1900; BEAN, 52d Ann. Rept. N. X. State Mus. 9S, 1900.

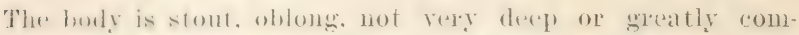

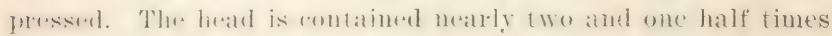

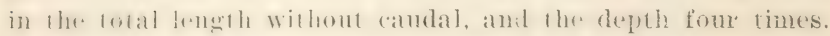
Thr. smont is moderately long. one and one half limes as loug

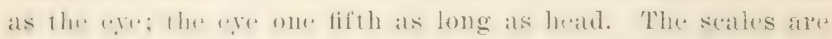

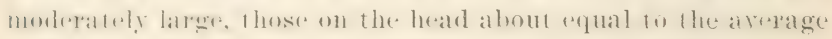

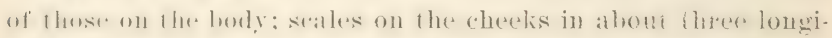

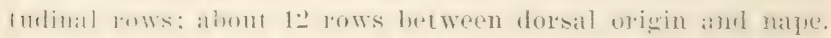
The ferelolal in huth sixes equals the distance from the midelle of the ere to the end of the hearl. The rentrial and anal are bomgere in the mate thatn in the female. In the mate the remital is one half as lomg as the head, in the female only about cou fifths of the heate. The longest anal ray of the male reblals form tifths of the length of the heate, while in the fomate it is srawely more than one half as long as the head. The dorsal of the male is differently shaped from that of the female, its lias rays lu.ing maty as long as the longest. while in the femal

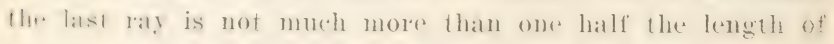
longest ray. D. 13-14; A. 11. Scales 35-15.

The sexes maty he at once distinguished by their differenes

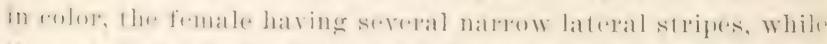
(hr. mal, has distinet eloss bamds ratrying from 12 to 20 in numBer. In the male the sides and uplue farts ale dark olivaceous;

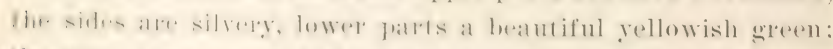

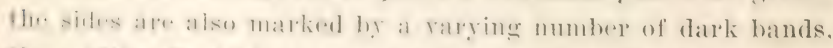

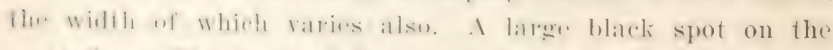

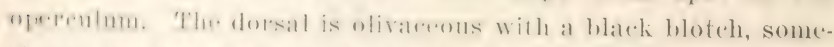

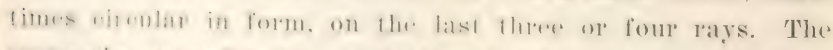

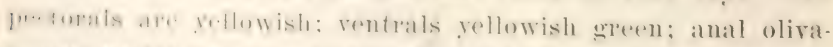

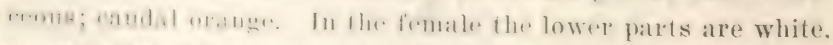

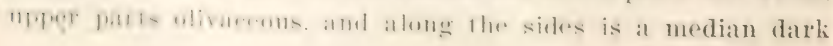


band, and below this are two short, interrupled dark hars. Two or more short. transverse, dark bars on the caudal peduncle.

The striped killifish, also known as the banded or striped mummichog, bass mummy, bass fry, mayfish, yellow-tail, and New York gudgeon, is the largest member of its family known on our eastern coast. Its range extends from Calpe Cod to Florida. Prof. Cope thinks that in Pennsylrania it frobably ascends the Delaware as far as the boundary of the state, and I see no reason to doubt its occurrence eren in fresh water.

The female is usually larger than the male, and examples measuring 8 inches in length have been recolded. It swarms in shallow balys and salt marshes, and though not used as food, it is extremely important for the subsistence of rennomic species and is, also, extensively used for hait. The name bass mummy, applied to the speries on Long Island, refers to its use in the capture of striped bass. The speries breeds in smmmer, and the roung arr abundant in shallow water among eel grass and other aquatic plants.

A permanent resident in Gravesend bay. In winter it inhabits deerp, muddy holes at the mouths of ereelis. In captivity it is the least hardy of all the marine killifishes.

\section{Fundulus heteroclitus (Linnaeus)}

\section{Killifish; Ifummichog}

Cobitis heteroclite Lrwyat's, Syst. Nat, ed. NII, I, 700, 1766, Charleston, S. C.

Poerilia macrolepirlota Walbalas, Artedi, Gen. Pist. III, 11, 1792, Long Island.

Esox pisciculus Mitchild, Trans. Lit. \& Phil. Soc. N. Y. I, 440, 1815, New York.

Esox pisculentus Mrtchil, op. cit. 441, 1815, New York.

Fundulus viridescens LE K.1Y, N. Y. Fauna, F'ishes, 217. pl. 31, fig. 99. 1842, New York.

Fundulus zebra DE KAY, op. cit. 218, 1812, New Tork.

Fundulus pisculentus STORER, Hist. Fish. Mass. 294, 1867.

Fundulus heteroclitus Gíntmen, Cat. Fish. Isrit. Mus. VI, 318, 18f6; Jornar \& Gilbert, Bull. 16, U. S. Nat. Mus. 336, 1883; Bean, 19th Rep. Comm. Fish. N. Y. 274, pl. XXIII, fig. 30, 1890; Fishes Penna. 86, pl. 28, fig. 52, 1893; 52d Aun. Rept. N. Y. State Mus. 98, 1 M0.

Fundulus heteroclitus macrolepidotus JorIsix \& Evermann, Bull. 47, U. S. Nat. Mus. 641, 1896, pl. CII, fig. 273, male, 1900; Mearns, Bull. Am. Mus. Nat. Hist. X, 317, 1898, salt creeks along the Hudson. 
The borly is short and stout in both sexts; its depth one fourti of the lenglh ineluding the tail and slightly greater than the Wngth of the lead. The lead is mothrately short, with an whase snoni and the space between the eves rery flat. The lower jatw projerts slightly. The ege is about two thirds as long as the snout and one fifth the length of the heatu. The pereforal reaches to the nintli or tenth reow of seate $;$ its leugth is equal to the base of the torsal. The riorsal is rensirderably nearer to the rnd of the tail than to the tip of the snont: its longest ray in the female one half the lengih of heat. The anai is rntirely under the dorsall: its longest raly enuals the hongest of the dorsal. its hase abont one third the length of bead. The rentral origin is under ahout the twelfth seale of the metian

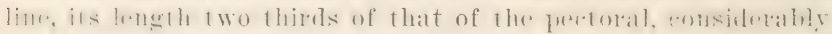
less tham half the head; when extended it reatehes neatly in rent. The least depth of the caudal peelunele is one serenth of

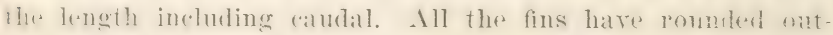

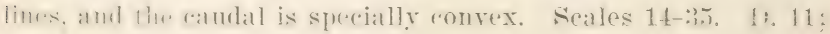
.1. 11 .

The frumales are nearly miform oliraceous, lighter leden: rambial with a metian natrow band of a palep rolor: most of the sagles having a narrow, dusky submareinal streak; the sealue of the hoal rery irregularly arranged amel unequal in size. The

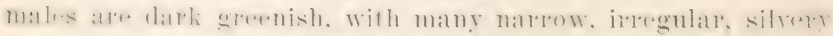
burs on 1he sides and with the belly yellowish or orange. The. sides all also more or less spettenl with white or yellow. The dureal. anal and ramblal are dark with many small pale spots.

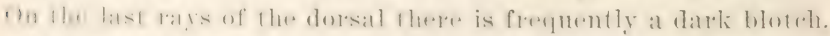

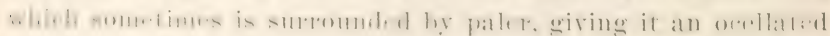

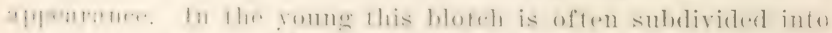
twe puth Xartow dark hatuls alre sometimes present in the young male.

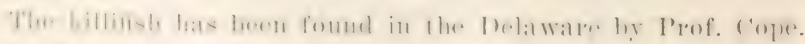

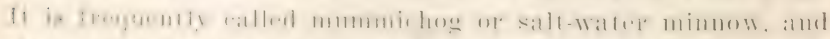

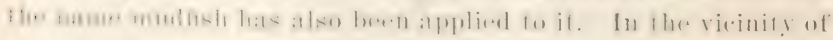
boston it is known to boys moler the name of cobbler, and on long Island it is called mummy or chogr-mummy. 
This is the killifish of selöptr. the yellow-hellied and the white-bellied killifish of Mitchill, and the big killifish and barred Millifish of Meray. The Indian name mummichog is applied to this as well as to of here slmejes, and some persons call it the saltwater minnow. In cireat south bay it is the mummy or chogmummy. It is extremely abundant in all parts of the bay, and serves as food for larger fishes.

The striking difference in the colors of the two sexes has led to their separation under distinct names by Mitehill, DeKay and other writers.

It grows to the length of 5 or 6 inches; it has no importance as a food fish, but is eaten in large numbers by many of the Taluable economic fishes, particularly the striped bass and the weakfish. Dr storer says it is an exeellent bait for smelts. Piscivorous birds consume it in large quantities, and domestic ducks have been known to swallow it with apparent great relish. Eggs have been found in this species as late as August. It spawns in the spring and early summer, and the roung are found in great schools in summor in the celgrass and on sandy beaches in company with other species of killifish, the common silverside and various other fishes.

The killitish is a permanent resident in Gravend bay, wintering in deep, muddy holes near the mouths of creeks. According to Eugene Smith, it stands captivity well and is often found landlocked in ice or quary ponds. The flesh has a sweet taste. The range of the species is from Maine to South Carolina. asually in shallow salt or brackish water, but sometimes ascending streams beyond tidewater.

\section{Fundulus diaphanus (Le Sueur)}

\section{Fresh-uater Killy}

Hullrargira diaphana Le Stetr, Jour. Ac. Nat. Sei. Phila. I, 130, 1S17, Saratoga Lake; DE FAY, N. Y. Fauna, Fishes, 219, 1842.

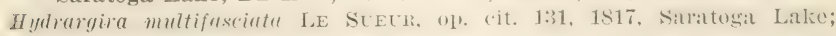
DE KAY, op. cit. 220.

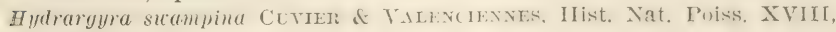
203, 1845, New Jersey.

Fundulus multifasciutus Gïvinst, Cat. Fish. Brit. Mus. VI, 324, 1S:6.

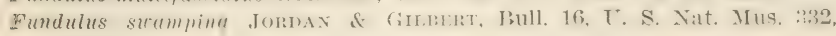
1883. 


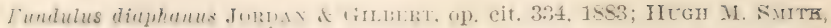
Bull. U. S. F. C. X, 65, 1890; Jordan \& Evermañ, Bull. 47, U. S.

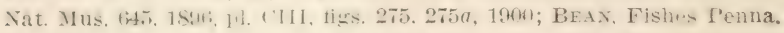
S5, 1893; 52d Ann. Rept. N. Y. State Mus. 9S, 1900; Mearns, Bull. Am. Mus. Nat. Hist. X, 318, 1898.

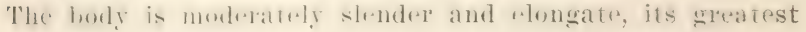
droth repualing almut two ninths of the total length witlout Lail, or somerwat less than the length of the head. The head

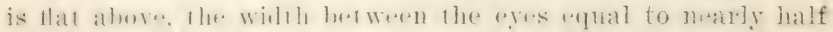

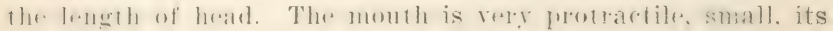

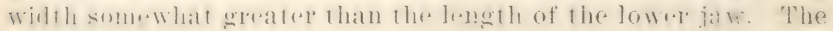

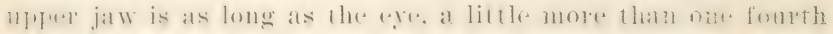

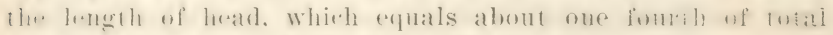

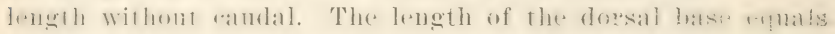

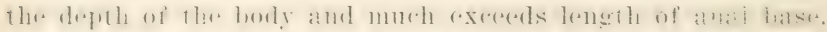

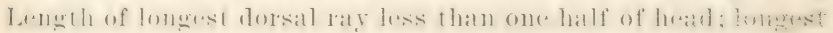

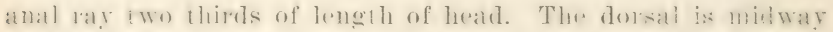

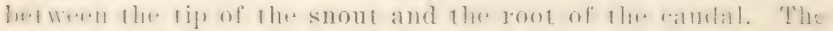

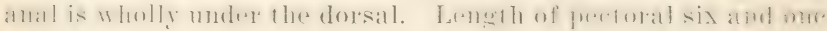

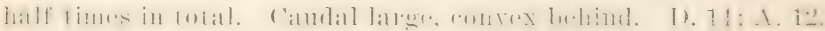
Scales 44-46-13.

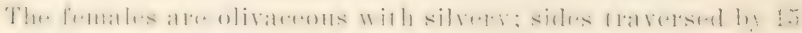

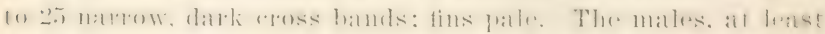

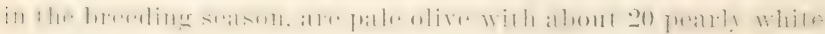
cross bands.

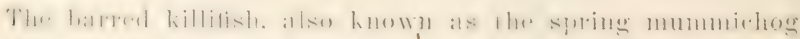

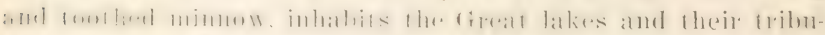

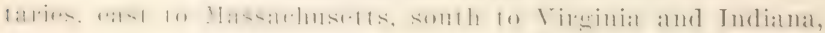
west to Colorato, according to Cope south to Texas. The species was first made known from Saratoga lake. It is rery abumclant in the Lake Ontario region, having been taken by I. s. Fish Commission collectors at the following New York Inealilirs.

Mnd rereek, Citpe Vincent

June 25

firruadier island. Latie Ontario

.Tune $2 \mathrm{~S}$

Morse island. Siarlietls Tlarbor

June 30

Mill rerek, Nalekells Marbor

July 2 
Stony Island

Little Stony brook, Henderson bay

Guffon creek, Chammont

Chaumont river

Great Sodus bay

Creek near I’ultneyville

Long pond, Charlotte
July 2 and 3

July 4

July $\tau$

July 10

Aug. 6

Aug. 7

Aug. 17

St Lawrence river, 3 miles below Ogdens-

burg

July 17

Acording to 1 ). Mrek, it is common on the flats and in the southeru end of Cayuga linke, also in streams on the uplands, at Cayuga and Montezuma. Ir Jearns took it in Echo lake and Long pourl of the IIudson IFighlands. The state mustum secured numerous individuals from shinnecock bay July 21, Scallop pond, Peconic bay July ¿\&, and Mecox bay Aug. 1, 1898.

The fish is very common in a lake at 110 th street and 5 th avenue, Central park, New York city.

In Eugene smith's experience the speries throve better in the aquarium than amy other killitish except F n nd ulus heteroelitus, and became very tame in raptivity, though always attacking the fins of other fishes. In the New York aquarium the fish proved to be rery delieate, usually dying from fungus attaclis before the salt water treatment remored the parasite.

In Ohio, and west, is found a rariety with rery distinct and somewhat irregular hands and the back always spotted, which has been called variety me nou a by Jordan and Copeland. Eastern specinens hate the back unspoited and the cross bands faint and regular, lut extremely variable in number. The difference in coloration of the sexes is very striking. sperially in the breeding seasom, when the alull males have silvery cross bands.

The barend killitish grows to the lenght of 4 inches. It rums down into brackish waters along the cast roast and ascends far up the streams, dulighting in cold watrer. It is raten in large numbers by the stripul hass and lla watish. In the fresh waters the black bass and trout also feed on it. 


\section{Genus Locara Girard}

The body whlong, compressed; lower jaw frominnest. the eleft uf the month short and very oblique: mouth moderate. the suout

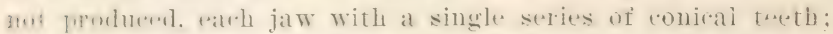

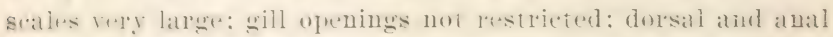
rays in moderate number. the dorsal ahore or shighty in adrame of the anal; anal fin not modified in the males. Viry small. wiparous tishes of the bratckish waters. swat? in ant shallow bass of the United States.

\section{Lucania parva (Baird \& Girard)}

Raimuater Fish

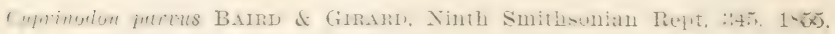
Greenport, Long Island; Güxthen, Cat. Fish. Brit. Mus, VI, 30i. 1866.

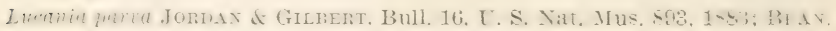
Bull. U. S. F. C. VII, 148, pl. II, fig. 1S, 1Sss; 19th Rep. Comm. Fish. X. Y. 275, 1830; Hugh M. Smth, Bull. U. S. F. C. X. 6S, 1890; JoRdAT \& Evemana, Bull. 47, U. S. Nat. Mus. 665, 1896, pl. CIX, fig. 292, 1900; BeAr, 52d Ann, Rept. N. Y. State Mus. 99, 1900.

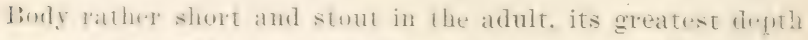

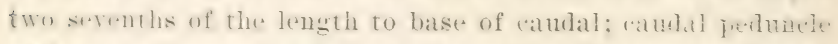
moderately long and dexp, its least depth nearly ome half tb: l.1tell of head; the mouth small, oblinge. with heary projectinge lowne jaw : snout short. nearly epulal to ere. about two ninthes as longe as lhe heanl: ege rather larege its horizontal diameter fwo seforthe as lung as the head: heatl stout, with obtuse muz.

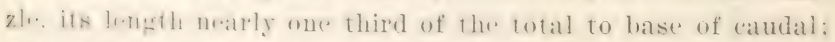
den-al migin millwa! hetwer.le tip of smomt amb hase of midde

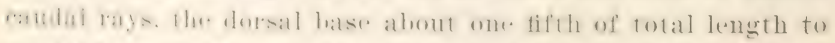

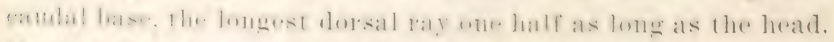

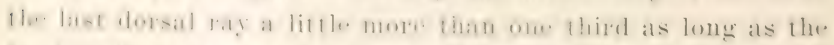

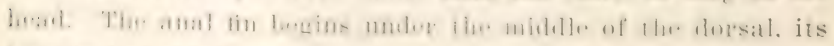

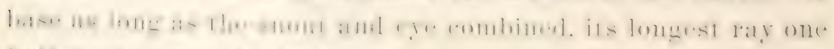

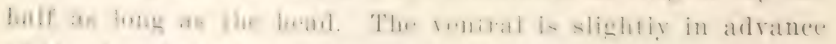

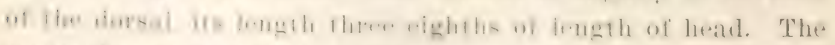

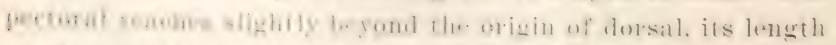

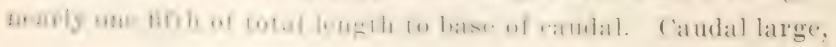




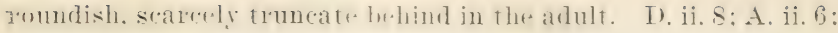
T. i, อ. Scales 10-2T.

Color in life: males olive or pale brown, with bluish reflections, edges of the scales dartiel, dorsal dusky orange, sometimes with a large. blark spot at the base in front, ocellated with orange, atulal orange rellow. tipped with black, rentrals and anal orange red. tipund with dusky. pectorals translucent; females with the fins pale olire. without black spot or edgings. Length $1 \frac{1}{2}$ to 2 inches.

The sprecies is fouml alumg the coast in hrackish waters from Massallhusetts to Florida: rery rommon on Loug Island. Abunsiant in Peconir. Shinnerock. aud Great south bays, and in a fresh-water stram at Water Mill L. I.; not ret reported from firaresend hay. It seldom exmeds 1? inches in length and is interesting chitefly on acrount of its translucent body and grace. ful movements. It has not fonved hardy in captirits.

The species was first described by Prof. Baird from Green. jort L. I.

\section{Genus cromixodox Lacépède}

Bodr very short and stout, the back elerated; mouth small, the bones of the jaws well formed: snout slort; teeth modrate. incisorlike, trirnspid, in a single series: seales ver's large: dorsal fin moderate. inserted in adrance of front of anal, its first ray not enlarged : anal smaller: rentral fins small. oecasionally wanting in specimens from destrt pools: intestinal canal little longer than hody: gill me-mhranes ansiderably united. free from the isthmus: gill ofenings restrirted. the opercle abore adnate to the shoulder girdle. Chuhby little fishes. inhabiting the brackish waters of middle America. sometimes liring in marm salt springs. their colors generally hrilliant. Oviparous; the sexes similar except in color.

\section{Cyprinodon variegatus Lacépède}

\section{Sheepshead Irinnow}

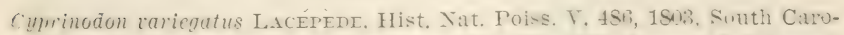
lina; Guxther. Cat. Fish. Brit. Mus. TI, 305. 1Sti6; Jondix \& Gilment. Bull. 16, L. S. Nat. Yus, 329. 1s-3; BExx, Bull. T. S. F. C. VII. 14S, 1SSs; 19th Rept. Commrs. Fish. N. Y. 275. 1san; 52d Ann. Rept. I. Y State Mus. 99. 1900; Jondux \& Everaraxx. Bull. 47. L. S. Yat. Mus. 671. 1896, pl. CXI, fig. $296,-296 a, 1900$. 
Esox olinus Mrtchili, Trans. Lit. \& Phil. Soc. N. I. I, 441, pl. IY, fig. 7 , 1815, New York.

Letios ovinus DE KAY, N. Y. Fauna, Fishes, 215, pl. 27, fig. 81, 1812.

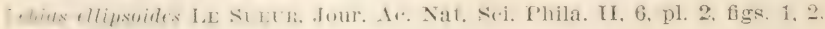
1821; Storer, Syn. Fish. N. A. 179, 1816.

Louly short and stout. leavy anteriorly, its width more than we half its hight, its greatest hight two fifths 10 nearly one half of total longlh to hase of candal. the males higher that the frmales; atulal pedmmele short, its least depth equal to fustorbital pall of head: head coniral, its wirlth at gill corers epual fo its longh without the snoist, its length one thired of folal withoml ratulal; jaws rery short, mouth smatl, ferminal, slighily obligue when rlosed, the lower jaw somewint promi-

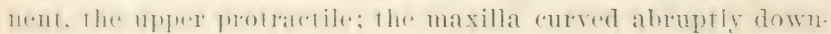
wall at the end. about as lane as the ere. not learhing to the

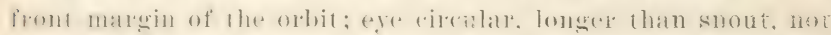

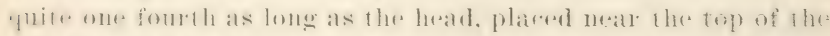

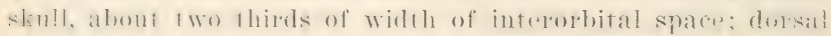

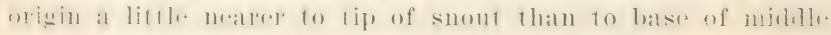

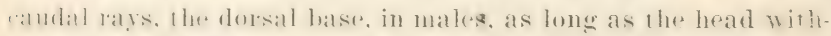

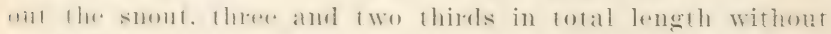

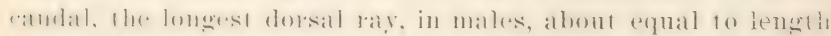

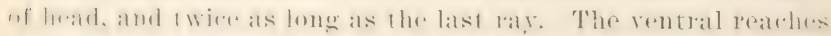

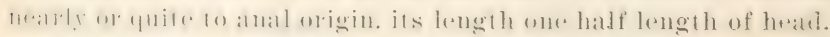

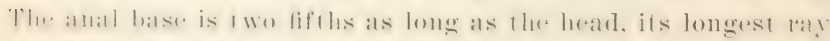

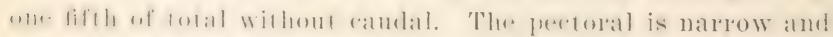

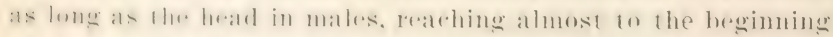

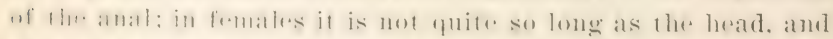
fores mol reateh leyomel the midelle of the lentral. Caludal tin

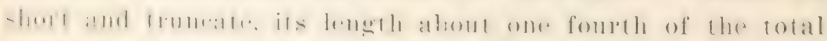

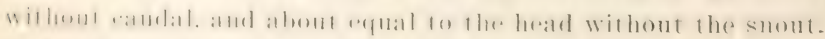
1). 11: 1. 10: B. 6. Seales 17-2S.

This is known in Gireat south bay as the porgy mummr. dfitehill recorded it as more rare than the other killifishes. heliay has it as the Sheepshead Lebias.

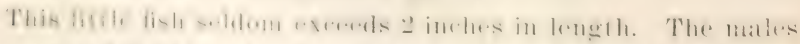

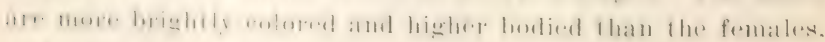
and have a narrow, dark malgein to the candal fin. 
The sheepshead killifish ranges from Cape Cod to Florida. It is not important except as food for other fishes. Tery common in salt water ditches.

One of the best of its family for aquarium purposes, as it thrires and breeds in captirity: the roung, howerer, may be eaten by. their parents.

\section{Order SYNENTOGNATHI}

Family ESOCIDAE

Needlefishes

\section{Genus tylosurus Cocco.}

Body elongate, vary slender, not much compressed; both jaws prolonged into a beak. the lower jaw somewhat the longer, much the longer in youm fishes, the rery young resembling Hemiram ph us ; rach jaw armed with a band of small, sharp teeth, beside which is a series of longer, wide set, sharp, conical, unequal teeth; no teeth on vomer or fralatines; seales small, thin; lateral line rumning along the side of the belly, becoming median on the tail; no finlets; dorsal fin more or less elevated anteriorly; caudal fin short, unequally lunated or forked; pectorals moderate; rentrals small, the latter inserted behind the middle of the hody: gill rakers obsolete; bones usually more or less gremn; size comparatively large. Species numerous. Toracious fishes, chiefly American; one species crossing to Europe; some of them entering rivers. This genus differs from the old world genus Es ox (Linnaeus) Rafinesque (= B e lo n e, Cuvier) in the absence of gill rakers and of romerine teeth.

\section{Tylosurus marinus (Walbaum)}

\section{Billfish; Sitver Gar}

Esor marinus Walbaum, Artedi. Gen. Pise. III, SS, 1792, based on Schöpr, Sea Snipe, Long Island.

Esox longirostris Mitchul, Amer. Month. Mag. II, 322, March, 1S1S.

Belone truncate Lf. Sufur, Jour. Ac. Nit. Sei. Phila. II, 126, 1S21; De KAY, ‥ Y. Fauna, Fishes, 227, pl. 3\%, tig. 112, 1842; fünther, Cat. Fish. Brit. Mus. YI, 244, 1666; Storer, Hist. Fish. Mass. 136, pl. XXIT, fig. 3,1867 .

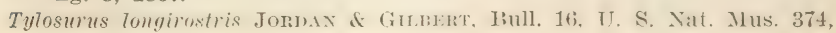
1883. 
Thlosurus marinus Jordan \& Fordice, Proc. U. S. Nat. MIus. 351. 1856; BEAN, Bull. U. S. F. C. VII, 146, 18ss; 19th Rept. Commls. Fish. N. Y. 273, 1890; Fishes Pemna. 97, 1893; Jordax \& Evermaxx, Bull. 47, U. S. Nat. Mus, 714, 1596; Mearss, Bull. Amer. Mus. Nat. Hist. X, 318, 1898; BEAN, 52d Ann. Rept. X. Y. State Mus, 99, 1900.

benly long. slemder and somewhat compressed. The depth of the body is less than one fifth of length of head: thr. "xe is Jather larege, two fifths of the length of the postorbital pirt of the heat. The pectoral is as long as the postorbital maxt of the head and twire as lomg as the ventral. The ristanee of the dorsal from the root of the catudal is one fonth its alistance. from thr tip of the low(r) jaw. The anal ends mudri the eud of the dorsal and hegius in alvance of the dorsal vrigin. The ren$11: a l$ is almost equilistant from the root of the rambal ant the hind margin of the eye. D. 15 to $16 ; \mathrm{A} .15$ to $17 ; \mathrm{V} .6$.

The body is green with a broad silvery band along the sides and a dark har on the opereulum. The seales and hones are green.

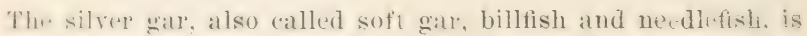
fomml along our coast from Maime to Texas, and, though at matrine species, it ascends rivers far above the limits of tirles. It has hern found in the Susquehanna river at Bainbridge l'a.. : Ind it alse runs up the Inelaware, the IIudson and other rivers.

s.lü̈rfl is anthority for the names sea pilie and sea suipe for

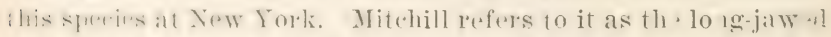

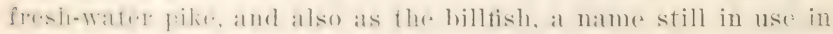

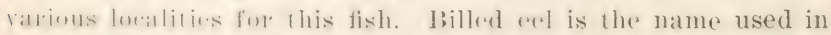

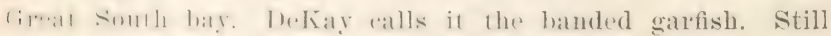

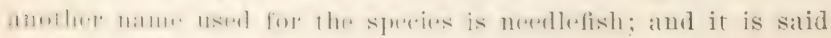
that gar is treriverl from a sianm word meaning needle.

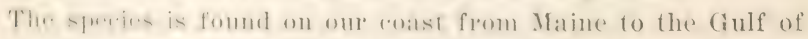

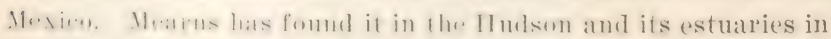

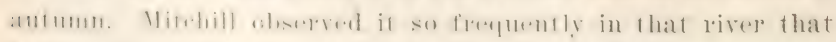
he considered it an inhabitant of fresh water. In Gravesend

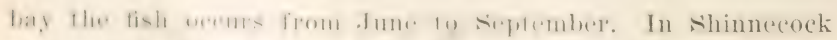

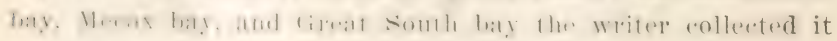
almost ererywhere. 
This species reaches a length of 4 feet. It is rery destructive to small fishes, which are readily seized in its long and strongly toothed jaws. In the Gulf of Mrxico the habits of the silver gar have been observed by Silas Stearns, whose notes are to be foumd in the Fishery Industries of the [nited States. It is found at Pensacola Fla. in the summer, but retreats farther south in the winter.

The silver gar swims at the surface and feeds on schools of small fish. On the New Tork coast it derours killifishes, anchovies, silversides, and other little species. Its movements are swift and its aim rertain. It has been known to seize mullet and other fish one third as large as itself and is sometimes killed by attempting to swallow spiny fish too large to pass through its throat. It spawns in the bays in May and June. $\mathrm{Mr}$ stearns found it to be an excellent food fish, though it is seldom eaten on the Florida coast.

Though the fish is our of excellent fiaror and, according to DeKay, greatly relished by epirures, it meets with little favor in northern markets. Nothing is recorded about its breeding habits except the statement of Silas Stearns that it spawns in the bays of the Gulf roast in May and June. The fish is not hardy in transportation and in captivity.

\section{Tylosurus raphidoma (Ranzani)}

\section{Houndfish ; Guardfish}

Belone raphiloma R.dxz.xi, Nor. Comm. Ae, Nat. Sci. Inst. Bonou. T. 3̈5, pl. 37, fig. 1, 1842, Brazil; G'Ntmer, Cat. Fish. Brit. Mus. VI, 249, 1866 .

Belone gerania Cevier \& Valenctexvis, Hist. Nat. Poiss. XVIIT. 497. 1846, Martinique; GüNTHER, op. cit. 241, 1866.

Belone crassa Poey, Memorias, II, 291, 1861, Cuba.

Belone melanochire Poer, op. eit. 24)4, 1861; Guxtmen, op. cit. 219. 1466.

Tylosurus gladius BE.1., Proc. L. S. Nat. Mus. 239, 480, 1SS2. Pensaleolat; Bull. U. S. F. C. VII, 146, pì. II, fig. 15, 18s8, Joung, Ocean City, N. J.

Tylosurus crassus Jordar, Proc. U. S. Nat. Mus. 112, 1881.

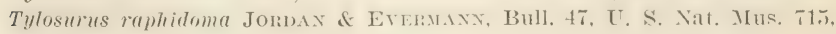
1896, pl. CXVI, fig. 308, 1900.

Body robust, little complessed, its greatest width a little more than two thirels its greatest depth, which is about one fourth 
the length of head and onre thirterenth of total to base of caudal; eandal perlunche slightly deperessed, a little broader than deep, wish a slight dermal kinel; head broal, broader above than below. three tenths of fotal length to base of andal: interorlital space nearly two thirds of length of postorbital part of head, with a broad. shallow, naked, median groove, which is wider behind and forks at the naje; supratehital hones with maliating striar; distane between nostrils a little more than one sixth of length of snout; jaws companatively short. strong. lapming, lery stiti, lower jaw wider and longer than upper, both jaws with boad bands of small teeth on the sides. within these a series of rery latere knife-sinaled texth. The lengin of the longest teeth is a lithle more thatn three times their hreadth. Posterior ath in both jaws directed backward, anterior tecth

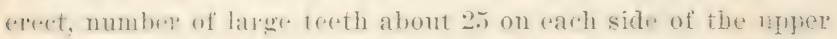
jaw and $2:$ below. leugth of the large teeth about one fifth of diameter of eye, no vomr.rine teeth. Epper jaw from eye about ont and three fomth times as lome as the rest of the heant: eye large, one severth as long as smout, three eighths of postorbital furt of head, and five ninths of interorbital width; maxillary

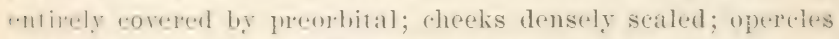
saly wuly along anterior malgin; srales minute, specially ofi the latek, somewhat lareger be-low. Dorsal tin rather high ic forn, beroming low posterionly, the hight of its anterior lobe

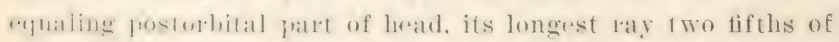
lenglt of dersal hase. In a young example, fit inches long, the prostrefor part of the dorsal is murh elerated. the longest ray equalume the distame from midmle. of pupil to end of head. iamdal tin lunate. its lower lole nearly one half longer than the ujyer: mithlle rays about as long as rye: anal fin falcate, low

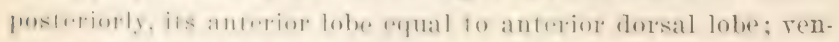
tral fins inserted midway bel weren base of calludal and middle of

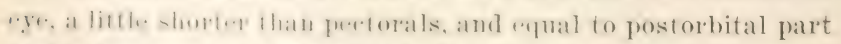

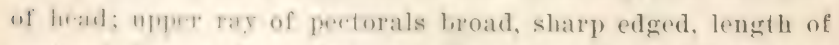
fwetoral chen and a wo firthe in head, and slightly gleater than

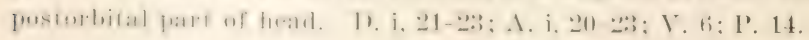


color dark green abore, silvery below; dorsal and pectoral blackish; rentrals somewhat dusky; anal yellowish. the lobe slightly soiled; caudal dusky oliraceous; no suborbital bar and no scapular spot: a slight dusky shade on upper posterior part of cheeks, and a rellowish bar on anterior edge of opercle; caudal keel black.

This speecies is very closely allied to T. fod i a to r Jordan \& Gilbert, describerl from Mazatlan, differing from it apparently in its longer jaws, slightly greater number of fin rays, and larger scrales. II rere described from the type of T. g l a di u s Bean, which is 29 inches long.

A young example was seined at Oeean City N. J. Aug. 1. 1587. D. i, 21; A. i, 20. Length $6 \frac{1}{2}$ inches.

I dark cutaneous flap attached along the side of the mandible and folded underneath, meeting its fellow of the opposite side and concealiug a small part of the lower jaw; dorsal black, except on the first six lays, which are pale, much elevated at the posterior part, where the longest ray equals the distance from the middle of the ere to the end of the head. 14 black blotehes on sides not extending to eaudal, the largest two thirds as wide as length of eye; paired fins and anal pale; caudal the same, except anterior half of upper lobe, on which the membrane corering the rays is black. while the intervals between the rays are pale; back greenish; under surface, except mandibular flap, silvery.

This species has not previously been recorded in the region.

The usual range of the species is from the Nest Indies and Florida Keys to Brazil; the young straying northward occasionally in summer. The fish reaches a length of 5 feet and is sometimes dangerous to fishermen in its powerful leaps from the water. The scales and bones are green; the flesh is little esteemed for food on this account. I description and figure of the young are published by Bean in the Rulletin of th. L. S. Fish Commission for 1887 , p. 146, pl. 2, fig. 15. 


\section{Tylosurus acus (Lacépède)}

\section{Houndfish}

Sphylnente acus LAcepede, Hist. Nat. Poiss. V, 6, pl. 1, tig. 3, 1503 , Martinique.

Belone latimana Poer, Memorias, II, 290, 1S61, Hatana; Güntrier, Cat. Fish. Brit, Mus. Y1, 249, 1866.

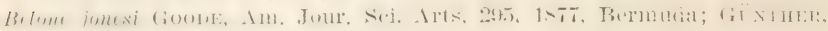

Ann. Mag. Nat. Hist. III, 150, 1879.

Belune crribbere Güntmer, Cat. Fish. Brit. Mrus. VI, 241, 1866, not of

LE SUEUR.

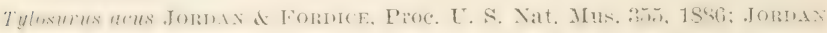

\& Evermanx, Bull. 16, U. S. Nat. Mus, 716, 1896, pl. CXV1, tig. 309. 1000 .

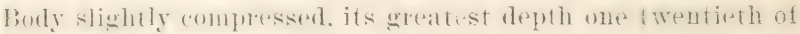
fotal lenglh, its greatest width about one twenty-1.ighth of the

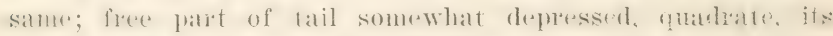

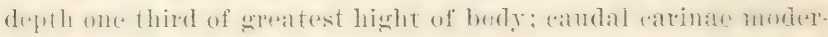

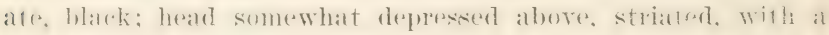
hrobl. shallow median groove whireh rxpands posterimly into at whle, sumewhat depressed triangulat area, length of heald renzttained there and one fomth times in total length without ratulal: supereilialy region sharply striated: snout equal to maxillatry. ume tiflh of total lometh, and thee times posturbital pat of head: mamblibe slighty shorter than distanee from smont to nafue. In times rertiral diameter of eye and frojerting beyond tip of uplue

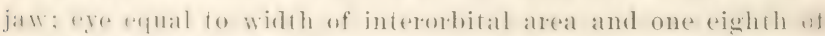

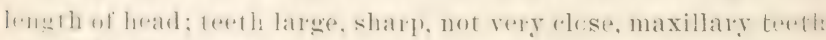

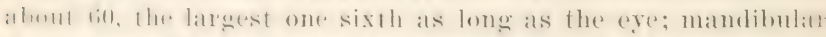

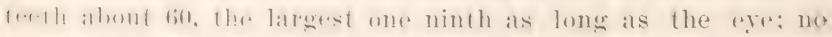

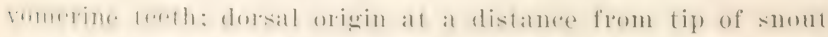

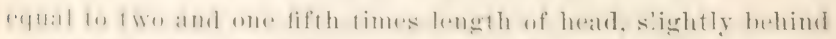

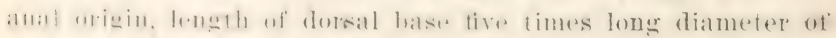

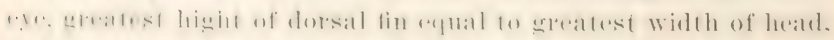

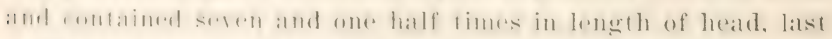

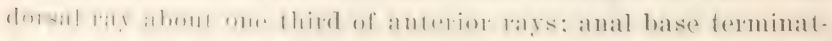

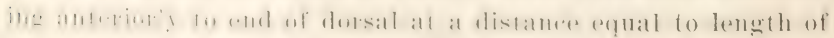
first dorsal ray; ventral origin midway between front of orbit

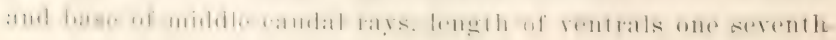


of length of head; length of pectoral slightly greater than that of postorbital part of head; caudal forked, the lower rays about one fourth longer than the upper. D. 23-24; 1. 21-2.); P. 13; T. 5; B. 12. Scales in lateral line (estimated) 380 .

Above deep green, below silvery white, opercles and cheeks silvery white, anterior rays of dorsal and pectoral fins blackish, caudal carinae also blackish.

"The houndfish, as it is called in Bermuda, is a graceful, active species attaining to the length of 3 feet or more. It frequents swift tide courses, where it preys upon small fishes, particularly the schools of silversides and anchories. It takes the hook well." Goode

The species occurs in the West Indies and sometimes strays northward as far as Buzzards bay in summer; it was first described from Martinique. Individuals have been recorded from. Beaufort N. C.

Family HEMIRHAMPHIDAE

\section{Balaos}

\section{Genus mpormamprus Gill}

Body elougate, moderately compressed, the sides of the body not rertical, but more or less convex; the dorsal outline parallel with that of the belly; upper jaw short, lower jaw prolonged into a slender beak, bordered with membrane, this beak shorter in the young; premaxillaries forming a triangular plate, the teeth of which fit against the toothed part of the mandible; maxillaries joined to premaxillaries; teeth feeble, mostly tricuspid; gill rakers rather long; head corered above with large, shieldlike seales; scales large, deciduous; no finlets; caudal fin more or less forked, the lower lobe the longer; dorsal and anal similar, opposite each other, not modified in the males, last ray of dorsal usually short; ventrals small, inserted well forward, nearly midway between operele and base of candal. Oviparous. Air bladder large, simple, not cellular. Joung with the lower jaw short. Sides in our species with a distinct silvery band, as iu A therina. Species numerous, in all wallm scias, 
gruing in large schools, but usually remaining near shore, feeding rhietly on green algae. Size comparatively small.

\section{Hyporhamphus roberti (Cur. \& Val.)}

\section{Halfbeat}

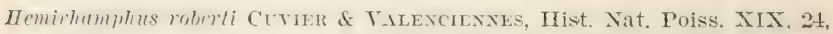

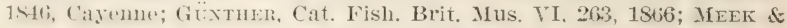
Goss, Proc. Ac. Nat. Sci, Phila, 223, 18s4; BEAN, Bull. U. S. F. C. VII, 147, pl. III, fig. 16, 18ss; 19th Rept. Commrs. Fish. N. Y. 274, 1890 .

ITenirhamphus unifusciatus Jornax \& Giebert, Bull. 16. I. S. Yat. Mus. $376,1853$.

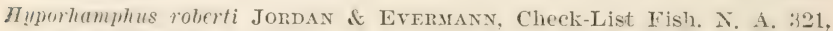

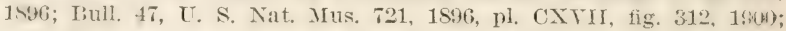
BEAx, 52d Ann. Rept. N. Y. State Mus. 100, 1900.

Body compressed, elongate, its greatest depth one eighth of total length to caudal base, its greatest width equal to postorbital part of head; caudal peduncle short and deep, its least depth mplual to eye. From eye to end of upper jaw equals one third the distance from end of mpper jaw to hind margin of oprele. Head including lower jaw three eighths of toral l+melh without caudal, without projecting part of lower jaw fwo werathe of the same; ere equal to interorbital width, alwat whre righth of length of head cone fourth of head to end

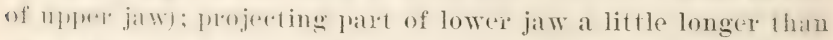
res of lwad: dorsal origin orer the anal origin, 34 rows of sales lwel wr..n it and the nalpe, base of dorsal equal to eye and

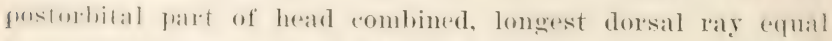

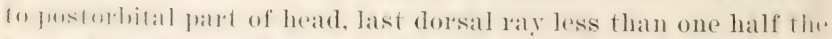
lon:erse and aboul two thirds of the ere; anal base slightly shorter thatn domsal hase. longest anal ray slightly longere than fostullital falle of head, last anal laty one half of eye; ventral

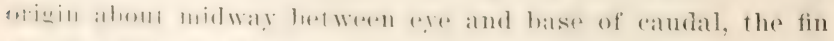

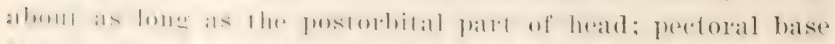

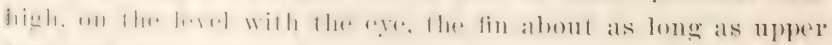

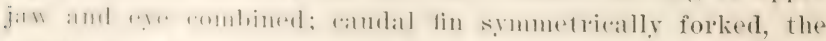

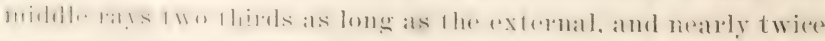

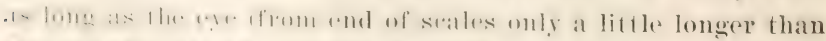

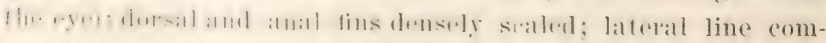




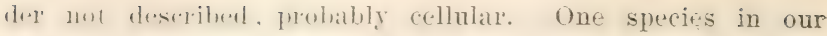
limits.

\section{Euleptorhamphus velox Poey (?)}

\section{Slender Halfbeak}

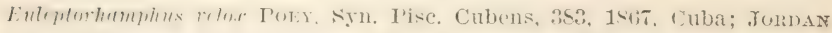
dE Erermaxy, Bull. 47, U. S. Nat. Mus. 724, 1896.

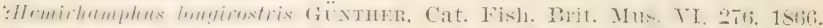

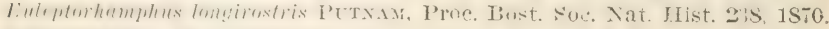

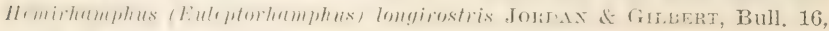
U. S. Nat, Mus. 37T, 1883.

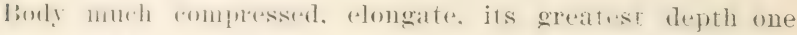

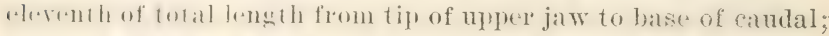
gleallest wilth of head refual to long dianeter of eye: least

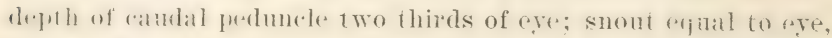
1hree and one thirel in head (length of bratd here is from tip of

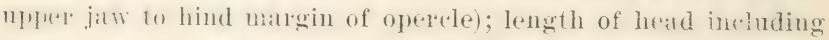
lowr. jaw I wo fifths of total to base of caudal, the lomer jatw forejerting beyond nypere a distance equal to three times rest

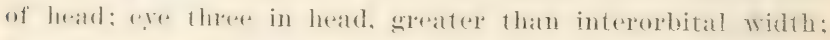
doisal migin at a distance from tip of snout equal to four and two thirds times length of head (without lower jaw), dorsal hase repual to nearly three times hight of body, longest donsal 1:1! I Wo thirds length of head; the anal begins nuder the third? ray of the dorsal, its base two and one third times hight of lod!y its longest ray equal to hight of body; rentral short. slighly shomere than rye. three and two thirds in head, extending nually half way to anal origin; pertorals long, reaching halt Way foum lextoral origin to anal origin, nearly twice as long as

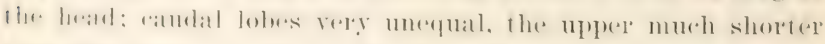

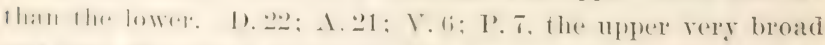

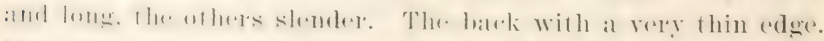

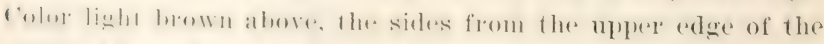

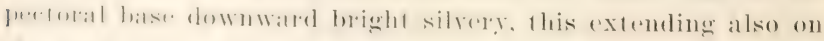
the he:ald.

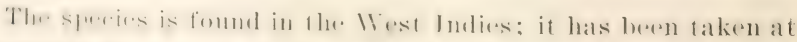
Vowport R. I., and at Cape Cod. It reaches a length of 18 inclues. The II emirhamphus macror hyehus of 
Guvier and Valenciennes, taken in the south Pacific, appears to e closely related.

Family SCOMBEIRESOCIDAE Sauries

\section{Genus scommeresox Lacépède}

Bodr elongate, compressed, corered with small, thin, deciduous seales, the general aspect being that of a mackerel; both aws in the adult more or less prolonged, forming a slender beak, the lower jaw always the longer, teeth very ferble, oninted, maxilaries joined fast to premaxillaries; pectoral and rutrals small; dorsal and anal low, sinilar to each other, each with four to six detached finlets, as in the Scombridae; gill aliers numerous, long and slender: pharrngeal boues essenially as in Exocoetus, fourth upere pharyngeal on each side wanting or fused with the third, third pharyugeal greatly nlarged, separate from its frllow, covered with tricuspid teeth, acond with simple teeth, first toothless, lower pharyngeals mited, forming a triangular bone with concave surface, covered with tricuspid teeth; into the hollow of this bone the upper haryngeals fit.

Pelagic fishes, swimming close to the surface in large schools n temperate regions. They hear strong analogic resemblances to the mackerels in form, color and habits, as well as in the lorsal and anal finlets. The significance of these resemblances s unknown.

Young with the jaws short, precisely as in the genus Coloa b is, but lengthening with age. which is not the case in Colola bis. Air bladder large.

Atlantic.

163 Scomberesox saurus (Walbaum)

Saury; Skipper.

Esox sanrus Walbaum, Artedi. Gen. Pisc. III, 93, 1792, Cornwall.

Scomberesox scutellatum LE Scecr, Jour. Ac. Nat. Sei. Phila. II, 182, 1S21, Newfoundland.

Scomberesox equirostrum Le Stexr. Juur. Ac. Nat. Sci. Phila. II, 182, 1821. 
Sicumberesox storeri DE KiY. X. Y. Fauna, Fishes, 229, pl. 34. fig. 111, 1St2, New York; Storen, Hist. Fish. Mass. 137, pl. XXIT, flg. 4, 1867.

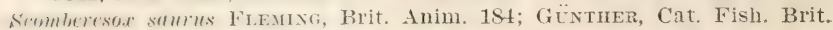
Mus. VI, 257, 1866; Goode \& BeAx, Bull. Essex Inst. XI, 21. 1879; Jominax \& (indint, Bull. 16, U. S. Nat. Mus. 375, 1853; Jorday \& Evermaxy, Bull. 47, U. S. Nat. Mus. 725, 1896, pl. CXVII, fig. 314, 1900.

body compressed, elongate, its greatest hight one ninth of total lengeth to base of caudal; anal equal to eye and postorbital part of head rombined; least hight of caudal pedunele equal to ere: both jaws slender and produced, the lower longer thau uplere, the distance from eve to tip of lower jaw equaling oue fifth of total to base of caudal; eye one third as long as postorbital part of head, about one fifth of length of npure jaw; small scales on operele, but none on suboperele; body covered with small scales; dorsal origin at a distance from front of eye equal to fire times hight of body, dorsal hase three times as long as the rye, longest dorsal ray one half as long as post orbital part of head, last dorsal ray equal to "ye, fire sefrarate finlots hehind the dorsal; anal under the dorsal, its base slighty Jongere as long as postorbital part of head, longest anal ray equal to longest of the dorsal, last anal ray seareely equal to (ye, six finlets hehind the anal; caudal fin deeply forked, symmol14. the outer rays as long as the anal base; rentrals mitwaly bel wern front of eye and base of catudal, length of fin about twir. diammeter of cyes, distance from ventral origin to anal origin rgual to length of upper jaw: length of pectoral ome formll the longhth of head to tip of uppere jaw; lateral line confaining mimme, rommlish pores, neat the ventral edere. in modi-

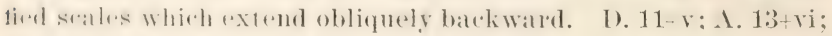

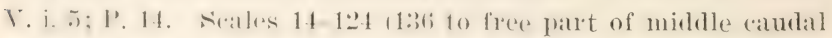

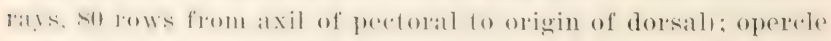
with about 8 rows of scales.

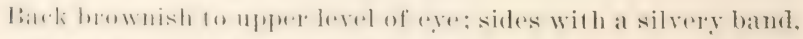

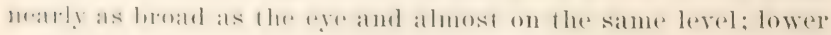
parts silvery with a golden tinge overlying it.

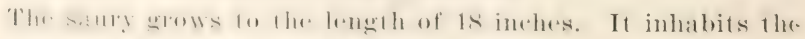

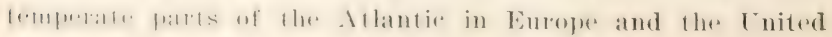


States, congregating in schools in the open seas, where it is preyed on by porpoises, tunny, bonito, cod, bluefish and other predaceous animals. At Prorincetown Mass., according to Storer, large quantities are yearly thrown on the shore, but they are considered worthless, while on other parts of Cape Cod they are taken in immense numbers, and are considered very nutritious food.

The saury, or skipper, is migratory, arriring on our coast in summer and departing on the approach of cold weather. It is a surface swimmer and, therefore, is particularly liable to the attacks of voracious fishes. Couch says:

It is sometimes seen to rise to the surface in large schooIs and fly over a considerable space. But the most interesting spectacle, and that which best displays their great agility, is when they are followed by a large company of porpoises, or their still more active and oppressive enemies, the tunny and bonito. Multitudes then mount to the surface and crowd on each other as they press forward. When still more closely pursued, they spring to the hight of several feet, leap over each other in singular confusion, and again sink beneath. Still further urged, they mount again and rush along the surface by repeated starts for more than 100 feet, without once dipping beneath, or scarcely seeming to touch the water. At last the pursuer springs after them, usually across their course, and again they all disappear together. Amidst such multitudes-for more than 20,000 have been judged to be out of the water togethersome must fall a prey to the enemy; but, so many hunting in company, it must be long before the pursuers abandon. From inspection we should scarcely judge the fish to be capable of such flights, for the fins, though numerous, are small and the pectorals far from large, though the angle of their articulation is well adapted to raise the fish by the direction of their motions to the surface. Its power of springing, therefore, must be ehiefly ascribed to the tail and the finlets. It rarely takes bait; and, when this has happened, the boat has been under sail, the men fishing with a "lash," or slice of mackerel made to imitate the living body.

The skipjack is frequently seen springing above the surface on our coasts, and no doubt at such times it is pursued by bluefish, bonito and, probably, mackerel or cod. 
Family ExOCOETIDAE Flying Fishes

\section{Genus Exocoetus (Artedi) Linnaeus}

Limly rlongaldr, hmald above, somewhat compressed; head shorl. blunt, Hallumerl hwlow; moulh small; jaws very short, aluont mpual; rhin willont harhed: maxillarirs not joined to the

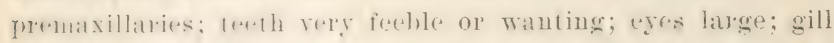

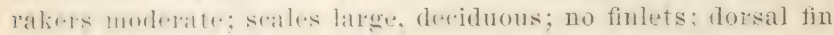
short. ofpusile anal; randal widely forkerl, the lower lobe the

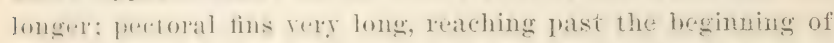
the anal. and selring as organs of flight, their great size en-

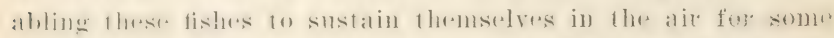

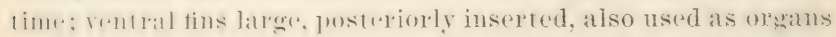
of tlight: air blathler very large; no pylorie caeca. Specius mum+rums in all watm seas, living mostly in the open water ant? swimming in large schools.

\section{Subgenus ExocorTus \\ 164 Exocoetus volitans Linnaeus}

\section{Flying Fish}

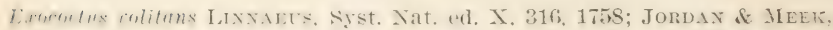
Proc. U. S. Nat. Mus. 57, 18s5; Jordan \& Evermand, Bull. 47, U. S. Nat. Mus. 734, 1896, pl. CXVIII, fig. 318, 1900.

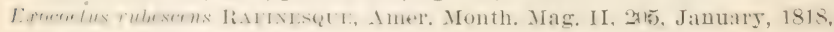
Banks of Newfoundland.

Exocoetus affinis GüNther, Cat. Fish. Brit. Mus. VI, 288, 1866.

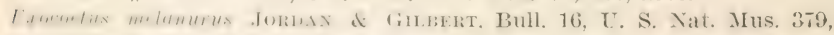
185:?

Érocontus exiliens Jordax \& Gilbert, op. eit. 380 and $904,1883$.

The hight of the huly is mearly one sixth of the total length

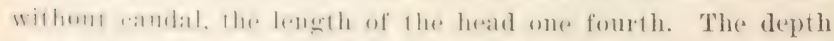

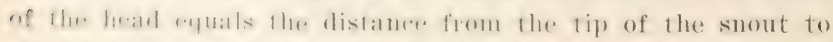

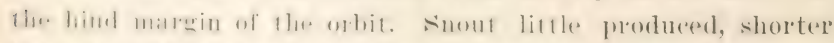

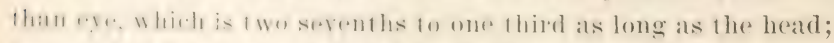

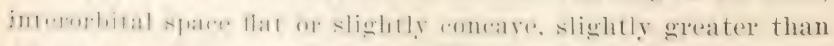

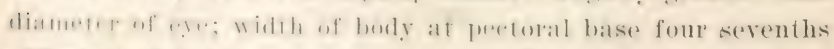

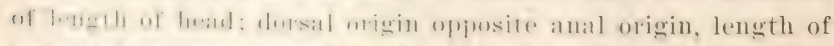

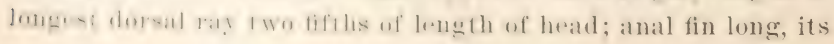


longest ray one third of length of hearl; pertoral fin reaching slightly berond dorsal and anal, its length five sevenths of that of the bodr; rentral origin midway between the eye and the base of caudal, the fin reathing beyond the middle of the anal hase, its length two serenths of length of body. I). 11-13; 1. 11-13. Scales 55130 to 35 rows hetween oeciput and dorsal origin; 25 rows before rentralsi, fi rows between the origin of dorsal and the lateral line.

Pectoral fin with an ohlique white blotch across its lower half, and with a narrow whitish edge; rentrals grayish or whitish, with a slight dusky shade in the axil; Horsal and anal withont dark markings.

The flying fish is found in open seas on the Atlantic coast; it extends northward to the Grand Banks of Nerfoundlaud; it is known also in southern Europe, aud in the Pacific and the Indian ocean.

The flight of the flying fish has been much discussed, for and against; but no doubt remains in the minds of those who have seen the action at close lange that the flight is genuine. Yot only can the fish start from the water and rise into the air, but it can also change its direction suddenly at will, to escape its pursuers, and it has been observed to hover like a humming bird or a great moth and then dart off suddenly out of reach of the net thrust out to secure it. Such an occurrence took place at Woods Hole Mass., some year's ago in the presence of the writer. The flying fish is an excellent food fish, but does not come to our markets frequently, because of its habitat in the open sea. It comes aboard ressels occasionally in storms or when trying to escape from its enemies, and is highly prized by its captors.

The species reaches the length of 1 foot.

\section{Subgenus crpseudrus Swainson}

\section{Exocoetus heterurus Rafinesque}

\section{Flying Fish}

Erocoetus heterurus Rafixesque, Caratteri Ale. Nuof. Gen, js. 1S10, Palermo; Jondix \& MeEr. Proc. L. S. Nat. Mus. 59, 1S5.); Joud.u \& Evermann, Bull. 47, U. S. Nat. Mus. 735, 1896. 
Exocoetus comatus Mitchil, Trans, Lit. \& Phil. Soc. N. Y, 418, pl. V, fig. 1, 1815. New York.

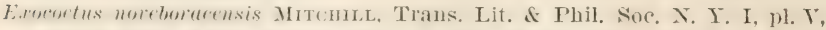
fig. 3, 1S15; Aner. Month. Mag. II, 32*, March, 1S1S; DE KIY, X. Y. Fanna, Fishes, 2:30, pl. 36, fig. 114, 1842, near New York; Jondan \& Gilbert, Bull. 16, U. S. Nat. Mus. 904, 1883.

Body slender, its greatest depth contained from five to fire and one third times in the total length without caudal; leugth of head contained four and two thirds in total to base of caudal; the snout sightly shorter than eje, its length three and three fourths times in head, while that of the eye is contained three and owe fifth times; dorsal origin in advance of anal origin, dorsal base from one and one half to two times as long as anal base; first ray of pectoral simple, second divided, third and fourth rars longest, extending to last ray of dorsal and contained one and four ninth times in total length without caudal; ventral origin midway between eye and base of caudal fin, the rentrals reaching last ray of anal, the length contained two and three fourth times in length of body. The lower caudal lobe is thiee fifths longer than the upper, which is equal in length to the hight of the body. 1). $14 ;$ A. $9 ;$ P. 15 ; V. 6. Sales $58-63,33$ rows befne the dorsal fin, 7 rows between the dorsal origin and the lateral line; vertebrae $31+14=45$.

Pertoral fins grayish brown with a broad whitish margin, an ohligue white band on their lower half; dorsal and anal uniform grayish withont hands; ventrals whitish, slightly dusky in the axils.

The spereses grows to the length of 15 inches. The young of ten hate a long hathel at the chin, this disalpearing entirels in the adult.

11. Mitehill described a speermen. 1 foot long, which was taken in a seine near New York.

This flyimg tish inhahits the . flantic orean and is most abundalla in l hre tropical parts. but strays northward to England and to the banks of Newfoundland. 


\section{Exocoetus furcatus (Mitchill)}

\section{Flying Fish}

Exocoetus furcatus Mifchill, Trans. Lit. \& Phil. Soc. N. Y. I, 449, pl. V, fig. 2, 1815; DE KAY, N. Y. Fauna, Fishes, 231, 1842.

Exocoetus uuttalli Le Stecr, Jour. Ac. Nat. Sei. Phila. 10, pl. IV, fig. 1, 1821, Gulf of Mexico; Günther, Cat. Fish. Brit. Mus. VI, 286, 1866. Cypselurus fureatus Jordan \& Gilbert, Bull. 16, U. S. Nat. Mus. 380, 1883.

Exocoetus furcutus Günther, Cat. Fish. Brit. MIus. VI, 2S6, 1866; JordaN \& Meek, Proc. U. S. Nat. Mus. 61, 1855; Jordan \& Evermann, Bull. 47 , U. S. Nat. Mus, $737,1896$.

Body slender, compressed, moderately elongate, its depth contained five and one fourth times in total length without caudal; head not rery broad, much narrowed forward, its length contained four and one half times in total without caudal; the snout rather pointed, more compressed than in other species; interorbital area flat, its width at anterior margin of orbit equal to diameter of eye, which is one third of length of head; mouth small, maxillary not reaching orbit, its length four and three fourths in head, mandible two and one half in head; snout four and one fifth in head; eve one third of length of head; pectoral fin long and broad, its length one and two ninths in length of bodr, extending to 10th ray of dorsal, first pectoral ray simple, slightly more than one half the length of fin, second ray divided, third and fourth rays longest; rentral origin midway between hind margin of eye and base of caudal, rentrals long, four ninths of length of body, their tips reaching almost to caudal fin; dorsal fin rather high, its longest ray two thirds as long as the head, its base nearly equal to head; anal fin inserted farther back than dorsal, its base three fifths as long as dorsal base, its longest ray one half as long as the head; lower caudal lobe two sevenths as long as the body. D. 13 ; A. 9 to 10 . Scales in lateral line 46 ; about 29 rows in adrance of dorsal fin and about 23 on the lateral line in advance of the reutrals; 8 rows between the dorsal origin and the lateral line.

Brownish above, silvery below; the lower posterior half of pectorals black, the upper pectoral rays with a broad white band, the tips of the rays whitish, other parts marbled with 


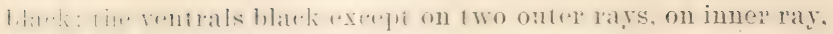

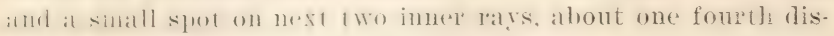

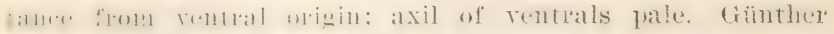

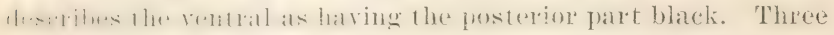

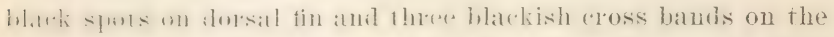

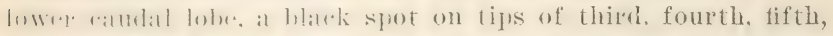

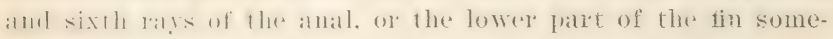
times black.

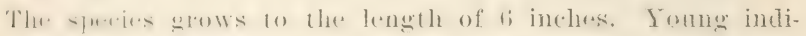
virluals have hatidels at the symplossis of the lower jaw. which

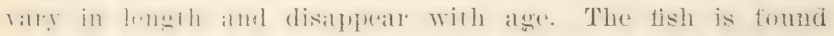

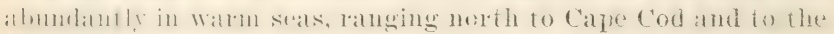

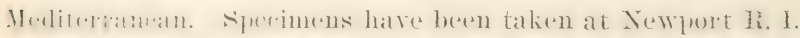

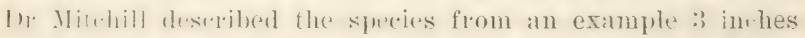

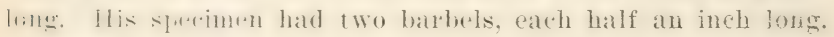

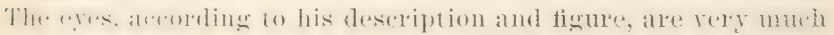
larger than in Exocoetus heteru $\mathrm{r}_{\mathrm{s}}$.

\section{Exocoetus gibbifrons Cur. \& Val.}

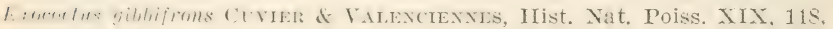
1846, Atlantic; JordaN \& MeEK, Proc. U. S. Nat. Mus. 65, 1855; Jomdix, l'roc. U. S. Nat, Mus, 528, 1886; Jordan \& Evermanx, Bull. +7 , L. S. Niat. Mus. $741,1896$.

liml! tohmst, li, le eompuessed, its greatest depth ome sixth uf the tulal lengh without caudal: hearl rather short, inter-

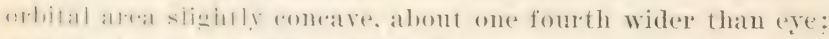

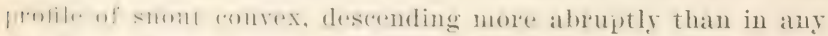

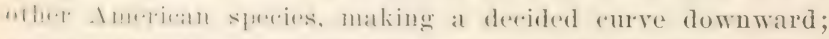

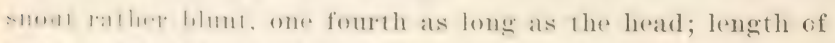

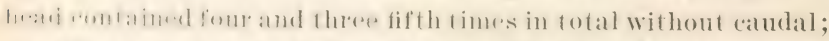

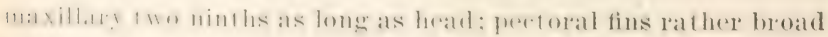

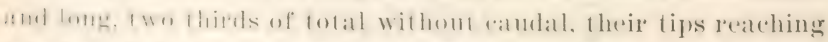

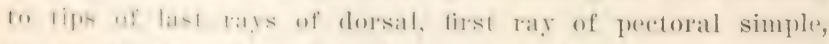

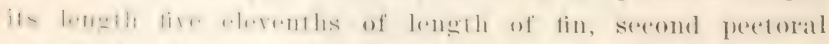

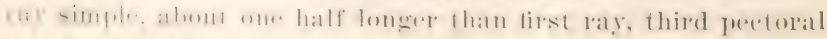

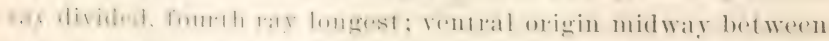

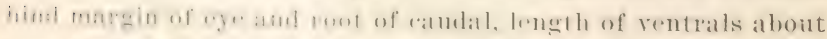

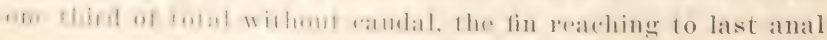


ray; dorsal origin far in advance of anal origin, longest dorsal ray five elevenths of leugth of head; anal base five eighths as loug as dorsal base, longest anal ray one third of length of head; least depth of caudal peduncle contained three and one fifth times in length of head, the lower caudal lobe two serenths of total length without caudal. D. 12; A. S. Seales before dorsil 30 ; before ventrals 25 ; between dorsal origin and lateral line $\tau$.

Color brown above, silvery below; on each scale on the upper. part of the body a darker brown spot near its posterior extremity, which gives the appearance of a dark brown streak aloug each row of scales; pectorals uniformly brown, or greenish brown; rentrals dusky, nearly black mesially, the posterior part of the fin still darker; no dark markings on dorsal or anal fins; caudal dusky, plain.

Atlantic ocean, two specimens known, both examined by Dr Jordan, from whose description the above was taken. One individual was secured by Samuel Powell at Newport R. I.; the other was obtained by Dussumier in the Atlantic ocean and by him presented to the Museum of Natural History at Paris. This example is 9 inches long.

\section{Order HEMIBRANCHII}

Half-gills.

Family gasterosteidaE

\section{Sticklebacks}

\section{Genus EuCALI Jordan}

Fresh-water sticklebacks, feebly armed, the slin not mailed, the dorsal spines few and nondivergent, the gill membranes forming a free fold across the isthmus, pubic bones fully united. One species known.

\section{Eucalia inconstans (Ǩirtland)}

\section{Brook Stickleback}

Gastmosteus inconstans Iirmthand, Bost. Jour. Nat. Hist. III, 27:?. 11. II. fig. 1, 1841, brooks of Trumbull County, Ohio; Stoner, Syn. INish. N. A. 64,1846 ; BeAn, Bull. 15, U. S. Nat. Mus. 130, 1879; Joridx \& Gilbert, Bull. 16, U. S. Nat. Mus. 394, 1883. 
Émoliu inconstums Jond 1x, I'roe. Ae. Nat. Sei. Phila. 65, 1877; Eigexmaxy, Proc. Ac. Nat. Sei. Phila. 238, 1886; BeAx, Fishes Penna. 98, 1893; Jordan \& Evermaxy, Bull. 47, U. S. Nat. Mus. 744, 1896; Evermain \& Kendill, Rept. U. S. Commr. Fish \& Fisheries for 1894, 599, 1896, Franklin County, Vermont.

The horly is more tongated than in the other sticklebacks Alescribed, and stouter. the caudal peduncle has no leel, and the skin is antirely smonth. The ventral spines and pubic bones atre very small, the latter roncealed under the skin. The homarir froweses are covered by the skin, slender and widely s'parated. The dorsal spines are short, nearly equal in length, plared in a stratight line, the anterior spines shortest. The ventral spines are small and serrated. The depth equals one forth and the head two sevenths of the total length without ("atudil. I). III-IV. I, 10; . I. I, 10. Males in the breeding seasoll an jot blatk, tinged entirely with coppery red. The females and young aro greenish, variegated with darker.

The hook sticklebark occurs in the fresh waters from Xew York West ward to I):Llota and is said to extend north to Greenland. I variety from c'ayuga lake has been described by Dr Jordan. It has the rentral spines longer than the pubic bones.

In I'mmsylvania the look stickleback inhabits the Ohio ralley. In Xis Fork it oreurs only in the western part, being sprerially almulant in the Ialke Ontario region. The U. S. Fish

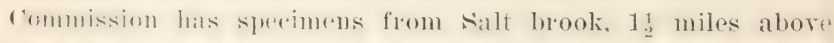
Nim, Mile print, Jume 11, 1s!), Mill resek, Sacket Harbor. July

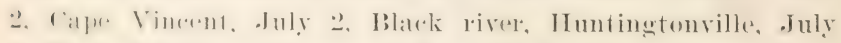

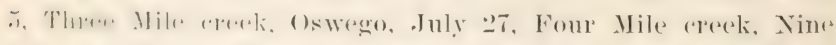

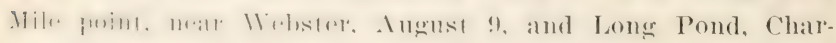

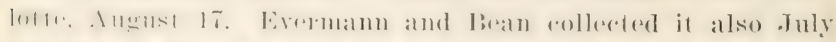

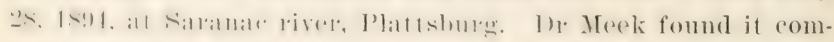

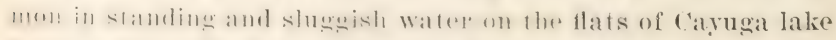

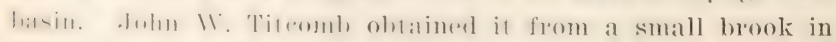

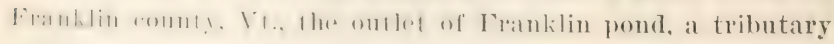
of like river, which flows into Missisquoi bay.

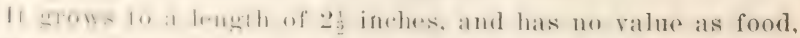

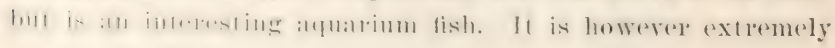


pugnacious, and, when these fish are kept in confinement, great mortality is caused by their quarrels. The species is abundant in small streams, where it secretes itself among aquatic plants and is always alert to attack small fishes and insects. Specimens have recently been obtained from an artesian well in South Dakota, the well haring a depth of 700 feet. From this great depth the fish were brought up in full strength and vigor, and they were kept in an aquarium several months afterward. A similar occurrence has been recorded by Mrs Eigenmann, in the Procedings of the National Museum for 1883, p.217, of Williamson's stickleback at San Bernardino Cal. The well in this case was only 191 feet deep. There is no doubt that the fish reach the wells through streams which become subterranean in a certain part of their course.

This species is a nest-builder and is rigorous in the defense of its eggs and young.

This fresh-water stickleback appear's to live better in balanced tanks than in flowing water and is not hardy in captivity. It feeds readily on chopped hard clams and $\mathrm{G}$ a $\mathrm{m} \mathrm{m} \mathrm{a} \mathrm{r} \mathrm{u} \mathrm{s,} \mathrm{the}$ iatter being one of its natural foods.

\section{Eucalia inconstans cayuga Jordan}

\section{Cayuga Lake Stickleback}

Eucalia inconstans cayuga Jordsx, Mau. Vert. ed. 1, 249, 1876, Cayuga Lake, Ithaca, N. Y.; MeEk, Ann. N. Y. Acad. Sci. IV, 312, 186s; Jordan \& Evermarn, Bull. 47, U. S. Nat. Mus. 744, 1896.

According to Dr Jordan, this rariety has longer rentral spines than the common brook stickleback, these being as long as the pubic bones (two thirds as long in inconstans). The size is generally smaller, but the fin rays are the same as in inconstans.

The rariety occurs in small brooks and in the lakes about Ithaca and Syracuse N. Y.

\section{Genus pxgosteus Brevoort}

This genus is characterized by the presence of 9 to 11 divergent spines and by the reakness of its innominate bones. 


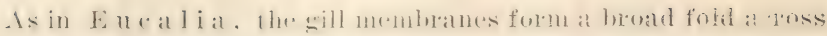

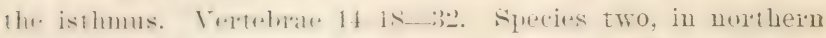
fremons. the following rosmopolitan: a second, P'ygos le us s ine ns is Guichenot, from China.

\section{Pygosteus pungitius (Linnaeus)}

\section{0 spined Sticliebact:}

Gusterosteus pungitius Lixsaecs, Syst, Nat. ed. X, 296, 175S, Europe; GüNtuer, Cat. Fish. Brit. Mus. I, 6, 1859; Storer, Hist. Wish. Mass. 43, pl. VIII, fig. 5, 1S67; BEAx, Bull. 15, U. S. Nat. Mus. 133, 134, 1879; Jordax \& Girbert, Bull. 16, U. S. Nat. Mus. 393, 1S83; BeAN, 19th Rept. Commrs. Fish. N. Y. 244, 1890.

Gasterusteus occidentalis DE KAY, N. Y. Fauna, Fishes, 68, pl. 12, fig. 135, 1S12; Storer, Syn. Fish. N. A. 63, 1846.

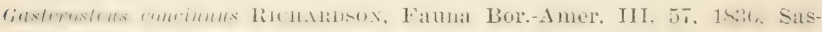
katchewan River and Great Bear Lake.

Gasterosteus nebulosus AgAssiz, Lake Superior, 310, pl. IV, fig. 2, 1850.

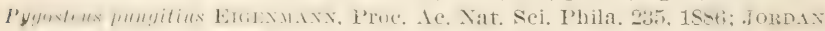
d Evemanx, Bull. 47, U. S. Nat. Mus. 745, 1896; Beax, 52d Ann. liept. X. Y. State Mus. 100, 1900.

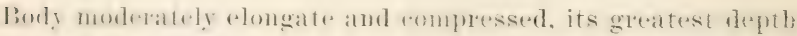
one sixth of lotal length to hase of ratudal rays, its width ome temth of the same. length and two fifths of the length of the

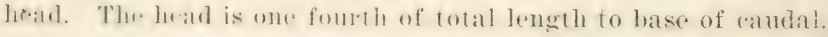
its willh fontaimed two and ome thirel times in its length: the length of the smout reputs the width of the intererbital spater.

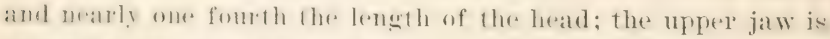
slighly more thate one fom the the length of head, and the man-

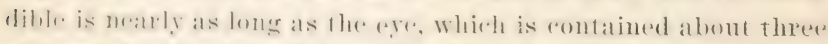
and one fontle times in lenght of head. The spinous dorsal

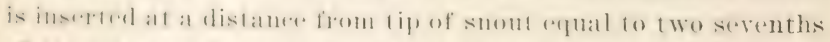
of tolal lengtl willout randal; its hase is al little longere than

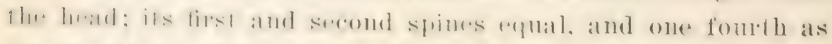

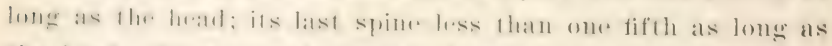

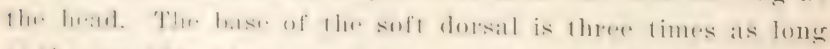

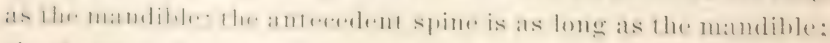
thr first ray is Iongest, and is twice as long as the mpper jar.

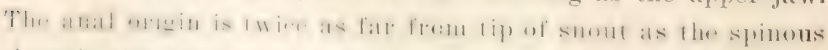
domsal; the anal hase is twice as long as the middle candal 
rays, and equals twice width of body; the first anal spine is about equal to one half the depth of body; the first anal ray longest and one half as long as the head. The middle caudal rays equal width of head and about three serenths of length of head; the external rays are slightly more than one half the length of head; the length of the eandal peduncle equals three times the length of last dorsal spine; the least hight of the peduncle is contained seven and one third times in length of head. The pectoral is twier as long as the mandible; the rentral is at a distance from tip of snout equal to three times length of rentral spine; the ventral spine is usually about two fifths as long as the hear, or somewhat more. The dorsal spines are all in the same line in a furrow, but they direrge so as to form a zigzag series. Pubic bone weak, lanceolate, not serrate, its leugth about two fifths head; rentral spines slender, pungent, serrulate above and below; gill membranes free from isthmus behind, gill rakers long and slender; caudal fin lunate, slightly emarginate. D. VII to XI, I, 9; A. I, S. Color brownish ahove, the upper part of sides with numerous darker blotehes simulating bands, lower parts silvery, pubic and thoracic regions often black. Length 3 inches.

The 10 spined stickleback inhabits the northern parts of Europe, the Atlantic coast of America from Long Island to the Arctic ocean; also tributaries of the Great lakes and northward into British America and Alaskit. In the Aretie fresh waters it is represented by a form with shorter rentral spine, smaller eye, iower fins, and other characters.

Notwithstanding its small size, this fish serves a very useful purpose as food for the salmon and trout, and arctic explorers have utilized it in vast numbers for ferding their dogs. Occurring as it does in shallow fresh-water lagoous in summer, apparently landlocked, and freezing solidly in winter, it has always been a mystery how it survives.

This stickleback is less abundant in fravesend bay than the two spined and three spined speries. In Great South bay it is known as the thornback. In 1890 it was seen only once. In 


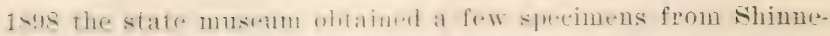
cock bay, Preonir hay and serrepal stations in Great South bay.

This spereies appuars on mum metram fatther than the others. In the arfuariun it often atlateks fish and tears flyeir fins into shreds. During the breding stason the mald beeomes of a rosy hue beneath. It is a hariy fisls, moluring captivity bettex than

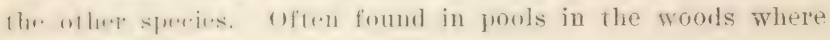
seemingly no other fish oceur. (After Eugene Smith ${ }^{1}$ )

\section{Genus Gastenostevs (Artedi) Linnaeus}

slieklebarks with the innominate bones coaleserent on the merdian line of the lwelly, whind and between the velutral fins,

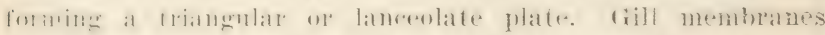

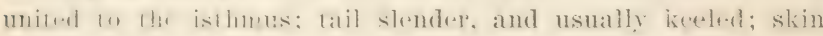
varionsly coremel with homy plates: dorsal spines there in mum-

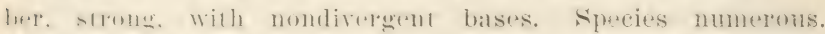
Fresh wallew and shores of all northern regions: the spretes

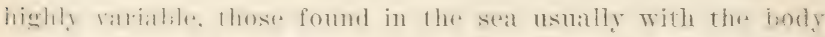

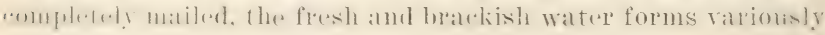
mailed or even altogether naked.

\section{Gasterosteus bispinosus Walbaum}

\section{Two spined. Stickleback}

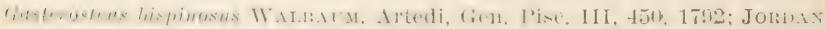

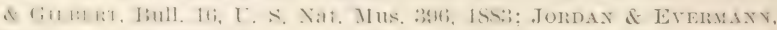
Inll. 47 , U. S. Nat. Mus. 745,1596 , pl. CXIX, fig. 320 , as aculeatus, 1900 ; Eugene Smitr, Proc. Linn. Soc. N. Y. 31, 1598; BeAN, 52d Ann. Rept. N. Y. State Mus. 100, 1900.

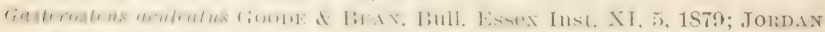
\& Gimmt, Bull. 16, U. S. Nat. Mus. 395, 1S8:3 Bean, Fishes Penna. 9S, 1S93; not of Limnaeus.

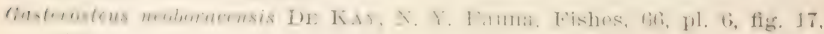
18.12.

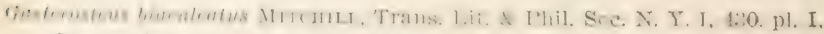
1). 10, 1815, Ňew York; Dr KAY, N. Y. Fauna, Fishes, 65, pl. 3, fig. 8, 1S12, New lork and IIudson IRiver to Albany; Stonen, Syn. Fish.

‥ 1. 62,1546 ; Hist. Fish. Mass. 40, 1)l. YIII, figs. 2, 3, 1867.

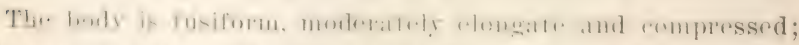

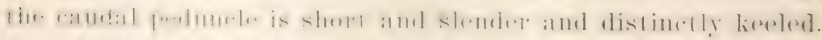
The highe of the hody is less thatl the lenghle of the head and 
about one fourth of the total without caudal. The ere is one fourth as long as the head. The sides are covered by about 33 bony plates. The processes from the shoulder girdle cover the breast exeept a small naked area between them. At the base of each dorsal spine is a large rough bony plate to which the spine is hinged in such a way that it may be fixed and immorable at the will of the fish. The pelvic bone is lanceolate. A cusp at the base of the rentral spine. The spines are all closely serrated, those in front of the anal and soft dorsal smallest. D. II, I, 11-13; A. I, 9.

The living fish is greenish olive, lighter on the sides, the lower parts silvery. The gill corers are silvery with dusky spots; the iris silvery; mupil black; fins pale; the rentral membrane sometimes red.

The two spined stirklebark or burn stickle is found on both sides of the Atlantic, its lange on our coatst extending southward at least $10 \mathrm{New}$ Jersey and northward to Labrador. This is the largest of the sticklebacks and is said to grow to a length of 4 inches. In the Jorth I'acific and Bering sea there is a related speecies, G. cat a phact us Pallas, which has been styled the salmon killer. In Pemmstrania Mr seal has found this fish abundant in pools and ditches along the Delaware.

De Kay found this stickleback in the salt crexks about New Fork and in the Hudson river as far up as Alhany. The state museum obtained it in 1898 in shinnecock bay, July 2.2, and in Scallop poud, Peconic bay, July 2s. It is not common in summer. The following notes are from an artiche by Eugene Smith of Hoboken.

Exceedingly common in the tidal creelis in the spring. The nest of this fish is made on and in the sand with the aid of bits of straw, weeds, etc. After the female has deposited the egrss, the male stands orer the nest and fans it with the pectorals, ouly leaving to get food, or to resent an intrusion; he often kills the female with whom he has pared. During this time the male is red below and bluish and greenish above, with indistinct darker bars. After the spanning season is over, they seem to die off, at least they do in captivity. With proper attention the young can be raised to quite a size. 


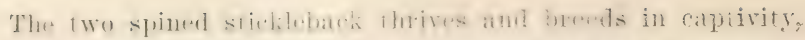
but will not endure es im me heat in sumumes, and the adults will eat their young.

\section{Genus apentes De Kay}

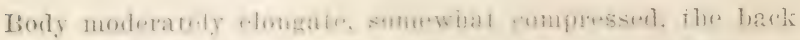

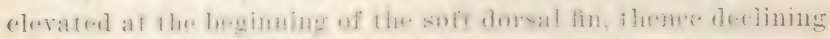

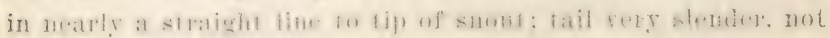

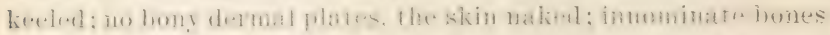

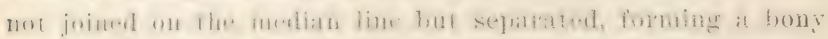

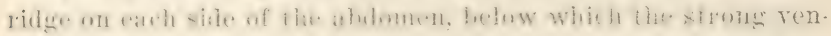

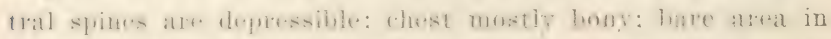

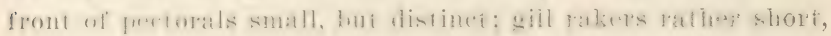

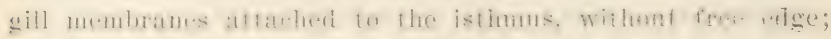

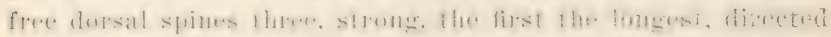

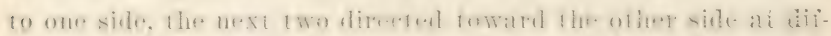

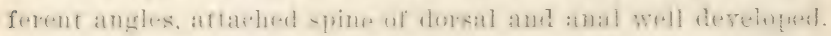
a bony ridge on each side of the spinous dorsal.

\section{Apeltes quadracus (Mitchill)}

\section{Four spined Stickleback}

Gasterostens quadraens IItcmile, Trans. Lit. \& Phil. Soc. N. Y. I, 430, pl. I, fig. 11, 1S15, New York; DE KAY, N. Y. Fauna, Fishes, 67. pl. 6. fig. 1S, 1S12, the generic mame A p e lt es proposed; Güxrmen, Cat. Fish. Erit. Mus. 1, 7, 1859; Stomen, IIist. Fish. Mass. 41. pl. VIII, fig. 4, 13ti. Gasterosteus millepunchutus Axmes, Bost. Jour. Nat. Hist. IV, 291, pl. III, dig. 3, 1S.4. Old Mans Harbor, Long Island.

A poltes quadracus Goode \& BEAx, Bull. Essex Inst. XI, 5, 1879; JoRdAN d (irline, 13ull. 16, U. S. Nat. Mus. 396, 1S\$3; BEAx, 19th Rept. Commurs. Fish. X. Y. 244, 1890; Fishes Pennil. 99, 1893; Jompdx \&

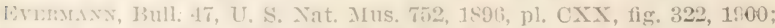

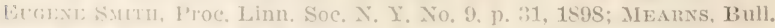

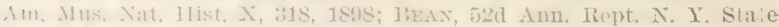
M(11:. 1119, 1900.

'The body is fusiform in shape, the snout pointed and the cambial frelumele slomere. The sides are somewhat compressed.

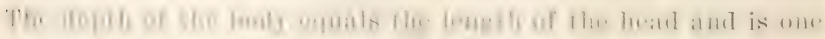
fourth of the folal without caudal. ]). TIT-IV, I, 11; 1. i, s. The skin is stateress. The first dorsal spine is the highest, its lenerth aloute lialf that of heati. 
The living fish has the mpere pirts grenish bown. Below the lateral line the color is dirker and is mottled by the extension upward of the white color of the abdomen. Toung specimens have the brown color aggregated into sereral cross bands, which herome indistinet in the adult. The rentral membrane is broad, scarlet in color, wiring rise to one of the popular names.

In Great South Bar the four spined stickleback is all d thormback. This is the "lhlonly stickleback" of Storer's Fishes of Ifussuchusett.s. It appears to h... the commonest member of its family in this bay in september and early Ortober. We fomel it common in varions parts of the bay at a time when the 1 wo spined stickleback, fiasterosteus bispinosus, was not once scined, and cinly a single sperinen of the 10-spined, P. pung i t i s, was seerured. Localities at which we hare collected the species are: Swan crerk. Blue Point core, Blue Point Lifestring station. Rreat River lwath and Fire Island. The sprecies is most plemtiful in brarkish streams where there is an abundance of atuatic ylants. In 1s!s the state museum obtained it from the following athitional localities: Shinnecock bay, Peconic bay, Menes hay, Ifowell's point, Great South bay, Bellport Lifesaving station, Yirhol's point and Fire Island inlet. Examples talian at l'athlogue dreust 24 were in fresh water.

This species reaches a length of 2 inches. It swarms in the shallow waters, speecially in the northern part of its habitat, and is particularly plentiful in brackish streams where there are numerous aquatic plants. In salt marshes it is one of the commonest of the little fishes, and it is not unrommon in the mouths of rivers. In Pennsylrania Prof. Cope reeolds it as abundant in the tide water streams and ditches of the Delaware. It runs up stream into purely fresh water and is commonly associated with the killies in small ditches and pools. This stickleback builds a rudimentary nest of plaut bits, and behares like the above mentioned P. P ung itius and (r. his p inos us, in most resperts. It is liardy and can he kept all the gear 


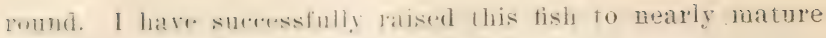
growth. (After Eugene Smith ${ }^{1}$ )

The remathable spimniug habits of lhis fish hatre besen

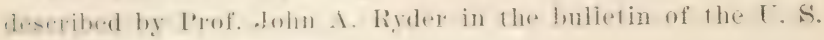
Fish Commission for 1881.

\section{Family FISTULARIIDAE}

\section{Cornet Fishes}

\section{Genus Fistemira Linnaeus}

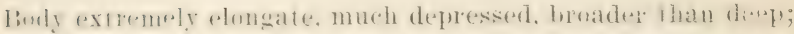
sualeless. hu hat viner lung plates present on varims parts uf the buly, mosily roveren hy the skin: head very long, the anderior bories of the skmll murh prodiuced, forming a long tubs. which

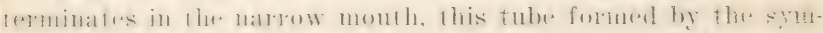

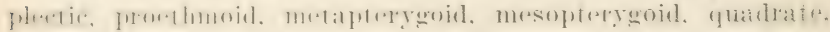

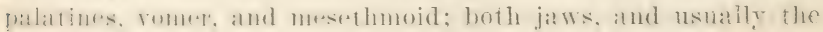

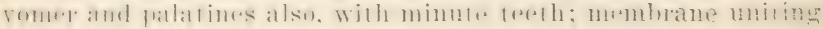

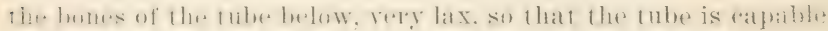

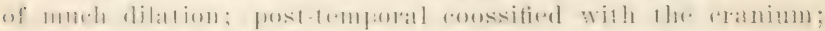

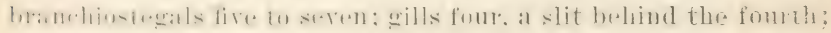

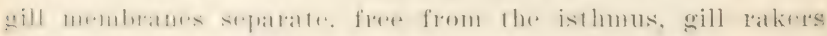

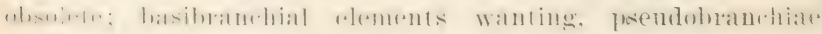

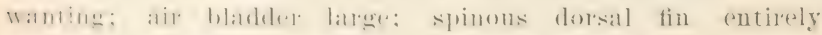
absent, soft dorsal short, posterior, somewhat elevated; anal fin opposite it and similar; caudal fin forked, the

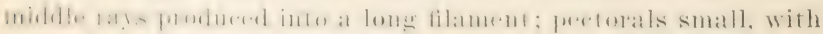

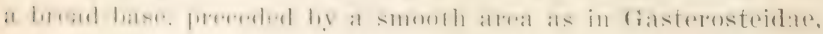

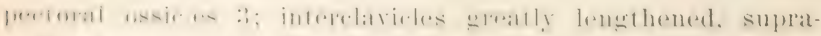

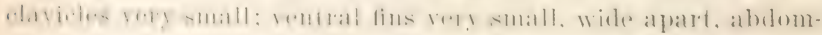

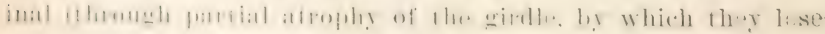
commerelim will the interelavicles), far in arrance of the dorsal, comprosed of six soft rays; pyloric caecal fow; intestine short;

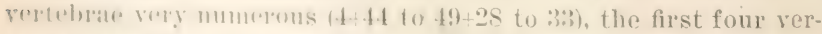
tebrate very lomer Fishes of the mopical seas, related to the

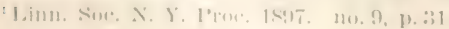


sticklebarkis in strurture, hut with prolonged snout and diffrent rentral fins. A single genus, with three species.

The bony shields, rhatarelotiste of this gemus, ale the following:

1 A nareow strip along the median line of the latek behind the skull (confluent neural spines).

"The pair of broader lateral dorsal shields are peculiar bones, separated prowesses of the occipital home. These shields are the lougest, movided antriorly with a ridge, which is protonged and rxtemds fal backward betwern the muscles of the bark. This ridge is flexible, and does not interfere with the lateral movements of the fish; it appreatre to serve as a base for the attarehment of muscular fibers.

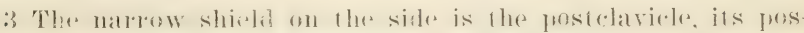
1erior fart heing dilated ame fixed to tho lateral dorsal shields.

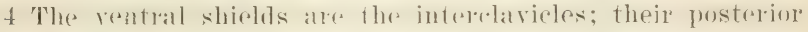

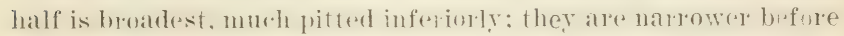
the middle. leaving a free lanreolate sfolde lefwern them, and are again a litte widemed anteriorly, where they join the raviele and nowhal. These plates extend as far barkward as the ankylosed vertebrae. (After Jordan and Evermann)

\section{Fistularia tabacaria Linnaeus}

\section{Trumpet Fish}

Fistularia tabacaria LinNaEus, Syst. Nat. ed. X, I, 312, 175S; DE KAY, N. Y. Fauna, Fishes, 233, 1842; Storer, Syn. Fish. N. A. 191, 1846; GüN-

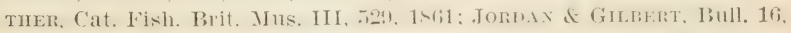
U. S. Nat. Mus. 389, 18s3; Bean, Bull. U. S. F. C. VII, 146, 18ss; 19th Rept. Commrs. Fish. N. Y. 273, 1890; JordaN \& Evermann, Bull. 47, U. S. Nat. Mus. $757,1896$.

Fistularia neoboracensis MrtchILI, Trans. Lit. \& Phil. Soc. N. Y. I, 437, pl. III, fig. 8, 1815.

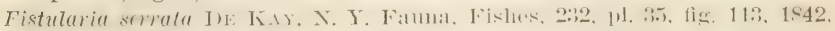

Massachusetts; Storer, Hist: Fish. Mass. 140, pl. XXV, fig. 1, 1867;

Goode \& BEAN, Bull. Essex Inst. XI, 4, 1879, Rockport Mass, not of Cuvier, Règne Anim. ed. 1, 349, 1817.

Body greatly deperesed, alomgate, ils depth about ond thirtyfourth of its length to base of randat and anl! ahout two thirds

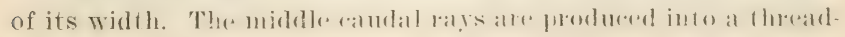


il., filanment, whirh is a litule longer than the suout. The suout

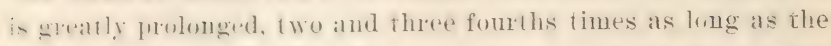
,.-1 of the hearl. Mouth at the end of the long tube oblique, the inn . . jaw jug jerting a disiance equal to one third of diameter of

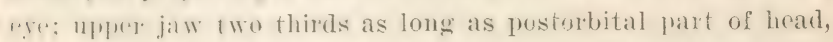

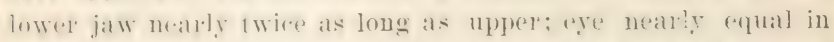
lemerth 10 upfere jalw, abont nine and oue half in length of head: smont 1 hree and 1 wo thirels in total length to c:atulal hase: malrgin of orbit with thin, shate points in foont and behind: dolsal origrin at a distanee from tip of snout expal to three times length of snont, latse of dorsal slightly longer than rex, lumgest densal ray mer fourth the length of snout; anal exactly opposite dorsal, its liase enfually long, its longest ray also equall to longest dorsal lay: ventrals small on a narrow base, their distance from tip uf snumt and end of external cautal rays nearly equal: je.totals short, on a hroad hase, their length one half the length of hadel without the snout: atudal lobes equal, the uplere external talys three fifihs as long as the head without the snout. 1). 14: A. 1:?; V. 7 .

Reddish hrown above, with numerous large, oblong. pale blue -puts ont the sisles and back, arranged in series; under surface of luad amd belly at least to rentral fins, pale and silvery.

The fish was known to Dr Mitchill and deseribed by him fromi a spreimen 14 inches long. We are not informed where he ob tainvl this example, but it was an individual in the fresh comdi. tiun. H1. We Kay ralled it the spotted pipefish and takes his account from the report of Dr Mitchill.

The trumpet tish is genreally eommonom in the West Indies and

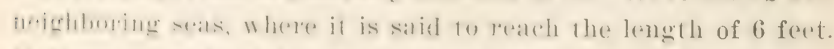

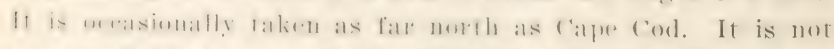

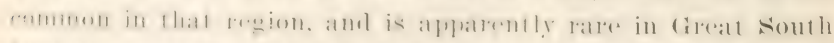

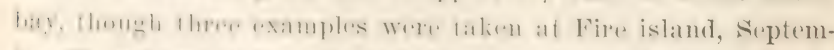

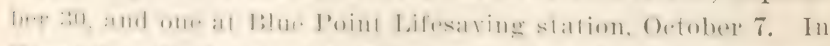
I I

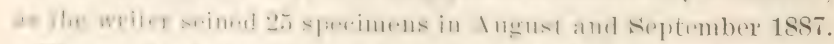

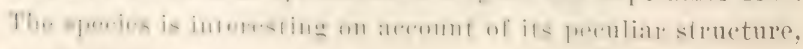
but is without economic value. 


\section{Order LOPHOBRANCHII}

\section{Tuftgills}

Suborder SYNGNATHI

Family SYNGNATHIDAE

Pipefishes

Subfamily SYNGNATHINAE

Genus smpostom Rafinésque

Body clongate, very slender, six or seren-angled, not comjuessed, tapering into a very long tail, the dorsal keels of the Hrmk not continuous with those of the tail; head slender, tapering into a long. tululike, subtrete snout, which bears the verr short, toothless jaws at the end; humeral bones firmly united with the "breast ring:" horly corered with a series of bony, leeted, radiated plates, arranged in linear series; dorsal fin distinct, rather short, inserted before or opposite the vent, which is near the middle of the body; caudal fin present, rather small; anal fin minute, close helind rent; pectorals dereloped, short and rather broad. Male fishes with an egg pouch along the under side of the tail, formed by two rutaneous folds, and splitting leugthwise to release the roung fishes. Species rery ummerous, inhabiting all warm seas; abounding in bays among the seaweeds, and entering the rivers. The females in most species are deeper than the males, with more robust trunk, with longer snout, and a more distinct ventral keel.

\section{Subgenus smmostoma}

\section{Siphostoma fuscum (Storer)}

Common Pipefish

Syngnathus fuscus STorer, Rept. Fish. Mass. 162, 1839, Nahant.

syngnathus peckianus Storer, op. cit. 16i3, pl. I, fig. 2, 1839, Holme's' IIole,

Marthas Vineyard; Sym. Fish. I. A. 23S, 1St6; Hist. Fish. Mass. 218.

pl. XXXIII, fig. 3, 1867.

Syngnathus fasriatus DE KAY, X. Y. Fauna, Fishes, 319, pl. 54, fig. 174, 1842. s'yngnathus viridestens DE KAx, op. cit. 821, 11. 54, fig. 176, 1842, Ifudson

River, at Sing Sing.

siphostoma fuscum and perkianum, Goone \& IBrix, Bull. Essex Inst. XI, 4, 1879.

‘iphostoma fuscum Jornax \& Gilbert, Bull. 16. T. S. Nat. Mus. 3S?, 1SS3; BeAx, Bull. U. S. F. C. VII, 134, 1Sss; 19 th Rept. Commrs. Fish. N. Y. 244, 1890; 221 Anu. Rept. X. Y. State Mus. 101, 1900; Jornd. \& Ever MANN, Bull. 47, U. S. Nat. Mus. 770, 1896. 


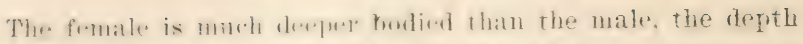
of body equaling wn. Ihime of lempth of head. while in males it

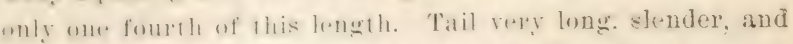

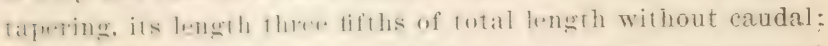

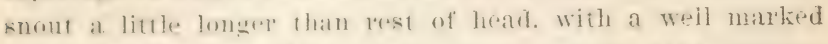

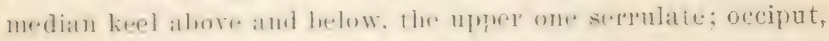

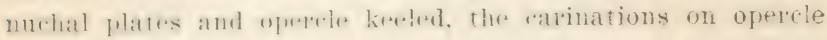
somerimes mealy obsolete: helly slightly eromes and with a

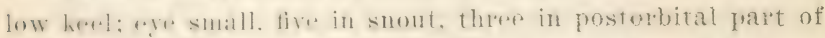
lurall: dorsal tin al a distaner fiom tip of smout ryual in two

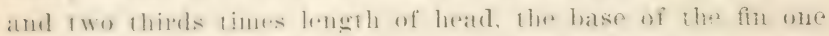

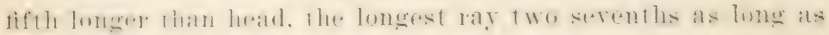

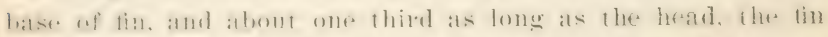

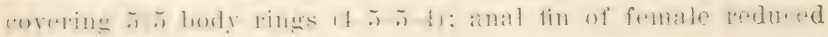
to two or three rays on a very narrow basp. its length about

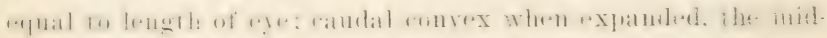

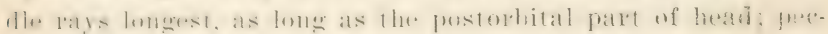

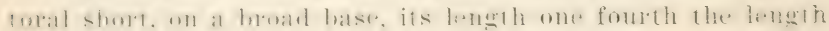
of head. D. 36 to 40 ; rings $19+37$ (or 18 to $20+36$ to 40 .)

Color brown above, pale below, everywhere mottled with

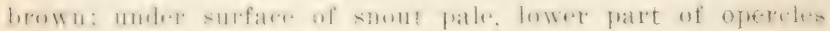
silvery.

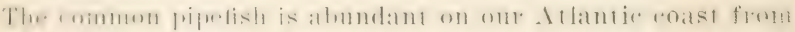

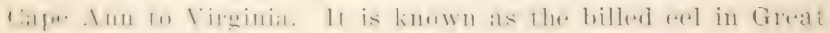

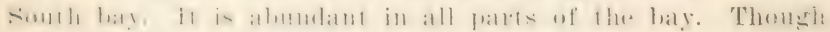

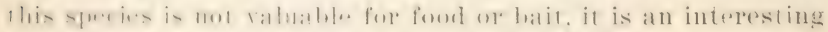

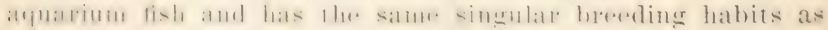

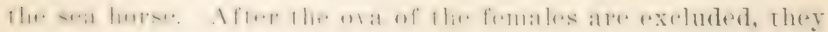

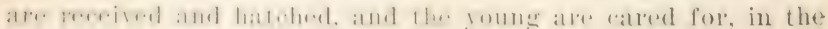
malsupium of the male. The species, according to De Kay.

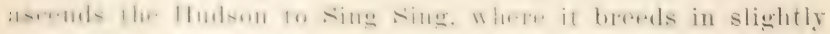
brackish water. It is to be fommd in shallow water among

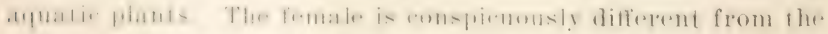

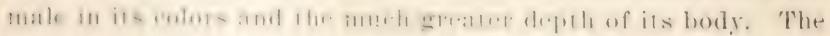

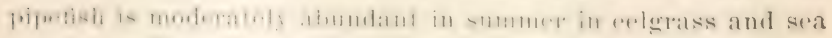
lettuce in firtresend hay. In 1898 the state museum had it from all frats of (ireat somth bay and from Shinnecock, 
Peconic, and Mecox bays. Both young and adults were abundant during the summer.

Males, females and young were abundant at Ocean City N. J. early in August 1857; but the males were more numerous than the females. The egg pouches of the males were filler with ejed embryos, arranged in four series on each side. A male $6 \frac{1}{2}$ inches long, taken near Ocean Citr, August 31, had the pouch unstmmetrically filled, the left side containing more than two thirds of the whole number of embryos and increasing in carrying capacity from behiud forward. This is the bilfish at Somers Point.

In the aquarium the species is fond of shrimp eggs and small G a m marus; but, on account of the difficulty of securing proper food, its life in captivity is usually short. In a slowly circulating tank, at a temperature of $j t^{2} \mathrm{~F}$. sereral individuals were alive and, apparently, in good condition.

\section{Subfamily HIPPOCAMPINAE}

\section{Genus mppocampus Rafinesque}

The body strongly compressed, the belly gibbous, tapering abruptly to a long yuadrangular, prehensile tail; head with a distinct curred neck, placed nearly at a right angle with the direction of the body, surmounted by a compressed oceipital (rest. on the top of which is an angular. star-shaped coronet; top and sides of the head with spines. Physiognomy remarkably horselike, like that of a conrentional knight at chess. Body and tail corerexd with bons plates. forming rings, those on the body each with six spines or tulureles, those of the tail with four; pectoral fins present, short and hroad; anal minute, usually present; dorsal fin moderate. opposite the rent; egg pouch in the male a sac at the base of the tail, terminating near the vent.

\section{Hippocampus hudsonius DeKay}

\section{Sea Horse; Horsefish}

Hippocampus hudsonius I)E KAY, N. Y. Fauna, Fislies, 322, jl. 53. fig. 171, 1842; Storem. Syn. Fish. N. A. 239, 1846; Hist. Fish. Mass. 222, pl. XXXIII, fig. 4, 1867; Jordax \& Fimbirt, 13ull. 16, L. S. Nat. Mus. 907, 1883; BeAn, 19th Rept. Commrs. Fish. N. Y. 24:, 1S:40; JordaN \& EverMANN, Bull. 47, U. S. Nat. Mus. 777, 1836, pl. CXXI, fig. 327, 1900; Mearns, Bull. Am. Mus. Nat. Hist. X, 318, 1895; Bean, $52 d$ Ann. Rept. N. Y. State Mus. 101, 1900. 


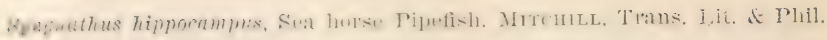
Soc. N. Y. I, $475,1815$.

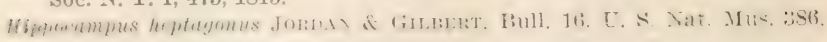
1SS3, not of RAFINESQUE.

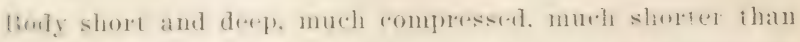
the prehensile tail, which is there times as long as fle head and mote than three times greatest depth of hosly: smomt as lomg ats [ustorbital part of luad, its depth tuo fiftlis of its longth: (ye circular, two fifths as long as the snont; interorbital space two thirds of diameter of eye: oceiput with a tive-jointed erest: a shatre spine abore the gill corers on each side. whe above the frosterion fate of the eye and one on each side of the throat; a blume spine letwern the nostrils; the edemes of the bong plates of hent! with the usual blunt spines. There ate un eitri gn the individual here describul, hut the speres is said to have them semetimes. HeKay does not mention eirri in his aceonut of the fish. Jorsal fin on $3 \stackrel{1}{2}$ rings: hase of dorxal on balf as long as head; lomegest dorsal ray ont half as long as snout. 1). 19; rimes 12.:3̈ to :36. Color light hown or dusky. withont spots, bue sometimes will fale grayish hlolehes which are shatroly

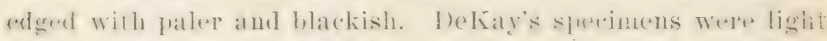
brown, with iridescent opercles, the iris jellow.

The siat horse is now known to oceme on the New Tork and Sere forsey enasts in molerate mumbers during the summer

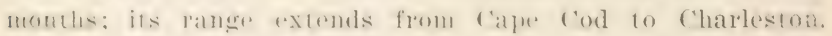

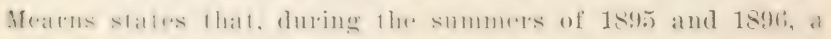
numbler of seat horses were laken hy fishermen when netting

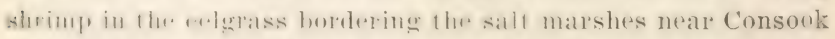

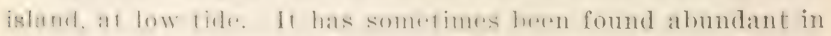

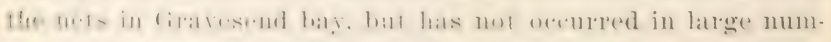

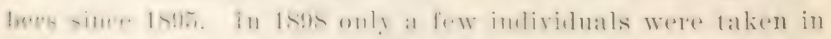

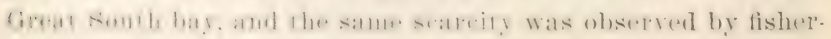
men at sonthampton 1. I.

In captivify it thrives best in balanced tanks, but its life is

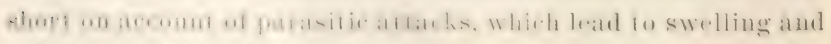
anhylueis of the jusye. Is fuml in llw apuarium inclucles If nciola and shrimp egres. The sea horse excites popular moverse 0 a a 
and the fact that the male carries the eggs and protects the young in a pouch behind the rent. In this egg sac the roung are protected till large enough to live independently, going out in search of food and returning to their shelter at pleasure.

\section{Order ACANTHOPTERI}

Spiny-rayed Fishes

Suborder SALMOPERCAE

Trout Perches

Family percopsidAE

Sand Rollers

\section{Genus percopsis Agassiz}

Body rather slender, pellucil, corered with rather thin seales; dorsal fin with two slender spines or simple rays; anal with owe; scales roughest posteriorly; lateral line developed; preoprrete entire or very nearly so; verteliale $1 \bar{\imath}+1 \bar{\imath}=? \mathbf{4}$. Atlantic slope, in cold or clear lakes and rivers.

\section{Percopsis guttatus Agassiz}

\section{Trout Perch; Sand Roller}

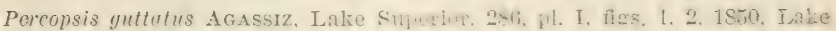
Superior; Güxtmer, Cat. Fish. Erit. Mns. YT. 2u- 14at: Jned dx \& Fit-

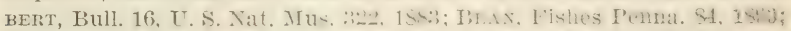

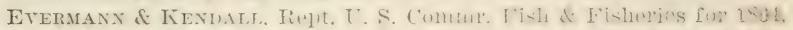

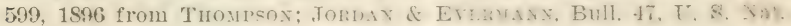
Mus. 784, 1896, pl. CXXI, fig. 329, 1900.

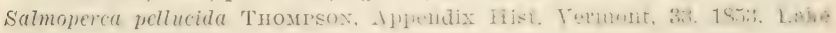
Champlain.

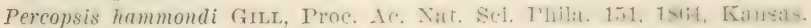

Body rather long and modruately emmerssed, comered with thin etenoid scales; head scaledess and without harbels: will openings wide; opureles well dereloped; gill rakers short. Intwercular; skull highly carernous; mouth small; the margin of the upper jaw formed by the short nonprotractile intermaxillarits: no supplemental maxillary boue; small villiform teeth om the intermaxilliaries and mandible. The tongue is short. not ine. at tip. Pseudobranchiae dereloped. Six hranchiostegals. The lateral line is contiunous. The first dorsal orer middle of hody, with nine to 11 developed rays; adipose fiu small; the anal and rentral eight rayed; eaudal long. forked; pectorals narrow; 


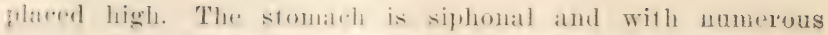

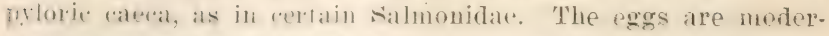
atrly large and are "xrluded though an oviduct. Air bladder present. The greatest hight of the body is about wo ninths of the lotal withont randal, the head about three elevenths. The maxillat dows not reach to tho eye. The lower jaw is slightly included. Scales in lateral line 47 to 50 .

culor fate olivaceous, or brown, the upper parts with rounded dark spuls made nj of minute dots; a silrepr mediau stripe, becoming obsolete in front; peritoneum silvery.

The tremt greroh is a common fish in the fireat lakes and their tributaries. It ranges notth to Ifudson bay, having been olvained at Moose Factory by Walton Hayden, also from Yelson riser, mar liock Factory, by Dr Robert Bell. It has heren ohtatined in the lowaware river by Ine r. C. Abbott. in the I'olomar by I'rof. Baird, in the ohio hy Iors Jordan, Menstall and livan, and lor cill has recolderi the sporeies from Kausas.

I) Merk ohtaimed no specimens from rapuga lake, hut he has mo douht it is fomnd llere. The C. S. Fish ('ommission hat if from lake (Ontario, Nine Mile point, noar Webster X. Y.. in

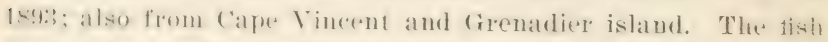
is a resident of Lake ('hamplatu, in which it was forst discovered by Thumpson, sereral years before Agassiz secured it in Lake Superior.

The lownt fereh is too small to be valuable for food. but is

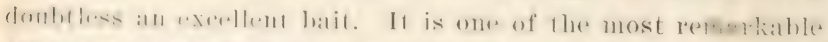
fishes of our fresh watres, romhining as it does the characters of the salmum ambl some of the purehes. Its name indicates this simsular rolationslify. It is vorarions, talies the hook freely, and spawns in the spring.

\section{Suborder XTNAROII}

l'amily AN'HREDODETRMAE

Pirate Perches

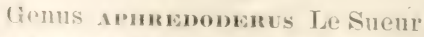

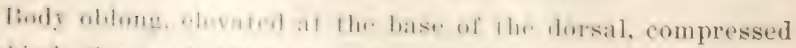

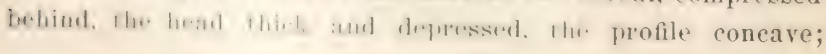


caudal peduncle thick; mouth moderate, somewhat oblique, the lower jaw projecting, maxillary reaching to anterior border of the ere; teeth in rilliform bands on jaws, vomer, palatines, and pterygoids; premaxillaries not protractile, maxillaries small, without erident supplemental bone: preopercle and preorbital with their free edges sharply serrate, operele with a spine; bones of skull somewhat cavernous, sides of the head scaly; lower pharyngeals narrow. separate, with villiform teeth; gill membranes slightly joined to the isthmus anteriorly; gill rakers tuberclelike, dentate; psendobranchiae obsolete; gills four, a small slit behind the fourth; branchiostegals six; scales moderate, strongly ctrnoid, adherent, lateral line imperfect or wanting; rent alwars anterion, its position varying with age, from just behind the rentral fins in the young to below the opercle in the adult; dorsal fin single, needian, high. with but three or four spines, which are rapidly graduated, the first being rer? short; anal small, with two slender spines; rentral fins thoracic, with a vere short spine, the number of soft rass usually seren; caudal fin rounded behind; air bladder simple, large, adherent to the walls of the abdomen; vertebrae $14+15$; pyloric caeca about 12. I single genus, with probably but on: species, confined to the United States.

\section{Aphredoderus sayanus (Gilliams)}

\section{Pirate Perch}

Aphredoderus sayanus DE KAY, X. T. Fauna, Fishes, 35, pl. 21. fig. 62, 1S12; near Philadelphia Pa.

Alhredoderus gibbosus Le Suctr, in Ctrifr \& VAlenciennes, Hist. Nat. Poiss. IX, 448, pl. 278, 1833.

A phredoderus sayamus DE KAx, N. Y. Fauna, Fishes, 35, pl. 21, flg. 62, 1842; Storer, Syn. Fish. N. A. $47,15 t 6$; Jorid of Gilmert, Bull. 16, U. S. Nat. Mus. 460, 1883; BeAv, Bull. U. S. F. C. YII, 145, 18sS; Fishes Penna. 101, 1893; Jordax \& Evermaxi, Bull. 47, U. S. Nat. Mus. 786, 1896, pl. CXXII, fig. 331, 1900; Etgexe Sutu, Proc. Linn. Soc. N. Y. No. 9, 33, 1898; BeAN, כ2d Ann. Rept. N. I. State Mus. 101, 190n, Patchogue, Long Island.

The body is moderately stout, oblong, somewhat compressed posteriorly. Suales ctemoid. The dorsal fin is continuous, with three or four spines and 11 soft rays. The anterior spines much the shortest. The anal has two spines and six rays. The mouth 
is iather latere for the size of the tish: the lower jatw somethat

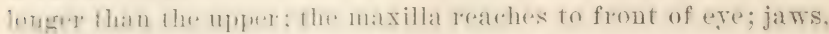

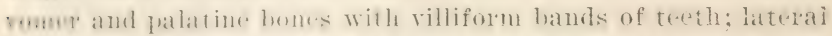
flue wanting. The degile of the body is two seremils and length of the head ome lhiml of the total withont ramial. The rye is two niuths as lemg as the heal. The origin of rionsal is much in adranee of the midele of the total length; the jeetorals do now lwath as far hatek as the ventrals; rentrats mole than one hall lenglh of heal: the longest anal spine throp serenthes of

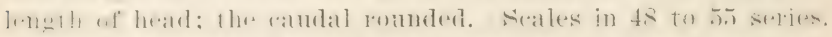
The . olow is rariable, sometimes olivaceons, at other limes dark hrown with numerous dark punctulations; a dark har at the. base of the caudal followed by a light one.

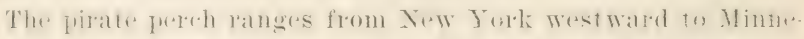
sota. and in the Mississippi valley it extends to Lonisiana. In

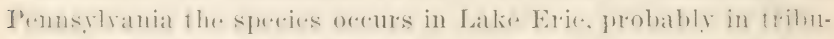
taries of the ohio and in the lower I) laware. (ommen in bas: lake at Patchogne and in the head of Swan river.

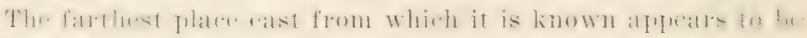
Suffolk county on Long Island. ${ }^{1}$

This is ome of the most interesting little fishes of the thesh

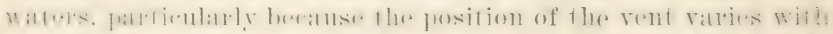

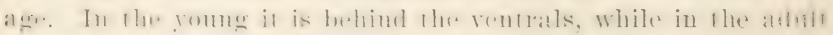
it is in the throat.

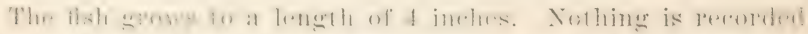

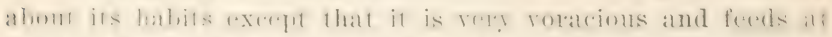

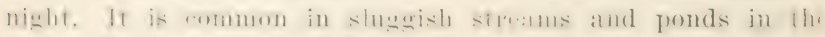
shelter of aquatic plants. In captivity it has never been

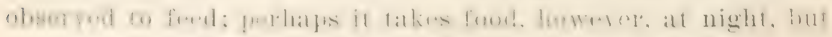
it does not thrive in the aquarium.

\section{Suborder PERCESOCES}

Eamily ATHEMTIDAE Silversides

(ienus mexmo (Bonaparte) J. \& G.

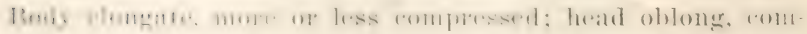

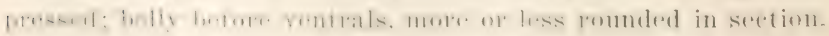

Wer Agres, Emmonation of the Fishes of Brookhaven L. I. ete. Bost. Jutur. Nitt. Hist. 1S14. 11. 
not compressed to an edge; mouth small, the galpe rmred, vere oblique, usually not reaching the ere: lower jaw short and weak; maxillary slipping entirely under preorbital; jal ws eatch with a band of simple, nsually villiform teeth; premaxillaties very freely protractile, their spines comparatively long, nearly equal to the eye, extending batekward beneath a fold of skin, which connects the basis of the maxillaries; posterior part of the premaxillaries broad; no teeth on vomer or palatines; both dorsals short, the usual radial formula being 1). Y-1, S. first dorsal usually, but not always in front of anal; soft dorsal and anal scaleless; scales rather large, entire.

\section{Menidia gracilis (Günther)}

\section{Slender Silversides}

Atherinichthys gracilis GüNtIIER, Cat. Fish. Brit. MIns. III, 405, 1861.

Henidia gracilis Jordax \& Evermaxy, Bull. 47, U. S. Nat. IIus. 797, 1896, Specimens from St George's Island, Potomac River.

The origin of the anteror dorsal fin is opposite to the rent, exactly in the middle of the distanee between the end of the snout and the base of the randal. The distanere between the origins of the two dorsal fins is somewhat more than one half of that betwern the origin of the posterior and the eaudal. The hight of the body is contained nine times in the total length, the length of the head fire and ome half times. The silvery band is narow, and oecupies a batrt of the fourth series of scales. Seales with the margin entire. caudal lobes exual in length; (atudal somewhat longere than the peetoral, and rather shorter than the head. 31 lines long. Probably young. Habitat unknown. D. IV, I, S; A. I, 19. Scales 9-40. (After Günther) The spereimens abore refered to, from st Georges island, lower Potomac river, were obtained by In Hugh M. Smith, of the U. S. Fish Commission, in the summer of 1890.

The specimens were eompared with the jublished deseriptions of M. beryllina (Cope) and were found to differ in some minor details, the dorsal formula being V. I, 10 instrad of $V$. I. 11, the anal rays atreraging I, 16 of I, 17 instead of I, 1s, and the silverẹ stripe apparently talking a different course. 
some larege exatmples l: inches long of the Potonac river silverside no. 4:3125, I'. S. National Museum, collected by TI. P.

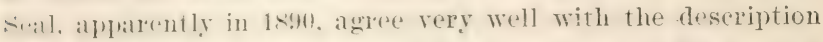

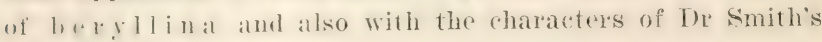
sperimens. It is frobable that copes name must be atsociated with this fresh-water form, and not the name gracilis of fimthre. None of ont individuals have four dorsal spines. and there is no "ertainty that Dr Gïnther's type cane from the Inited sitates. I have, however, followed Jis Jordan and Erermann in their identification.

The species is said to range from Woods Mole Mass. to Mlbemarle sound.

\section{Menidia beryllina (Cope)}

\section{Fresh-uvater Silversides}

rhirestrmu brryllinum Core, Traus. .1m. Phil. Soc. 403, 1866. Potomile River. at Washington, D. C.

Menidia bryllina Jorday \& Gilbert, Bull. 16. U. S. Nat. Mus. 408, 1853; I:r.sx, Fishes Penua, 100, 1893; 52 d Ann. Rept. N. Y. State Mus. 102. 1900.

Menillin mracilis berylling Jordax \& Evermane, Bull. 47, U. S. Niat. Mrus. 797, 1896, pl. CXXIV, fig. 33S, 1900.

The body is shorter than usual among the silversides. The spinous dorsal is well separated from the soft dorsal, and is posterior margin extends almost to the vertical from the first anal ray. The rentral reaches to below the first ray of the dorsal. The length of the head is contained four aud one fourti fimes in the folal length without ratulal. The ere latrge, orbit one thirel as lowg as the head: mouth small; the mandible slighly longer than the maxilla and slightly eurved; grealest dephlı of lunly one sixth of total length without caudal. Seales

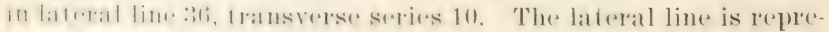

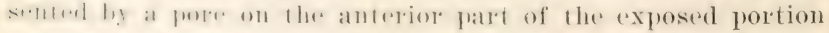

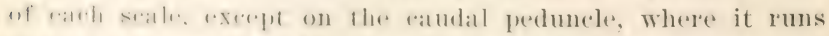

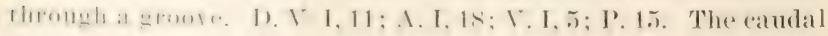
is deeply forliert.

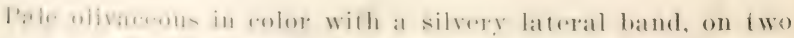
and one hall lums of seales. with a lead rolored margin. The anal base is lead colored; sides of the head silvery. 
This species corresponds in many particulars with II e $\mathrm{n} \mathrm{i} \mathrm{d} \mathrm{i} \mathrm{a}$ penins u la ef Goode \& Bean, but in that species the silvery streak covers only one and one half rows of scales. The soft dorsal in M. pe n in sula e appears to show considerable variation in the number of rays.

The fresh-water silversides was first described from the Potomac river, where it has recently been rediscovered in abundance, both in fresh and brackish water. It is rery common at Water Mill L. I. and in fresh-water tributaries of Great South bay. Sereral examples were seined in 1898 in salt water at Clam Pond cove.

In some of the Water Mill specinens the following characters were noted: D. V, I, 10; A. I, 16-17. Scales 8-40.

Its associates in fresh water at Water Mill were: F u n d u l u s diaphans, Lucania parva, Eupomotis gib bosus, and Lucius reticulatus. In 1898 it was obtained also in Shinnecock bay, Scallop pond (Peconic bay) and Mecox bay. The localities in Great South bay were: Swan river, south side of Great South bay, Horsefoot creek and Bellport Lifesaving station.

\section{Menidia notata (Mitchill)}

\section{Silversides; Friar; Whitebait}

Atherina notata Mitchili, Trans. Lit. \& Phil. Soc. N. Y. I, 416, pl. IV, fig. 6, 1815, New York; DE KAr, N. Y. Fauna, Fishes, 141, pl. 28, fig. 88, 1842, New York; Stonen, Hist. Fish. Mass. S7, pl. XVI, fig. 1, 1867.

Atherina viridescens MitchilL, op. cit. 447, 1815, New York.

Chirostoma notutum Goode \& BEAN, Bull. Essex Iust. XI, 21, 1879, and of many other authors.

Atherina menidia DE KAY, op. cit. 142, pl. 74, tig. 236, 1812, New York; not of LinNaEus.

Atherinichthys menidia and notata Gürmmer, Cat. Fish. Brit. Mus. III, 406, 1861.

Atherinopsis notatus BAInd, Ninth Ann. Rept. Smith, Inst. 338, 1855.

Menidia notata Jordan \& Gilbert, Bull. 16, U. S. Nat. Mus. 407, 1853; BEAN, Bull. U. S. F. C. VII, 146, 18s8; 19th Rept. Commrs. Fish. N. Y. 271, 1890; Jordan \& Evermann. Bull. 47, U. S. Nat. Mus. 800, 1896; Eugene Smitr, Proc. Linn. Soc. N. Y. No. 9. 32, 1895; Bean, 52d Ann. Rept. N. Y. State Mus. 102, 1900.

Body elongate, compressed, its greatest depth contained six and one third times in total length without caudal, and equaling 


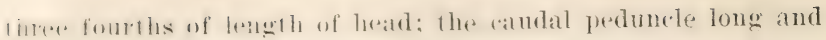

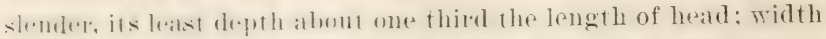

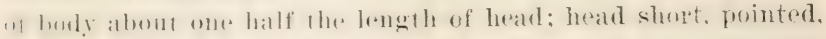

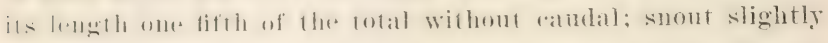

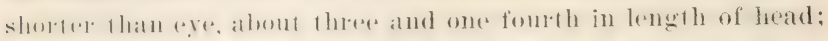

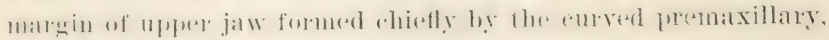

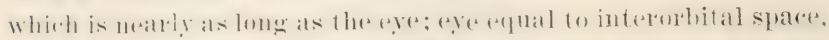

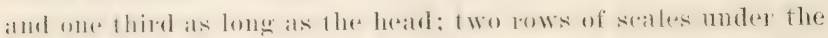

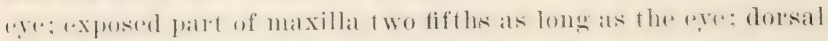

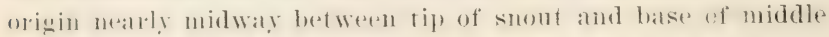

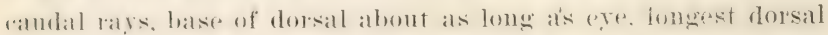
spine one thire ats longe as the head, fifth dorsal spine one fifth

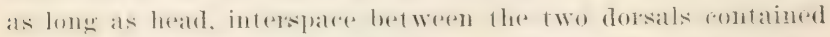
10! times in total lemgth without randal, secomd dorsal base one

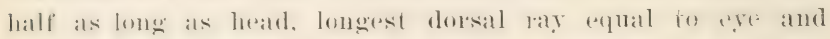

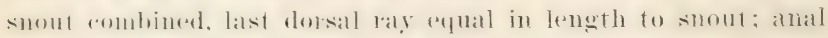

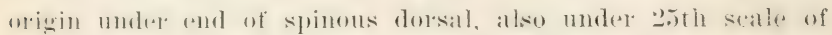

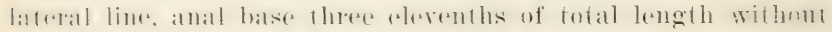

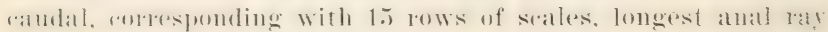

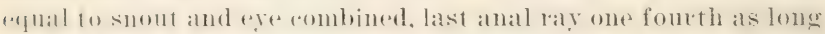
as hearl. The rent is moler lhe last spine of the dorsal. The

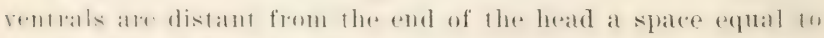

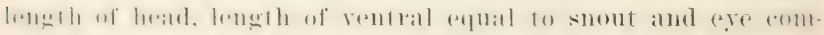

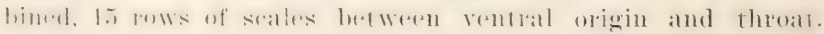

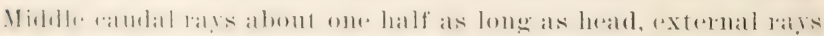

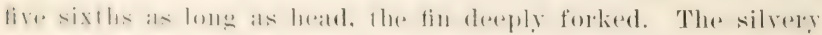

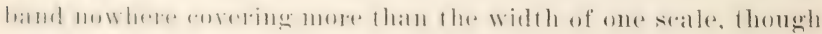
not limitred to one row.

T'ranslucent grexen; lateral band silvery, mostly on the level of tho "yo, its width less than one half the diameter of eye.

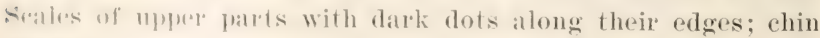
spereklent.

The (1) mmon silversides grows to a leneth of 6 inches.

The silversides was tirst made known by Dr Mitehill muder the manme of small silverside. I i heri lla notata, and he despribed the yommg of the sime species as the green-sided silver-

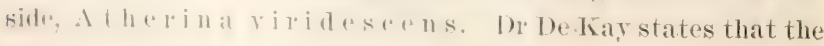


silversides was known in the harbor of New Tork as the anchory and the sand smelt. Friar is a New England name for the species; capelin is in use about Boston, and merit fish in the vicinity of Watch Hill. Nyrling is a name recently applied to this spereses by some tishermen, and we have known persons to offer the silversides as whitebait. In Great south bay it is known as shiner.

The silversides is known to ocem on the coast from Maine to Virginiat. It is one of the most abundant of the small fishes in our Waters, swimming in immense schools made up of fish of different sizes, and it forms a considerable part of the food of more valuable species, such as the mackerel, bluefish, weakfish and flounders, and is very much in demand as a bait for hook and line fishing. We seined the silversides in all parts of Great South bay, and found it to be one of the most abundant and characteristic species.

The common silversides, or spearing, lives in Gratresend bay almost all the rear, hibernating in spring holes in winter. It is well suited for a captive life and ran endure a temperature of $71 \frac{1}{2}^{\circ}$ in the salt water.

In 1898 the speries was found for the state musem at all Long Island localities visited, Peconic bay, Mexox bay, the ocean at southampton, and throughout (rreat south bay. Small individuals are sold in the markets as whitebait. In the time of De Kay the fish was called anchory and sand smelt and was esteemed a sarory food. 20 years before he wrote of the fishes of New York, it was caught from the wharves and sold for bait.

\section{Genus кrrtaxma Joldan of Evermann}

This genus is close to 11 e $n$ i d i a . but differ's from it in having the scales lareiniate and the dorsal and anal fins scaly. Three species known from the Thited states and Martinique.

\section{Kirtlandia vagrans (Goode \& Bean)}

\section{Rough Sitversides}

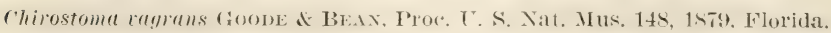
Menidia vagrans Jordax \& Gilbert, Proe. U. S. Nat. Mus. 267, 1882, Bull. 16, U. S. Nat. MIus. 407, 1853. 


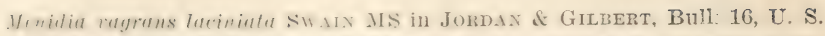

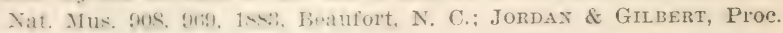
U. S. Nat. Mus. 589, 1853.

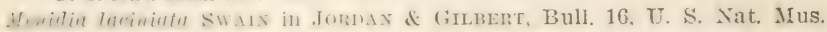

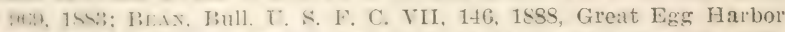

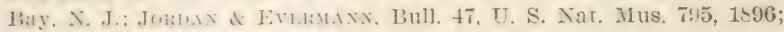
BEAN, 52d Ann. Rept. N. X. State Mus. 102, 1900.

Kirtlandiu ramams Tormax of Evrmans, Bull. 47. U. S. Nat. Mus. 794, 1896, pl. CXXIY, fig. 336, 1900.

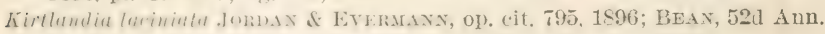

Rept. N. Y. State Mus. 102, 1900.

Hight of the body contained fire and one half to six times in longth withont candal, and six and two thirds times in total length. considerably less than length of head and lergih of pectoral; origin of spinous dorsal fin situated behind a frint midway betwern origins of ventral and anal fins and opposite the middle of the interspatee between anal fin and rent; eye longer than snout. whe third as long as the head, and less than width of interonthital space; mouth slightly protractile, lower jaw equal to length of eye; length of head contained four and three fourths times in total length without caudal, and equal to length of peetoral: pectoral reaching only a rery little beyond origin of rentral when extended; ventral not reaching to vent, its length one hatf the lenghth of head; anal base about as long as the lexal; watal slightly forked, the lobes equal; rertical fins exmssirely saly: stales of body latrge, laciniate, some of thr. espusted edpes with 12 points. 1). IV to V-1, T; A. I, 18 to

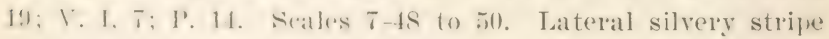
andering line lower two thirds of the third series of scales and the upper one third of the fourth series.

l.ipht gmentish abour; sides and belly silvery; tip of snout and

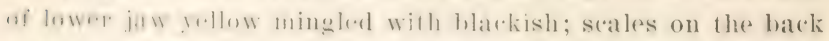

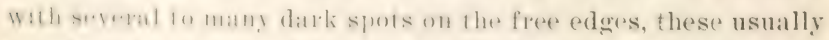

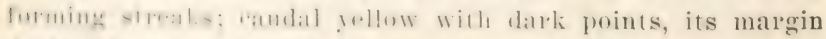

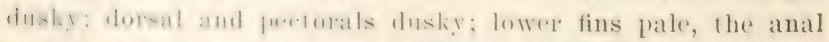
witl dark points at its base.

As here described, the species includes M. I a c i n i a t a

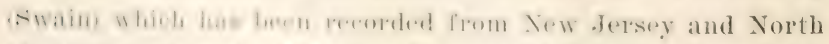

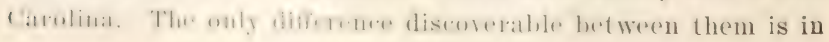


the number of the dorsal spines, which is generally four in la ciniata, but sometimes five, as observed in examples from Great Egg Harbor bay, N. J., no. 45158 U. S. National Museum.

The rough silversides grows to the length of 4 inches; it is not important for food, but serves as food for the larger fishes. It was found abundant at Somers Point N. J. in August 1887, where it had previously been unknown. The largest individual taken in Great Egg Harbor bay, $4 \frac{1}{3}$ inches long, was secured at Longport N. J.

The only example so far kuown in New York water's was caught in Mecox bay, L. I. Aug. 1, 1898. Though the bay was seined repeatedly afterward in search of the fish, no other specimens were seen. The following notes were obtained: D. V, I, 7; A. I, $20 ;$ P. $14 ;$ V. I, 5. Scales $7-47$.

\section{Genus habidesthes Cope}

This genus differs from Menidia chiefly in the prolongation of the jaws, both of which are produced into a short depressed beak. The scales are small as in Le urest hes and $\mathrm{B}$ a s il i chthys, their edges entire.

\section{Labidesthes sicculus (Cope)}

\section{Brook Silversides; Skipjack; Glassfish}

Chirostoma sicculum Cope, Proc. Ac. Nat. Sci. Phila. 81, 1865, Crosse Isle, Detroit River.

Labidesthes sicculus Cope, Proc. Am. Phil. Soc. Phila, 40, 1870; Jordan \& Gilbert, Bull, 16, U. S. Nat. Mus, 406, 18s?; Meer, Aun. N. Y. Ac. Sei. IV, 312, 1885, Montezuma, N. Y.; BEAx, Fishes Penna. 100, 1893; Bull. Am. Mus. Nat. Hist. IX, 357, 1897; Chautauqua Lake; Jordan \& Evermann, Bull. 47, U. S. Nat. Mus. 805, 1896.

The body is slender and elongate, its depth one sixth or one serenth of the total without eaudal. Length of head about two ninths of total; eve two sevenths of length of head, two thirds of length of snout. D. IV, I, 11; A. I, 23. Scales 14-75. Caudal deeply forked.

Color olivaceous, the fish in life translucent, the upper parts with small black dots, the silvery lateral band edged above with lead color and covering one row and two half rows of scales; cheeks silvery. 


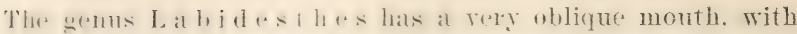
thre uple jall flat alure and coneare beneath, the intermaxillardes forming a ronflike beak. The mandible is renrex.

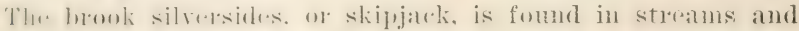
fombls in the (thio and Mississippi valleys. It has also been dis-

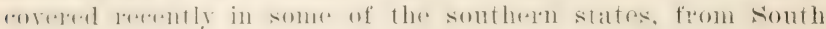
Carolina to Florida. In New York it is recorded from near

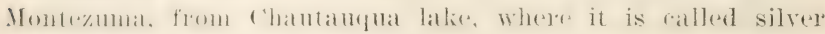

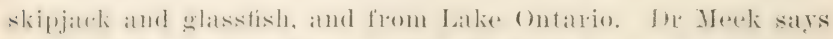

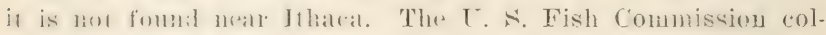
lectors obtained it at the following places in New York:

$\begin{array}{lr}\text { Stony Island } & \text { July } 2 \text { and } 3 \\ \text { Great Sodus bay } & \text { Aug. } 6 \\ \text { Long pond, Charlotte } & \text { Aug. } 17 \\ \text { Sandy creek, North Hamlin } & \text { Aug. } 20\end{array}$

'The tish glows to the length of + inches and is important only

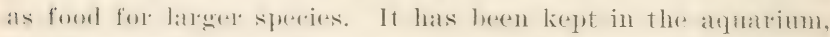

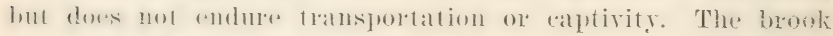

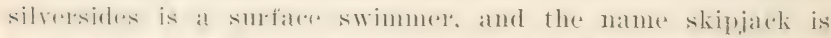
derivel from its lathis of slipping ont of and along the surfare

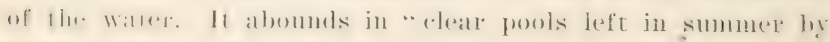
1he fall of the Wallers in the streams. Whieh has filled them."

\section{Family MUGILIDAE}

\section{lilulets}

\section{Genus mgr. (Artedi) Linnaeus}

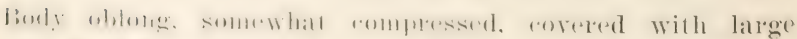

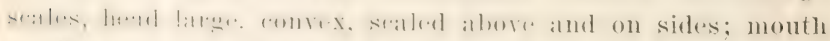

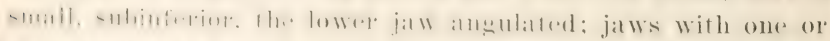

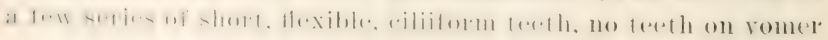
or latalines; fye large, with a large adipose eyelid, which is little derelopert in the yommg; stomach muscular, like the grizatral of a fowl. Sipecies rery numerous, living on mud and

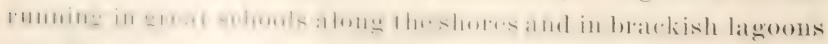

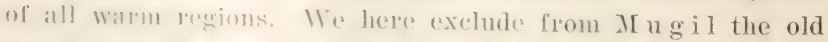

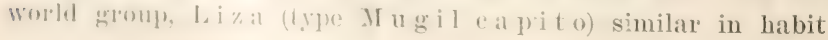


to M u gi l, but lacking the adipose eyelid. (After Jordan \& Evermann)

\section{Mugil cephalus Linnaeus}

\section{Striped IIullet}

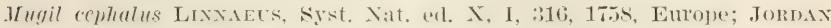
\& Swain, Proc. U. S. Nat. Mus. 263, 1854; Jordar \& Evermanx, Bull. 47 , U. S. Nat. IIus. 811, 1896, pl. CXXVI, fig. 343, 1900; BeAN, $52 d$ Ann. Rept. N. Y. State Mus. 103, 1900.

Mugil albula Linvaeus, Syst. Nat. ed. XII, 520, 1766, Charleston, S. C.; Jordan \& Gilbert, Bull. 16, U. S. Nat. Mus, 403, 18s3; BeAv, 19th Rept. Comm. Fish. N. Y. 272, pl. XXI, fig. 26, 1890.

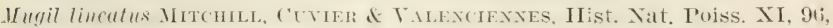
1836, New Jork; DE KAY, X. Y. Fauna. Fishes, 14, pl. 15, fig. 42, 1812. New York; Stonen, Hist. Fish. Mass, 39, pl. XVI, fig. 4, 1867.

Body fusiform, elongate, stout, its greatest width contained one and three fourths times in length of head and equal to length of rentral tin, greatest depth of body one fourth of total length without caudal; suont narrow and somewhat pointed, is length about one fifth of length of head, its profile scarceres more convex than profile of lower jaw; interorbital syater little convex, its width one half length of head; thichness of upper lip scarcely more than one third of leugth of premaxillary; space between the mandibles oblanceolate, its greatest width about one fifth of its length; eres corred by an adipose membrane leaving a free space only about as wide as the pupil; leugth of head contained three and one half to four times in total length without caudal; eye about two sevenths as long as the head; teeth in upper jaw in a rather broad band, the outer row slightly enlarged, teeth in lower jaw similar but much smaller; scales smaller than in M. c urema, about 24 or 25 rows of scales between tip of snout and origin of spinous dorsal, some scales on top of head slightly enlarged, soft dorsal and anal fins almost sealeless; origin of spinous dorsal midway between tip of snout and base of middle caudal rays, alout over the middle of the rentral, base of spinous dorsal one third as long as the lead, first spine longest, one half as long as the head, last spine one half as long as the first, interspate between dorsals about one half length of head, npler margin of soft dorsal deeply concare, base of the fin a little more than one third of 
lenglh of head, longest ray one half the length of head, last ray one fourth the lenghth of headi caudal deeply forked, its middle rays one half as long as the head, its exirnal rays nearly as long as the head; pectoral reaches to the 11 th row of seales from its axil, about as far back as the end of the ventral appendage, its length two thirds of length of heals; rentral origin midway between tiy of slome ans fifth ray of anal, its lemgth fom sevenths of length of head, the fin extending to below the end of the base of spinous dorsal, the tip distant from the anal origin a space about eyual to the

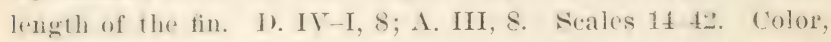
dark bluish above: the sides silvery; exposed frart of seales, sperially of right or 10 upper series, darker that body color, rausing a stripeel appearance; belly and lower part of sides yellowish; rentral fins yellowish; soft dorsal, anal and reutials dusky; tip and base of pectoral dusky.

The striped mullet grows to the length of 2 feet, but the average size in New York waters is much less.

The fish is kuown in Great fouth hay as mullet and jumping mullet; the name mullet is applied to it also in the Gulf of Mrexieo, and is in general nse aloug the east roast; it is lnown in the Chesalpake as mullet or fatbateli. The latter name is probably applied to more than one species.

The strijed mullet is known on our coast from cape cod to

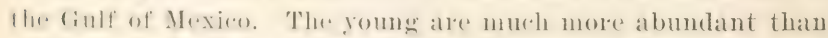
ilue adults. In ripal somb hal we found the speecies not uncommon: I wo examples were talien at the mouth of swan ereek,

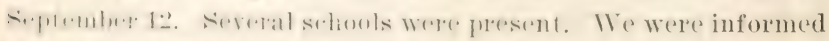
that they apluar measionally, and ome gentleman of Patehogue

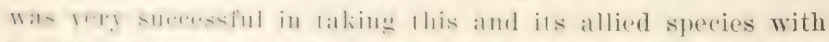
hawh aml lime. De. Kaly stalles thal the striped mullet was first

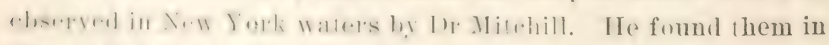

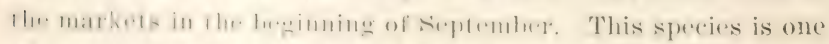

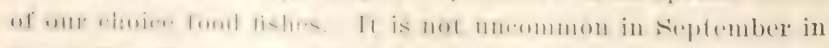

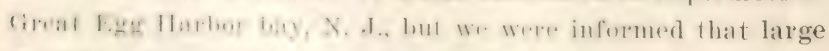
specimens are never talien in that body of water. 
In 1898 the striped mullet was not abuudant in the waters seined till fall; the great schools were absent till October. Sereral individuals were obtained in Mecox bay August 2 and a larger number in Clam Pond cove, Great South bay, August 22.

The young of this species are abundant in Graresend bay in midsummer; larger ones appear in September and October. One winter, some year's ago, mullet hibernated in the mud in Sheepshead bay and were taken with eel spears. The mullets feed and thrive most of the rear in captivity, but will not surrive the intense heat of summer. In the aquarium their food includes hard clam and shrimp.

In 1883 Jordan and Gilbert established a genus Queri. m a $\mathrm{n}$ a for "little mullets with but two spines in the anal fin and with the teeth in the jaws less ciliform than in $11 \mathrm{ugil}$. Adipose eyelid wanting; preorbital serrate." The genus was based on If $\mathrm{xus}$ harengus of Günther. Querimana is nothing more than the young of II ugil. The only good character by which it was distinguished is the presence of two anal spines instead of three; in all other respects Querim a n a and II ugil agree perfectly. Is a matter of fact, all young II u $\mathrm{g}$ i Is pass through a $\mathrm{Q} u$ er i m a n a stage in which only two of the three anal spines are developed, the adipose eyelid is rudimentary and the teeth are comparatively stouter than in the adult. The third anal spine of $\mathrm{M} \mathrm{ug}$ i 1 is really a simple articulated ray till the fish reaches a length varying from about $40 \mathrm{~mm}$ to $50 \mathrm{~mm}$. The first simple ray of the anal becomes a spine by the breaking off at an articulation, the subsequent sharpening of the point, and the deposit of hald material in the articulations, thus forming a somerbat slender', but perfect, spine.

This fact of development was carefully studied in large series of specimens in the U. S. Nationa! Museum, and it is both interesting and important from the fish cultural as werl as the systematic standpoint. In M $u g$ il ceplial $1 \mathrm{~s}$ onte example, $41 \mathrm{~mm}$ long, shows the third anal spine very plainly; it is well developed and has a sharp point, but sereral articulations still 
m-main. (Mher ('ximpules of equal length have the first simple anal laly sarterely derelopul into a spine, and in still others this

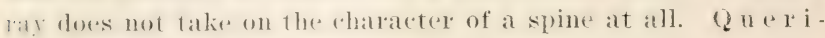

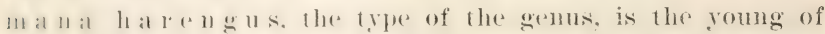

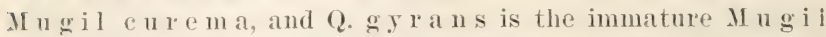

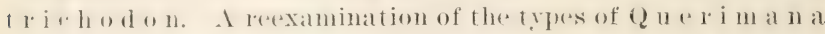
y y l a 11 s shows the presences of :3:3 rows of seales in some examples instead of 29 , as originally recorded.

\section{St Mugil curema Cur. \& Val.}

\section{White Wullet}

Mugil eureme Cuvier \& Valenciennes, Hist. Nat. Poiss. XI, S7, 1836, Brazil; Martinique; Cuba; BEAx, Bull. U. S. F. C. VII, 145, 1ss8; 19 th Rept. Comm. Fish. N. Y. 272, pl. XXI, fig. 26, 1590; JordAN \& Evermaxx, Bull. 47, U. S. Nat. Mus. 813, 1896, pl. CXXYI, fig. 344, 1900; BEAx, 52d Ann. Rept. N. Y. State Mus. 103, 1900.

Mugil petrosus Cuvier \& Valexcientes, op. cit. 88, 1836, Brazil to New York; DE KAY, N. Y. Fauna, Fishes, 147, 1812.

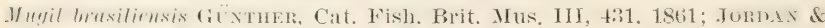
Gilbert, Bull. 16, U. S. Nat. Mus. 403, 1883.

IBody shaped like that of the striped mullet, its width equaling two thirds of length of head, its greatest depth contained there and ome half to three and fire sixths times in total length with(Hut ratulal; least depth of ratudal peduncle ergul to one half the

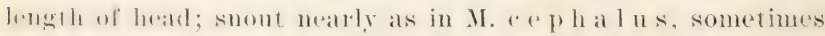
with is ontline mote declivous, its length one tifth of length of luald interembital slater slighty convex, its width nearly one

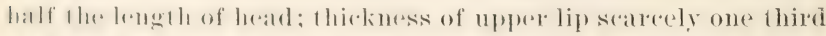

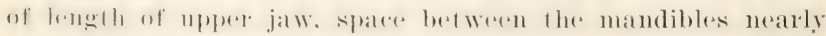
latmerolalle, ils willh ome sixth of its length: reses rovered with all allipose mombloane loaving only a spare about as wide as the

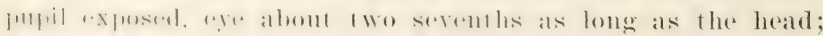

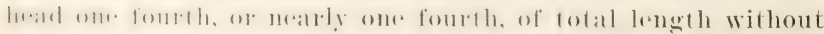

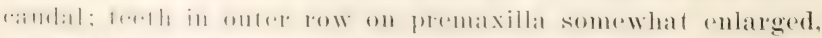

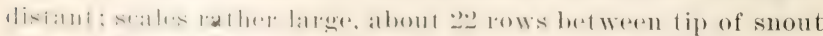

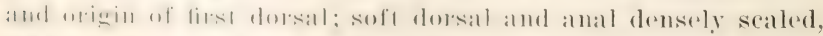

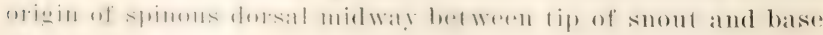
of extrmal candal rays, directly over the 10 th row of seales, counting from the axil of the pectoral, the first spine nearly

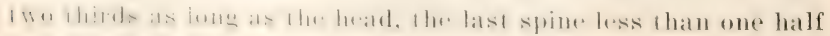


as long as the first, interspace between the dorsals equal to three fifths of length of head, upper margin of soft dorsal deeply concare, base of fin equal to length of postorbital part of head, the longest ray three fifths of head, the last ray one fourth the length of head; caudal deeply forked, its middle rays one half as long as the head, its external rays equal to the head; peetoral reatehes the eighth row of scales, its length equal to head without snout; ventral origin midway between tip of snout and third ray of anal, its distance from rent equal to its own length, which is two thirds of length of head; about 24 rows of seales between the head and the anal origin, base of anal three fifths as long as the head. longest anal ray equal to length of postorbital part of head, last anal ray two serenths of length of head. D. IV-I, s; A. III, 9. Scales 12-38.

color silvery, bluish above; no dusky streaks along the sides in life, but faint stralis are evident after preservation in spirits; a small dark bloteh at base of pectoral: "audal pale, yellowish at base, dusky at tip); anal and rentrals yellowish; two yellow blotches on side of head.

The white mullet reaches the length of 1 foot. On the Atlantic coast it ranges from cape cod to Brazil; in the Patcitic it is recorded from California to chile. It is a rery important food fish.

The white mullet appeats with the striped speciess, but is less abundant in Gravesend bay and is smaller in size. The young were taken in Great south bay in Iugust 1898, and half grown individuals were abundant in serptember and Oetober. Adults were scarce.

I) Mitchill calls this the summer mullet. He records a spereimen that weighed 21 pounds, the heariest coming under his observation. DeKay found the species in New York markets in July and August.

\section{Mugil trichodon Poey}

\section{Whirligig IIullet (young); Fantuil IIullet}

Ifugil trichodon Poer, Ann. Lyc. Nat. Hist. N. Y. XI, 66, pl. 8, figs. 4 to 8 , 1875, Cuba; Jordan \& Evermann, Bull. 47, U. S. Nat. Mus. \$16, 1896.

Mugil brasiliensis Jondax \& SWAn, Proe. L. S. Nat. Mus. 270, 185t; not of Agassiz fide Jordan \& EverdianN. 


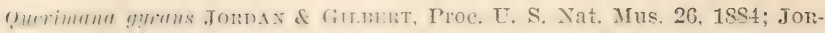
DAN \& EvermanN, Bull. 47, U. S. Nat. Mus. 818, 1896.

Borly rohmst, its gratest depth three elevenths of the total longth withoul randal; hearl short, its length contained four and one fifth times in fotal to caudal base; snont moderately acnte, its upper and lower portes equally oblique; interorbital space little convex, its willh two fifths of the length of the

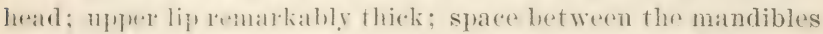
molerenath narrew, oblanerelate, rather pointed behind; an adipose membrane (eorering all but the ceutral part of the epe; terethe compalratirely large and wide set, about as long as the mostril: about 201 rows of scales between origin of spinous dorsal and tip of smout, soft dorsal and anal densely scaled, the margin of soft drirsal eoncare, the second, and longest, ray two and three fomthe times as long as the serenth; anal similar to soft dorsal; the pectoral short, not reaching nearly to rertical from fromt of spinous dorsal; (autlal large, deeply forked. 1). IV-I, 8; A. III, 8. Scales 33-11.

Iylue farts dusky, olivaceous, with bluish reflections, lower farts silvery; seales without dusky spots; a dark blotch at hase of pertoral; dorsals and caudal pale, the dorsals with minnte dark points. anudal with a dark margin; anal and rentrals yollewish: pertorals fale, with fine brown punctulations.

The fantail neullet ranges from Brazil to the Florida Keys

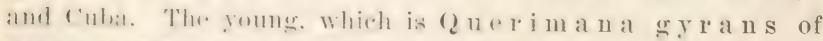
Jurdan di Cillupt. migrates northward in summer to Cape Cod; it has bern rendeled from lomg lsland and the vicinity of Woods Hole Mass.

The species reaches the length of 10 inches.

$$
\text { Family SIPITRAENIDAE }
$$

Barracudas

Genus sphroma (Artedi) Bloch \& Schn.

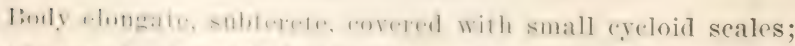

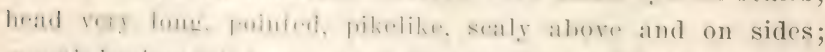

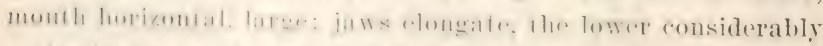

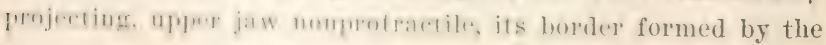


premaxillaries, behind which are the broad maxillaries, large, sharp teeth of unequal size on both jaws and on palatines; none on the vomer; usually a rery strong, sharp canine near the tip of the lower jaw; opercular bones without spines or serratures; gill openings wide, the gill membranes not united, free from the isthmus; gill rakers rery short or obsolete; branchiostegals seven; gills four; pseudobranchiae well developed; air bladder large, bifurcate anteriorly; many pyloric caeca; lateral line well developed, straight; pectoral fins short, placed in or below the line of the axis of the body; rentrals I, 5, abdominal, in advance of the middle of the body; first dorsal over ventrals, of five rather stout spines, second dorsal remote from first dorsal, similar to and opposite anal; caudal fin forked; vertebrae 24 ; first superior pharyngeal absent, second, third, and fourth separate, with teeth, lower pharyngeals separate.

\section{Sphyraena guachancho Cuv. \& Val.}

\section{Long Barracuda}

Sphyraena guachancho Cuvier \& VAlexcienxes, Hist. Nat. Poiss. III, 342, 18 29 , Havana; Jordan \& Evermanx, Bull, 47, U. S. Nat. Mus. 824, 1896.

Sphyraena guaguancho Goode \& BEAN, Proc. U. S. Nat. Mus. II, 146, 18s0; Jordan \& GiLbert, Bull. 16, U. S. Nat. Mus, 411, 1883.

Sphyraena guaguanche Poex, Memorias, II, 166, 1860; Meer \& Newland, Proc. Ac. Nat. Sci. Phila. 70, 1884.

Sphyraena güntheri HALY, Ann. \& Mag. Nat. Hist. XV, 270, 1875, Colon.

Body moderately elongate, subcylindric, its greatest depth one seventh of the total length without caudal, its width two thirds of its depth and one third of length of head; the caudal peduncle stout and not elongate, its least depth one fourth the length of head. The head is long, nearly one third of total without caudal, its width two sevenths of its length; the lower jaw projects a space one half as long as the iris, the top of head flat and with a long and well marked median groove; the interorbital space equal to iris; the maxilla broadly expanded and abruptly bent downward, its width at the posterior end one fourth of its length, its end reaching about to front of orbit; mandible as long as head without postorbital part; preocular ridge three fourths as long as iris; 


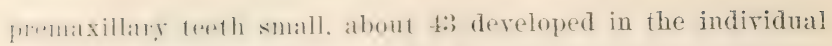

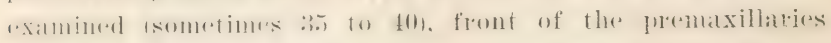

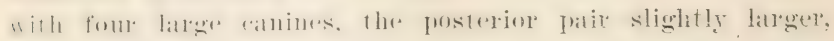

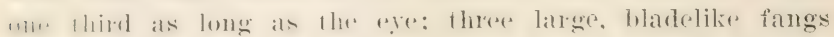
on each side of palatines; a large compressed fang at symplysis of lower jatw. mandible with abont 17 modere

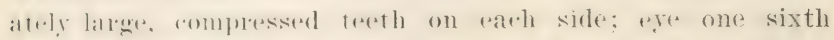

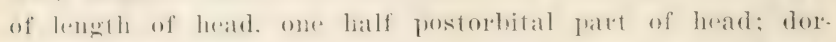
sil origin at a distance from smout refual to three times length

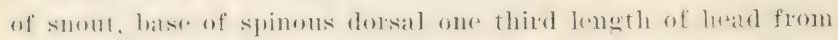

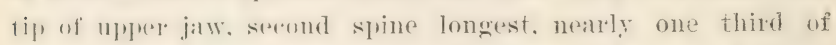

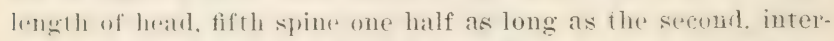
spater luwwen first and second dorsal equal to smout and ere (a)mbined. base of serend dorsal f wo sevenths of length of head. inclubling lowere jaw, lomgest raty as long as base of find last raty

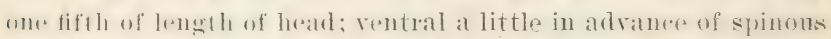
dursal, its distance from the head equal to length of pectural, its lellgll 1 wo sevenths of length of hoad; alual origin andere middle of dorsal hase, anal hase one fourth the length of head, lomeres allall ray equal 10 ventral. last ray one half the postore-

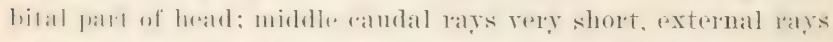
as lomp as smomt and eye combined; pectoral as loug as postor-

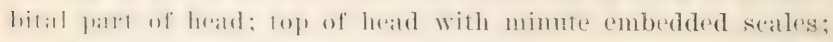

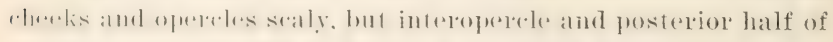
oprere naked. 13. VII, D. V-I, 9; I. I, S; T. I, 5; P. I, 12. Scales 15) to 16-11:2 to 121-13 to 17 .

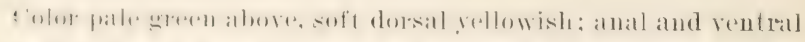

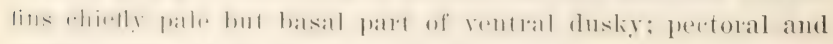

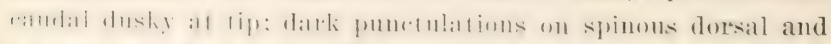

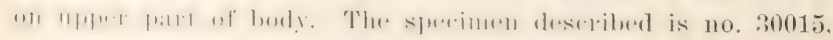
Jamaica, in the U. S. national museum.

In individual 213 inches long was taken at Woods Hole

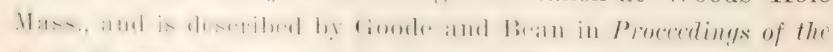

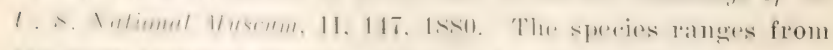

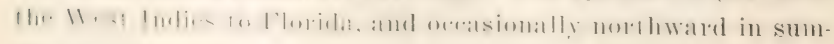
mer to ciape corl. 


\section{Sphyraena borealis De Kay}

\section{Northern Barracuda.}

Sphlyruend borentis De Ki.1Y, X. Y. Fatuna, Fishes, 39, pl. 60, fig. 196, 1842.

New York; Meek \& Newland, Proc. Ac. Nat. Sci. Phila. 75, 1884; BeAN, Bull. U. S. F. C. VII, 145, 1888; 19th Rept. Comm. Fish. N. Y. 271, 1890; Jordan \& Evermann, Bull, 47, U. S. Nat. Mus. 825, 1896. Spplyyraena spet Jordix \& Gilmert, Bull, 16, U. S. Nat. Mus. 411, 18s:; not of HÄUY.

Body moderately elongate and compressed, its greatest depth equal to length of snout, and contained seven and one half times in total length without caudal its width equaling two serenths of leugth of head; caudal peduncle subterete and tapering, its least depth one fifth of length of head. The head is one third of total length without caudal, its width one fourth of its length, the lower jaw projecting a space equal to pupil, top of head slightly convex, a rery shallow median groove, the interorbital space equal to length of exe; maxilla broadly expanded posteriorly, its greatest width one fourth of its length, its end not reaching front of orbit by a space two thirds as long as the eye; mandible as long as snout and eye combined; preocular ridge two thirds as long as the eye, not rery prominent; premaxillary teeth small, smaller anteriorly, about 45 in number, front of the premaxillaries with three large canines on each side, one of them much larger than the other's, one third as long as the eye; two large fangs on one side of the palatines, three on the other, followed on each side by three smaller teeth; a large, compressed fang at the srmphysis of lower jaw, mandible with 10 to 12 teeth, increasing in size and becoming more widely separated posteriorly; eye equal to interorbital width and its length contained six and one fourth times in length of head; dorsal origin at a distance from tip of snout equal to a little more than three times length of suout, base of spinous dorsal nearly one third as long as the head, second dorsal spine longest, about one third length of head, last dorsal spine one half of postorbital part of head, interspace between dorsals one half of length of head, base of second dorsal equal to longest doraal ray and two sevenths of length of head, last dorsal ray equal to long diameter of eye, 
and num. serenthof lengthof head: rentral under the second spint a) Hor dussal. its distane from the head one half of length

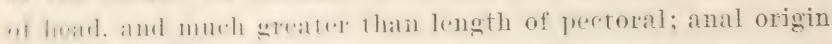
murler fourlh lay of serend dorsal; the anal base fwo serenths

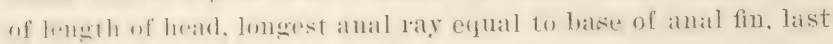

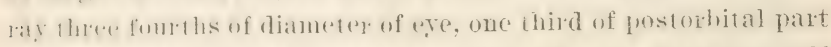
of heall: midllle ratulal rays rery short. external rays one half

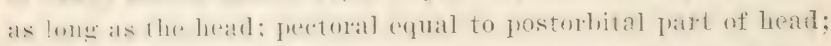
loj, al luanl with numeroms minute, embededed srates and with

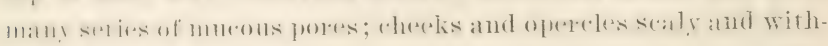
out naked spaces. B. VII; D. V-II, 9; A. III, S; V. I, 5; P. I, 12. Scales $13-126-13$.

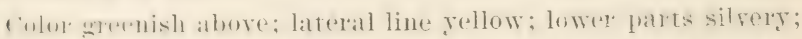
iris gulden: youmg with dusky blotrles on the batck and along the lateral line.

This tish sernos 10 have been moknown to the early witers on Xiw Vork fishes, the speries not appearing in ant publieation

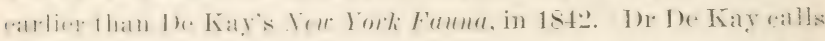

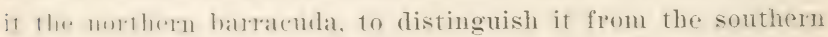
species.

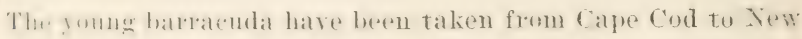

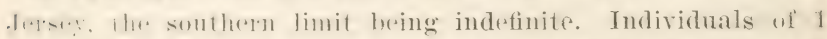

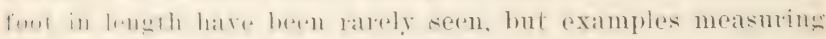

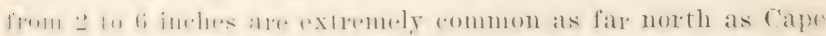

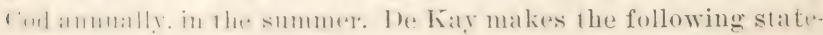

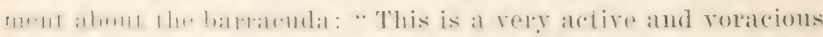

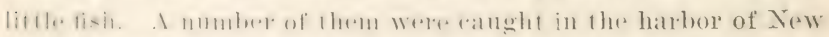

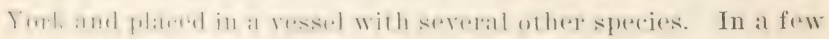

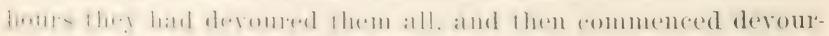

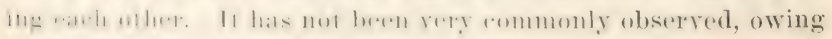

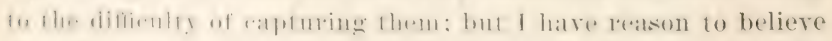
flat lhey are not rery rare." In Great Ego Harbor bay the

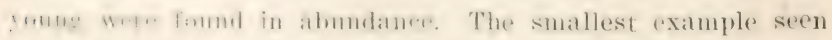

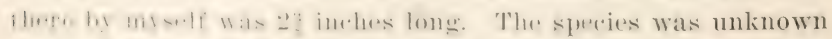

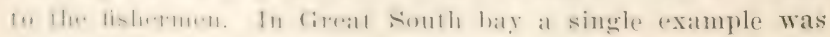
rafulured at ()ak island September 30. 
This barmarda is not seen in our markets, bet the adults of more southeriy species are considered excellent fond fishes. It Key West and on cozmmel island, and in the West Indies, the barracuda is highly prized.

Several young baracuda were "aught in Gravesend bay in September 1896. The spereies is not common in that bay. In

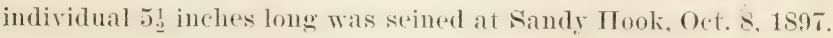
The fish does not live long in eaptivity.

Suborder RHEGNOPTERI

Family pol yNemidae

Threadfins

Genus polydotrus Lacépède

Anal fin not murh longer than soft dorsal, of about 13 or 14 rays; romer with tecth; properemlum serrate; free filaments of pectorals mostly shorter than bodr; teeth in villiform bauds on both jaws, romer, palatines, and pterygoids: preopercle sharply serrated on its posterior margin, its angle with a sealy flap; seales rather small, finely ctenoid; first dorsal with seren or eight feeble, rather ligh spines, the first and last short, soft dorsal and anal fins about equaling each other; pectoral filaments three to nine; pyloric atecal in great number. Species numerous, in warm seas.

\section{Polydactylus octonemus (Girard)}

\section{T"hreadfin}

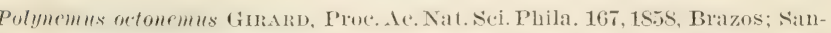
tiage; Galveston; young; (ï̈mter, Cat. Fish. Brit. Mus. II, 320, 1Sto; Goode \& BeAN, Proc. U. S. Nat. Mus. II, 128, 1850; JordaN \& Gilbert, Bull. 16, U. S. Nat. Mus. 413, 1853.

Polyduclylus octonemus Jornix \& Evermax, Bull. 47, T. S. Nat. Mus. S:30, 1896, pl. CXXVIII, fig. 350, 1900; BEAN, Bull. Am. Mus. Nat. Hist. IX, 358, 1897 .

Trichidion octofilis GILL. Proc. Ac. Nat. Sci. Phila. 2S0, 1861, Nerv York; adult.

Trichidion octonemus GILL, op. cit. 280, 1861.

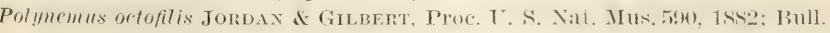
16, U. S. Nat. Mus. 413, 1883.

Body compressed, moderately elongate, its greatest depth from one third to two serenths of the total length without caudal, its thickness equal to two fifths of length of head; 


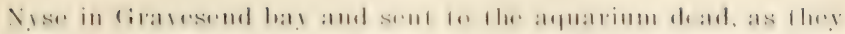

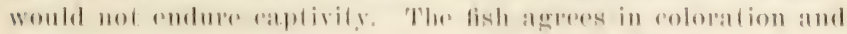

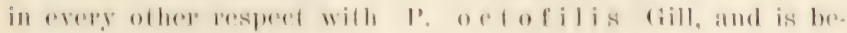

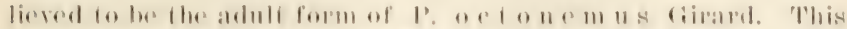

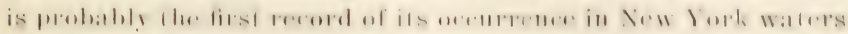

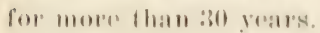

\section{$1111: 211: 11111: 5$}

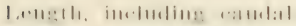

III) lwin

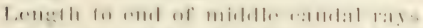

(2),

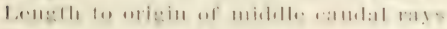

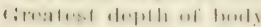

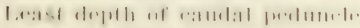

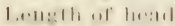

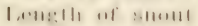

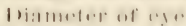

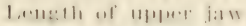

lemeth of mandible.

bength of lomgest peoforal filament

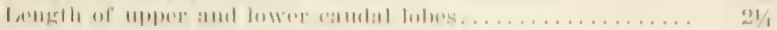

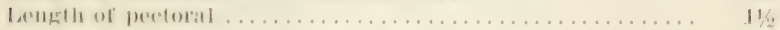

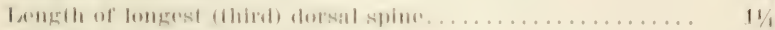

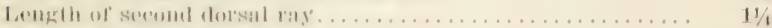

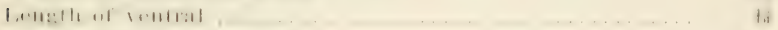

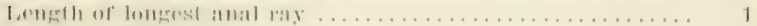

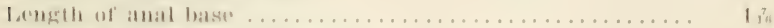

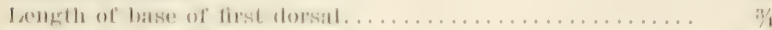

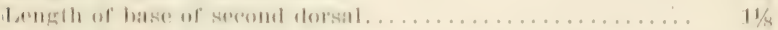

The lomerest pereforal filament. deaches to below the inter-

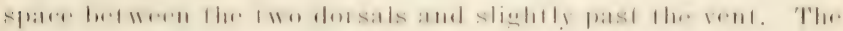

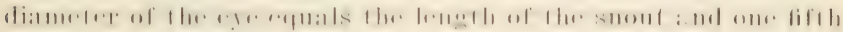
lhe lowell of the hearl.

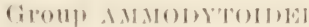

Eamily

\section{samd lameres}

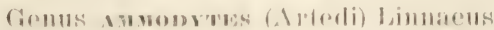

liody olongate, lanceolate, Hos skin with many transverse

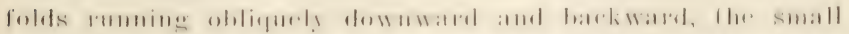

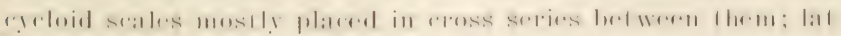

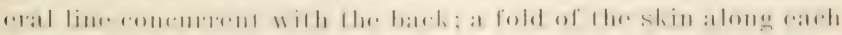

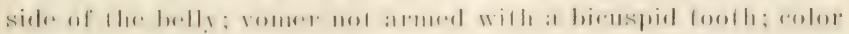

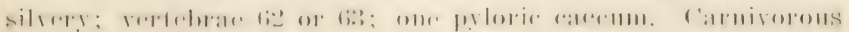


tishes inhahiting sand! shores in able regions, living in larege

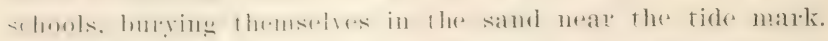

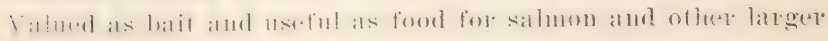
fishes.

\section{8!) Ammodytes americanus De Kay}

\section{Sand Lance: Sand. Eel.}

Ammolutes americumes DE KAY, N. Y. Fauna, Fishes, 317, pl. 52, fig. 167 , 1St2. queens County, New York, and Stratford, Comn.; Srorer, Hist. Fish. Yass, 216, pl. XXXIII, fig. 2, 1867; Goode \& BEAx, Bull. Essex Inst. YI. 20, 1S79; JokmAx \& Gilbert, Bull, 16, U. S. Nat. Mís. 414,

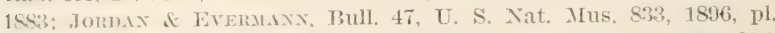
(XXIX, tig. 351, 1900; Brax, Buil. Am. Mus. Nat. Hist. 1X, 359, 1897. Ammolytes viltutus DE KAs, X. Y. Fauna, Fislres, 318, pl, 60, fig. 197, 1812, New York, apmarently based upon a mutilated specimen, fide JorDAN it Evemaraxy.

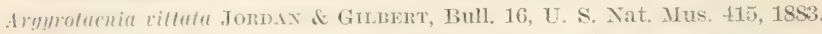

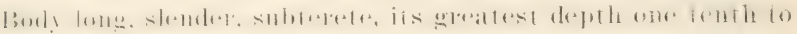

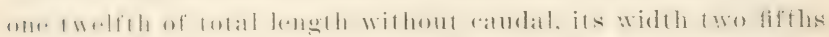

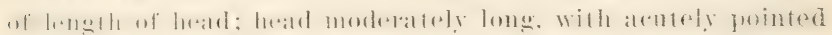

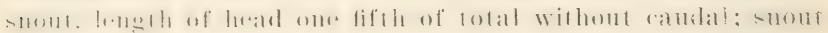

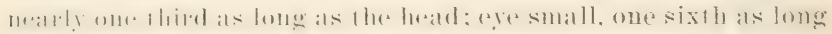

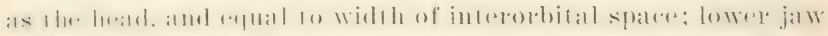

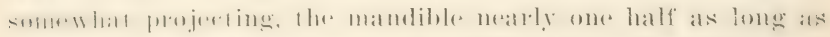

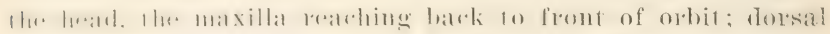

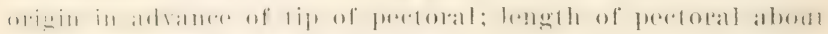

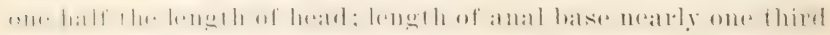
of total wilhout candal; dorsal and anal rays about equal in lemgth and not much longer than the eye; intermaxillary pro-

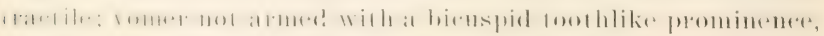

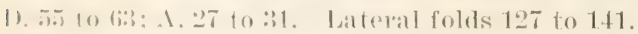

The sprecimems axamined atre from ti to 7 inches long, from

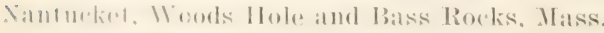

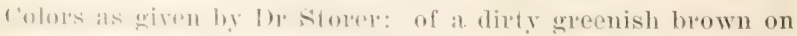
How hark. Ho sides and abdomen silvery, the top of the head llesh-enlonerl, the preopereles silvery, opereulum erpreous and silvery, pupils blateli, iris silvery.

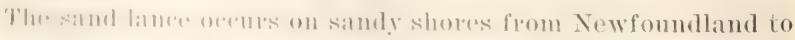

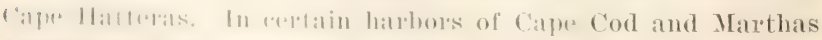

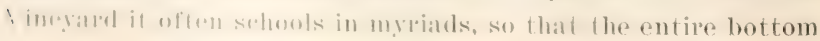


is covered flom 1 to 2 inches deep and appears like an immense sheet of silver. These little fish are a very important sourere of food for the rod, salmon and other valuable fishes and are excellent for bait.

De Kay found the roung frepuently washed on shore after heavy northerly gales.

The sand lanes appears in Gravesend bay in July, but is more plentiful in winter. The fish buries itself in sand and sometimes, whell alatmed, will leapl 4 inches above the sand. In raptivity it swims rontinnally and soon dies. It will not thrive for want of sand and proper food.

\section{Group BERYCOIDEI}

Family MIULIDAE

\section{Surmullets}

\section{Genus mulus Linnaeus}

Villiform westh in the lower jaw and on the vomes and palas tines, none in the mplex jaw, the bone forming a hook over the maxillary well developed; operele without spines; interortital spare flat and wide. Otherwise as in $\mathrm{I}^{+} \mathrm{p}$ ene $\mathrm{ns}$. the head rather shorter. One species known.

\section{Mullus auratus Jordan \& Gilbert}

\section{Red Iullet; Goatfish}

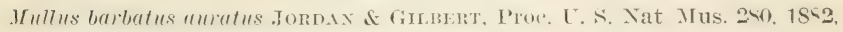
Pensacola, Florida; Bull. 16, U. S. Nat. Mus. 931, 1883.

Ifullus amratus Jordan. Proc. U. S. Nat. Mus. 39, 1884; BeAn, Bull. Am. Mus. Nat. Hist. IX, 359, 1897; Jordan \& Evermann, Bull. 47, U. S. Nat. Mus. 856, 1896, pl. CXXXII, fig. 360, 1300.

Body moderately dere and rompressed, its width equal to postorbital length of head, its greatest depth nearly equal to length of head and rontained theres and one half times in total length without rauclal; least depth of raudal peduncle equal to postorbital fart of head; head two serenths of total length without caudal; anterior frofile rather steep; intermaxilla protractile; month smatl, terminal, the mpere jatw one thirel as long as the head and about equal to Jength of mandible; (2ye placed high, intreorbital spare neally flat, its wirlth greater 
than long diameter of the eye, and about two serenths of length of head, eye about three elerenths of length of hear: barbels one fifth of total length to end of scales, and equal to length of pectoral. The spinous dorsal begins over the fifth seale of the lateral line, its base one half as long as the head, its longest spine two thirds as long as the head, its last spine scarcely as long as the eye, interspace between dorsals equal to one third the length of head, base of second dorsal one half as long as the head, longest ray slightly more than one half the length of head, last ray as long as the eye. The rentral origin is under the axil of the pectoral, also under the third scale of the lateral line; the length of the ventral is one fifth of total length to end of scales; the ventral fin reaches a little farther back that the pectoral, to a point below the twelfth scale of the lateral line. The anal origin is under about the third ray of steond dorsal; the base is as long as postorbital part of head: the longest ray one half, and the last ray two sevenths of length of head. Caudal dreply forked, the middle rays, from and of scales, two fifths as long as the outer rays, which are threet fourths as long as the head. Pectoral fin three fourths as long as the hear, reaching to below the 12th scale of the lateral line, and and of spinons dorsal base. D. VII-I, S; A. II, ii: V. I. 5; P. 16 . Scales $3 \frac{1}{2}-35-6$.

Color searlet: side with two yellow longitudinal stripes; suout and cautal fin scarlet, the latter with about five narrow dusk? bands after preservation in spirits; first dorsal fin with an orange band al hase and a yellow band higher up, the rest of the fin pale: serend dorsal fin with about three narrow bands of searlet; anal and rentrals pale; pectoral peddish; iris violet or golden; sides of head silvery, iridescent.

Thered mullet ranges from cape cod to Floridal it is found

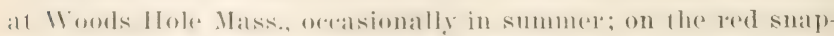
. per banks oft lensaleola Flat it is morlerate? y abundant. The tish glows to the length of 8 inches. It has no economice value. but furmishes foul for the red snapper. grompers and other food fishes. 
Three individuals of $\mathrm{M}$ u $1 \mathrm{lus}$ were captured in a seine at Sandy Hook X. J. Oct. 8, 189T, and brought alive to the New York aquarium, where they are now (Nov. 30, 1897) in good condition and feed freely on shrimp. Is the fish are living. it is uncertain whether or not they are M. a u r a tus; but they agres in the main with the description of that species. Their endurance of water at a temperature of $50^{\circ} \mathrm{F}$. is unexpected. Fishermen at Sandy Hook reported that large numbers were seen there in September and October 1897.

Recent examination of one of the specimens above referred to No. 48796, L. S. National Musemin shows its entire agreement with the type of Mullus a ratus.

\section{Group SCOMBROIDEI}

\section{Family SCOMBRIDAE}

\section{Mackerels}

\section{Genus scomber (Artedi) Linnaeus}

Body fusiform, rather elongate, somewhat compressed; caudal peduncle slender, without median keel, but with two small keels on each side; mouth wide. with a single row of rather small, slender terth in each jaw and on the romer and palatines; maxillary slipping under the broad preorbital, a fleshy lobe on each side of lower jaw near its junction with maxillars; scales very small, wot forming a rorselet; first dorsal of nine to 12 feeble spines. separated from thr serond by an interspace greater than the base of the fin, secom dorsal small, followed by five to nine detached finlets: anal similar to second dorsal, with similar finlets; pectorals and rentrals small, the former placed high. on the level of the eyes; candal fin small, widely forked; pyloric appendages exreedingly numerous; air bladder small or wathting: verteblat normally formed, $14+17=: 31$; gill rakers long and slender.

\section{Subgenus SComber}

\section{Scomber scombrus Linnaeus}

Common Mackerel

Scomber scombrus Lixatels, Syst. Nat. ed. X, 297, 1758, Atlantic; Goode \& BeAx, Bull. Essex Inst. XI, 14.1879; Jordax \& Gilbert, Bull. 16, U. S. Nat. Mus. 424, 18S3; Jordax \& Evermans, Bull. 47, U. S. Nat. Mus. S65, 1896, pl. CXXXIII, fig. 363, 1900. 
Sconsber vernatis Mrtcmid, Trans. Lit. \& Phil. Soc. N. Y. I, 423, 1S15, Sandy Hook, New Jersey; DE KAY, name omitted from chapter heading, X. Y. Fauna. Fishes. 101, 1). 12, fig. 34, 1842, New York coast; SંTon:R, Ilist. Fish. Mass. J., pl. XI, fig. 2, 1867.

Sermber scomber Irxakes, Syst. Nat. ed. XII, 492, 1766; Günther, Cat. Fish. Brit. Mrus, II, 3.57, 1860.

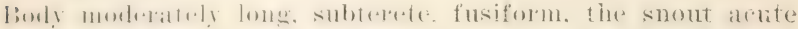

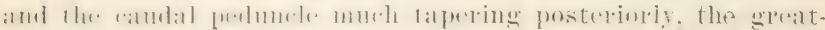

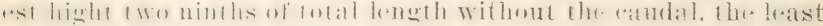

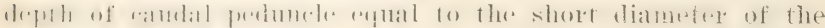

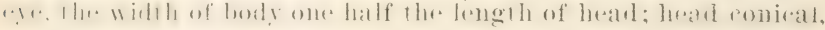

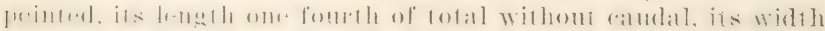

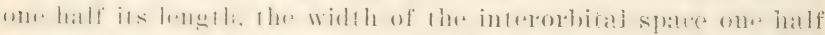

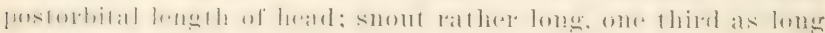

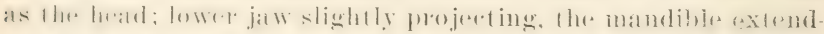

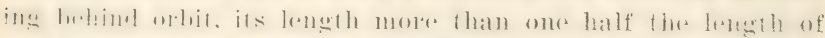

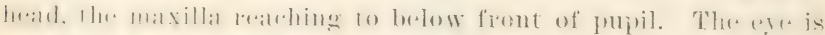

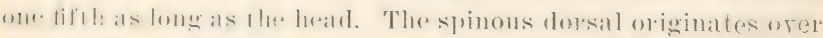

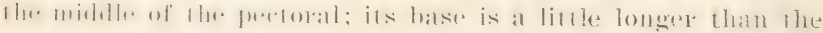

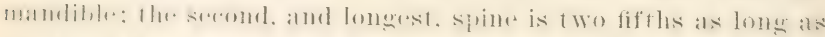

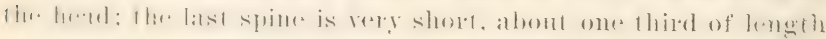

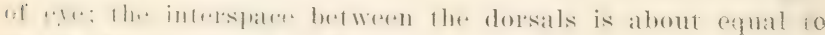

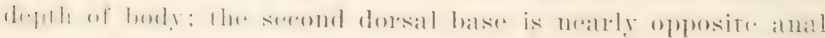

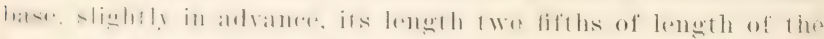

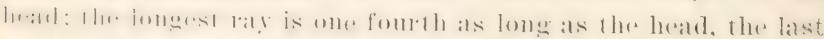

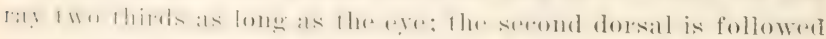
hy five finlets, each as long as the last ray. The anal origin is

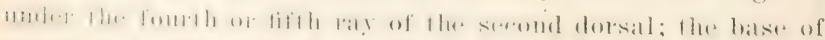
llw fin is one third as long as the head; the longest ray is one hatf of postorbital length of head; the last ray is two thirds as long as the eye; the fin is followed by five finlets which are

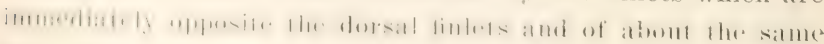
size. The midelle caudal rays, from end of seales, are equal to

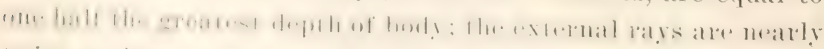
fwim as lome as the middle rats. The ventral origin is rery slighly! in advanee of hlo origin of spinous dorsal, its distance from life of stroml cqualing the distance from origin of second

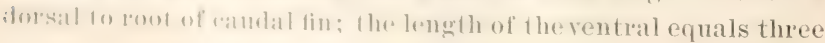


righths of length of head. The pectoral is one half as long as the head; the fin reaches to below the sixth spine of the dorsal. No air bladder. D. XI-I, 11-V; A. I, 11-V; V. I, 5; P. I, 16.

Color datk blur. or greenish blue, above, the upper parts with 30 or $1100^{\circ}$ waty transwerese bands of a datker hue, these extending belew the lateral line and nealy to the median line of the body: heneath the ends of these lines aud slightly separated from thrm is a narrow, lomgitudinal, dark streak running almost

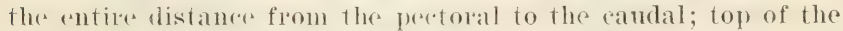
head rely dark: a dark bloteh in the axil of the pectoral; gill

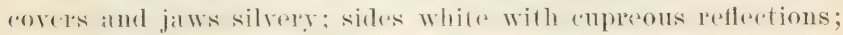
belly white.

The matelerel is one of 1 he best known food fishes of the north Atlantic, fanging from Vorway to Spain in Europe and from Labiador to rape IIatteras in Nortle Imerica. It reaches the length of 18 inches. The fisl: is migratory and frequently disappears for a short or lomg period of time from its aceustomed localities. (3n the New Jork coast the mackerel appeats in May and Junr in great schools. hut the number vares greatly in different years.

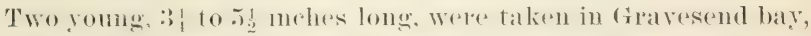
T. I., May 2.:, 1896, in John B. H) Nyses shad fylie. No more were sexth, and these were the first for the rear. They come about the time of the appearanes of anchory and weakfish. They ale oftenserenswimming at the surfares of the bay in small

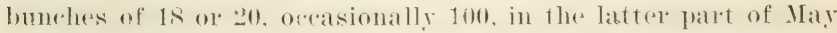
or early in .June. They ate always split up into small bunches, probably by the attacks of watkfish and other predaceons species whirh ale plesent at the time. Flukes attark them also in shallow water.

\section{Subgenus PNEumpromors Jordan \& Gilbert \\ 192 Scomber colias Gmelin}

\section{Chub Mackerel; Thimbleeye Hackeral}

Scomber colias Gumetr, L. Syst. Nat. 1329, 178s, Sardinia; DE KAY, N. Y. Fauna. Fishes, 104, pl. 11, fig. 33, 1842; Jordav \& Evermand, Bull. 4ī,

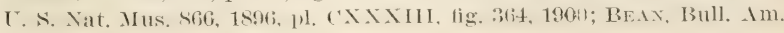
Mus. Nat. Hist. IX, 360, 1897. 


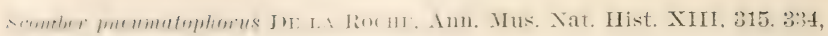
1S09. Balearic Islands.

Senmber grex MrtenLl, Trans. Lit. \& Phil. Soc. N. Y. I, 422, 1815; Storer, Svn. Fish. N. 1. 90, 1816.

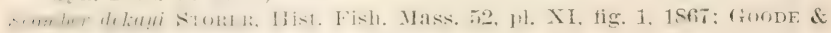
BEAx, Bull. Essex Inst. XI, 15, 1879.

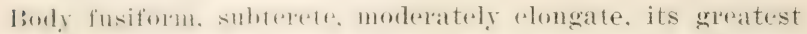
droth 1 wo ninfles of tolal lemglh to hase of ramial fin: least depuh of rambal pedunele two thirds of the short diameter of llwe fre its willh mole than one half the length of head and

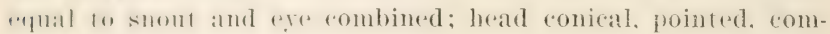

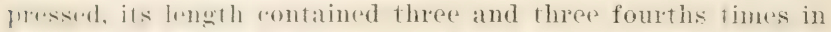
lotal to hase of ratudal, its width rqual to onie half its length, width of inferollital slace thee fifths of length of postorbital fall of head: subut long. pointed, two serenths as long as the lıad: lower jaw slighty projecting. the mandible extending to lwluw himb alge of pupil, its length less than one half the

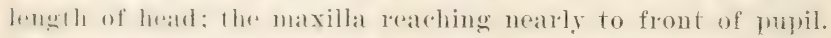

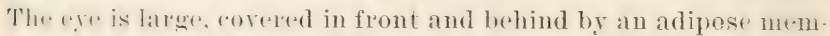
hranr, ils length three elevenths of length of head or two thirds of lelloll of postorlital patrt of head. The spinous dorsal originales orer lhe mighle of the peretoral, a little behind the inserelioll of the rentlat: the base is as long as the head without the stmmt and is monh lomger than the mandible; the second spinte. longers. mole half as lome as the head, the last spine minute.

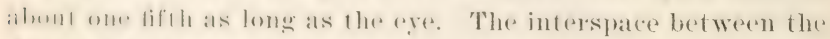

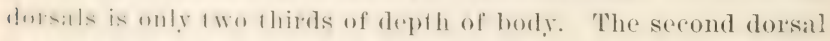
l, -1 is rhichl ofjusife anal hase, hut more in adrance than in

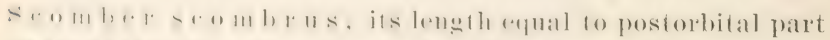

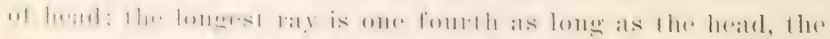
last ray one laalf as long as the eye; the second dorsal is fol-

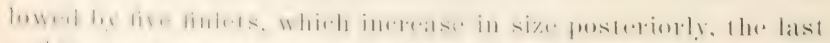

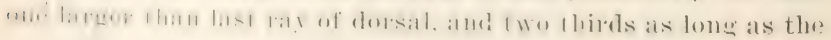
"ye. "The antul origin is moler the fifth or sixth ray of the

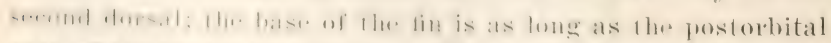

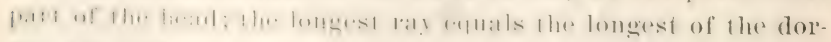
sal: llw last ray is one latf as long as the eye; the fin is follomed hy live finlets of the same size as the dorsal finlets and 
placed nearly opposite to them. The middle caudal rays are very short; the exterual rays are as long as the snout and eye combined. The rentral origin is equally distant from tip of snout and vent; the fin is two fifths as long as the head. The pectoral is one half as long as the head and reaches to below the fifth spine of the first dorsal. Lir bladder present. D. IX to $\mathrm{X}-\mathrm{I}, 11$ to $12-\mathrm{T}^{2}$; A. I-I, 11-V or VI; V. I, 5; P. I, 19 . Scales nearly 200.

Colors essentially the same as in $\mathrm{Scomber}$ s co m b r u s, the wary transverse bands about 30 in number; sides mottled with small dusky blotehes below the median line; about 20 black specks on base of preopercle, usually arranged in more than one series; belly and sides silvery; a black blotch in axil of pectoral.

The ehub mackerel is found in the Atlantic and Pacific oceans, north to England and Naine and to San Fraucisco; very common in the Mediterranean and in southern California; sometimes abuntant on our eastrin roast and frequently absent for long periods. It reaches the length of 14 inches and is an important food fish.

July 25, 1887, the schoone Perer Cooper caught 6000 thimbleeyc mackerel off Mamasquan N. J. About 50,000 mackerel were taken by the menhaden steamer, A. Morris, near Ocean City, July 19, 1887. Some of these were preserved in brine by W. B. Steelman, and I found them to be S. colias.

The thimbleeyes usmally arrive in August. In 1886 they were often raught. This species was not found in large numbers in Graresend bay in 1897 , but in 1896 it abounded in all the little areeks, and in some instances the fish conld be dipped up by the boat load with scoop nets. The fish reached 10 inches in length before the end of the summer.

\section{Genus ards Cuvier}

Body oblong, plump, mostly naled posteriorly, anteriorly covered with small scales, those of the peetoral region enlarged, forming a corselet; snout rery short, couical, scarcely rompressed; mouth rather small, the jaws equal; teeth rery small, mostly in a single series, on the jaws only; tail rery slender, 


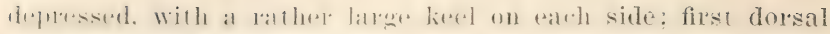

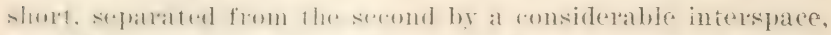

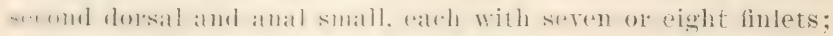

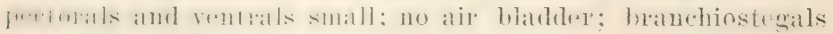

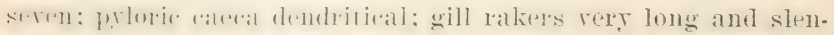

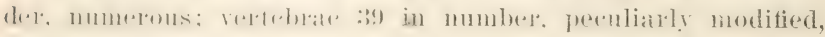
essentially as in G y m n o s a d a.

\section{Auxis thazard (Lacépède)}

\section{Frigate ILackerel}

Scomber thanarl LAcepene, Hist. Nat. Poiss. III, 9, 1802, Coast of. New Gruinea.

Auxis vulgaris Covier of Valexciennes, Hist. Nat. Poiss. VIII, 139, 1831, Mediteranean.

Auxis rochei Guntmen, Cat. Fish. Brit. Mus. II, 369, 1860; Jordax \& GreBERT, Bull. 16. U. S. Nat. Mus, 425, 1883.

Auxis thuzard Jordax \& GILBERT, op. cit. 911, 1883; JordAN \& EvERMANN, Bull. 47, U. S. Nat. Mus. 867,1896 , pl. CXXXIII, fig. 365, 1900.

limly stml, sublerete, fusiform, tapering to a very low :atudal

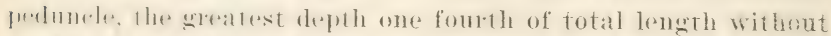
ratulal. thr width meally two thirds of the depth: the least depth of randal fulmmelo almut two fifths of length of iris: head short.

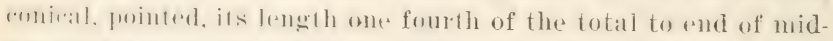

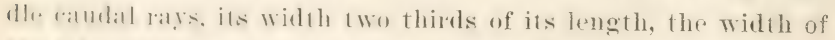

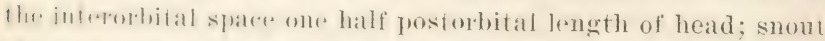

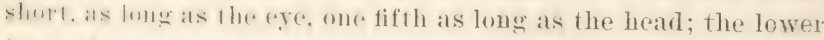

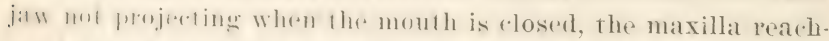
ing lo lu.low midtle of pupil, the mamdihle two fifths as lomg as

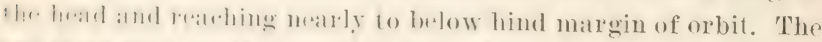

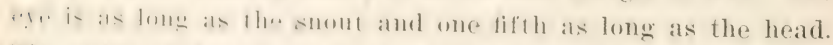

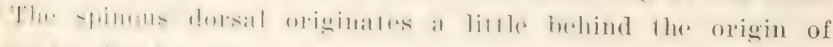

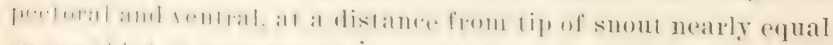

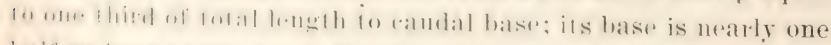

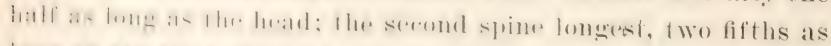

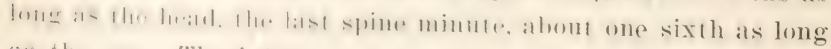
as the eyo. The interspace between the dorsals equals the

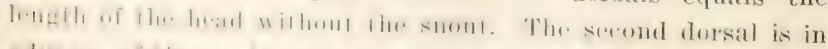

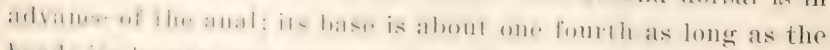

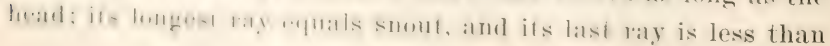


one half the snout; the fin is followed by eight finlets, which decrease in size posteriorly. The anal origin is below the interspace between the end of the second dorsal and its first finlet; the anal base is as long as the seeond dorsal base; its first ray is as loug as the snout, its last ray is one half the short diameter of the eye; it is followed by seren finlets, decreasing in size posteriorly. The middle caudal rays, from end of keel, are one fourth as long as the outer rays, which are one half as long as the head; the caudal lobes form a rery obtuse angle with the caudal peduncle. The rentral origin is directy under the root of the pectoral; the fin is as long as the snout and eye combined, the rentral sheath about as long as the fin. The pectoral is falcate, many-rayed, its length four ninths of length of head; the fin reaches to below the last spine of the first dorsal. T. X-12VIII; A. 13-VII; V. I, 5; P. 22; B. VII.

Color dark blue above with reticulated markings on the back, chiefly in the second half of the length and all above the lateral line; sides, lower parts and head silvery; rentral dark.

The frigate mackerel is found in all warm seas and ranges northward occasionally to Cape Cod; it is a rare visitor in our water's, but sometimes appear's in immense schools. It has little value as food. It reaches the leugth of 16 inches. The species was unknown on our shores till 1880 , when it arrived in almost countless numbers. Its food is the same as that of the common mackerel.

\section{Genus grmosnmon Gill}

This genus according to Lütken differs from $\mathrm{T}$ h u n $\mathrm{n} \mathrm{u} \mathrm{s} 1$ ) in the absence of teeth on vomer; 2 ) by the complete absence of scales outside of the corselet ffor in Th u $\mathrm{nu} \mathrm{u}$ s of the same size the skin is coreled with small scales; and the limits of the corselet in the tumuy and albicore are obscure, so that it can not properly be said that they have distinct corselets), and 3 ) by an important osteologic character, wamely the peculiar development, in the form of a network or trellis, of a portion of the abdominal part of the backbone, between the rertebrae proper and the hemapophyses. Vertebrae 38. Species of smaller size than the tunnies, also pelagic, and of little value as food. 


\section{Gymnosarda pelamys (Linnaeus)}

\section{Oceanic Bonito}

seumber pelamis Lixideus, Syst. Nat. ed. X, I, 297, 1758, tropical seas.

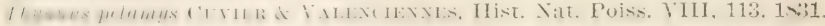

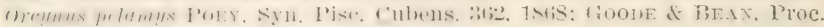

U. S. Nat. Mus. I, 24, 1878; Bull. Essex Inst. XI, 15, 1879.

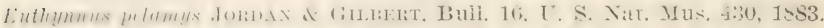

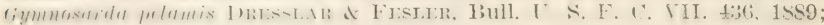
Jomdx of Everamax, Bull. 47, U. S. Nat. Mus. S68, 1896.

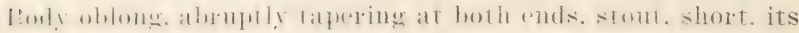

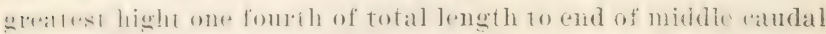
rays, is wilth a little more than one half the length of head. ryual to gostorlital patet of head: least hight of enadal peduncle whe half the lellyth of eye: leel one fometh as long as the head; heatr lathler long. sumewhat romplessed, acute in front. conical. is lemglh 1 wo sevenths of the total without randal. its wioth

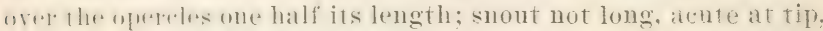

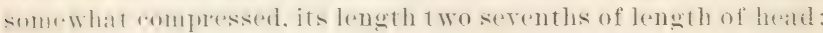

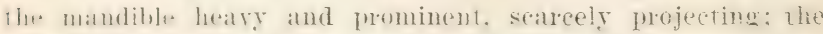
maxilla with rommled extremity rxtends to below miditle of lmpil: the matmlible txtends to below hind matrin of ere, its lemell meally ene half the lemgth of head. The eve is obliguely

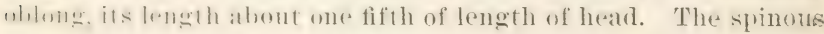

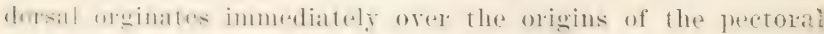

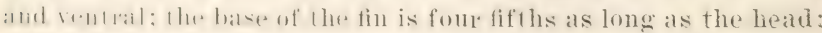
thr. fir-1 and longest spine ond half as long as the heat, the last

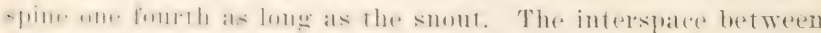

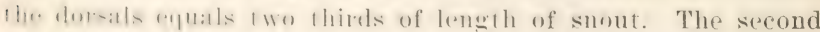

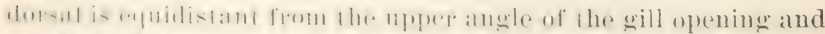

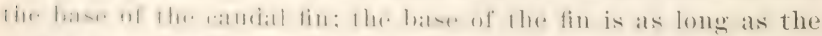

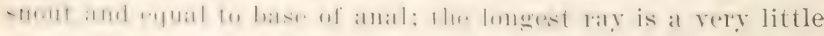

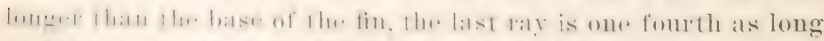

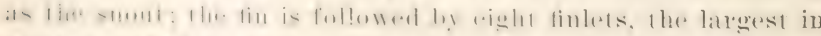

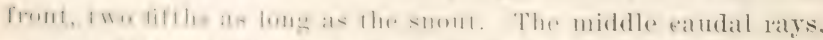

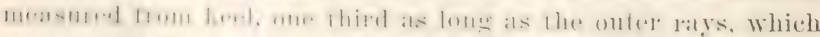

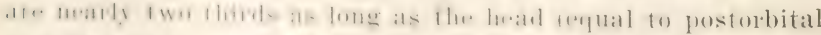

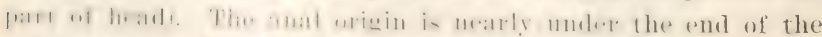

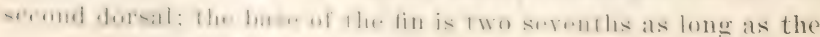


head; the longest ray is as long as the base of the fin, the last ray one third of length of snout; the fin is followed by seven finlets, which are rather broader than those of the dorsal. The ventral origin is directly under the origin of spinous dorsal; the length of the fin is two fifths of length of head; the rentral sheath is bifureate and less than one half as long as the fin. The pectoral is scarcely falcate, its length one half the length of head, the fin reaching to below the 11th spine of the dorsal. D. XIT to XT, II, 12-VIII; A. II, 12-VII; P. 2S; V. I, 5.

The corselet is very prominent. Its contour is defined by lines at the edge of the branchial cleft, about midway between the axil of the pectoral and the median line of the belly, extending below, beyond, and around the extremity of the pectoral (which, when normally placed, touches with its tip the outer margin of the corselet), then extending beyond its tip for a distance nearly equal to its length, around up into the lateral line, down which a narrow tract of scales continues to its extremity, though narrowed to a single row after passing its curre; passing the lateral line, the contour of the corselet cures forward and inward, then, ascending to a point distant from the median line of the back about the diameter of the orbit, it follows backward in a direction parallel to this line, to a point opposite the posterior extremity of the second dorsal, where it curves ujurard to the median line of the body, and completes its circuit.

When riewed from above, the rows of scales appear to be arranged concentrically about the origin of the first dorsal fin. The scales are largest along the edges of the pectoral arch and the dorsal fin, decreasing rapidly in size as they recede from these regions. There are about 30 rows between the dorsal and the upper margin of the pectoral, normally placed.

The upper parts deep bluish in life; the belly and flanks below lateral line, the opercles and throat pearly opalescent white; the lower part of the pectoral arch and tracts at the base of the rentrals and anal, as well as those parts of the opercles where the bone is close to the outer skin, challiy white. The corselet is bronzed brown in the alcoholic specimen. There are four dis- 
timet housh limes on the sibles. whirh are mearly parallel with the

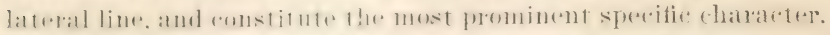

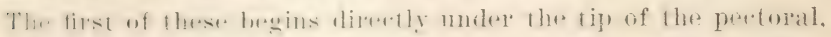

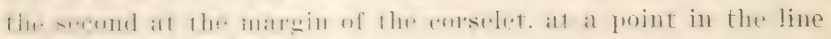

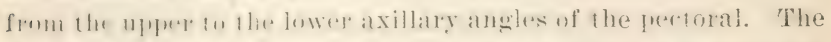

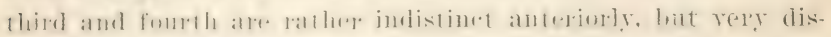

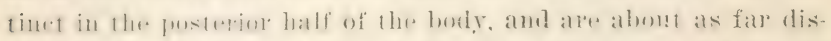

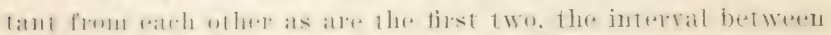

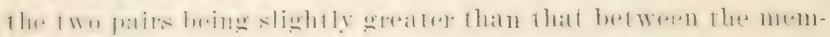

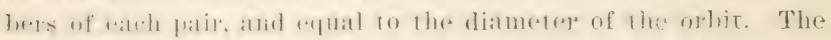

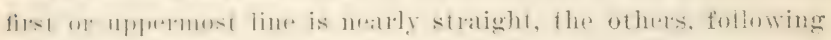

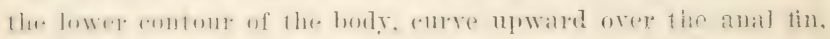

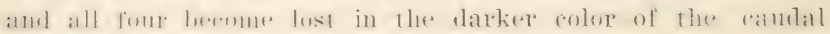
peduncle.

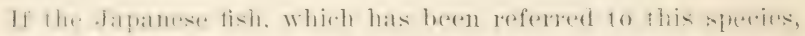

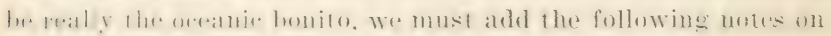

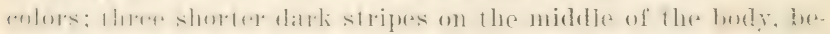

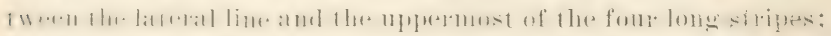

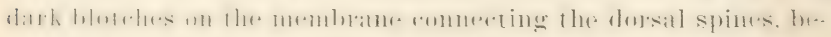

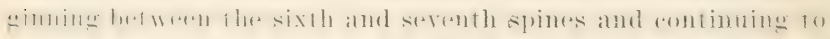
the end of the fin. It is not at all certain, in my estimation,

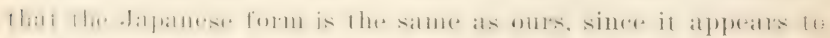

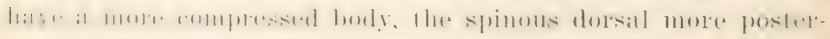
iorly plared, and the color differences above mentioned.

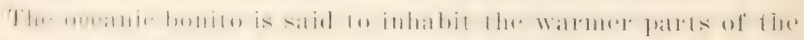

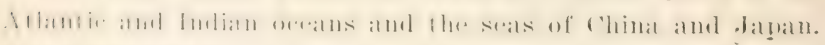

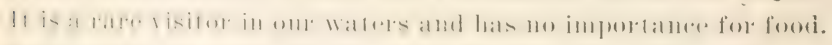
P'ersons who have aten it say the flesh is dry and, sometimes,

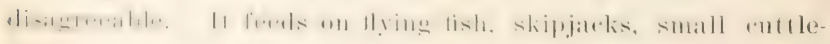
lish, molluskis, and marine plants. The maximum length recorrient is :30 inchers.

\section{9.- Gymmosarda alleterata (Rafinesque)}

\section{Lille I'umm!}

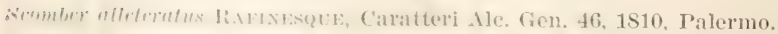

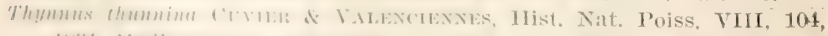

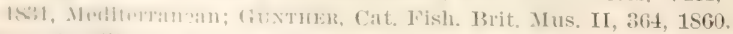

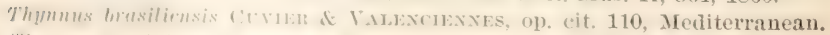

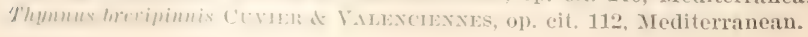




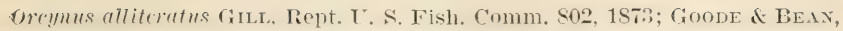
Bull. Essex Inst. XI, 15, 1879.

Euthymus alliteratus Jordax \& GIlbert, Bull. 16, U. S. Nat. Mus. 430, 1883.

Thynnus affinis GÜNTHER, op. cit. II, 363, 1860.

Thynnus brevirostris GÜNTHER, op. cit. II, 365, 1860.

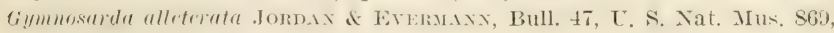
1896, pl. CXXXIV, fig. 366, 1900.

liody fusiform, mueh tapered at both ends, moderately comfuressed. its greatest hight one fourth of total length without catudal, its width one half the length of the head; least depth of catudal peduncle one thied of length of snont; keel well developed. there eighths as long as the head; head moderate, pointed in front, its length one fourth of the total to rud of midelle caudal rays, its width orer the opereles epual to eve and snout rombined; snout not long, arutre at tip. its length two serenths of length of head; the intrerthital spater erpual to snout; the mandible heary, not projerting, the maxilla expander posteriorly, extending to besow middle of pupil; the mandible extends to below hind margin of orbit, its length nealy one half the length of head. The ("ye is one fifth as lone as the head, and two thirels of width of introrbital spatce. The spinous dorsal originates directly above the insertion of the ventral and slightly behiud that of the pertoral; the base of the fon is nearly as long as the head; the longest spine is one half as long as the head, the last spine abont one half as long as the eye; the interspace between the dorsals "xtremely short. The second dorsal is frecerled by a short, stiff suine. Which is ahout one Thirel as long as the eve; the base of serend dorsal is one fourth as long as the head; the longest ray is two ninths as long as the head, the last ray one half as lome as the "ye; the fin is followed by eight finlets, of whirh the fourth is longest, two thirds as long as the eye. The middle ratudal latys. meatsmed from the root of the fin, ale two fifths as long as the outer ray, which are two thirds as long as the heal. The anal origin is under the first detached finlet; the lase of the fin is as long as the snout; the longest ray two ninths as long as the head, the last ray two thirds as long as the "ye; the fin is followed by seven finlets, which are similar to the dorsal tinlets. The 
remtral origin is at a distanes from tip of snout equal to one third of total lenoth to ratulal base: the tin is two fifths as lone as the head, "xtending as far back as the pectoral, to a foint helow the ninth spine of the dorsal. The rentral sheath is little hifurate at its lip. its length little more than one half the length of verutral fin. The pertoral is somewhat falcate, its length repual to postorbital part of lead. D. XV-T, 12-VIII; A. ii, 12-VII; V. I, 5; P. I, 26.

Color hluish above, sides and lower parts silvers; sereral wary, more or less interrupted, dark streaks above lateral line, beginning under the middle of the spinons dersal: five or six roundish bromn spots, about as large as the pupil, betweren the frertoral and rentral fins; tip of spinous dorsal and inmer sme face of ventral dusky.

The litule tmm is eommon in the Mediterranean ant the Wrest Indjes and ranges northrard oceasionally to Cape rod. It is sald to reareh the length of $t$ fert. hut no individuals of that size

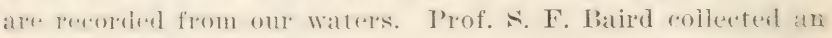
example ahout 2 feet long at 11 oods Mole Mass. in 1871. A spoxcimen 1:; inches long was taken at Pensacola Fla. by silas searns in 1s:s. Though eaten in Meditereanean countries, the Ilesh is not much esteemed.

\section{Genus Trunvos South 。}

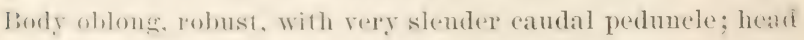
ronieal: month wiole, with one sereies of small, conical teeth in Hlr. jaws and hands of minnte villiform or sandlike teeth on

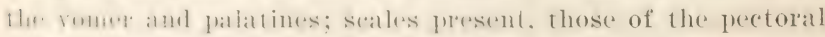

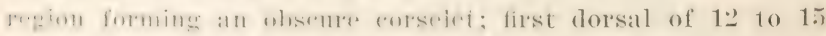

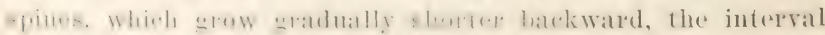

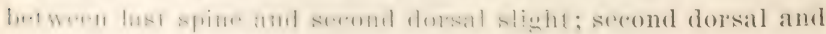

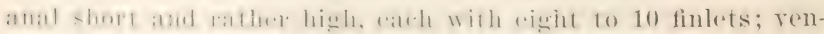

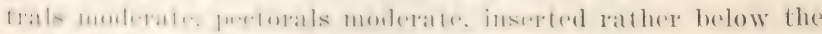

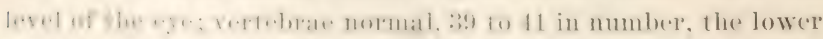

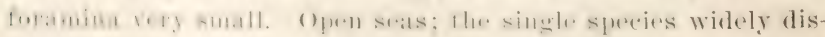
tributed. size very large. 


\section{Thunnus thynnus (Linnaeus)}

\section{Tunny; Horse Mackerel}

Scomber thymus Lrxyate, Syst. Nat. ed. X, 297, 175S, Europe.

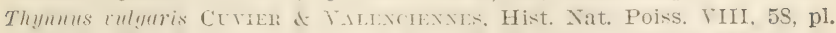
210. 1S:31. European Seats: DE Ki.15. N. Y. Fauna, Fisles, 105, pl. 10, fig. 2S, 1842, after STORER.

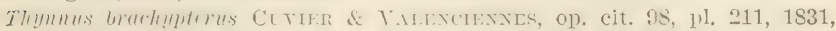
Mediterranean.

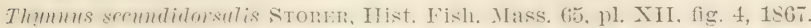
Oriymus thymmus Goove it BeAx, Bull. Essex Inst. XI, 15. 1579; JordAx \& Gilbert, Bull. 16, U. S. Nat. MIus. 429, 1883.

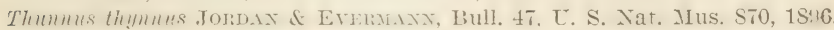

Body oblong, tapering greatly at both ends, rers robust, its greatest depth neally one fourth of the total length to end of middle caudal rays, its greatest width one sixth of the same length. The least depth of caudal peduncle equals the length of the eye. The head is two sevenths of total length without the caudal; the snout is rather short, acute, its length contained three and one third times in length of head; the maxilla does not quite reach to below front of eye; eye small, two fifths as long as the snout, one serenth as long as the head. The spinous dorsal originates abore the insertion of the pectoral; the fin is rer. long, reaching almost to second dorsal, high in front and rapidly am regularly diminishing in hight posteriorly, its first spine longst. four ninths as long as the head, the last spine ahout as lone as the pupil. The second dorsal base is as long ns the anal base and two fillhs as long ass the head; the fin is

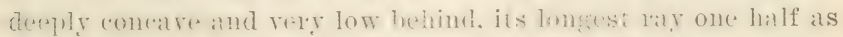
long as the heat: the fin is follumed by nin finlets which are alont two thirts as long as the are. The anal origin is umler thes end of the second dolsal; the hatse of the fin is two tifths ats long as the head; the longest ray is neally one half as long as the head; the fin is deeply concave like the second dersal, and is followed by eight finlets of about the same size as the dorsal finlets. The caudal fin is rery deeply forked, almost lunate in shape, the middle rays, measured from caudal base, contained two and one third times in the outer; the caudal keel is enormously developed, its length equal to length of snout. The rentral origin is under the second spine of the dorsal; the fin is 
one half as long as the luetel: when extended it reaches to below

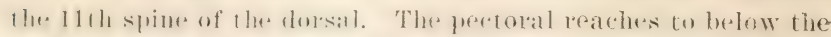
loh spine: it is fallate. its lengthe equal in length of head withmil the slment. The anselet is not so well defined as in some

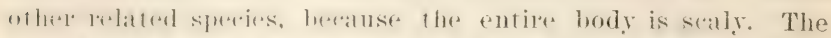
latrat line andes downware from a point under the origin of the second dorsal. D. XIV, i, 13-IX; A. i, 12-VIII; T. I, 5.

Color datk hlue abore: gratyish below with silvely spots: pupil bark, iris golden with gerenish reflections; ays of spinous dorsal dusky, the connecting membrane nearly black sedend dor.

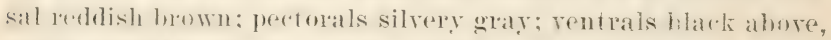
white lwmatl; dorsal and anal finlets bright rellew, datk at base and on anterior edge; gill covers silvery gray.

The tunny is the latgest fish of the matekel family, reathing

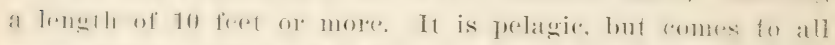

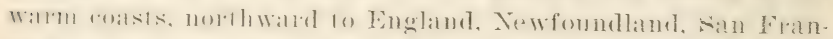

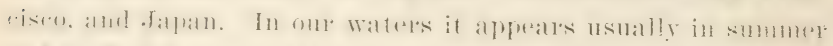

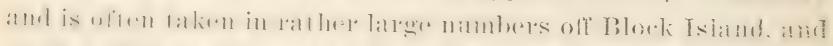

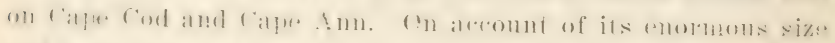

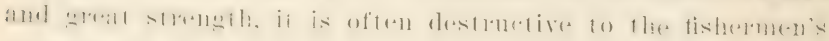
fixed nets.

1). Storer says it comes into Massachusetts bay about the middle of June and remains till early in October. It was not

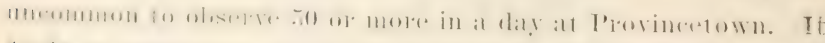

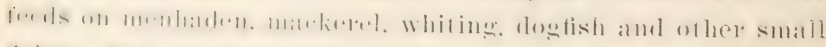

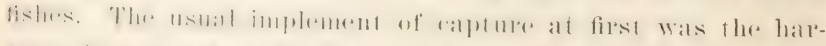

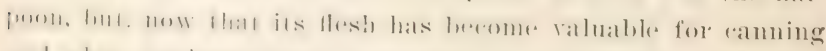

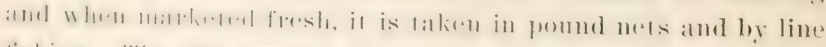
lishing. The tish arrives on the coatst in poor comblition and

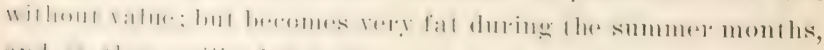

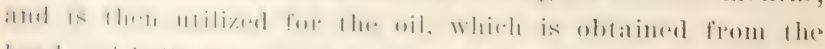

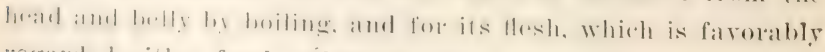
regalded, either freste, salted or preserved in cans.

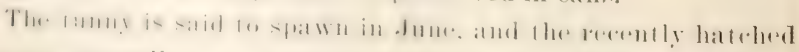
youmg, aceoreling to Yarrell, weigh 1] ounces, growing to 4 ounces by Anerust and 30 ounces in October. Adults often 
weigh 1000 pounds. The liller whale is the most dreaded enemy of the tunny.

In southern ralifornia this fish is hightr prized by anglers who are fond of big game and hatel play. In the Bay of Chaleur and off Caraquette, in the fiulf of st Lawrence region, 100 tumy were captured by means of haited lines, and the fishing was considered exciting beranse the fish pulled with such riolence as to endanger the lives of the fishermen by dragging them orerboard. This kind of exereise might be had near Rockport Mass. or off the Yew Jersey coast ammully in summer.

\section{Genus sırms Curier}

Body rather elongate, covered with small scales, those of the pertoral region forming a corselet; atudal peduncle slender. strongly leeled; head large, pointed, compressed; mouth latrex; tereth in the jatws rather strong, conisal, slightly eompressed, similat teeth on the palatines, hut none on the romer' maxillary

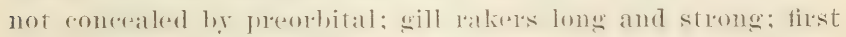
dor-sal long and rather low of is to 2.2 rather stout spines, which atre gralually shertened behind: interal between the last spine and the second dolsal sholet serond dorsal small, followed hy S-9 finlets: anal fin similir, usually with one less finlet: patied fins small; pectomals plated helow the level of the pupil; no air bladder; pyloric areat very numerous. treclike; reltebrae normally formed, in to it in number. Fishes of rather large size, of metallic rolotation. CAfter. Tordan and Erermann)

\section{Sarda sarda (Bloch)}

\section{Bonito}

Scomber sarda BLoci, Ichth. X, 35, pl. 334, 1793, Europe.

Pelamis salda DE, KAY, X. Y. Fauna, Fishes, 106, pl, 9, fig. 27, 18+2; GüTher, Cat. Fish. Brit. Mus. II. 367, 1S60; Storer, Hist. Fish. Mass. 63, pl. XI, fig. 5, 1867.

Sarda pelamys Goode \& BEAN, Bull. Essex Inst. XI, 15, 1879.

Sarda mediterianea Jordix of Gilment, Bull. 16. T. S. Nat. II1s. 427. 1883.

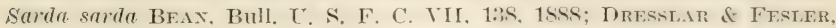

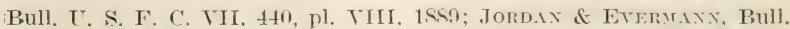
47. C. S. Nat. Mus, 872, 1896; Besx. Bull. Am. Mus. Nat. Hist. IX, s(6), 1897, Gravesend Bay. 


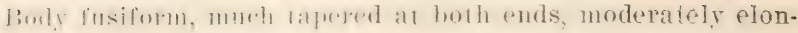

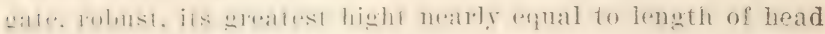

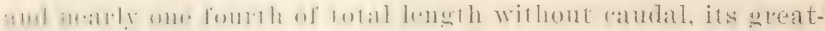

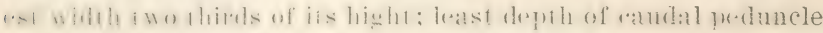

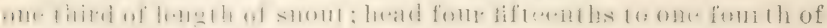

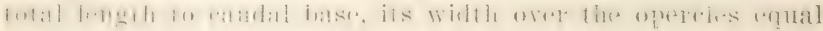

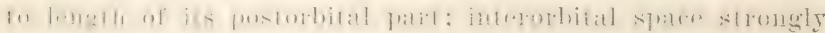

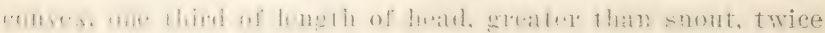

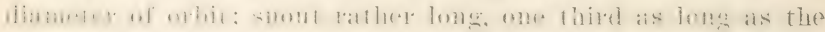

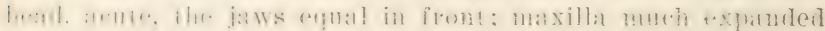

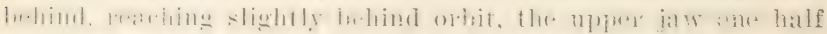

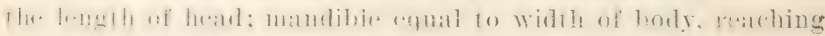

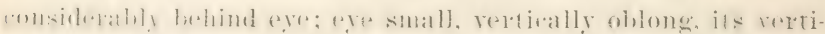
fal diatmelwe ahout one half the length of snout. The spinoms

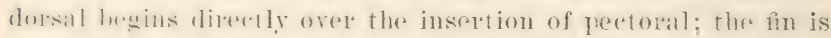

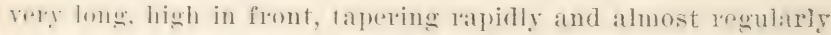
(0) the last spine, which is only about one sixth as long as the stromt, and longest, this being two tifths as long as the head. Ther interspater hetwern the dolsals is one half as long as the frre. The serond dorsal hase is as long as the suout and pye

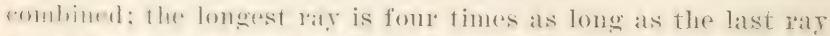

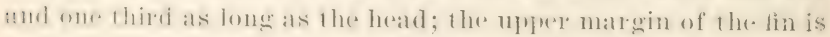

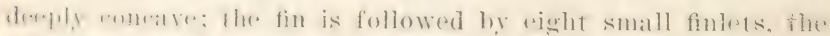

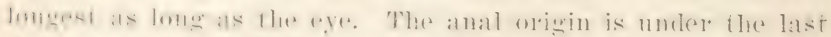

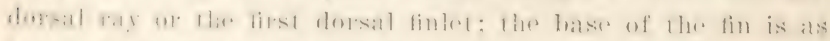

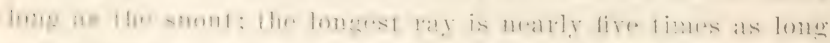
as the last ray and three cighths as long as the head; the fin is followet ly soven or eight finlets (usually seven) the longast mpual to length of eye; the anal is decply concave, like thr serond dorsal. The candal fin is ereseentic, the rotermal mays there times as long as the middle rays and the lobes narrow and tapering, their width at base about once thirel of their lengih and one fourth the length of lowal. The ventral origin is meler the second or third spine

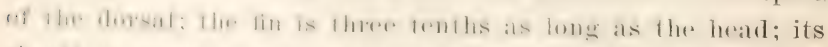
slenth is smatl mal ma!lihe. less than ome half as long as the

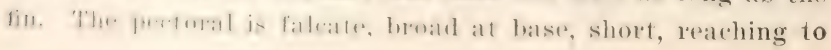


below the eleventh spine of the dorsal, its length one half the leugth of head. The lateral line rery wavy but with no great curves; the caudal keel nearly as long as the eye and suout combined. The corselet is dereloped only as a narrow stripe exfending from the naje to a point a little behind the tip of peetoral, its width about one fifth of iis length, and about equal to wye. J). XX to XXI, 1: to 1t-YIII; A. 11-YI or VII; V. I, 5; P. I, 24.

Color stee blue ahore. the sides silvery, the ahdomen and under surface of head silvery white; from 10 to 20 dark bluish, narrow bands obliquely downwald and forward from the back, some of them almost reaching the belly; iris yellowish; first dorsal fin sometimes pale, sometimes nearly black; pectoral dark above, light beneath.

The bonito inhabits the Atlantic ocean on both coasts and is common in the Mediterranean. On our coast it ranges habitually north to Calpe Ann. It reaches the length of 30 inches and the weight of 10 or 12 pounds. Though not generally esteemed as a food fish, it meets with a steady sale either fresh or salted, like the mackerel. The fish is believed to live in the open sea, coming to the shores only to feed or to deposit its eggs. It is predaceous and active, feeding insatiably on mackerel and menhaden; it takes trolling bait as freely als the bluefish, to which it is not inferior in quality of flesh.

The fish is generally searee in cimalesend bay. Fire were raken in one day in a pomed net in s)-\{ober 1897 , an numsual number for that species. The bonito will not live in captivity.

\section{Genus sconmenonoms Lacépède}

Body elongale, wholly covered with rudimentary scales, which flo not form a distinct colselet; head pointed, comparatively short and small; mouth wide, the strons teeth in the jaws more or less compressed or knife-shaped; villiform or sandlike teeth on the vomer and palatines; maxillary not concealed by preorbital; gill rakers few; caudal peduncle with a single keel; spinous dorsal low, of 14 to 18 feeble spines; soft dorsal and anal short, similar, somewhat elevated and falcate, each followed by 


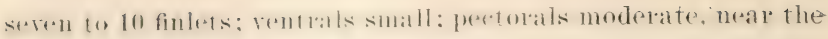
level of the eve; air bladder present; vertebrae normally

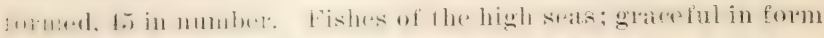

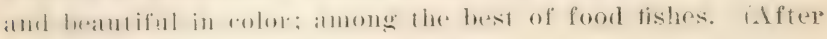
. Toxdan and Evermanni)

\section{S Scomberomorus maculatus (Mitchill)}

\section{Spanish Mackerel}

Sermher meculatus Mrternte, Trans. Lit. \& Phil. Soc. N. Y. I, 426, pl. VI, fig. S, 1S15, New York.

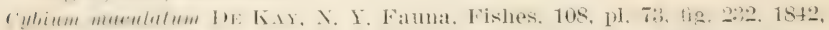
New York; Güxтmer, Cat. Fish. Brit. Mus. II, 372, 1860; Storer, Hist. Fish. Mass. 68, pl. XIII, fig. 1, 1867; Goode \& BEAx, Bull. Essex Inst. XI, 15, 1879 .

Scombermorus maculutus .Jordax \& Gilbert, Bull. 16, U. S. Nat. IIs. 426 , 1SS:; BEAx, Bull. U. S. F. C. YII, 13S, 18ss; 19th Rej. Comm. Fish. N. Y. 27t, pl. VII, fig. 9, 1890; JordaN \& EverMarN, Bull. 47, U. S. Nitt. Jus, S7t, 1896, pl, CXXXIY, fig. 368, 1900.

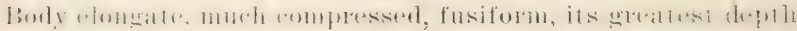

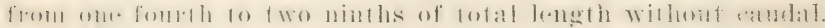

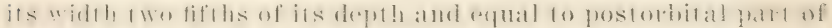

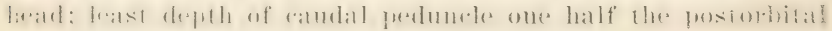
part of head; head rather short, compressed, the lower jaw

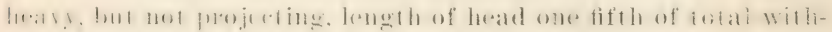

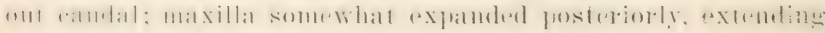

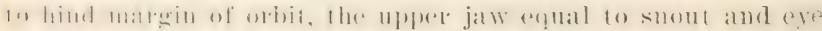

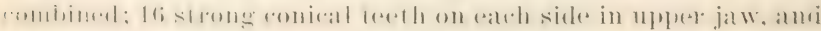

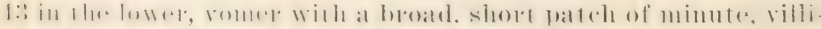

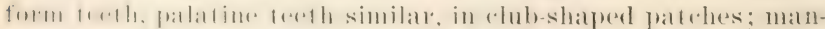

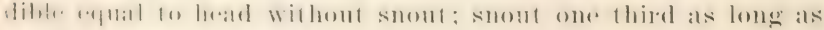

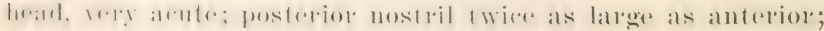

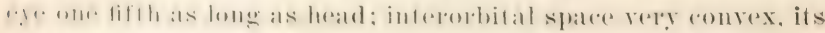

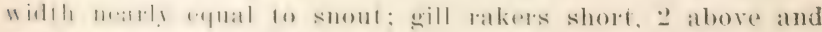

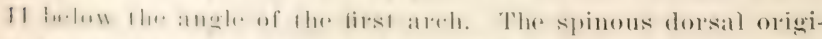

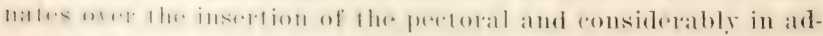

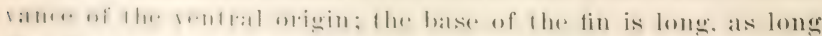

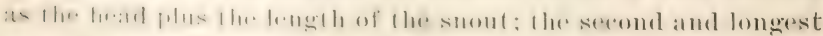
spino je three seremths as long as the head and four times as

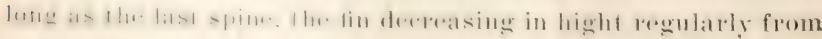


the second to the last spine. The interspace between the dorsals is about one half the length of the eye. The second dorsat base is three fourths as long as the head; the longest ray nearly four times as long as the last ray, and one half as long as the head; the fin is followed by eight finlets, none of which are longer than the eye. The anal originates under the midale of the soft dorsal; its base is two thirds as long as tine hearl, its longest ray three and one half times as long as its last ray, and one half as long as the head; the fin, like the second dorsal, is deeply concare; it is followed by eight finlets equal in size to the dorsal fulets. The caudal is rery deeply forked, its outer rays as long as the head. The rentral originates under the fourth spine of the dorsal, its length three elerenths of leugth of head, the fin reaching to below the ninth spine of dorsal; there is no rentral corering, the inner rays of the two sides being slightly united at the base. The pectoral is broad, falcate, extending to below the 10th dorsal spine, its length equal to head without snout. 1). XVII to XVIIf-16 to 1N-VIII to IX: A. ii, 16; to 17; Y. I, 5; P. i, 21. Latteral line strongly dereloped, with a morle1ate "urve under the second dorsil, its course from there to caudal somewhat wavy.

Color silvery; uplex parts bluish; sides with numerous oblong spots of a dull orange, none of them more than one third as long as the snout, these spots fully as numerous above the lat teral line as below it; the membrane connecting the first eight spines of the dorsal black, the rest of the fin white; soft dorsal with a yellowish tinge, its margin dark; anal and rentral white; pectoral black inside, yellowish with dark borders outside and covered with dusky points; caudal dusky except at base.

The Spanish mackerel inhabits the Atlantic and Pacific coasts of North America, on our coast ranging north to Maine and south to Brazil. It is one of the choicest of our food fishes and grows to the length of 3 feet and the weight of 10 pounds. The species spawns on the Long Island coast in August or earlier. The eggs are very small, about $\frac{1}{25}$ inch in diameter, and they float in salt water. The rate of growth is unknown, as the 


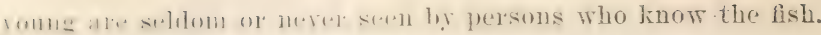

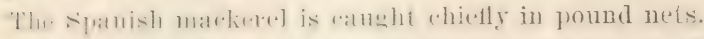

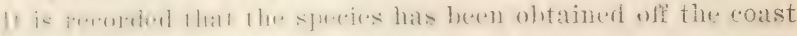

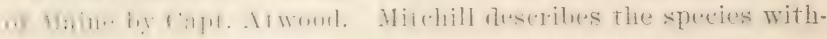

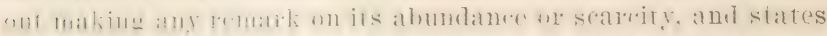

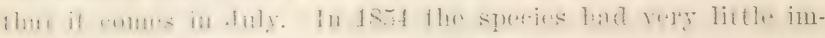

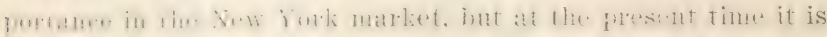

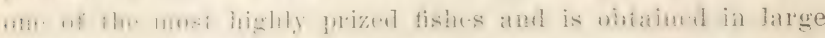

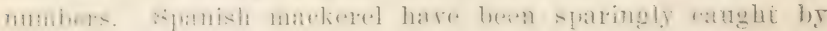

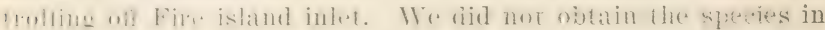

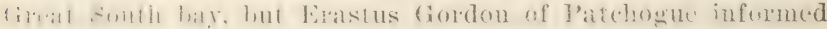

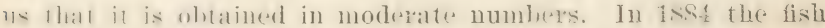
was mot plemifnl and the avelage prier was about s1 cateh. Thry alpera in New Jork waters in July and nsually leare in sirflember. The sfatwing season at Long Island begins late ju August and ("ontinues about a month. The Spauish matherel fongrewatr. in rnomous schools. Mr Earll records the apjearame. of at shoul off Lome Island which was estimated to contain sereat millim imlivirluals. The fish are taken prineipally in

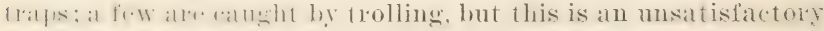
method of capture.

\section{Scomberomorus regalis (Bloch)}

\section{Cero}

Ścumber retulis Brocir, Ichth. pl. 333, 1795, Martinique.

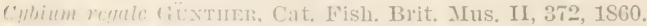

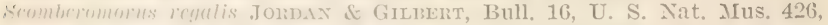

188\%; Jomis \& Fvrimax, Bull. 47, U. S. Nat. Mus. S75, 1596, pl.

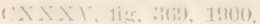

1.1.y sinilar in shatpe and general appearance to S. m a c u la 1 11: 1 low wratest depth of body one fifth of total length

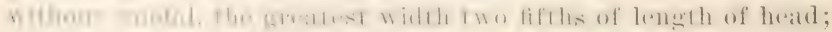
the loust droth of caudal peduncle one half the length of snont; Hevil lomere than in S. ma e u lat us, two ninths of

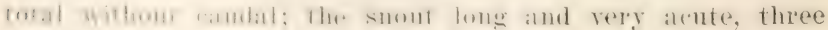

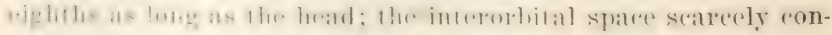

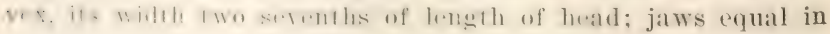


front, maxilla not reaching to hind margin of orbit. the upper jaw equal to snout and ere combined and much more than one half the length of head; the mandible equal to head without snout, reaching to below hind margin of orbit; 15 or 16 large, compressed, conical teeth in each side of upper jaw, and about the same number of similar terth in lower; eye large, more than one fifth of length of head, nearly equal to interorbital space; gill rakers $3 \div 12$, the longest one half as long as the ere. The spinous dorsal originates a little farther back than the pectoral and nearly orer the insertion of the rentral; the base of the fin equals its distance from tip of snout; the second spine is the longest, one half as long as snout and exe combined; the fin is shaped as in S. m a cu l a tus, the last spine being ver.y short. The interspace betreen the dorsals is about one third the diameter of the ere. The second dorsal base is one half as long as the head and equal to its longest ray; the last lay is one half as long as the "ye; the fin is followed hy aight ol" nine finlets; its upper margin. Iike that of the anal, is deeply convex. The anal origin is under the middle of the serond dorsal; the longest ray a little exceeds longest of dorsill; the last ray one half the length of eye: the fin is followed by eight finlets. The caudal keel is one third as long as the head: the caudal fin is rery deeply forked, the outer rays as long as the head and the lobes narrow at the base. The ventral origin is midway between tip of snout and rent; the fin is two thirds as long as the snout and extends to below the serenth spine of the dorsal. The pectoral is broad at the base, falcate, its length equal to snout and eye combined, the fin extending to below the 10th spine of the dorsal. D. XVII-i, 15-TIII: A. ii, 14-VIII; V. I. 5; P. i, 24. Lateral line curved downward below the second dorsal and the second half of it more or less undulating; pectoral scaly.

Color silvere; a narrow lougitudinal stripe of brownish or bronze beginning behind the pectoral and rumning to hase of caudal; numerous oblong brownish spots mostly below this stripe, none of them more than one half the diameter of eye; 


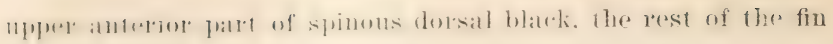
white.

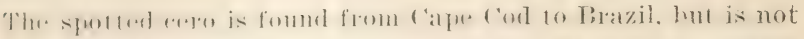

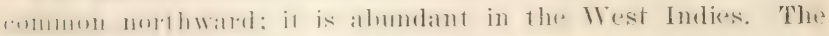

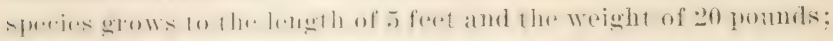

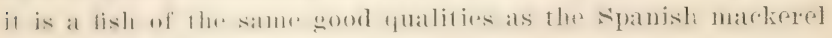
and is readily caught by trolling.

\section{Scomberomorus cavalla (Cuvier)}

\section{Kingfish : Sierra}

Cybinm caralla Cevier, Règne Anim., ed. 2, II, 200, 1829, Brazil.

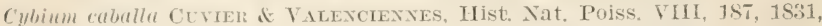
Caribheam Sea; Stoner, Strn. Fish: N. A. 93, 1St6; Guxtmer, Cat. Fisin. Brit. Mus. II. 373, 1860.

Sémineromons cobulla Jorbax \& Gilbert, Bull. 16, U. S. Nat. Mus. 427, $158: 3$.

Sermberamerns cacalla Dumsslar \& Fesler, Bull, U. S. F. C. TI1, 444, pl.

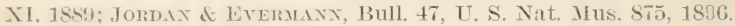

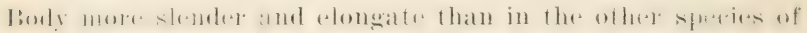

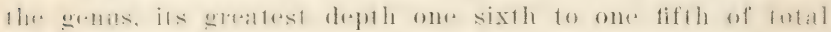
length withont caudal; rather less compressed than in s.

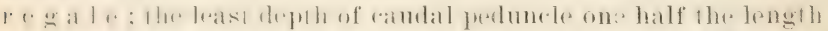

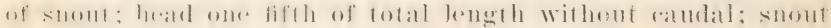

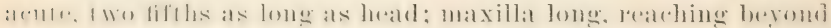

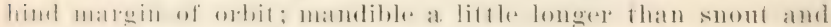

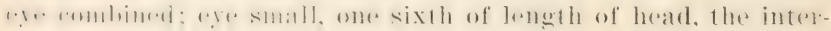

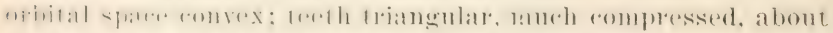

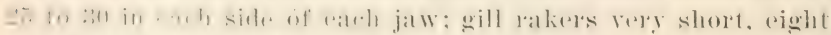

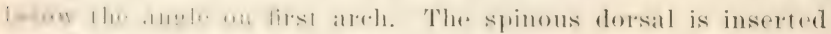

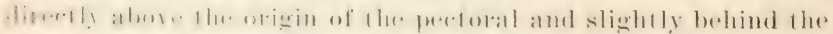

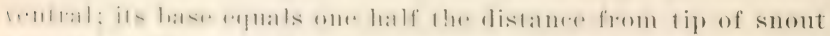

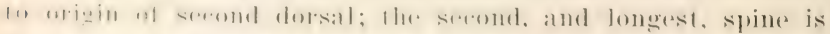

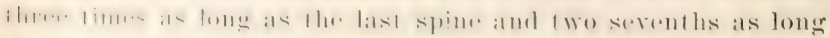

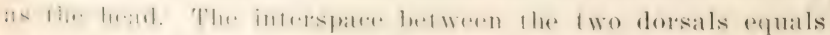

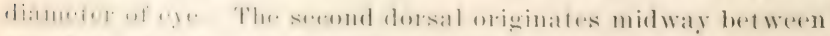

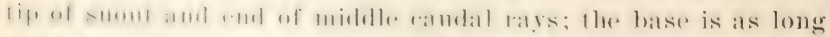

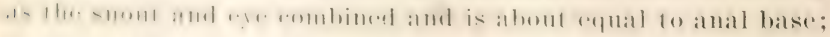
Hhe lonerest ray is six limes the lengih of last ray and equal to

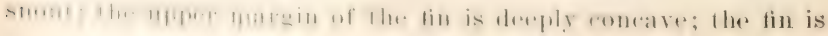


followed by nine small finlets, all nearly equal in size, about two thirds as long as the eye. The caudal fin is crescentic, the width of the lobe at base two fifths of its length, the external rays two and one half times as long as the middle rays, measured from reot of fin, and one third of distance from tip of snout to origin of sereond dorsal. The anal origin is under the middle of the second dorsal; the longest anal ray is four times length of last ray and equal to snout; the upper margin is deeply concave; the fin is followed by eight finlets, the longest about one half the diameter of eye. The rentral is a little in adrance of pectoral; its length one half the length of mandible, the fin reaching to below the sixth spine of dorsal. The peetoral is falcate, median, its length equal 10 snout and eye combined, and rearhes to below the ninth sume of dorsal. I patch of elongate scales on head behind and helow the eye and at the nppere angle of the gill opening; several much enlatrget scalles behind the head, in front of and ahove the base of peetoral. The lateral line makes a deep down whel curve undere the end of the spinous dorsal, and its second half is sinnous. I well dereloped caudal keel. D. XIV to XV, i, 15-VIII to IX; A. î, 1.5-IIII ; I. I, 5; P. i, 23.

Color grayish silvery, the sides sometimes with dark spots, or rellowish in the young; spinous dorsal blackish above, or without dark blotch.

'The kingfish, or cavallat, is a rery important and raluablo food fish of the tropical Atlantic, coming in inmense numbers to the Florida Keys, the West Indies, and north to charleston, occasionally, in summer, to Cape cod. Southward it extends to Africa and Brazil, frequenting the open seas. It grows to the length of 6 feet and the weight of 100 pounds. In habits it resembles the spanish mackerel; it is caught by trolling, and at Key Test it is so abundant that two men in a small sailboat sometimes catch more than 100 in a day. The flesh is excellent, either fresh or smoked. 


\section{Family TRICHIURIDAE Cutlas Fishes}

\section{Genus rricmores Linnaeus}

burly "xtremely romgate, bandlike, the tail vers slender: tapkring to a fine point, without candal tin; head long. with a rery widr momth: Ihe jals armed with unequal and rely stroug

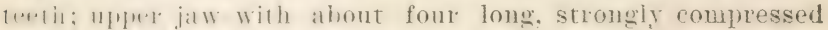

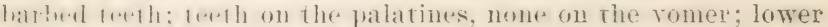

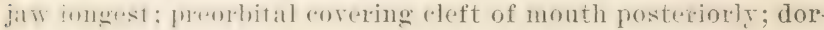
sal tin single. luw. oceupyiug the whole of the batk, the spines not distinguishable from the suft rays; anal very lome. its base mome than half the length of the body, composed of detached spines whirh are rery short, nearly hidden in the skin, tho anterine direreded bakwald, the posterior forward; rentral fins wanting: prelurals small; no suales; lateral line decurred, concurent with the lelly; retebrae $39-120$, ribs excessively frail. culn sils :y. Vorateins fishes of the high seas, reaching a consirlesable size. (After Jordan and Evermann)

\section{Trichiurus lepturus Linnaeus}

\section{Scabbard Fish; Hairtail}

Trichinus lepturus Lrixaeus, Syst. Nat. ed. X, I, 246. 175S, America; Curier et Valexcrenates, Hist. Nat. Poiss. VIII, 237, 1S31; De KAY, X. X. Fauna, lishes, 109, pl. 12, fig. 35, 18t2, Jamaica, Sandy Hook;

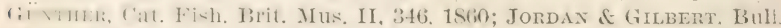
16, U. S. Nat. Mus, 422, 1583; Jordan \& Everaranx, Bull. 47. U. S. Niat. Mus. S59, 1896, pl. CXXXVIr, fig. 375, 1900; BEAx, Bull. Am. Mus. Nat. Hist. IX, 360, 1897.

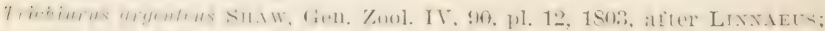
Mrtuml, Trans. Lit. \& Phil. Soc. N. Y. I, 364, 1815.

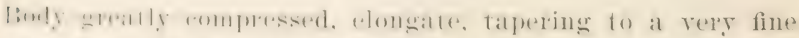

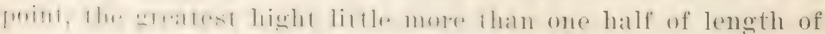

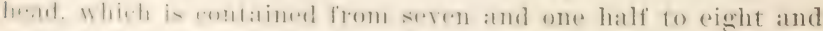

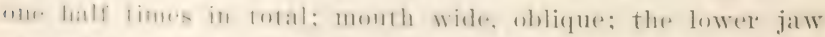

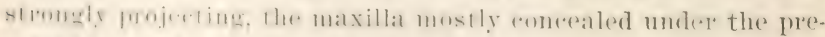

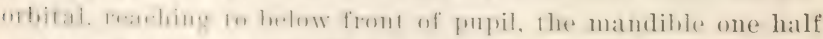

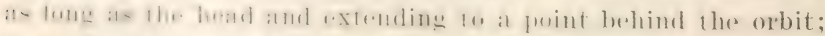

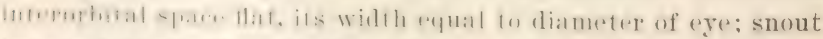

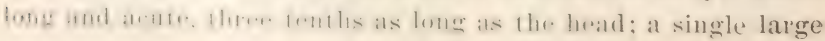


nasal opening near the front of the orbit; "ye round. one sixth as long as the head; gill raker's spiny, few, about seren above the angle of the first arch, those below the aroh mostly small or obsolete, the longest above angle about one third of diameter of ere; opereulum produced into a long, thin flap, ar:ute behind. The dorsal fin begins at a distance flom tip of snout equal to two thirds of length of head; its origin is not far behind the eye; the longest ray is about three eighths as long as the head. The pectoral is partly rovered by the opereular flat: its length equals lrogeth of snout. The rent is at a distance from tip of snout whirh e(puals two and three fourths times length of head. The anal fin, consisting of low, almost concealed, detarhed spines, begins rose beloind the rent; its base is five and one half times as long as the head. The latreal line drops rapidly downwal from the upper angle of the gill opening to a point below the median line. Four long and strong fanglike teeth in the front of the upper jaw and one or two fangs on the fromt of the mandible, from seven to 10 share teeth in each side of each jaw; small teeth on the palatines, none on the romer. I). 135; A. 10!). The individual described was taken at Point Pleasant X.J. It is number 492:24, I'. S. National Musemur. Color silvery.

The scabbard fish frequents warm seas and ranges north to Cape cod and Lower California; it is very abundant in the West Indies. The fish is a roracious inhabitant of the high seas, and reaches the length of 5 feet. It is highly esteemed for food in Jamaica and at I'ensacolat in .Tamaica it forms the object of a very important hook and line fishery.

The scabbard fish is rarely seen in fravesend bay. I young individual was obtained from. John B. Ite Nyse's pound in Iugust 1897. It had been captured by another fish while in the pound; but was rescued in good condition.

Family ISTIOPHORIDAE

Sailfishes

Genus Istropromos Lacépède

Body slender, much compressed, covered with elongate seales; numerous small teeth on the jaws and palatines: ventral fins 
J1\%

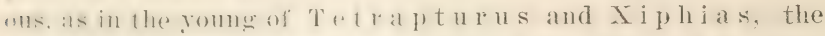

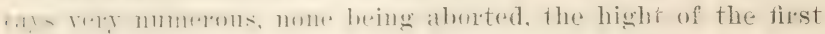

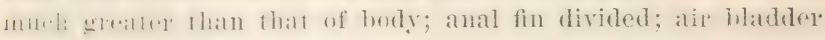

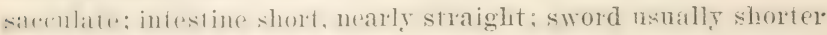

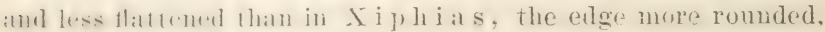

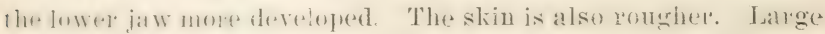
fishes of the watron seas: the number of species uncertain, probably several. (After Jordan and Evermann)

\section{Istiophorus nigricans (Lacépède) Sailfish; Spikefish}

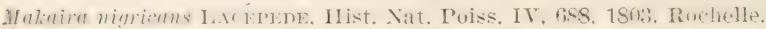

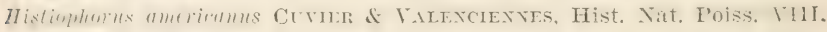
303, 1\$31, Brazil.

Istiophorus nigricans Jordax \& Evermaxs, Bull. 47, U. S. Nat. Mus. 891. 1596, pl. CXXXVII, fig. 376, 1900; Smin, Bull. U. S. F. C. XVII, 97, 1S9S; Goode, Proc. U. S. Nat. Mus. IV, $415,1582$.

borly eompressed, highest in fromt, clomgate. the gireatest light one serenth of the total length from tip of uplere jaw to mol of midhlle rambal rays; least hight of caudal pedumele oum half of fostorlital lemgth of head; the upper jaw projecting heyome the

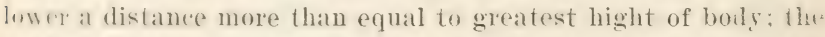
frentile of the heatd deserending very steeply from the origin of the flus:al (1) the ege; the lower jaw extending in front of the eye at distamererual to postorbital part of head. The dorsal fin begins nn the nafw and extends maty the entire length of the barli. hut the lirst is separafed from the serond by a very dexpl and

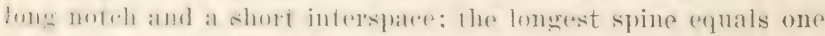
half the distane from the eye to the second dorsil and is one

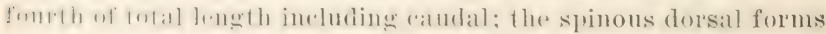

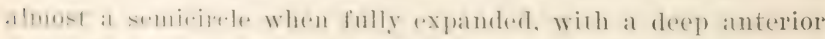

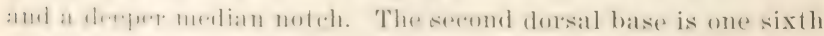

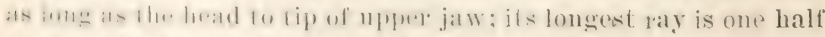

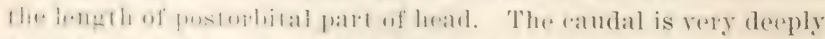

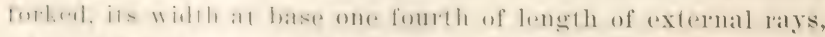

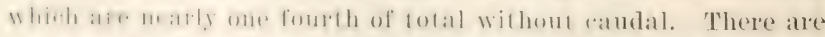

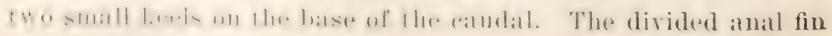


begins under the $3:$ d spine of the dorsal, the base of the two fins "qualing one fourth the distance from tip of upper jaw to origin of second dorsal; the longest ray equals pestorbital part of head; the seconel anal is similar to the second dorsal, but somewhat smaller. The rentral originates under the fifth spine of dorsal; its length is a little more than one fourth of total length to end of middle caudal lays. The pectoral is one half as long as the beak aud eye combined and nearly ('quals the gleatest hight of body. Eye smail, one third of postrrbital part of head. 1 . XLIV-7; A. 9 to $10-7 ;$ V. 2.

('ulor bluish black, paler below; dorsal dusky bluish, with mumerous roundish black spots, from one third to one fourth the diameter of orbit, on its membrane.

The sailfish lives in the warmer parts of the Atlautic, ranging morthward to France and, occasionally, to Cape Cod. Here described from a drawing of specimen taken at Woods Holr Mass.; color notes from Dr Jordan. The species reaches the length of 10 feet. It is valuable for food but rarely comes to our markets.

\section{Genus tetraptorus Rafinesque}

Body much compressed, covered with rudimentary embedded scales; sword rounded on the edge; cautal keel double; small teeth in the jars and on the palatines; ventral fins represented each by a single spine; dorsal fins seprarate in the adult, part of the midhle rays being aborted, not greatly elevated, their hight not greater than the depth of the body; air bladder sacculated; rertebrae $12+12$; intestine short, nearly straight: ryloric caeca very nummous. Large fishes of the decp seas. They swim in deepl water, according to Poey, and pass cuba in pairs in summer, bond for the Gulf of Mexice. Males smaller than females. (After Jordan and Erermann)

\section{Tetrapturus imperator (Bloch \& Schneider)}

\section{Billfish; Spearfish}

Tiphias imperator Brocti \& Scrinerden, Syst. Ichth. 93, pl. XXI, 1501, Mediterranean.

Ietrapturus belone Curien \& Valenciennes, Hist. Nat. Poiss. VIII, 280, 1833 . 
Tetranturus albidus PoEY, Memorias, II, 237, 1861, Havana; JoRdax \& Ginmert, Bull, 16, U. S. Nat. Mus, 420, 1883.

Histiophorus belone GüNTHEn, Cat. Fish. Brit. Mus. II, 513, 1860.

Tetrupturus imperator Goode, Proc. U. S. Nat. Mfus. IV, 417, 1852; Jondax (E Evemaxx, Bull. 47 , U. S. Nat. Mus, 892, 1896; Smtr, Bull. U. S. F. C. XVII, 97, 1895.

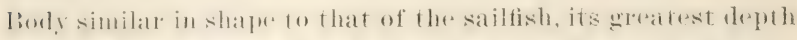
entatimed six and ome fomth times in total length without

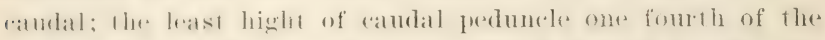
greatest depth. The head forms one thired of total hereth with-

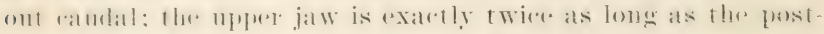

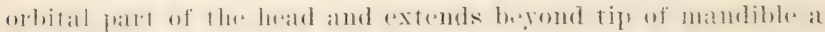

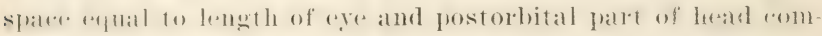

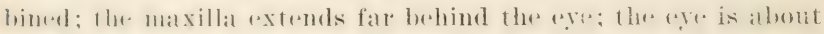

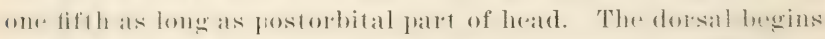

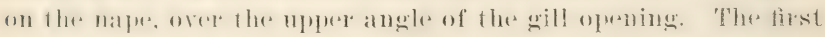
dorsal arempies neatrly one half of the total longth without ralurlal: its antrolor sixtl is related and the rest of the fin

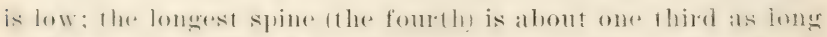
as the heade, the 10th is only one serenth as lomg as the heral.

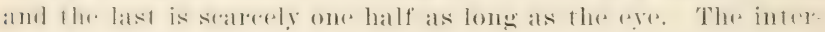

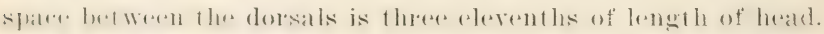

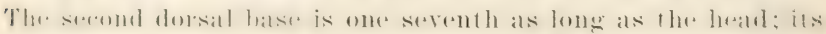
first ray is one and one half times as long as the eye, and its

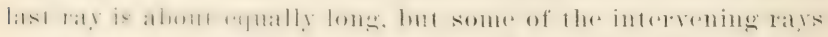
are shorter. The caudal fin is narrow, crescentie, its width at

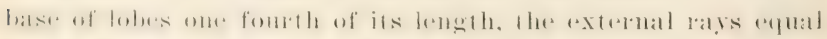
to one fourth the distance from eye to caudal base. The first

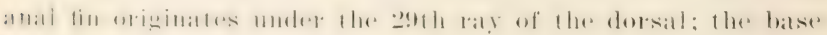

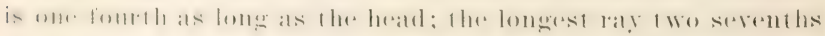
ats forge as the head, the last ray minute. The interspace betwonth the anals is one third as long as the head. The base of the seromil anal equals one third of postorbital length of

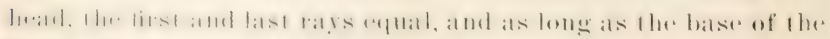

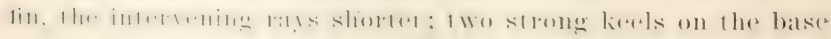
of the catulat, rach of them about twice as long as the eye. The vemtal is very slemder and long; it originates under the

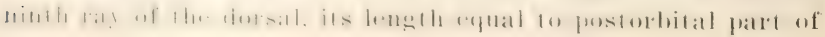


head. The pectoral insertion is under the sixth ray of the florsal; the fin is nearly one half as long as the head; its position is in the lower fouth of the hight. The sword is romeled on the edges and murh narrower than in the swordtish. I). III, 35 to $39-6 ;$ A. II, $13-6$; T. I, 4; P. 19 ; vertebrae $12+12$.

Color deep blue above, a little lighter on the flanks. passing into white below; tins intense blue, second anal and outside of pectoral charere first dorsal with rounded spots. more intense, of same color; iris clear blue, cornea blackish.

Body coremed with lameolate, embedded scales. The color notes here given are from Dr Gooders excellent description in

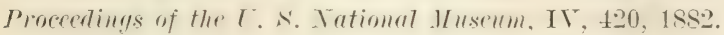

The speratish is found in the West Indies and on our Atlantic coast, ranging northward to cape cod. Individuals more than 7 feet long have been taken, and the speedes is said to reach the length of ef feet. It Woods Ifole it is generally rare; but between 1ss. and 1s!m numbers were atptured in the traps in Tineyard somel and Buzzards bay during July aud August, according to In Hugh M. Smith. Most were caught in the trap farthest up Buzzards bay, at Quissett harbor.

The speartish in one waters is sald to resemble the swordfish in its movements and manner of ferding. Nothing is known of its breeding habits or its youmg. It is talien by means of hooks in derep water or by spearing all the surface. The hook fishing is not alogerther a safe jastime, as the fishermen alre often liable to bie wombled or dlowned hy the firereness and strength

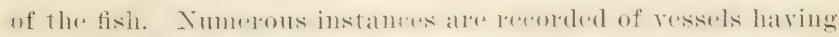

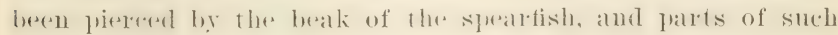

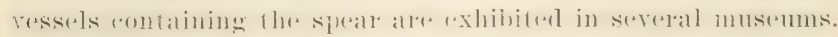
The Hesh of the speatefish is highly esteremed in some localities.

Family xipHIDAE

Swordfishes

Genus xirmus Linnaeus

sworlfishes without teroh, and without rentral fins. Body

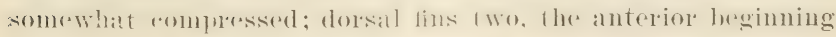
"pposite ile gill openings. falcate and wevated, its hight rather 


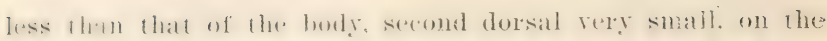

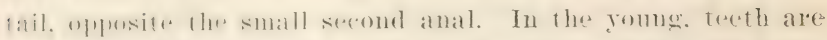

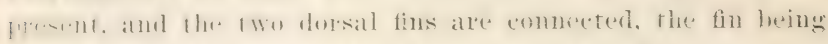

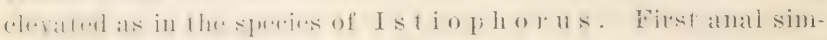

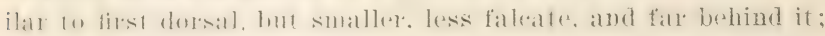

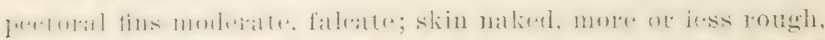

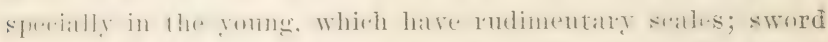

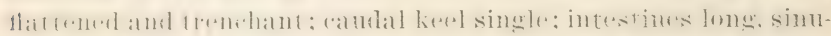

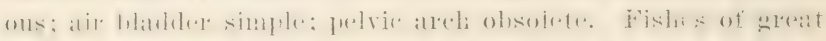

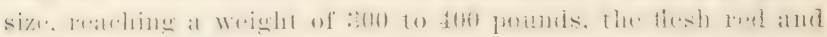

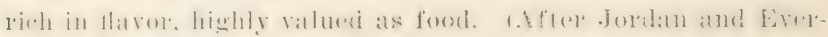
mann)

\section{Xiphias gladius Linnaeus}

Suordfish

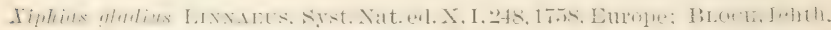
pl, 76, 1781; Mitcmil, Am. Month. Mag. II, 242, Feb. 1S1S; Curier \& TAlexciexnes, Hist. Nat. Poiss. VIII, 255, pl. 225, 226, 1831; DE KAx, స.. Y. Fauna, Fishes, 111, pl. 26, tig. 79, 1842; Güxtren, Cat. Fish. Bxit. Mus. II, 511, 1S60; STorer, Hist. Fish. Mass. 71, pl. XII, fig. 2, 1S67; Goode \& Beax, Bull. Essex Inst. XI, 14, 1879; JordaN \& Gilbeirt, Bull. 16, U. S. Nat. Mus, 420, 1883; JordaN \& Evermaxx, Bull. 47, U. S. Nat. Mus. 894, 1896; Smrm, Bull. U. S. F. C. XVII, 97, 1898.

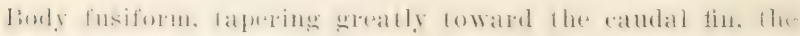

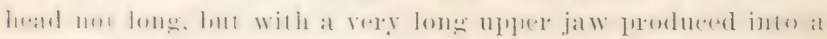
lwak of " sword," lhe greatest depth of the boty one sixt?

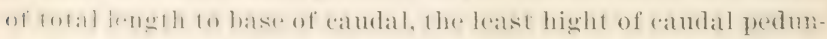

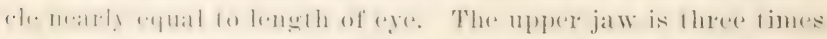
as long as lhe rest of the heate the ". swored" is hroad and

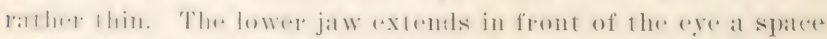

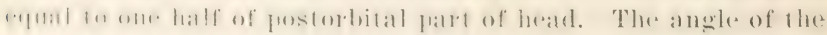

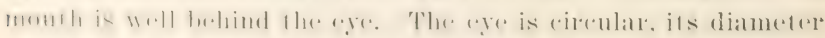

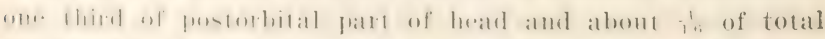

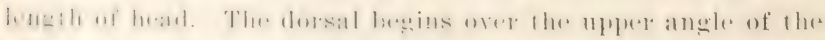

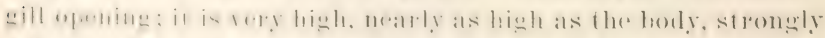

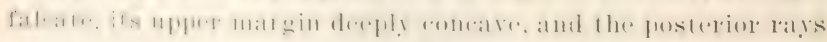
very short. The distance hetween the dorsals is less than one

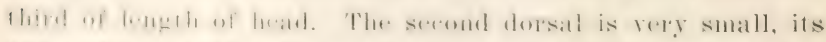

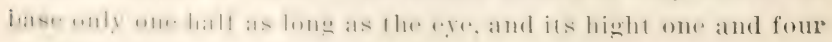


fifths times its length of base; it is located a very little in front of the caudal keel. The caudal is crescentic, its external rays two fifths as long as the head. The caudal keel is single, median, its length nearly one sixth of length of head. The seroud anal is directly under the secont dorsal and is of about the same size; the first anal is equidistant from the root of the caudal and the end of pectoral base; its base is as long as the caudal keel; its longest ray equals postorbital part of head, its last ray minute; the margin of the fin deeply concare. The pertoral origin is below the hint margin of the operewlum; the base is narrow, about one fifth of length of fin, which is efual to depth of body. I). 39 to $40-2$ to $4 ; .1$. 18 to $21-3 ; I^{\prime} .211$.

Color "above rich purplish blue, shading into whitish beneath, the sides and belly with a silvery Iuster. Fins dark bluish with silvery sheen except dorsil. Top of head rich purplish blue, the color extending upon the rostrum. Lower side of rostrum rich brownish purple. Eye deep blue."

The swordtish inhabits the Itlantic and comes near both coasts; it is most abundant between Cuba and Cape Breton, rather common in the Yfediterranean, and is occasionally taken off southern California. The fish appear in the vicinity of Sandy Hook about June filst, and the fishing season continues as far east as Marthas Tinerard and Nantucket shoals till about the middle of september. They disalperar to the southward as soon as the cold winds begin to blow. They feed on mackerel, menhaden, and squid. They are often caught on trawl lines, but the chief means of capture is the harpoon.

The average length of swordfish is 10 feet, but individuals measuring 16 feet are on record. An individual weighing 750 pounds was killed in 1874 off Portland.

The flesh of this fish is rery palatable, and the tishery is an important one as well as an exciting occupation.

Young swordfish have the skin corered with small. rongl excrescences, the jaws much more nearly exual, and the dorsal and anal fins not divided into two separate parts. 


\section{Family CARANGIDAE Crevalles}

\section{fiemus ohgorites Gill}

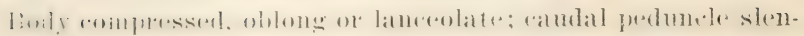

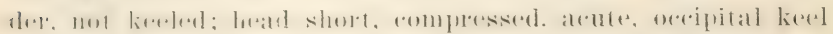

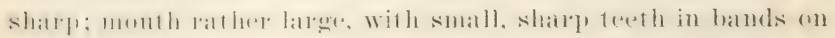

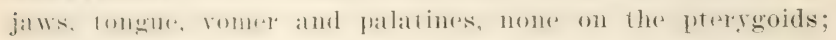

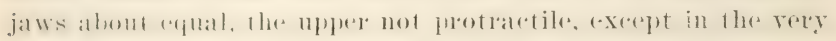

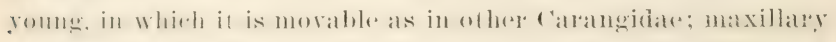
very natrow. Without distinet supplemental home; gill ratires

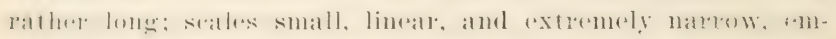

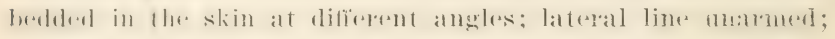

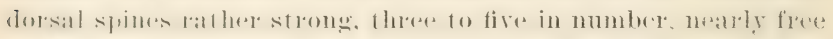

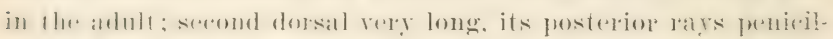
lattel aml matly or quite distommerted, forming finlels: anal

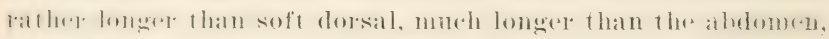
its last rags forming similat finlets, anal spines strong: ventral

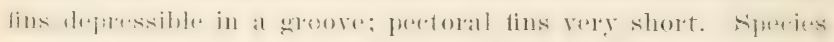

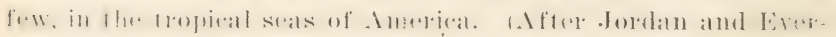
m:1111)

\section{- ()) Oligoplites saurus (Bloch \& Schneider)}

\section{leather . Jacket}

Sermber sumlls bloch \& Scmetder. Syst. Ichth. 321, 1801, Jamaica. Chorinemus ocridentulis Güxtmer, Cat. Fish. Brit. Mus. II, 475, 1860; not Gustemstens aredentulis Loxiders, Syst. Nat. ed, XII. I, 490.

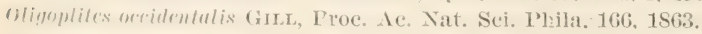

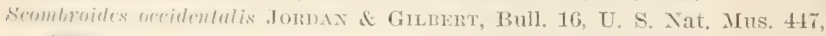
1 $\mathrm{s}: \mathrm{A}$.

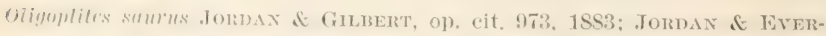
Max, 13ull. 47, U. S. Nat. Mus. 89S, 1S96, pl. CXXXVIII, fig. 378,

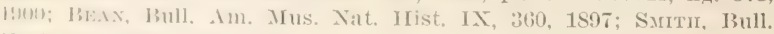
1. . . F.

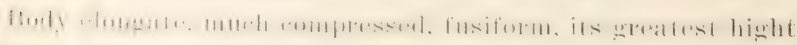
contaimed there and two thirds times in total length without ('andal 1.t limes in tolal to end of mishlle (atudal lays), its width two seventhe of its hight and two tifths of length of head; least

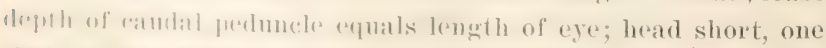
tifll of tolal without rambal, its width thoes sevenths of its

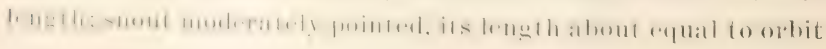


and threseseventles of length of head; nostrils a little no: reer to 'ye than to tip of smout, the anterior tubular and much smaller than the posterior: interorbital space convex but with a narrow, sharp, low keel, the width of the space equal to length of snout; the slender maxilla reaches to helew the hind margin of the eve, the length of the nypere jaw being a little mose thath the snout and ere combined; the mandible is two thirels as long as the hrad; a double series of small, sharp), rmered, conical treth in each jaw; romer and falatines with bands of villiform teeth, an oblong pateh of villiform texth on the tongue; gill ratiers about 15, mostly below the angle, the longest two thireds as long

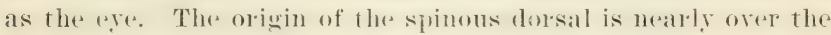
tip of the feretoral and at a distance form tip of suout renual to one thirel of total length without ("aldalal; the length of the base eguals length of head without the suout; the first spine, depressible forward as woll as batekwot, is nearly ats long as the foupil. the thirel and fifth equal and nearly as long as the snout; the membrane behind the second to fifth spines one half the hight of spines; the interspare between the dorsals is rery short. The second dorsal base eruals one half the distance from eve to loot of caudal; the fin

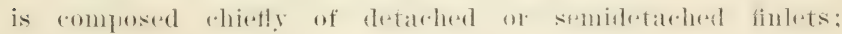
the longest ray is equal to length of snout and eye comhined: the last timlet equal to length of rye. A well dereloged

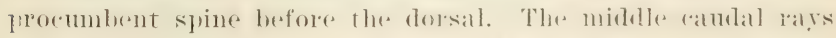

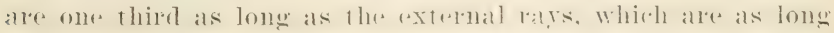

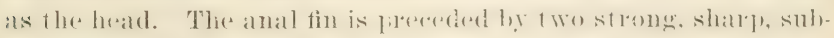

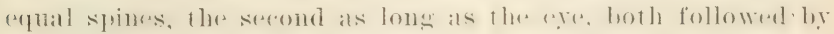

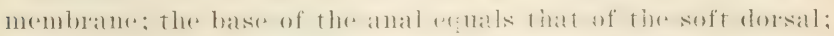

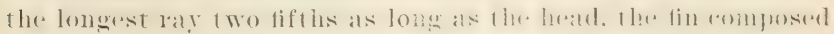

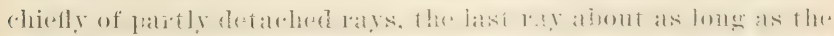

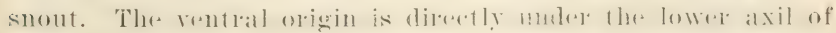

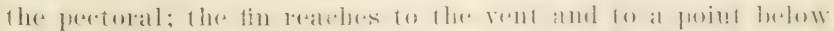

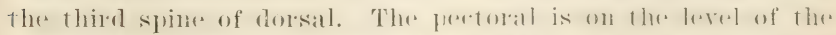

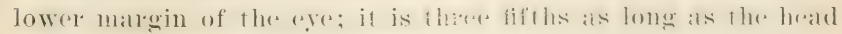
and reatehes to below the second spine of the dorsal. If atd 


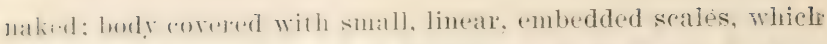

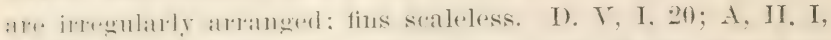

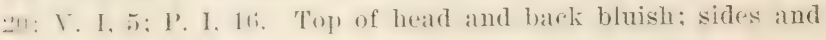
lower parts silvery; fins, interoperele and iris yellow.

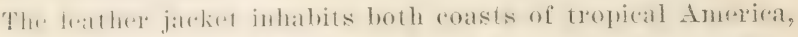

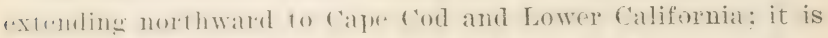

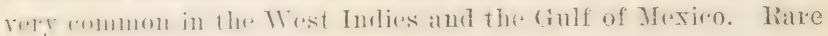

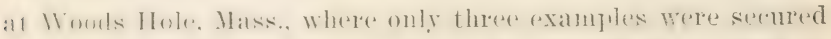

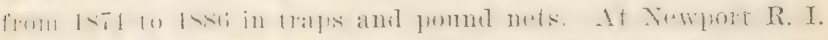

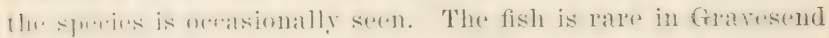

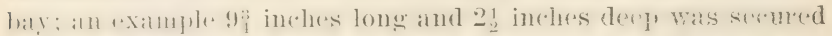

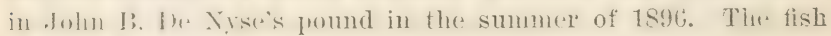
has no value as food.

\section{Genus sacreates Rafinesque}

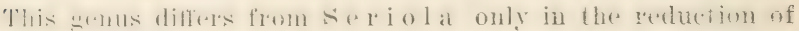

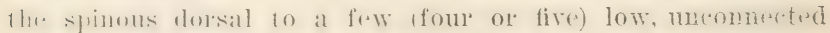
spines. The young, called $\mathrm{N}$ a uclerus and $\mathrm{X}$ ystoph -

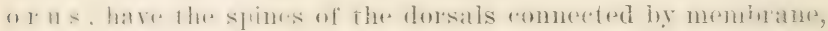
and at more or less distinet strong spine at the angle of the

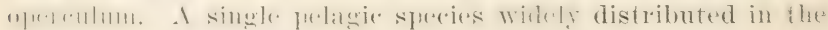
open seas.

\section{Naucrates ductor (Linnaeus)}

\section{Pilotfish}

Giusternstews ductor Lrxwats, Syst. Nat. ed. X, I, 295, 1758, pelagic. Scomber ductor Mrtemld, Trans. Lit. \& Phil. Soc. N. Y. I, 42t, 1815.

Nancrates noveloracensis Cuvier \& Valenciennes, Hist. Nat. Poiss. VIll, 325,$1831 ;$ DE KAY, N. Y. Fauna, Fishes, 112, 1842, and figure of tanerates duetor, pl. 74 , fig. 235.

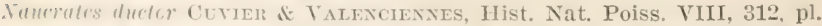
272, 1S31; GüNther, Cat. Fish. Brit. IIus. II, 374, 1860; JoRdAN \& fillizit, 13ull. 16, U. S. Nat, Jus, 443, 1853; Jordan \& Evermaxy, Bull. 47, U. S. Nat. Mus, 900, 1896, pl. CXXXIX, fig. 379, 1900; Sмптн, Bull. 1. \&. I. C. XVII, 97, 1898.

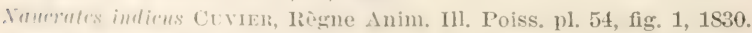

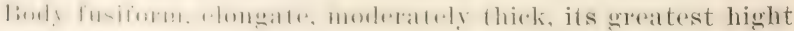

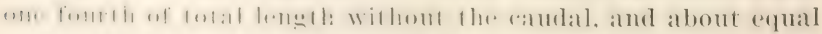

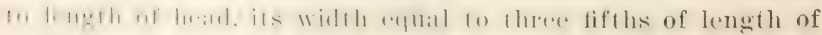
hrad: least dopth of caudal peduncle about equal to long

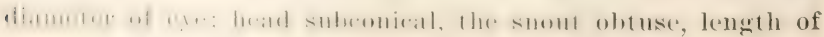


head one fourth of total without caudal; snout two serenths as long as the head; interorbital space convex, its width one half the length of head without the snout; maxilla expanded behind. reaching to below front of eye; mandible three serenths as long as the head, reaching to below hind margin of exe; top of head and rheetis sealy, most of operele and preoperele and all of interoperele naked; teeth in bands in the jatrs but compratatively few and weak; vomerines and palatines also small and the lingual patch narrow; gill raker's stout, short, about 17 below the angle, the longest one half the leneth of eye; we one sixth as long as the heate. The spinous dorsal eonsists of four short. isolated spines, the first located nearly above the end of the base of rentral, the serond and third spine's the longest and about one fometh as long as the snout. The secomel dorsal begins neidway between tip of snout and base of caludal; the base of the fin is nearly three times as long ats the peretorall the sereond lay is longest and one half as long as the head, the last ray as long as the ere; the 1]yer matrin of the fin is slightly e(11-

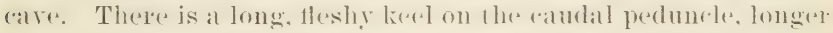
than the postorbital part of the hearl. The caudal is deeply forked, its onter rays more than twice as long as the middle rays, both measured from base of caudal fin; the outer rays are as long as the head. The anal is precteded ly two very small spines; the base of the fin is as long as the head; the longest ray is as long as the snout and eye combined. the last ray ats long as the snout. The rent is under the 10th ray of the dorsal. The rentral fin is under the lower axil of the pertoral; its length is three fifths of length of head; when extended, it reaches to below the origin of the second dorsal. The pectoral fin is below the level of the eye; its length is about "apual 10 length of rentral; it reaches to below the third spine of the dorsal. D. IV-I, 26 to 27 ; A. II, I, 16 to 17 ; V. I, 5; P. I, 20. Scales minute, about 55 rows betwern gill opening and origin of second dorsal. Color bluish with five to seren broad, dark bands, some of these extending on the fins; outre matgin of caudal, ventral and pectoral nearly black. 
The pilotfish is pelagic in all tropical and tempreate seas; it is occasionally taken on our coast as far north as Provincetown Mass., but is not at all rommon. It was reported at 1 oods Hole Mass. by Prof. Baird in 1871. The youmg are dereloped in the open owan and are so different in appearanere from the adult that they have been described as a distinet genus. The fish has no economic value.

\section{Genus seriola Cuvier}

Body oblong, moderately compressed, not ulevated; oeciput and hreast not treuchant; head usually more or less conical. not very blunt: month comparatively large, with broad bands of rilliform terth on both jaws, tongue, romer and palatines; a broad, strong, supplemental maxillary bone; premaxillaries juro. tractile; sralles small; lateral line slightly arehed. forming a keed on the ratudal preduncle, not armed with bouy plates; sides of head with small scalles; first dorsal with about seren low spines, commereted by membrane; sereond dorsal very long, relevated in front; anal similar to the soft dorsal but not nearly se lome. shorter than the abdomen, preceded by two rery small free spines. which disappeatr in old fishes; no finlets; rentral tims rery long: pertorals short and hoad; gill rakers moderate. Species of moderate or large size.

\section{Seriola zonata (Mitchill)}

\section{Banded Rudder Fish}

Scomber zonutus MrтенlL, Trans, Lit. \& Phil. Soc. N. Y. I. 427. 1815. New York Bay.

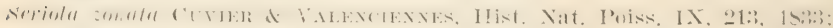

DE KAY, N. Y. Fauna, Fishes, 128, pl. 9, fig. 26, 1842, Long Island

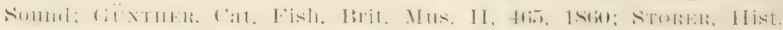
Fish. Mass. 79, pl. XV, fig. 5, 1867; Jondax \& Gilbert, Bull. 16, U. S. Nit. Mus. 44.), 1883; GoOde \& BeAn, Bull. Essex Inst. XI, 16, 1879; BEax, Bull. U. S. F. C. VII, 139, 1885; Jordan \& Everjaxy, Bull. 47. L. S. Nat. Mus. 902, 1896; BeAN, Bull. Am. Mus. Nat. Hist. IX. 360. 1 s!it; sмтт. Bull. U. S. F. C. XVII. 97. 1898.

Halatrartus zonatus Gill, I'roc. Ae. Nat. Sci. Plila. 412. 1862.

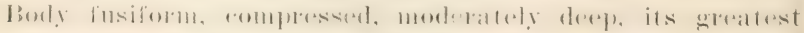

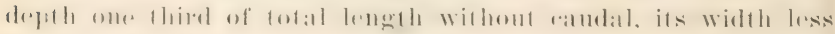

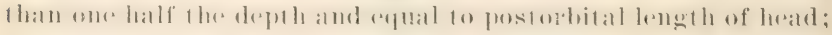

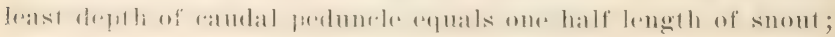


head rather long and subconical, compressed, its length nearly equal to depth of body, nearly one third of total length without caudal; snout long and pointed, three eighths as long as the head, twice as long as the eye; interorbital space convex, indistinctly keceled, its width equal to length of snout; maxilla broadly expanded behind, reaching to below middle of pupil; mandible extending to below hind margin of eye; nostrils small, midway between tip of snout and eye' gill rakers ? 1:? the longest two thirds as long as eye. The spinous dorsal oricinates a little behind the pectoral insertion and directly orer the origin of the rentral; the base of the fin is as long as the postorbital part of the head; the first spine is much shorter than the second, the third or fourth is longest, about as long as the eye, the last is minute. The serond dorsal is prexeded by a rery short, stout spine; the base of the fin equals its distance from the nostril; the longest ray is ecpual to postorbital part of head, the last ray one fourth as long as the head and reaches to the base of the caudal fin. A low, unarmed kexel is developed on the caudal peduncle. The caudal fin is deeply forked, the outer lays being nearly as long as the head. The anal fin is preceded by a single rery small spine; thr longest ray is one third as long as the head, the last ray one fouth as long as the head; the margin of the second dorsal and anal fins is rery slightly concare. The ventral is very long, reathing nearly to the rent, and to below the 13ith ray of the dorsal, its length nearly equal to length of head. The pectoral rearlies io below origin of second dorsal, its length equal to snout and eye combined. Lateral line strongly arched over the peretoral. D. VII, I, 37 to 38 ; A. I to II, i, 20 to 21 ; V. I, 5; P. i, 19.

color bluish above, lower parts white; five or six broad dark bands on the sides, extending on the dorsal and anal fins; a narow dark band obliquely from the spinous dorsal to the eyr; spineus dorsal black; rentral black above. pale beneath; tips of "andal fin white. The bands berome fainter or disappear in old fish.

The banded pilot is found on our rast roast from rape Inn to Cape Hatteras; it reaches the length of 2 or $;$ feet. The 


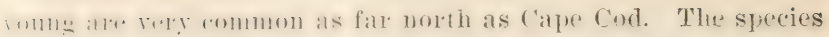
is soldom userl for fombl. The manne, shark's pilot, is in use at somers Point N. J.

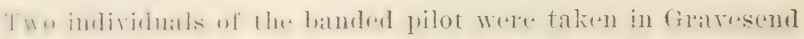
hat! in sinflumber 1s!t. The species will live in raptivity only

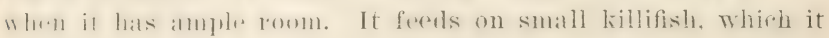
fakes with a rush much like that of the brook trout.

\section{¿os Seriola lalandi Cur. \& Val. (?) \\ Amber Fish}

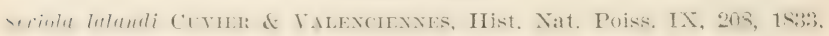
Brazil; Güntmen, Cat. Fish. Brit. Mus. II, 463, 1860; Goode \& BeAN, Bull. U. S. F. C. I, 43, 18s1; Jordan \& Gilbert, Proc. U. S. Nat. Mus. 271, 18s2; Jordan, Proc. U. S. Nat. Mus. 122, 123, 1SS4; Jord.1. \&

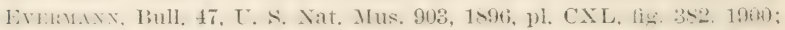
IEAx, Bull. Am. Jus. Nat. Hist. IX, 160, 1897; Surtri, Bull. U. S. F. C. XVII, 97, 1898.

Seriola gigas PoEY, Memorias, II, 227, 1860, Cuba.

Zonichthys gigas PoEr, Syn. Pisc. Cubens, 371, 1868.

Iowy ohlomg. moderately elongate, robust, its greatest light fontaimed foum and one fourth times in the total length withont ramulal, its width seven times; the least depth of the atudal

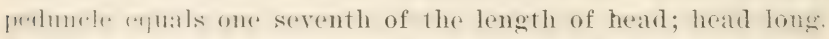

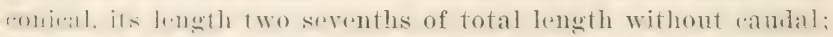
strill lome and somewhat pointed. its length two and one tifth

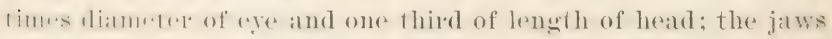

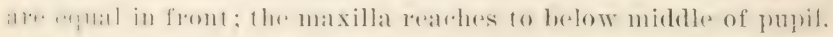

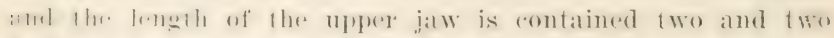

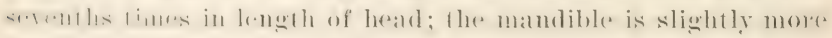

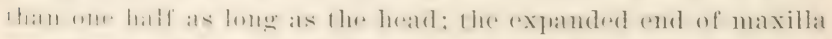

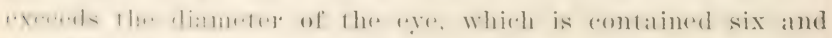

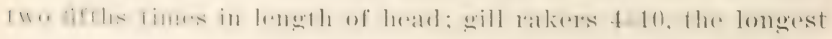
nualy as long as the eye, very thin, much wider at base, and

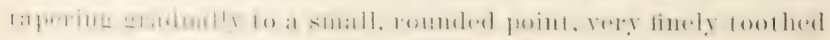

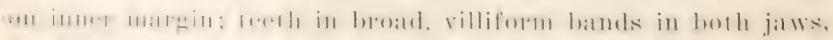

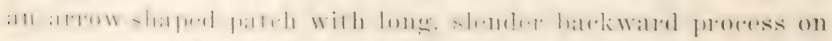

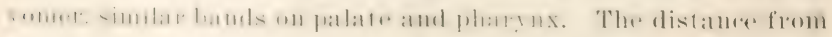
sinul fo vitieal from origin of spinous dorsal is nearly three

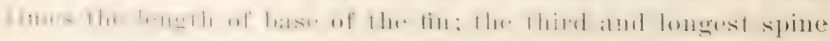


is seven and one half times as long as the last spine and nearly one fourth as long as the head; the base of spinous dorsal is contained two and two serenths times in length of head. The interspace between the two dorsals is less than the length of the eye. The second dorsal base is one and one half times as long as the head; the second ray is the longest and equals three times the length of the eye, the last ray about one third as long as the second. The anal origin is under the middle of the second dorsal and at a distance from the rent equal to one fourth the length of head; the anal base is as long as the head; the longest ray is nearly one half as long as the head, the last ray about equal to the last of the dorsal; the anal and second dorsal fins are elevated in front but very low for the most of their length. The reutral origin is directly under the insertion of the pectoral; the fin when extended reaches to below the last spine of dorsal, its length more than one half the length of head. The pectoral is broad at its base, somewhat falcate, its length nearly one half the length of head, the fin extending to below the serenth spine of the dorsal. I). TII, 36; A. I, 24; V. I, 5; P. 21. Scales about 24-160-30.

The ground color is gray with purplish iridescence. A golden bronze stripe begimning on the snout and continued behind the "ye to the caudal in a nearly stratioht line, slightly aboves the median line. Another bronze stripe begins above the "ye and extends to the first dorsal. In life two dark bands showed between the eyes and extended to the first dorsal. Sides and lower parts much mingled with silvery white; iris gray overlaid with golden yellow; pupil bluish blark; all the fins rolored like the body except the rentrals, which are whitish underneath, and gray mingled with white above.

The weight of the fish was 13 pounds $1 \frac{1}{2}$ ounces.

The specimen deseribed was obtained by Mr De Nyse in Graves-

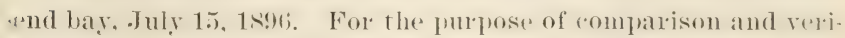
firation of this identifeation, a series of measurements is here given in tabular form. 


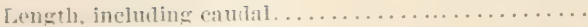

I. ength to end of midille caudal rays............ $301 / 2$

Length of exte:nal candal lobes from pit.......... $\bar{\tau}$

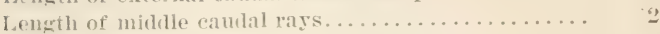

Greatest depth of body $\ldots \ldots \ldots \ldots \ldots \ldots \ldots \ldots \ldots \ldots . \quad 6 \ldots \ldots$

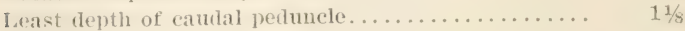

Greatest thickness of body ................ 4

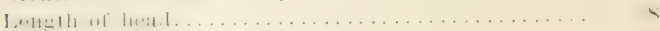

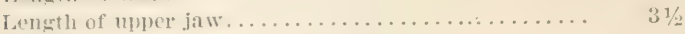

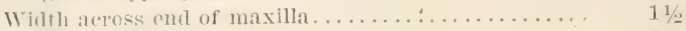

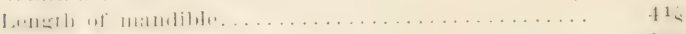

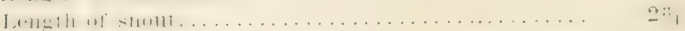

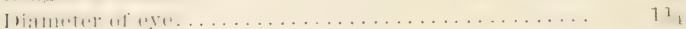

Diameter of pupil. . . . .

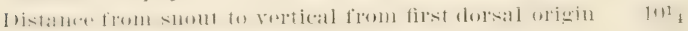

I. (menth of first dorsal base. . . . . . . . . . . .

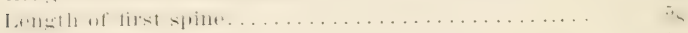

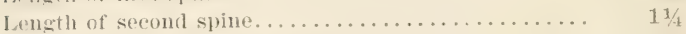

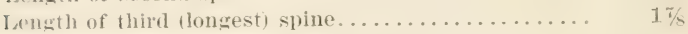

Length of seventh spine................. $1 / 1$

Distance from snout to second dorsal (obliquely).... $1 t^{1 / 4}$

Length of second dorsal base. . . . . . . . . . . . . $11 \%$

Length of second lay of second dorsal ........... $33_{1}$

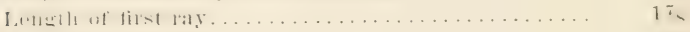

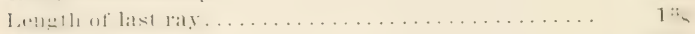

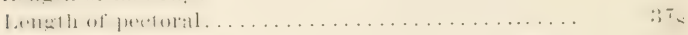

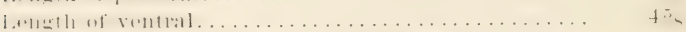

Distance from rentral origin to anal origin........ $101 \%$

bistance from vent to anal origin.............. 2

The amber jark her. mentioned is supposed to be idemtical with the S. la la nd $\mathrm{i}$ of Curier \& Valenciennes, a species

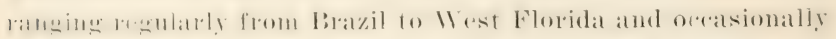

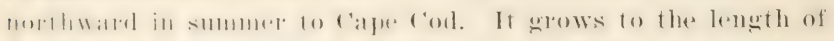

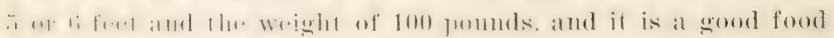
fish as woll as a lobust and vigorous prize for the angler.

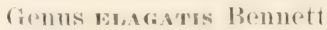

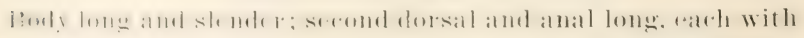
one chelarderl finlot fomposed of tyo rays behind the rest of the

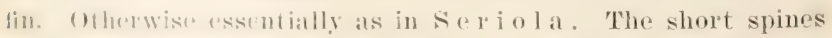
proreding the anal fin are somewhat remote from the rest of the lin. limanchiostreats 7 ; lateral line not armed; villiform fmelh in bamble in the jaw, on the vomer and the palatines. 


\section{Elagatis bipinnulatus (Quoy \& Gaimard)}

\section{Runner}

Seriola bipinnulata QUor \& GaImand, Voyage Uranie, Zoöl. I, 36:?, pl. 61, fig. 3, 1824, Keeling islands.

Seriolichthys bipinnulatus G̈̈̀ntmer, Cat. Fish. Brit. Mus. II, 468, 1860. Seriola pinnulata, PoEx, Memorias, II, 233, 1860.

Elagatis pinnulatus Jomnax \& Gilmert, Bull. 16, U. S. Nat. Mus. 446, 1883. Elagatis bipinmulatus Jordan \& Evermaxx. Bull. 47. U. S. Nat. Mus. 906, 1896; BEAN, Bull. Am. Mus, Nat. Hist. IX, 361, 1897.

Body moderately elongate, slender, fusiform, its greatest depth one fourth of total length without caudal, its width three eighths of length of head; least depth of caudal peduncle equals diameter of eye; head conical, compressed, its width orel opercles equal to length of postorbital part; a low occipital keel; snout moderately long, obtusely pointed, its length nearly equal to width of interorbital space, and contained three and one fourth times in length of head; lower jaw slightly projecting; maxilla almost reaching to below front of eye, the upper jaw one third as long as the head; mandible reaching nearly to below front margin of pupil, its length equal to postorbital part of head; interorbital space with a low keel between two shallow furrows, its width one third of length of head; eye one fourth the length of head (in roung examples 5.1 inches long), about one fifth in older fish; gill rakers $9+27$, the longest one half as long as the snout. The spinous dorsal base is short, equal to postorbital part of head; the spines are rery slender, closely placed, the longest not so long as the eye; the spines are depressible into a sheath; the origin of the fin is over the middle of the length of the pectoral. The soft dorsal originates about over the end of the ventral, midway between tip of snout and base of caudal; the longest ray is as long as the postorbital part of the head; the fin is shaped as in Seriola, the second half being very low, the last ray about two thirds as long as the eye; the fin is followed by two finlets, the longest as long as the eye. The caudal is deeply forked, the middle rays, from base of fin, one third as long as the outer rays, which are as long as the head; no keel on the caudal peduncle. The anal origin is under the 15th ray of the dorsal; the base of the fin is as long as the head; 
the lomgest ray is there reghths as long as the head; the last ray two thilds as long as the ere; the tin is followed by two finlets, lle lomger as leng as the ere. The rential reaches a litele be. yome the origin of the sofl dolsil: the length of the fin is equal to sucul and eyrenmbined. The pertoral is as long as the rentral: it reatehes on below the last spine of the forsal; the fin originates slighty in alvance of the ventral insertion. Body eoveled with small. ryeloid seales; head naked exerent on sub-

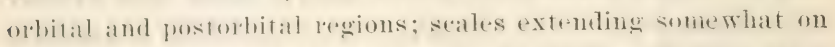

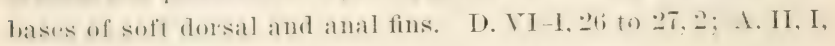
16 to 17,$2 ;$ V. I, 5; P. I, 20. Scales 16-110-20.

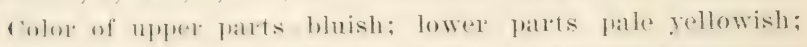
atulal fin yelluwish. the matrin dusky: rentrals and pertorals yellowish tinged with hlue; a blue hand as wide as the tere form

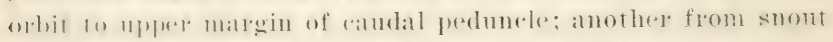

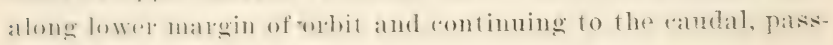
ing above the pectoral.

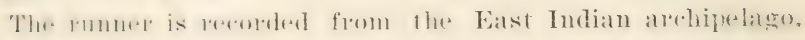

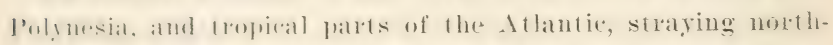

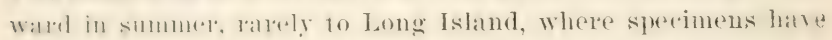

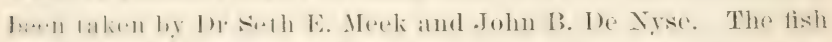
altains to the lemglh of :30 inelues. The example raptured hy

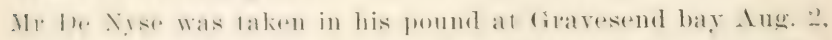

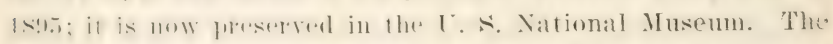

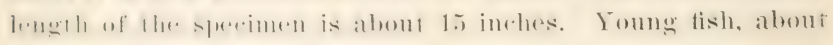
4 to 6 inches long, are before me from Florida and Cuba.

\section{Genus Deciments bleeker}

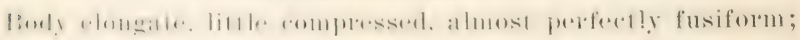

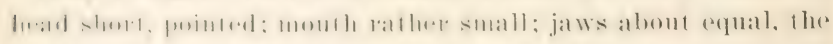

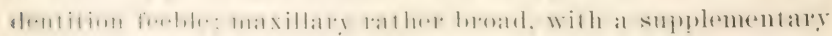

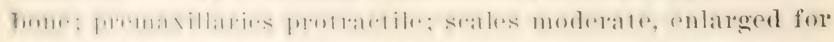

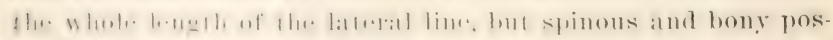

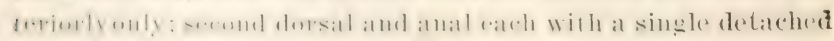

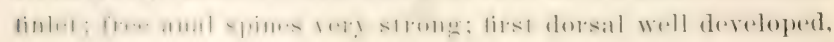
persistrul: pertorals compatratively short; abdomen rather shorfur than anal fin; gill ralkers long and slender. Species nแmแก) 


\section{Decapterus punctatus (Agassiz)}

\section{Scad; Round Robin}

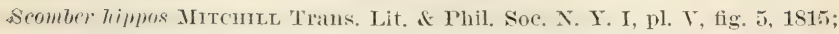
Am. Month. Mag. II, 246, Feb. 1818, not of Livxaeus.

Caranx punctatus Agassiz, spix. Pise. Bras. 108, pl. 56a, fig. 2, 1829, Brazil; Cutier \& Valenciennes, Hist. Nat. Poiss, IX, 38, 1833; De Kay, N. Y. Fauna, Fishes; 122, pl. 73, fig. 233, 1842; Güntuer, Cat. Fish. Brit. Mus. II, 426, 1860.

Decapterus punctatus Poey, Syn. Pisc. Cub, 368. 18tis; Jordan \& Gitbert, Bull. 16, U. S. Nat. Mus. 432, 1883; Beax, 19th Rep. Comm. Fish. N. Y. 256, 1890; Bull. Am. Mus. Nat. Hist. 362, 1897; Jordan \& Evermanx, Bull. 47, U. S. Nat. MIus. 907, 1896; Smrtr, Bull. U. S. F. C. XVII, 97, 1898.

Body suombriform, moderately elongate, its greatest depth one fifth to two ninths of total length without caudal, its width one half the length of head; least depth of caudal peduncle one sixth the length of head; head subconical, moderately rompressed, its width one half its length, the snout obtusely pointed, as long as the eye, two serenths as long as the head, the jalws subequal in front; maxilla expanded posteriorly, reaching to below front of ere; premaxilla projectile; mandible one half as long as the head, reaching to below front of ere; eye round, equal to snout, two serentlis of length of head; interorbital space conrex, corered with small scales, its width equal to eye; a low, but distinct nuchal lieel; operenlar bones partly naked; gill rakers very numerous, long and slender; a small prominence on the shoulder girdle in front of base of pectoral; teeth in jaws uniserial, teeth on romer and palatines, present or absent on tongue. The spinous dorsal originates over the 13 th or 14 th scale of the lateral line and slightly in advance of the middle of the peetoral: the base of the fin is as long as the head without the snout; the first spine is rerr slender, and as long as the eye; the longest spine as long as the snout and ere combined. The soft dorsal base is one third of total length including the caudal: the longest ray is one half as long as the head, the last ray two thirels as long as the eye: the fin is followed by a single finlet concisting of two rays, the length equal to length of ere. The middle caudal rays are two fifths as $\operatorname{long}$ as the outer, which are five sixths as long as the head. The anal base is one 
third of total length withont caudal; the fin is preceded by two short, stifl spines with a membrane behind each, the first of these spines two thirds as long as the ere; the longest anal ray is one half as long as the head and three times as long as the last ray; the fin is followed by a single two-rayed finlet which is three fourths as long as the exe. The rentral origin is equally distant from tip of snout and anal origin; the fin reaches to below the sixth spine of the dorsal, its lengtli one half the length of head. The pectoral reaches to below the end of the spinous dorsal, its length three fourths of length of head. Head sealy except on the nasal, mandibular and preorbital regions; body covered with small scales; dorsal, anal and pectoral fins more or less scals at base; lateral line with a long arch in its anterior one half, passing through enlarged scales in its curred part and armed with 41 scutes in its straight part. D. VIII-i, 31-I; A. II-i, 24 to 27-I; V. I, 5; P. i, 20.

Color slaty blue above, silvery below; a small, dark, opercular spot, smaller than the pupil; a series of 12 or 13 dark points in the curved part of the lateral line.

The dotted scad, or round robin, is a rery common fish at the limmudas and in the West Indies. On the east coast it is found from cape Cod to Brazil, but only young or half grown specimens are taken on Long Island and around Cape Cod. The species grows to the length of 1 foot. In the Bermudas it is ar: important food fish and furnishes infinite sport for the small angler's.

[1. Mitrhill illustrates it in fig. 5, pl. 5, of his Fishes of Tew Jorli, and names it the hippos mackerel. In Dr De Kay's New Sinte finum it is the spotted caranx. It is taken not uncommumly at 11 mols Hole Mass. The species appears to be rare in New York watrers, as it was known to De Kay only from the deseriptins of Mithill and Cuvier. The fish has not been recognized in firavesumd bay, but it is abundant in August at South. amplos 1. 1. and hats beren talien at Fire Island in Oetober during the fall migration. 


\section{Decapterus macarellus (Cur. \& Val.)}

\section{Mackerel Scad}

Caranx mucurellus C'trter \& TALexciennes, Hist. Nat. Poiss. IX, 40, 1833 (Martinique); Günther, Cat. Fish. Brit. Mus. II, 426, 1860.

Decapterus macarellus Poer, Enumeratio, 79, 1575; Jordax \& Gilbert, Bull. 16, U. S. Nat. IIus. 433, 18s:; Jorday \& EverMAxs, Bull. 47, U. S. Nat. Mus. 909, 1896, pl. CXL. fig. 353, 1900; BEAx, Bull. Am. Mus. Nat. Hist. IX, 362, 1897; SмrтH, Bull. U. S. F. C. XVII, 97, 1898.

Body elongate, fusiform, subterete, its greatest depth one fifth of total length, its width one half the length of head; least depth of caudal peduncle one eighth of length of head; head long, subconical, snout obtusely pointed, lower jaw slightly projecting, length of head one fourth of total without caudal; maxillary not quite reaching to front of orbit; the upper jaw equal to length of snout; mandible extending to below front of eye, its length equal to postorbital part of head; nostrils on top of lead, nearer eye than to tip of snout; eve large, one fourth the length of head; interorbital space convex, its widh equal to eye; a very low keel on top of head; no scales on nasal and preorbital regions; gill rakers $S+30$, the longest two thirds as long as the ere. The spinous dorsal originates at a distance from tip of suout equal to one third the total length without caudal; the longest spine is one half as long as the head, the last spine minute. The interspace between the two dorsals is one half the diameter of eye. The second dorsal base equals one thixd of total length to end of middle caudal rays; the anterior -one fourth of the fin is much higher than the rest, the longest ray one thild of length of head, the last ray one half as long as the snout; the fin is followed by a single finlet of two rays, the longer two thilds as long as the eye. The caudal fin is moderateily forked, the middle rays, from base of fin, four serenths as long as the outer, which are equal to snout and eye combined. The anal fin is preceded by two slort, sharp spines, the first longer, one half as long as the snout; the rays begin under the minth ray of the second dorsal; the base is as long as the distance from rentral origin to preanal spines; the longest ray about one third as long as the head, the last ray one half as long as the snout; the fin is followed by a single two-rayed finlet, 
which is two thirds as long as the snout. The rentral insertion is moler the lower axil of the peretoral; the fin extencls to below 1ly. fifth spine of the dorsal, its length equal to postombital part

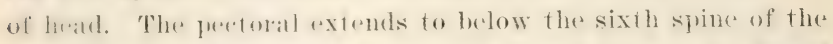
dorsil, its length epual to the hearl without the snout. simall

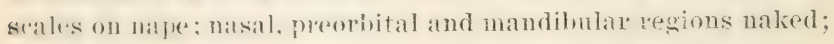
sides of head mostly with enlareded. thin scales; small suales on

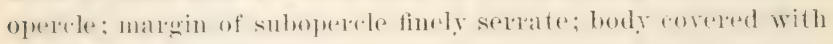
small srates: anteriol half of lateral line with a sliglu cuive, the scales frominent: posteriol half of lateral line straight and almed with about : it liesed sentes, the almed portion roustituting the second half of the length. D. VIII-i, : it-1; II-i, :S-1; T. I, 5; P. i, 24. Scales 15-100+31-18.

color slate blue of plumbers above, silvery below: a small,

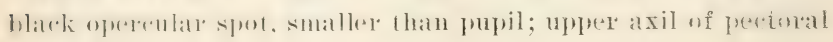
blatek.

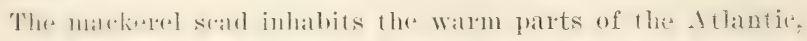

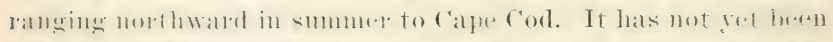
reported in firstessed bay, hut was seined in abumlance in the

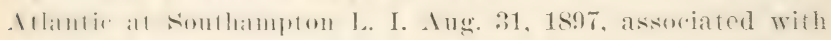
Decapterus punctatus, young Scomber, Poma. tomus, Rhombus, Clupea, Etrumeus, two species of Stolephorus, and Paralichthys.

The species grows to the length of 1 foot. It is excellent

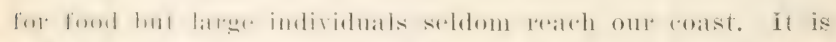

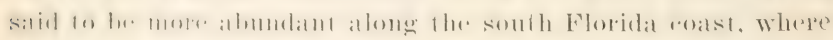

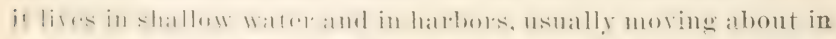

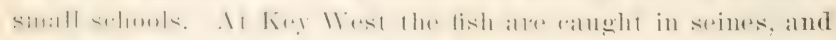
ato caten.

\section{Genus trucmurs liafinesque}

liony rather elongatr, somewhat compressed, not elevated,

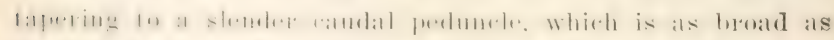

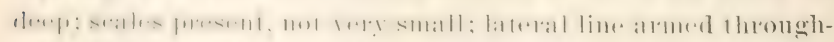

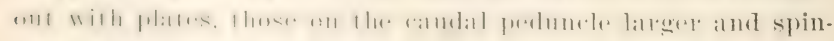
ons; an aneressory dorsal branch to the lateral line: snout rather

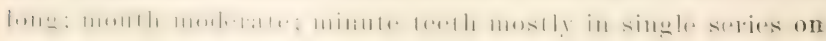


jaws, romer and palatines; dorsals two, the first preceded by a procumbent spine, no finlets; two strong spines before the anal, connected by membrane; pyloric cata numerous. About 4 species known; found in all warm seas.

\section{Trachurus trachurus (Linnaeus)}

\section{Gascon; Saurel}

seomber trachurus Lixxifts. Syst. Nat. ed. X. I, 298, 175s, Mediterranean. Caranx trachurus Cutier of VAlenciennes, Hist. Nat. Poiss. IX, 11, pl. 246, 1833; Cuvier, Règne Anim. Ill. Poiss. pl. 57, fig. 1.

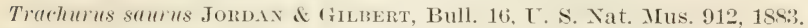

Trachurus trachurus BLocir, Naturgesch. Ichth. II, 138, pl. 36, 178t; Güntier, Cat. Fish. Brit. Mus. II. 419. 1860 (in part); Lütken, spolia Atlantica, 125, 1880; Jordan \& Gilbert. Proc. U. S. Nat. Mus. 269, 1852; Jordan \& Evermann, Bull. 47, U. S. Nat. Mus. 910, 1896, pl. CXL, fig. 3St, 1900.

Body strongly compressed and moderately deep, the depth contained four times in the length of the bodr; head rather long, its length being contained three and one half times in that of the bodr; eye large, equal to snout, its length contained four times in that of the head; month moderate, the maxillary reaching the front of the eye; arch of lateral line short, reaching scarcely beyond pectoral, one and one third in the straight part, the plates high, nearly as high anteriorly as posteriorly, their hight more than half of ere. (amenish, sides silrery; a dusky opereular spot. Length one foot. North Itlantic, chiefly on the coasts of Europe, south to spatin and Yilples; it is rery rare on our coast, recorded from Newport R. I., I'ensacola, and Cape San Luras. D. VIII-I, 29; A. II-I, 28; scutes 40+37.

The saturel, or sead, rallges north to the Trondhigen fiord, latitude 65, and is said to oecur as far south as Portugal. On the coast of IIolland it is known as the marse bemlier, or hors. It is interesting to American ichthyologists, since the similarity of its habits to those of the menhaden caused the latter fish to be called amoug the early Dutch colonists of New York by the same name.

The scads are deseribed by Europeatn writers as ocrurring on those coasts in enolmous sehools. moving like menhaden but with feeding habits similar to those of om bluefish. They are fairly 
grood food fishes, but of small size. seldom exceeding 1 foot in length. Only a few specinems have been recorded on our Atlanir. coast from Newport R. I., Pensarola Fla., and Cape San Lucas, Lower California.

\section{Genus Trachurors Gill}

This genus is cluse to ('a ra $\mathrm{n} x$, differing in the more elongate form and specially in the structure of the shonlder girdle, which has a derep ('poss furrow at its junction with the isthmus, with a fleshy projection abore the furrow.

\section{1:; Trachurops crumenophthalmus (Bloch) Big-eyed Sead; Goggler}

Scomber crumenophthalmus BLocH, Ichth. pl. 343, 1793.

Scomber mlumicri Bloch, op. cit. pl. 344. 1793, Antilies; Storen, Syn. Fisin. N. A. 100,1816 .

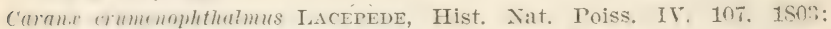

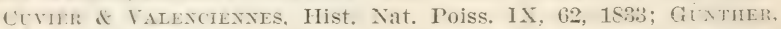
Cat. IYish. lirit, IIus. II, 429, 1860; Jordan \& Gileert, Bull. 16. U. S. Nat. Mus. 434, 1883.

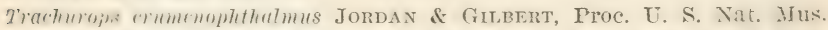

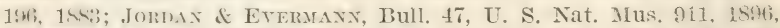

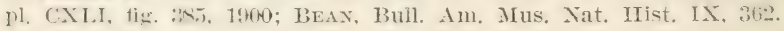
1897; Sмiтн, Bull. U. S. F. C. XVII, 97, 1898.

Fody ohlome rengate, little compressed, the back not elerated. The derth is contained three and one half times in the length. Ifead wongate, rather pointed, the lower jaw projecting; maxillary reathing fast the front of the eye, which is very large. longre than smout. murh deeper than rheeks, and greater than the introrthial width. The leneth of the head is contained three and ond half times, while that of the ege is contained three times in the length of the body. I single series of teeth in each jaw, very watk terdh w vomer and palatines, a pateh of teeth

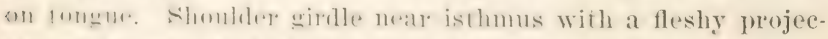
tim. in front of which is a derp aross furrow; adipose eyelid

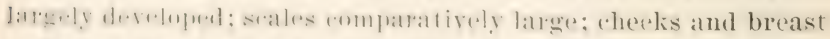

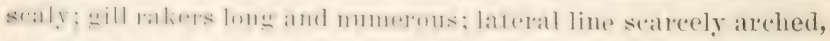

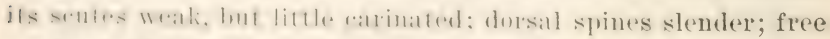

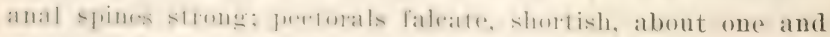

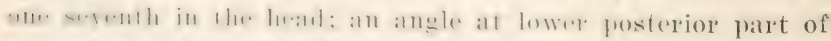

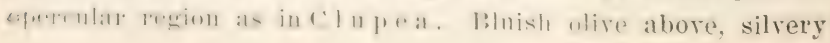


below; a faint opereular spot. Length about 2 feet. D. VIII-I, 26 ; A. II-I, 22 ; scutes 35 .

Found on both coasts of tropical America, and extending northward on our east coast to Cape Cod; common in the West Indies and on the west coast of Mexico; also found on the coast of Africa and in most tropical seas; abundant in the Caribbean sea in winter.

This is the goggler or goggle-eyed jack of the Bermudas and the Cicharra of Cuba. In the Bermudas it is a food fish of some importance. In Januarț 18sa a few individuals were seined at the island of Cozumel, off Yucatan. The fish was found to be excellent for the table.

At Toods Hole Mass., according to Dr Smith, it is common every year from about October 15 to November 15 , the individwals taken measuring from 4 inches to 6 inches in length.

July 25, 1901, a single example, about 4 inches long, was picked up dead on the ocean beach opposite Clam Poud core; one of a number of little fish which had probably been driven ashore by bluefish or some other predatory species, for the fish had recently died, and there had been no storm. Seven species in all were found in a distance of about 2 miles; they were common mackerel, bluefish, mackerel scad, two species of anchovy, young sea herring, and the big-eyed scad.

The big-eyed scad is taken in the fall in Graresend bay. It was found Aug. 31, 1897, in the surf at Southampton L. I. This fish will not endure close confinement, but will live within suitable limits of temperature in large bodies of water. In captirity it feeds on small killifish, shrimp, and chopped clams.

\section{Genus caraxx Lacépède}

Body ovate or oblong, compressed, the back sometimes considerably elevated, sometimes little arched; head moderate or rather large, more or less compressed; mouth moderate or large, oblique; maxillary broad, with a well developed supplemental bone, extending to below eye; premaxillaries protractile; teeth dereloped in one or few series, unequal, or at least not in villiform bands, villiform teeth usually present on vomer, palatines, 


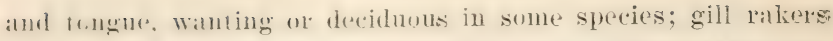

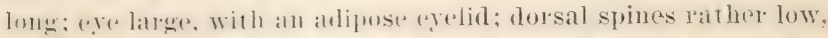
ronnexted; second dorsal loug, usually elerated in front, both fins d. prexsible in a wrome; anal fin similar to second dorsal and nearly as lomg, foreceled by two rather strong spines. ito base longer than the abdomen; camdal fin strougly forlied, the jedumele very slemder; rentral fius moderate; metorals falcate; no finlets: sables piestent, mostly very small; laterall line with its josteror part armed with strong bony plates, whirh grow larger on the tail, each plate armed with a spine, a short dorsal branch uf latreal line nstlally fresent; preoperele entire in the adult. serlate in fles young, msually with a membranaceons horder. Species very numerous in all warm seas.

\section{Subgenus Trmormenus Rafinesgue}

\section{$21 \pm$ Caranx hippos (Limnaeus) \\ Crevallé}

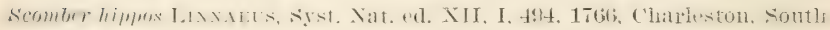
Carolinat

Caranx carangus Cutien \& Vatexciexises, Hist. Nat. Poiss. 1X, 91, 1833; Güxtmen, Cat. Fish. Brit. Mus. II, 448, 1860.

Caranx defensor DE KAY, N. Y. Fama, Fishes, 120, p1. 24, fig. 72, 1512: HoLıноо, Ichth. s. C. S7, pl. 12, fig. 1, 1860.

Carangus hippos Git., Proe. Ac. Nat. Sci. Phila. 433, 1862; Goode \& BeAx, Bull, Essex Inst. XI, 16, 1579.

Caranx hipmes Jommax of Gilners, Bull. 16, U. S. Nat. Mfus. 437. 185: Jordax \& Gimbrt, Proe. U. S. Nat. Mus, 200, 1853.

Caranx hippos Briv, Bull. U. S. F. C. VII, 139, 18ss; Bull. Am. Mus. Nat. Uist. 1X, 362, 1597; 52d Ann. Rept. X. Y. State M[us. 103. 1900; Jomox et Evmmaxx, Bull. 47, U. S. Nat. Mus. 920, 1896, pl. CXLI. 1ig. :387, 1900; Menmss, Bull. Am. Mus. Nat. Hist. X, 318, 189S; SuItir,

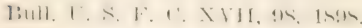

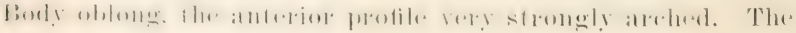

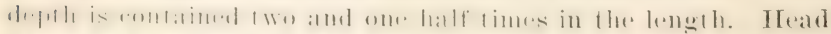

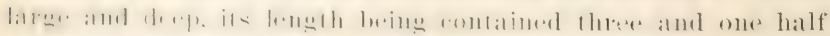

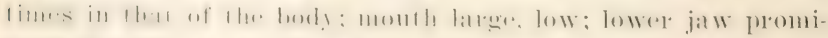

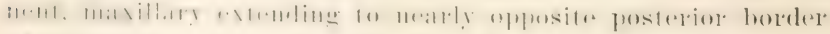
of ("yo, two and one third in head; teeth in upper jaw in a. lonad villifolm hamd, an onter series of laroe, wide set, coninal twefh, terth of lower jaw in one row, a distinct ranine on each side of sympleysis; villiform teeth on vomer, palatines, 
pterygoids, and tongue; lateral line with a wide arch, its length one and one third in straight part, the angle under fifth dorsal ray, plates not covering all of the straight part, lateral line (scutes) about 30; dor'sal spines short, rather stout; gill raker's stout, rather long, 15 below angle; occipital keel sharp; eye not very large; pectoral falcate, one fifth longer than head; breast naked, with only a small triangular patch of scales in front of rentrals; caudal lobes equal, nearly as long as head. D. VIII-I, $20 ;$ A. II-I, 17.

Olivaceous above, sides and below golden; a large, distinct black bloteh on opercle, bordered behind with pale; a large faint black spot on lower rays of pectorals, the latter sometimes wanting in young; axil of pectoral with a black blotch; edge of soft dorsal black; upper edge of caudal peduncle duskr.

The crevalle is found on the east coast from Nova Scotia southward, ranging to the West Indies and Brazil. The roung are rery common aloug the coast of southern New England in summer. De Kay calls it the yellow caranx, and Mitchill mentions it as the yellow mackerel. The specimens seen by both these authors came from the bay of New York.

It Woods Hole Mass. the poung arrive in July and leave in October. In Great Egg Harbor hay, X. J., roung individuals were taken sparingly in Ingust. The Kay records the species as abundant in Jew York bay in september and Or.tober. The writer saw several examples from a fish trap at Islip I. I.. oct. 1, 1890.

Young crevallé make a croaking sound when captured in a net or held in the hand.

On the gulf coast of Florida, Alabamal and Mississippi the fish is migratory, just as it is herr; it makes its appearance in April, spanns in July or Angust, and then disappears and is replaced by the young. It feeds on small fish, which it pumsues eagerly, and is preyed on by sharks and porpoises.

It grows to the length of 1.5 inches and is highly prized for food.

The crevalle can be suceessfully kept in raptivity in large pools with a temperature ahove 50 in winter. The fish oceasionally school together under a large shark atnd follow it about. 


\section{Subgenus piratractus Gill}

\section{Caranx crysos (Mitehill)}

\section{Tellow Mackerel}

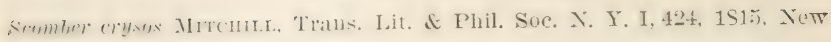
York.

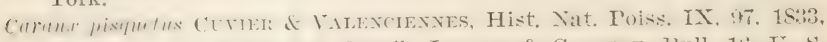

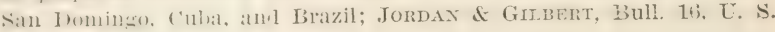
Xat. Mus, 435, 1SS3.

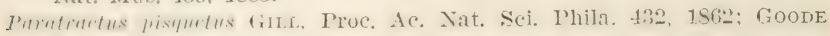
\& Beax, Bull, Essex Inst. XI, 16, 1879.

Caranx chrysos Storer, Hist. Fish. Mass. 75, pl. XIV, fig. 3, 1867; Güxtmer, Cat. Fish. Brit. Mus. II, 445, 1860.

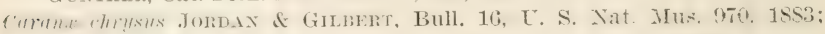
BeAx, 19th Rep. Comm. Fish. N. Y. 256, pl. VII, fig. 10, 1890.

Caranx crysos DE KAY, N. Y. Fauna, Fishes, 121, pl. 27, fig. S5̆, 1812; .Tordar \& Evermaxx, Bull. 47, U. S. Nat. Mus. 921, 1896, pl. CXLII,

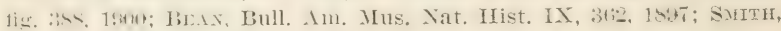
Bull. U. S. F. C. XVII, 9S, 1898.

Bod oblong, moderately elevated, the dorsal and rentral ontlims alumt efually arehed. The depth of the body is conlained alume there and one fourth times in the length. Profile forming a miform rure. The length of the head is contained lliree and three fourths times in the length of the body. Suent rathlor shatrl: mouth slightly oblignue, a little bedow axis ot borly: maxillary reathing about to midalle of orbit: tecth

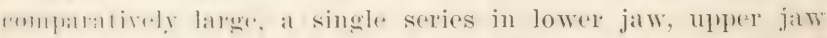
will an inner sereies of smaller terth, no eanimes, teeth oni fommer. fralatimes and fongur ; eye rather small, shorter than

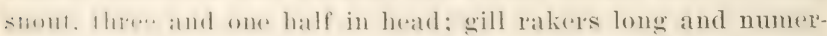

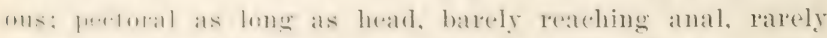

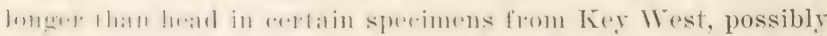
referable to C. caballus; scales moderate; cheeks and

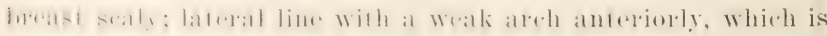

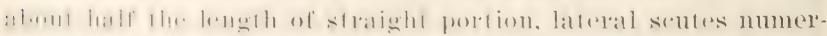

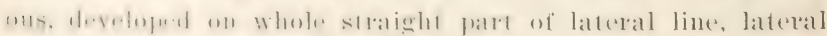
lime 50 (scutes). D. VIII-I, 24; A. II-I, 19.

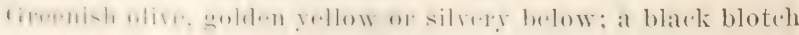

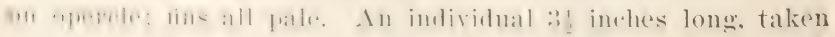


at Beesleys Point N. J. Aug. 11, 1887, showed the following colors: caudal yellow; basal half of elevated part of anal yellow; cheeks and lower half of sides also yellow; a black opercular spot, but none on pectoral; several narrow pale bars on sides; tip of elevated part of soft dorsal dusky; membrane between dorsal spines dusky; iris copper color.

The yellow mackerel is a widely distributed fish in warm seas; it is recorded from the East Indies, both coasts of tropical America, and northward to Cape Ann and the Gulf of California. The young are common at Woods Hole Mass., where they appear in July and become most abundant in October. Indiriduals 1 inch long have been obtained there about July 1; larger fish occur in the fall. In August 1898 only a few young ones were secured in Great South bay and at Southampton L. I.

The fish probably spawns in west Florida in May in the salt water bayous, as the young fish are seen coming out of such places in schools in the fall on their way to the sea. Fish weighing about a pound or two are considered equal to pompano for the table, but large fish are not esteemed, the flesh being dark and almost tasteless. The species reaches the weight of 20 pounds.

The yellow mackerel resembles the big-eyed sead in its endurance of captivity and its feeding habits. At the end of November it has been known to thrive in a pool containing about 50,000 gallons of water in company with the crevalle, the bigeyed scad and other species.

\section{Genus alectis Rafinesque}

Body rhomboid, deep, strongly compressed, more or less completely corered with minute embedded seales, sometimes apparently naked; scutes on the straight part of the lateral line enlarged, bony and spinous, as in $\mathrm{C}$ a $\mathrm{r}^{\mathrm{a}} \mathrm{n} \mathrm{x}$, but much less dereloped; mouth moderate, with bands of villiform teeth on jaws, vomer, palatines and tongue; first dorsal fin little developed, the spines short and rudimentary, mostly disappearing with age; soft dorsal and anal similar to each other; the first five or six 


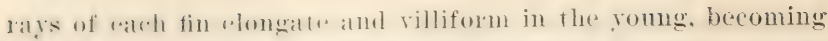
shorter with age: ventral fins plongate in roung, short in the adult: perterals filleate; no finleto; caudal peduncle narrow, the ratudil willely forlind: aill raliers moderate, stout. This gemus

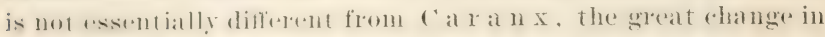
form arising from mo important modifation of the skeleton.

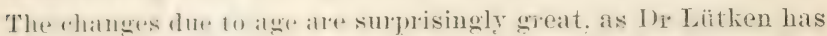
shown, the rhatrateres of the nominal geterera being relietly stages in 1 he growth of individuals. The young individuals atre almost orbirulat in form, with the tilaments excessirely long. 'lropical seas.

\section{Alectis ciliaris (Bloch)}

\section{Threalfish; Cobblerfish; Shoemakerfish.}

Zens ciliaris BLocr, Ichth. VI, 29, pl. 29, 1785, East Indies.

Zeus crinitis AKERLY, Amer. Jour. Sei. Arts, XI, 144, pl. 2, 1826, Shoreham.

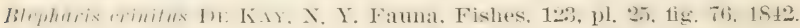
Blepharichthy/s crinitus Gild, Proc. Ac. Nat. Sci. Phila. 262, 1862.

Caranx sutor Güthen, Cat. Fish. Brit. Mus. II, 454, 1860.

Alectis crimitus Jomdx \& Gimbert, Bull. 16, U. S. Nat. Mus. 438, 1883.

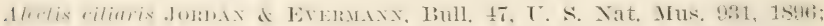

BeAx, Bull. Am. Mus. Nat. Hist. IX, 362, 1S97; 52d Ann. Rept. ㅊ. I.

State Mus. 103, 1900; Smitr, Bull. U. S. F. C. XVII, 98, 189 S.

lioly wal. murh hompressed, highest at the elevated liases of [he dursal and anal fins. The depth of the body is containet

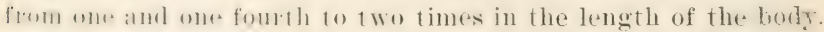

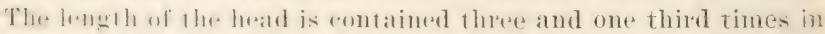

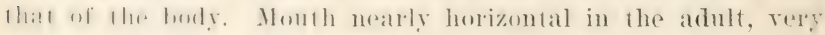

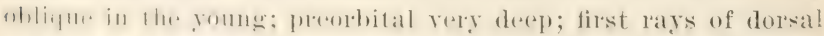

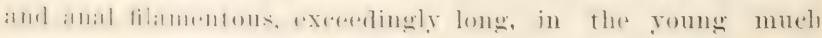

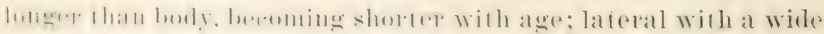

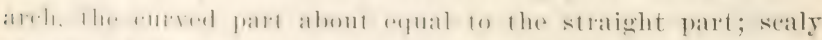

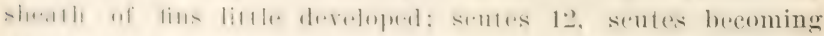

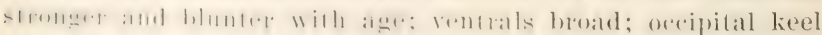

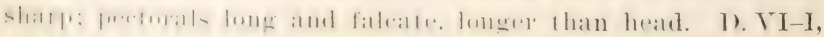

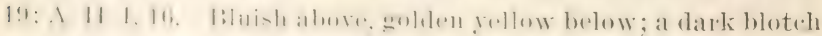

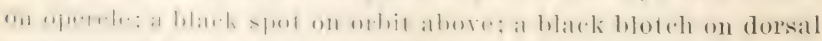
and anal in fromt.

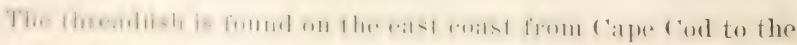
Carihhuan sar and on the Pacifie coast of tropical America. In 
Western Mexico it attains to the length of 3 feet and is used for food. It Woods Hole Mass, it is usually uncommon, but sometimes abundant, appearing about the middle of June and remaining till November.

De Kay described a specimen from Long Island sound, the only one observed by him. One was taken in a pound net at Islip Aug. 1s, 1898, by W. F. Clock. The threadfish enters Gravesend bay occasionally in summer. In captivity it will not endure a water temperature much below $60^{\circ}$.

\section{Genus vomer Cuv, \& Val.}

This genus is closely allied to $\mathrm{C}$ a $\mathrm{r}$ a $\mathrm{n} \mathrm{x}$, from which it differs only in its distortion of form, and in its weak teeth and very low fins. Body broad, orate, rerr strongly compressed, all the outlines sharply trenchant; head rery gibbous above the eyes, its anterior profile vertical; lateral line strongly arched, its posterior part with very weak shields; seales minute, rudimentary; soft dorsal and anal extremely low, not falcate. Joung much deeper in form than the adult, all the fins higher, resembling Selene. Warm seas.

\section{Vomer setipinnis (Mitchill)}

\section{Horsefish; Moonfish}

Zeus setupimis Mrtemle, Trans. Lit. \& Phil. Soe. N. Y. I, 3St, pl. I, fig. 9, 1815, New York.

Tomer bounii Crtien of Valenciennes, Hist. Nat. Poiss. IX, 189, pl, 256, 1833, New York \& West Indies; DE KAY, N. Y. Fauna, Fishes, 127, 1)l. 25, fig. 78, $18 \pm 2$.

Arm!rciosus setipinnis Güxtmer, Cat. Fish. Brit. Mus. II, 459, 1860.

Selene setipinnis Jordan \& Grunert. Bull. 16, U. s. Nat. Mus, 4t0, 1883.

Tomer setipinnis Gtld, Proe. Ae. Nat. Sci. Phila, 436, 1862; JondaN \& GILBerT, Bull. 47, U. S. Nat. MIs. 934, 1896, pl. CXLIV, fig. 392, 1900; Bexx, Bull. Am. Mus. Nat. Ilist. IX, 362, 1s:7; Sutri, Bull. U. S. F. C. XVII, 98, 1898.

Body oblong, rhombic, less elevated than in Selene romer; plofile anteriorly nearly vertieal, highest above eye, snout somewhat protruding, belly mostly arched in youngr; mouth oblique; maxillary reaching vertical from front of orbit. The depth of the body is contained twies in the length in an adult but only from one and one fourth to one and three fourths in the young. The length of the body is three and one fourth times the length 
uf the head. Scutes 20 ; rentral fins minute; dorsal aud anal rery low, specially in adult, the long rays disappearing rery

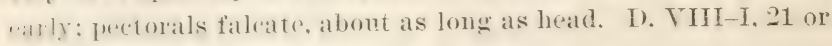
22 ; A. II-I, 19 or 20.

Culur above plumbeous or arexish; sides and lower parts lustrous silvery; membrane of second dorsal light yellow at base, the membrane with minute black points; pectorais greenish, tinged with dusky; young with a black bloteh, smaller than the eye, at the begimning of the straight part of the lateral line.

The horsefish inhabits the seas of tropical America, ranging from Maine to Brazil and from Lower California to Peru. In summer it is sometimes abundant as far north as Saco Me. and at IVouls IIole Mass., in Buzzards bay and Vineyard sommi. but sometimes it is rare in those waters. When present, it aprears in August and remains till September. The fish is also repurted in western Africa. Mitchill calls it the bristly dory. He records it from New York bay. De Kay states that it appears in New Jork waters in July and August, and that it is estemmed for food. In individual was brought from Graresend bas Or.t. 21, 1.tgt, and a young ('xample, known there as dollarfish, was received from the same locality Oct. 22, 1896.

The spreies reaches the length of 1 foot. It is esteemed an r.renllent article of food. It fiuds its way to New York in emensirlorahl. numbers rery gear but is rarely seen in other markets. Nothing is known of its breeding habits.

Thr. horsefish has sereral additional eommon names: sumfish. juruhado (f'uha), humt-nosed shiner, jug-nosed shiner, and hump'backed. butterfish.

\section{Genus seuexe Lacépède}

limly r.1.y resuly compressed and much elerated, the profile

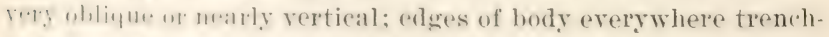

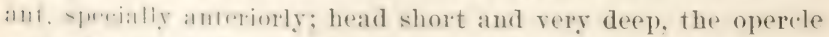
B.ry slome, and the preorbital extremely deep; an abrupt angle al 1 hr. andifital region: momth rather small; premaxillaries pro-

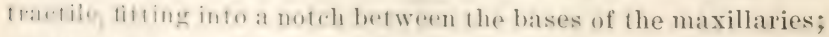
matillarios broml, ratrh with a supplemental bone; tongue nar- 
row, free; teeth minute, on jaws, tongue, romer, and palatines; gill rakers long and slender; spines of fins usually weak, more or less filamentous in the young; free anal spines immovable, sometimes obsolete in the adult; soft fins falcate, much elevated; no finlets; head naked; scales minute; lateral line wholly unarmed. Coloration silvery. Tropical seas. Notwithstanding its extraordinary form, this genus differs in no important regard from Caranx.

\section{Selene vomer (Linnaeus)}

\section{Lookdown; Moonfish}

Zeus vomer Linnaeus, Syst. Nat. ed. X, I, 266, 1758, America.

Argyreiosus romer IACÉpède, Hist. Nat. Poiss. IV, 566, 1803; DE IÁ, N. Y. Fauna, Fishes, 124, pl. 75, fig. 238, 1St2; Güxtmen, Cat. Fish. Brit. Mus. II, 458, 1860; Gill, Proc. Ac. Nat. Sci. Phila. 437, 1S62; BEAN, 19th Rep. Comm. Fish. N. Y. 256, 1890.

Argyriosus romer Goode \& BEAN, Bull. Essex Inst. XI, 16, 1879.

šelene argentea LACÉPÊDE, Hist. Nat. Poiss. 1V, 560, pl. 9, fig. 2, 1803, (adult). Zeus capillaris Mitchild, Trans. Lit. \& Phil. Soc. N. Y. I, 3S3, pl. II, fig. 2, 1815, (young), New York.

Zeus rostratus Mitcmil., Trans. Lit. \& Phil. Soe. N. Y. I, 3St, pl. II, fig. 1, 1815, (young), New York.

Zeus geometricus Mitchill, Am. Month. Mag. II, 245, Feb. 1S1S, (adult), New York.

Argyreiosus capillaris DE KAY, N. Y. Fauna, Fishes, 125, pl. 27, fig. S2, 1812, New York.

Setene romer Cuvier \& Valenciexnes, Hist. Nat. Poiss. IX, 177, 1833;

Brevoort, Ann; Lyc. Nat. Hist. N. Y. V, 68, pl. 4, 1853; JordAN \& Gilbert, Bull. 16, U. S. Nat. IIus. 439, 1883; Jordan \& Evermand, Bull. 47, U. S. Nat. Mus. 936, 1896, pl. CXLIV, fig. 393, (young), pl. CXLV, fig. $393 a$, adult, 1900; BeAx, Bull. Am. Mus. Nat. Hist. IX, 363, 1897, 52d Ann. Rept. N. Y. State Mus. 103, 1900; Siпtн, Bull. L. S. F. C. XVII, 98, 1898.

Selene gallus BEAN, Bull. U. S. F. C. VII, 139, $18 s 8$.

The depth of the body is contained one and one half times in the length; while the length of the hatd is contained three timas in the length of the body. Diameter of eye, length of operele, and distance from eye to profile about equal; eye twice in maxillary, two and one half in preorbital; mandibles very deepr, the dentary bones thin, approximate; one or two of the dorsal spines greatly elongate and filamentous in the roung, short in the adult; rentrals variable in length, usually as long as the eye in the adult, variously elongate in partly grown specimens; the 


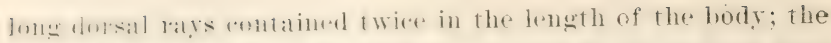

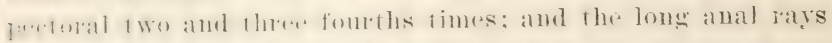

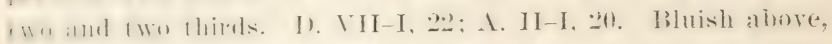
sirles amb lulnw silvery with golden reflections: anteriol relge of soft dorsal black; axil dusky.

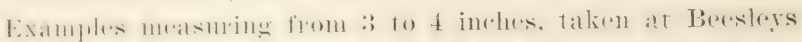

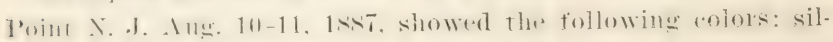

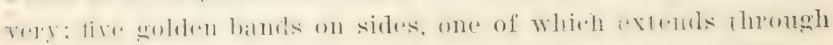

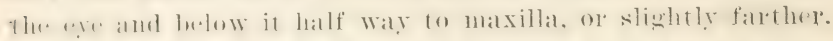

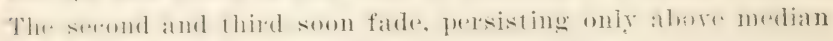
line and at their lower extremities.

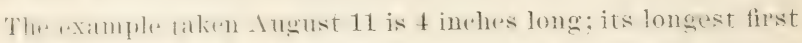

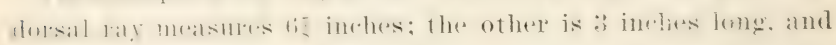
has a filamentous spine measuring 5 inches.

The lomklomen is fomme on hoth coasts of tropical America

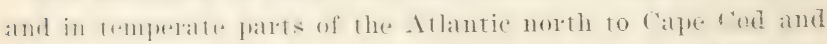
l

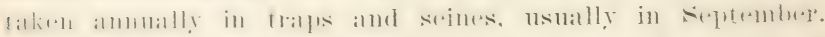

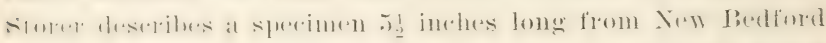
Mass. Mitr.hill mentions the tish muler two names. hatir-timmed

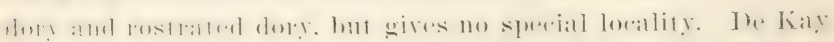

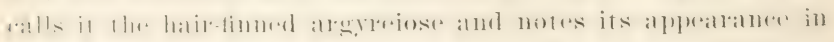
New York waters about the latter end of Angust and its cap-

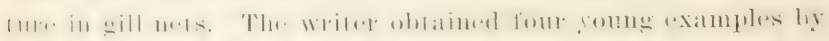

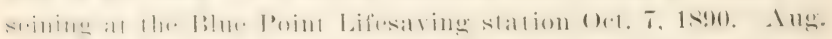

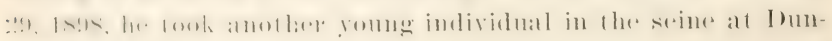
failis rereck, (ireat south bay.

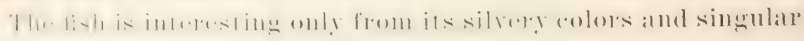
shape. which make it a great attraction for the aquarimm.

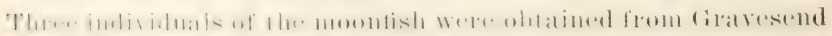

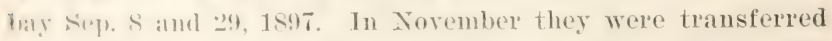
fo a talnk in which the water was at a temperature of $68^{\circ}$ to $70^{\circ}$ F. and they weresucessfully kept through the winter.

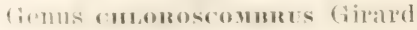

borly olilong ovatr, rlosely complessed, but not elevated; the alutomen furominemt anteriorly, its emre being much greater 
than the eurve of the back; oceiput and thoracie region trenchant; caudal peduncle very narrow, the fin widely forled scales small. smooth: lateral line arehed in front, marmed, or with a few small plates; head nearly naked; preorbital low; mouth rather small, oblique, lower jaw seareely projecting, upper jaw protratete: maxillary broad, emarginate behind, with a large supplemental bone; jaws, vomer and palatines with feeble teeth, mostly in single series; first dorsal of feeble spines, connected by membrane; second dorsal and anal long and low. similar, much longer than the short abdomen; no finlets.

\section{Chloroscombrus chrysurus (Linnaeus)}

Casabe; Bumper

Scomber rerysurus I.IXxiets, Syst. Nat. ed. XII. I, 494. 1766. Charleston. Seriola cosmopolite Cuvien \& Valenciennes, Hist. Nat. Poiss. IX, 219, pl. 259, 1833; DE KAY, N. Y. Fauna, Fishes, 129, pl. 74, fig. 237, 1812.

chloroscambrus caribuacus Ginard, Mex. Bound. Surr. Zoül. 21, pl. 9, fig. 6, 1859, Joseph Island, 'Texas.

Micropteryx chrysurus Günther, Cat. Fish. Brit. Mus. II, 460, 1860:

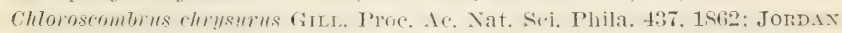
\& Gilbert, Bull. 16, U. S. Nat. Mus. 4t1, 1883; Jordan \& EvermaxN, Bull. 47 , U. S. Nat. Mus. 938, 1896, pl. CXIV, fig. 394, 1900.

The depth of the body is contained two and one third times in the length: length of head contained three and three fourths fimes in the length of the body; head rather deep than long; opereles very short; snout short: mouth rery oblique; maxillary reaching anterior margin of eye; ege very large, longer than snout, about thee in head; chord of eurred part of lateral line searcely longer than head, one and two thirds to one and three fourths times in length of straight part; lateral line wholly unarmed; candal peeduncle longer than deepe its diameter less than that of the ere: rentrals rery small, fitting into a groove in which the rent is situated; pectorals long. falcate, one third the length. D. VIII-I, 26; A. II-I, 26.

Color of upper parts pale greenish: sides of head and body silvery irideseent a nearly square blatek bloteh on caudal pedunrle abore; dark spots on operele and axil of pertoral; inside of mouth blark: first dorsal translurent with a yellow tinge anteriorly and with minute dusky points, second dorsal translueent 
al hase. numbrous blark points anteriorly, margin yellowish, [n-toral yeflowish, rentral white. preanal spines and comnecting membrame white, anal nanslucent at base, rest of tin rellowislis with a few dusky points.

The rasible is a small fish of wide distribution along our east coast, ranging from rapu cod to Brazil; it is common in the Gulf of Mrexiro, 1 he caribbean, and in cuba, but rathex rare from charleston northward. The only authority for its occurrence in Xin York waters till recently has been Curier and Talenriemes, who rlaimed to have a specimen from Nert Jork. De Kily did not reward it as a member of the fish fama. In 189:9, howerer. W. I. We Nyse secured sereral fine examples at firavesentl heilel., L. I., and one of these, $S$ inches long. is now in :he Y. S. Xational Museum, where it is numberea 49219.

The lish grows to the length of 10 inches. It has no value aty food, but is a beautiful species.

\section{Genus tracmotus Lacépède}

Bonly compressed, moderately elevated, the general outlime orate: randal peduncle short and rather slender: abdomen mot fromblant, shorter than the anal fin; head moderately com[messed. very blunt. the snout abrupty truncate; mouth dear?] hrrizental the maxillary reathing the middle of the eyo: premaxillaries fmolrarlile; maxillary without distinet supplementid bone: jaws. vomer and palatines with bands of rilliform teeth. which are deriduens with age; preoperele entire in the adult; gil ralives shorl; gill memhrames considerably united ; spinous dorsal represented hy sis rather low spines, which are commected hy mesubran. in the yomm hout are free in the adult. In old specimens the spinrs alpear small on aleount of encroatehments of th.. Hh-sh, and ultimatrely often disalfumatr. Second dorsal long,

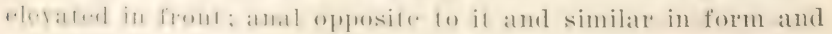

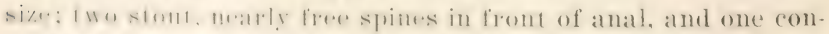

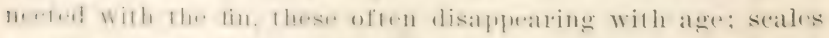
small. smmoth: lateral line matrmed, lithle areherl: no ratudal lienel. 
Trachinotus falcatus Jordax of Evemaxa, Bull. 47, U. S. Nat. MIus. 941, 1596. pl. CXIYI, fig. 396, 1900; BEAx, Bull. Am. MIus. Nat. Hist. IX, 303, 1897; Sмті1, Bull. U. S. F. C. ХVII, 98, 1898.

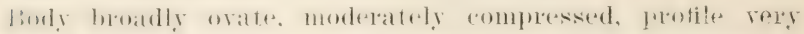

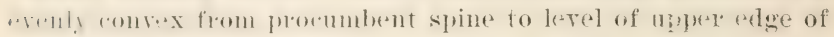
ere. Whele it deserenels almost veletirally. The depth of the body is entlatimed ont and there tifths times in the length: the length of the head is enntained three and three fomeths times in that of the houly. The veltiral part is about one and onte thirel times

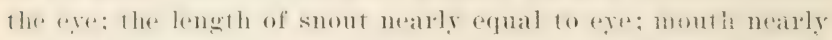
lorizontal: maxillaty reatching to vertical from mithle of eye, its lemgth two and two thibds in heatd: jaws withome letth in adule: dorsal splues short and thick, not romnerest hy memhane in alult: rentrals short, their tips scatrely leatring half

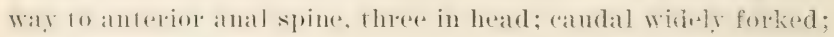
boles alout two and two thirds in length of body ablesal and

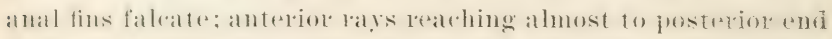
of fins: in alules, dorsal loles two and two thirels, anal hols fome and one half, in length of body. D. VI-I, 19; A. II-I, 1 .

roler. bluish above, silvery below; the tios all hluish with

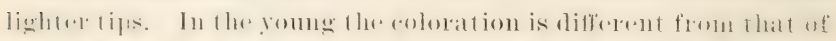

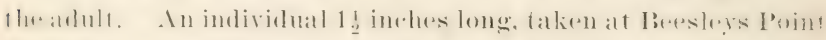

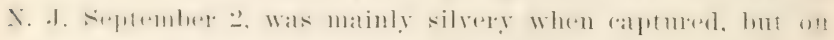

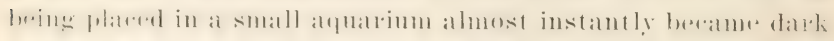

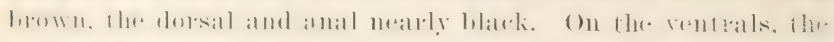

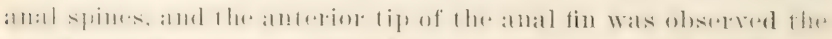

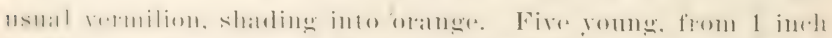

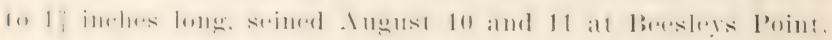

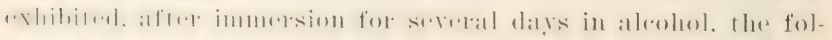

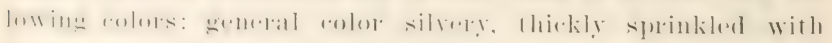

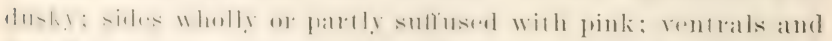

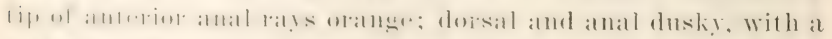

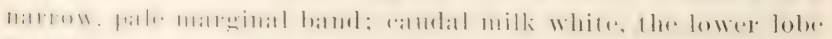
faintly linged with yellow; iris pink.

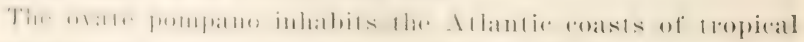
and tempreate Americal; it is common in the West Indies; on

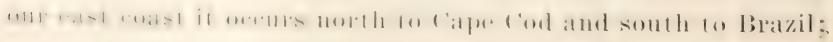


young individuals are rery common about Cape Cod in summer, but no adults are seen. The young, from $\frac{1}{2}$ to 1 inch long, appear in July, according to Dr IHugh M. Smith, and by september, when they disappear, they are two inches long. 1:3 young, areraging a little more than 2 inches in length, were obtained at Oak Island beach September 30.

The young of the round pompano ale caught occasionally in summer in Gravesend bay. Early in September 1897 a small one was placed in a tank, where it lired and fed regularly till Norember. The low temperature of the water then killed it.

Mitchill gires a figure of the fish in the Transactions of the Literary and Philosophical Society of New York under the name spinous dory, but no description. De Kay calls it the spinous trachinote, and describes a specimen 3 inches long from the harbor of New York, taken in september 1817. He mentions it as at casual visitor from the south.

Aceolding to 11. Goode the species is known in the south as the shore pompano and in the Bermudas as the alewife. About the Bermudas this pompano is sometimes rery abundant as, in 1875, a school containing 600 or 700 was seined on the south shore of the islands. The fish is highly esteemed there for table use.

The ovate pompano grows to the length of 15 inches and is generally prized for food.

\section{Trachinotus argenteus Cur. \& Tal.}

\section{Silvery Pompano}

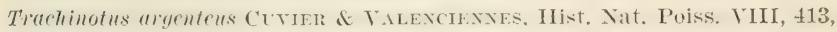
1831. New York and Rio Janeiro; DE KAr, N. Y. Fauna, Fishes, 116, 1842; BeAN, 19th Rep. Comm. Fish. N. Y. 255, pl. X, fig. 13, 1890; Jordix of Evermax, Bull. 47, U. S. Nat. Mus. 94t, 1896; Surtir, Bull. U. S. F. C. XVII, 98, 1898.

Trachinotus cupreus Cuvier of Valexciexyes, Hist. Nat. Poiss. VIII, 414, 1831, Martinique.

Body oblong, compressed, deep, its greatest depth one half of total length without caudal, its thickness one fourth the depth and nearly one half the length of head; least depth of caudal peduncle one sixth of greatest depth; head short, two serenths of total without caudal; eye small, circular, equal to snout, one 
fmllth as long as hratl: interorlital space convex, its width two

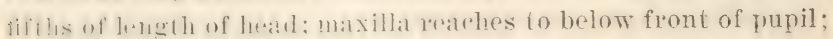

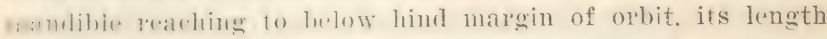

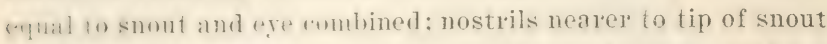
fhatn wo ere, the antrion in a rely short tube; tecth in villiform batuds in hoth jitws, hin mome developed in the lower than in the uplere gill rakers short and stout, the Iongest about one half as lom as eyu. The origin of spinous dorsal is at litte helind wigin wf rentral: the hase of the fin equals posturbital length of

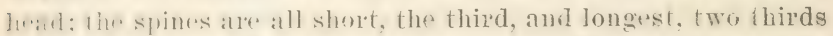
as lon" at the eye. The antecedent spine of the soft dorsal is Iwo thimls as fome as the eye; the base of the fin equals three

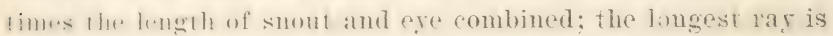
thre+ limms as lomg als the last lay and twe thinds as long as the

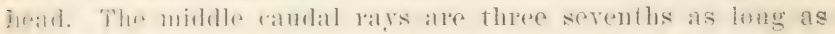

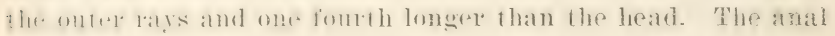
origin is nudhe the sixth ray of the soft dorsal: the fon is prearded hy I wo shor: isolated spines and a third closely connectid will the tirst lay : the seromel of the anteredent spiues is two thirels as long as the "ye; the longest ray is 1 wo thirds ats lone as the head, and the last ray is ahout as long as the eve. The

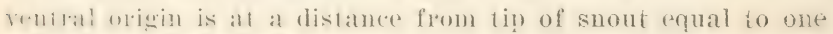

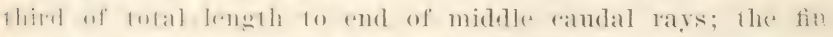

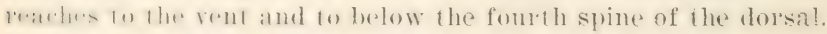

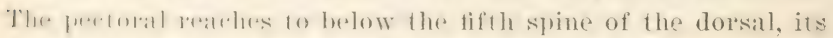
tenelh +ffual to length of leatl without the suout. 1). Y, I. 2t: 1. I1. I. …: I. 1. .;: I'. I, 17. C'olor silvery, with tips of anterior

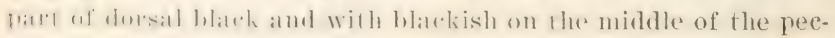
toral.

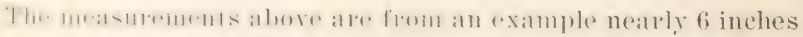

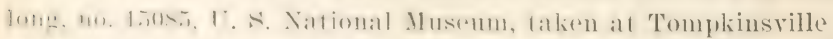

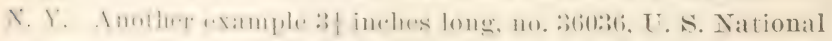

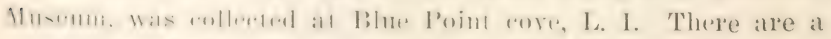

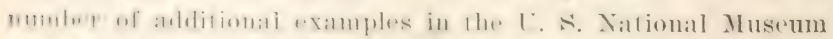

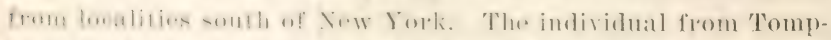

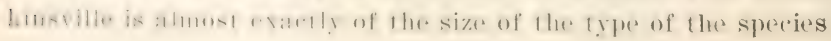




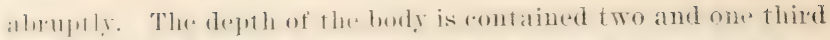
limes in its length: lhe lenghth of the lexat is contained four times in that of the hody. Horsal and anal falcate. their holes

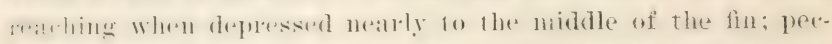
toral leathing to oppusite the rent. (iill rakess short: slender in lle fonng. heroming thick in the adult. Length 1 s inches. D. VI-I, 25; 1. II-I, 23.

Iniform hluish abore, sides silvery. golden in the atult. without bands, fins plain silvery or dusky.

This tish has 110 other name on onl east coast exerpt the somllelu valliation of pompermose. In cireat south bis the

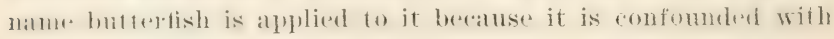
the Poronotus triacanthus, to which the name

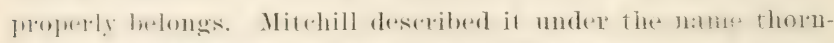

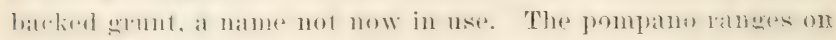

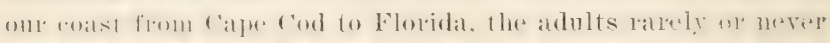

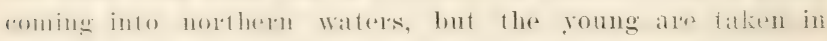
valdible mombers evely leatl. At Woods Hole they sometimes

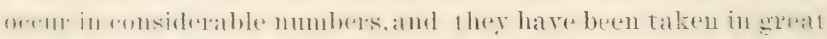

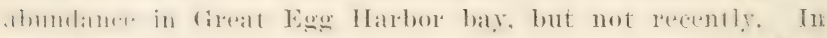

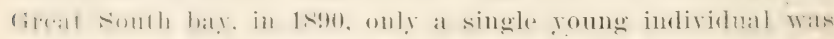

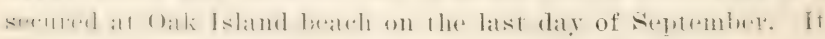

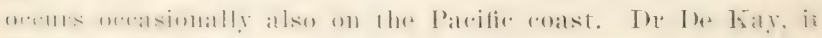

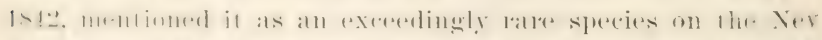

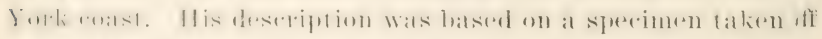

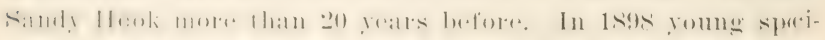

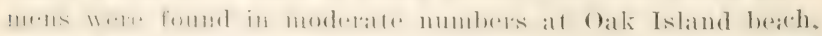
Great somth bay, september 1t, and on the east side of rire Istand hearh september 16. The roung are summer and fall

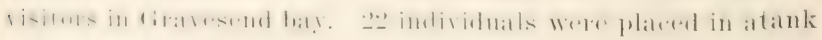
in Imgnst 1s97, and grew rapidly till the temperatume f the

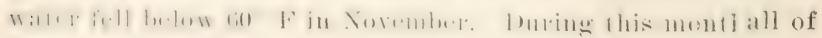
thim direl.

'l'he spreies reaches the leugth of 20 inches. It is or of the finnst of onl food fishes. 


\section{Family pomatomidae}

\section{Bluefishes}

\section{Genus pomstoms Lacépède}

Body oblong, romperssed, covered with rather small scales, which are walky etenoid; randal peduncle rathere stont: head large, compressed; mouth larege, oblique; premaxillaries protractile; maxillary not slipping under the preorbital, provided with a large supplemental bone, lower jaw projecting; bands of villiform teeth on vomer and palatines, those on the vomer forming a triangular patch; jaws each with a single series of very strong, compressed, mequal teeth, widely set, upper jaw with an inner series of small depressed teeth; villiform teeth on the base of the tongue; oceipital kees strong; free edge of preoperele produced and serated; gill membranes free from the isthmus, not united; branrhiostegals seren; gills four, a slit behind the fourth; psendobrauchiate latger gill rakers slendere, rather fer: operele ending in at flat point. cheek and opereles scaly; lateral line present, unarmedi dorsal fins two. the anterior of about right weak, low spines romnected by membrane and depressible in a groove; sexomd doisal long, similar to the elongate anal, both fins being densely sealy; fin rays slender; two rery small, free anal spines, sometimes hidden in the skin; rentrals thoracie, I, 5; peduncle stout; pectorals rather short; caudal fin forked, the lobes broad; air bladder simple, with thin walls; prloric caeca rery numerous; rertebrat $10+14=24$ as ustal in carangidae. I single speceses, foumd in nearly all warm seas.

\section{Pomatomus saltatrix (Linnaeus)}

\section{Bluefish: Snap Wackerel; Snapper}

Perea saltatix Linnaeus, Syst. Nat. ed. X, I, 293, 1758, Carolina.

Gasterosteus sultatrix Linnaeus, op. eit. ed. XII, 491, 1766.

Scomber plumbeus Miтcnild, Trans. Lit. \& Phil. Soc. N. Y. I, 424, pl. IV, fig. $1,1815$.

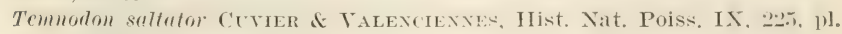
260, 1833; DE Ir Y, N. Y. Fauna, Fishes, 130, pl. 26, fig. 81, 1842; HoLBRooK, Ichth. S. C. 62, pl. 9, fig. 2, 1856; Guntmer, Cat. Fish. Brit.

Mus. II, 479, 1860; Storer, Hist. Fislı. Mass. 81, pl. XV, fig. 1, 1867.

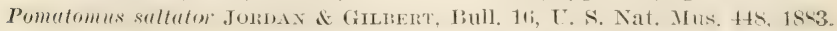




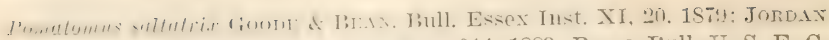
\& Gilbert, Bull. 16, U. S. Nat. Mus. 914, 18s3; BeAN, Bull. U. S. F. C. TII, 145, 1SSs; 19th Rep. Comm. Fish. N. Y. 269, pl. XX, fig. 24. 1590; Bull. Am. Mus. Nat. Hist. IX, 363, 1S97; 52d Ann. Rept. N. Y. State IIus. 10t, 1900; Smitr, Bull. U. S. F. C. XVII, 9S, 189S; MEArNs, Bull. Am. Mus. Nat, Hist, X, 319, 1895; Jordax \& Everarixa, Bull. 47 U. S. Nat. Mus. 946, 1S96, pl. CXLVIII, fig. 400, 1900; EugeNe Smitr, Proc. Linn. Soc. N. Y. 1897, 32, 1898.

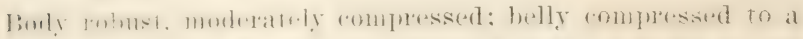

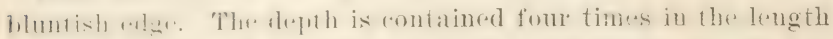

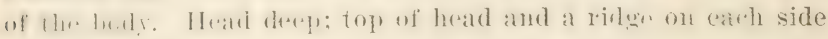

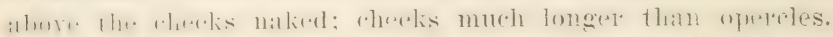

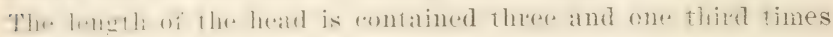
in the leneth of the houly. Peretorals plared rather how. their

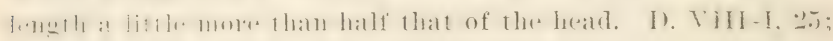
A. II-I. 26; Lat. 1. 95. Bluish or greenish, silvery below, a black blotch at the base of the pectoral.

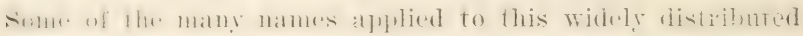

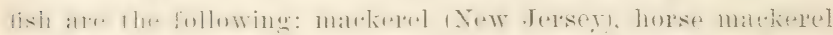

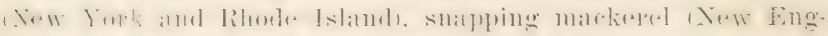

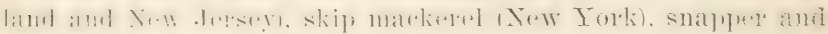

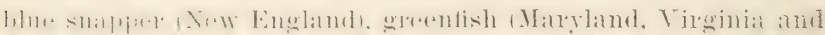

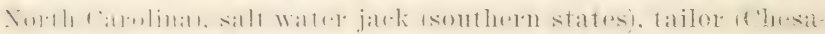

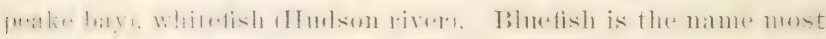
extensirely used on the coast and in the Gulf of Mexico.

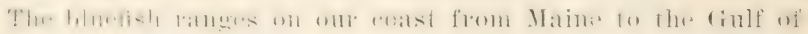

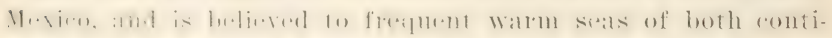

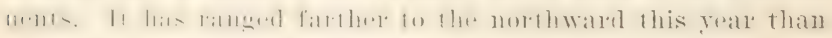
for many years before. We have heard of its eapture in the vicinity of Momnt lresert Me. On our coast and elsewhere its

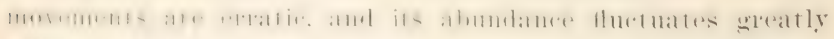

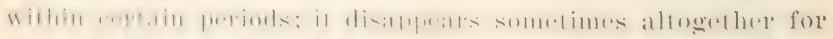
a wrm of years. The young: muler about 1 inch in length,

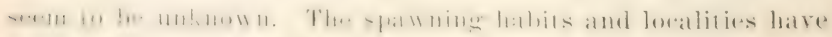
not bern rerorded. The smallest known examples were obiamerl at the surfate oflishore hy the U. S. Fish Commission. 'The writre hats seined individuals a little mole than an inch

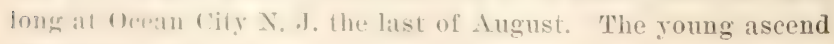
rivers into firesh water. 
This is one of the most destructive of all fishes. It feeds ravenously, and, when gorged with food, continues to destroy its rictims for the sake of gratifying its killing propensity. It follows the great schools of alewires, weakfish, mullets and other valuable food fishes along our coast in summer, and the young may be discovered in shallow bays and sounds pursuing the silversides, young herring, anchovies and other fishes smaller than themselves. According to De Kay bluefish were unknown on the New York coast till about 1810, when a few appeared. In 1815 Dr Mitchill wrote: "Young ones are taken plentifully with the hook at our wharves by the bors in August." The largest mentioned by Mitchill was 13 inches long, 3 inches deep and weighed about 14 ounces. The name bluefish was in use at the time of Mitchill's report.

De Kay noticed the gradual disappearance of the weakfish with the increasing abundance of bluefish.

The best known methods of taking bluefish are by trolling at the surface with a squid of metal or hone and by hearing and hauling in the surf near the mouths of streams into which alewires are rumniug. Artificial minuows are also used with a light rod, when young bluefish are seen feeding near the surface. The most recent method in use by anglers is that of chumming in the manner usually employed in striped bass fishing. This method, which inrolves the use of lod and reel, was in use near the inlet at Fire Island early in Ortober 1890. During the summer, in this bay, it was not an uncommon thing for anglers to catch 150 or 200 small bluefish with hook and line in a single day. The species is to be found in all parts of the bay risited by us. It was taken at the following localities: Blue Point cove, Oak Island and Fire Island. Large numbers of bluefish were caught late in September by means of gill nets set in the ocean near Blue Point Lifesaving station. I fisherman eaught 450 at one time and 250 at another, the dates being serp. 23 and 24, 1890. In August of that year bluefish drove immense schools of round herring (Etrumeus teres) on the ocean beach, near the Lifesaving station. September 24 , while walking along the beach of East Island, not far from the Blue Point station, in 
it distaner of half a mile. I sat 51 round herring lying on the

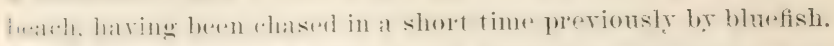

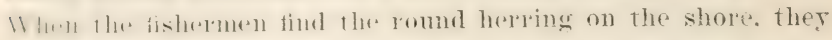

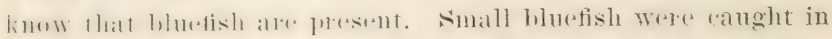

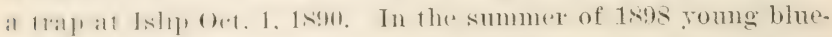
fish were almutant in all the waters risited in Peronic bay and Great South bay and were taken as late as October 16.

Inting the watm seatson they often run up the rivers, the romeng. ralled snappers. frequently inte nearly fresh waters. (After Eugene Smith ${ }^{1}$ )

The huedish is so active in its movements that it is difficult to

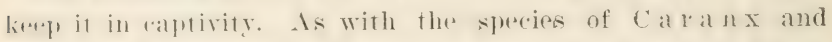

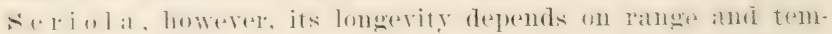

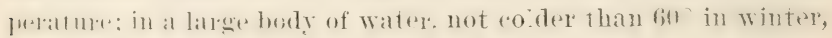
it can be maintained easily.

\section{Family rachYCENTRIDAE Sergeant Fishes \\ Genus ricmoextrox Kaup}

lsuly elongate, fusiform, subeylindric, covered with rery small, smmoll, allurent stales: lateral line nearly parallel with thes

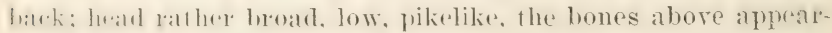
ing thrush the thin skin: month rather wide, nearly horizontal, 1h. maxillaty about rearhing frout of ere: both jaws, vomer. palattimes and tomgue with hands of shont, shatrp teeth, lower jaw

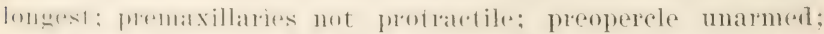

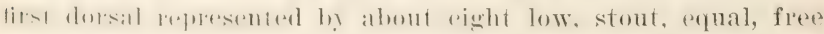

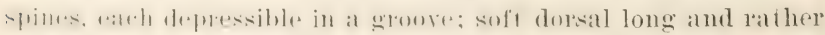

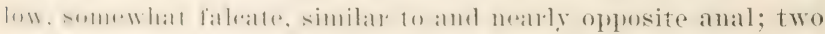

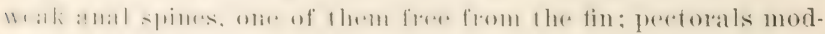
mate placed low; ventrals thoracic, I, 5; candal fin strong,

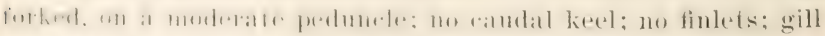

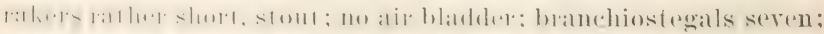

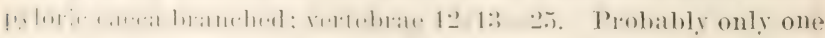
sprecies: a barge, strong, vorateious shore fish, found in all warm simas. Its relations are with the scombroid fishes, though not 
siruged and ate erery tish in the ear. In A. K. Fisher of Washmeton has found the romge of the crabeater in the Fudson near sing sing. Though we have no specimens of the erabeater from (iveal sumb bay, there is scarcely a doubt of its accurpence in that body of water.

A young example, :3 inches long, was caught at Somers l'oint X. .T. near the club house, Aug. 2, 1857, by Capt. Richard Chamlerlain. Ground color nearly black; a white stripe, about as wide as pupil, from upper augle of gill opening to caudal; another one. but narower, begins at lower extremity of pectoral base, eurves very slightly upward, fading out near the tail: upper atudal lobe with a narrow whitish margin along its upper surface, relieved by a trace of orange red at its base; lotrer caudal lobe with a narow orange red margin; pectorals, ventrals. and atudal hlack; back fades to a dark green; belly gratisi white; iris golden bronze. This species has not previously been recorded from fireat Egg IIarbor bay, and the young seems not to have been described.

Innther example 4 inches long. was seined in one of the thorcmohfires in thr bay August 2:3. This has the same markings as 1hr. first. The caudal when fully expanded, is rounded, the enc trmmalle; there is no murerination as in the adult. A figume of Hh. !nung is published in the bulletin of the U. S. Fish rommission, 18s8, r. T, pl. 2, fig. 13.

Family Coryphaenidae

\section{Dolphins}

\section{Genus conprinasa Linnaeus}

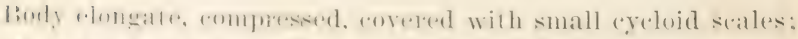

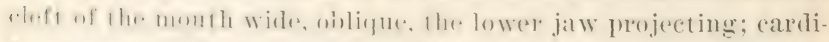

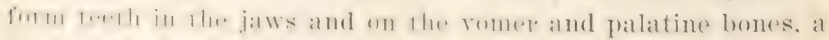

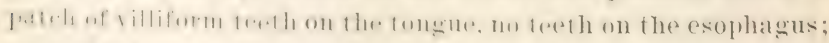

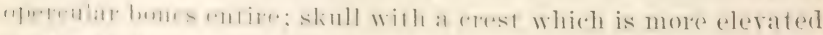
in the oulule than in the young: a single. many-1ayed dorsal fin.

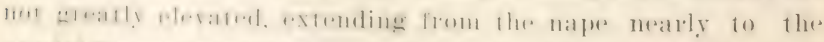

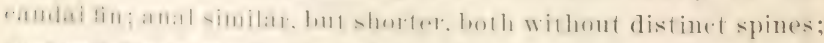

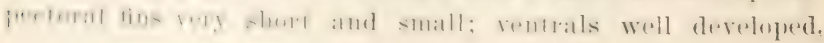


fin malrginate anteriorly. The rentral origin is dectly under the fuetoral batse and under the 13 th spine of the dorsal, its frraglh whe sixth of totill length without eardal. The pectoril migin is below the 1 ish spine of the dowal; the fin extemes to below the wat spine, its length equal to length of hear withont smout. 1). 51; (5.1: 1. 25.30): V. I. 5; P. I, 19. Seales abolit 175; gill ralicl's 10, all below angle, the longest one half as long as the eye.

folens in life hrillant, dhanging suddenty at death: greenist alure, white or golden below, with bright blue spots. the latgest (1n) the hack and head, forming bands on the suent; dorsal purplish hlue, with pale longitudinal lines; other fins tinged with how: antal rellow; in spirits. silrexy with blakish spots, smaller than the puril, on the sides below the lateral line.

The dolphin inhabits all warm seats; it is eommon in the diulf

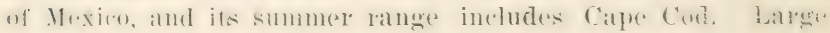

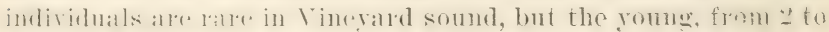
12 inclus long, are observed nearly every year in thating sulf weed, usually in July and August.

Withill mentions the species without referring to a particular spreimen: lut the kay states that an individual t2 inchess long:

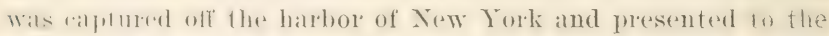

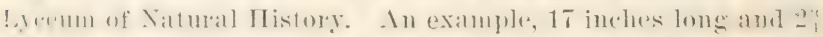

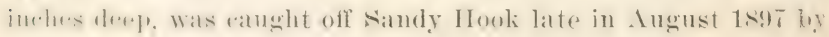
a fisherman while trolling for bluefish.

The dolphin attains to the length of o foet. It is an exerellent food fish.

\section{Coryphaena equisetis Linnaeus}

\section{Small Dotphin}

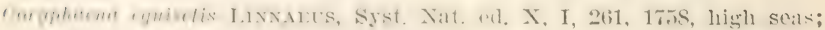

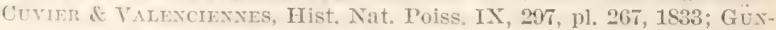
THan, Cat. Lish. Brit. Mus. II, 107, 1860; Jordax \& Gilbert, Bull. 16, 17. S. Nat. Mus. 914, 18S3; JonnAN \& Evermaxx, Bull. 47, U. S. Nat. Mus, :50, 159\%.

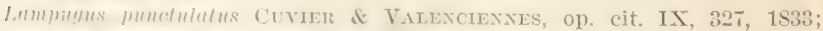

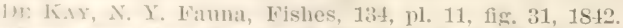

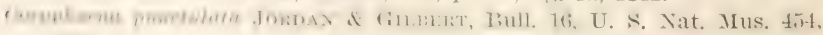
$1 \times 4 ;$ 


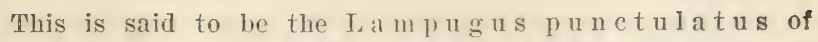
Curier and Yalenciennes, ${ }^{1}$ to which is aseribed the following characters. Hight of body contained nearly fire times in its length; head five and one fourth times; depth of head five serenths of its length; profile obliquely descending; pectorals one tenth of total length; rentrals one eighth; caudal lobes one fifth; $100 \mathrm{or}^{2}$ 12 posterior rays of dersal and anal dilated at their extremities and projecting beyond the connecting membrane. Color silvery, blackish on the back, with a few small black dots on the body. D. 51 ; A. 25; V. I, 5; P. 19.

The specimen described is 13 inches long. It was talken in the Atlantic at the equator.

De Kay has described a dolphin meisuring 2 feet which was taken on a hook at the light-ship oft the harbor of New York and which he supposed to be identical with the species just mentioned. The character's of the fish are giren as follows. Length of head rather less than one eighth of lotal length; hight of body one eighth and of caudal peduncle at its lowest part one twentieth of total; eye latrge, its length contained four and four serenths times in length of head and more than one diameter distant from tip of snout; dorsal fin beginning just behind the orbit, its last 10 or 12 iays somewhat elevated and projecting beyond the connecting memhrane; pectoral origin under ninth dorsal spine; the fin one twelfth of total length including caudal; rentral length contained nine and three fifths times in total; anal origin nearly midway between posterior margin of orbit and base of caudal. Length $2 t$ inches; head $3 \frac{1}{5}$ inches; hight 3 inches. I). 5.; 1.25 ; I. I. 5; I'. 20.

color sea green above the lateral line; silrery on the sides, with metallic reflections on the opereles; iris rellowish; dark reddisb brown stripes across the head; a series of distant rounded spots along the base of the dorsal fin: a fer scattering ones on the back part of the head, aml confused series of similar spots on the sides below the latrral line; dorsal, pectorals and rentrals brown; anal and candal fins light colored. 


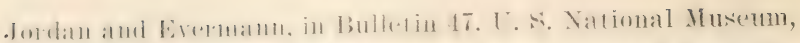

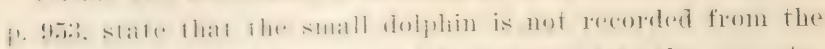

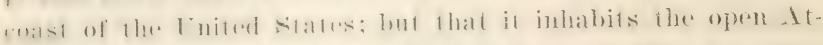

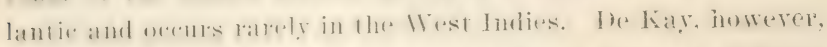

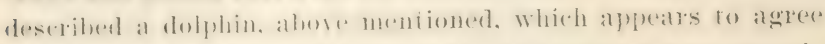

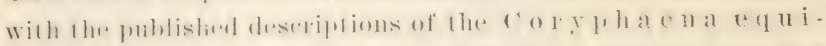

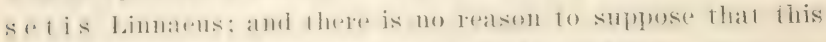

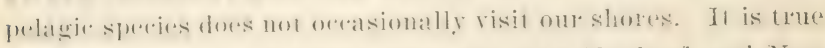
that all the youmg tolphins forme the New England and New

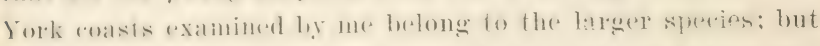

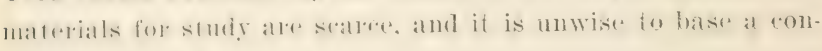
clusion on insufficient investigation.

\section{Family CENTTROLOPHIDAE}

\section{Rudderfishes}

\section{Genus parmurichers Bleeker}

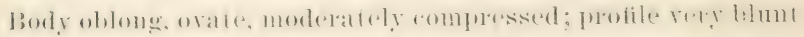

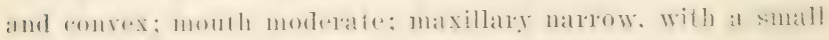

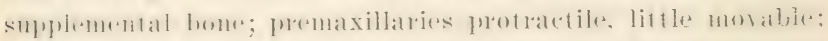

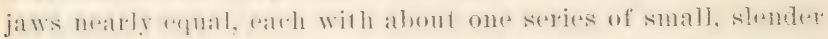

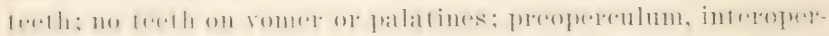

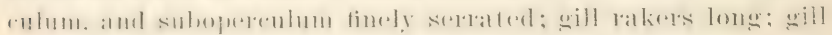

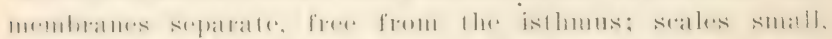

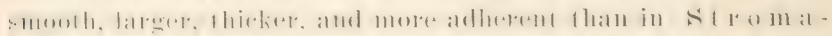

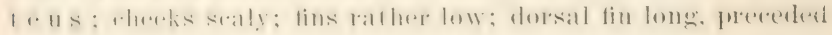

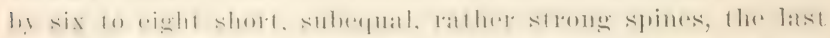

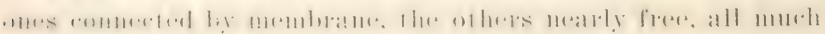

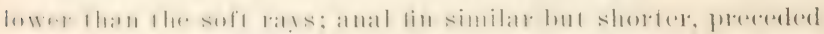

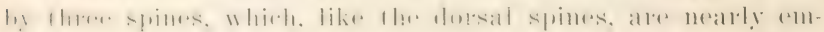

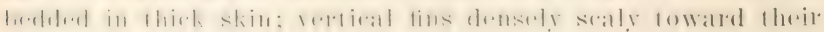

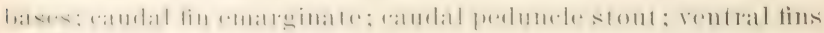

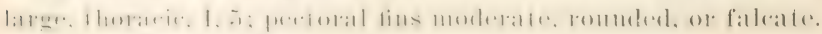

\section{2..7 Palinurichthys perciformis (Mitehill)}

\section{Rulderfish: Bluek Pilot}

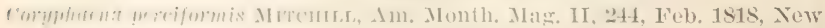
York Harlor.

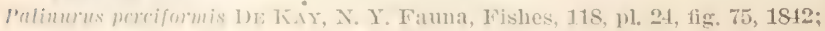

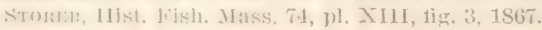


Pammetas pereiformis Göntner, Cat. Fish. Brit. Mus. II, 4S5, 1860. Lirus pereiformix Jorm.x d Gilbert, Bull. 16. L. S. Nat. Mus. 452, 1583.

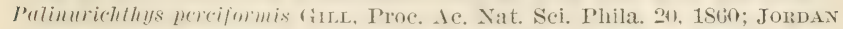
\& Evermann, Bull. 47, U. S. Nat. Mus. 964, 1896; Goode \& Bean, Bull. Essex Inst. XI, 16, 1879; BEAN, Bull. Am. Mus. Nat. Hist. IX, :363, 1897; SмmтH, Bull. U. S. F. C. XVII, 99, 1895; BEAN, 52d Ann. Rept. N. Y. State Mus. 10t, 1900.

Body orate. complessed, its depth two fifths of its length without the candill; head short, blunt, its profile conrex, its length two sevenths of the total without aaudal; mouth moderate; maxillary narrow, ratrhing to ofposite front of pupil; a small supplemental bone; "ye with adipose eyelid; eye nearly equal to snout, two niuths as long as the head; top of head scale-

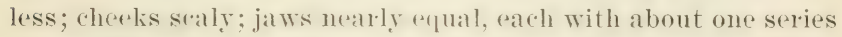
of small, slender texth, no texth on voner or palatines; gill rakers long; pretorals noarly as long as the head. D. VIII, 20; 1. III. 16. Iateral lins 7\%. Blarkish green, everywhe dark. the belly almost similar and not silvery, sides often mottled with linear blotches. Length 1 foot.

The rudderfish is fommd on the Atlantir roast of Nortin America from Maine to cape Hattrats; usually off shore under drifting logs, boxes and other objects, but occasionally entering bays; one specimen was taken off cornwall, having drifted across the Atlantic. The rudrerfish is rate in Gravesend bay. One or two will usmally ajplear there during the smmmer, but some years none are serm. The fish is common 2013 miles off shore, and its capture with a dip net is not dificult. Numerous young and half grown ex:mples were so taken off Southampton L. I. Aug. 3, 1S!Is, and a fine adult was captured by Capt. George Sarrington in Clam Pond core, Great south bay, Oct. 11, 1898.

Aug. 4, 1901, a sehool of rudderfish numbering about 50 was seeu at the dock at Watex Island. Great Fouth bay, and one of them was obtained for the state museum.

Family STRONATEIDAE Harvestfishes

Genus rноmвus Lacépède

Body ovate or suborbieular, stromgly compressed, tapering into a slender candal peduncle, which is not hereder or shirleled; 
head short, compresset, the profile obtuse; mouth small, terminal, the jaws suleeţal: premaxillaries not protractile; jans abll with a single serires of weale teeth; scales rery small, cyelohd, silvery, lomsty inserted. extending on the rertical fins; opereular homes entim, gill m+1nhranes separate, free from the isthmus: gill rakers moderate; lateral line continuous, concuxrent with the batek: dersal tin long. more or less elevated in front. preceded loy a lew indistinet spines - usually one or more proembent spimes in fromt of dorsal and anal, earh of these with a free proint loth anteriorly and posterior!y: anal fon similar to dorsal, or shorter, usually with there small spincs: ventral tins wanting; a single small. sharp spine, attateded to the

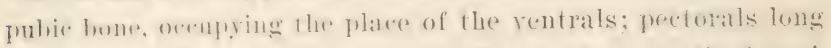
and narrew; andulal widel! forked. Species fer, mostly Aneri-

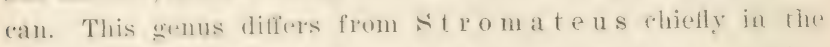
frominene of the pelvic bone, which projects as a latminal beyond the skin. (After Jordan and Erermann)

\section{Subgenus rномив}

\section{Rhombus paru (Linnaeus)}

\section{Harvestfish; Pappyfish}

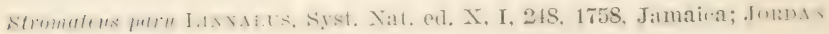
\& Gilmert, Bull. 16, U. S. Nat. Mus. 914, 1893.

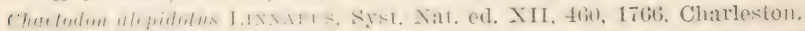

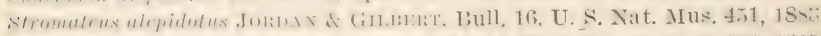

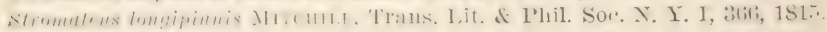

New York Bay.

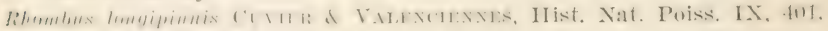
pl. 274, 1S33; De Kìy, N. X. Fauna, Fishes, 136, pl. 75, fig. 239, 1812. Stromaleus furdenii Güxtmen, Cat. Fish. Brit. Mus. II, 399, 1860. Rhomlus paru Jomdax of Everamax, Bull. 47, U. S. Nat. Mus. 965, 1896, pl. CL, 1ig. 404, 1900; BEAx, Bull. Am. MLus. Nat. Hist. IX, 361, 1897; Sмmтн, Bull. U. S. I'. C. XVII, 99, 1998.

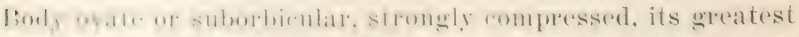

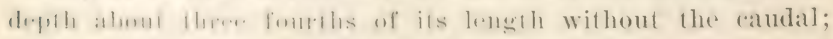

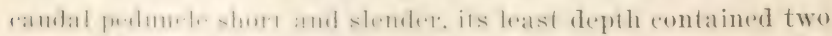

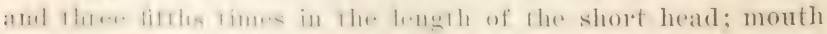

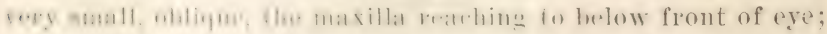

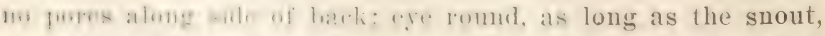
and about ane fomth as loug as the head; jurofile of head very 
obtuse; dorsal origin a little behind pectoral origin, base of dorsal almost equal to greatest depth of body, front of fin elerated, the longest ray as long as the pectoral, its length contained two and three fifths times in total length without caudal; aual base nearly as long as dorsal base, the longest anal ray nuch longer than the pectoral, the last dorsal and anal rays rery short, scarcely two thirds as long as the eye, caudal deeply forked, its lobes equal, the longest rays as long as the pectoral. Scales small, thin and deciduous. I). IT to $T, 45 ;$. . II, 43. Seales about 90 ; rertebrae $\mathbf{1 5}+\mathbf{1 5}$.

Color greenish above. golden yellow below. Mitchill gives the following description: "silvery, with tints of blue, green and iridesent; dusky on the head, and with inky patches on the belly towards the tail, which in certain lights appear beautifully red and purple; bark bluish, with oceasional clouds."

The harrestfish inhahits thr. West Indies and is found on our Atlantic coast from cape Cod southward, ranging to Brazil. The young are frequently seen swimming beneath the Portuguese men-of-war.

De Kay had sereral specimens of the species, but found it less common than the short-finned harrestfish, $\mathrm{R}$. t r i a c a $\mathrm{n} t \mathrm{hus}$. At Charleston the fish is called rudderfish.

The species reaches a length of 8 inches. It is a valuable food fish. It is a summer visitor in Graresend bay and is some. times rare, but was formerly abundant there. It is not adapted to a captive life. It Woods Hole Mass. Dr Smith reports it as usually rare, but occasionally common. Is a rule only three or four are taken in a season, but one real 300 or 400 were obtained. It occurs mostly in Jume and July, associated with the butterfish, R. triacanthus.

\section{Subgenus porovotus Gill}

\section{Rhombus triacanthus (Peck)}

\section{Butterfish; Harvestfish}

Stromateus triacanthus Peck, Mem. Amer. Acad. II, part 2, 48, pl. 2, fig. 2. 1500 , Piscataqua River, N. H.; Jordas \& Gilbert, Bull. 16, U. S. Nat. Mus. 451, 1883; Günther, Cat. Fish. Brit. Mus. II, 398, 1860. 
Strumatens ermptosus Irtcmile, Trans. Lit. \& Phil. Soe. N. Y. I, 365, pl. I, figs. З3. 1S15. New York Bay.

Rhombus triuctulhus I)E K.1Y, X. Y. Fauma, Fishes, 137, 11.'26, fig. S0, 1842;

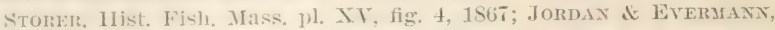
Full. 47, L. S. Xat. Mrus. 967,1896 , pl. CL, fig. 405,$1900 ;$ BEAx, Bull. Am. Mus. Nat. Hist, IX, 803,1897 ; Smrur, Bull. U. S. F. C. XVII, 99, 1S9S: BE..х, 521 Ann. Tiept. N. Y. State Mus. 104, 1900.

Ponomotus trincanthus Goode \& BeAr, Bull. Essex Inst. XI, 16, 1879; BEAN, Bull. U. S. F. C. YII, 140, 18ss; 19th Rep. Comm. Fish. N. Y. 257, 1). Xr, tig. 1t, 1590 .

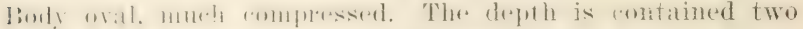

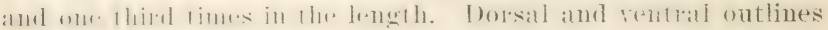

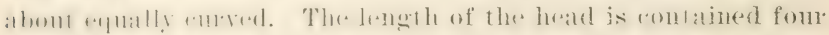

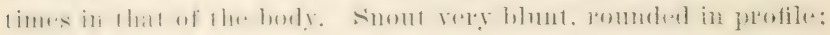

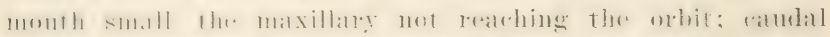

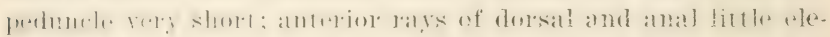

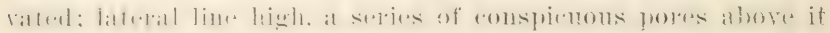

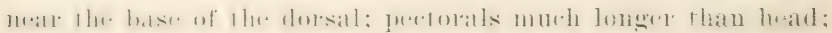

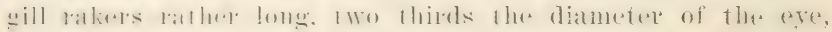

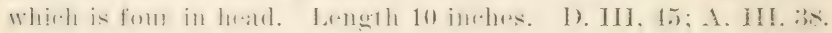

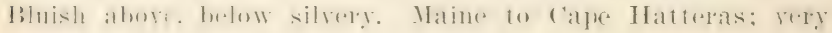
abundant.

This is hanwh as ihe dollatefish, hatrestfish and lafareter.

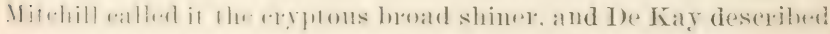

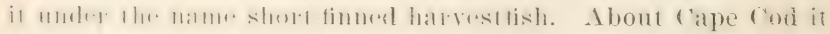

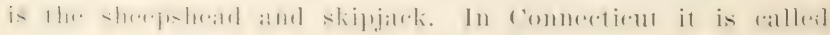
pumplin seed and at Norfolk starfish.

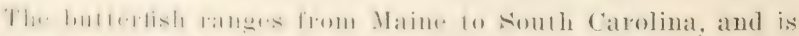

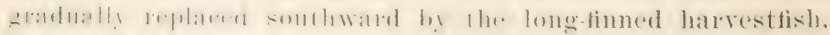
li hom bus par 1 . It is a smmmer risitor, associated with

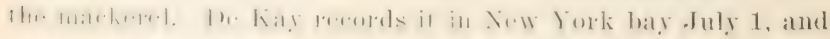

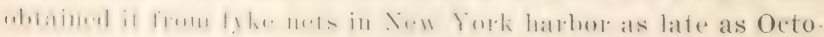

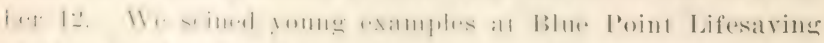

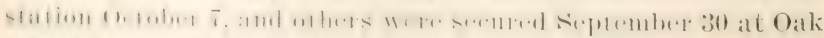

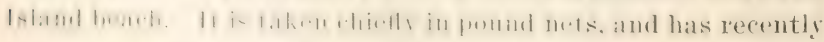
horome a highly prizod marliet fish. A few Jeal's ago it was

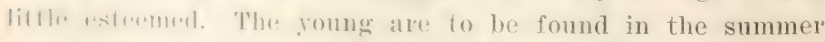
momblis swimmine at the surface in sheltered bays and fre- 
In the rappie the reputh of the hody is two fifths of the total longhl, wn induding llw tail. The length of the hearl is one thitd of the fotal. The month is ohliegue and larger than in the

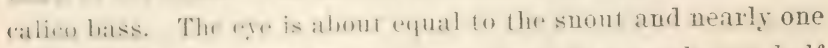

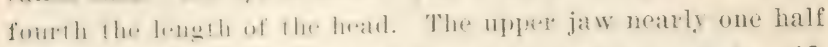
the lemglh of heal: the maxillat leatehes slightly beyond the middle. of the eye. The longes ratys of the dorsal and anal are about one half as long as lhe heate. The fretoral is longer

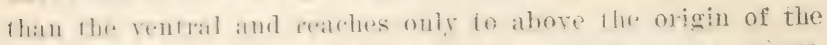
anal. The rentral when baid hark reitehes to the rent. D. TI,

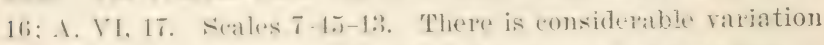
in the number of spimes and rays in the dorsal and anal tens.

folor releat silvery olive, the silles mottled with dark greenish

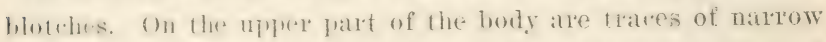
vertical hats. The dorsal and ramdal are mottled, but the anal is usually uniform pale.

Imong the many names which have been applied to the erap-

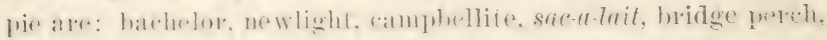

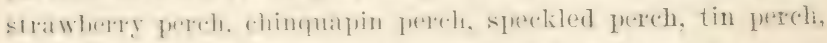

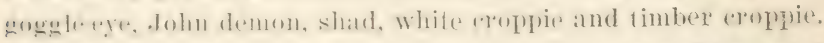

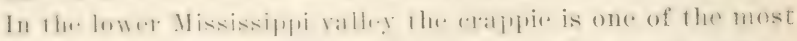
commun tislers. It is almmbant also in the Ohio salley and on-

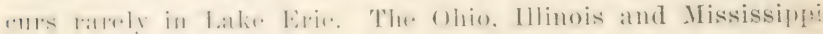
ricers are partirularly noted for an abmulamee of crappies, and

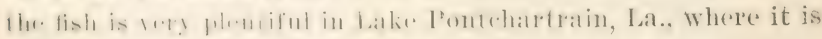

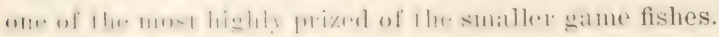

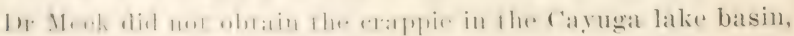

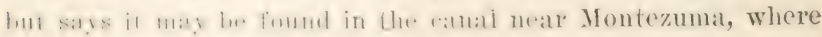
the calico bass is said to be frequently taken.

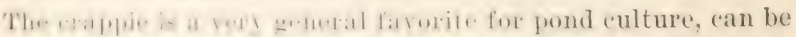

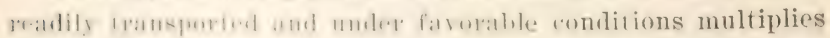

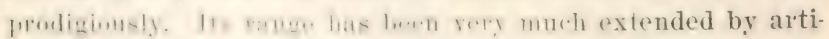

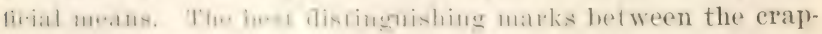

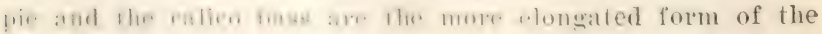

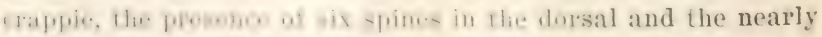
uniform whitish molor of the anal. In llw wappie the greatest 
depth of the body is usually contained two and one half times in the total length without the tail, while in the calico bass the depth equals one half the length. These two species are so similar in size and habits that ther are rarels distinguished except by ichthyologists.

The crappie grows to a length of about 1 foot and usually weighs 1 pound or less; but in a lake near St Louis an individual weighing 3 pounds has been recorded.

Crappie fishing usually begins in June and lasts till the coming of cold weather. Large numbers of these fish are collected near Quincy Ill. for distribution to other waters. At P'eoria Ill. Prof. Forbes has taken them in March and Ipril; he has found them also in Pistaliee lake and at Ottawa. C"edar lake', Ind. and King's lake, Mo. are celebrated craprie waters. Near Covington Ky. in private ponds belonging to . Toseph Schlosser there are myriads of crappies as well as other game fishes.

Prof. S. A. Forbes has studied the foeding habits of the crappie, and finds that the roung live rhiefly on entomostraca and small insect larvae. The adnlts subsist on the same food when obtainable, but in times of scarcity they feed to some extent on other fishes. Small minnows and darters have been fomm in their stomachs. In the antumn Prof. Forbes has found a larger percentage of small fishes, sometimes constituting rearly two fifths of their food. The hellgramite is eaten hy the crappie. In cold weather it does not consume one fourth the amount of food which it talies in the early spring. The crappie prefers still waters, thriving eren in warm and muddy water, and has been taken in large numbers in midsummer at depths of only a few feet; in cold weather it retires to deeper water, becomes rather sluggish and takes little food. Ir Henshall states that the crappie is found about dams and in deep still parts of streams and ponds, specially about logs, brush and drift.

The crappie is a very free biter and can be caught readily with minnows or worms. Spoon bait has been successfully used in trolling for this species. It is recolded that two men have 


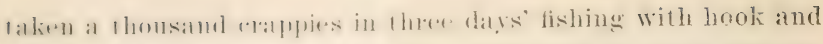

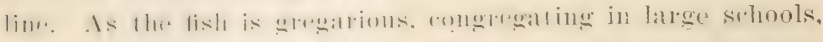

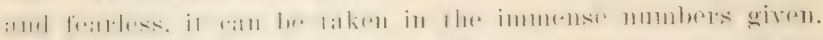
The luse hait for arappore is a small shimer. It rises well also

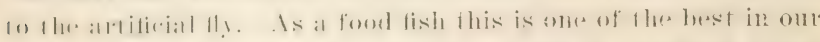

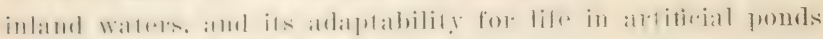
should make it a favorite with fish eulturists.

\section{Pomoxis sparoides (Lacépède)}

\section{Calico Bass; Strawberry Bass}

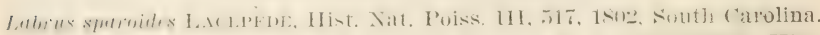

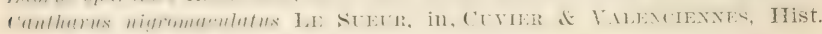
Nat. Poiss. III, SS, 18:9, Wabash Rirer.

Centrarchus heracanthus Curier \& VAlenciennes, Hist. Nat. Poiss. VII, 45S, 1S31, Charleston, S. C.; Kimtrand, Bost. Jour. Nat. Hist. III, 4S0, pl. XXIX, fig. 2, 1811; Gǜmier, Cat. Fish. Brit. Mus. I, 257, 1859.

Pomotis hexacanthus Holbrook, Iehth. S. C. 15, pl. 3, fig. 1, 1856.

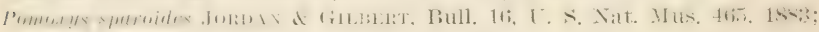
BEAx, Fishes Penza. 102, color pl. 9, 1893.

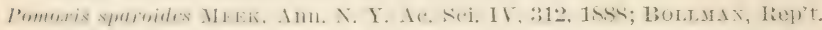

U. S. F. C. XYI, 559, pl. 6S, fig. 2, 1892; Jordan \& Evermann, Bull. 47, U. S. Nat. IIus. 957, 1896, pl. CLIV, fig. 416, 1900; Eugene SMith, Proe. Linn. Soe. N. I. 1or 1897, 33̈, 1S9S.

The ralien hass has I he dephlo about one half the length, not

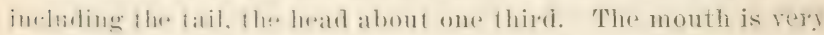

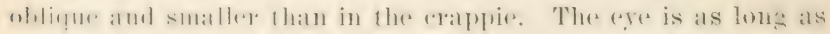

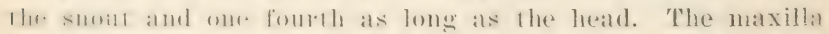

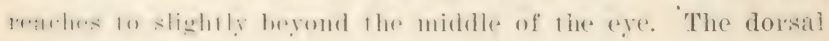

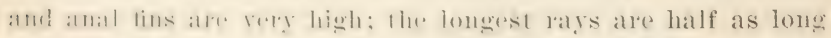

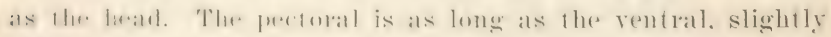

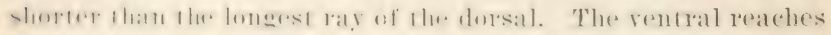

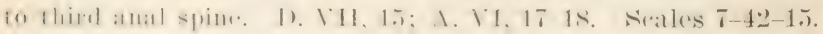

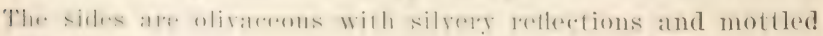

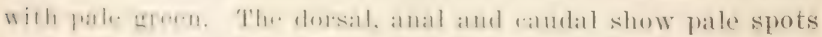
surrounced by ereen reticulations.

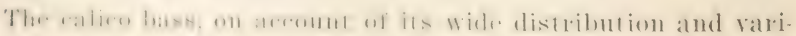

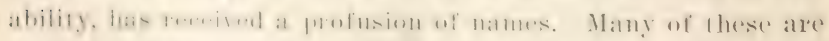
variations of the term hass. It is known, for example, as straw-

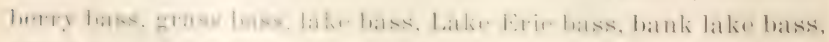
silfre latss, and hig-fin hass. Oller manes for the species are 
strawberry perch, whinquapin pereh, gogghterye pereh, silver perch and sand perch. Still other names of local application are barfish, bitter head, timmonth, sace-lat, lamplighter, razorback, goggle-eye, black croppie and lake croppie. The species is mentioned in the fish laws of Pennsylyania under the name of Lake Erie bass or grass bass.

The distribution of the ealico bass is naturally extensive, and it has been still further increased by artificial introduction. The fish has been carried to France, and examples measuring about $S$ inches in length were recolded there sereral years ago. There is, howerer, some confusion in that country between the calico bass and the common sunfish, and there is no doubt that some of the latter speries have been introduced into Germany muler the mistaken belief that they were calico bass.

This bass is indigenous east of the Illeghanies from New Jersey southward to crorgia. It abounds in the Great lakes region, Mississippi valley south to Lonisiana, most common northward and oceuss in the Missoni. In the Ohio valley it was rather vncommon till its introduction in large numbers. It was introduced into the Susquelanna river by the Pennsylrania Fish Commission, and has berome acclimatized there; also into the Monongaheda, the Lehigh, and of her waters.

Fishermen of the rexion about Montezuma informed Dr. Meek that the fish is frequently talien from the canal neal that place, where it is known as calieo bass. The IT. A. Fish Commission oblained two examples in Lomg pond, al chatrotte N. Y. Aug. 17, 1894.

This bass grows to a lenglh of about 1 foot and a maximmu weight of nearly :s pounds, but the arelage weight is about 1 pound. It spawns in the spring, and the elose season in some states extends to Jume 1. Glatid fomales were ranght neale Ifave de cirate Md. in May. These were talien in the suseruehamil and Tidewater amal, where the species is beroming rather abumdant. The food of the caliro bass consists of worms, small crustaceans and fishes. Though a native of deep, sluggish water's of western rivers and lalies. it readily adapts itself to 


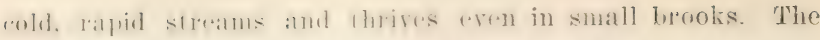

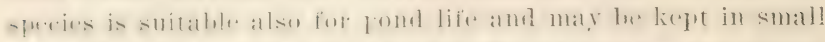

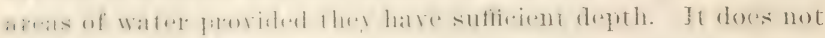

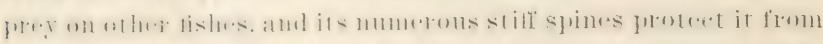

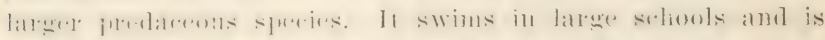

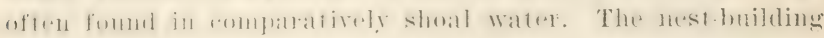

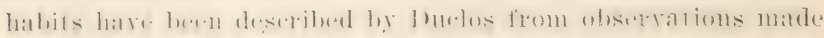

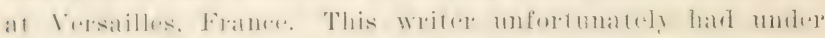

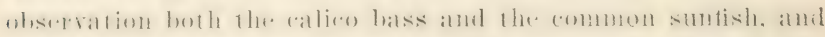

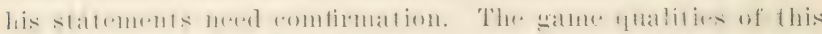

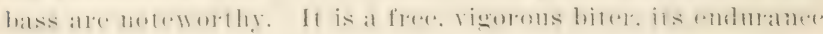

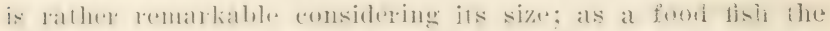

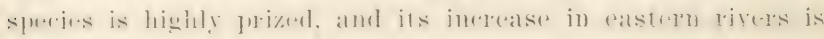
greatly to be desired.

\section{Genus acavrirancuus Gill}

Body oblong, robust, not much compressed or elevated;

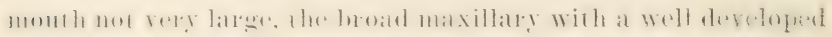

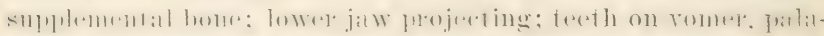

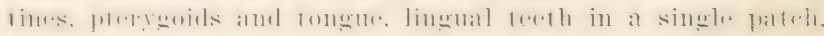

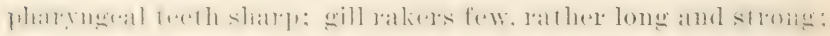

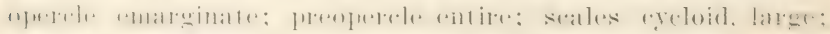

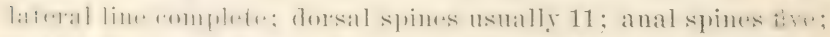

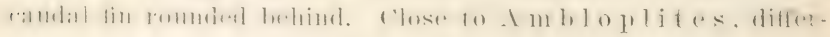
ing chicfly in the rounded caudal. One species known.

\section{3: Acantharchus pomotis (Baird)}

Mud Sunfish

fentrurehes pomilis 13دm1), Ninth Smithson. Rep't, 325, 1855, New Jersey,

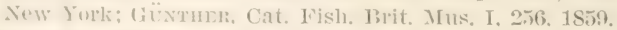

Ammlhurchus pomolis Jomblx of Grmmer, Bull. 16, U. S. Nat. Mus, 469. IAs; 131.1., 1sull. U. S. F. C. VII. 113, 18s5; Fishes Penna. 107, 1893; Jompax de limmaxa, Bull. 47, U. S. Nit. Mus. 9S9, 1S96, pl. CLY,

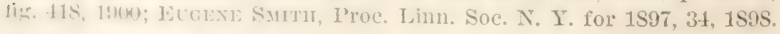

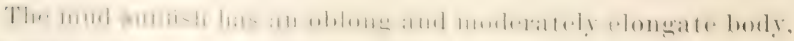
iis erveatest depth, neall the velut, two fifths of the total length

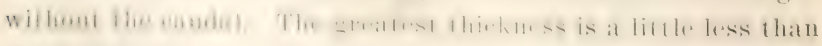
one: half the deptli. The cambal peduncle is short and deepe, its least depth two fifthe of greallest depth of body. The head 
is moderately large, rather more than one third of total length without the caudal, its width equal to the length of its postorbital part. The snout is rery short and obtuse, its length about one half that of the ere. The ere is placed high, its diameter contained three and two thirds times in the length of the head. The interorbital space is slightly conver, its width three fourths the length of the eye. The month is large, the maxilla broadly expanded behind and reaching nearly to below the hind margin of the eye. A well dereloped supplemental maxillary bone, two thirds as long as the eye. Six roms of scales on the cheeks. The opereulum ends in two thin, flat points, between which there is a black spot, about two fifths as long as the eye. Gill rakers short and few, fire developed on the first arch, the longest two fifths as long as the "ye. The spinous dorsal begins over the fifth seale of the lateral line; its base is as long as the head without the snout. The first spine is rery short, one half as long as the ere; the spines increase repr gradually in length to the last. Which is as long as the ere and snont combined. The soft dorsal base is two thirds as long as that of the spinous dorsal; its rays are longer than the spines, the longest (fourth to sixth) about one half as long as the head. The anal begins under 18 th scale of the lateral line; the first spine one half as long as the eye; the spines increase in length to the last, which is one third as long as the head; the rays are long, the longest (fourth) equal to postorbital length of head. The ventral reaches to the rent. The pectoral reaches to below the 15th scale of the lateral line. The caudal is rounded, its middle rays five sevenths as long as the heat. The laterall line is complete and runs parallel to the dorsal ontline. I). XII, 11; 1. VI, 10; V. I, 5: T'. 14. Scales li-4:3 12. In spirits the color is dark brown; two or three dusky stripes on the sides below the lateral line; a dark shade aromel the nape extending barkward behind the eye; two dark stripes areross the rhecess and opereulum; a dark opercular flap as deseribed above; the fins

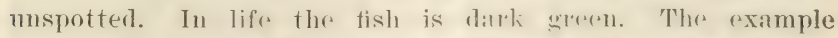
described, no. 17814 U. S. National Musemm, from New Jersey, 


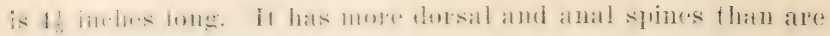
usually present in this sumfish.

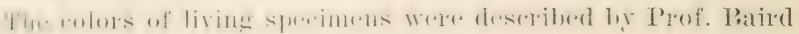
as follows:

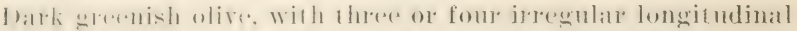

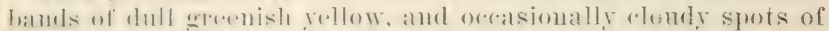

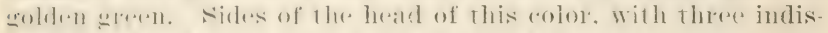

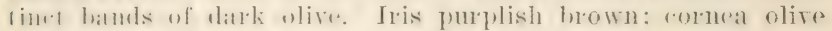

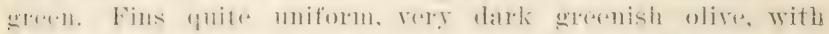

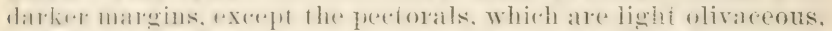

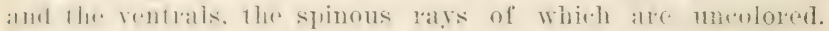

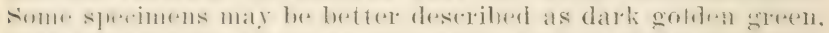

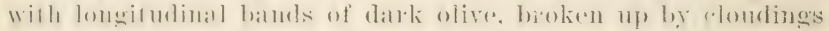
of greenish.

liairal ralled it the hass sumfish heratuse of its resemblance in

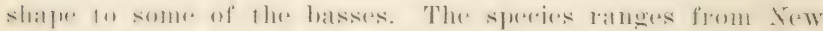

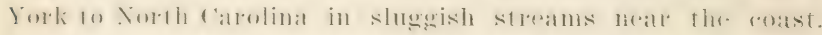

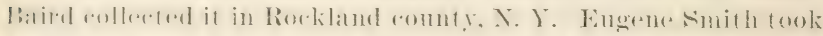

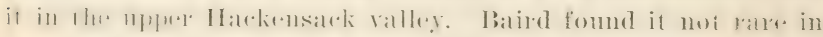

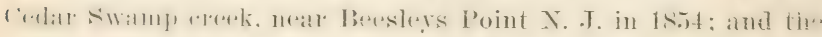

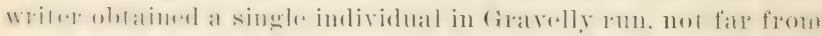

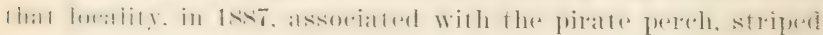
mul minnow, barred killifish and young pickerel.

The murl sumfish reaches a length of 6 inches. It prefers

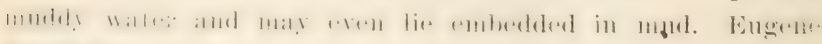
smill salys it is shy, sechsive and nocturnal in its habits.

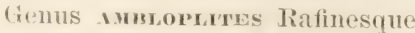

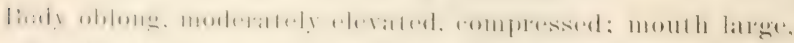

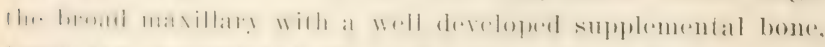

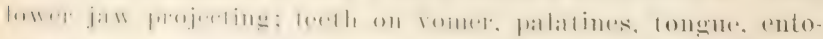

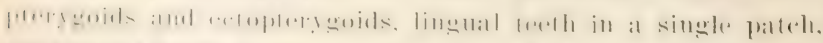

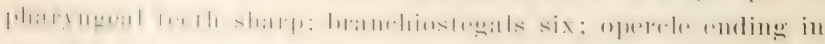

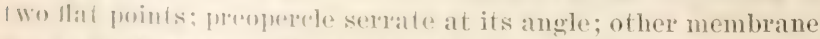

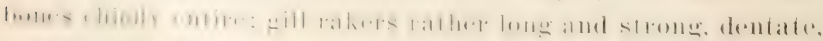
less llatn 10 in mmmlure, developed only on the lower part of the atrell; seales latrow, somowhat romoid; lateral line complete, the

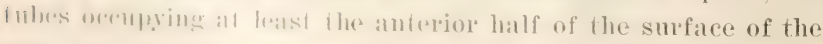
sralle; dorsil fin murh mowe deveroped than the anal fin, with 10 
or 11 rather low spines; anal spines normally six; pectorals btusely pointed with $1 \pm \mathrm{or}^{\circ} 1 \mathrm{5}$ rays, the upper longest; caudal in emarginate.

\section{Ambloplites rupestris (Rafinesque)}

Rock Bass; Redeye

Bodianus rupestris RAFINesQue, Am. Month. Mag. II, 12 ), Dec. 1S17, Lalies of New York, Vermont \& Canada.

Cichla aenea Le Sueur, Jour. Ac. Nat. Sci. Phila. II, 214, pl. 12, 1S22, Lake Ontario.

Centrarehus aenens Cutier of VAlfactexyes, Hist. Nat. Poiss. III, 84, 1829; DE Ki.ı, N. Y. Fauma, Fishes, 27. pl. 2, fig. 4, 1S12, Lake Champlain, Great Lakes, streams of westeru New York, Iudson River; Storen, Syn. Fish. N. A. 37, 1846.

A mbloplites rupestris Jorddn \& Gilment, Bull. 16, U. S. Nat. Mus, 466, 1S8?; Bean, Fishes Penna. 105, color pl. 10, 1893; Evermañ \& Kendal, Rept. U. S. F. C. for 1S94; 600. 1S96; Jord.n \& Everaraxx, Bull. 47 , U. S. Nat. Mus. 990, 1S96, pl, CLYI, figs. 419. A, B, C; Meer, Ann. N. Y. Ac. Sci. IV, 313, 1S9S; Evgene Swith, I'roe. Linn. Soc. N. Y. for 1897, 33, 189S; Mramxs, Bull, Am. Mus. Nat. Hist. X, 319, 1s9s; BeAx, 521 Ann. Rept. N. Y. State Mus. 104, 1900.

The rock bass has a robust oblong body; its depth is contained two and one third times in the total length without caudal, the head two and four fifths in this same length. The caudal peduncle is stont, almost as deep as long. The dorsal profile is rather steep; strongly concare orer eye. The eye is large, about one fomth the length of head, equal to snout. The mouth is large, the maxillary reaching to vertical from posterior end of pupil. The heavy lower jaw projects slightly. The vomer, palatines, tongue and pterygoid bones all toothed; the teeth on the tongue in a single patch. The pharyngeal teeth are sharp. The opercle ends in two flat points; preopercle serrated at its angle. Gill rakers long and strong, less than 10 in number; six brauchiostegals; scales large, those on the cheeks in about eight rows; caudal rather deeply emarginate. The dorsal base is about one and one half times as long as that of the anal. The spines of both fins are stout and rather short. The first spine of the dorsal is orer the serenth scale of the lateral line, and the last spine is orer the 25th seale. The first soft ray is over the 26th scale, and the last ray over the 35th. The anal origin is under the middle of the spinous dorsal, and 
the last anal ray is nflusil. the last dorsal rag. First dorsal

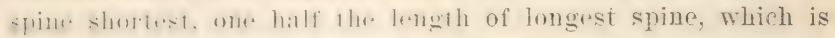
alumt llowe tiflhs as lomp as the longest ray. The spines and

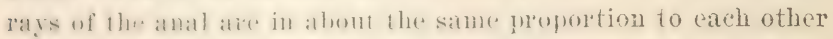

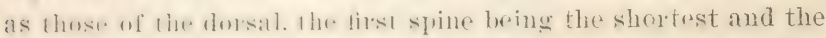
longest almul thro. tifths as long as the longest anal ray. The soft palls of lhe lorsil and anal atre high and rounded. The Jurlural is rathre shore and broald. The rentral long and

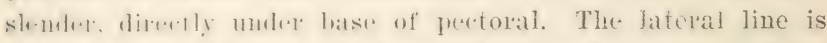
(omplolr, Jharel high on body and follows the contour of the back. D. XI, 11; A. VI, 11. Scales 5-46-14.

folor olive areren with a brassy tinge and mueh dank wotaling;

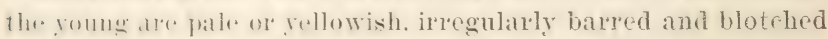
wilh hatk: adulss will a dark spot at the base of rach seale, thrse sputs forming interrupted black stripes; a dark spot on the $11 \% \cdot r \cdot 1$, ; soft dorsill, anal, and caudal fins with dark mottlings; iris golden overlaid with crimson.

'The rock hass is linown under a rariety of names. Among

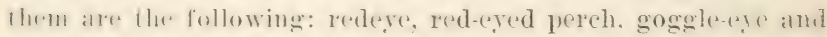
lakir hass. It is fommd in Lower Canada, Termont and through. wat lhe Cireat lakes region, west to Manitoba, and it is native in Minm-sula and Inkola: somtluward it ranges through the Mississippi vallyy to Trxas. In the Ohio valley it is rery common. whil. in llw. Mirlll. Mlantic states. east of the Mlleghanies, it has frobathly bun infouluerel. Its existence in the susqur.

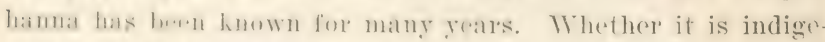

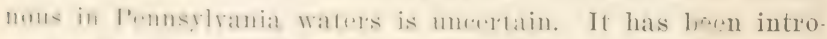

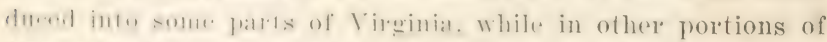
that kfale it is malive. It is indigenums in North Carolina. Its

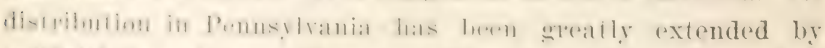
artigintal intrulumion, and is is mow woll established in the

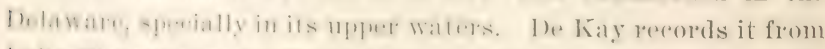

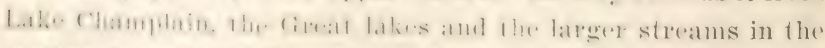

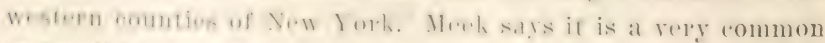

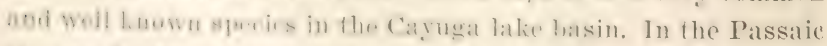

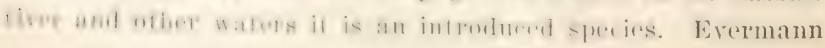


and Bean obtained a specimen in scioto creek, Coopersville N. Y. July 19, 1894. In the Lake Ontario region the U. S. Fish Commission collectors secured it at the following localities in New York state in 1894 and previous years.

Marsh creek, near Pointbreeze.

Mouth Little Salmon creek

Chaumont river

Guffon creek, Chaumont

Mill creek, Sacketts Harbor

Black creek, tributary of Oswego river, Scriba Corner

Sandy creek, North Hamlin

Mouth Salmon river, Selkirk

Cape Vincent

Little Stony brook, Henderson bay

Long pond, Charlotte

Cemetery creek, Watertown

Great Sodus bay

Grenadier island, Lake Ontario

Salt brook, $1 \frac{1}{2}$ miles above Nine Mile point

Nine Mile point, Webster

Under circumstances farorable as to water and food supply the rock bass grows to a length of 14 inches and a weight of 2 pounds. It increases in depth and thickness with age. The largest example we have examined is one of 2 pounds weight, length 14 inches, from the James river, Ta., taken near Richmond. Dr William Orerton reports that rock bass weighing $3 \frac{3}{4}$ pounds have been taken in his vicinity at Stony creek, Va.

In February and March this fish frequents the mouths of small streams, and in summer it seeks shady places under high banks or projecting rocks. The species is gregarious, going in large schools. It thrives where there is not much current and is very well adapted for culture in artificial ponds. It is as common n lakes and ponds as in the streams. Sluggish, pure dark water suits it best.

The fishing season begins in . Tune and lasts till the approach f cold weather. The rock bass feeds on worms, crustaceans 
and larvae of inserets ary in the seasous later its food consiste wi mimows and wathtish. The young feed on inserets and their latsar. The spatwing season is May and June, and gratelly shoals are resolted to for depositing the eggs.

The rock hass hiles wrir freely and is a fair game fish and exerllent for the table. It fights rigorously, but its endurance

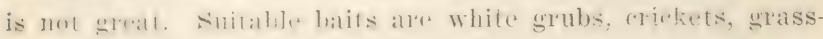
hoflu.rs. raw tish ame small minnows, Common sarthworms are also successfully used.

\section{Genus chanvonrytus Gill}

This genus has the grenteral form and dentition of $1 \mathrm{mblo}$. plites. With the ronvex operele, 10 dersal and these anal spines of Lepom is. l'reprerele entire; branehiostegals six;

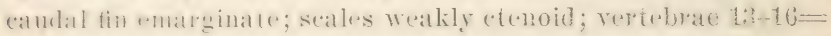

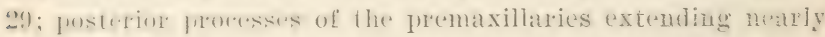
to the fromals: frontals posteriorly with a transverse ridge connerting the parietal aud supratocipital erest, which are rery strong.

\section{Chaenobryttus gulosus (Cuv. \& Val.) \\ Warmouth; Goggle-eye}

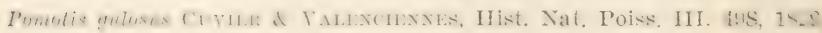
Lake Pontehartrain and lagoons about New Orleans.

Centrurchts viridis Curier \& VALENCIENnES, op. cit. VII, 460, 1S31, Charleston, S. C.

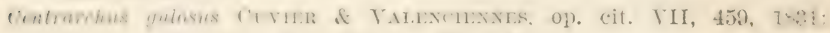
GüNtuer, Cat. Fish. Brit. Mus. I, 258, 1859.

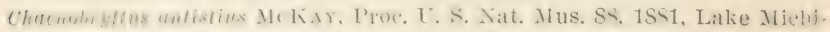
gan; Jomdax \& Gilbert, Bull. 16, U. S. Nat. Mus. 467, 1883.

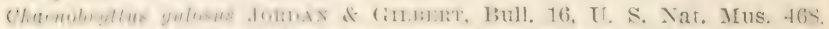

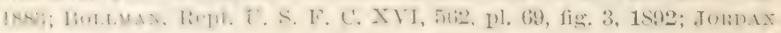
\& Everamax, Bull. 47, U. S. Nat. Mus. 992, 1896, pl. CLVII, fig. 421. 1900.

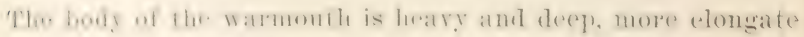

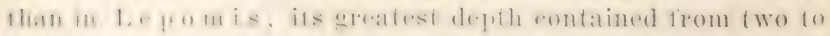

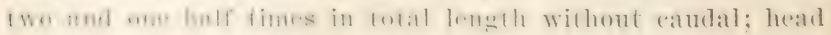

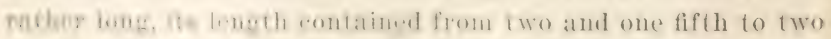

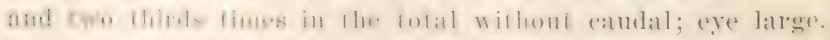

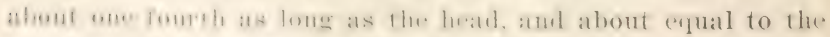

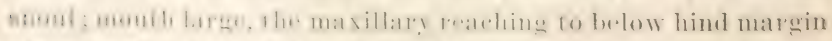

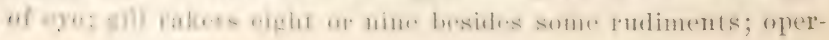


cular spot about as large as the eye. The dorsal begins farther back than the pectoral, its spines low, the longest equal to distance from tip of snout to middle of pupil; pectoral short, not reaching to anal; rentrals nearly reaching vent, the spine about one half the distance from origin of rentral to vent. D. X, 9 to 10 ; A.III, 8 to 9 . Scales $(j-40$ to $46-11$ to 12 ; pores 37 to 42 ; 6 to 8 rows on cheek.

Color in life clear olive green clouded with darker, usually without red or blue; a dusky spot on each seale more or less distinct; vertical fins mottled with dusky; a faint spot on last rays of dorsal bordered by paler; three oblique dusky bars radiating from eye; belly yellowish.

The warmouth inhabits the eastern Cnited States from the Great lakes to South Carolina and Texas, ranging west to Kansas and Iowa. It occurs chiefly west or south of the Alleghanies. The fish reaches a length of 10 inches and is a food species of some importance. It is extremely voracious and, consequently, a farorite for angling. In form and color it varies greatly.

\section{Genus Exvencaxthus Gill}

Body rather short and deep, compressed; mouth small; the supplemental maxillary bone well developed; teeth on romer and palatines, none on the tongue; opercle ending behind in two Slat points, with a lermal border; preofercle entire; scales rather large, the latral line sometimes interrupted; gill rakers short, nine or 10 below angle of areh; dorsal fin continuous, normally with nine spines; anil fin smaller than the dorsal, with three spines; caudal fin convex behind; branchiostegals six. Species of small size amd bright coloration, intermediate between $\mathrm{L}$ e pom is and Centrar r hus. Abmormal variations in the number of dorsal atud anal spines have given rise to the nominal genera $H$ e m i oplites and Copelandia.

\section{Enneacanthus obesus (Baird)}

\section{Banded Sunfish}

Pomolis obesus Bamd, 9th Anu. Rept. Simith. Inst. :324. 18.r. Buesleys Point, N. J.

Bryttus fuscirtus IIncвronk, Jour. Ac. Nat. S*i. I'hilat. 51, pl, 5. fig. 3, 1555, St John's River, Fla.; Guntmen, Cat. Fish. Brit. Mus. I, 260, 1859. 


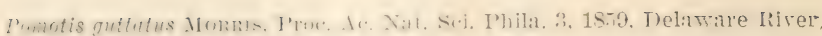
Philadelphia, Pa.

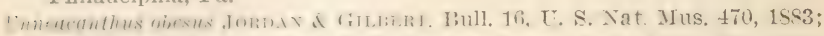

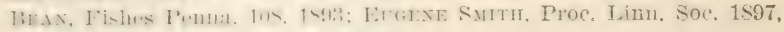
34, 1S9S, Hackensack Talley, N. Y.

The body of the hamded smomfis is elliptic in form, its depth more than wne laalf the tutal length without candal, its thicliness equal to two tiftles of its repth. The "andal pedmele is short and stout, jts least dupth one third of greatest degih of body. The heall is short. two fifths of total length withont the candal; the snout is very short and obligue, its length abunt two thirds of the diameter of the eye, which is one third as long as the hear, and recerds the width of the interorbital space. The mouth is obligue. moderate in size, the maxilla broadly pxpanded pusteriorly and reaching to below the midale of the pre; a supplemental maxillary bone. I blark operenlar flat, two thiris as long as lhe eye. Suales on checks in four rows. Gill raleres short and sring, 1:3 dereloped on the first areh, the longest seare:s one latif as lome as lhe eve. The first dorsal spine is orey the jeetoral hase, minnte, less than ome half as long as the secomi, whirh is two flomk as long as the eye; the spines increase in sime lo lle last. which is onte half as long as the head; the fourth and lougest suft ray is two thirds as lomg as the head. The

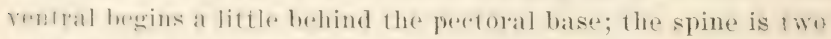

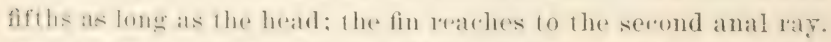

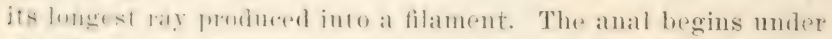
Hhe l:Bll seale of the lateral line: the hase is 1 wo thirds as long as the heaml: Ihe first spine is two thirds as long as the seeond.

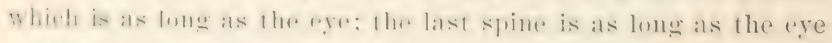

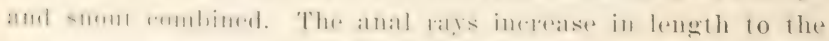
fifth. which is as long as the head without the snout. The

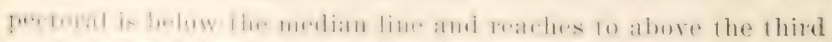
anal spine. 'The candal is rommeded, the middle rays as long as the hath wifhomi the snont. The lateral line is imperfect after

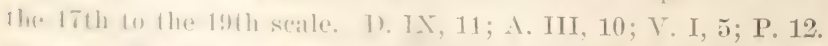

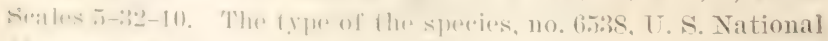

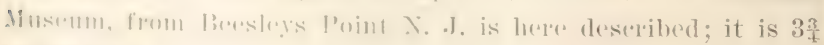
inclite lone. 
The banded sunfish inhabits coastwise streams from Massachusetts to Florida. It occur's in southeastern Pennsvivania but is rare.

This species grows to a length of 3 inches. It is olive green in color with five to eight dark cross bars intermingled with golden or purplish spots. There are lines and spots also on the cheeks. The flap on the opercle contains a relrety black spot with a purpie border. Below the eye is a dark bar. This is a beautiful little species, but has no economic importance.

In our vicinity it inhabits the entire Harkensack valley, preferring quiet, weedy places. For the aquarium it is the most desirable of all the sunfishes, as well on account of its hardiness as of its harmless nature. Eugene Smith

\section{Enneacanthus gloriosus (Holbrook)}

\section{Blue-spotted Sunfish}

Bryttus gloriosus Holnnoor. Jour. Ac. Nat. Sci. Phila. 52, pl. 5, fig. 4, 1855, Cooper River, S. C.; Gtхтиек, Cat. Fish. Brit. Mus. I, $260,1859$. Hemioplites simulans Cor'E, Jour. Ac. Nit. Sci. Phila. 218, 1868, Tuckahoe Creek, near Richmond, Va.

Enneacrnthus simulans Jordan \& Gilbert, Bull. 16, U. S. Nat. Mus. 470, 1883; Bean, Fishes Penna. 108, 1893, Trenton, N. J.

Enneacanthus eriarchus JordaAx of Gilbert, Bull. 16, U. S. Nat. Mus. 4t:, 1883.

Enineacanthus eriarchus JoRdAN \& GILBERT, op. cit. 469, 1883.

Enneacanthus gloriosus Bollmax, Rept. U. S. F. C. XVI, 5Gt, 1892; Jordan \& Evermanx, Bull. 47, U. S. Nat. 1I us. 993, 1896, pl. CLVIII, fig. 442, 1900; Mearns, Bull. Am. Mus. Nat. Hist. X, 319, 1898.

The blue-spotted sunfish has an elliptic body, its greatest depth one half of the total length without the caudal, its thickness nearly two fifths of its depth. Caudal peduncle short, its least depth one third of greatest depth of body. Head moderately large, three righths of total length without the caudal; suout rery short and oblique, two thirds as long as the eye, nhich is nearly one third as long as the head; mouth moderately Iarge, oblique. the broadly expanded maxilla reaching nearly to below front of pupil; lower jaw slightly projecting; the operculum ends in two flat points, betwen which there is a dark spot wo thirds as long as the pye and bordered below by a narrow pearly stripe; gill rakers short and stont. 11 derelojed on first 


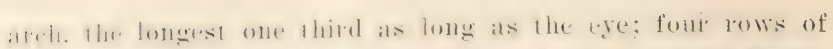
-rales on the rheeks. The spinoms dorsal begins orer the fourth

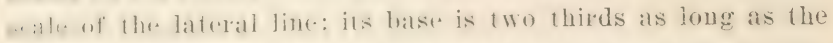
He:all: Hhe tirst spine is nearly one half as long as the eyr; the spines graduatly increase in length to the fomth, which is equal 10 these that follow it and to the length of the pestorbital part of the heatt; the tifth, and longest, soft ray is as long as the head without the smont: the last soft ray is as bong as the fosturbital fart of the head. The anal origin is muler the lth seate of the lateral line; the base of the anal the is as long as the head without the snout; the tirst spine is one fommlta long as the head; the third and longest spine minals Ihe forstorbital fart of the head in length; the third and fourt? soft rays are longest, as long as the head without the sin)ut. The rentral ratehes to the second anal ray, its spine as longeas the postorbital part of the head. The peetoral is platerl below the median line of the borly; it reaches to below the 1tth scalle of the lateral line. The caudal is rounded; its milde rays are thre fourths as long as the head. The lateral line is usnally emmplete, somelimes imperfect on one side. D. 1., 11: A. III, 10; V. I, 5; P. 11. Scales 4-31-10.

In sprits the color is hownish; abotit seven or eight rows af sates belew the lateral line with parly blotehes forming inter.

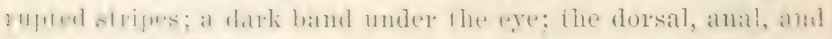
camdal pofusely sputted with roundish, pearly spots. Young indiviluals are ubsurely handerl. In life the spots of the male are bue, and the fins arr higher than in the female; the operete.

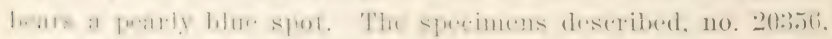

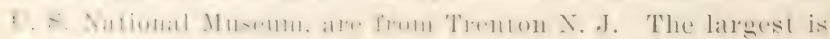
3 inches long.

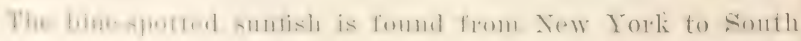

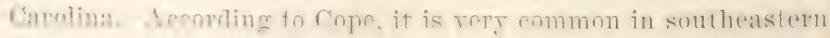
f'ouneylvanin. Mratns ohfirincd it unly in Long pond, a sheet

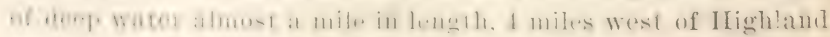
Fills $\mathbf{N}$. J. IIe discovered the species there more than 23 years aco, and reports it still common. 
This is a small species, not much larger than the banded sunfish. It is a handsome fish, but has no importance for food.

\section{Genus apomotrs Rafinesque}

This genus is very close to $\mathrm{L}_{4}$ e p o m is, from which it differs only in the derelopment of the supplementary maxillary bone, which becomes rudimentary or wanting in the adult of $\mathrm{Le}$. po mis. The mouth is largest in the species in which this bone is best dereloped. Lower pharyngeals narrow, with acute teeth; gill rakers well developed, long and stiff; pectoral blum ish, shorter than head; scales moderate, 43 to 50 . Species widely distributed in American waters, similar in habit to the species of L e o mis.

\section{Apomotis cyanellus (Rafinesque)}

\section{Green Sunfish; Redeye}

Zepomis cyanellus IinFINESQTE, Jour. de Phys. 420, 1819, Ohio River; Jordan \& Gilbert, Bull. 16, U. S. Nat. Mus. 473, 1S83; Bean, Fishes Penna. 110, pl. 31, fig. 61, 1893; Meerk, Ann. N. Y. Ac. Sci. IV, 313, 1888; Evermann \& Kendall, Bull. U. S. F. C. XII, 111, 1894.

Pomotis longulus B.mrd of Grand. I'roe. Ae. Nat. Sci. Phila. 391, 1553.

Otter Creek, Arkansas; Marcy's Expl. Red River, 245, pl. 12.

Bryttus longulus B.mind of Girard, l. c. 25, 18jt; Güxtmer, Cat. Fish. Brit.

MIus. I, 259, 1859.

Culliurus longulus Girind, L. S. Parcif. R. R. Lxp. Fishes, 16, pl. 5, figs. 5-8, pl. 6, figs. J-S, 15is; Iept. I. A. Mex. Bound. Surv. Ichth. 5, pl. IV.

figs. 1-4, 1859 .

Calliurus formosus Ginand, Proc. Ac. Nat. Sri. Phila. 200, 1857, Arkansa-;

U. S. Pacif. R. R. Exp. Fishes, 14, pl, 5, figs. 14, 1858.

A pomotis cyanellus R.ATINesqe, Juur. de L'bys. Paris, 420. 1S19; Boulexger,

Cat. Fish. Brit. IIus. I, 21, 1S96; Jordix of Evermisx, Bull, 47, U. \$.

Nat. Mus. 996, 1896.

The green sunfish has an obloug body, its greatest depth, at the rentrals, equal to three serenths of the total length without the caudal, and its thickness three eighths of its depth. The least depth of the caudal peduncle equals four fifths of its length, and about one third of greatest body depth. The head is one third of total length without the raudal, its width nearly one half its length. The snout is moderately pointed, and as long as the eye, whirh is two ninhls as long as the head. The interorbital space is nearly that, its width a little greater than the length of the "ye. The natpe is moderately arehed. The 
ings, and the anal is margined in front with orange. The iris is red and the cheeks are striped with blue. The specimen

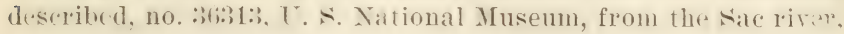
Mo., is 7 inches long.

The blue-spotted sunfish, also known as the green sunfish and redeye, oceurs from the freat lakes region, throughout the Ohio and Mississippi valleys sonth to Mexico. It does not occur in the Middle Atlantic states east of the Alleghanies. Dr Meek did not find this fish near Ithaca. A few specimens were taken near Montezuma N. Y. None of the eollectors of the U. S. Fish Commission ohtained it in the Lake Ontario region.

The species reaches a length of $T$ inches, and is an extremely variable one. I'rof. Coue refers to it as a good panfish and states that it is abundant in the Ohio basin. In the Ohio ralley it is one of the characteristic fishes, inhabiting ponds and ascending small streams. It frequents deep holes and the shelter of overhanging roots.

\section{Genus mером Rafinesque}

Body oblong or ovate, more or less compressed, the back in the adult somewhat "levated; month moderate or small, the jaws about equal; maxillary narrow, the supplemental bone reduced to a mere rudiment, or altogether wanting; teeth on romer and usually on palatines, none on tongue or pterygoids, lower pharyngeals narrow, the teeth spherical or pared, all or nearly all sharp, few or none of them conical; gill rakers mostly short; preoperculum entire; operculum ending behind in a conrex flap, black in color, which in some species becomes greatly dereloped with age; branchiostegals six; scales moderate; dorsal fin continuous, with 10 spines; anal with three spines: caudil fin emarginate; pextorals long or sliort; rertebrae usually $1:-16$ or $17=29$ or 30 . Coloration hrilliant, but eranes. rent. A large genus, one of the most diftrult ju our fish fauna in which to distinguish species. The form of body derelopment of ear flap, and hight of spines rary with age and condition. While the general appearance and the numbers of fin rays and seales are essentially the same in all. Sereral at- 


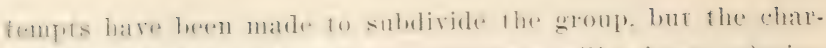
areres used. drawn from the platryngeals, gill rakers. palatine 3enth, and pertural tins, alre themselses subject to rartation, whanging or disappraring ly degrees withoml narked gals.

\section{Lepomis auritus (Linnaeus)}

\section{Long-cared Sunfish}

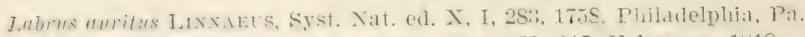

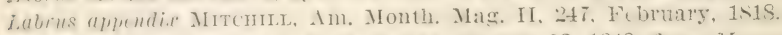

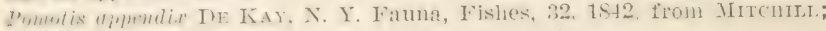
Storer, Hist. Fish. Mass. 1t, pl. III, fig. 4, 1867.

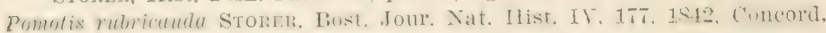

N. H.; GüNther, Cat. Fish. Brit. Mus. I, 262, 1859.

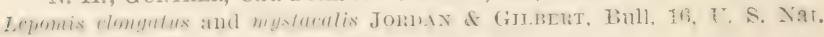
Mus, $475,1883$.

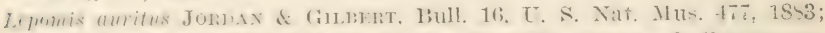

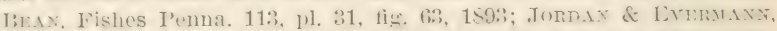

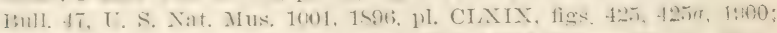

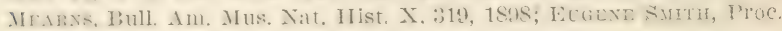
Linn. Soc. N. Y. 1897, 34, 1898.

The longeatred sunfish has an oblong, moderately elougate body, is depth neariy one half of the length without the camlal and its lhicliness a little more than one third of its dereth. The

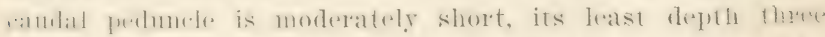
fomblis of is lemgth and ome lhird of greatest depth of boily. The hear is rather large, its length without the flap one thire of the [ntal without randal, its widlh one half of its length.

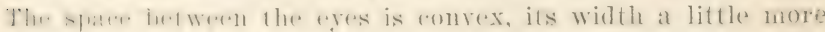

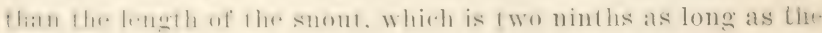

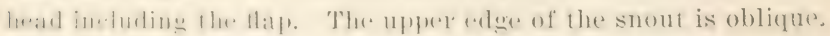
The ere is ouf fomple as lome as the head without the flape Whe aumfle is muderate in size, llw maxilla not rery broadly expomded betiond and extending to helew the front of the pupil. Ther sunles on l her rherehs are very small, in about eight rows.

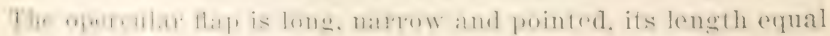

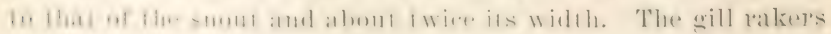
are shori and stout, about 11 developed on the first arch, the

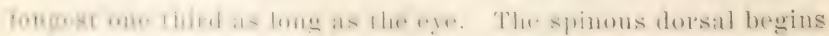
over the sixth seale of the lateral line: its hase is two sevenths

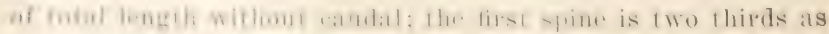


long as the second, which is as long as the eje; the fourtl (longest) is one and one half times as long as the eye; after the fourth the spines slightly decrease in length, the last being little longer than the eye; the fifth (longest) soft ray is as long as the base of the soft dorsal and equal to the snout and eye combined; the last soft ray is a little more than one half as long as the longest. The anal begins under the 21st scale of the lateral line; the length of its base equals that of the soft dorsal; the spines are short and stout, the first two thirds as long as the second and one half as long as the third, which is one and one half times as long as the eye; the fourth (longest) soft ray is as long as the base of the fin; the last ray is two thirds of this length. The caudal is emarginate, the middle rays two thirds as long as the outer. The ventral reaches beyond the rent, sometimes to the origin of the anal. The rentral spine is one half as $10 n g$ as the fin. The pectoral has a broad base and extends to below the 19 th scale of the lateral line. I. X, 10; A. III, 9; V. I, 5; P. 14. Scales 7-43-13. The lateral line follows the curve of the back.

In spirits the color is pale brown; the fins somewhat paler; the ear flap black; a brownish streak in front of the eye and another horizontal one beneath it. In life the color is olivaceous; the belly, specially in breeding males, orange. The scales on the sides have reddish spots on a bluish ground. Dorsal, anal and caudal usually rellowish. The stripes on the head are bluish.

The specimen described, no. 33152, U. S. Yational Museum, from Bainbridge $\mathrm{Pa}$. is $5 \frac{1}{2}$ inches long.

The long-eared sunfish has a very extensive range and is known under many common names, among wbich are the following: bream, red-tailed bream, redhead bream, red-bellied bream, perch, sun perch, red-bellied perch and redbreast.

The species is common in streams east of the Alleghanies from Maine to Florida, and in tributaries of the Gulf of Mexico to Louisiana. In the southern states the typieal long-eared sunfish is replaced by a variety with larger seales on the cheeks 
and belly and a dusky botch on the posterior part of the soft dorsal fin.

Mrarns foumd this sunfish ahundant in the Hudson and in I'oplupen's creete, a llibutary of the Hudson; he took it also in Highland latie. Eugem. Smith reported it to be very common in the uper l'assaic river. in the Great swanp and in the Bronx river.

The longealed sunfish arerages about 8 inches when adult and weighs ahout 1 pound. In the south the size and number of individuals are greatly increased. This fish feede on worms, insect larrae, crustareans, molluslis and small fishes. In the Susquehanna this is one of the most common of the surfishes; in the Delalware also it is abundant, and reaches a lapge size. Though not important commercially, it is taken in large aumbers on the look and is an excellent food fish. It talies any kind of live bait rery readily and furnishes good sport also with the artificial 1ly. In the Hudson Highlands region, according to Mearns, it is rommonly sold in the markets; fishermen take it in fykes, and by angling, using dough, grasshoppers and anglewurms for bait. He has caught it in the most rapid parts of I'ophonen's creek when angling for brook trout.

\section{Lepomis pallidus (Mitchill)}

Bluegill; Bhue Sunfish

Lubrus pullidus Mrtent., 'Trans. Lit. \& Phil. Soe. N. Y. I, 407, 1815, near New York.

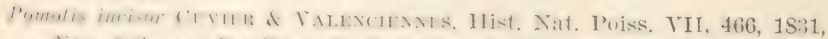

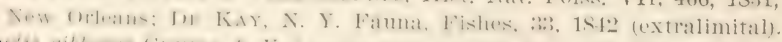

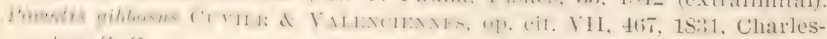
tons, S. C.

I'omotis speriosus Güntuer, Cat. Fish. Brit. Mus. I, 263, 1859.

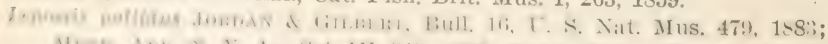

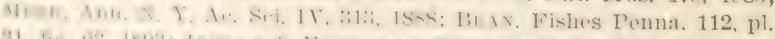

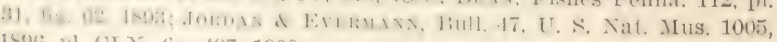
1S96, 1). CLA, fig. 427, 1900 .

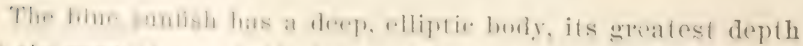

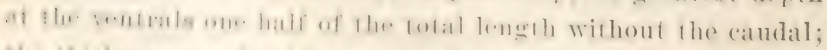

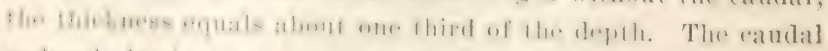

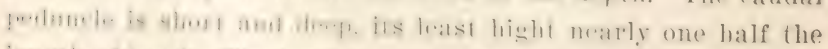

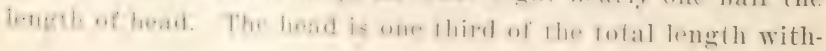


out the caudal; its width equals one half of its length. The snout is short, obtuse and obligue, less than the eye in length. The interorbital space is slightly convex, its width one third of the length of the head. The mouth is small, oblique, the maxilla not greatly expanded behind, reaching to below the front of the eye. The width of the preorbital equals one half the diameter of the eye. Scales on the cheeks in five rows. The gill rakers are short and stout, about 15 developed on the first arch, the longest little more than one fourth as long as the eye. No supplemental maxillary bone. No palatine teeth. The lower pharrngeal bone narrow, with teeth in only about four series, chiefly acute. The spinous dorsal begins orer the fourth scale of the lateral line; the spines are stout, the first as long as the snout and one half as long as the fifth and longest; the spines following the fifth not much shorter; the first seren soft rays about equal in length and one half as long as the head; the last ray one third as long as the head. The base of the spinous dorsal is nearly as long as the head; the soft dorsal is two thirds as long as the spinous. The anil begins under the 20th scale of the lateral line; its base is as long as the head without the snout; the spines are short and heavr, the first five sixths as long as the eye, the second a little longer than the exe, and the third one half as long as the head without the snout; the longest rilys are the fourth to the serenth, which are one half as long as the head. The caudal is notched, its middle rays three fourths as long as the outer. The rentral reaches almost to the anal, its spiue being one half as long as the head without the snout. The pectoral is broad and reaches to below the 1Sth scale of the lateral line. The lateral line follows the curre of the back. D. X, 11; A. III, 10; V. I, 5; P. 13. Scales $7-41-15$.

In spirits the color is pale brown, the scales with a pale margin; a large dark blotch on the hind part of the soft dorsal; a black opercular slap, its width and length about equal, shorter than the ere. The living fish raries with age from light green to dark green. The young have the sides silvery, tinged with 


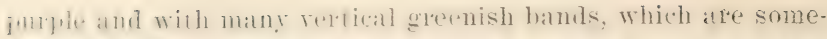

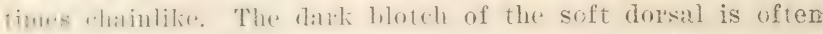
massinet in the young. In rery old indiriduals the belly is

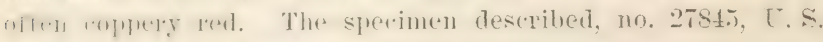
National Museum, from Peoria Ill., is $7 \frac{1}{2}$ inches long.

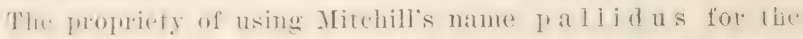

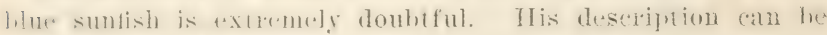

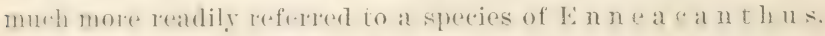

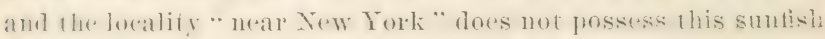
among its natire species.

Thr blue sunfish, blue bream, copperenosed herem or dollamlee, is a rery widely diffused species and valies gereaty in size. eolor and length of the ear thap. It is foumd in the fireat lalies and throughout the Mississippi valley to Mrxire. Fast of

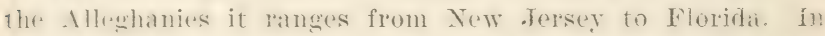
Pemmelyania it is abundant only in the wastern part of the state. including Latie Erie. Ior Abbott has recorded it from the Melaware river. In Meeli says that it is found in the cityoa 1.1.6 haxin in small numbers with the blue-spotted sunfish I f o mot is cyanell us, which he took near Momrezumb.

The hlur. sunfish grows to a length of neally 1 fool, and indi:

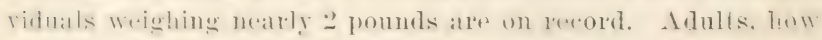

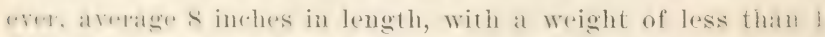
Jumun. The size of the individuals depends on the habitat. In. latre. lak hes and streatus it grows to a greater size than in smatl? burlies of water. In southern waters it aftains to a larger size llam in northern watres. It lives in ponds as well as in streams

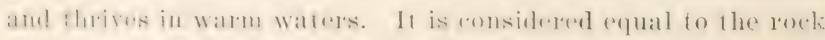

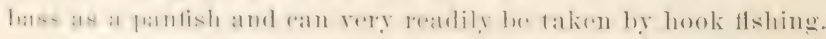

\section{Genus mupomotrs Gill \& Jordan}

Very closely related to $\mathrm{Lep}$ o $\mathrm{mis}$, differing only in the

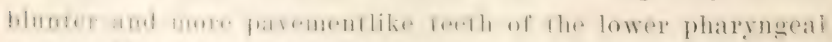

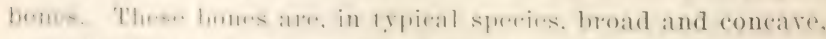

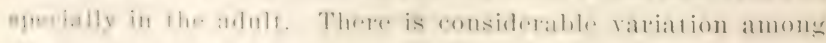

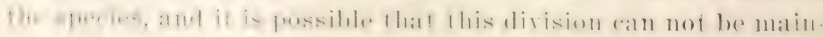
tainchl. Most of thr species have long pectoral fins, the sup- 
lemental maxillary lost or rery much reduced, and the percular flap always with an orange patch on its lower osterior part. Gill raker's various, usually short. The retenion of this genus is possibly justified by convenience, but either the longer pectorals nor the blunt pharyngeals separate $\mathrm{t}$ sharply from L e p o m is.

\section{Eupomotis gibbosus (Linnaeus)}

\section{Sunfish; Pumpkin Seed}

'erca gibbosa Linnaeus, Syst. Nat. ed. X, I, 292, 1758, Carolina.

parus aureus Walbaum, Artedi. Gen. Pisc. 290, 1792, lakes of. New York. Iorone maculata MitchiLL, Report in Part, 19, 1814.

omotis vulgaris Cuvier \& Valenciennes, Hist. Nat. Poiss. III, 91, 1S2?, Lake Huron, New York, Virginia; and Carolina; DE K.1Y, N. Y. Fauma, Fishes, 31, pl. 51, fig. 166, 1S12; Iоцвпоок, Ichth. S. C. 6, 11. 1, fig. 2, 1856.

Pomotis auritus GÜNTHer, Cat. Fish. Brit. Mus. I, 261, 1859.

epomis gibbosus Jordan \& Gilbert, Bull. 16, U. S. Nat. Mus. 4S2, 1S83; Meer, Anu. N. Y. Ac. Sci. IV, 313, 1Sss; Bean, Fishes, Penna. 115, pl. 32 , fig. 65, 1893.

Zupomotis aureus MATHER, App. 12th Rept. Adirondack Sulv. N. Y. 7, 1886.

Eupomotis gibbosus Jordan \& Evermanx, Bull, 47, U. S. Nat. Mus. 1009, 1896, pl. CLXI, fig. 429, 1900; BEAn, Bull. Am. Mus. Nat. Hist. IX, 36t,

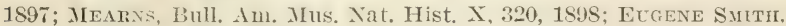
Proc. Limn. Soc. N. Y. 1897, 35, 189S; BeA x, 52d Ann. Repr. N. Y. State Mus. 104, 1900.

The body of the common sunfish is nearly orate, its depth ne half the total length without caudal; its thickness one third f the depth. The caudal peduncle is short and compressed, ts least depth less than the thickness of the body. The head moderately large, one third of the total length without audal, its width one half its length. The snout is short and lepressed, its length four fiftis of the diameter of the eye, which is one fourth as loug as the head. The interorbital space s nearly flat, its width one and one half times the diameter of he eye. The month is small and obligue; the maxilla not much xpanded behisid and reaching to below the front of the ere. sales on the cheeks in fonr rows. The operenlar spot is short, ess than two thirds the diameter of the cyend and has a whitish nargin behind. The gill raliers are rery short, moderately tout, 10 or 11 developed on the first arch, the longest less than 
one fourth the diameter of the eye. The spinous dorsal begins crer the third scale of the lateral line; its base is as long as the head without the operenlar tlap; the first spine is two thirds as long as the eye; the spines increase in size, the fourth, fifth and sixth being neaty equal in length and about as long as the eye and snont combined; the sixth and longest soft ray is as long as the postorbital part of the head, while the last ray is less than one third as long as the head. The base of the soft dersal is as long as that of the spinous dorsal. The anal origin is under the $2: 3 d$ scale of the lateral line. The anal base is two thirds as long as the head; the first spine is about one half as long as the third (longest), which is two fifths as long as the leatd. The first and second rays are the longest, nearly as long as the balse of the fin. The last ray is two thirds as long as the first. The rentral reaches beyond the rent; its spine is one half as long as the head without the snout. The pectoral reaches 10 ahove the anal origin. The caudal is emarginate, its midde rays four fifths as long as the outer. The lateral line follows thr arve of the back. I). X, 12 ; A. III, 10; V. I, 5; I. 13. Scales 6-42-13.

In spirits the color is pale brownish, the opereular flap black with a narrow whitish margin behind and beneath, and the dursal fin with faint dusky blotches. In life this is one of the must hrilliant of suntishes, the upper parts being greenish olive wilh a buish tinge, the sides profusely spotted with orange, Ihe belly and lower fins orange and the dorsal and eaudal fins bulsh with orange spots. The eheres are orange with undulating bhe stripes: the operenlar flap is black, emarginated behind and underneath with bright scarlet.

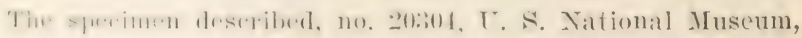

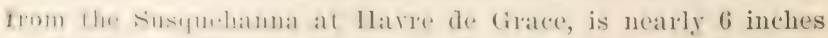
loilg.

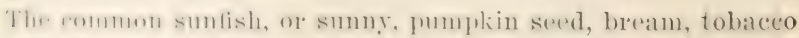
lons and pumblish is one of the hest linown fishes of the United Silates.

11 is formul foum diane westward fhrongh the ripeat lakes

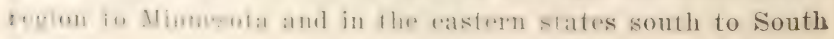


Carolina. In western rivers, however, it is seldom found south of the latitude of Chicago. In New York the sunfish abounds almost everywhere, in the lowlands as well as the highlands and in brackish as well as fresh waters; it has eren been taken occasionally in salt water on Long Island. Large indiriduals have been received from Canandaigua lake and from lakes in the Adrondacks. Dr Meek found it very common throughout the Cayuga lake basin. The collectors of the U. S. Fish Commission obtained it in almost all the water's visited by them (21 localities) in the Lake Ontario region. Eugene Smith reports it from most of the moraine ponds of Long Island and Staten Island, and in quarry ponds of the Palisades, wherein it is frequently placed by boys. Ponds and lakes in the parks of New York city are well stocked with this species. Mearns reported it as abundant in the Hudson and in all the ponds and slow streams of the Hudson Highlands. Mather recorded it as a common fish in most of the Adirondack waters, the exceptions being Piseco lake, G lake, Coald lake, Sents` lake, T lake, Willis pond, Murphy, Warner and Bug lakes.

The common sunfish grows to a length of $S$ inches and a weight of about $\frac{1}{2}$ pound. Its food is similar to that of the long-eared sunfish; and it is one of the readiest biters known to the angler. The habits of this fish have been described by Dr Theodore Gill and W. P. Seal. The latter states that the male in the breeding season is readily identified by his brighter coloration, conspicuous ear flaps and a luminous border around the fins while in the water. The nest is a depression in the mud, sand or gravel, hollowed out by means of the fins. In the Potomac he found a number of nests which were located from a few inches to several feet apart. The male watches the nest and drives away all intruders. The rgags are ouly about at of an inch in dianeerer and not very numerous. They are attached to stones and aquatic plants. Mr. seall hats reason to believe that the male alone is concerucd in building the nest and in the care of the eggs and young.

The species is usually hardy in captivity, but is subject to fungus attacks which yield readily to treatment with brackish 
water. In the aquarium, aroording to Fugene suith, the combun smotish by incessant attatelis often kills associates of many ands. 11 is a very gam tish. common everywhere and is usually fonnd in the eomplaty of shiners, minnows and killies. In quarry fomds, of the l'alisades, says the same anthor, the tish will thrive and multiply as freely as the goldish, provided there is water enough throughout the year.

\section{Genus mcropterus Lacépède}

Budy oblong, compressed, the back not much elerated; head oblong. conical; mouth rery large, oblique, the broad maxillaty reaching nearly to or beyond the posterior margin of the rye, its supplemental bone rell developed; lower jaw prominent; teell on jaws. romer and palatines in broad rilliform batuls, the inmer depressible, usually no teeth on the tongu('; preoperete entire; ofereulum ending in two flat points without cartilaginous tlap; hanchiostegals normally six; gill rakers long and slrmbler; scales rather small, weakjy ctenoid; lateral line comIllew, the luhes straight, oceupying the anterior has of tath scale: dorsal fin divided by a deep noteh, the spines low and

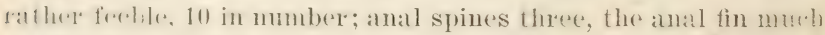

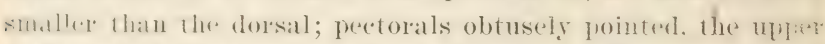

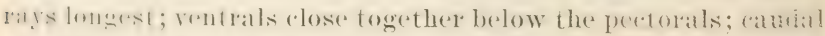
fin rmatrinatle; posterior processes of the premaxillaries not

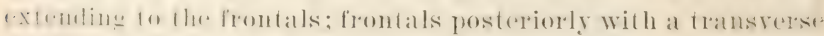
ridere rommeting the patrictal and supeaoceipital arests, which

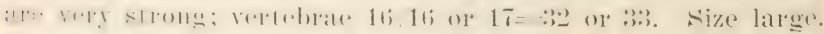
Two speries, among the most important of Ameriean " game" fishes.

\section{Micropterus dolomieu Lacépède} s'mall Mouthed Black Bass

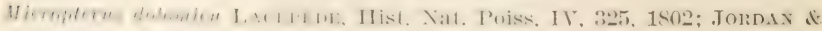
(infmikт, Iiull. 16. U. S. Nat. Mus, 455, 1SS3; MAtmer, App. 12th Rept. Alironlatels surv. N. Y. 5, 1886; МЕEK, Ann. N. Y. Ac. Sei. IV.

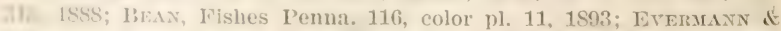

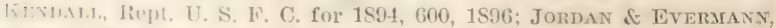
I’ull. 47, I], S. Nat. Mus. 1011, 1S96, pl. CIXII, figs. 430, 430a, 1900;

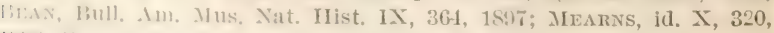

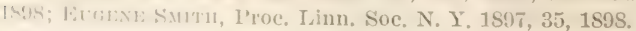


Centrarchus obscuru. De Ti.1. N. T. Fauna, Fishes, 30, pl. 17, fig. 48, 1842, Onoudaga Creci. ‥ I.; Güxtuer, Cat. Fish. Brit. Mus. I, 25s, 1859.

The small monthed bass difires most markedly from the lan:-12 monthed in the sime of its jatrs, the shallower notr.h in the flor:at fin and the smaller scales. There are about 11 rows of athore the lateral line and seven below it; $72-7 . t$ scales in the lateral line. The ninth spine of the dolsal is longere than the ege and fully two thirds as loug as the fifth and longest spine. The upper jaw extends backward to below the hind margin of the rese. The body is ovate oblong in shape, its greatest depth about equal to length of the head and one third of the total without caudal, becoming deeper with age. The eye is less than two thirds as long as the snout and about one sixth the length of head. The pectoral is not much longer than the ventral and slightly more than one half the length of head. The soft dorsal and anal are more scaly at the base than in the large-mouthed species. The scales on the cheeks and breast are very much smaller than those on the middle of the sides. D. X, 13-15; A. III, 10.

The young are dull yellowish green, the sides mottled with darker spots, which sometimes form short vertical bars. Three dark stripes on the head; caudal rellowish at the base; a broad black band near middle of tail and a broad whitish margin behind. The dark lateral band characteristic of the large mouthed species is not found in the small-mouth. In the adult the Irevailing color is olive green, the stripes on the head remaining more or less distinct.

One of the early names for the small mouthed black bass is that of growler, which appears in the writings of Cuvier, who was under the impression that the name was applied because of a noise sometimes produced by this bass. At the time of his writing the name growler was pretty generally identified with the black bass. Among the names applied to this fish by Rafinesque are lake bass, big bass, spotted bass, and achigan. IIe also mentions it under the names painted tail, bridge perch, yellow bass, gold bass, brown bass, dark bass, minny bass, little 
hass, heg hass, yellow pereh, black perch, trout perch, streaked. hratl. White trout and hrom trout. In the southeru states the small mouth is known as the trout, perch and jumper. In thabatmat it is alled mommain trout. Some persons style it the bronz. barkele. The most appropriate name and the one by which it is best known is that of black bass or smail mouthed black bass.

This speedes is indigenous to the upper parts of the st Lawreme hasin. the Great lakes region and the basin of the Mississipui. East of the Alleghanies it is native to the headwaters of the ormulgee and chattahoochee rivers. but north of these stratus. though not originally an inhabitant of the waters it has bu+n witely distributed by artiscial introduction.

In the st Eawrenee river Evermann and Bean obtainesi the

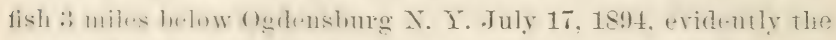

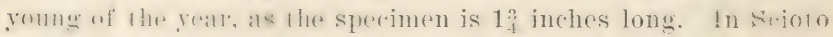
arek at conferesille X. Y. they secured an example 15 indhes

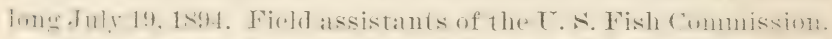
whluting in the Latke (Ontario region of New York in 1R!t and jormaling rars, took specimens in the following loealities.

Big Stony creek, Henderson Harbor

Mouth Salmon river, Selkirk

Marsh creek, Point Breeze

Four mile creek, Nine Mile point, Webster.

Wart ereek

Black river, Huntingtonville

Cape Vincent

Ilouth Little Salmon creek

Great Sodus bay

Sindy creek, North Hamlin

Long pond, Charlotte

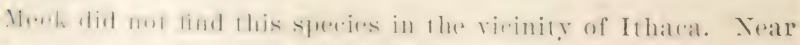

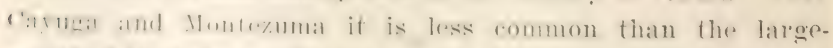

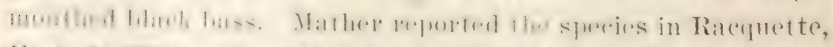

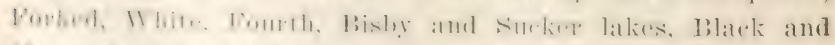

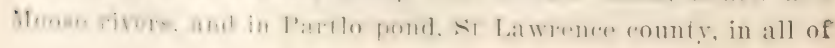


which it has been introduced. The fish is not uncommon in Lake Champlain; it is abundant in the vicinity of Caledonia N. Y. Eugene Smith records it from the Passaic river. The writer has found it abundant in the Bronx. Mearns mentions it from Long pond, in the Hudson Highlands, where it reaches the weight of 5 or 6 pounds.

This bass does not grow so large as the large mouthed, seldom exceeding $S$ pounds in weight and averaging but 21 pounds. A fish of the latter weight will measure 15 inches in length, while one of $S$ pounds will measure 2 feet.

The food of the black bass consists of crawfish, frogs, insects and their larrae, minnows and other aquatic animals of suitable size. The roung can be fed on small fresh-water crustaceans, such as Daphnia and Crclops. Among the successful baits for this species are stone catfish, hellgramites and crickets.

The black bass prefers rapid water, is extremely active, and frequents clear, pure, swiftly flowing streams, and thrives at greater elerations than those prefered by the large mouthed species. It hibernates in the winter and spawns in the shallows on gravelly bottoms in spring. It follows its prey into shallow water and frequently leaps far out of the water in its efforts to escape from the hook or when frightened by the sudden approach of an enemy. It swims in schools and is often found in the shelter of sunken logs and in the ricinity of large rocks.

The sparning season begins in March and ends in July. The period of incubation lasts from seren to 14 days. The eggs are bound together in bands or ribbons by an adhesive substance. They adhere to stones on which they are deposited. The parent fish build nests and protect the eggs and young. In the Delaware the current is more rapid and the temperature lower than in the Susquehanna; hence the bass spawn earlier in the latter than in the former. The spawning fish have nearly all left their spawning beds in the Susquehanna early in July, but at this time most of the nests in the Delaware are still full of eggs. $\mathrm{Br}_{2}$ some writers it is beliered that the female prepares the nest before the male joins her. The males fight for the 
finseression of the fromale and are sald to help the rnocess of

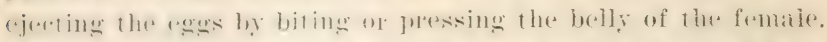
Afrer the eggs are deposited, the female guards the nest from thr altarks of the rrawfish and other fishes. The young

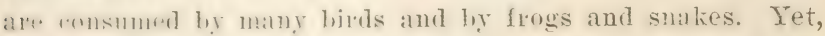

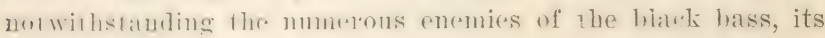
multiplication has been rapid and enormous.

The small monthed black bass ceases to take food on the

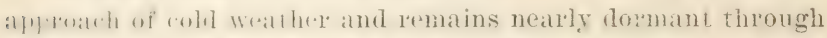
llue winler, exerpt in artiferally heated water. A number of

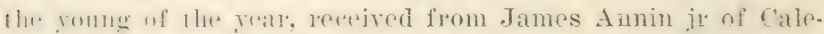
Innia X. I. Oet. 6, 1.996. searcely fed at all in the following wintel. hut when the spring was advanced they fed "ager ly and grew rapidly.

\section{Micropterus salmoides Lacépède}

\section{Large monthed Black Bass}

Laturus salmoides Lackípide, IIist. Nat. Poiss. IV, 716, 1802, Sonth Carolina. Hurm nigricans Cuvier \& Valexciennes, Hist. Nat. Poiss. II, 121. pi. 17. 152S, Lake Iluron; Du Kar, N. Y. Fauna, Fishes, 15, pl. 69, tig. 224, 1842; Günther, Cat. Fish. Brit. Mus. I, 255, 1859.

Mirmplrus pallidus Gonen of Beax. Bull. Essex Inst. XI, 19, 1879.

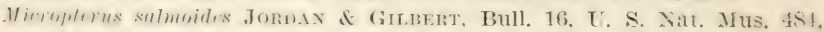

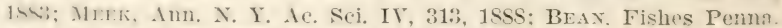

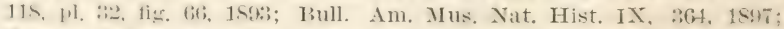

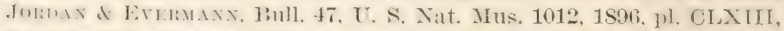

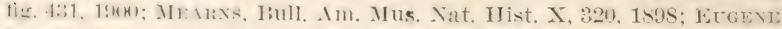
Smitir, Proe. Linn. Soc. N. Y. 1597, 36, 1898; BEAN, 52d Ann. Rept. N. Y. State MIus. 105,1900 .

Ther latere mombled blark bass takes its aommon name from the size of its jatws; the lower jaw frojerels repry strongly, and Here Inasilla in the adult extemels beyomet the hind margin of the eyre. The dephls of the burly is about one third of the total with-

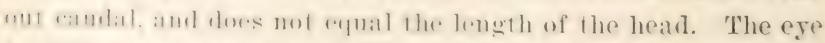

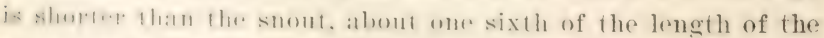
heat. The fmetulat is half as long as the head, much longer th:all 1he wolmal. The spinoms dolsal is very low, its ninth and

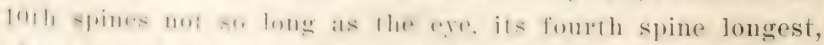

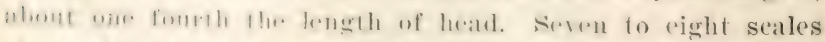

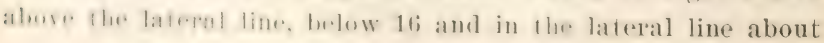


68. The color is grenenish, silvery bolow. The roung have a broad dark lateral band. D. I, 13; A. III, 10-11.

This species may best he distinguished from the small mouthed black hass by the size of its mouth and the number of rows of scales alove the lateral line. The young of the small mouthed speceses, also, never have a dark lateral band.

Common names for this species are. Oswego bass, ricer bass. gpen hass, moss bass, bayou hass. trout, jumper, chub and Trelshman. Throughout the north it is generally known as bass, in Virginia and North Carolina as chub and in Florida and west to Texas as trout.

The large mouthed bass has a wide distribution, being indigrnous to the eastern Cnited States, from Manitoba to Florida and Texas, except New England and the Middle Atlantic states east of the Alleghanies, where it has been extensively introduced. It inhabits the fresh-water ponds, lakes and sluggish streams. It is found also at the mouths of rivers emptying into the Gulf of Mexico, where the water is brackish.

Dr Meek found the large mouthed species scarce near Ithaca and more common near Montezuma and Cayuga. James Annin jr collected the young at Caledonia. The U. S. Fish Commission had it from the following places in the Lake Ontario region:

Lakeview hotel, 7 m. n. e. of Oswego

Marsh creek, Point Breeze

Mouth Salmon river, Selkirk

Mouth Little Salmon creek

Stony Island

Four Mile creek, Nine Mile point, near Webster

Creek at Pultneyville

Chaumont river

Great Sodus bay

Three Mile creek, Oswego

Long pond, Charlotte

Dr Mearns first observed the species in the Irudson in the autumn of 1882 , where the fish were caught in fyke nets during October and November. Eugene Smith records it from all lakes and rivers adjacent to New York city. 
Foung individuals, from $1 \frac{1}{2}$ to 2 inches long, were seincd in Bronx river in August 1897.

The arerage weight of the large mouthed bass in southern waters is less than j pounds, and still less in northern waters. In Florida it attains a large size, as much as 3 feet in length, and a weight of 25 pounds. Its growth and size depend on the waters whre it is found, and the natural food supply of small fish, erawfish and frogs.

It is a rery actire fish; its morements are affected hy suatsonal rhanges and the search for food and places for spawning. In polluted streams the bass are often compelled by the impuritires 10 serel new haunts in pure water. The soung bass fecel on animal fout al an early age. The latge mouthed bass is situl to

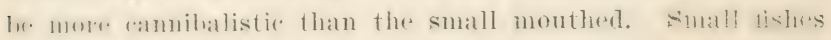
minnowsi of all kinds, crawfish, frogs, insects and their larvate, aml aquatir animals of all kinds, suitable in size, make mi the diel of this fish. It feeds both at the surface and on ihe hote fon. fursuing its prey with great activity. Then smontmind

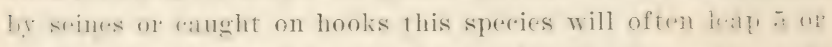
if frel ont of the water, and its habit of jumping orer the ark lines of seines has given it the name of "jumper."

for fold wrather the bass seetis deep platees. often hibermainer numer rorks. sunkirn logs and in the mud. Farorite lowalities are muler orerhanging and brush-covered banks. in the summer, and anomg alputic plants, where the fish lies in wait for its prey.

The statwoing statson of the latege mouther bass is about the

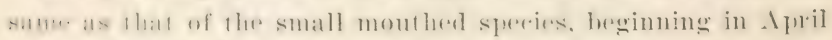
and lasting lill July. Its eges are adhesire, stieking to stomes

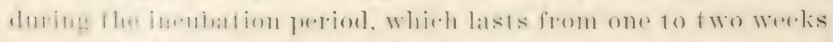
ateoraling to the temperature of the water. The rome hass remain in the Jerst a werels or 10 dalys. amel at the age of two wowh will measure ahomi if of an inch in length. In suitable

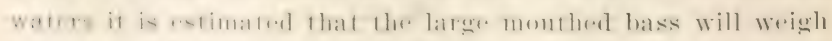
at the agre of three years from 2 pounds to 4 pounds.

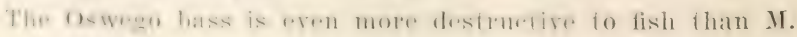

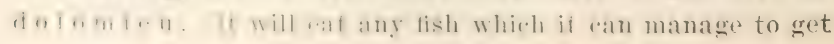




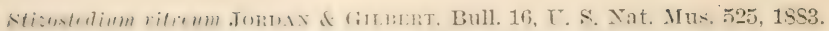
Lucioperce vitrea Eugexe Smin, Proe. Linn. Soc. N. Y. 1897, 3S, 1895.

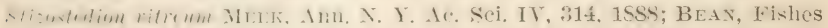
Penina. 127, color pl. 13. 1893; Eremuxy and Kexdalt, Rept. U.S. F.C. for 1594. 601. 1596; Jomdax \& Evemaxn, Bull. 47, U. S. Nat. Mus,

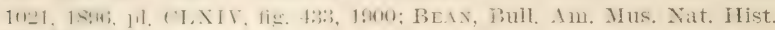
IX, 361,1597 .

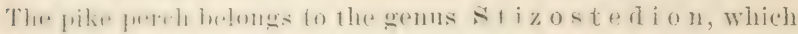

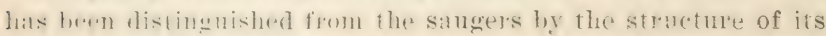

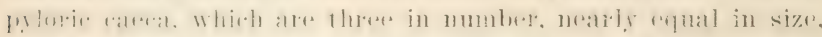
amb atumb ats long as the stomateh, and also hy the prosence

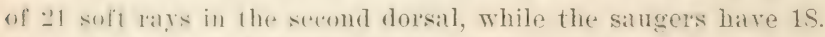
It may he lemallied that all of these characters are more or less variable. The s. Y it re $11 \mathrm{~m}$ has the body long and muderately deel), its deph varying with age and equaling from one sixth to une fomth of the total length without candal; the length of the hrad is contaned in the same standard four and two thirds times; the eye is moderate, about two thirds as long as the snout aml a little more than one sixth of the length of the head; the lowrr jaw projects slightly: the maxilla reaches to beyond the jupil: the hewe and opereles are more scaly than in thesaugers; 1h1. suft dorwal is nearly as long as the spinous; length of long[s d borsal spine about half the length of head. D. XIII, I, 21; . 1. 11. IZ 10 1:3. Ihout 90 seales in lateral line, 10 above and 19

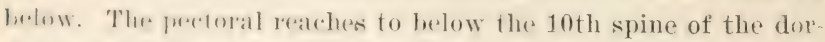
sil: it is as lones as lhe ventral and one half the length of head: the vent is under the fifth ray of the second dorsal.

folme olivarents. mingled with hassy: sirles of the head rere

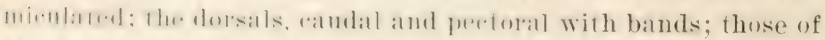

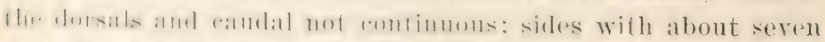

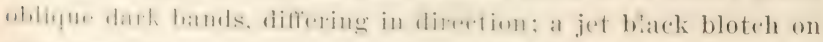
the membrane behind the last spine of the dorsal.

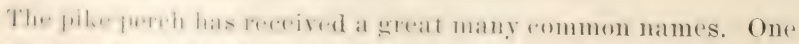

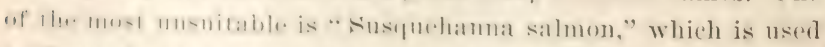

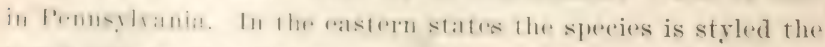

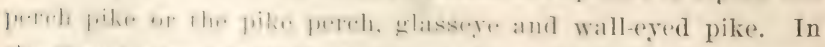

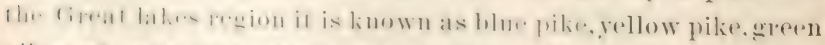

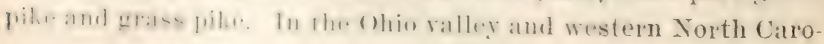


lina it is the jack; in Lake Erie and Canada, the pickerel; in some parts of the Ohio valley, the white salmon or jack salmon. The Cree Indians call it the okor and the French Canadians doré or picarel. Among the fur traders of British America it is called the hornfish.

The pike perch or walleyed pilif inhabits the Great lakes region and extends northward into British America, where it has been recorded as far as $58^{\circ}$ north by Dr Richardson. It ranges south in the Mississippi valley to Arkansas, and in Atlantic streams to Georgia. According to Ir Meek the speries is found in Casuga lake, but is not common. In Lake Champlain it is one of the principal game fishes. James Innin jr of Caledonia obtained specimens in the Canandaigua lake region. It has been introduced into numerous lakes by the Fisheries, came and Forest Commission of New York. The U. S. Fish Commission secured examples in the Oswego river at Oswego and at Point Breeze in August 1894.

This species is said to reach a weight of 50 pounds, but the average weight of the market specimens is less than j pounds. In the Susquehamua it occasionally reaches 10 pounds or upward in weight. The pike perch feeds on the hottom on other fishes, and has been charged even with destroying its own young. It prefer's clear and rapid water's, and lurks under submerged logs aud rocks, from which it can readily dart on its pres. Spawning takes place in April and May, and in Pennsylrania continues till Jume. Favorite spanning localities are on samly bars in shallow water. The period of hatching raries from about 14 to 30 days, depending on the temperature of the water. The eggs vary from about 17 to 25 to the inch, and a single female has been estimated to contain from 200,000 to 300,000 . In a state of nature only a small percentage of the eggs are hatched out; the greater froportion are driven on the lake shores by storms or deromest by fishes on the spawning beds. The number of pike pereh annually hatched by artificial methods is enomous. This alvance is due to improvements in the treatment of adhesive egges. Formerly these were hatched by platcing them on glass plates, to 
Which they readily adhere. Tecently it has been found that the -lirky substance can be washed off the eggs, after which they al.. plated in jars and hatched like eggs of the shad and whitefish.

"I H.xter." in Furest and strom, Alug. 14, 1890, makes the following statwment about the labits of this species in the lakes.

These fish run up the rivers before or as soon as the ice is out, and after spatwing lie of the river's mouth feeding on and off the sand flats, as the spring rains bring down plenty of worms, and pobally other matter which they feed on. As soon as the watrr gets warm, they sag off and work along the shores in 10 10 :30 fret of water. preferring cobbly bottom; from hite they go into rery deel, watere, coming on the reefs to feed, and when the wind hlows rery hard, or for a day or so after a big blow, you will find them right on top of a reef. I think the wind changes the water orer the reefs, making a new current and cooler water, so they come up to feed. They are a bottom fish, and to fish for them sucessifully one must go to the bottom for them. They are

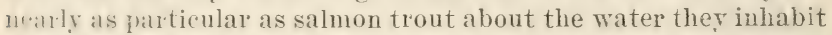
ant conseguently rank rery high as a food fish, being white, solid and extremely free from bones.

The (u)lors of the pike perch change remarkably with age. The yomo have ohligue dark bands much like those of the kingfish uf our eart wast, and bear little resemblance in the pattern of whoration to the parent. The eye of the living fish is like a giowing rmerald. The rate of growth must be rapid. In July $18 s 8$ We trok examples from 4 to 6 inches long, some of which seemer to be the young of the year.

This is me of the fincst food and game fishes of the Cnited siatrs. Ils \|lrsh is firm and white, flaky and well flarored. Com-

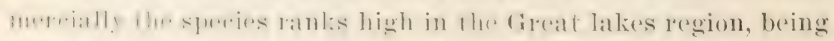
mos in fmplotume to the whitefish. In angling for the pike

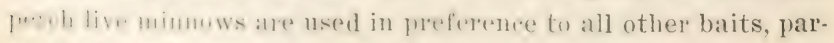
linaturly mach as are more or less transparent and with silvery

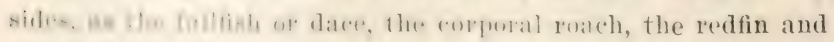

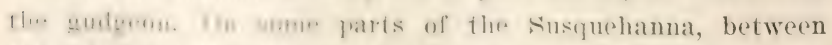

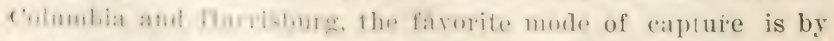
trobling with the groun with the same lind of tatekle as is used for the black bass. 
James Annin jr of Caledonia sent two individuals Ap. 23, 1896, for identification. They furnisher the following notes and measurements in inches.

\begin{tabular}{|c|c|c|}
\hline Length, including caudal........... & $18 \%$ & 18 \\
\hline Length to end of middle caudal rays. . & 18 & $171 / 8$ \\
\hline 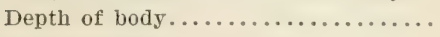 & $31 / 2$ & \\
\hline Least depth of caudal peduncle...... & $11 / 8$ & \\
\hline 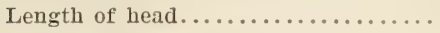 & $4 \frac{3}{4}$ & \\
\hline 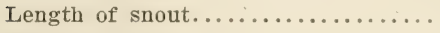 & $1 \frac{1}{4}$ & \\
\hline 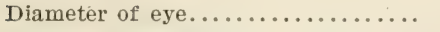 & $\frac{1 \pi}{16}$ & \\
\hline 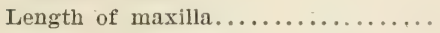 & 2 & \\
\hline 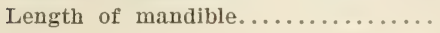 & $23 / 4$ & \\
\hline sal $\ldots \ldots \ldots \ldots \ldots \ldots \ldots \ldots \ldots \ldots \ldots \ldots \ldots$ & XIV, I, 21 & XIV, I, 20 \\
\hline Anal $\ldots \ldots \ldots \ldots \ldots \ldots \ldots \ldots \ldots \ldots \ldots \ldots \ldots \ldots$ & III, 11 & III, 11 \\
\hline 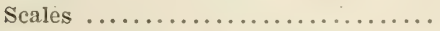 & 92 & . 93 \\
\hline
\end{tabular}

The pyloric carca are long and loaded with fat. The male is brassy; the female gray and whitish.

In November of 1896 and $1897 \mathrm{Mr}$ Annin shipped adult individuals from Canandaigua lake by express without an athudiant, and there was scarcely any loss of fish in transportatin. inuugh the journey lasts 12 hours.

The blue pike of Lake Erie, or white salmon of the Ohio river, was formerly distinguished by name from the common pike perch, but is now considered unworthy of a separate name. This is a very small variety seldom exceeding 15 inches in length and a weight of 2 pounds. The dorsal has 14 spines and 20 rays. The spines are rather lower than in the pike perch, the coloration similar, but the adult is bluish or greenish and has no brassy mottling. The fins are darker, and there is a trace of a band along the dorsal, besides the black blotch on the hind portion.

Jordan \& Evermann say of this variety: "The name sal. m o n e u m has been applied to the so called 'blue pile' originally described from the Ohio river, but more common in the Great lakes, particularly Ontario and Erie. It is smaller and deeper in body than the ordinary $\mathrm{r}$ it $\mathrm{r}$ e $\mathrm{um}$ and different in color, but it is not likely that any permanent distinctions exist, this species, as usual among.fresh-water fishes, varying largely with the environment and with age." 


\section{Subgenus cropenca Gill \& Jordan}

\section{Stizostedion canadense (Smith)}

Sauger; Sand Pike

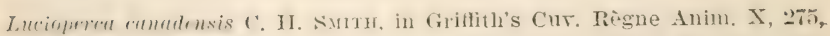
pl. T, 1834; DE KAY, N. Y. Fauna, Fishes, 19. pl. 6S, fig. 221, 1842 (extralimital); Güxtmer, Cat. Fish. Brit. Mus. I, 75, 1859.

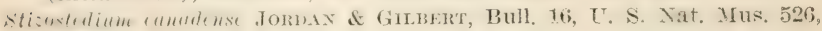
1883.

Stižostedion canadense MEEK, Ann. N. Y. Ac. Sci. IV, 314, 188s; BEAN, Fishes Penna. 130, pl. 34, fig. 70. 1893; Everuaxy \& Kexdald, Rept. U. S. F. C. for 1894, 601. 1896; Jordan \& Evermand, Bull. 17, U. S. Xat. Mus, 1022,1896, pl. CLXIV, fig. 434, 1900.

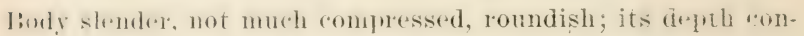
litimed four and one half to five times in the total withour candal. Thr. luanl is pointed, about two serenths of standird length and combins lhe eye five to fire and one half times. The mmuth is smather than in the pile pereh; the maxilla reaches to 11.. lind matrin of the ere. 1). XII to XIII, I, 17 to 18; A. II,

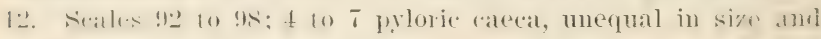
all of theri shorter than the stomach.

folur ulivarentis above: sides brassy or pale orange, mottled will liarli in llo. form of irregular dark blotehes, which are?

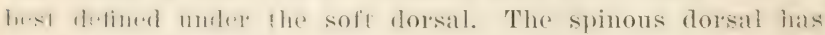

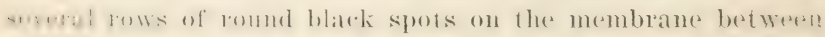
lle. :pines: an hlark hloleh on the hind part of the spinoms

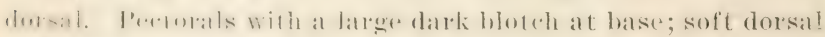

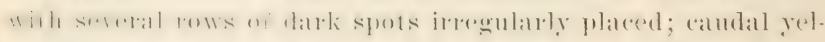
lowish with dark spots forming interrupted bars.

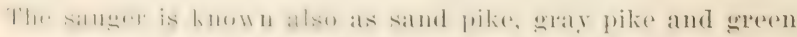

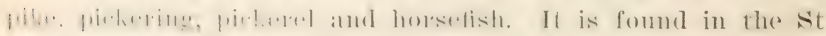

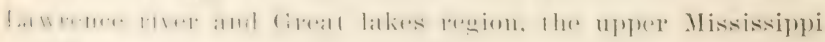
and Ilissomri rivers and in the Ohio, where it is said to have

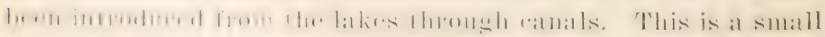

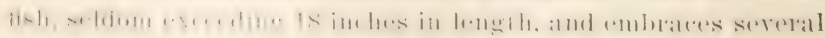

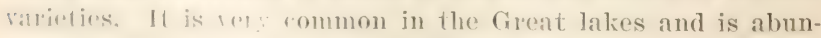

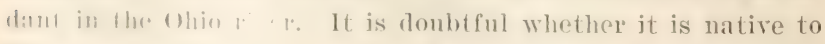
Ohin w infoulare: 1 is also found rately in Cayuga lake. liov: Kitulueli 'T'ho: in his II istory of Termont, says it is much 
less common in Lake Champlain than the pike perch, but is frequently taken in company with it. It usually swims rery near the bottom of the water', and hence it has received the name of ground pike (pike perch). Is an article of food this species is locally held in the same high esteem as the common pike perch.

John W. Titcomb of St Johnsbury V't. informed Evermann and Kendall that the sauger, or rock pike, as it is locally called, is caught in seines while fishing for the pike pereh. It does not grow as large as the latter, and is not much ralued as a food fish. The authors mentioned received two examples of the fish from 1. L. C'ollins of Swanton Vt., one of them a nearly ripe female $14 ! 3$ inches long, weighing three fourths of a pound, the other an unripe male 15 inches long. weighing three fourths of a pound. These specimens were believed to indicate that the sauger spawns earlier than the pilie perch. The stomach of the male contained a three inch minnow, too badly digested for identification, and a number of small insects.

It is very extensively used for food, but is not generally considered equal to the pike perch.

\section{Stizostedion canadense griseum (DeKay)}

\section{Gray Pike; Sanger; Sand Pike}

Lucioperca grisea DE KAY, N. Y. Fauna. Fishes, 19, 1S12, Great Lakes; streams and inland lakes of western New York; GüNthen, Cat. Fish. Brit. Mus. I, 76, 1859.

Lucioperca pepinus Estes, in H.tLlock's Sportman's Gazetteer. 322. 18т, Lake Pepin.

Stizostedium canadense var. griseum Jordax \& Gilbert, Bull, 16, U. S. Nat. Mus. 526, 1883.

Stizostedion canadense griseum Jordax \& Evermaxx. Bull. 47, U. S. Nat. Mus. 1022, 1896.

This is the common sand pike or sauger of the Great lakes region and southwestward. It differs from the typical can a de $\mathrm{n}$ se chiefly in the smoother opercles and head bones, the fewer opercular spines, and the less complete scaling of the head. The two need fuller comparison and may prove to be distinct species, but this is unlikely. Length 10 to 18 inches. 


\section{Genus penca (Artedi) Linnaeus}

Body oblong. somewhat compessed, the back elerated; whentis staly: opereles mostly naked; the operenlum armed with a sirgle spine; meojmele and shoulder girdle serrated; preoperele with retrorse, looked serrations below; mouth moderatc. torminal: furmaxillares protractile: teeth in rilliform bamls on jaws. romm, and palatines. uo caniue teeth; branchiostemals seren: gill membranes separate; pseudobranchiae smatl. bu1 perfwe : no anal papilla; scales rather small. strongly r.tenoid, latral line complete, the tubes straight and not extending to the extremity of the scale; dorsal fins eutirely separate, the first of 12 to 16 spines; anal fin with two slendei spines, well srparated from the soft rars; rentral spines well derelopeel, the ventral fins near together; caudal emarginate; air

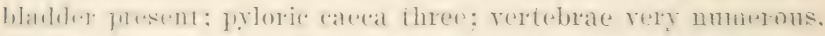
2120 or $21=41$ or 42 . Fresh waters of northern regions; three renclu related species now known, Perea fluriatijis in

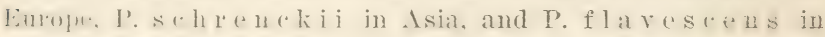
North America.

\section{Perca flavescens (Mitchill)}

\section{Yollow Perch; Ring Perch}

Morone plarescens Mrtcmil, Report in Part, 18, 1814.

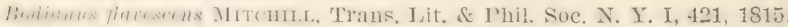

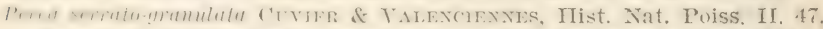

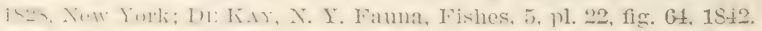

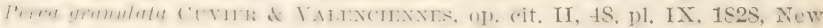
York; DE TAY, op. cit. 5, pl. 68, fig. 220, 1842.

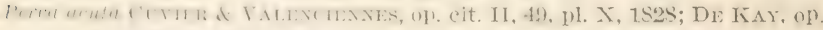
eit. 6, pl. 6S, fig. 222, 1842.

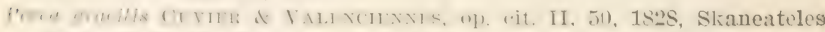

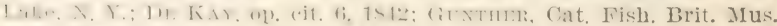
I, $(60,1859$ )

Peren umericunt Jorddix \& Gilbert, Bull. 16, U. S. Nat. Mus. 524, $18 S 3$.

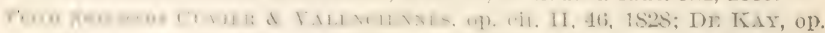

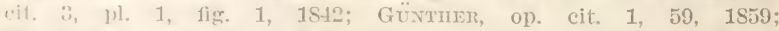
STom:1, Hist. Fish. Mass. 4, pl. II, fig. 1, 1867; MeEr, Ann. N. Y. Ac. sci. IV, :31, 1SS5; BnAx, Fishes Penua. 126, color pl. 12, 1893; Ever-

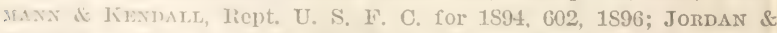
Evituxx, IBull. 47, U. S. Nat. Mus. 1023, 1S96, pl. CLXV, fig. 435, I9uo; lim., 1kull. Am. Mus. Nat. Hist. IX, 365, 1897; MEArns, Bull. am. Mus. Nint. Hist. X, 320, 189S; Eugene Sarmm, Proc. Linn. Soc. $\therefore$ Y. 15!7, : $: 7,1598$ 
The yellow perch has a fusiform and moderately elongate body, its greatest hight at the rentral origin two sevenths of the total length without the caudal and nearly equal to the length of the head. The least depth of the caudal peduncle equals one third of length of head. The greatest width of the body equals one half its greatest hight. The head is moderately long, its length contained three and one fourth times in the standard, with pointed snout, one and one third times as long as the eye. The interorbital region is flat, its width one and one half times the diameter of the ere. The mouth is rather large, the jaws equal, and the maxilla reaching to below middle of pupil. The preopercle is coarsely dentate on its hind margin, the teeth on the superior border directed partly upward and partly backward. those on the lower limb pointing downward and some of them forward. The scapula and humerus are finely serrate. Scales on the eheeks in about 13 rows from before backward; a single row or two imperfect rows of scales on the suboperele; four short rows of seales on the upper anterior part of the opercle. Gill rakers $6+14$, the longest one half as long as the eye. The spinous dorsal begins over the base of the pectoral; the first spine is one third as long as the head to the end of the opereular spine; the fourth and longest spine is as long as the eye and snout combined; the last spine is minute and concealed in the dorsal furrow. The soft dorsal in the specimen described is preceded by two spines, the first two thirds as long as the eye and one half as long as the second; the longest ray is as long as the longest spine, and twice as long as the last ray. The ventral origin is under the fourth spine of the dorsal; the fin equals one fifth of the total lengti without the caudal. The anal origin is under the fourth or fifth soft dorsal ray; the first anal spine one third as long as the head and nearly as long as the second; the last anal ray less than one half as long as the longest, which is one half as long as the head. The caudal is notehed, the middle lays contained one and one third times in the length of the onter mays. The pectoral is as long as the ventral. I). XT. II, 1?: A. II, S; 


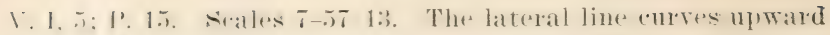

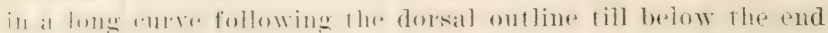

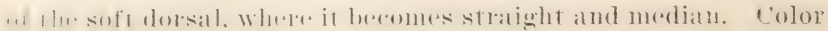

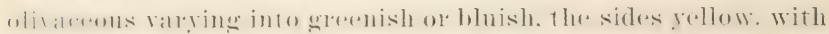

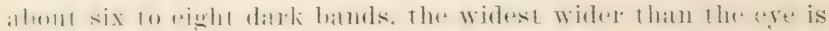

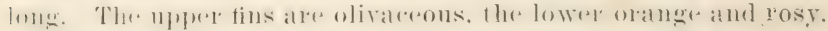

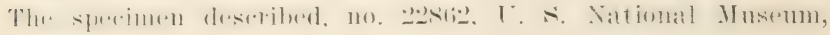
Washingtom D. C., is 9 inches long.

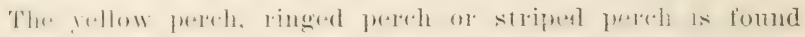

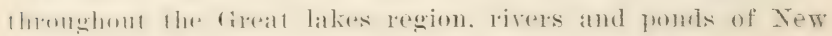

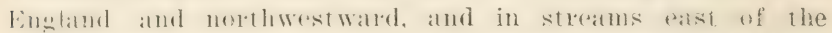

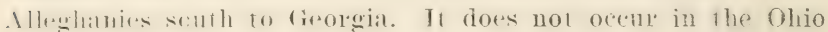
valley of somblowst, though, after the ronstruetion of the ohio (atmat. Firtland recorded it from the Ohio river. In 1790

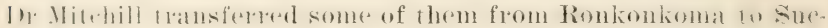
ress fumd, a distane\% of 40 miles. Whele they soon multiplied.

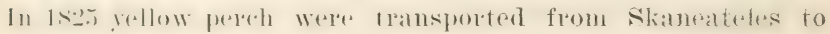

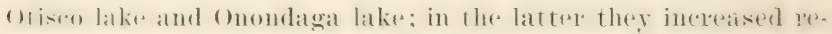
malliahly. In ()tsego lake Inekay raught some weighing nextrly

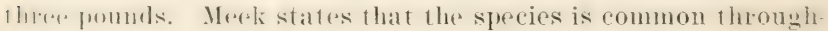

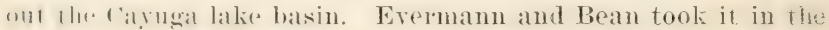

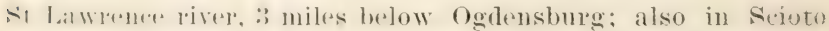

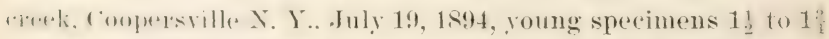

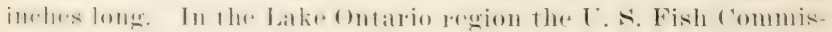

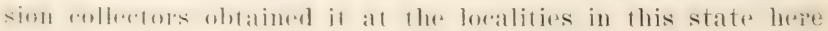
mentioned.

Moutl of Salmon river

Ifouth of Little Salmon creek

Jilarli creek, tributary of Oswego river. Seriba Corners

simty r.rexk, Hamlin

fifruatiel island

vitony islatud

f'hammont l.ive'le

Hutlet of lome pond, Charlotte

l.it1r stomy hrouk, Iraderson bay

f ilpe: lincent 
Creek at Pultneyville

Great Sodus bay

Four Mile creek, 1 mile above mouth

Lakeview hotel, $7 \mathrm{~m}$. n. e. of Oswego

Three Mile creek, near Oswego

Long pond, Charlotte

Salt brook, $1 \frac{1}{2}$ miles above Nine Nile point.

The yellow perch is one of the most abundant fishes of Lake Champlain and in the mouths of rivers falling into that lake.

The fish abounds in the parks of New York and Brooklyn. In the Hudson Highlands Dr Mearns reported it as abundant in the Hudson as well as in all of the larger mountain lakes and ponds. It habitually frequents Poplopen's creek from its source to its mouth. In the Hudson, he was informed, it is unusual to take specimens weighing more than 1 pound; but in Poplopen's pond he has taken a number that weighed about 2 pounds each. In the same pond Jerome Denna caught two which weighed 21 to 3 pounds each; and a fisherman named Samuel Rumnels assured 1)r. Mearns that he had taken a yellow perch there which weighed 4 pounds. The fish continue to feed in that region throughout the winter. Eugene Smith obtained the fish in Greenwood lake. Orange co., and in Hackensack streams, in Rockland county.

The species reaches a length of 1 foot and weight of two pounds. It is one of the best known of our food fishes and has excellent game qualities. Its flesh, however, is rather soft and coarse and is far inferior to that of the black bass and other members of the sunfish family. It is a roracious feeder, its food consisting of small fishes, crustacems and other animal matter.

The yellow pereh spawns early in the spring. The egas are adhesive and inclosed in thin transluerent strips of adhesive mucus. The spawning of this speries was described by William P. Seal in Forest and strerm of $\Lambda_{p}$. 17, 1ston. The spalwning season extends from December to . Ipril. Mr seal deseribes the egg mass as having the shajue of a loug tube, closed al the ends 
and aranged in folds like the beilows of an accordion. When

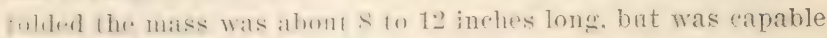
wf lu.ing drawn out fo a lengh of $:$ or 4 feet. Spawning in the afuatrum touk plar. at night and was observed br Trilliam Maynard, who descrilus it as follows. . The female remained fuif in whe spet on the luttom of one of the hatehing aquaria lanks on. ar mor of the mates hovering oser and about her with fertulal the viluating with intense artivity. The males womld at limes lir. olose alongside of her and at oflere times

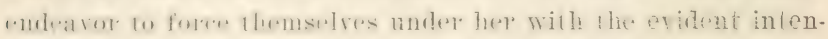

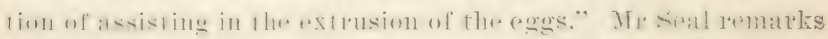

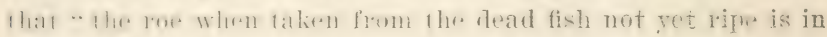

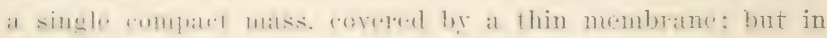

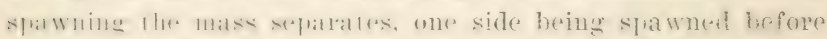

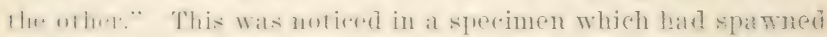

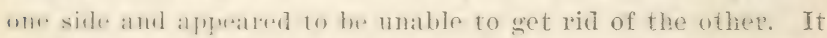
was sfripjed from her and antiuteially fertilized suecessfully, Mr. Sal believes lhat dhe yellow pereh spawns at the age of one year.

The rellow furch thrives moderately in captivity, though susmplihte fo atlatels of fungus, which are easily overeome by the 11se of hrarkish watrep. Its food in calptivity consists chiefly of Hhr|lut hatrd elams; sommimes live killifish are used.

\section{Genus pencrsa Haldeman}

lind: remgale. slightly compressed, covered with small,

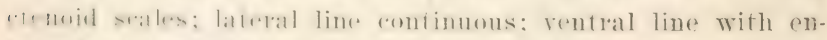

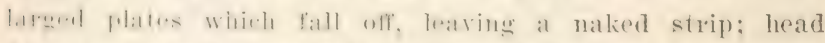

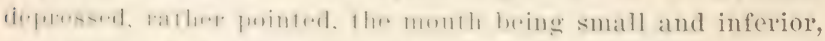

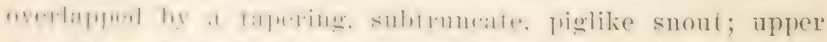

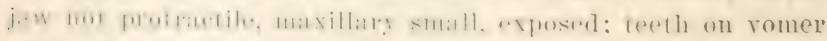

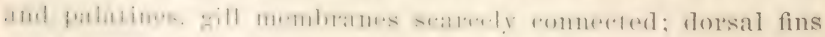

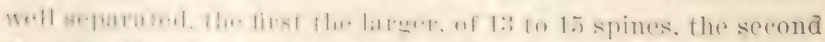

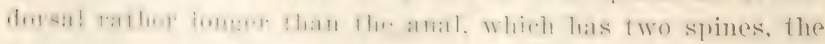
first of which is usually the shorter; pectorals symmetric, mondmal of huntly printed, their rays 14 or 15 , their spines moleratr; ventml fins well separated, the interspace about 
equal to their base; air bladder and pseudobranchiae present, rudimentary; vertebrae (P. c a p rodes) $23+21=t t$. General pattern of coloration olivaceous, with dark vertical bands alternately long and short. Size largest of the darters, approaching that of $A \mathrm{~s}$ P ro, a genus to which it is more nearly related than the other darters are.

\section{Percina caprodes (Rafinesque)}

\section{Log Perch; Hogmolly}

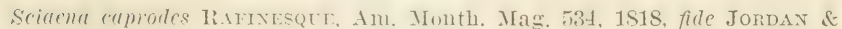
EVERMANN.

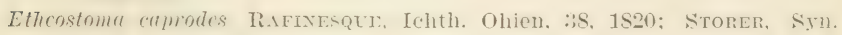
Fish. N. A. 18, 1846; Bean, Fishes Penna. 122, pl. 33, fig. 68, 1893.

Pilcoma semifuscintum Di Ii.u. X. Y. Famma, Fishes, 16. pl. 50, fig. 162, 1812; GüNrher, Cat. Fish. Brit. Mus. I, 76, 1859.

Percina celmorles Jot:n.从 \& (imbent. Bull. 16, U. S. Nat. Mus. 499, 1S83; Evemaxa \& KExD.1Lt, Rept. L'. S. F. C. for 1S91. 602, 1S96; Jordan \& Evermand, Bull, 4T, UT. S. Nat. Mus, 1026, 1896, pl. CLXT, fig. 436. $436 \mathrm{a}, 1900$.

Body loug, moderately compressed; head long, with pointed snout; mouth small, the lower jaw not reaching near to tip of snout, and the maxilla not extending to the front of the eye. The head forms one fourth of the total length without the caudal, and the depth equals about one sixth. Scales on cheeks and gill corers, also on the space before the first dorsal; breast scaleless. I row of enlarged plates on the belly; which are sometimes deciduous. Fins moderately low and rather long. D. XV, 15; A. II, 9. Lateral line with 92 scales. Color greenish rellow: sides with about 15 dark cross bands, extending from back to belly; alternating with these above the lateral line are fainter bars. Fins barred. A black spot at the base of the caudal.

The log perch, hogfish, hogmolly, rockfish or crawl-a-bottom is found in the Great lakes region, Quebec and the eastern states south to Trirginia, also in the Mississippi ralley south to Alabama and Texas. De Kay obtaned it at Westpolt on Lalie Champlain, where it appeatred to be very abundant, as well as in many streams in that vicinity. Its local name there he gives as little pickerel or pickerel, which it slared in common with 


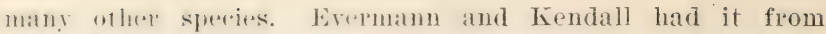
Romse l'oint and l'lattshurg. on the west shore of Take Champlain.

This is "lhe laterest of the darters. reaching a leugth of $S$ influes, and in many resperets resembles the perehes. It lakes the hook very readily. The $\log$ wereh is found in rapid streams with grawly or rocky hottom and prefers clear waters.

\section{2ts Percina caprodes zebra (Agassiz)}

\section{Manitou Darter}

l'ileoma zebra AGAssiz, Lake Superior, 308, pl. IV, fig. 4, 1550.

Pereina maniton Jordax, Proc. Ac. Nat. Sci. Phila. 53, 1577.

Percina caprodes var. manitou JondAx and GILBEnT, Bull. 16, U. S. Nat. Mus. 500, 1853.

Percina caprodes zelir Jordan and Evermaxy, Bull. 47, U. S. Nat. Mus. $1027,1896$.

Ilead four and one fourth; depth severo; maje alwals naked: latratal blark batrs short. shorter thath in caplodes. not Pxfonding mureh above lateral line, these also more or less con.

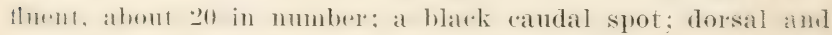
ratudal mottled. D. XV-14; 1. II, 10. Scales 90.

latirs of nortlurn Indiana. Michigan. Wisconsin and north.

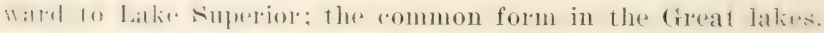

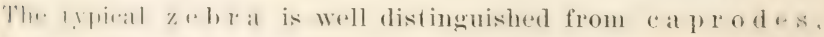

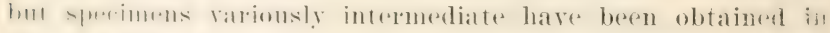

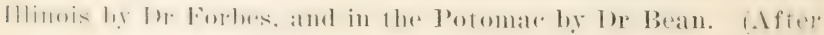
Jordan and Evelmann)

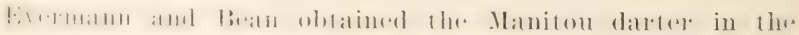

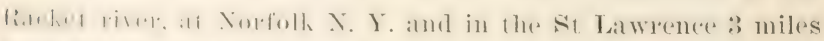
lol lon (1)

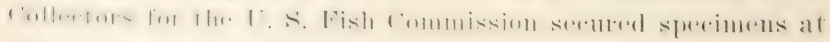
thr. following plates in 1S!?:

Vine: Mile point, Lake Ontario

June 11

limenatien istatnil

Tulne 27

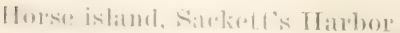

June 30

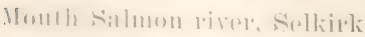

July 25

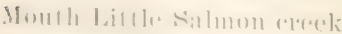

July 25

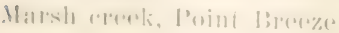

Iug. 2 


\section{Genus hamopteres Agassiz}

Body rather elongate, compressed or not; mouth rather wide, terminal, the lower jaw included, the snout above not protruding beyond the premaxillaries, which are not protractile; teeth on vomer and usually ou palatines also; gill membranes separate or more or less ronnected; seales small, ctenoid, covering the body; belly with a median series of more or less enlarged spinous plates or ctenoid scales, which in most species fall off at intervals, leaving a nalied strip, in some species persistrat and but slightly enlarged; sides of head scaly or not; lateral line complete or nearly so; fins large, the soft dorsal smaller than the spinous or the anal; anal spines two (one of them very rarely obsolete); dorsal spines 10 to 15 ; rentral fins more or less widely separated, specially in species with eaducous plates. Vertebrae 39 to 44 ; H. a s pro, $19+23=42$; H. evides, $18+2=40$; H. s c i e r us. $18+22=40$; H. phox o cepha I us, 19-20=39. Parietal region more or less depressed, not strongly conrex in cross-section; suprat-occipital crest usually present, but small. Prloric caeca two to four. Coloration bright, often brilliant, sides usually with dark blotches.

\section{Subgenus axvorbrus Girard \\ 249 Hadropterus aspro (Cope \& Jordan)}

\section{Black-sided Darter}

Atrordius uspro Cope \& Jondin, Proc. Ac. Nat. Sci. Phila. 51, 1577, substitute for Etheostoma blenuioides of Kirtland and Agassiz; Jordax \& Gilbert, Bull. 16, U. S. Nat. Mus. 501, 1883.

Ethcostoma aspro BEAN, Fishes Penua. 123, 1893.

Hadropterus aspro Jordan \& Evenur.1xx, Bull. 47, U. S. Nat. Mus, 1032, 1896. pl. CLXVI, fig. 438, 1900.

Body slender, fusiform, elongate, its greatest depth one sixth of length without caudal; least depth of caudal peduncle nearly one third of length of head; head rather long and pointed, one fourth of total length without caudal; the maxilla extends slightly past front of rye; the mandible is included; the ere large, equal to length of snout and to one fourth the length of head; gill membranes slightly connected; postorbital part of head a little longere than the remainder" the naje scaly or nalied; weeks 
with rery small sralles, sometimes hardly risible: large seales wn ofwreles: dorsal wrigin at a distance from eye equal to lengrh wif funtoral, hase of spimms de!sil nearly equal to one third of tolal leluglh willoul antull, fourth to serenth spines longest, mplal to suon and +.y. anmbined. last spine two thirds as long as the first and teplat to snomt: hase of seenud dorsal one half

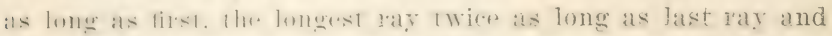

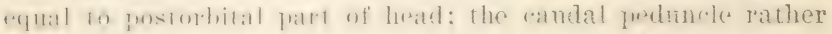

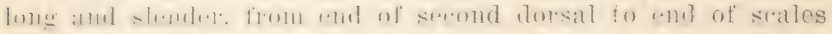

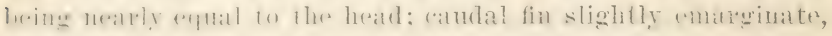

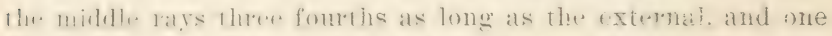
third of lengh of heats the anal origin at a distance from tip

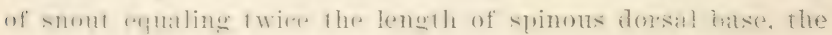

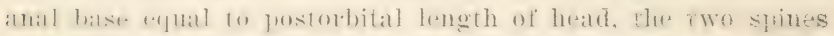

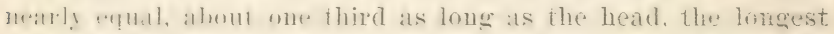
mat ditth mpual to one half the length of spinous dorsal bitse: the rentral not far behind the base of the gretoral. its length about nne half thr. distane from its origin to erigin of anal; pectoral un. fifth of total length to end of middle candal rays; lateral line straight. "xtemling from "ye to base of caudal fin: breast lualind: a series of pularged radueous scales on median line of

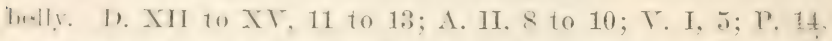

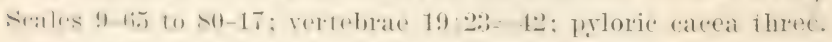

Thr. sides arr slraw rolored or greenish rellow. with dark tessellations and mablings above and with about seren large darli hluteles, which are party confluent; the fius are barred, and there is a small spot at the base of the caudal.

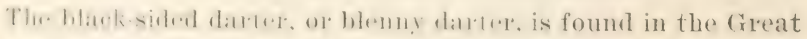

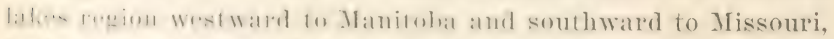

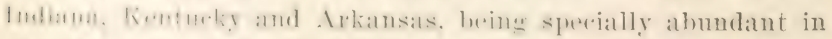

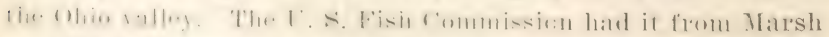

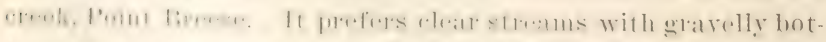
foms smit is mog.e actide in its hahils lhan most of the other

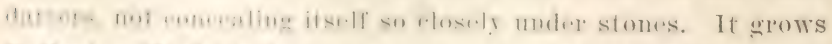

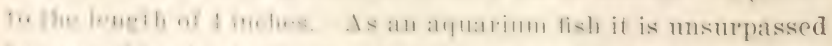

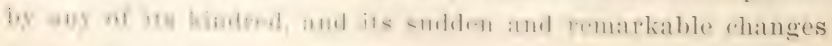


of brilliant colors during the breeding season render it unusually attractive.

\section{Genus cotrogaster Putnam}

Body rather robust, little compressed; head moderate, bluntish; mouth morlerate or small; the lower jaw included; premaxillaries protractile or occasionally (in s h u $\mathrm{mar}$ di) joined by a narrow frenum to the frontal region; maxillary not adherent to the preorbital; teeth on romer; gill membranes nearly sepalate: sales ctenoid: the middle line of the belly anteriorly maked or with caducous stales: lateral line continuous; dorsal fins large. the serond nsually smaller than the first and smaller than the anal: anal spines fwo, the first the louger;

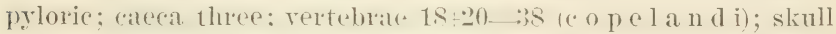
short, the frontal region not very narrow, parietals little convex transrersely, sutures distinct; no supra-occipital crest. Coloration not brilliant. Size moderate.

\section{Cottogaster copelandi (Jordan)}

\section{Copeland's Darter.}

Bolcosoma tessellatum Trompsox, Appendix Hist. Vermont, 5, 1853, not of DE KAY, N. Y. Fauna, Fishes, 20, 1842.

Rheocrypta copelandi Jordas, Bull. 10, U. S. Nat. Mus. 9, 1877.

Cottogaster mutnami Jordan \& Gilbert, Bull. 16, U. S. Nat. Mus. 498, 1883. Cottogaster copelandi Jordan \& Erermann, Bull. 47, U. S. Nat. Mus. 1045, 1896.

Body rather slender and elongate, the depth being contained from five and one half to six and one half times in the length; head rather large and long, somewhat narrowed, resembling that of $\mathrm{Boleos} o \mathrm{ma}$. Its length is contained from three and three fourths to four and one fourth times in the length of the bodr. Mouth small, horizontal, subinferior; cheeks naked; opercles and neck each with few scales; throat naked; rentral plates well developed; seales moderate, strongly ctenoid; pectoral as long as head. D. X to XII 10 to 12 ; A. II, S or 9. Scales $6-44$ to $56-8$.

Color bromnish olive: a series of rather small, horizontally oblong, black blotches along the lateral line, forming an interrupted lateral band; back tessellated; blarkish streaks forward 
and downward from ere; rentral fins dusky in the male; reptical fins with lusky sperelis: a small inklike sperk at base of caudal

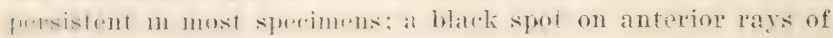
spinous dorsal.

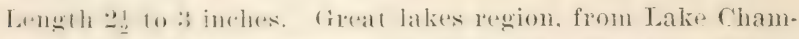
flatin to Lakt IImon: Jepresented in New York Watres by the subspecies C. put n a mi.

\section{Cottogaster cheneyi Evermann \& Kendall}

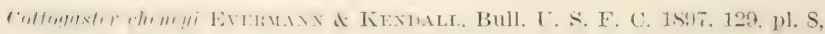
fig. S, 1S9S, Iacket River near Norfolk, N. Y.; Jordas \& Everurars, Bull. 47, U. S. Nat. Mus. III, 2851, 1898.

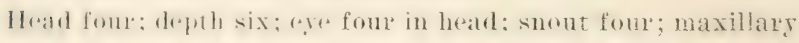
three and one half: inferentital width fire and one half. D. II-12: . I. II, s. Sales 7-o6-6. Mody rather stout. heary for-

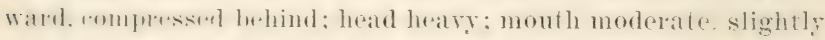

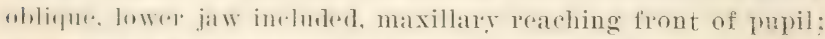

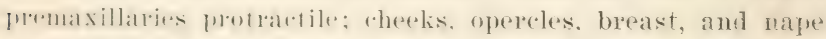

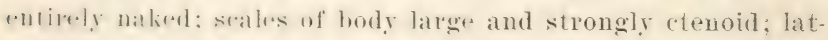
rral lime complede. slratght: median line of belly naked ante-

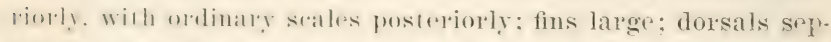

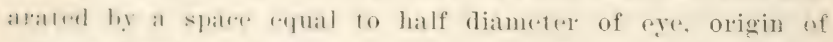
spimous dolsal a litle nealer origin of soft dorsal than lip nf

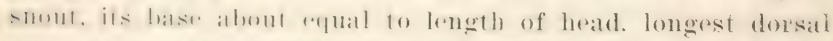

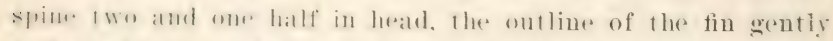

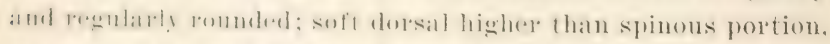

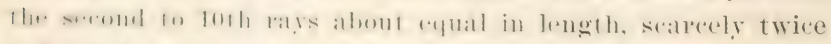

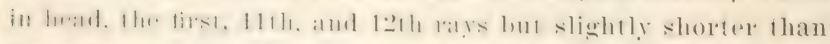

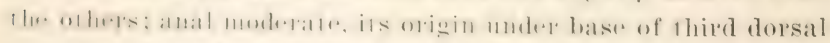

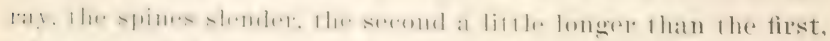

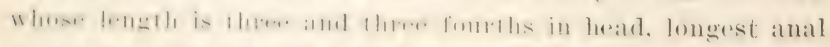

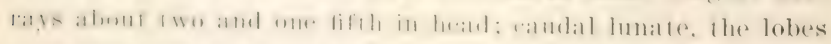

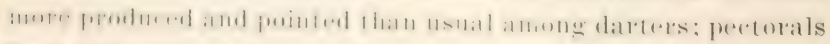
lolgg and pointerl, the midale rays longest, about one and one

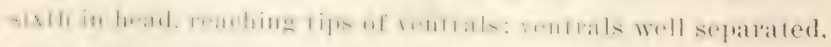
mot matrly reaching vert, the longest rays one and one fourth in hrad. folor in aloohul, back dark lorownish, eovered with 
irregular spots and blotches of darker; side with about eight or nine large dark spots lying on the lateral line; belly pale; top of head dark; snout black; lower jaw and throat dark; a broad black line downwarl from eye to throat; cheek and opereles rusty; spinous dorsal crossed by a median dark line; rentrals blue black; other fins pale, but dusted with rusty specks.

In examination of the 14 rotypes shows some variation in the species. In two examples there is a well dereloped frenum, rendering the fremaxillaries nomprotractile, and in a third specimen the frenum is partially dereloped: in some individuals the origin of the spinous dorsal is exactly midway between the tip of snout and origin of soft dorsal. The females and immature males are less highly colored than the adult male described above. Length $1 \frac{3}{4}$ to $2 \frac{1}{4}$ inches.

This species serms most closely related to cot tog a s ter s h 1 m a r d i. from which it may be readily distinguished by the shorter snout, the naked cheeks and opercles, the smaller soft dorsal, the smaller anal and the coloration.

1.) examples of this interesting darter were obtained July 18 , 1894, by Erermann and Bean in the Racket river near Norfolk, St Lawrence co. $\mathrm{X}$. Y. It did not seem to be rery common, as only 15 examples resulted from numerous hauls of the collecting seine.

Named for A. Nelson Cheney, state fish culturist of New York in recognition of his raluable contributions to our knowledge of the food and game fishes of that state. (Ifter Evermann and Kendall)

\section{Genus Diplesiox Rafinesque}

Body rather elongate, subterete; head rery short and blunt, with tumid cheeks; the profile very convex; month small, inferior, horizontal; premaxillaries protractile, little morable, joined to the forehead mesially by a slight frenum; maxillary not protractile, adnate for most of its length to the fleshy skin of the preorbital; lower jaw very short; teeth in jaws strong, no teeth on vomer or palatines; gill membranes broadly con- 
nerted; gill rakers rery short: scales moderate, rough; lateral line emplete; no enlargerl ventral plates; dorsal fins large, the - prims dorsal lomger and lower than the second, of about 13 spines; anal smalle. thatu second dorsal, with two strong spines;

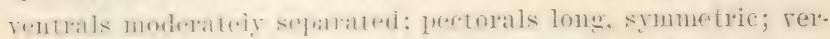

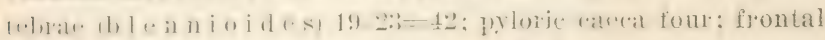

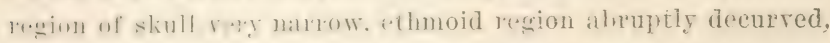

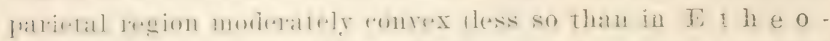

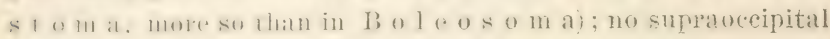
crest. Coloration largely green.

\section{Diplesion blennioides (Rafinesque)}

\section{Green-sided Darter}

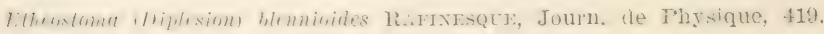
1819.

Etheostoma Utennioides BEAN, Fishes Penna. 121, 1893.

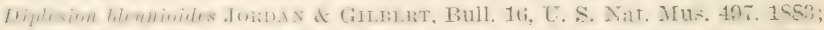

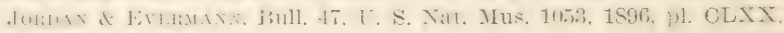
fig. $449,1900$.

The londy is stoml and long; the head moderate in size. its length emutaned four and one half times in the cotal wirlont (andial and slighly exeeding the depth of the body: month smatl: lower jaw ineluthel within the upper; eres large, plated high and narmoly srparated by a longitudinal furrow: scales raller smatl exwpl some larger ones on the belly, which are not

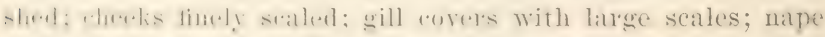
sably: hreast nakerl. The males have a large anal papilla.

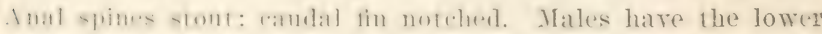

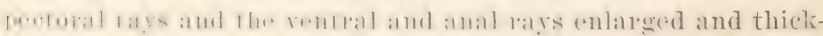
encid. J). AIII-13; A. II, S. Scales 65 to $7 S$; rertebrae 42.

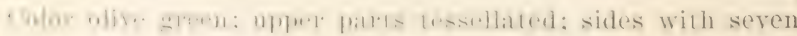

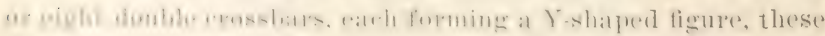

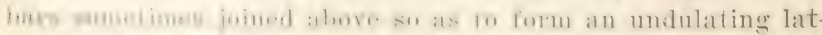

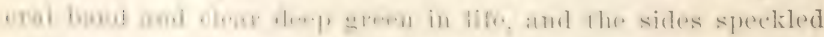
will mallge. There is a dark bar from the eye forward and amother downward, hesides some olive stripes on the head.

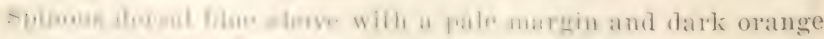

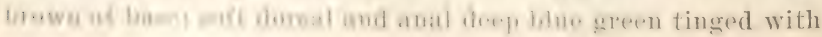


red; caudal greenish with faint bars. Females and young are less conspicuously colored, but in the same general pattern.

The green-sided darter extends from Pennsclrania westward to Kansas and south to Alabanı. The U. S. Fish Commission had specimens from Saudy creek, North Hamlin N. Y., Aug. 20. The species is notable for its beautr; it grows to a length of 5 inches; it is common in gravelly streams and occurs only in clear water. In habits it is similar to the Johnny darter, but it is less tenacious of life than that fish. In the aquarium it is shy and retiring, spending most of its time in the concealment of water plants or decorative rock work.

\section{Genus воцеомом De Kay}

Body moderately elongate, fusiform, but slightly translucent; head small, narrowed forward, the profile convex; mouth small, horizontal, the lower jaw included; premaxillary protractile; maxillaries not adnate to preorbital; romerine teeth present; seales large; lateral line continuous or interrupted behind; belly with ordinar's scales; gill membranes broadly or narrowly connected; dorsal spines usually nine, rery slender and flexible, soft dorsal much larger than anal; anal normally with a single, short, slender spine, the first soft ray simple, but articulate; ventrals well separated; vertebrae (I3. n i g r um) 15:22=37; pyloric caeca three to six; frontal region of skull rery short and narrow; parietal region flattish abore; no supraoccipital crest. Coloration oliraceous and speckled, the males with inlsy black in spring; no red or blue. Size small. Tery actire little fishes, abounding among: weeds in clear streams.

\section{Boleosoma nigrum (Rafinesque)}

\section{Johnny Darter}

Etherstoma nigrum Rifexesque, Ichthyol. Ohien, 37, 1520; PEAx, Fishes Penna. 120, 1893.

Bolensoma maculalum Agassiz, Iake Superior, 30., 1)l. IV, fig. 3, 1550, Fort William; Güntrer, Cat. Fish. Brit. Mus. I, 77, 1859.

Boleosoma nigrum Jordiv \& GILBert, Bull. 11;. C. S. Nat. Iius. 492, 1S:3; Jordax \& Eversins, Bull. 47, U. S. Nit. Mus. 1051;, 1S96, pl. CLxX. fig. $450,1900$.

The body is slender, spindle-shaped. The conical head is contained slightly more than four times and the depth about fire 
libus in the total length. The snout is somewhat decurved. Mnmll small and the lower jat included within the mper. The

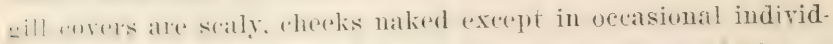
mais. and the natge is usually scaled. The fins ate high, but lower

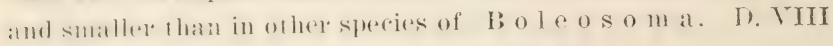
to $\mathrm{X}, 10-14 ;$ A. I. 7 to 9 ; scales $5-44$ to $55-9$.

folm olivareons: whe bark with brown tessellations: sides with many 11 -shated blotehes. The head is sperkled abore: in males

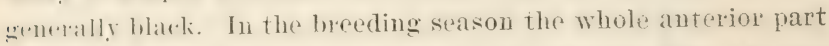
of the male is often black. I dark line formard frem the eve amd smmetimes amothere downward. This is one of the small spreim, attaining a length of only zy inches. It is found on the luttom in rleat small brooks, where it lies partly concealod by simd, and rhanges its rolors according to its survoundiugs.

The Jolmuy darter langes from western P'ennsylyania ho Mis somri and l)akota. In the (ireat lakes region it is abmulant, and it is one of the commonest darters in the streams of Ohio. 11 does not merul in eastern Pemmsylrania. In New Iork is appears to oceur in the Great lakes region only.

\section{Boleosoma nigrum olmstedi (Storer)}

\section{'Tessellated Darter}

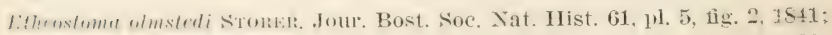
Hist. Fish. Mass. 30, pl. IV, fig. 1, 1867; BEAx, Fishes Peuna, 120,

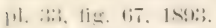

Boleosoma olmstedi Goode \& BEAx, Bull. Essex Inst. XI, 19, 1879.

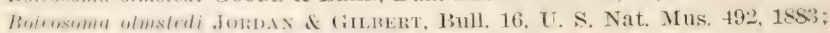
Bfax, Bull. Am. Mus. Nat. Hist. IX, 365, 1897.

Ftheostoma nigrum olmstedi MeEk, Ann. N. Y. Ac. Sci. IV, 313, 185.

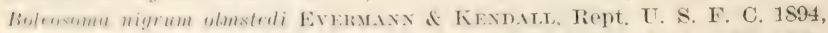

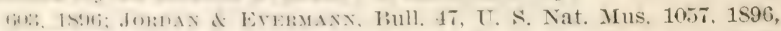

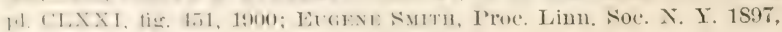
:36. 1898 .

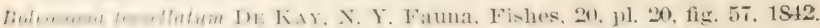

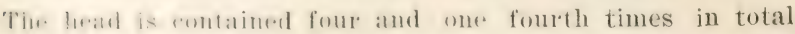

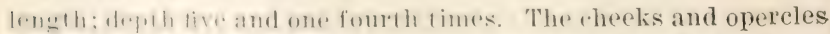

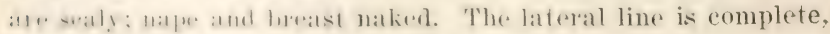
With alumt 50 scules. 1) 1X, 14; A, I, 9.

The molew is whrmomus: fins with many malrow hars: the back

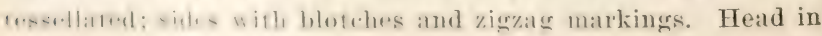


pring males black. A dark streak forward from the eye and inother downward.

This darter secretes itself on the bottom in small clear brooks, wimming rapidly for a short distance when alarmed. The sexes ure very different in appearance, the males having higher and nore brightly colored fins than the females. The males are arger than the females and in the spring are much spotted with lack. The common darter, or tessellated darter, is found from Iassachusetts to Georgia. It is replaced in Cayuga lake and some other regions to the southward by a black spotted variety, rhich differs from the common form still further in having the ape and breast closely scaled. De Kay states that it occurs n most of the fresh-water streams of the state. It is found in Lake Champlain. Evermann and Bean took it in Scioto creek, at Coopersville, in the Saranac, at Plattsburg, in the St Lawrence river, 3 miles below Ogdensburg, and in Racket rirer, at Norfolk. In the Lake Ontario region the U.S. Fish Commission collectors obtained it in the following localities:

Cape Vincent

June 21

Mud creek, Cape Vincent

June 25

Grenadier island

June 27

Horse island, Sackett's Harbor

June 30

Mill creek, Sackett's Harbor

July 2

Stony Island

Little Stony brook, Henderson bay

Cemetery creek, Watertown

Guffon creek, Chaumont

Chaumont river

Spring brook, Pulaski

Mouth of Salmon river, Selkirk

Mouth Little Salmon creek

Three Mile creek, Oswego

Great Sodus bay

Long pond, Charlotte

Sandy creek, North Hamlin

$\begin{array}{rr}\text { July } & 2 \\ \text { July } 2 \text { and } & 3 \\ \text { July } & 4 \\ \text { July } & 5 \\ \text { July } & 7 \\ \text { July } 10 \\ \text { July } 24 \\ \text { July } 25 \\ \text { July } 25 \\ \text { July } 27 \\ \text { Aug. } 6 \\ \text { Aug. } 17 \\ \text { Aug. } 20\end{array}$


Areording to Dr Mreek it is common at each end of Cayuga lake. hut is not found in the streams at the southern end above 1hr: falls. The species was obtained in small numbers by the writer in Broux river in August, 1897. Engene Smith has obtainel it in tidal reeks where the water is impure but not saline. It is rerorded from streams of Long Island.

The tesserlated darter grows to the length of $3 \frac{1}{2}$ inches. It is a near relative of the Johnny darter, B o l e os o m a $\mathrm{n}$ ig r u $\mathrm{m}$ of Rafinesulue. In eaptivity Eugene Smith has found it delicate, ahle to live only in water of low temperature and not deep unless in circulation. In balanced tanks it thrives and feeds freely on minced clam, G a $\mathrm{m} m$ a $\mathrm{r} u \mathrm{~s}$, and earthworms, the last to be used only occasionally.

De Kay observed it usually at the bottom of clear springs or streams, lying for a while perfectly still near the bottom, and then suddenly darting off with great velocity at its prey, a habit from which is derived its name of darter. He mrntions also the name arand-oranche, applied to it in New York by the descremlints of the Inteh colonists, but this name is not sutisfactorily explained.

The best account of the movements of the fish is given by Zarlerk Thompson in his 7 istory of Termont. He noted its power of broling its neck and moving its head without moving the body, a rery unusual faculty among fishes.

\section{Genus etmeostoma Rafinesque}

Louly rohust, or rather elongate, compressed; mouth terminal, or subinfurer, varying in size; the lower jaw included or projuflug: promaxillaries not frotratete; maxillary movable; fwelh lather strolig, usually present on romer and palatines; zill membrames separate or nure or less broadly connected;

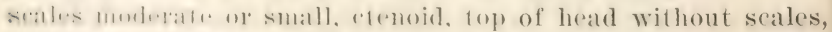

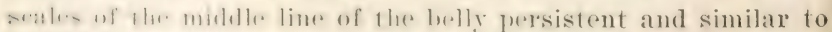
Her whers: lateral line well dereloped, nearly straight, often wantime fusteriofly; lins laree, with strong spines, first dorsal

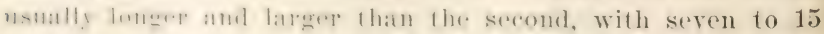

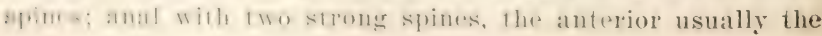


arger, the second rarely obsolete, anal fin always smaller than he soft dorsal; rentral fius more or less close together; skull arrow, the parietal region very strongly convex in crosssection, supraoccipital crest very small or wanting; lower haryngeals very narrow; rertebrae 33 to 39 , usually $15+21=36$; oyloric caeca three or four; bones rather firm. Coloration rarious, often brilliant. As here understood, a rery large genus covering a great rariety of forms. Many attempts at further subdivision have been made. Intergradations of all sorts occur, and the technical characters do not always indicate the real relationship. Many of the species are excessively variable, each orook having its peculiar race.

\section{Subgenus oligocephatus Girard}

\section{Etheostoma coeruleum Storer}

\section{Blue Darter; Rainbow Darter}

Etheostoma coerulea Storer, Proc. Bost. Soc. Nat. Hist. II, 47, 1845, Fox River, Ill.

Poecilichthys coeruleus Jordan \& Gilbert, Bull, 16, U. S. Nat. Mus. 517, 1883.

Etheostoma coeruleum MeEk, Bull. U. S. F. C. 119, 131, 155, 1891; BEAN, Fishes Penna. 125, 1893; Jordan \& Evericavi, Bull. 47, U. S. Nat. IIUs. 1088, 1896.

Body short, comparatively stout; head large; mouth moderately large, the lower jaw included within the upper. The maxilla extends to the front of the eye. The length of the head is contained three and three fourth times in the total length without the caudal, and the depth of the body four and one fourth times. Five rows of scales abore the lateral line, eight rows below the lateral line, and 45 rows from head to base of caudal, nape and breast generally scaleless. D. I, 12; A. II, 7. The body of the male is oliraceous with darker blotches on the back, 12 bars of indigo blue running obliquely downward and backward across the sides. The spaces between the bars are orange, as are also the throat, breast and chceks. The base of the spinous dorsal is crimson, surmounted by orange and margined with blue. The soft dorsal is orange, its base and margin blue. In the female the blue and orange color's are 
chietly wanting, and the dorsal, aual and caudal are checked or barred.

The blue darter, bluc Johnuy, rainbow darter, or soldier fish, is found in the Ohio valley and in some parts of the Mississippi valley. It abounds in gravelly streams and ascends small brooks. but not in large numbers. The C. S. Fish Commission obtained many indiriduals in Marsh ereek at Point Breeze N. Y. Aug. 2, and a few in Salt brook, $1 \frac{1}{2}$ miles above Nine Mile point, June 11, 1893.

The blue darter reaches a length of 3 inches. It is not so active as some of the other darters, but in coloration it is the most beatutiful of all. One of the most interesting aceonuts of its habits is republished in Bulletin 47, U. S. National MLusm, from the writings of Jordan and Copeland. It will follew to the smrface of the water a piece of meat suspended by a thread ari has been seen to catch a water insect by a swimming leg and release it several times, apparently for the mere pleasure of playing tricks.

\section{Subgenus ETHEOSTOMA}

\section{Etheostoma flabellare Rafinesque}

\section{Fantail Darter}

Eihegstoma flalelluris Iidfrisesque, Jour, de Physique, Paris, 419, 181 ?.

Etherstume linsleyi Storer, Proc. Bost. Soc. Nat. Hist. 37, 1551, Moleot. Wayne County, N. Y.

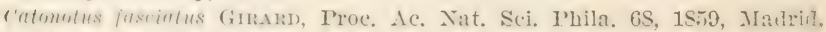
X. Y.

Culumblus flutullulus Varraxt, Recherches sur Etheostom. 121. 1873. with plate.

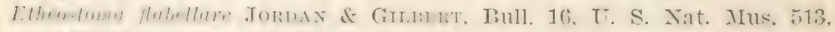
1SS:; Meek, Ann. N. Y. Ac. Sci. IV, 314, 18sS; Bean, Fishes Penna.

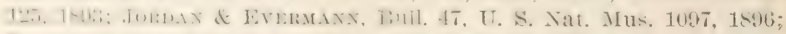
Evemate Suriti, Proc. Linn. Soc. N. Y. 1897, 37, 1S9S.

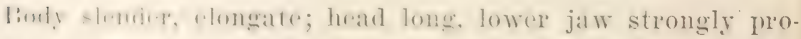
jorting. The speries is readlily reromented by its low fins,

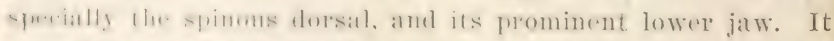
Fmy, lom

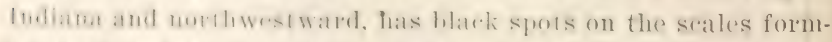

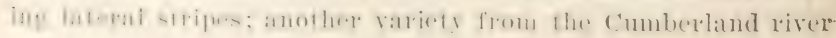


s distinguished by its thick jaw and nearly plain coloration. In he male the spinous dorsal is one half as high as the soft lorsal. The female has higher spines than the male; the spines are fleshy tips. No scales on nape, head and breast. A large black humeral scale. The length of the head equals one fourth f the total length without caudal, and the depth one fifth. D. III, $12 ; A$. II, S. Scales $7-50-7$. The lateral line ends at the niddle of the length.

The general color is olivaceous, the upper parts dusky; the ides with dark streaks formed by the spots at the base of the cales. The males have dusliy crossbars; the soft dorsal and audal barred. The spinous dorsal of the male has an orange nargin.

The fantail darter is found from western New York to North Yarolina, and in the Ohio valley. In the Lake Ontario region he U. S. Fish Commission collector's obtained it from the follow$\mathrm{ng}$ places in 1893 :

alt brook, $1 \frac{1}{2}$ miles above Nine Mile point

June 11 rrenadier island June 28 and 29

Horse island, Sackett's Harbor

June 30

Iill creek

ittle Stony brook, Henderson bay

Jemetery creek, Watertown

July 2

July 4

July 5

July 10

Chaumont river

July 12

July 24

July 24

July 27

Aug. 6

Ang. 9

Aug. 20

Aug. 21

'our Mile creek, Nine Mile point, Webster andy creek, North Hamlin Iarsh creek, Point Breeze

Writing of the fishes of Cayuga lake basin, Dr Meek makes he statement that the fantail darter is found with the essellated darter at each end of Cayuga lake; that these two 
are the only species of darters in the lake, and neither of them occurs in the streams on the uplands.

Though usually considered as being limited to western Yew York, Eugen. Smith says it is not altogether rare in the Hackensack valley streams, perhaps the easternmost locality in which it occurs.

It grows to a length of $2 \frac{1}{2}$ inches and abounds in clear rocky streams. It is very active and tenacious of life and is an excellent species for the aquarium.

\section{Genus moxeichtrys Girard}

This genus contains small and slender species allied to those of the section Oligocephalus under Etheostoma. The lateral line is incomplete and has a slight upward curre anteriorly instrad of being straight, as in all the species of Etheostoma. Top of head not scaly. Lowland streams and swamps. The species few, variable and hard to determine.

\section{Boleichthys fusiformis (Girard)}

Bolersomu fusiformis Gin.und, Proc. Bost. Soc. Nat. Hist. 41.1554.

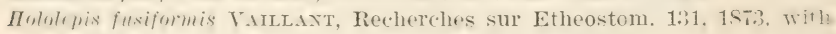
plate.

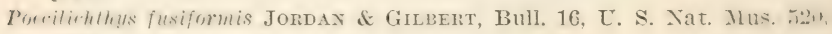
1883.

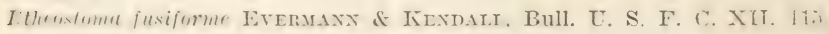
1894; Eugene Surmir, Proc. Linn. Soc. N. Y. 1897, 37, 1898.

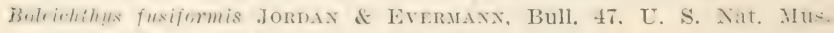
1101, 1896, pl. CLXXVII, fig. 469, 1900.

lionly mulleratrly clongate, strongly compressed. The depth is enutimed six times in the lenglh. Head rather long and

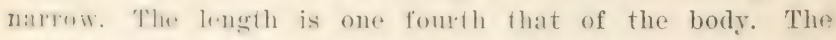

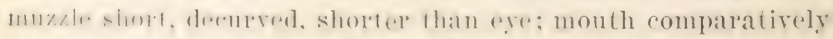
larger, frominal: maxillary rearling fast front of eye; cyes

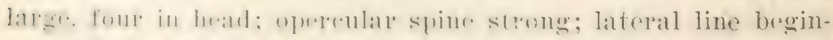

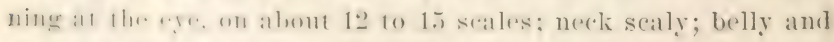
throat scaly. D. X-9; A. II, 7; lateral line 55.

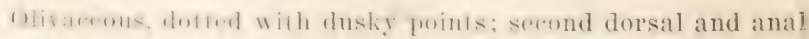
sjueckled. 
This little darter is recorded from Massachusetts to New rersey and will doubtless be found in New York. It grows to he length of 2 inches.

\section{Boleichthys fusiformis eos Jordan \& Copeland}

Boleichthys eos Jordan \& Copeland, Proc. Ac. Nat. Sci. Phila. 46, 1877, Rock Rirer, Wiseonsin; Wisconsin River, Wisconsin; Fox River, Illinois.

Poecilichthys eos Jordan \& Gilbert, Bull. 16, U. S. Nat. Mus. 520, 1883. Boleichthys fusiformis cos Jordan and Everirativ, Bull, 47, U. S. Nat. Mus. 1102, 1896.

Body elongate, slender, somewhat compressed, specially ehind, rather heavy forward, with very long and slender caudal eduncle; head long, rounded in front; mouth small, little blique, the upper jaw a very little the longer; dorsal fins high, about equal; caudal truncate; cheeks, opercles, and neck closely caled; breast naked, or with a median series of small scales; ateral line dereloped on 22 to 26 scales. Head one fourth of otal length without caudal; depth $\frac{3}{16 .}$ D. IX-11; A. II, 7; ateral line 58 .

Color dark olive, with darker markings; 10 or 12 dark dorsal pots or bars, and as many short dark blue bars across the ateral line nearly opposite the dorsal bars, but not continuous rith them; the interspaces between these bars, as well as most f the rentral region, bright rimson in the males, nearly plain n the females; lower parts of the sides, cheeks, etc. with rarious harply defined but irregular black markings; second dorsal, audal, and pectorals strongly marked with wavy bands; first corsal bright blue in the males, with a broad median band of rimson, speckled in the females; top of head dark; black streaks ownward and forward from eye.

The describers of the species recorded its distribution from ndiana to Minnesota; abundant in clear cold streams. It grows o the length of 21 inches, and is one of the prettiest of the larters. Specimens were obtained for the U. S. Fish Commission n Mud creek, Cape Vincent $\mathbf{X}$. Y. June 25, the species being bundant there, at Grenadier islant, June 27, and in Guffon reek, Chaumont N. Y. July 7. 


\section{Family SERTANIDAE}

Sea Basses

\section{Genus Roccus Mitchill}

lase of tongue with one or two patches of teeth; anal spines graduated; dorsal fius entirely separate; anal rars III, 11 or 12 ; surraocipital crest scarcely widened abore; lower jaw projecting. Vertebrae $12 \div 13=25$. Otherwise as in Horone, the body more elongate, the seales smoother, and the fins more slencler than in Ir o ro ne. Species all American. valued as food fishes. In both $\mathrm{R}$ oc $\mathrm{cus}$ and $\mathrm{Hor}$ one, the antrorse Ine(opereular spines (characteristic of the European genus or subgenus Dicentrarchus) are wanting.

\section{Roccus chrysops (Rafinesque)}

\section{White Bass}

Perca clirysops Rafinesque, Ichthyol. Ohien. 22, 1820.

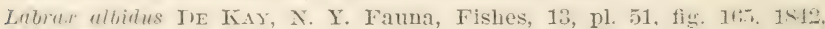
Buffalo.

Labue notatus Richandsox, Fauna Bor.-Amer. III, 8, 1836; G̈̈xtuen, Cat. Fish. Brit. Mus. I, 67, 1859.

Roerus chrysops Gill, Rept. Capt. Simpson's Surr. Great Basin Utah, 391, pl. 1. fig. 1-7, 1976; Jormax \& Gilbent, Bull. 16, U. S. Yat. Mus. 529. 1683; Beax, Fishes Penna. 132, pl. 34, fig. 71, 1893; Bull. Am. Mus. Nat. Hist. IX, 365, 1897; Jordan \& Evermann, Bull. 47, U. S. Nat.

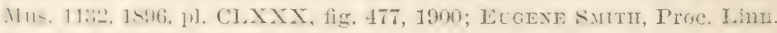
soc. ․ Y. $1897,38,1898$.

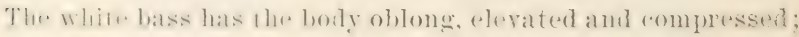

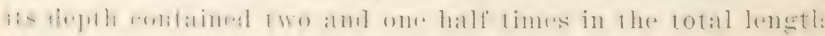

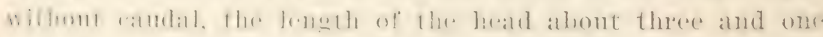

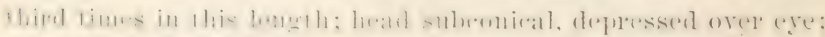

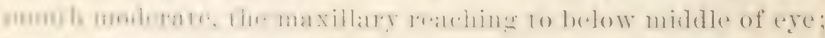

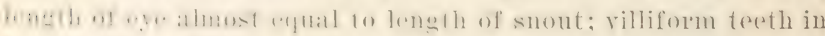
bauls an jasve, falatines, vomer ame lomgure; the dorsal outline is much curred, the fins well separated.

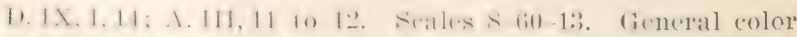
silvery, linged 11 ill golden on siles; aight or more blackish longladinal sldraks on sirles, those below more or less interrinited. 
The following measurements were taken from a specimen obtained by $\mathrm{Ir}_{\mathrm{r}}$ James Annin jr, in Oneida lake, Sep. 4, 1896.

Inches

Extreme length................ 121

Length to end of middle caudal rays....... 11

Length to end of scales.............. 10

Depth of body................. 4

Least depth of caudal peduncle......... $1 \frac{3}{8}$

Length of head................. 3

Length of snout...............

Diameter of eye ..............

Length of fourth dorsal spine.......... $1 \frac{3}{8}$

Length of second dorsal ray........... $1 \frac{3}{4}$

Length of second anal ray........... $1 \frac{3}{4}$

Weight, $16 \frac{1}{2}$ ounces.

The white bass is sometimes called striped bass, and is probably the silver bass of Canada. Its center of abundance is the Great lakes region, but it is also widely distributed over the Ohio and Mississippi valleys. In Pennsylvania the species is found in Lake Erie and in the tributaries of the Ohio river. The U.S. Fish Commission secured three specimens at Horse island, Sacketts Harbor N. T., June 30. The Xew Jerse Fish Commission has introduced the fish into Greenwood lake.

The white bass weighs from 1 to : pounds, and its flesh is considered ahmost if not equally as good as that of the black hass. It prefers the dereper parts of rivers and thrives best in lakes and ponts. In April and May they leare the deeper watex's and go in near shore or to the mouths of rivers where they spawn. The spatwing period is in May and June.

The whit bass feeds upon minnows, crawfish and other freshwater crustaceans, also minute mollusks or shellfish, and it is said to devour many young whitefish upon the spawning grounds of that species.

It is a game fish and affords good sport to the angler. 


\section{Roccus lineatus (Bloch)}

\section{Striped Bass; Rockfish}

Srivent lineata BLocrr, Ichthyol. IX, 53, pl. 305, 1792.

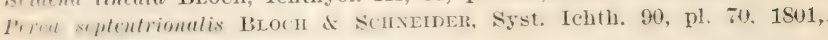
New York.

Roccus striatus Mrrmul, Rep. Fish. N. Y. 25, 1814.

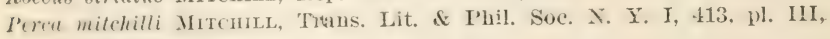
fig. 4, 1815 .

I'eren mitehilli alternate Mrternl, Trans. Lit. \& Phil. Sne. N. I. I, 415. 1815.

Peret mithilli intermpte Mitchill, Trans. Lit. \& Phil. Soc. N. X. I, 415, 1815 .

Labrax lineatus DE KAY, X. Y. Fauna, Fishes, 7 , pl. 1, fig. 3, 1St2;

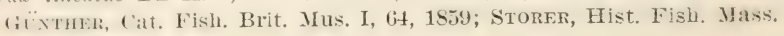
6, pl. I, fig. 4, 1867.

Rurus limutus Gir.t, Ichth. Rep. Capt. Simpson's Expl. Great Fisin L'tal, :31. 1sit; Goote, Fish of Fish. Ind. L. S. I, 425, pl. 170, 1884; 13Edx, 19th Rep. Comm. Fish. N. Y. 267, pl. XVIII, fig. 22, 1890; Fishes

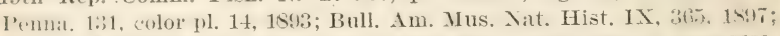

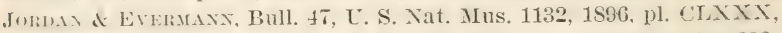
fig. 478, 1900; Eugene Sarmi, Proc. Linn. Soc. N. Y. 1897, 38, 1898; Mearns, Bull. Am. Mus. Nat. Hist. X, 321, 1898; H. M. Sirmir, Bull. I. S. F. C for 1597, 99, 1S95; BEAx, $52 d$ Ann. Rep. N. Y. State Mus. $105,1300$.

The genus rioceus, to which the striped bass belongs, hils two fallehes of small teeth on the base of the tongue, the anal spines increasing regularly in size backward, the lower jaw

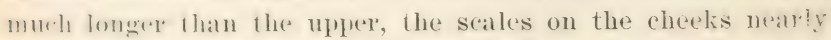
smomh along their margin and the dorsal fins separated by at nalrow intrespatre. The hody is moderately elongate aud rather

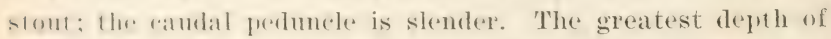
i!n. lue! is a wo sevenths of the fotal leneth without caudal and fynals lengul of head. Eye small, one half as long as the suout and more sisth to one eighth the length of the head. The eges

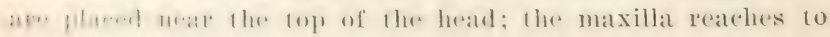

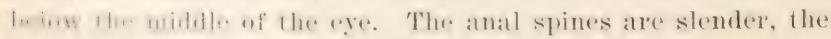

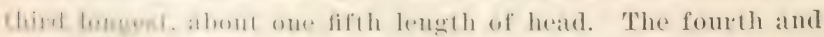

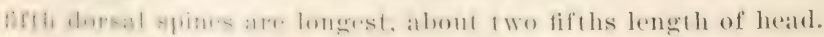

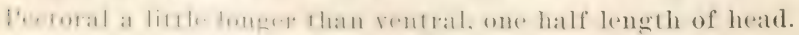

1). IX, 1, 11 to 12; \. III, 10 to 11. Scales 7-65-19.

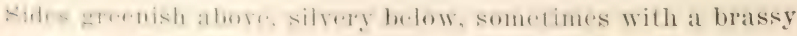

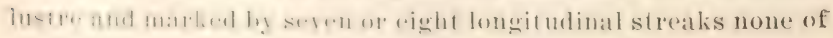


which are half as wide as the ere, one of them passing along the lateral line; the lowermost stripe is somewhat below the middle. of the depth.

In the southern United States from New Jersey to Florida the striped bass is known as the rock or rockfish. In the northern states the name striped bass is more generally used than the other, specially along the coast. In the Delaware, Susquehanna and Potomac rivers it is called rockfish. Greenhead and squid hound are names applied to large individuals found in the sea in New England waters. One of the old names of the fish is streaked bass.

Rockfish and striped bass, according to Schoepff (1787), are among the early New York names for this highly prized species. Dr Mitchill (1814) calls it Mitchill's perch, striped basse and rockfish. De Kay describes it as the striped sea bass. Streaked bass is another name in use in 1815, and a rery interesting account of the fish under this name is published by Dr James Mease in the first volume of the Transactions of the Literary and Phitosophical Society of New York. Dr ITease in this article states that rockfish weighing from 25 pounds to 60 pounds are called greenheads. At the time of his writing the fishing-ground for the Philadelphia and New York markets was between Long Branch and Cranberry inlet, an extent of about thirty miles, and the great places of winter resort were Notetecunk, 30 miles from Long Branch, and the rirer's of Elk and Egg Пarbor.

At the time of $\mathrm{Dr}^{2}$ Mitchill's report the greatest rum occurred late in the fall, and great hauls were made during the coldest season, including some very large fish. Пe saw, howrer, a dozen at a time weighing 50 pounds each in New York market during very mild weather in early October.

The range of the striped bass or rockfish includes the entire Atlantic coast from the Gulf of st Lawrence to the fulf of Mexico, the fish entering rivers and asernding them long distances. In the Alabama river this fish is known to be taken erery year and some large individuals have been olitained from that stream. It has been captured also in the lower Mississippi. 
It is rery abundant in the great bays and sounds from North Carolinat to Cilpe Cod. In Albemarle sound many large individ11als: are said to occur. In the St John's river, Florida, according to I) Goode, the fish is rather rare. In the ricinity of Pensacola the late filas stearms occasionally obtained a specimen of the fish.

The striped bass has been introduced into California and has now breonte farly acelimated there. In the Delaware and suspumbannal rivers this is one of the common fishes and it is one of the most highly esteemed.

This is a fermanent resident of Gravesend bay, hut the hight 6f the tishery oceurs from October 10 to Norember 10 . Large fish, up 10 hy pounds, are caught in May, but the fall fish range from 9 inches to $2 t$ inches in length. In Great South bay the writr has obtained specimens at Blue Point cove, Great river, Nichols's point, and off Widow's ereek. A great haul was made an Lon* Ifill Middleground about the midale of October, 1901. The fish remains in some of the tributaries of Great South bay throughout the year. According to Dr Mearns the species is taken in great numbers in nets set through the ice of the Hud. -nn in winter, and in drift nets by shad fishermen in spring. langer individuals of fol pounds and upward are sometimes ranght in the wintre and waly spring. He once took a specimer

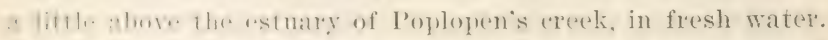

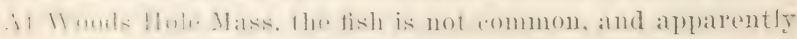

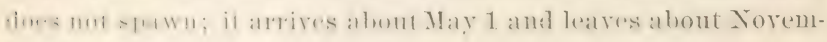
ber 1; in size it ranges from $\frac{1}{2}$ pound to 65 pounds.

Thus lish lis in hly sea or in hackish or fresh water indiffer-

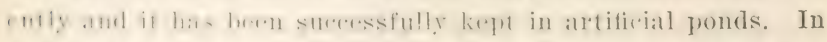

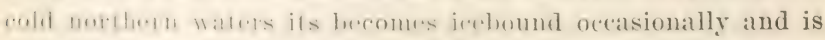
salil in hibrenale. It profers rold water, is carnivorous and pre-

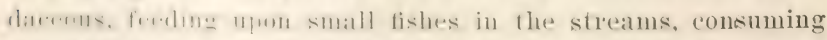
spentally lare... qualltilies of lle alewife or river herring and hlo !nomg of the shatl. In the shallow hals along the coasts fill fond ronsists of killifish, silversiles, anchories, lant and

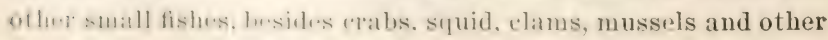


marine invertebrates. Its morements while feeding depend greatly on the tides. It is to be found frequently at the mouths of small creelis and in tidewass, where it lies in wait for the large schools of small fishes, which constitute its food.

The largest striped bass recorded was said to weigh 112 pounds. At Aroca, North Carolina, Dr Capehart took a striped bass weighing 95 pounds. It reaches a length of four and one half or five feet.

Spawning takes place from April to June, either in the rivers or in the brackish waters of bays and sounds. Eggs have been hatched artificially in May on Albemarle sound. Dr Capehart took a 58 pound spawning fish April 22, 1891. The eggs are smaller than those of the shad and after fertilization they increase greatly in size and become light green in color. This 58 pound fish probably contained more than one half million eggs. Dr Abbott has found the roung an inch long in the Delaware the second week in June and by the middle of October some of these had grown to a length of $4 \frac{1}{2}$ inches. The striped bass has been kept in a small pool of fresh water and fed upon crabs and oysters increasing in about eleven months from 6 inches in length to 20 inches. In the aquarium the species is hardy and grows rapidly; it can be kept in good condition almost indefinitely. In a Rhode Island poud it is stated that bass weighing $\frac{1}{2}$ pound to 1 pound in June had reached a weight of six pounds in the following October.

In fresh water, salted eel tail is a favorite bait for taking striped bass, and the spoon or spinner is also a good lure, but live minnows are preferred to all other baits. For surf fishing shedder crab well fastened to the hook is a rery killing bait.

\section{Genus monoxe Mitchill}

Body rather short and deep, compressed; maxillary broad, naked, without supplemental bone; teeth subequal; lower jaw scarcely projecting; no canines; no movable teeth; base of tongue without teeth; edge of tongue with linear pratches of teeth. Lower margin of preopercle fincly serrate or entire, the serrae not greatly increased in size toward the angle, and none 
of them devoloped as antrorse hooks. Syines strong, 10 in the dursil fin; dorsal fins more or less comnected by membrane; s.r.mil anal spine mueh (-mlarged, not shorter than third; anal rals III, eight or nine. Tertubrae $12 \div 13=25$. Scales rather larege. ('troid: tofl of head sealy; lateral line little arched. Ventrals insereded well behind pectorals. Two known species, both American.

\section{Morone americana (Gmelin)}

\section{Thite Perch}

J'erea americana Guelix, L. Syst. Nat. I, III, 1308, 1788, New Iork. Iforone Rufa Mrtchill, Rep. Fish. N. Y. 18, 1814, New York. Jorone P’allida MrtcmLL, Rep. Fish. N. Y. 18, 1514, New York. firdirnus rufus MrтenLl, Trans. Lit. \& Phil. Soc. X. Y. I, 420, 1515.

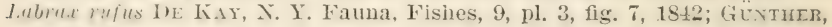
Cat. Fish. Brit. Jfus. I, 65, 1859.

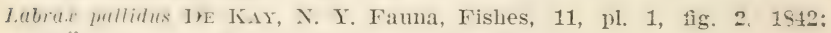
Güxtrer, Cat. Fish. Brit. Mus. I, 67, 1859.

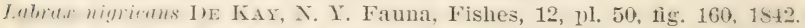

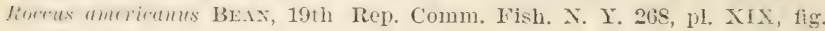
$23,1890$.

Morme amerirnnu Gill, Ichth. Rept. Capt. Simpson's Surv. Great basiu Utah, 397, 1876; BeAx, Fishes Penna. 133, pl. 15, 1893; Jordar \& Everdaxi, Bull. 47, U. S. Nat. Mus, 1134, 1896, pl. CLXXXI, fig. 47!) 1!m!: Bedx, Bull. Am. Mus. Nat. IIist. IX, 366, 1897; Mfards. liull. In. Mus. Nat. IIist. X, 321, 1S9S; Evgexe Sumti, Proc. Linn.

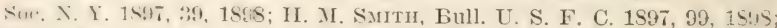
BEAx, 52d Ann. Rept. N. Y. State Mus. 105, 1900.

Th" grms II o rone of Gill differs from Roceus in havine tlue dorsals joined. the spines strong, the anal with 10 soft lalys its spines not graduated, the jaws subequal and base of thre tomene tomthless. It inclutes the common white pereh and the yellow bass.

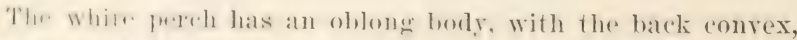

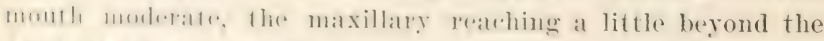

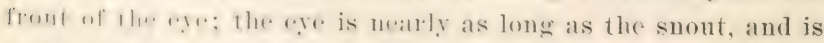
1.mmtaimed tide and one half times in the length of the head; the

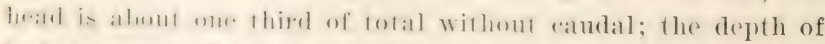

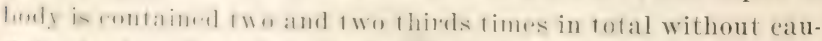
Ial; the fourth anal spine is 1he longest. 1 wo fifths longth of

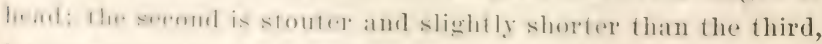
its Jenerth one third that of head. 
I. IX, I, 12; A. III, 10. Scales $7-51-11$. The dorsal fins are separated by a very deep notch, but connected by membrane; upper parts grayish or greenish; sides silvery; young individuals have pale, longitudinal streaks.

This is the perch or river pereh of Schoepff, which he records as an inhabitant of the coasts of New York and Long Island, in and at the mouths of fresh-water streams. Dr Mitchill (1815) gives it the name of red perch, and states that when not in the breeding season it is called black perch because its colors are browner and darker. De Kay describes it, in the Fishes of Now York, as the ruddy bass. In Great Egg Harbor bay individuals taken from salt water are sometimes called yellow perch or peerch.

The species is found from Nova Scotia to South Carolina, and inhabits both salt and fresh water. Mitchill saw specimens 14 inches long and nearly 5 inches deep, from Quag, Long Island. There is an important winter fishery for the white perch at Bellport. It is taken in seines and gillnets. The writer has occasionally found this species in various parts of Great South bay, for example, at Smith's point, Whale House Hole, Swan river; also in the east end of Shinnecock bay, in the fresh water of Head of Creek, near Southampton. The fishermen affirm that when its feeding grounds are disturbed by seining the fish suddenly leave the locality. The white perch is never plentiful in Gravesend bay; it is abundant in fresh-water lakes of Central park, New York, and Prospect park, Brooklyn. Near Montauk, Long Island, the species is abundant and reaches a large size. Eugene Smith has found it common in brackish water's near New York, where it occurs all the year; he had it also from fresh water. Mearns states that it remains in the Fudson throughout the year and is taken in abundance in winter in nets set through the ice. In Oscawana lake, Putnam county, individuals weighing 2 or 3 pounds were reported to him.

In the vicinity of Woods Hole Mass. the fish is abundant in fresh-water ponds connected with salt water.

It is said that the white perch formerly extended south to Florida and the Gulf of Mexico, but this is discredited by com- 
Jutent observers. The perch of Lake Ponchatrain is very likely the species now known in many portions of the western. taltis as the fresh-water drum, A plo d i notus grun. n iens.

The arerage length of the white perch is about 9 inches and its weight $\frac{1}{2}$ pound or less, but numerous specimens measuring 14 inches and weighing 2 pounds or more have been taken, specially in New. England waters.

At the time of Dr Mitchill's writing the species was a favorite in Yew York markets, and it is now one of the best known speries though probably not ranking among the chnicest kinds.

Thatdeus Norris was one of the most earnest supporters of the white fweh, and has published interesting observations con("rning its habits. Comparatively little, however, is known about its life. It is an associate of the striped bass, and, acording to In Abbott, resembles this species in its feeding habits. It diflers from the striped bass in its tendency to seek warm waters.

The white pereh is a lorer of brackish water, and may be fouml in tidlal creelis in rast numbers associated with mummirhugs silversides and eels, feeding upon shrimp aud minnows. Spawning lakis plate in May and June. Aecording to Professur John . I. Irder, the eger of the white perch is rery adhesive. and on this anount is troublesome to hateh artificially. In the expreinnts mate ly him the exgs were taken upon cotton Iarn. Which was drawn up through a funnel into which the eggs and mill hat hern stuerged from the spawning fish. The cord, ansereal with the adhering engs. Was then wrapped upon a

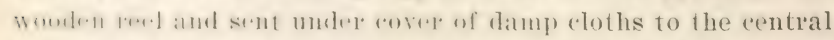
slation, wher lhey andired in time condition, almost exery egg

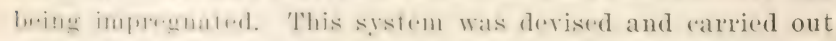

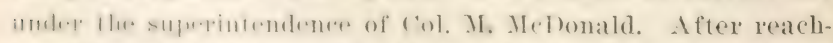

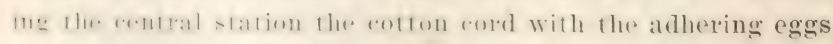

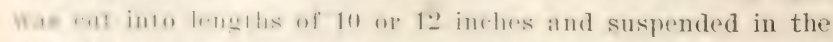

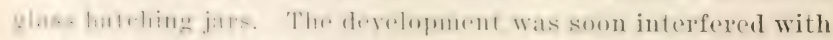

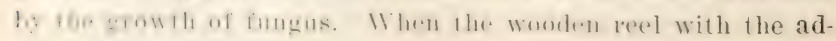


lering eggs was introduced into a wide aquarium fungus also attacked the eggs as before but the results were somewhat nore favorable. With the water at $58^{\circ}$ to $60^{\circ} \mathrm{F}$. the eggs aatched out in 6 days.

The white perch congregates in large schools and is one of the freest biters among fishes. The shrimp is one of the best aaits, though worms, sturgeon eggs, minnows and strips of cut ish with silvery skin are equally effective. Dr Abbott has nnown as many as 20 dozen to be taken with a line in a few ours, and spangler mentions catches of six or seven hundred n a day by two rods, the fish ranging in weight from $\frac{3}{4}$ to $1 \frac{1}{t}$ ounds.

Eugene Smith, on sereral occasions, found a long, green, mackish-water alga (Enteromorpha) in stomachs of white perch, indicating that they sometimes eat regetable mater, though perhaps only for the minute organisms found upon it.

In captivity the fish is rery susceptible to fungus attacks, but he parasite is readily killed by changing the water supply rom salt to fresh, or vice rersa.

\section{Genus pouyprion Cuvier}

Body robust, moderately elerated, not much compressed, corred with small, firm, ctenoid scales which extend on the bases of the vertical fins. Lateral line complete, partly concealed ander adjacent scales, the tubes covering the whole length of he scale. Mouth large, the lower jaw projecting; maxillary rith supplemental bone. Teeth in broad, rilliform bands on aws, vomer, palatines, and tongue; no canine teeth. Head caly. Preopercle serrate; orbital region with spinous projecions; opercle with a strong spine and with a strong, rough, ony longitudinal ridge; gill membranes separate; gill rakers ong, few. Dorsal fin continuous, low, with 11 strong spines nd 11 or 12 rays, the spinous portion longest; caudal rounded; nal short, with three spines, the third the longest; rentrals arge, inserted below, little behind pectoral; caudal rounded or runcate; pectorals short, unsymmetrical, of 18 or 19 rays, the 


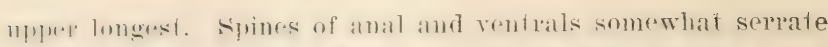

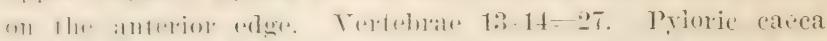

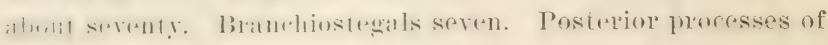

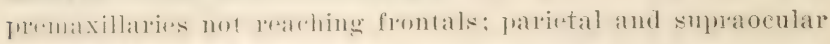

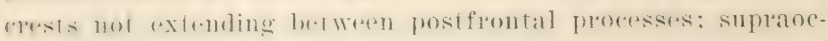

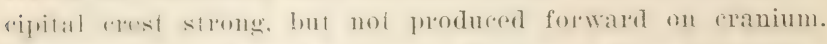

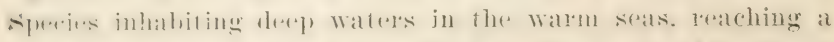

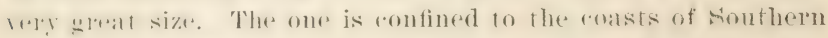

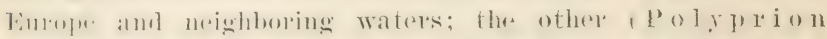

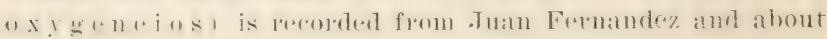
New Zealand.

\section{zi; Polyprion americanus (Blorh S Nehmeider)}

\section{Treckfish; Stone Bass; Cernier.}

? Amphimrion americanus BLocm \& ScInNemer, Syst. Iohth. 205, 11. XLVII, 1801.

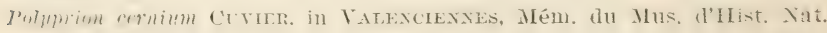
XI, 265, pl. XVII, 1824; Cuvier \& Valenciennes, Hist. Nat. Foiss. III, 21, pl. 42, 1829; Günther, Cat. Fish. Brit. Mus. I, 169, 1859.

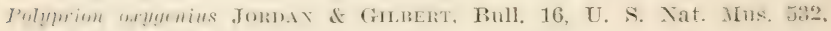
$185: 3$,

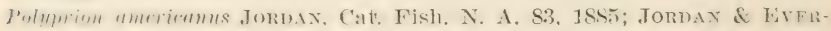

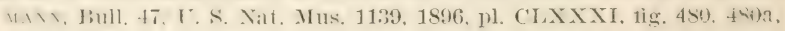
ski111, 1900.

lindy rohust. moderately elevated, the depth being contained from I II0 and 1 wo thirds to there and one half times in the

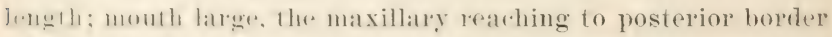
of r.!es: 1,ell in villiform bands on jaws, vomer, palatines, and

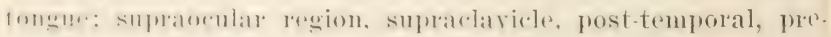

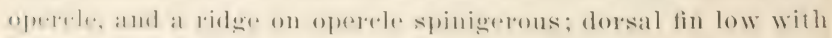

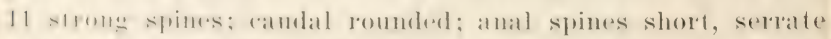

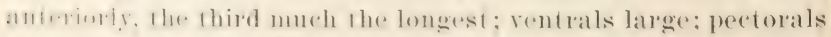

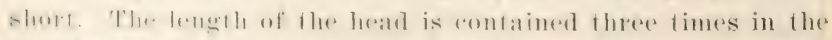

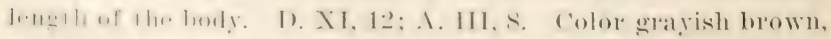

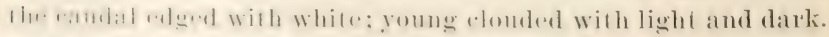

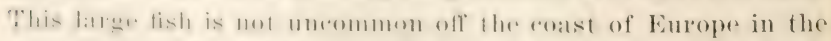

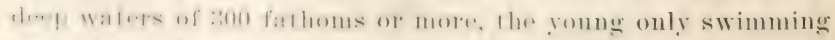

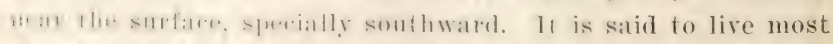

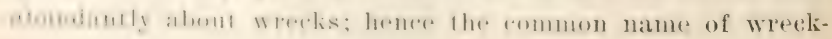


fish. It reaches a length of $5 \mathrm{or}^{2} 6$ feet. A single young sperimen has been taken in deep waters of the Gulf stream by the $F^{*}$. F. Fish fommission, but these is no other recold from America.

\section{Genus Eprneruetus Bloch}

Body stout, complessed, rovered with small, ctenoid seales, which are often somewhat emberded in the skin; scales of the lateral line triangular, "roloid; soft fatrts of the vertical fins generally more or less saaly. C'ranium narrow above. Parietal erests not produced on frontals which are without transverse ridge postriorly; frontals with a process or linob on each side behind interorbital areat premaxillary frocesses fitting into a notch or cavity on the anterior end of the frontals. Preoperele moderately serrate behind, its lower limb entire, withont distinct antrolse spine; oferele with two strong spines. Nostrils well separated. Mouth latege; maxillary latres, with a welldevelopert supplemental bone, its surface usually with small seales. fanine teeth few, large in the front of the jaws; enlarged teeth of the inner series of earle jaw repressible. Ciill rakels short and rather fer. Inorsal spines usually 11, rarely 10, not filamentous, the last ones somewhat shorter than the midtle ones. Anal spines threx, the serond nswally the latrger the number of soft rays seren to nine. Candal fin rounded or lumate. Pyloric capea few usually 10-20). Pertorals rounded. shortish. nearly symmetrice, of 15 to 20 ratys. Tentrals moderate, inserted below per.torals, chose togethere wath with a strong spine. Fipecies very numerous, most of them of latroge size, aboumding in all the tropical seats, wheres they are valuable food fishes. This is the largest and nost important genus of the se r a a 1 i d a e, and its spereses are most wirloly distributed.

\section{6:3 Epinephelus niveatus (Cur. \& Val.)}

\section{Spotted Grouper; Snowy Giouper.}

semanus mirentus Cuvier \& VAlexcifaxes, Hist. Nat. Pojss. II, 3S0, 1S28; G̈̈xtmen, Cat. Fish. Brit. Mus. I, 130, 1859. 


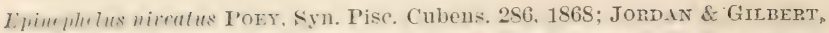
IBull. 16, U. S. Nat. Mus. J41, 1Ss3; Jordax E Evermaxn, Bull. 47. U. S. Xat. Mus. 1156, 1596; II. M. Smiti, Bull. C. S. F. C. 1897, 99, 1895; op. cit. $1901,32,1901$.

Body oblong, compressed, the back elerated; the anterior protile somewhat convex: the snout short, rather sharp, its length contained three and three fourths times in length of hest. Ifead threse serenths and depth of body about one third of total length without eaudal. Mouth large, the maxillary extruding to below fosterior margin of eye, its length one half length of head. Cinines rather strong, specially in mpere jatw. Low jaw considerably projecting. Eye rather large. Interorbital spare flattish, its width contained seren and one half times in length of head and twiee in length of snout. Preorm.r.le with a salient angle armed with stronger teeth, a slight notrh above the angle. Ciill rakers 15 below the angle of first areh, the longest as long as the gill fringes. Dorsal spines rather high, the fourth contaimed about two and these fifthe times in length of head; soft dorsal of moderate hight; cautal

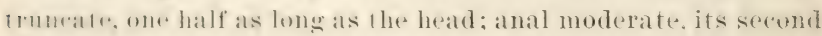
sprom abunt as long ats the third. theee eighths as long as the

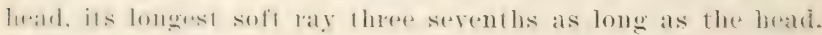
fo.eforals not reathing to the tipes of the long rentrals, about nine half as long as the head. Vemtrals about as long as peretorals. nealy reathing vent. D. XI (rarely X), 14 or 15; A. III, 9; seales $18-115$ to $120-50$; pores of lateral line 67 to 75 .

folor of yomge in alcohol: bown, with round whitish spots on the leods, rather smallere than pupil, regularly arranged in lerifeal and hurizontal series, about fire in horizontal and four

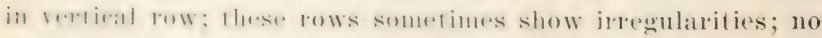

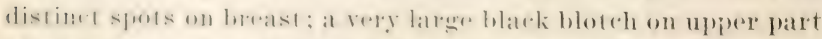
of rambal pendunele extending fo below lateral line: a dark mus-

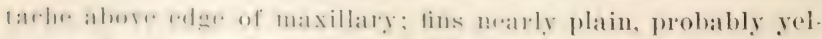
lew ish in life. Ahe dustill wilh a median row of dusky spots on

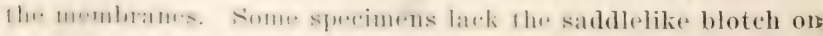

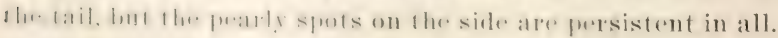


The spottea grouper oecurs in the West Indies and south to Brazil frecquently straying northward in the Gulf Stream as far as Cape Cod. A roung specimen was taken many years ago at Newport R. I. and others have been secured in Rhode Island waters. At Woods Hole Mass. according to Dr H. M. Smith, it is not rare. First reported in 1895, when as many as 10 or 12 specimens were obtained in the Woods Hole region. In 1897 several others were taken in summer and fall; one was caught August 7 in a dredge in Vineyard Sound in 6 fathoms of water and in November several were taken in a fyke net in Great Harbor. All have been of small size (3 inches or less), and most of them have been brought up in lobster pots. Dr Smith also recorded 35 specimens, taken in Katama bay on nine occasions between August 15 and October 26, 1900.

The example described by Dr Günther, from South America, under the name Serra $\mathrm{n}$ u $\mathrm{s}$ margar it if er was $11 \frac{1}{2}$ inches long. The colors of his specimen were as follows:

The ground color is reddish olive, lighter on the belly; on each side of the body are four series of pearl-colored spots, each occupying the place of five or six scales. The uppermost series reaches from the occiput along the base of the dorsal fin to the black blotch of the tail, and is composed of eight spots; the second, following the lateral line, of six; the third, from the angle of operculum, of four; and the fourth, from the base of the pectorals, of fire. There is a blackish streak behind the maxillary bone. The black bloteh on the tail oceupies nearly the whole space between the dorsal and caudal fins and between the two lateral lines. The fins are nearly unicolored; a single pearl-colored spot is to be seen on the seventh spine and on the rentral fins; the anal has a whitish edge; rentrals blackish, with whitish lateral margin; pectorals uniform yellowish.

\section{Genus centropristes Cuvier}

Body robust, somewhat compressed, covered with rather large ctenoid scales. Mouth large, formed as in Serran us and P a ra l a b a $x$, the canines small. Tongue smooth. Preopercle serrate, the lower teeth somewhat antrorse. Gill rikers vather long and slender. Supraoccipital and parietals with strong crests extending forward to between postfrontal processes; frontals posteriorly with an angular transverse ridge in front of 


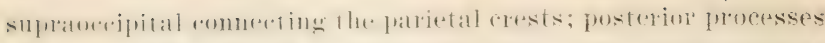

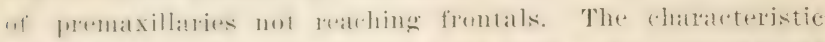

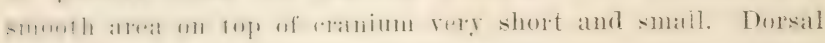
short, its lays $X$, 11; anal rays III, 7 ; caudal usually

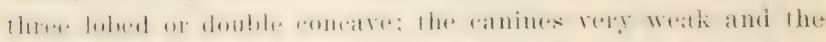

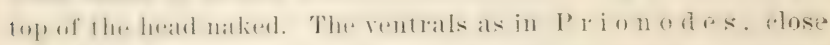

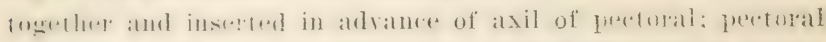

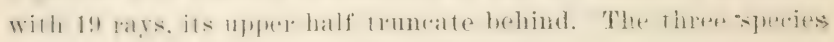
of Centropristes are closely related.

\section{$26 \pm$ Centropristes striatus (Linnaeus) Sea Bass; Blackish}

Labrus striutus Lixxatus, Syst. Nat. ed. X, 285, 1758, America.

Percu atraria Lixydeus, Syst. Nat. ed. XII, 485, 1766, Carolina.

Peren raria Mrtenil. Rep. Fish. N. Y. 11, 1814; Trans. Lit. \& Phil. Soc. ․ Y. I, 415 , pl. 3, fig. 6,1815 , New York.

Centromistes nigricuns Cuvien \& Valexcienzes, Hist.' Nat. Poiss. III, 37, pl. 44, 1S29, New York; DE KAY, N. Y. Fauna, Fishes, 24, pl. 2, fig. 6r 1842; BEx, 19th Rep. Comm. Fish. X. Y. 266, pl. XVII, fig. 21, 1890.

Centromistes atrurins Güxmen, Cat. Fish. Brit. Mus. I, S6, 1859; Goode \& BE.x; Bull, Essex Inst. XI, 19, 1879.

Serremus atrerins Jolndx \& Gilbert, Bull. 16, U. S. Nat. Mns, 533, 1883. Serranus nigrescens Jolıd in \& Gmbert, Bull. 16, U. S. Nat. Mus. 917, 1883. Centropristes striatus Jondax \& Etgexmand, Bull. U. S. F. C. VIII, 391 , 11. 64. 1894; Jokndx \& Everutaxx, Bull. 47. U. S. Nat. Mus, 1199, 1896, 1)l. CAC, fig. 500,1900 ; BEAx, Bull. Am. Mus. Nat. Hist. IX, 366, 1897; 11. М. Sмити, Bull. U. S. F. C. 1S97. 100, 1S9S; BEAx, $52 d$ Am. Rep. ‥ Y. State Mus. 105, 1900; Sienwood \& Edwards, Bull. U. S. F. C. $1: 101,25,1941$.

Body ovate, robust, the back somewhat elevated; axis of

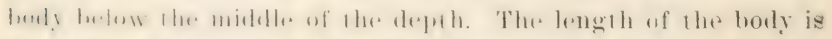

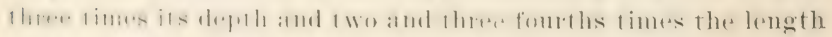

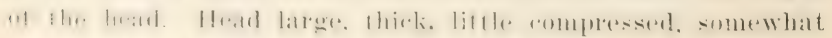

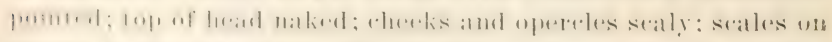

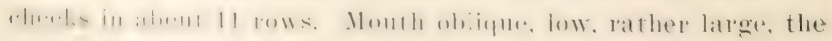

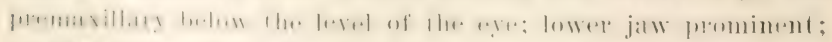

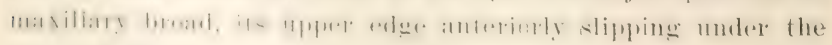
oflere of the preorbital, which is nearly as wide as the "y". Lye latro, wirler than interorbital space, less than

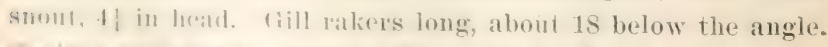

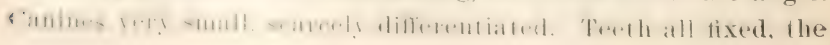


bands rather broader than usual. Dorsal spines rather strong, not filamentous, the middle ones rather higher than the posterior, which are considerably lower than the soft rays, the highest spine as long as from snout to middle of eye. Anal short and high, its spines graduated. Pectoral rery long. $1_{4}^{1}$ in head, reaching rent. Tentrals long. nearly reaching rent, inserted below front of the base of pectorals. Caudal slightly double concave; fins little scaly except at base; a rudimentary groove at base of spinous dorsal, orer which scales do not pass. Length 12 inches. D. X, 11; A. III, 7; Lat. 1.50 to 55 pores; eaeca $4-7$.

Dusky brown or black, adults often bluish; more or less mottled, with traces of pale longitudinal strealis along the rows of seales; young greenish, often with a dark lateral baud, sometimes broken up forming crossbars; dorsal fin with several serits of elongate, whitish spots, forming interrupted lines; other fins dusky, mottled.

The sea bass is the P' e c a ra $\mathrm{r}$ i a of Mitchil, Fish. I. Y. p. 415. Common names given by this author are sea basse, blackharry, hamna hills and bluefish. S(hoeplì (17st) gives the New York name as blackfish: Ihe Kay has it as the black sea bass, also black bass and blarkfish. Ir Storer records the Massachusetts name of black pereh. Other common names on the coast are black will (Middle states) and rock bass (New Bedford).

The sea bass is found from Vinerard sound southward, its southern limit not being accurately determined, but probably not extending below Cape Hatteras. The southern form, which was described by Linnaeus from South Carolina, may be distinct from the northern, and if so it should be designated by the Linnaean name a $\mathrm{t}$ a $\mathrm{r}$ ia.

The northern form has been found oreasionally north of Cape Cod, at Nahant, Salem. and Beverly bar. 1) Smith reported it as very common at Woods Hole in 1s9s, where it arrives in May and departs from the inshore waters about October 1 , being most abundant from July to september. It spawns there in June. The young are first seen about dugust 1 . The maximum weight is 6 pounds. In 1900 the sea bass was said to be remarkably scarce 


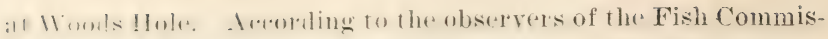
sim this tish is dereatsing l'apidly in numbers. Tandlining, even

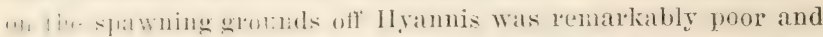

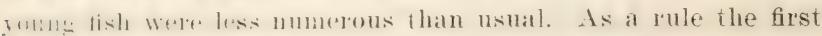
arlials allumit in their seasumal migration during the first or semond $\| \cdots+k$ in $11: 19$. When the water has reached a temperature of I 10 in F. Howerer, in spite of the cold of 1900, they aplu-alrel at r 'utyhunk and Menemsha Bight on Aprii 28-with

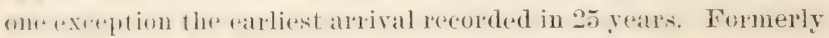
the yomb wrere abmulant evrrybere, but at present they are restriefed to a fow localities-Katama bay, Quissut harbor, and Willolam river. The tirst fry were seined July 31 and measmed a of an inch in length. On October 20 young fish 2 to :3 inches long were very plentiful in Katama bay.

In lat the writer obtained young examples only, and these in morlerate mumbers, at Fire Island near the end of Sutember. In 1 s.m a few individuals were observed in a net at Islipg. In 1.4x. alululs Were laken in abundance offshore at Southampton in . Ingnst and halfgrown specimens were secured from a pound

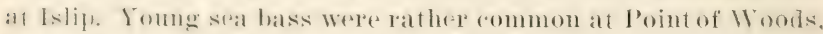
fireat somtl bay, Clam I'omd cove, Fire Island inlet, Oak Island

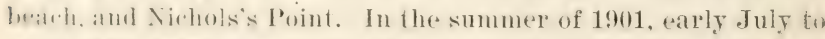
thr. midelle of (t) tohere only a few young individuals were taken, and thes weres serured in eel pots off Midows' Creek. Greas South bay.

The sal hass malies its appearance in ciravesend baty in Ilay. It is mot alomulamt. The youme in October are found in thent shatss, measmring from $1 \stackrel{1}{2}$ to 20 inches in length. The

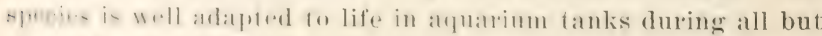
Hhe coldest months.

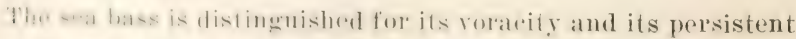

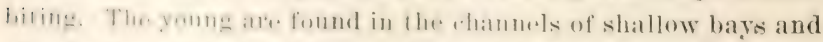

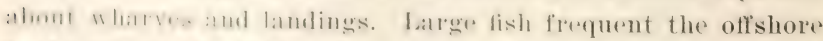

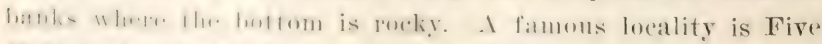

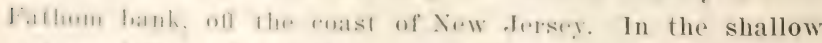
walers of limal lige llathor hay lommluds of small-sized sea 


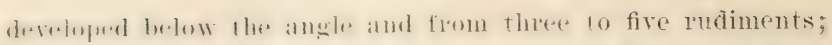

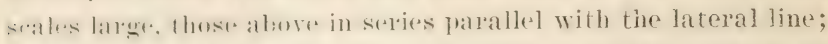
sarims on lowast smatl. Third domal spime extremely long,

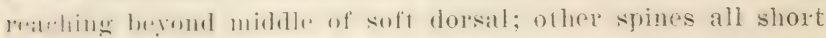
atul eren: suft dorsal modroute, a little scaly at base; dorsal

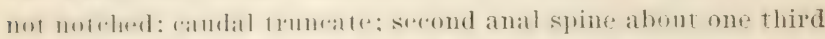

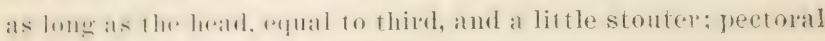
about one half as long as the head.

D. $\mathrm{I}, 13 ; \mathrm{A}$. III, 7 ; seales $6-4 S-15$, pores 45 to $50 ;$ B. 6 .

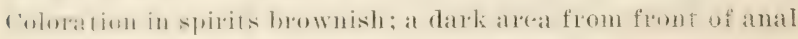
11) lo soft dorsal: before this a whitish area; uypre frats with faint. interruphed dark streaks along the rows of scales: a dark

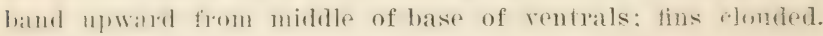
Length 10 inches. (After Jordan of Evermann)

1). Ka!y deseribed a spereimen 4 ! inches long as of a yellom ish-

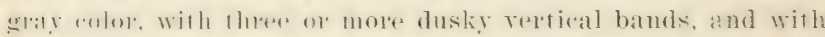
rembal fins linged with blarkish towand their tips. He re. Earloled it as an areidental visitor flom the tropies. The sub-

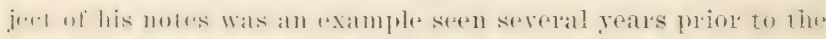
fmblisalion of his work in the eollection of Mr Hamilton. who infurdued him that it hat heren taken in the hatbor of Jew Jark.

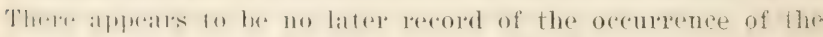
species on oul coast. De Kay refers to a specimen from

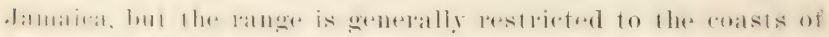
lixazil and Uruguay.

\section{Genus repreos Curier}

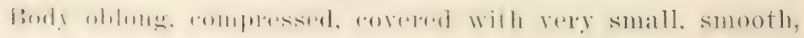
(2mberded scales. Lateral line normal; head scaly. Mouth

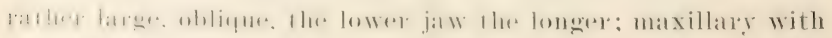
a smpplonirmal bone, as in Epinephelus, with which

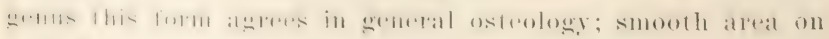
lop of (ranium vely litrege, transversely convex, much longer

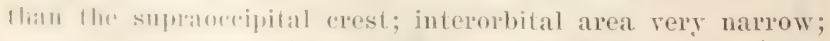
|ririrtal and smpracocipital bones short, with feeble crests:

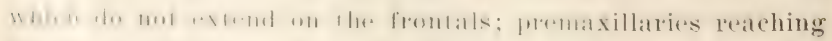
fromlals, which have a fossa in front; teeth all villiform, in 
Color. Insky olive brown. somewhat clouded; sides with a few irewular whitish spots: young spotted with brownish.

Sumb Llantic coast. I. S.. straying northward to coast of lihul. Island. The species is frequently taken in moderately deep water off ('harleston, Peusacola and Kre West. Mitchill described it from the straits of Bahama. The common name is given in allusion to the soapy feeling of the slin. The fish is small and has no value for food. Nothing is recorded of its habits.

\section{Family LOBOTIDAE Triple-taits}

\section{Genus цовотеs Curier}

liondy ublong, compressed, and elevated, covered with moderatr-sizd. wakly ctenoid scales; profile of head concare, the snout frominent: mouth moderate, oblique, with thick lips; upper jaw rery protractile; lower jaw the longer; maxillary withene supplemental bone; jaws with narrow bands of villiform fmeth, in front of which is a row of larger conical tecth flirelen hatkward; no teeth on romer or palatines; prestbital natrower thath ere; preperele strongly serate. Branchi. astruals six. borsal fin continuous, with 12 spines which may [1. drpussed in a shallow groove; soft rays of dorsal and anal fins relentled anal spines gratuated: bases of soft dorsal and anal thirkemed and staly; andal rounded. Air bladder present. l'yloric caeca three.

\section{Lobotes surinamensis (Bloch)}

\section{Flasher; Triple-tail}

Holuentrus surinumensis BLocri, 1ehthyol. pl. 243, 1790, Surinam.

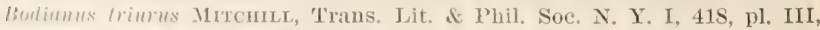
lier. I1), 1815, Powles Hook. N. J.

Lobutes nurformm Güntmer, Cat. Fish. Brit. Mus, I, 338, 1859.

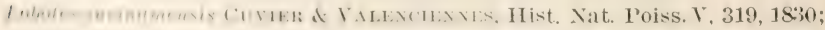

1): К.1\%, \. У. Fauna, Fishes, SS, pl. 18, fig. 49, 1842, New York;

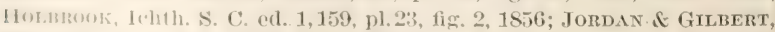
I\$nll. 14i, I. \&. Nat, Mus, 555, 1883; Jordan of Everarann, Bull. 47, I. X. Nat. Mus. 12:55, 1896, pl. CXCIT, fig. 510, 1900; H. M. SMmTh, HuH. I'. S. F', (1. 1897, 100, 1898; SHemwood \& EDwards, Bull. U. S. F.

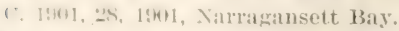

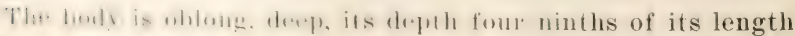

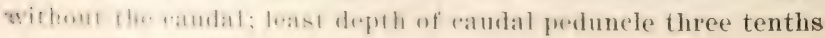


of body depth; profile of head rery oblique; nuchal region convex; head short, its length less than one third of total without caudal; lower jaw prominent; maxillary very heary, extending beyond middle of orbit, its width one half diameter of eye; snout about equal to eye which is one sixth as long as the head; scales around eye very small, those on opercle large; first dorsal spine shortest, two thirds as long as the second, two fifths as long as the third, one fourth as long as the fifth and longest, which is three eighths as long as the head; the longest ray of soft dorsal is one half as long as the head, and about equal to the longest ray of the anal; anal spines graduated, the first being two thirds as long as the eye and the third one fourth as long as the head; the pectoral reaches to below the serenth spine of the dorsal, its length one half the length of head; the ventral origin is under the lower axil of the pectoral; the rentral fin equals the postorbital part of the head in length, and reaches to below the tenth spine of the dorsal. Base of soft dorsal, anal, and caudal with fine scales. D. XI, I, 16: I. III, 11; V. I, 5; P. I, 15 ; scales 59 (pores about 53).

Blackish above, silvery gray on the sides, often blotehed and tinged with yellow; fins dusky gray, sometimes mingled with yellow.

The flasher is a large species, found in all warm seas, ranging on our coast from Cape Cod to Panama; it reaches the length of 3 feet and is used for food. At Woods Hole, according to Dr Smith, it is very rarely taken. Specimens were secured, however, in August 1873, December 1875, Sep. 20, 1886, and in August 1890. The individual obtained in 1886 was caught in a trap at Menemsha, Martha's Vineyard. The Rhode Island Fislr Commission has a specimen weighing 6 pounds and measuring 22 inches, which was taken Sep. 10, 1900, in a trap off Prudence island, Narragansett bay. The example described and figured by Mitchill was taken at Powles Hook N. J. Aecording to Mitchill specimens weighing four or five pounds were occasionally secured, and the fish was sometimes called black grunt. De Kay knew the fish only from the accounts of it given by Mitehill and Holbrook. 


\section{Family PRIACANTHIDAE}

\section{Catalufas}

\section{Genus Prercastus Cuvier}

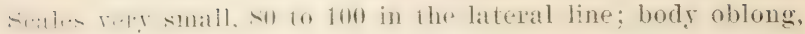

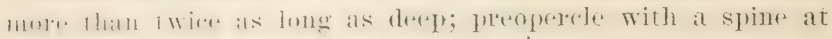

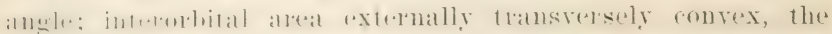

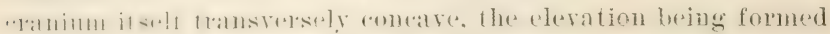

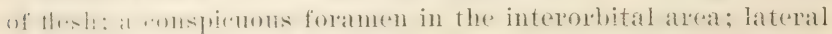

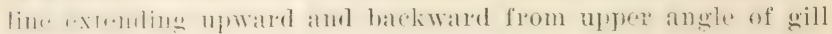

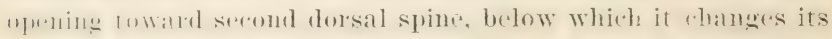

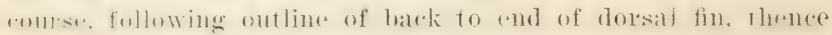

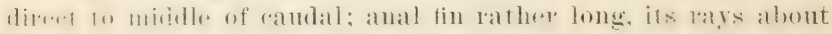

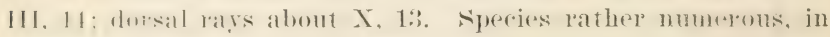
the tropical seas.

\section{Priacanthus arenatus Cuv. \& Val. Catalufa; Bigeye}

Priactuthis arenatus Cutier \& Valenciennes, Hist. Nat. Poiss. III, 101; 1529, Brazil; Jordax \& Gilbert, Bull. 16, U. S. Nat. Mus. 971, 1853; Jordax \& Evermaxy, Bull. 47, U. S. Nat, Mus. 1237, 1856, pl, CxeV, tig. 511, 1900; H. M. Sмнтн, Bull. U. S. F. C. 1897, 100, 1898, Woods Hole. Mass.

Prienethes macrophthalmus Curier \& Valexciexnes, Hist. Nat. Poiss. Ill. :7. 1529. based upon Authias maerophthalmus BLocH, an Asiatic species; 1;lomther, Cat. Fish. Brit. Mus. I, 215, 1859; Jordar \& Gilmert, Bull. 1ti, I. \&. Nat. Mus, 54t, 1883.

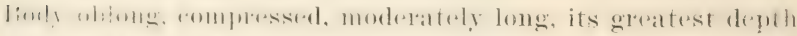

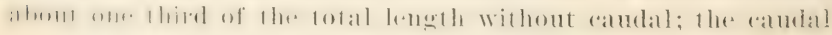

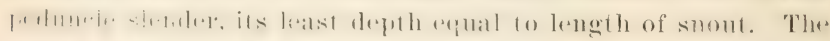

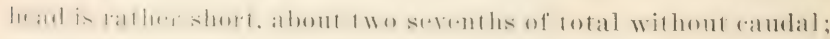
fho smont is short, one fourth as long as the head, and two thirds as long as the eye; the interorbital space is narrow and

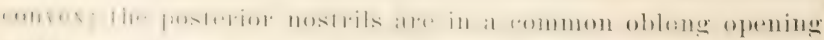

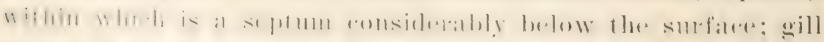

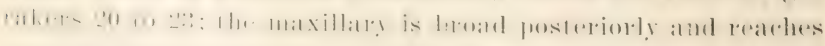
as loluw the fromt of the pupil; the lower jaw projects consider-

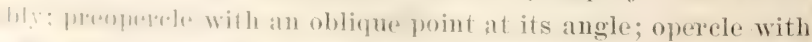
1 11:1 fmintul spinc, not projecting. Dorsal spines all slender, Ihe limet whls one late as long as the last and two ninths as 
long as the head; the anterior portion of the spinous dorsal is regularly graduated; no noteh between the spines and soft rays and the soft rays are not longer than the spines; dorsal spines more or less granulate on the edges. Caudal slightly concave, its lobes subequal, the middle rays nearly one half as long as the head. Tentral origin slightly in advance of origin of spinous doesal: the fin reaches to a point nearly under the eighth spine of the dorsal, but not to the anal origin. Pectorals about one half as long as the head. First anal spine two thirds as long as the third; and one fourth.as long as the head; the longest anal ray is less than one half as long as the head. I) X, 14; A. III, 15; V. I, 5; P. I, 16; seales 9-98 to 11.)-42; pores wanting on some of the scales.

color, silvery red; anal, soft dorsal, and caudal with a black edge; no spots on dorsal; posterior half of rentral black; about eight small dark blotches along lateral line, the largest less than one half as long as the pupil.

The catalufa is a native of the tropieal parts of the Atlantic; it has been recorded from Brazil, the West Indies, and Madeira, and sometimes migrates northward in the Gulf Stream to Narragansett Bay, Vineyar sound, and neighboring waters in summer.

At Woods IIole it is rare; seren specimens were obtained in September asd October 1876 , and afterward for several rears three or four were caught anuully. On Oct. 2, 1885, a specimen $3 \frac{3}{4}$ inches long was taken in a seine at Quisset Harbor.

\section{Genus pseudopricantuds Bleeker}

Scales large, very rough, 35 to 50 in the lateral line; hody. ovate, not twice as long as deep; preoperele with two small spines at angle; interorbital space broad and flat, there being little flesh between skin and skull; no foramen in interorbital area; lateral line changing its course below the fourth dorsal spine; anal short, its rays III, 9 to 11; dorsal X, 11. Otherwise essentially as in I'riaca $n$th us, the sprecies living in deeper water. 


\section{Pseudopriacanthus altus (Gill)}

\section{Short Bigeye}

Prumblhus ultus Gil.t. I'roe. Ae. Nat. Sci. Phila. 132, 1862, Narragausett Bay; Jordan \& Gilbert, Bull, 16, U. S. Nat. Mus. 545, 1883.

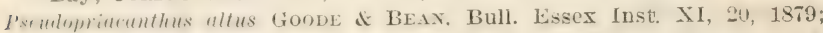
Jordan \& EtgexMANN, Proc. U. S. Nat. Mus. 269, 1887; Jordait \& E.rim.xx, IBull. 47, [. S. Nat. Mus. 1239, 1896, pl. CXCV, fig. 512.

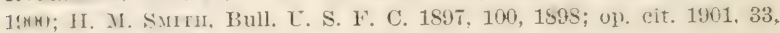
1901, Woods Hole, Mass.

Imoly wate. compressed, its greatest depth one half of the fotal l.ngth without caudal; the caudal peduncle short and stou1. its leatst depth two thirds of its length and equal to fostmrlital part of head. Irofile little oblique; mouth larese, subwrtinal: sunut short, one half as long as the eye, which is nearty ome late as long as the head; maxillary very broad posterionly, its wiblh matrly one half its leugth. extending to beyond the midlle of the pupil. Mead large, nearly two fifths of total longlt without raudal; teeth in upere jaw in a narrow villifom band. the muter series enlarged; similar teeth in the lower jaw, but the inmer ferth larger than in the upper jaw; preortuital stronely serrate, narrow, one half diameter of pupil; preoperele s.rate, lle serrate of the lower margin largest; no preopereular ypine: operele and suboperele serrate on their lower margins. lowsal spines from the first to the fifth graduated, the first twe fiflis as long as the fifth, which is as long as the snout and eye comhined; the last spine is one half as long as the head; the mas suft ra! is I wo thirds as long as the head, and the longest suft ral engals lhe lemgth of the head without the snout, the fast dorsal raly is alomut as long as the first dorsal spine. The randal is slighly andex, its midlle rays equal to snout and eye combined. Inal spines graduated, the first one third as long as the leat. the third nearly one late as long as the head; the andrior soft mas a1\% produred as in the dorsal, the longest as fone as stmul amb eye combined. The short and broad pectorals

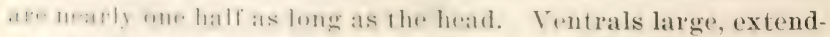
lane the the ibirel spine of anal fin. Seales all extremely rough,

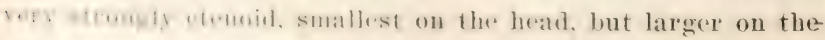


iaxilla than elsewhere on the head; lateral line ascending over he pectoral, then nearly following the outline of the back to he caudal peduncle, where it becomes median.

D. X, 11; A. III, 9; scales 10-45-23.

Color in life bright red or crimson; the fins, except the peeorals, with black tips; the e'e glowing like molten gold.

The species is found in rather deep water in the West Indies nd from the Caribhean to Charleston, the young often followag the Gulf Stream northward in summer to Cape Cod. The argest individual recorded is 11 inches long. Most of the specilens taken near Cape Cod are small. The northern limit of the sh appears to be Marblehead Mass., where an example was aken Sep. 3, 1859.

The trpe of the species was collected in Narragansett bar. ndividuals were obtained at Woods Hole Mass., Sep. 29, 1875, 1. 26, 18 7 and Yor. 28, 1885. On Nor. 1, 1890, a specimen ras found in the Acushnet river, at NeW Bedford. In 1899 orer 00 specimens were takc'n at $\Pi$ oods Hole, and in 1900 only niue rere observed between Ingust 15 and soptember s. The writer btained the species in moderate numbers in the Gulf of Iexico in 1886. The colors of large individuals appear to be as brilliant than in the roung. but the fish is always strikingly andsome.

\section{Family lutianidae}

\section{Snappers}

\section{Genus Neonaens Girard}

Body oblong. compressed, the back somewhat elevated; heal ong, naked above, except for a broad oblique band of scales at he nape; nostrils normally (lose towether. neither with a tube: louth large, the jaws with bands of rilliform teeth, besides hich there is usually an outer series of larger teeth in each $\mathrm{w}$, and two to four stronger teeth or canines in front of upper aw; romer with villiform teeth; villiform teeth on the palaines; usually one or more patches of teeth on the tongue in he adult; no molar teeth; no teeth on pterygoids; preopercle ithout notch or with a shallow emargination; posterior liunb 


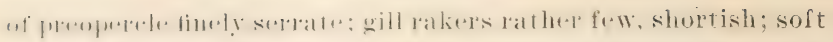

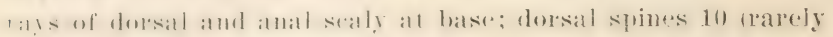

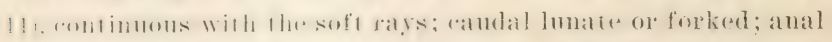

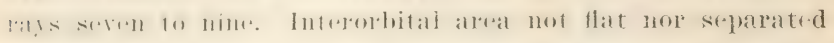

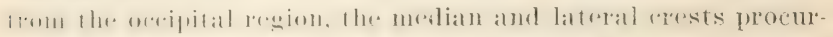

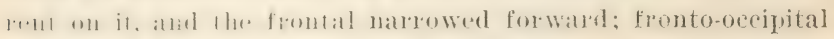

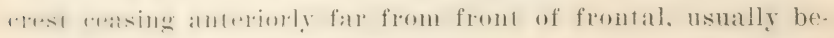

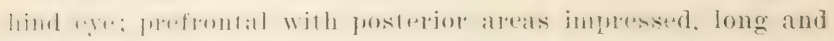

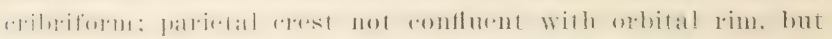

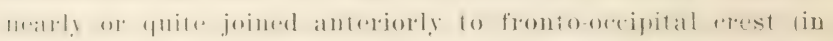

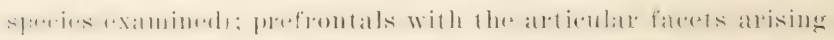

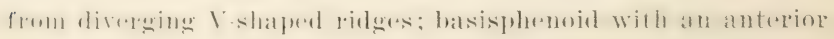
Iobiform extension. Vertebrate $10+14=24$.

\section{Neomaenis griseus (Linnaeus) \\ Gray Snapper; Mangrove Snapper}

Laturus yrisens Lrxwates, Syst. Nat. ed. X, I, 283, 1758.

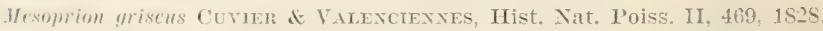
Sin Domingo.

lobotes emaryinulus Band \& Grard, 9th Smithson. Rep. 332, 155.5, Beesley's P'oint, N. J.

I/esoprion cabullerote Powr, Repertorio, II, 157. 1868.

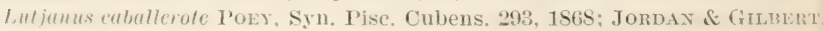
I3ull. 16, U. S. Nat. Mus. 921, 1S53; Goode \& BEAx, Proc. U. S. Niat. Mus. VI, 42, 185t.

Lutiunus steumsii Goone of Brax, Proc. U. S. Nat. Mus. I. 179, 1578, Pensacola Fla.; Goone, Fish \& Fish. Int. U. S. I, 396, pl. 142, 1584.

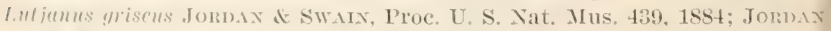
E Fesiak, Rept, U. S. F. C. 1859 to $1891,441,1893$.

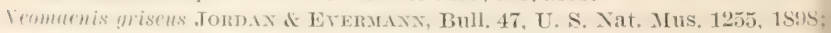
I1. II. smit, Inull. U. S. F. C. 1897, 100, 1895; op. cit. 1901, 33, 1901.

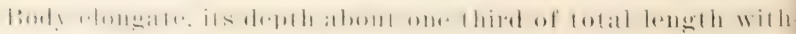
ont atulal; hack not much compessed; profile from snout to

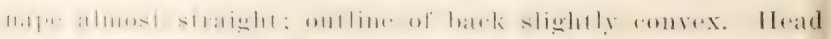

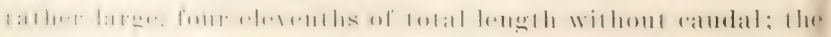
stmut pointal, ond third as long as the head; eye small, two thids as long as the snont, rather more than one fifth as long

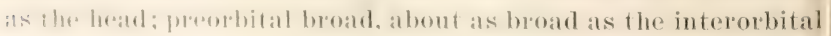
spater which is gently comvex and one sixth of length of head;

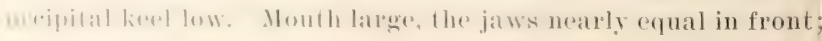


the maxillary reaches to below front of pupil, its length contained two and threse fiftles times in length of head; eight developed gill rakers on the first arch, one above and seven below the angle, the longest on half as long as the ere; there are seven rows of seales on the eheress the single patch of lingual teeth twier as long as broad: romerines in a triangular patch on the head. with a long. narrow hackward extension; palatines in a broad hatud; seales extend upon the membranes of the dorsal, anal and ratudal fins for about one half their hight, or rather more on the caudal: two very strong ranines in the uppere jaw, and two murh smaller ones between these and the symphysis; mandible without enlarged canines; preprecte fincly serrate abore, roalsely serate at angle, the posterior margin nearly rertical, with a broad and derep noteh; scales comparatively lareere in horizontal rows below the lateral line, those above lateral line rumning parallel with it till below the soft dorsal, where they berome slightly irregular and oblique; seven rows of seates on rherek; an cmbedded row on interoperele; a row on suboperele, and seven rows on operele; temporal region with about these lows of large scales; top of head, snout, and jaws naked.

The first dorsal spine is one eighth as long as the head, one half as long as the sereond and the last: the fourth and longest spine is one third as long as the head; the longest ray of the soft dorsal is equal to the longest spine: the last ray is one half as long as the upper jaw. The "atulal is slightly emarginate, the nupere lobe slightly the longere, the middle lats five ninthe as long as the head. The first anal spine is theep sevenths as long as the third which is neally as long. but not so strong, as the second and nearly one fourth as long as the head; the secend anal ray is longest, neally four ninths as long as the head. and more than onfe serenth of total length without raudal. Ventrals one fifth of total length without raudal; pertorals one fourth of the same length, and seareely reaching rent. I. VII ;

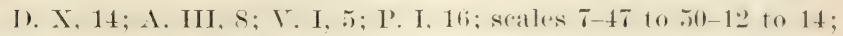
47 pores in lateral line. 


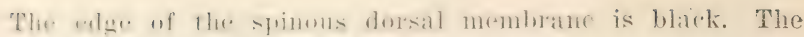

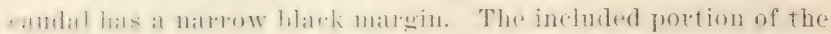

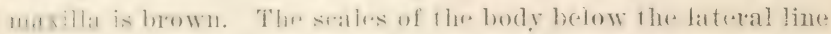

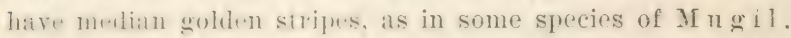

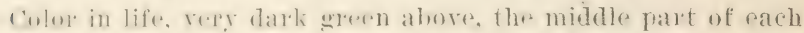

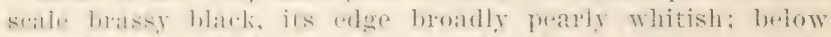
lateral line the duskiness of the midelle of the seale passes into

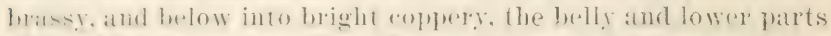

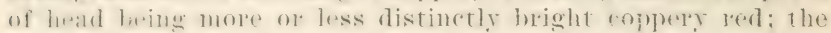

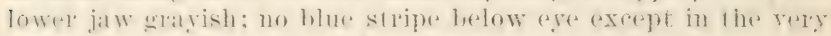
romme: (1) of head hlarkish olire: dorsal blatekish. its margin

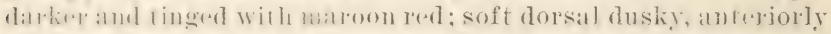

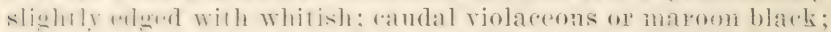
anal wine (.olol, edgerl with whitish; pectorals pale flesh eolor; relltals whitsh, fantly marlied with reddish. Jommg with a

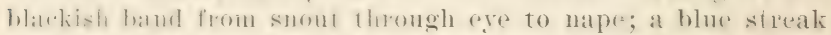
lu.low $\because \cdot 1$ : spinoms dorsal with a maroon rolored haud along edge.

The waty smapper inlabits the Mest Indies, the f'atibluen

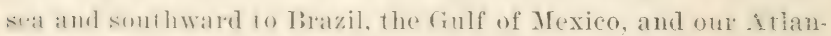

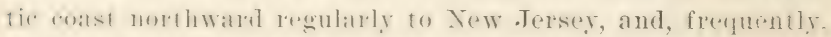
10 f atpe roul. The fish is valualle as food: it probably rearlues

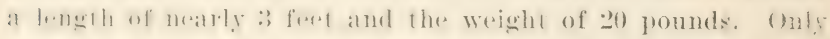

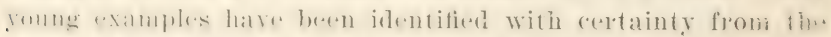

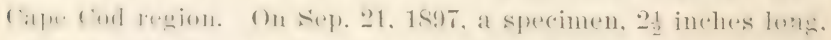

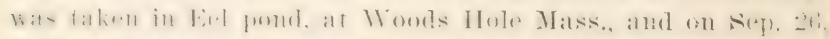

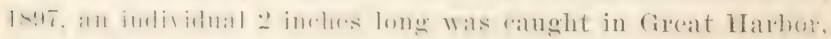

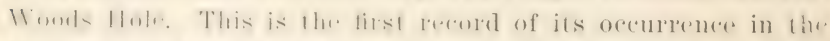

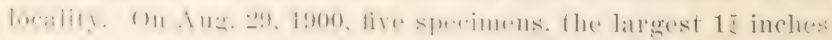

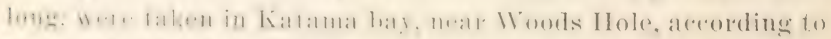

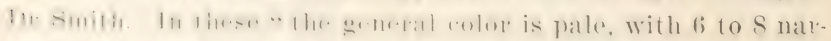

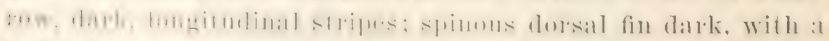

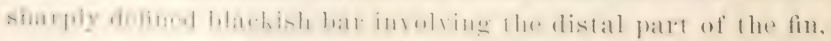
thr axtreme eden being white."

\section{$\because 71$ Neomaenis blackfordi (Goode \& Bean)} lícal S'napper

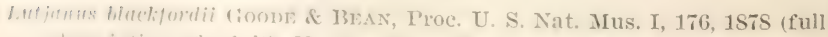

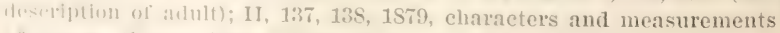
wi young; (ioont, Game Fishes X. A., 16, 1878, with colored plate. 


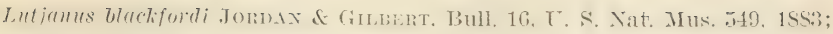
BeAn, 19th Rep. Comm. Fish. N. Y. 263, pl. XVI, fig. 20, 1890.

Lutjanus campeachiamus Jordar \& GILBERT, op. cit. 971 (not IIesomion campeachanus Poex, Mém. Cub. II, 149, 1860); Jondan, Proc. U. S. Nat. Mus. VII, 35, 1884.

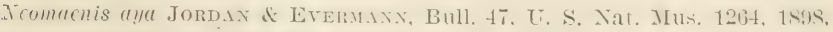

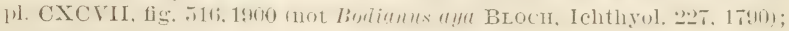
H. M. Sмттп, Bull. U. S. F. C. 1897, 100, 1898.

Neomaenis blackfordi H. М. Sмrтн, Bull. U. S. F. C. 1901, 33, 1901.

Body much complessed: its upler profile ascending from the smont, with a slight concavity in front of eye, to the origin of the spinous dorsal. thence descending in a long curve to the loase of the caudal: under profile much less arched. Jams equal. Gireatest hight of body equals lenglh of head, which is three eighths of total length without caudal. Least depth of caudal peduncle equals one third of the distance flom the snout to the pectoral. Preoperculum fincly and evenly serrated, except at the angle, where the denticulations are coarser; a slight emargination above the angl(', in which is received an elevation upon the interopercle, and two shallower emarginations above. Maxillary not reaching to below front of orbit; mandible not below middle of orbit. Lingual teeth in two patches. Vomerine patch a quadrilateral figure, with enucave sides, and with the longest sides posteriorly. Palatine patches somewhat spatulate, broadest posteriorly. Ere circular, its diameter contained seven and one thild times in length of head. Snout nearly equal to maxillary. Mandible equal to one half hight of body at ventrals. Thistance of spinous dorsal from snout about three times length of sunnt; length of its base about equal to prectoral. Longest dorsal spine three times as longas the first, and twice as long as the second anal spinc; it is mearly as lomg as the snout. The longest dorsal ray Isixth) is contained three and one fourth times in the length of the head. The anal base is a little longer than the mandihle: llor first anal spine is nne half as long as the second, which is ome third as long as the rentral fin; the third spine is slenderer and slightly lomerer than the second; the longest ray of the anal is twire as long as the snout. Caudal much emarginate. ceresernt-shaped; the middle 


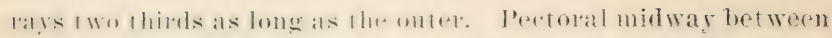
stm ant anl migin of anal. its lometh twier that of the maxillaty.

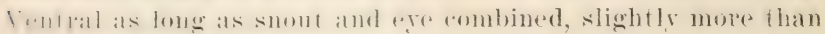

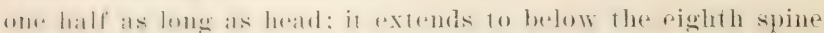
of the dorsal. 13. VII; 1). X, 14; A. III, 9; V. I, 5; P. I, 16; seales 8 to $9-50-15$ to 16 ; gill rakers on lower arch, 8 .

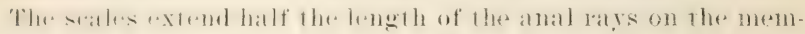

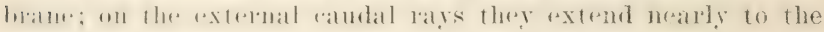
tip. and wilh slight trates mpun the spinous dorsal in front of

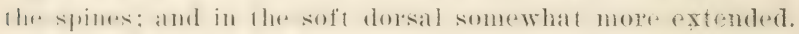

Color miform searlet. Center of seales lighter, also the lully, "hirh is silsere: inside of axil of pertoral dather matroon.

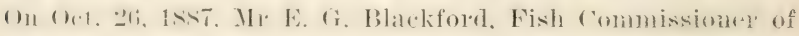

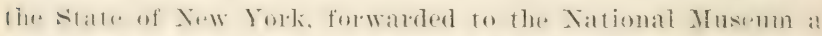

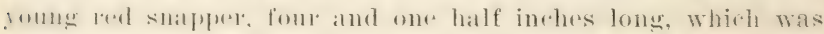

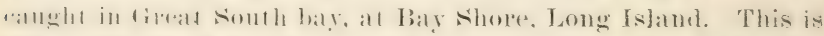

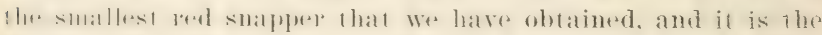

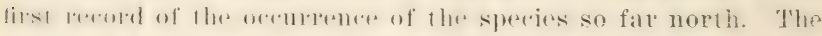

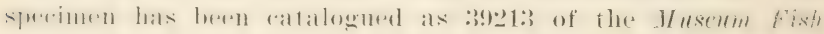
liegister.

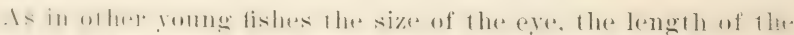

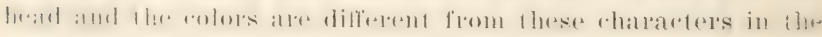
:110111.

I description of the colors of the fresh fish follows:

A datk band nearly as wide as the diameter of the eye is

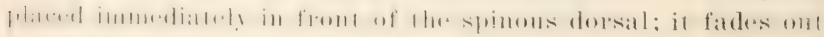

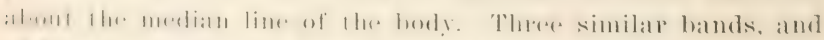

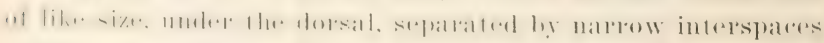
and fanding ont below. The fompth band contains a bloteh as large as lhe eye which passes slightly beneath the lateral line. I tifll hamb is muler the last third of the soft dorsal and con-

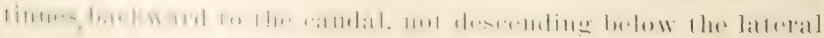

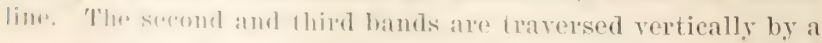
natrent mulian stripe of the rosy boty color. Tembrane of dursals and ratudal will at natrow black adge. Spine and exlormal ra! of woul mal milk white. Inal losy, except membrane

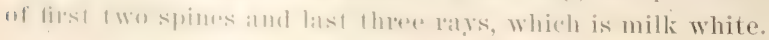


On July 12, 18:0, Mr Tinal X. Edwards obtained a spereim:n of the red snapper. which weighed 12 pounds, from a bass trap set in 10 feet of water, at Wenemsha, Iaththa's Vineyard. Mr Edwards believed this to be the first one taken on the Massatchusetts coast. but thought one was eaught some years ago near Block Island.

On October 10, 1890, a sperimen weighing $8 \frac{1}{2}$ pounds was taken at the same place. On september 7 and 11, and Oetober 20, 1900, nine sperimens were taken in the ricinity of Woods Hole Mass. and recorded in the artirle of Dor smith. The laresest of these was under 2 inches long. Dr. Smith described the colors as follows: "fieneral rolor, red like the adult fish; body marked hy about seven double dark ross-bands; in the ross-band nearest the junetion of the two parts of the dorsal fin is a large jet black bloteh extending from the fin to below the lateral line; spinous dorsal dusky; soft dorsal with a dusky median zone and a dark edge: raudal pale, with a dark marow border."

The red smappere has become one of the most famoms fishes of our noptheren markets, and is always attractive on areomint of its larese size, billiant colol, and the exeellence of its flesh. We know that the speries is to be found on our east roast from calpe cod to the carribbean seal. It is latere howeres, north of cape IIatteras and the prineipal fisheries alre located of the coasts of reorgia and Florida, and in the Gulf of Mexico.

When the red snapper Was named in homol of Mr. Engene: 6. Blackford, in recognition of his invaluable coutributions to the science of ichthyology, the describers of the sprecies hat carefully considered the question of nomenclatme and satisfied themselves that none of the names known to them rould with certainty be associated with this fish. Tarious earlier names have been suggested from time to time by several authors as possibly avalable for the speries. In 1Ss:; I) I). S. Tordan (onn-

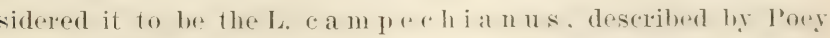
in 1860. This. howerere, is a spureies with much smallere suales if the description he aceurate. The type has not beren examined by any one in the Tnited states so fat as I an informed. 


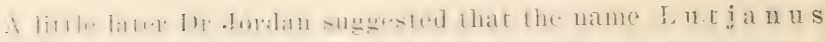
i is a 1111 s af ('ur. it Vil. should be aceepred for the red

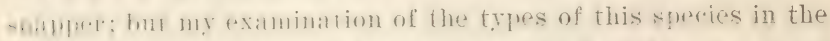

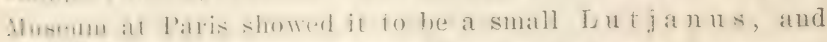

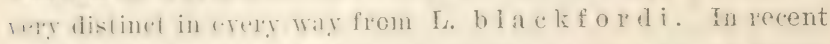
lisis lor. Iordan has alopled the specitic natue a y a of Bioch,

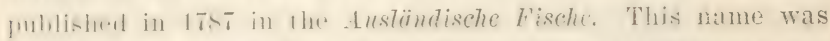

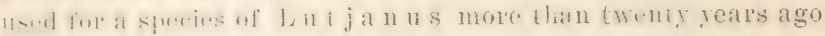
by Di 'Theodore Gill.

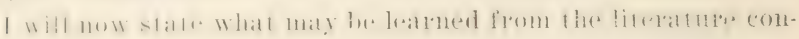
cerning the a y a. The Bodianus a $\mathrm{y}$ a of Bloch is dis-

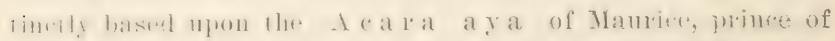

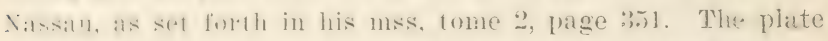

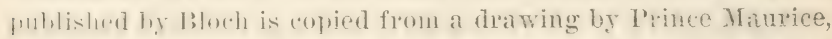
and his discriplion is dratwh flom the same sompr. The fish whirh formed the suhjere of the deseription and illustration oy

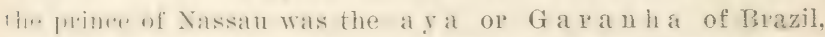

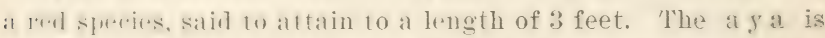

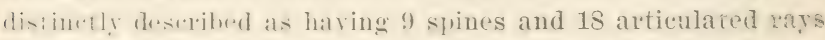
iil llur dorsil. It is represented as having 40 scales in the

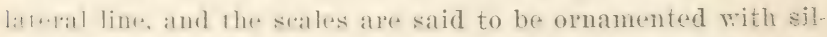
l.r. sulmatramal stripes. Bloch was informed that the tist

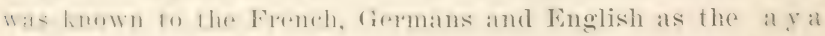

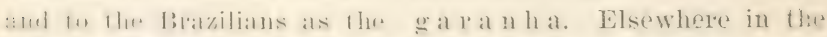

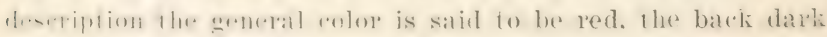

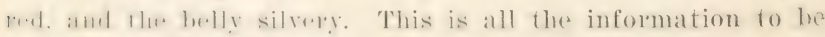

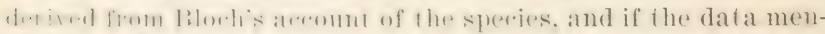

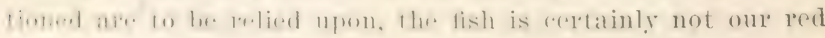

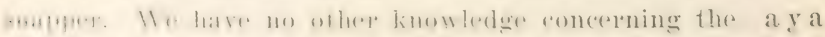

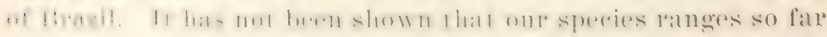

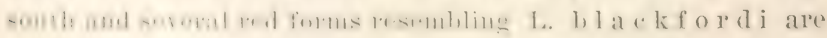
ascoriafed with it. Various interpretations of the a y have

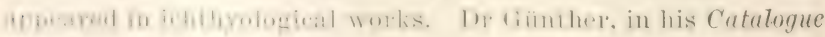

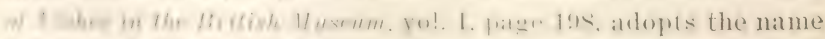

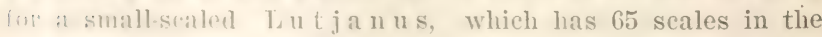
lat refal line and :3- in a transterse series. Of this he has a fine 
specimen flom South America. A very curious translation of the earlier descriptions of the a y a is to be found in Lacépède's account of the species. which is given below. The diagnostic characters are stated as follows:

Nine spines and 18 articulated lats in the dolsal; one spine and eight divided rays in the anal; the caudal crescent-shajed; rach opelele teminating in a long and flat spine; the general color red; the back blood color; the belly silvery.

The anthor, in anothre part of his Tatural Historly of Fisfese. writes:

A figule of the aya lias been published by Marcgrave, Piso, Willughby, Jonston, Russch, the prince of Nassau [Maurice] and Bloch, who has copied the drawing of Prince Iranice. It is found in lakes of Iraizil. It frequently reaches a length of one meter, and it is so plentiful that large numbers of this species are salted or sum-dried for export. It may be very desirable and, perhaps, sufticiently easy to acclimatize this large and beautiful bodiamus, the flosh of which is very agreeable to the taste, in the fresh waters of Europe, and particularly in lakes and ponds of France.

\section{Family HAEMULIDAE}

\section{Grunters}

\section{Genus orthopristrs Girard}

Body moderately elongate, compressed, the back arched: head compressed, the snout usually long; mouth rather small, placed low; teeth in jaws in rilliform bands, the outer teeth abore somewhat enlarged; exe moderate; preopercle with its vertical limb straight, fincly serrate or entire; gill raliers rather long and slender; dorsal spines rather slender, 12 or 13 in number, the fin usually not much notched; soft dorsal long and lom. usually with 15 or 16 rays, the membrames usually naked: aual spines small; caudal lunate. Srales rather small, those abore lateral line arranged in series not parallel with it; usually no smaller accessory scales at base of the larger ones. This gr-mms contains a considerable number of species differing from Po m a d a s is in the long anal fin, the smaller s'alles, anrl in the less development of the dorsal spines. Nearly all the species are American. 


\section{0rthopristis chrysopterus (Linnaeus)}

\section{l'igfish; Hogfish}

Perel chlysopter Lixxuses, Syst. Nat. ed. XII, 485, 1766, Charleston, S. C. Lubrus fulcumaculatus Mltchis, Trans. Lit. \& Phil. Soc. N. Y. I, 406, 1815, Nirw lork.

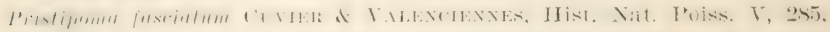
1830, New York, youmg; Guxtien, Cat. Fish. Brit. Mus. I, 301, 1859, New orleans.

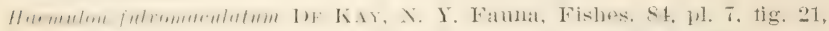
184', New Jork; HoLmrook, Ichth. S. C. 156, pl. 22, fig. 2, 1856.

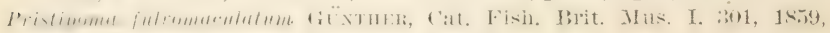
eopied from HoLnßook.

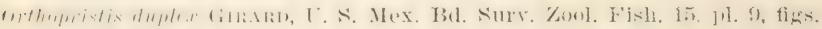
1 to 4,1659 , Texas.

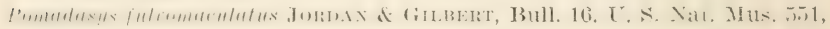
$18 \times: 3$.

() rhomristis chrysopterus BeAx, Bull. U. S. F. C. VII, 142, pl. III, fig. 11, 18s5; Jordax \& Fesper, Rept. U. S. F. C. 499, 1893; Beax, Bull, Am. IIs, Yat. Hist. IX, 366, 1897; Jordan \& Evermaxa, Bull. 47, U. S. Nat. Ifus, 1338, 1S!S, pl. CCX, fig. $541,1900$.

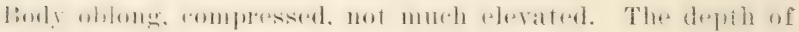

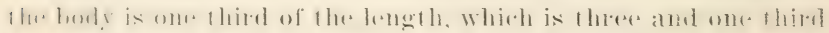

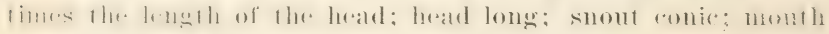
low and small, Hhe maxillaty hately reathing to the mostrils:

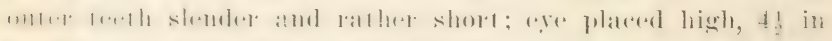

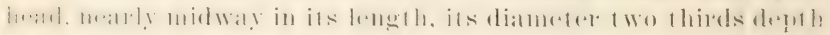

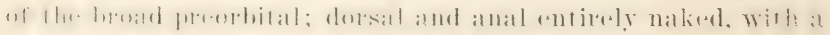

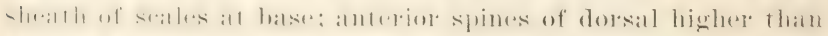

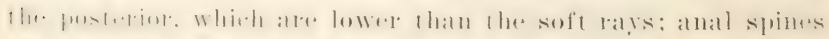

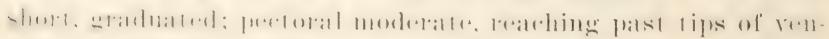

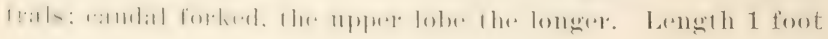
(6) 1 in inchus.

1). NII, 16; I. III, 12; Lat, 1, 75; pyloric caleca six.

light brown, silvery below; sides with numerous orange

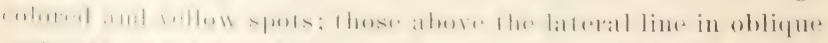

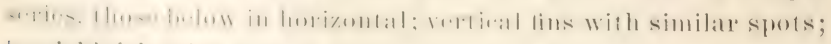
lumal bluish will yollow spots; angle of mouth and gill memlo:alles witl o1:allow.

The pigfish ranges along the Atlantic coast from New York

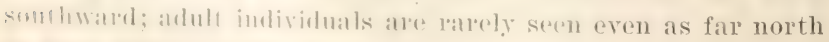

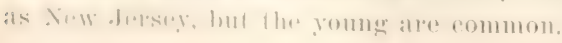


It Beesley's Point X. J. Ang. 10, 1Ss, many young individuals were taken in the seine. D. XII, $16 ; \mathrm{A}$. III, 13 ; scales, 75 .

I dark stripe beginning on nape and dividing sends one branch along the back on eateh side not far from dorsal ontline; a dark stripe from ere to root of caudal; rheelis and opereles with sereral narrow orange stripes: a narow orange stripe betweren the two dark body stripes and another below the lower dark stripe; below the serond orange stripe with numerous arange spots, not continuous. These specinems are from less than 1 inch to more than 2 inches long.

Young examples were seined at somers Point, August 13, and abundantly at Ocean city, August 1li. The croaking some made by these little fishes is quite noticeable.

September 5, Mr W. S. Keates bromght in two examples which had bren caught on a hook with rlam bait; these are $5_{\ddagger}^{1}$ inches long. and much larger than the average size. Specimens from $4 ! \frac{1}{2}$ to 5 inches long were "aught at Bersley"s Point, August 2y; in these there is only a tratere of the blark lateral stripe along the median line, and the sides have sereral broad, dark bands.

September 9 an individual jo inches lomg was taken at Beres ley's Point. This sprecies is mknown to the fishermen. One angler described its croaking as resembling the quarking of a duck.

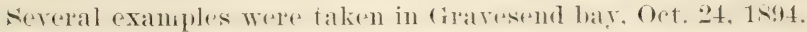
De. Kaly mentions it as a rare fish, but oceasionally aplearing. Jre was informed, in New York harbor in ronsistrable numbers. He states that it is a very sarory food.

Family SPARIDAE

\section{Porgies}

\section{Genus stevotoms Gill}

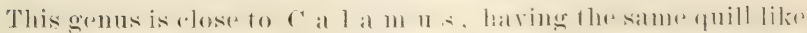
interhatemal bones, the flattened intisurs and antrolste dorsal spine mainly distinguishing it; tempomal erest obsolete; fontal bones not gibbous nor porous: antromse spine attareded to the

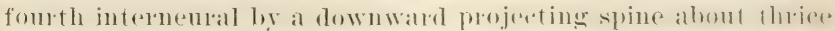
as long as the spine; lateral arest nowhere ableseding with the 


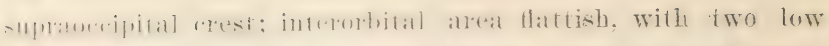

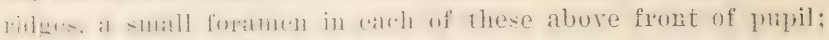

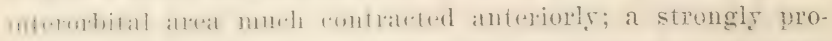

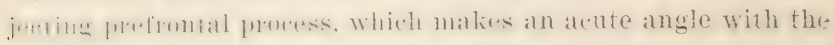
suprarorbital. American shore fishes.

\section{Stenotomus chrysops (Linnaeus)}

\section{Scup; Porgy; Sand Porgee}

Spanus chrysops Linnaeus, Syst. Nat. ed. XII, 471, 1766, Charleston S. C.

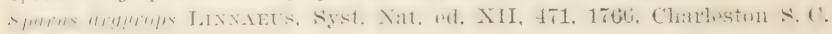
young.

J.abris versicolor Mrtchile, Trans. Lit. \& Phil. Soc. N. Y. I, 404, pl. III, fig. 7, 1815, New York.

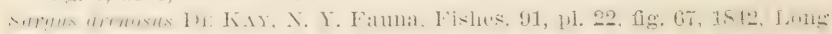
Islaud, young.

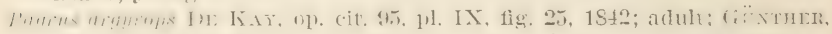
Cat. Fish. Brit. Mus. I, 472, 1859.

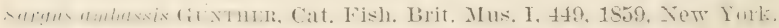

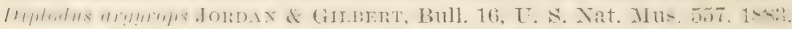

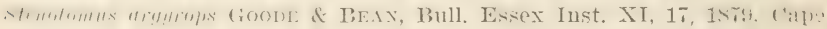
Ann Mass.

S'tonntomus chrysops BEAN, Bull. U. S. F. C. VIl, 142, 188s; 19th Rej). Comm. Fish. N. Y. 261, pl. XIV, fig. 18, 1890; JordaN \& FesLe1, Rept. U. S. F. C. 1859 to 1S91, 507, 1893; BEAN, Bull. Am. Mus. Nat. Hist. IX, 366, 1897; H. MI. SMITI, Bull. U. S. F. C. 1897, 100, 189S; JoRdAN \& I: JiFAx, 52d Ann. Rept. N. Y. State Mus. 106, 1900; SHerwood \& Enwarns, Bull. U. S. F. C. 1901, 28, 1901.

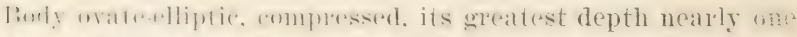

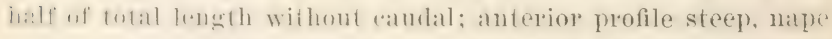

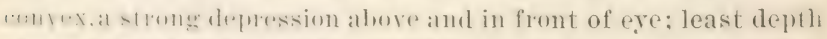

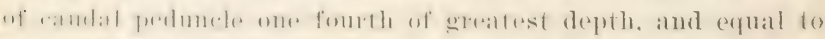

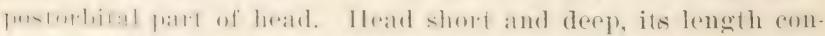

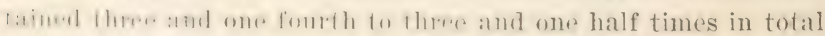

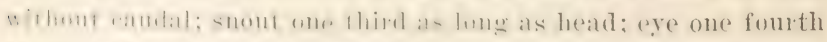

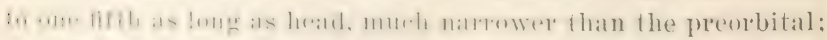

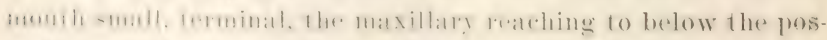

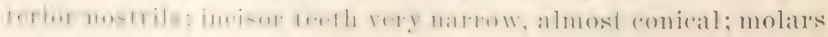
in two rows above; cheeks short and deep, with four rows of

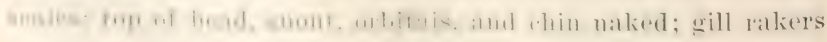

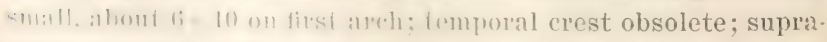
moipital erest comtimusus with the frontal bones; a procumbent 
spine in front of the dorsal; first dorsal spine as long as the eye; third. and longest, dorsal spine as long as the head without the snout; last dorsal spine nearly one third as long as head; soft dorsal highest in the middle, its longest ray (sixth) equal to suout. Caudal deeply forked, its middle rays two fifths as long as the external, and equal to snout. First anal spine three fourths as long as the exe; second and third about equal, two aerenths as long as the head; soft rays rather short, the first and second about as long as the snout. Pectoral long, reachiug to above the second ray of the anal. Tentral four fifths as long as the head, reaching nearly to vent. D. XII, 12; A. III, 11; Y. I, 5; P. I, 15. Scales 8-50-16.

Color silvery, with bright reflections, dusky above, upper frart of head deep brown; dorsal horn color, the last rays with a yellowish tinge; axil of pectoral dusky; young with fire or six dusky bars; iris golden, mottled with silvery and brownish. Length, about 1 foot.

The scup is one of our best known fishes. In many places it is better known under the name porgee. Mitrhill and De Kay described it as the big porgee. Another spelling for the same name is pogy. Scup is an abbreviation of scuppaug, which in turn is a shorter form for the Narragansutt name, misheuppauog. The name faimaid, which is said to be given to the seup on the Virginia coast, does not rightfully belong to this suecies, but rather to the sailor's choice ( $L$ a g o o $(l \circ$ n). The name fairmaid is regularly applied to the latter species at Cape Char'es Ta. according to B. A. Bean. In Norfolli Va. Mr. Bean heard tler name maiden for the young of the common scup.

The scup seldom migrates north of Cape Cod, though it has been taken occasionally off Cape Ann. Attempts to introdure it into Massachusetts bay have been unsuceessful.

The scup comes into our northern waters in great schools, the large spawning fish coming first, making their appearance in New York waters in May. The species feeds upon small crustaceans, mollusks and annelids, and is one of the readiest biters along the coast. The fishery fluctuates greatly; in certain years 


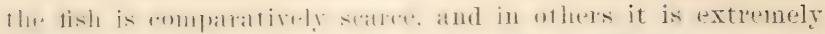
almmblant. It is ranght in funnds and traps. and remains in

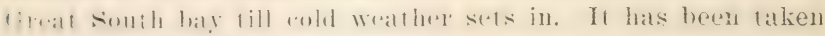

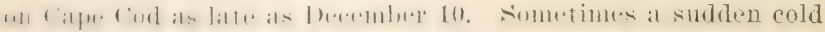
spell kills the fish in large numbers.

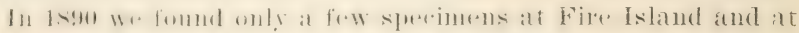

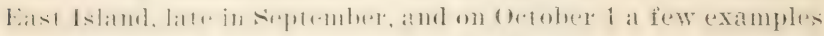
were taken in a trap at 1slip. In 1898, adults were taken in

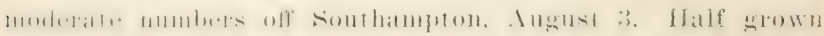

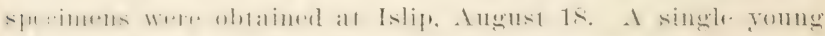

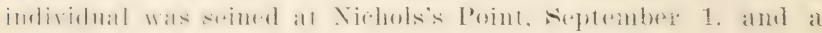

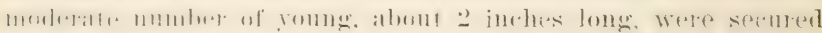

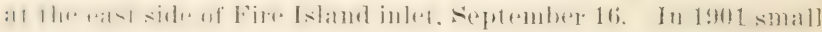

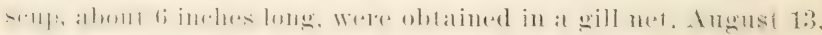
and in IIats's pound, July 31, in Clam Pond cove.

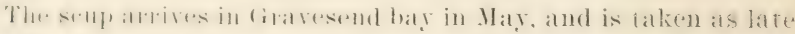

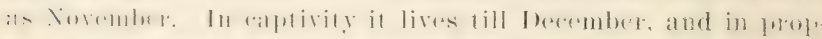

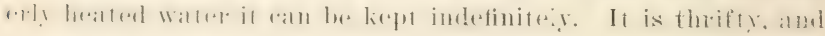
is seldom in bad condition.

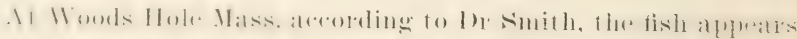

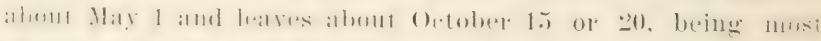

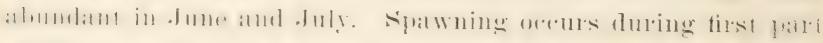
nf . Inue, and foung $\frac{1}{2}$ inch to $\frac{3}{4}$ inch long are observed by the

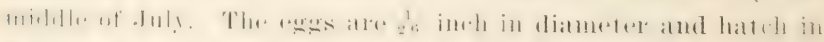
fonl days at a mean temperature of $620 \mathrm{~F}$. In 1900 , the senp) arrived off Newport April 21, at Cutty Hunk April 26, and at Moods Holo May 1. IImulreds of young are killed there anmally hy a sudden fall of temperature. The growth of the

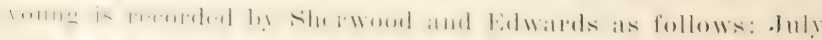
$\therefore$ lomglh 1 to 1 inches; Ingust is, $1 \frac{1}{2}$ to 2 inches; Septembel 6 .

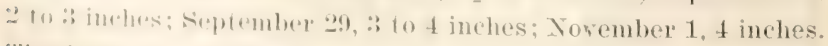
The latreses individual observed weighed 3 jounds.

The young atre divomed in latre mumbers by cod, weakfish, blurfish and ofher predaleeous species. 


\section{Genus Lagobor Holbrook}

The essential chatrater of this genus is in the form of the skull. Supracoipital and temporal crests nowhere coalescent. the interorbital area not swollen; frontal bone in the interorbital area thin, concare in transresese section; temporal crest low serpatrated from supratoceipital crest by a flattish area which extends forward on each side of supraoceipital crest and to groore of flemaxillary spines. ()therwise essentially as in $1 \mathrm{r}$ e hos a $r^{2}$ \& $11 \mathrm{~s}$, the antrorse dorsal spine present, the second interhamal not modified. One speries, the incisols deeply notched.

\section{Lagodon rhomboides (Limmaeus)}

\section{Sailor's Choice}

Sparus rhomboides Lixwaeus, Syst. Nat. ed. XII, 470, 1766, Charleston S: C. Saryms rhomboides Cuvier \& Valenciennes, Hist. Nat. Poiss. VI, 68, pl. 143, 1830; DE KAY, N. Y. Fauna, Fishes, 93, pl. 71, fig. 228, 1S42, copied from Cuvier \& Valencrenses; Günther, Cat. Fish. Brit. Mus. I, 447, 1854.

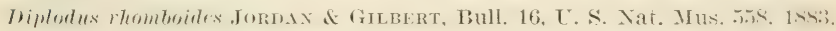
Lrgodon rhomboides IIoLbrook, Ichth. S. C. ed. 1, 56, pl. S. fig 1. 1856; ed. 2, 59, 1860; BEAx, Bull. U. S. F. C. VII, 142, 18ss; 19th Iiep. Comm. Fish. N. Y. 263, 1890; Bull. Am. Mus. Nat. Hist. IX, 366, 1897; H. II. SMmti, Bull. U. S'. F. C. 1897, 101, 1895; Jordax \& Evermaxx, Bull. 47, U. S. Nat. Mus. 135s, 1898, pl. CCXV, fig. 552, 1900.

Body orate, rlliptic. compressed, and somewhat elevaterd, the axis of the body near the middle of its depth; snout about in the axis. The depth of the body is contained two and one third times in its length. Ilead rather sharp, the length contained three and one half times in that of the bodr. Mrouth small, the upper jaw more freely protractile than usual. Molars in two series: anterior incisors eateh derply notrhed. ('heelis with 5 or fi rows of scales; scales on the breast little reduced in size. I procumbent spine before the dorsal fin; dorsal spines high, much higher than soft lays. the fourth highest: second anal spine little larger or longer than the third. Peetorals as long as the head; ventrals two thirels as long, not reaching to vent. I), XII, 11; 1. III, 11. Seales $8-66-18$.

Brownish. white below; sides of head and body with horizontal stripes of light blue and geolden; six or seren rery faint 


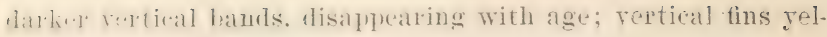
lowish, with bluish stripes; a dark axillary spot.

This is called the salt water heam by schoupf and the rhomimblal purgee by 1)eKay. In Chesapeake bay it is the fairmaid. It is also ralled pintish, syuirel fish, porgee, yellowtail and shiuer. In Gireat fouth bay the name of the fish was unknown 10 the fishermen, and this is true in cireat Ege Harbor bay, where the young are not uncommon in summer.

In tiraterend bay it is not a rommon fish, but is found occasionally in summer.

A single individual was obtained at Fire Island. Ortober 1. The sailor"s rhoier ocems as far north as Cape Corl, but it is not juresent in sufficint mumbers to be considered amoug the important food fishes; south of Cape IIatteras, where it is alundant, it is rallathle for food, and in many places is considered suyerior In shereshead this is specially so in the St John's rirer.

The sailor's rhoice feeds upon small invertebrates and minmws. It is caught with the hook and in cast nets and seines.

The egge are described as pale blue in color and as large as mustard sered. Spatwning takes place in the Gulf of Mexico in winl.. or early spring. The colors of the fish are very beati. ful. flu. sides being ormamented with golden stripes on a pearly white ginum and hatring numerous dark rertical bands.

\section{Genus arcmosangus Gill}

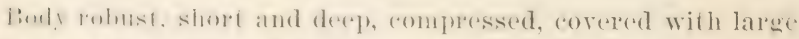
calde. Alaad derep, mouth moderate. the jaws with broad in1. iens in from and roanse molars on the sides; incisors entire or whik a shallum motrls; posturior mostril slitlike; opereles entire. bers.t and atual spimes strome, lle soft frarts of the fin short

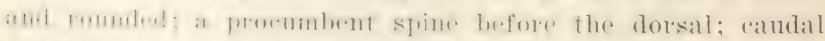
fonbal. Gill rabers small. Supranceipital and temporal erests

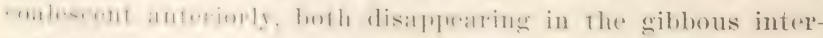

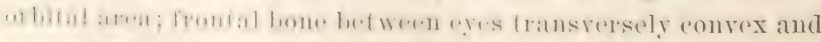

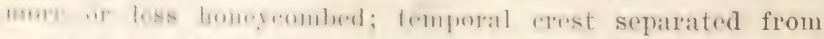

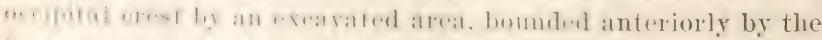

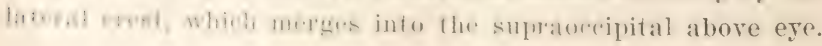




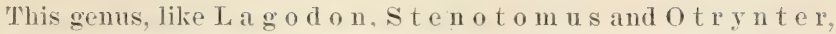
which show the same rhatratere of the procumbent dorsal spine,

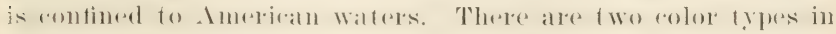

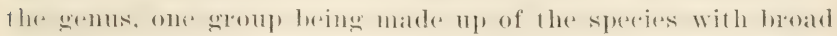

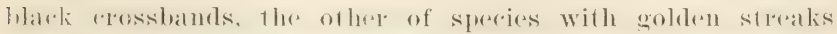
and imeonspicuous reosshands, resembling the speries of I. a 200 d 0 n .

\section{Subgenus archosmiges}

\section{¿75 Archosargus probatocephalus (Walbaum)}

\section{Shcopshead}

sparus mobutocephalus Walbaum. Art. Gen. Pisc. 295, 1792, New York. spatus oris MLtenll, 'J'rans. Lit. \& Phil. Soe. N. Y. I, 392, pl. 2. fig. 5, 1815, Jew York.

Sallus otis Curier \& Valexciennes, Hist. Nat. Poiss. VI, 53, 1830; DE KAY, N. Y. Fama, Fishes, 89, pl. 8, fig. 23, 1842; Holnnoor, Ichth. ‥ C. ed. 1. 51, pl. S, fig. 2, 1856; Güxtmer, Cat. Fish. Brit. Mus. I, $47,1859$.

Diplodus mohatocephalus Jordax \& Gubert, Bull. 16, U. S. Nat. MIus. 55S, $188: 3$.

Arhosargus probatocephalus. GiLL, Cat. Fish. Last Coast N. A. 27. 1573: BEAx, Bull: U. S. F. C. VII, 142, pl. III, fig. 10, 18s8, Somers Point N. J., young; 19th Rep. Comm. Fish. N. Y. 262, pl. XV, fig. 19, 1S90; Bull. Am. Mlus. Nat. Hist. IX, 366, 1897; II. M. Smmtr, Bull. U. S. F. C. 1S97. 101. 1S9S; Jordax \& Everum.x. Bull. 47, U. S. Nat. Mus. 1361. 1S95, pl. CCXVI, fig, 554.1900.

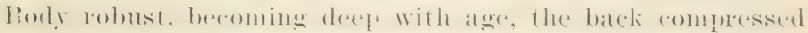

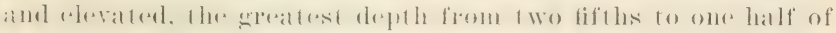

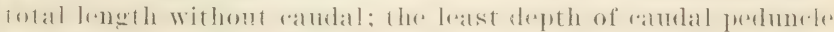
rflual to righth dorsal spine. and there righths lemgth of hearl.

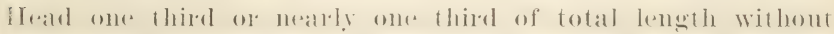
alurlal: ere platerel high, one fifth to one fourth length of heald:

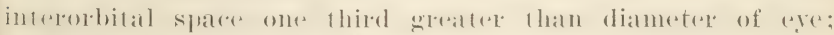
mouth low, horizontal; maxillary rearehing nearly to berow front of pmpil, slighty more than one thirel as long as the headr ;

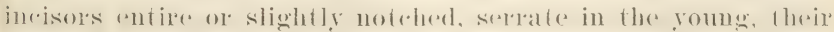
hreatth about one half their leneth: molars in theres sereies

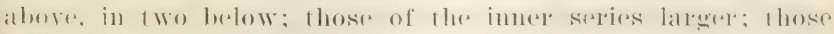
betind the incisors rery small. (Aill rakers about $3+6$. Cheeks with six rows of scales; scales on breast very small. row whed. Oreipital rest hoad. Horsal spines very 
strong. the last ensiderably shortened so that the outline of the tin is matruinale. Ihe fifth spine longest. four sevenths as lory as the head, Ifre tirst spine shorter than the eye; the third and fomm hoft bugs longest. two fifths as long as the head. The semel anal spine more than twier as long as the first, rery stromg. I Wo fifths as long as the head. and as long as the longest

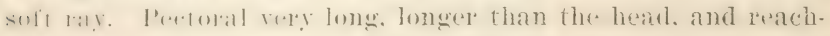

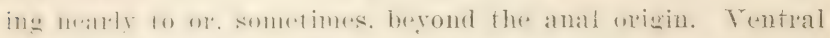

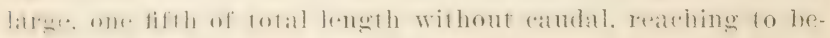
low 19 th spine of the dorsal.

D. XII, 10 to 12 ; A. III, 10 to 11 ; V. I, 5; P. I, 14 . Scales 7 to $8-45$ to $48-15$ to 16 .

tratish, with about wight rertical black bamls, which are alwn as houd as the interspaces; dorsal dusky; rentrai and anal barek: base of peetoral dusky: the dark bauls are most distinct in the young.

The sherpshead ratnges along the coast from citpe foul to Trexas: it is very rare as lar north as Toods Hole Mass, but in somblem walles it is still abmolant. The speeres reaches a

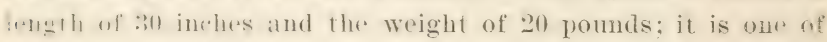
the most valuable of our food fishes and is highly prized for its game qualities.

In Angust 1S, T, the sherephead was known to have bred in A real Egg Iartur hay. X. T., where about 20 young indiriduals mansuring from 1 inch to 1 in inches were seined between A ugust [11 and sippember ?). Idults at that time were present in the

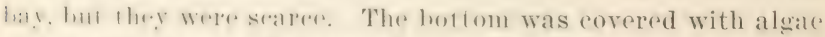
amal inmwnim hiding flawes were found under the sod banks.

The. lish is very umsual in ciraresend bay, Long Island. A lup... indivilual. weighing $1: 3$ pounds, was caught September 16 , 19th at come leland. Thas example proved hardy in captivity

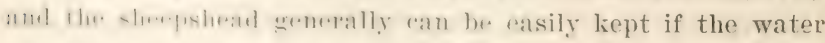
temperature be properly maintained.

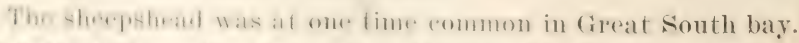
Hof this siafermeni we have the atuthority of Mr Erastus Gordon,

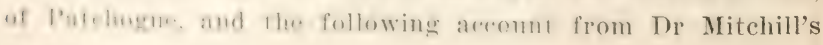


Fishes of New Fork will substantiate the fact: "The sheepshead swims in shoals and is sometimes surrounded in great numbers by the seine. Sereral hundreds have often heen taken at a single haul with the long sweeping-nets in use at Raynortown. Babylon and Fire Island. They eren tell of a thousand brought to land at a draught. . This fish is sometimes speared by torchlight in the wide and shallow bars of Queens connty and Suffolk. IIis term of continuance is only during the warmest season: that is, from the beginning of June to the middle of september. ... I have howerer, known him to stay later; for one of the most numerous collections of sheepshead I ever saw in the New York market was on October 4, 1814; I have seen them as late as the 17th."

Scott. in 1875, referred to Fire Island as a good locality for sheepshead fishing, and also mentions superior feeding places in the South bay and about the wreck of the Black Warrior, near the Narrows.

We did not obtain the sheepshead in Great South bay, and beliere it occurs there rery rarely at the present time, though fishermen still seek them in a fer localities and, I am informed, occasionally eatch onc. In smith says not one has been seen or heard of in Tineyard sound or Buzzards bay since 1894; but formerly it was quite common and was often caught while linefishing for tautog and scup.

\section{Family GERTIDAE}

\section{Mojarras}

\section{Genus Eucıostomus Baird \& Girard}

Interhaemal bone of the second anal spine greatly modified, expanded into a hollow cylinder, into which the posterior end of the air bladder enters. Preopercle and preorbital entire; body comparatively elongate, subelliptic in form; anal spines three; the second anal spine and fourth dor'sal spine not greatly enlarged. Species numerous in warm seas, remarkable for the structure of the second interhaemal, which is formed somewhat as in $\mathrm{Calamus}$, but much more modified than in the latter genus. 


\section{¿T(G Eucinostomus gula (Cur. \& $V$ al.)}

\section{ILjarra de Ley; Silver Jenny}

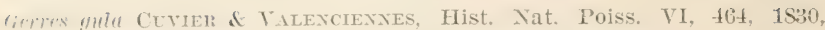
Martinique; Güxtmer, Cat. Fish. Brit. Mus. I, 346, 1859.

Eucimostomus aryenteus Bamd of GIRARD, 9th Smithson. Rep. :345, 185.5, Beesley's P'oint, $\mathbf{X}$. J.

(imers aryenteus Jondix \& Gilbert, Bull. 16, U. S. Nat. Mus, 584, 185:3;

Fi:.x, Bull. U. S. F. C. VII, 138, 18ss, Great Egg Harbor Bay, ․ J.

Lincinostomus gula Jordax \& Everuaxa, Bull. 47, U. S. Nat. Mus. 1370.

1898: II. II. Sintir, Bull. U. S. F. C. 1897, 101, 1S98; BeAN, 52 d Ann.

Rep. X. Y. State Mus. 10ti, 1900.

lody elliptic, compressed, back moderately elevated, the

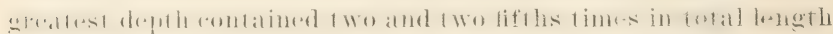

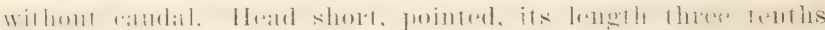

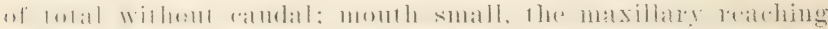

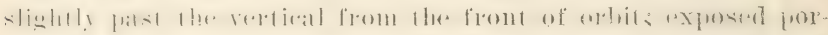
lion of maxiltaly natrly ohbong. its length twir. its with and equal to one fourth or one fifth the length of the head; pre-

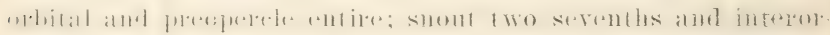

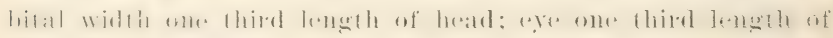
head. Gill rakers small and weak, seven below the angle of

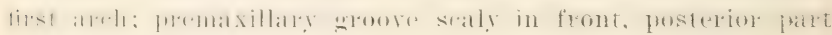
maked forming a sort of pit. Longest dorsal spine two

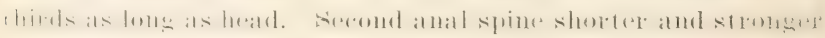
than third, about three tenths as long as the head. Ventrals reach neatrly to rent, five sevenths as long as head. Pectorals

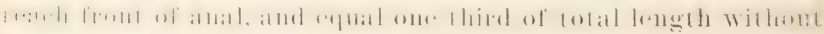
ratudal. Feceond interthamal hollow and enlarged.

1). IX, 10; I. III, S; scales 5-42 to $45-9$; vertebrae $9+15$.

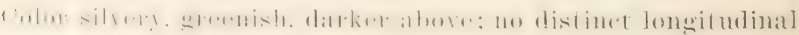

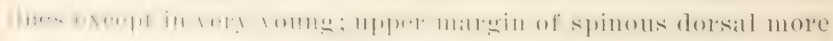
or. luss blark; dorsal amd anal fins dusky; other fins pale.

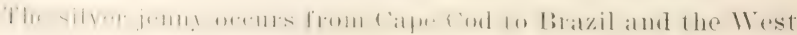
Indies; anly the young come far north in summer. The species inalues a bength of $\mathrm{f}$ inches and is used for bait.

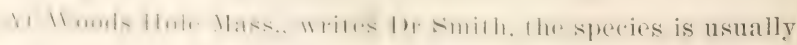
iny mmommon. In 1897 fire specimens were taken at one suin. hanl in (2uissue harbol on August 14; two in the same 


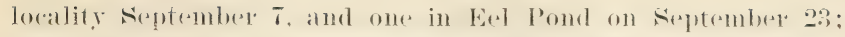

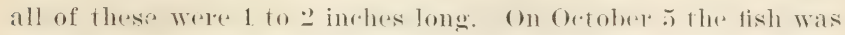
abundant, in Quisset harbor.

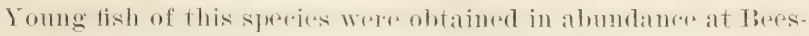

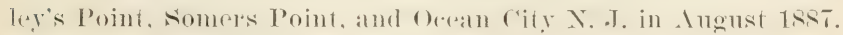
No adults were seen.

The only individual observerl in fileat sonth hay was a very small one. seined in ('lanm l'omel rove. Ang. 2.2, 1, s!s. Hiligent

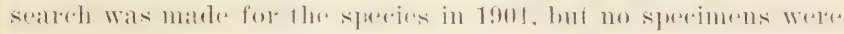
taken.

\section{Family IS PHOSIDAE}

\section{Rudder fishes}

\section{Genus nrpmosus Lacépècle}

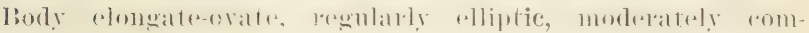

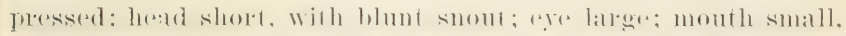

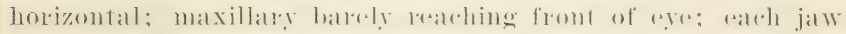
with a single series of rather narow obtusely lanceolate

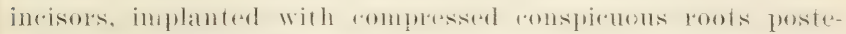

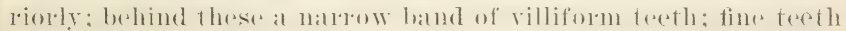

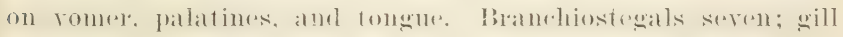

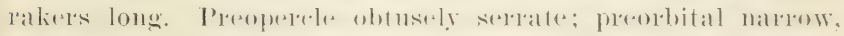
covering but little of the maxillary. Squamation very com-

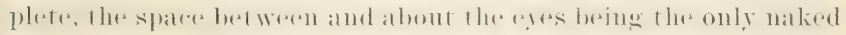

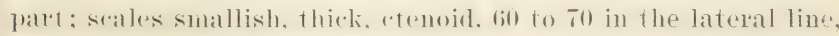
whirh is rontinuous: similat seales ontirely eorering the soft palles of the veltionl fins, and extending upon the pationd fins.

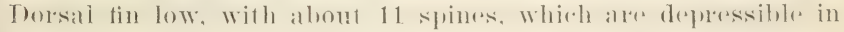

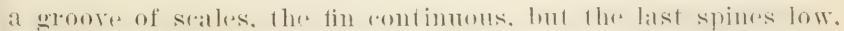
so that a deperesion oremes betweren the two patets of the fine

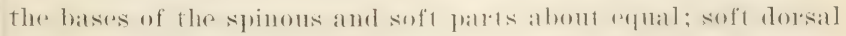
ratlex low in fiont. not falratr. pointed luhind: anal similat

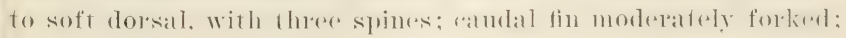

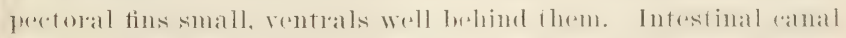
long; pyloric caecal rery numerous. Tertebrae ? or $10+15 \mathrm{or}^{\circ}$ $16=25$. 


\section{Kyphosus sectatrix (Linnaeus)}

\section{Bermuda Chub}

Perea sectatrix Lrnxateus, Syst. Nat. ed. XII, 486, 1766.

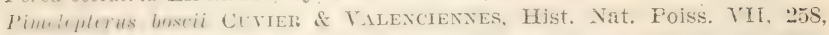
11. 1S , 1s:31; IDE KAY, X. Y. Fauna, Fishe's, 100, pì. XX. fig. $36,18 \pm 2$, copied from Cuv. \& VAL.; JordaN \& GILBERT, Bull. 16, U. S. Nat. II us. 561, 1883.

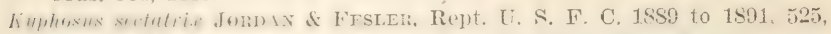

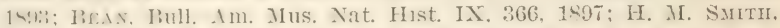

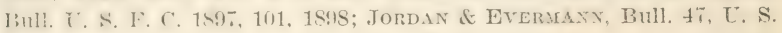
Nat. Mus, 1387, 1898, pl. CCXIX, fig. 559, 1900.

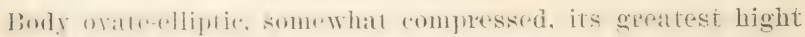
1wo lifths of lhe fotal lenghl without caudal; the least depth of

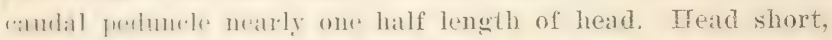
an. fomll of total leneth without candal: snout short: mouth small. Ihe maxillaty leatreling to below front of orbit: teeth

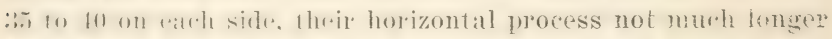

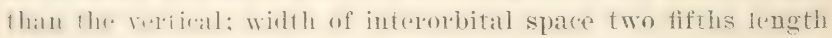

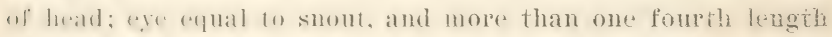

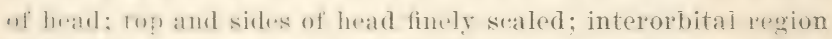

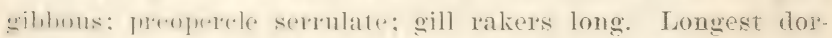

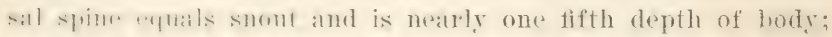
lomeres bay of sult dorsil two sevenths as long as the buadl. The senomel anal spine is ahout two thirds as long as the egre:

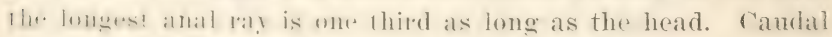

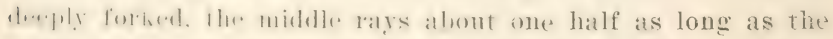

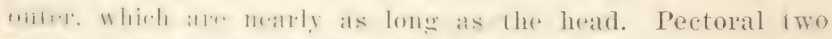
llibls as lome as l he head, aml rqual to reutral, which reaches 1.) lafou the nimth spime of the dorsal. Soft dorsal and anal elosuly sealed; most of caudal scaly.

1). III, 12; A. III, 11; V. I, 5; P. i, 16; scales 10-66-16; vertobrate $9+76$.

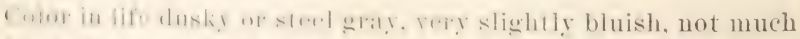

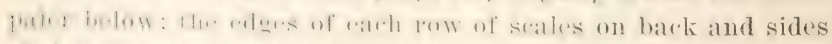

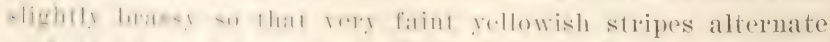

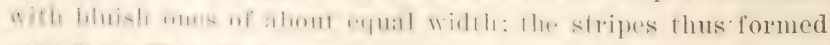

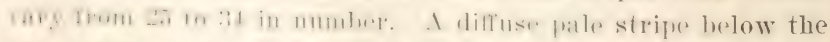

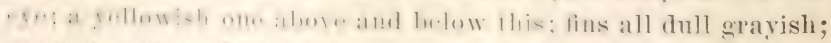

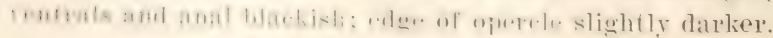


The Bermula chub grows to the length of 18 inches. It ranges from Cape Cod to the Mrest Indies, the Gulf of Mexico, across the ocean to the Canary Islands, and is accidental in the Mediterranean. Its name of rudder fish refers to its habit of following ressels, presumably to secure the waste food thrown from them. The fish is said to have game qualities.

At Woods Hole Mass. according to Mr Smith, the species is not rare in smmmer and fall and has oreasionally been found in April; it is sometimes taken among gulf weed at the surface. Only young sperimess. up to $f$ inches long, have been secured there.

The Bermula whub is a rale fish in cravesend bay, but was

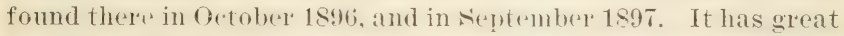
endurance in raptivity and will surve the winter in artificialle heated water.

\section{Family SCIAENIDAE \\ Croakers}

\section{Genus crroscrox Gill}

Body elongate, little compressed. the back not elevated. Head conical, rather pointerl: mouth very large, terminal, not very oblique, the lower jaw projecting, the symphysis produced, the angle at base of maxillary not prominent. Maxillary rery broad. Teeth sharp. not relosely set, in rather narpow bands; tip of the lowe jaw without canines: upper jaw with two long (anines, one of which is sometimes ohsolete: anines tapering from base to tip; lateral treth of lower jaw larger than anterior. Preppercle with its membranaceons edge serrulate, the bone entire. Lower pharyngeal hones separate, their teeth all pointed. Gill rakers strong, rather long. Vertebrae about $14+10$ (instead of $10-14$ as in sciaenoids generally). Pseudobranchiae well dereloped; dorsal spines slender, the fins closely contiguous: anal spines one or two, very feeble, the soft rays seven to 13 ; second dorsal long and low, more than fwice length of anal: ventrals inserted below pectorals, the pubic bne long and strong; caudal fin subtruncate or luuate. Large fishes chiefly of the waters of Americar, closely related to the old World genus o to $\mathrm{ith}$ th , from which they are distinguished 
hy the absence of canines in the lower jaw. All of them rank

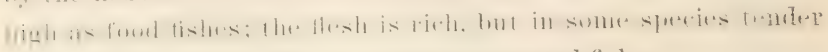
anel easily tolen, hence the popular natme wealkfishes.

\section{Subgenus crvoscrov}

275 Cynoscion regalis (Bloch of Schneidrr)

\section{IIralifish: Squeteague}

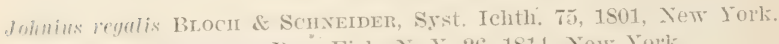

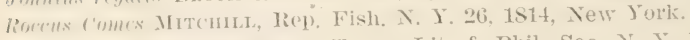

Lubus squetequne Mrtomus, Trans. Lit. \& Phil. Soc. X. Y. I. 396. 1). 2. lik. (i, 1s1. , New lork.

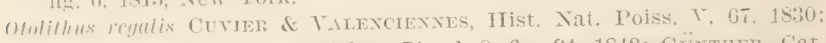

I) K. К. N. Y. Fauna, Fishes, 71, pl. S, fig. 24, 18t2; GüNTner. Cat.

Fish. Brit. Mus. 11, 307. 1860.

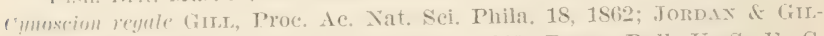
ma1, Full. 16, U. S. Nat. Mus, 581, 18s3; Bexx, Bull. L. S. I. C.

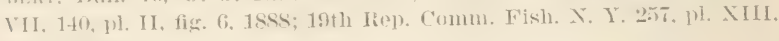

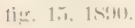

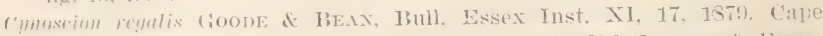
Iun: Brax, Bull. Am. Mus. Nat. IIst. IX, 367, 1897; Jordax d Evrk-

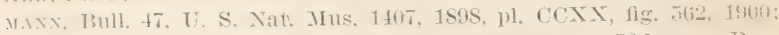

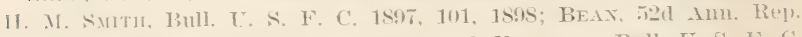
․ Y. State Mus, 106, 1900; SHFnwoon \& EDwards, Bull. U. S. F. C. 1!101. ㄹ․ 1!M1.

borly elomgate, little eompressed, its gareatest depth contained forl and one fourth times in the total length without caudal: How least depth of caudal perlunele one third length of head, whirh is three tenths of total length without caudal. Eve moderale. Horee fomeths length of snout, and one fifth to one serenth length of hearl. Maxillaty reatehing to below hind margin of 1 y\%, its longth neally two fifths length of head. Teeth shatrl, in natrow hands; camines larege. Gill rakers long and slatrl, i above and 11 below the angle of the first areh. The sionmel ambl lomerest dorsal spine is two fifths as long as the head: Hue tios spime is ono thind as lomy as the head; the last two spines alr vory short: the lomerest soft lay of the dorsal is one flidel as long as fhe loatd. Candal lumate belind, the longest

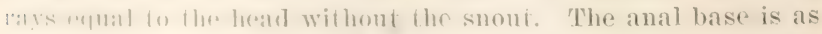
leme a the smomt ame eyo emombined; the longest ray slightly

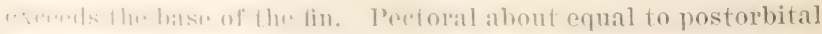

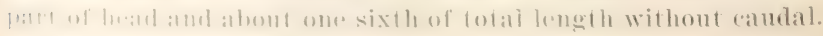


Ventral about one half as long as the hearle reaching to below the seventh spine of the dorsal.

D. X, I, 26 to $29 ;$ A. I, 11 to 13 ; scales $8-78-17$, about 66 pores in lateral line.

Silvery, darlier above and matred with many small, ireegular dark blotehese some of whirh form molulating lines rmunge downward and forwated bateliand head with bright reflections: dorsal and raudal fins dusky: wentrals, anal, and lowere edge of randal gellowish, sometimes sperckled. The yomeng show traces of a few dusky batuds on the sides, one moles the spinous dow sal

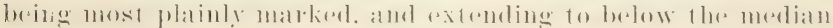
line.

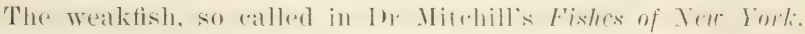

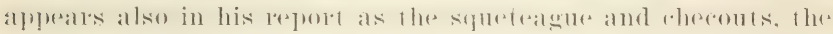
former being a Nalrakgalnsett fudian name and the lattere derired from the Moherans. The Nalratgansett name is somedimes

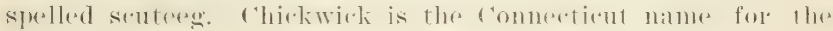

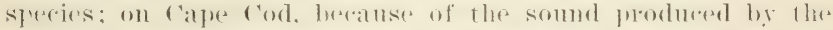
fish. it is alled the drummer: latrere walifish in Buzzards hay

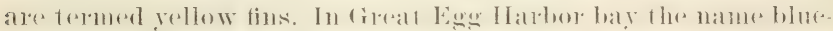
fish is applied io it, notwithstanding lle presenese of the leal

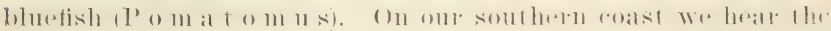
names trout, with its rariations gray trout, sea trout, shad tromt, sun tront and salt-watere tront. The latter name is nsed

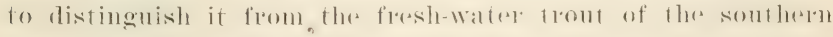
states, which is the black bass. Dr Mitchill thus arcounts for the name reakfish: "He is called weakfish, as some say, be

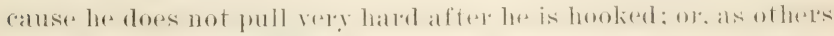

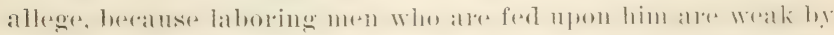

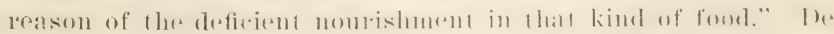

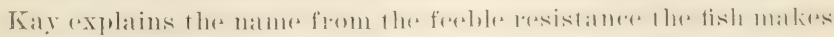
on the hook and the fareility with whele it hrealis al aly flom it by reason of its delicate structure. At the time of De Kiay's

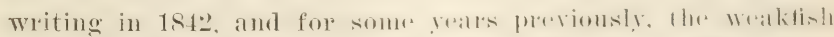
was present on one coast in diminished mumbers. The blue

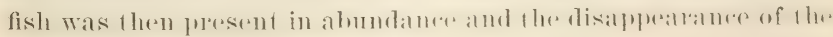


Wrahlish wats supposed to he commerted with the reappearance nf hh. hluntish. I similar uhservation was made by Dr. Storer

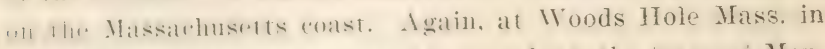

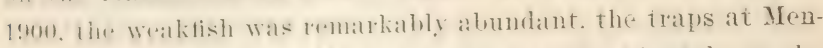

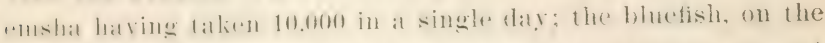

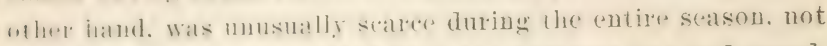

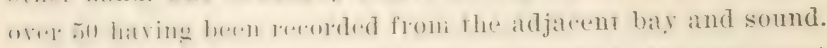

The wralitish ratmeses from the Bay of Fundy to the rast coast of Floridit. It thurtuates in ahumbance from year to yeats. The lat. I:1ph. I. E. Atwood is atuthority for the statement that in

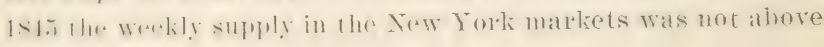
1000 pounds.

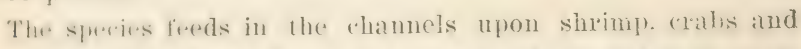
small lish. In firat somih bay we found them eating linge

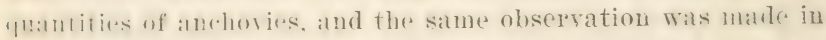

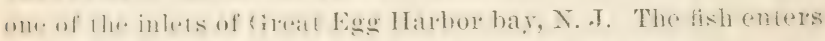

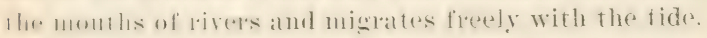

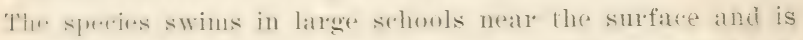
1.1.y rmateions. destroying the young even of its own kind. A

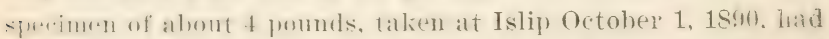

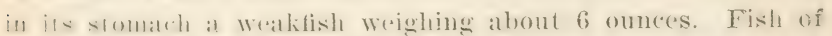
1 foumls and a little latrere were moderately abundant at this date.

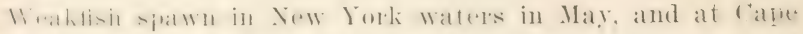

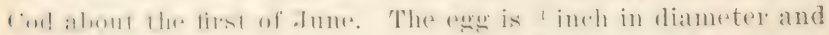

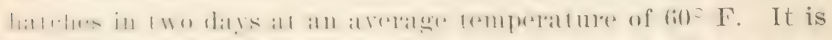

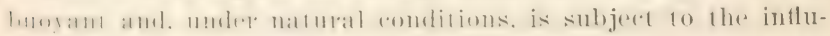

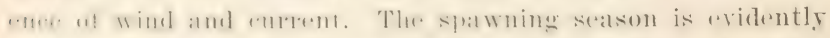

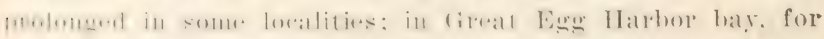

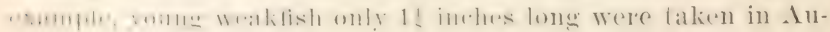
gnst. Hlit is, several months after spawning began.

'he traliest arrival in Yew York was on May 12, 1859, at

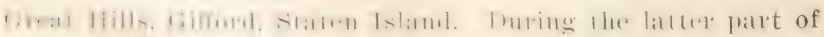

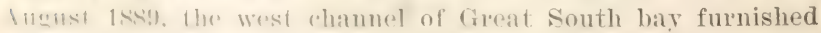
truall mmblus of weakfish. The young were found in Blue

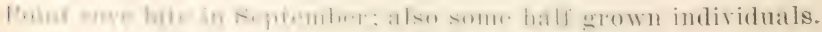


The fish are in their finest condition during the fall migration in September and October. On September 21, 1887, two men caught 200, including some rery large ones, on a single tide near the inlet of Great Egg Harbor bay, N. J. The most farorable tide for eatching this species is generally considered the latter half of the flood and first half of the elob. At night the weakfish runs up the creeks to feed in the salt meadows and will take the hook freely.

Some of the best bats for the reakfish are the common shrimp, soft or shedder crabs, pieces of clam and common mussel, the white skin of the throat of weakfish, and sometimes the eye of this species; other good baits are silversides and anchovies. In Great South bay the fish are taken extensively in pound nets and gill nots. The gill nets are set in the shape of a horseshoe, and the attending sloop sails back and forth across the open end of the horseshoe, one of the crew meanwhile beating the derk with his heels to frighten the fish into the nets. This method, called drumming, is in great disfaror among those who follow other modes of fishing.

In 1901, young weakfish were seldom taken in Great South bay and only two loralities-Duncan's creek and Smith's Point - furnished them in very small numbers. Adult fisb, lowever, were remarkably abundant and were caught in many parts of the bay.

The weakfish endures aptivity rery well and can be kept during winter in water of the proper temperature. The species is said to reach the weight of 30 pounds.

\section{Cynoscion nebulosus (Cur. \& Val.)}

Spotted TVealfish; Sea Trout

Labrus squetenge var. maculatus Mitchir. Trans. Lit. \& Plil. Soc. X. Y. I, 396, 1815, New York; not Labrus maculatus BLocr.

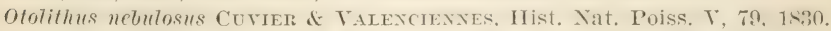
Otolithus carolinensis Cuvien \& Vulexcrexxes, Hist. Nat. Poiss, IX. 475. 1833, South Carolina; DE KAY, N. Y. Fauna, Fishes, 72, 1842, extralimital; Holnioor, Ichth. S. C. ed. 1. 1:3, pl. 19, fig. 2, 1S.ti; fïntumen, Cat. Fish. Brit. Mus. II, 306, 1860, New York.

C'mnoscion maculatum Jorday of Gilmert, Bull. 16. T. S. Nat. Mlus. is1, 1883. 
femescion netulosus Jondax \& Evermaxa, Bull, 47, U. S. Xat. Mus, 1409, 1S!1S. 1)l. C'XXI, fig. 563, 1900.

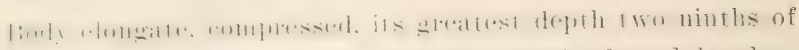

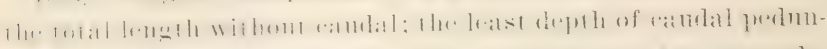

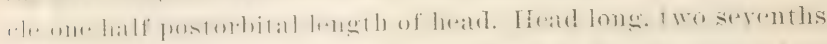

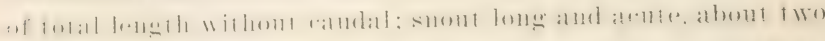

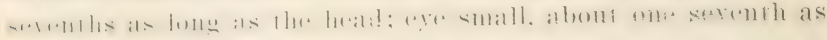

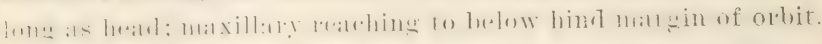
as long as snout and eye combined; canines strong; lower pharyngeals narrow, each with seven or eight series of short freth. the inner enlared gill rakers short and thick, about 4-7 on first areh; maxillary. preorbital, and lower jaw naked. spinoms dorsal base as long as postorbital part of head; first dorsal spine one half as long as second, which is one third

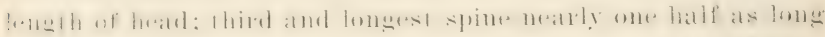

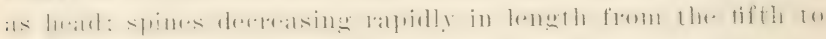
the last, which is minute; soft dorsal base one thied of total

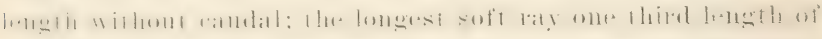
hase. fauclal shallow (oneave, the midrle rays one half as loug ais the head. Inal base short, one third as long as the head; lomgesi anal ray one half depth of body. Pectoral short, reaching 10 bxlow sixth spine of dorsal. Ventral longer than pee-

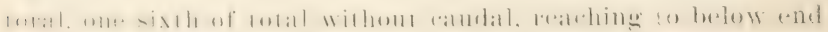
of spinous dowsal. Ventral appendage nearly as long as the

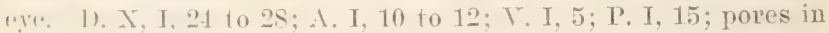

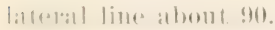

lindy silvery with bright reflections; numerous black spots on

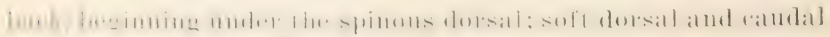
similarly spottrel. the latrexest spots smallex than pupil; anal fin Iliskis:

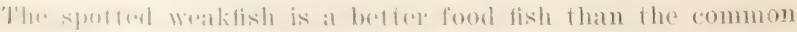

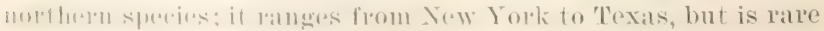

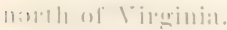

Genus 1.

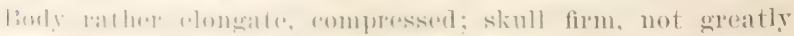

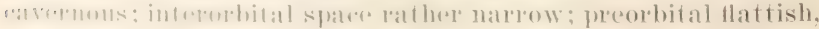

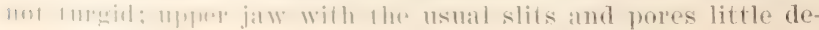


reloperl: no billuels: no ranines: snout rery short; month larege, terminal, very obligue or eren reletical, the lower jaw projert-

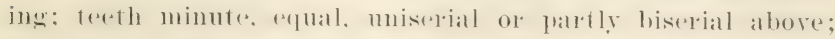
freopercle entile or mearly so. Without bony terth. Fuales

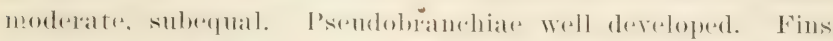

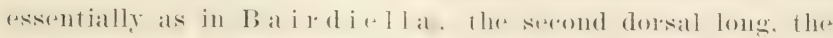
anal short. its spines moderate ol small: tins not thirkened by accessory scales. Gill rakers long and slender. Vertebrae $10+1 t=24$. Silvery fishes, all American.

\section{Subgenus LArmus}

\section{¿S0 Larimus fasciatus Holbrook}

\section{Bander. Larimus}

Larimus faciatus Holbrook, Ichth. S. C. 15:, pl. 22, fig. 1, 1556, Charleston; Gëxtmer, Cat. Fish. Brit. Mus. II, 269, 1860; Jordan \& Gilbert, Bull. 16, L. S. Nat. Mus. 578, 1883; Jombax \& Ergenurax, Rep. U. S. I.. C. for 1856, 376, 1859; BeAx, Bull. Am. Mus, Nat, Hist. IX, 367. 1897 ; H. M. SMItI, Bull. U. S. F. C. 1897, 101, 1898; JordAN \& Evermaxx, Bull. 47, U. S. Nat. Mus. 1424, 1898.

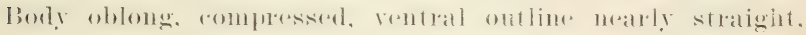

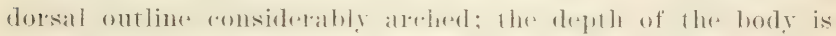
eontained abont there times in the length. Sinout very short, murh less than diameter of the latege rye: mouth latege, rexy

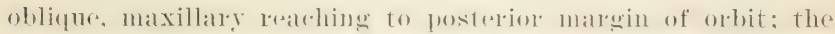
length of the head is contained thress and one half times in that of the body. Tip of mandilele on lerel of lower patrt of pupil;

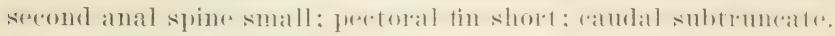
D. X-I, 24; A. II, 6; Lat. 1. about 62 .

silvere gray, clomded abore; sides manked with about seren mearly rextieal dusky batrs. rumbing from batek to besow the

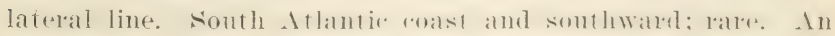

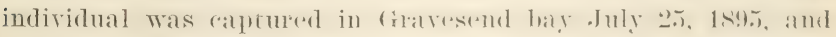
another one Iugust 2 of the samm yeatr. These feed frexly, and

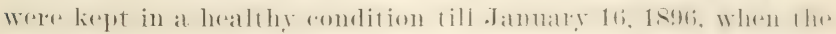
low lemperature of the water libled them. The fish is not (o)m-

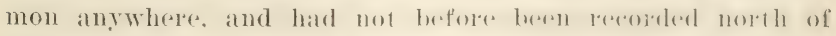
Chesapeake bay, exrefit a simgle example which was lakken at

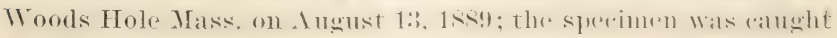
in a trap at the breakwater, Buzzards bay. 


\section{GenuS BAIRDIELLA Gill}

This gruts is rhatrardized by the oblicule mouth, little

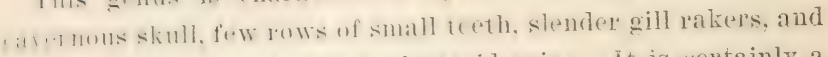
ihr fuenferele armed with a plectroid spine. It is certainly a wry nallmal Eromp, aml worthy of resognition as a distinct wnmus. llumen is relationships with ophioseion and

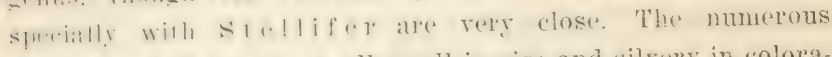

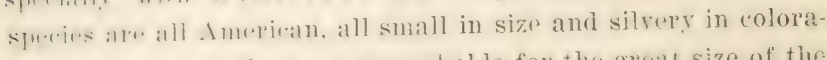
finn. aml sume of them are rematiable for the great size of the sreoml anal spine. In oflers this spine is quite small. These

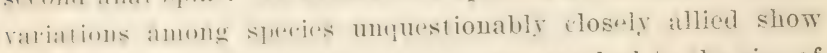
how slight is the sistomatic value to be attached to the size of this spine.

\section{Subgenus BAIRDIELLA}

\section{Bairdiella chrysura (Lacépède) \\ Yellowtail; Silver Perch}

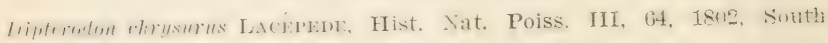
Carolina.

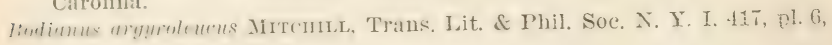
fig. 9, 1815, New York.

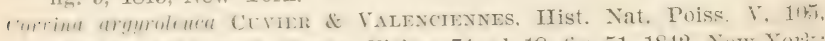

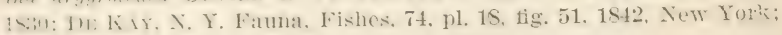
Gümen, Cat. Fish. Brit. Mus. II, 299, 1860.

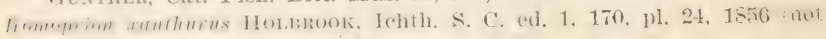
Liostomus xanthurus LACEPEDE).

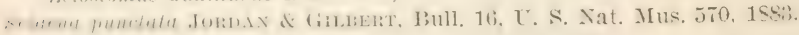

Serinent chrysura Jondan \& GILBERT, op. cit. 933, 1883.

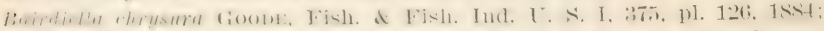

Br:Ax, 13ull. U. S. F. C. VII, 141, pl. I, fig. 9, 1S8s; 19th Rep. Comm.

Fish. N. Y. 259, 1590; Bull. Am. MLus. Nat. Hist. IX, 367, 1897; JorD.N

\& Evmmaxi, Bull. 47, U. S. Nat. Mus. 1433, 1885, pl. CoXXII, fig. sifi, 1!m0; Tran, 52d Ann. Rep. N. Y. State Mus, 106, 1900.

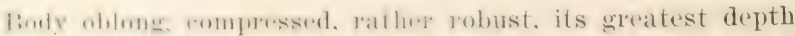

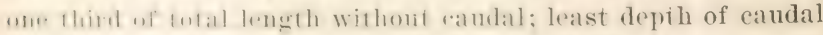

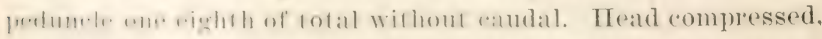

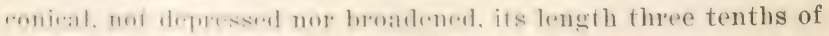

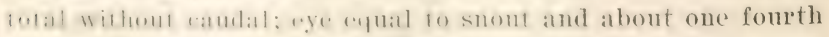

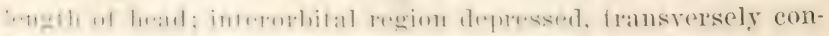

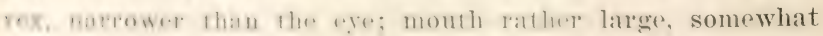

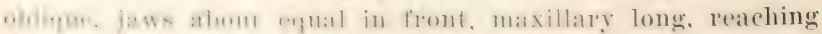


nearly to below hind margin of orbit, its width posteriorly nearly one third of its length; both jaws with stout recurved teeth. behind which, in the uprer jaw. are a fer series of smaller teeth; mandibulary tecth mostly in one series outside of which are a few smaller teeth: properele strongle serrate or spinous at its angle; gill rakers slender, moderately long, $8+16$ on first arch; lower pharyngeals small, with sharp teeth. Spinous dorsal high in front, triangular, the first spine rery short, the fourth longest. equal to postorbital part of head; base of soft dorsal one third of total length without caudal, longest ray equal to snout and eye combined. last ray two thirds as long as the eye. Caudal concaro-conrex, the middle rats equal to longest dorsal spine. Inal base three eighths as long as the head: longest anal ray equal to suout and eye combined; first anal spine very short. second two fifths as long as the head. Soft dorsal and anal fins considerably sealy. Pectoral and veutral of equal length, one tifth of total without caudal, the pectoral scarcely reaching to below end of spinous dorsal. D. XI, I, 22; A. II, 9 or 10; scales 8-50 to 54-11.

Greenish above, silvery bulow, each seale with series of dark punctulations througl: the renter. usually vere conspicuous, sometimes obscure, these forming marrow somewhat irregular streaks along the sides: fins flain, the caudal yellowish.

Dr Mitchill describes this fish as the silver perch, and De Kia explains the origin of this name from the resemblance which the yellowtail bears in its appearance and habits to the common white perch. At Pensacola Fla. the name mademoiselle is applied to the species. In Great South bay we heard the name lafarette given it, hut this belongs more properly to the spot Liostomus xanthurus.

The yellowtail ocems on our coast from Cape Cod to Florida. It was a common fish in Great fiouth bay in September 1890 , and during the early part of October, occurring at Blue Point cove, at the Blue Point Lifesaring station, Great River beach and Fire Island. It is frequently taken in the pounds. In 1898, the roung were found in abundance at Nichols's Point, Great 


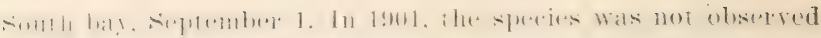

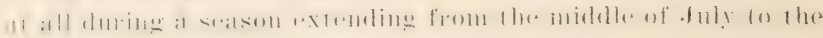
mirkile of ()etober.

The breeding season must continue into early summer as

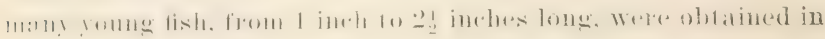
Gireat Foge llarbor bay. X. J. early in August.

The young of the silver perch are found every summer in filalvesend bay, and adults are to be seen oceasionally. On Sep-

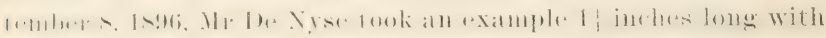
a) shrimp net in eclgrass back of the flats at extreme low tide. P'ools containing 2 feet of water are common here, and many

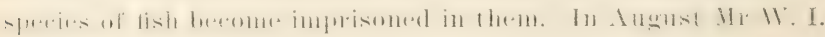

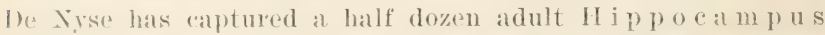
in surh localities. On October 5. 1896, and again in the fall of Is!) the silver pereh was obtained in the bay.

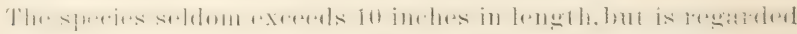
as an excellent panfish, and is secured in enormous numbers.

\section{Genus semevors Gill}

This genus is close to Oph i o s c i o ll, from which it differs in the loss of its preopereular armature with age, the serrate edge of the bone becoming entire. The caudal fin is truncate

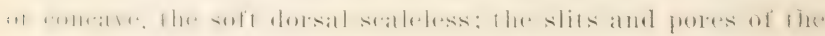

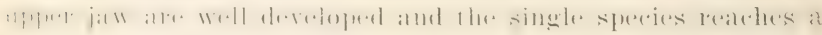
very later size. The group is not well separated from $\mathrm{O}$ p h i o s. c i on on the one hand, or from Sciaena on the other, but its retention serms to be ronvenient.

\section{ㄴ.2 Sciaenops ocellatus (Limmats) lied l)rum: (Yhanmel biass}

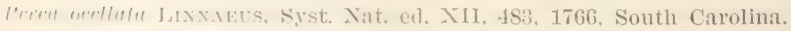

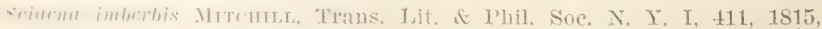
Nin lisk

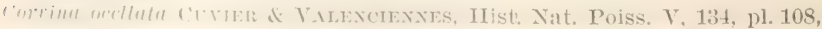

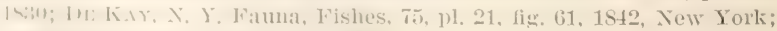
Itotatom, 1ehth, s. C. ed. 1, 149, pl. 21, fig. 2, 1856.

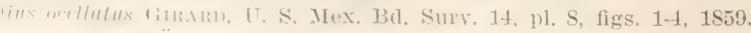

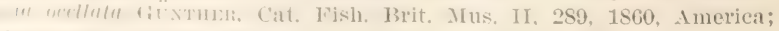

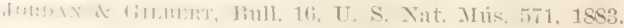


Sciaenops ocellatus BeAN, Bull. Am. Mus. Nat. Hist. IX, 367, 1897, New Jersey; H. M. Smitr. Bull. U. S. F. C. 1897, 101, 1898; JordaN \& Evermann, Bull. 47, U. S. Nat. Mus. 1453, 1898, pl. CCXXII, fig. 567, 1900 .

Body elongate, robust, its greatest depth one fourth of total length without caudal, least depth of caudal peduncle about one third of greatest depth; back somewhat arched; profile of head convex. Head rather long, three tenths of total length without caudal; eye small, about one seventh as long as the head; snout obtuse, two ninths as long as the head. Mouth large, nearly horizontal, the lower jaw rather shorter than the upper; the maxillary reaching to below the hind border of the orbit, its length more than two fifths length of head; bands of rilliform teeth in both jaws, the outer teeth of the upper jaw much enlarged; lower jaw with subequal teeth. Preopercle strongly serrate on its bony margin in the young, entire in large individuals and with the edge of the bone covered by skin. Gill rakers $5+7$ on first arch, shorter than the diameter of the pupil. Spinous dorsal triangular, the first spine minute, the fourth, and longest, four ninths as long as the head, the last two thirds as long as the eye; base of soft dorsal twice as long as that of spinous dorsal, the longest ray one third as long as the head. Anal base short, one third as long as the head, two thirds as long as longest anal ray; the end of the anal base is under the 17th ray of soft dorsal, second anal spine about three eighths as long as the head; caudal nearly truncate, the middle rays one half as long as the head. Pectoral equals postorbital part of head, the fin extending to below the end of spinous dorsal. Ventral equal to pectoral, and not reaching nearly to vent. Scales of the breast embedded, cycloid; no scales on soft dorsal except in a very narrow strip at its base. D. X, I, 24 to $25 ; \mathrm{A}$. II, 8; scales $4-45$ to $55-10$ to 12 . Color grayish silvery, iridescent; often washed with coppery red; each scale with a center of dark points forming obscure undulating stripes along the rows of scales; a jet black ocellated spot about as large as the cye at base of caudal above; sometimes two or more such spots are present; the body occasionally covered with ocelli.

The red drum is one of the largest of the food fishes of the southern waters, reaching the length of 5 feet and the weight 


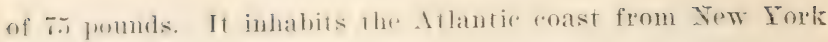
to Texas, and has once been taken near Cape Cod.

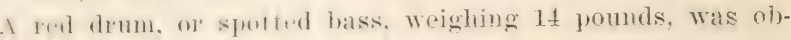
tained hy Mr E. G. Fiarkford from Jew Jersey, and was pur. chased alive for 1 hr. Yom lork aquarim. At the time of writ-

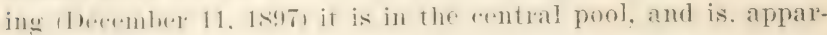
folly. in juffere health. It swims sometimes immediately under the samd shatk. Its foud consists of latge pireses of herring, which it takes readily.

The wnly sperinen known to have bexn taken at raperod was ('ancht in a rraj) in Buzzards bay at the breakwater in 189. The example is : 4 inches long and weighs about 14 pounds. On areomint of the orellated markings at the base of the caudal fin it has sometimes been called the branded drum.

\section{Genus LEı⿻sтомиs Lacépède}

linily oblong, ovate, the back compressed; head ohtuse: mouth small. hori\%ontal. the upper jaw with a band of feeble teetli, the lower nearly or quite toothless: slits and pores of npjere jaw whil developed: lower pharyogeals semarate, the teeth fatred: preoper.le with a memhranaceous border; dorsal slines

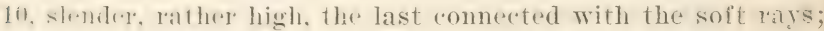
soft flotsal and anal long; anal spines two, the serond not latrow; ranulal tin rmalreinalr; gill memhranes slightly commected; gill

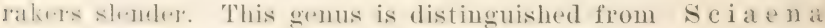

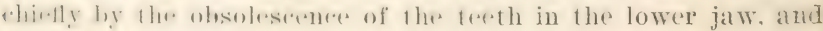

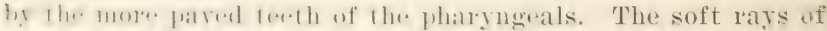

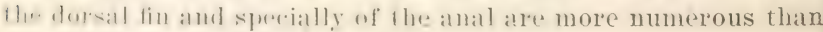
in related groups. One species.

\section{Leiostomus xanthurus Lacépède}

$$
\text { Spot; Lafayette }
$$

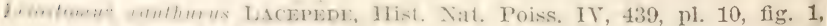
1802, Carolina; Cuvier \& Valenomennes, Hist. Nat. Poiss. V, 142, 18:30; 1)E K.1Y, N. Y. Fauna, Fishes, 70,1812 , extralimital; Jondax

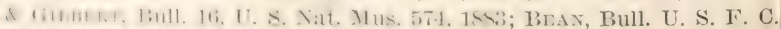

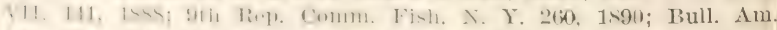

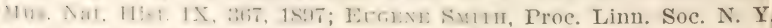

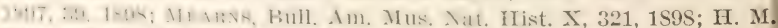

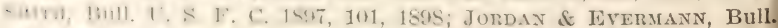
[i, U. S. Nit. Mus. 145S, 1S98, pl. CCXXIII, fig. 569, 1900. 
Mrugl obtiqums Mrтcmul, Rep. Fish. N. Y. 16, 1814, New York: Trans. Lit. \& Phil. Soc. N. Y. I, 405, 1815, New York.

Leiostrmus obliquus DE. Kix, X. Y. Fauna, Fishes, 69. pl. 60, fig. 195, 1512. Sciaena obliqua Günther, Cat. Fish. Brit. Mus. II, 28S, 1860.

Sciaena xanthurus GüNTHER, op. cit. 288, 1860.

Body short, deep, compressed, its greatest depth one third, or more than one third, of the total length without the caudal; least depth of caudal peduncle three serenths length of head; back in front of dorsal compressed to a sharp edge; profile steep, conrex, depressed orer the eres; dorsal outline conrex, highest at dorsal origin. Head short, its length contained three and one third to three and two thirds times in the total without caudal; snout short and rery blunt, about two serenths as long as the head and slightly longer than the eje. Mouth small, inferior, horizontal; maxillary rather more than one third length of head, extending to below middle of pupil; lower jaw toothless in the adult, upper jaw with a series of narrow minute teeth; gill raker's short, slender, $8+22$ on the first arch; lower pharyngeals small, with three series of molars posteriorly and many rilliform teeth anteriorly; preopercle entire; preorbital about equal to eye in width. spinous dorsal triangular, but rounded at tip, the first spine rery slender and rery closely attached to the socond, the third and fourth longest, three fifths as long as the head, the last two spines very short, only about as long as the pupil. Soft dorsal long and low, the base twice as long as that of spiuous dorsal, the longest ray three eighths as long as the head. Caudal forked, the middle rays one half as long as the head. Anal elevated in front, low behind, the longest ray more than one half as long as the head, the last shorter than the eye; the second anal spine as long as the eye; the first spine rery small. Pectoral large, extending to below the sixth ray of second dorsal, nearly ats long as the head. Tentral as long as the head without snout, not reaching nearly to rent. Seales small, ctenoid, extending on caudal and base of pectorals, but not on other fins; soft dorsil, however, has a sheath at base formed by a single series of srales; srales below lateral line in oblique series. Lateral line little curved anteriorly. 
I) X, I, :31 10:32: I. II, 12; P. I, 17; scales 9-60 to 70-12 to 14.

("olor hluish above, silvery below; about $1: 3$ to 15 narrow dark lines extending from the dorsal fins downmard and forward to below the lateral line; a roundish black humeral spet about two thirds as long as the eye; fins plain olivaceous.

This little fish was formerly limown on the New York coast as lafalette. Mitchill calls it the little porges. According to De Kay its appeatrance on the New York coast in the summer of 18.'t happened to roincide with the arriral of General hafarette and his name was bestowed upon the species. The naum spot is derived from the presence of a dark bloteh about as big as the 'ye near the root of the pectoral fin. Other names for the species are goody, oldwife, roach and chub.

The spot is found from Cape Cod to Florida and is sometimes abundant as far north as New York. In Great South bay sereral specimens were taken early in October in Great river. A single example was seen among some fishes taken in a joundn+L in Islip. ().t. 1, 1890. In 189S the species was not obtained by the writer, and in 1901 only a few specimens, mostly adults, Werr sremed at Quantic bay, Duncan's ereek, and Witow's ereek.

liatleer ("ommon in Giratesend bay from July to as latie as Thermber, and is well adapted to eaptive life. It is most almmelant usually in September.

Hr Mearins states that the fish, locally known as the sand

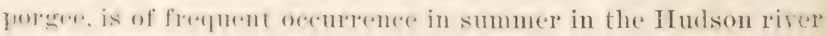
and its estuatres. M. M. smith records it as common in the fall in the vieinily of Woods. Mole. Mass. leaving in October or Sincmblup. when the water temperature reaches 45 F. All the spreimens olserved there were alout 6 inches long.

11 is a small fish, seldom exceeding 10 inches in length, but is onf of thr. falorites among the panfishes. The spot feeds $0 ! 1$ ih. lmotmo om small invertuluates, and ean be taken readily will lomk and line. In rimeal somth bay it is caught in seines amet formol mols. It ascends crecks into brackish water and is

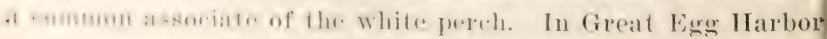


bay it is extremely common in summer and is sometimes known as porgee.

\section{Genus moropogox Cuvier \& Valenciennes}

Bodr moderately elongate, compressed, somewhat elevated; preopercle strongly serrate; teeth in villiform bands, the outer row in the upper jaw enlarged; lower jaw with a row of minute barbels on each side; gill rakers short, thickish; spinous dorsal rather short of 10 or 11 stoutish spines; second anal spine moderate; caudal fin double truncate; lower pharyngeals narrow, distinct, with sharp, conical teeth; air bladder with long horns. A well marked genus, the species all American, allied to Ophioscion and sciaenops, but distinguished by the presence of barbels; species all closely related, similar in form, size, and color.

\section{Micropogon undulatus (Linnaeus)}

\section{Croaker}

Perca undulata Linnaeus, Syst. Nat. ed. XII, 483, 1766, South Carolina. Bodianus costatus Mitcmll, Trans. Lit. \& Phil. Soc. N. Y. I, 417, 1815, New York.

Micropogon lineutus Cuvier \& Valenciennes, Hist. Nat. Poiss. V, 215, pl. 119, 1830, New York.

Hicropogon costutus De KisY, N. Y. Fauna, Fishes, S3, pl. 72, fig. 230, 1842. Micropogon undulatus Cerier \& Valexciexnes, Hist. Nat. Poiss. V, 219, 1S30; De Kir, N. Y. Fauna, Fishes, St, 1812, extralimital; HoLbrook, Ichth. S. C. ed. 1, 145, pl. 21, fig. 1, 1856; Günther, Cat. Fish. Brit. IIus. II, 271, 1860, in part; Jordix \& Gilmert, Bull. 16, U. S. Nat. MIus. 57. 1883; BeAx, Bull. Am. Mus. Nat, Hist. LX, 368, 1897; H. M. SMiti, Bull. L. S. F. C. 1897, 101, 1898; Jordan \& Evermany, Bull. 47, U. S. Nat. Mus. 1461, 1898, pl. CCXXIV, fig. 570, 1900.

Body rather elongate, little compressed, its greatest hight equal to length of head, and two sevenths of total length without caudal; caudal peduncle short, its least depth egual to snout, and about one third length of head. Head long, two serenths of total length without caudal, the snout prominent, obtuse, nearly twice as long as the eye, which is one fifth as long as the head. Month rather large, nearly horizontal, the maxillary reaching to below front of eye. Ireoperele strongly serrate, the spines near angle diverging. Dorsal fins nearly separrate, the spinous dorsal triangular, the filst and last spines 
sherere than eye, the third and fourth longest, equal to snotit and eye combined. the base of the fin as long as the rentral. suft dersal long and low, one fouth longer than head, the lomerst ray ome third as long as head. Candal slightly produced in the middle. the middle rays one half as long as head. Lual

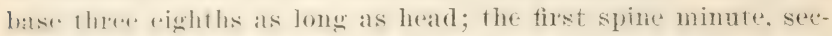
ond spine one fourth as long as head, first rat about onte half length of head, last ray two ninths as long as head. Pectoral lomer. reathing beyond origin of soft dorsal. Tentrai one sixtle of tofal length without eaudal, not reaching nearle to vent. Interorbital widh somewhat exceeds diameter of eye.

1). I, I, 27 to $30 ;$ А. II, 8; V. I, 5; P. I, 16; seales 9-60-12; pyloric caeca eight; gill rakers $\mathbf{7 + 1 6}$.

color wratish silrery, with bright reflections; sides and back with nitruw, irregular, undulating lines of dots; dersal fins with three lines of dots along base.

The ervalier inhabits the east coast of the United states. ranging from cape cod to Texas; it is not very common north of the Chesalpeake. It grows to the length of 15 inches and is an important food fish. The fish was deseribed be Mrehill but was unkunwn to De Kay from personal obsertation. Thongh known in Gravesend bay, the species is a rery uncommon

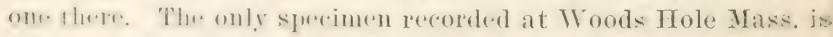
1. infues long: it was taken in at trap at the breakwater in Buzzards bay on Sep. 9, 1893.

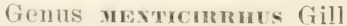

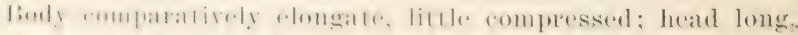

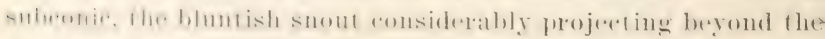
month fmonth small, hori\%omal, lonh jaws with batnds of villi-

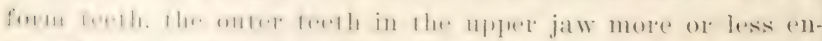

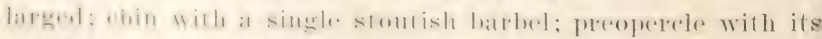

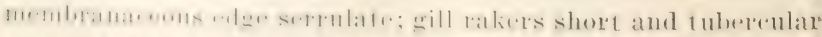

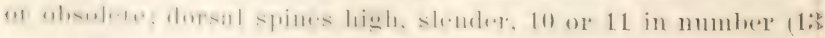
in (: irrim(-11s); second dorsal lone and low; caudal fin

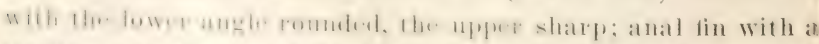

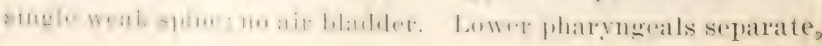


the teeth rarying from sharp to rery obtuse. This genus is one of the most strougly marked in the family. It has been confounded by all European writers with $\mathrm{U}$ mbrina, with which it has not rery much in common except the presence of the barbel at the chin. All the species are American, and all bottom fishes. The low, elongate body, the large pectorals, and the obsolete air bladder are all characters related to this peculiarity of habit.

\section{Subgenus mevtromrus Gill \\ 285 Menticirrhus saxatilis (Bloch \& Schneider)}

Kingfish; Whiting; Sea Jink

Johnius saxatilis Blocin et Scmeider, Syst. Ichth. 75, 1801, New York. Seiena nebulosa Mitchill, Trans. Lit. \& Phil. Soc. \. Y. I, 40S, pl. 3, fig. 5, 1815.

Umborina alburnus DE KiY, N. Y. Fauma, Fishes, 7s, pl. 7, fig. 20, 1812.

Lmbrina nebulosa Gǜtmer, Cat. Fislı. Brit. Mus. II, 275, 1860; Storer, Hist. Fish. Mass. 46, pl. IX, fig. $4,1867$.

Menticirrhus nebulosus Goode de Brix, Bull. Essex Inst. IX, 17, 1879; Jordan \& Gilbert, Bull. 16, U. S. Nat. Mus. 577, 1883.

Menticirhus statilis BExx, Bull. L. S. F. C. TII, 141, pls. II, III, figs. 7 and S, 18s8; Jordax \& Eigenarax,, Rep. U. S. F. C. for 1s56, 431, 1859; Bexx, 19th Rep. Comm. Fish. X. Y. 259, pl. XII, tig. 11, 1ะ90; Bull. Am. Mus. Nat. Hist. IX, 368, 1897; H. M. Sirrth, Bull. U. S. F. C. $1897,101,1898$; Jordan \& EvernanN, Bull. 47, U. S. Nat. Mus. 1475, 1S98; BeAN, 52d Ann. Rep. N. Y. State Mus, 106, 1900.

Body robust, elongate, its greatest depth ahout two rinths of total length without caudal; the least depth of caudal peduncle one third length of head. Head one fourth to two sevenths of total length without caudal; snout one fourth as long as the head; ere small, two thirds as long as snout. Mouth large, the maxillary reaching to below middle of eye. Outer teeth of upper jaw not much enlarged. Spinous dorsal elevated, the third spine longest, two thirds as long as the head, reaching slightly past origin of soft dorsal; first spine minute. last two spines rery short. Base of soft dorsal one third of total lemeth without caudal; the longest ray less than one third length of head. Caudal concare above, convex below, the middle rays about one half as long as the head. Anal base under the middle portion of the soft dorsal, its length about equal to least depth of caudal peduncle, the spine one third as long as the pectoral, the longest 


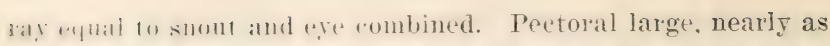

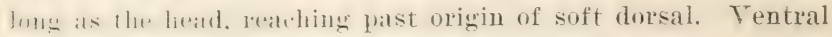
4h1. half as lomg as the hearl. Seales all ctenoid. I. X, 1, 26 or $27 ;$ - I. I, S; seales $7-53-14$.

1 1.11 dusky graly aluwe, sometimes blackish, the back and sides with distinet dark oblique reoss bands ramning downward and formatd, the anterior one at the nape extending lownward,

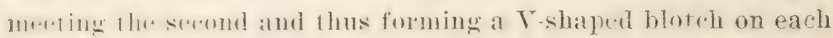
sill.: a datk lateral streali bounding the pale color of the bells, most distinct posteriorly, and extending on lower lobe of caudal; inside of gill cavity scarcely dusky; pectorals dark.

Thr lingtish, ateording to I Hay, was so named by the early Fonglish rolonists hecause of its excelleut flavor. The name hake is wirn to it in Xew Jeraey and Delaware; in the Chesapeake it is stmmelimes alled blatek mullet; in North Carolina, the sea mink: in thr south it is the whiting or Bermuda whiting; or the Connecticut coast it is known as the tomcod.

The kingfish occurs northward to Cape Ann and soutb to the Gulf of Mexi(o). Large indiriduals are not common as fal $10 \mathrm{l}$ th as r afp f iol, but the young may be seen in moderate numbers in

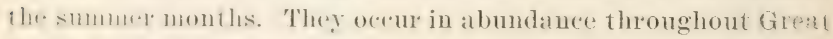
Sumb haly and near the inlet their number is increased. We hare

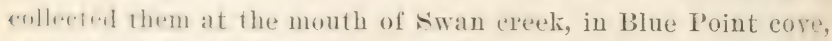

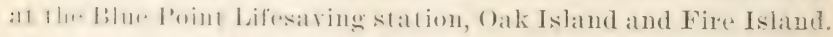
In imlividual wals ohtained october 7 , in the bay, and others wrer fommd during september. Adult kingfish used to be com-

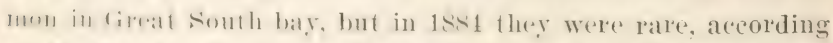

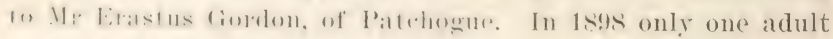

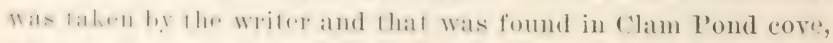

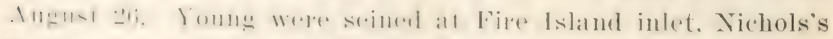

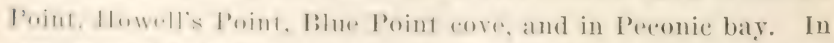

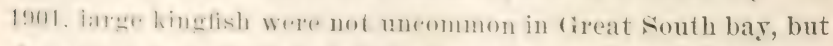
:11. y+1115

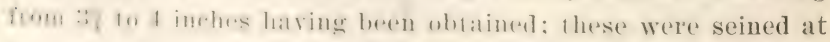
imnum's creek, September 14.

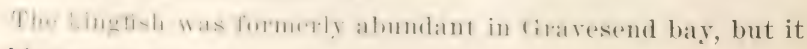
seliom ocems there now. 
The species evidently breeds at Woods Hole Mass. Dr Smith says that adults full of spawn are common there in June and uncommon after July 15. The young about an inch long appear in the middle of July, and the young are numerous on sandy beaches during the summer and till early October, when they leave, having attained a length of 4 or a inches. Some of the young are almost entirely black, while other's of the same size taken at the same time show the color markings of the adults. The maximum weight there is about 2 pounds.

The species is a farorite in New York water's and well merits its reputation as a choice food fish. It takes the baited hook very readily. Hard clam, cut small, shedder crab, black mussels and various kinds of fish are good baits. It goes in schools and associates with the weakfish.

The name kingfish is said to have been given it in honor of the king by colonial New Yorkers, who esteemed the fish highly.

\section{Genus pogovias Lacépède}

Body short and deep, the dorsal outline much elevated, the ventral nearly straight. Mouth moderate, the upper jaw longest; teeth small, in villiform bands, the outer not enlarged; lower pharrngeal bones large, fully united, armed with strong paved teeth; lower jaw with numerous barbels, each about one half as long as the eye; preoperculum entire, with a membranaceous edge. Dorsal fius slightly connected, the spines high and strong; caudal fin subtruncate; first anal spine short, the second exceedingly large, nearly as long as the soft rays; pectorals and ventrals long: gill rakers short and bluntish. Psendubanchiae large. Marine species, reaching a very large size, among the largest of the Sciaenidae, two species known.

\section{Pogonias cromis (Linnaeus)}

\section{Drum}

Labrus cromis LinNaEus, Syst. Nat. ed. XII, 479, 1766, Carolina.

Pogonias fasciatus Lacépède, Illist. Nat. Poiss. III, 137. 1N12; C'Trier \& VAlenciennes, Hist. Nat. Poiss. V, 210, pl. 118, 1830; DE KAY, N. Y. Fauna, Fishes, S1, pl. 14, fig. 40, 1S42; Giviner, Cat. Fish. Brit. Mus. II, $270,1860$.

II ugil grunniens MiтchiLl, Rep. Fish. N. Y. 16, 1814, New York.

II ugil gigas MrtchrL, Rep. Fish. N. Y. 16, 1814, New York. 
I.ubrus mrmuim. Mrremin. Trans. Lit. \& Phil. Soc. X. Y. I, 405, 1815.

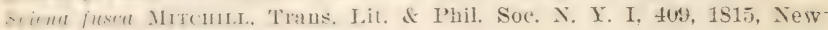
York.

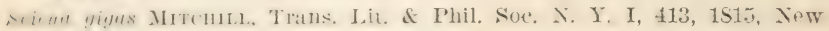
York.

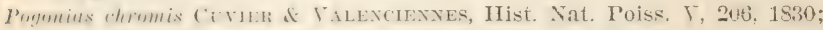
De KAY, N. Y. Fauna, Fishes, S0, 1842; Holbrook, Ichth. S. C. ed. 1, 112. pl. 1ti, liz. 2. 14.ti; Gётнer, Cat. Fish. Brit. Mus. Ii, 270, 1S60; Jompar of Gilmert, Bull. 16, U. S. Nat. Mus. 568, 1853; BEAN, 19th Rep. Comm. Fish. N. Y. 261, pl. XIII, fig. 17, 1890.

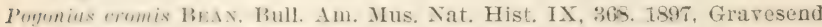

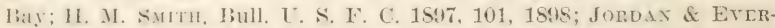

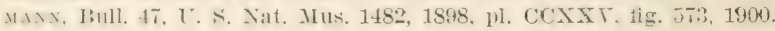

Junly oblong. compressed, leaty forwards, its greatest depth two fifths to one third of total length without candal; least hight of ratudal judumele one third length of head. Ifead large, its length about two sererenths of total without caudal: spout short, strungly derlivous, a very shallow depression orer the fyes, nalke much alehed. Lower jaw slightly shorter in fiont thatn mpere: maxillary reathing to helow midale of ere. Teeth in hroal hands, the onter series in maxillary searcely enbrenged; luwer pharymgeals larger. (.ompletely united. rovered with many hom molats and al small fatch of conical teeth at the outer

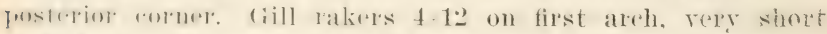
amd slemler. Nimoms dorsal triangular, the fourth and fifli

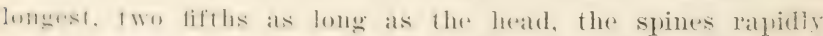
siminishing in siz. lo the front and rear, the first one being mimule; I he hase of spimous dorsal as long as the head without

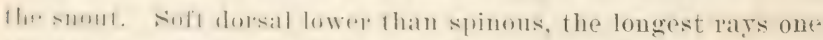

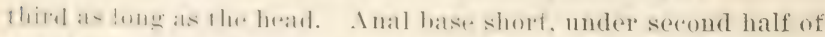

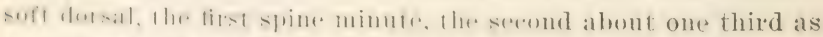

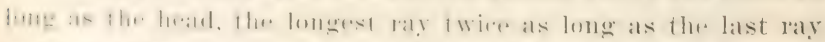

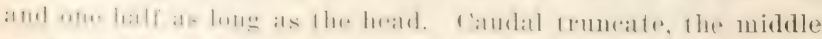

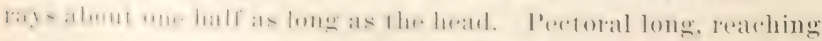
In holow the fomth ray of soft dorsal, as long as the head. Tenfral rypal to fostorlital part of heat, reaching to below the origin of solf dorkil. Suales on breast small, others large. D.

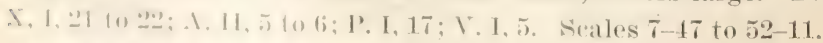
f'olur gratyisli silvery, with five broad dark bars three of which

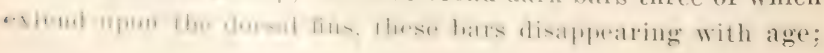


usually no oblique dark streaks along rows of scales abore; fins dusky.

Dr Mitchill describes the drum under the names, black drum and red drum. The black drum which he deseribed weighed 34 pounds. He had a specimen of 80 pounds, and states that he was credibly informed of one that weighed 101 pounds. The species, according to Dr Mitchill, was taken abuudantly during the summer with line and net. The name drum, he says, is derived from the drumming noise made by the fish immediately after being taken out of water. "He swims in numerous shoals in the shalIow bays on the south side of Long Island, where fishermen during the warm season can find them almost like a flock of sheep; is a dull sort of fish." The red drum he considered merely a variety of the black drum. Dr. De Kay says of the species, which he calls the big drum: " They are gregarious, and frequently taken in great number's by the seine during the summer along the bays and inlets of Long Island." We Kiay adopted a different specific name for the roung of this species, and called it the banded drum. Other names for this stage given by De Kiay are: grunter, grunts, young drum and young sheepshead. He saw the young in September, and states that it is found in Tew Tork waters also in October and Norember. The adults, according to De Kay, are a coarse food, but the young are considered a great delicacy.

The drum is occasionally taken on our coust as far north as Cape Cod; southward it extends to the (iulf of Mexico.

The drum is an occasional summer visitor in Gravesend bay. In the fall of 1896,14 young individuals, \& inches long. Were brought from there alive to the aynarimu, and lived till Felnuary 10, 1897, when the low temperature of the water (38) killed them. In the fall of 1897 none were seen in the bay.

In the vicinity of Woods Ifole Mass. the drum is rery rate. Dr Smith records the first one as having beren taken Maty 7 , 187t, and it has been observed only there or fom limes sincer. The recent specimens have been alught in traps all (2uisset Harbor, in the latter part of september or tarly in (t)toher: 
these sperimens weighing atch $4 \frac{1}{2}$ or 5 pounds. The largest drum rerorded was taken at st Augustine Fla. and weighed 146 pumuls. The large fish are not much valued for food, but small ones are said to be excellent.

\section{Genus apLodivotus Rafinesque}

liody oblong, the snout blunt, the back elevated and compressed; mouth rather small, low, horizontal, the lower jaw incluted: tecth in villiform bands, the outer above scarcely enlarged; no barbels; pseudobranchiae rather small; gill rakers short and blunt; lower pharyngeals very large, fulis mited, with coarse, blunt, pared teeth, as in Pogonias; meopercle slightly serrate; dorsal spines strong and high, with a close fitting sealy sheath at base, the two dorsals somewhat conneected; serond anal spine very strong; candal double truneate; air bladder very large, simple, with no appendages; prorio careat seven; vertebrar $10-1 t=24$. Fresh waters of the Enited states: latger, coarse fishes, feeding chiefly on crustateat and mollusks. The genus is apparently allied to Pogonias, and both maly be descended from allies of $\mathrm{R}$ on c a d o r, which is intermediate between them and $\mathrm{S} \mathrm{c}$ i a e $\mathrm{n}$ a .

\section{Aplodinotus grunniens Rafinesque}

\section{Lresh-water Drum; White Perch}

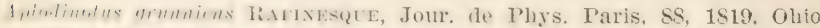

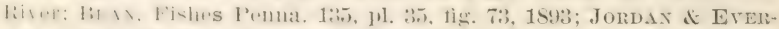

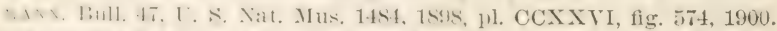

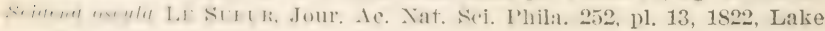
()ntario.

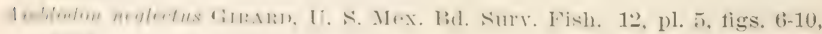
18.59.

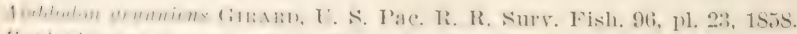

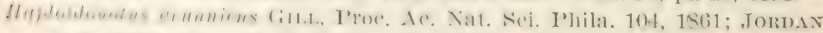
4 Gimant, 13ull. 16, U. S. Nat. MIus, 567, 1853.

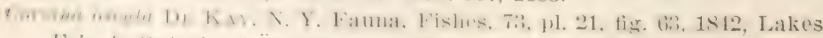
Erle de Ontario; Güntuer, Cat. Fish. Brit. Mus, II, 297, 1860.

The shape of the fresh-water drum is similar to that of the

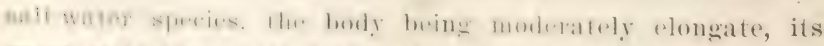

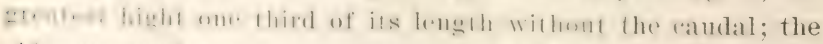

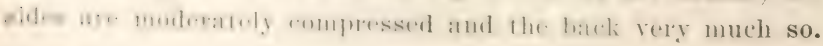


The least depth of the tail is less than one third of the depth of the body. The head is rather short, its length contained three and two thirds times in the total without caudal. The eye is about four fifths as long as the snout and one sixth length of head. Snout obtuse. The maxilla reaches to below the middle of the eye; the lower jaw is shorter than the upper. The pectoral is nearly as long as the head and reaches to below the beginning of the soft dorsal. The ventral is about two thirds length of head. The third dorsal spine is the longest, nearly one half as long as the head. The second anal spine is much the longer and stouter, its length two fifths that of head. The rays of the soft dorsal are longest near the end of the fin. The scales are very irregularly placed, about 55 in the lateral line.

\section{IX, I, 30-31; A. II, 7.}

The color is grayish, darker on the back; lower parts silvery. Young specimens have dark spots along the rows of scales, forming oblique lines.

The fresh-water drum has received a great number of common names. In the Ohio ralley and South it is known as the white perch; in the Great Lake region it is called sheepshead or freshwater drum on account of its resemblance to the salt-water drum. At Buffalo and Barcelona, New York, it is known as sheepshead. The name crocus, used on lakes of northern Indiana is a corruption of croaker, a name of a marine fish of the same family. In the southern states the name drum is generally applied to the species, and in addition the terms thunder pumper, gaspergou and jewel head are used. Gaspergou is a term used in Arkansas, Louisiana and Texas. The names drum, croaker and thunder pumper have reference to certain sounds produced by the fish either by means of its air bladder or by grinding together the large molarlike teeth in the pharynx. The name jewel head probably refers to the otoliths or earbones, frequently called lucky stones, which are found in the skull of this species. In Texas, adjacent to Mexican territory, occurs the name gaspagie, a rariation of the name gaspergou. The fresh-water drum is widely distributed; it occurs in Lake 
Champlain and the entire Great lakes region, the Ohio and Mississippi ralleys southwarl to Texas. The T. A. Fish Commissinu whaned a specimen at Point Breeze X. Y. on Lake Ontario. Jh. Kal reported it as rers common in Lake Lrie and called sheepshat at Buflalo. It the time of his writing the fish was searety ever eaten. It is found principally in large streams and lakes and rarely ruters ereels and small rirers. In western Texas the sprecies is rare. In the wilds of Texas, NeW Mexinn and morthern Mexico Mr Turpe has found this tish in Gear limestome streams emptying into the Rio Grabele.

This spereies is usually found on the bottom, where it feeds whitfly on relustaterans and mollusks and sometimes smali tishes. It is spucially fond of cratwfish and small shells such as f'y las and L'a l ud i na. Mr Turpe mentions wattr plants as forming part of its food and states that it will talke a look baited with worms or small minnows.

The fresh-water drum grows to a length of 4 feet and a weight

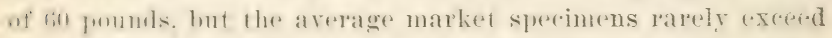
Zf fint in length and in many parts of the West much smaller mar. are preferred. Nothing is recorded about the breseding habit- of this spereies and as to its edible qualities there is the grwates alifirene of opinion. Some writers claim that its flesh is tumph and roarse with a disagreealle odor, specially in the dirat takes. Individuals from the Ohio river and from more

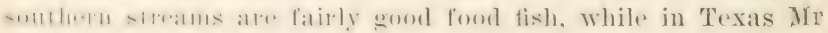
Turpe comsitlers it one of the most exerllent of the fresh-water

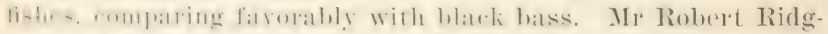

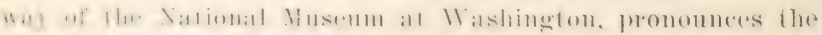
speyles from llan Wabalsh river in Indiana, a fine table fish

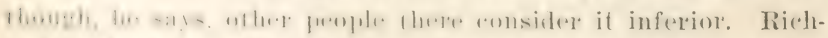

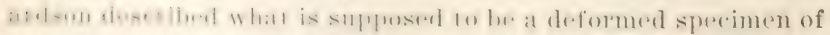

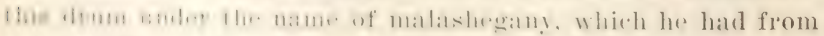

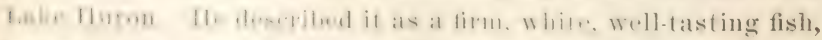
but merer fat and recpuring much boiling. 


\section{Suborder PHARYNGOGNATHI}

\section{Labroid Fishes}

\section{Family LABRIDAE}

Wrasse Fishes

\section{Genus ravtogocaneus Günther}

Body oblong, not elerated, comparatively slender and compressed; head moderate, more or less pointed, but the jaws not notably produced; teeth in the jaws in several series, the outermost very strong; the teeth unequal, conical and pointed; no posterior canines. Cheeks with small scales; opercles with large ones; interopercles naked; prenpercle with the vertical limb finely serrated. Branchiostegals five. Gill membranes considcrably united, free frow the isthmus; gill rakers short. Scales moderate, 35 to 50 in the lateral line; lateral line continuous, abruptly bent opposite posterior part of second dorsal; dorsal long and low, the spinous portion much longer than the soft, of 18 or 19 low, subequal, rather strong spines; soft dorsal slightly elevated; anal fin similar to soft dorsal, with three strong graduated spines; caudal truncate; pectorals short, the ventrals inserted behind their axils. Species two, both American. This genus is very close to the European genus C t e $n o$ $1 \mathrm{abrus}$, differing in the less perfect squamation of the head and in the greater number of dorsal spines and rertebrae.

\section{S8 Tautogolabrus adspersus (Tralbaum)}

\section{Bergall; Cunner; Chogset; Nipper}

Labrus adspersus WaLBAuM, Art. Gen. Pisc. 254, 1792.

Tautoga Caerulea Mitcinls, Rep. Fish. N. Y. 24, 1814, New York.

Labrus chogset MitcmLL, Trans. Lit. \& Phil. Soc. N. Y. I, 402, pl. 3, fig. 2 , 1815, New York.

Labrus chogset fulva MrтchiLL, 1. c. 403, 1815, New York.

Ctenolabrus uninotatus Cuvier \& VAlencievnes, Hist. Nat. Poiss. XIII, 239, 1839, New York, young; DE KAr, N. I. Fauna, Fishes, 174, pl. 29, fig. 90, 1S42; GüNmier, Cat. Fish. Brit. Mus. IV, 90, 1862.

Ctenolabrus burgall GüNTHER, 1. c. 90, 1862, Canada.

Ctenolabrus chogset Cuvier \& VAlenciennes, Iist. Nat. Poiss. XIII, 237, 1839.

Ctenolabrus ceruleus DE KAY, N. Y. Fama, Fishes, 172, pl. 29, fig. 83, 1812. Ctenolabrus adspersus Jondan \& Girmert, Bull. 16, U. S. Nat. Mus. 599, 1SS3: BeAN, 19th Rep. Comm. Fish. N. Y. 251, pl. IV, tig. 6. 1S!10. 
Tuntomblutus alspersus Goode \& BEAN, Bull. Essex Inst. Xi, 14, 1579; Meax. Proc. U. S. Nat. Mus. 87, 1850; Bull. Am. Mus. Nat. Hist. IX, 3tS. 1S97; H. М. SMIt, Bull. U. S. F. C. 1897, 102, 1898; JoRdAN \& lirmmax, Bull. 47, U. S. Nat. Mus. 1577, 1898, pl. CCXXXVi, fig. ST, 1900; BeAx, 52d Ann. Rer. X. Y. State Mus. 107. 1900; SHerwood \& Edwards, Bull. U. S. F. C. 1901, 30, 1901.

Body fusiform, stout, its greatest depth nearly one third of total length without caulal, the profile much less courex than in the tautog: least depth of caudal peduncle one hali of greatest depth of body. Head one third of total length without caudal, the snout pointed, and forming one third of the length of head; ere placed high, its diameter one fifth iength of head; preorbital bone not equal in width to the eye; jaws equal, with thick lips; mouth moderate, the maxillary nearly reaching to rertical from front of eje; fire canines in front of upper jaw, about four in lower, the teeth on sides of jaw largest in front: bands of small concave teeth behind canines; gill rakers rery short, about 6+11 on first arch; scales rather small; top of heid, preorbital, maxillare, mandible, interopercle, and posterior chese of preopercle and opercle naked; preopercle with about fire rows of small scales; opercle with four or five rows of lareger ones; fins naked. Iase of spinous dorsal two and om. half times as long as that of soft dorsal; the spines gradually infrasing in length uy to the seventh, from which they are alumil eyual, the serenth about three eighths as long as the hrad. Ihe first only one sixth as long as the head. Soft dor'sal a lifll. higher than spinous, the longest ray one half as iong as the heat. raudal rounderl, its middle rays about one half as long as the head. Anal muder the second half of the dorsal, its hase as lome as the heald without the snout; the spines stout aml sharl. Ihe tirst equal to the eye in length, the second and llifd nfarly efpual and a little more than one third length of lorall: Ihw foulth and fifth soft rays equal, longest, one half as long as thre hroth. Preforal broad, short, one half as long as the |ratil. Jintral slightly longer than pectoral, not reaching to vent.

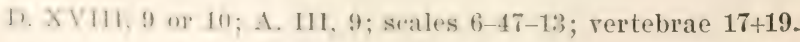


Color bluish or brownish, usually with a brassy luster on sides; head and back sometimes spotted with brassy; roung with darker blotches and markings. and often with a black blotel near the middle of the dorsal fin. Some individuals are yellow ish and the young are often green.

The cunner is known also as chogset and bergall th the changed to bengal in Great Egg Harbor bay, X. J.). Mitchill gires the name of bluefish as in use in New York in 1S15; perch, sia pereh and blue pereh are New England names given for this fish. Names used with reference to its bait-stealing propensities are: nipper and bait-stealer.

The cumner is common from Labrador to at least as far south as New Jersey.

The bergall is found in firavesend bay throughout the year. In 1898, the writer found it in Peronic bay and the adjacent Scallop poul; south sirle of Gieat South bay opposite Patchogue; Fire Island inlet; Blue Point core; and Duncan's creek. In 1899, young (xamples Were taken at Watep Island ocean beach, June (i. In 1901, young of a yollow rolor and only $1 \frac{\text { s. }}{5}$ inches long were seined in a creek near Fire Island inlet, August 15. Half grown and adults were caught at a wreek on Tobey's Flat, August 14, and at Suith's Point, August 23.

At Woods Mole Mass. the cumner is very abundant and remains during the entire year. Thous:unds perish from cold every wittter. The fish spawns in June. The egg is about inch in diameter, buoyant, and has been hatched in the tirlal cond-jar in fire days in water of a mean temperature of $56^{\circ} \mathrm{F}$. By August 1 the young an inch long are observed. Outside of Gayhead and Cuttyhunk the fish reaches a weight of $2 !$ pounds, but the usual weight is from to $\frac{1}{4}$ jouncl. In Fohruary 1901, thousands of cunners were killed b! extreme cold at lloods Ifole.

The cunner endures aptivity rery well, individuals having been lept three years or longer. The species is usually associated with the tautog or blackfish; in many places it proves a great annoyance to tishermen. In some parts of New England the fish is highly esteemed, but farther south it is not in high 
repunte, the hard salus and stith. sharp spines making it inconvenient to prepare for cooking.

Dr. Mithlitl describes a yellow variety of the emuner, and De Fay has considered lhe young, which has a black spot on the

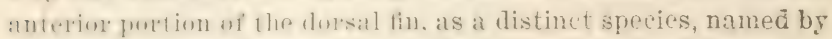
him the spotted bergall.

The young vary grmally in rolor. We haw spen some dull beum, others that were yellowish, and still others of a bright gwen. lusky bands are characteristice also, of the young stages. Raximples were taken at Blue Point core and at Fire Island. The emmere is a permauent resident. and does not

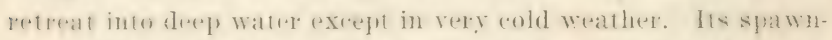
ing takes plate in fune and July. The speries is fisled for with lhe hook, and is taken in nets. which are baited and set monge the rocks. The atch of the Irish comner boats of Boston has

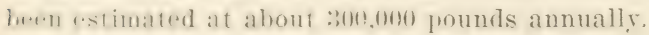

\section{Genus TaUtoga Mitchill}

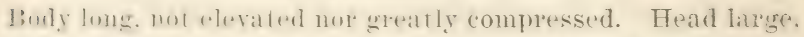
nearly at dow as long. with a ennvex profile. Mouth ratien suall. Teeth very strong. coniral, in two series; the nutr. conewhat incisorlike: the 1 wo anterior teeth in each jaw srone; the prosterior tretl small, without canines. Epe small, hieh ul. Cheelis with small siales; interopercle naked; operch.s

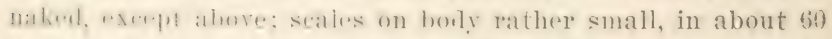
transwere series, those m rentral region reduced in size; lat-Tul line antinums, atrupul! decurved opposite the end of the son dersal. Worsil tin lome. low, continnous. the spinous part mong the longer, with about lif low. strong. subequal spines,

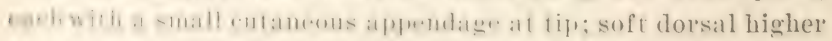

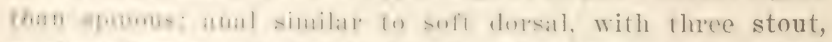

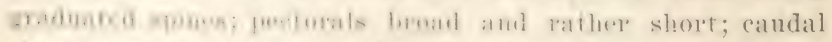

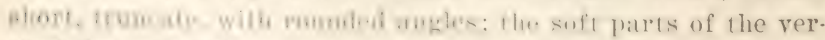

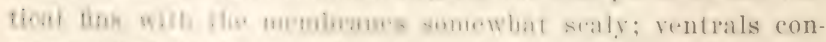

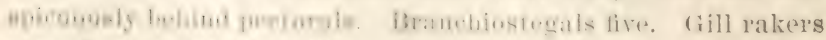

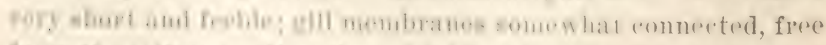

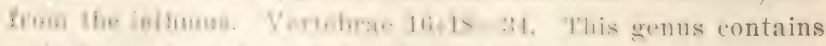

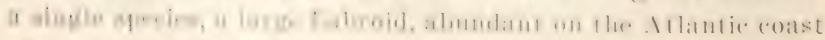
of the linited siates. 


\section{Tautoga onitis (Linnaeus)}

\section{Blackfish; Tautog}

I. abrus onitis Lrxiaeus, Syst. Nat. ed. X, 286, 175S; ed. XII, 478, 1706.

Tautoga niger Miтchill, Rep. Fish. N. Y. 23, 1814, New York.

Labrus tautoga Mitchill, Trans. Lit. \& Phil. Soc. N. Y. I, 399, 1815, Long Island.

Tautoga americana DE KAY, N. Y. Fauna, Fishes, 175, pl, 14, fig. 39, 1842; Storer, Hist. Fish. Mass, 110, pl. XX, fig. 2, 1867.

Tautoga onitis Günther, Cat. Fish. Brit. Mus. IT. 88, 1862; Goode \& BeAN, Bull. Essex Inst. XI, 14, 1S79; Jordax \& Gilbert, Bull. 16, U. S. Nat. MIus. 600, 1883; BeAN, Bull. U. S. F. C. TII, 137, pl. III, fig. 3, 1S88; 19th Rep. Comm. Fish. X. Y. 252, pl. V, fig. 7. 1590; Bull. Am. Mus. Nat. Hist. IX, 368, 1897; I. M. Smrn, Bull. U. S. F. C. 1897, 102, 1898; Jordan \& Evermanx, Bull. 47, U. S. Nat. Mus, 1578, 1898, pl. CCXXXYII, fig. 596, 1900; BEAx, 52d Ann. Rep. N. Y. State Mus. 107, 1900; Sherwood \& Edvards, Bull. U. S. F. C. 1901, 30, 1901.

Body deep, moderately compresserl. the outline of head and back convex, the greatest depth three eighths to one third of total length without caudal, the least depth of caudal peduncle equal to postorbital part of head. Mead short, blunt, its length contained three and one fourth to three and one half times in total without caudal; profile of snout rers steep; preorbital very wide, wider than the eye; mouth small, with rery thick lips, the maxillars reaching the rertical from antrrior or posterior nostril; ere one fifth as long as the head; snout one third as long as the head; jaws nearls equal in front, with two or three large canines and smaller ones on the side, gradually diminishing in size backwards. A patch of small scales behind ere extending downward to middle of chenk where there are five or six series; a small patch of seales at upper edoe of oprere: head elsewhere naked. About $3+6$ rery short and hlunt gill rakers on first arch. Spinous dorsal composerd of stout. sharp spines. thr. connecting membrane between them projecting beyond them; the first spine as long as the eye; the spines gratually increasing in length to the 11th which is one thirel as long as the head and twice as long as the first: the remaining spines are about equal to the 11th: thre hase of soft dorsal is ome half as long as the head; the longest ray is maly twiee as long as the last ray and more than one half as long as the head. Caudal convex, the middle rars about one half as long as the 


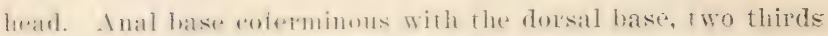

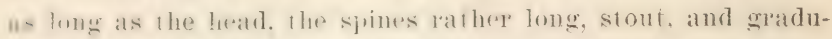

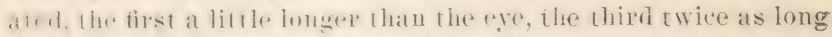
as the (yen: the third and fourth rars lomgest, as loug as foost-

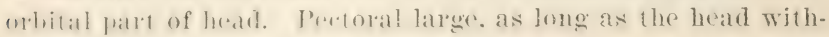
out the suout, reathing to besow the 10th spine of the dersal.

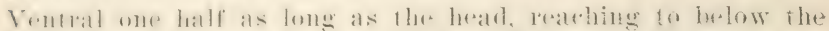
12th spine of the dorsal. D. XVI to XVII, 10; A. IJI, 8; V. I, 5; 1. I, 15. Scales 14-60 to 65-29.

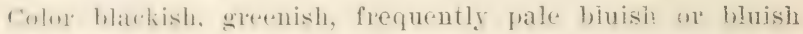
blatk with metallic reflections. Often with irregular baturs of

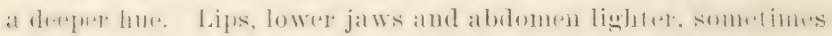
lakle, sprinkled with black poiuts, and sometimes of the same color as the rest of the body. Eye greenish.

This is hullw known in Now York as the blackfish; farthor sumblit is stylud chul, or salt-water chub. Moll, Will Genrue and myle. fish. Mitehill grires the name tautog as of Mohegan origin. Il, publishes for the speecies the names toad, blarkfish and r.mmer. Ther Mohregan name lantog, aceording to fle fiay; is s:irl 10 mean hlark. The fish is found from Nova Srotiat to

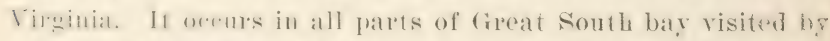
11:. Sume of the lowalities at which it was dalien are the fol-

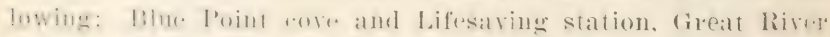
luarli and Fire Island. The name used at P'atchogne is blarels-

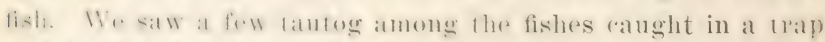

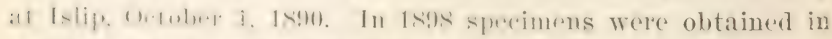

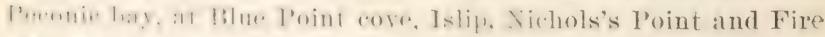

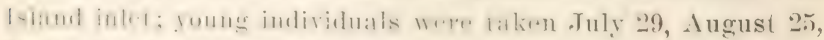

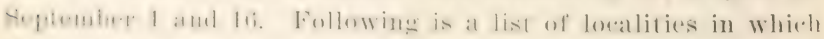

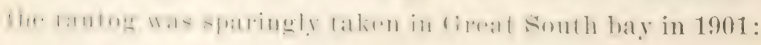

Slam l'ond cove. July 19

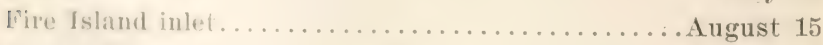
('herry Girove Angust 17 sinith's l'oint. August 23 
Dr Mitchill gives a most entertaining account of the habits and mode of capture of this well known suecies. It the time of his writing, in 1814 , the price varied from eight to 12 cents a pound.

It has been known to reach a length of 3 feet and a weight of 21.2 pounds. Individuals of 12 to 14 pounds have occasionally been taken off Cape Ann. The fishing season begins in April and may last till winter. Examples are sometimes speared in the winter months in New England rivers. The tautog is not migratory, but hibernates in cold weather, going into the mud in Norember or December. It is sometimes destrored br freezing; such accidents hare occurred in ponds on Martha's Vineyard and elsewhere.

The spawning season begins late in April. The eggs are deposited in depths of 6 to $S$ feet or more among the rocks. In the fish cultural operations at Woods Ifole Mass. it was found that the egg is buoyant and ouly inch in diameter; in the automatic tidal box they hatched in about five dass with the water temperatme at 69 F., and in 1 wo or three days with the temperature at $71^{\circ}$.

There is great diversity in the colors of the roung, just as in the case of the foung rumners. Some are bright green, others brown or red and some are mottled with hrown, red and green, intermingled with pale areas. The foot of the tautog consists of mollusks and crustaceans: crabs, and spetially fiddlers, ballnacles, clams and lobsters are among the farorite artirles of food. The annclids, known as sandworms, are also very attractive to it.

The tautog is an excellent food fish and one of the commonest of our market species. It is a permanent resident in the bays and is hardy in captivity. Individuals have been lept longer than three rears and some of them have grown remarkably. Their food includes chopped hard rlatm. live killifish, shrimps, and fiddler crabs, of which lather they are extremely fond. Spawning takes place regularly in the tanlis in spring, but, as the eggs are rery small and buorant, they must invarially be lost at the orerflow. As the newly hatched embryos are only $\frac{1}{12}$ inch long they too would flow out unseen if any ware left for development. 
Group ZEOIDEA

Family ZEIDAE

\section{John Dories}

\section{Genus zevorsis Gill}

borly ovate. much romjuressed, mithont seales, and without warts or humps in the adult. Heat deeper than long, its anterior profile ster.j). Trouth rather large, upper jaw protractile; teeth small on jaws and romere, none on the palatines, Various bontes of the head and shoulder girelle armed with spines. Series of bony plates along the sides of the belly and the bases of hoth dorsal and anal, each plate armed with a strong spine. Eve larege, placed high. Gill rakers short. Dorsal spoines rery strong, usually 10 in number, some of them filamentous; a oal gpines three; rentral fins long, the rays I. sis op I, seven. Catudal pedunclo slinder, the fin not forlied. Three sprecies known, diflering from the European genus Zeus mainly it the frresence of three anal spines instead of four, and in the Exeater develupment of the spinous armature. Pelagir.

\section{Zenopsis ocellatus (Storer)}

\section{John Dory}

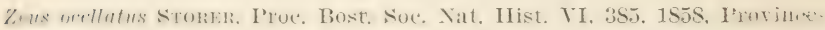
town Mass,; Putnam in Storer, Hist. Fish. Mass. 279, 1867.

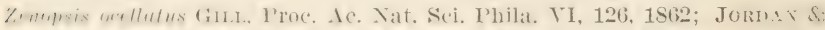

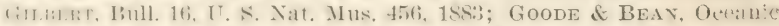

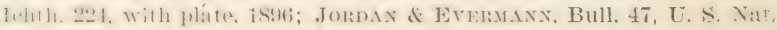
Mus, 1660, 1898, pl, CCXLVI, fig. 618, 1900.

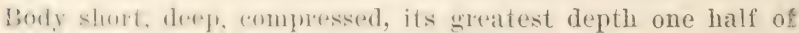

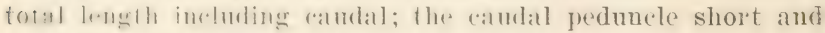

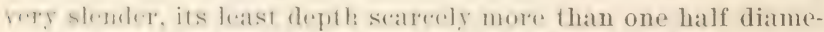
lof of eye. Ilead subpuadrangular. larege, the mouth large and sory abligur, llo maxillary ane sisth of tolal length without

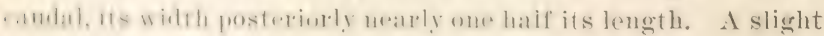

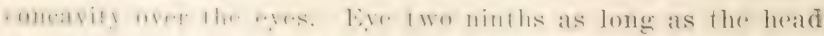

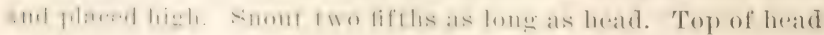

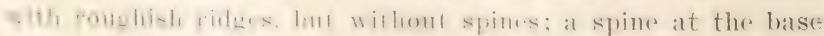

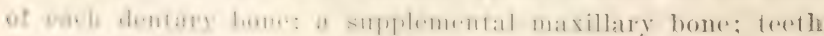
nearly olsolete. (iill rakers short. Skin naked rxeept for the 
bony bucklers which are armed each with a central spine hooked backward and marked with radiating ridges; seren bucklers along the base of the dorsal, the fifth and sixth largest, these located under the fifth to the 19 th dorsal ray; two on the median line in front of the rentrals. the second larger, as long as the exe; about eight plates between ventrals and ayal origin, and five along base of anal. Dorsal spines stout and long, the first four or five filamentous, the second longest, equal to total length without the head and the caudal fin; the base of the fin five sixths as long as the hearl. Soft dorsal base a little longer, as long as the head; the rays short, the longest, near the end of the fin, equal to diameter of eye. Caudal fin short, rounded, the middle rays as long as the postorbital part of head. Pectoral short, about as long as snout. Ventrals long, nearly as long as the head, and almost reaching to the anal origin. Anal long, one half of total leugth without caudal, the spinous and soft portions scarcely connected; the first spine longest, one and one half times as long as the third, and one fifth as long as the head; the longest anal ray nearly one third as long as the head. D. X, 24; A. III, 24; V. I, 5; P. 12.

Color silvery, nearly plain; a black lateral ocellated spot in life, disappearing in spirits.

Of this pelagie species only one sperimen is known; this was taken off Provincetown Mass. and presented to the museum of the Boston Society of Natural History by Capt. N. L. Itwood.

\section{Suborder SQUAMIPINNES}

Scaly Fins

Family epHipidida

Spadefishes

\section{Genus chattodp'terus Lacépède}

Body much elevated and compressed, its outline nearly orbicular, the anterior profile nearly rertical. Scales small, 5.5 to 70 in the comse of the lateral line. Jaws about equal; no teeth on vomer or palatines; teeth on jaws slender, somewhat movable; preopercle finely serrulatr. Mram hiostegals six. I)orsal fins two, somewhat connereterl. lhe tirst of usnally uine spines, 
The third of which is rongate: anal spines three, small, the second the longest; rentral with a large areessory scale. Pylouic Gema four to six. Ameriean; distinguished from the Asiatic germus E plu i f y us by the rery much smaller seales.

\section{Chaetodipterus faber (Broussonet)}

\section{Spadefish; Triple-tail; Angelfish; Moonfish}

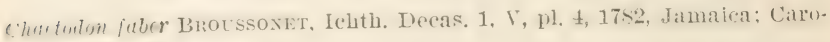
lina.

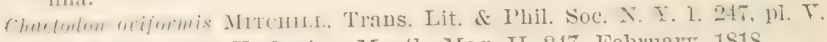
fig. 4, 1815, New York; Am. Month. Mag. II, 247, February, 181s.

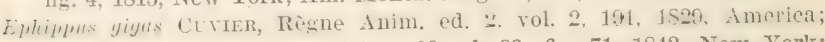
De KAY, N. Y. Fauna, Fishes, 99, pl. 23, fig. 71, 1842, New York;

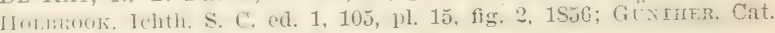
Fish. Brit. Mus. II, 61, 1860.

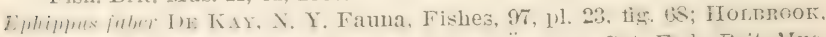

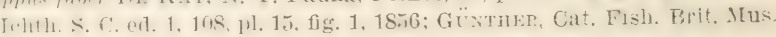

II, 61,1860 .

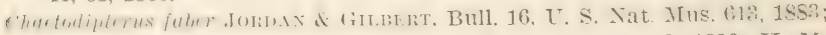
BeAx, 19th Rep. Comm. Fish. N. Y. 253, pl. VI, fig. S, 1890; H. II.

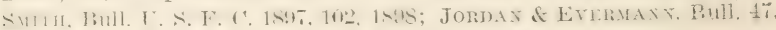
U. S. Nat. MIus. 1668, pl. CCXLVII, fig. 619, 1900.

Bewly whlomgorate, its greatest depth equal to the distanoe from d he re to the end of the dorsal base or anal base; least A. Hith of camblal perduncle one half length of head. Mead short. iwo sirentis of fotal length without candal; snout two fifils as bung as the heati preorbital deepe, equal to diameter of eye whinh is ibree fenths as long as the head; month moderatr. marly horizomal. Ile maxilla reaching to below front of eye: whin with a row of pores: dorsal and rentral outlines similar, geratle conyex. First dorsal spine minute; second rery short,

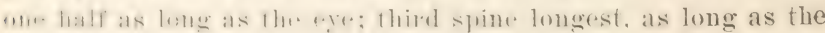

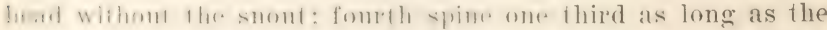

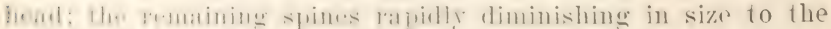

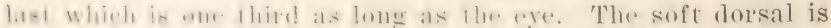

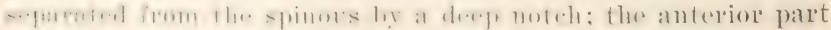

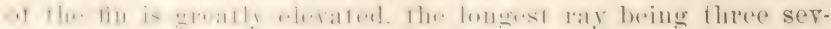
ontles of total leneth withont eautal: the fin is fallate. the last mas being short. Cambal resecntie with the onter rays produced, and about as lone as the head. Anal similar in shape 
fo the soft dorsal; the first spine one half as long as the ere, the second as long as the ere. and the third three fourths as long as the second; the longest rays equal one half of greatest depth of body. C'ectoral short, rounded, one half as long as the head. Tentral much longer, as long as the head, reaching berond the vent.

1). VIII, I, 20 to 20; A. III, 1S: V. 1, 5; P. I, 16; lateral line 60 to 65 ; pyloric caeca 4 to 6 ; rertebrae 9 or $10-14$.

Crayish; a dusky band across the eye to the throat; a second similar band, hroader, leeginning in front of the dorsal and exfending across the hase of the peretoral to the belly; a third hand, narrower, (xtending to the middle of the sides from the hase of the fourth and fifth dorsat spines: a fourth broader band from the last dorsal spines to anal spines. the remaining bands alternately short and long: all of these bands growing obscure and disappearing with age; ventrals black.

The moonfish is the sherphleat "hatetodon of Mitrhill, and the

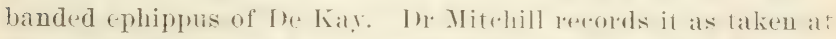
the east end of Long Island. July -27. 1N1.5. De Kay, in his Ter Tork Funn, has the following ronerening the sperese: ". Ibout trenty years since. they waw raught here in seines in great numbers and exposed in the marlets for sale. Some of them were 18 inches long. Those described hy Mitchill were captured in 1815 and 1817. The popular names of threetaled sherephead and threetailed porger were given them by the fishermen in allusion to their prolonged dorsal and anal fins. . Achoepff states that it is called angelfish in South Carolina."

The species is called spadefish in the states hordering the Gulf of Mexico.

The moonfish has orasionally luen talien as far north as Cape Cod. In Smith reords it as a rery rate stragglep in Tinerard Sound, Mass. I specimen was obtaimed in 1889. and three hare been observed since. All were taken in traps at Mrenemsha in August and september. The fish were uniform in size and about 16 to 18 inches long. The species reaches a length of

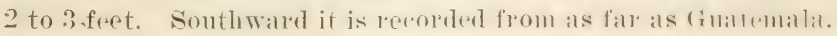




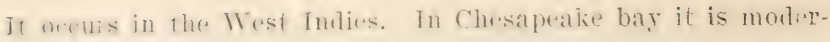
ately common.

As a foud fish this sumeies is lighly prized by those who are faniliar with its qualities.

\section{Family CHAETODONTIDAE}

\section{Butterfly Fishes}

\section{Genus cmatemox (Artedi) Linnaeus}

lindy shert, derel, yery stromely compressed, specially alone and bhiml: head small, compressed. almost ererymere scaly; mouth very small, ferminal, the jams provided with long, slenAler, flexible, hristlelike terah; vomer sometimes with teeth; pretre.peulum entire or nearly so, without spine. Dorsal fin sinEli. continuous, not noteherl, the spinous part longer than the soft ratet of ahout 12 spines. the spiues not gradiated. somie of 1he middl. ones being longer than the last; last rays of soft forsal usually rapidly shortened, some of them orrasionally iblamentous tin kast Indian species); ramelal gedumele shote, the canclal fin fan-slated: anal similat to soft dorsal. inereded by Hhree or four strong spines. Dody covered with rather larese

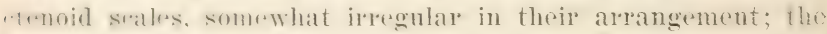
lateral line renved, high, farallel with the back. Gill vpeninges rather narrow. Hhe memhanes natrowly joined to the isthums; hranchiostegals six. A rery latege genus of singular and hearitful fishes abommlime in the tropical stals, specially about rol-

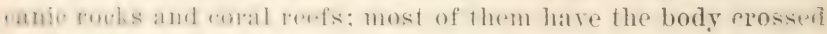
by imastrese hateli hars. They are all rery actire, feeding on small animals.

\section{Subgenus cmatrodontors}

\section{Chaetodon ocellatus Bloch}

\section{Parche}

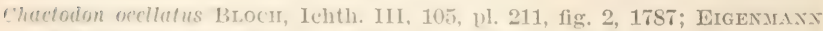

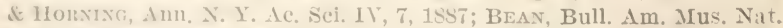
llist. IX, 3tis, 1897; II. M. SмrTI, Bull, U. S. F. C. 1897, 102, 189S; Jomm. e Evemaxi, Bull. 47, U. S. Nat. Mus. 1674, 1S98, pl. CCXLIX, fi:. (i21, 1960); II. М. Sмттн, Bull. U. S. F. C. 1901, 33, 1901.

Chontorlon bimaculutus litocm, Iehth. 1)1. 219, fig. 1, 1790; Cuvien \&

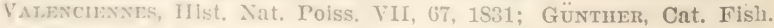
Brit. Mus. 11, 9, 1860; Jonnay \& Gimment, Bull, 16, U. S. Nat. Mus.940, 1883. 
Sarothrodus maculocinctus Gili, Proc. Ac. Nat. Sci. Phila. 99, 1S61, Newport R. I.; young.

Chaetodon maculocinctus Jordan \& Gilbert, Bull. 16, U. S. Nat. Mus. 616, 1883; BeAN, Bull. U. S. F. C. VII, 138, pl. I, fig. 4, 1888.

Body suborate, strongly compressed; greatest depth three fifths to two thirds of total length without caudal; least depth of caudal peduncle about one third length of head. Head two fifths of total without caudal; the upper profile concare except for a slight protuberance orer eyes; snout equals five sixths diameter of eye, which is one third as long as the head; the maxilla reaches to below the anterior nostril, its length equal to lengtl of snout; lower jaw somewhat produced; suborbital bone one half as wide as the eye. First dor'sal spine one fourth as long as the head; second spine about one half as long as head; third and fourth spines longest, as long as the head without the snout; last spine two fifths as long as head; longest soft ray one half as long as the head. Anal fin under the posterior half of the dorsal; the first spine as long as the snout; the second longest, nearly one half as long as the head; the third nearly as long as the second; the longest ray as long as the second spine; the base of the fin equals one third of total length without caudal. Caudal rounded, the middle rays one half as long as the head. Pectoral reaching to below the 10 th spine of the dorsal, as long as the head without the snout. Ventral reach. ing to the second anal spine, four fifths as long as the head.

D. XII or XIII, 18 to 20 ; A. III, 16 to $18 ;$ V. I, 5 . Scales $S-15$ to $50-20$.

Color golden gray, sometimes yellow or orange; a large, oblong, dark blotch on base of soft dorsal extended downward by a black band crossing the body and continuing faintly upon the base of the anal; a dark band from the origin of the dorsal through the ere and extending lownward across the rhek. The bands are nowhere more than one half as wide as the 'ye'.

The parche belongs to the West Indian fama; it is common at Havana, and the young follow the riulf Sitream northwarl in summer to New Jelsey, Long Istand, Rhode Islann, and rape Cod. In the vicinity of Moods In Mass. aceording to Dr Smith, 
it must now le regarded as a common species, for, in 1900 . the number of specimens taken at Katama bay was 12:; these were whicred on 1:3 different occasions between August 15 and Or.pober 20: on Septembrer \& the number taken was 20 and 21 were seined on (w.tober 3 . Tp to 1897 only a few specimens hatd been serenred ammally in October and Xovember-uot more than fire in any one season.

I single indiridual, 1 in inches long. was tahen in the seine at Beesley's Point N. J. September 2.

The general eolor of the sides was yollow, mole persistent in alewhol on the vontral surface and caudal pedunele than risewhere.

I. XIII, 21$)$; A. III, 1S: lateral line, 45 ; third and fourth dorsal spines erpual, and as long as the head without the snout.

The farele is very rare in Gravesend hat. Two small individuals were taken by Mr he Xyse in Oetober 1895. Mr De Jyse informs me that the romolish black spot in the soft doreal pematins tixed under all combitions. while the band extending frum it to the anal fin sometimes disappears. The whole body of thr. fish al times appars to have an orange tinge, but at other times it is gray.

An indisidual about 2 inches long was obtained from a tigh

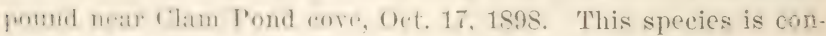
spietumaly lwatutiful on areount of the orange color of its fung nontrasting sharply with the dath bamds on the head and body.

\section{Family TEUTHIDIDAE}

\section{Surgcons}

\section{Genus weurrs Iinnaeus}

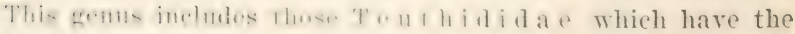
tail armed with a shurp. anferse, lanertlike. movable spine;

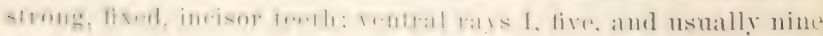

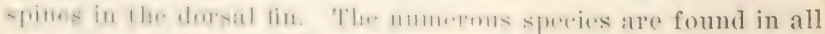

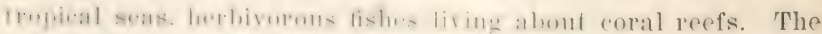

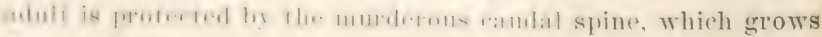
larerer with age. 


\section{Teuthis hepatus Linnaeus}

\section{Surgeons; Doctor Fish; Tang}

Teuthis hepatus Linnaets, Syst. Nat. ed, XII, 507, 1766, Carolina; MeEk \& Hoffun, Proc. Ac. Nat. Sci. Phila. 229, 1854; Beax, Bull. Am. Ius. Nat. Hist. IX, 368, 1897; Jorday \& Evermann, Bull. 47, U. S, Nat. Mus. 1691, 1898.

Acanthurus phlebotomus Cevier of Talencienses, Hist. Nat. Poiss. X, 176, 1835, New York, etc.; De K.1Y, N. Y. Fauna, Fishes, 139, pl. 73, fig. 234, 1842.

Acanthurus chirurgus Cuvier \& Valexciennes, Hist. Nat. Poiss. X, 168, 1835; Günther, Cat. Fish. Brit. Mus. 329. 1861; Jordan \& Gilbert, Bull. 16, U. S. Nat. Mus. 617, 1883.

Acanthurus nigricans JoRdAN \& GILBERT, 1. c. 941, 1883.

Body orate, its greatest depth one half of total length without caudal; anterior profile moderately convex, forming an angle of $45^{\circ}$ with axis of boly. Catulal lumate, its inner rays about two thirds length of outer rays; caudal lobes subequal, the upper never filamentous. Tead rather short, two sevenths of total length without caudal. 1). IX, 26; A. III, 24.

Color dark olive brown, more or less distinctly greenish; middle of sides paler; sides with about 12 distinct blackish vertical bars, rather narromer than the interspaces, most distinct orer frout of anal; a hownish stripe along base of dorsal; spinous dorsal with alternate stripus rumming mprard and backward, of dark blue and hronze olive, the two colors of about equal width; soft dorsal with a hluish streak on the anterior side of each ray, and a bronze stripe behind it; fins rers dark, often almost black.

The surgeon is common in the West Inties and from Florida to Bahia and northrard in summer to Cape Cod.

A young individual, alont 3 inches loner. was ranght in Mr John B. De Nyse's pound, Glaresend hay, Oc.t. 2.2, 1897. The species had not been certainly known before to oreur north of Charleston S. C. De Kay described and figmed it as a New Tork species solely on the authorily of Curier and Yalenciennes. Dr Smith records the capture of a fow specinems in the vieinity of Toods Hole Mass. during the summer of 1900. If was last obserred on Octoher 3 when one example was taken. 


\section{Group PLECTOGNATHI}

\section{Suborder \&CLERODERMI}

Family BALISTIDAE

\section{Triggerfishes}

\section{Genus matstes (Artedi) Linnaeus}

Buly compressed, covered with thick, romgh scales or plates of moderate size, 50 to 75 in a lengthwise series; a nalied groove hefore eye below nostrils; lateral line more or less developed, very slender, undulate, eonspicuous only when the scales are Ary, extending on the eheels. I'elvic flap large, norable, supported ly a series of slender, pungent spines. Caudal peduncle rompressed, its stales unarmed, without spines or differentiated cubereles similar to those on rest of body. Gill opening with mlarged bony scutes behind it: cheeks entirely scaly, without naked patehes or grooves. Both jaws with irregular, incisorlike teeth, usually four on earh sid. in each jaw. First dorsal of three spines. the anterior of which is much the largest, the second acting as a trigger, locking the first when erected; the llird nearly as large as serond and remote from it; second dursal and anal long, similar to wath other. in the adult alwass faliate or filamentous in frout; caudal fin rounded, with the outer rays much produced in the adult: branchiostegals six: s.r.tebrae 7410 . Species rather few, chiefly American; some of them straying to the Old World.

\section{Subgenus carruscus Rafinesque}

294 Balistes carolinensis Gmelin

Leather Jacket; 'I'urbot; Triggerfish

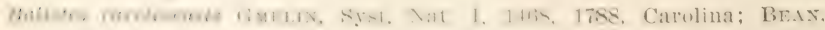
Bull. Am. Mus. Nat. IIst. IX, 368, 1S97; H. M. Smrm, Bull. U. S.

F. C. 1897, 104, 1898; Jordan \& Everaman, Bull. 47, U. S. Nat. Mus. 1701,18918, pl. CCI 1111 , fig. 632, 1900.

Balistes capriseus GMvls, Syst. Nat. I, 1471, 17S8, Indian \& American Ocrans; (ivstmin, Cat. Fish. Brit. Mus. VIII, 217, 1870; Goode \& Inux, IBull. lisspx Inst. XI, 3, 1879; Jordan \& Gilbert, Bull. 16. 1'. S. Nitt. Mus, 8.5. 1883.

Inlikt.: fulighusus 1): KAY. X. Y. Fauna, Fishes, 339, pl. 57, fig. 188, Imiz, Nity jork. 
Body oblong, compressed, its greatest depth one half of total length to end of middle caudal rays; least depth of caudal peduncle one third length of head. Head nearly one third of total length without caudal; ere small, placed high, one fourth as long as the snout, and one fifth as long as the head; mouth small, terminal, the maxillary as long as the eje. Dorsal origin slightly behind rertical of hind margin of orbit; base of spinous dorsal one fourth of total length without caudal; first spine longest, one half as long as the head; second spine slender, one third as long as the head; third spine stouter than second, one fifth as long as the head. An interspace between spinous and soft dorsal. Soft dorsal base slightly longer than the head; the third and fourth rays longest, as long as the snout; the last ray shorter than the eye. Middle caudal rays one half as long as the head; external rays five sixths as long as the head. Anal opposite and similar to soft dorsal, its base as long as the head, its longest ray one fifth of total length without caudal. Pectoral short, one half as long as the head, reaching to below third spine of dorsal. Tentral flap large, supported by several slender pungent spines. D. III, 27; 1 . 25; seales 55 to 63 (58 in specimen examined), about 38 in a transrerse series from vent upward and forward. Lateral Jine rery inconspicuous, extending from the ere backward to below the third dorsal spine, where it descends to a point nearly orer the sisth or seventh ray of the anal; here it turns to form a $T$-shaped figure ascending to the median line and along the middle of the caudal peduncle to the base of the caudal tin; a branch from behind exe extends obliquely downward and forward to the breast below pectorals; the lateral lines of the two sides are connected by a cross branch at the nape.

Color in life olive gray; a more or less distinct darker crossbar under front of second dorsal and one under last rar; some small riolet spots on upper part of back; usually a ring of blue spots, alternating with olive green streaks, about (y'?; riolaceous marks on sides of snout; first dorsal spotted and clouded with bluish; second dorsal pale yellowish with clear sky-blue 
spens sulatated ly nliwe green reticulations, the spots arranged In rows; bhe markings all fading in alcohol, learing the olivawome streaks; base of dorsal with three or four dark difuse shates in the roung; base of pectoral bluish. with olive spots; anal colored like soft dorsal; pectoral greenish.

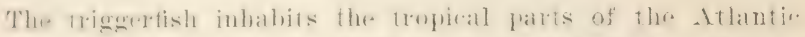
areabionally following the diulf strean northwath as far ats

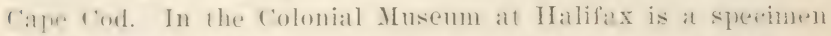
said to have heen taken on the coast of Nosa Scotia. At Whorls Ifuld Mass. it is very rare and dors not exur pery year; the young have not been observed there.

The speries is uneommon in Gravesend hav. Lonn Island, but is siren uratainnally in summer in the bays opening into the Arlantic. Dr. Kaly described a specimen measuring $1: 3$ inches. In

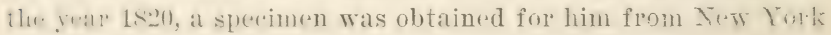
harbor.

\section{Subgenus BaListes}

\section{Balistes vetula Linnaeus}

\section{Blue-striped Triggerfish; Bessy Corka}

Nelater ilulu I.1xwatra, Syst. Nat, ed. X. T. 329. 17.8, Ascension Islaud;

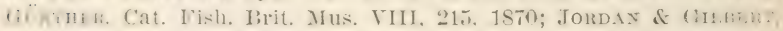
Bull. 16, U. S. Nat. Mus. 855, 1883; H. M. Smrtr, Bull. U. S. F. C.

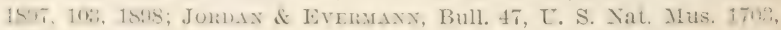
$1 \mathrm{SuS}$

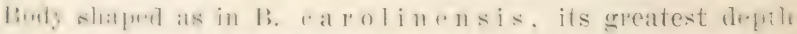
Hive uinfles of tolat length withomt ratulal. Head one third ut

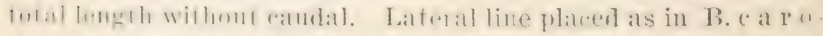
I In+nsis. hut the median part. from hase of first dorsal to

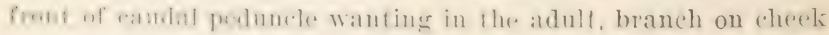

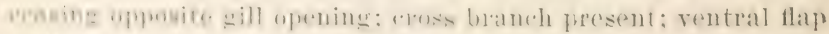

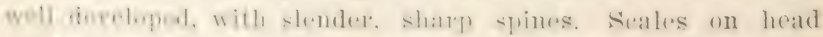

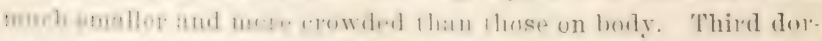

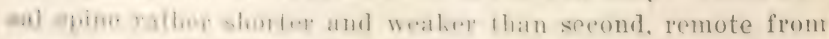
If 1 oudal tou whely forlacel. ilue lolus tilamentous and about

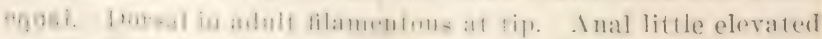
anteriorly. 1). 111, 29); 1. 27; lateral line 63.

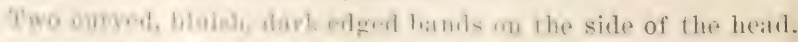

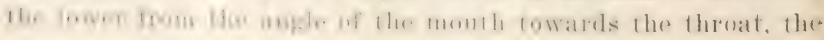


upper from above the snout to the root of the pectoral; a black light-edged line, similarly curved below the exe; sereral other similar lines radiating from the eye; caudal fin margined above and below with bluish, and with an intramarginal bluish band; dorsal and anal fins with transverse bluish bands; soung with some irregular oblique black lines following the rows of scales.

The blue-striped triggerfish is commou in the Wrist Indies and occurs oceasionally northward on our coast as far as Cape Cod. According to Dr Smith it is found in Vineyard Sound erery season, mostly in September, adult specimens being taken in some numbers in the traps at Menemsha. During summer and fall the young, $1 \frac{1}{2}$ or 2 inches long, are found at the surface in Vineyard sound in gulf weed and also around the shores.

Family MONACANTHIDAE

\section{Filefishes}

\section{Genus movacantmus Cuvier}

Body short and deep, rery strongly compressed, covered with minute, rough scales. Mouth very small; upper jaw with a double series of incisorlike teeth, usually 6 in the outer and 4 in the inner series; lower jaw with about 6 incisors in a single series; teeth connivent, unequal; gill opening a small slit, shorter than the eye, nearly rertical, below the posterior part of the eye, and just in frout of upper edge of pectoral. Dorsal spine large, armed with two series of retrorse barbs, and no conspiruous filaments; second dorsal and anal fins similar to each other, of about 25 to :3 rays each; caudal fin moderate, rounded: pelvic bone with a blunt, movable spine, the bone connected by a movable flap of varying size; side of tail often with a patch of spines, specially in the males. Vertebrae $\tau+11$ to $14=18$ to 21 . Species very numerous, in warm seas, most of them reaching a small size. 111 are lean fishes with leathery skin and bitter flesh, unsuited for food.

\section{Subgenus stephanolepis Gill}

296 Monacanthus hispidus (Linnaeus)

\section{Filefish}

İalistes hispidus Linnafes, Syst. Nat. ed. XII, 405, 1766, Carolina.

Balistes broceus Mitchile, Trans. Lit. \& Phil. Soe. N. Y. I. 46ī, 181,

New York. 


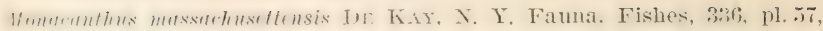
fig. 187, 1S12, Massachusetts Bay; Storer, Hist. Fish. Mass. 231, pl. XXIV, fig. 4, 1867.

Monacanthus setifer DE KAY, N. Y. Fauna, Fishes, 337, pl. 59, fig. 194, 1812, New York Harbor; Goode \& BEAx, Bull. Essex Inst. XI, 4, 1879 .

Monteanthus broceus DE KAx, N. Y. Fauna, Fishes, 335, pl. 56, fig. 183, 1842; Jordax \& Gilbert, Bull. 16, U. S. Nat. Mus. 856, 1883.

Monacanthus hispidus BEAN, Bull. U. S. F. C. YII, 133, 1SS8; 19th Rep. Comm. Fish. N. Y. 241, 1890; Bull. Am. Mus. Nat. Hist. IX, 369, 1897; H. M. Smit, Bull. U. S. F. C. 1897, 104, 1898; Jordan \& Erermaxx, Bull. 47, U. S. Nat. Mus. 1715, 1898, pl. CCLIX, fig. 635, 1900; BeAr, 52 A Amn. Rep. N. Y. State MIus. 107, 1900, Great South Bay.

Indy rather dere. the length heing one and thiee fourths times the depth and three and two fifths times the length of the head; jaws suberual; exps large, more than one third length of suout: will opening about as long as eve, separated fom the eye by an

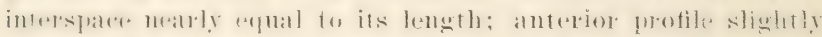
romeare" dorsal spine somewhat shorter than snout, inserted above gosterior patre of exe. stout. lough. armed hehind with two rows of retrolse barbs: first ray of soft dorsal sometimus filat montum, une half of total length without caudal: pectorals smanl, one half length of snout: pelvic bone long. ending in a short. hlunt. movalule spine, beyond which the abdominal flap does mot

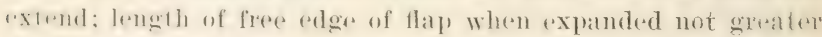

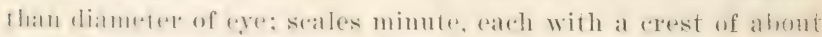

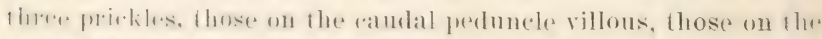

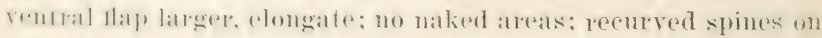
tail. length 10 inches. D. I- 32 to $33 ;$ A. 32 to $33 ;$ P. 15.

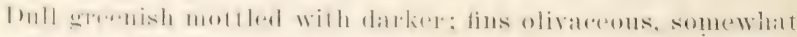

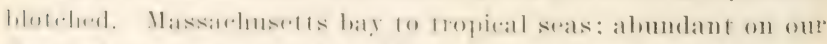

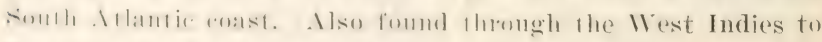
lirazil, in the Canaries and Madeira.

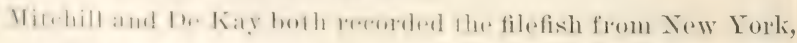
where it was not uncommon in smmmer.

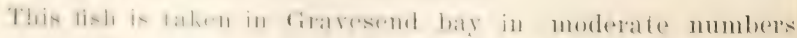
ocossionally in the fall. Individuals were sent from there in

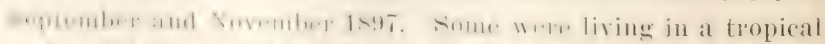

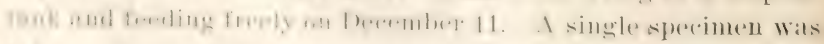

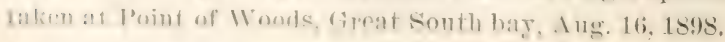


In the vicinity of Wools Mole Mass. according to Dr Smith, it occurs every year; some years rather scarce, some year's abundant. In 1897 it was extremely numerous in July and August, and several hundred were often taken in one day in the seine. It may often be obtained umder gulf weed, but is usually most plentiful in eelgrass and rockwered. To large fish are observed, the size ranging from 1 inch to vearly 4 inches. The smallest are rather uniformly dull brownish or grenish yellow in color, but those 3 or 4 inches long are mottled with white and several shades of dark green. In aquaria, small filefish often annoy and injure other fish, biting their fins, eyes, and other parts.

At Beesley's Point X. .T. the writer seined an individual, Aug. 23,1857 , which had sereral parasites attached to the fins.

\section{Genus atumena Cuvier}

Body oblong or rather elongate, strongly compressed, covered with minute, rough seales; mouth and tecth essentially as in II o n a c a n thus, but the lower jaw more projecting, so that the lower teeth are directed obliquely upward and backward; gill opening an oblique slit, longer than eye, situated below and in adrance of eye, its posterior end buhind base of pectorals; pelvic bone long, falcate, movable under the skiu, without spine at its extremity; dorsal spine small, inserted orer the eye, rough, but without barbs; soft dorsal and anal long, each of 36 to 50 rays; caudal fin convex; pectorals small.

\section{Subgenus ceratacinthus Gill}

\section{Alutera schoepfii (Walbaum)}

\section{Orange Filefish}

Balistes sehocpfii W'Atsulu, Art. Gen. Pisc. 461, 17!2, I.ong Island.

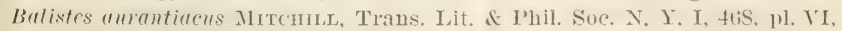
fig. 1, 1815, New York; adult.

Bulistes cuspicuda Mrfenth, Am. Month. Mag. II, 326, March, ISIS, New York; young.

Aiuteres cuspicanda DE KAY, X. Y. Famma, Fishes, 3is, pl. 59, tig. 192, 1842, New York; young.

Monacanthus andantiaens Gïnstren, Cat. Fish. Brit. Mus. VIII, 22,4, 1870. Aluter schoepffi Jorman \& Giliserit, Bull. 16, U. \$. Nat. Mus. \$.s, 184\%;

BEAN, Bull. 'U. S. F. C. VII, 134, 1888. 
Ilutru sefurplii doonf of Brax. Bull. Essex Inst. XI. 3. 1879; BeAx, Bull. Am. Mus. Nat. Hist. IX, 369, 1897; H. M. Smтr, Bull. U. S. F. O. 1897, 101, 1898; Jordan \& Evermann, Bull. 47, U. S. Nat. Mus. 171S. 1895, pl. COLX, fig. 636, 1900; BEAN, 52d Ann. Rep. N. I. State Mus. $107,1900$.

Forly oblong, rather elongate, narrowed posteriorly; the great. wet denth four ninths or nearly one half of total length without andial: least depth of atudal peduncle nearly one thind length of leatd. Profile of head rery oblique; space between dorsials almost horizontal; ventral outline convex. Ifead short, its length antained three and one fourth times jn total without caudal; the gill opening oblique, two and one half times as long as the "ye: eye small, one fifth as long as the head: twice its own diameter from top of head, and placed far back over the posterior part of the will opening; snout one fourth of total length withont can dal: month very small, the lower jaw prominent. Inorsal spine

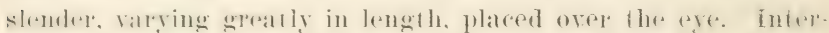
spatere hetween the dorsals as long ats the head. Base of serondel dorsal one third of total length without caudal; the longest dor sal ray equals one third length of dorsal base; the ontline of the tin wreatly convex. Catudal moderately long in adult, pounders lwhind, muth produced in pommg; the middle rays in adult as lomg as the snont. Anal similar to soft dorsal, but extending firthre hark, its hatse somewhat longer than dorsal batse, its longerst rays andial to longest of dorsal. Pectoral short. ome

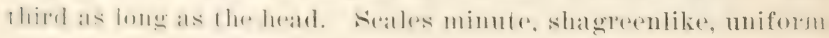
over the body. D. I, $36 ;$ A. 38 .

Coloration wealy uniform dirty olive gray, valying to orange

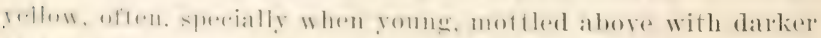
h.hish or dull orange: aludal sommimes dusky, edged with white. usually dull yellowish in the adult. Length 24 inches.

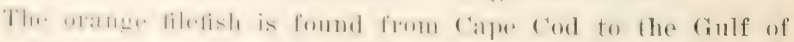

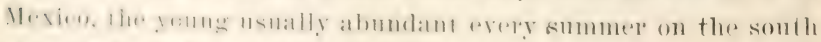
shore of Long Island and in the bays.

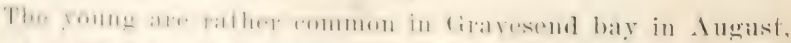

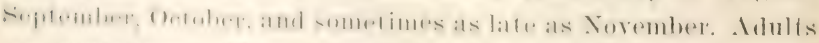

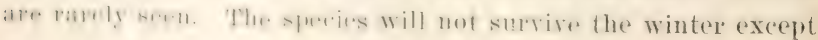


in warmed water. It feeds freely when the temperature is agreeable.

Young individuals were obtained in 1898 at the ocean beach, Southampton, Iong Island, August 3, Islip, August 18, and Fire Island inlet, September 16 . No adults were seen; the largest example was about 9 inches long. In 1901, an adult was obtained from Watts's pound, in Clam Pond cove, August 13, and another was speared in Fire Island inlet, August 1; no young were observed.

At Woods Hole Mass. according to Dr Smith, it is rather common every year in August and September. The largest are 18 inches long, the smallest 3 inches. The position constantly assumed in the aquarium is with the head down. Succulent algae are often eaten by the fish in captivity, the long branches of some species being bitten off and swallowed in a surprisingly short time. The color of the young is a dirty white, with large reddishbrown mottlings or blotches; the larger are orange-colored with the same mottlings as when young.

The species is seldom found north of Cape Cod. An individual taken at Forest River lead works, Salem, Mass. Aug. 9, 1845, was preserred in the museum of the Essex institute. At Somers Point N. J., a few young were found in August and September, but the adults were absent. This is called sunfish at Somers Point.

\section{Suborder OSTRACODERMI}

\section{Trunkfishes}

Family OSTRACIDAE

\section{Genus LActopmes Swainson}

Trunkfishes with the carapace three-angled, the ventral surface flat or concave, nerer carinate; carapace closed behind the anal fin; carapace with or without frontal and abdominal spines; dorsal rays nine or 10 ; caudal rays always 10 . This genus contains five species, fom of them American, and differs from the Old World genus Ostracion only in the form of the carapace. The median dorsal ridge of the earajace is much more developed than the others, so that the body is three-sided and 


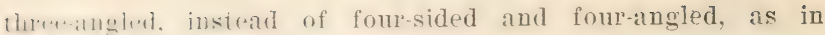
Os 1 racion. Though this character is a striking one it

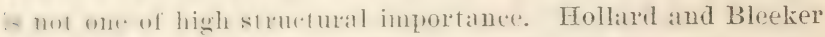
hatre distalleded it as being of no real systematie ralue. All

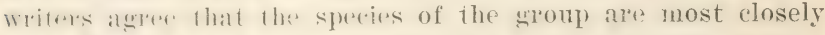
Irelated, and that the relations of the speres are closer than they alyetr. Withink, with I) Goods, that the shape of the "araflate atlords " the most reliable guide in the arrangement of thr spreis. of the gemus," and we think it not improper to

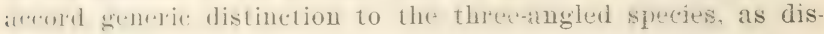
timet form the mores sfereialized four-angled forms. fortan and Evomann.

\section{$29 S$ Lactophrys trigonus (Linnaeus) Subgenus LAcropHeys \\ Trunkfish; Cuckold}

Ostracium trigonus Linnatus, Syst. Nat. ed. X, 330, $175 \mathrm{~S}$.

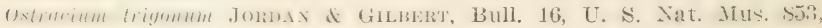
185:3.

Ostrucion trigonus Günher, Cat. Fish. Brit. Mus. VIII, 256, 1870.

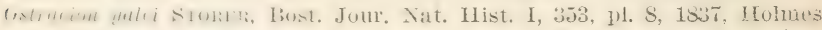
Hole, Marthas Vineyard.

J.4. Stтoner, Мem. Am. Ac. VIII, 429, pl. 35, fig. 3, 1861.

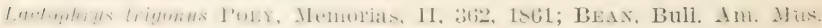
Nat. Hist. 1x, 369, 1897; Jordan \& Eversann, Bull. 47, U. S. Nat.

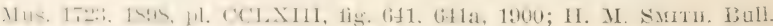
U. S. F. C. 1S97, 104, 1898.

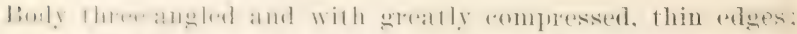

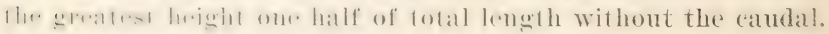

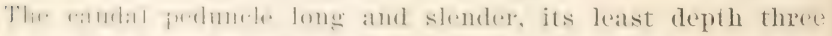

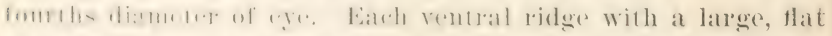

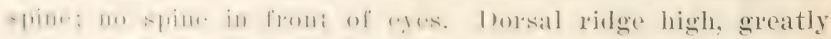

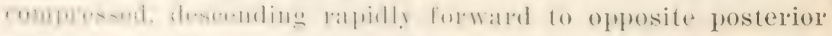

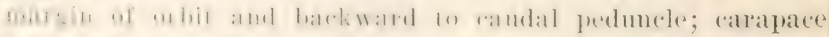

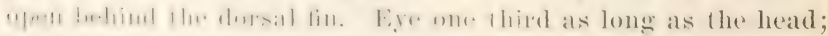

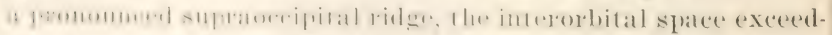
ing diameter of "ye. Dorsal base five sixths as long as the

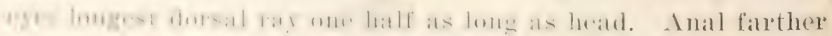

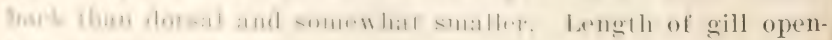
Ing nos refual to rye.

is. $10 ; \mathrm{x}$. $10 ; y^{2}, 12$. 
Four teeth in each side of lower jaw.

Color olive gray or brownish; a faint bhe spot in the center of each of most of the scales; nostril in a yellow spot; boundaries of upper seutes blackish, of lower bluish; outlines of various scutes behind gill opening black, forming a dusky area, specially distinct in the foung; a similar smaller dusky area on side on level of eye; iris yellow; fins all pale olive; vent yellow; belly light olive, outlines of the scutes bluish; base of pectorals yellowish.

The trunkfish reaches the length of about 1 foot; it is common in the West Indies, the Bermulas, and the eastern part of the Gulf of Mexico, occasionally migrating northward in summer under gulf weed as far as Cape cod. In Storer had it from Holmes Hole, on Marthas Vineyard. Dr H. M. Smith records no adults from the vicinity of Woods Hole Mass. but young individuals are not uncommon and are taken every year. They are found from July to October. On quiet days they are seen, singly or in scattered bodies, in the exlgrass about the wharres. The largest specimens seremed by Dr smith are 1 inch long, and the smallest 1 inch. They are taken under the gulf weed, in surface tow nets and in shore seines. Several dozen have been obtained at one seine haul.

De Kay knew the fish only from the description by Dr Storer.

The only individual taken in Gravesend bay was found in August 1897; it was 3 inch loug. The fish lived a rery short time in a balanced jar, though it appeared to feed freely upon minced hard clam.

\section{Suborder GYMNODONTES}

Family TETRAODONTIDAE

\section{Puffers}

\section{Genus I:qocerpuxus Swainson}

Body comparatively elongate; skiu smooth or rariously prickly, the prickles most developed on the abdomen; abdomen (apable of rery great inflation. Dorsal and anal rather long, falcate, of 12 to 15 rays each; "aludal lunate. Nostril without distinct papilla, each one with two distinct openings; mucous 
lules on ufyele part of head and on sides of body rery conspicmous. Luwr. side of tail with a fold. Species reaching a rather large size, rhirefly tropical. one of them, L. 1 a gocepha $l$ us 1.. Wathing thr coasts of southern Europe. Tertebrae in increased number labout $\left.s_{-}-1,-21\right)$. The increased number of vertebrate and of rays in the vertical fins mark a transition toward the allied family, Ch o n e r hin i d e , in which there are ahout 29 rerebrate, the dorsal rays abont 35 , the anal 30.

\section{Lagocephalus laevigatus (Linnaeus)}

Smooth Puffer; Rabbitfish

Tetrulun luevimulus Lixxders, Syst. Nat. ed. XII, 411, 176ti, Charleston, S. C.; Mrtcmul, Rep. Fish. N. Y. 28, 1814; Güxther, Cat. Fish. Brit. MIus. V1II, 274, 1870.

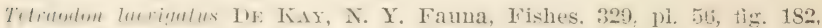
$18+2$.

Titrulem ctritus Mtrenul, Trans. Lit. \& Plil. Soc. X. Y. I, 474. 1815; New York; young.

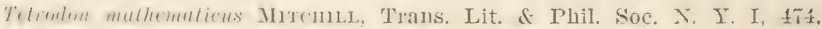
pl. VI, fig. 6, 1815 .

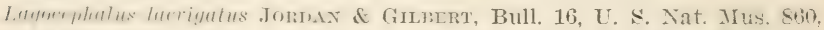
1853; BeAx, Bull. U. S. F. C. VII, 133, 1888; Bull. Am. Mus. Nat.

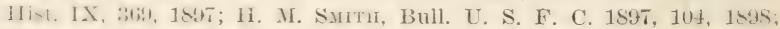
Jompan \& Evermann, Bull. 47, U. S. Nat. Mus. 1728, 1898, pl.

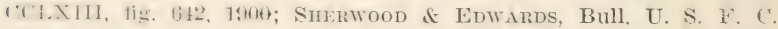
1901, 30, 1901.

Jimly alongate, stout, its depth about one fourth or two ninths of twial lemelh withont the eatudal. Citudal peduncle rather

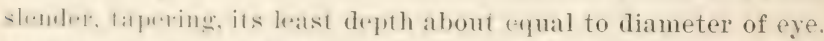
lleml shorl. liry ohtuse in frout, its length two serenths of |ot:1l withum the ratulal. Mouth rerysmall, terminal. Nostrils

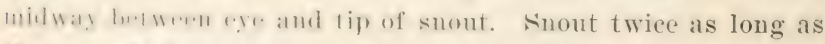

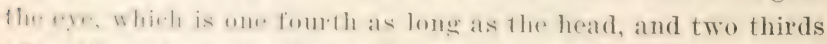
of width wi inferofhital spare. Dorsal and anal fins opposite,

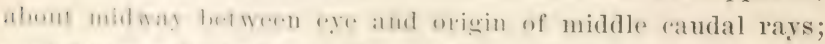

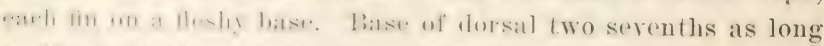

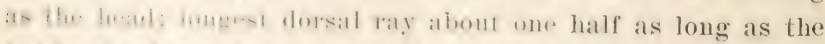

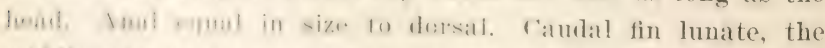

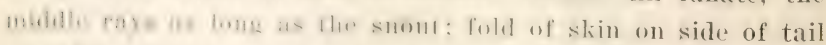
very distim. Jiack and sides smooth; belly prickly, the spinous

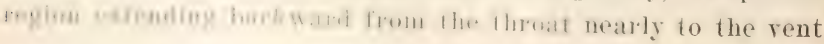


and on the sides as high as the base of the pectoral; spines rather large, three-rooted, well separated, and with no smaller' ones intermixed. Pectoral short and deep, its longest rays nearly one half as long as the head.

D. 14 ; A. 12 ; P. 15.

Upper parts greenish, sides and lower parts silvery white; no distinct markings.

The smooth puffer is a common resident of tropical seas, on our coast ranging from Cape Cod to Brazil. It reaches a length of 2 feet. According to Parra its flesh is poisonous. No recent observations have been recorded, however, on this subject.

In the waters of Cape Cod the species is not common though a few specimens are taken annually in traps in Buzzards bay and Vineyard sound, chiefly in September and October. Tine young are not found at all, the individuals observed being 11 or 12 inches long. During 1900 sereral specimens were taken in the vicinity of Woods Hole Mass. The Rhode Island Fish Commission secured three specimens in Narragansett bay, the largest weighing 10 pounds.

Occasionally taken in the fall in Gravesend bay. Five young were obtained in October 1897, but all of them died in November, notwithstanding that they had been taking food readily. The temperature could not be endured.

Though this fish was unknown to the fishermen met in Great Egg Harbor bay in 1887, it was moderately common there, 13 examples having been taken from August 27 to September 18. It has the same habit as the swellfish of inflating its abdomen.

\section{Genus spheromes Lacépède}

Body oblong, not elongate; skin variously prickly or smooth, sometimes with cirri. A single, short, simple nasal tube on each side, with two rather large openings near its tip. Dorsal and anal fins short, little falcate, of six to eight liss each; caudal truncate or rounded, rarely slightly concare. T'ertebrae $8+10=18$. Frontal bones expanded sidewise and foming the lateral roof of the orbit, the postfrontals limited to the posterior portions. Species numerous, in warm seas; largely 


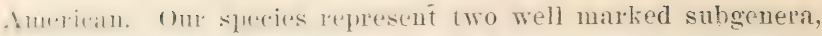
the extremes of which appear very difierent from each other so Lat as the skulls are concerned. Some of the typical species of fill.roides appoach Canthigaster in the narrowness of the frontal area.

\section{Subgenus SPHERomes}

:3n) Spheroides maculatus (Blorh is sichneider)

$$
\text { Swellfish; Puffer }
$$

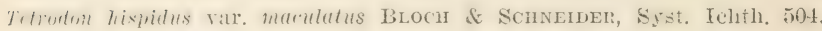
1801, Long Island.

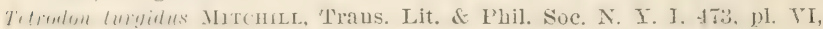
fig. 5, 1815, New York; Günther, Cat. Fish. Brit. Mus. VIII, 285,

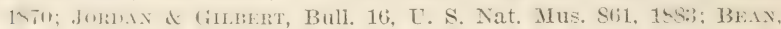
Bull. U. S. F. C. VII, 133, 18ss; 19th Rep. Comm. Fish. N. Y., 212, 1890.

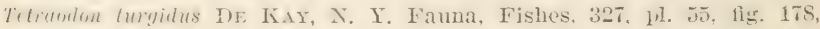
$18+2$.

Spheroides maculatus Jordan \& Edwards, Proc. U. S. Nat. Mus. 232. 1.st; Brax, Hull. Am. Mus. Nat. Hist. IX, 369, 1857; H. M. smrth Bull. U. S. F. C. 1897, 104, 1898; JordaN \& Evermann, Bull. 47, U. S. Nat. Mus, 1733, pl. CCLXIV, fig. 645, 1900; BEAN, $52 \mathrm{~d}$ Ann. Irep. N. Y. State Mus. 108, 1900.

limb fusiform. thirk, its width and depth about equal and mor third of tolal longth withont the caudal. Head moderately latren, three righths of the length without candal. Eve small, about $f$ wn fiflas of inferorbital width and one ninth as ionge as lhe heall. Fnoml lomg, four sevenths as long as the head.

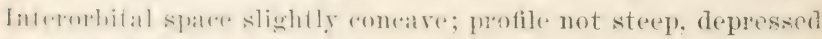
in from w the eres. Howsil origin twire as far from midrle of fy as foum base of midelle randal rays; base of dorsal fin as

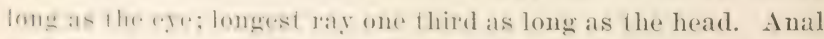

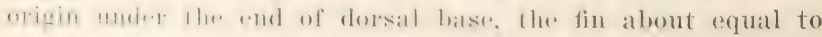

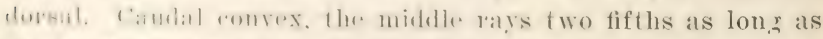

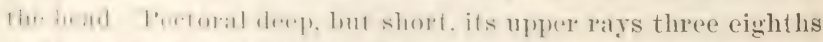

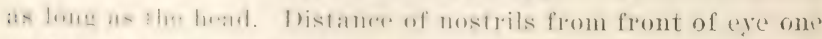

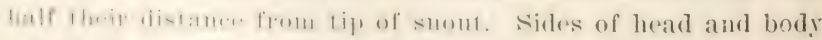

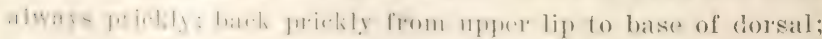

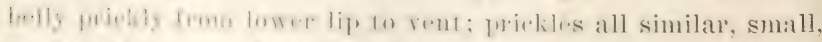

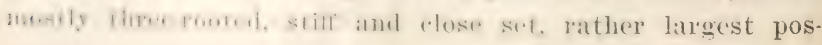


teriorly on back and belly, never obsolete; sides without cirri. D. 7 ; A. 6 ; C. 7 ; P. 16.

Color darkish olive green on the upper part of the hatrl, hody and tail, with a rellowish tinge along the sides. Nides and under surface white. Along the sides from beneath the eye to the caudal fin is an indefinite series of six to eight oblong black blotches, which occasionally take the appearance of transverse bars. De Kay obserred some individuals which were nearly a uniform black above. Caudal fin nearly uniform pale, the tip darker.

The swellfish inhabits the Atlantic coast from Cape Ann to Florida; it grows to a length of 10 inches. In most localities the fish is not eaten, but at Somers Point X. J. certain persons professed to find in it excellent food qualities. De Kay states that the species is searcely erer eaten in New York.

This species is known also by the additional names, puffer, blower, eggfish, swelltoad, sucking toad, toadfish (at Somers Point N. J.) It is the puffer and toadfish of Mitchill's Fishes of New York.

The swellfish is extremely abundant about the eastern end of Long Island, and is caught by hundreds at a time in pound nets during the summer. The writer has taken it at the following localities in Great South bay: Fire Island inlet, Oak Island beach, Clam Pond cove, Islip, Cherry Grove, Nichols's Point, Blue Point. In Graresend bay the species is found at all times except during the cold months; it is hardy in captirity, but can not be kept with other fish because of its predatory habits.

In the ricinity of Woods Hole, according to Dr Smith, it appears about June first, and is abundant during the run of seup. It is common throughout the summer at the head of Buzzards bay. The spawning season is June 1 to 10 . From about July 1 to October 15, the young, from $\frac{1}{2}$ inch to 1 inch long, are extremely abundant at Woods Hole, frequenting chielly sandy beaches, where as many as 100 are often talien in one seine haul. The fish leaves as soon as cold weather sets in. 
The nalme. swellish is derived from its babit of inflating is welf hy means of air or watre. It can be made to inflate itself

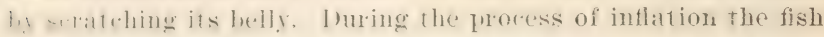
malirs a smeling smmul, from which doubrless comes the Chesa-

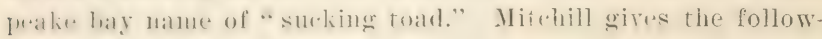
ing account of the inflation:

The atr is inhated with a sureking of swilling noise. When rencened inte the ravity it is confined there ly a ralse in the throat. This vallow is so strong and so tight that suot a particle

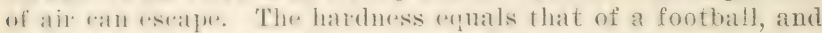
1h. tish will bear 10 he kireked about withont dischanging it. I hatre seren them stitmped upon and still retain their ebarge of alir. I hatr. kuown then to bounce from the surface of a rock, against which they have benth thowne as turgid as rever. And it is a piten of sport. common enough among fisherement of burst

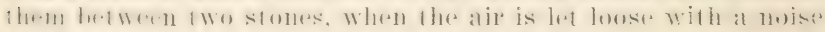
almost equal to the report of a pistol.

The habit of inflation is a protective one. By means of it the

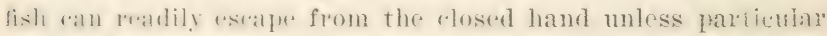
rffort is made to retain it. When the abomen is inthated the swellfish wfen rematiss on the surfare of the water, and is dris.n by wiml and tide till it desires to sink, when the air is

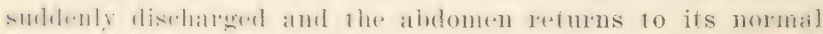
state.

If often bakes a baitud hook, notwithstanding the small size: of its month and its clumsy teeth.

\section{Subgenus crenchтих Müller}

\section{Spheroides testudineus (Linnaeus)}

\section{Globefish; Blowfish}

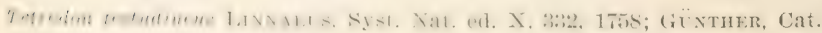

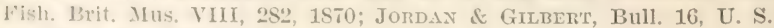
Nitt. Mus. Sti1, 188:3.

Simproides testudineus Joman \& EDWards, Proc. U. S. Nat. Mus. 239, I.ts sti.

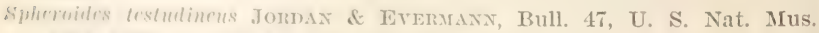

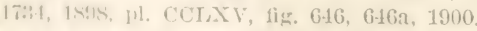

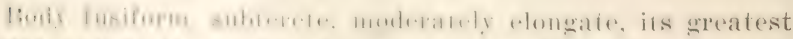

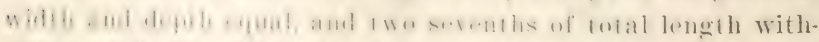

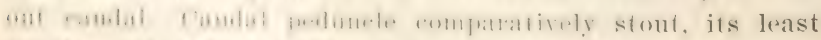

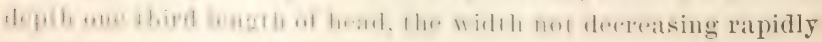


toward the base of the candal. Head one third of total length without caudal; eye small, its length nearly one fomth length of snout and nearly one serenth that of head; interorbital width two fifths length of head; nostrils one diameter of the eje in advance of eje. Gill opening one fourth length of head. Origin of dorsal fin twice as far from front of eye as from root of middle caudal rays. Dorsal base one fifth as long as the head, two fifths as long as longest dorsal ray. Anal origin slightly behind dorsal origin, the anal fin a little smaller than the dorsal, and mostly opposite to it. Caudal slightly concavoconvex, the lower lobe a little the longer, the middle rays two thirds as long as the head. Pectoral very deep but short, its longest ray two fifths as long as the head. Lateral line beginning behind the nostril, extending under the nostril to the middle of the suout, thence cmrving back on the cheek, ascending below and behind eye in a broad curve, its highest point on the lerel of the eye, to the middle of the caudal peducle and thence nearly straight to the base of the caudal. Small, sparsely set prickles on back from nape to about middle of total length; larger, closely set mickles on belly from throat to vent, extending up to lower edge of pectoral fin; these prickles rarely obscure or absent; sides sometimes with cirri.

Back dark brownish or grayish and with whitish narrow curved lines and streaks, one of these usually a rhomb in the middle of the back surrounded by a long ellipse which often contains also a short crescentic streak. 'Two half ellipses on posterior part of back between dorsal and caudal fins. Two pale streaks across the interorbital space. Entire body and head, except back aud helly, profusely covered with roundish black spots, the largest smaller than the pupil. A dark bar at base of pectoral. Caudal dusky at base, then pale, the posterior half blackish. D. 8 ; A. 7 ; C. 10 ; P. 15.

The globefish abounds in the Trest Indies, oceasionally ascending rivers, and sometimes ranging northward in the (iull Stream as far as Newport R. I. No specimens have yet heen recorded from New York waters, but its occurrence is to be 
r.xp+1+4l in bays of the south side of Long Island. The species fanthes the lenglh of 7 or \& inches; it is known in Cuba as the Tambor.

\section{Spheroides trichocephalus (Cope)}

\section{Hairy Blowfish}

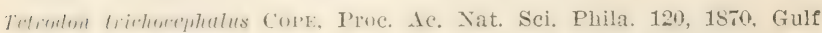
Stream off Newport, R. I.; JordaN \& Gilbert, Bull. 16, U. S. Nat. IIus. 862,1853 .

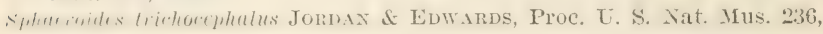
$1 \mathrm{SS} 6$.

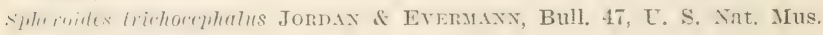
1737,1898 .

Ilatd I wo s.venths of total length; eye two sevenths as long as 1 l1 latul; introrbital width four fifths diameter of eye. l'rotile smblenly dexirnding from prefrontal region to premaxillary, arehel from the former point backward; belly spinous to Inal lent; dorsal rengion spinous from a little behind the nares

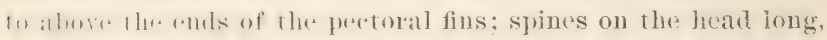
Hus. s. l. like seal hristles; caudal fin truncate, with prominent angles.

\section{1.. $: ; ., 7$.}

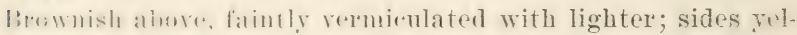
inwish, butning white below; fins miform light yellow: a brown spot at base of pectoral. (After Cope)

Th: hair! howfish is linown only from the small specimen

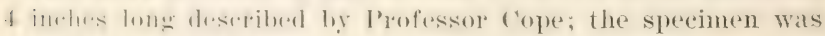

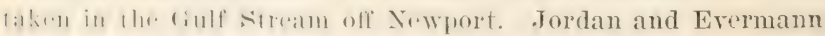

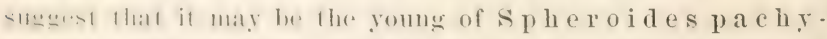

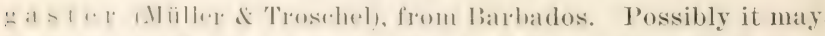

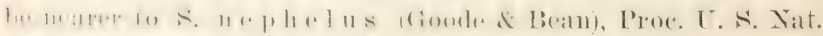

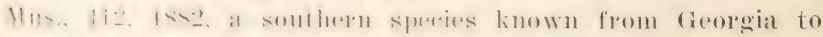
T'xas.

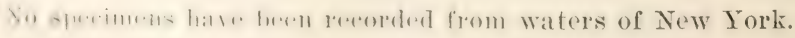

Family DIODONTIDAE

Porcupine Fishes

(ienus trucrodrodon Bleeker

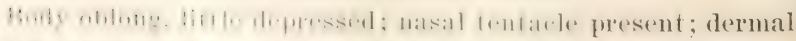

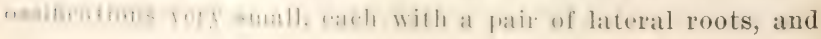


each termiuating in a fine, flexible, bristlelike spine; fins as in D i o d o n, of which the species are possibly the very young.

\section{Trichodiodon pilosus (Mitchill)}

Hairy Poreupine Fish

Diodon pilosus MItchill, Trans. I.it. \& Phil. Soc. N. Y. I, 471, pl. VI, fig. 4, 1815; supposed to be from New Iork IIarbor; specimen $1 \frac{1,2}{\text { inches }}$ long.

Trichodiodon pilosus Günther, Cat. Fish. Brit. MIus. VIII, 316, 1870; Jordan \& Gilbert, Bull. 16, U. S. Nat. Mus. 862, 1S8;, name but probably not description which is from DE KAY; JORDAN \& EverMANN, Bull. 47, U. S. Nat. Mus. 1743, 1898.

Mitchill's description as giveu by .Jordan and Evermann is as follows: "Hairy diodon (D i o d o n p i l o s u s), with a covering of bristly hair. Le'ugth about 1. inches; breadth less than $\frac{1}{2}$ inch; depth nearly a quarter, making a blunt lump of a fish; corered all over-back, sides, head and belly-with bristly hair. The bristles strong and flexible, without the power to serateh or to prick; hair about $\frac{1}{8}$ inch in length. Complexion dun or brown, with spots on the back, sides, and toward the belly; has, at first glimpse, the appearance of a young mouse. Mouth small, midway, and horizontal. Eves reptical, lateral, and large. No ventral fins. P'ectorals broad. Dorsal and anal rery far back, and no hair between them and the tail. This is but a small projection from the thick and clumsy body, and is terminated by a fin of seren rays. Dorsal, anal, and pectoral fins contain each about 13 rays."

Günther (Cat. Fish. Brit. Mus., VIII, 316, 1870) describes a young example, s. inch long, and by some author's supposed to be of the same species as Mitehill's hairy diodon, as follows: "Trichocrcuss. Jaws without median sutme. Body corered with long, hairlike bristles. No nasal tentarle. (J)orsal and anal fins absent ?). 1. Trich o c y clus erinaceus.

Owing to the indifferent preservation of the specimen, I can give but an incomplete description of it. It is $\xi$ inch long, and the longest hairs (which are those on the sides) about 33 inch. The entire body, except the suout, is covered with such hairs. The jaws are prominent, depressed; and the upper terminates 
in a slight hook, oferlapping the lower jaw. The caudal fin a distimel, and the fretoral a narrow fringe behind the gill "1n+11ing: hut I an muable fo find a trace of the dorsal and anal fins." Habitat unknown.

I mele the natm. I) iodon pilos us De Kay deseribes aud figmes at sperimen 2 indhes long which he considered identical with th. Jliodon pilas us of Mitchill, hut which may be

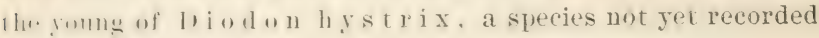
in New York' waters.

\section{Genus cmuomycteres Bibron}

bouly hoad, depressed, moderately inflatable. Derual spines short, stont, immovable, triangular, each with three roots; natsal lule: simple, with two lateral openings; the tube somelimes romuldel. somelimes flattened, and with the partition fre.t, a and wasily torn so that the tentacle appears divided; ramial pulumele short: tins small, formed as in $\mathrm{D}$ i o d ou : jaws withmu median stume. Sprecies numerous, of smaller size than thus of 1 ) i d d 11 . The spines broader and lower, their bases forming a coat of mail.

\section{Subgenus crchomту Kaup}

304 Chilomycterus schoepfi (Walbaum)

\section{Spiny Boxfish; Burfish; Cucumberfish}

l)iudun schoepfi WALBdus, Art. Gen. Pisc. 601, 1792, Long Island.

I) iodon maculostrialus MrtcmiLt, Trans. Lit. \& Phil. Soc. N. Y. I, 470, pl. VI, 1ig. 3, 1815, New York; DE IAY, N. Y. Fauna, Fishes, 323, 1). $56,1 \mathrm{ig} .185,18.2$.

l)imlon rimulatus Cơrien, Mém. Mus. Hist. Nat. IV, 129, pl. 6, 1818, New iork.

Dioulon nimolineutus Armes, Bost. Jomx. Nat. Hist. IV, 68, 1842, Brookhaten, Long Isl:and.

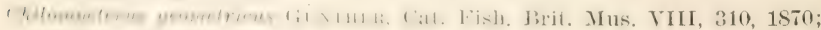
Jomm.i de (imment, Bull. 16, U. S. Nat. Mus. S63, 1883; BeAN, Bull. I. S. I', C. TII, 132. 1885.

1'hilmmpeterus schocypii 13E.ıx, 13ull. Am. Mus. Nat. Hist. IX, 369, 1897. thilmuletrus schnepfi Jontux and Evemarax, Bull. 47, U. S. Nat. Mus. 17.15, 1598, pl, CCLAVI, 1ig. 619, 1900; H. M. Smiti, Bull. U. S. F. C. 15:17, $10.5,18: 98$.

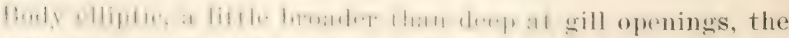

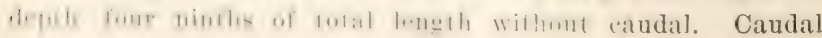


peduncle very short, one third as long as the head, its least depth one half of its greatest depth, and less than diameter of eye. Eye placed high, one fourth as long as the head, about equal to width of gill opening; interorbital space broad, concave. Snout nearly equal to eye. A cirrus, longer than pupil, above each ere. Origin of dorsal four times als far from tip of snont as from base of midd!e eaudal rars. Jorsal base one thiril as long as the head; longest dorsal ray one half as long as the head. Anal immediately under the dorsal and about equal to it in size. Caudal rounded, the middle rays as long as the postorbital part of the head. Pectoral one half as long as the head, its depth when expanded six sevenths of length of head. A small cirrus on chin. About nine spines between eye and tail, their hight about two thirds diameter of eye; spines on belly much smaller, partly embedded in skin; some of the posterior with cirri; spines on caudal peduncle; anterior root of each spine little if any larger than others. D. 12 ; A. 10 ; C. 9 ; P. 20.

Color of a living specimen as given by Ite Kay: "Bright seal green above, with longitudinal olive-brown irregular stripes on the back and upper part of the sides; on the cheeks, below the eyes, these stripes are oblique; transrerse across the snout, and sloping downward orer the fleshy portion of the tail. The large olive-brown spots are irregularly rounded, occalsionally approaching a quadrate form, and eight in umuber; one on each side, above the base of the peetorals, of an oblong oval form; one on wach flank, behind and partially corered ly the prectoral, irregularly subquadrate; one on each side of the base of the dorsal, ascending upon that fin; this is considered by curier as a single spot; finally a small oblong spot on rach side, about midway between the dorsal fin and the rent. Abdomen light. colored, with a light tinge of pink. Spines on this portion of the body inclining to orange. P'upils dark greenish; irides yellow." Othere writers speak of the spots and stripes ats of at black color, and state that the belly is of ten blatek in the young. The spiny boxfish grows to the length of ten inchess. It is cound on our coast from cape corl to Floridia. The hody is 


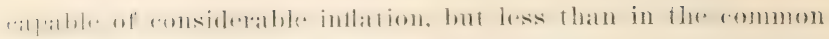
swellfish.

.1 roung example, 3 inches long, seined at Longport $\mathrm{X}$. J.

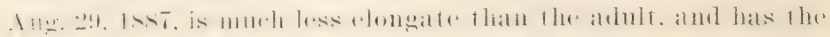

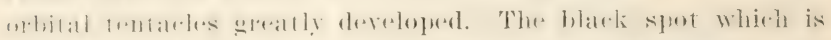

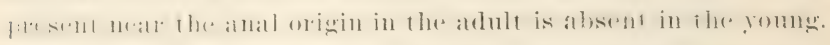
The sprexies is known as "Cucumberfish" at Somers T'oint X. J.

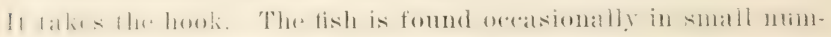

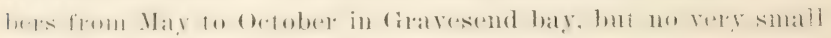
ones are seen. It lives in the aquarium in winter only in water Ineated to a temperature of $68^{\circ}$ to $70^{\circ} \mathrm{F}$.

\section{;0.) Chilomycterus fuliginosus (De Kay)}

Burfish; Unspotted. Balloonfish

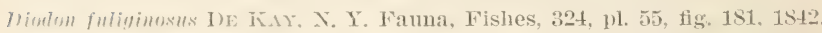

Xew York IIarbor; Bumd, Ninth Ann. Rep. Smith Inst. 351, 1K-iv. (ireat lige Harhor liver, N. J.

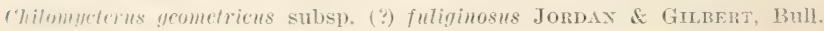
11i. I. S. Nat. Mus. S6t. 1853.

('hilom!neterns fuliginosus BEAx, Bull. U. S. F. C. VII, 138, 18s5; 19th liep. (') Imm. Fish. N. Y. 24:3, 1890 .

The following is the original description of the species:

liocly subcubical, rather more slender toward the tail. Irregular series of triangulat spines on the upper surface, the fxtrmities of which, in the living animal, are furmished with lones strips of membrane. Similar spines, but more numeroms. smaller and recurved, on the abdomen. Three spines over eareh

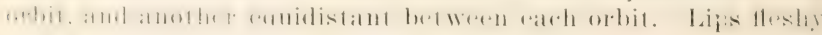
and susceptible of being drawn over the teeth. Three or form

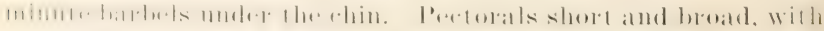
if slighly sinuous margin; the upper rays longest. Dorsal

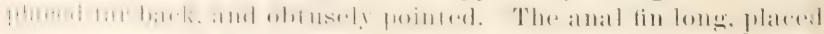
un an elongated fleshy base. T'ail slender, supporting a laneeolall calutal tin. 111 the fins exceedingly feeble and delicate.

c'nlor: Slume date olive-green, tinged with brown, with mrandring dnely lines. . chin vellowish white. Ibdomen bilace : loul the hases of the spines are bright orange. which so liar frratuminatus as to give this color to the whole muderside.

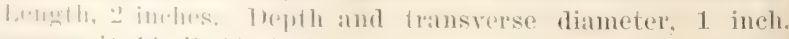

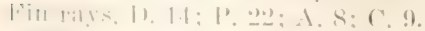

This spreins, which might be mistaken for the young of the

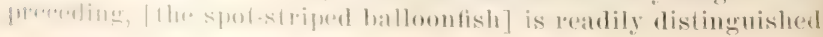


by its lanceolate tail. . The specimen which furnished me with the above description was found in a net in the harlor of New York in the latter part of October.

Iyy some idhthyologists this hats been ronsidered the young of the common C. geometricus, but by Ins Goode and lisan. who base their opinion on a sperinen taken at Block Island and the rample found in freat south bay in 1884, neall the lBhe Point Lifesaling station, it is areepted as a valid spereises. I'ro fessor Baird recognized it also in Great Egg Inarbor river. N. J. in 1854 .

The following is a recent description:

Entire body covered with latge three-looted spines, which are mumerous and ciose set, sperially on the belly; spines of the belly as large or even larger than those on the back; not embedded. D. $12 ;$ A. 10.

bark brownish olive above, with wary dusky lines; belly black, the base of the spines bright orange. Atlantic coast, from Cape Cod southward; not common.

Family MOLIDAE

\section{Headfisties}

Genus mora Cuvier

Body ovate, strongly compressed, covered with a thick, rough, leathery, eastic skin, which is without bony plates. Profile forming a projecting fleshy nose above the mouth. Ihorsal fin legimning not far behind pectorals, short and high, falcate, confluent with the anal aromel the tail; no linge spines on the body. rlumsy fishes, found in most warm seas, learhing a great size; the young (Molacanthus) with the body deeper, much complessed, without tratee of caudal fin, its platere talken by a row of marginal spines.

\section{Mola mola (Limnateus) \\ Sunfish; Mola; Headfish}

Tetrodon molø Lixwaeus, syst. Nat. ed. X. 334, 412. 1758, Mediterranean. Cephulus brevis MitcinLt, Trans. Lit. \& Phil. Soe. N. Y. I, 471, 1815.

biodon cerinatus Mitcmel, Ann. Lyc. Nat. Hist. X. Y. II, 264, pl. 5, fig. 1. 1S15, New York; young.

1eanthosoma carinatum DE KAx, N. Y. Fauna, Fishes, 330, pl. 万e, fig. 179), $18+2$. 
Orthugoriscus mola Stoner, Rep. Ichth. Mass. 170, pl. 3, fig. 1, 1839; DE KAY, X. Y. Fauma, Fishes, 331, pl. 59, fig. 193, 1842, New York

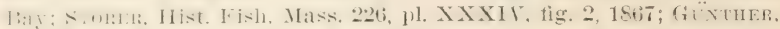
Cat, Fish. Brit. Mus. VIII, 317, 1870.

Orthayuriscus unalis AYres, Proc. Cal. Ac. Sei. II, 31, fig. 54, 185̌t, San Fintir-ision.

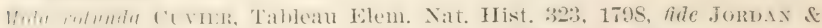

Evermaxi; Goode \& BeAN, Bull. Essex Inst. XI, 3, 1879; Jordan \& Gilbeit, Bull. 16, U. S. Nat. Mus. S65, 1883.

Mole mole. Tordax \& Everdiann, Bull. 47, U: S. Nat. Mus. 1753, 189S, 11. CCLXYII, fig. 651, 1900; H. M. Smrtr, Bull. U. S. F. C. 1897, 105, 1ه9S, Vineyard Sound.

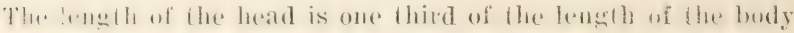
In hith is one and three fifths times the depth of the borly: dorsal aml atnal fins hiwh in front, rapidly decreased batckwits: catudal fin lus, and with a way outline; dentb always more than half 1.11:-11. and in the youmg the vertical diameter areediug the lumpinminal; furm valying with age, the body becming mone

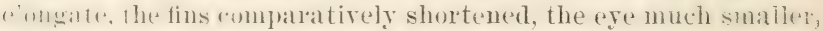
and a hump being developed above the mouth, topped by an osseous tubercle. D. $17 ;$ A. 16.

lark gra!y ; sides grayish brown, with silvery reflections, bully du-liy: a hroat hachish bar rumning along the bases of the dor rill. rallulal, and anal fins. Pelagic, imhabiting most temperate a:ml llopilal seals, swimming slowly near the surface, with the high dorsal fin exposed.

If ranges mothward to San Francisco, Cape Aun, and kng

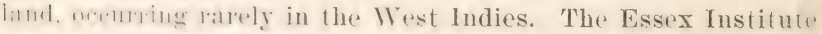
hat-a -pweimen whirle was taken in salem harbor in the summer ni Inti, In individual, 4 feet long, was vaught off Gloucester

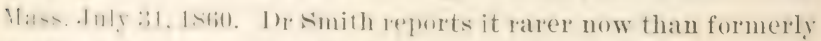

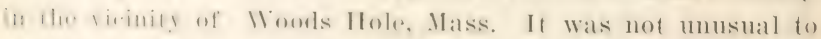

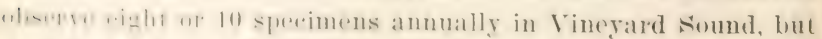

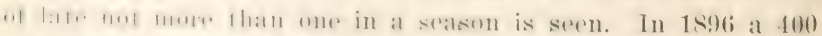

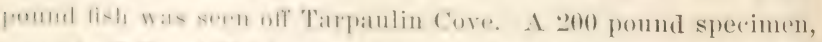

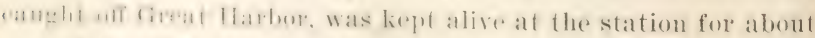

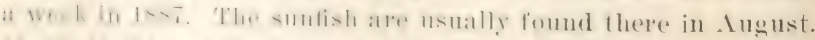

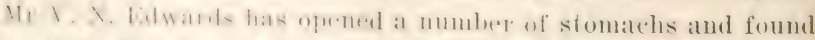

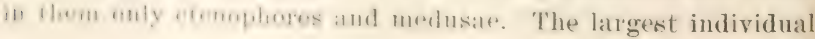


recorded was captured at Redondo Beach, California, in June 1S93; this was 8 feet 2 inches long and weighed 1500 pounds. The specimen mentioned by Mitchill and De Kay from lower New Sork bay, within Sandy Hook, was 54 inches long and weighed 200 pounds.

The sunfish is not edible. 1)e Kay states that various parasites are frequently found adhering to its bod $s$; this is rendered easy on account of the sluggish movements of the fish.

The young sunfish is very different in appearance from the adult and has been described under various generic names and even referred to a distinct family.

Suborder LORICATI

Mail-cheeked Fishes

Family SCORPAENIDAE

Rockifishes

Group SEBASTINAE

Genus sebastes Cuvier

Body oblong, compressed. Head large, scaly above and on sides; cranial ridges well developed. Mouth terminal, very broad, oblique, the broad, short maxillary extending to below the eye; lower jaw projecting, with a bony knob at the symphysis, fitting into a rostral notch; villiform teeth on jaws, vomer and palatines. Eye very large, close to upper profile, preopercle with five diverging spines, opercle with two; suprascapular spines strong; gill rakers long, slender. Scales small, ctenoid, irregularly arranged; no dermal flaps. Dorsal fin contiunous, very long, the spinous part much longer than the soft part, of 15 strong spines; anal spines three, strong; caudal emarginate; pectorals long, narrow. Branchiostegals seren. Tertebrac 1:+ 19=31. Coloration mostly red. Ovoviviparous. One species known, in the North Atlantic.

\section{Sebastes marinus (Linnaeus)}

Rosefish; Norway Haddock

Perca marina Linnaeus, Syst. Nat. ed. X, I, 290, 1758, Norway. Sebustes norkegicus Cuvier \& Valenciennes, Hist. Nat. Poiss. Il, :2a, pl. 87, 1829; Günther, Cat. Fish. Brit. Mus. II, 95, 1860. 


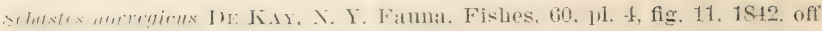
New York in deep water; Stonen, Hist. Fish. Mass. 38, pl. VII, fig. 1, $186 \bar{T}$.

Sebretes marinus Goone \& BeAN, Bull. Essex Inst. XI, 14, 1879; JoRDAN \& (immert, Bull. 16. U. S. Nat. Mus. 651, 18S3; Goode \& BeAx, Oceanic Ichth. 260, pl. LXIX, fig. 248, 1896; H. II. Smiti, Bull. U. S. F. C. 1597, 105, 189S: Jordax of Evermaxx, Bull. 47, U. S. Nat. Mus. 1760, 1S:8, pl. CCLAYIII, fig. 653, 1900.

The depth of the hody is contained two and four fifthe times in the length of the body which is three times the length of the

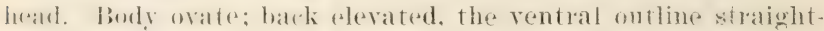
islı: loge of head evenly sealed: interorbital spalee with two low ribges, between which it is concare; nasal spines present:

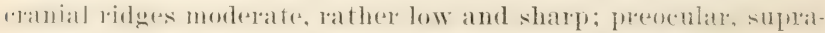
m.malr, fosturular, tympanic, and occipital ridges present. the battre with tips abruptly divergent; suprascapulat spines rery sharp and prominent: oferember spines long and sharlo: sub-

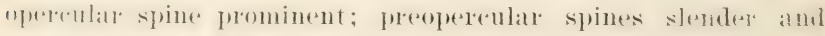

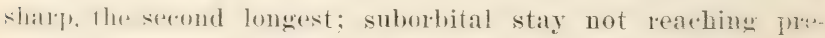

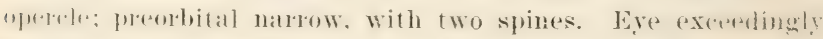

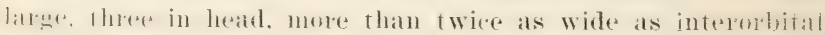

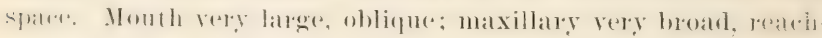

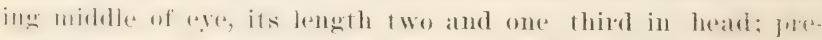

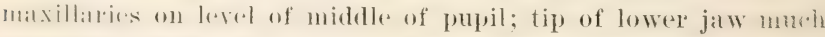

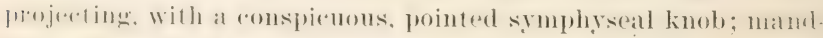

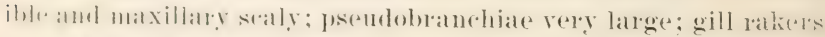
lomg. stift and stromg. I moral spines shatre, the lomgest about as

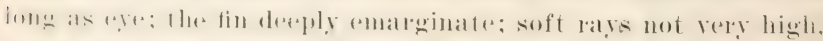

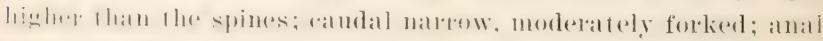

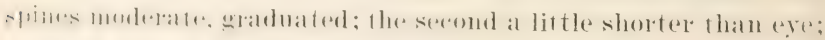

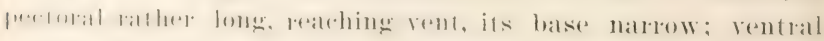

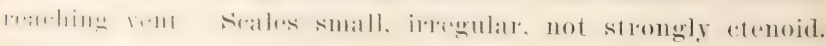
I'ritonemm brownish. 1). XV-1:3; 1..IH, 7; Lat. 1. 40 (tubes); s(ralox about S.).

() range-led, neally miform, sometimes a dusky opereular

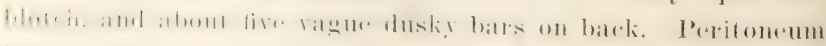
hremmisls.

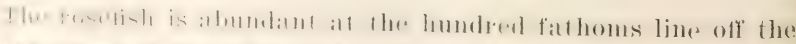

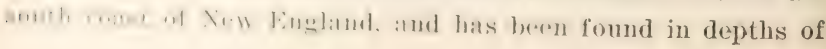


180 fathoms. It brexels abmudantly in late summer at these depths, and there is no reason to bedieve that the romeng rise to the surface. The fre weres atught by the busher in the trat net of the U. S. Fish Commission steamer Fish Hawi.

The species was originally described from Norway by

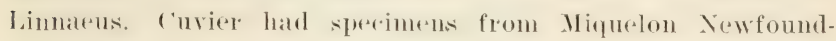
land. I)ay mentions a numbre of localitios of its alphume about the lireitish Isles, but it is rate somth of Faroe Islands. It orems on the southwest roast of syitzhergene, and on the Nollwerian

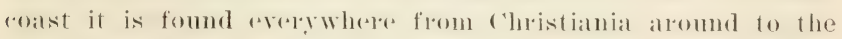
Varanger-Fiord. It also orcurs in Greenland, and from Labrador, as a shore form, as fall south as calue coul, and in deeper water as far south as New Jersey:

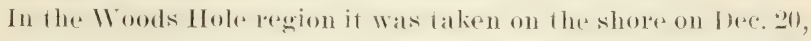

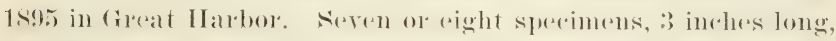
were fomml in a hole on a that where they hat been left by the tide; fome or tive of these had been stranded and were deat ; the otheres were alive when raptured. Fishremen elaim that they sometimes atoh these fish in traps very late in fall at Province. town. (After Smith)

Ie Kay has the following remarks mon the fish:

This is a very later fish in our waters. It is alled by oul fisher-

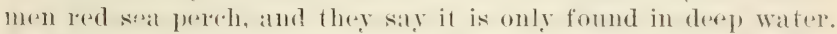
liy the fishermen of Massachusetts it is known muder the vallous names of rosefish, hemolurgon and smapjex. Fabricius states

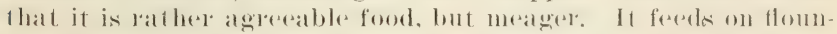
ders and other fish, and takes the hook readily.

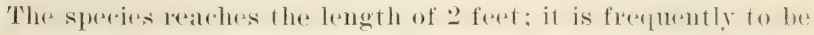
found in the Boston markets and is seren oceasionally in the

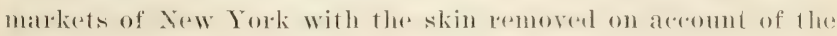
hard scales.

\section{Genus Hecromenus Goode \& Bean}

Body oblomg, somewhat rompressed; head latrere ctemoid

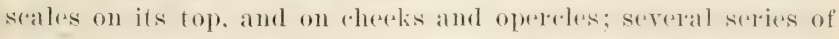
spinoms ridges on head. but no oreipital pit: month latrene, w ith bands of rilliform tereth on jatws. vomere and patatines. Horsal

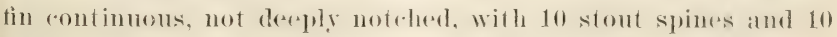
to 12 rays; anal with three spines and six rays; pectoral broad, 
fan-shatjerl. with bays arranged in three groups, the first of two simple lays. 1he seromd of right or nine branched rays, the third "1' right simple rays, sometimes prolonged, with their tips f.rmbillike and frese from membrane for one half their length of less; soft dorsal with tips free from membrene: suborbital lirel smmoth, wr with a single anter.or spine under 'ye; preorbital with spines small and hidden beneath the stin. Tertebrae $10+14=24$; no air bladder. Atlantic.

\section{:3) Helicolenus dactylopterus (I) la Rorhe}

\section{Redfish; Seran Imperial}

sirnlutul durfyloptera DE IA Roche, Ann. Mus. Paris, XII, 316, 337, pl.

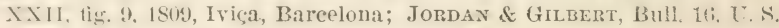
Nat. Mus. $679,1883$.

Sebastes dactylopterus Günther, Cat. Fish. Brit. Mus. II, 99, 1860.

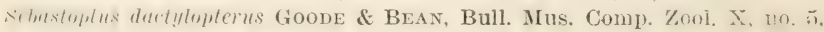
214, 1883.

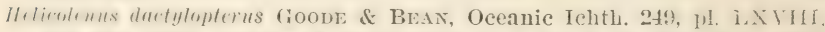

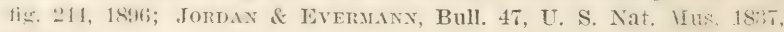
$189 \mathrm{~S}$.

1). la Iioche states that at Iriga this form is found on! y at comsidratble drpths, outside of the regions commonly frequented hy thr fishrment inderet, that it is very rare, or seareely at all kenown, in thre marlieis of the fowns where the fishermen ale not in thr habit of going far out to sea. Пo saw many individuals 1:1 ken ofl I vic:al at a derth of 260 to 290 meters, and in the viciui!y of Latrenloma saw the same spereies from a depth of 540 meters. It loisen the spereies is known as the Seran imperial, and at barecelona as the Fanegal.

likso sa w sperimens at Vice in which locality of the Meditere

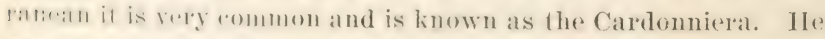
:als s it arows lo a lemgth of :30 (rentimeters (about 1 foot) and a

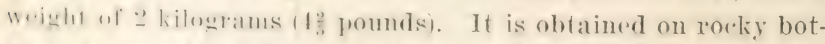

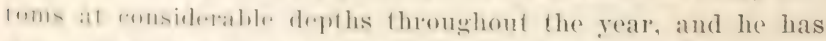

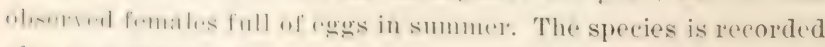
aiso from Naples, Genoa, Messina and Catania.

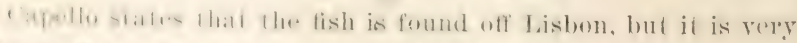

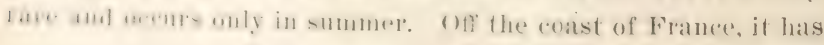


been identified from Marscilles, st Jean de Luz, Biarritz, Valence, and Arcachon.

In the western Atlantic the redfish or.ur's in numerous localities in deep water from Narragansett hay to :hesapeale bay.

Family COTTIDAE

Seulpins

\section{Group CotTinaE}

Genus cotrus (Artedi) Linnaeus

Fresh-water sculpins. Body fusiform. Head feebly armed; skin smooth or more or less relvetr, its prickles, if present, not bony or scalelike; villiform teeth on jaws and romer, and sometimes on palatines. Gill openings semarated by a wide isthmus, over which the membranes do not form a fold; no slit behind fourth gill. Branchiostegals six. Iorsals nearly or quite separate, the first of six to nine slender spines, rentrals moderate, each with a short, concealed spine and four soft rays. Lateral line present, usually more or less chainlike, sometimes incomplete. Preopercle with a simple spine at its augle which is usually curved upward, its base more or less covered by skin, very rarely obsolete; usually two or three spines turned downward below this; suboperele usually with a concatre spine turned downward. Vertebrae $10+3: 3=3: 3$. I'yloric alual ahout four. Fishes of small size, inhabiting clear water's in the northern parts of Europe, Asia and America. The species are extremely numerous and are very diffieult to distinguish, all being very similar in form, coloration and habits.

The species are most destructire to the eggs of salmon and trout.

\section{Subgenus PEgedictis}

309 Cottus ictalops (Rafinesque)

Miller's Thumb; Blob

Pegedictis ictalops Rafinesque, Ichth. Ohien. S5, 1820, spring neat Lexington, Kentucky.

Cottus Richardsoni Agassiz, Lake Superior, :300, 1S5̄), Montreal River; Girard, Monograph Fresh-Water Cottoids N. A. 39, pl. 1. figs. 1, 2, pl. 3, figs. 18-21, 1850; Günther, Cat. Fisb. Brit. Mus. II, 15s, 1866. Cottus Bairdii Gmand, Monograph Fresh-WVater Cottoids N. A. 44, pl. 1, figs. 5, 6, 1850. 
Yrenilea richartsoni JompAx of Gilmert, Bull. 16, U. S. Nat. MIus. 696, 1883;

Br.ix, Fishes Penna. 136, pl. 35, fig. 74, 1893.

cottus ictulops bairdi MeEk, Ann. N. Y. Ac. Sci. IV, 315, 1898.

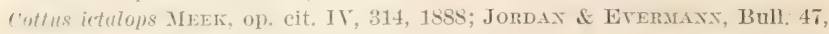
[. S. Nat. II $1950,1898$.

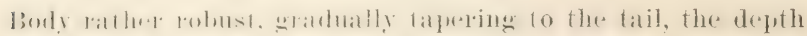
varying fomm ant fonth to whe sixth of the lemgth: the length of the heath is ronlationl alumt there and one thirel fines in the

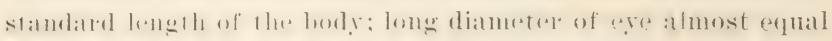

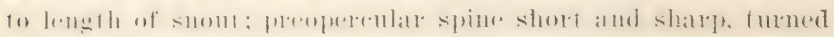
"1pwatrl and hatelwated. With 1 wo smaller spines helow it: skin

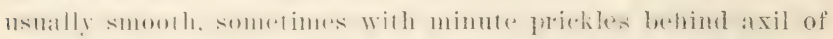

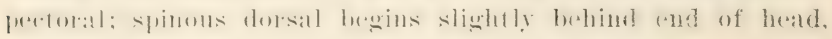

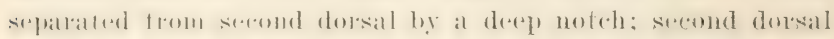

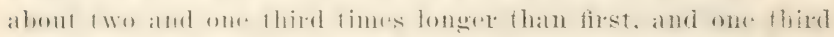

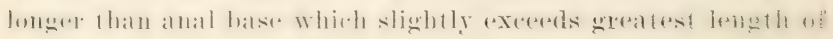
head; pectoral, ventral, and caudal fins well dereloped.

1). VI-VIII, 16; \. 12-13; V. I, 4. Lateral line conspicuous, sometimes wanting on caudal peduncle.

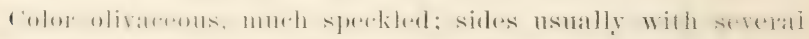

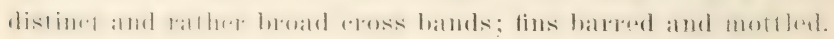

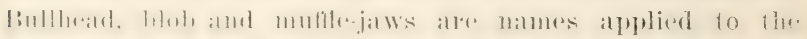

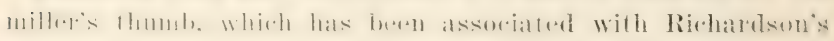
$11: 1110$.

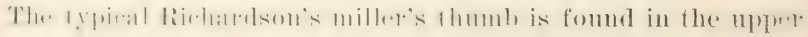

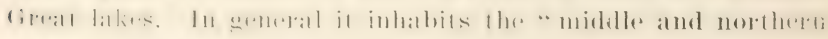

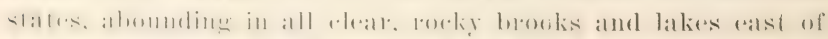

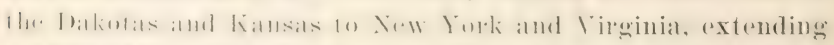

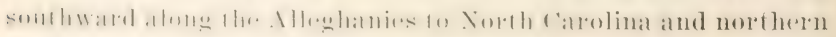

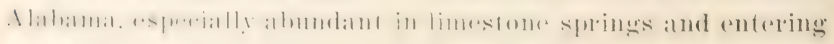
$1 \because 11, \cdots$

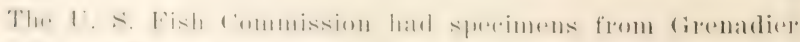

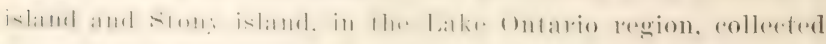
!H110 20 and . July : 3 ; also from the St Lawrence river, 3 miles

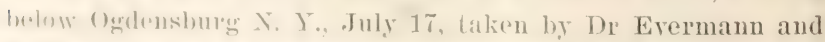
Ml licum in 1s!). Mrek recorels the species from the southern 


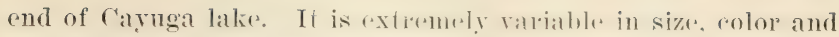
length of fins and number of rays.

This species grows to a length of $T$ inches murlel farolable ciremmstances and is one of the most destruetive ('memies of the eggs and yommg of blook trout and ot lex menteres of the salmon family.

\section{Genus urixidea De Kay}

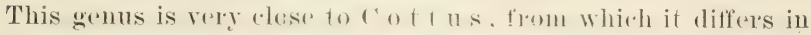

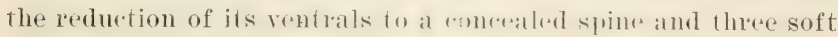

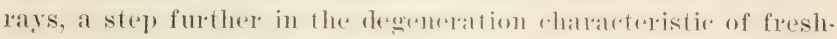
water types. The skin is smooth, ol vely nealy so, the plese opereular spines small, and there is nsually no trater of teeth on

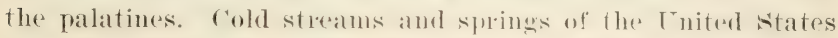
from New England and the Great lakes lo the l'aleitir roatst.

\section{Uranidea gracilis (Heckel)}

\section{Miller's Thumb}

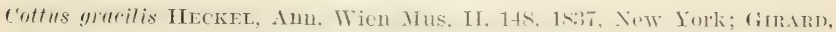

Monograph Fresh-Water Cottoids N. A. 49, pl. 1, figs. 11, 12, 1851;

Günther, Cat. Fish. Brit. Mus. II, 157, 1860; MeEk, Ann. N. Y. Ae.

Sci. IV, 315, 1888; Eugexe Sirtir, Proc. Linn. Soc. N. Y. 1897, 10, 1898. Uraniden quiescens DE KAT, N. Y. Fauna, Fishes, 61, pl. 5, fig. 14, 1842, stream and lake in Hamilton comuty, N. Y.

Uianidea gracilis Jomdan \& Gilbert, Bull. 16, U. S. Nat. Mrus. 699, 1883: Bean, Fishes Penna. 137, 1893; Jordan \& Everannn, Bull. 47, U. S.

Nat. Mus. 1968, 1898.

The body is moderatery slender, spindle-slutped; mouth large,

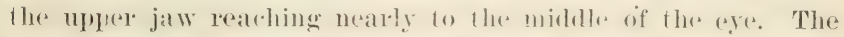

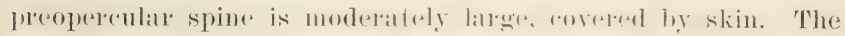
pectorals reach to the orjegin of the anal, and the rentrals to the rent. The depth of the body is one tifth, and the length of the head two serenths of the total without alublal. Teeth in villiform bands on the jaws and vomer. nome on the firlatine bones.

D. VIII, $16 ;$ A. 12 .

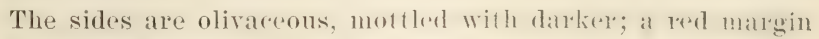
on spinous dorsal.

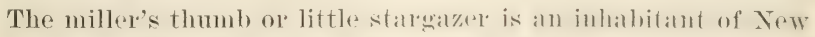

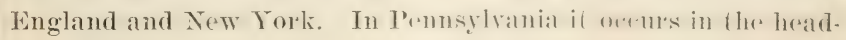


Watels of thr. Nusquahanma and Allogheny rivers. In New Tork it Was first taken in a stroum emptying into Round lake, Hamilluit rominty, and in latke P'leasant, of the same county. Dr Me.k examinted specimens from the southern end of Cayuga lake,

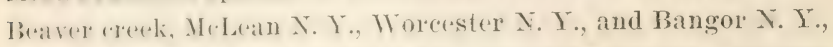
hut it was not so abundant as the preceding species. Eugene smith sals that it is rery plentiful in the lotad streams of the II rekrusalek and silddle rivers in New York and Jew Jeresey, in rompany with blarkinosed dace and darters. This species glows 10 a longht of 4 inches and is representer by several varivies, our of which has the bory robust instead of slender and another has the slender body as in gracilis, but with longer fins.

This fish in fommd under stones in clear, rocky and giavelly brooks. It has no importance either as food or bait and is rery destructive to the eggs of other fishes.

\section{Uranidea formosa (Girard) \\ Lake Blob}

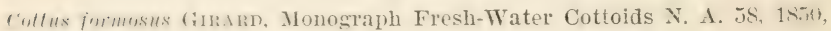

Lake Ontario off Oswego, in stomach of Lota maculosa.

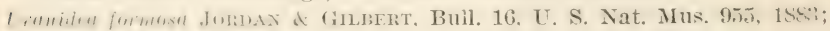
Jompax \& Evermann, Buil. 47, U. S. Nat. Mus. 1969, 1898.

fiols slunder and granful; head small, depressed above; the

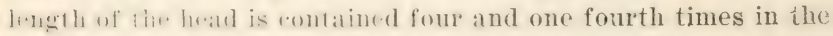

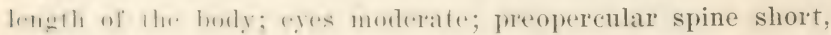

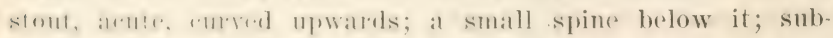
"y lueinning umler lhirel ra! of soft dursal; pectorals not reaching to prosforof malegin of spinous dorsal; ventrals not nearly to vent.

i). VII 16: . I. II; I. 1, :. Inngth :3) inches. Deep water in Lake Ontario.

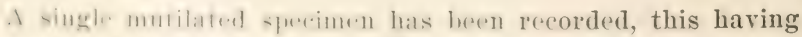

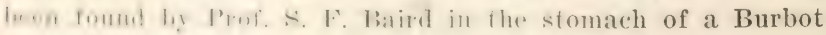
$(1,0)$ a ma c u l o s al) off Oswego N. Y., in Lake Ontario. 


\section{Genus myoxocephatus (Steller) Tilesins}

Body slender or robust, subfusiform, rovered with thick skin, in which are sometimes embedded prickly plates; deciduous, granular, or stellate tubercles also sometimes present, but no true seales. Head large. Mouth terminal, large, the lower jaw always included, the uppermost the longer; villiform teeth on the jaws and romer, none on the palatines; suborbital stay stroug; preopercle with two strong straight spines above directed backward, and one below directed downward and for. ward; operele, nasal bomes, orlital rim, and shoulder girelle more or less armed; gill membranes forming a fold across the rather narrow isthmus; slit behind last gill reduced to a mere pore, or wanting; vertebrac about 2S. Branchiostegals mostly six. Dorsal fins two, s'parate, the first short, its spines rather slender; ventral rays I, 3; caudal fin moderate, fall-shaped; pectoral fin broad, its lower rays procurent. Lateral line well developed, its tubes sometimes provided with bony or cartilaginous plates, never chainlike nor reduced to separated pores. Species numerous, in the seas of northern regions; coarse fishes, little valued as food.

\section{Subgenus aслмтносоттus Girard}

312 Myoxocephalus aeneus (Mitchill)

\section{Grubby; Brassy Sculpin; Pigmy Sculpin}

Cottus aneus Mitchul, Trans. Lit. \& Phil. Soe. N. Y. I, 3S0, 1S15, New

York; Cuvien \& Talenciennes, Hist. Nat. Poiss. IV, 189, 1829;

De KAY, N. Y. Fauna. Fishes, 52, 1842 (not figure); Goode of BeAx,

Bull. Essex Inst. XI, 13, 1579; Jordax \& Gilmert, Bull. 16, U. S. Nat.

Mus. 702, 1883; BEAN, 19th Rep. Comm. Fish. N. Y. 251, 1890.

Cottus scorpio Mitchill, Trans. Lit. \& Phil. Soc. N. Y. I, 380, 1815, New York.

Cottus mitchilli Cuvier of Yalexcienves, Hist. Nat. Poiss. IV, 1S8, 1829,

New York; DE KAY, N. Y. Fauna, Fishes, 53, pl. 17, fig. 47, 1842;

Günther, Cat. Fish. Brit. Mus. II, 164, 1860.

Cottus (Acanthocothes) anceps SACYAGE, Nour. Archiv. Mus. I'aris (2), I, 14.5, pI. 1, fig. 13, 1878, New York.

Ácenthocottus aneus BEג., Bull. Am. MIs. Nat. IIist, IX, 369, 1897; II. M.

Sмгтн, Bull. U. S. F. C. $1897,105,1898$.

Myorocephalus aneus Jorni. \& Evimix., Bull. 47, T. \&. Nill. Mus. II, 1972, 1898, pl. CCXCV, fig. 716, 716a, 1900. 
Wepth of body one fom th of total length without caudal.

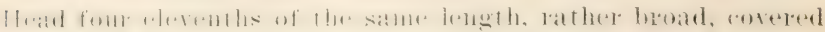

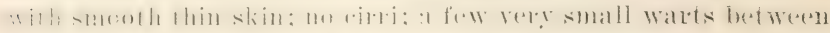

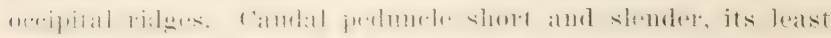

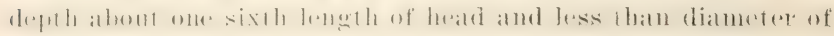
(2ye. Maxillary three sevenths as long as head, reaching to

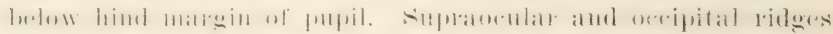

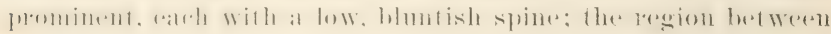
the supratocular spines rather conrex, the space before and

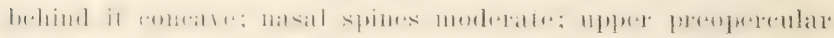

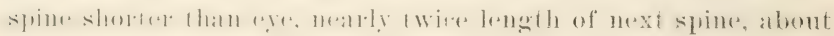
reatching middle of operele. Ere two thirds as long as snout,

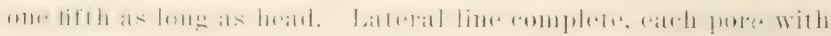

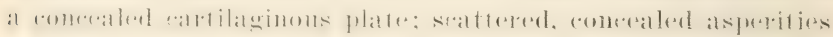
on skin of sides. No lrace of slit behind last gill. Dorsal base

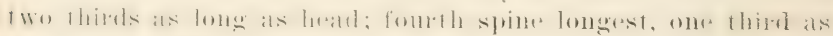

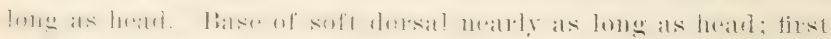

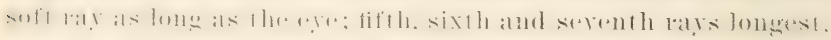

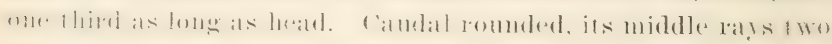
fifths as long as head. Anal origin under third ray of soft

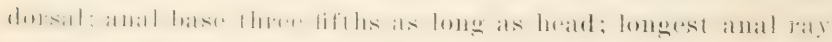
nearly one thild as long as head. Pectoral reaches to below

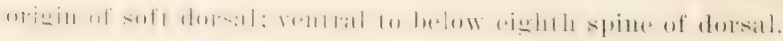

1). IX, 1:; 1. 10; V. I, 3; I’. 1.).

firayish olire, much varegated with darker"; no distinct paler

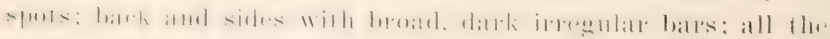
fins barred; mandible mottled; belly pale.

'This little sculpin was known to Mitehill as the brazen bullhead and also fo De Kay, who satid it is frequently taken with

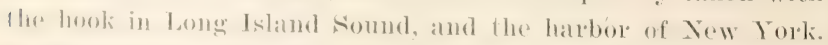
1he Kay deseriber il asain undere ihe name of the smooth heowed bullhwal and states that it is commonly taken with the hook in remplatuy will the Hal lishes.

Therembly seldom axcoeds a inches in length. It ranges from

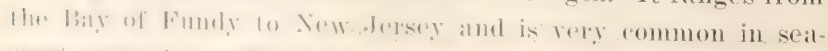

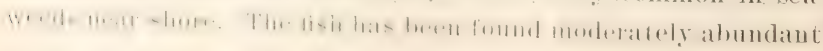


at Fire Island in September. In fravesend bay it is practically a permanent resident, spawning in winter; the eggs have a beatrtiful green color. In the vieinity of Woods Hole. Mass., aleroleling to Dr smith, it is very rommon, remalius during the entires reatr, and is the only seuplpin found in summer. In winter from 10 to 50 are caught daily in fylie nets set in the hathol: The tish is then in a spawning condition, and the exgos athere to the twine.

\section{Myoxocephalus octodecimspinosus (Mitchill)}

\section{8-spined Sculpin; Hackithead}

Cottus octodecimspinosus Mitcmul, Trans, Lit. \& Phil. Soe. N. Y: I. 380. 1815, New York; Cuvier \& VAlenctexxis. Hist. Nat. Poiss. IV. 181. 1829; Günther, Cat. Fish. Brit. Mus, II, 163, 1860; Goode \& BEAN. Bull. Essex Inst. XI, 13, 1879; Jordax \& Grlbert, Bull. 16, U. S. Nat. Mus. 701, 1883; BEAv, Bull. U. S. F. C. VII, 137, 1889.

Cottus virginianus DE Kix, N. Y. Fauna, Fishes, 51, pl. 5, fig. 13, $18+2$. Acanthocottus virginianus Storen, Hist. Fish. Mass. 28, pl. IV, fig. 2, 1867. Acunthocottus octodecimspinosus BEAx, Bull. Am. Mus. Nat. Hist. IX, 370, 1897 ; H. M. Sмmтir, Bull. U. S. F. C. 1897. 105. 189 .

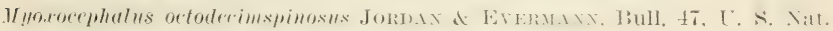
Mus. II, 1976, 1S98, pl. CCXCYI, fig. 71S, 1900.

Body moderately robust anteriorly. 1apering posteriorly, ils depth contained four and one half times in the standard lengih while the least depth of the camdal peduncle is less than one sixth length of head, the length of the lattre being contained two and two thirds times in the standild length; maxilla twice long diameter of eve and (omtained two and one lalf times in the length of head; the spines of the head atre long. the upper opercular spine being longex than in any other species of the genus; the first dorsal originates over the hase of the pertoral, its third and fourth spines being longest, alount four tiftles as long as the base or equal to the distance from the posterior margin of the eve to the tip of the suout; the length of the second dorsal base equals the length of the head, and the longest rays of the second dorsal equal the length of the spines: anal base shortere than second dorsal base; lomgest rays of anal replat fo length of sixth-dorsal spine: ratudal slightly trumrate. its length equal to the depth of body; pectorals lomes, hroad, fheir hases equal to half the length; the length of the ventrals is equal to the dis- 


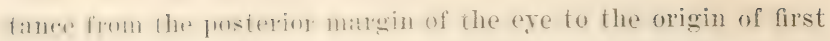
dorsal. D. IX, 16; A. 14.

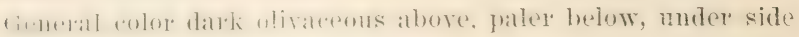
of head and belly white; fins barred and mottled.

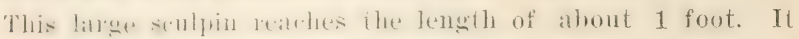

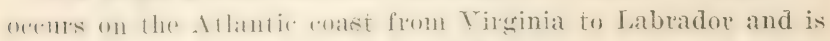
very somthren forte of its hallitat it is found only in late fall and

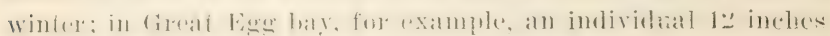

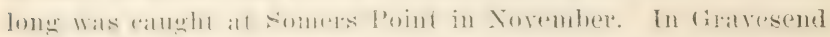

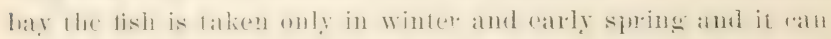

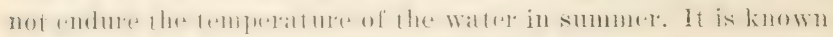
to the fishermen of that ricinity as the hacklehead.

1). Ka!y does mot montion any jarticular locality for the speries, hut salys it ranges from Vireginia to Newfomndland, arud ferlates farther morth. Te makes the following adritional remarks: "This smeres. which, on areount of its uncouth form.

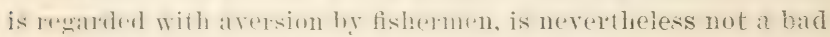

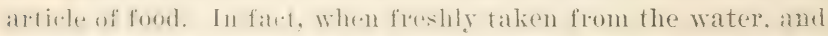
imitated. they do present rather a formidable appeatrance. The

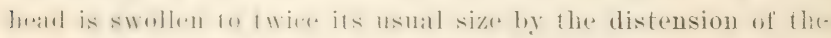
hramehial memheame: line spimes stand out prominentle, and the

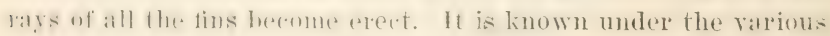

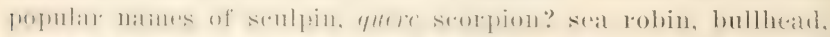

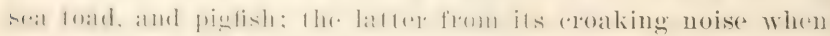
drawn from the water."

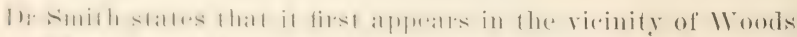

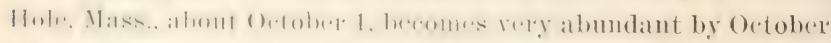
!

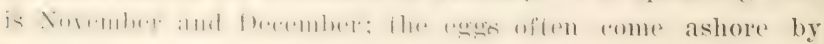
burketfuls on Nobska beach.

\section{:31.4 Iryoxocephalus groenlandicus (Cuv. \& Val.)}

\section{Daddy Sculpin}

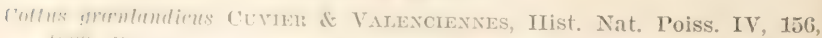

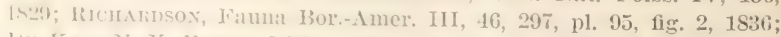
1) Ka K, X. Y. Fauna, Fishes, 54 , pl. 4 , fig. 10, 1842; Gümuer, Cat. l'is!. Lirit. Mus. 11, 161, 1860. 
Cottus scorpius gronlandirus GoodE \& BEAx, Bull. Essex Inst. XI, 19, 1879;

Be.dn, Bull. 15. U. S. Nat. Mus. 118, 1879; JordaN \& Gilmert, Bull. 16, U. S. Nat. Mus. 703, 1883.

Acanthocotlus raviabilis Storen, Hist. Fish. Mass. 26, pl. IV, fig. 1, 1867. Acanthocottus granlandicus H. M. NмIтr, Bull. U. S. F. C. 1897, 105. 1898. Iyozoceplialus gramlandiens Jordix \& Evemanx, Bull. 47 , U. S. Nat. Mus. II, 1974, 1898.

The length of the body is four and one half times the depth. Head large, the length being contained two and one half times in the length of the body. Mouth large, the lower jaw included; maxillary reaching posterior edge of orbit, its length three serenths length of head; the supraorbital and occipital spines blunt, tuberclelike, without cirrus; a small tubercular spine on front of occipital ridge; upper preopercular spine short, only reaching the middle of opercular spine, its length equaling eye, not twice that of the spine below it; opercular spine sharp; nasal spines sharp; suprascapular spine rather strong and short. Sides of body above lateral line with a series of embedded prickly plates, below which are numerous scattered spines and prickles. Dorsal and anal fins high, their hight more than one seventh total length without caudal. Ventrals long. Pectorals reaching to rent. Eye large, equal to width of interorbital space. D. X, 17; A. 14; V. I, 3; P. 18.

Dark brown abore, with broad darker bars; below yellowish, the belly in the male with large pale spots; back and top of head with grayish blotrhes; fins brown and yellow, all of them spotted and barred. Sexual differences great, the males more brightly colored; the round white spots strongly marked; females with rough crests on the head.

The daddy sculpin is the largest of its kind on our east coast as it grows to the length of 25 inches. It ranges from New York to Greenland, but is common in New York and Massachusetts waters only in fall and winter. The Kay bad met with a single specimen which was taken near Ifell tate. Storer records it as ibundant on the coast of Massachusetts feeding on small fish, erabs, sea urchins and other invertebrates; but not valued as food. I) Smith remarlis that it arrives at Woods Hole in Octojer, remains till December or January, spawning in November 
and Jecembre when there is a great loss of egge through storms. Tabricius records its spawning in Greenland in December and fannary and describes its agos as red colored. The eggs, he states, are deposited on seaweed. The Grenlanders eat the fish for their daily food and they eat its eggs raw.

\section{Genus TRIGLopsis Girard}

Body and head slender; skin naked: lateral line chainlike; tecth on vomer, none on the palatines; eye large, the interorbital area concare; bones of lower part of head extensively cavernous; a small but distinct slit behind last gill; gill membranes almost free from the isthmus, forming a broad fold across $i t$; preopercular spines straight, simple, 4 in number, the lower turned downward; fins large. Fresh-water lishes, closely related to Oncocottus, from which they have doubtless become degraded through fresh-water life. There is no tangible diffor. ence in structure in any part of the body.

\section{Triglopsis thompsoni Girard Lake Sculpin}

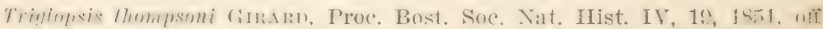
Oswero, Lalie (Hitario; Monograph Fresu-Water Cottoids, X. A. 4is.

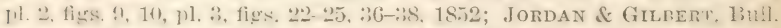

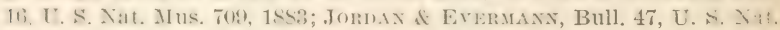
MI Us. II, 2005, 1898.

Trinlopis stimpsoni Hor, Trans. Wisconsin Ac. Sci. 98, 1872, Lake Michtgan.

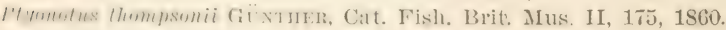

Body elongate, repy slender, the depth being one sixth of the lengeth. Ilead long. depressed above, the length being one third of the length of the hody. Snont long and pointed; ege quite large, maty as long as snont, much wider than interorbital viare, oue fourth as long ats lhe head; jaws subequal; mouth latere, the maxillary extemding rather beyond middle of eye; pre.

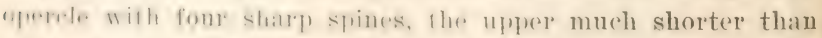

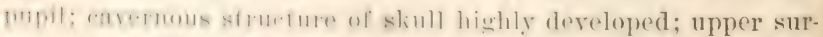

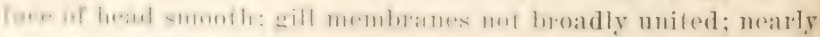
fre from istlumus. Jursal fins well separated; spinous dorsal whers and low, its hight lithle more than length of snout; second 
dorsal rery large, three times hight of first, its longest rays about as long as head; anal high, half as high as second dorsal; pectoral long, reaching past front of anal; ventrals well dereloped; lateral line chainlike, conspicuous; skin perfectly smooth. Length 3 inches. D. VII-18; A. 15; V. I, 3; pyloric caeca seven.

Pale olivaceous, with darker blotches; upper fins faintly banded.

Deep water's of the Great lakes; specimens have been taken sparingly in Lakes Ontario and Michigan. The U. S. Fish Commission obtained two examples at Nine Mile Point N. Y. and on June 10, 1893, a single indiridual was collected at the same place. The type of the species was taken by Spencer F. Baird off Oswego, Lake Ontario. Dr William Stimpson obtained a specimen in deep water of Lake Michigan which formed the type of Dr Hoy's Triglopsis stimpsoni.

The close relationship of $\mathrm{Tr}$ iglops is and $\mathrm{Oncocottus}$ has been pointed out. Both young and adults of $\mathrm{O}$ n c o o o t t u s have been found occasionally in fresh water and the descent of the lake sculpin from a species of $\mathrm{O} \mathrm{n} \mathrm{c} \mathrm{o} \mathrm{cot} \mathrm{tus}$ is highly probable.

\section{Genus hemitripterus Cuvier}

Body moderately elongate, scaleless, but the skin covered with prickles and bony protuberances of various sizes and forms. Head large, with numerous bony humps and ridges and fleshy slips above; orbital rim much elevated, the interorbital space deeply concave; a depressed area at the occiput, behind which are 2 blunt spines on each side. Month very wide; jaws, vomer, and palatines with broad bands of teeth; no slit behind last gill; gill membranes broadly united, free from isthmus; preopercle with stont, blunt spines; suborbital stay very strong, forming a sharp ridge. Spinous dorsal much longer than the soft part, of 16 to 18 spines, of which the first two are the highest, and the fourth and fifth shorter than the succeeding ones, the fin thus deeply emarginate; pectoral fins rery broad, much procurrent; ventrals $I, 3$. Large fishes of singular appearance, inhabiting the North Atlantic and Pacific: 


\section{:16 Hemitripterus americanus (Gmelin)}

\section{Sea Raven}

Seornena americana GMelin, L. Syst. Nat. 1220, 1788.

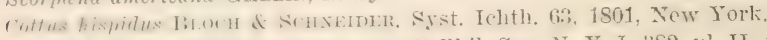

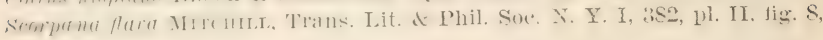
1815.

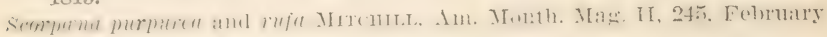
$1 \$ 18$.

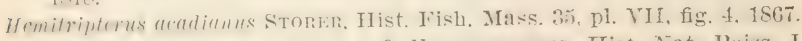

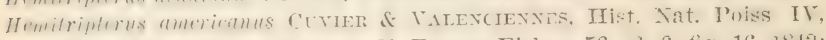

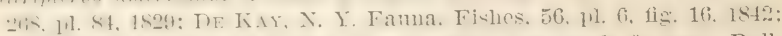

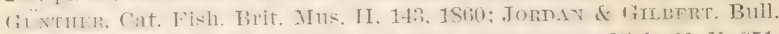
16, U. S. Nat. Mus. 685, 1Ss:; Br..., 19th Titp. Comm. Fisi. X. Y. 2.51. 1890; Bull. Am. Mus. Nat. Hist. IX, 370, 1897; H. M. Smrtm, Bull.

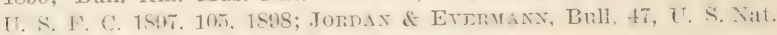
Mus. II, 2023, 1898, pl. CCCT, fig. 738, 1900.

The length of the body is three and three fourths times the depilh and two and two thirds times the length of the head.

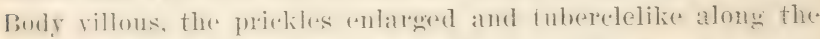

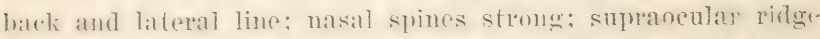
murh elevaled, with dermal flaps and two blunt spines; threes pairs of fleshy slips on nakal bomes, and two on supraveular ridgrs; smaller airri on maxillary, on preorbital, and several on lower jaw; interocenlar space rere deeply roncave; two bhint

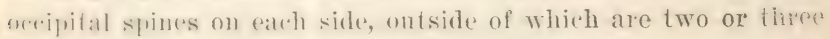
others: "1nerele small, with a bumy rilge: preopercle with two hlunt spines, helow which are one or two others; lower jaw slighly projenting: maxillary reathing beyond eye, and about hall as lome as the head peretorals nearly jeaching anal; highest

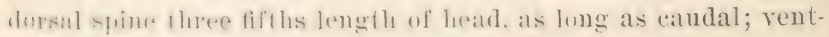
lals reaching half way to anal.

1). IV, XII-I, 12; \. 13; Lat. 1. 40; vertebrae $16+23$.

lividiste brown, mathled with darker hown, and mueh varie-

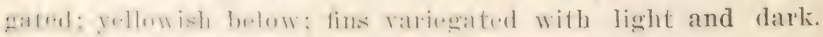

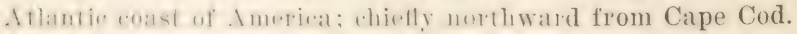

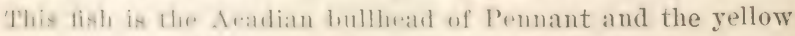
8 64 y

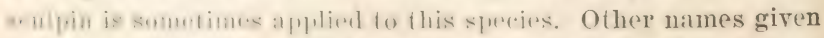

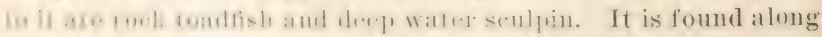
the cast const from Nova Scotia to Chesapeake bay. 
De Kay saw it very rarely. In Graresend bay, specimens have been taken by John De Nyse in April, May, October, November and December.

Tre are indebted to Captain Lewis B. Thurber, of Patchogue, for specimens, which were taken in the fall of 1884 . These were all the more remarkable for having attached to the head and back a peculiar hydroid.

In the ricinity of Woods IIole Mass. the fish is common in October and Norember, the individuals usually measuring about 16 inches; the young are rare. It grows to a length of 2 feet and is one of the most brightly colored of the marine fishes. Its colors are subject to great rariation. The head is furnished with numerous fringes and the dorsal spines are often produced into filaments. The mouth is large, the skin rough and the belly very distensible at the will of the fish, making this species one of the curiosities of the sea. It feeds upon mollusks and all other invertebrates of suitable size.

The sea raven is not eaten, though its flesh is of excellent flavor. It is useful as a scarenger and as bait for the eel and lobster.

The sea raven spawns in Norember. Eggs observed Nov. 29, 1897, were in masses adhering tightly together. The egg at that date was $\frac{5}{3}$ inch in diameter, and showed the form of the fish distinctly. Its color when first deposited is yellow but soon changes to salmon and then to amber before hatching.

Family AGONIDAE

\section{Group AGONINAE}

\section{Genus Aspidophoromes Lacépède}

Body and head more or less slender; head 4 to 6 . width 5 to 8 in length of body; eight longitudinal rows of plates, the lateral line in the upper lateral row; about 40 plates in the dorsal series. Terminal rostral plate present, unarmed; mouth terminal; teeth on jaws, vomer, and palatines. Supraocular and occipital spines absent; plates of body more or less keeled, without spines. First dorsal absent; second dorsal and amal small, opposite each other, each with four to seren rays. Ciill mem- 
branes united, narrowly joined to isthwus anteriorly, free behind.

\section{Subgenus ulciva Cramer}

:317 Aspidophoroides monopterygius (Bloch)

\section{Sea Poacher}

Cottus montofer!yius BLocir, Ichth. If, 156, pl. 175, figs. 1. 2, 17S6.

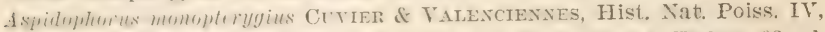
22-4, 1s?!; VI. K4, pl. 169, 1S30; DE FAY, N. Y. Fauna, Fishes, 62, pl. 2, fig. 5, 1842.

1.ppidophomides momopterygius Stoner, Rep. Ichth. Mass. 22. pi. 1. fis. 1. 1S:3); Gïntuler. Cat. Fish. Brit. MIus. II, 216, 1S60; Norre, Hist. Fish. Mass. 32, jl. YIII, fig. 1, 1867; Goode \& BeAx, Bull. Essex Inst. XI, 12, 1si!); Jordan and Gilment, Bull. 16, U. S. Nat. Mrus. 724. 1S.; (

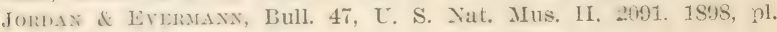
CCCXII, figs. 756, 756a, 1900.

Body rery slender, tapering, elongate, its greatest depth nearly one twelfth of total length without caudal, its greatest width about one tenth of the same length. Head iriangular, Imuch narrowed anteriorly, its length one sixth of total without caudal; nasal spines very large, diverging, inserted near tip of snout; no other spines anymere; eyes very large, longer than snout, one fouth as long as the head; supraocular ridges rery high; a ridge extending backward from eye along tempora! region; lower jaw slightly included. Caudal peduncle rery long and slemder, forming about two fifths of the length. Breast with llat plates. Dorsal ridges high anteriorly, the median line of lack from snumt to dorsal fin concave. Dorsal origin mid. way hetwern himd margin of orbit and base of middle caudal rays: hase of dorsal one half as long as the head and equal to f.rogh of serend,and longest ray. Anal immediatelyunder dorsal and warly equal to it in length of rays. Caudal convex behind, the midhle rays fwo thirds as long as the head. Ventral two fifthe as long as lwarl. Pereforal reathing to eighth plate of the

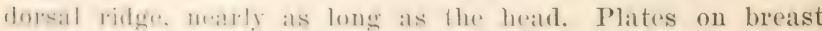
radially striate. fle two median cones larewer than the rest; a foy emall plates an himlep median part of gill membranes, and

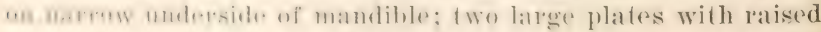
*uth.... in from of and four to cight small spineless plates in one 
or two series on base of pectoral. D. 5 or $6 ; \Lambda .5$ or $6 ; \mathrm{P} .9 ; \mathrm{V}$. I, 2; C. 10 or 11; pyloric caeca four or five; lateral line about 50.

Color brownish, pale below, with indefinite cross bands of darker, two in frout of, and one under dorsal, and two or three on caudal peduncle; rays of dorsal and upper rays of pectoral brownish, interrupted by lighter, giving an indefinite appearance of cross bands; caudal dark; rentrals and anal in hoth sexes pale.

This fish reaches a length of 6 inches; it is found in moderate depths from Greenland to Rhode Island and doubtless occurs off Long Island in suitable depths though specimens have not been recorded in New York waters. The species is very frequently obtained from the stomachs of haddock and cod, and the trawl has taken it in depths as shallow as 44 fathoms. In $187 t$ the head of a sea poacher was dredged up on the "Pecten Ground," off Watch Hill R. I. The fish exists in great abundance in Massachusetts bay and farther north.

\section{Family CYCLOPTERIDAE}

\section{Lump Suckers}

\section{Group CYCLOPTERINAE}

\section{Genus cychopteros (Artedi) Linnaeus}

Body more or less compressed toward the back, somewhat triangular in a transverse section at the first dorsal, covered with conical, rough, bony tubercles; head short, thick, subquadrangular in a cross section; snout blunt, rounded; mouth anterior, opening slightly upward; teeth simple, small, arranged in a band; eye moderate, lateral; dorsals two; caudal distinct; disk moderately large, auterior, below the head; no barbels about the mouth; first dorsal fin in the adult completely hidden by the skin, the larger tubercles of the flanks, though in regular series, having a scattered appearance. One species, reaching a considerable size, in the north Atlantic.

\section{Cyclopterus lumpus Linnaeus}

\section{Lumpfish, Lumpsucker}

cyclopterus coeruleus Mitchul, Trans. Lit. \& Phil. Soc. N. Y. I, 4S0, pl. II, fig. 7, 1815, New York Harbor.

Lumpus anglormm IDE KAY, N. Y. Faunil, Fishes, 305, pl. 54, fig. 175, 1S12; Storer, Hist. Fish. Mass. 208, pl. XXXII, fig. 2, 1867. 


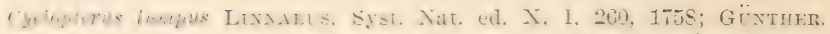

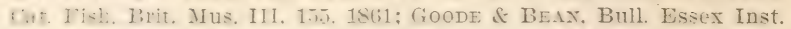

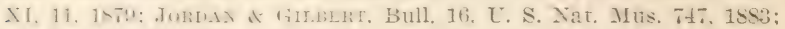
Beגx, Bull. Am. Mus. Nat. Hist. IX, ริ70, 1897; H. M. Sмmт, Bull.

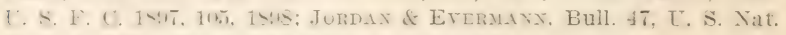
Mus. If, 2096, 1S98, pl. CCCXIII, fig. 757, 1900.

Body massive. compressud. subtriangular in transverse seetion through the midnle. lelly tlatteied, the portion hehind the abluminal chamber much compressed, and less than one half the length of the bods proprer: greatest depth of holy one half or mur than one half of total length including cantal. Caudal jeduncle short, its least depth one third length of head. Head short, subquadrangular in transrerse section, furiluad broad, flattented: length of head one fourth of total length with caudal. Vape high. snout short, broad, blunt, one fourth as long as the lead. Mouth wide, terminal, oblique, the maxillary reaching to below the front malgin of the urbit. Eye lateral, placed high, as long as the snout, aud one third as wide as interorbital space. Nostriis small, the hinder smaller, near the eses on interorbita! space, the anterior farther forward, halfway to the molith, with a short tubr. Cill opening nolerately wide, about three fifths length of head, its lower thirel in front of base of peetorai. Fins with rommlul margius, rough, with small tubercles. I'ist dersal distinet in very young individuals. variable in shapes. thick and theshy, with weak rayss in older stages; second dorsal always distinet, hootul, roumded, its urigin two and one half times as fat foom lip of suout as from hase of midale caudal rays. its lomgers ray more half as long as head. Caudal broad,

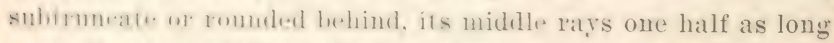

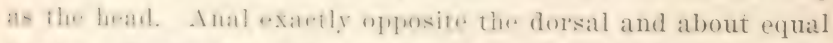

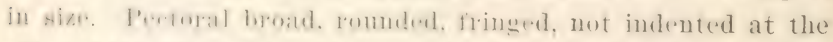

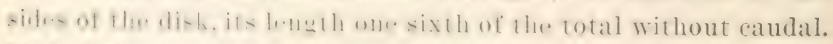

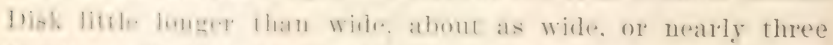
fomotis as lomg, as the hrabl. Skin thirkly rovered with small,

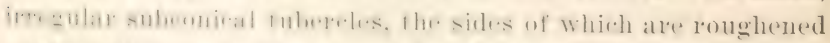
with smabl, manienl protulerances. On older individuals, larger,

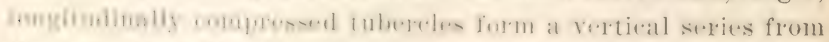

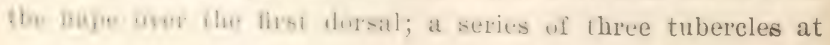


each side of the space between the dorsals; a row of larger ones extends from the supraorbital region along the flank to the upper rart of the tail; a series, starting a little abore the pectoral, passes to the lower portion of the tail; and a third lateral series reaches along each line of the lower surface from the side of the disk to the anal. The fleshy ridge enveloping the first dorsal is subject to considerable variation; it usually continues formard on the nape and becomes indefinite at the occiput. D. VI to VIII, $11 ; 1.9$ or $10 ;$ T. 6 ; P. $20 ;$ C. 12 to $14 ;$ B. 6 ; rertebrae $11+18=29$.

Colors in alcohol, brownish or olive to gravish, the tubercles darker. In life the tints rary from yellowish or greenish in the roung to more or less brilliant red in males, or bluish to dark brown in females; spots, blotehes, cloulings, or other markings are not infrequent. The young of ten take the color of their surroundings. The Kay had a specimen with the following colors: abore deep blue, becoming paler on the sides, which are tinged with jellowish beneath, approaching to red. Ventrals bright yellow, and in the spawning season, bright red. Irides yellowish. Kumlien had one with iris umber.

The lumpfish is called cock-paddle and hen-paddle in Scotland, lumpsucker, lumpfish, and sea owl in Englaud, Licorne de Mer in France. Its habitat is in the North Atlantic, on rocky shores of both coasts, south to NeW York and France. It is said to attain to a weight of 17 pounds and a length of 20 inches, but is usually much smaller. The species is rarely used for food in our country, but in Scotland it is said to be considered a great delicacy.

By means of its rentral disk it can adhere firmly to any solid substance. Pennant relates that upou throwing one of these fishes into a pail of water it adhered so strongly that upon taking hold of the fish by the tail he lifted the whole ressel containing several gallons of water.

The lumpfish is found in fraresend bas in May. It will not live longer than a few weeks in captivity. Adults are common in the ricinity of Woods Hole Mass. in April and a fer are seen 
in May. The young are very common throughout the summer in Vimeyard somnd among driftweed. Spawning oceurs in April, -mm timm in March, near the shore. After spanning the female irirms to dere water and the male guards the eggs which hatch among seaweed.

\section{Family LIPARIDIDAE}

\section{Sea Snails}

\section{Group LIPARIDINAE}

\section{Genus Neoumaris Steindachner}

This gemus difrers from Lip a r is in haring a deep notch in the dorsal fin anteriorly, separating the spines from the soft rays. The speries approach more nearly to the cottoid type, from which the liparids are descended. In general the rertebrate are fewer, the fin rays fewer, the rentral disk larger, and tbe rertical fins hetter separated than in the more degenerate members of the family. The retention of the notch between the dorsals fully justifies the recognition of $\mathrm{N}$ e oli $\mathrm{p}$ a $\mathrm{r}$ is as a distinct genus.

\section{Neoliparis atlanticus Jordan \& Evermann}

\section{Sea Snail; Lumpsucker}

Lipuris montu!ni Crvier, Reigne Anim. ed. 1, rol. 2, 227, 1S17; Jondax \&

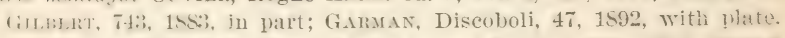

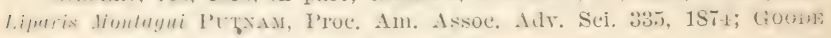
d BEAx, Bull. Essex Inst. XI, 12, 1879.

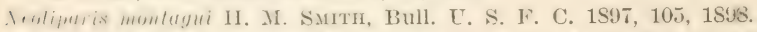

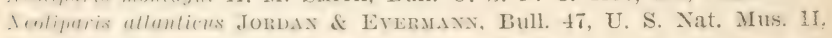
$2107,1898$.

liuly widnst at gill opening, compressed posteriorly, deepest b.luw thind dursal spine, its depth two ninths to one fourth of Hhe lolal lenghth without camblal. Heatd broader than deep,

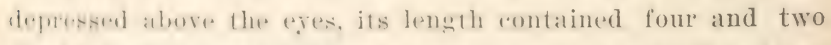

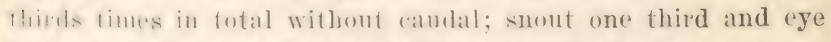
whe hifth a long as the head. Mouth natrow, its cleft transverse and revending lo anterior nostril; lower jaw included; teeth

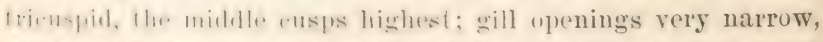

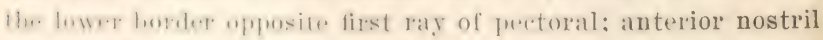

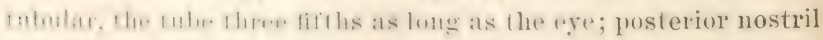
whoh of low Ilap; shin lomse, lying in fo!ds. Origin of dorsal not

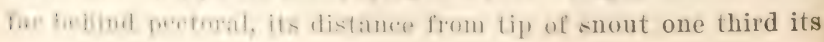


distance to base of caudal. Dor'sal with a very shallow notch, the spines nearly continuous with the soft rays; in the males much elevated, the tips thickened and membranes deeply incised; the first or longest spine as long as head; the sixth or last not quite one half as long as head; middle rays of soft dorsal one half as long as head; dorsal and anal joined to base of caudal; caudal nearly as long as head; pectoral almost reaching anal, slightly longer than head; lower rays exserted, forming a slight lobe. Ventral disk one half to four sevenths as long as the head.

D. VI, 25; A. 23 ; P. 30.

Color reddish brown, with small scattered light or bluish dots over the body; fins darker, clouded with pale, the dorsal broadly edged with darker. Described from a specimen about 5 inches long, from Godbout, Quebec, and from other specimens collected at Salem Mass., and Woods Hole Mass. (After Jordan and Evermann)

The sea snail is generally common along rocky shores from Newfoundland to Connecticut. At. Woods Hole it is not common in the shallow waters near the shores. In Massachusetts bay it is a resident of rocky bottoms among the roots of the Kelp ( $\mathrm{L}$ a m in a ria s a c c harin a), but is less frequently taken than the striped lumpsucker. Putnam recorded specimens from Salem and Nahant. The species reaches a length of about 5 inches.

\section{Genus LIPAnIs (Artedi) Scopoli}

Body rather elongate, covered with smooth skin, which is usually freely morable; head short, flattened abore; mouth horizontal, the jaws equal or the lower jaw included; teeth in several series, close set, always more or less tricuspid, the adult with the outer cusps often worn or obliterated; maxillary corered by skin of preorbital region; anterior nostrils tubular or not; ventral disk well developed on the breast, its front below or behind the middle of the head, its surface with 1:3 lobes; an anterior median lobe, and one corresponding to each of the six rays in the fin; each lobe with a horny papilla covering, which is sometimes lost; vent well behind the head, about midway 
letween the sucking disk and anal fin; dorsal fin continuous, undivisted. its spines not differentiated; caudal well dereloped; Inrsal fin free from caudal or joined; pectoral broad, procurrent all hase, emanginate and free at tips, some of the lower rays produced; rertical fins enreloped in the lax skin; rertebrae 35 to 55. Northrom seas, near the shores; the species less arctic in distributiun and. in general, inhabiting shallower water than is the case with careproctus and Paraliparis, a fact assoriated with the reduced number of rertebrae in $L$ i p a r is. The speries are numerous, but in general well defincl, their characters rarying with age. In most of the species color rarieties oceur, several having the body often marked everywere with concentric curved stripes or rings.

\section{Subgenus LIPARIS (Artedi) Scopoli}

\section{Liparis liparis (Linnaeus)}

\section{Sea Snail; Striped Sea Snail}

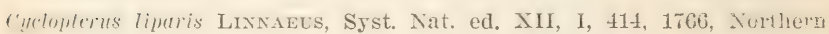
Ocean.

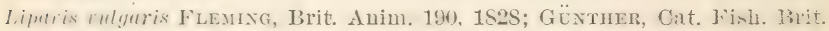
Mus. III, 159, 1S61; (inODE \& BE.x, Bull. Essex Inst. XI, 12, 159; BEAN, Bull. 15, U. S. Nat. Mus. 115, 1879.

Jipuris linetu Jorndx \& Gilbent, Bull. 16, U. S. Nat. Mus. 712, 185:.

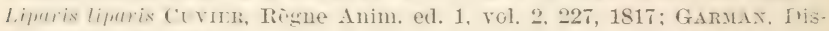
coboli, 57, 1892; JondaN \& Evermanv, Bull. 47, U. S. Nat. Mus. II, 2116, 189S; H. M. Smiтr, Bull. U. S. F. C. 1897, 105, 1898.

burly thick and subcylindric anteriorly, compressed posfrriorly, ('mveluped in an unctuous, thin, loose skin; its greatest diphth about one fiftl of the total length. Head obtuse, one fouthl of total length; nape slightly swollen. Snout broad, not depressed, moderately long. Cleft of mouth horizontal, not loalhing vertiral from front of eye; lips rather thick; upper jaw lamger I hatn lower. Buth jaws with a batnd of villiform teeth, bermming ratrllike in very latege indivinluals. Eye lateral, but

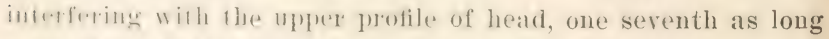
as la:al, w1 late as long as smout and wne half of width of interwhital slater. Xistril rlose hefore fye. Cill opening redued to

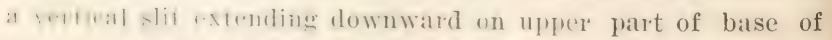

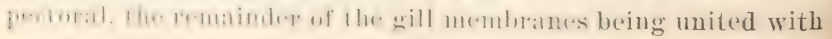


the base of the pectorals and with the isthmus. Gills $3 \frac{1}{2}$; pseuode branchiae not evident. Pectoral rery broad, extending downward and forward under the throat; the twelve upper rays reach to the rertical from the origin of the anal, the remainder gradually becoming shorter as far as the last but six, which are considerably produced. The six rays which constitute the base of the reutral disk may be easily distinguished; the disk is surrounded by about 13 soft and flat papillae. Dorsal fin commencing above middle of pectoral and slightly connected with caudal; its middle rays highest. Caudal moderately long and rounded, its rays simple, articulated. Inal origin below seventh ray of dorsal, the fin continuous with the caudal. Vent midway between ventral disk and anal fin.

B. $6 ; 33$ to $36 ; \mathrm{A}$. 27 to $29 ;$ P. 34 to 37 ; $\therefore 10$ to $14 ;$ y ylorir. caeca 10 to 16 ; vertebrae 38 to 42 .

Color very variable. Some specimens are pale yellowish brown, mottled and spotted with dark brown. Others are reddish graly, with broad, irregular black spots; fins reddish, with black dots arranged in transrerse bands. Other's, again, are brownish, with irregular darker longitudinal streaks on the head and body. (After Günther)

The species grows to the length of $J$ inches. It inhabits the North Atlantie, on both coasts, extending southward to Long Island Sound and France.

It Woods Inole Mass., aceording to Dr Smith, it is common in winter on rocky bottoms, and is found full of spawn in December and January. In Massachusetts bay it is a resident of rocky bottoms amoug the roots of the kelp. Mr J. H. Sears discovered it in the vicinity of salem, near Baker's island, in 6 feet of water. Kumlien found it fastened to kelp in Cumberland gulf in depths of 5 to 7 fathoms. It is to be noted that Kumlien's specimens had an increased number of rays in the dorsal and anal fins.

Richardson mentions this sea snail from the west side of Davis strait, in lat. $70^{\circ} \mathrm{n}$. and from Regent's inlet.

Professor Collett found the alinentary canal of one specimen filled with small amphipods, one of them being Ca p I'ella 
seretentrionalis. together with wany indiriduals of I'rotom de ia tasciata. Tr Günther found the stomach of a large specimen filled with shrimp.

\section{Group GOBIOIDEI}

(Gobies)

\section{Family GOBIDAE}

\section{Subfamily GOBIINAE}

Genus gonıosoma Girard

Body entire] naked; month moderate, horizontal; snout hlunt; fweth in sereral series, the outer row enlargesl; no canines; dorsal spines normally seren, rarely five or six; second dorsal and anal short; no barbels about head; shoulder girdle without flaps. Species chiefly American.

\section{Gobiosoma bosci (Tacépède)}

\section{Naked Goby; Nud Creeper; Oysterfish.}

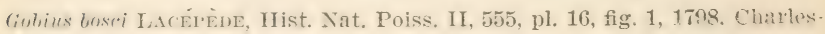
ton, S. C.

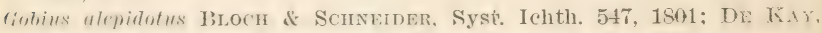

․ Y. Fatuma, Fishes, 160, pl. 2:, fig. 70, 1842, New York Harhor.

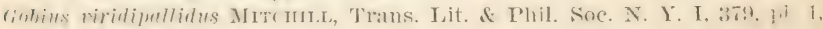
fig. 8, 1815.

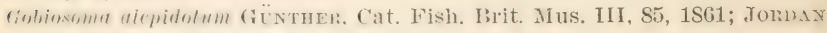
\& Gribert, Bull. 16, U. S. Nat. Mus. 638, 1883.

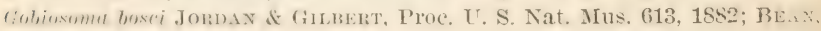

Bull. U. S. F. C. VII, 136, 1SsS; 19th Rep. Comm. Fish. N. Y. 219 , 1890; Bull. Am. Mus. Nat. Hist. IX, 370, 1897; Jordan \& Ever-

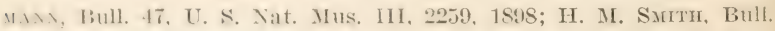
U. S. F. C. 1897, 105, 1898; BeAn, 52 d Ann. Rep. N. Y. State Mus. $109,1900$.

lion!y moderately elomgate. its depth one fifth or one sixtle

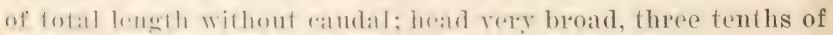

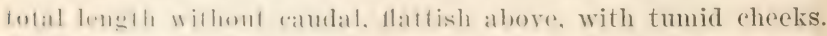
lyr smal!, lomger than suont, wne fifth as long as the head.

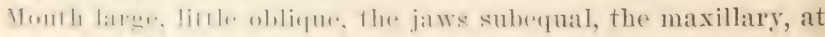

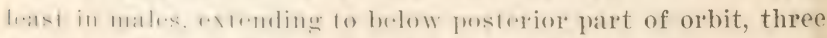

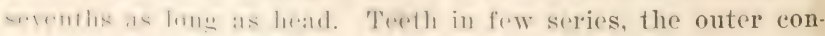

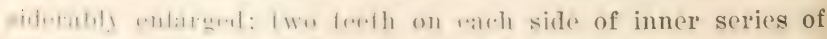

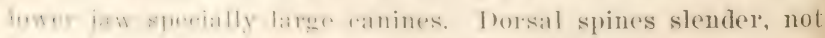
lilanentous. Caudal rounded. D. VII, 14; A. 10. 
Olivaceous or grayish, with darker cross shades of rounded spots; seren or eight paler transverse bar's over the body and tail; fins dark brown, with a bluish shade. De Kay says the body is greenish brown, with seren rertical dusky bands, and the caudal fin with two or three curved bars.

The naked gobr, or mud creeper, is found on the Atlantic coast from Cape Cod to Florida.

This is the variegated goby of Drs Mitchill and De Kay. Dr Mitchill described it as Gobius viridi-pallidus. He had specimens 21 inches long from the bay of New York, and illustrates one of them in fig. 8, pl. I, of his Fishes of New Tork.

The rentral fins of this little fish form a sucking disk of comparatively great power, as may be appreciated from the following sentence of $\mathrm{IP}^{\circ}$ Mitchill: "One of the individuals now lying before me adhered so firmly to a stone that he was lifted out of the water by an oysterman." The rariegated goby does not exceed 21 inches in length, and is now known from Buzzard's bay southward, its southern limit being undetermined. In the Gulf of Mexico oceurs a form which was set apart as a distinct species by Girard, but this may be merely a color variety. The fish has no economic value. Its name in Great South bay is mudcreeper. Numerous examples were found at the mouth of Swan creek and in Blue Point cove. Several were obtained also at Fire Island. All of these were secured late in September.

In 1901 , the young, measuring from $\frac{1}{2}$ inch to $1 \frac{1}{1}$ inches, were taken in Swan river, August 8, and on September 14 some large individuals were secured in empty oyster shells off Duncan's creek. Numerous specimens were caught in eel pots off Swan river and off Widow's creek, and the species was obtained once in fresh water in Swan river.

Taken in moderate numbers in oyster dredges at Eaton's Neck Long Island, in the fall of 1890. Several individuals lived all winter in a balanced tank, and took food greedily, but on the approach of summer all died.

On August 13, August 30, and September 16, 1887, the writer seined a few examples at Somers Point and Ocean City N. J. 
It the latter place they rere associated with $F u n d u l u s$, Cyprinodon, Lucania, Mugil, Bairdiella, A ng illa, and swarms of shrimp.

This little goby seizes its food with a snap, and immediately darts ofì to conceal itself in a rock crevice or behind plants.

\section{Group TRACHINOIDEI}

Trachinoid fishes

Family URANOSCOPIDAE

Stargazers

\section{Subfamily UTRANOSCOPINAE}

\section{Genus astroscopus Brevoort}

Iony robust. Head above not entirely corered with bone, the occipital plate ceasing much behind the orbits; from the midale line anteriorly a Y-shaped bony process extends forwam, the tips of the fork between the eyes; a trapezoidal space on either side of the Y, covered by naked skin, bounded by the Y. the ryes, the suborbitals, and the ocejpital plate. A covered furow buhind and on the inner side of earh eye terminating near front of orhits, its odges fringed. Iread rithout spines; humeral spine olsulefe: lips and unstrils fringed; no retractile tentacle in mumth. Jomng indiviruals with top of head largely corered by bume. Htand scaleless: batek and sides covered with close sent stales; belly mostly nalied. No spine before the rentrals. First dorsil small, of four w five low, stout, pungent spines, connected hy memhrame to the seend dorsal which is rather high and long: jerrorals and rentrals lange. Sureies American, distinguished frum the old Wortd genus. I ran os oopus, chirefly by the unarmed head.

\section{Astroscopus guttatus Abbott}

\section{Spotted Stargazer}

Astimsenms flultalus Aвпотт, Proc. Ac. Nat. Sei. Phila. 365, 1860, Cape May, N. J.; Bran, Bull. Am. Mus. Nat. Hist. IX, 370, 1897; Jordan ¿ Evтumx, 13ull. 47 , U. S. Nat. Mus. III, 2310, 1898.

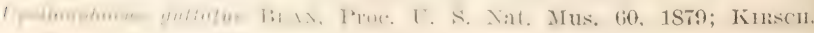
l'roce. Ae. Nat. Sel. P'hila. 264, 1889.

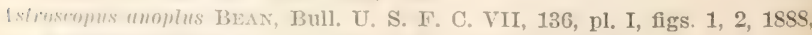
somers L'oint, X. J., not Uranoscopus anoplos C. \& V. 
Depth of body contained four times in its length in the young, three and one fourth times in the adult. Eye small, its diameter rontained five and one half times in interorbital spare. Yaled space between forks of $\mathrm{I}$ on top of head short and broad, but longer than the rertical limb of the I. which is rery short. Two distinct spinules directed forward before eye; white spots on borly rely small and irerenlat, without dark rings; hase of dorsals equaling in length the distance from front of first dorsal to tip of snout; base of first dorsal twire length of its longest spine; first spine equaling serond in length, and three times length of last. Middle caudal rays a little shorter than ventral fin. Pectoral slightly longer than rentral, two serenths of total length to caudal base, and extending to fifth anal ray.

D. IV or V, 13 or 14; A. 13; V. I, 5.

Color of upper parts of hody and lower jaw bright chocolate; belly and throat white: darker portions corered with numerous circular spots murh lighter than ground color: membrane of first dorsal blark; second dorsal white with three irregular bands of dull black obliquely across it: the raudal with three parallel bands of blackish hrown, the middle of which appears to be the continuation of a variable longitudinal band on the center of each side; the anal having a variabls haud of dull brown, darker upon the posterior termination.

If the romes stargazer identified as $I \times t r o s c o p u s$ a nop 1 us by the writer in his paper ou the Fishes of the Great Egg Harbor Bay, be identical with the $\mathrm{A}$. \& ut a tus of Abbott, the following notes will be of interest in connection with the species under discussion:

A single young individual, 1 inch long. was seined at Ocean City, August 1. The species has not previousiy been recorded from this bay.

Another example. 2! inches long. was waght at Lougport, August 26, not far from the inlet. The colors of the specimen, August 2S, are as follows: Top of head, cheeks, sides, and a narrow strip along dorsal bases, plum rolor; back, olive; lower part of head, belly, rentrals, anal, and soft dorsal, whitish; caudal, 
pale, with a fainl yellow hloth at base and a dusky streak on middle portions: spinons dowal. black; chin with a yrllow T-hapert marking. the stem of the $\mathrm{T}$ bounded on each side by a wingshaput hoteh of pmrple, which has a dark inner edge; pertoral, plum color. its lower margin whitish. D. IV, 14; A. 13. I prominent anal papilla. A low fold of skin extends from the ventrals along the median line of the helly to the anal papilla. Two slight furrows befween the eyes, with two rows of papillae along thrip inner margins. Behind these furrows are naked spares, little dreloped, but quite distinct. Nostrils survounded by a row of papillae.

The same stargazer wals caught in Gravesend bay ort. 24. 1894. Ii livel ahust a month in captivity and then was lilied by the low temperature of the water.

This stargazer inlabhits the Itlantic coast of the Tnited states from Long Island to Virginia, bui is nowhere plentiful. It has beren renerded frome Gravesend bay, X. Y., Tomplinsville X. Y. somers Point X. J., Cape May X. J. and Norfolk Val. The

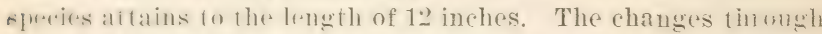
which the fish passes from youth to adult age are rather remarkable.

\section{Family batrachoididae \\ Toadfishes}

\section{Genus orsaxus Rafinesque}

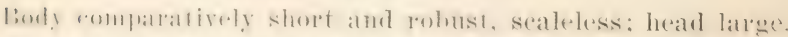

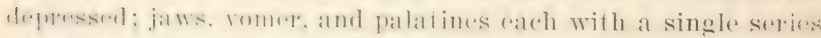
of stong blum lowh: mamlible with an additional external

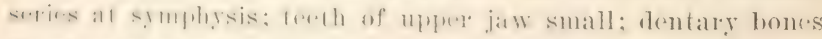

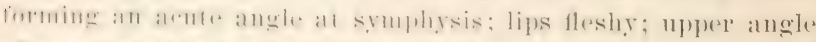

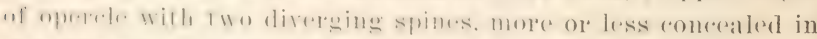

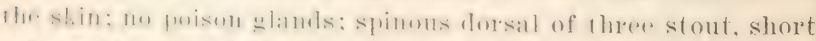

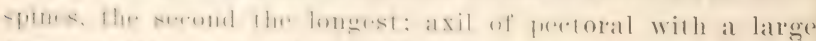

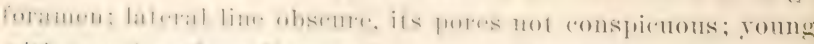
wilh a series of small, lufted rirri on hate and sides; branchi

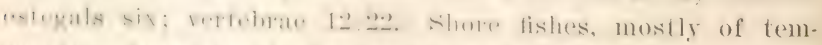

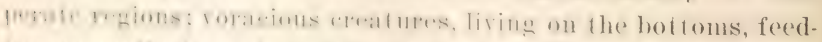

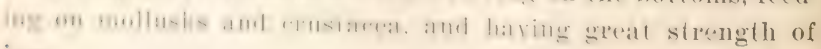
jaw. 


\section{0psanus tau (Linnaeus)}

Toadfish; Oysterfish

Gadus tau Linnaeus, Syst. Nat. ed. XII, I, 440, 1766, Carolina.

Lophius bufo Mitchild, Trans. Lit. \& Phil. Soc. N. Y. I, 463, 1815, New York.

liutrachus celatus DE K.ı., X. Y. Fama, Fishes, 170, pl. J0, fig. 14i1, 1812. New York.

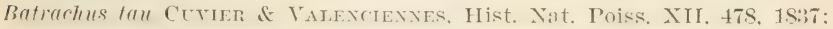
DE KAx, N. Y. Fauná, Fishes, 168, pl. 28, fig. 86, 1812; Güntiner, Cat. Fish. Brit. Mus. III, 167, 1861; Storer, Hist. Fish. Mass. 105. pl. XIX, figs. 1, 2, 1867; Goode \& BEAN, Bull. Essex Inst. XI. 11. 1879; BeAN, Bull. U. S. F. C. VII, 135, 1885; 19th Rep. Comm. Fish. N. Y. 249, 1890.

Body robust, naked, its depth ahout one fourth of the standard length; depth of caudal perduncle one fourth length of hearl; head broad, its length about one third that of the body with head; mouth large; jaws strong. armed with blunt teeth; well developed teeth on romer; long diancter of "ye one third length of mandible; a broad flap above orbit: tip of maxillary, lower side of mandible, and margin of prenperele fringed with cirri; subopercle ending in a sharp spine: first dorsal small. placed orer base of pectorals; socond dorsal long. its hase about one half of total length withont caudal; pertorals broar, the width of their base equaling one half length of head.

D. III, 26-28; A. 24.

Color dark olive; under parts lighter' blark markings on sides forming irregular hars: manp pale or yellowish spots on body: soft dorsal, anal, pectoral, and caudal fins with light cross bands formed of light colored spots.

In some parts of the south this species is known as the oysterfish, from its habit of liring in dead orster shells. The toadfish ranges on our east coast from Cape Cod to the Gulf of Mexico. The fish is said to grow to the length of 15 inches. It is a voracious species, feeding upon other fishes, and upon shellfish, crabs and other crustacea, annelids, etc.

On rocky bottoms it oceurs miler stones. and on sandy and muddy areas it frequents loralities abounding in relgrass. The toadfish lies in concealment for its prer, and darts out quickly to effect a capture. Its breeding season is during the summer 
momths. The habits are fully described by setore in the Fishes

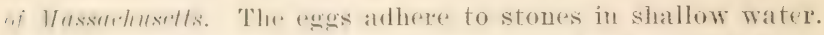

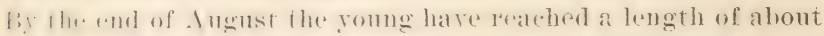
oll. inch. The nest and young are gualeded by the parent fish. The spereiss is not an attractive one, and though the foesh is swref amd palatable it is rarrely aten. To the fislermen this is

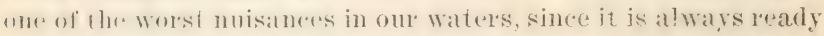
10 talie the hook and swallow the bait intemeded for more useful fish. In fireat Fouth hay the toaldish was talifu at lye mouth of kiwan rereliand in Blue P'oint rove late in Geptrmber. Young individuals were rollected september 10 at the Blar. Point Lifesaving station.

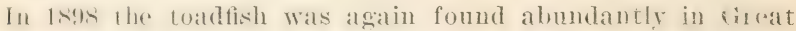
fomth bily in August and september. They ate distributed in all portims of the haly. (2xeret where the water is meary fresh. In 191111 hr. ages were foumd upon the point of hatringe in thr. midlle of . July and in the month of August. On July 1ti, a lot of ("mbryos measmeing from $\frac{3}{16}$ to $\frac{1}{16}$ of an inch were ob

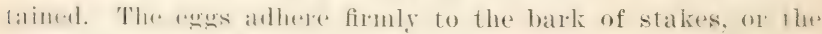

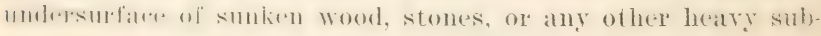
stance which will answer the purpose of concealment.

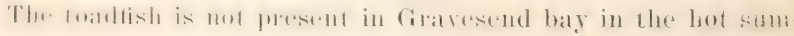

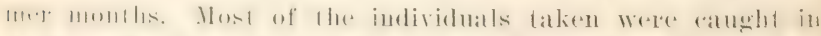

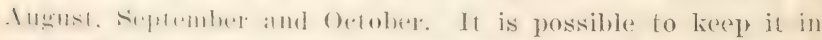

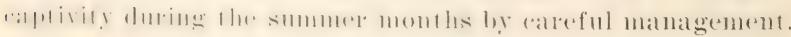

\section{Group BLENNIOIDEI \\ Blonnylike Fishes \\ Family BLENNIIDAE Blemics}

\section{Gemus Brenvius (Artedi) Linnaeus}

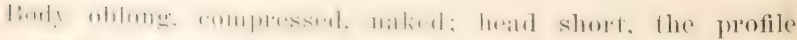

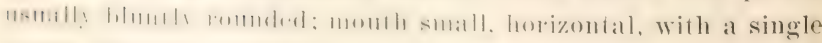
srries of long, slender, curved, close set teeth in each jaw, lusiules which, in the lower jaw at least, is a rather short and stom fanclilie camine toolh on each side; premaxillaries not

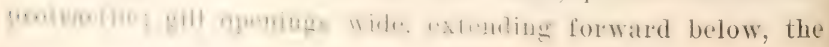


membranes free from the isthmus, or at least forming a broad fold across it. Dorsal fin entire, or more or less emarginate, the spines slender; pectorals moderate; ventrals well developed, I, :3; no pyloric cacea; lateral line developed anteriorly. Species numerous, lurking under rocks and algae in most warm seas; some species in the lakes of northern Italy. The European species in general are larger in size than ours, with higher fins.

\section{Blennius fucorum. (Cuv. \& Val.)}

\section{Seaveed Blenny}

Blemius fucorum Cuvier \& Valexcrences, Hist. Nat. Poiss. XI, 263, pl. 324, 1836, 240 miles south of Azores; DE KAY. N. Y. Fauna, Fishes, 149, pl. 22, tig. 66, 1812, in seaweed, not fax firom New York coast; Güntiler, Cat. Fish. Brit. Mus. III, 217, 1S61; Jordan \& Gilbert, Bull. 16, U. S. Nat. Mus. 759, 1883; Jordan \& Evermanx, Bull. 47 , U. S. Nat. Mus. III, 2379, 1898.

Blcunius oceanicus Cuvier \& VAlenciennes, op). cit. 265, 1836, open Atlantic, $29^{\circ} \mathrm{N}$., $50^{\circ} \mathrm{W}$.

The length of the body is five times the length of the head; orbital cirri nearly as long as head, bifid above, and with fringes at the base; dorsal fin slightly emarginate, free from the caudal, the spines rather stiff. Ilead very short and deep, its profile nearly vertical; 24 teeth in each jaw; both jaws with very strong canines. Gill membraues free from isthmus posteriorly. Fyes very large, one third as long as head. I). XI, 17; 1. 18.

Color olive green, becoming darker above, with numerous brown spots on cheeks and sides of hody; below faintly reddish; dorsal with a large black spot in front, behind which are some smaller spots; spinous dorsal edged with paler.

The seaweed blenny was obtained by D. Kay in a voyage from Constantinople to Tew Tork in 18:31. IIe met the species swimming about searreed not far from the coast of New York and made notes of it at the time, considering it as either a young individual of some larger speries or undescribed. This specimen was not more than $1 \frac{1}{2}$ inches long. The type of the species was taken south of the $A$ zores. The coloration as stated by De Kay is as follows: "Soiled greenish, changing to brownish above, with numerous brown spots on the cheeres and side of the body; 


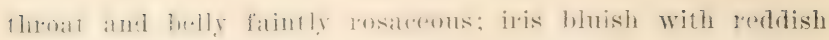
points radiating about the pupils."

The largest specimen recorded is $2 \frac{1}{2}$ inches long.

\section{Genus chasmodes Cur. \& Val.}

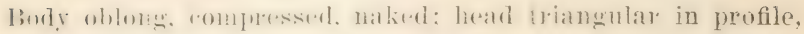

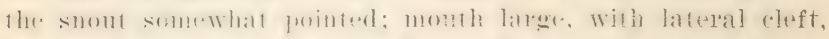

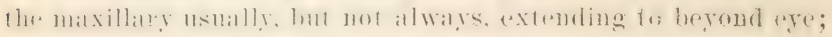

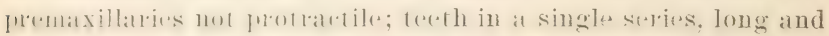

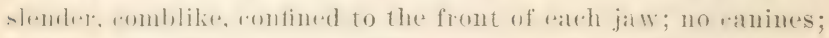
r irri very small or wanting; gill ojunings very small. their lower reler alowe the mithle of the base of the peretorals; lateral line

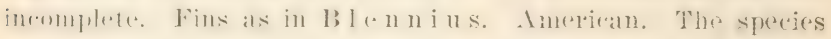

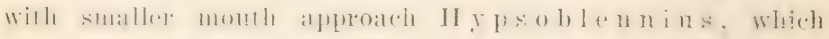
genus is not far separated from $\mathrm{Chasmodes.}$

\section{Chasmodes bosquianus (Lacépède)}

\section{Banded Blenny}

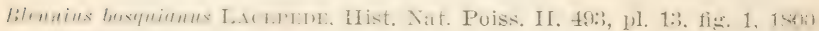
South Carolina.

Blennius photis Mrtemld, Trans. Lit. \& Phil. Soc. N. Y. I, 374, 1815.

thasmorles boscianus Guxtner, Cat. Fish. Brit. Mus. III, 229, 1861.

Chasmoules bosrniunus Curmer \& VAlexcmennes, Hist. Nat. Poiss. XI, 29.

pl. :32

Tew York Harbor; Jordan \& Gilbert, Bull. 16, U. S. Nat. Mus. 750.

1853; Jomdan \& Everimann, Bull. 47, U. S. Nat. Mus. III, 2394, 1898.

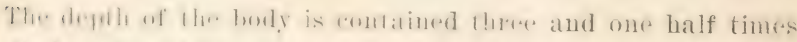

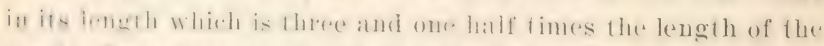

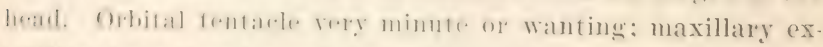

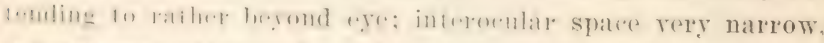

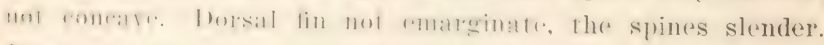
Dorsal joincd to base of caudal; anal free. D. XI, 19; A. 20.

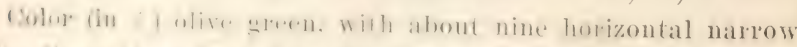

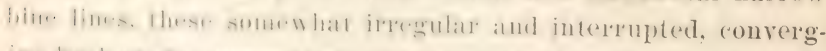

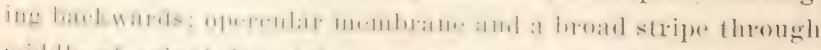

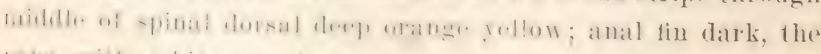

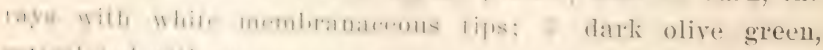

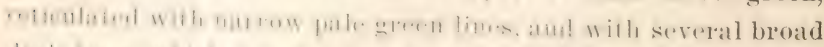

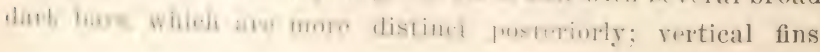


similarly marked; head finely dotted with black; a dusky spot at base of caudal in both sexes. New York to Florida.

Mitchill found a specimen of this little blenny in an oyster, and described it under the name Blennius pholis. Another specimen was sent to Cuvier from New York, and a specimen in the Lyceum in New York, described by De Kay, was obtained from New York harbor. This blenny is common southward in shallow water. It seldom exceeds the length of $3 \frac{1}{2}$ inches.

\section{Family XIPHIDIDAE}

Rock Eels

\section{Genus phours (Gronow) Scopoli}

Body long and low, considerably compressed, somewhat bandshaped, the tail slowly tapering; head small, compressed, naked; mouth rather small, oblique; jaws with rather small teeth in narrow bands or single series; romer and palatines usually toothless; gill membranes broadly united, free from the isthmus; scales very small, smooth; no lateral line. Torsal fin long and Iow, beginning near the head, composed entirely of stiff, sharp, subequal spines; anal similar in form, of two spines and many soft rays; caudal fin short and small, more or less joined to dorsal and anal; pectorals short, rather shorter than head; ventrals very small, of one spine and a rudimentar ray; intestinal canal short, without careca. Shore fishes of the Norther'n seas.

\section{Pholis gunnellus (Linnaeus)}

\section{Butterfish; Rock Eel}

Blennius gumnellus Lixidaeus, Syst. Nit. ed. X, I, 25̄, 1758, Atlantic Ocean.

Centronotus gunnellus Llocir \& Scmverder, Syst. Ichth. 16it, 1S01; GüNther, Cat. Fish. Brit. Mus. III, 285, 1861.

Ophidium mueronatum Mitchuct, Traus, Lit. \& Phil. Soc. N. I. I, 2-49, pl. 2, fig. 1, 1815.

Gunnellus mucronatus De KAY, N. Y. Fauma, Fishes, 153, pl. 12. fig. 3ti. 1842, New York Inarbor; Stoner, Hist. Fish. Mass. 14, 11. Xlil, fig. $2,1867$.

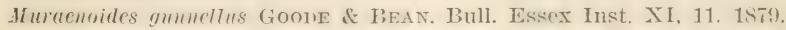

Pholis gunnellus BEגx, Bull. Am. Mus. Nat. Hist. IX, 3T0, 15!t̆; II. M. Simtir, Bull. U. S. F. C. 1897, 106, 1898; Jordan \& Evermann, Bull. 47, U. S. Nat. Mus. III, 2419, pl. CCCXLII, fig. 832, 1900. 


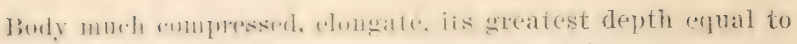

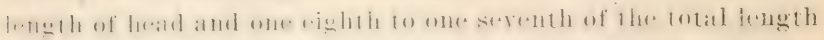

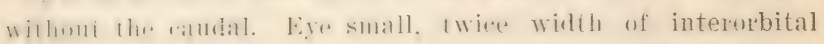
spate. and whe fifth lomgh wh heat. Maxillary une thind as long

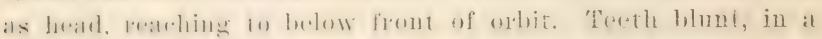

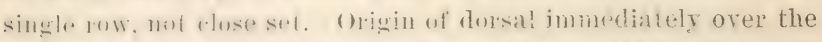

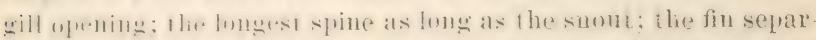

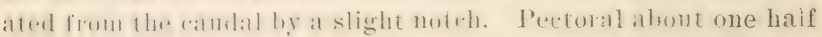
as long as head, rathing to below sixih spinc of dorsal. Fentral minute. D. LXXVI to LXXXV; A. II, 38 to 44; V. I, 1; P. 12 .

color glayish or brownish, with a series of oval rertical dusky rings on the sides: abdomen grayish white. tinged with sollow: Anssil fin glay, with about 1.4 black iertival distant

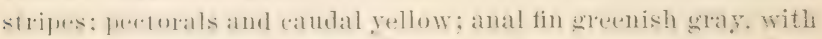
alternate darker stripes; iris white.

This tish rearlars the length of 12 inches. It is found in the North Mlante from Labrador south to cape coel and from for. way south to France.

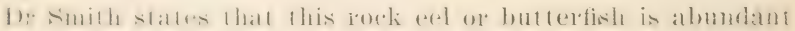

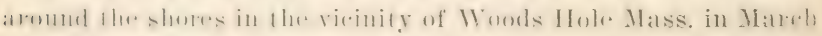
and. pril, hut is rare at other times. It may be taken in Tine yaml simml with a dmelge at almost any seasum at a depth of 1 or 5 fathoms. It oceurs only on gravelly bottoms.

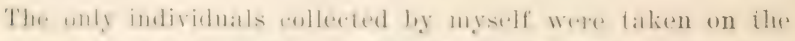

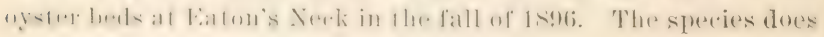
not live long in eaptivity.

On June 6, 1899), Captain H. E. Swezey obtained a few

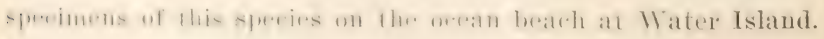
Mitchill deseribed the rock eel or butterfish (O p hid i um m 11 c r o 11 a t 14 m) in Trans. Lit. \& Plill. Soc. N. Y., I, 249, pl. II,

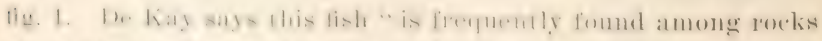

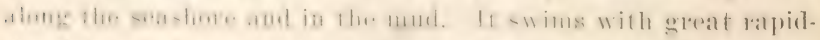

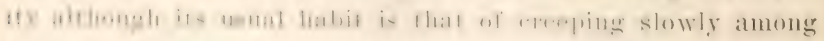
perclis, in which it is probably assisted by its spiny ventrals. It abmunds in liobyn's reef, in the harbor of New York." 


\section{Subfamily STICHAEINAE}

\section{Genus unvaria Jordan \& Evermann}

This genus is very close to $\mathrm{Eumesogram} \mathrm{mus}$, from which it differs in the absenee of the lowermost or third lat teral line, the median line being bifurcate.

\section{Ulvaria subbifurcata (Storer)}

\section{Radiated shanmy}

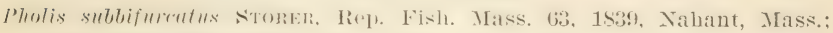
Hist. Fish. Mass. 92, 1867; DE KAY, N. Y. Fauna, Fishes, 150, 1812. E'umesumrammus subbifurutus fioole of BFAx, IBull. Essex Inst. XI. 10, 1879; Jordax \& Gilbert, Bull, 16, U. S. Nat. Mus. 775, 1853.

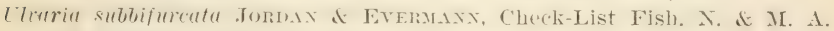
475, 1896; Bull. 47, U..S. Nat. Mus. III, 2440, 1898, pl. CCCXLY, fig. 842 .

Body moderately compressed, fusiform, its greatest depth about one fifth of the length without candal. Head moderately large, narly one fourth of total length without eaudal; mouth large. the maxillary atrending to below the middle of the eye, the jatws equal in fromt; "ye large, a little longer than the snout, one fourth as long as the head. Ihorsal origin at a distance from tip of snont ergual to leugth of head; longest spines abont in the middle of the fin two fifths as long as the hrad; first spine two thirds as long as the ere. Caudal rounded, its midrle rays one half as long as the head. Anal origin muder the 14 th spiue of the dorsal, the fin not exteuding to the caludal, its longest ray one third as long as the hearl. I'ectoral cixtending slightly fast the vertical from the ninth spine of the dorsal, its length one sixth of total without caudal. Ventral in advance of dorsal origin, three eightlos as long as head. Batrk somerbhat archerl; ventral outline nearly straight. Median

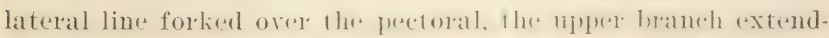
ing about as falr hatek as the extemeled fuetoral. Fiales rery small.

D. XLIV; A. 2S to $30 ;$ V. I, $3 ;$ P. 14.

"Color, abore redelish brown. ()perele and preperele ger lowish. Light cololed r.irenlat faltehes along the hase of the dorsal fin; beneath the lateral line lighter. Abolomen rellowish 
white. From bemeath the eyt a broatl black band. which is

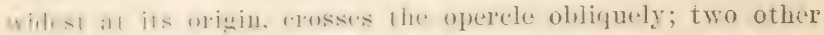

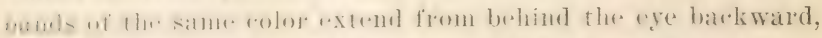

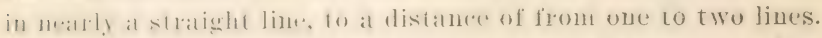

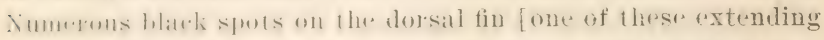

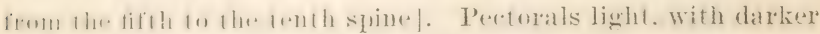

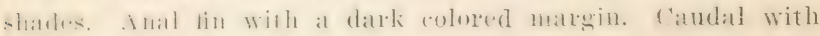

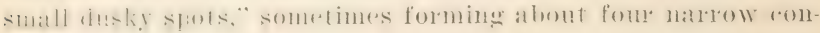
centric bar's.

The fish reaches the length of about 6 inches.

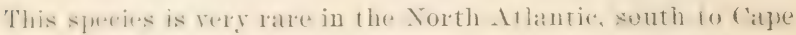

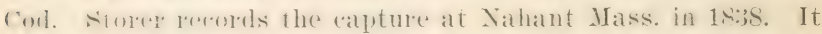

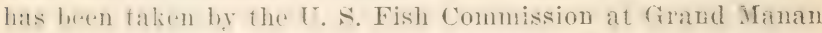

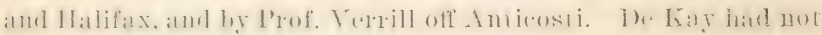

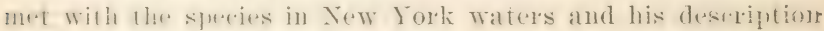

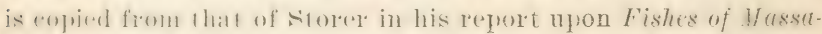

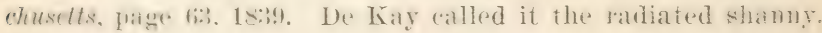
Its occurrence in New York waters remains to be noted.

\section{Genus stromatus Reinhardt}

liody monlerallely womgate, fovered with small seales; terelh

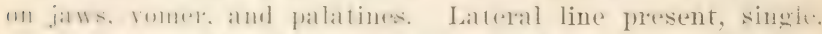
mmming alomg silk of back; pectorals and rentrals well derol-

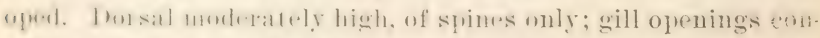
finm-d furwarel below, the membranes seareely united to the isthmus; pyloric eaeca present. Arctic seas.

\section{Stichaeus punctatus (Fabricius)}

\section{Spotted Blenny}

filennias pmetulus Faßnicros, Fauna Grönl. 15̄3, 17so, Greenland. Clinus muctulus Ricindioson, Fauna Bor.-Amer. III, SS, 1836.

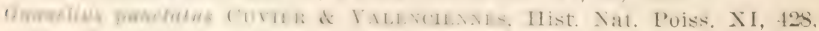
Is:iti.

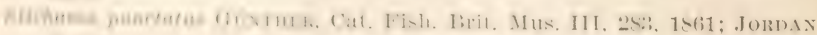
Nillmim, Bull. 16, U. S. Nat. Mus. 775, 1S83; Jordan \& Eversanx, Iinll. 47, U. S. Nat. Mus. III, 2439, 1S98, pl. CCCXLV, fig. $\$ 41,1900$.

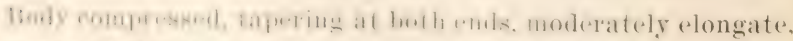

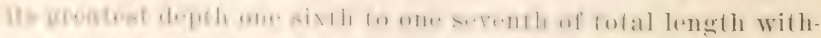

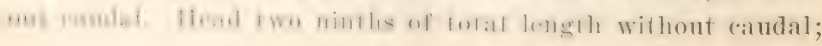


mouth moderate, the maxillary extending to below front of pupil, one third as long as head, the lower jaw slightly shorter than upper; eye small, one fifth as loug as head; snout slightly longer than eye. Dorsal origin over top of gill opening; dorsal fin subcontinuous with the caudal, its longest spine two sevenths as long as the head. Caudal fin rounded in adult (emarginate in young), the middle rays two thirds as long as the head. Anal origin under 17 th spine of dorsal, the fin well separated from the caudal, its lougest ray one third as long as the head. Pectoral extending to below the 14 th spine of the dorsal, its length one sixth of the total without caudal. Yentral nearly under dorsal origin, one third as long as the head. Back little arched; ventral outline also arched. Lateral line single, in the upper fourth of the hight of body, and ending about the middle of the total length including caudal. Scales small, but larger than in Ulvaria subbifurcata. D. XLVIII to L; A. 32 to 36 ; V. I, 3 ; P. 15.

Color bright scarlet, the cheeks with five or six small dark blotches; smaller dark blotches on opercle and interoperele; a dark streak from snout through eye and extending behind the eye; five roundish dark spots, about as long as the eye, each with a white band near its upper margin, on the dorsal fin at almost regular distances apart; the anal fin with eight to ten narow oblique crossbars; caudal with about six narrow, concentric, dark rings.

This blenny inhabits the Arctic seas from Greenland to North Siberia, south to Bristol Bay and Cape Cod. Joung individuals were found in considerable numbers in Plorer bay, Siberia, and at Cape Lisburne, Alaska. The species grows to the length of about 7 inches. The young are so different in appearance from the adult that they have been described as the type of a distinet genus. The occurrence of the species in New Iork waters is very doubtful.

\section{Genus mumpenus Reinhardt}

Body greatly elongate, moderately compressed. corred with small scales; lateral line indistinet or olssolete; head long; snout 
short; no cirri; "yes large, flaterl high: moulh moderate, with a single row of rather small conic teeth on cach jaw, palatine in fhesent or alsent: will openings prolonged forward below, lery narrow ty mitnd anteriorly to the isthmus, not forming a fren fold atross it: dorsal composed of numerous sharp, flexihl. Father high spines: raludal tin long; anal many-raged; juetorals large, more than one half length of learl, the middle

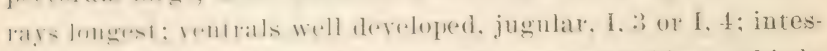

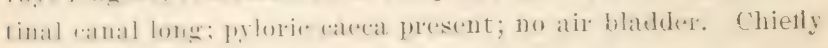
herbivorous. Northern seas.

\section{Subgenus Leptontexrus Gill}

:3:! Lumpenus lampetraeformis (Walbaum)

Eel Blenny; Snakefish

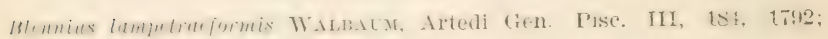
Iceland.

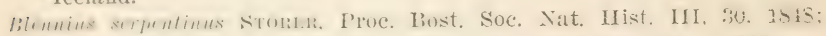
Massachusetts Bay; Hist. Fish. Mass. 91, pl. XVII, fig. 1, 1867.

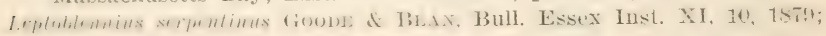

Massachusetts Bay; Jordan \& Gilbert, Bull. 16, U. S. Nat. Mus.

$778,1853$.

Stichnens islandiens Güxtmer, Cat. Fish. Brit. Mus. III, 281, 1861.

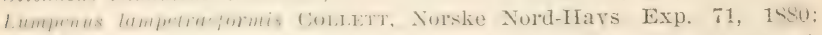

Joltpax it GILBERT, Bull. 16, U. S. Nat. Mus. 778, 1883; Jordan \&

Evimany, Bull. 47, U. S. Nat. Mus. III, 2438, pl. CCCXLIV, fig. 810. 1898.

The drepth of dhe hody is one fifternth of the length, which is

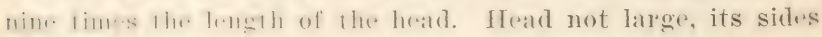

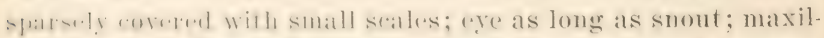
lar! reathe fromt of pupil: gill openings rxtending forware

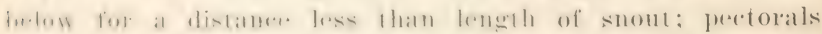
lume, seren wiphths lenghli of head: ventrals molerate, two and two thirds in lead. D. LXXV; A. 50; V. I, 3.

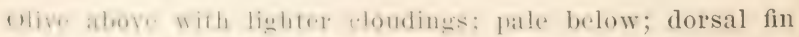

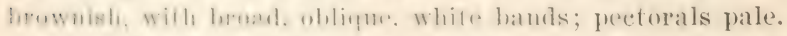

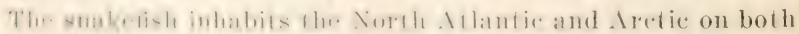

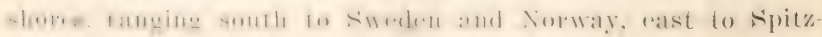

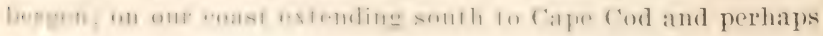
long Island. It is at common resident of the deep waters of Massathuseffs baty, where it is a farorite food of the cod and 
halibut. The species grows to the length of 12 to 15 inchess. Other names for it are eel blenny and suake blenny. No record of its occurrence in New York waters has yet appratred, but it may be found in moderate depths off Long Islaud.

\section{Family CRYPTACANTHODIDAE}

\section{Wrymouths}

\section{Genus Cr.p'TACANThodes Storer}

Body long and slender, compressed, naked, without lateral line; head cuboid, with rertical cheeks and conspicuous muciferous eavities; eyes small, placed high; mouth large, rery oblique, the rery heary lower jaw prominent in front; jaws, romer, and palatines with stoutish conir teeth, in fur series; gill openings prolonged forward belew, narrowly attarled to the isthmus; dorsal fin of stoutish spines, hidden in the skin; dorsal and anal joined to caudal; pectorals short; rentrals wanting.

\section{Cryptacanthodes maculatus Storer}

\section{Ghostfish; Wrymouth}

(ryptacunthodes murulutus Storer. Ti(). Fish. Mass. 2S. 1S39; Hist. Fish. Mass. 34, pl. VIII, fig. 6, 1S67; DE KAY, N. Y. Fauna, Fishes, 63, pl. 18, fig. 50, 1842, from Massachusetts specimen; Linsley, Am. Jour. Sci. Arts, XlviI, 60, 1844. Long Island Somnd; Gürmer, Cat. Fish. Brit. Mus. III, 291, 1861; Gooot \& BeAN, Bull. Essex Inst. XI, 10, 1879; Jordan \& GILbert, Bull. 16, U. S. Nat. Mus. 780, 1883; H. M. Sмптн, Bull. U. S. F. C. 1897, 106, 1898; Jordan \& Everalann, Bull. 47, U. S. Nat. Mus. III, 2443, 1898, IV, pl. CCCXLV, fig. 843, 1900 .

The depth of the body is one thirterenth of the length, which is six and one half times the length of the heat. Eyes small, placed high, not so wide as interorhital space. which has two ridges and three pits; orbital rim raised; two deep pits behind ere at the temples, a deepere pit on top of head between them; a raised ridge eontinued backwarl on rath side of heat behind orbital rim; maxillary extending to beyond eye: psendobram hiate small; pectorals short, three in head. their lips reathing beyond front of dorsal; vent a little in front of the midlle of the body.

D. LXXIII; A. 50.

Light brownish, wihl sereral series of smallish dark spots, arranged in more or less regular rows, from the heart to the 
hase of the ramial: rertical fin rosels spotter with darker; hwad abowe thirkly spreliled: body sometimes ("inoinatus") "udiwly immatrilalt. The wrymouth or ghostfish has been taken

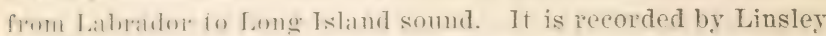
in his rat:ilogut of the Fishes of Commecticut. The species grons fo a lelleth of 24 inches or more. Areording to Dr Smith, it is rery rape af Wouls IInle Mass. I sperinen from Woods Mole, now in the National Musemm. was taken about 1875. Sep. 18 ,

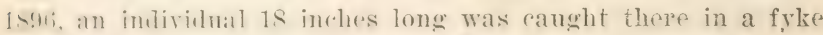
net set in rerrat harhor. In Massathusetts bay the fish is also rather rare. Storer. in his Mistory of the Fishes of Massachusetts. 1sit. mentioned seren sperimens: one from Nahant, one from borkhester, one form Provinceiown, three from Massachusets haty; the serenth was from a beach in Nora Seotia. The T. S. Fish Commission eollerted seren specimens on the coast of Mass arhusells prerious to 1879. There is an albing form of this fish. of whirh four individuals were known prior to 1879. One of Hhrse was ohitimel at Mathlehrad and another at Swampsentt.

\section{Family ANARHICHADIDAE Wolf Fishes}

\section{Genus avarmoms (Artedi) Linnaeus}

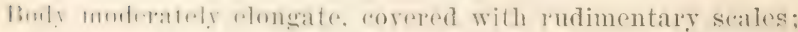

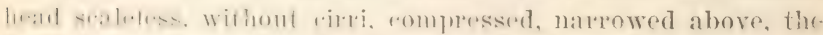

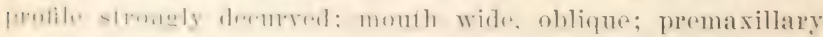

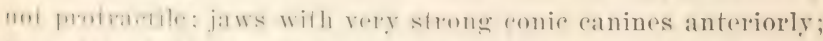
l.tedal we.th of hom jaw either molars or with pointed tuber-

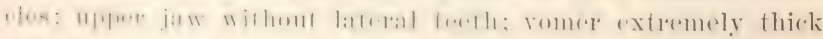

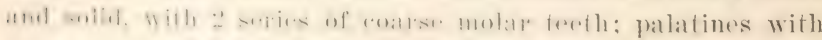

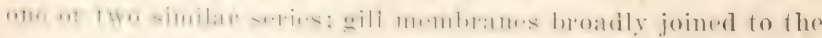

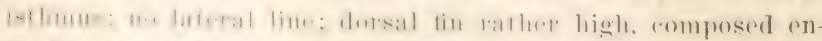

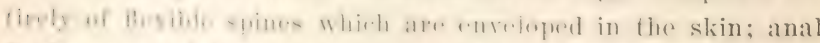

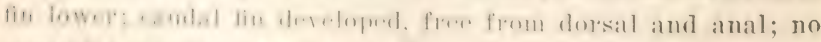

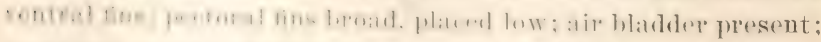
no pylorie racen. Northern seas. 


\section{Anarhichas lupus Linnaeus}

Wolf Fish

Anarlichle lupus Linnaeus, Syst. Nat. ed. X, 247, 1758; H. M. Smith. Bull. U. S. F. C. 1897, 106, 1898; JordaN \& EverMaNN. Bull. 47. U. S. Nat. Mus. III, 2446, 1898; IV, pl. CCCXLVII, fig. 846, 1900.

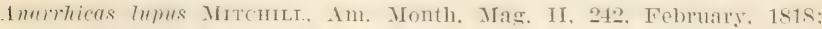
Storer, Rep. Fish. Mass. 69. 1S39: De K.1Y, N. Y. Fauna, Fishes, 15S, pl. 16, fig. 43, 1842. Anarrhichas lupus GoodE \& BEAN, Bull. Essex Inst. XI, 11, 1879. Anarhirhas mmerimus Storer. Hist. Fish. Mass, 9?, nl. XTIII, fig. 1. 19fit.

The depth of the body is contained five and one half times in its length. which is six times the length of tlie hearl. IIaxillary reaches beyond orbit; band of romerine teeth extending much farther back than the short palatine band; pectorals large. rounded, two thirds length of hearl; dorsal high, beginning orer the gill openings, its longest rays about half length of head.

D. LXII; A. 42.

Brownish; sides with numerous (9-12) rery dark transverse bars, which are continued on the dorsal fin. besides numerous dark spots and reticulations; fins dark; candal tipped with reddish.

This is the sea wolf of Mitchill. mentioned by hin in the American Monthly Magazine, v. 2, p. 242. De Kar writes of the species as follows:

The voracious and savage character of this fish is manifest in the formilable array of treth with whirh he is provided, and by his ricious and pugnacious propensities when first drann from the water. . He is known under the various fopular names of eat. wolf fish, and sea cat. Tis ill-faroled aspeet causes him to be regarded with aversion hy fishermen. hut his flesh is br no means msaroly: when smoled it is said to have somewhat the flaror of salmon. He prefors rockr eoasts and is said to spawn in Mar. Tot unfrequentls taken off Rockaway beach, as I am informed, in company with the common (orl. This I suppose to be the most extreme sontherly limit ret obserred. In high northern latitudes it is said to attain to the length of 6 and 8 feet.

In the deep waters of Massarhusetts bay it ocruls frepuently. approaching the shore, particularly in winter. In Vinerard sound it is quite rare and has been taken late in fall in traps 


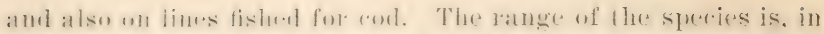

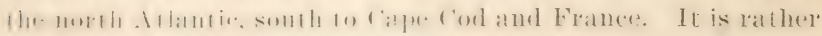

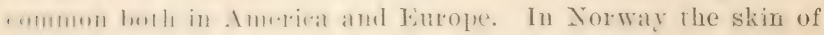
the fish is tanned and makes a very good leather.

\section{Group OPHIDIOIDEI \\ Eelpouts}

Family ZOARCIDAE

\section{Genus zoarces Gill}

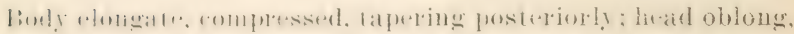

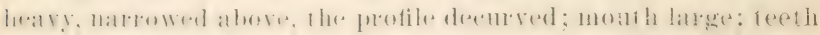

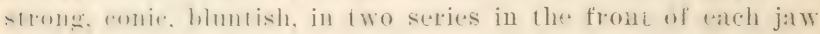

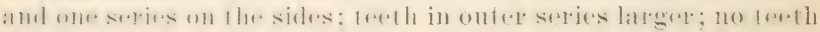

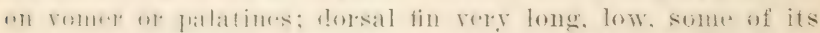

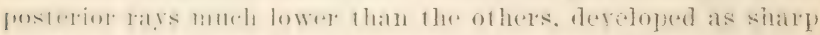

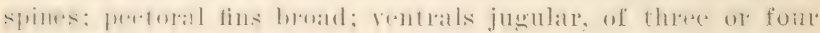

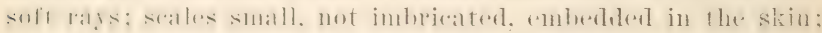

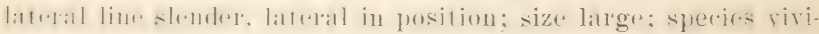

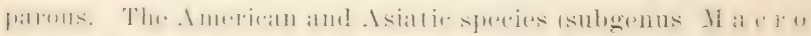
zo a recs) difler from the European type of Zoarees

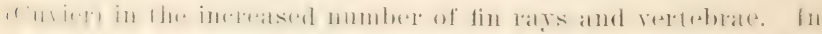
\%

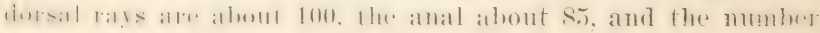
f) vertehrate is joportionally diminished.

\section{:3:2 Zoarces anguillaris (Peck) \\ Uuttonfish:; Ling; Eelpout}

Bimnins anguillaris PEck, Mem. Am. Ac. Sei. II, 46, figure, 1804, New 11:ampshire.

litemius ciliatus. Mrtentr., Trans. Lit. \& Phil. Soc. N. Y. I, 374, pl. I, fig. 6, $1 \mathrm{s1.1.}$

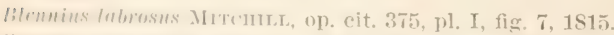

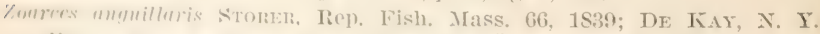
Fanma, Fishes, 15., pl. 16, fig. 15. 1812; Gütmen, Cat. Fish. Brit. Mrus.

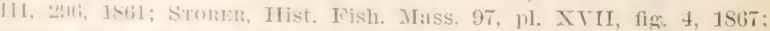

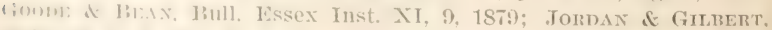

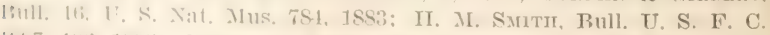

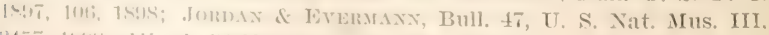

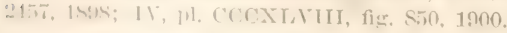

The defoll of the hody is one seventh of the length, which is six times the lometh of the head. Maxillaty reaching beyond 
orbit; pectoral long, about two thirds length of head; ventrals one fifth head; highest ray of dorsal about equal to snout; the posterior spines about one third length of eye; first ray of dorsal above preopercle. D. 95, XVIII, 17; A. 105.

Reddish brown, mottled with olive, the scales paler than the skin about them; dorsal fin marked with darkire; a dark streak from eye across cheek and opercles; lower jaw included.

This fish grows to the length of about 3 feet. De Kay noticed it most abundantly in the New York market in February and March. He states that it is caught on the coast in company with the common cod. It feeds on various marine shells and affords a very sarory food. At the time of his writing it was called by the fishermen ling and conger eet. De Kay employed for it the English name eelpout. Fishermen who go out for cod off Sandy Hook at the present time catch this fish in large numbers and know it under the name of muttonfish. The range of the fish is from Labrador to Delaware. It is rather common north of Cape Cod. Dr. Smith says it is abundant in the fall off Gayhead and Cuttyhunk; it is caught while line fishing for cod on rock bottom and occasionally late in fall in Vineyard sound, off Great harbor, on lines baited for tautog. In Massachusetts bay it is a common resident of deep water, frequently approaching the shore.

\section{Family OPHIDIDAE}

\section{Genus Rissola Jordan \& Evermann}

This genus contains species agreeing with $\mathrm{Ophidion}$ in general characters, but with the air bladder short, broad, spherical or kidney-shaped, with a posterior foramen. Species chiefly of the Mediterranean.

\section{Rissola marginata (De Kay)}

\section{Slippery Dick}

Ophidium marginatum DE KAY, N. Y. Fauna, Fishes, 315, pl, 52, fig. 169, 1812, New York Harbor; BaIRd, Ninth Ann. Rep. Smith. Inst. 351, 1855; Jordan \& Gilbert, Bull. 16, U. S. Nat. Mus. 792, 1S53; Be.1., Bull. U. S. F. C. VII, 135, 1888.

Rissola marginata JoRdan \& EvERMANN, Check-List Fish. N. \& M. A. 4S:3, 1896; Bull. 47, U. S. Nat. Mus. III, 2489, 1898; IV, pl. CCCLIII, fig. 868, 1900; Bean, Bull. Am. Mius. Nat. Hist. IX, 370, 1897. 


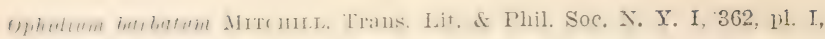
fig. $2,1815$.

De Kay writes of the species as follows:

This rery raw and rminus species was talien in a seine in the harbur of Xin lork in company with a school of the striped hass. It is doubless the (). barbatulu of mr renerable

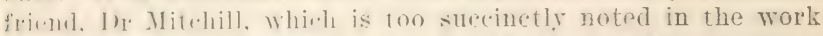
(cited above. . It has so murh the habit of some of the Gadidae,

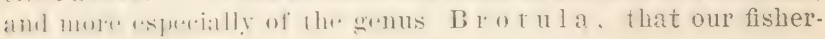
men call it the little cusk.

The tish inhathis the coalst of the Puited States frem Tew York south to Pensalobla and Texas. It is not rery common. It glows to the lemeth of about 10 inches. A speciuen was taken in direat lege Harlone hay during the winter of 1853-5t, bul whllentors who hate visited the region sine hatre not found it anain. In firavesembl hay, where the species is rare, an exam-

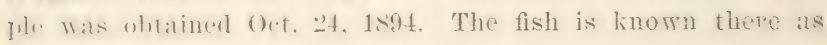
Slippery Dick.

\section{Suborder CRANIOMI}

Family TFIGLIDAE

\section{Gurnards}

Genus prioxotus Lacépède

limbly subfusiform; furolite of head descembing to the broat. d.pur.ss.d snout, whith is murh longer than the small eye; fies

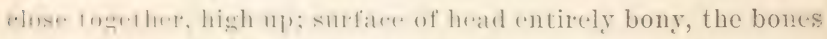
touch with rider.s and granulations; scates on heat few or nome;

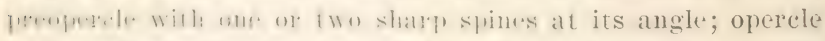
wials a bhapp spine: nate with (wo strong spines, a spine on

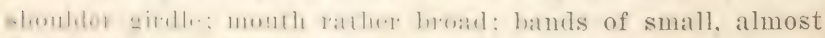
H9anahur, tw.th on jaws, vomer. and palatines; gill membranes

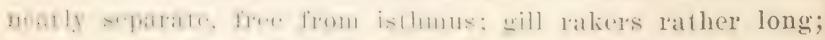

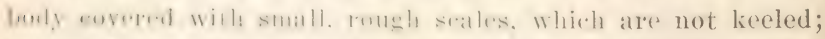

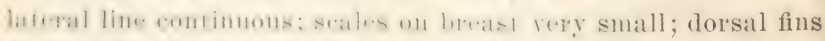

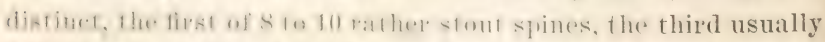
highest, hut mostly shorfer llan lead: anal fin similar to soft dormal; frectoral tin with the three lower anterior rays thickened,

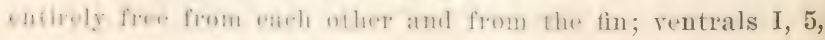


wide apart. with a flat space between them, the inner rays longest; prloric cac'a in moderate number; air bladder generally with lateral muscles and divided into two lateral parts; rertebrae 10 or $11 \div 1.5$. Species numerous, all but one being American. Representing in Anerica the old world genus T r i g lat . Some of them in deep watre. They are well defined and easily recognized, but rary considerably with age, and are not easily thrown into subordinate groups. . Young examples in most cases differ from the adults in the following respects, in addition to those characters which usually distinguish young fishes. The spines on the head are sharper. more conspicuous, and more compressed in the youmg, and some spines. specially those on the side of the head, disalperar entirely with ate. The interorbital space is more coneare in the poung. The pertoral fins are also much shorter. The gill rakers are longere in the young, and proportionately more slender, and some of the color markingsspecially the darker cross shades-are more conspicuous, while the spots on body and fins are less so.

\section{Prionotus carolinus (Linnaeus)}

\section{Sea Robin; Gurnard}

Trigla carolina Linnaeus, Mantissa, 528.

Trigla palmipes MitcmLI, Trans. Lit. \& I'hil. Suc. X. Y. I, 431, pl. IV, fig. 5, 1815, New York Harbor.

Primotus palmipes stoner. Mist. Fish. Mass. 14. 11. V. fig. 1. 1S6i; Jordan \& Gilbert, Bull. 16, U. S. Nat. MIus. 734, 1883; Goode, Fish \& Fish. Ind. U. S. I, 255, pl. 71, 1884.

Primotus carolinus Cevien d Vilenciexies. IIst. Nat. Poiss. T1, 90, 1S29; De Kay, N. Y. Fauna, Fishes, 46, pl. 5, fig. 15, 1842; Günther, Cat. Fish. Brit. Mus. II, 192, 1860; BEAx, Bull. Am. Mus. Nat. Hist. IX, 371, 1897; H. M. SMrTH, Bull. U. S. F. C. 1897, 106, 1898; JordaN \&

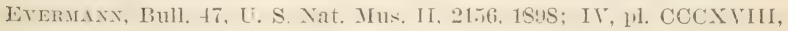
fig. 768,1900 .

The depth of the body is one fifth of the length, which is three times the length of the head. Ifearl comparatively smooth; preopereular spine strong; band of palatine teeth short and broad, shorter than eye; pertorals short, not reaching middle of second dorsal, two and one third in length; pectoral appendages strong, more or less dilated at their tips; rentrals long, reaching anal; 
gill rakers rather short about 10 below angle; maxillary three and one third in head. D. X-13; A. 12; Lat. 1. .58.

limowish above, clouded with darker; throat and branchiostegals dark; a distinct dark blotch abore on membrane between fourth ani fifth dorsal spines, this ocellated below; two longitulinal light streaks below dorsal bloteh; second dorsai with obligue whitish streaks.

The seat robin, known also as llee red-wingerl sea robin, common gurnard. Hying fish, butterly fish, wingfish, grunter, and cuckoo fisl, is very rommon on our cast coast, its range extending from the enast of Maine to south Carolina, rhiefly northward. Thr name tlying fish is applied to the species in Creat Ege lay, X.J. This sea robin appears in Graresend bay in $\mathbf{M a 1}$, and is ranght in the shat fyle nets. It is the entriest of the sea robins to arrive. At Woods Mole Mass., aceording to ly sulth, it appears in May or June and remains till

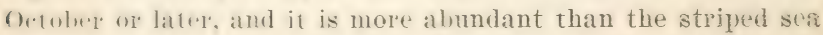
robin.

This tish grows to the length of about 1 foot. It is not a mar kirtahle tish, amel eauses fishermen a great deal of annoyance by Its womlerful rorateily, and yet its flesh is firm and white, and lhe speries deserves a plare among the food fishes. It fecds an rahs, shrimp and similar crustaceaus, and occurs on clean botfoms. This sea rohin Jugins to spawn at Woods Hole early in Jum. Jis age are hright orange. The young are very common in Waquoil hay in summer, !nit arr rather rare elsewhere. The

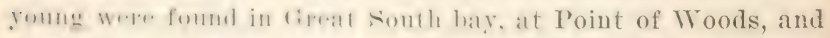

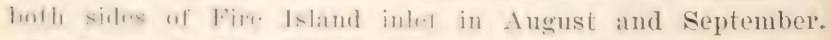
Adule arralow fouml in large numluers at Fire Island and at ofluep fatro of rirat south baty. This tish is taken in enomous mumbers in pumbl ue-1s in spring and summer. C'uriously remuth. Whe Ka! refers to this as a lory rate species. II salys that in thr. comre. of wight years he has not met with more than sis of whth imditiduals. One sperimen which he examined, had its stomach filled with the remains of crabs. 


\section{Prionotus strigatus Cuv. \& Val.}

\section{Red-winged Sea Robin}

Trigla lineate MrtemLl. Trans. Lit. \& Phil. Soc. X. Y. I, 430, pl. IV, flg. 4, 1815; not Trigla lineata BLocir.

Trigla striguta CrTier. liegne Anim. ed. II, 2. 161, 1829, New York.

Primotus lincatus DE Ki.M, X. X. Fauna, Fishes, 45, pl. 4, fig. 12, 1842; Günther, Cat. Fish. Brit. Mus. II, 192, 1860.

Prionotus elolans var. lineutus. Jordax \& Gilbert, Bull. 16, U. S. Nat. Mus. 736, 1883.

Prionotus erolans Goode, Fish \& Fish. Ind. U. S. I, 255, rl. 71, 1881; not Trigla evolans .LinNaeus.

Prionotus strigatus Cerien of Vilexciexies, Hist. Nat. Poiss. IV, S6, 1829; Jordan \& Gilbert, Bull. 16, U. S. Nat. Ifus. 97t, 18s3; Beax. 19th Rep. Comm. Fish. N. Y. 250. 1590; Bull. Am. Mus. Nat. Hist. IX, 371, 1897; H. M. SMitr. Bull. U. S. F. C. 1897, 106, 189S; Jorda. \& Evermann, Bull. 47, U. S. Nat. Mus. II, 2167, 1898.

The length of the head is rontained two and two thirds times in the length of the body, which is four and one half times the depth of the body. The length of the eye is contained two and one half times in the length of the snout. Gill rakers rather long and slender, 15 helow angle; band of palatine teeth wide, shorter than exe: spines on head morlerate in size, compressed, the one at upper posterior angle of orbit little developed; membranous edge of opercle scaly; rentral reaching to front of anal; pectoral reaching past middle of soft dorsal and anal, from one and seven eighths. to two and one fourth in length. D. X-12; A. 11; Lat. 1. about 60 .

Olive brown above, mottled and spotted with blackish; whitish below; a narrow streak along the lateral line, with a broader one below it, which terminates behind in a series of spots and blotches; lower jaw and branchiostegal membranes sometimes bright orange yellow; pertorals blackish erger with oliraceous and orange, with numerous transrerse dirle lines; membrane of spinous dorsal with a black bloteh leetween thirel and sixth spines; soft dorsal plain or with two black blotches at base; rentrals and anal orange; pectoral appendinges slender, dusky. Cape Cod to Cape Hatteras; common northward. I'rhaps a

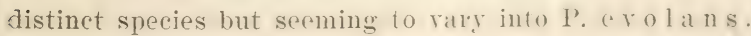


The red-winged sait robin is distinguished from the striped ana pobin hy the following characters: pectoral with its rars an Herossed by fine blark bars. these specialle distinct toward the base of the tin: fore rays spotted: scales comparatively small. 10. 1+2:? in a retuinal line from last dorsal spume to rent; interortitai area broal and almost flat. its width a little more than length of eye; tirst dorsal spine gramulated: serond spine

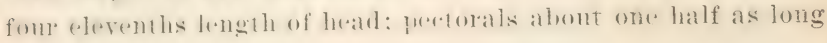
as bodr.

In the slriped seat robin the pertoral rays are all platin blark-

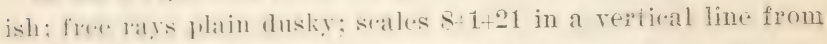
last dorsal spine to rent; interorbital space more decply concave, its widlls in adult not quite length of eye: first dorsal sprine neatrly smonth: stecond spine one third length of heari; [m-1mals a lind]. morr. than whe half as long as body.

This tish is found on on . Ilantic roast from Cape cod to Yirginia. it is very remmon in shallow water and is extremely close to Prionotus erolans, of which it may be a geo-

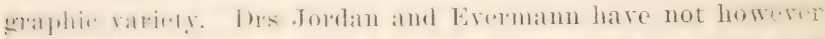

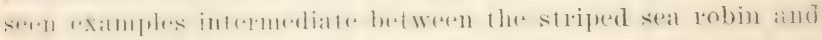

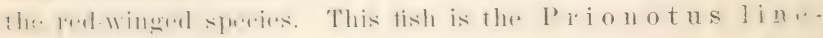

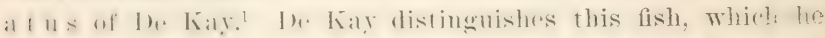

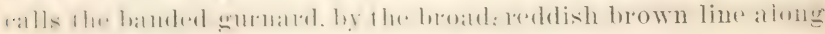

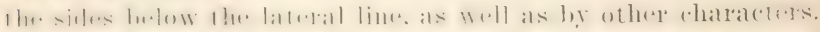

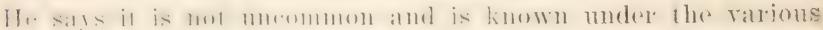

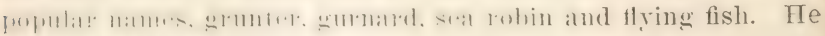

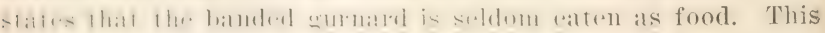
is also the gurnard or sea robin, 'Trigla lineata, of Mitchill in the Trans. Lit. \& Phil. Soc. X. Y. I, 430, pl. 4, fig. 4. 1:15.

The red-winged seat robin comes into Gravesend bay in May, but batre than the common species. It was found more abundantly in firat somth bay than the mustriped species. Indi-

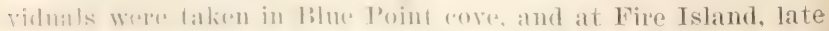
in siptrunber. This tish grows litrger than the other species 
and is much handsomer: the young are specially interesting on account of the great derelopment of their pectoral fins.

\section{Prionotus tribulus (Cuvier)}

Big-headed Sca Robin

Trigla tribulus Cuvien, Règne Anim, ed. 2, II, 161, 1829, America.

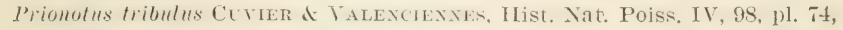
1529, New York; DE K.T. N. Y. Famu, Fishes 48, pl, 70, fig. 226, 1842;

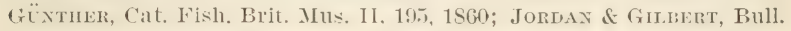
16, U. S. Nat. Mus. 735, 1583; Jordan \& Eversians, Bull. 47, 'U. S. Nat. Mus. II, 2171, 1898.

Pectorals rather short, not reaching (nd of dorsal, twice in length to base of candal; pectoral appendages thick, tapering. Body robust. The depth is one fourth of the length of the body, which is two and one half times the length of the head. Head shorter and broader, snout shorter, and bones more strongly striate than in I'. e rola n s; interorbital space deeply concare; occipital and superorbital spines rery strong and much compressed; band of palatine teeth as long as eye; gill raliers shortish, nine below angle; membranous edge of opercle scaly. D. X-12; A. 11; Lat. 1. about 50.

Jark brown above, with darker blotches and numerous small, pale spots; belly pale; a black blotch at base of mandible; membrane of spinous dorsal, between the third and sixth spines, with a black blotch aborr; secoud dorsal with brownish spots, forming oblique bars, and with two dark blotches at base, the posterior blotch continued obliquely downmasd and formard to below the lateral line; pectoral olive brown. with dark crossbars, which are more distinet toward the tip of the fiu, its upler edge white, pectoral alpendages with ditrk spots; hasal half of caudal paler.

This gurnard is very common on the somth delantic coast and occasionally ranges northwallel to Longer Island. It is well separated from the othere seat robins of the Ithantic by the greater development of the spimes of thr head. " The yomes

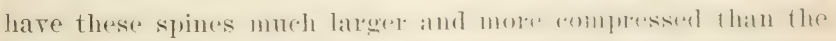
adult, and in the rery yomng three or four strong knifelike 
spines are developed on each side of the snout. In very roung individuals the spine at the base of the preoperevlar spine is imn harger than the latter." De Kay obtains his description of this tish from curier and Valenciennes, but he saw rery small indiviluals which he at first confounded with the young of the red winged seal robin. Curier staws that he received numerous sperimens of the spectess from New York. De Fay mentions among the rhatreteristies of the fish the long pectoral which reaches lhe end of the anal fin and acute spines of the lead which atr Hat w.med like sword blades. As for colors he gires the following. " The first dorsal fin has a black spet beineren 1hw fomlh and sixth ray. The second with two blate spots alone its hase; one from the fifth 10 the serenth. the other betwenthe fourth and sixth rays; pectorals blackish, more sige"ially on the interion where the upper border is whitish. Body brownish above, lightish beneath." specimens $S$ inches long are recorded.

\section{Genus mrigra (Artedi) Linnaeus}

This genus diflers from Che lid on iteh thys, with which it agrees in the absenere of palatine teeth, in having the sides of thr. body armed with transterse bony plates, crossing the laterat lim. Species numerous; rery abundant in the Mediterranean.

\section{Genus chenmonichthys Kaup}

This grnus diflus from Prion ot us chiefly in the absence of palatime towth. The scales are much smaller, and the pee-

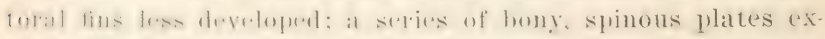
femb aloug l he hase of the dorsal fin, a pair of them to each ray, the lin fhus fuming in a shallow groove; there are no plates

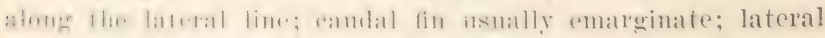

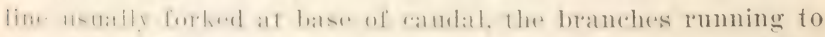
t11. ut lin. The numerous spredies abound on the coasts of Europe, Afriea and India, ranging north to Japan.

:3:37 Trigla cuculus Linnaeus

Red Gurnard

Trivfit rueulus Imxames, Syst. Nat. ed. X, I, 301, 1758; Cuvien \& Valen-

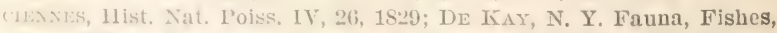
13, 11. 70, fig. 245, 1842; Jomman \& Evermaxn, Bull. 47, U. S. Nat. IIus. 11, 2177, $189 S$. 
The depth of the body is one fifth of the length, which is three and one half times the length of the head. Rose-red; profile of snout rather steep, slightly concare; preorbital with short denticulations; maxillary nearly reaching front of orbit; lateral line with a series of unarmed plates, which are deeper than long; first dorsal spine tuberculated; second longest, two thirds length of head; pectoral reaching past front of anal. D. IX-1S; A. 17; Lat. 1. 75 .

The red gurnard is a native of southern Europe. It is said by Curier to have been once brought from New York by Milbert, lut this is a rery douldful record. as no collector has recently found any species of Trigla in American waters. De Kay did not see this fish on the coast of New York, and he copied lis description from Curier and Valenciennes. De Kay states that curier and Valenciemne's mention having received " a spevimen from Xew lork, which so much resembles the T. c u c u l us, not only in all its generalities but eren in its most minute details, that it is very dificult for us not to consider it the same species; but, as our specimen was not recent, it may possibly present some distinct characters."

\section{Family cephalacanthidae}

\section{Flying Gurnards}

\section{Genus cephalacavmus Lacépède}

Body elongate, subquadrangular, tapering behind; head rery blunt, quadrangular, its surface almost entirely bony; nasals, preorbitals, suborbitals. and bones of top of head united into a shield; nuchal part of shield on each side produced backward in a bony ridge, ending in a strong spinr, which reaches past front of dorsal; interocular space deeply concare; preorbitals forming a projecting roof abore the jaws; preoperele produced in a rery long rough spine; cheeks and opereles with small scales; opercle smaller than cre; gill openings narrow. rertical, separated by a rery broad, scaly isthmus; pseudobranchiae large; gill rakers minute; mouth small. lower jaw included; jatss with granular teeth; no teeth on romer or palatines; scales 
bony. smonely kereled; two serrated. Knifelike appendages at uase of rail; tirst dorsal of fom ar fire rather high flexible spines. He. Hirs whe or l wo spimes nealy fres from the others: an immovable spine betweren the dorsals: anal awel secoud dorsal

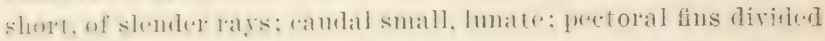
to the hase into two farts, the anteriof portion about as long as the head, of about six lays, rosely comnected; the postrerior atme larger portion more than twier length of bead. reaching nearly to cantal in the adult, much shorter in the roung; these rays rery slemeler, simple, wide apart at tip; venteal sars 1.4 , the long tins pointed, their bases elose together, the inner rays shortest: air bladkler with two batral parts. weh with a latrge

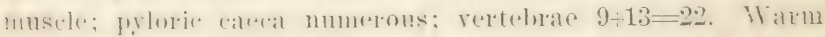
seas: the adult able 10 more in the air like the true flying tish,

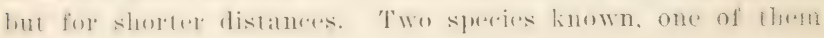
(C. spinarella) East Indian.

\section{Cephalacanthus volitans (Limnaeus) Flying Gurnard; Flying Robin}

Trigla volilans Linvaeus, Syst. Nat. ed. X, I, 302, 1758.

Polynemus sexradiatus Mrtenul, Trans. Lit. \& Phil. Soc. N. Y. I, pl. IY, fig. 10, 1815; Am. Month. Mag. II, 323, March, 1818.

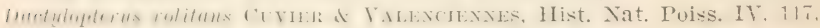
1829; DE Kí., X. Y. Fama, Fishes, 49, pl. 17, fig. 46; Günther, Cat. Fish, Brit. Mus. II, 221, 1860.

cephalacanthus volitans BEAx, Bull. U. S. F. C. VII, 136, 1SSS; Bull. Am. IIus. Nat. Fist. IX, 371, 1897; H. M. Smrn, Bull. U. S. F. C. 1897. 106, 1S9S; Jordan \& EverManN, Bull. 47, U. S. Nat. Mus. II, 21S3, 1S9S; IV, pl. CCCXXIII, fig. $778,1900$.

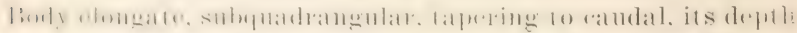

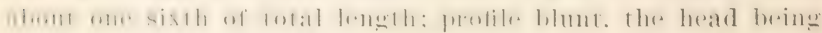

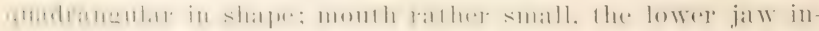
clucled; gramular tecth in jaws; no teeth on vomer and palatines; "yo latrer, its diameter being contained about three and one half limes in length of head; bones of top of head, pre-

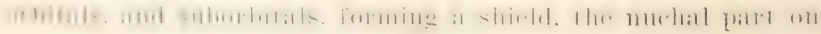

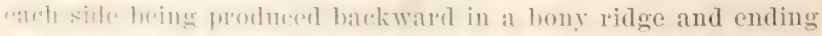
in at stomer spine which reaches to the fourth or fifth dorsal sprime: another spine rxturls backward from the preoperele fats vontrals; pertorals in alults reaching almost to caudal, 
shorter in the young; the first dorsal originates orer the ventrals, its longest spine is equal in length to the distance from tip of snout to posterior margin of orbit; the second dorsal rays are slightly longer; anal base shorter than either dorsal base, equal to base of first six rays of second dorsal; caudal emarginate; ventrals as long as head. D. II-T, S; A. 6.

Color of varying shades of greenish, olive, and reddish brown on upper parts of body, paler underneath; irregular markings of dusky and vermilion, varying to salmon yellow; pectorals with bright blue streaks near base, and blue spots and bars toward the tip, their under sides glancous blue edged with darker; three brownish red bars on caudal fin.

The flving gurnard is found in the Atlantic ocean on both coasts. It is rery abundaut on our south Atlantic coast and in the Gulf of Mexico. It ranges as far north as Cape Cod. Sereral specimens were obtained in Great Egg Harbor bay in August and september 1s87. Their lengths were respectively $2 \frac{1}{2}, 6 \frac{1}{2}$ and $7 \frac{7}{11}$ inches. In Gravesend bay, L. I., this is an uncommon species. In indiridual was taken there Oct. 30, 1897. Dr Smith says that a few are taken every year late in the fall in the ricinity of Woods IIole Mass. They sometimes come ashore in Buzzards bay and Tineyard somd, benumbed by cold. They are not so abundant now as they were prior to 18st. Mitchill described and figured the fish in 1sis under the name Pol y n e mus sexradiatus.

De Kay ealls it the sea swallow and has the following notes on it:

Dr Mitehill, in his memoir on the Fishes of Xer Tork in 1814 (1815), gave a good figure of this speries: and in his supplement to this memoir in the American. ILnthly Ma!nsine in IS18 furnished a detailed description whirh sufherently establishes its identity with I). rolitans. . The subject of our examination was caught in a net in the hatrore in the month of . Ingust. If our species be identimal with that of Emope. it has a wide geographical distribution. On the Ameriann coast it ranges from Brazil to Newfoundland. By means of its immense pecetorals, it is enabled to spring from the orean and support itself for some time in the air. This is often dome to fureteret itself from its enemies. It feeds on various small crustacea. 


\section{Suborder DISCOCEPHALI}

Family ECHENEIDIDAE

\section{Remoras}

\section{Genus echeners (Artedi) Linnaeus}

Body comparatively clongatu, the rertebrate $14 \div 16=$ : 30 ; disk long, of 20 to 28 laminae: pectoral pointed, its rays soft and flexible; soft dorsal and anal long, of 30 to 11 rass each; caudal lunate in the adult, convex in the young. Speries of wide diswihution, attaching themselves mainly to sea turtles and large fishes.

\section{Echeneis naucrates Linnaeus}

\section{Sharksucker; Sucking Fish}

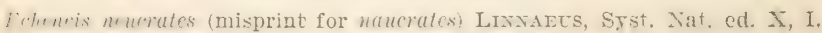
$261,1758$.

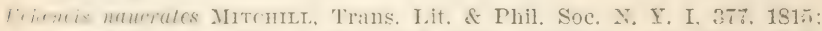
In: Kar, X. Y. Fauna, Fish. 30S, 1S42; Gixther, Cat. Fish. Brit. Mus. II, 3St, 186n; Jonnan \& Gilbert, Bull. 16, U. S. Nat. Mun. 416.

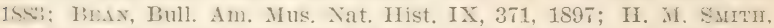

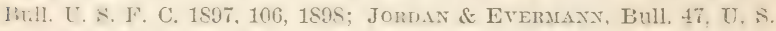

tiat. Mus. III, 2269, 1898; IV, pl. CCCXXIX, fig. 796, 1900.

Erkeneis ulburtula Mrtruicr, Am. Month. Mag. II, 244, February. 1818.

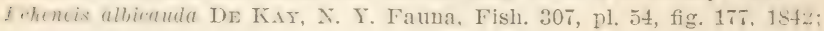

Long Island; Hudson River.

body elongate, subterete, slender. The length of the body is five and one half times the length of the head. The disk is confained thr.e and two thirds times in the length of the body, which is almut seren and one half times the width between the jonctorals; disk long. Dorsal and anal fins longer than the disk; imm.r ra! s of rentral tin narrowly adnate to the abdomen; caudal becotning ematginate with age. Vertehtae $11+16$. Tertical fus

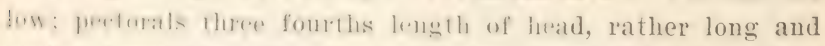

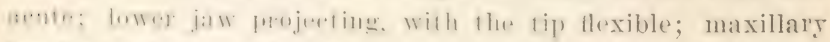

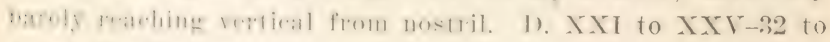
$11 ;$ 1. $34(32-38)$.

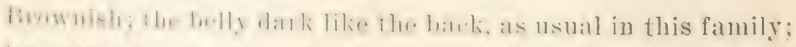

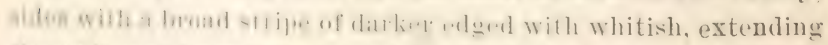

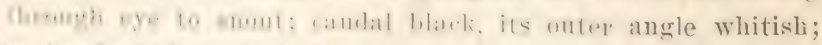

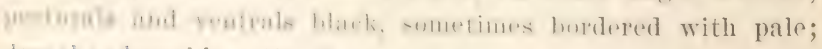
dorsal and anal broadly edged with white anteriorly. 
The sharksucker or sucking fish is also known as the remora. It inhabits all warm seas, ranging north to Cape Cod and San Francisco. De Kay describes this species under the name of the white-tailed remora, and the Indian remora. He figures the species on pl. 54, fig. 177, of his New York Fauna. He says it is not uncommon on the coast of Long Island, and has been several times brought to him by those who took it in ordinary seines. He states that it is called sharksucker. He saw a specimen which had ascended a considerable distance up the Hudson river. He states further that it appears most commonly in July and August. In Mitchill's account of the fishes of New York, an individual measuring 31 inches in length, and weighing 4 pounds 10 ounces is mentioned. In Graresend bay the species is found in summer only attached to sharks, usually the sand shark, Ca r c h a r.ias lit t o r a lis. An individual obtained there July 28, 1897, lived and fed till Norember 13, when it ceased feeding, and Nov. 23 it died because of the low temperature of the water. In captivity the fish usually remains stationary on the bottom, with the head and anterior part of the body slightly raised, but will often rise to the surface to take pieces of clam or fish from the hand.

At Woods Hole Mass., according to Dr Smith, the fish is not uncommon. An example 21 inches long was caught at West Falmouth July 16, 1897, on a hook baited with fresh clam. In August 1901 an individual of medium size was caught with a hook on the Cinders, Fire Island, by an angler. This was the only specimen seen during the summer.

\section{Echeneis naucrateoides Zuiew.}

\section{Pilot Sucker}

Echeneis naucrateoides ZuIEw, Nora Acta Ac. Sci. Imp. Petropol. IV, 279, 1789; Goode \& BeAN, Bull. Essex Inst. XI, 20, 1879; H. M. SMrtr, Bull. U. S. F. C. 1897, 106, 1898; Jordan \& Evermant, Bull. 47, U. S. Nat. Mus. III, 2270, 1898.

Echeneis holbrooki Güntmer, Cat. Fish. Brit. Mus. II, 382, 1860.

The form of the body is similar to that of the sharksucker; its depth forms $\frac{1}{11}$ of the total length. The length of the head is one fifth of the total. The cephalic disk is very long, nearly 
m... Fom th of the total. and equal to twice the width of the imbly betwen the pertorals. The number of laminae is 20 or 21 , surl they are far apart. The radial formula, D. XX or XXI-32 to 35 ; A. 33 to 35 .

The color is the same as in the sharksucker. This species ranges from Cilpe Cod to the West Indies. It is common on our sunth Atlantic roast. In indiridual was recorded by Prof. Fatrd at Woods Hole Mass. in 1sit, and a number of specimens were taken during the next 10 years. Acrording to Dr Smith, however, it has not recently been collected there.

\section{Genus remora Gill}

Body rathep rohust. thr. vertebate $12-15=27$; disk shortish, of 1:3 to 1S laminae; pectoral rounded, its rays soft and flexible; suft dorsal and anal modrate. of 20 to 30 rays; catidal subtrunate. Species attakhing themselves to large fishes, specially to sharks.

\section{Remora remora (Linnaeus)}

\section{Remora}

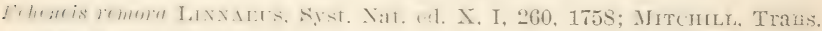
Lit. \& Phil. Soc. N. Y. I, 378, 1815; De KAY, N. Y. Fauna, Fishes, 309,

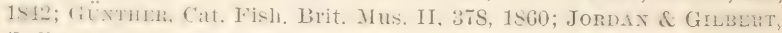
Bull. 16, U. S. Nat. Mus. 417, 1883.

Remora jacobaea Goode \& BEAx, Bull. Essex Inst. XI, 21, 1879.

Limmia remora Jolidin \& Evermax, Check-List Fish. N. A. 490, 1596; II. М. Sмпти, Bull. U. S. F. C. 1s97, ivt, 1Sts; Jondix \& Evemindx, Bull. 47, U. S. Nat. Mus. III, 2271, 1898.

lindy and tail comparatively robust, the latter compressed. The lomgth of thr hody is four time's the length of the head, two and thre fourthe times the leneth of the disk and fire and one

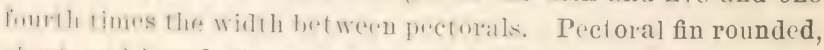

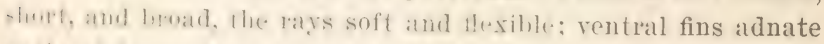

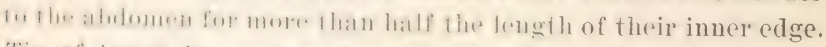
Tin of lowre jaw not produced into a llap. Vertebrae $12+15$.

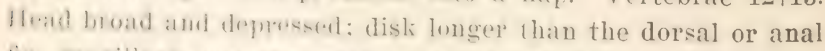
fin; maxillary swarerly rearlhing front of orbit; caudal lunate; vertica! thus rather high; pretoral three fifths length of head. D. XIIII-23; A. 25.

1 itform Aark irown. Warm seas, north to New York and

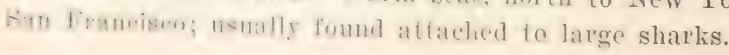


In 1S15, Mitchill described this speres under the name of small oceanic sucker. De Kay did not see the fish but obtained his information from the writiugs of Mitchill and schoefir. He states that schoefl sal this remora taken from the bottoms of ressels in the harkor of Xiw York. At Woods Hole Mass, according to I). smith, the remora is rare. It was reported by Prof. Baird in 1571, and the specimen in the collection at that place was taken in July. It is usually found attached to large sharks. In 1870 Messis loude and Bean found in the museum of the Exsex Institute, at Salem Mass. a specimen which was reported to have come from Salem harbor. If it really was obtained in that locality, it must hare been attached to the bottom of some vessel from a southern port.

\section{Remora brachyptera (Lowe)} Swordfish Sucker

Echencis brachyplera Lowe, Proc. Zool. Soc. Iond. S9, 1S39. Madeira, G̈̈nther, Cat. Fish. Lrit. Mus. II, 37S, 1S60; Jorday \& Gilbert, Bull. 16, U. S. Nat. Mus. 417, 1883.

Echeneis quatuordecimlamimutus SToner, Rep. Fish. Mass. 155, 1839;

DE KAY, N. Y. Fauna, Fish. 309, 1812 (extralimital); Storer, Hist.

Fish. Mass. 212, pl. XXXII, fig. 4, 1867.

Remoropsis bruchypterus GiLL, Proc. Ac. Nat. Sci. Phila. 60, 1864.

Remoropsis brachyptera Goode \& BEAx, Bull. Essex Inst. XI, 21, 1 S79.

Remora brachyptera Jord.1x \& Evermaxx, Check-List Fish. N. A. 490, 1596.

H. M. Sarti, Bull. U. S. F. C. 1S97, 106, 1S98; Jordan \& Evemaraxi. Bull. 47 , ᄂ. S. Nat. Mus. III, 2272, 1Sงs; IT, pl. CCCXXX, tig. 797 $797 \mathrm{a}, 1900$.

The length of the head is contained nearly four times in the length of the bodr, which is six and one half times the width between the pectorals. Body robust, the greatest depth nearly twice the length of the short pectoral fins; disk shorter than base of dorsal, rather broad; upper jaw angular; candal nearly truncate. D. XVI-30; A. 26.

Light brown, darker below; fins paler.

The swordfish sucker is an inhabitant of warm seas, ranging northward to Cape Cod, and to Japan. It is a small species and has usually been found attached to the swordfish. Dr Storer, in his Report on the Fishes of Massachusetts, 18:3, recorded a specimen from Holmes Hole, Marthas Vineyard. At Woods Hole 
Mass. this suclier is rare. There is in the U. S. National Museum $\therefore$ indiridual from that locality. Storer again describes the species in his History of the Fishes of Massachusctts, 1S67, and gives a figure of it. De kiay refers to this description on page 309 of his Tex Tork Fauna. He regards this fish as one of the cxtralimital species. Goode and Bean in 1879 recorded it as a parasite of the swordfish, which not infrequently accompanies that species into Massachusetts bay. They had also seen specimens from Newfoundland.

\section{Genus rномвоснгтеs Gill}

This genus agrees with Remora in every respect excepting the structure of the pectoral fins. These are short and broad, rhombic in outline, the rays all flat, broad and stiff, being partially ossified, though showing the usual articulations; upper rays of pectoral broader than the others. One species known.

\section{Rhombochirus osteochir (Cuvier)}

\section{Spearfish Sucker}

Echencis ostcochir Cuvien, Règne Anim. ed. 2, II, 348, 18z9; Güntièr, Cat. Fish. Brit. Mus. II, 381, 1860; Jolid.1. \& Gilbert, Bull. 16, U. ‥ Ni1. Mus. 418, 1883.

Thombrehims osteochir Jordan \& Evermanx, Check-List Fish. N. A. 490 . 18:66; II. II. Sintif, Bull. U. S. F. C. 1897, 106, 1898; Jondax \& Evrt. MAxx, Bull. 47, U. S. Nat. Mus. III, 2273, 1898; IV, pl. CCCXXX, fị 798,1900 .

The length of the body is four and two thirds times the lengrlis of the head, two and one fourth times the length of the disk and five times the width between the pectorals; mouth very small, maxilary not reaching to the line of orbit; disk very large: broater and rougher than in Echeneis remora, extending forward beyond tip of snout; caudal fin emarginate, with rommled angles. I). XVIII-21 to 23 ; 1. 20; P. 20.

light hrown; undere side of head, ventral line, part of ventrals and a spot on pectorals pale.

This small sprecies inhalits the West Indies and ranges northward ormatsionally to Cape corl. It is parasitic on the species of sprartisb, and is lathlue rare. It was reeneded at Woods Hole Mesa. Hy l'rof. Fiard in 1S71. Aceording to Dr Smith, a speci-

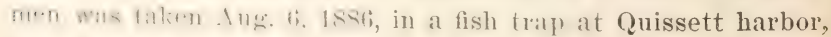
near Woods Hole. 


\section{Suborder ANACANTHINI}

\section{Jugular Fishes}

Family MERLucimae

\section{Thitings}

\section{Genus mertucrus Rafinesque}

Body elongate, wovered with small, deciduous scilles; head slender, conic. the snout long, depressed; at well-defined, oblong, triangular excariation at the forehead, bomded by the ridges on the separated frontal bones. these ridges converging back. ward into the low oreipital crest: we rather large; edge of preopercle free; prenercle with a rhamnel behind its crest, crossed by short radiating ridges: mouth large, oblique; maxillary extending to opposite the eye: lower jaw louger; no barbels; jaws with slender teeth, of varions sizes, in about two series, those of the inner low longer and movable: vomer with sintar teeth; palatines toothless; branchiostegals seven; gill rakers long; gill membranes not united; dorsal fins 1 wo. Well separated, the first short, the second long, with a deer emargination; anal emarginate, similar to second dorsal; rentral fius well developed, with about seren rays; rertebrae peculiarly modified, the neural spines well developed and wedged into one another; frontal bone double and the skull otherwise peculiar in sereral respects. Species sereral, rery similar in appearance, ill-farored fishes of soft flesh and fragile fins, inhabiting water of some depth. Large, roracious, little valued as food.

\section{Merlucius bilinearis (Mitchill)}

\section{Whiting; Silver Hake}

Stomodon Bilinearis MrtemLL, Rep. Fish. N. Y. 7, 1814.

Gadus merlucius Jrtchile, Trans. Lit. \& Phil. Soc. N. Y. I. 371, 1815.

Gadus albidus MrtchiLt, Jour. Ac. Nat. Sci. Phila. I, 409, 1817.

Iferlucius albilus DE KAY, X. Y. Famna, Fishes 2S0, pl. 46, fig. 148, 1S12; Storer, Hist. Fish. Mass. 185, pl. XXVIII, fig. 2, 1867.

Merlucius bilinearis Goode \& BEAx, Bull. Essex Inst. XI, 9, 1S79; Jordax \& Gilbert, Bull. 16, L. S. Nat. Mus. S09, 1SS3; BeAx, 19th Rep. Comm. Fish. N. Y. 249, pl. IV, fig. 5, 1890; Goode \& BEAN, Oceanic Ichth. 386, fig. 330,1896 ; H. M. SMith, Bull. U. S. F. C. 1S97, 107, 1898; JoRI N \& Evermaxi, Bull. 47, U. S. Nat. Mus. III, 2530, 1895; BeAx, 521 Ann. Rep. N. Y. State Mus. 109, 1900. 
The length of the body is six and one half times the depth of If... hody and three and three fourths times the length of the l, ratl. Top of head with W-shaped ridges rery conspicuous; eye sherter than snout and less than interorbital in width; maxillary reathing posterior borker of pupil; teeth not rery large, smalles thitn in Ir. sm iridus; scales larger than in other species: Juetorals and rentrals long, the latter reaching three fourths distance to rent. their length being three fifths that of the head. D. 13-41; A. 40; Lat. 1. 100-110.

cirayish, darlier above, dull silvery below; axil and edge of fwetoral somewhat blackish; inside of opercle dusky silvery; inside of mouth dusky bluish; peritoneum nearly black.

The whiting io known by the additional names of hake and silver hilke. Mitehill describes it as the hake, ir a $d$ us mer. $111 \mathrm{c}$ i $11 \mathrm{~s}$. IIe states that it is eaught with the other coul. 1W. Kil called it the American hake. He styles it a rare fish in the waters of New York, and, when caught, always assiated with the common cod. The specimen described by Le Kay was

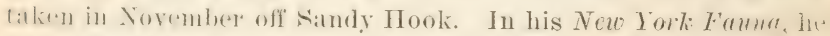
mentions Mitrhill's deseription of a specimen which measured 21 inches in length.

The whiting ranges from Labrador to Virginia. Young tex. amples latse lwen found ren farther south in very deep water. This tish aremes in ciravesend bay in spring and fall. In Great sind haty mo individuals were sern by the writer during the sumIm.1, hut an individual was ohtained late in the fall by Capt.

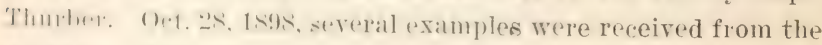
Allantic, off Southampton.

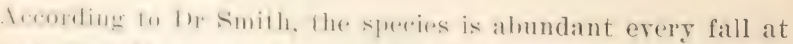
II ombls |lu|, Mass. and sum years it is common in summer. The

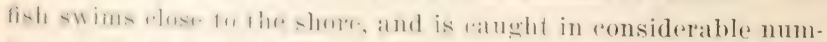

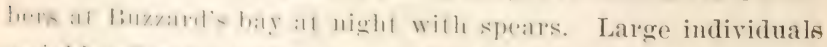

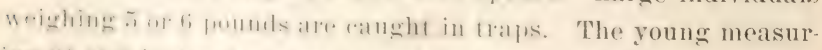

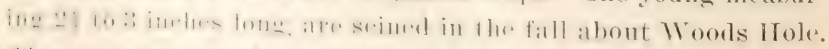

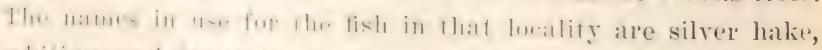

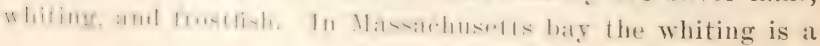


frequent visitor to the shores and is probably a resident of the middle depths. The young are frequently trawled in deep water.

\section{Family GADIDAE}

\section{Codfisties}

\section{Genus poxuachus Nilsson}

Body rather elongate, covered with minute scales: mouth moderate or large, the lower jaw projecting; barbel very small or obsolete; villiform teeth on vomer, none on palatines; teeth in jaws equal or the outer slightly enlarged; gill membranes more or less united; subojerele and postclaricle not enlarged and not ivorylike; dorsal fins three: anal two: candal lunate; rent under first dorsal. Large fishes of the northern seas.

345 Pollachius virens (Linnaeus)

\section{Pollack}

Gadus virens Linnaeus, Syst. Nat. ed. X, I, 253, 1758

Gadus purpureus Mrtchll, Trans, Lit. \& Phil. Soc. N. Y. I, 370, 1815.

Merlungus purpureus STorer, Rer]. Fish. Jass. 130, 1839; DE KAr, N. Y.

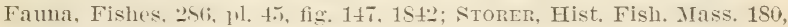

pl. XXVII, fig. 3, 1867.

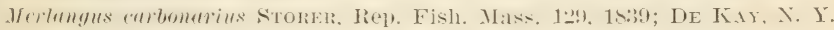

Fauna, Fishes, 287, pl. 45, fig. 14t, 1842.

Merlungus leptocephalus DE KAs, op. cit. 2SS. pl. 45, fig. 146, Long Island.

J'olluchius carbonarius Goode \& BEAN, Bull. E-sex Inst. XI, S, 1879.

Polluchius virens Jordix \& Evermaxx, Cheek-I.ist Fish. N. A. 4!):, 1S96;

Bean, Bull. Am. Mus. Nat. Hist. IX, 371, 1597; H. M. SмIтн, Bull.

U. S. F. C. 1897, 107, 1898; Jordan \& Evermann, Bull. 47, U. S. Nat.

Mus. III, 2534, 1898; IV, pl. CCCLIX, fig. 856, 1900.

The length of the body is four and one fourth times the depth of the body and four times the length of the head. Body rather elongate, compressed; snout sharp and conic; mouth rather small, oblique; maxillary reaching beyour front of orbit; lower jaw slightly the longer; teeth in upper jaw nearly equal, the outer series not specially enlarged; barbel rudimentary or obsolete; gill membranes considerably mited, free from isthmus; vent under first dorsal; caudal fin lunate: pectorals short, scarcely reaching anal; ventrals short. I) 13-22-20; A. 25-20; Lat. 1. about 150 ; vertebrae 54 .

Greenish brown above; sides and below somewhat silvery; lateral line pale; fins mostly pale; sometimes a black spot on the axil. 
The fullatr is a native of the not th Itlantic. It is common

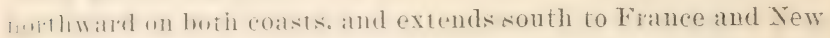
I. I.y. Mithill deserihed the fish moler the mame of the New Surk follatek. Ine Fily mentions it under sereral names: the

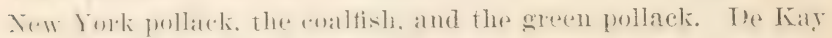

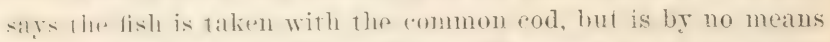

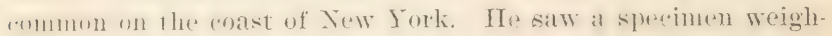
ing 17 penmels and measuring : inches in length. In anothere deseleption he states that the roalfish is offen talken oft the hather of Xen Jork in rompany with the corl, and is kuowe as jollark and hatek pollark. The third form moler which the fist

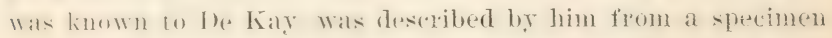

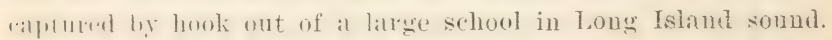
The pullati enters frovesend bay in the fall. In captivity it is

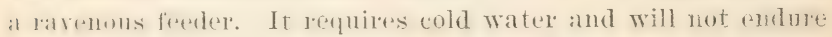
high temperatures.

11. Kaly slater that the tish flipped in the same manner as the

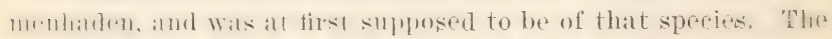
s.lumb sermend to he rery timid: for, on a rery slight noise in the boat, they all disappeared.

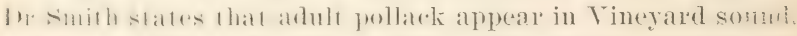

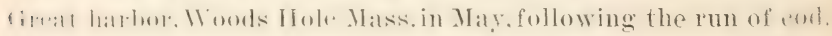

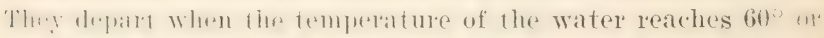
li.i. In Ifril there is a r.m of pullark, measuring from 1 to 1! im.hes lome. liy fum. when lhese fish leave, they have reacher

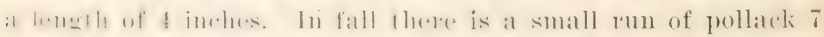

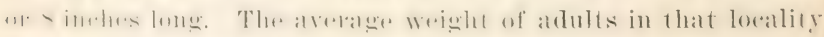

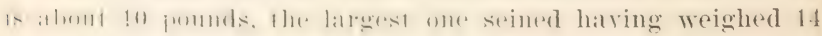

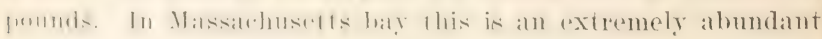
stereics, and constitutes an important food resource.

\section{Genus momormes Gill}

Viny small codfishes allied to $\mathrm{G}$ a $d \mathrm{us}$, but with the vent

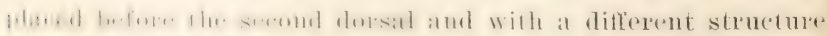
of the cratuimm. The following is Prof. Gill's account of the

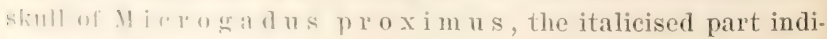

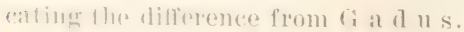


The cranimm is proportiomally hoakler towat the front and less flattened, while the brain "as is tlattened below, decidedly strollen on each side of a depresside sphemoidul groore, and has an ovate cardiform shape: the prowecipitul or epiotic is not produced into an angle behind, but is ohtusely romded, and its josterior or outuardly desending ridye blunt: the opisthotic is well developed, oblong, and with its resutering angle high up, and, on a line with it, the surface is dirided into two parts-a murow and flattened one, and a lower, expanded one, much swollen; the alisphenoid or prootir is oblony, acutely emarginate in front. swollen from the region of the high anterior sinus, and above a little produeed forward; the great frontal is a little longer than broad, with supraorcipital crest continued formard on the bone, and near the front expanded upward, and with the expanded portion behind dividing into narrow lateral wings; the lateral testiform ridges of the frontal are continued forward and curred outuard toward the antero-lateral angles; the anterior frontals are mostly covered in front hy the great frontal, and are much developed in the direction of the antero-lateral angles, the inferior expanded axillary portion being very narrow; the nasal has a rounded ridge in front. continued well below, and its posterior erest is laminar and trenchant.

Species American; valued as food.

\section{Microgadus tomcod (Walbaum)}

Tomeod; Frostfish

Gadus tomeod WALbaum. Art. Gen. Pisc. III, 133, 1792.

Gadus tomcodus Mitchill, Trans. Lit. \& Phil. Soc. N. Y. I, 368, 1815; Storer, Ren. Fish. Mass. 126, 1839; Gïxtmer, Cat. Fish. Brit. Mus. IV, 331, 1862 .

Gadus pruinosus Miтchil, Rep. Fish. N. Y. 4, 1814.

Morrhua pruinosa. DE KAY, N. Y. Fauna, Fish. 278, pl. 44, fig. 142, 1S42: Storer, Hist. Fish. Mass. 179, pl. XXVII, fig. 5, 1867.

Mirmgadus tomerdus Goone \& BE.1N. Bull. Essex Inst. XI, S, 1879: Brix. 19th Rep. Comm. Fish. N. Y. 248, pl. III, fig. 3, 1890.

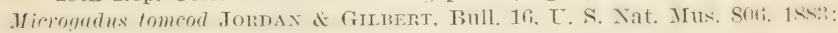

Bean, Bull. Am. Mus. Nat. Hist. IX, 371, 1597; Mearns, Bull. Am.

Mus. Nat. Hist. X, 322, 1898; Eugene Smrth, Proc. Linn. Soc.

N. Y. $1897,40,1898$; H. М. SмIтн, Bull. U. S. F. C. $1897,107,1898$; Tordan \& Evermann, Bull. 47, U. S. Nat. Mus. III, 2540, 1898; IV, pl. CCCLX, fig. S90, 1900; BEAN, 52d Ann. Rep: N. Y. State MLus. 109, 1900. 
lionly subfusifurm. mulfately robust, ito depth slightly less thais Jingth of head or abunt one fifth of the total length; depth .1 ramblal freluncle contained three and one half times in greatest d. plith of hody; snout rounded. the distanee from eye to tip of smont twice diancter of eye. the latter being container fire and on. latel times in length of head; length of maxillar! contained two and there tifths times in length of head; mandible much shorter; mandibulaty hathel well dereloped; first dorsal ras instrled ofer midde of length of pectorals, the distance of this lay from lip of snout heing about equal to its distance from end of seromil iolsal base: the length of the iatter being equal to the distaner from first dorsal ray to first ray of second dorsill; lungh of thirel dorsal hase regual to that of second anal, these fins heing opposite each other: first anal opposite second dorsal, its hatse slighty longer: length of pectoral equals base of thind dorsil: ventral filamentous, longer than pectoral. 1st 1). 13-15; 2 d D. 15-19;3d D. 16-18; 1st A. 18-20;2d A. 16-20.

rolor olive hown with reticulations and blotehes of darker: sides and bark juofusely rovered with dark punctulations; umder parts lighlur: dorsal. "andal and anal fins with dark blotehes; pectorals and rentrals dusky.

This tish is lery generally known in New York waters munter Alr. nam of frostlish. It langes from Nova Scotia to Virginia. alml is rxmssively rommon in shallow hays in cold weatlex.

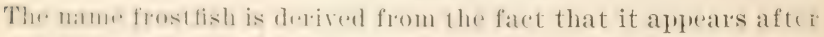

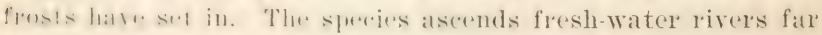

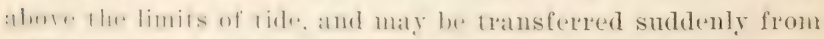

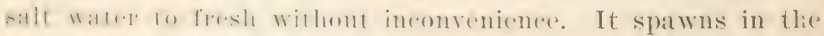

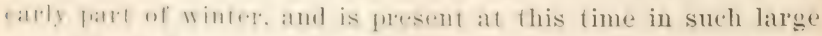
numblers as to make is alphme with dip nets comparatively

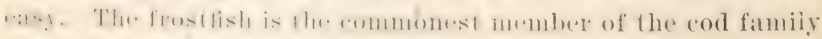

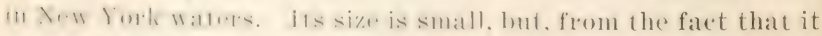

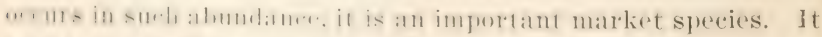

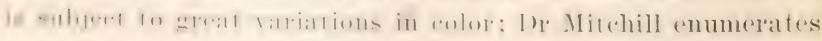
among its valleties five forms: the brown, yellow, yellowish

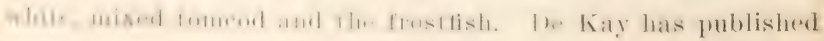


the statement that he has known the frostfish to be talien out of the water along the shores of Long Island in great numbers with a common garden hoe. He was informed that the species occasionally ascends the Hudson as far as Albany. In Great South bay we found large numbers of tomeod, which were corered with a lernaean parasite. The same thing has been observed frequently at Woods Hole Mass. and other northern localities. We found the species in nearly all parts of the bay late in September in moderate numbers, and more plentiful at Fire Island October 1.

July 29, 1898, a few young tomeod were seined in Peconic bay, near Southampton. In Gravesend bay the fish is a fall and winter risitor. It does not live in captivity in summer. Dr Hearns has found this fish in the Hudson river, where it is usually called frostfish by the fishermen, who eatch many of them in their fyke and ice nets during fall and winter. It bites readily and is esteemed as an article of food. Hr Mearns has found it during the entire year, and in August has found young tomeod fully an inch or two in length. He states that this fish is rery often found in eel grass along shore, half dead, floating on the surface, but able to swim a little. Mr Eugene Smith says that the tomcod runs up stream into nearly pure fresh water in the vicinity of New York city. At Woods Hole Mass. it is abundant in winter, coming about October 1 and remaining till May 1 . It spawns in December. In Massachusetts it is a resident species, entering brackish waters; it is common about the wharves and bridges in summer and is taken with nets and hooks in winter, in company with the smelt.

The tomcod reaches the length of about 10 inches. It is an important food fish and its eggs have been hatched artificially by the New York Forest, Fish and Game Commission in large numbers.

\section{Genus Gadus (Artedi) Linnaeus}

Body moderately elongate, compressed and tapering behind; scales very small; lateral line present, pale; head narrowed anteriorly; mouth moderate, the maxillary reaching past frout of 


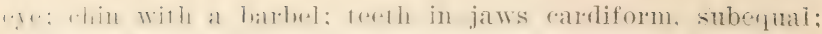

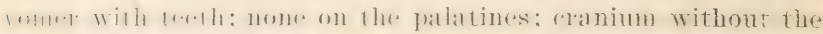

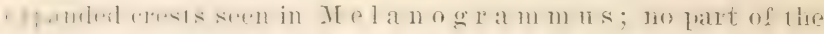

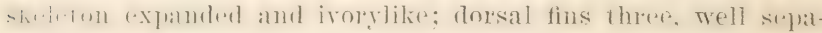

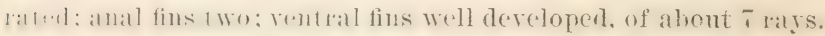
species of the northern seas; highly valued as food.

\section{Gadus morrhua Linnacus Cod}

Ginlus enllarias Lrixaeus, Syst. Nat. ed. X, I, 252, 1758, young; Mitcriml, Rep. Fish. N. Y. 5, 1S14; Trans. Lit. \& Phil. Snc. N. Y. I, 367, 1S15;

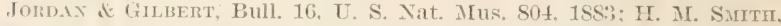
Bull. U. S. F. C. 1897, 107, 189S; Jordax \& Evermaxx, Bull. 47, U. S.

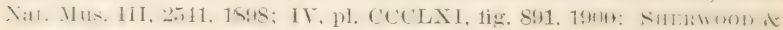
Edwards, Bull. U. S. F. C. 1901, 30, 1901.

Gulus arenosus and rupestris MITchILI, Trans. Lit. \& Phil. Soc. N. I. I, 36S. 1815.

Morrhue americana Stoner, Rep. Fish. Mass. 120, 1839; DE KAY, N. Y. Fauna, Fishes, 274, pl. 44, fig. 140, 1842.

Vorrhut americams. Storer. Hist. Fish. Mass. 165, pl. XXVII, fig. 4, 1867. Gadus mortun Lrxiseus, Syst. Nat. ed. X, I, 252, 1758; Mrtcmil, Rep. Fish. X. Y, 6, 1814 .

Cimins momhina Günther, Cat. Fish. Brit. Mus. IV, 328, 1562; Goode \&

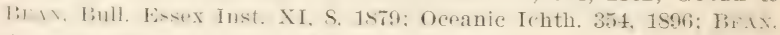
Bull. Am. Mus. Nat. Hist. IX, 372, 1897.

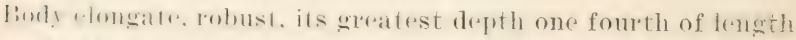

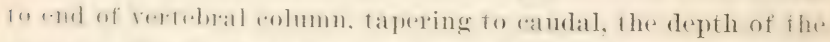

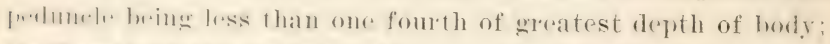
the lengll of the lexal slighty more than depth of body. one

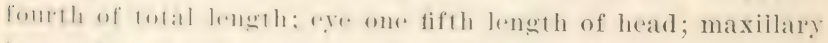

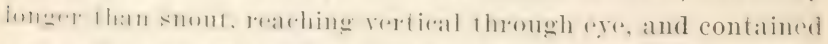

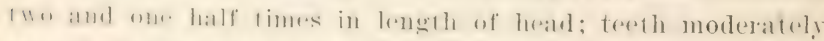

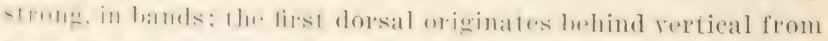

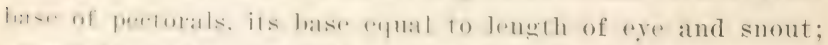

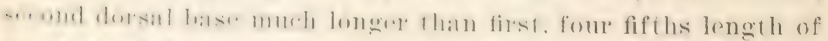

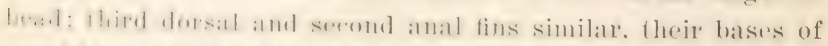

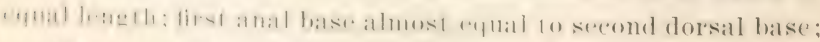

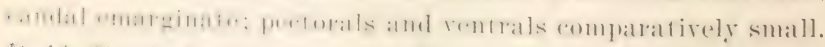
1). $14,21,19): 20,1 \mathrm{~S}$.

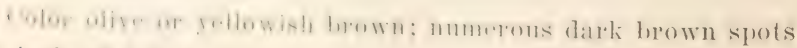
oul houly: fins dark. 
The cod is an inhabitant of the north Atlantic and the north Pacific. It is a very important food fish and grows to a large size. Individuals weighing about 100 poumds have occasionally been taken. Ifitehill has described this fish under sereral names: the torsh, or common cod, or rock cod of Xer Tork. De Kay calls it the Imerian cod. In November 189 the rod was abundant in Gravesend bay. It thrives in captivity duriug the winter and spring, but can not be kept during the warm months without rooling the water. In Vineyard sound, according to Dr. Smith, the cod appear about $A$ pril 1 to about $A$ pril 15 , when the dogfish drive them away. After the middle of October the cod come again but in less numbers than in the spreing. remaining till the first wintry weather. The fish spawns during the late fall and winter. The roung are first observed at Toods Hole about the first of I pril, when fish about 1 inch long are seined. Most of the young leave by Jume 1.5, having attained a length of from :; to 4 inches. To corl are seen between small fish of that size and fish weighing from $1 \frac{1}{2}$ to 2 pounds, which are caught in traps in the spring. Oft the coast of Xew England cod are very abundant in the deep waters, and thes come up to the shoals and near the shores to spawn, from Yorember about Cape Ann till February on Georges banks.

\section{Genus melanogramus Gill}

This genus is distinguished from G a d us by its smaller mouth, the produced first dorsal fin, blark lateral line, and specially by the great enlarement of the hypocoracoid, which is dense and ivorylike. The lateral line is always black, and the surraoccipital and other crests on the head are largely droveloped. Food fishes of large size.

\section{:4 Melanogrammus aeglefinus (Linnaeus)}

\section{Haddock}

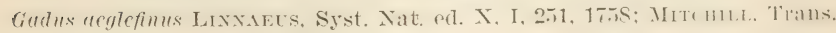
Lit. \& Phil. Soc. N. Y. I, 370, 1815.

Morrhua aeglefuus Stoner, Rep. Fish. Mass, 124, 1839; DE KAY, N. Y.

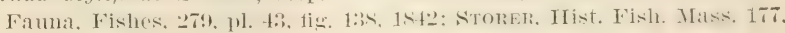
pl. XXYIII, fig. 1, 1567 . 


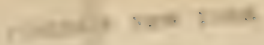

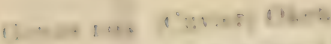

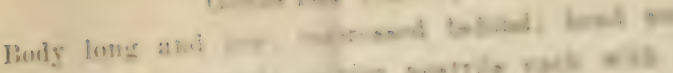

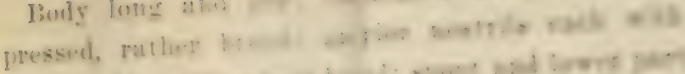

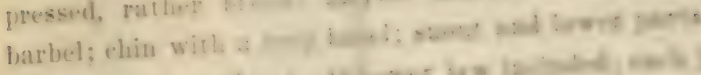

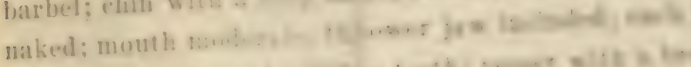

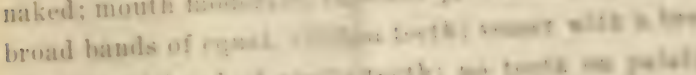

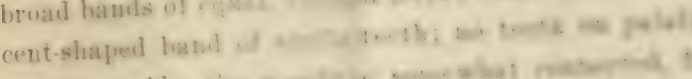

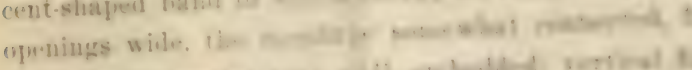

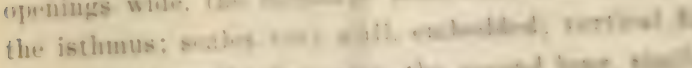

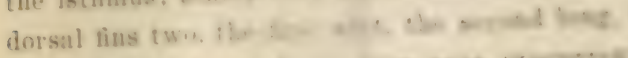

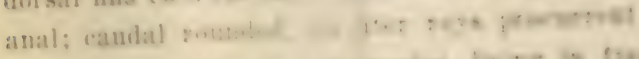

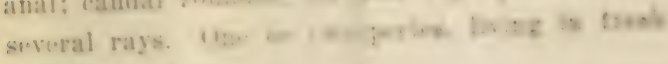
northern regions.

\section{0:

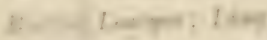

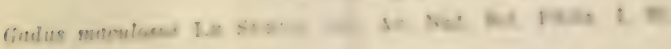
Erle.

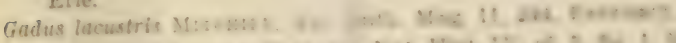
Lote Grosmiene : :

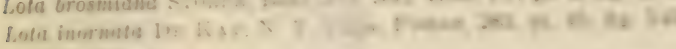
son Rilver.

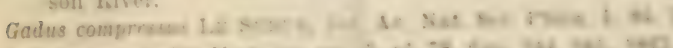

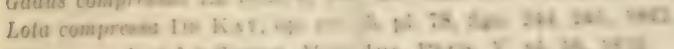

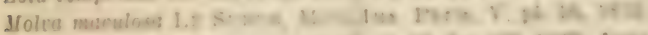

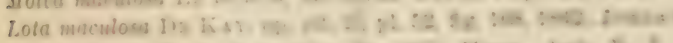

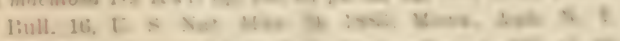

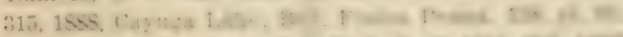

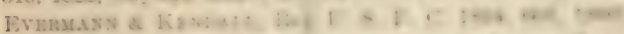

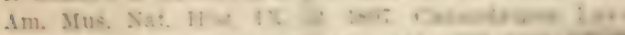

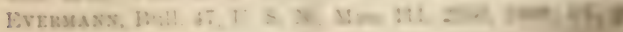
fig. $89 \bar{i}, 19=1$.

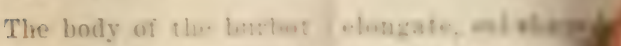

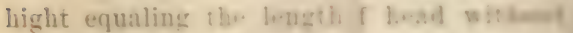
one sixth of total without rsilal: it is trobs a

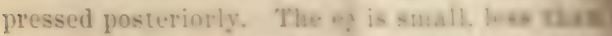

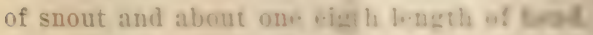
reaches slightly heyond thuind murgin of the row three sevenths length of tad. Thw lewrt $y=$ within the upper, and has stout harter shiale ve fifth as long as the head; th rentral is longer this 


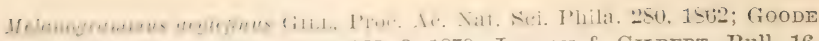
it BEAx, Bull. Essex Inst. XI, S, 1S79; JordaN \& Gilbert, Bull. 16, U. S. Nat. Ilus. S03, 1SS3; Goode \& BEAN, Oceanic Ichth. 354, 1896;

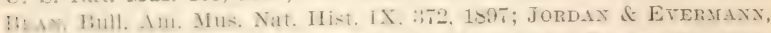

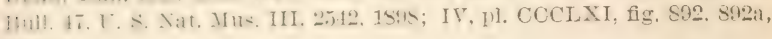
I! (4).

The h.11gh of Ih. houly is four and one half times its depth and then ame three fourths times the length of the head. sout long and natrow, overlapping the small nonth; maxillary barely Irateding front of orbit: teeth suberpat, large, in a cardiform

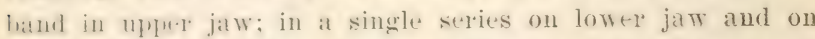

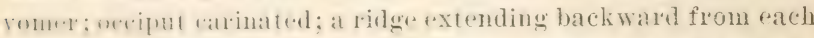
whit: 1.1. very large, (wo thirels length of smout, four in head.

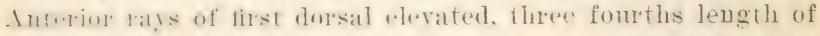
heat. the fin fointed, higher than sicond and third dorsals; atmla! lunate; r.ne lwelow front of second dorsal. The skull in

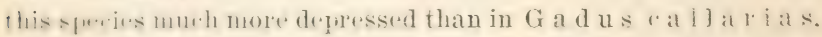

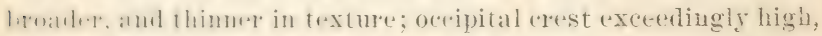
mun h highr. than in (i a d $1 \mathrm{~s}$, 1he winglike projections at its ian and rimly sprealing wirlely, raised above the surface of the skull. D. 15-24-21; 1. 23-21.

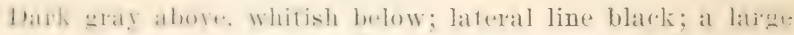

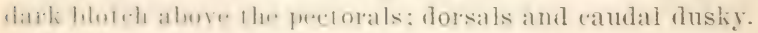

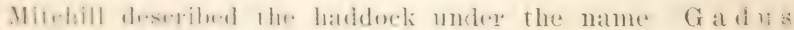

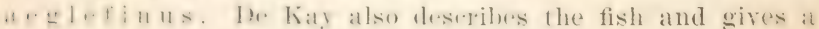

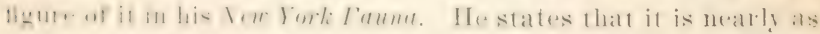

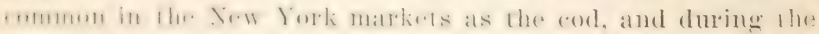
summer it is even more abundant than the cod.

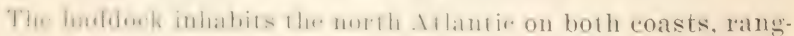

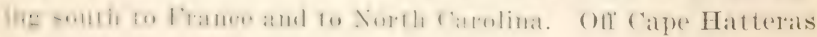
it ocens in the decper water. It is an important food fish,

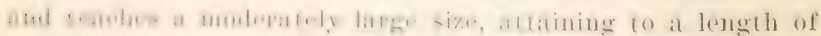
mearly :3 feet.

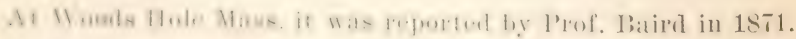
$1 \%$ smith, howrere, salys it is not found in Vineyard sound or

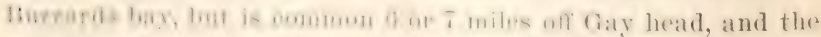
orean side of Marilias Vincyart. In Massachusetts bay it is a 


\section{Genus цота (Cuvier) Oken}

Body long and low, compressed behind; head small, depressed, rather broad; anterior nostrils each with a small barbel; chin with a long barbel; snout and lower parts of head naked; mouth moderate, the lower jaw included; each jaw with broad bands of equal, villiform teeth; romer with a broad, crescent-shaped band of similar teeth; no teeth on palatines; gill openings wide, the membrane somewhat connected, free from the isthmus; scales very small, embedded; vertical fins scaly; dorsal fins two, the first short, the second long, similar to the anal; caudal rounded, its outer rays procurrent; rentrals of several rays. One or two species, living in fresh waters of northern regions.

\section{Lota maculosa (Le Sueur)}

Burbot; Lawyer; Ling

Gadus macilosus Le Sueur, Jour. Ac. Nat. Sci. Phila. I, 83, 1817, Lake Erie.

Gadus lacustris Mrtchil, Am. Month. Mag. II, 24t, February, 1818.

Lota brosmiana Storen, Bost. Jour. Nat. Hist. IV, pl. 5, fig. 1, 1839.

Lote inornata DE K.1Y, N. Y. Fauna, Fishes, 28:3, pl. 4., fig. 145. 1St2. IIutson River.

Gadus compressus Le Sueur, Jour. Ac. Nat. S.j. Phila. I, St. 1817.

Lota compressa DE KAY, op. cit. 285, pl. 78, figs. 244, 245, 1842.

Molva maculosa Le Sueur, Mém. Mus. Paris, T, pl. 16, 1819.

Lota maculosa DE KAY, op. cit. 284, pl. 52, fig. 168, 1842; JoRdan \& Gilinert,

Bull. 16, U. S. Nat. Mus. 804, 1883; MEek, Ann. N. Y. Ac. Sci. IV,

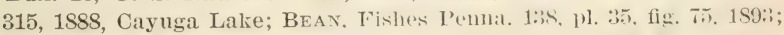

Evermann \& Kendat.t. Rept. L. S. I. C. 1S34, 603, 1S96; Beds, Bull.

Am. Mus. Nat. Hist. IX, 372, 1897, Canandaigua Lake; JondAN \&

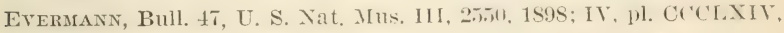
fig. 897,1900 .

The body of the burbot is elongate, eel-shaped; its greatest hight equaling the length of head withont snont, and about one sixth of total without caudal; it is roundish, somewhat compressed posteriorly. The eye is small, less than one half lengih of snout and about one eighth length of head. The upper jaw reaches slightly beyond the hind margin of the eye, its length three sevenths length of head. The lower jaw is included within the upper, and has a stout barbel which is nearly one fifth as long as the head; the rentral is longer than the pectoral, 


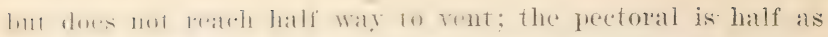

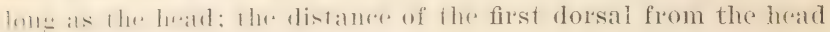

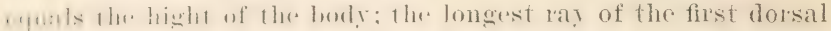

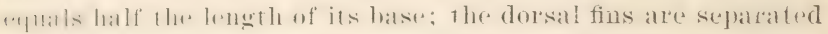

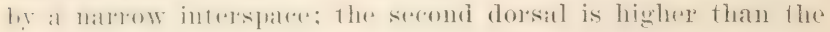
lirst. and the lougth of its hase is neaply one lalf total without

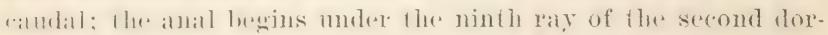
sil aml exlumb as fal batek as that fin: camdal rommeded; the

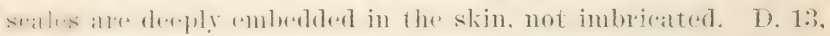
68 to 76 ; 1.67 ; V. 7 ; vertebrae, 22 to $23+38$ to 39 ; pyloric caeca, 30 to 138 .

Thu rolor is dark olivaceous. reticulated with blackish: the lowrer palts yollowish or dusky: the dorsal, anal and eavelal fins with a narrow dark edge.

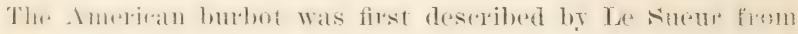
bake Eite in 1s17, and also from Northampton Conn. under it ditherent name. This rommon fish has received a great man! manms, inclubling the following: mathy, methy, losh, edpont.

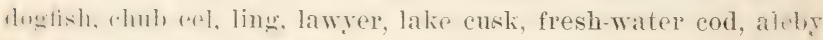
trout and mother-of-eels.

The som hern limit of this fish appears to be Kansas City Mr.:

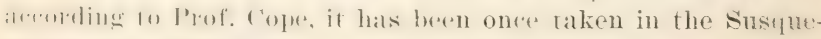

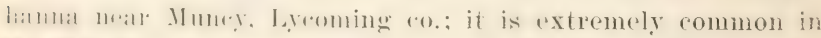

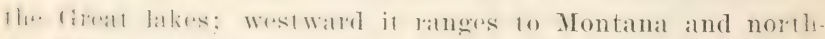

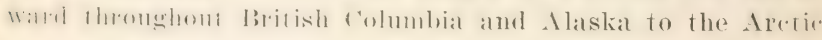

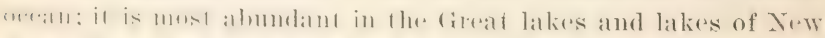

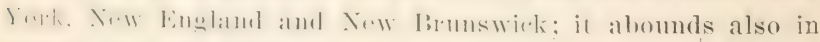
rivins and lakes of Mlaska.

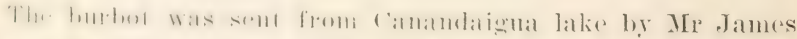

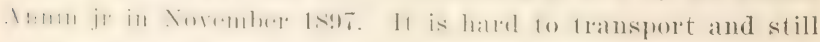
liamlur to kecp alive in eaptivity, being specially liable to at1:arkix of funens.

11. 11. M. Be+ancliamp, writing from Baldwinsville N. Y. Ap. 9. IST!. said that the bubot is fomnd in Seneca river and is

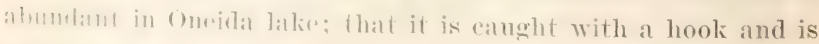

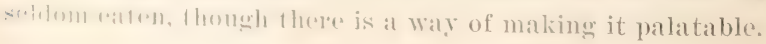


According to Dr Mexe it is foumd raredy in Cayuga lake.

The avelage length of this species in the rreat lakes region is about 2 feet; in Alaska, according to Dr Dall, it reaches a length of 5 feet and orcasionally weighs 60 pounds; the size of the fish depends chiefly on the amount of food aceessible. to it.

It is stated that the bubot is usually fomd in deref water on mud bottom, except during the spawning season, in Marrh, when it frequents hard or rocky bottoms. The eggs are small and numerous, and are beliered to be deposited in deep water: In Dall estimates that some indiriduals contain sereral millims of eggs; in Alaska the eggs are of a creamy yellow color, and the fish are found full of spawn from Norember to Jannary. From the observations mentioned, it will be seen that the spawning period extends at least from Norember to March; aceording to Dr Dall the males are usmally much smaller than the females and have a smaller liver: in some males he found two or three gall bladders opening into a common duct, but he never observed this phenomenon in the female; the eggs are laid separate or loose on the bottom of the river. According to Baron Cederströn, a medium-sized female of the European burbot, which is a near relative of the American speries, contaned about 160,000 eggs; in the Emopean burbot, some wygs are clear, some rellowish and other's almost colorless: the period of incubation orrupies from three to four Weelis; the "yes appear in 15 or 16 days; the embryos swin by quick morements of the pectorals, usually toward the surfare of the water, whence they fall passively to the bottom.

The burbot is extremely roracious, and feeds on bottem fishes and crustaceans. It destroys the pike and such spiny fishes as the yellow perch aud sunfish. In Mlaskinn rivers it feeds on whitefish, lampreys and other speecies; large stones harr sometimes been found in its stomach. Mr Graham touk a stone weighing a pound from the stomach of a burbot.

In the Great lakes region the burbot is considered worthless for food, occasionally the livers are eaten; in Lake Winmene- 
-imlier. When ratught through the ice in winter, the fish is nichly estermed: in the fur countries the roe is an articie of foml: on the Vuken river the liver is eaten and the flesh is liked by some gresons; in Montanat the burbot is in great demind for food: the quality of the flesh appears to depend chiefly on the nature of the habitat of the fish.

This is the only member of the cod family permanently resident in the fresh waters of America.

\section{Genus uropirycrs Gill}

Jionly rather elongate; head subconic; mouth rather large, lhe maxillaty ratehing to below eye; lower jaw inchubed; chin with a small hathel; jaws and vomer with broad bauds of slibepual. puinted terth; palatines toothless; dorsal fins two, llu tirst somelimes produered at tip); second dorsal long, similar 16 the anal: rentrals wite aluat, filamentous, each of threes senJ.r latys closely joined, appearing like one bifid filament: gill membrames somewhil (m)mected. marrowly joined to the isthmus.

\section{Subgenus Urophycis}

350 Urophycis regius (Walbaum)

\section{Spotted Codling; Spotted Hake}

IJlennius regius Watbaum, Art. Gen. Pisc. III, 186, 1792.

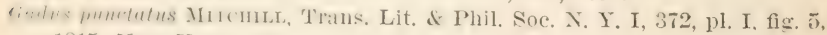
1815, New York; De KAY, N. Y. Fauna, Fishes, 292, pl. 46, fig. 149, 1812.

l'hycis regalis Güntrier, Cat. Fish. Brit. Mus. IV, 354, 1862.

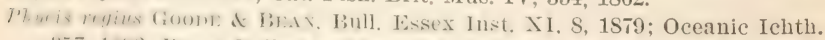

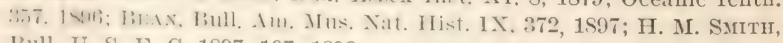
Bull. U. S. F. C. 1597, 107, 1898.

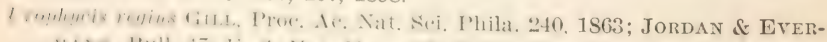

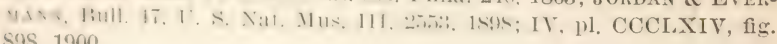
S9S, 1900.

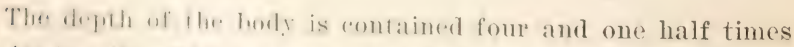

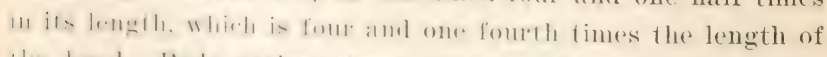

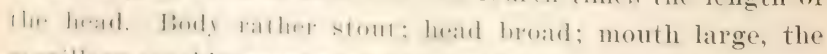

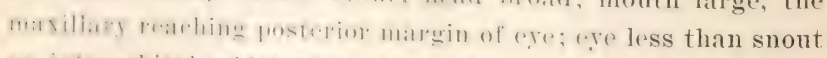

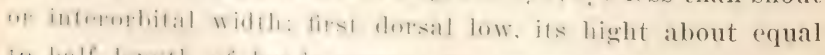

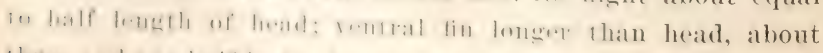

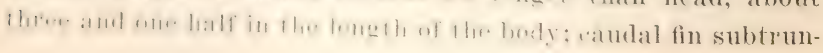


cate. D. S-43; A. about 45; scales rather large, about 90 in the lateral line.

Pale brownish, tinged with rellowish, the lateral line dark brown, interrupted by white spots; inside of mouth white; first dorsal largely black, this color surrounded by white; second dorsal olivaceous, with irregular, round, dark spots; caudal, anal and pectorals dusky; rentrals and lower edge of pectorals white; two rertical series of round dark spots on the sides of the head.

Mitchill described and figured the spotted codling under the name of fa a dus punctatus. De Kay called it the spottud codling. Ph y e is p $11 n$ ct a tus, and he gives a good figure of it. His example was 10 inches long. He says it is an cxceedingly rare but distinct species, and that it occurs from the coast of Nerl York to the Gulf of St Lawrence. Is a matter of fact, the species extends even farther north. The codling ranges southward to Caje Fear. In the northern part of its habitat it is found in shallow water, but at the southern limit it lives in considerable depths, having been taken from $16 \pi$ fathoms. The fish is said to exhibit electrical powers in life.

The spotted codling appears in Graresend bay in small number's in the fall. It lives in water below $60^{\circ} \mathrm{F}$., and is easily kept in captivity by refrigerating the water in summer. Its habit of lying on the side, in imitation of the tautog and other labroids is often observed. Prof. Alexander Agassiz discovered electric powers in this fish.

At Woods Hole Mass., aceording to Dr Smith, it is taken in the seine only late in the fall. It varies in length from 7 to 12 inches. The species has been observed at Halifax X. S.

\section{- Subgenus Emprycus Jordan \& Evermann}

This subgenus differs from $U \mathrm{r} 0 \mathrm{ph} \mathrm{r}$ is in having the first dorsal fin elevated, with one or more of its rays filamentous.

\section{Urophycis tenuis (Mitchill)}

\section{Hake; White Hake}

Garlus tenuis Mtrmild, Rep. Fish. X. Y. 5. 1814; Trans. I.it. \& I'hil. Soc.

N. Y. I, 372, 1815, New York. 


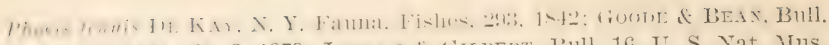

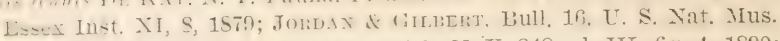
7!19. 1SS3: BEAx, 19th Rel). Comm. Fish. x. Y. 248, pl. III, fig. 4, 1890;

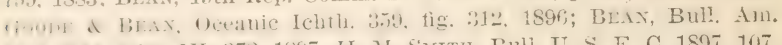

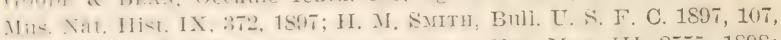

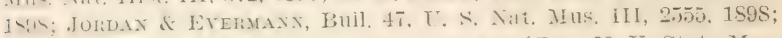
IY, pl. CCCLXY, fig. 901,1900 ; BEAN, 32 d Ann. Rep. X. Y. State Mus. $109,1900$.

The lengh of the body is tive and one half times the depth of 1h. huly and four and one fourth times the leught of the head.

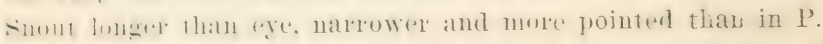

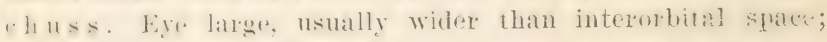
maxillaty reateling heygond pupil: filamentous dorsil ralg about two thirels length of head: rentral fins about reacling rent; scales very small. D. 9-57; A. 48; Lat. 1. 138.

Jirum nish. lighter and yellowish helow; fons rery dark. ris-

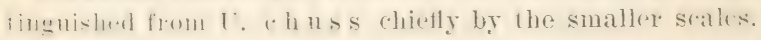

11. Kay ralls the hake the Americall codling, adopting Mituhill's rmmmon name for the species. He sigs it appears to fund rhirfly on smaller crustaceal; that it is very abumdant at sones

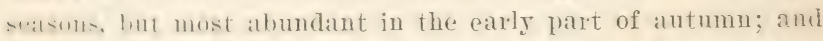
varies in wright from is pounds to 30 pounds. He states that it is ralled indiseriminately latke and rodling by New Sorls

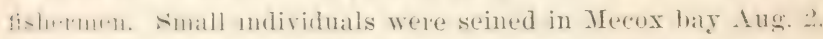

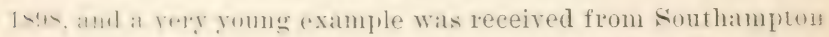
sip. 11. This wats ratught in the Atlantic. In Great south bay -mall + damples were fomd sparingly at blue l'oint cove and Fire Island late in September.

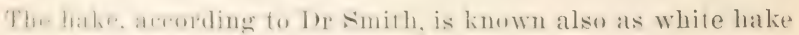
amal stuinw hakr in llw virinily of Woods Hole Mass. Fish

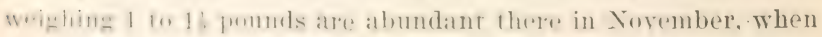

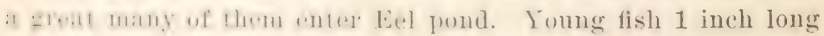

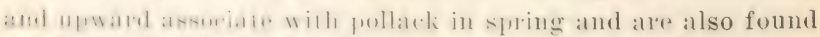

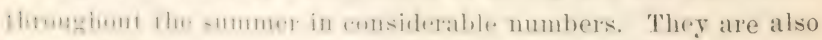

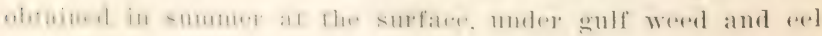
mils:

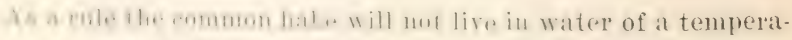

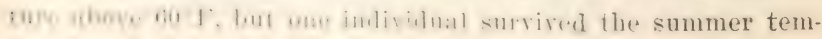




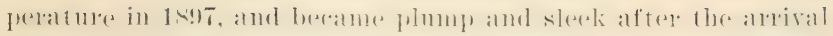

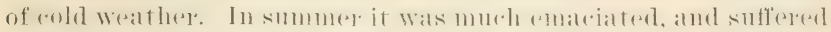
greatly from fungus attacks.

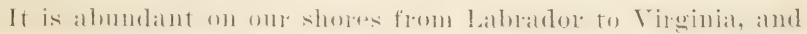

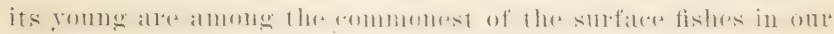

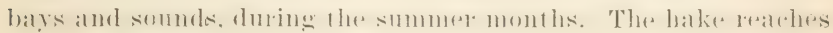
a weight of to pommels, hut in the malledets the arelatere weight is

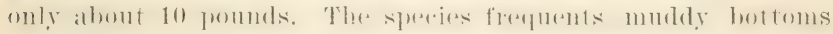
and is local in its habits. Its food romsists of (.aths and oflue crustaceans, besides small fishes.

The chief fishery for hake takes flater in the fall and wintere months, and they will take the hook at night as well as during the day. Traw limes ate the nsual implements of atpume.

\section{Urophycis chuss (Walbaum)}

\section{Squirrel Halie}

Blemius chuss Waldaux, Art. Gen. Pise. III, 186, 1792.

Gulus lomgipes Mrtcmul, Rep. Fish. X. Y. 5, 1814; Trans, Lit. \& Phil. Soc. N. Y. I, 372, pl. I, fig. 4, 1815, New York.

Phycis filamentosus Storer, Hist. Fish. Mass, 189, pl. XXIX, fig. 4.1867.

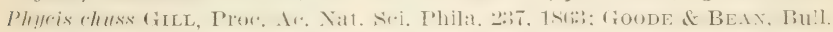

Essex Inst. XI, 8, 1879; Jorday \& Gilbert, Bull. 16, U. S. Nat. Mus. 799. 1883; Goode of BEAn, Oceanic Ichth. 359, fig. 311, 1896; BEAN, Bull. Am. Mus, Nat. Hist. IX, 372, 1897; H. M. Smтн, Bull. U. S. F. ${ }^{\circ}$. $1897,107,1898$.

Urophycis chuss Jordax \& Everumax, Bull. 47. U. S. Nat. Mus. III, 2555, 1S98; IV, pl. CCCLXY, fig. 902, 1900.

The depth of the herly is one tifole of its length. whirh is fome

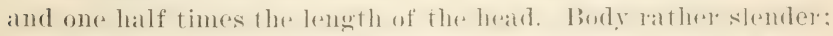

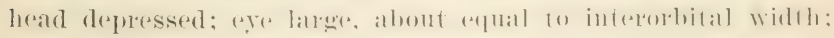

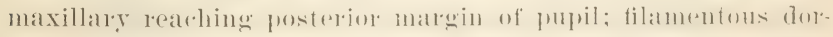

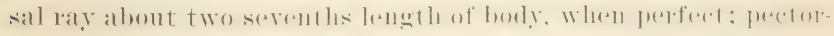

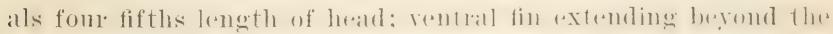

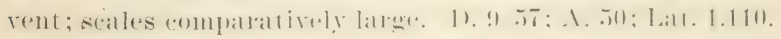

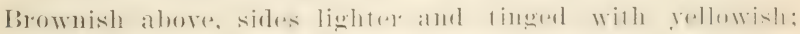

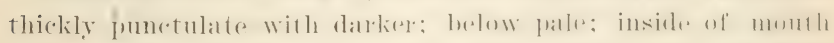

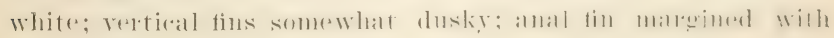
pale; lateral line not dark.

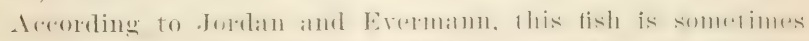
called codling. It inhatits the It lamtic anast foum the (imll af 


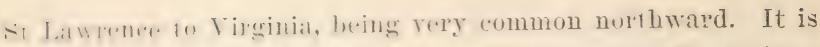
-mantimes fomm in walers as deep as 200 fathoms. The squirrel

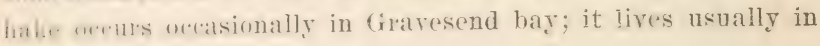
the deep water off shore.

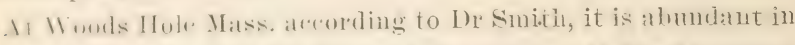
Ma! and Inme. and in October and Vovember. It fills the traps and fansis the fishemen much amogance, as they cam not sell 1h. fish. Its weight there is from 2 to 5 pounds. In Massachus.l1s liay it is less abundant than the common bake. It was 1...relibel and figmed by storer in 186\%, muder the name Ph $\mathrm{g}$ eis filamentosus.

\section{Genus gamoropsrus Rafinesque}

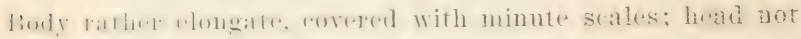

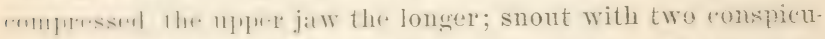

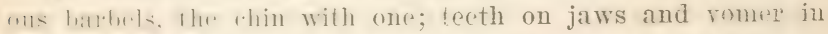

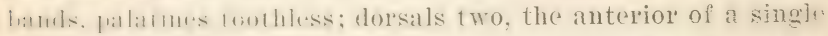

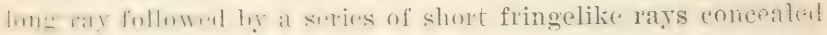
in a cromse: stomm norsal and anal long, similar to eath other:

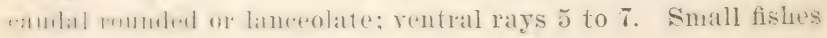
of the northern seas, descending to deep water.

\section{Gaidropsarus argentatus (Reinhardt)}

Silvery Rockling; Wackereh Midge

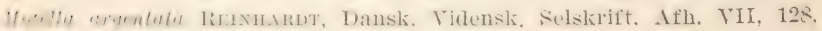
18:S, Greenland.

rmuthiu armenluta Gëxtmer, Cat. Fish. Brit. Mus. IV, 365, 1862. Ciliata argentata Gild, Proc. Ac. Nat. Sci. Phila, 241, 1863.

(mus reinhurlti firt., op). eit. 241, 1863; Jordan \& GILBert, Bull. 16, U. S.

Nat, ILus, 797, 1883; Goode \& BEAN, Oceanic Ichth, 383, 1896.

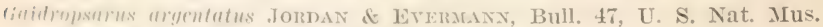

111, 2ป59, 1898; IV, pl. CCCLX VII, tig. 906, 1900.

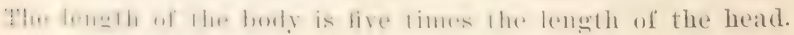

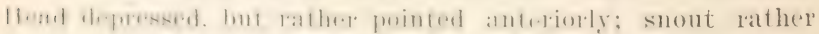

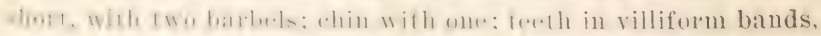

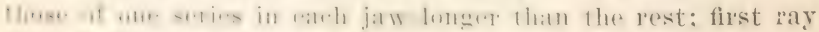

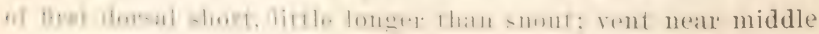
(1) Irments: distance from snout to first dorsal three tenths of lemgili. 1). 51 ; A. 45: V. 8. 
Lniform reddish brown; cirri and tips of fins red. Greenland. The silvery rockling, or mackerel midge, inhabits the coast of Greenland, and extends southward probably as far as Long Island, the young haring been taken in Vineyard sound.

\section{Gaidropsarus ensis (Reinhardt)}

\section{Rockling}

Jotellu ensis Iieminant, Dansk. Vinlensk. Selskrift. Afli. VII, 15. 1S38, Greenland.

Onos rufus Gils, Proc. U. S. Nat. Mus. 259. 1S53, Gulf Stream; Proc. Ac. Nat. Sci. Phila. 172, 1884.

Onos ensis Gill, Proc. Ae. Nat. Sci. Phila. 211, 1863; Jordax \& Gilbert. Bull. 16, U. S. Nat. IIus. 797, 1s5:3; Goors \& BEAN, Ocenuic Ichth. 381, fig. $327,1896$.

Gaidropsurus ensix Jornax of Evemarax. Bull. 47. U. S. Nat. Mus, III, 2558, 1898.

Body unusually de(ep), its greatest depth at rent equaling two ninths of total length without ('audal; head small, a little more than one sixth of total without the raudal; eye rather large, nearly as loug as snout, equaling interorbital area, and situated in first half of head; posterior margin of orbit nearly equidistant from tip of snout and posterior margin of operele; mouth normal; supramaxillary ending under posterior margin of pupil; teeth in a narrow band in each jaw, some of those at least in outer row of upper jaw slightly enlared and brownish colored; romerine teeth in two rows forming a short curved band; nasal barbel about equal to diameter of tre: chin barbel small and not much exceeding one half diameter of eye; foremost ray of first dorsal springing from batrli abore opercular margin; second dorsal fin low in front, but rising rapidly to seventh or eighth ray, behind which it is nearly uniform for a lono distance and highest at posterior portion: anal fin much lower than second dorsal; caudal slightly emarginate. almost truncate behind, its median rays about two thirds as lome as the head: peretorals nearly three fourths as long as the hear. produced tuward the upper angles, the third ray being lomgest: ventrals with their bases mostly in adrance of pertorals. the longest ray filamentums and nearly equaling pectoral: lateral line obsolesent. I). s!l; A. 44 to $46 ;$ P. 22 to $27 ;$ V. S. 


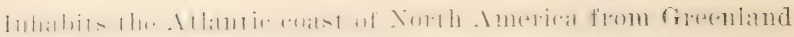

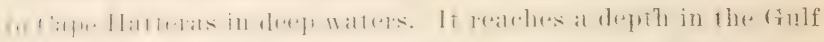

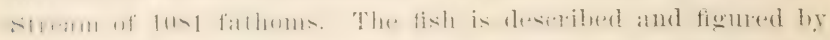
Foorle and linan in Ocennic Tchthyology, p. 3S1, fig. 327. It is a

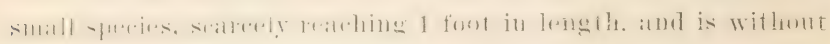
importance as food.

\section{Genus excheryopes Bl. E Schn.}

liarbels four, one at each nostril, one at tip of snout, and one

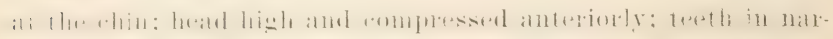

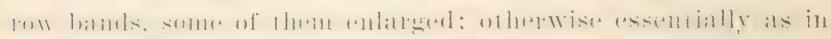
Ga idropsar r s . North Atlantic.

\subsection{Enchelyopus cimbrius (Limnaeus)}

\section{Four-bearded Rockling}

Cimdus cimbrius Iixxaeus, Syst. Nat, ed. XII. I, 4t0, 1766, Itlantic Ocean. Motellu cunducutu storer, Hist. Fish. Mass. 18:3. pl. XXIX, fig. 1, $186 \pi$.

Onos cimbius Jorndx \& (illbert, Bull. 16, U. S. Nat. Mus, 79T, 1883.

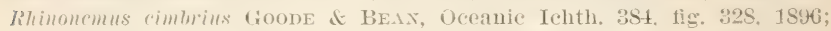

II. M. Nimti, Bull. U. S. F. C. 1S97, 107, 1898; SHerwood \& Edwards, Bull. I. S. F. C. 1901, :31. 1901.

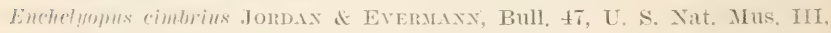

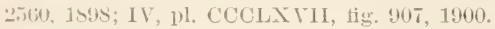

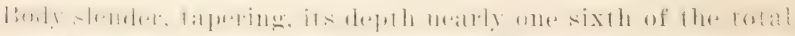

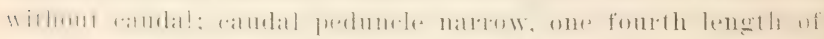

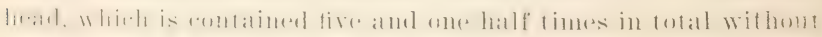

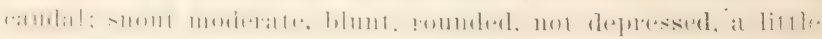
shorter than the ere, which is one fomth as long as the head; informbital space narrow; one sixth length of head; teeth villi-

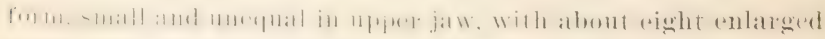
in fromi, long, slender, and equal in lower jaw, a few somewhat

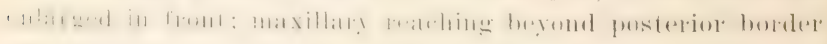
af eye: it hatherl at wath nostril, one on tip of snout and one on

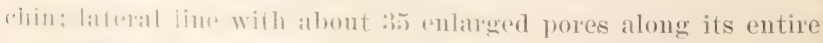
lomglle; first ffree) ray of dorsal neally as long as the head;

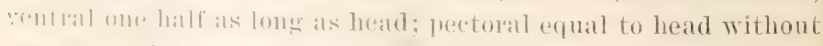

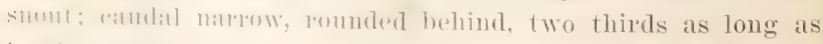
limill.

('ulur, lighli rufous or salmon redi first dorsal ray and posfurom end of domsal amel amal abruptly black; lower half of caudal 
blatek: pectorals and ventrals fale: sides of head sompwhat silvery; cavity of mouth dark bluish.

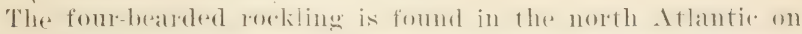
both roasts, langing somb in dere water to the frulf stream. It is rommon in Massatehusetts lay. This fish is also deseriberl

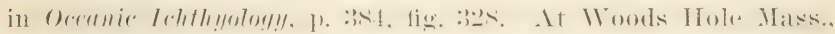

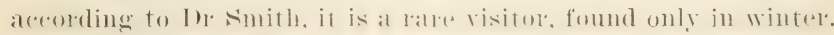
It was once taken in a fyke net in Great harbor. In 1900 , areording to sheswod and Edwalls, young rockling weres taken

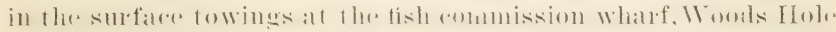

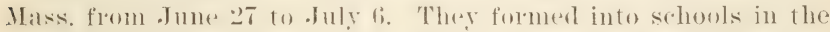
eddies, alomol the whatres and were mixed with young stivklebarkis. In example measmling 10 inthes in lemgth was speatreet

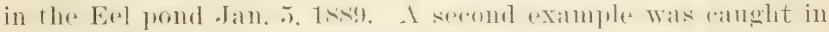
Little harbor also in the winter.

Fitorer described and figmed this fish moder the mame Motella ca u d c u t a. It is a resident of the deep waters of Massachusetts bay, where it ocems in eomsiderable abmolanee. The young swim at the surface and have often been erroneously

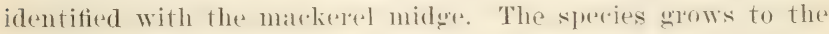
length of 1 foot.

\section{Genus mrosne (Curier) Oken}

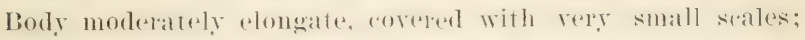
month lather latege. with teeth in the jaws. vomere and palatines, some of those on the vomer and patatines enlanged: rhin with a barbel; branchiostegals seven; dorsal fin single, contimuons, not

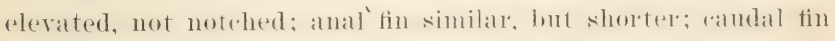
rounded; rentral fin several-rayed. Northern seas.

\section{Brosme brosme (Miiller) \\ Cusk}

Gadus brosme Müller, Prodr. Zool. Dan. 41, 1776, Denmark.

Brosmius vulgaris? De KAY, X. Y. Famm, Fishes, 289, pl 44, fig. 143, 1842.

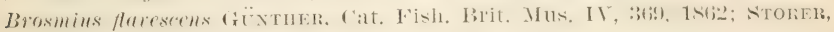
Hist. Fish. Mass. 190, pl. XXIX, fig. 2, 1867.

Brosmius trosme Güntuer, op. cit. IT, 369, 1862; Goode \& BEAN, Bull. Essex Inst. XI, 9, 1879; Jordax \& Gilbert, Bull. 16, U. S. Nat. Mus. S02, 1883; Goode \& BEAN, Oceanic Ichth. 385, fig. 329, 1896; H. MI. Sмiтн, Bull. U. S. F. C. $1897,107,1895$.

Brosme brosme Jordax \& Everuans, Bull. 47, U. S. Nat, Mus. III, 2561, 1898. 


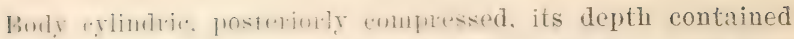

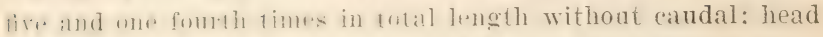

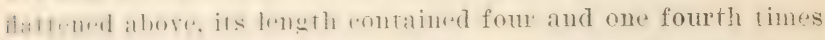
in fulal: month litreg. uhlique, maxillatry reaching beyond orbit:

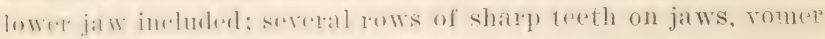
and palate: harleel abume one fifth as long as the head; intermhilal wilth greater than diameter of rye: urigin of dorsal

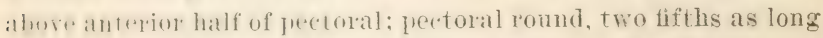
as luall; ratulal 1+umeled hehind. 1). 98; A. 71; P. 24; V. 5.

fulol hownish ahore, lhe sides yellowish. sometimes dint tled "ith hown; yomm nnifom dark slate, or with transperse rellow lamels: veltimal dins hordened with blackish, and with a white edge.

The rusk is anscribed and figmed by Te Kay, but he did not sur thr tish and (opied his information from Storer and others. stumer m1ntions a sperimen weighing 20 pounds, but the fish

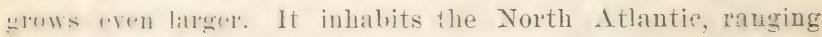

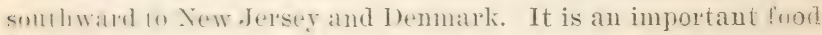

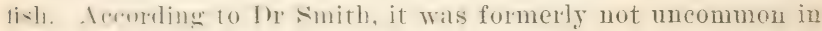
limyand somnd, and was andeht with cod in April and Mar. It

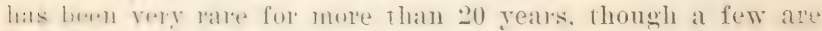
sill tahern in I lmil. The arerage weight of individuals in these. watres is i pumbls, and the maximum weight from 12 to $1:$; pmmmls. It is known alsu as ling. In Massachusetts bay and

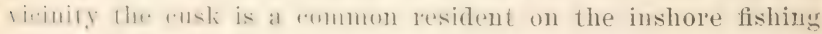

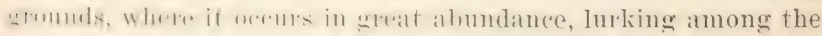

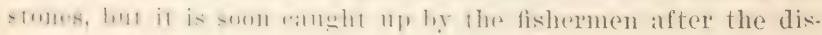
eovery of a new bank.

\section{Family AICIRUTIDAE Grenadiers}

\section{Genus coenonmychus Giorna}

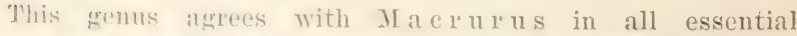

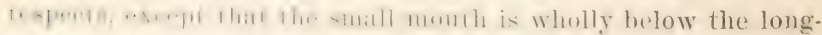

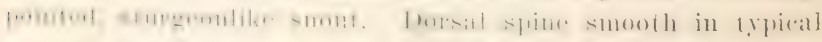
spreries, those with serrate spine loving been lately sepa-

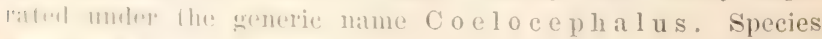
1111106rems. 


\section{Coelorhynchus carminatus (Goode)}

\section{Grenadier}

Macrurus carminatus froodr, Proc. L. S. Nat. Mus. III, 246, 475. 1Sso.

Macrurus (Coelorhynchus) carminatus Guntmer. Challenger Report. Deepsea Fishes, XXII, 129, pl. 5, fig. 13, 1887.

Coelorhynchus carminatus Goone \& BF.1x, Oceanic Ichth. 398, fig. 336, 1596; Jordan \& Evermany, Bull. 47, T. S. Nat, Mus. III, 258s, 1S9S; IT, pl. CCCLXIX, fig. 914, 1900.

The body is stout anteriorly, tapering rery rapidly to a rather long and slender tail. The depth is one eighth, and the length of the head about one fifth of the total length. The ere is large, one fifth as long as the head, equaling the interorbital width. The snout is as long as the eje. The body is less elougate than in Baird's grenadier. The snout is long, sharp, depressed, triangular. Strong horizontal ridges run from the supraorbital margins to the gill openings, parallel with the subocular ridges. The nostrils are immediately in frout of the orbit; barbel rery short; teeth small, conic, somewhat recurred, arranged in villiform bands; base of first dorsal fin two ninths as long as the distance from its origin to the snout. The first dorsal spine is rery short, hardly perceptible above the skin. The second spine is about one half as long as the head, slender and unarmed; when laid back, the tip reaches to or beyond the origin of the second dorsal. The spines decrease in length very gradually, the sixth being nearly as long as the second. The second dor:al begins in the perpendicular from the serenth anal ray. The anal fin is much higher than in Baird's grenadier, nearly equal to one half of the interorbital width; its origin is under the 18th scale of the lateral line; its longest ray is as long as the interorbital width. The distance of pectoral from snout equals twice its own length, and about equals thr longest dorsal spine; the origin of the pectoral is below the middie of the depth of the body, and below the level of the midule of the orbit: the tip of the pectoral does not reach the origin of the anal. The insertion of the rentrals is behind the pectoral, slightly in advance of the first dorsal, its distance from the snout greater than twice its length, its long filament not reaching the anal. Color silvery gray. Length of the specimen deseribed 10 indwes. 


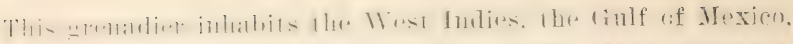

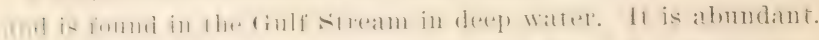

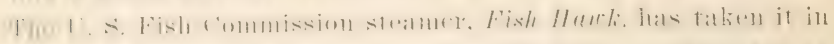

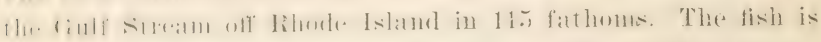

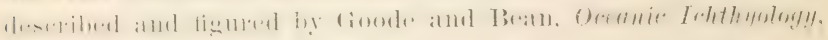
[1. :39s, fig. 336 .

\section{Order HETEROSOMATA}

\section{Flatfishes}

Family PLEURONECTIDAE

\section{Floumalers}

\section{Genus mproghossus Curier}

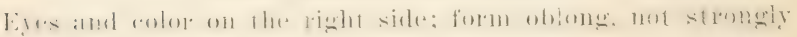

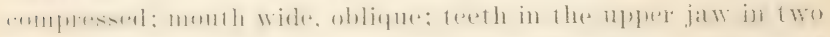
series, those below in one, anterior teetl in upper jaw, and lateral teeth in lower, strong, no teeth on romer or palatines,

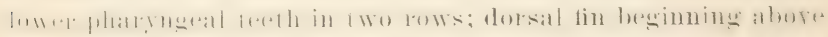

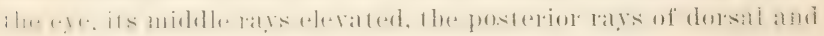

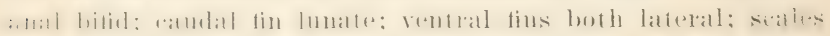

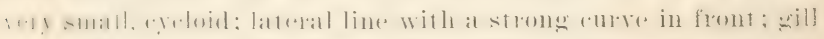
raliers few, short, compressed, wide set. Vertebrae 16+3.t.

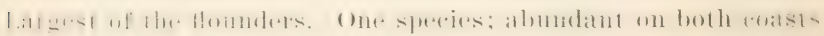
of the north itlantic and of the north l'acific.

\section{:\%ॅS Hippoglossus hippoglossus (Limnaeus)}

\section{Halibut}

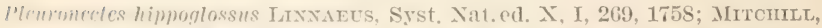
liop. Jish. X. Y. 10, 1\$14; Trans, Lit. of L'hil. Soc. N. Y. I, 386, 1515.

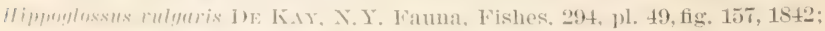
firmun, Cat. Fish, Brit. Mus, IV, 40:3, 1862; Stoner, Hist. Fish.

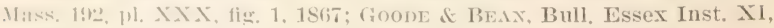

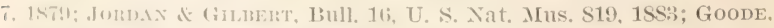

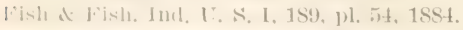

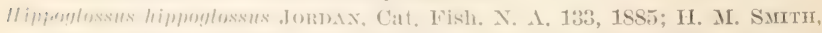

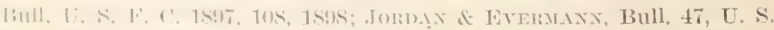

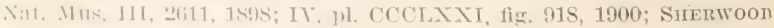
at EmW

limbly (mompatratively alongate, not strongly compressed, deep

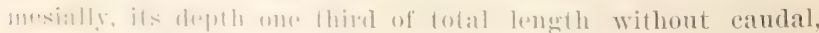

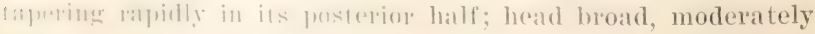


long. its length contained these and theee fourthe times in total length without randal: month latere, the maxillaty reatehing to

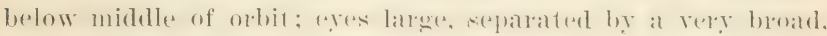

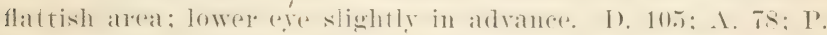
$19: 1:$. 1i.

Color, nearly uniform dark brown; blind side white.

The hatilut lives in all northern stats, ranging southward to Samdy Ilook, or heromel, and oreasionally to the Farallones off San Franciseo.

The halihut was deseribed by both Mitehill and for Kat under its present name. De Kay salys that the capture of the halibut on the shores of Xanturelet at one time atforded emploprnent to sol ressels of from bo to sll toms ealleh. He salys the fish is rery voracions, swimming neatr the gromed and devouring other flat fishes as well as shells and relustaleams. It oremes on both shores of the Itlantic as also in the nolth l'ateitie, miglating south on the alpleateh of spring and returning in .June or July. An indi-

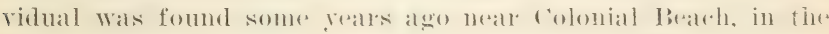
Potomate river. The tish grows to the leugth of se feet or mores. and the weight of sereral hunderel pounds. It is at very valuable food fish. In the Pareifie, alerending to Jordan and Erermann, it extends its range southwat to the Farallones, off siln Francisen.

The halibut was formerly not rery nnemmone in Vinerated sound, where it is now very rare. In 1872 and $1873, \mathrm{~V} . \mathrm{N}$.

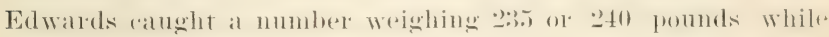
fishing for corl. Ap. 16, 1900), a halibut weighing 100 pounds was caught off Blork island ly rod fisherement, and wak talien to Yewport. The tish was very alomindint at one time in Massalehusetts

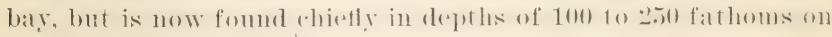
the slopes of the outer hanks. In August 1sts a halihut weigh. ing orer 200 poumds was calught in crloncestere hatrlute

\section{Genus mppogrossomes Gottsche}

Eyes and color on the right side (except sometimes in $H$.

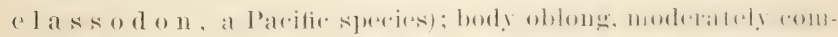

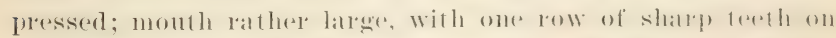
each jall: no teedh on vomere or palatines: will ralkers ratthere 
lumb amb slumler: srales cromoid; lateral line nearly straight, simple: dorsal fin low in front, herinning orer or before the cye;

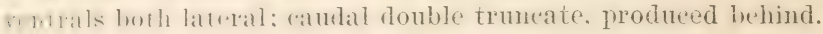

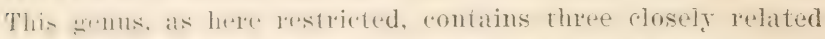
sfer.ies. 1 wo of the north I'arific, one of the north Atlantir. All al* +s.rentially arctic sperips, inhabiting shallow waters in the regions where they are most abundant.

\section{::i) Hippoglossoides platessoides (Fabric!ns!}

\section{Rough Dab}

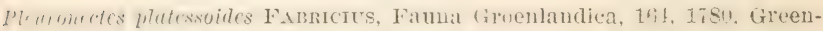
land.

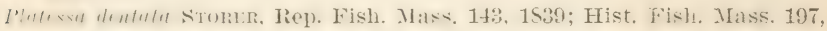

pl. XXX, fig. 3, 1S67; DE IAI, N. Y. Fauna, Fishes, 298, 1812, New

York markets.

Hipurgleswrides dentatus Günther, Cat. Fish. Brit. Mus. Mr. fur, 1s62.

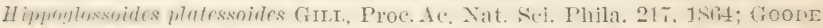

A Infix, Bull. Essex Inst. XI, 7, 1S79; Jornix \& filbert. Eull. 16, U.

S. Nat. Mus. 826, 1883; Goode, Fish \& Fish. Ind. U. S. I, 197, pl. 55,

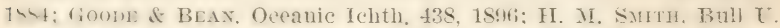

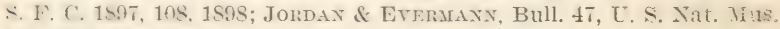
III, 2614, 1898; IV, pl. CCCLXXII, fig. 919, 1900.

The leboth of the body is 1 wo and one half times its derth and three ame three fourths times the length of the head. Fong

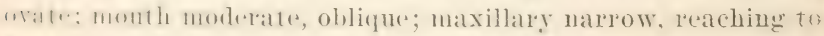
luymul fmpil. 1 wo and two thirds in lewgth of head: teeth rathei small, .m li, latrere anteriorly, in one row in each jaw, those

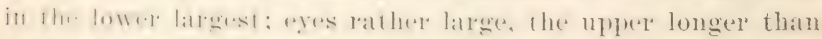

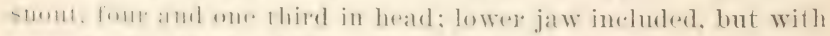

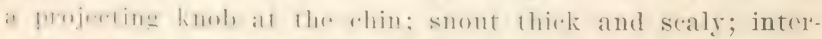

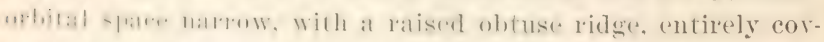
ored will romele sables in aloum six sories; mandible with a

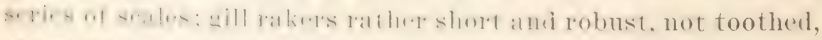

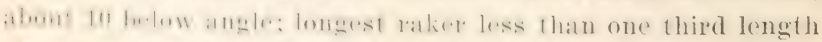

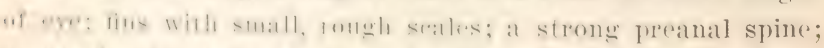

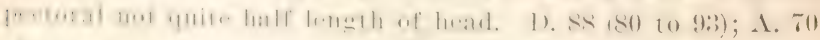
(lit to 75$)$; Lat. 1.90 (pores).

lichlish hromn, nearly plain. North Atlantic; abundant morthanl on hoth coasts. 
De Kay described this flounder under the name of the toothed flatfish. He said it was extremely common in New Jork markets, where it is called the summer flounder, and that it grows to the length of 25 inches. It is a rather common food fish of the deep waters northward on both sides of the north Atlantic, ranging habitually sonth to cape cod and the coasts of England and Scandinaria. It Woods Ilole it is sometimes called sand dab and rusty flounder. 1n smith says it is not common there, but is found some years in winter in inshore waters adjacent to Woods IIole; specimens have been taken in February on lines. One year some were caught in a fyke net in Great harbor. In Massathusetts bay it is a common species in the deep waters, approaching the shores in winter.

\section{Genus paramchthys Girard}

Eyes and color normally on the left side; body oblong; mouth large, oblique; each jaw with a single row of usually slender and sharp teeth, which are more or less enlarged anteriorly, no teeth on vomer or palatines; gill rakers slender; seales small, weakly ctenoid or ciliated; lateral ine simple, with a strong ('urve anteriorly; dorsal fin beginning before the eye, its anterior rays not produced; both rentrals lateral; caudal fin double truncate, or double concave, its middle rays producerl; no anal spine. Species numerous, found in all warm seas. This genus. as now restricted, contains a considerable number of sprecies, inhabiting both coasts of America and the eastern and southeru coasts of Asia. As indicated by the reduced number of rertebrae, the species range farther southward than do those of the type of Hippoglossoides.

\section{Paralichthys dentatus (Linnaeus)}

\section{Summer Flounder}

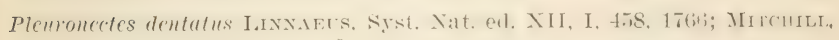
Trans. Lit. \& Phil. Soc. N. Y. I, 390, 1815.

Pleuronectes melanogaster Mrtchil, op. cit. 390, 1815, New York.

Platessa ocellaris DE KAY, N. Y. Famma, Fishes, 300, pl. 47, fig. 152, 1812.

Pseudorhombus ocellaris Guntrer, Cat. Fish. Init. Mus. IV. 4:31, 1Stiz.

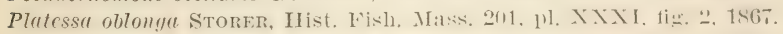

Pseudortiombus dentutus Goone \& BeAx, Bull. lisex Iust. XI. T, 1s79. 


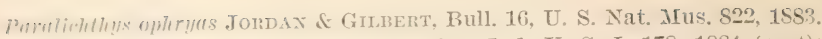
Parulirhthys dentutus Goode, Fish of Fish. Ind. U. S. I, 17S. $185 t$ (part); Jomp.x. ('at. Fish. X. A. 134. 185.); Beax, 19th Rep. Comm. Fish. N. I. 246, pl. II, fig. 2. 1S90; Bull. Im. Mus. Nat. Hist. IX, 372, 1897; I1. M. Smitr. Bull. U. S. F. C. 1897, 108, 1898; Jordan \& Eremana. Bull. 47. U. S. Nat. Irus. III, 2629, 1S98; IV. pl, CCCLXXII, fig. 922.

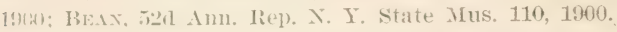

'The depth of the body is contained two and one third times in its length, which is three and two thirds times the length of the heat. body oblong, moderately compressed; mouth wide,

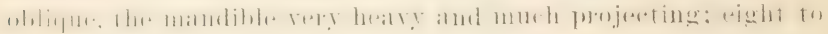
10 terth on side of lower jaw, the two anterior teeth rery long; anterior teeth of upper jaw strong. but smaller than those in the lower jaw; the lateral teeth rery small and close set; eyes

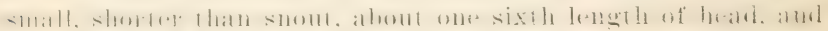

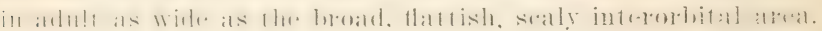

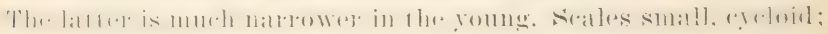
accessory seales few; gill raker's lanceolate, dentate, stoutish.

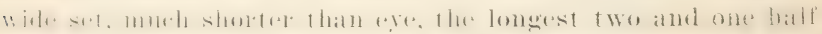

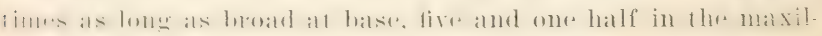

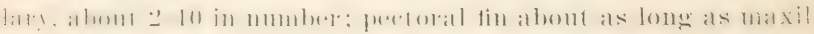
lary. which extends beyond the eye, and is rather more than

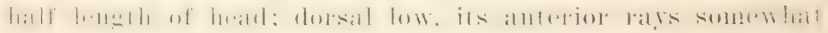

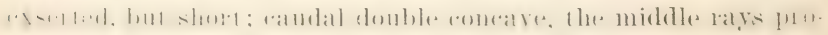
Hured; anal spinc obsolete; ventrals small; fins all scaly. I).

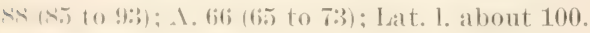

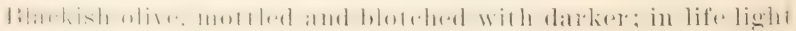
lorom; adults with numerous small white spots on body and rertical tins; sometimes a series of larger white spots along halsus of dorsal and anal; about 14 oeellated dark spots on sides. Ihese somedimes inconspicousts. but alwars present; a series of font of fire along dorsal base, and thee or four along anal

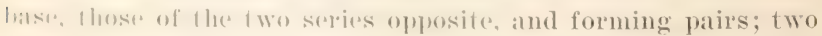
falim of smallue, less distince spots midway between these basal

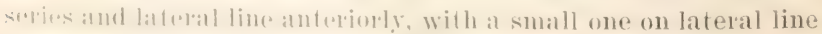

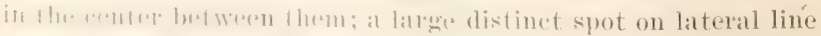
lubimal midslle of stratght portion: lins without the round dark hilutelins. 
Is styled flounder, or summer flounder, turbot flounder, wotherl flattish. Huke, and, in Gireat south batr, it shatres the name flatish with the Pseudopleurouectes ameri-

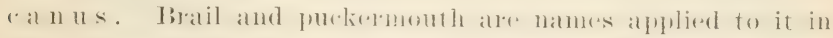
Rhode Istand. The name thule is the one most frexpuently nsed on Long Island.

The finke is a very abundiut fish and is fommel on the (atsteren

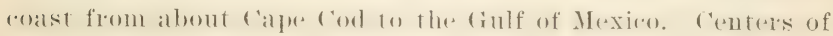
abundance are found on the rommentient roast and on Lamp Island.

It is a summer risitor in Gravesend bay, arriving in May or Jume, and leavinge when eold weather bergins. It frecluente the samdy flats for the purpuse of fereding on lithle fishes. which it destroys in lange numbers. I fluke will often be fomel with

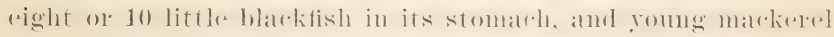
suffer gleatly from its deperelations. In direat south bay this fish Wats foumd at blue loint aore and at Fire Island late in

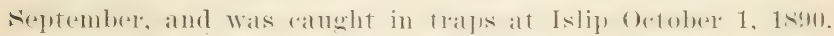

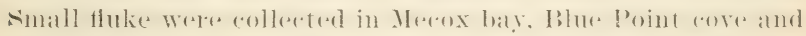
at Islip in August 1SGS. Adults were ubtained at Fire Islanm

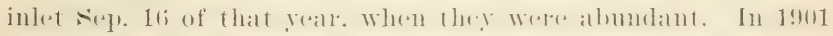
the fish were taken at loire Island inlet. Bhore l'oint, and smiths foint. Ane. 1 they were fereding on small menhaden. The next

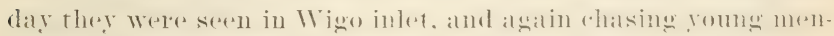

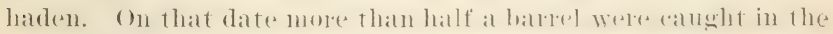

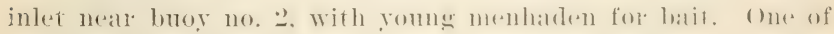
the fluke disgorged a sand lanee.

It feeds on small fishes, roustatratns. molluskis and matsion-

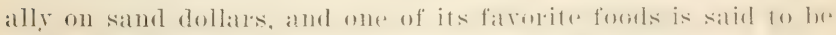

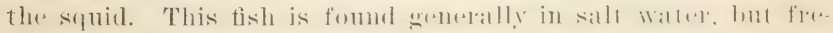

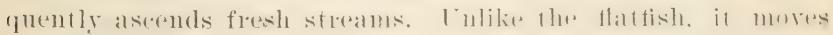

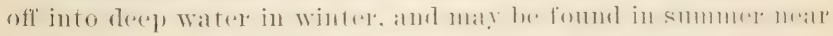
the shores. The fluke hats the salue habit als the llattishe of

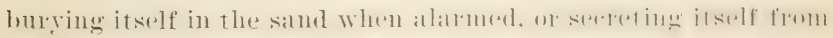

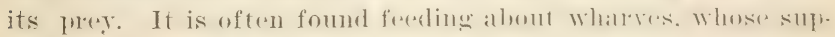
ports furnish it a suitable hiding plater from whith to dall on 


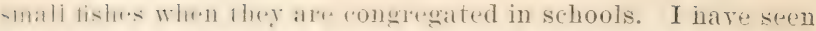

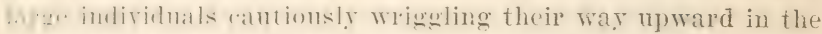

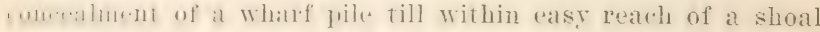
uf silfersides, when a sublen dart into the midst of the sehool womld result in the rafume of at tish, and the flomeler would l.ismmly sink to digest its rietim and prepare for another mo-langht. It hate heen known to reach a weight of 26 pounds.

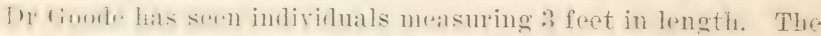

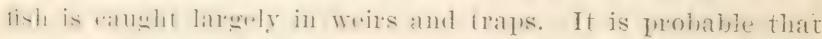

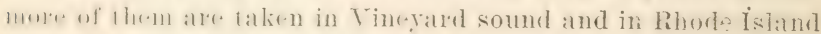

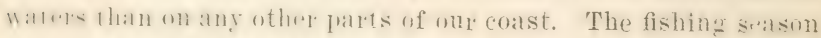

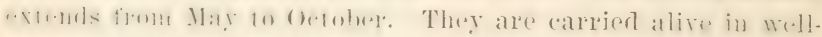

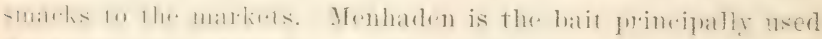
for the capture of the fluke by hook and line.

\section{Paralichthys lethostigmus Jordan \& Gilbert}

\section{Southern Flounder}

I'lutrse whlon!u DE KAY, X. Y. Fauna, Fishes, 209, pl. 48, fig. 156, 1812, New lork, not Pleuronectes oblongus MitchiLL.

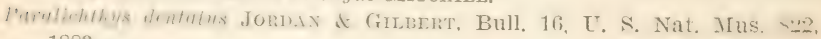
1883.

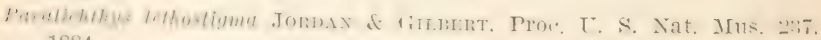
1854.

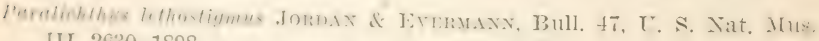
III, 2630, 1898 .

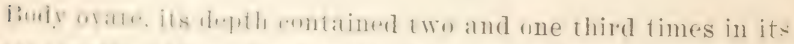

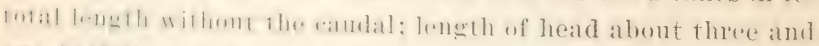

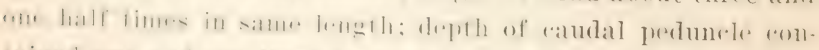

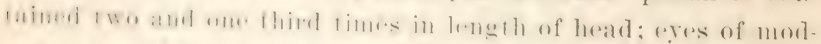

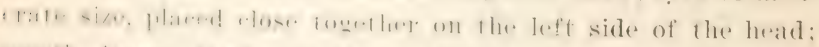

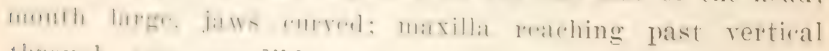
through ryo: mandible projecting; anterior teeth of jaws strong; postrrior small and elose set; gill rakers $2+10$. lanceo.

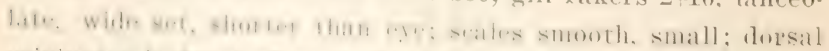

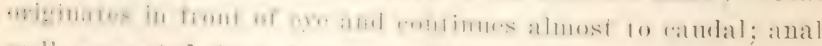
woll separatod from the ventrals; pectorals short, less than

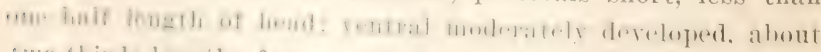
two thiteds length of peretoral. T). 90; 1. 70; T. 6 .

tulue dusky olive, with a few datrer mot thugs and spots. 
This is the fish which was described by Jordan and Gilbert under the name of the southern flounder. It inhabits the south Atlantic and Gulf coast of the United States, ranging north to New York. De Kay described and figured it as the oblong flounder, which he says grows to the length of 15 to 20 inches and occasionally larger. He states that it is common along the sandy shores of New York, and is procured abundantly in the months of September and October; that it is excellent eating, and usually sells at from $6 \mathrm{c}$ to $8 \mathrm{c}$ a pound; that it is tenacions of life and can be preserved in good condition for a long period.

The southern flounder is very closely related to the fluke or summer floumder. It is, howerer, always darker in color and almost miform, while the fluke is usually profusely spotted. The character by which it is best distinguisher from the fluke, is the number of gill rakers. The southern flounder has only 12, of which 10 are below the angle of the first arch, while the summer flounder has from 20 to 24 , of which from 15 to 18 are below the angle of the first arch.

\section{Paralichthys oblongus (Mitchill)}

\section{Fourspotted Flounder}

Pleuroncetes oblongus Mrtchile, Trans. Lit. \& Phil. Soc. N. Y. I. 391, 1915.

Platessa quadrocellata Storer, Hist. Fish. Mass. 203, pl. XXXr, tig. 3, 1867. Pseudorhomlus oblongus Goode \& BEAN, Bull. Essex Inst. XI, T, 1879.

Paralichthys oblongus Goode, Proc. U. S. Nat. Mus. 472, 1850; Jordan \& Gimbert, Bull. 16. U. S. Nat. Mus. S24, 1883; Gonde \& BF.1. Oceanic

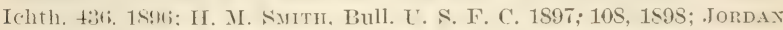
\& Everirann, Bull. 47, U. S. Nat. Mus. III, 2632, 1898; IV, pl: CCCLXXIV, fig. 924, 1900.

Body comparatively elongate, strongly compresserl. The depth of the body is contained two and one fourth times in the length of the body, which is four times the length of the head. Eyes large, nearly four times in head, separated by a prominent narrow, sharp ridge; upper jaw with very numeroms small, close set teeth laterally, and four or five canines in front, the lateral teeth abruptly smaller than the anterior. "ach sicle of lower' jaw with seren to 10 teeth; chin prominent, maxillary nareom. reaching past middle of pupil, two and one fourth in length of 


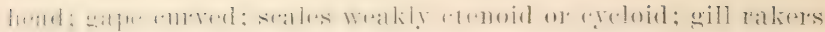

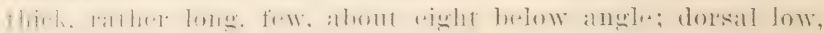
1.

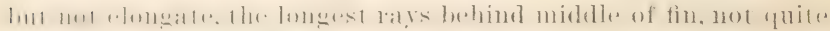

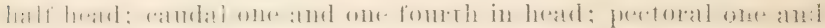
three fifths; anal spine obsolete. D. 72; A. 60; Lat. 1. 93.

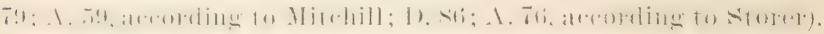

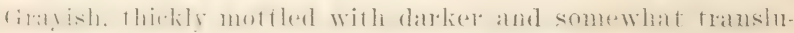

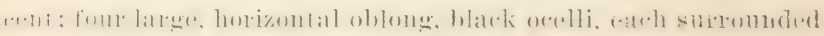

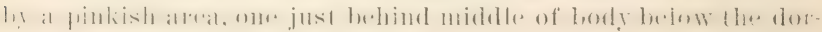

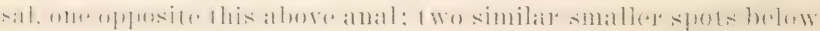

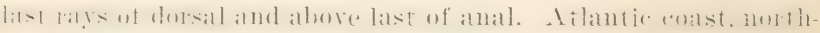
wark: not abmulant.

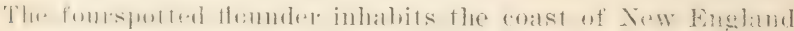
and Xew York. It is very common on the coast of New York

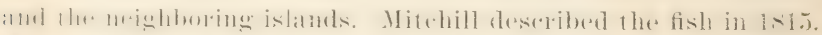

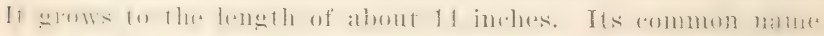
relates to the four large horizontal oblong black ocelli. It

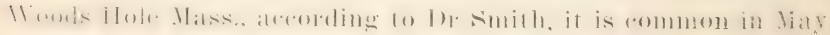
and fune, scarce at other times. It is most abundant about June, during the rum of seup.

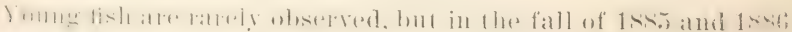
larwe mumbers, two or three inches long, were seen. The aver-

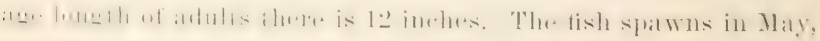
amol is rges have heen experimentally hatehed at Woods Hole.

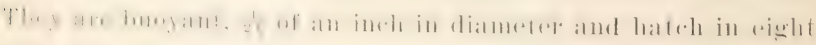
datys in water baving a mean temperature of $51^{\circ}$ to $56^{\circ} \mathrm{F}$. In 1 liy the l. s. Fish commission.

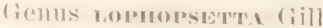

lifes and rolor on the luft side; body broadly ovate, strongly

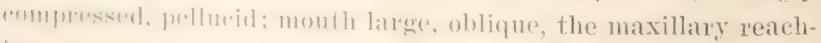

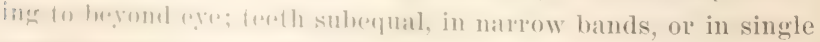

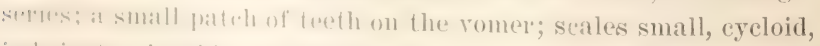
imbricate. Ilu skin without lomy tubereles; lateral line strongly

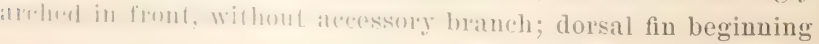


on the smont, its anterior rays exsereted; no preanal spine; rentral of left side frese from the anal, insereded nearly on the ridge of the abdomen, its base broad, the rays well separated; pectoral and ventral tins moderate. One species. Tery close to the Europerin genus $\mathrm{B}$ ot hus Rafinesque, from which it differs in the more numerous gill rakers, pellucid body and produced dorsal rass. The European turbot, Pset t a Swainson, is also closely related, but the typical species, I'set ta $\mathrm{m}$ a $\mathrm{x}$ i m a, is a large, robust fish, scaleless and beset with bony tubercles.

\section{Lophopsetta maculata (Mitchill)}

Hindow Pane

Plemonectes maculatus Mrtchill, Rep. Fish. N. Y. 9, 1814, New York; DE KiY, N. Y. Fauna, Fishes, 301, pl. $4 \overline{7}$, fig. 151, 1842; Storer, Hist. Fish. Mass. 204, pl. XXXI, fig. 4, 1867.

Plemonetes aquosus Mitchil., Trans. I.it. \& Phil. Soc. X. Y. I. 389, pl. II, fig. 3, 1S15, New York.

Rhombus aquosus Günther, Cat. Fish. Brit. Mus. IV, 411, 1862.

Bothus maculatus JorDdx of Gilibert. Bull. 16. T. S. Nat. Mus. S15, 1S83; BeAn. Bull. Am. Mus. Nat. Hist, IX, 372, 1897; H. M. Sмrтt, Bull. U. S. F. C. 1897, 108, 1898; BeAx, 52d Ann. Rep. N. Y. State Mus. 110, 1900 .

Lophopsetta maculata Gill, F'roc. Ac. Nat. Sci. Phila. 216, 1862: Groodf \& BeAN. Bull. Essex Inst. XI, 6, 1879; BeAN, 19th Rep. Comm. Fish. N. Y. 247, 1890; Jordax \& Everirañ, Bull. 47, U. S. Nat. Mus. III, 2660, 1898; IV, pl. CCCLXXXII, fig. 938, 1900.

The length of the loudy is one and there tifths times the depth of the hody and three and three fom ths times the length of the head. Hody broadly rhomboid, verestrongly enupressed; interorbital aleat flattish; (Pe rather large, about equal to snout; tecth in both jaws in one sereses laterally, in a rery narrow band in front; maxillary nearly half length of head: gill rakels rathere long and siender, nmmeroms, about 25 below the angle of the:

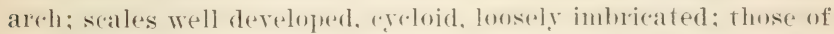
the blind side a little smallere; no bomy tubereles; vertioal tins scaly; anterior rays of dorsal elevated. Hanched, with free tips. D. 65 ; A. 52; Làt. 1. 85 .

Light olive brown, almost translucent, everyhere marbled with paler, and with many romedish, irregulatr, blackish hloteles; fins spotted. Lengeth 1s inches. Atlantic roast of the Inited States, very common northward. Size rather small. 


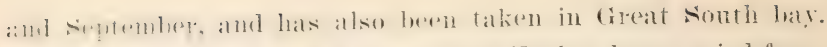

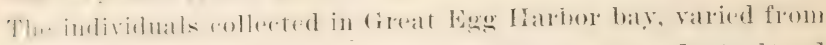
2 inches to $t_{3}^{1}$ inches in length. One of these was dextrai and all the rest sinistral as usual.

\section{Genus maxpa Gottsche}

Teeth chiefly nuiserial; lateral line with a distinct areh in

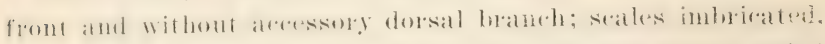

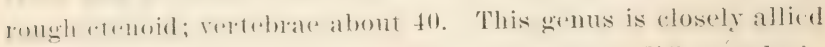
to P'seudopleuronectes, from which it differs only in the presenew of an areh on the anterior part of the lateral line.

\section{Limanda ferruginea (Storer)}

\section{Sand Dab}

Plutess fermginea Storer, Rep. Fish. Mass. 141, pl, 2, 1839; Hist. Fish. Mass. 198, pl. XXY, fig. 4, 1S67; DE KAY, N. Y. Fauna, Fishes, 297, pl. 48, fig. 155, 1812.

Platesse rostrata H. R. Stonen, Bost. Jour. Nat. Hist. V, I, 268, pI. VIII, fig. 2,1557 .

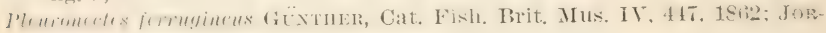
DAx \& Gilbert, Bull, 16, U. S. Nat. Mus. 834, 1883.

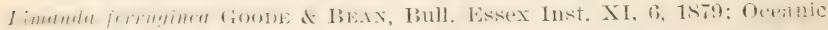
Ichtlı, 427, 1896; Goope. Fish \& Fish. Ind. U. S. I, pl. 49, 1854; H. M. Surtir, Bull. U. S. F. C. 1897, 108, 1S98; Jordax \& Evermaxx, Bull. 47. U. \$. Nat. Mus. III, 264t, 1898; IV, pl. CCCLXXVII, fig. 929, 1900.

The Irogeth of the body is two and one fifth times its deptle amel

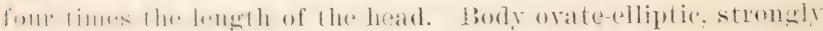

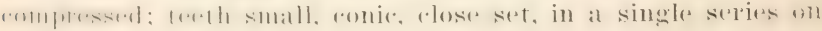

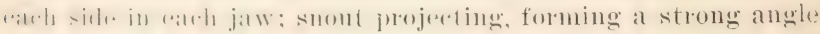

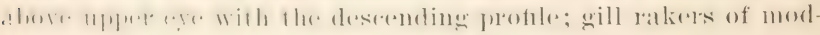

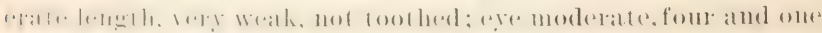

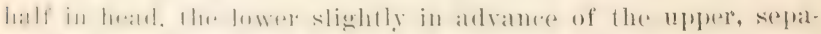

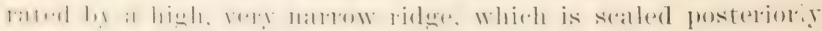

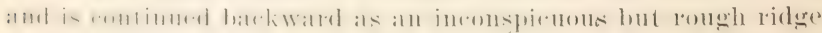
fo the berimnine of the lateral line; scales imbricate, neatro uni-

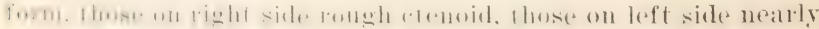

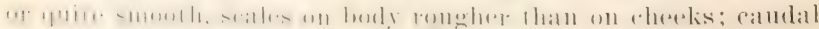

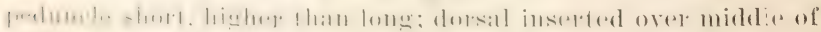
"yo, its middle ray highest; pectomal less than two fifths length

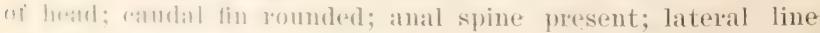
simple, will a rather low arch in fornt, the depth of which is 
barely two fifths the length: a concealed spine behind rentrals; ventral of colored side partly lateral, the other wholly so; anal spine strong. D. 85; A. 62 ; Lat. 1. 100.

Brownish olive, with numerous, iregular reddish spots; fins similarly marked; left side with caudal fin, caudal peduncle, and margins of dorsal and anal fins lemon vellow. Atlantic coast, chiefly northward.

This is also known as the lusty dab. It inhabits the coast of North America from Labrador to New York. De Kay calls it the rusty flatfish, which he says is a lare species, reported by the fishermen to oceur only in deep water. The sperimen described by him was 18 inches long. According to Dr Smith, it is rery common in Vinerard sound and observed br him in water from 10 to 12 fathoms deep. where it mar be found throughout the rear. There is no fishery, but numbers are caught incidently while bottom fishing for other speries. In Great harbor a few are taken in fyke nets, only in winter. The average length there is about 14 inches. In Massachusetts bay it is a common resident speries, inhabiting deep waters in summer, and approaching the shores in winter.

\section{Genus pseudopleuronectes Bleeker}

Body oblong, with firm flesh; the seales firm, regularly imbricated, strongly ctenoid on eyed side in both sexes; fin rays scaly; mouth small; teeth uniserial, incisorlike, fose set, all more or less blunt. lower pharyngeals very narrow, each with two rows of separate, conic teeth. This genus is distinguished from Ple uronectes chiefly by the well imbricated ctenoid scales, and from L i m a $\mathrm{n}$ a a , which it more closely resembles, by the want of arch to the lateral line.

\section{:366 Pseudopleuronectes americanus (Walbaum)}

\section{Flatfish; Winter Flounder.}

Plemonectes americanus Walbata, Art. Gen. Pise. III, 113, 1792: Günther, Cat. Fish. Brit. Mus, IV, 413, 1S62; Jondix \& Gildert, Bull. 16;. U. S. Nat. Mus. $837,1883$.

Plemonectes planus Mitchill, Trans. Lit. \& Phil. Soc. N. Y. I. 3S7, 1815, New York.

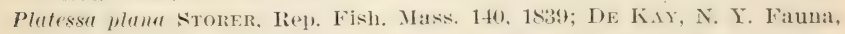
Fishes, 295, pl. 48, fig. 154, 1842; Stoner, Hist. Fish. Mass. 195, pl. XXX, fig. 2, 1867 . 
Plutesan pusilla Dr Kix, op. cit. 296. pl. 47. fig. 153, 1S42, New York.

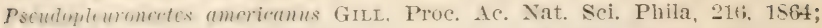
Goone, Fish \& Fish. Ind. U. S. I, 1S2, pl. 44, 18S1; BeAs, 19th Rep. Comm. Fish. N. Y. 245, pl. I, fig. 1, 1890; Bull. Am. Mus. Nat. Hist.

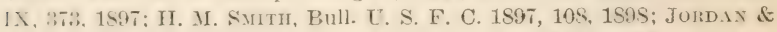
Everirann, Bull. 47, U. S. Nat. Mus. III, 2647, 1898; IV, pl. CCCLXXIX, fig. 933, 1900; BeAr, 52d Ann. Rep. N. X. State ILus.

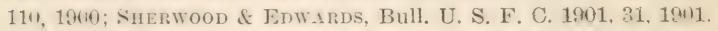

liony elliptic, an angle above eye. The length of the body is two amb one fometh times its depth and four times the lementh of the heath. Heat covered ahore with inbricated, strongly ctenoid s'ales similat to those on hodỵ; blind side of head nually naked; intrembital spatce rather hroad, strongly convex, its widilu half

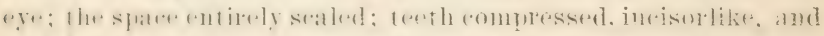
wirlemel towated tips, rose ser. forming a continmons a $11+1 \mathrm{ing}$

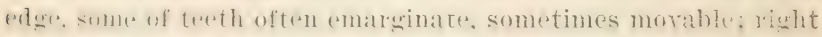
side of luth jaws touthless: highest dorsal rays less than loneih

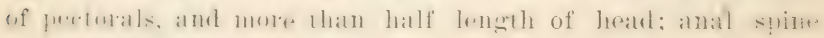
present. D. 65; 1. 48; Lat. 1. 8?.

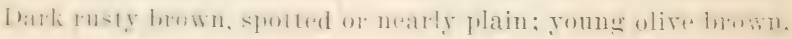
more or less spotted and blotehed with reddish.

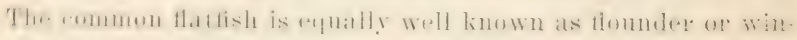

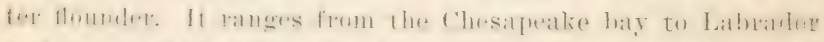

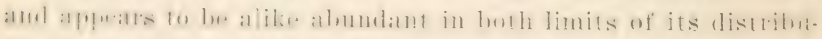

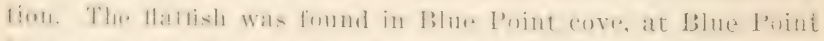

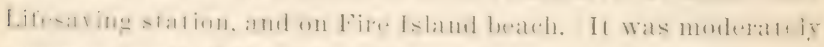
enmmon in all of these lexalities. The spereies is a permanent

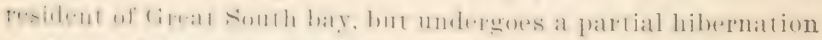
in ilew mmel in winfr.r, and the adnlts in summer migrate into

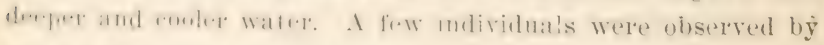
me in a fish pound at Islip Oct. 1, 1890.

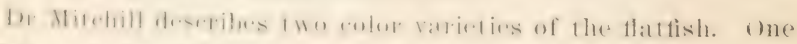

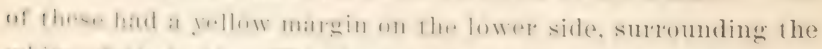

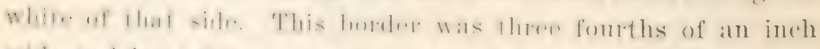

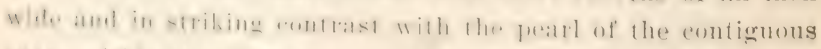

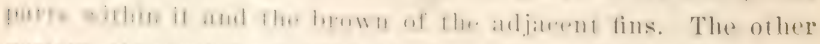

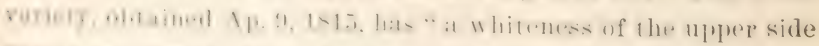
umurly as reatr as that of the nether surface over rather more 
than half its extent. The anterior part is blanched in this manner. The dorsal fin rery sensibly partakes of the lighter hue; but its dark brown is tinctured with yellow, specially on the rays. Something of the same kind, though less distinct, is observable on the rentral fins, and on about a dozen rays of the anal. The length of this indiridual was 5 inches and the breadth 3 . Dr De Kay obtained a specimen in April which was reversed and double. "Its color on both sides was uniform bronze, with a white patch on its right side near the chin, almost entirely denuded of scales; it bad the singular protuberance orer the eye, noticed by Dr Mitchill in his melanogaster."

On the New Jersey coast young individuals are very common in summer, but the adults are lare'y found except in the winter.

At Woods Hole Mass. this is a rery abundant permanent resident, frequenting muddy or grassy bottoms. The average weight of those taken in the immediate vicinity of the Fish Commission station was only 1 pound, but larger fish are fomnd in the deeper water of the sound and bay. In Octoher fish averaging 2 pounds and apparently migrating are taken with lines in Vineyard sound on sandy bottom.

In the markets this species is extremely rommon in the winter and spring months and the flesh is delivions eren when the roges are nearly mature. It feeds on small sheils. cralis and other invertebrates living in the mud. When at rest it partly submerges itself in the sand or mul, and rhanges its color to suit its surroundings.

In Long Island bays the flatfish spawns from February to the end of March, and in July the romg have attained to the length of half an inch. It Woods Hole Mass. according to Ir Smith, it spawns from February to April. On being transferred to tanks containing running water, many deposit their eggs during the night. The eggs ale $\frac{1}{30}$ of an inch in diameter and very grutinous, sticking together in masses of various sizes. The arerage number to a fish is 500,000 . Mar. 6, 1897 , a fish that weighed $3 \frac{1}{2}$ pounds after spawning furnished 30 fluid ounces of eggs, numbering $1,462,000$. The eggs hatch in 17 or 18 dals, when the mean water temperature is $37^{\circ}$ or $38^{\circ} \mathrm{F}$. 


\section{Genus PLAtophrys Swainson}

Erres and anlor on the left side; body orate, strongly com-

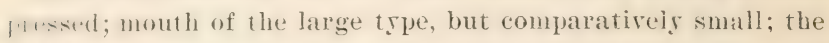
maxillat? one third or less of the length of the head: tecth smatl, subrepual, in one or two series, no texth on romer or falatines; interorbital spatce broad and concare, biondest in alult males; gill raliers moderate; dorsal fin breginming in front of "re, all its rays simple; rentral of colored side on ridge of abelemen: caulal convex behind; peetoral of left side usually with one or more filamentous rays, longest in the males scales rely small, etemoid, atherent; lateral line with a strong areh in front; coloration usually variegated.

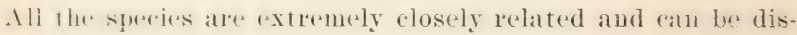
tinguished with difticulty. On the other hand, the variations dure to differences of age and sex are greater than in any other of our genera.

\section{Platophrys ocellatus (Agassiz)}

\section{Sand Flounder}

Rhomluns ocellutus AgAssiz, Spix, Pisc. Brasil. S5. pl. 46, 1829, Brazil.

Platophrys nebularis Jordan \& GILbert. Proc. U. S. Nat. Mus. 31, 143, 185t, Key West; Goode \& BEAx, Oceanic Ichth. 441, 1896.

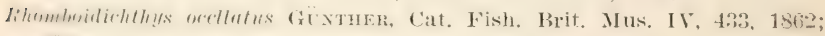
Poey, Syn. Pise. Cubens. 408, 1868.

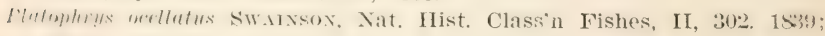
Reax, 19th Rep. Comm. Fish. N. Y. 247, 1890; Jordan \& Evermanx,

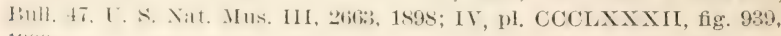
IIFK).

limb! rhomberd ovalte. its depth one half of the total length;

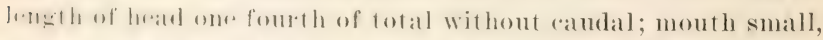

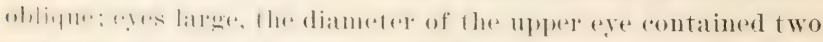

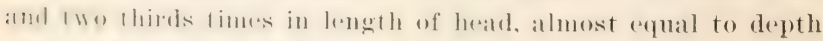

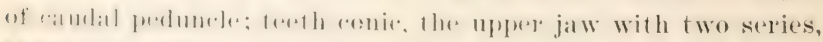

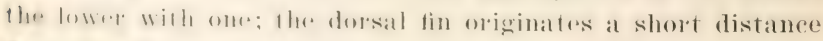

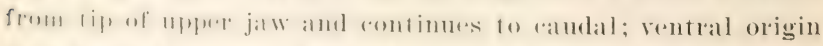

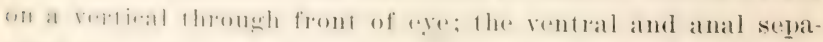
lated hy a short space; pectoral of eyed side about equal in

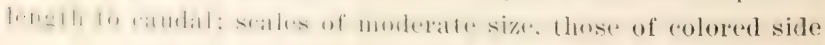


retenoifl, of blind side smooth; lateral line sharply arehed over two thirds of pectoral. D. $85 ; \mathrm{A} .64 ; \mathrm{V} .6$ ( 5 on blind side).

color light gray with reddish tinge: spots and blotehes of darkere on head and body; also lighter rings inclosing spaces of eroumd rolor" dorsal and anal with a black spot on each sixth or eighth ray.

The sand floundere or spotted flomelere is a native of the western Atlantie, from New York southward to the culf of Mexieo and the West Indies, and perhaps to Rio Janeiro on sandy shores. It is a small spexedes, the largest individual taken being only :3 inches in length. Two small examples of this little flounder were rollerterl at Fire Island inlet beach sep. :30, 1890. These spereinens were obtained on a sand beach in shallos water. The discovery of this fish in Great south bay was entirely mexpected, as this is many degrees north of its original labitat.

Family SOLEmAE

Soles

\section{Genus acmirus Lacépède}

Eres and color on the right side; body oblong, bluntly rounded anteriorly; head small; eyes small, close together, the upper eye in advance of the lower, the two separated by a bony ridge; mouth small, somewhat turned toward the colored side; nasal flaps present. the nostril of the blind side fringed; lip of the colored side fringed; teeth very small, on blind side only; gill openings rather narrow, but renfluent below, not reduced to a slit; the branchiostegal region sealed; head rlosely scaled ererywhere, the seales on the colored side similar to those on the body, those of the nape and chin much enlarged; seales on the blind side anteriorly with their pectinations more or less pro duced. forming cirri, sales of both sides extremely rough, extending on the fins; lateral line straight, simple; edge of preoperele covered by the seales; dorsal beginning on the snout, low in front and thickly sealed, its rays divided; anal fin similar, without spine; caudal fin free, conrex; caudal peduncle very 
shore and derely juetoral fin of left side wanting, that of right sille small or olsolete; rentral rays thee or four, the rentral in we the eolored side long, connected with the anal by at meme hane. This strongly marked genus contains numerous species, rll very closely related, and nearly all American.

\section{Achirus fasciatus Lacépède}

\section{American Sole; Hogchoker}

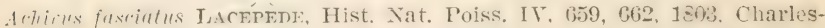
ton: Jompax \& Goss, Rep. U. S. F. C. 1886, 315, 1889; Bean, Bull, Am. Mus. Xat. Hist. IX, 373, 1597; H. M. Smtr, Bull. U. S. F. C. 1897, 108,

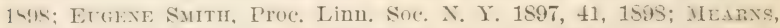

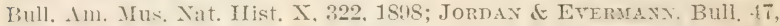

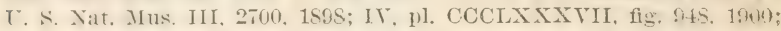
BEAx, 52 d Ann. Rep. N. Y. State Mus. 110, 1900.

Plemoncetes mollis Mrtcmul, Rep. I'ish. N. Y. 9, 1814; 'Trans. Lit. \& Phil. Soc. N. Y. I, 388, pl. II, fig. 4, 1815.

Achirus mollis DE KAY, X. I. Fauna, Fishes, 303, pl. 49, fig. 159, 1842; Storer, Hist. Fish. Mass. 206, pl. XXXII, fig. 1, 1S67; BeAx, Bull.

U. S. F. C. VII. 134. 1858; 19th Rep. Comm. Fish. N. Y. 244, 1890.

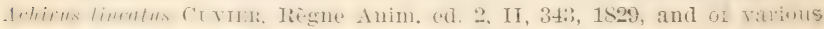
American authors.

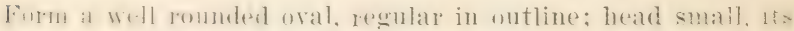

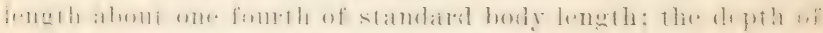

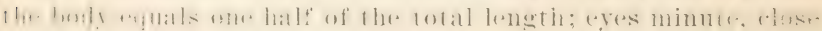

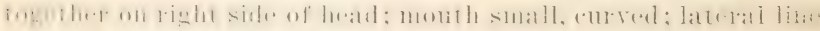

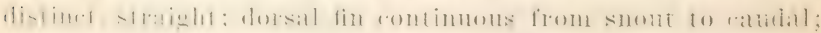

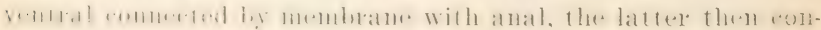

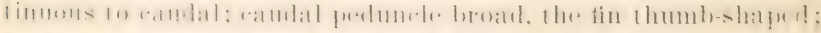

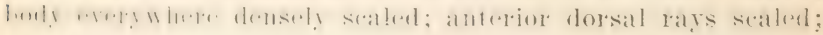
ahout Tis rows of scales along lateral line. D. 55; 1. 40; Y. 4.

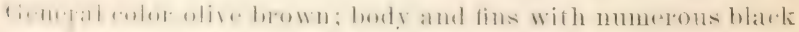

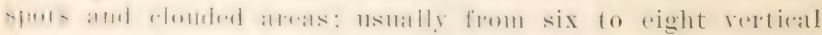

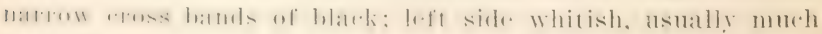
mottled with dark spots and shadings.

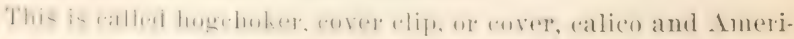

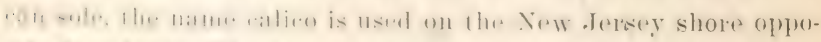

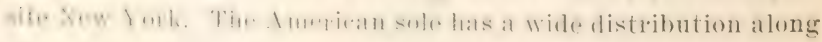
w11: rast cosst, but is not important for food, and sometimes froves very inconvenient to pigs, as may be inferred from one 
of its common names. Ir Ihe Kay has eaten the species, however, and pronounces it to have a delicate flavor. Dr Mitchill also describes it as "delicate eating." De Kay records it as high up the Hudson as Peekskill. The following interesting observations are to be found in his work: "When it is taken from the water, it escapes readily from the hand by an undulating morement, in which it is aided by its mucous surface and by an elevation of its seales beneath. Pry the sime means it can make considerable progress over a moderately smooth surface. It is extremely tenacious of iffe, and I liept one alive four days out of water." Another very curious habit of the American sole is that of clinging to the glass front or side of an aquarium for an indefinite length of time. It is common on the shallow flats of Great South bay in the summer and early fall. We obtained speceimens at the mouth of swan creek and in Blue Point cove in september 1sen. This spereses is abmulant in swan creets, at Patchogue L. I., and malny very goung examples were talien there in the summer and fall of lses, where the watre was brackish and, at low tirle, fiesh. In 19301 this species wats talien at Howell's point, Duncan's ereek and Smith's point.

Eugene Smith wanght one rery small example in a tirlal cresek of the Hackensatel rirer, where the water was fresh. Ife stat tes that it is believed that soles spawn in fresh water.

The dmerican sole, or calico flounder, has been ohtained in Gravesend bay erery month of the rear exeept the first fom. It is hardy in captivity. Its habit of clinging to the glass frout and the walls of its tank is interesting.

Order PEDICULATI

Pediculate Fishes

Family LOPHIIDAE

Fishing Frogs

\section{Genus Lophrus (Artedi) Linnaeus}

Head wide, depressed. vely large; body contrateded. conic, tapering rapidly backward from the shoulders: mouth exceedingly large, terminal. opening into an enormous stomarh; upper jaw protractile, maxillary withut supplementary bone; lower 
jaw projereting: both jaws with rerg strong. uuequal, cardiform meth, some of the teeth raninelike, most of them deperessible;

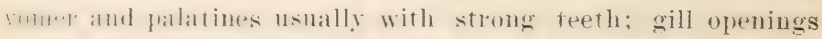
compatative? large, in the lowere axil of the peetorals; pseudohathliare present: ne gill rakers; gills three; skin mostly smouh, nalked, with mamy dermal flaps about the head; spinous dorsal of three isolithed. tentarlelike spines on the heatd, and three smatler ones behind, which form a continnons tin; secoud flursal moleralle similar to the anal; pertoral mitmbers starcely

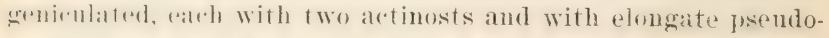
bathia: remtrals jugular, I, 5, widely separated, large, much enlanged in the foung. Young with the head spinous. Pyloric rateal fresent. V'ertebrate numerous, about 30 in number. Living on sea bottoms, at moderate depths; remarkable for great roracity.

\section{Lophius piscatorius Limnaeus}

\section{Angler; Goosefish; Bellows Fish}

Lophius piscatorins Livvaeus, Syst. Nat. ed. X, I, 236, 1758; Mrtcrill, Trans. Lit. \& Phil. Soe. N. Y. I, 465, 1815; GÜnther, Cat. Fish. Erit. Mus. III, 179. 1961; Goone \& IBfax, Bull. Essex Inst. XI, 2, 1579; JonDax \& Gremert, Bull. 16. U. S. Nat. Mus. 814, 1883; Bean, Bull. Am.

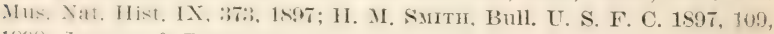
1898; JomDan of Etemanax, Bull. 47, U. S. Nat. Mus. III, 2713, 1898; IV, pl. CCCLxxxym, fig. 952 (skeleton), 1900; SHenwood \& Emwarns, Bull. U. S. F. C. 1901, 31, 1901.

Lophlius piscator Mrtmbl, Rep. Fish. ‥ Y. 28, 1814, Long Island.

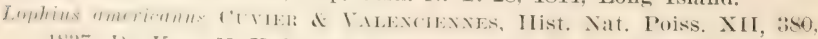

18:37; DE KAY, N. Y. Fauna, Fishes, 162, pl. 28, fig. 87, 1S42; Storer,

llist. Fish. Mass, 101, pl. Xím, fig. 2, 1867.

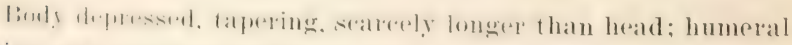
spime " ith prints. of which the pusterion is the longest: head sur-

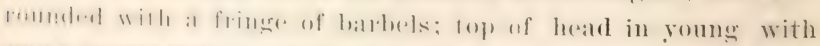

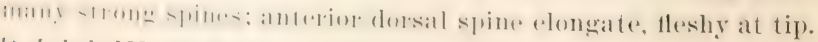
1). I-1-1, III-10: 1,9 .

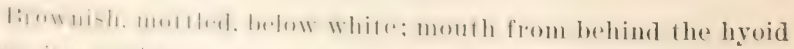

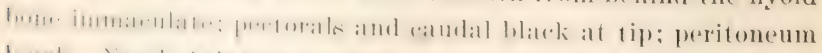

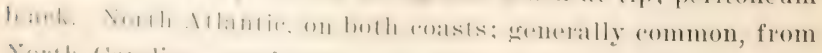
North camolina northward. A fish of singular ugliness of apprarance. 
11.1h: wrist and perenal tin slemeler: ventrals elongated; soft fursal and anal vertirally rxpandel. Finall fishes of fantastic shape in the Test Indies and Gulf Stream.

\section{Pterophryne histrio (Linnaeus)}

\section{Mousefish}

Lophius histrio Lixxaeus, Syst. Nat. eđ. X, I, 237, 1758.

Chironceles lactigatus Storer, Tiep. Fish. Mass. 78, 1839; DE KAY, N. Y. Fauna, Fishes, 165, pl, 27, tig. S3, 1842.

Antenuarius histrio Jordan \& GILbert, Bull. 16, U. S. Nat. Mus. 846, 1883. I'trombrime histrin Gil.t, Prue. L. S. Nat. Mus. 216, 1878; Goode \& BEAv,

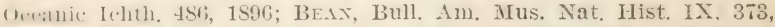

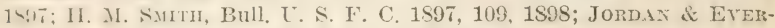
MAx, Bull. 47, U. S. Nat. Mus. III, 2716, 1898.

'The lemelh of the hody is one and four fifths times its depth amel 1110 and one fonth times the length of the head: skin of

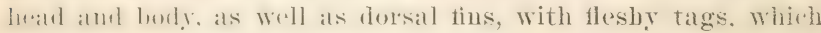
arre most mumeroms on lihe dorsal spines and abdomen; wrist

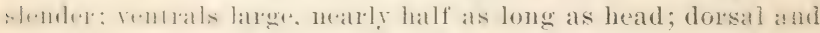

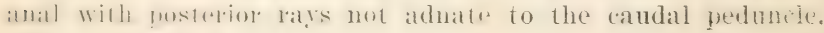
1). $111-14 ; A .7 ; \mathrm{V} .5$.

Jillowish. mathled with hrown: three dark bands radiating

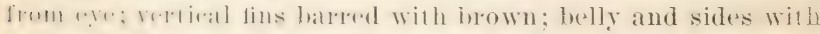

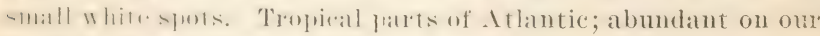
Gulf coast and occasional northward.

The momstish inhabis the roppical parts of the Atlantic.

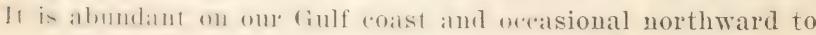

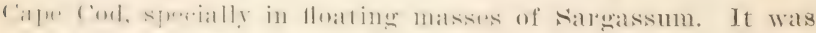

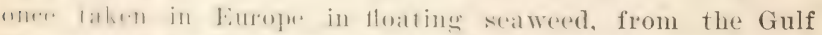

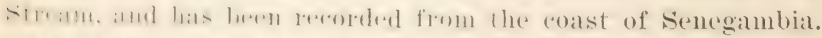

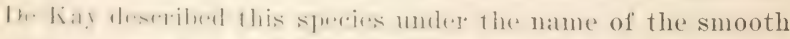

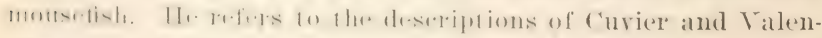

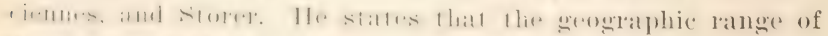

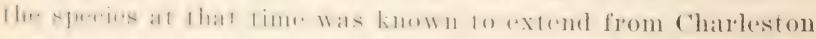
(o) Iinsion.

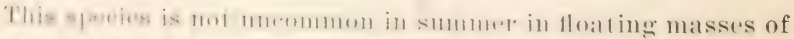

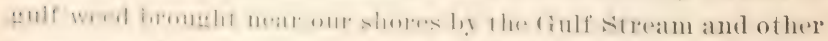

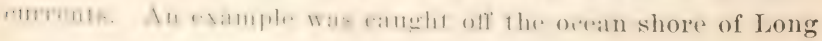


Island in August 1897. At Woods Hole Mass., aceording to Dr smith, it was taken in 187\%. In Norember 1855, 12 specimens were seined in Quissett harbor. From that year till 1897 none were observed, but in 1897 the fish were comparatively common in Tineyard sound. Juring July there was an unusual prevalence of southerly winds, and a large quantity of sargasso weed was blown in from the Gulf stream, and with it this fish, which he calls the marbled angler. In Vinerard sound, a few miles from Woods Hole, 50 indiriduals were taken July 24, 1897. Probably not less than 100 specimens were taken during that rear. Many were kept alire in aquaria for sereral weeks. Some remain under or among the gulf weed at the surface, some conceal themselves in the algae on the bottom, some hide behind stones and other objects, and some seek crevices among rocks. While clumsy in their morements, they were adept in approaching and capturing other fishes. They were camnibalistic, one about 6 inches long swallowing another 4 inches long, and they frequently bit off the fleshy dermal appendages of their fellows. In August sereral spawned in the aquarium. The eggs are connected in long bands, like those of the angler. It is reported that in the summer of 1859 the fish was not uncommon off Nantucket, and in 1897 , eight specimens were taken in gulf weed off that island.

\section{Family ogcocephaltdaE Batfishes}

\section{Genus ogcocephatus Fischer}

Body stoutish, tapering backward; head rery broad and depressed, triangular in form, the forehend elevated and produced; eyes large, lateral; mouth rather small, subinferior under the snout; villiform teeth in bands on jaws, vomer and palatines; skin covered with rough, bony tubereles; dorsal and anal fins rery small; rostral tentacle mesent. retractile into a cavity under a bony prominence on the forehear; rentrals present, I. 5 , well separated; pectorals large, placed horizontally; gills 2! ; no air bladder; no prloric caeca. Tropical America, in shallow water. Small fishes of singular form, often regarded by the ignorant as venemous. 


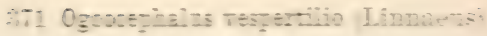

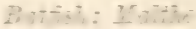

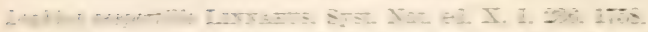

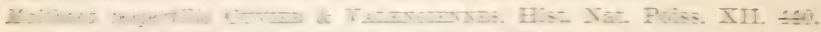

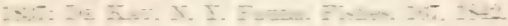

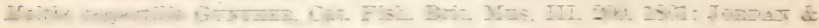

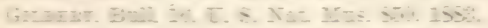

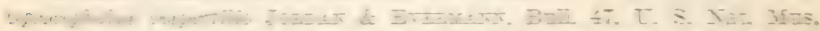

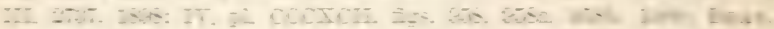

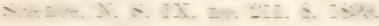

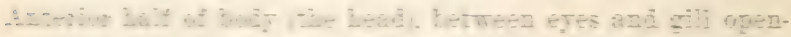

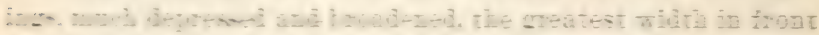

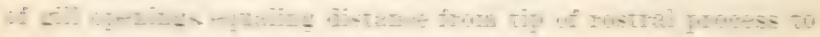

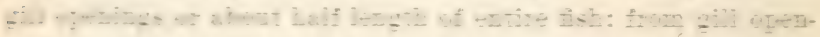

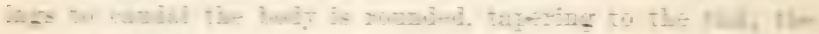

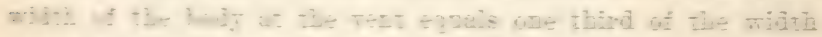

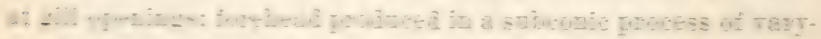

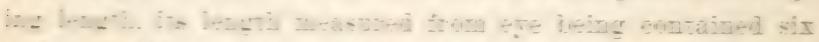

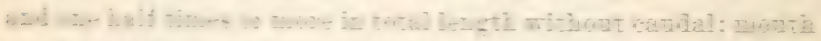

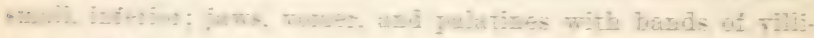

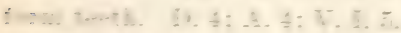

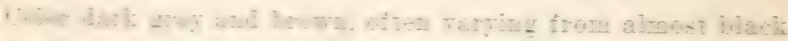
Q.

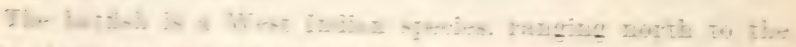

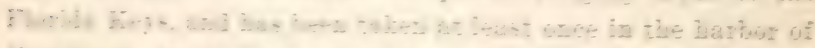

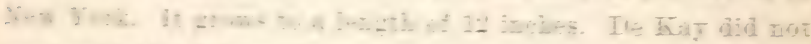

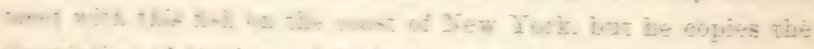

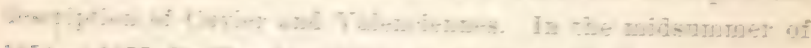

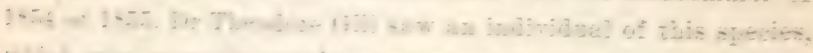

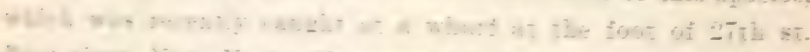

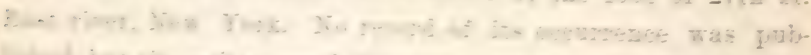

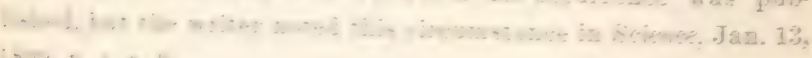
$\therefore \cdots \cdots+\cdots$ 
RECORDED DISTRIBLIIOS OF NEW FORK FISHES

1 Perrom Ged moricus.

2 P. marives acialio

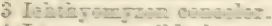

1 Ismoers

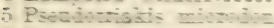

5 Mrsteics caris.

I Gsleveenlo tignim

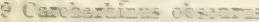

11 C. milberti.

11 Avtioncion isuder

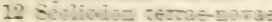

13 Sptyos tibu=0

14 s. zyouecs

25 Alogion Dins

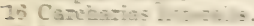

17 Ioums debayt

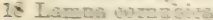

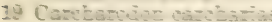

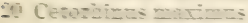

21 Somains acantinas.

22 Sinution soustina

23 Rosic ezinodéa

21 R. veethass

$25 \mathrm{~B}$. equarteris.

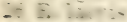

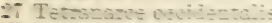

28 Dasranis tementan

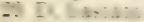

31 $\Gamma$. 355

31 Prempiszes mavim

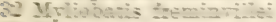

23 Rinousers benasts

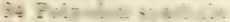

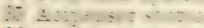

A. A. robieneins

it A brerimomis.

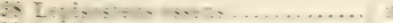

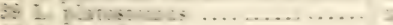

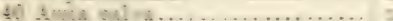

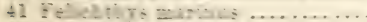

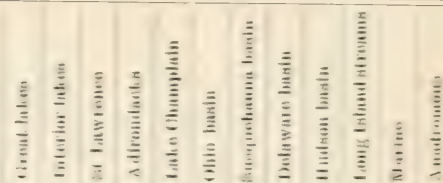

4. Cal:- $y=$. 3.

4. Iendares

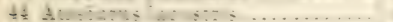

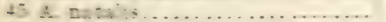

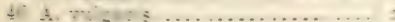

to A at?

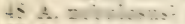

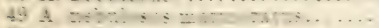

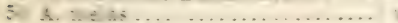

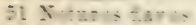

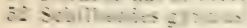

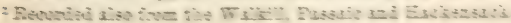




\section{Recoricd distribution of Ner Yorle fishes (continued)}

\section{3}

5

55

56

57

58

59

60

61

62

tis

$6 !$

65

66

67

68

69

\section{7}

\section{7}

$\frac{7}{i}$

$\$ 1$

32

I1 Ilyhopsis dissimilis

11. ambloms

(1) 11. storeriamms

S11i 11. kimomekiensis.

97 Comesus plumberis

sax lixmelosomm maxillimgut

:19) ('arassaus aturatus

sue ('yprimus estrpios.

s. minrus....................

Carpiodes thompsoni

C. eommersoniil

Erimszon sucetta ${ }^{2}$

ตoxostoma anisurum

Campostome anomaluing--

Chrosomus ersthrogaster.....

P. notatus

I iti it turea

elongatus.

Abramis crssolencas 1 .

renatus

to1 Aimgillat ehrysypa

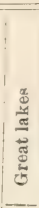

告

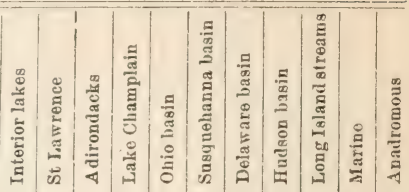

\section{$\mathbf{X}$}

$\frac{x}{x}$

$x$

\section{.}

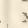 \\ $\mathrm{X}$}

$\mathrm{x}$

$\mathrm{x}$

$\mathrm{x}$

$\mathrm{x}$

(n)

.. $x$

$x$
$x$

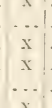

..

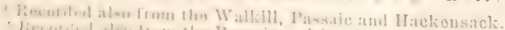

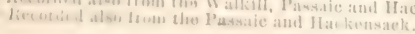


Recorded distribution of New York fishes (continued)

102 Leptocephalus conger

103 Tarpon atlanticus.

101 Elups saurus.

10.5 Albula vulpes.

106 Hiodon tergisus.

$107 \mathrm{H}$. alosoides .

108 Dorosoma cepelia..............

109 Etrumeus teres ................

110 Clupea harengus...............

111 Pomolobus chrysochloris .......

112 P. mediocris.

113 P. psendobarengus

114 P. cyauonoton ..................

115 Alosa sapidissima .............

116 Harengula sp..

117 Opisthonema oglinum

118 Brevoortia tyraunus

119 Stolephorus brownii

$120 \mathrm{~S}$. argyrophanus.

121 S. perfasciatus

122 S. mitehilli

123 Coregonus qnadrilateralis

124 C. clupeiformis ...............

125 Argyrosomus osmeriformis......

126 A. artedi.

$127 \mathrm{~A}$. hovi

128 A. prognatlus

129 A. tullibee

130 Oncorhynchus chouicha

131 Salmo salar.

132 S. salar sebago

133 S. henshawi

134 S. gairdueri

$135 \mathrm{~S}$. fario

136 S. trutta levenensis

137 S. irilleus .

138 S. lemanus.

139 Cristivomer namayensh

140 Salrelinus fontinalis 1

141 S. alpinus?

142 S. alpinus anreolus ${ }^{3}$

143 Osmerus mordax.

144 Synodus foetens.

145 Úmbra limi

146 U. pygmaea ${ }^{4}$

147 Lucius americanus.

148 L. vermiculatus.

149 L. reticulatus 1 .

150 L. lucius

151 L. masquinongy

\begin{tabular}{|c|c|c|c|c|c|c|c|c|c|c|c|}
\hline & $\frac{\frac{a}{0}}{\frac{0}{E}}$ & $\begin{array}{l}8 \\
0 \\
0 \\
0 \\
0 \\
0\end{array}$ & 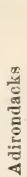 & 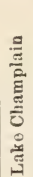 & $\frac{a}{0}$ & 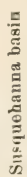 & 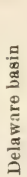 & 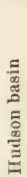 & 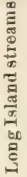 & $\frac{\stackrel{0}{\Xi}}{\stackrel{\Xi}{\Xi}}$ & 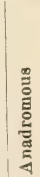 \\
\hline
\end{tabular}

1 Recorder also from the TValkill and Passaic.

2 Introduced into Sterling lake.

3 Introdnced into Lake George.

* Recorded from the Passaie and Hackensack. 
liocorded distribution of New York fishes (continucd)

152 L. m. ophiensis (Kirt.)

158 limululus matialis

154 l. Aureroclitus.

15i) $\mathrm{F}$. diaphamus 1 .

15i Lueania parva.

157 Cyprinodon variegatus .........

15* Tylosurus marinus

1.9 T. raphidemat ..................

14it) 'T. aceis .

161 Hyporhamphus roberti.

16 E Euleptorbamphus velox

1ti. Scomberesox saurus

164 Exocoetus rolitans.

1ti- Cypsilurus heterurus.

litic C. fureatus

$11:-$ C. gribbifrons

live Enealia ineonstans........................

1.. E. incunstans capuga.............

171) Pygostens pungitius ${ }^{1} \ldots . . . . . . \times \mathrm{x}$

171 Gasterosteus bispinosus ........ $\mathrm{x}$

17: Apeltes quadracus...............

17. Fistularia tabacearia

1it Siphostoma fusemm

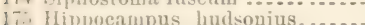

17 Pereopsis guttatus............

$17 i$ Aphreiloderus saranus........ $\mathrm{x}$

17 Meniclia gracilis

17u vi broflina

19) M. Writat.

int Kirtlandia vargans.

1.: Labinlesthes sicentus.

14.3 Mngil cephalus.

is: M. Nureura....

Io syphraena guachancho.

16 n twomali-

in. Polydactylus octonemus

18 Ammonlytes americanus

(15) Bullaseonatus.

(W) seomber scombrus.

19.? - ...tins

16. Ansis thasari

fus Gymmosarela pelanis

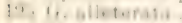

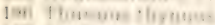

$157-$ inds $=$ ardin.

10. Sincomberomorns maculatus.

1W. segalis

ar \&. envalla

ol 'Trichinrus lepturus

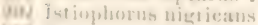

Ito Tiensipturus imperator

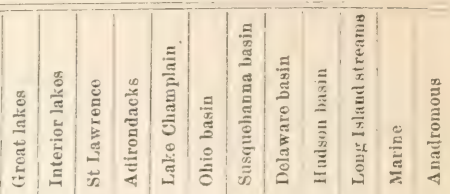

fince riled altu from the Jassaic and llackmanck. 
Recorded distribution of New York ishes (continued)

204 Xiphias gladins

205 Oligoplites saurus.

206 Nancrates duetor

207 Seriola zouata

208 S. lalaudi

209 Elagatis bipinnulatus

210 Decapterus punctatus

211 D. macarellus

212 Trachurus trachurus

213 Trachurops erumenophthalmus.

214 Caranx hippos

-215 C. errsos

215 Alectis ciliaris

-17 Vomer setipinnis.

218 Selene vomer

219 Chloroscombrus chrysurus

220 Trachinotus faleatus.

$221 \mathrm{~T}$. argentells

222 T. carolitius

$22: 3$ Pomatomus saltatrix

-).

225 Coryphaena hippurus

2.26 C. entuisetis

227 Palinurichthrs perciformis

228 Rhombus paru

229 R. triacauthus

230 Pomoxis annularis

¿31 P. slaroinles..........

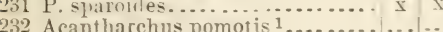

233 Awbloplites rupestris ?

234 Chaenobrsttus gulosus

235 Enmeacanthns obesus ${ }^{1}$

$236 \mathrm{E}$ E. mloriosus 3.

237 Apomotis cranellus

238 Lepomis auritus

239 L. palliı?us

2240 Enpomotis gibbosus 4 .

211 Micropterus dolomieu ${ }^{5}$.........

24:2 M. salmoinles ${ }^{6}$...............

243 Stizosterlion ritreum ..........

$2+4$ S. camalense.

$245 \mathrm{~S}$. cavarlense griseum

216 Perea Harescens ${ }^{i}$

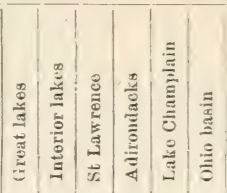

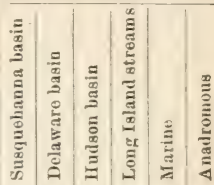

247 Percina caprodes.

248 P. caprodes zebra

219 Hadropterus aspro

250 Cottogaster copelandi

$2,31 \mathrm{C}$. cheneyi.

${ }^{2}$ Recorderl in the Hackensack.

2 Introduced into the Passaic and Long Island maters.

3 Recorded from Long jond, Hudson Highlands.

s Recerded also from the Walkill. L'assaic and Hackensack.

s Introduced into the Passaic.

Recorded from the Walkill, Pasagic and Brons.

Recorded from the Fassaic and Hackensack. 
Recorded astribution of New Tork lishes (continued)

\begin{tabular}{|c|c|c|c|c|c|c|c|c|c|c|c|c|c|}
\hline & & 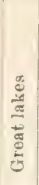 & 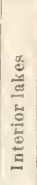 & 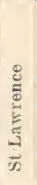 & & 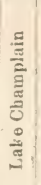 & $\begin{array}{l}\frac{a}{\pi} \\
\frac{a}{2} \\
\frac{0}{\frac{a}{b}}\end{array}$ & 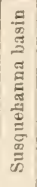 & 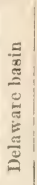 & 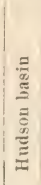 & 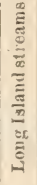 & 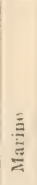 & 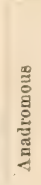 \\
\hline 252 & Diplesion blenniodes ........... & $\mathrm{x}$ & & $\cdots$ & & & & $\cdots$ & & .. & & & \\
\hline 253 & Boleosuma nigrum .......... & $\mathrm{x}$ & & ... & & ... & . . & $\ldots$ & ... & . & & $\cdots$ & \\
\hline 251 & B. nigrum olmstedi ........ & $\mathrm{x}$ & $\mathrm{x}$ & $\mathrm{x}$ & & $x$ & $\cdots$ & & & & $\mathrm{x}$ & -. & \\
\hline 255 & Etheostoma cueruleum ........ & $x$ & ... & & & ... & $x$ & & & & & & \\
\hline $27.5:$ & E. increale $\ldots \ldots \ldots \ldots \ldots$. & $x$ & & $\mathrm{x}$ & & & & $\cdots$ & & .. & & & \\
\hline 256 & $\begin{array}{l}\text { E. Habellare } 2 \\
\text { Boleichthys fusiformis }\end{array}$ & $\mathrm{x}$ & $x$ & $\mathrm{x}$ & & & $x$ & & & & & & \\
\hline 257 & $\begin{array}{l}\text { Boleichthys fusiformis } \ldots . . . \\
\text { 13. fusiformis } \theta 0 \text {............... }\end{array}$ & $\mid \begin{array}{l}x \\
x\end{array}$ & & & & & & $\begin{array}{l}\cdots \\
\ldots\end{array}$ & & & & & \\
\hline $\begin{array}{l}258 \\
259\end{array}$ & $\begin{array}{l}\text { 13. fusiformis } e 0{ }^{3} \ldots \ldots \ldots \ldots \ldots \\
\text { Roccus ehrs sops }{ }^{3} \ldots \ldots \ldots \ldots\end{array}$ & $x$ & & $\cdots$ & & $\cdots$ & $\mathrm{x}$ & $\cdots$ & & ... & & & \\
\hline $2(i i)$ & 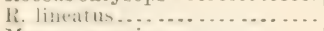 & $\cdots$ & & $x$ & & ... & ... & $\mathrm{x}$ & $x$ & $\mathrm{x}$ & $x$ & ... & $\mathrm{x}$ \\
\hline 261 & Morone anericana .......... & ... & $\cdots$ & $\ldots$ & & ... & ... & ... & .. & $x$ & $x$ & & $\mathrm{x}$ \\
\hline 262 & Polyprion americanus ......... & & & ... & & ... & -.. & ... & & ... & ... & $\lambda$ & \\
\hline 263 & Eviuephelus niveatus ......... & ... & .. & ... & & ... & ... & ... & ... & ... & ... & $\mathrm{x}$ & \\
\hline 264 & Centripristes striatus ......... & $\ldots$ & & .. & & $\ldots \cdot$ & ... & ... & .. & & ‥ & $x$ & ... \\
\hline $21: 5$ & Thule aurigat ................. & & & & & & ... & & & & & $\mathrm{s}$ & \\
\hline $26 ;$ & ligptens bi-tri-pints. ........ & & & & & & .. & & & & & $\ddot{x}$ & - \\
\hline 267 & Lobotes surinamensis ......... & $\cdots$ & 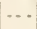 & ‥ & & ... & $\cdots$ & .. & -. & $\cdots$ & & $\mathrm{x}$ & ... \\
\hline 268 & Priacanthus arenatus ........ & & & & & & $\ldots$ & ... & & & & $x$ & ... \\
\hline atis & 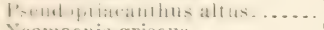 & & & & & & & & & & & $x$ & \\
\hline 270 & Neomaevis griseus ............ & & & & & & & & & & & $\mathrm{x}$ & - \\
\hline 21 & $\begin{array}{l}\text { D. blarklind } \\
\text { Orthopristis chrysopterus ...... }\end{array}$ & $\ldots$ & & & & & & & & & & $\mathrm{x}$ & \\
\hline 272 & $\begin{array}{l}\text { Orthopristis chrysopte } \\
\text { Scenotomus ehrysops. }\end{array}$ & & & & & $\cdots$ & $\cdots$ & … & $\cdots$ & & & 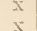 & .. \\
\hline 271 & 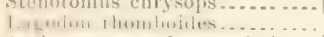 & & & & & & & & & & & $i$ & \\
\hline 275 & Arclusararens probatocephalis.. & & & & & ... & . & & & & & $x$ & \\
\hline $2 \pi$ & 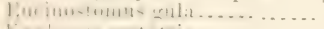 & ... & & . & & & . & & & & ‥ & 1 & \\
\hline 277 & 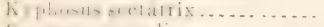 & & & . & & & . & & & & & $\mathrm{A}$ & .. \\
\hline$\because 7$ & 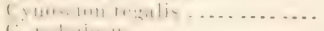 & & & & & & & & & & & $\mathrm{x}$ & . \\
\hline 271 & 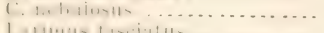 & ... & & .. & & & & & & & & $\lambda$ & \\
\hline $\begin{array}{ll}\cdots+1 \\
\cdots=1\end{array}$ & 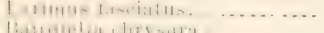 & & & & & & & & & & & $x$ & \\
\hline 28 & 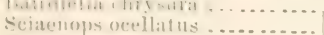 & & & & & & & & & & & $\hat{x}$ & \\
\hline $2 \times 3$ & Leciostomms xanthurus & & & & & & & & & & & $\frac{x}{x}$ & \\
\hline $\ln 1$ & Mieropmeng undulatns......... & & & & & & & & & & & $\mathrm{x}$ & \\
\hline$\therefore$ & 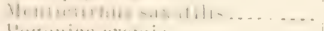 & & & & & & & & & & & $x$ & \\
\hline $2 \times 6$ & l'ngunias cromis ... & & & & & & & & & & & $\mathrm{x}$ & \\
\hline$\because \times 7$ & Aploutimotus yrumbiens & $\mathrm{x}$ & & & & $x$ & & & & & & & \\
\hline 288 & Tautengelitbrus iudspersiss ...... & & & & & & & & & & & $\mathrm{x}$ & \\
\hline (N) & 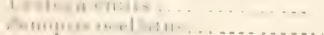 & & & & & 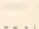 & & & & $\cdots$ & & i & \\
\hline 291 & Clactorlipterus fither... & & & & & & & & & & & & \\
\hline $2: 12$ & ('hatefodon ocellatus.......... & & & & & & & & & & & $\hat{x}$ & ... \\
\hline 2293 & Tenthis hepatus............. & & & & & & & & & & & $\mathrm{x}$ & ... \\
\hline 2919 & Kalistus varolimensis.......... & & & & & & & & & & & $x$ & \\
\hline $2 ! 4$, & 15. vetulat ...... & & & & & & & & & & & $\mathrm{x}$ & .... \\
\hline 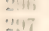 & Monananthus hicpiclus. & & & & & & & & & & & $\mathrm{x}$ & \\
\hline tis & 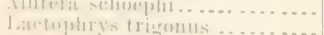 & & & & & & & & & & & $x$ & \\
\hline 2599 & lagemeplialus laverigatus. & & & & & & & & & & & $x$ & \\
\hline$\because(10)$ & 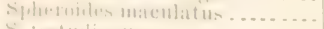 & & & & & & & & & & & $x$ & \\
\hline 301 & 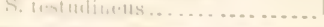 & & & & & & & & & & & & \\
\hline
\end{tabular}

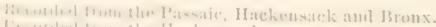

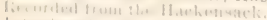

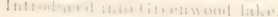


Recorded distribntion of New York fishes (continucd)

302 S. trichocephalus

303 'r. trichorliodon pilosus

304 Chilomycterus schoepfi

305 C. fuliginosus.

306 Mola mola

307 Sebastes marinus

308 Helicolenus dactylopterus......

309 Cottus ietalops

310 Uranidea gracilis ${ }^{1}$

311 U. formosa.

312 Myoxocepbalus aeneus

313 M. octodecim-spinosus

314 M. groenlandieus

315 Triglopsis thompsoni

316 Hemitripterus americanus......

317 Aspidophoroides monopterygius

318 Cyelopterus lumpus.

319 Neoliparis atlanticus . . . . . . ....

320 Liparis liparis

321 Gobiosoma bosci

322 Astroseopus guttatus.

323 Opsanus tau.

324 Blennius fucorum

325 Chasmodes bosquianus

326 Pholis gunnellus.

327 Ulvaria subbifureata.

328 Stichaens punctatus

329 Lumpeus lampetraeformis

330 Cryptacantbodes maculatus

331 Anathichas lupus

332 Zoarces anguillaris.

333 Rissola marginata.

334 Prionotus caroliuus

335 P. strigatus.

336 P. tribulus.

337 Trigla euculus

政

340 E. vaucrateoides

341 Remora remora

342 R. hrachyptera

343 Rhombochirus osteochir.......

344 Merlucias bilinearis.

345 Pollachius virens

346 Mierogadus tomeod

347 Gadus morrhua

348 Melanogrammus aeglifinus

349 Lota maculosa...

350 Urophyeis regins.

351 [i, tenuis

$352 \mathrm{U}$, chuss

353 Gaidropsarus argentatus.

354 G. ensis.

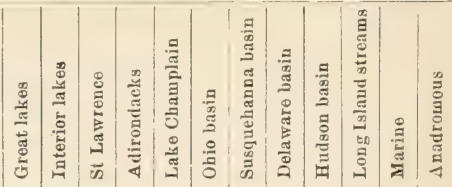

${ }^{1}$ Recorded also in the Hackensack and l'assaic. 
Recorical distribution of New Yorle fishes (concluded)

\begin{tabular}{|c|c|c|c|c|c|c|c|c|c|c|c|c|}
\hline & 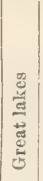 & $\frac{\frac{0}{9}}{\frac{0}{5}}$ & 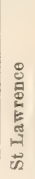 & 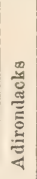 & 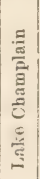 & 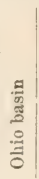 & 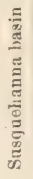 & 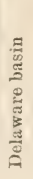 & 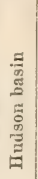 & 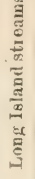 & 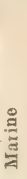 & 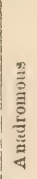 \\
\hline 55 Rhinonemus cimbrius.......... & $\cdots$ & ... & $\cdots$ & $\cdots$ & $\cdots$ & $\cdots$ & & $\cdots$ & $\cdots$ & $\cdots$ & $\mathbf{x}$ & ... \\
\hline 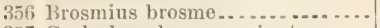 & $\ldots$ & ... & ... & ... & $\ldots$ & $\ldots$ & $\cdots$ & ... & $\ldots$ & ... & $x$ & $\ldots$ \\
\hline 357 Coelorhynchus earminatus..... & $\ldots$ & ... & ... & $\ldots$ & $\ldots$ & $\cdots$ & $\cdots$ & & $\cdots$ & $\cdots$ & $\mathbf{x}$ & ... \\
\hline 358 Hippoglossus hippoglossus..... & $\ldots$ & $\ldots$ & $\cdots$ & $\cdots$ & $\cdots$ & $\cdots$ & $\cdots$ & $\cdots$ & $\cdots$ & $\cdots$ & $\mathbf{x}$ & ... \\
\hline 359 Hippoglossoides platessoides... & $\ldots$ & $\ldots$ & . & $\cdots$ & $\cdots$ & $\cdots$ & $\ldots$ & $\cdots$ & $\cdots$ & $\cdots$ & $x$ & $\ldots$ \\
\hline 360 Paralichthys dentatus.......... & $\cdots$ & $\cdots$ & $\cdots$ & $\cdots$ & $\cdots$ & $\cdots$ & $\cdots$ & $\ldots$ & $\cdots$ & $\ldots$ & $x$ & $\ldots$ \\
\hline 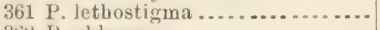 & $\cdots$ & $\cdots$ & $\ldots$ & $\cdots$ & $\cdots$ & $\cdots$ & $\cdots$ & & & $\cdots$ & $\mathrm{x}$ & $\ldots$ \\
\hline 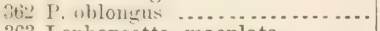 & $\cdots$ & $\cdots$ & $\cdots$ & $\cdots$ & $\ldots$ & $\cdots$ & & $\cdots$ & $\cdots$ & $\ldots$ & $\mathbf{x}$ & $\cdots$ \\
\hline 363 I.ophopsetta maculata......... & $\ldots$ & $\cdots$ & $\cdots$ & $\cdots$ & $\cdots$ & $\cdots$ & $\cdots$ & $\cdots$ & $\cdots$ & $\cdots$ & $x$ & $\cdots$ \\
\hline 361 Etropus wicrostomus............ & $\ldots$ & $\ldots$ & $\cdots$ & $\cdots$ & $\cdots$ & $\cdots$ & $\cdots$ & $\cdots$ & $\cdots$ & $\cdots$ & $x$ & $\cdots$ \\
\hline 365 Limanda ferruginea............ & $\cdots$ & $\cdots$ & $\cdots$ & ... & ... & $\cdots$ & $\ldots$ & $\cdots$ & ... & $\ldots$ & $\boldsymbol{x}$ & $\cdots$ \\
\hline 366 Pseudopleuronectes americanus. & $\ldots$ & $\ldots$ & ... & $\ldots$ & $\ldots$ & ... & $\cdots$ & ... & ... & ... & $x$ & .. \\
\hline 367 Platoplirys ocellatus........... & $\ldots$ & $\ldots$ & & ... & $\ldots$ & ... & $\cdots$ & ... & $\cdots$ & $\ldots$ & $x$ & $\cdots$ \\
\hline 368 Achirus fasciatus $1 \ldots \ldots \ldots \ldots \ldots$ & $\ldots$ & $\cdots$ & $\ldots$ & $\cdots$ & $\cdots$ & ... & $\cdots$ & & $x$ & $x$ & $\mathrm{x}$ & $\therefore$ \\
\hline 369 Lophius piscatorius............ & $\cdots$ & $\cdots$ & & $\ldots$ & $\cdots$ & $\ldots$ & & $\ldots$ & $\cdots$ & $\ldots$ & $x$ & $\cdots$ \\
\hline 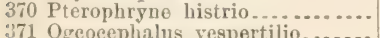 & $\cdots$ & $\cdots$ & $\ldots$ & $\ldots$ & $\ldots$ & $\ldots$ & $\ldots$ & $\ldots$ & $\cdots$ & $\cdots$ & $\mathrm{x}$ & $\cdots$ \\
\hline 71 Ogeocephalus vespertilio........ & $\ldots$ & & & & & & & & $\ldots$ & $\ldots$ & $x$ & $\ldots$ \\
\hline
\end{tabular}

${ }^{2}$ Hecorded also from the Hackensack. 


\section{N D E X}

Abramis, 132-34

americanus, 132

chrysoleucas roseus, 134

crysoleucas, 132-34

Smithii, see Cyprinus (Abramis?) Smithii

versicolor, 132

Acadian bullhead, 646

Acantharchus, 464-66

pomotis, $464-66$

Acanthias americanus, 43

rulgaris, 43

Acanthocottus, 639-44

aeneus, 639

anceps, see Cottus (Acanthocottus) anceps

groenlandicus, 613

octodecimspinosus, 641

Tariabilis, 643

virginianus, 641

Acanthopteri, 351-608

Acanthosoma carinatum, 629

Acanthurus chirurgus, 607

nigricans, 607

phlebotomus, 607

Acara aуa, 554

Achigan, 487

Achirus, 731-33

fasciatus, 732-33

lineatus, 732

mollis, 732

Acipenser, 63-69

brevirostris, 68

brevirostrum, 68-69

maculosus, 66

oxyrinchus, 64

rubicundus, 66-67

sturio, 63-65

var. oxyruynchus, 64

Acipenseridae, 63-69

Aelurichthys marinus, 77

Agonidae, $6 \pm 7-49$

Agoninae, 647-49
Albula, 181-83

conorhynchus, 182

ery throcheilos, 182

Parrae, 182

rulpes, 182-83

Albulidae, 181-83

Alburnellus amoenus, 150 rubrifrons, 149,150

Alburnops blennius, 138 heterodon, 137

Alburnus rubellus, 147 rubrifrons, 149

Aleby trout, 702

Alectis, 431-33

ciliaris, 432-33

crinitus, 432

Alewife, 5, 199-201, 441

river, 192

Alligator, 71

Alligator gar, 71

Alopecias rulpes, 33

Alopias, 32-3t

rulpes, $33-34$

Alopiidae, 32-34

Alosa, 203-S

alosa, 204

chrysochloris, 195

cyanonoton, 202

lineata, 197

mattowaea, 197

menhaden, 211

praestabilis, 204

sapidissima, 201-8

teres, 189

tyrannus, 199

Alutera, 613-15

schoepfti, 613

schoepfii, 61:-15

Aluteres cuspicauda, 613

Alvordius, $50 \pi-9$

aspro, 507

Amber fish, 416-1s

Amber jack, $41 \mathrm{~s}$ 
Amblodon grunniens, 590

neglectus, 590

Ambloplites, $466-70$

rupestris, $467-70$

Ameiuxus, $81-90$

catus, S5-S6

lacustris, $81-83$

melas, 90

natalis, $8 \pm$

nebulosus, S5, 87-S9

marmoratus, $\$ 9$

vulgaris, $84-85$

American angler, 735

American cod, 699

American codling, 706

American hake, 692

American shad, 20t

American sole, 732-33

Amia, 73- 66

calva, $74-76$

oecidentalis, it

Amilatae, $73-76$

Amiurus albidus, $\mathrm{S} 6$

borealis, 81

catus, ST

cauda-fureatus, so

deliayi, St

marmoratus, ST, S9

natalis. St

nigricans, S'2

ponderosus, S2

[mllus, 90

vulmaris, S.4

Ammocoetes branchialis, 11 ;

"enterolor: 14

nieser, 1t;

unicolor, 1:;

dmmorlytes, :375-77

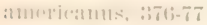

viltallus, : :

Ammoulytidar, : $: 57-7 \pi$

Ammodytoldei, :37.- -7

Amphisulent allosnicles, 1S5)

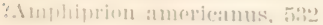

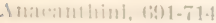

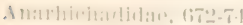

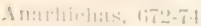

!umus, t:- $: 3-7 \cdot 4$

……
Anchories, 213-19, 359

banded, 217-1S

silvery, 216-17

striped, 214-15

Angel fish, 45-46, 57, 602-4

Angel sharks, $45-46$

Angler, 734-35

American, 735

marbled, 737

Anguilla, 169-74

blephura, 170

bostoniensis, 170

chrisypa, 170

chrssypa, 170-7t

conger, 175

macrocephala, 170

oceanica, 175

rostrata, 170

tenuirostris, 170

tyrannus, 170

vulgaris, 170

Anguillidae, 169-74

Antennariidae, 735-37

Antennarius histrio, $736^{2}$

Apeltes, 342-44

quadracus, $342-44$

Apliredoderidae, 352-5t

Aphredoderus, 352-ริ

gibbosus, 353

sayanus, 353-วัt

Aplodinotus, 590-92

grunniens, 590-92

Apodes, 169-7

Apomotis, 475-77

cyanellus, $475-77$

Aprionodon, 28-29

isotion, $25-29$

punctatus, 28

Archosargus, 561, 562-65, 563-65 probatocephalus, 563-65

Argentinidae, 282-85

Argyreiose, hairfinned, 436

Argyreiosus capillaris, 435

setipinnis, 433

vomer, 43 -

Argrieus atrouasus, $15 \pm$

nasutus, 152

Argyriosus romer, 435 
Argyrosomus, 230-41

artedi, 233-35, 241

hoyi, 235-37, 237, 241

osmeriformis, 230-33, 241

prognathus, 237-38, 241

tullibee, 238-41

Argyrotaenia vittata, 376

Arius equestris, 7s

felis, is

milberti, $7 \mathrm{~s}$

Aspidophoroides, 647-49

monoptery gius, 648-49

Aspidophorus monopterygius, $6 \pm 8$

Asterospondyli, 17-43

Astroscopus, 65s-60

anoplus, 658

guttatus, 658-60

Atherina brownii, 214

menidia, 357

mordax, 282

notata, 357

viridescens, 357

Atherinichthys gracilis, 355

menidia, 357

notata, 357

Atherinidae, 354-62

Atherinopsis notatus, 357

Atlantic salmon, 241-48

Autumnal herring, 197

Auxis, 3\$3-85

rochei, $38 \pm$

thazard, 384-S5

vulgaris, $38 t$

Аรa, 9, 55t

Bachelor, 460

Bachforelle, 255

Baione fontinalis, 272

Bairdiella, 576-7S

chrysura, 576-7S

Bait-stealer, 595

Balaos, 323-27

Balistes, 605-11

aurantiacus, 613

broceus, 611

eapriscus, $60 \mathrm{~s}$

carolinensis, 60S-10

cuspicauda, 613

fuliginosus, 608

hispidus, 611
Balistes (continucd)

schoepfii, 613

vetula, $610-11$

Balistidae, 608-11

Balloonfish, spot-striped, 628

unspotted, 628-29

Banana fish, 182-83

Banded anchovy, 217-18

Banded blenny, 6t4-65

Banded dace, 146

Banded drum, 589

Banded Ephippus, 603

Banded garfish, $31 \mathrm{~S}$

Banded gurnard, 680

Banded larimus, วั7ร

Banded mummichog, 309

Banded pickerel, 292-94

Banded pilot, 415

Banded rudder fish, 414-16, 42S-29.

Banded sucker, 104

Banded sunfish, 471-73

Bank lake bass, 462

Barfish, 463

Barndoor skate, 50-ร̌1

Barracuda, 368-73

long, 369-70

northern, 371-73 ,

Barred killifish, 311, 312

Barred maskalonge, 304-7

Basking shark, 41-13

Bass, bank lake, $t 62$

bayou, 491

big, 487

big-fin, 462

black, 587

brown, 487

calico, 462-6t

channel, 57S-SO

dark, 487

gold, 4S7

grass, 462,468

green, 491

hog, 485

lake, 462. 468, 45i

Lake Erie, 462,463

large-mouthed black, 490-93

little, $48 \mathrm{~S}$

minny, 487

moss, 491

Oswego, 491, 492 


\section{Bass (rontinucd)}

Otsego, 225

river. 491

rock, $467-70,537$

ruddy, 5-9

sea, 520-42

silver. $155,462,523$

smill monthed black, $486-90$

spotted, 4S7, 580

stone. 532

strawberrs, 462-61

streaked, 525

striped, 523, 524-27

striped sea, 525

white. 52-23

rellow, 457

Bass frr, 309

bass killy, 307-9

B:1ss mummr, 309

Jass sunfislı, 466

Basse, striped, 525

Bat tishes. 737-3S

Batoidei, $46-60$

batrachoididae, 660-62

Batraclus celatus, 661 tat 17, tit;1

Bayou bass, 491

Bellows fish, 731-35

Belone euribuaea, 322

crassa, 919

corania, 319

jomesi, :32-1

latimana, 322

nerlinochira, 319

raphis\}oma, :319

trituratat, :317

lienteal was

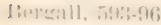

spustard, ith;

liepmutat cluub, jes-699

Iiemumbt whiting, 586

Jiervenisled, $37-69$

limsicy artan, 1;10-11

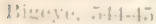

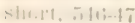

lizerend herring, 192

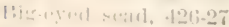

Him lin lass, Hig

lim-lamuthed (at, Sf)

isithel $\cdots 1,215,3: 15$
Billfish, $61,70-72,317-19,319,405-7$

Bitter head, 463

Black bass, 537

large-mouthed, 490-93

small-mouthed, 486-90

Black bullhead, 90

Black croppie, 463

Black drum, 589

Black grunt, $5 \pm 3$

Black lamprey, swall, 16-17

Black mullet, 586

Black-nosed dace, 5, 15t-56

Black-nosed sucker, 108

Black perch, 485, 529, 537

Black pilot, $45 \pm-55$

Black pollack, $69 \pm$

Black salmon, $26 \pi$

Black sea bass, 537

Black-sided darter, 507-9

Black sucker, $10 t$

Black will, 537

Blackfin whitefish, 228

Blackfish, 536-39, 597-99

Blackharry, $53 \%$

Blackhead minnow, 118-19

Blennies, 662-65

banded, $661-65$

eel, 670-71

seaweed, 663-6t

snake, $6 \pi 1$

spotted, 665-69

Blenniidae, 662-65

Blennioidei, 662-7t

Blennius. $60+2-64$

anguillaris, 674

bosquianus, $66 \pm$

cluuss. 707

ciliatus, 674

fucorum, 663-64

gumnellus, 6tj

labrosus, (iTt

lampetraeformis, 670

ocennicus, 603

pholis, 664

punctatus, 668

regius, 704

serpentinus, 670

Ilemny darter, jos

- Blennylike fishes, 662-74

Blepharichthys crinitus, 432 
Blepharis crinitus, 432

Bloater, 237-38

Blob, 635-37

Bloody stickleback, 343

Blower, 621

Blowfish, 622-24

hairy, 624

Blue bream, 482

Blue cat, 80 great, 82

Blue darter, 517-18

Blue herring, 195-96

Blue Johnny, 518

Blue perch, 595

Blue pike, $303,494,497$

Blue shark, 39

$$
\text { great, } 25
$$

Blue snapper, 446

Blue-spotted sunfish, 473-75, 477

Blue-striped trigger fish, 610-11

Blue sunfish, $480-82$

Blueback, 202-3

Bluefin, 228

Bluefish, 445-48, 537, 571, 595

Bluegill, 480-82

Blunt jaw, 117

Blunt-nosed minnow, 120-21

Blunt-nosed shiner, 434

Bodianus argyroleucus, 576 aya, 554

bistrispinus, 541

costatus, 583

flavescens, 500

l'ufus, 528

rupestris, 467

triurus, 542

Boleichthys, 520-21

eos, 521

fusiformis, 520-21

eos, 521

Boleosoma, 513-16

fusiformis, 520

maculatum, 513

nigrum, 513-14

olmstedi, 514-16

olmstedi, 514

tesselatum, 509, 514

Bone fish, 182-83

Bone shark, 43
Bonito, 393-95

oceanic, 386-88

Bonnet skate, 48

Bonnethead, 30-31

Bony fishes, 76-212

Bony gar, 71

Bony pike, 71

Bony-scaled pike, 6

Bony sturgeon, 66

Bothrolaemus, 439

pampanus, 443

Bothus, 723

maculatus, 723

Bowfins, $73-76$

Boxfish, spiny, 626-28

Brail, 719

Branch herriug, 199-201

Branded drum. 5so

Brassy sculpin, 639-41

Brazen bullhead, $6 \pm 0$

Bream, 133, 484

blue, 482

copper-nosed, 482

salt water, כ62

Breroortia, 211-13

tтramnus, 211-13

Bridge perch, 460, 487

Bridled minnow, 135-36

Brier ras, 49-50

Bristly dory, 434

Broad shiner, cryptous, 458

Brochet. 299

Bronze backer, $45 S$

Brook lamprey, 16

Brook minnor. 15 4 -56

Brook silversirles, 361-62

Brook sticlileback, 335-37

Brook sncker. 101

Brook trout, 6, 255, 272-75

Brosme. 711-12

brosme, 711-12

Brosmius brosme, 711

flarescens. 711

vulgaris?. 711

Brotula. 676

Brotrn bass, 4ST

Brown eatfish. 90

Brown tomend, 696

Brown trout, 254-57, 488 
Brrttus fasciatus, 471

gloriosus, 473

longulus, 475

Buflalo fish, 71

Bugfisb, 212

- Bullhead, S7-89, 636, 642

Acadian, 646

black, 90

brazen, 640

smooth browed, 640

Bullhead shark, little, 46

Bullpout, 87

Bumper, $437-34$

Bunker, 212

Burbot, 701-4

Burfish, 626-29

Burn stickle, 341

Butirinus vulpes, 182

Butter chub, 168

Buttertish, 44. 457-59, 665-66 limmbacked, 434

Butertly fishes, 60t-6, 67S

Buttertly ray, 5tu-5

Calico hass, $46 i_{-}-6 t$

Calien tlounter.

Calico sole, 73:2

Calliurus formosus, 475

longulus, 475

Camplielite, 460

Campostoma. 112-14

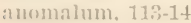

(ใแh)imm. 11::

Cantharus nieromaculatus, 462

('i) Jelin, :ing

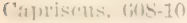

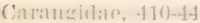

C:arantus hipmes, tas

(':11:anx, +27-3:31

1:ar:111011:, 428

chrysus, 10301

vorysiss, laito

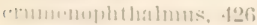

(1)y:ens, -1:30-8:1

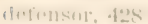

hilpus . $128-29$

hipmus, ides

manareflus, fo:

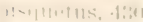

$111115 ;, 1 \div 1$
Caranx (continued)

spotted, 422

sutor, 432

trachurus, 425

yellow, 429

Carassius, $16 \pm-66$

auratus, $16 \pm-66$

Carcharias, $34-37$

americanus, 34

atroodi, 40

caeruleus, 26

glaucus, 25

(Prionodon) glaucus, 25

isodon, $2 \mathrm{~S}$

(Aprionodon) isodon, 28

littoralis, 34-37

(Prionodon) milberti, 26

obseurus, 25

(Prionodon) obscurus, 25

punctatus, 28

terrae-novae, 29

(Scoliodon) terrae-norae, 29

rulpes, 33

Carcharidae, 34-37

Carcharinus, 25-2S

glaucus, 25

milberti, 26-2S

obscul'us, 25-26

Carcharodon, 40-41

carcharias, 40-41

Cardonniera. 634

Carp, 112-69.

golden, 165

lake, $9 \mathrm{~S}$

leather, $10 \mathrm{~S}$

mirror, 167

scale, 167

Carpe blanche, 101

Carpiodes, 97-9s

thompsoni, 9S

Carplike fishes, 97-169

Casabe, 437-3S

Cataluias, $5 \cdot 4-7 \tau$

Cattishes, $76-97$

big-mouthed, S6

blue. so

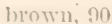

channel, \$0-81, 85-86

cliubloy, 81

common, st 
Catfishes (continued)

flannel-mouth, 82

Florida, 82

great blue, $\$ 2$

great fork-tailed, S2

lake, $\$ 1-\$ 3$

long-jawed, 84-85

marbled, s9

Mississippi, 82

mud, 82

Schuylkill, 86

sea, $77-78,78-79$

silver, so

spoonbill, 61-63

spotted, s0-S1

stone cat, 91-92, 93-94

white, S0, S5̃-86

vellow, St

Catonotus fasciatus, 515

flabellatus, 518

Catostomidae, 97-112

Catostomus, 99-104

anisurus, 109

aureolus, 110

carpio, 109

catostomus, 99-101

commersoni, 101

commersonii, 101-3

communis, 101

cyprinus, $9 \mathrm{~S}$

duquesnii, 110

fasciatus, 108

luudsonius, 99

longirostris, 99

melanops, $10 \mathrm{~s}$

nanomyzon, 99

nigricans, 103-4

oneida, 110

pallidus, 101

sucetta. 105

teres, 101

tuberculatus, 105

Cavalla, 401

Cayuga lake shad, 200

Cayuga lake sticklebacks, 337

Centrarchidae, 459-93

Centrarchus aeneus, 467

gulosus, 470

hexacanthus, 462

pomotis, 464

viridis, 470
Centrolophidae, 454-5็

Centronotus gunnellus, 66.5

spinosus, 449

Centropristes, 535-39

atrarius, 536

nigricans, 536

striatus, 536-39

Cephalacanthidae, 683-85

Cephalacanthus, 683-85

spinarella, $68 \pm$

volitans, $684-85$

Cephalus breris, 629

Ceratacanthus, 613-15

Ceratichthys biguttatus, 159

cataractae. 152

dissimilis, 157

lucens, $15 \mathrm{~s}$

micropogon, 159

plumbeus, 161

prosthemius, 161

Cernier, 532

Cero, 395-400

spotted, 400

Cetorhinidae, $41-43$

Cetorhinus, 41-13

maximus, $42-43$

Chaenobrytus, 470-71

antistius, 470

gulosus, 470-71

Chaetodipterus, 601-4

faber, $602-4$

Chaetodon, 604-6

alepidotus, 456

bimaculatus, 604

faber, 602

maculocinctus, 605

ocellatus, $60 t-6$

oviformis, 602

sheepshead, 603

Chaetodontidae, 601-6

Ohaetodontops, 604-6

Chain pickerel, 6, 296-98

Channel bass, 578-80

Channel cat, $80-81,85-\$ 6$

Chasmodes, 661-65

boscianus, 664

bosquianus, 664-65

Chatoëssus cepedianus, 187

ellipticus, 187

signifer, 209 


\section{Checouts. 571}

Cheilichthys, 622-24

Chelidonichthys, 6\$2-\$3

Chickwick, 57]

Chilomycterus, 626-29

fuliginosus, $625-29$

seometricus, 626,629

subsp. (?) fuliginosus, 628 schoepfi, 626 28

Chinook salmon, 241-44

Chinquapin perch, 460,463

Chironectes laerigatus, 736

Chirostoma beryllinum, 356

notatum, 357

sicculum, 361

vagrans, 359

Chivey, 2\%1

Chivin, 122-23

Chloroscombrus, 436-38

caribbaeus, 437

chrysurus, 437-8s

(:110:-nummy, 310

Chorset, 593-96

Chondrostei, 63-69

Chonerhinidac, 61s

Chorinemus occiclentalis, 410

Chrosumus, 114-16

erythrogaster, 11t-16

Chn1), 12:1-26, 163 491, 582, 598

I:ermuta, 568-69

lintter, $16 \%$

risiy, 10:;

linerued. 15!)-(i0

imlian, 160

litke. 1ti1- $(;-2)$

niseser, 160), 1632-63-4

rivere. 1-is?-(it)

-illt-water, 59s

-ilver. 1:20.2:3

r'hulh ext. 70)

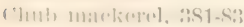

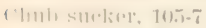

nemplhern, Jori

thishles (:a1, s1

rirthla :11010:1. 4h:7

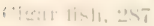

f'illat:1 :14:ernt:1t:1, 7os

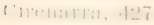

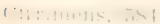

Cisco, 180, 233-35, 241

mooneye, 235-3i

Citharichthys, 724

microstomus, 725

Clear-nosed skate, $49-50$

Clinostomus, 128.29

margarita, 130

Clinus punctatus, 668

Cliola analostana, 144

hudsonia, 140

procne, 139

storeriana, 1£2, $15 \mathrm{~S}$

whipplei, 144

Clupea, 192-9t

aestivalis, 202

alosa, 204

chrysochloris, 195

coerulea, 192

cyanonoton, 9

elongata, 192

halec, 192

harengus, 192-94

heterurus, 187

hudsonia, 140

mattowaca, 197

mediocris, 197

menhaden, 211

pseudoharengus, 199

pusilla, 192

sadina, 190-91

sapiclissima, 204

tyrannus, 211

rermalis, 199

rirescens, 197

vittata. 214

Clupeiclae, 185-219

Coachman, 539-10

Coalfish, 694

Cobbler, $\$ 10$

Cobblerfish, 492-33

Cobia, 449-50

Cohitis heteroclita, 309 matalis, $: 307$

Cock-paclale, 651

Conl, (5!1:-4)!)

American, 699

rommon, 699

fresil-water, 702

rocek, (ig)!)

udlishes, 199:3-712 
Codling, 706, 707 American, 706 spotted, 704-5

Coelocephalus, 712

Coelorhynchus, 712-11

carminatus, 713-14

Conger eels, 174-77

Conger niger, 175

occidentalis, 175

vulgaris, 175

Copelandia, 471

Copeland's darter, 509-10

Copper-nosed bream, 482

Coregonus, 220-30

albus, 224

artedi, 233

clupeiformis, 224-30, 233, 240

harengus, 233

hoyi, 230,236

labradoricus, 9, 224

latior, 224

novae angliae, 221

osmeriformis, 230

prognathus, 237

quadrilateralis, 221-24, 240

sapidissimus, 224

tullibee, 239

Cornet fishes, 344-46

Corrina argsroleuca, 576

ocellata, 578

oscula, 590

Coryphaena, 450-54

equisetis, 452-54

globiceps, 451

hippuris, 451

hippurus, 451-52

perciformis, 454

punctulata, 452

sueuri, 451

sueurii, 451

Coryphaenidae, 450-5t

Cottidae, 685-47

Cottinae, 635-47

Cottogaster, 509-11

cheneyi, 510-11

copelandi, 509-10

putnami, 509, 510

Cottus, 635-37

aeneus, 639

(Acanthocottus) anceps, 639
Cottus (continued)

Bairdii, 635

formosus, 638

gracilis, 637

groenlandicus, $6 \pm 2$

hispidus, 646

ictalops, 635-37

bairdi, 636

mitchilli, 639

monopterygius, 648

octodecimspinosus, 641

Richardsoni, 635

scorpio, 639

scorpius groenlandicus, 643

virginianus, 641

Couchia argentata, 70s

Couesius, 160-62

dissimilis, 161

plumbeus, 161-62

prosthemius, 161

Cover, 732

Cover clip, 732

Cow-nosed ray, 59-60

Crab-eater, 449-50

Cramp fish, 51-52

Cranberry, mountain, S5

Craniomi, 676-85

Crappie, 459-62

Crawl-a-bottom, 104, 505

Creek chub, 125

Creek fish, 106-7

Crevalles, 410-44

Cristivomer, 266-71

namaycush, 266-71

Croakers, 569-92

Crocus, 591

Croppie, black, 463

lake, 463

timber, 460

white, 460

Cryptacanthodes, 671-72

maculatus, 671-72

Cryptacanthodidae, 671-72

Cryptous broad shiner, 458

Ctenolabrus, 593

adspersus, 593

burgall, 593

ceruleus, 593

clogset, 593

uninotatus, 593 
Cuckold, 616-17

Cuclioo fish, 678

Cucumberfish, 626-2S

Cunner, 593-96

Cusk, 711-12

lake, 702

little, 676

Cut-lips, 162-6t

Cutlas fishes, 402-3

Crbium caballa, 400 caralla, 400

maculatum, 396

regale, 398

Cyclichthys, 626-29

Crcloganoidea, $73-76$

Crelonteridae, 619-ร์

Cyclopterinae, 649-52

Crclopterus, 649-52

coeruleus, 619

liparis, 654

lumpus, 6-19-ॅ2

Crelospondrli, $43-46$

Crlindrosteus, 72

Cynoperea, 49S-99

Crnoscion, 569-74

maculatum, 578

neibulosus, 573-74

regale, 570

recalis. $570-73$

Cyprinella whipplii, 143

Crprinidae, 112-69

Cyprinodion, 315-17

parrus, 814

variogatus, 315-17

Crprinus, 166-69

atromaculatus. 128

atronasus, 154

anratus, 16it

limllaris, 122

(arpio, 167-69

catostomus, 99

"ommersonnii, 101

"romutus, 14 .

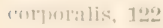

r.ry:uhnuा

heminlus, 1:32

inlus. 1::1

In:1xillinsen:1, 16i2

memeslepis: 1.5

whitullems, 106;
Cyprinus (continued)

(Abramis?) Smithii, 184

sucetta, 105

teres, 101

tinca, 126

vittatus, 154

Cypselurus, 331-35

furcatus, 333

Dab, rusty, 727

sand, $717,726-2 \overline{7}$

Dace, 122-23, 146

banded, 146

black-nosed, 5, 15£-56

horned, 123-26, 160

long-nosed, 152-54

mud, $28 s$

red-bellied, 114-16

Dactylopterus volitans, 681

Daddy sculpin, 612-44

Dark bass, 487

Darter, black-sided, '507-9

blenny, $50 \mathrm{~s}$

blue, 517-18

Copeland's, 509-10

fantail, 518-20

greensided, 512-13

Johnny, 513-14

manitou, 506-7

rainbow, 517-18

tessellated, 514-16

Dasibatis hastata, 54

Dasibatus centrura, 53

Dasyatidae, 53-57

Dasyatis, 53-56

centrura, 53-54

liastata, 54-55

say, 55-50

Dasybatis sayi, 55

1) ay chub, 163

Daylight, 724

1)ecapterus, 420-24

macarellus, 423-24

punctatus, 421-22

1)eep water seulpin, 646

1)iodon carinatus, 629

fuliginosus, 628

liairy, 625

lıystrix, 626

maculostriatus, 626 
Diodon (continued)

nigrolineatus, 626

pilosus, 625

rivulatus, 626

schoepfi, 626

Diodontidae, 624-29

Diplesion, 511-13

blennioides, 512-13

Diplodus argyrops, 558

probatocephalus, 563

rhomboides, 561

Dipterodon chrysurus, 576

Discocephali, 686-90

Distribution of New York fishes, $739-46$

Doctor fish, 607

Dog shark, 23

Dogfishes, 43-45, 75, 288-89, 702

horned, 44

smooth, 23

spined, 43-45

Doliodon, 439

Dollardee, 482

Dollarfish, 434, 458

Uolphin, 450-5t

common, 451-52

small, 452-ว4

Doré, 495

Dorosoma, 186-88

cepedianum, 187-8S

notata, 187

Dorosomidae, 1S6-88

Dory, bristly, 434

hair-finned, 436

rostrated, 436

spinous, 439

Dotted scad, 422

orum, 9S, 587-90, 591

banded, 589

big, 589

black, 589

fresh-water, 590-92

red; 589

Joung, 589

1rummer, 571

Duck-billed cat, 61

Dules, 539-40

auriga, 539-40

Dusky shark, 25-26

Dwarf salmon, 246
Eagle rays, 57-60

Eastern pickerel, 297

Ecaille, grande, 177-79

Echeneididae, $686-90$

Echeneis, 656-85

albacauda, 686

albicauda, 686

brachyptera, 689

holbrooki, 687

naucrateoides, 687-8S

naucrates, 686-87

neucrates, 686

osteochir, 690

quatuordecimlaminatus, 689

remora, 688

Eel blenny, 670-71

Eelpouts, 674, 702

Eels, 169-77

billed, 318,348

chub, 702

conger, 174-77

lamprey, 11-13, 67

rock, $665-71$

sand, 376-77

sea, 175-77

true, 169-74

iggfish, 621

Elacate atlantica, 449

Canada, 449

nigra, 449

Elagatis, 418-20

bipinnulatus, 419-20

pinnulatus, 419

Eiectric ray, 51-52

Llephant shark, 42-43

Ellwhop, 199

Eliwife, 199

Elopidae, 177-S0

Elops, 179-80

inermis, 179

saurus, $179-80$

Emerald minnow, 147-49

limphycus, 705-S

Enchelycephali, 169-77

Enchelyopus, 710-11

cimbrius, $710-11$

Engraulididae, 213-19

Engraulis argyrophanus, 216 brownii, 214

mitchilli, 218 
Engraulis (continucd) perfasciatus, 217 vittata, 214 rittatus, 219

Enneacanthus, 471-75 eriarchus, 473 gloriosus, 473-75 obesus, 471-73 simulans, 473

Ephippidae, 601-4

Ephippus, 602 banded, 603 faber, 602 gigas, 602

Epinephelus, 533-35 niveatus, 533-35

Erimystax, 157-58

Erimyzon, 10t- 7 goodei, 105 sucetta, 105-6 oblongus, $106-7$

Esocidae, 317-23

Esox aflinis, 296 americanus, 292 boreus, 299 crassus, 294 eypho, 294 estor, :29) fasciatus, 292 llavulus, 307 immaculatus, $30-4$ Iongirostris, 317 lucius, 5,298 fameric:anus, 292 marinus, 317 mistuinongy, 302 immaculatus. 80.4

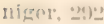

nohilior, : 20 른

oxsents, ti, it)

ovinus, :31t;

phatelatus, 2ate;

yiseremlus, :3u!

pherulentus, :30!

porosus, 29-1

1:15. rovirulatus, :ag;

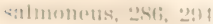
Qturus, :3:-7

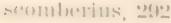

\section{Esox (continued)}

tridecenilineatus, 296

umbrosus, 294

rermiculatus, 294

rulpes, 182

zonatus, 307

Etheostoma, 516-20

aspro, 507

blennioides, 512

(Diplesion) biennioides, 513

caprodes, 505

coerulea, 517

coeruleum, 417-18

flabellare, 518-20

flabellaris, 518

fusiforme, 520

linsleyi, 518

nigrum, 513

olmstedi, 514

olmstedi, 514

Etropus, 724-26

microstomus, $725-26$

Etrumeus, 189-91

sadina, 8, 189

teres, 189-91

Eucalia, 335-37

inconstans, 333-34, 336

cayuga, 337

Eucinostomus, 565-67

argenteus, 566

gula, 566-67

Eugomphodus littoralis, 34

Eulamia milberti, 26

Euleptorhampluus, 325-27

longirostris, 326

velox, 326-27

Eumesogrammus subbifureatus, 607

Liupomotis, $482-86$

aureus, 4S3

gibbosus, 483-S6

Euthynmus alliteratus, 389

pelamys, 356

Liventognathi, 97-169

Exocoetidae, 330-35

Exocoetus, 330-35

aflinis, 230

comatus, $33: 3$

exiliens, 330

furcatus, 333, 335-37

gilubifrons, $334-35$ 
Exocoetus (continued)

heterurus, 331-32

melanurus, 330

noreboracensis, 332

nuttalli, 333

rubescens, 330

volitans, $330-31$

Exoglossum, 162-64

annulatum, 162

dubium, 113

(Hrpentelium) macropterum, 103 maxillingua, 162-64

nigrescens, 162

vittatum, 162

Fairmaid, 559, 562

Fall herring, 197-98

Fall shad. $19 \tau$

Fallfish. 122-23

smaller, 125

Fanegal, 634

Fantail darter, 518-20

Fantail mullet, 367-68

Fario gairdneri, 252

lemanus, 264

Fatback, 364

Fathead, 11S-19

Fathead minnow, 118

Federation pike, 297

Felichthrs, $76-78$

marinus, $77-78$

Fiddlefish, 46

Filefish, 611-15

orange, 613-15

Fishing frogs, $733-35$

Fistularia, 344-46

neoboracensis, 345

serrata, 345

tabacaria, $345-46$

Fistulariidae, 344-46

Flannel-mouth cat, 82

Flasher, 542-43

Flatfish, 714-33

rusty, 727

toothed, 719

Florida cat, 82

Flounders, 714-31

calico, 733

fourspotted, $721-22$

oblong, 721
Flounders (continued)

rusty, 717

sand, $724,730-31$

small-mouthed, 725-26

southern, 720-21

spotted, 731

summer, 717-20

turbot, 719

watery, 724

winter, 727-29

Fluke, 719

Flying fishes, 330-35, 678, 680

Flying gurnards, $683-85$

Flying robin, 684-85

Fork-tailed cat, 82

Four-bearded rockling, 710-11

Fourspotted flounder, 721-22

Fresh-water cod, 702

Fresh-water drum, 590-92

Fresh-water killy, 311-13

Fresh-water salmon, 246

Fresh-water silversides, 356-57

Friar, 357-59

Frigate mackerel, 384-85

Frost fish, 221-24, 240, 692, 695-97

Fundulus, 307-13

diaphanus, 311-13

fasciatus, 307

fuscus, 289

heteroclitus, 309-11

macrolepidotus, 309

majalis, $307-9$

multifasciatus, 311

pisculentus, 309

swampina, 311

viridescens, 309

zebra, 309

Gadidae, 676, 693-712

Gadus, 697-99

aeglefinus, 699

albidus, 691

arenosus, 698

brosme, 711

callarias, 698

cimbrius, 710

compressus, 701

lacustris, 81,701

longipes, 707

maculosus, 701 
Gadus (continued)

merlucius, 691

morhua, 698

morrhua, 698-99

pruinosus, 695

punctatus, 704

purpureus, 693

rupestris, 698

tau, 661

tenuis, 705

tomcod, 695

tomeodus, 695

rirens, 693

Gaff topsail, 77-7S

Gaidropsarus, $708-10$

argentatus, $705-9$

ensis, 709-10

Gairdner's trout, 252-54

Galeichthys felis, is marinus, 77

Galeidae, 22-30

Galeocerto, 23-24

tigrinus, 24

Ganoid fishes, 60-76

Ganoidei, 60-76

Gar, alligator, 71

bony, 71

short-noser, 72- 73

silver, 317-19

sott, 318

Gar pikes, 69-73

Gartish, banded, 318

Gascon, 425-26;

Gaspagie, 591

Gaspereau, 200

Gaspergou, 591

Gasterosterilae, 33-i-4t

Ginstrorostens, 310-12

aculeatus, 3.40

biaruleatus, sto

hispinosus, :30-12

(") 11:1dns, 4.4!

emrolinus, $41:$ :

cataphatutus, : : 11

concinmus, :3is

Janelor, +12

Ineonstans, :3:-

millemmur:atus, : 1 12

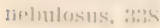

nowhmacensis, :3.4n
Gasterosteus (continued) occidentalis, 338

pungitius, 338

quadracus, 342

saltatrix, 445

Gerres argenteus, 566 gula, 560

Gerridae, 565-67

Ghostfish, 671-72

Gizzard shads, 186-88

Glasseye, 494

Glassfish, 361-62

Globefish, 622-24

Glossodon harengoides, $1 \mathrm{~S} 1$

Glut herring, 9, 202-3

Goatfish, 377-79

Gobies, 656-5s

naked, 656-58

variegated, $65 \pi$

Gobiidae, 656-58

Gobiinae, 656-58

Goblo cataractae, 152 plumbeus, 161

Gobioidei, 65̄6-58

Gobiosoma, 656-5S alepidotum, 656

bosci, 656-5s

Gobius alepidotus, 656

bosci, 656

riridi-pallidus, 657

vividipallidus, 656

Goggle-eye, 460, 463, 465, 470-7T

Goggle-eye perch, 463

Goggle-eyed jack, 427

Goggler, 426:27

Gold bass, 457

Gold nertling, 131

Gold shad, 195-96

Golden carp, 165

Golden idie, 131-32

Golden mullet, 111

Golden red horse, 111

Golden shiner, 132-34t

Golken sucker, 111

Golden tront. "27S-8:

Golditish, 16t-6i(;

Goody, is?

Goosefish, 734-35

Grand-oranchee, 516;

(irass bass, 462 , 463 
Grass pike, 300,494

Gray-back, 200

Gray pike, 498, 499

Gray snapper, 548-50

Gray sucker, 101

Gray trout, 267

Grayling, 246

Greenback, 198

Green-backed shark, 30

Green bass, 491

Green pike, 296-98, 494, $49 \mathrm{~S}$

Green pollack, 694

Green-sided darter, 512-13

Green sunfish, 475-77

Greenfish, 446

Greenhead, 525

Grenadiers, 712-14

Grey trout, 571

Grilse, 246

Grindle, 75

Ground shark, 35

Grouper, snowy, 533-35

spotted, 533-35

Growler, 487

Grubber, 183

Grubby, 639-41

Grunt, 589

thornbacked, 444

Grunters, 555-57, 589, 678, 680

Guardfish, 319-21

Gudgeon, 142-43

New York, 309

Niagara, 152-54

Gunnellus mucronatus, 665 punctatus, 668

Gurnard, 676-83

banded, 680

common, 678

flying, $683-85$

red, 682-83

Gymnodontes, 617-31

Gymnosarda, 385-90

alleterata, 388-90

pelamis, 386

pelamys, 386-88

Hacklehead, 641-42

Haddock, 699-700

Norway, 631-33
Hadropterus, 507-9

aspro, 507-9

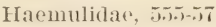

Haemulon fulvomaculatum, 556

Hair-finned argyreiose, 436

Hair-finned dory, 436

Hairtail, 402-3

Hairy back, 188

Hairy blowfish, 624

Hairy diodon, 625

Hairy porcupine fish, $625-26$

Hake, 586, 692, 705-7

American, 692

silver, 691-93

spotted, 704-5

squirrel, $706,707-8$

white, 705-7

Halatractus zonatus, 414

Half-gills, 335-46

Halfbeak, 324-25

slender, 326-27

Halibut, 714-15

Hammerhead, 104

Hammerheaded shark, 30-32

Hanna hills, 537

Haploidonotus grunniens, 590

Haplomi, 287-317

Harvestfishes, 455-59

short-finned, 458

Headfishes, 629-31

Hecht, 299

Hedgehog ray, 47-48

Helicolenus, 633-35

dactylopterus, 634-35

Hemdurgon, 633

Hemibranchii, 335-46

Hemioplites, 471

simulans, 473

Hemirhamphidae, 323-27

Hemirhamphus longirostris, 326

(Euleptorhamphus) longirostris, 326

macrorhynchus, 326

roberti, 324

unifasciatus, 324

Hemitremia bifrenata, 195

heterodon, 137

Hemitripterus, 645-47

acadianus, 646

americanus, $646-47$ 
Hen-paddle, 651

Herring, 185-219, 241

autumnae, 197

big-eyed, 179-S0, 199

blue, $195-96$

branch, 199-201

fall. $197-98$

glut, 9, 202-3

lake, 233-35, 241

Loug Island, 197

river, 199

round, 8, 189-91

satin striped, 215

sea, 192-94

shad, 197-9S, 203, 209-11

sprat, 209-11

spring, 199

Staten Island, 197

summer, 203

thread, 185, 209-11

toothed, 18t85

wall-eyed, 199-200

Heterosomata, 714-33

Hexanematichthys, $78-79$

felis, 78-79

Hickors shad, 9, 1SS, 197-9S

Hicks, 198

IIiodon, 18:-S6

chrysopsis, 155

clodalus, 181

tergisus, 1St-S5

IIjulontidae, 1S3-86

I1ippocampinae, 349-51

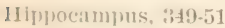

heptagonus, :350

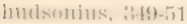

Himposlossojides, 715-17

dentatus, 716;

wassoulon. 715

platessolules, 71ti-17

Hippoglossus, 614-15

hipfoglossils, 71.4-1.5

vulsuris, 714

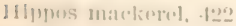

Illstipuhorts americamus, 101 betome, so6;

llog lass, 4se

Ilug mullet, 10H

Iloce suclier, 10:3-1

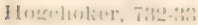

Hogfish, 505, 556-57

Hogmolly, 104, 505-6

Holocentrus surinamensis, 512

Hololepis fusiformis, 520

Homoprion xanthurus, 576

Horned chub, 159-60

Horned dace, 123-26, 160

Horned dogfish, 44

Horned pout, 87-89

Hornfish, 495

Horny head, 160

Hors, 425

Horse mackerel, 391-93, 446

Horsefish, 349-51, 433-34, 498

Houndfish, 23, 319-21, 322-23

Hoy's whitefish, 241.

Hudsonius amarus, 142

Humpbacked butterfish, 434

Huro nigricans, 490

Hybognathus, 116-18

nuchalis, 116-18

osmerinus, 116

procne, 139

regius, 116

IIybopsis, 156-60

bifrenatus, 135

dissimilis, 157-58

heterodon, 137

hudsonius, 140

kentuckiensis, 159-60

procne, 139

storerianus, 142, 158-59

IIyborhynchus notatus, 120

Hybrid trout, 5, 257-59

Hydrargira atricauda, 288

diaphana, 311

iusca, 288

limi, 2SS

multifasciata, 311

Hydrargira fusea, 288

majalis, 307

Stwampina, 311

IIyodon alosoides, 15.5-S6

amphiodon, 185

elandalus, 184

clodalis, 181, 185

Iypentelium macropterum, see Exoglossum (IIypentelium) macrontermm

Hyperoantii, 11-17 
Hyporhamphus, 323-25

roberti, 324-25

Hyporthodus flavicauda, 533

Hypsilepis cornutus, 145

gibbus, 147

diplaemia, 151

kentuckiensis, 144

Hypsoblennius, 664

Hypsolepis frontalis, 147

Ice fish, 282-85

Ichthyomyzon, 14-15

argenteus, 15

concolor, 14-15

Ictalurus, 79-81

albidus, 85

lacustris, 81

lophins, 85

nigricans, 81

punctatus, $80-81$

Ide, golden, 131-32

Idus, 131-32

idus, 131-32

melanotus, 131

Indian chub, 160

Indian remora, 687

inomi, 285-87

Irish roach, 134

Isospondyli, 177, 285

Isospondylous fishes, 177-285

Istiophoridae, 403-7

Istiophorus, 403-5

nigricans, 404-5

Isuropsis dekayi, 38

Isurus, 37-39

dekayi, 38-39

Jack, 297, 299, 495

goggle-eyed, 427

salt-water, 446

Jack salmon, 495

Jenny, silver, 566-67

Jerker, 160

Jewel head, 591

John-a-grindle, 55

John demon, 460

John dories, 600-1

Johnius ocellatus, 578

regalis, 570

saxatilis, 585
Johnny, blue, 518

Johnny darter, 513-14

Jorobado, 434

Jugular fishes, 691-714

J umper, 48s, 491, 492

Jumping mullet, 364

Kenoza, 292

Killifishes, 307-17

barred, 311, 312

big, 311

sheepshead, 317

striped, 309

white-bellied, 311

yellow-bellied, 311

Killy, bass, 307-9

fresh-water, 311-13

King, silver, 177-79

King salmon, 241-44

KKingfish, 400-1, 585-87

Kingston, 46

Kiouk, 203

Kirtlandia, 359-61

laciniata, 9, 360

vagrans, 9, 359-61

Kit, 54-55

Kyphosidae, 567-69

Kyphosus, 567-69

sectatrix, 568-69

La quesche, 185-86

Labeo elegans, 106 esopus, 105

gibbosus, 105

oblongus, 106

Labidesthes, 361-62 sicculus, 361-62

Labrador whitefish, 9, 224-30

Labrax albidus, 522

lineatus, 524

nigricans, 528

notatus, 522

pallidus, 528

rufus, $52 \mathrm{~S}$

Labridae, 593-600

Labroid fishes, 593-601

Labrus adspersus, 593

appendix, 47S

auritus, 478

chogset, 593 
Labrus (contimucd)

fulva, 593

cromis, 587

falcatus, 439

fulromaculatus, 556

griseus, 548

grumniens, うsS

onitis, 597

pallidus, 480

salmoides, 490

sparoides, 462

squeteague, 5i0

var. maculatus, 573

striatus, 536

tautoga, 597

rersicolor, $55 \mathrm{~S}$

Lactophrys, 615-17

trigonus, 616-17

salei, 616

Ladytishes, 1S1-S3

Lafayette, 458, 57 5 . 580-83

Lagocephalus, 617-19

laevigatus, 618-19

lagocephalus, $61 \mathrm{~S}$

Lagodon, 561-6:

rhomboides, $5(; 1-6 ; 2$

Lalie bass, $462,468,487$

Lake blob, 635

Lake carp, $9 S$

Lake eatfish, 81-83

Ialie (chu1), 161-fi2

Lalie eroppie, 468

Lake cusk, 702

Lake Erie bass, 462, 463

Lake herring, 2:3:-19. 2-1

Salie lamprey, 1:-1.1

Latie minnow, 158-5?

Morse, 16;1-1;

Latio mullet, 111

Ialit: pilie, :300

Lake sculpin, 6il4-45

Jake shimer, "2:36, "211

Lake sturemon, (iti-tiz

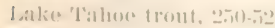

Lalia trout, 2L(sti-7)

swiss, 2 - ti:3-4tit;

1.ง

ช"and:ata, 27

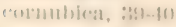

mumet:at:t, :3s
Lamnidae, 37-41

Lampetra, 15-17

wilderi, 16-17

Lamplighter, 463

Lamprey eel, 11-13, 67

Lampreys, 11-17

brook, 16

great sea, 11-13

lake, 13-14

mud, 16

silver, 14-15

small black, 16-17

Lampugus punctulatus, 452,453

Lances, sand, 375-77

Landlocked salmon, 246, 248-50

Lantern fishes, 285-8T

Larimus, 574-75

banded, 575

fasciatus, 575

Lawyer, 75, 701-4

Leather carp, 168

Leather jacket, 410-12, 60S-10

Lebias ellipsoides, 316

ovinus, 316

sheepshead, 316

Leiostomus, 580-83

obliquus, 581

ranthurus, 580-83

Leopard shark, 24

Lepidsosteus osseus, 71 platystomus, 72

Lepisosteidae, 69-73

Lepisosteus, 69-73

bison, 70

osseus, $70-72$

platostomus, 72-73

platyrhincus, 72

Lepomis, $477-82$

auritus, 47S-SO

cyanellus, 475

elongatus, $47 \mathrm{~s}$

gibbosus, 483

mystacalis, $47 \mathrm{~s}$

pallidus, 4SO-S:2

Leptoblenuius, 670-71 serpentimus, 670

Leptocephalidae, 174-7

Leptocephalus, $17 \pm-77$ conger, 175-77

Lemeiseus, 114, 127-31 
Leuciscus (continued) atromaculatus, 123 atronasus, 154 biguttatus, 159 chrysopterus, 122 cornutus, 145 elongatus, 128-29 erythrogaster, 114 frontalis, 147 heterodon, 137 hudsonius, 140 idus, 131

leuciscus, 128 margarita, 130-31 nasutus, 152 nitidus, 122 procne, 139 proriger, 128 pygmaeus, 289 rubellus, 147 rubrifrons, 149 spilopterus, 143 storerianus, 142, 158 vittatus, 145

Leucosomus corporalis, 124

Lichia carolina, 443

Licorne de Mer, 651

Limanda, 726-27 ferruginea, $726-27$

Ling, 674-75, 701-4

Liparididae, 652-56

Liparidinae, 652-56

Liparis, 653-56 lineata, 654 liparis, 654-56 montagui. 652 vulgaris, 654

Lirus perciformis, 455

Lizard fishes, 285-87

Tobotes, 542-43 auctorum, 542 emarginatus, 548 surinamensis, 542-43

Lobotidae, 542-43

Loch Leven trout, 259-61

Log perch, 505-6

Long-eared sunfish, 478-S0

Long Island, species from, Ј-6; Long Island herring, 197 Long jaw, 237-38, 241
Long-jawed catfish, 84-S5 Long-nosed dace, 152-54

Long-nosed sucker, 99-101

Long-tailed porbeagle, 27

Lookdown, 435-36

Lophiidae, 733-35

Lophius, 733-35

americanus, 734

bufo, 661

histrio, 736 .

piscator, 734

piscatorius, 734-35

vespertilio, 738

Lophobranchii, 347-51

Lophopsetta, 722-24 maculata, 723-24

Loricati, 631-56

Losh, 702

Lota, 701-4

brosmiana, 701

compressa, 701

inornata, 701

maculosa, 701-4

Lucania, 314-15

parva, 314-15

Luccio, 299

Luciidae, 291-307

Lucioperca americana, 493 canadensis, 498

grisea, 499

pepinus, 499

vitrea, 494

Lucius, 291-307

americanus, 292-91

lucius, 298-301

immaculatus, 304

masquinongy, 302-4

immaculatus, 304reticulatus, 294, 296-9s vermiculatus, 29t-96

Lumpenus, 669-71 lampetraeformis, 670-71

Lumpfish, 649-52

Lumpsucker, 649-52, 652-58

Lumpus anglorum, 619

Lunge, 267

Lutianidae, 547-55

Lutjanus aya, 554

blackfordi, 551

Blackfordii, 550 
I.utpanus (continued)

caballerote, 548

campenchianus, 551

campechianus, 553

griseus, 548

stearnsii, 548

viranus, 554

Luxilus, $145-47$

dissimilis, 157

elongatus, 128

ersthrogaster, 114

kentuckiensis, 144, 159

lucidus, 151

Mackerel, 379-401, 446

chub, 381-S3

common, 379-81

frigate, 384-85

lippos, 422

lorse, 391-93, 446

skip, 446

suap, $445-48$

saapping, 446

spanish, 396-9s

thimbleeye, 381-83

yellow, 430-31

Mackerel midge, 708-9

ditckerel pike. '92

Mackerel scad, 423-24

Mackerel shark, $37-41$

Mackinaw, 267

Macrozonarees, 6it4

Macruridae, 712-14

Macrums carminatus, 713

(Cirelorlynchus) carminatus. 713

Yarlemolselle. 57

M:!hen, กับ

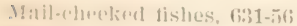

Malialra nigricans, 40-1

Malasheg:nuy, 5!92

Malthata vespertilio, Tas

Malthe, 7as

vespertilio, T:Bs

Man-1:เtr., f11-11

. 1 anะmove sn:1

Manftou darter, , הus:-

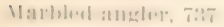

M:arhimal ant, s!!

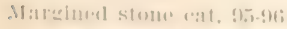

M:1r:m hamlier. 425
Marsipobranchii, 11-17

Marthy, 702

IIascalongus, 301-7

Iaskalonge, 302-4

barred, 304-7

spotted, 302-4

unspotted; 304-7

Maskinonge, 303

Mastieura, 53-59

Mayfish, 309

Megalops atlanticus, 177

cepediana, 187

elongatus, 177

notata, 209

oglina, 209

thrissoides, 177

Melanogrammus, 699-700

aeglefinus, 699-700

Irelanura annulata, 289

pygmaea, 289

Meletta suoerii, 195

Menhaden, 5, 211-13

Menidia, 354-59

beryllina, 356-57

gracilis, 355-56

beryllina, 356

laciniata, 360

notata, 357-59

vagrans, 359

laciniata, 360

Irenominee whitefish, 221

Menticirrhus, 581-87

nebulosus, 585

saxatilis, $585-87$

Merit fish, 359

Merlangus carbonarius, 693 leptocephalus, 693

purpureus, 693

Merluciidae, 691-93

Merlueius, 691-93

albidus, 691

bilinearis, $691-93$

Mesoprion caballerote, 54S

griseus, tits

Methy, 702

.11 ierogadus, 694-97

proximus, 694

tomcodus, 695

Micropogon, 5S3-84

costatus, 583 
Micropogon (continued)

lineatus, 583

undulatus, 583-84

Micropterus, 486-93

dolomieu, 486-90

pallidus, 490

salmoides, 490-93

Micropteryx chrysurus, 437

Milbert's shark, 26-28

Miller's thumb, 635-37, 637-38

Minister, 87

Minnilus blennius, 138

cornutus, 145

var. frontalis, 147

dinemus, 148

diplaemius, 151

notatus, 120

percobromus, 149

plumbeolus, 145

rubellus, 148

rubrifrons, 149

Minnow, blackhead, 118-19

bluntnosed, 120-21

bridled, 135-36

brook, 154-56

emerald, 147-49

fathead, 118

lake, 158-59

Morse lake, 161-62

mud, 287-91

pearl, 130-31

plumbeous, 161-62

red-bellied, 115

rosy, 147-49

rosy-faced, 149-50

salt-water, 310

sheepshead, 315-17

silvery, 116-18

spotted, 120-21

steel back, 113

straw-colored, 138-39

striped mud, 289-91

toothed, 312

top, 307

Minny bass, 487

Minytrema, 107-9

melanops, 108-9

Mirror earp, 167

Mishcuppauog, 559

Mississippi cat, 82
Mitchill's perch, 525

Mixed tomcod, 696

Mojarra de Ley, 566-67

Mojarras, 565-67

Mola, 629-31

mola, 629-31

rotunda, 630

Molacanthus, 629

Molidae, 629-31

Moll, 598

Molva maculosa, 701

Monacanthidae, 611-15

Monacanthus, 611-13

aurantiacus, 613

broccus, 612

hispidus, 611-13

massachusettensis, 612

setifer, 612

Mongrel whitefish, 238-41

Monk, 46

Monkfish, 45-46, 735

Mooneye, 183-86

northern, 185-86

Mooneye cisco, 235-37

Moonfish, 433-34, 435-36, 602-t

Morone, 527-31

americana, 528-31

flavescens, 500

maculata, 483

pallida, 528

rufa, 528

Morrhua aeglefinus, 699

americana, 698

amevicanus, 698

pruinosa, 695

Morse lake minnow, 161-62

Moss bass, 491

Mossbunker, 211-13

Motella argentata, 708

caudacuta, 710

ensis, 709

Mother-of-eels, 702

Mountain trout, 4SS

Mousefish, 736-37

smooth, 736

Moxostoma, 109-12

anisurum, 109-10

aureolum, 110-12

crassilabre, 112

macrolepidotum, 111

oblongum, 106 
IIud eat, s2

Ind ereeper; 6.5-5s

IInd dace, 2SS

sruel eel, 15

Mud lampres, 16

Ifud minnow, 287-91

striped, 259-91

Ind shad, 1Ss

Mud sucker, $10 t$

Ind sunfish, 46t-66

Mudish, $74-76,810$

Mrufle-jaws, 636

Il ugil, 9, 362-6S

albula, 363

brasiliensis, 366, 36 t

cejlialus, 36:-66;

curema, s66-67

giqas, ist

slunniens, 587

lineatus, 363

obliquus, 581

jetrosus, 366

trichodon, 9, 366, :367-6s

Intrilidae, 362-6S

Mullet, 106. 111, 362-68

Wlack, ise

fantalil, 367-6s

enclen, 111

immping, 364

litlie. 111

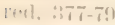

stripert, :ans-6f;

:mmumer, 36-

Whirligig, 307-68

white. :36; 3 -fi

Mullidan, s77-7!+

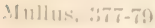

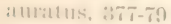

bathatus amatus, :37t

Mnmminelong, :309-11

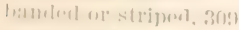

-pring, :312

Mmmmy, :310

lurtoy, : :16;

Muraun bostoniensis. 17̈1)

conserer, $16-5$

rustrat:1, 17)

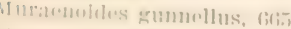

Wuseahouger, : :

1111-1:a1lum:41, :06?

\section{Muskellunge, 303}

IIustelus, 22-23

canis, 23

Muttonfish, 674-75

Mrliobatide, 57-60

Myliobatis, 57-58

acuta, 58

freminvillei, $5 \mathrm{~S}$

? say, 55

Mroxocephalus, 639-44

aeneus, 639-41

groenlandicus, 642-44

octodecimspinosus, $641-42$

Myxostoma anisura, 109

Myxus harengus, 365

Naked goby, 656-58

Namaycush, 266

Narcobatidae, 51-52

Nauclerus, 412

Naucrates, 412-14

ductor, 412-14

indicus, 412

noveboracensis, 412

Needle-fishes, 317-23

Nematognathi, 76-97

Neoliparis, 652-53

atlanticus, 652-53

montagui,. 652

Neomaenis; 547-55

aуa, 551

blackfordi, $9,550-55$

griseus, 548-50

Nerfling, gold, 131

New York gudgeon, 309

New York pollack, 694

New York shadine, 190-91.

Newligut, 460

Niagara gudgeon, 152-54

Nigger chub, 160, 162-6t

Nipper, 593-96

Nocomis, 159-60

Northern barracuda, 371-73

Northern chub sucker, 106

Northern mooneye, 1S5̄-S6

Vinthern pickerel, great, 299

Northeru sucker, 99, 100

Norwity haddock, 631-33

Notemigonus, 132-34

"hrysoleuens, 132

lucillus, 151 
Notropis, $135-52$

amarus, 141,142

amoenus, $150-51$

anogenus, 136

atherinoides, 147-49

bifrenatus, 135-36

blennius, 138-39

cayuga, 136-37

cornutus, $145-47$

frontalis, 147

dilectus, 149

dinemus, 149

heterodon, 137-38

liudsonius, 140-42, 143

amarus, 142-43

lythrurus, 151

megalops, 145

frontalis, 147

photogenis, 151

procne, 139-40

l'ubrifrons, 149-50

umbratilis 1ythrurus, 151-52

whipplei, 144

ivhipplii, 143-45

Noturus, 91-92

flavus. 91-92

gyrinus, 93

insignis, 95

lemniscatus, 95

marginatus, 96

miurus, 96

Numbfish, 51-ร2

Oblong flounder, 721

Oceanic bonito, $386-88$

Oceanic sucker, 689

Odontaspis americanus, 34

Ogcocephalidae, 737-38

Ogcocephalus, 737-38

respertilio, 738

Ohio golden shad, 192

Ohio river sturgeon, 66

Okow, 495

Oldwife, 582

Oligocephalus, 517-18

Oligoplites, 410-12

occidentalis, 410

saurus, 410-12

Oncocottus, 64t, 645
Oncorhynchus, 241-44

chouicha, 242

orientalis, 242

quinnat, 241

tschawy tscha, 2 $41-44$

Oneida súcker, 111

Onos cimbrius, 710

ensis, 709

reinhardti, $70 \mathrm{~s}$

rufus, 709

Ophidiidae, 675-76

Ophidioidei, 674-75

Ophidium barbatum, 676

marginatum, 675

mucronatum, 665

Ophioscion, 576, 578, 583

Opisthonema, 209-11

oglina, 209

oglinum, 209-11

Opsanus, 660-62

tau, 661-62

Orange filefish, 613-15

Orcynus alliteratus, 389

pelamys, 386

thynnus, 391

Orfe, 131

Orthagoriscus analis, 630 mola, 630

Orthopristis, 555-57

chrysopterus, 556-57

duplex, 556

Osmerus, 282-\$5

mordax, 282-85

viridescens, 282

Ostariophysi, 76-738

Ostraciidae, 615-17

Ostracion, 615

trigonus, 616

yalei, 616

Ostracium trigonum, 616

trigonus, 616

Ostracodermi, 615-17

Oswego bass, 491, 492

Otolithus, 569

carolinensis, 573

nebulosus, 573

regalis, 570

Otsego bass, 225

Ouananiche, 249

Orate pompano, 439-41

Oysterfish, 598, 656-58, 661-(i2 
Paddlefishes, 60-63

Pagrus argyrops, 558

Painted tail, 487

I'ale sucker, 101

Palinurichthss, 45t-55 . perciformis, 454-55

Palinurus pereiformis, 454

Pammelas perciformis, 455

Panhagen, 212

Pappytish, 456-57

I'aralichthys, 717-22

dentatus, $717-20$

lethostigma, 720

lethostigmus, $720-21$

oblongus, $721-22$

ophryas, 718

Paratractus, 430-31

pisquetus, 430

Parche, 60t-6

Parr. 245

Pastinaca hastata, 53,54 maelura, 56

Pearl minnow, 130-31

Pearl roach, 134

Pediculate fishes, $733-3 \mathrm{~S}$

Pediculati, 733-3S

I'egedictis, 635-37

ictalops, 635

['eixe carago, 18-22

L'elamys sarda, 398

P'erea, 500-1

acuta, 500

americana, 500, 528

atruria, 5:30;

chrysops, 522

chrysoptera, 506

flavescens, 500-1

fluviatilis, 500

gibbosa, 483

sraeilis, 500

stranulata. 500

matrinat, fi: 1

mitchilli, 52:4

alternata, 52-4

interrupta, ieg

oceellata, sits

*nltitrix, f45

sehremedili, soo

sectatrix, stis

seputemtrionalis, 5.2-1
Perca (continued)

serrato-granulata, 500

undulata, 583

varia, 536, 537

vitrea, 493

Percesoces, 354-73

Perch, 488, 493-521, 529, 595

black, $488,529,537$

blue, 595

bridge, 460,487

chinquapin, 460, 463

goggle-eye, 463

$\log , 505-6$

Mitchill's, 525

pike, 493-97

pirate, $352-54$

red, 529

red-eyed, 468

red sea, 633

ring, 500-4

river, 529

sand, 463

sea, 595

silver, 463, 576-78

speckled, 460

strawberry, 460,463

striped, 502

tin, 460

trout, 351-52, 488

white, 528-31, 590-92

yellow, 6, 488, 500-4, 529

Perch pike, 494

Perchlike fishes, 459-599

Percidae, 493-521

Percina, 504-6

caprodes, 505-6

var. manitou, 506

zebra, 506-7

manitou, 506

Percoidea, 459-599

Percopsidae, 351-52

Percopsis, 351-52

guttatus, 351-52

hammondi, 351

Petromyzon, 11-14

americanus, 11

appendix, 11

coneolor, 14

marinus, 1i-13

subsp. dorsatus, 13 
Petromyzon (continucd)

unicolor, 13-14

nigrum, 16

Petromyzontidae, 11-17

Pharyngognathi, 593-601

P'holis, 665-66

gunuellus, $665-66$

subbifurcatus, 667

Photogenis spilopterus, 143

Phoxinus, 114, 130-31

elongatus, 128

margaritus, 130

Pluycis chuss, 707

filamentosus, 707

punctatus, 705

regalis, 704

regius, 704

tenuis, 706

Picarel, 495

Pickerel, 5, 298-301, 495, 498, 505

banded, 292-94

chain, $6,296-9 \mathrm{~s}$

eastern, 297

great, nolthern, 299

little, $294-96,505$

trout, 295

Pickering, 495

Pigfish, 556-57, 642

Pigmy sculpin, 639-41

Pike, 291-307, 493-97

blue, $303,494,497$

bony, 71

bony-scaled, 6

common, 298-301

federation, 297

gar, $70-72$

grass, 300,494

giay, 498, 499

great, 303

green, 296-98, 491, 498

lake, 300

long-jawed fresh-water, $31 \mathrm{~S}$

rock, 499

sand, $498-99$

sea, 318

wall-ezed, 493-97

yellow, 494

Pike perch, 493-97

Pikelike fishes, 287-317
Pileoma semifasciatum, $50 \overline{5}$

zebra, 506

Pilot, banded, 415

black, 45t-55

shark's, 416

Pilot-fish, 221, 412-14

Pilot sucker, 687-88

Pimelepterus boscii, 568

Pimelodus atrarius, 85

catus, 87

cupreus, 84

Havus, 91

insigne, 95

lemniscatus, 96

livrée, 96

marmoratus, 89

natalis, $8 \pm$

nebulosus, 87

nigricans, 81

pullus, 90

rulgaris, 84

Pimephales, 118-21

notatus, 120-21

promelas, 118-19

Pinfish. 562

Pipefish, 347-49

common, 347-49

spotted, 346

Pirate perches, 352-54

Pisces, 17-738

Plaice, 724

Platessa dentata, 716

ferruginea, 726

oblonga, 717,720

ocellaris. 717

plana, 727

pusilla, $72 S$

quadrocellata, 721

rostrata, 726

Platophrys, 730-31

nebularis, 730

ocellatus, 730-31

Plectognathi, 608-733

Plectospondyli, 97-169

Pleuronectes, 727

americanus, 727

aquosus, 723

dentatus, 717

ferrugineus, 726

hippoglossus, 714 
Prickly skate, $47-4 \mathrm{~s}$

Pridle, 16-17

Prionace, 24-25

slauca, 25

Prionodon glaucus, see Carcharias (Prionodon) slaucus

milberti, sce Carcharias (I'rionodon) milberti

obscurus, sce Carcharias (Priono(Ion) obseurus

Prionotus, 676-S2

earolinus, 677-7S

evolans, 679

var. lineatus, 679

lineatus, 679

palmipes, 677

strigatus, 679-81

tribulus, 681-\$2

Pristipoma faseiatum, 556

fulvomaculatum, 5อ 6

Promicropterus, $5+1-42$

Psetta, 728

Pseudopleuronectes, $726,72 \tau-29$

americanus, $727-29$

Pseudopriacanthus, 545-47

altus, 546-47

Psendorhombus dentatus. 71 -

oblongus, 721

ocellaris, 717

Pseudotriakidae, 17-22

Pseudotriakis, 17-22

microdon, 18-22

Pterophryne, 735-37

histrio, 736-37

Pteroplatea, 56-57

maclura, 56-57

Ptyonotus thompsonii, 614

Puckermouth, 719

Puffers, 617-24

smooth, 618-19

Pug-nosed shiner, 434

Pumpkin seed, 458, 483-86

Pygosteus, 337-40

pungitius, 338-40

sinensis, 338

Querimana, 9, 365

gyrans, 9, 366, 368

liarengus, 366

Quinnat salmon, 241-4t
Rabbitfish, (18-19

Rachycentrilae, 448-50

Iachycentron, 448-50

canadus. $449-50$

Iadiated shanny, 667-6S

Iaia eglanteria, 49

laeris, 50

ocellata. is

Iainbow darter, 517-1S

Iainbow trout, 261-63

Rainwater fish, 314-15

Raja, 46-51

bonasus, 59

centroura, 53

diaphanes, 49

eglanteria, 47, 49-50

erinacen, $47-48$

erinaceus, 47

laevis, 50-51

maclura, 56

ocellata, 4S-49

say, 55

torpedo, 51

Rajidae, 46-51

Rakehead, 32

Ray, 46-60

brier, 49-50

butterfly, 56-57

common sting, 53-54

cow-nosed, 59-60

eagle, 57-60

electric, 51-52

hedgehog, 47-48

southern sting, 55-56

spotted, 48

sting, 53-57

whip, 55

whip sting, 55

whip-tailed, 53̈-59

Razor back, 463

Red-bellied dace, 114-16

Red-bellied minnow, 115

Red drum, 578-80, 589

Red-eyed perch, 468

Red gurnard, 652-83

Red horse, 110-12

golden, 111

Red mullet, 37\%-79

Red perch, 529

Red sea perch, 638 
Refl-sided shiner, 125-29

[iml-sinterl sucker, 100

[im] smapper, 9. 5.50-55

lied sturgeon, 6it

Iierltail, 160

Ixillimoat trout, 250-52

IRed trout, 20\%

lierl-winged sea robin, 67s, 679-81

Rienleye, $467-70,475-77$

Reslfin, 145-47, 151-5:2

Iiedish, (3ist-3.

Iiemora, tisti-90

inachyptera, 659-90

Inclian, 6si

facobaea. 685

remora, (iSS-S:)

white-tailed, (ist

I:(noropsis brachyptera, 689 lwachypterus, 689

lieniceps tiburo, :30

IRecutiem sharks, 2-2-80

dihemopteri, : :3:3-in

liheoeryntil copelandi, 509

lahina squatina, tis

lihinichthys, 15iz-ot;

atronasus, 154-at;

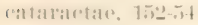

marmoralus, 152

mastutus, 15i2

()

Ithinonemus eimbrius. 710

Ithimoptura, is-60)

bumalsus, s!l-(6)

unu:ulrilulı:, i!!

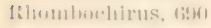

ustrex hir, (itm)

lihemblosanoirleat, (i:!-7::

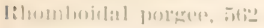

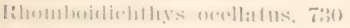

lilumblus, tain

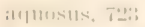

lonsipinnis, ton:

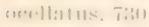

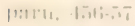

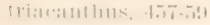

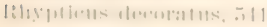

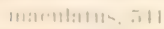

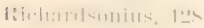

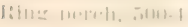

Lissola, 675- 76

marginata, 675-76

River alewife, 192

River bass, 491

River chub, 159-60

River herring, 199

River perch, 529

Roach, 6, 132-34, 582

Irish, 134

pearl, 134

Robin, flying, 684-85

Roceus, 522-27

americauns, 528

chrysops, 522-23

comes, 570

lineatus, 52t-27

striatus, 524

Rock, 525

Roek bass, 467-70, 537

Rock cod, 6999

Rock eels, 665- 71

Iiock pike, 499

Riock sturgeon, 66

liock toadish, 646

Rockfish, 155, 505, 524-27, 631-35

Iiockling, 709-10

four-bearded, 710-11

silvery, 70S-9

lioncador, 590

Rosefish, fi31-33

Rostrated dory, 436

Rosy-faced minnow, 149-50

Ross minnow, 147-49

liough (lab), 716-17

liough-head, 1t6

lioumh silversides, :39-61

found herring, 8, 189-91

Rounct pompano, 439- $\$ 1$

liomel robin, 4:21-22

liomed whitefish, 2201-204

Roumber sucker, 106

lioundtisls, 22:1, 22:20

limblertish, 4.5-5.5, 4.5, 567-69

batncled, 41t-16, +28-29)

limuliy bass, 5ege

kimuly sturgeom, dit;

Rimner, +11!-200, Jis

limsiy (lab), 7:-7

liusty Hattish, 7:27

liusty flomuder. 717 
Rutilus anomalus, 113 storerianus, 158

Rypticus, 540-42

bistrispinus, $541-42$

Sac-a-lait, 460,463

Saibling, 275-78

Sailfishes, $403-7$

Sailor's choice, 561-62

Salar ausonii, 254

Salmo, 244-66, 257-59

adirondacus, 266 alpinus, $275,27 \mathrm{~s}$

amethystinus, 266

amethystus, 260

ascanii, 275

canadensis, 272

clarkii henshawi, 250

clupeaformis, 224

colii, 276

confinis, 266

erythrogaster, 272

fario, 254-57

ausonii, 254

foetens, 286

fontinalis, 272

gairdneri, 252-54

gaildnerii, 252

gloverii, 248

grayi, 276

(Coregonus) harengus, 233

henshawi, 250-52

hoodii. 266

immaculatus, 272

iridens, 261-63

shasta, 261

killinensis, 276

(Coregonus) labratloricus, 224

lemanus, 263-66;

levenensis, 259

mykiss, 250

henshawi, 250

namayeush, 266

pallidus, 266

perisii, 276

purpuratus, 252

var: henshawi, 250

(Coregonus) quadrilateralis, 221

quinnat, $2+1$

rivalis, 276
Salmo (continuca)

salax, 2t4-48

sebago, 245-50

var. sebago, 248

salmarinus, 275

salvelinus, 275

sebago, 248

siscowet, 266

trutta, 268

levenensis, 259-61

tshawytscha, 241

(Coregonus) tullibee, 238

umbla, 275

willughbii, 276

Salmon, 61-62, 219-82

Atlantic, 2t4-4s

black. $26 \pi$

chinook, 241-44

dwarf, 246

fresh-water, 246

jack. 495

king, 241-14

landlocked, 246, 248-50

Quinnat, 2 $41-14$

Susquehanna, 494

white, 495, 497

Salmon killer, $3 \pm 1$

Salmon shark, 40

Salmon trout, 180, 252-54, 266-71

Salmonidae, 219-82

Salmoperea pellucida, 351

Salmopercae, 351-52

Salt water bream, 562

Salt-water chub, 59S

Salt-water jack, 446

Salt-water mimuow, 310

SaIt-water trout, 571

Salvelinus, 271-82

alpinus, 275-7S

aureolus, $278-82$

aureolus, 278

foutiualis, 272-75

namayeush, 266

Saud dab, 717, 726-27

Saud eel, 376-77

Saud flounder, 724. 730-31

Sand lances, 375-7\%

samd perch, $46: 3$

Samd pike, 2ST, 498-99

Sand porgee, 55s-61, 58\% 
Sind rollers, 351-62

sanul sliark, $3 \pm-37$

s:mml smelt, 359

sancl sucker, 108-9

sinrenra, $46-52$

sarila, $393-95$

mediterranea, 393

pelam 1 s. 393

sarclat, 393-9j

sardine, scaled, 209

sardinella, 208-9

$s p, 209$

Sargus ambassis, $55 \mathrm{~S}$

arenosus, $55 \mathrm{~s}$

oris, $50 ?$

rhomboiles, 561

sarothrodus maculocinctus, 605

Satin striped herring, 215

Sauger, 49S-99

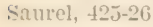

Sauries, 327-29

Saurus foetens, 256

mexicanus, 286

Sawbelly, 200

Scabbard fish, 402-3

Seat, 421-2.2, 425

big-eyed, 426-27

dotted, 422

mackerel, 423-24

Scale carp, 167

sialed sardine, 209

Scoaly fins, 601-S

Si-hillheorles, 92-97

syrinus, 93-94

insienis, 95-96

nimutus, ! $60-97$

Sielworlic trout, $24 t^{\circ}$

sehurlkill eat, s6

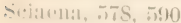

aipureules, ento

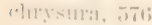

imlueluis, its

limeatal, it.

molumlosil, 54.

1hlimpla, तs

11:1:a, , तis

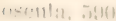

mometatal, ant:

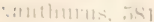

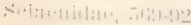

Sciaenops, 578-S0, ј83

ocellatus, 57S-S0

Sciena fusca, jss

gigas, 585

Sclerodermi, Gos-15

Scoliodion, 29-30

scoliodon terrae novae, 29-30

Scolopsis sayamus, 353

Scomber, 379-\$3

alleteratus, 388

chrysurus, 437

colias, 381-83

crumenophthalmus, $t^{2} 6$

crysos, 430

dekayi, 382

ductor, 412

grex, 382

iilppos, 421, 425

maculatus, 396

pelamis, 386

plumbens, 445

plumieri, 426

pneumatophorus, 382

regalis. 398

sarda, 393

saurus, 410

scomber, 380

scombrus, $379-81$

thazard, 384

thymmus, 391

trachurus, 425

rermalis, 380

zonatus, $41 \pm$

Scomberesocidae, 327-29

Scomberesox, 32 $7-29$

equirostrum, 327

saurus, 327-29

scutellatum, $32 \pi$

storeri, $32 \mathrm{~S}$

Scomberomorus, 39ॅ-401

cavalla, 400-1

maculatus, 396-9S

regalis, $395-400$

Scombridae, 379-401

Scombroidei, 379-459

Scombroides occidentalis, 410

Scorpaena americana, 646

(lactyloptera, 634

flava, 6.46

рuтрurea, $6-16$

rufa, 6.46 
Scorpaenidae, 631-35

Scorpoeni, yellow, $6+6$

Sculpin, 635- 47

brass $y, 639$

daddy, 6t2-4t

deep water, $6+6$

1S-spined, $6+1-12$

lake, $614-45$

pigmy, 639- +1

sèa, 616

Scup, 555-61

Scuppaug, 5.9

Scuteeg, 571

Sea basses, 522-42, 536-39

striped, 525

Sea catfish, $77-7 \mathrm{~S}, 7 \mathrm{~S}-79$

Sea deril, 735

Sea eel, 175-77

Səa herring, 192-94

Sea horse, 349-51

Sea lamprey, great, 11-13

Sea mink, 5S5̃-87

Sea owl, 651

Sea perch, 595

red, 633

Sear pike, 318

Sea poacher, 648-49

Sea raven, $646-47$

Sea robin, $642,677-78,680$

big-headed, 6S1-S2

red-winged, 67s, 679-S1

Sen sculpin, $6 \pm 6$

Ser snails, 652-56

striped, 651-56

S 2 suipe, 318

Sea swallow, 685

Sea toad, $6+2$

Sea trout, 571, 573-7t

Sea molf, 673

Seatreed bleuny, 663-6t

Sebago trout, 246

Sebastes, 631-33

dactylopterus, 634

marinus, 631-33

norvegicus, 632

norwegicus, 631

Sebastinae, 631-35

Sebastoplus dactylopterus, 634

Seering, 150

Selachii. 17-60
Selachostomi, 60-63

selachus maximus, 42

Siclene, 434-36

argentea, 435

gallus, 435

setipinnis, 433

vomer, $435-36$

Semotilus, 121-26

atromaculatus, $123-26$

liguttatus, 159

i)ullaris. 122-23

corporalis, 122, 124

Seran imperial, 634-35

scrgeant fishes, 448-50

Seriola, $414-18$

bipinnulata, 419

cosmopolita, 437

gigas, 416

lalandi. $416-1 \mathrm{~S}$

pinnulata, 419

zonata, $414-16$

Seriolichthss bipiunulatus, 419

Berranidae. 522-42

s'errauus atiarius. 536

brasiliensis, 539

flariventris, 539

margaritifer, 5:33

nigrescens, 536

niveatus. 5.93

shad, 192. 204-S, 460

Cayuga lake, 200

fall, 197

gizzard, 186-88

gold, 195-96

hickory, 9, 1S8, 197-9S

little, 200

mud, 185

Ohio golden, 192

stink, 188

tailor, $19 \mathrm{~S}$

white, 205

white-eyed, $18 \mathrm{~s}$

winter, $18 \mathrm{~S}$

Sllad bait, 194

shad herring, 197-9S, 203, 209-11

Shad trout, 571

Shad-maiter, 221, 224-30

shadine, 190-91

Shanny, radiated, 667-68

Shark ray, 46 
Sharks, 17-1i0

:111:0l, 4.i-t4i

basking, +1-4:3

h114, :3!

binme. $4: 4$

tom, :-2:;

dusky, 21-206

elephant, $42-43$

ereat blue, :-i

sreat white, $4(0)-41$

erreen-hatched, 30

eroumel, :3.)

lammerheaded, 30-32

leopard, -4

little bullhearl. 46

mackerel. : : $:-11$

Milloert's, 20ti-2ys

reguiem, 2:-30

salnom, f11

sind, $34-37$

sharp-nosed, 29-30

shovelhead, :30-31

shovelnose, 32

small blue, :-7

swingle-tail, :3is-ist

thresher, :32-34

tiger. 24

Shark's pilot, 416

Shatksucliex, 6S6-87

shatr-nosed shark, 29-30

sterepshead, 45s, 5ti3-4i.5, 591

thrm-tailed, $60 \%$

youmg, 5ष!

Sherpsheal chatedodon, tol:3

slowespeat killitish, :317

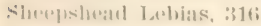

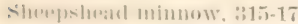

Shimer, 1:3!10, 145-17, 160, 335-37, $2+1,3,3,510$

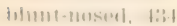

aryptoms laroum, 458

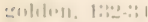

lakir. 2:3t;

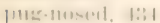

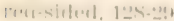

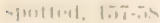

Shenemaliel: 101

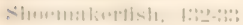

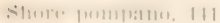

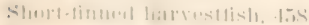

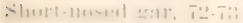

Short-nosed sturgeon, 68-69

Shovel fish, 61

Shovelhead shark, 30-31

Shovelnose shark, 32

Sierra, 400-1

Siluridae, $76-97$

Silurus catius, 85-87

felis, 78

ayrinus, 9:3

niarinus, $7 i$

melas, 90

punctatus, 80

Silver bass, $185,462,523$

silver cat, 80

silver chub, 1:22-2:

Silver gar, 317-19

Silver hake, 691-93

Silver Jenny, 566-67

Silver king, $177-79$

Silver lampley, 1t-15

Silver perch, 463 , 576-7s

Silver trout, 278-52

Silverfin, 143-45

Silvertish, 165

silversides, $35+62$

brook, 361-62

fresh-water, 356-57

rough, :359-61

slender, :35-56

small, sis

Silvery anchory, 216-17

Silvery mimow, 116-1s

Silvery pompano, $4+1-43$

Silvery rockling, 70s-9

siphostoma, $347-49$

fusemm, $347-49$

peckianmm, 347

skate, $17,46-51,49$

barmdoor. .0--̌1

big. 48-49

bonnet, ts

clear-nosed, 49-50

common, 47-48

mickily, ti-ts

spotted, 48-4!)

stummer. 45

winter, +19

skip malckerel. $t 46$

skipjakel, 19!2, 195-96, 361-62, t.is

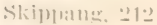


Skipper, 327-29

Slender halfbeak, 326-27

Slender silversides, 355-56

Slippery Dick, 675-76

Smelt, 140-42, 143, 282-8j

sand, 359

Smelt of New York lakes. 230-8:?

Smolt. 245

Smooth browed bullhead. 640

Smooth dogfish, 2:3

Smooth mousefish: 736

Smooth putfer, 6is-19

Snake blenuy, 671

Snakefish, 287, 670-71

Suap mackerel, 445-4S

Snapper, 445-48, 547-5), (633

blue, 446

gray, 5 $48-50$

mangrove, 545-50

red, 9, 550-55

Snapping mackerel, 446

Snipe, sea, 318

Snowy grouper, 533-85

Soaptish, 5 $+1-12$

Soft gar, 318

Soft sucker, 108

Soldier fish, 518

Soleitiae. 731-33

Soles, 731-33

American, 732-83

calico, 732

Southern flommer. 720-21

Spadefishes, 601-4

Spanish mackerel, 396-9s

Sparidae, 5ร7-65

Sparus argyrops, 5.5

anreus, 483

chrysops, $55 \mathrm{~s}$

oris, 563

probatocephalus, 563

rhomboidles, 5 61

Spawn-eater, $140-12$

Speartish, 28т, 405- 7

Spearfish sucker, 690

Spearing, 359

Speckled perch, 460

Speckled trout, 273

Sperling, 194, 359

Sphatroides trichocephalus, $6: 24$
Spheroides, 619-24

maculatus, 62022

nephelus, 624

pachygaster, 624

testudineus, 622-24

triclsocephalus, 624

Sphyxaena, 368-78

acus, 322

borealis, 371-73

guachancho, 369-70

guaguanche, 369

quaguancho, :369

wiintheri, 369

spet, 371

Sphrraenidae, 365-73

siphyrna, 30-32

tiburo, $30-31$

zyqaena, 31-32

sphyrnidae, 30-32

spiketish, 40t-5

spinax acanthias. 48

spined dogfish, 43-45

syinous dory, 439

spinons trachinote, 441

spiny boxtish, 626-28

Spins-layed fishes, 351-608

spoon-billed sturgeon, 61

Spoonbill, 61

spoonbill cat, 61-63

Spot. 580-83

Spot-striped balloon fish, 625

Spotted bass, 487. 580

spotted bergall, 596

Spotted blenny, 6is-69

spotted caranx, 422

spotted eat, 80-s1

spotted cero, 400

Spotted codling. $704-5$

spotted flommder, 7:31

Spotted grouper, 53:3-35

spotted hake, 704-5

Spotted maskalonge, 302-4

Spotted minnow, 120-21

Spotted pipefish, 346

Spotted ray, ts

Spotted shimer, 157-5s

spotted skate, 48-49)

spotted stargazer, 6.5-60

spotted sucker, 10s-9

spotted turbot, 724 
Stromateus alepidotus, 456

cryptosus, 458

gardenii, 456

longipinnis, 456

partu, 456

triacanthus, $45 \pi$

Sturgeon, (63-69

bon $y, 66$

common, 63-65

lake, $66-67$

Ohio river, 66

red, 66

rock, 66

ruddy, 66

short-nosed, 68-69

spoon-billed, 61

Suckers, 97-112

banded, 104

black, 104

black-nosed, 108

brook, 101

chub, 105-

common, 101-3

golden, 111

gray, 101

log, 103-4

large-sealed, 104

long-nosed, 99-101

mud, 104

northern, 99, 100

oceanic, 689

Oneida, 111

pale, 101

pilot, 687-ss

red-sided, 100

rounded, 106

sand, 108-9

soft, $10 \mathrm{~s}$

spearfish, 690

spotted, 108-9

striped, 108-9

sweet, 106

strordfish, 689-90

white, 101

white-nosed, 109-10

Sucking fish, 686-S 7

Sucking toad, 621

Summer flounder, $717-20$

Summer herring, 203

Summer mullet, $36 \tau$
Summer skate, 45

Sun trout, 571

Sumapee trout, 278-82

Sunfish, 434, 459-93, 483-S6, 615. 629 banded, $471-73$

bass, 466

blue, 480 - 52

blue-spotted, $473-75,475$

green, $475-77$

long-eared, $47 \mathrm{~s}$

mud, $46 t-66$

Sunny, 48t

Surgeous, 606-7

Surmullets, 377-79

Susquehanna salmon, 494

Sireet sucker, 106

Swellfish, 620-22

Swelltoad, 621

Swingle-tail shark, 33-3̈t

Swiss Lake trout, 263-66

Swortfish sucker, 6S9-90

Swordfishes, $71,407-9$

Synentognathi, 317-35

Syngnathidae, $3 \pm 7-49$

Syuguathinae, $347-49$

Syngnathus fasciatus, 347 fuscus, $3+7$

hippocampus, 350

peckianus, $3 \pm 7$

viridescens, $3 \pm 7$

Srnodontidae, 285-87

Synodus, 285-ST

foetens, $286-87$

Tadpole stonecat, 93

Tahoe trout, 250-52

Tailor, 446

Tailor shad, 198

Tambor, 62t

Tang, 607

Tarpon atlanticus, 17 $7-79$

Tarpons, 177-S0

Tarpum, 177-79

Tautog, 597-99

Tautoga, 596-99

americana, 597

cacrulea, 593

niger, 597

onitis, $597-99$ 


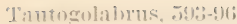

atlopersus, 59:3-96;

"ivetustondyli, 45-46

Telemster. T(j-T:3S

Toleostomi, (it)-7t;

Temmodon siltator. His

Tenth, 12:i-2-i

T'essellated darter, $71 \mathrm{t}-16$

Tetraoton latevigatus, (is

tureiclus, $($ ize

'Totratodontidae, 617--24

Tetrapturus, 40.ร-т

allihlus, 406

belone 405

imperator, 40.-7

Tequelon eurvus, $61 \mathrm{~s}$

hisplulus ear. maculatus, 620

lavigatus, 618

mathematicus. 61S

mola, 629?

watudineus, fi2s

1riehocephalus, 624

turemidus, 620

T'uronarce, 51-52

necidentalis, 51-52

J'enthislidac, 606-7

l'enthis, (6006-7

lie.patus. 607

'Thimble-eye mackerel, : BS1-8.

'Thom batek, ses?, s-t:?

Thom-luaclied grunt, $4+4$

Thareat herriner, 1S5, 200-11

'Tlumatlins, :378-7.

'T'huratilish, 210, 4:32-83

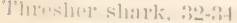

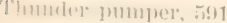

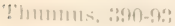

1!y่muns, :391-9?

Thyomms atlonis. : :s!)

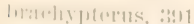

homsilinnsis, ans

morilumuis, ass

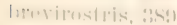

|m-1:mmys, :ast;

andmulielursalis :3!1

ilumunina, :as

Maleatris, :391

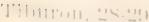

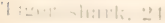

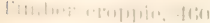

'Tin mouth, 463

Tin pereh, 460

'Tinca, 126-27

tinca. 126-27

rulgaris, 126

'Toun, 59s

sucking. 621

'Toudfish, 621, 660-62 rock. (it6

Tobaceo box, $48 \pm$

Togue, 267

Tomeod. 586. 645-97

brown, 696

mixed, 696

yellow, 696

rellowish white, 696

Toothed Hatfish, 719

Toothed herring, 184-85

'Toothed minuow, 312

'Toy mimnows, 307

Topsail, gaff, $7 \pi-78$

Torpedo, 51-52

occidentalis, 51

'Tor'sl, 699

Trachimoidei, 65S-62

Trachinote, spinous, 441

Trachinotus, 435-14

argentens, 441-43

carolimus, $44: 3-14$

("ip)reus, 441

falcatus, $439-11$

fuscus, 439

1):1mpanus. $44: 3$

rlomboicles, 439

spinosus, 43!)

Trachurojes, $426-27$

crumenophthalmus, 426-27

1'rachums. 424-26

salurus, $4 \cdot 2 \cdot 5$

11:aclnurus, 425-26

Trichynotus, $4: 39$

(arolinits. $4+3$

ovatus, t:3!

pampanus, 445

rlomboides, fing

'Trichiclion octotilis, 37?

ortonemus, :373

Trielinuiclite, tom-3

Trichimus, 40 -3:3

artwentens, 402

lepturus, 402-? 
Trichocyclus erinaceus, 625

Trichodiodon, 624-26 pilosus, 625-26

Trichopterus, 428-29

Trigger fishes, 608-11 blue-striped, 610-11

Trigla, 677, 682 carolina, 677 cuculus, 682-83 evolans, 679 lineata, $6 \pi 9$ palmipes, 677 strigata, 679 tribulus, 681 rolitans, 684 'Triglidae, 676-83 Triglopsis, $644-45$ stimpsoni, 644 thompsoni, 6t4-45

Triple-tails, 542-43, 602-4

Trota, 255

'Trout, 48S, 491, 571

aleby, 702

brook, 6, 255, 272-75

brown, 254-57, 48S

Gairdner's, 252-54

solden, 278-82

gray, 267, 571

hรbrid, 5, 25т-59

lake, 266-71

Lake Tahoe, 250-52

Loch Leven, 259-61

mountain, $48 \mathrm{~S}$

rainbow, 261-63

red. $26 \%$

red-throat, 2อั0-ร2

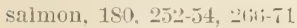

salt-water, 571

Schoodic, 246

sea, 571, 573- โ4

Sebago, 246

shad, 571

silver, $278-82$

speckled, 273

steelhead, 252-54

sun, 571

Sunapee, 278-82

Swiss Lake, 263-66

white, 488

Trout perches, 351-52, 4S8
'I'rout pickerel, 295

Trout pike, 287

'True fishes. 60-70

'T'uite. 255

Trumpet fish, $345-46$

Trumkishes, 615-17

Trutta. 244

Trygon hastata, 50-54

sayi, 55

Tuftgills, 347-51

T'uladi. 267

'T'ullibee, 2:38-41

T'unny, 391-93

little. $388-90$

'Turbot, 608-10

spotted, 724

Turbot flounder, 719

Tylosurus, $317-23$

acus, $322-28$

crassus, 319

gladius, 319

longirostris, 317

marinus, :317-19

raphidoma, 319-21

Ulcina, 6 $48-49$

Ulvaria. 667-6S

subbifureata, 667-6S

Umbra, 287-91

limi, 285-89

1) xma 259

prgmaea. 289-91

[mbriclae. $287-91$

Umbrina, 5\$5

alloumus, 585

nebulosa, 585

Unspotted balloonfish, 628-29

Unspotted maskalonge, 304-

Epsilonphorus guttatus, tas

Lranislea. 6:37-is

formosa, 635

gracilis, $637-38$

quiescens, 63t

richardsoni, 6:36;

Uramoseopidae, (i.js-tin)

Uranoscopinae, (i. $S$-til)

Urophycis, t04-8

chuss. 707-s

legius, $704-\bar{t}$

temuis. $70.7-7$ 
Variegated solsy, 65\%

Varicuated stone cat, 96-95

Vinnel, f:3:3-:3t

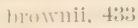

stipinnis, $433-34$

vou IBelix trout, 255

Wall-eyed herring, 199-200

Wall-eyed pike, $49: 5-97$

IV:11nouth, $470-71$

IV:atery flomeler, $72 \pm$

15:alitish. $.70-7:$

s]utted, $\pi 53-7 t$

Wiresick. 1!s

Winslman, t!1

IIliip ray, 5.

Whip sting ray. 5.5

Whip-talled ra!ys, -æ3-59

IVhirligig mullet, 36it-6s

White bass. 520.203

Whitr-lellied killitish, 311

White calt, s0. 8.,-86

I!hite (ropple. 460

W'hitereverl slital. 185

Wlite halie. T(I.)-

Mllite mullet. :366-6it

Mlite-110sed sucker, 109-10

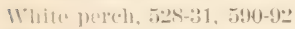

11 hitr salmon, 4!). 497

Mhite sluat, 20.5

Whitu sllatk, ereat, $40-41$

Hhite stroliter. 101

11 hitu-tailect remor"a. (ist

Wlitw trout. AKs

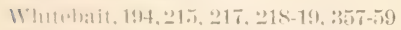

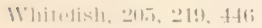

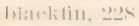

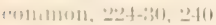

iI $10 y^{2} \times 2,211$

1.athrat(o), !), 2.:-4-:30)

M1:11

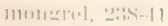

mumml. $201-21$

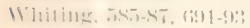

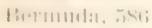

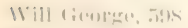

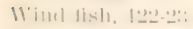

Mimbew lizh!. .."

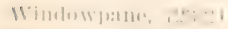

II illatish, 17 is
Winninish, 246

Winter flounder, 727-29

Winter shad, 1SS

Winter skate. 49

Wolf fishes, 672-7t

Wrassefishes, 598-600

Wreckfish, 532-33

Wrymouths, 671-72

Xenarchi, 35ะ-๖t

Xiphias, $407-9$

sladius, 408-9

imperator, 40 s

Niphididae, 665-71

Xiphiidae, $407-9$

Xystophorus, 412

Yellow laacks, os

Yellow bass, 487

Yellow-bellied killifish, 311

Yellow caranx, 429

Yellow cat, $8 \pm$

Yellow fins, 571

Yellow mackerel, 430-31

Yellow perch, 6, 485, 500-4, 529

Yellow pike, 494

Yellow srorpoena, 646

Yellow-tail, :309, 562, 576-7s

Yellowish white tomeod, 696

Zeidae, $600-1$

\%enopsis, 600-1

ocellatus, $600-1$

/heoiclea, 600-s

zeus capillaris, 435

ciliaris, $4: 3: 2$

erinitus, 432

geometricus, 4:35

ocellatus, (jok)

rostratus, $4: 5$

setapimnis. $4: 3: 3$

spinosus. 4:39

vomer, $4: 35$

Zoarees, (it $4-75$

anguillaris, 6itatis

viviparus, 674

\%oarciclate, (6- $4-7$.

\%onichthys gigas. 416

\%ygarena mallens, 31

tiburo, :30 


\section{New York State Museum}

\section{MUSEUM PUBLICATIONS}

Any of the University publications will be sold in lots of 10 or more at $20 \%$ discount. When sale copies are exhausted, the price for the few reserve copies is advanced to that charged by second-hand booksellers to limit their distribution to cases of special need. Such prices are inclosed in brackets.

All publications are in paper corers, unless binding is specified.

Museum annual reports 1847 -date. All in print to 1892,500 a volume, $75 \mathrm{c}$ in cloth; $1892-$ date, $75 \mathrm{c}$, cloth.

These reports are made up of the reports of the director, geologist, paleontologist, lotanist and entomologist, and museum bulletins aud memoirs, issued as adrance sections of the reports.

Geologist's annual reports I88I-date. Rep'ts I, 3-13, I 7-date, O. ;

2, $14-16, Q$.

The aunual reports of the early natural history survey, 1837-41 are out of print.

Reports $1-4,1881-84$ were publisbed only in seprarate form. Of the 5 th report 4 pages were reprinterl in the $39 \mathrm{th}$ museum report, and a supplement to the 6 th report was included in the 40 th musenm report. The 7 th and subsequent reports are included in the 41 st and following museum reports, except that certain lithographic plates ih the 11th report (1891) and 13th (1893) are omitted from the 45 th and 47 th museum reports.

Separate volumes of the following only are available.

$\begin{array}{cccccc}\text { Report } & \text { Price } & \text { Report } & \text { Price } & \text { Report } & \text { Price } \\ 12(1892) & \$ .50 & 16 & \$ 1 & 19 & \$ .40 \\ 14 & . .75 & 17 & .75 & 20 & .50 \\ 15 & 1 & 18 & .75 & & \end{array}$

In 1898 the paleontologic work of the State was malle distinct from the geologic and will hereafter be reported separately.

\section{Paleontologist's annual reports 1899 -date.}

See fourth note under Geologist's annual reports.

Bound also with museum reports of which they form a part. Reports for 1899 and 1900 maty he had for $20 \mathrm{c}$ each. Since 1901 these reports have been issued as bulletins.

\section{Botanist's annual reports I869-date.}

Bound also with musenm reports 21-date of which they form a part; the first botanist's report appeared in the 21 st museum report and is numbered 21 . Reports 21-24, 29, 31-41 were not published separately.

Separate reports $25-28,30,4250$ and 52 (Museum bulletin 25) are out of print. Report 51 may be had for $40 \mathrm{c}$; 53 for $20 \mathrm{c}$ : 54 for $50 \mathrm{c}$; 55 (Museum bulletin 54) for $40 \mathrm{c}$. Begimuing with 1901 these reports will be issued as bulletins.

Descriptious and illustrations of edible, joisonous and unwholesome fungi of New York have been published in volumes 1 and 3 of the 48 th museum report and in volume 1 of the $49 \mathrm{tb}, 51 \mathrm{st}, 52 \mathrm{~d}, 53 \mathrm{~d}, 54 \mathrm{th}$ and $551 \mathrm{~h}$ reports. The descriptions aud illustrations of edible and unwholesome species contaived in the $49 \mathrm{th}$, 51 st aud 52d reports have been revised and rearrauged, and combined with others more recently prepared and constitute Musem memoir 4.

Entomologist's annual reports on the injurious and other insects of the State of New York r882-date.

Reports $3-17$ bound also with museum reports 40-46, 48-55 of which they form a part. Beginning with 1898 these reports bave been issued as bulletins. Reports 3-4 are out of print, other reports $w i t h$ prices are:

$\begin{array}{ccccccr}\text { Report } & \text { Price } & \text { Report } & \text { Price } & \text { Report } & \text { Price } \\ 1 & \$ .50 & 8 & \$ .25 & -13 & \$ .10 \\ 2 & .30 & 9 & .25 & 14(\text { Mus. bul. } 23) & .20 \\ 5 & .25 & 10 & .35 & 15(\text { “ } & 31) & .15 \\ 6 & .15 & 11 & .25 & 16(\text { “ } & 36) & .25 \\ 7 & .20 & 12 & .25 & 17(\text { “ } & 53) & .30\end{array}$

Reports 2, 8-12 may also be obtained bound separately in cloth at 25c in addition to the price given above. 
Museum bulletins is87 iate. (). To atiunci subsribers, \$2 a year or $50 \mathrm{C}$ a year for those of any one division: (1) geology, including in tology, (3) botany, (4) entomology.

13ulletins are also found with the aunual reports of the museum as follows:

\begin{tabular}{|c|c|c|c|c|c|}
\hline Bullutins & Report & Bulletins & Report & Bulletins & Report \\
\hline & 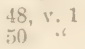 & $\begin{array}{l}20-25 \\
26-31\end{array}$ & $\frac{52}{53}$, v. 1 & $\begin{array}{l}35-36 \\
37-4 t\end{array}$ & $\begin{array}{ll}54, & \text { v. } 2 \\
\text { " } & \text { v. } 3\end{array}$ \\
\hline $18-19$ & 51 "6 & $32-34$ & 51 & $45-18$ & "6 \\
\hline
\end{tabular}

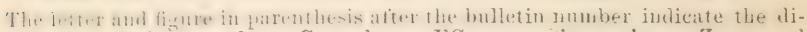
vision and series number. $\mathbf{G}=$ geology, $\mathbf{E G}=$ economic geology, $\mathrm{Z}=$ general

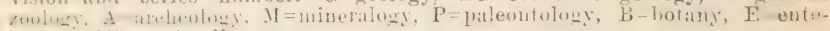
molory, Mise=miscellaneous.

Volume s. 6 nos. \$r.50 incloth

I ï., Mar-hall, W: H. Preliminary List of Nex I ork Lnioniclae. 2op. Mar. I892. 5c.

2 (lii) l'erk, ( $:$ H. Contributions to the Botany of the State of New York. 66p. 2pl. May i 887 . [35c]

3 (EGI) Smock, J: C. Building Stone in the State of New York. i 52 p. Mar. 1888 . Out of print.

4 I. I i Xasun, F. I. Some New York Ninerals and their Localities. 2op. Ipl. Aug. 1888 . 5c.

5 (Er) Lintner, J. A. White Grub of the May Beetle. 32p. il. Nor. I 888 . IOC.

$6(\mathrm{E} 2) \longrightarrow$ Cut-worms. $36 \mathrm{p}$. il. Nov. 1888 . IOC.

Volume 2. 7 nos. $[\$ 1.50]$ in cloth

7 I: (iz) smot. I: ( . First Report on the Iron Mines and Iron Ore Districts in New York. 6+7op. map. June r889. Out of print.

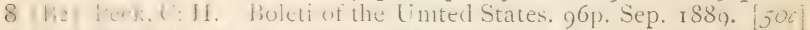

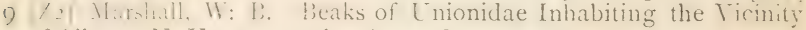
of Albany, N. Y. 24p. Ipl. Aug. 1890 . IOC.

Io ( $\mathrm{EG}_{3}$ ) Smock, J: C. Building Stone in New York. 2 rop. map. tab. Sep. 189c. 406 .

I I li , Merrill, I: J. H. Filt and Givsum Industries in New York. 92p. I $2 p l .2$ maps, r I tab. Ap. r893. 400.

I2 ( $\mathrm{E}_{5}$ ) Ries, Heinrich. Clay Industries of New York. I74p. 2pl. map. Mar. 1895 . 30c.

I3 $\left(V_{3}\right)$ lintner, J. 1 . Some Destructive Insects of New York State; sin José Scale. 54 p. 7 pl. Ap. 1895 . $15 \mathrm{c}$.

I4 (GI) Kemp, J. I. Geology of Moriah and Westport Townships, lissex ( $). N$. Y., with notes on the iron mines. 38 p. 7 pl. 2 maps. S(p). IS95. $10 c$.

I5 (LiG) Merrill, F: J. H. Mineral Resources of New York. 224p. 2 majos. Sep. 1895 . $40 \mathrm{C}$.

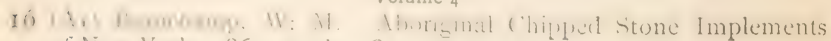
of New York. S(sp. 23pl. Oct. $1897.25 \mathrm{c}$.

I7 (1:(i7) Merrill, F: J. H. Road Materials and Road Building in Sew York. 52p. I + pl. 2 maps $34 x+5,68 x 92 \mathrm{~cm}$. Oct. 1897 . I5c.

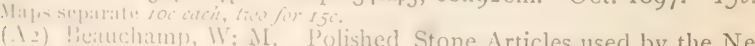

I8 (.12) !hituchump, IV: M. Polished Stone Articles used by the New Yurt: Mhorizines. 10.15. 35pl. Nor. $1897.25 \mathrm{c}$.

In ( $(; 2)$ Merrill, li: I. H. Guicle to the Study of the Geological ColC. tirnis of the New York State Museum. 162p. I 19 pl. map. Wine. 1Sigs. $.10 i$ 
2 I (G3) Kemp, J. F. Geology of the Lake Placid Region. 24p. Ipl. map. Sep. 1898 . 5c.

$22\left(\mathrm{~A}_{3}\right)$ Beauchamp, II: M. Earthenware of the New York Aborigines. $78 \mathrm{p} .33 \mathrm{pl}$. Oct. $1898.25 \mathrm{c}$.

23 ( $\mathrm{E}_{5}$ ) Felt, E. P. r 4 th Report of the State Entomologist 1898. I 5 op, il. 9pl. Dec. I 898. 20c.

24 (E6) - Memorial of the Life and Entomologic Work of J.A. Lintner Ph.D. State Entomologist $1874-98$; Index to Entomologist's Reports I-I3. 316p. Ipl. Oct. I899. 35c.

Supplement to 14 th report of the state eutomologist.

$25\left(\mathrm{~B}_{3}\right)$ Peck, C: H. Report of the State Botanist r898. $76 \mathrm{p} .5 \mathrm{pl}$. Oct. I899. Out of print.

\section{Volume 6}

$26\left(\mathrm{E}_{7}\right)$ Felt, E. P. Collection, Preservation and Distribution of New York Insects. 36p. il. Ap. r899. $5 c$.

27 (E8) - Shade-tree Pests in New York State. 26p. il. 5pl. May 1899. $5 c$.

$28\left(\mathrm{~B}_{4}\right)$ Peck, C: H. Plants of North Elba. 206p. map. Iune 1899. $20 \mathrm{C}$.

$29\left(Z_{3}\right)$ Miller, G. S. jr. Preliminary List of New York Mammals. r 24 p. Oct. I 899 . I5c.

30 (EG8) Orton, Edward. Petroleum and Natural Gas in New York. ז 36 . il. 3 maps. Nov. I 899. I5c.

3 I (F.g) Felt, E. P. I $5^{\text {th }}$ Report of the State Entomologist I899. I $28 \mathrm{p}$. June I9o0. $15 \mathrm{C}$.

Volume 7

32 (A4) Beauchamp, WV: M. Aboriginal Occupation of New York. igop. I6pl: 2 maps. Mar. 1900. 30c.

$33\left(Z_{4}\right)$ Farr, M. S. Check List of New York Birds. 224P. Ap. 1900. $25 \mathrm{c}$.

34 ( Pr) Cumings, E. R. Lower Silurian System of Eastern Montgomery County; Prosser, C: S. Notes on the Stratigraphy of Mohawk Valley and Saratoga County, N. Y. 74p. Iopl. map. May I9oo, $15 \mathrm{C}$.

35 (EGg) Ries, Heinrich. Clays of New York: their Properties and Uses, $456 \mathrm{p}$. r4opl. map. June Igoo. $\$ I$, cloth.

36 (EIo) Felt, E. P. r6th Report of the State Entomologist I900. I 8 p. I6pl, Mar. I9or. 25c.

\section{Volume 8}

37 (EIr) _ Catalogue of Some of the More Important Injurious and Beneficial Insects of New York State. 54p. il. Sep. I9oo. roc.

$38\left(Z_{5}\right)$ Miller, G. S. jr. Key to the Land Mammals of Northeastern North America. 106p. Oct. 1900. $15 \mathrm{c}$.

$39\left(\mathrm{P}_{2}\right)$ Clarke, J: M.; Simpson, G: B. \& Loomis, F: B. Paleontologic Papers I. $72 \mathrm{p}$. il. I6pl. Oct. rgoo. I5c.

Contents: Clarke, J: M. A Remarkable Occurrence of Orthoceras in the Oneonta Beds of the Chenango Valley, N. Y.

Paropsomema Cryptophya; a Peculiar Echinoderm from the Intumescenszone (Portage Berls) of Western New York.

Dictyonine Ifexactinellicl Sponges from the Upper Devonic of New York.

The Water Biscuit of Squas Island, Canandaigua Lake, N. Y.

Simpson, (r: B. Preliminary Deseriptions of New Gevera of Paleozoic Rugose Corals.

Loomis, F: B. Siluric Fungi from Western New York.

40 (Z6) Simpson, G: B. Anatomy and Physiology of Polygyra albolabris and Limax maximus and Embryology of Limax maximus. 
$42\left(\mathrm{l}_{3}\right)$ Ruedemann, Rudolf. Hudson River Beds near Albany and their Taxonomic Equivalents. ri4p. 2pl. map. Ap. I901. $25 \mathrm{c}$.

$43\left(\mathrm{Z}_{7}\right)$ Kellogg, J. L. Clam and Scallop Industries of New York. 36p. 2pl. map. Ap. 19or. roc.

44 (Liro) Ries, Heinrich. Lime and Cement Industries of New York; Eckel, E. C. Chapters on the Cement Industry. 332p. 10rpl. 2 maps. Dec. rgor. 85c, cloth.

\section{Volume 9}

45 ( Vicinity. 286p. il. I8pl. map. Ap. Igor. $65 \mathrm{c}$; cloth goc.

46 (EI2) Felt, E. P. Scale Insects of Importance and a List of the Species in New York. 94p. il. r5pl. June r9or. $25 \mathrm{c}$.

47 (EI3) Needham, J. G. \& Betten, Cornelius. Aquatic Insects in the Adirondacks, 234p. il. $36 \mathrm{pl}$. Sep. 1901. $45 \mathrm{c}$.

$48\left(\mathrm{G}_{4}\right)$ Woodworth, J. B. Pleistocene Geology of Nassau County and Borough of Queens. $58 \mathrm{p}$. il. 9pl. map: Dec. rgor. $25 \mathrm{c}$.

\section{Volume ro}

49 (P5) Ruedemann, Rudolf; Clarke, J: M. \& Wood, Elvira. Paleontslogic Papers 2. 240p. I3pl. Dec. 1901. $40 c$.

Contents: Ruedemaun, Rudolf. Treut on Couglomerate of Rysedorph Hill.

Clarke, J: M. Limestmes of Central and Western New York Interbediled with Bituminous Shales of the Marcellus Stage.

Wood, Elvira. Maruellus Limestones of Laneaster, Erie Co. N. Y.

Clarke, J: M. New Agelacrinites.

- Value of Amuigenia as an Indicator of Fresh-water Deposits during the Devonic of New York. Ireland and the Rhiueland.

50 (A6) Beauchamp, W: M. Horn and Bone Implements of the New York Indians. I1 2 p. 43pl. Mar. 1902. 30c.

5 I (Z\&) Eckel, E. C. \& Paulmier, F. C. Catalogue of Reptiles and Batrachians of New York. 64p. il. Ipl. Ap. I902. I5C.

Eekel, E. C. Serpents of Northeasteru Uuited states.

Panlmier, F. C. lizaris, Tortoises and Batrachians of New York.

52 ('PG) Clarke, J: M. Report of the State Paleontologist rgor. 280p. il. 9pl. map. I tab. July x $902.40 c$.

53 (F.14) Felt, E. P. 1 7 th Report of the State Entomologist I9or. 232p. il. 6pl. Aug. 1902. 306.

54 (135) Peck, C: H. Report of the State Botanist rgor. $58 \mathrm{p} .7 \mathrm{pl}$. Nov. 1902. $40 c$.

55 (A7) Beauchamp, W: M. Metallic Implements of the New York Indians. 94p. $3^{8} \mathrm{pl}$. June $1902.25 \mathrm{c}$.

$50\left(G_{5}\right)$ Merrill, F:J. H. Geologic Map of New York. In press.

57 (E.15) lieit, E. P. E.lm Leaf Beetle in New York State. 46p. il. Spl. Aug. 1902. 15 C.

58 ( $\mathrm{M} 2$ ) Whiteck, H. P. (iuide to the Mineralogic Collections of the New Yorl. State Murcum. I5op. il. 3ypl. I I models. Sep. r902. $40 c$.

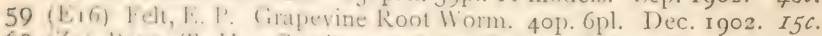

$60(79)$ Beaw, T. 11. Citalegue of the Fishes of New York. $784 \mathrm{p}$. Ieb. 1903. \$I, cloth.

6r (EGm, Dickiusm, II. T. Quarries of Bluestone and other Sandstones in New York. In press.

62 (Misen) Merrill, 1: I. H. Directory of Natural History Museums in United States and Canada. In press.

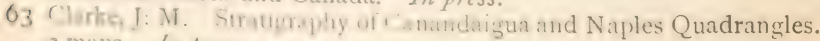
2 maps. In press.

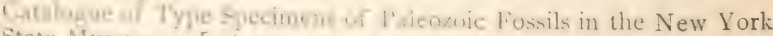
State Museum. In press.

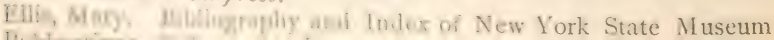


Museum memoirs I889-date. Q.

I Beecher, C: E. \& Clarke, J: M. Development of some Silurian Brachiopoda. 96p. 8pl. Oct. I889. Out of print.

2 Hall, James \& Clarke, J: M. Paleozoic Reticulate Sponges. 35op. il. 7opl. $1898 . \$ 1$, cloth.

3 Clarke, J: M. The Oriskany Fauna of Becraft Mountain, Columbia Co. N. Y. I28p. 9 pl. Oct. I9oo. $80 c$.

4 Peck, C: H. N. Y. Edible Fungi, 1895-99. 106p. 25 pl. Nov. 1900. 75 c. This includes revised descriptims and illustrations of fungi reported in the 49 th, 51 st and $52 d$ reports of the state botanist.

5 Clarke, J: M. \& Ruedemann, Rudolf. Guelph Formation and Fauna of New York State. In press.

6 Clarke, J: M. Naples Fauna in W'estern New York. In press. Felt, E. P. Insects Affecting Park and Woodland Trees. In preparation.

Natural history of New York. 30v. il. pl. maps. Q. Albany i 842-94.

Division 1 zoologr. De Kay, James E. Znology of New York; or, The New York Fanna; comprising derailed descriptions of all the animalis hitherto observed within the state of New York with hrief notices of those oceasionally found near its horeler, and accompanied by appropriate illustrations, 5r. il. pl. maps. sq. Q. Albany 1842-44. Uut of print.

Historical introduction to the series by Gov. W: H. Seward. $178 \mathrm{p}$.

v. 1 pt1 Mammalia. 13+146p. 33pl. 1842.

300 copies with hand-colored plates.

v. 2 pt2 Birds. $12+380$ p. 141pl. 1844 . Colored plates.

r. 3 pt3 Reptiles and Amphibia. 7+981). pt4 Fishes. 15+415p. 1842. pt3-4 bound together.

v.4 Plites to accompany r.3. Reptiles and Amphibia 23pl. Fishes 79pl. 1842. 300 copies with hand-colored plates.

v. 5 pt5 Mollusea. $4+271 \mathrm{p} .40 \mathrm{pl}$. jt6 Crustacea. $70 \mathrm{p} .13 \mathrm{pl}$. 1813-44. Haud-colored plates: pt5-6 bound together.

DIVISION 2 Botaxy. Torres, John. Flora of the State of New York; comprising full descriptions of all the indigenous and naturalized plants bitherto discovered in the State, with remarlis on their economical and medical properties. 2v. il. pl. sq. Q. Albany 1843. Out of print.

$\checkmark .1$ Flora of the State of New York. $12+484 \mathrm{p}, 72 \mathrm{pl} .1843$. 300 coples with hand-colored plates,

v. 2 Flora of the State of New York. 572p. 89pl. 1843. 300 coples with hand-colored plates.

DIVIsion 3 mineralogr. Beck, Lewis C. Mineralogr of New York; comprising detailed deseriptions of the minetals hitherto found in the State of New York, aud notices of their uses in the arts and agriculture. il. pl. sq. Q. Albany 1842. Out of print.

v. 1 pt 1 Economieal Mineralogr. jt2 Descriptive Mineralogy. 24+536p. 1842. 8 plates additional to those printed as part of the text.

Drvision 4 Georogr. Mather, W: W.; Emmons, Ebenezer; Yanuxem, Lartner \& Hall, James. Geology of New York. 4v. il. 1l. \&1. Q. Alhany 1842-43. Out of print.

v. 1 pt l Mather, W: W. First Grolngieal District. $3 \bar{\imath}+6 \overline{3} 3 p .46 p 1.1813$.

v.2 pt2 Emmons, Ebenezer. Second Geological District. $10+1371.17$ 1. 18.12.

v. 3 pt3 Vanuxem, Lardner. Tbird Geological District. $306 \mathrm{p} .1842$.

v. 4 pt4 Hall, James. Fourth Geologimal District. '2- $+68.3 p . ~ M a p$ and $19 \mathrm{pl}$. 1843.

DITision 5 Agriculture. Emmons, Ebenezer. Agricultme of New York; comprising an aceount of the classification, composition and rlistribution of the soils and rocks and the natural waters of the different seological formations, together with a eondensed view of the meteorology and agrienltural produce tions of the State. 5v. il. pl. sq. Q. Albany 1846-54. Out of print.

จ. 1 Soils of thy State, their Composition and Distribution. $11+3711.21$ 1. 1846. 


BINDING SECT. FEB 281977 .

\title{
PLEASE DO NOT REMOVE CARDS OR SLIPS FROM THIS POCKET
}

\section{UNIVERSITY OF TORONTO LIBRARY}

\author{
Bean, Tarleton $\mathrm{H}$ \\ Catalogue of the fishes \\ of New York State Museum
}

\section{$\mathrm{ESCl}$}


